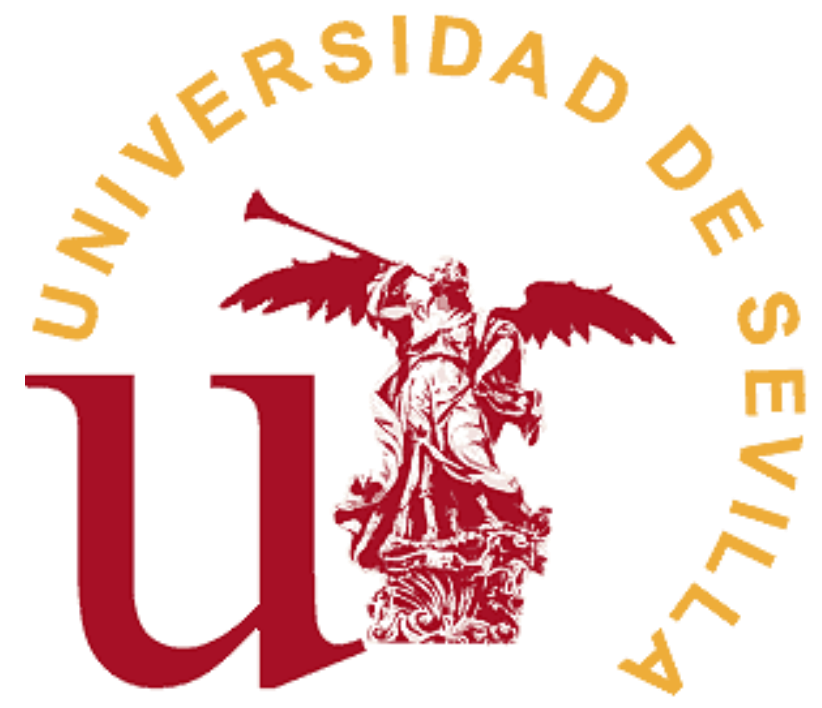

\title{
LAS SECTAS EN DERECHO PENAL
}

\author{
Tesis Doctoral que presenta el Doctorando \\ CARLOS BARDAVÍO ANTÓN \\ para optar al Grado de Doctor en Derecho por la Universidad de Sevilla, \\ bajo la dirección académica del
}

Prof. Dr. Dr. h. c. mult. Miguel Polaino NavarRete

Facultad de Derecho

Curso Académico 2015/2016 



\section{CAPÍTULO I \\ CONCIENCIA, VOLUNTAD, MORAL, SOCIEDAD Y LA OBJECIÓN DE CONCIENCIA}

I.- Planteamiento

II.- Conciencia, voluntad y Moral en el pensamiento clásico …........................................................................... 14

III.- Repercusiones del idealismo moralizante en las teorías sociológicas hasta la irrupción de la teoría de los sistemas de Luhmann: cambio de paradigma

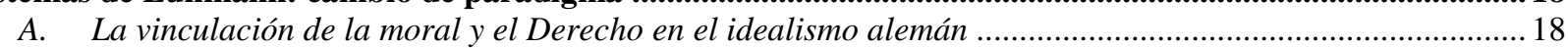

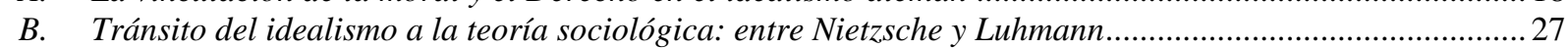

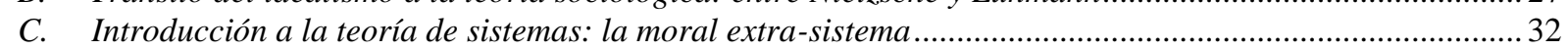

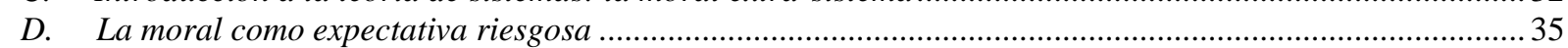

IV.- Libertad, determinismo neurocientífico y psicológico en la responsabilidad penal ................................40

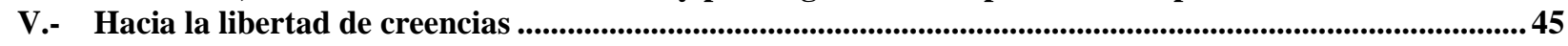

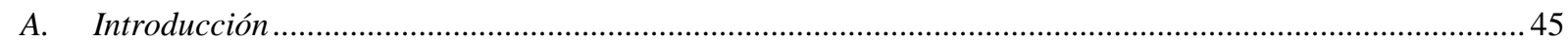

B. El reconocimiento de la libertad de conciencia como objeción de conciencia en nuestro ordenamiento

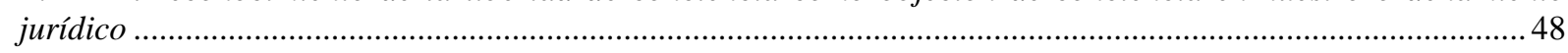

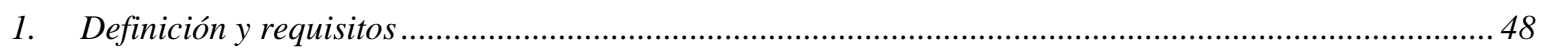

2. Límites de la libertad de manifestar y practicar las creencias: orden público, salud y seguridad públicas

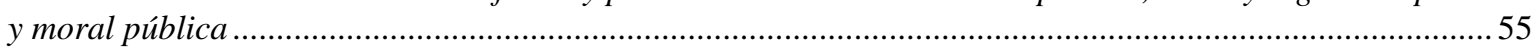

C. Obligatoriedad del deber jurídico ante el deber moral y desobediencia civil ...........................................59

VI.- Trascendencia del reconocimiento de la libertad de conciencia en grupos religiosos y sectas.................. 62

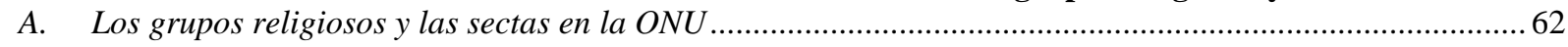

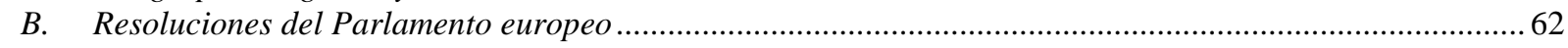

C. Las resoluciones del Consejo de Europa sobre la problemática de la libertad de conciencia en las sectas 65

D. Jurisprudencia europea sobre la problemática de la libertad de conciencia en los grupos sectarios religiosos...

1. La jurisprudencia del Tribunal Europeo de Derechos Humanos ......................................................66

2. La jurisprudencia del Tribunal de Justicia de la Comunidad Europea en materia religiosa de grupos

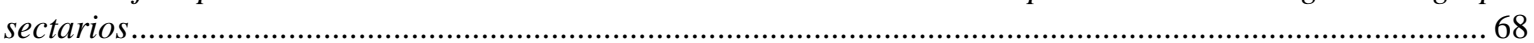

E. Dictamen, Propuesta, Conclusiones e Informe en materia de sectas en el Pleno del Parlamento español de

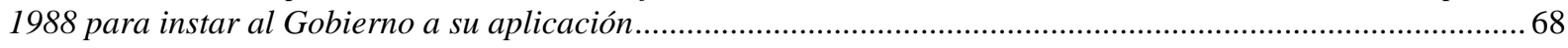

F. Problemáticas en la inscripción de grupos religiosos en el Registro de Entidades Religiosas .....................70

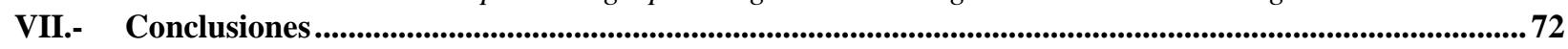

\section{CAPÍtulo II \\ AUTOR DE CONCIENCIA, AUTOR POR CONVICCIÓN Y PELIGROSIDAD CRIMINAL DESESTABILIZADORA}

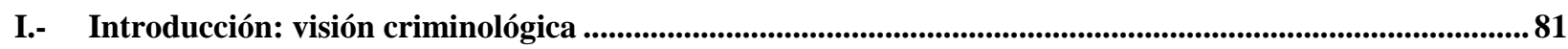

II.- Los conceptos de autor por convicción y de conciencia en la doctrina penal .....................................................8

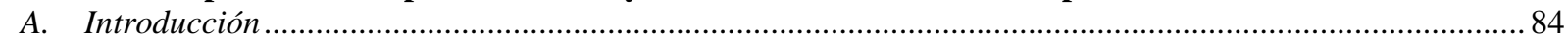

B. Primeras consideraciones doctrinales sobre el autor por convicción y de conciencia .................................86

C. Consideraciones actuales sobre el concepto de autor por convicción y de conciencia.......................................94

D. ¿El autor de conciencia y por convicción culposos?: Reflexiones sobre la posibilidad jurídico-penal de un autor por convicción o de conciencia imprudente ................................................................................... 102

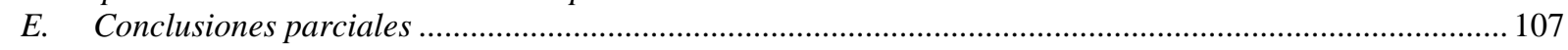

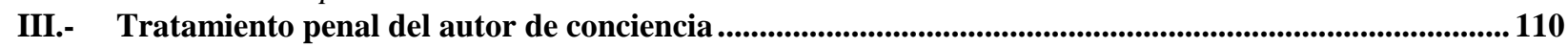

A. Introducción: máxima responsabilidad de la autoría de conciencia y por convicción ................................110

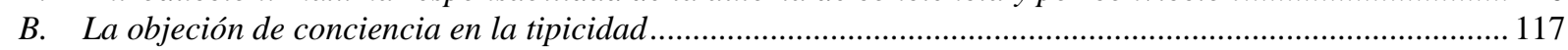

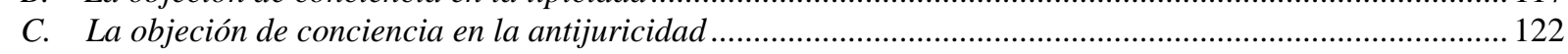

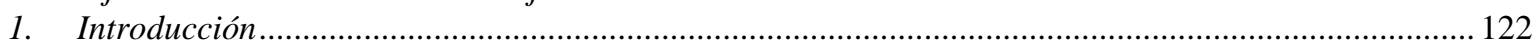


2. Problemática del consentimiento como causa de atipicidad o de justificación en la conducta del autor

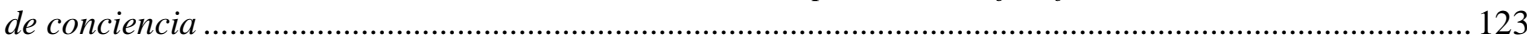

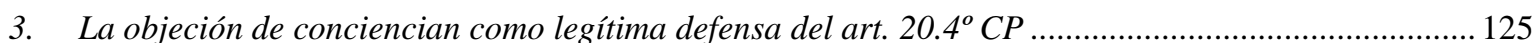

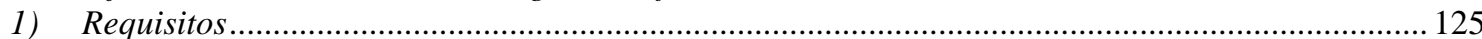

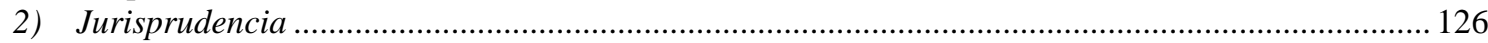

4. La objeción de conciencia como estado de necesidad justificante .................................................. 127

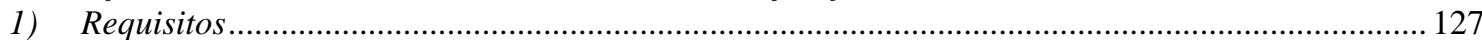

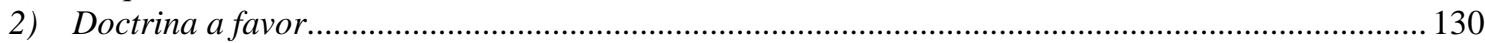

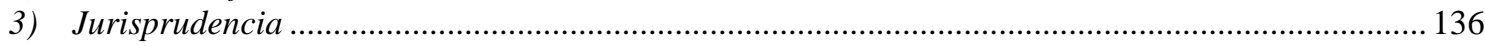

5. La objeción de conciencia como ejercicio legítimo de un derecho................................................... 141

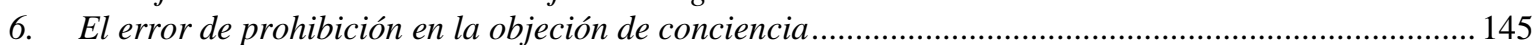

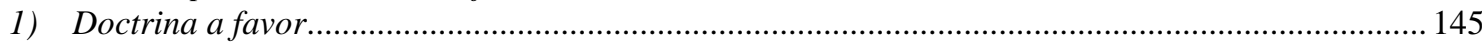

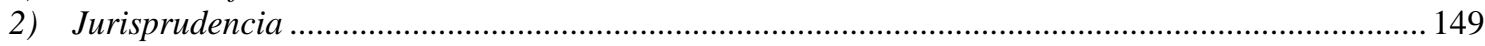

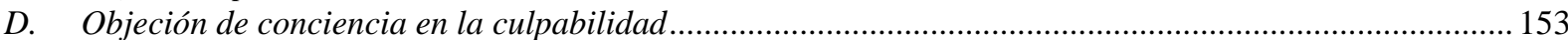

1. Postulados doctrinales sobre el concepto material y formal de culpabilidad ....................................... 153

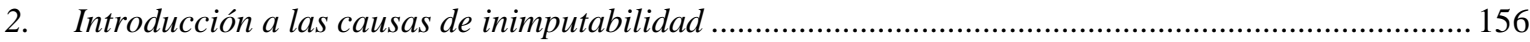

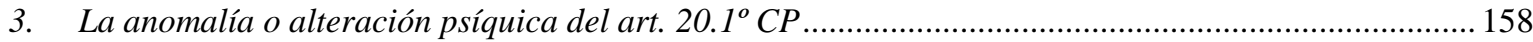

4. El trastorno mental transitorio del art. $20.1^{\circ}$ segundo párrafo y del art. $20.2^{\circ}$ del CP en los conflictos de

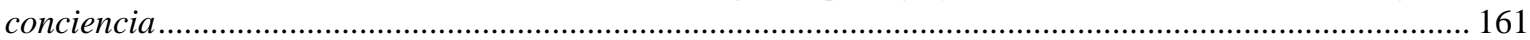

5. La alteración de la percepción del art. $20.3^{\circ}$ del CP, como imposible eximente en los autores por

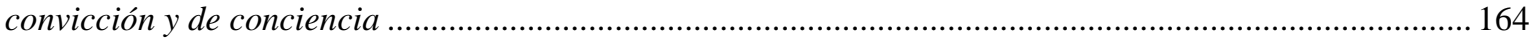

6. Breve referencia a la minoría de edad en los autores de conciencia .................................................. 165

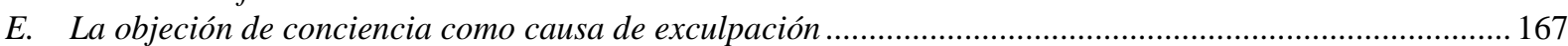

1. Introducción: el principio de inexigibilidad y las causas de exculpación ............................................ 167

1) Doctrina a favor de aplicar el estado de necesidad exculpante en la autoría de conciencia ............ 178

2) Doctrina a favor del principio de inexigibilidad de otra conducta en la autoría de conciencia ...... 183

2. El miedo insuperable como causa de exclusión de la culpabilidad en los autores de conciencia.......... 189

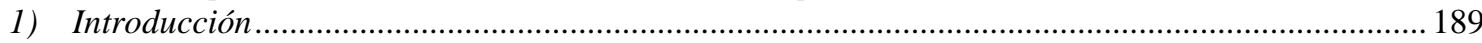

2) Requisitos del miedo insuperable ..................................................................................... 191

3) Doctrina a favor de la aplicación del miedo insuperable en la autoría de conciencia ..................... 194

F. Doctrina a favor de la falta de merecimiento de una pena o su disminución en la autoría de conciencia.. 196

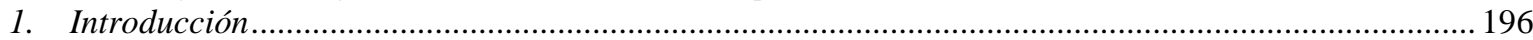

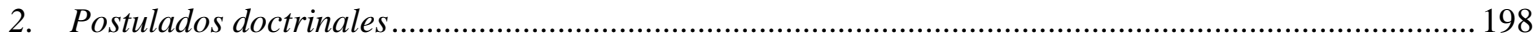

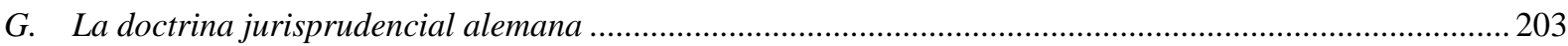

IV.- Especial referencia a los planteamientos del funcionalismo normativo: déficit de socialización ............205

A. Introducción al funcionalismo normativo: sociedad, norma y personas ..................................................2205

B. Función de la norma penal: Prevención general positiva y motivación de la norma versus norma como orientación de conductas y mantenimiento del sistema ............................................................................. 210

C. Bienes jurídicos o quebrantamiento normativo y vigencia de la norma ....................................................2 213

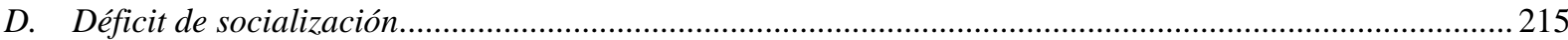

V.- Proposiciones conclusivas: vinculación del autor por convicción y el enemigo, y su diferenciación con el

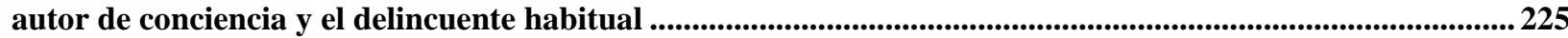

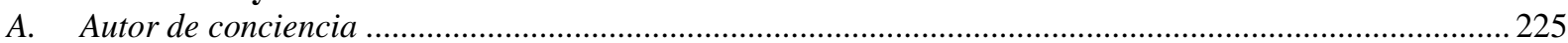

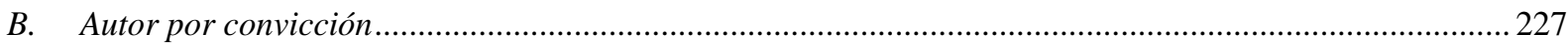

C. Concepto normativo de enemigo....................................................................................................2234

D. Criterio funcional de delimitación de las indicadas categorías: el sentido de la comunicación del hecho

delictivo y la alternatividad de comportamiento ..........................................................................................2 235

E. Delincuente habitual: determinación de tipologías ............................................................................2238

F. Fundamentos generales del tratamiento penal del autor de conciencia y por convicción ..........................240

1. Déficit de comunicación/socialización en el autor de conciencia atribuido a la norma ........................ 240

2. Déficit de socialización del autor de conciencia, del autor por convicción y del enemigo atribuido a

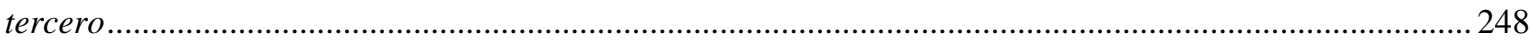

G. Fundamentos especiales del déficit de socialización del autor de conciencia atribuido a la norma:

reformulación de los requisitos del estado de necesidad exculpante ...........................................................251

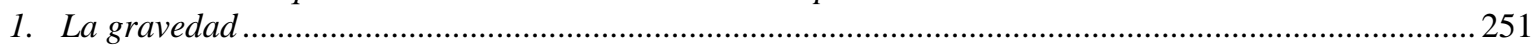

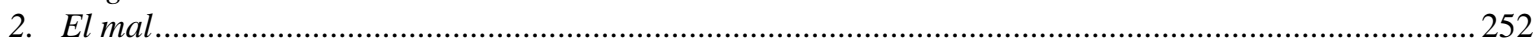

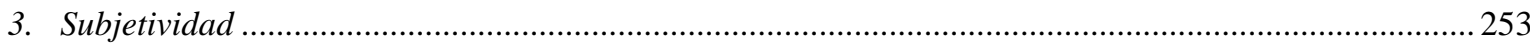

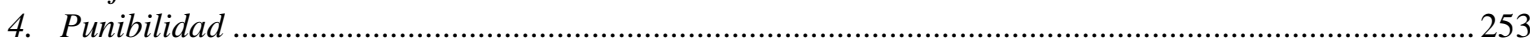




\section{CAPÍtulo III \\ CONFLICTOS DE CONCIENCIA PARTICULARES EN SECTAS}

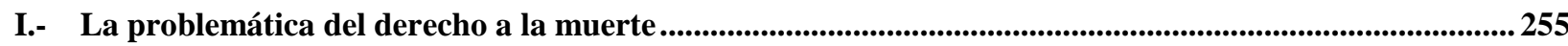

A. Introducción: La ética médica como presupuesto previo al conflicto moral ..........................................255

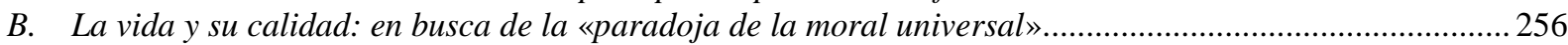

C. El consentimiento informado y el derecho a no consentir un tratamiento médico vital por su titular o para

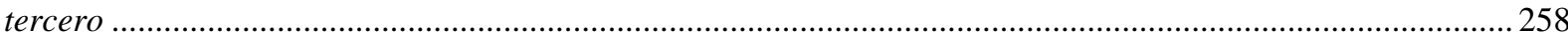

D. La conciencia ante el valor de la muerte: el bien jurídico de la vida y el derecho al suicidio ...................266

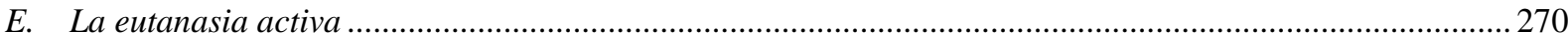

1. El «auxilio al suicidio» y la punibilidad de la acción de impedir un suicidio ........................................2 270

2. El fundamento de la atenuante de la eutanasia del art. 143.4 CP ..................................................2275

F. La eutanasia pasiva directa e indirecta .......................................................................................2 280

1. La eutanasia pasiva directa como interrupción o no iniciación del tratamiento por el rechazo al tratamiento vital de forma consciente y con plenas facultades mentales de un mayor de edad ................... 280

2. La eutanasia pasiva indirecta ...........................................................................................28

II.- Trasfusiones de sangre de terceros diferentes al titular del bien jurídico en manifiesto peligro de muerte: omisión del deber de socorro y homicidio en comisión por omisión .......................................................................283

A. Introducción al conflicto de conciencia en las transfusiones de sangre .................................................283

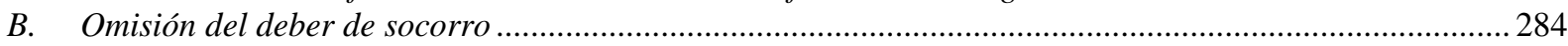

C. Comisión por omisión del art. 11 CP y los conflictos con los arts. 195 y 196 CP ....................................2288

1. Debate doctrinal sobre la delimitación objetiva de los preceptos ...........................................................28 288

2. Solución funcionalista: intercambiabilidad de la acción y la omisión en los delitos de dominio e infracción de deber .............................................................................................................................295

1) Imputación objetiva y funcionalismo normativo: La desobediencia a la norma como quebrantamiento

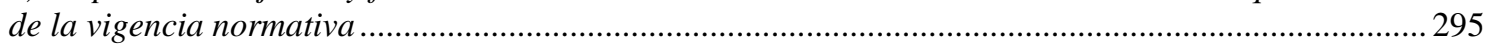

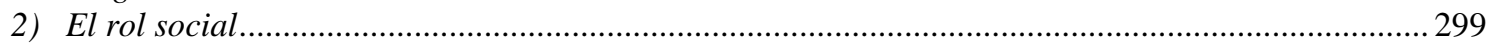

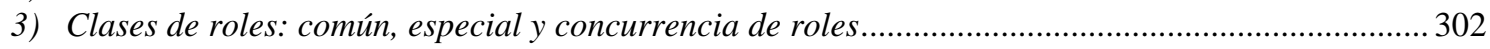

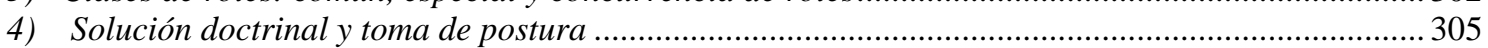

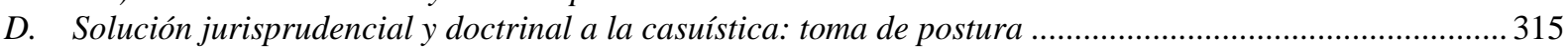

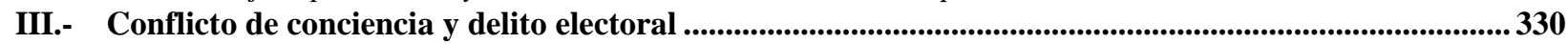

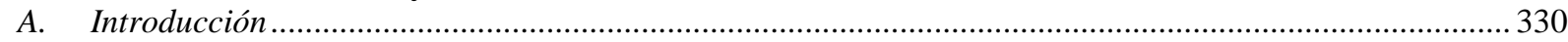

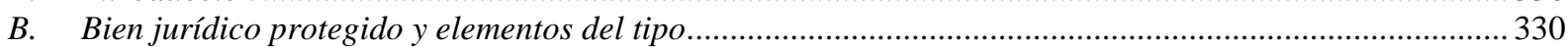

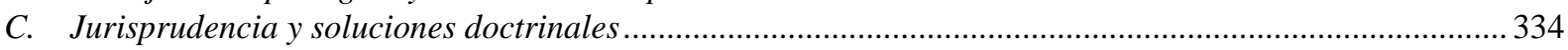

IV.- Conflicto de conciencia y participación en el Tribunal del Jurado..........................................................341

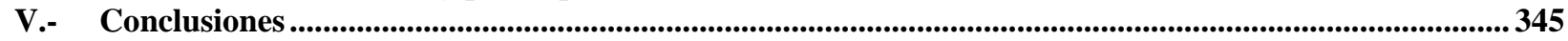

\section{CAPÍtulo IV \\ ESTRUCTURA CRIMINOLÓGICA Y JURÍDICO-PENAL DE LAS SECTAS CRIMINALES}

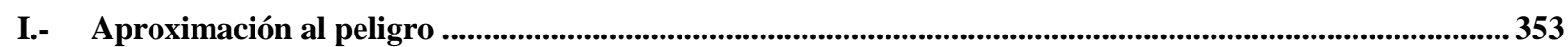

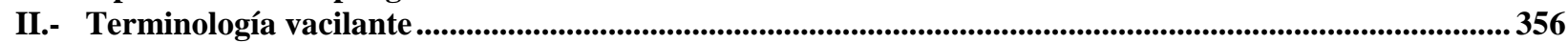

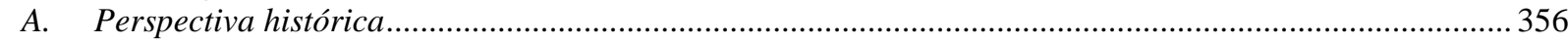

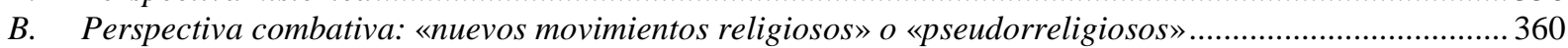

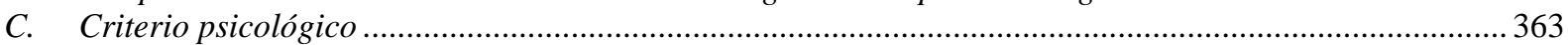

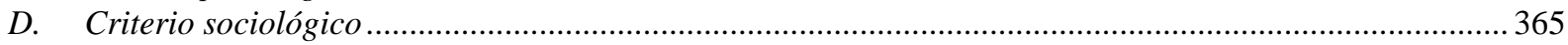

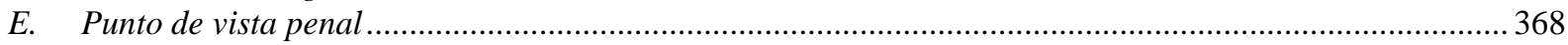

F. $\quad$ Propuesta de terminología jurídica: sectas «criminales» y especialmente «coercitivas» ......................... 370

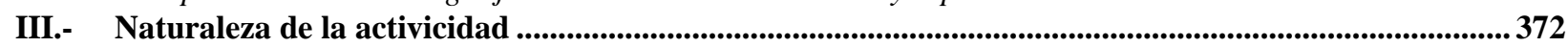

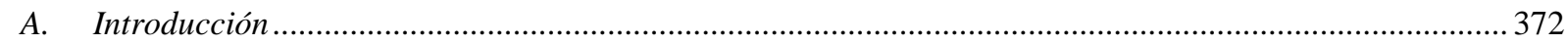

B. Tratamiento del sectarismo: modelo del «lavado de cerebro», modelo causal y sistémico........................ 374

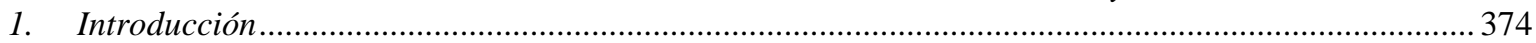

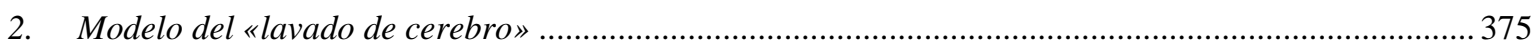

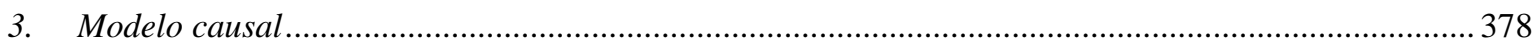

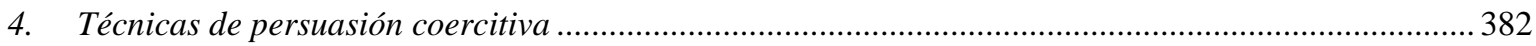

5. Extrapolación desde la teoría de sistemas y sociología de la religión de Luhmann .................................386

C. $\quad$ El líder, jefe, co-líderes, miembros activos y simples adeptos: roles sectarios .........................................38 


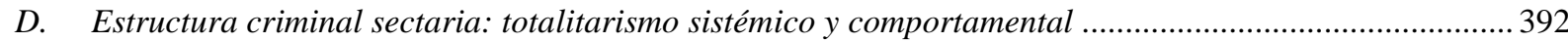

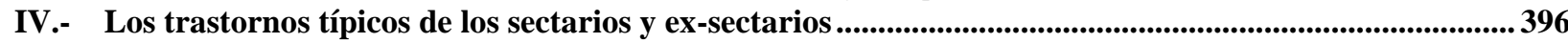

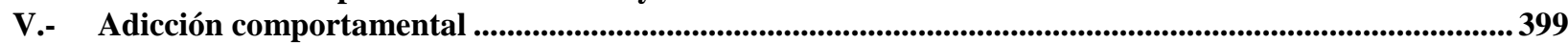

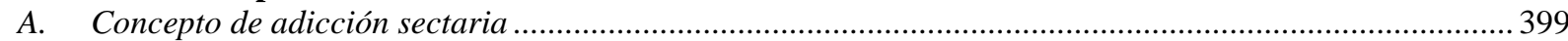

B. Teorías sobre la adicción: la adicción comportamental y sus consecuencias penales ............................. 405

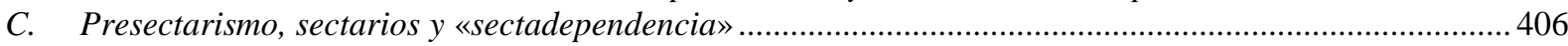

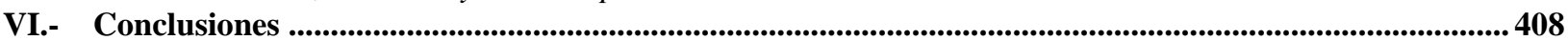

\section{CAPÍTULO V \\ DELIMITACIÓN DEL «DELITO SECTARIO»: LA RELEVANCIA TÍPICA DE LA «PERSUASIÓN COERCITIVA»}

I.- Introducción histórica al acto delictivo de la «persuasión coercitiva» y Derecho comparado .................411

II.- Persuasión coercitiva como «proselitismo ilícito» .........................................................................425

III.- La persuasión coercitiva como «delito contra la integridad moral» ............................................................436

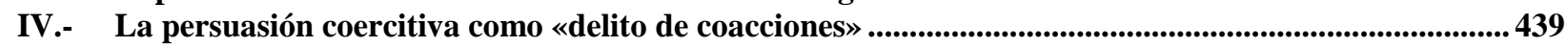

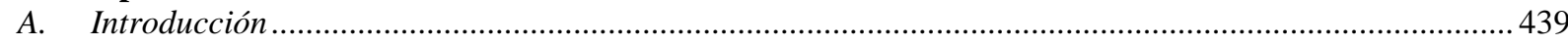

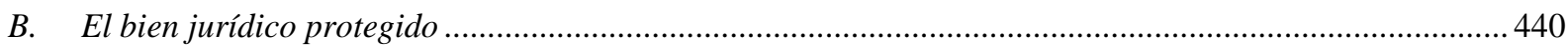

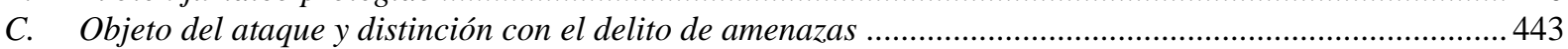

1. La libertad de capacidad/formación de la voluntad: la capacidad de la libertad ................................ 443

2. La libertad de decisión de la voluntad o capacidad de actuación de la propia voluntad..................... 444

3. La libertad de ejecución de la voluntad o libertad de voluntad conforme a motivos propios ............... 449

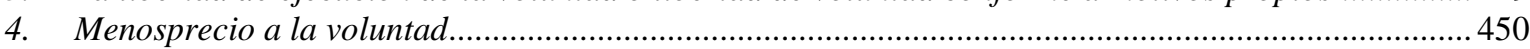

D. Los elementos objetivos del tipo: la violencia/vis absoluta, la intimidación/vis compulsiva ......................450

E. Otras formas de violencia: violencia sobre terceros, por omisión y mediante medios indirectos o engaños

F. $\quad$ Conclusiones parciales: eliminación de alternativas como incapacidad de formación de la voluntad, y restricción de alternativas como incapacidad de formación de horizontes de expectativas y como incapacidad de

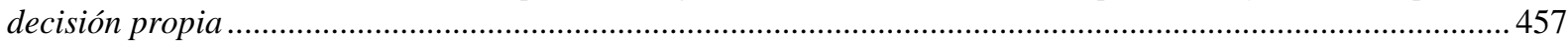

G. La violencia mediante anestesia, narcóticos, suero de la verdad o hipnosis ........................................ 460

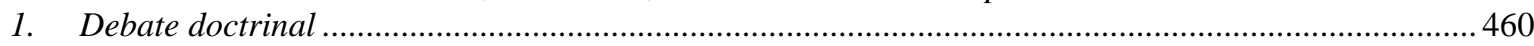

2. ¿Los medios sofrológicos y la hipnosis como medios violentos?: la sugestión como persuasión

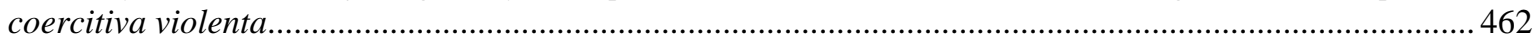

3. Relevancia jurídico-penal de la voluntariedad de la acción e injusto de la hipnosis, sofrología y de la persuasión coercitiva en la autoría y participación ........................................................................................465

4. Conclusiones: la persuasión coercitiva como violencia en el delito de coacciones ...............................467

H. El tipo subjetivo en el delito de coacciones y en la persuasión coercitiva ..............................................469

I. ¿Concurrencia de agravantes en las coacciones por persuasión coercitiva? ........................................... 470

J. Delimitación y similitudes del delito de coacciones como persuasión coercitiva con el delito de detención

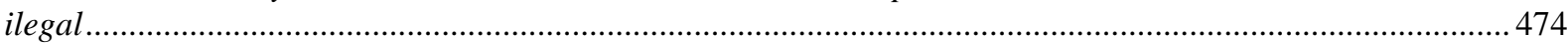

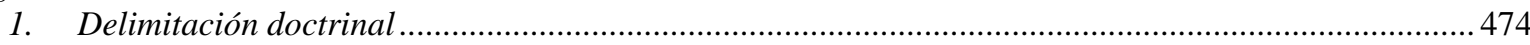

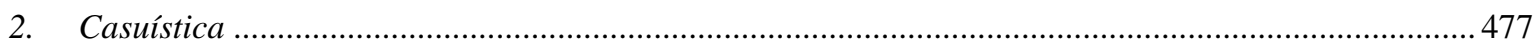

K. Conclusiones sobre el delito-fin sectario estricto sensu: la persuasión coercitiva como delito de coacciones

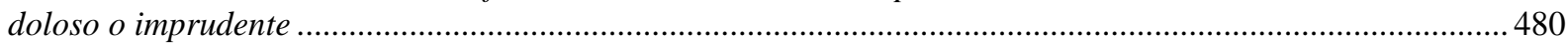

V.- Delitos contra la libertad sexual con reclamo sexual flirty fishing ................................................................ 483

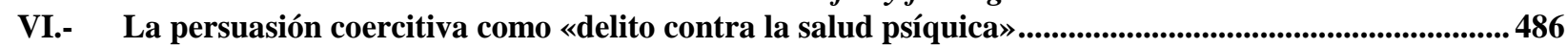

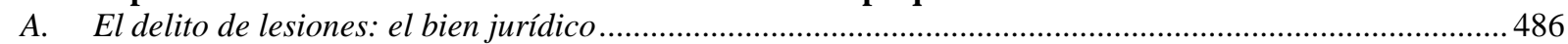

B. La persuasión coercitiva como alteración o anomalía psíquica ...............................................................488

C. La persuasión coercitiva como adicción comportamental que causa un delito de lesión psíquica.............................

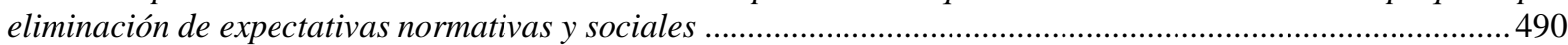

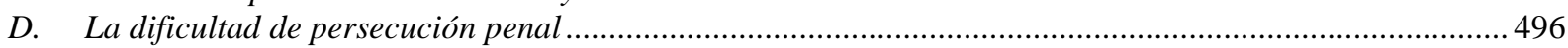

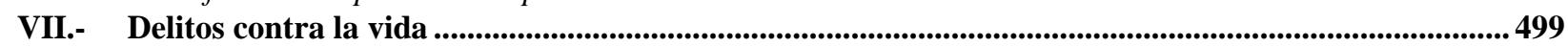

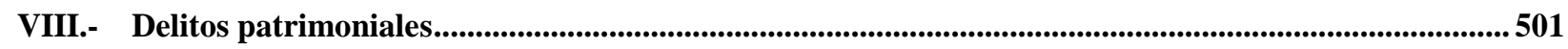




\section{CAPÍTULO VI \\ IMPUTACIÓN OBJETIVA EN LA «PERSUASIÓN COERCITIVA» COMO EJEMPLO DE \\ DÉFICIT DE SOCIALIZACIÓN ATRIBUIDO A TERCERO}

I.- Introducción

II.- Instituciones de la imputación objetiva en la persuasión coercitiva como déficit de socialización atribuido a tercero

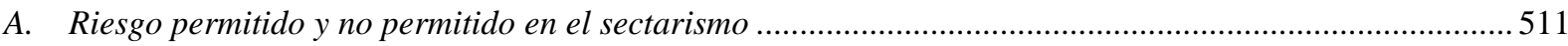

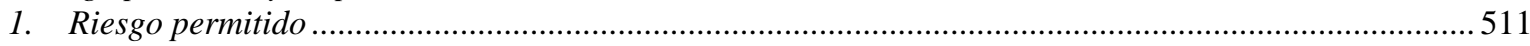

2. Riesgo no permitido: el quebrantamiento normativo de los roles sectarios .......................................514

3. Fundamento de punibilidad y tentativa de las técnicas de persuasión coercitiva y de la dinámica

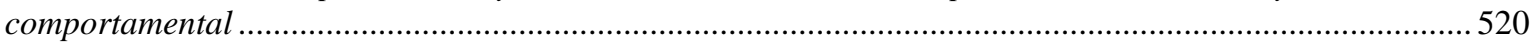

B. Sobre la relevancia del consentimiento en las coacciones y en el delito de lesiones: ..............................532 su ubicación jurídico penal y trascendencia en la persuasión coercitiva y en la adicción comportamental .......532

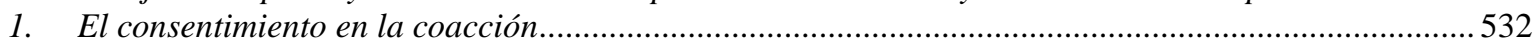

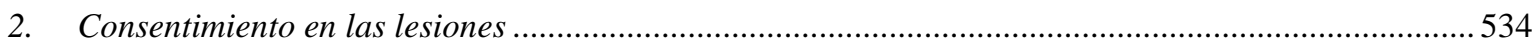

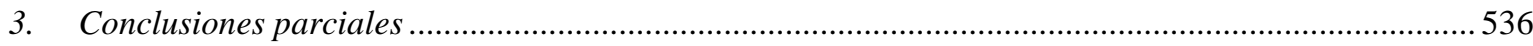

4. Autopuesta en peligro, imputación de la víctima sectaria de las consecuencias por su ingreso sectario y consentimiento de la persuasión coercitiva ................................................................................................ 537

5. Principio de confianza. El vicio del consentimiento informado como fundamento penal en la persuasión coercitiva: "comunidad especial de confianza» y «garantía de expectativa cognitiva deficitaria» ...............543

6. Prohibición de regreso en la permisión de creencias y «comunidad especial de confianza» y «garantía

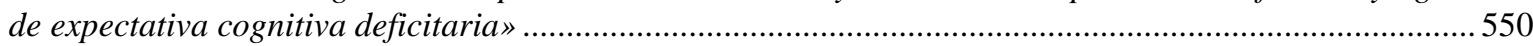

C. Imputación objetiva de los resultados dañosos tardíos: lesiones psíquicas .............................................553

1. Introducción a la dimensión temporalmente tardía del resultado ....................................................553

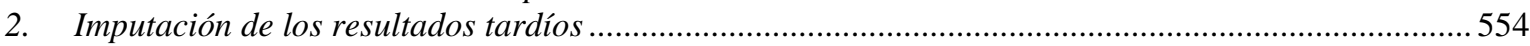

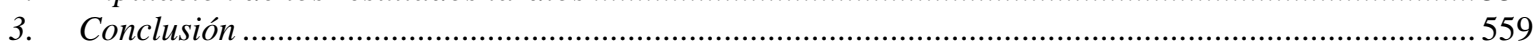

III.- Déficit de socialización del autor atribuible a tercero y estado de necesidad exculpante .......................559

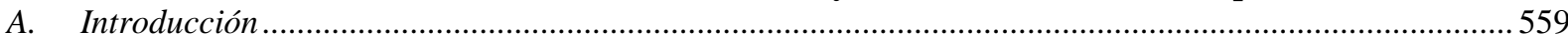

B. Imputación del déficit de socialización por educación totalitaria y/o criminal y estado de necesidad

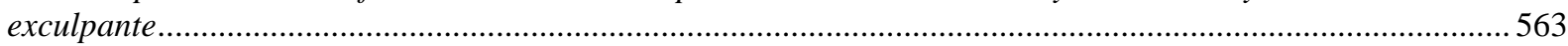

C. Imputación del déficit de socialización por educación cultural y tradicional y estado de necesidad

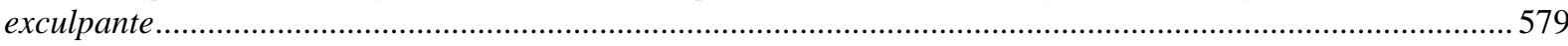

D. Imputación del déficit de socialización del autor atribuible al mismo: imputación a la víctima .................582

E. Trascendencia jurídico-penal del estado de necesidad exculpante por déficit de socialización atribuido a tercero: completación de la reformulación del estado de necesidad exculpante .............................................583

IV.- $\quad$ La persuasión coercitiva y pluralidad de víctimas .....................................................................................555

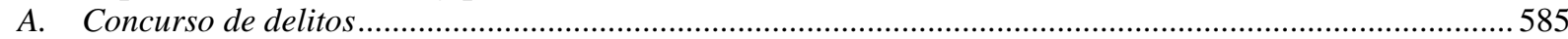

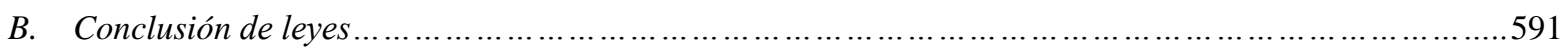

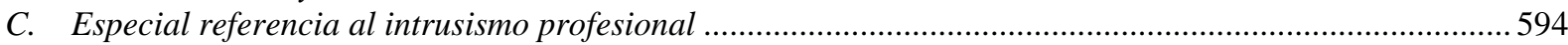

V.- Posibilidad de apreciación de actio libera in causa: desvirtuación de la libertad personal válida ...........599

A. Introducción y planteamientos ......................................................................................................59

B. Conclusión y trascendencia de la actio libera in causa en la tentativa de persuasión coercitiva y en la

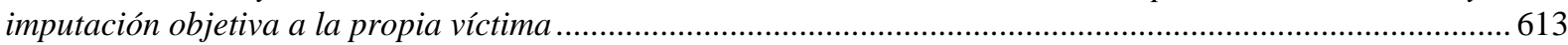

VI. Proposiciones conclusivas y de lege ferenda ....................................................................................................6.616

\section{CAPÍTULO VII \\ DINÁMICA COMPORTAMENTAL DE LOS DELITOS-FIN EN LAS SECTAS COERCITIVAS COMO INJUSTO SISTÉMICO}

I.- Inducción y persuasión coercitiva en los delitos-fin sectarios

A. La persuasión como forma de inducción y diferenciación normativa con la persuasión .............................621

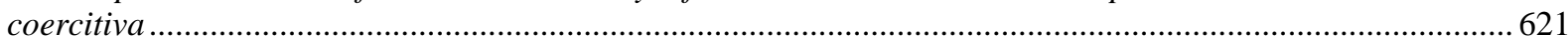

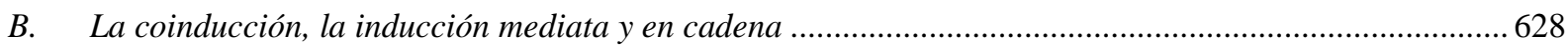

C. La inducción y la persuasión coercitiva omisivas y en comisión por omisión.............................................631

D. La inducción o persuasión coercitiva mediante doctrinas no neutrales..................................................633

E. Conclusiones parciales: inducción como injusto autónomo de persuasión coercitiva e ............................634

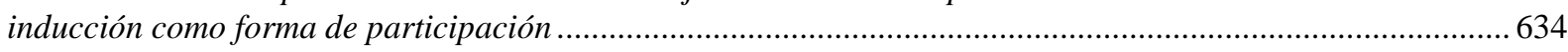


II.- Intervención delictiva en la creación y/o utilización del déficit de socialización exculpante y en la adicción comportamental .

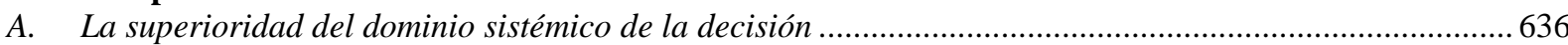

1. El dominio de la voluntad en virtud de creación o aprovechamiento de coacción................................636

2. Dominio de la voluntad en virtud de error ................................................................................. 644

B. La intervención delictiva en aparatos organizados de poder: criterios de imputación y su trascendencia en

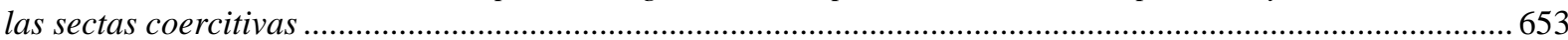

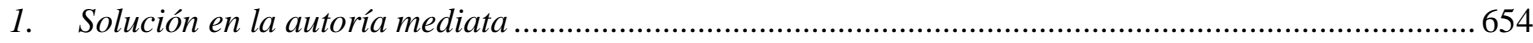

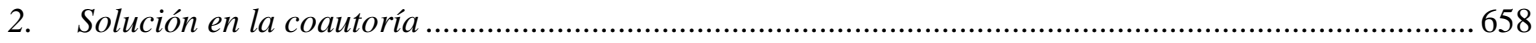

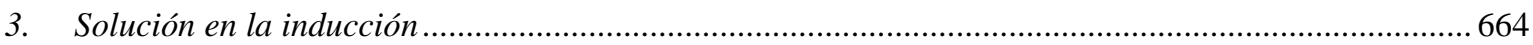

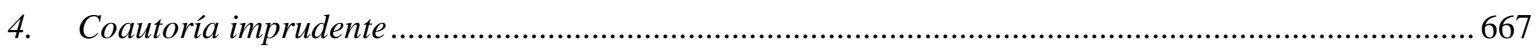

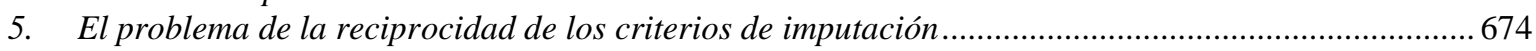

III.- Autoría y participación en los delitos-fin prototípicos de las sectas coercitivas ...................................679

A. Desconexión de injusto autónomo de persuasión coercitiva y formas de participación en el delito-fin...... 679

1. Desconexión objetiva: el concurso entre el delito de coacciones mediante persuasión coercitiva y el delito-

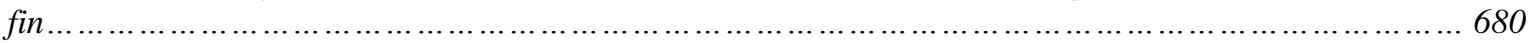

2. Desconexión subjetiva: del título de imputación por dolo o imprudencia y de la responsabilidad de los

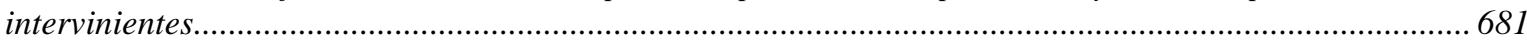

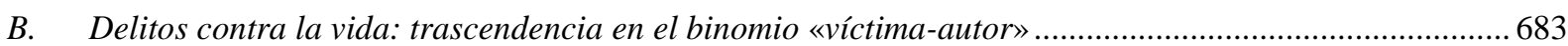

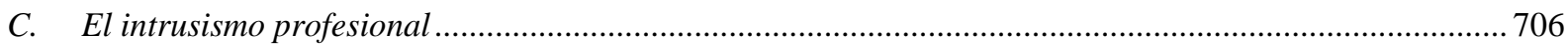

D. Estafas y falsedades documentales: trascendencia en el binomio «víctima-autor» .................................708

E. Delitos de abuso sexual mediante o sin reclamo sexual ...................................................................... 712

\section{CAPÍTULO VIII \\ LA ASOCIACIÓN ILÍCITA, LA ORGANIZACIÓN CRIMINAL Y LOS GRUPOS CRIMINALES COMO INJUSTO SISTÉMICO}

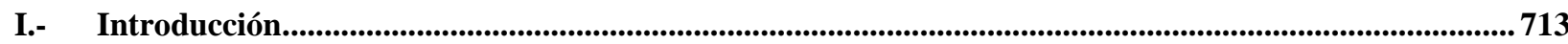

II.- El injusto sistémico .....................................................................................................................................................719

III.- Fundamentos de imputación objetiva del injusto sistémico: doctrinas sectarias coercitivas, totalitarismo y dinámica comportamental grupal............................................................................................................................... 736

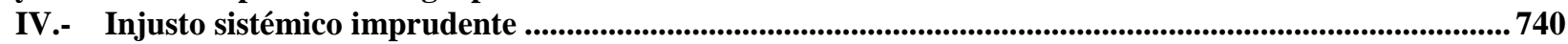

V.- $\quad$ Breve referencia a procesos penales a grupos religiosos por asociación ilícita ............................................. 742

A. El proceso penal a la Iglesia de la Cienciología ............................................................................... 742

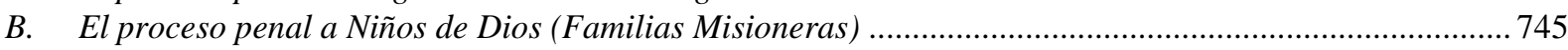

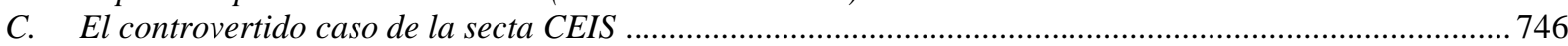

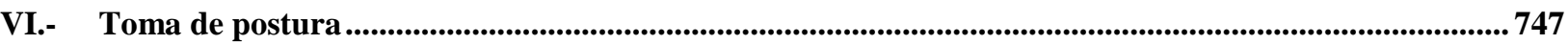

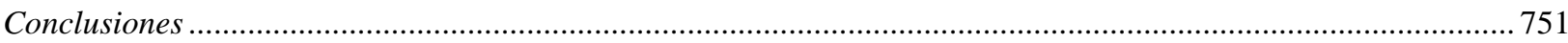

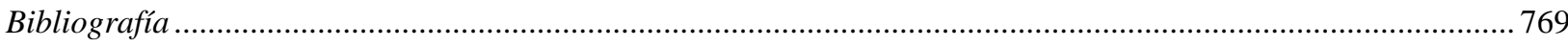




\section{Abreviaturas}

ADEE Anuario de Derecho Eclesiástico del Estado (Revista)

ADPCP Anuario de Derecho Penal y Ciencias penales (Revista)

AP Actualidad Penal (Revista)

AP Audiencia Provincial

art. artículo

AT Strafrecht, Allgemeiner Teil

BGH / BGHSt Bundesgerichtshof

BVerfGE Bundesverfassungsgesetz

CC Código Civil

CDJ Cuadernos de Derecho Judicial (Revista)

CDJP Cuadernos de Doctrina y Jurisprudencia Penal (Revista)

CE Constitución española

CEDH Convención Europea de Derecho Humanos

CJ Cuadernos Jurídicos (Revista)

coord. Coordinador

$\mathrm{CP} \quad$ Código Penal

CPC Cuadernos de Política Criminal (Revista)

CPd Código Penal derogado

$\mathrm{CPv} \quad$ Código Penal vigente

DGAR Dirección General de Asuntos Religiosos

dir. Director

DUDH Declaración Universal de Derechos Humanos

ed. edición

Ed. Editorial

Edit. editores

EDPC Estudios de Derecho penal y Criminología

$F G \quad$ Festgabe

FJ Fundamento Jurídico

FS Festschrift (Libro Homenaje)

GA Goldtammer's Archiv für Strafrecht (Revista)

GG Ley Fundamental alemana

Ibidem. en el mismo lugar

ID. idéntico

InDret. Revista para el análisis del Derecho (Revista)

intr. introducción

JuS Juristische Schulung (Revista)

JZ Juristenzeitung (Revista)

LAP Ley Autonomía del Paciente

LECrim. Ley de Enjuiciamiento Criminal

LGS Ley General Sanitaria

LL La Ley: Revista jurídica española de doctrina, jurisprudencia y bibliografía (Revista)

LO Ley Orgánica

LOLR Ley Orgánica de Libertad Religiosa

LOPJ Ley Orgánica del Poder Judicial 
LORGE Ley Orgánica del Régimen General Electoral

LOTJ Ley Orgánica del Tribunal del Jurado

núm. número

op. cit. opus citatum (obra citada)

p. ej. Por ejemplo

$\mathrm{p} / \mathrm{pp}$. página/s

PE Parte Especial

PG Parte General

PIDCP Pacto Internacional de Derecho Civiles y Políticos

pról. Prólogo

RCP Revista de Ciencias Penales (Revista)

RDPC Revista de Derecho Penal y Criminología (Revista)

rec. recurso

RECPC Revista Electrónica de Ciencia Penal y Criminología (Revista)

$R E D C$ Revista Española de Derecho Constitucional (Revista)

reimp. reimpresión

RG Reichsgericht (Tribunal Supremo del imperio alemán desde 1879 hasta 1945)

RGLJ Revista General de Legislación y Jurisprudencia (Revista)

RGSt Sentencia del Reichsgericht

RP Revista Penal, La ley (Revista)

RPDJP Revista Peruana de Doctrina y Jurisprudencia Penales (Revista)

RPJ Revista del Poder Judicial (Revista)

SAP Sentencia Audiencia Provincial

ss. $\quad$ siguientes

STC Sentencia del Tribunal Constitucional español

STEDH Sentencia del Tribunal Europeo de Derecho Humanos

StGB Strafgesetzbuch

STS Sentencia del Tribunal Supremo español

T. Tomo

TEDH Tribunal Europeo de Derecho Humanos

TJCE Tribunal de Justicia de la Comunidad Europea

TR Tratado de Roma

trad. Traductor

ult. loc. última locución

Vid. Videtur

Vol. Volumen

vv.aa. varios autores

ZENIT Kerygma, ltd., Lyon, 30 julio de 1997 (Revista)

ZStW Zeitschrift für de gesamte Strafrechtswinssenschaft (Revista) 


\section{INTRODUCCIÓN}

La presente investigación comenzó sobre el estudio de las sectas y el Derecho penal; sin embargo, y quizá por vicio del autor de esta obra, fue adquiriendo dimensiones mayores en cuanto se adentró en la comparación de varios ámbitos de estudio. Concretamente se analizaron la autoría de conciencia, por convicción y el enemigo, y de aquí resultó algo que no parecía tan evidente a primera vista: la necesidad de confrontar estas tipologías criminales con la estrictamente dedicada a las sectas criminales, y con cualquier tipo de organización que ponga en peligro el Sistema, la Sociedad.

La doctrina penal que ha estudiado detalladamente la tipología del autor de conciencia, los conflictos de conciencia o la objeción de conciencia suele encontrar argumentos normativos a favor de la disminución o exención de la responsabilidad, en contraposición a la categoría conceptual del autor por convicción sobre la que se fundamenta la máxima responsabilidad, hasta el punto que en las últimas décadas un sector de la doctrina ha elevado algunos casos del autor por convicción a la paradigmática categoría de enemigo, de modo que, además de reclamar su máxima culpabilidad, ha irrumpido una manifiesta evolución legislativa especialmente combativa contra el enemigo: el Derecho penal del enemigo.

Del enfrentamiento comparativo entre las diversas tipologías ha resultado un nexo en común en la moral y en el comportamiento adecuado a la moral: la moralidad. En ocasiones el Derecho adecúa su normativa contra ciertos focos de peligro resultantes de la moral.

En esta investigación nos hemos propuesto delimitar normativamente cada tipología, y la única forma que hemos encontrado para ser fieles a una solución global es confrontarlas normativamente. El resultado es del todo paradójico porque las diferentes tipologías se van trasformando a golpe de conveniencia o desde la perspectiva del observador: unas veces por el investigador, otras por la norma y otras por el Derecho mismo. Pero esto únicamente pone de relieve la fragilidad de la dogmática cuando no analiza las problemáticas desde la perspectiva de un observador más alejado del objeto de estudio.

Desde la lejanía se ha observado que en estas tipologías subyace, unas veces ocasionalmente, otras casi generalmente, un elemento: el déficit de socialización. La pregunta que se ha tratado de contestar es cómo actúa este déficit, a quién puede ser atribuido y qué trascendencia tiene en la responsabilidad penal. Por norma general este déficit es imputable a la libertad del sujeto, otras veces se puede atribuir a un tercero (persuasión coercitiva y adicción comportamental), y en otras a la misma norma: déficit de comunicación normativa. 
Hemos dedicado los primeros tres capítulos de la investigación al estudio de la evolución de la moral y su fuerza vinculante en el comportamiento en relación al Sistema, los límites legales y su concreción en la libertad de conciencia o religiosa desde el prisma de conductas libres, lo que nos ha ayudado a situar la problemática y una previa distinción entre autoría de conciencia, por convicción y enemigo.

Se han confrontado desde este prisma de conductas libres, las soluciones doctrinales entre autor de conciencia, por convicción y enemigo, y se ha llegado a la primera de las sorpresas: tradicionalmente estas categorías se han analizado una por una, lo que ha impedido una comprensión global del fenómeno de la moral como fuente de criminalidad. Hasta la fecha, las soluciones adoptadas son tan fijas que no permiten una valoración normativa adecuada. Sin embargo, con la confrontación de todas ellas se ha podido comprobar que también en todas se encuentran motivos para atenuar, eximir de responsabilidad o culpar con la máxima pena sin que con ello se afecte al núcleo conceptual de cada una. Esto pone de relieve que el Derecho penal ha de aportar soluciones dogmáticas globales, sin embargo, esto no puede confundirse con que la habitualidad o generalidad de comportamientos criminales sea la regla; en ocasiones, la excepción que supone cada comportamiento criminal es la solución global.

Del capítulo cuarto a octavo hemos confrontado las anteriores soluciones del autor de conciencia, autor por convicción y del enemigo, a un ámbito escasamente estudiado por la doctrina penal, las sectas, pero desde el prisma de las conductas coaccionadas y los déficits de socialización atribuido a tercero: la persuasión coercitiva y la adicción comportamental. Se ha puesto de manifiesto la falta de interés en proteger adecuadamente un derecho inherente de la persona: el derecho a la formación de la conciencia y la acusada relevancia del horizonte de expectativas que orienta el Sistema cuando se restringe o se elimina.

Se han contrastado tanto las conductas libres como las coaccionadas en la institución de la autoría e intervención criminal. Aquí se han hallado fundamentos comunes en todas las tipologías criminales, pero a la vez una crítica a la actual dogmática penal, que mucha de las veces sigue anquilosada en el angosto punto de mira que tiene un observador en un solo objeto. 


\section{CAPÍtulo I}

\section{CONCIENCIA, VOLUNTAD, MORAL, SOCIEDAD Y LA OBJECIÓN DE CONCIENCIA}

\section{I.- Planteamiento}

En la obra cumbre del Marqués de SADE «Justine o los infortunios de la virtud», el autor relata la historia catastrófica de la joven Justine (renombrada en la obra Teresa), quien a pesar de seguir fielmente los mandatos de la moral más pulcra e inocente, sufre en un sinfín de situaciones las desdichas de la convicción de los demás con la más pura maldad. En una de tantas ocasiones en que Justine fue raptada para el uso más cruel contra un ser humano (torturas, violación, sodomización) sus captores discuten sobre la justificación del asesinato, la utilidad del mal y de la organización criminal contra la ley:

- «En verdad no valía la pena cometer tres asesinatos por una suma tan pequeña.

- Despacio, amigos míos, respondió la Dubois, si os he aconsejado que no tengáis piedad de ninguno de esos viajeros no es por la suma, sino sólo por nuestra seguridad. Es la ley quien tiene la culpa de estos crímenes y no nosotros: mientras quiten la vida tanto los ladrones como a los asesinos los robos no se cometerán nunca sin asesinatos. Ambos delitos se castigan de igual manera ¿por qué renunciar al segundo si sirve para encubrir el primero? ¿Y de dónde sacáis que doscientos luises no valgan tres muertes?... Siempre hay que calcular las cosas a través de la relación que tengan con nuestros intereses. La cesación de la existencia de cada uno de esos sacrificios no nos afecta para nada. A buen seguro que no daríamos ni un céntimo porque esos individuos estuviesen vivos o en la tumba. Por consiguiente si tenemos el más mínimo interés en alguna de estas dos alternativas, debemos determinarla sin ningún remordimiento preferentemente a nuestro favor. Porque tratándose de algo completamente indiferente, si somos sensatos y dominamos la situación, tenemos indudablemente que hacerlo tornar del lado que nos resulte más favorable, abstracción hecha de todo lo que pueda perder el adversario. Porque no existe ninguna proporción razonable entre aquello que nos afecta a los demás. Lo primero lo sentimos físicamente y lo otro sólo llega moralmente hasta nosotros y las sensaciones morales son engañosas. Lo único real son las sensaciones físicas (...) Lo que detiene a los tontos en la carrera del crimen es la debilidad de nuestros órganos, la falta de reflexión, los malditos prejuicios en que nos han educado y los vanos terrores de la religión o de las leyes, eso es lo que les impide lanzarse. Pero todo individuo lleno de fuerza y vigor, dotado de un alma enérgicamente organizada que se prefiera, como es su deber, a los demás, sabrá sopesar los intereses del prójimo en la balanza de los suyos, burlarse de Dios y de los hombres, desafiar a la muerte despreciar las leyes, convencido de que solamente debe beneficiarse a sí mismo, sentirá que la multitud más extensa de las lesiones sobre los demás, de las que nada puede sentir, no puede compararse al más ligero de los goces adquiridos por este inaudito encadenamiento de las fechorías. El goce le halaga, está en él, el efecto del crimen no le afecta, está fuera de él. Me pregunto qué hombre razonable no preferiría lo que le 
deleita a lo que es extraño a él y quien no consentirá en cometer esa cosa extraña que no le hace sentir nada desagradable para procurarse aquello que le conmueve lisonjeramente.

- ¡Oh! Señora, dije a Dubois, pidiéndole permiso para responder a sus execrables sofismas, ¿No sentís que vuestra condena está escrita en lo que acabáis de proferir? Solamente a una persona lo bastante poderosa como para no temer nada de los demás podrían convenir semejantes principios. Pero nosotros, señora, que continuamente estamos temiendo la humillación, proscritos por todas las gentes de bien, condenados por todas las leyes ¿debemos admitir unos sistemas que solamente pueden aguzar contra nosotros la espada suspendida sobre nuestras cabezas? (...) ¿No está autorizada la sociedad a no tolerar en su seno a quien se declare en su contra? ¿Y puede el individuo que se aísla luchar contra todos? ¿Puede alardear de ser feliz y estar tranquilo si, al no aceptar el pacto social, no consiente en ceder un poco de su felicidad para garantizar el resto? La sociedad sólo se sostiene por perpetuos intercambios de bondades, esos son los lazos que la cimentan. Quien en lugar de esas bondades solamente ofrezca crímenes, al tener que ser temido desde ese momento, será necesariamente atacado si es el más fuerte y sacrificado por el primer ofendido si es el más débil, pero, en uno u otro caso, destruido por la poderosa razón que empuja al hombre a buscar su reposo y a eliminar a aquellos que quieren estorbarlo. Esta es la razón que hace imposible la duración de esas asociaciones criminales...

- Los verdaderos sofismas son los que nos oponéis Teresa, dijo Corazón-de-hierro, y no lo que había dicho Dubois. No es la virtud la que sostiene nuestras asociaciones criminales: es el interés, el egoísmo (...) No es por virtud por lo que, creyéndome, como supongo, el más fuerte de la banda, no apuñalo a mis compañeros para tener su parte, sino porque, al encontrarme entonces solo, me privaría de los medios para garantizar mi fortuna que espero de su colaboración (...) Pero de ahí nacerá, me diréis, un estado de guerra perpetua. ¡Bien! ¿Y no es ese el estado de la naturaleza? ¿No es ese el único que nos conviene realmente? Los hombre nacieron aislados, envidiosos, crueles y déspotas, pretendiendo tenerlo todo y no ceder nada y peleándose sin cesar para mantener o su ambición o sus derechos. Llegó el legislador y dijo: Cesad de pelear así, cediendo un poco por ambas partes renacerá la calma. Yo no censuro la postura del pacto, pero sostengo que las dos clases de individuos no debieron someterse jamás a él. Los que se sientan más fuertes no tenían necesidad de ceder nada para sentirse más dichosos y los que se sentían más débiles tenían que ceder en cantidad infinita ya que nada se les garantizaba (...) Y el estado de guerra que existía antes resultaría infinitamente preferible a que permitía a cada cual el libre ejercicio de sus fuerzas y de su industria cosa que no le autoriza el pacto injusto de una sociedad que siempre quitaba demasiado a unos y no concedía nunca lo bastante a otros. Luego la persona verdaderamente sensata es aquella que, afrontando el riesgo de restablecer el estado de guerra que reinaba antes del pacto, se declara su irrevocable enemigo, lo viola cuantas veces puede, seguro de que lo que retire de estas lesiones será siempre superior a lo que podría perder si resultara ser el más débil. Porque igualmente lo era respetando el pacto: violándolo puede convertirse en el más fuerte y si las leyes le vuelven a colocar en la clase de la que ha pretendido salir lo peor que puede pasarle es que pierda la vida lo que es una desgracia infinitamente menor que la de existir en medio del oprobio y la miseria. Esas son nuestras alternativas: o el crimen que nos hace felices o el cadalso que nos impide ser desdichados. ¿Y pregunto, es necesaria la comparación, bella Teresa, podrá vuestro ingenio encontrar un argumento capaz de vencer a éste?»1.

1 SADE, Justine o los infortunios de la virtud, $5^{\mathrm{a}}$ ed., Ed. Espiral, 2000, pp. 55 a 60. 
Pues bien, tras este breve relato de la obra Justine, la presente investigación tratará de deslindar aquellas conductas que, si bien injustas, pertenecen a la Sociedad y al estado de paz, de aquellas que hacen peligrar dicho estado, unas veces por convicción, otras por una clara enemistad.

De aquí que no todas las conductas criminales supongan dicha enemistad ni convicción de lucha, sino más bien conductas que la Sociedad puede permitir, aunque no sin sanción, pero que las da por supuestas y las ha tenido en cuenta en su funcionalidad. Las otras irrogan el riesgo de la destrucción de la Sociedad porque contradicen su propia operatividad. La Sociedad las excluye. Para esta exclusión crea un sistema al objeto de combatir las conductas que hacen peligrar su existencia como si de una isla remota se tratara, mientras que aquellas con las que sabe que puede funcionar las sanciona sin consideración a los motivos.

En este capítulo vamos a abordar la tradicional problemática del fundamento de la moral y su fuerza vinculante con la voluntad, con el objetivo de discernir entre conductas ineludibles de la moral de aquellas más caprichosas, para después determinar qué trascendencia han tenido los diferentes pensamientos en la culpabilidad penal. De aquí parte la originaria pregunta sobre el libre albedrío: determinismo o indeterminismo.

A lo largo de la historia de la humanidad se han planteado las mismas preguntas: si el ser humano es libre o, por el contrario, si está determinado y en qué medida. Lo que sabemos es que el hombre se siente, se intuye y se constituye a sí mismo bajo el presupuesto de la libertad, pero no sabemos muy bien si nuestra voluntad está determinada por nuestra conciencia o es nuestra voluntad la que determina nuestra conciencia sobre la base de previas percepciones.

El debate tradicional de la filosofía se ha centrado en si la libertad de conciencia supone un prerrequisito de la libertad de obrar conforme a la conciencia y si, en tal medida, la manifestación de nuestra libertad de voluntad se cumple más vigorosamente con la libertad de conciencia moral. ¿Puede una construcción moral, espiritual, ideológica, determinar nuestra voluntad de obrar de forma inevitable? ¿Y qué trascendencia tiene en el Derecho? Estas son las preguntas.

Para llegar a tal objetivo es necesario conocer previamente las diferentes corrientes filosóficas y científicas sobre la conciencia y la voluntad, en concreto si la conciencia libremente adoptada por un sujeto sobre el mundo y del deber ser moral dirigen y determinan la voluntad: si la voluntad tiene también un carácter inmaterial. A la vez será conveniente conocer si la conciencia moral viene determinada por una voluntad a priori e innata del ser humano, y por último, si la voluntad puede imputarse penalmente cuando proviene de una conciencia moral, cuestión que 
dejaremos para los siguientes capítulos, en el tan interesante y a la vez polémico debate doctrinal entre autoría de conciencia y autoría por convicción.

Podemos anticipar que la voluntad es el «pre-requisito» para ejecutar una acción o mantener una omisión. Desde esta premisa, el sujeto siente que la acción o la omisión adoptada son imputables a su propia voluntad, y en tanto así considera una acción libre porque proviene de la libertad de la voluntad. Sin embargo, la psicología motivacional y otras ciencias como la neurobiología consideran grosso modo que existen motivos inconscientes que influyen directamente sobre la voluntad, o que la actividad neurológica determina nuestra voluntad. Si fuere así, la formación de opiniones, entonces, también la formación de una conciencia o de la moral, dependerían de motivos inconscientes previos o de la actividad neuronal, lo que pondría en duda el paradigma del libre albedrío y, en consecuencia, todo el sistema de imputación penal, y más concretamente la responsabilidad de conductas realizadas por motivos de conciencia, por convicción o de enemistad.

Pues bien, en la actualidad existe a este respecto una tensa dialéctica entre el cientificismo y la filosofía. Esta polémica requiere de una primera aproximación de la evolución filosófica de la libertad de conciencia, en la libertad de voluntad y, en definitiva, sobre qué fuerza tiene en el destino la conciencia y las percepciones morales en la voluntad.

\section{II.- Conciencia, voluntad y Moral en el pensamiento clásico}

EPICTETO ${ }^{2}$, brillantemente, explicó que culpar a los demás de nuestras desdichas es muestra de ignorancia, culparnos a nosotros mismos constituye el principio del saber, pero abstenerse de atribuir la culpa es muestra de perfecta sabiduría.

La libertad de la voluntad es el tema metafísico por excelencia. Ya en el pensamiento presocrático se tienen noticias del debate acerca de si el ser humano es enteramente libre. Por ejemplo, Homero en su Odisea trajo el mito de Ulises y el forzoso destino de los hombres predeterminados por los dioses. La filosofía platónica también se pronunció en ese sentido, trascendiendo hasta hoy la idea de que nuestra razón, y por ende el fin de nuestra voluntad, parten de la creación de representaciones e ideas no claramente ciertas y objetivas.

Suele mencionarse el mito de Antígona de SófOCLES como la primera narración -aunque filosófica y literaria- de la disputa entre la libertad de conciencia y la ley. SófOCLES narró la conducta ilegal de la hija de Edipo, Antígona, cuando enterró a uno de sus hermanos en contra de

2 EpIcteto, Manual, Disertaciones por Arriano, trad. intr. y notas Paloma Ortiz García, Gredos, 2001, I-28, pp. 125 y ss. 
lo establecido por un decreto de Creonte. Antígona consideraba que su hermano Polinices debía ser enterrado aun a pesar de la prohibición de una disposición legal ${ }^{3}$.

Aunque tradicionalmente se ha concluido que Antígona apeló a motivos de conciencia, sin embargo, Souto PAZ muy acertadamente considera, en contra de la opinión tradicional, que este mito no versa sobre el conflicto entre la libertad de conciencia y la ley, pues «Antígona no invoca su conciencia para justificar su actuación, sino la superioridad de las leyes divinas sobre las leyes humanas. Ella ha actuado de acuerdo con las leyes divinas y, por consiguiente, no desobedece a la ley, no quebranta el orden jurídico, sino que se somete a él». Concluye que, puesto que la época clásica se constituía en una comunidad político-religiosa (cultural) ${ }^{4}$, Antígona no hace más que someterse a la ley divina, que en definitiva es el orden jurídico. No pertenece a un conflicto de conciencia.

Después del mito de Antígona, suele mencionarse a SócRATES como el primer objetor de conciencia, al ser condenado a muerte por la acusación de «impiedad» (vilipendio de la religión del Estado) que le realizó MELETo ${ }^{5}$. Durante el proceso judicial se prueba la falsedad de la acusación, pero la Asamblea le condenó a la pena de muerte. CRITón le propuso huir de la cárcel sobornando a los carceleros, pero SóCRATES le respondió que precisamente lo justo es obrar conforme a la ley del Estado ${ }^{6}$.

La conciencia socrática constituye uno de los primeros reconocimientos de la relevancia de la vigencia de la norma como comunicación social, la conciencia sería una cuestión de adecuación social a la norma por una identificación mutua entre norma y sociedad. SÓCRATES se somete a la norma porque ésta es fiel reflejo de la conciencia de la sociedad. SócRATES, al igual que también dirán más tarde Platón y ARISTÓTELES, consideraba que el hombre esencialmente es un ciudadano, por lo que la ética y la conciencia social determinan los deberes esenciales del ciudadano $^{7}$. En la conciencia y en la ética socrática tampoco existe una verdadera estructura

3 Antígona se justifica así ante Creonte: «No creía que tus órdenes tuviesen una autoridad tal que un mortal pudiere permitirse transgredir las leyes no escritas, pero imprescriptibles de los dioses. Pues estas leyes no están en vigor de hoy ni de ayer, sino desde siempre, y nadie sabe cuándo fueron promulgadas», SófocLES, Antígona, en Antígona, Edipo rey, Electra, Círculo de Lectores, Barcelona, 1995, p. 19.

Souto PaZ, José Antonio, Comunidad política y libertad de creencias. Introducción a las libertades públicas en el Derecho comparado, 2a ed., Marcial Pons, 2003, p. 290.

5 Concretamente: «Sócrates delinque corrompiendo a los jóvenes y no creyendo en los dioses en los que la ciudad cree, sino en otras divinidades nuevas», PLATón, «Apología de Sócrates», Diálogos I, intr. general Emilio Lledó Íñigo, trad. y notas de Calonge Ruiz, E. Lledó Iñigo y García Gual, $2^{\mathrm{a}}$ reimp. de la $1^{\mathrm{a}}$ ed., Gredos, Madrid, 1985, 24 c, p. 159.

6 Platón, «Critón», Diálogos I, op. cit., 50 b, p. 204.

7 De Crescenzo, Luciano, Historia de la filosofía griega, II, 6a ed., Ed. Seix Barral, 1997, p. 148. Después de las enseñanzas de SÓCRATES se impuso en el Imperio romano la ética estoica, que entendía que lo bueno (lo perfecto) es la negación de las pasiones (placer, dolor, deseo, y temor) por medio de la razón, vid. ID., ibidem, op. cit., pp. 168 y 169. De otra parte, la ética del epicureísmo concebía la sociedad como una comunidad de amistad por 
moral individual, sino la adecuación de la voluntad a la ley, ley en todo caso supeditada a la ley divina o a ley de la conciencia de la sociedad. No existe en SócRATES un verdadero conflicto entre la conciencia propiamente interna e individual y la ley, sino el sometimiento a la ley divina o a la conciencia general de la sociedad, de manera que no puede atribuirse a su filosofía ningún atisbo de moralidad, sino de adecuación de la voluntad a la vigencia de la ley.

En los primeros pasos de la filosofía occidental no puede hablarse de que las personas tuvieran una moral propia o un sentimiento individual sobre el bien y el mal, sino de una conciencia que se circunscribía como presupuesto de una sociedad determinada, pero a la vez, diferenciada en los presupuestos de la sociedad clásica. Esta sociedad viene determinada por su clara estructuración segmentaria o jerarquizada, cuyas normas pendían de la religión ${ }^{8}$, lo que significa que la moral y la ética estaban claramente insertadas en la estructura societaria, se identificaba una clara postura religiosa con lo normativo o, dicho de otro modo, la ley divina y la ley jurídica son idénticas, por lo que tanto ANTíGONA como SócraTES actuaron no por conciencia o por convicción estrictamente personal, sino en clara adecuación y expresión normativa de la ley y, en último término, de su inspiración divina, y no por una propia resolución moral.

Se puede concluir, con LUHMANN $^{9}$, que no es hasta épocas más recientes cuando se fusiona religión y moral, de modo que ésta última adquiere sentido en la propia personalidad como impulso de la voluntad.

Con ARISTÓTELES se inicia la filosofía de la voluntad: la voluntad es el deseo ${ }^{10}$. La voluntad en cuanto representa la razón y el conocimiento no puede contradecirse consigo misma, impera el «principio de no contradicción» ${ }^{11}$. Por eso la ética aristotélica significa comportamiento,

medio de la cual se podía conseguir siempre satisfacción de los deseos naturales y necesarios (los que garantizan la vida como el comer, beber, etc.) y así llegar a la sociabilidad y al buen trato a los demás, Vid. ID., ibidem, op. cit., pp. 149 a 152.

8 Ampliamente al respecto, LUHMANN, Niklas, «La dogmática religiosa y la evolución de las sociedades», trad. Marco Ornelas, LuHMAnN, N., Sociología de la religión, Herder, 2009, pp. 75 a 194. El artículo corresponde a la traducción al inglés del capítulo «Religiöse Dogmatik und Gessellschaftliche Evolution» en LUHMANN, N., Funktion der Religion, Suhrkamp, Frankfurt, 1977, pp. 77 a 181, trad. Peter Beyer y que apareció en el libro Religious dogmatics and the evolution of societies de Niklas Luhmann, New York, Ed. E. Mellen Press., 1984; ID., «El proceso de diferenciación de la religión», trad. Pedro Morandé, LuHMANN, N., Sociología de la religión, op. cit., pp. 195 a 288. Corresponde al capítulo IV en LuHMAnN, N., Gesellchaftsstruktur und Semantik. Studien zur Wissenssoziologie der modernen Gessellschaft, T. III, Suhrkamp, Frankfurt, 1989.

9 LUHMANN, N., «El proceso de diferenciación de la religión», op. cit., p. 211.

10 Comenta que la voluntad «tiene su porqué; aquello de lo que es deseo, es aquello desde donde se determina el entendimiento deliberativo como tal», vid. HeIDEGGER, Martin, Nietzsche, trad. Juan Luis Vermal, Ariel, $4^{\mathrm{a}}$ impresión de la $1^{\text {a }}$ ed. 2014, p. 61.

11 Señalaba ARISTÓTELES al respecto que «lo mismo al mismo tiempo presencie y no presencie, esto es imposible en lo mismo y respecto de lo mismo», vid. HEIDEGGER, M., Nietzsche, op. cit., p. 477, y ampliamente pp. 480 y ss. 
costumbre. La ética es la moral, la forma de comportamiento para llegar al bien. El bien sin embargo constituye la felicidad ${ }^{12}$, pero la felicidad no se consigue con los placeres físicos, ya que una vida basada en tales placeres sería una vida propia de las bestias. El bien consiste en cumplir las funciones que le son propias al ser humano: la acción de razonar para llegar a la virtud. La virtud ética es la medida justa entre vicios opuestos. Su pensamiento ha impregnado en la historia de la sociedad la idea de que la felicidad se identifica con el comportamiento moral, y dicho comportamiento proviene de la comunidad (koinonía), el hombre es un animal de ciudad, cívico ${ }^{13}$, por lo que las conductas desviadas de la moral suponen un quebranto de la identidad societaria. En él también anida la identificación de la moral con el comportamiento social de la generalidad, por lo que no puede concluirse que en la filosofía aristotélica exista una propia identificación de la moral y la conciencia individual.

Ya la filosofía de SANTO TOMÁs, a raíz de la influencia aristotélica, concibe que la conciencia es el mismo acto o conocimiento de una respectiva cosa a través del acto ${ }^{14}$. Si partimos de la base de su configuración del «juicio de conciencia», con el que se llega mediante la intención o el fin recto a la «virtud moral» ${ }^{15}$, se vislumbra una conclusión muy clara en la conciencia tomista: si la voluntad entra en conflicto con la razón, la conciencia obliga al ser humano siempre en su voluntad, a pesar de que tal conciencia pueda ser errónea, existe un deber superior, un principio de la ley natural que obliga al ser humano a desobedecer la ley jurídica a favor de la conciencia $^{16}$.

Esto nos lleva a concluir que también SANTO TOMÁs concibe la moral como conciencia general de la sociedad en la religión. La conciencia tomista refrenda y justifica la conexión de las conductas, también criminales, que tienen su sustrato esencial en la conciencia del sujeto como una ley natural de inevitable cumplimiento. De esta manera, en la filosofía tomista se inicia el intenso debate de los conflictos de conciencia y la ley jurídica, si bien la conciencia no es un acto tan individual, sino enmarcado en los principios de la ley divina. La aportación tomista estriba en la vinculación de la religión y la ley natural o general que después concluirá la filosofía kantiana y su teoría del Derecho.

12 ARISTÓteles, Ética a Nicómaco, pról. Teresa Martínez Manzano, trad. Julio Pallí Bonet, Ed. Gredos, 2014, pp. 23 y ss., pp. 287 y ss; ID., Ética eudemia, intro. trad. y notas Carlos Megino Rodríguez, 1a reimpresión 2009 de la $1^{\text {a }}$ ed., Alianza Editorial, pp. 43 y ss.

13 ARISTÓteles, Política, intro. Carlos García Gual, trad. Patricio de Azcárate, Austral, 2011, pp. 37 y ss.

14 SAnTo Tomás, Suma de Teología, I, Parte I, $4^{\mathrm{a}}$ ed., reimp., Biblioteca de Autores Cristianos, Madrid, 2001, C 79, art. 13 .

15 ID., ibidem, op. cit., C 113, art. 1; ID., Suma de Teología, II, Parte I-II, $2^{\text {a }}$ ed., Biblioteca de Autores Cristianos, Madrid, 1989, C 55 a 67.

16 Santo Tomás, Suma de Teología, II, Parte I-II, op. cit., C 19, arts. 5 y 6, y C 96, art. 1 y ss. 


\section{III.- Repercusiones del idealismo moralizante en las teorías sociológicas hasta la irrupción de la teoría de los sistemas de Luhmann: cambio de paradigma}

\section{A. La vinculación de la moral y el Derecho en el idealismo alemán}

La filosofía del pacto social anticipó los sólidos argumentos de la teoría del idealismo alemán. Para Thomas HobBEs la finalidad del pacto social es la paz y el orden, y el medio de alcanzarlos la supremacía de la voluntad del monarca y no la voluntad popular ${ }^{17}$. La filosofía hobbsiana se puede resumir en el pensamiento de que el hombre es un ser egoísta que busca inevitablemente su supervivencia. Así pues, HoBBES se distancia de RousSEAU en que intenta fundamentar no la democracia sino el poder absoluto del soberano como principio del Derecho, del poder y de la política. Para RouSSEAU, «(l)o que el hombre pierde con el contrato social es su libertad natural y un derecho ilimitado (...); lo que gana es la libertad civil y la propiedad de todo lo que gana» ${ }^{18}$, el contrato social lleva a la democracia. Aquellos que no validen el ordenamiento deben desaparecer de la sociedad ${ }^{19}$.

En el apartado previo de este capítulo hemos narrado los argumentos criminales de los captores de Justine. Éstos huyen de la conciencia general de la sociedad y de las motivaciones morales generales. El argumento se ubica en la propia individualidad y su manifestación contra la generalidad. En este conflicto nace el acuerdo social de la mayoría en el bien común. De esta manera se contradice el sentimiento moral o religioso con un principio mayor: el pacto o contrato social. Éste no necesita de la moral, sino de algo mayor: el acuerdo general en no dañar. De esta manera el Sistema se perpetúa contra los sentimientos individuales o generales. El pacto social supone un fin mayor que la moral general: el inicio del Sistema y la repulsa de la moral en sus propias operaciones, el Derecho. Sin embargo, a pesar del pacto social, tradicionalmente tanto la filosofía como la religión han tratado de impregnar que el fundamento primigenio es la moral, sin la cual el Sistema tampoco puede sobrevivir. Este fundamento se consolidará en la filosofía kantiana y en el idealismo alemán de manera definitiva. La cuestión es si esto sigue vigente.

17 HobBes, Thomas, Del ciudadano y Leviatán, $4^{\mathrm{a}}$ ed., Tecnos, 1996.

18 Rousseau, Jean-Jacques, El contrato social o Principios de derecho político, estudio preliminar y traducción María José Villaverde, 2a ed., Tecnos, 1992, p. 19 y 20.

19 Al respecto comentaba que «todo malhechor, al atacar el derecho social, se convierte por sus delitos en rebelde y traidor (...). Entonces, la conservación del Estado es incompatible (...), es preciso que uno de los dos perezca, y cuando se da muerte al culpable, es menos como ciudadano que como enemigo», ID., ibidem, op. cit., pp. 34 y 35 . 
Ya con KANT se inicia la concepción de que el deber es la necesidad de realizar una acción conforme a una ley, siendo ésta una ley práctica de la razón ${ }^{20}$. La voluntad es entendida como facultad desiderativa, lo querido es ya determinante para la misma acción como representación general de una idea ${ }^{21}$. De tal manera que la voluntad es libre en sí misma. Hacer el bien es un deber en sí mismo, por lo que cuando tal acto se ve impregnado de interés personal, a pesar de seguir constituyendo un bien, no constituye una representación de la razón práctica, no es una máxima aunque tenga las mismas consecuencias. La máxima de KANT del imperativo categórico que siempre busca la Felicidad realizando su propia máxima moral ${ }^{22}$ da inicio en la filosofía occidental una forma de pensar que ha impregnado el sentimiento democrático y jurídico de la sociedad $^{23}$.

La libertad de la voluntad, para KANT, es el principio a priori de la ley moral, el deber, una adecuación necesaria y práctica a aquélla ${ }^{24}$, por eso la buena voluntad se alinea con la ley de la autonomía o libertad de la voluntad. El imperativo hipotético busca fines o posibles fines de la voluntad adecuando los medios para ese fin, sin embargo, el imperativo categórico designa acciones que son en sí mismas buenas al margen de otros fines. De esta manera, hacer el bien supone no el altruismo hacia los demás, sino obligación, naturaleza si se quiere, pero imperativo.

KANT distingue entre el código bueno/malo que proviene de nuestros deseos y el código bien/mal que nace de la moral: el castigo es algo malo para nuestros deseos pero un bien para la ley moral ${ }^{25}$. De este modo KANT llega a la conclusión de que la libertad es una simple idea cuya objetividad no se puede probar según las leyes de la naturaleza ni por la experiencia, es un presupuesto necesario de la razón de los seres que creen tener conciencia de su voluntad, así, la libertad es una capacidad diferente de la simple capacidad desiderativa, distinta a la capacidad de

20 KANT, Immanuel, Crítica de la razón práctica, versión castellana y estudio preliminar de Roberto R. Aramayo, $5^{\text {a }}$ reimpresión, Alianza Editorial, 2007.

21 HEIDEGGER, Martin, Nietzsche, op. cit., p. 61

22 El imperativo categórico kantiano reza de la siguiente manera: «obra de forma que la máxima de tu voluntad pueda valer siempre como una ley natural universal», KANT, I., Crítica de la razón práctica, op. cit., p. 28. También así: «(o)bra siempre de forma que trates siempre a la humanidad, tanto en tu persona como en la persona de cualquier otro, siempre al mismo tiempo como fin y nunca como medio», KANT, I., Fundamentación para una metafísica de las costumbres, trad., estudio preliminar y apéndices Roberto Rodríguez Aramayo, $3^{\text {a }}$ reimp. 2008 de la $1^{\mathrm{a}}$ ed. 2002, Alianza Editorial p. 116. Esta máxima de la naturaleza es universal -dice KANT- siempre y cuando no se niegue por ella misma (KANT, I., Fundamentación para una metafísica de las costumbres, op. cit., p. 78) o suponga un medio para otro fin, ID., ibidem, op. cit., p. 122.

${ }_{23}$ Kant, I., Crítica del juicio, ed. y trad. Manuel García Morente, $2^{\text {a }}$ ed., Austral, Ciencias y Humanidades, 2009

24 KANT, I., Fundamentación para una metafísica de las costumbres, op. cit., pp. 122 y 123.

25 KANT, I., Crítica de la razón práctica, op. cit., I, capítulo 2. 
determinarse como inteligencia/razón más allá de $\operatorname{los}$ instintos ${ }^{26}$, por eso la libertad está en nuestra propio yo. Amén de ello el imperativo categórico nace de la libertad ${ }^{27}$.

Entonces la responsabilidad (también la imputación penal) es un principio de la moral, para $\mathrm{KANT}^{28}$, cuyo pensamiento sobre la voluntad culpable pasa por comprender la facticidad de la libertad, la de que hay que respetar la ley universal, pero hay veces en que la libertad hace una excepción a favor de nuestra inclinación aunque sólo por esta $\operatorname{vez}^{29}$. Esta excepción supone igualmente la culpabilidad o responsabilidad de la conducta porque ésta igualmente es producto de la libertad. En KANT enraíza la delimitación entre móviles y motivos, y en dicha distinción se inició para la doctrinal penal un fundamento y graduación de la responsabilidad, al entender que los primeros son subjetivos, fundamentan el deseo, mientras que los segundos son el fundamento objetivo del querer, de ahí que los fines subjetivos descansen en móviles, y los fines objetivos en motivos «válidos para todo ser racional» ${ }^{30}$.

De este pensamiento se puede afirmar que aquellos móviles que no llegan a ser un fin en sí mismos, aquellos que no son motivos, no contienen fuerza ineludible en la voluntad, o al menos son intercambiables por otros, existen móviles alternativos, sólo los motivos constituirían un principio inexcusable de la voluntad. En este razonamiento encuentra fundamento algún tipo de exculpación penal y delimitación entre la autoría de conciencia, como la que tradicionalmente se entiende que puede merecer algún tipo de atenuación de la responsabilidad, y la autoría por convicción o las conductas enemigas, como las que tradicionalmente se consideran peligrosas y merecen la máxima respuesta punitiva. Por ejemplo, y según se puede interpretar de la filosofía kantiana, quien mata por dinero también puede hacerlo por una promesa, el motivo se confunde con el móvil, lo que hace que no exista nada objetivo a la los ojos de los demás o de cualquier observador, sin embargo, quien mata por «amor» tiene un motivo bien fundado, constituye un fin en sí mismo objetivo para los demás, lo que sucede es que el cómo, es decir, lo que se consigue es por medio de un delito: delito y motivo se funden en el motivo, sin el delito no se puede consumar el fin.

Esta distinción entre móvil y motivo en KANT, trasladada al Derecho penal -según interpretoha trascendido en el pensamiento occidental de la responsabilidad de la conducta de conciencia y

6 KANT, I., Fundamentación para una metafísica de las costumbres, op. cit., p. 158.

ID., ibidem, op. cit., p. 160.

Concretamente dice «que el concepto de lo bueno y lo malo no habría de quedar determinado antes de la ley moral (aun cuando conforme a las apariencias tendría que haber sido colocado incluso como fundamento de la misma) sino que tal concepto (como también sucede aquí) sólo habría de verse determinado tras contar con esa ley e igualmente ser determinado por la ley misma», KANT, I., Crítica de la razón práctica, op. cit., p. 146.

${ }_{29}$ KANT, I., Fundamentación para una metafísica de las costumbres, op. cit., pp. 69 a 71.

30 ID., ibidem, op. cit., p. 113. 
por convicción, cuestión que tendrá especial transcendencia en las conductas de los miembros de sectas criminales, aportando un principio de la delimitación de las conductas ineludibles de la conciencia respecto de las simplemente realizadas por convicción. El móvil es siempre alternativo o fungible, intercambiable.

De ello cabe extraer la conclusión de que la filosofía kantiana ha impregnado la distinción que entre motivo y móvil existe la inevitable voluntad en el primero, mientras que en el segundo, una forma de tantas de manifestarse la voluntad. Este pensamiento ha impregnado la concepción de que el autor de conciencia actúa ineludiblemente por un motivo de su conciencia y el autor por convicción actúa simplemente convencido de un fin pero cuyos medios (imperativo hipotético) no son constitutivos del fin, pues el delito es sólo un medio, por ejemplo aterrorizar.

Otra idea kantiana que -en nuestra opinión- ha servido a la doctrina penal para delimitar el concepto de autor por convicción y de conciencia es que el hombre en «estado de naturaleza», el que se aparta decididamente de la configuración normativa de la sociedad, priva a los demás de la necesaria seguridad ${ }^{31}$. KANT distingue entre sujetos y personas: los primeros suponen inseguridad para todos los demás que adecúan su comportamiento a la norma, inclusive demuestran la enemistad declarada para la sociedad, de modo que ésta puede apartarlos de la configuración normativa, atribuirles la máxima punibilidad. En él subyacen parte de los postulados del denominado Derecho penal del enemigo, si bien en su distinción entre móviles y motivos, además de contener un principio de imputación y de reprochabilidad, se vislumbra un criterio distintivo entre conductas ineludibles de conciencia y aquellas que, más que cumplir una máxima de la conciencia, anteponen medios injustos. Dichos medios, al ser fungibles, no suponen nada inexcusable en la conciencia del sujeto, sino un puro acto egoísta y antisocial.

Estos principios kantianos han influido de manera decisiva en la tradicional distinción entre autor de conciencia y autor por convicción, y por la que subsiste una diferencia estrictamente moral, esto es, se distingue desde el punto de vista de un observador moral. Entre móvil/medio y motivo/fin se introduce la máxima kantiana de la ley universal de la naturaleza. Quien actúa sometido imprescindiblemente a su conciencia cree estar en su derecho-moral, por lo que parece incapaz de lesionar constantemente a la sociedad o suponer una amenaza a la sociedad. Mientras que un autor convencido de lo que hace, pero introduciendo medios injustos, se sitúa en un estado de naturaleza que amenaza la seguridad.

31 Decía KANT que «me está lesionando ya, al estar junto a mí en ese estado, no de hecho (facto) ciertamente, pero sí por la carencia de leyes de su estado (statu iniusto), que es una constante amenaza para mí (...) si un vecino no da seguridad a otro, cada uno puede considerar como enemigo a quien le haya exigido esa seguridad», por lo que «yo puedo obligarle a entrar en un estado social-legal o a apartarse de mi lado», KANT, I., Sobre la paz perpetua, trad. Joaquín Abellán y presentación Antonio Truyol y Serra, 6a ed., Tecnos, Madrid, 1998, p. 14, nota 3. 


\section{En KANT hay una distinción estrictamente moral de la reprochabilidad penal en ambas}

tipologías criminales, en las que se valora de forma que sólo aquellas conductas que encuentran adecuación en la conducta general de la sociedad pueden encontrar algún tipo de atenuación o de exención penal, mientras que las que se forman en la estricta individualidad merecen calificarse de enemigas o cuando menos fundamentan la máxima reprochabilidad del autor. Esta idea ha impregnado hasta nuestro días la filosofía y la determinación de la culpabilidad jurídica ${ }^{32}$.

32 HegEL critica parcialmente por sus consecuencias la máxima kantiana de la libertad y del Derecho que se refieren a la limitación de la libertad, o arbitrio, mediante la coexistencia con el arbitrio de los demás según una ley general. HEGEL afirma que «sólo contiene en parte una determinación negativa, la de la limitación, y en parte la positiva, la universal o así denominada ley de la razón (...) y desemboca en la conocida identidad formal y en el principio de contradicción (...) Aceptado tal principio, lo racional sólo puede, en efecto, aparecer como limitador de esta libertad, no como lo racional inmanente, sino como universal exterior, formal. Ese punto de vista carece asimismo de todo pensamiento especulativo y ha sido rechazado», HEGEL, Georg Wilhelm Friedrich, Fundamentos de la filosofía del Derecho, Ed. K.H. Ilting, trad. Carlos Díaz, Libertarias/Prodhufi, $1^{\text {a }}$ ed. 1993, pp. 156 y 158. La persona mala, para HEGEL, está llena de menosprecio por abstracta, esto es porque la personalidad sólo comienza donde el sujeto además de autoconciencia general tiene autoconciencia de sí, ID., ibidem, op. cit., pp. 176 a 178 . Si se pierde la autoconciencia de sí puede deberse a que el sujeto voluntariamente se ha apartado de sí mismo y por ende de las cosas, del mundo, del Derecho, o por enajenación de la personalidad: por esclavitud, servidumbre, o incapacidad para poseer, ID., ibidem, op. cit., p. 262. Podría decirse que HEGEL no vería ningún impedimento en aceptar que la pérdida de la personalidad es el mayor desastre que un ser humano puede sufrir. El punto de vista moral, el deber, es una figura del derecho de la voluntad subjetiva. Al respecto comenta que «mi propósito, finalidad, interés que llegue a ser reconocido, tenido por mí -como- 'por' bueno», ID., ibidem, op. cit., pp. 378 y 379. De esta manera la responsabilidad -también penal- parte de la imputabilidad de la acción, de lo objetivo «mío» como expresión de la intención, del cambio y de lo producido, ID., ibidem, op. cit., pp. 397 y 424 . No resultará extraño concluir que en HEGEL subyace una intuitiva conformidad y comprensión de las acciones sometidas a la conciencia, aquellas que se consideran buenas subjetivamente, pero que para el sujeto son objetivas. Esta forma de explicación de la moral tiene también reminiscencias con la tradicional concepción del autor de conciencia, aquel que actúa conforme a su conciencia. Por el contrario, quien actúa considerando su acción parcialmente buena, o que no alcanza la objetividad (todo espacio y tiempo), actúa simplemente bajo la subjetividad, lo que podría asimilarse a la concepción tradicional del autor por convicción, aquel que considera su acción lícita, pero no en cualquier circunstancia o espacio-tiempo.

De otra parte, el ateísmo científico de FICHTE le llevó a fundamentar una teoría del conocimiento que se centró en otorgar plena validez a la «duda». La duda es motivo de sentirse libre, dudar es un principio para obrar libremente. La duda obliga a decidir, obliga a representar las «cosas» sin duda alguna, lo que lleva a que en determinadas ocasiones se eleve a $f e$ como manifestación de la voluntad absoluta, infinita y eterna. En este tránsito entre duda y fe viene el cumplimiento de los dictados de la conciencia moral, el Ser. Para llegar a esta conclusión, FICHTE desarrolla su pensamiento en la premisa de que el ser humano se ha de plantear dudas sobre las cosas que en principio percibimos como objetivas, FICHTE, Johann Gottlieb, El destino del hombre, trad. Juan Ramón Gallo Reyzábal, Ed. Sígueme, Salamanca, 2011, p. 23. En concreto afirma que puesto que «(m)i conciencia inmediata, la percepción en sentido propio, no va más allá de mí mismo ni de mis determinaciones: inmediatamente yo tan solo sé de mí mismo; todo lo que sea capaz de saber más allá de esto, lo sé por deducción (...) y como tal debe ser encontrada en la conciencia (...) Y también por esa misma razón me percibo como libre en acontecimientos concretos de mi vida», ID., ibidem, op. cit., p. 35. De tal modo, la libertad llega en sí misma, según un concepto que puede elevarse a una ley moral, ID., ibidem, op. cit., p. 40. De esto deduce que la «culpabilidad y responsabilidad no tienen otro sentido que el que les corresponde en un derecho exterior. Se hace culpable, y será hecho responsable de su proceder aquel que obliga a la sociedad a aplicar fuerzas exteriores artificiales con objeto de suprimir los efectos de sus impulsos perjudiciales para la seguridad común», ID., ibidem, op. cit., p. 42. De esto se extrae que sólo una fuerza impulsora, un alto deseo, gobierna la voluntad, sin embargo, una conciencia que no suponga una ley moral (aquella aplicable a todo espacio-tiempo) tiene mayor reprochabilidad porque es más un capricho que la ineludible conformidad de la voluntad con la conciencia. Toda conciencia es un ejercicio de fe que proviene de la voluntad y que sólo busca justificarse ante sí: la verdad únicamente procede de la propia y auto-creada conciencia moral, ID., ibidem, op. cit., pp. 124 y 125. Cualquier conducta fuera de nuestra conciencia moral contraría nuestra propia naturaleza, nuestra personalidad, ID., ibidem, op. cit., p. 138 afirma: «yo trazo simplemente mi línea con el ángulo 


\title{
En conclusión, la filosofía kantiana y el idealismo alemán (también el existencialismo) ${ }^{33}$ han
}

\author{
impregnado, tras la vinculación propiciada por la filosofía clásica entre moral y ley divina, la
}

correcto, y de esta manera quedarán determinados los puntos por los que mi línea debe pasar. El fin no determina el contenido del precepto, sino que ocurre lo contrario: el contenido inmediato del precepto determina el fin». Entiende que el hombre sólo puede autoafirmarse en el mundo mediante la confianza de las expectativas, dirigiendo la voluntad obediente a la ley de la razón, al bien, superando las leyes de la naturaleza como confirmación de la libertad, ID., ibidem, op. cit., p. 172. Así es como FICHTE asume la máxima kantiana de la razón/ley práctica. El hombre puede y debe ajustarse a la ley moral en cualquier estado, el conflicto entre conciencia y ley se supera a favor de la primera, por lo que los ciudadanos no pueden apelar a leyes jurídicas temporales que no estén refrendadas por la ley general de la naturaleza. La moral o conciencia moral orienta nuestra conducta como un haz de luz orienta nuestra visión en un objeto o cuando éste penetra en nosotros bajo esa orientación guiada.

Por otro lado, SCHOPENHAUER niega lo que KANT denomina reino de los fines, anteriormente denominado imperativo categórico. Critica la construcción kantiana de los fines en sí mismos y los niega por completo, SCHOPEnhauer, Arthur, El fundamento de la moral, trad. D. Díaz Crespo, Ed. Atlante, pp. 24 y ss. y pp. 49 y ss. Introdujo la idea de que todo valor es relativo, incluso la moral, ID., ibidem, op. cit., pp. 138 y ss. Sobre esto comenta que «(u)na necesidad moral no tiene sentido ni valor sino por su relación con una amenaza de castigo o con una promesa de recompensa», ID., ibidem, op. cit., p. 18. La necesidad es el fundamento oculto. Advierte que la lucha de la moral se encuentra precisamente en la lucha contra el egoísmo y su fiel compañera, la maldad, ID., ibidem, op. cit., pp. 49 a 53. La acción buena, la moral buena y, en definitiva el fundamento de moral, es «la piedad o voluntad persiguiendo el bien de otro», ID., ibidem, op. cit., pp. 101. La libertad es entendida como una manifestación negativa: ausencia de estorbo, de fuerza. Libre significa con arreglo a la propia voluntad, el hombre hace siempre lo que quiere, pero lo hace necesariamente, «ser necesario» $\mathrm{y}$ «ser consecuencia» son intercambiables: lo necesario y su consecuencia es el resultado de la libertad. Niega la esencia del liberum arbitrium: la libertad es necesidad irremediable, SCHOPENHAUER, A., Sobre la libertad en la voluntad, $4^{\mathrm{a}}$ reimp. 2010 de la $1^{\mathrm{a}}$ ed., 2000, Alianza Editorial, pp. 48, 110 y 151 a 157. ID., De la voluntad en la naturaleza, trad. Miguel de Unamuno, pról. y notas Santiago González Noriega, $1^{a}$ reimp. 2006 de la 1 a ed. 2003, Alianza Editorial, en Área de conocimiento: Humanidades, 2006, p. 132. Para él, el Derecho penal no es otra cosa que un indicador de contramotivos de los comportamientos, ID., Sobre la libertad en la voluntad, op. cit., p. 160. La justicia es meramente negativa, se basa en el principio neminem laede (no dañar), si bien lo fundamentó moralmente como un principio inherente de la moral y directamente de la piedad, ID., El fundamento de la moral, op. cit., 17 y ss., p. 105. Tanto la piedad como la compasión suponen principios morales vinculados a la cosa en sí o voluntad, ID., El mundo como voluntad y representación, T. I, trad. y pról. Eduardo Ovejero y Maury, $1^{\text {a }}$ ed., Losada, Buenos Aires, 2008, Libro IV, 62 y ss; ID., Parerga y Paralipómena (Escritos filosóficos sobre diversos temas), pról. trad. y notas José Rafael Hernández Arias, Luis Fernando Moreno Claros y Agustín Izquierdo, 1ª ed., Valdemar, 2009, T. II, VIII y IX, pp. 719 a 780. Sin embargo, la injusticia es positiva, se trata de hacer mal a otro, ID., El fundamento de la moral, op. cit., p. 108. De aquí SCHOPENHAUER consigue distinguir claramente dos tipos de deberes: uno negativo consistente en no dañar, un deber que es general y del que se nutre el pacto social, y otro positivo vinculado a instituciones tales como las obligaciones adquiridas y trasmitidas por el Estado, o las inherentes a una condición como la de los padres con los hijos («por el simple efecto de determinado acto»), ID., ibidem, op. cit., p. 112. El incumplimiento de este deber positivo supone una «injusticia repetida» o «injusticia redoblada», Por ejemplo en situaciones tales cuando «un hombre ha aceptado expresamente la obligación de proteger a otro en cierta cosa determinada, pues el descuidar esta obligación sería ya hacer mal al protegido, cometer una injusticia; también la hay cuando, no contento con esto, el mismo protector ataca y perjudica al que él debía proteger en la cosa en la que le debía protección», ID., ibidem, op. cit., p. 111. De aquí también deriva un «derecho a mentir» para evitarse un mal injusto criticando la ley universal kantiana de la verdad, ID., ibidem, op. cit., p. 114 y ss. De este modo, puesto que la justicia emana de un deber negativo consistente en no dañar, se puede realizar tanto con acciones como por omisiones, y del mismo modo, el deber estrictamente positivo pueda causar una injusticia tanto con una «agresión positiva, un acto», como también cuando «hay actos cuya sola omisión constituye una injusticia; esos actos se llaman deberes (...) El deber es, pues, un acto cuya simple omisión por mi parte causa a otro un perjuicio, es decir, le hace injusticia», ID., ibidem, op. cit., op. cit., p. 112.

33 El existencialismo se basa en la idea de que la conciencia nos lleva a plantearnos el poder ser, desde el aquí y ahora (ser ahí / Da Sein). La voz de la conciencia sería la interpretación del ser ahí, nos replantea la acción para alcanzar el poder ser, no en el ser real, sino en su posibilidad, HEIDEGGER, M., Tiempo y ser, intr. Manuel Garrido, trad. Manuel Garrido, José Luis Molinuevo y Félix Duque, Tecnos, reimp. 5a ed., 2013, p. 124; ID., El ser y el tiempo, Fondo de Cultura Económica, trad. del original Sein und Zeit de 1927 José Gaos, $3^{\mathrm{a}}$ reimp. de la $2^{\mathrm{a}}$ ed., México, Buenos Aires, 2014, pp. 49 y 50. Así, no contradice la idea kantiana del tribunal de la conciencia del Reino de los fines, ID., El ser y el tiempo, op. cit., pp. 264 y ss., y 291 a 321. Pero a la vez confirma la idea de HEGEL 
conceptualización de que la Sociedad puede sobrevivir con conductas que no se apartan de la estricta moral universal y por ende no ponen en peligro al Derecho, pues éste es moral, como serían las conductas del autor de conciencia a diferencia del autor por convicción. Esto se debe a la tradicional concepción de que el Derecho es moral. Entonces, las conductas especialmente recalcitrantes por no suponer una conducta ineludible de la relación conciencia-voluntad, sino una conducta generalmente considerada como egoísta, caprichosa o medio injusto (existen alternativas), suponen una conducta inmoral que ha de ser rechazada por la moralidad del Derecho.

Esta tradición ha de ponerse en reserva en la actualidad. Tal reserva o crítica se inició con los postulados del individualismo y su diferenciación con la función de la Sociedad y el Derecho y especialmente se expresó por NIETZSCHE: “;No hay hechos sino interpretaciones (morales) de los hechos!" 34 ."Un hombre que se eleva no es más hecho moral que la caída de una piedra"35. Este es su legado. Para NIETZSCHE los valores históricamente hablando se pueden invertir, de manera que la comprensión de los valores (positivo/negativo) significa que pueden ir más allá de $s i^{36}$. Denunció que la evolución del hombre libre sólo puede producirse con la negación de los valores morales que hasta su momento imperaban. La moral dominante se inspira en el miedo de los más débiles ${ }^{37}$. Es así como entiende que la evolución del ser humano supone la irremediable negación de la moral a través de la inversión de todos los valores. Un espíritu libre es quien realiza la voluntad de poder ${ }^{38}$ : esto es el Ser. Lo bueno es «todo lo que eleva en el hombre el sentimiento de poder, la voluntad de poder, el poder en sí», mientras que lo malo es «todo lo que hunde sus raíces en la debilidad», mientras que la felicidad en definitiva sería «sentir que aumenta nuestro poder, que superamos algo que nos ofrece resistencia» ${ }^{39}$. Nótese aquí que NIETZSCHE no habla de bien/mal, sino que reduce lo absoluto de la moral al interés positivo/negativo: el hombre libre es «el que tiene una voluntad permanente e inquebrantable,

acerca de que lo verdadero no es la sustancia sino el sujeto: lo absoluto conforma la unidad de acción de la conciencia y la voluntad, ID., Tiempo y ser, op. cit., p. 102. Sin embargo, tampoco HEIDEGGER, a pesar de ubicarse en el pensamiento del siglo XX y en el contexto de las teorías sociológicas, acaba por otorgar relevancia a la socialización.

34 NiETZSCHE, Friedrich, La Voluntad de Poder, pról. Dolores Castrillo Mirat, 17ª ed., Edaf, 2009, II, 133.

35 ID., ibidem, op. cit., III, 466 a 468.

36 HEIDEGGER, M., Nietzsche, op. cit., pp. 392 y ss.

37 NiETZSCHE, F., El anticristo, Edimat, 1998, p. 32.

38 Nietzsche, F., Así habló Zaratustra, Alianza Editorial, 1997, p. 177: «Sólo donde hay vida hay también voluntad: pero no voluntad de vida, sino- así te lo enseño yo- ¡voluntad de poder!».

39 NieTZSCHE, F., El anticristo, op. cit., p. 30. 
posee también su medida del valor: al mirar a los otros desde sí mismo, los honra o los desprecia» ${ }^{40}$.

NIETZSCHE estima que el Derecho penal, y en concreto la finalidad de la pena, es la prevención general positiva, y no extraña que llegue a tal conclusión, porque la sociedad y la norma se identifican de tal modo que los movimientos que ambas realizan son al unísono. La norma responde a un comportamiento social, pero a la vez, la norma es la voz de la sociedad que dice a los sujetos cuál es el comportamiento que es adecuado en la sociedad ${ }^{41}$.

La pregunta esencial que se hace NIETZSCHE es por qué determinados sujetos obran contra la norma y no se sienten culpables de actuar contra la sociedad. La respuesta no es otra que «la vuelta contra su poseedor de los instintos de hostilidad y de crueldad, del placer de perseguir, agredir, trastocar y destruir ${ }^{42}$. La buena conciencia es la de los hombres que asumen su rol en la sociedad y que buscan la libertad moral, de forma inevitable el actuar tiene su origen en la misma sociedad, por eso su acción puede comprenderse, sin embargo otros criminales actúan por el placer de destruir la norma, vuelven al instinto de hostilidad, su obra es la negación de la sociedad.

En este sentido, la mayoría de la doctrina partidaria del libre albedrío aboga de modo irremediable por la culpabilidad total de los autores por convicción. Esto no es casual. Los presupuestos del libre albedrío fundamentan el castigo culpable de quién se ha movido a través de la razón (también por motivos) y no inconscientemente, por lo que faltando ese conocimiento el hombre deja de ser libre, sería inimputable ${ }^{43}$. Para NIETZSCHE, el libre albedrío es una ilusión necesaria ${ }^{44}$. De aquí que el arrepentimiento sea una absurda contradicción que niega que se haya actuado racionalmente ${ }^{45}$. Entiende NIETZSCHE que los postulados del libre albedrío llevan a conclusiones contradictorias. Se trata culpablemente a quien actúa irracionalmente y en su propio perjuicio al tratarse a sí mismo como no-persona, pero tradicionalmente, a quien actúa racionalmente, movido por un ineludible motivo de conciencia se le trata de exculpar o comprender. ¿No será que es menos libre, más irracional, quien actúa «sin pensar», y sólo por

\footnotetext{
40 NiETzSCHE, F., Genealogía de la moral, Edimat, 1998, p. 80.

41 Comenta que «(e)l castigo pretende evitar un perjuicio futuro, quiere intimidar. Realmente, en el castigo se asocian los dos elementos tan diferentes del odio, y esto es quizás lo que más contribuye a mantener esta confusión de ideas, en virtud de la cual el individuo que se venga no sabe generalmente lo que quiere». Pero también acepta una finalidad retributiva porque «mediante el castigo jurídico, quedan resarcidas tanto la doctrina privada como la social, lo que equivale a decir que (...) el castigo es una venganza», NIETZSCHE, F., El caminante y su sombra, estudio preliminar Enrique López Castellón y trad. Luis Díaz Marín, Edimat, 1999, pp. 58.

42 NiETZSCHE, F., Genealogía de la moral, op. cit., p. 107.

43 NIETZSCHE, F., El caminante y su sombra, op. cit., pp. 48 y 49.

44 NietzSCHE, F., La Voluntad de Poder, op. cit., I, 247; ID., El caminante y su sombra, op. cit., pp. 36 y 37.

45 NietzSCHE, F., El caminante y su sombra, op. cit., p. 60 comenta que «(e)1 remordimiento es algo tan necio como la mordedura de un perro en una piedra».
} 
motivos que están directamente unidos a la voz de la conciencia, que quien ha pensado sobre dichos motivos y ha podido obrar de forma diferente?

NIETZSCHE desarrolla un motivo de duda o de inversión de los fundamentos de responsabilidad $^{46}$, sobre el que debemos analizar si las tradicionales conductas de conciencia, normalmente atenuadas por la doctrina penal que se ha ocupado especialmente del tema, y las cometidas por convicción y enemigas, tradicionalmente agravadas en la culpabilidad y pena, pueden intercambiarse de manera tal que subyazca en verdad no tanto un fundamento normativo, como tradicionalmente se dice encontrar, sino una imposición estrictamente moral que se eleva a la paradoja del absurdo cuando se intercambian los fundamentos normativos de la autoría de conciencia a la autoría por convicción, y viceversa.

De tal forma se puede reconocer en él el pensamiento de que quien actúa por motivos de conciencia considerando que su obrar es eternamente justo está comunicando a la sociedad que su «error» irrevocable es la verdad de su ser, la Verdad de su personalidad, mientras quien actúa por motivos de conciencia que ni el propio sujeto puede justificar como una Verdad más que transitoria, no comunica su personalidad, sino la contradicción de su personalidad, se niega a sí mismo, lo cual supone un evidente peligro para la sociedad. Sujetos que a sí mismos se niegan no pueden suponer una expectativa confiable para los demás, sin embargo quien ineludiblemente comunica su personalidad, aun contradictoria con la norma, comunica a la sociedad que se puede confiar en él, es previsible porque su actuar no tiene otra dirección, supone una expectativa que, si bien errática, es circunstancial, por eso es confiable. De este modo, se aprecia una inversión de la moral, de la ética los valores, como advirtió HARTMANN ${ }^{47}$.

NIETZSCHE denuncia la moral universal kantiana y el imperativo categórico, porque la moral depende de las culturas y de la sociedad de cada tiempo; al negar el imperativo categórico, está

46 QUINTANO RIPOLLÉS escribió muy acertadamente en su día que NIETZSCHE no negó la Justicia natural, sino el idealismo kantiano, como si fuera tan fácil diferenciar justo e injusto. Ambos están estrechamente relacionados y por eso el Derecho positivo es algo arbitrario, QUINTANO RIPOLLÉS, Antonio, «Ideas jurídicas de Nietzsche», Anuario de Filosofía del Derecho, Madrid, 1957, p. 182.

47 Señala HARTMANN que «(l)a ética material del valor, en la medida en que ha abierto las puertas del reino del valor, ha llevado a cabo la síntesis de dos clases de ideas básicas crecidas históricamente sobre suelos muy diferentes y formuladas en mutua oposición: la aprioridad kantiana de la ley moral y la diversidad del valor, contemplada por Nietzsche sólo desde lejos (...) Devuelve al apriorismo ético su rico contenido originario y auténtico; y a la consciencia del valor, la certeza del contenido invariable en medio de la relatividad de la valoración humana. De este modo queda indicado el camino (...) De todas las evidencias que me ha proporcionado el nuevo estado del problema, apenas ninguna me ha resultado más sorprendente y a la vez más convincente que ésta: que la ética de los antiguos era ya ética material del valor muy desarrollada, no en cuanto al concepto o en cuanto a una tendencia consciente, pero sí en cuanto a la cosa misma y al proceder efectivo (...) Nos encontramos aquí con un engranaje insospechadamente profundo de viejas y nuevas conquistas intelectuales; y en el giro de la ética ante el que estamos, se trata de una síntesis histórica de mayor calado que la síntesis de Kant y Nietzsche: de una síntesis de la ética antigua y moderna», HARTMANN, Nicolai, Ética, presentación y trad. Javier Palacios, Ed. Encuentro, 2011, prólogo, pp. 26 a 30. 
afirmando los imperativos hipotéticos ${ }^{48}$. De esta conclusión resulta una idea precursora, que ha adquirido relevancia gracias a LUHMANN ${ }^{49}$, en concreto al aseguramiento mediante la formación de horizontes/perspectivas (acción de esquematizar) en donde seleccionar significa llegar a éxitos y resultados ${ }^{50}$. Resumidamente, si hablamos de posibilidades (elección) dentro de un horizonte/perspectiva estamos suponiendo expectativas prácticas, con lo cual llegamos también a que el aseguramiento de perspectivas/expectativas procede de la esquematización (subsumir) las posibilidades más o menos fijas (hipotéticas). De tal modo, con la seguridad cognitiva de la previsibilidad o confiabilidad de la operación (comportamiento) se reduce la complejidad.

\section{B. Tránsito del idealismo a la teoría sociológica: entre Nietzsche y Luhmann}

En WEBER ${ }^{51}$ comienza la teoría moderna de la sociología. La legitimación de las normas viene de un primer sustrato: la racionalidad conforme a fines o proceso de racionalización que se institucionalizan en el consenso racionalmente motivado. Por este motivo siguen tomando relevancia los conceptos «medio» y fin» de la tradición idealista, y asienta la concepción de que la religión desarrolla la racionalización social, y posteriormente la ética religiosa protestante (las nuevas organizaciones y los roles que se constituyen) fundamentan la configuración societaria capitalista, su espíritu. En definitiva, en WEBER se comienza a comprender que es a golpe de racionalidad social, prácticamente religiosa y filosófica, la manera en la que evoluciona y se constituye el Sistema Social.

FREUD llega a conclusiones parecidas ${ }^{52}$. La internalización social de la comunicación fundamenta la autoridad. Bajo este postulado, interesa singularmente su concepción sobre la conciencia de las masas, de los grupos sociales y en consecuencia también de los grupos

48 NiETZSCHE, F., La Voluntad de Poder, op. cit., IV, 243: «Vive de tal modo que debas desear volver a vivir, es el imperativo».

${ }_{49}$ LuHMANn, N., Sistemas sociales. Lineamientos para una teoría general, $2^{\text {a }}$ ed., Anthropos, 1998.

50 HeIDEGGER, M., Nietzsche, op. cit., pp. 455 a 458.

51 Weber, Max, La ética protestante y el espíritu del capitalismo, ed. Jorge Navarro Pérez, y pról. José Luis Villacañas, Editorial Istmo, Madrid, 1998; ID., Ensayos sobre sociología de la religión, Madrid, 1992, Vol. I y Vol. II; ID., Sociología de la religion, La Pléyade, Buenos Aires, 1978.

52 Sin embargo ya FREUD explicó los elementos sobre los que se forma la identidad y la socialización. Dividió la conciencia en tres partes: Ello (Es) o el inconsciente donde están instalados los deseos primarios y los instintos; Ego es el yo consciente; y el Super-yo en donde se instaura la cultura, la educación y la experiencia pero también las creencias. De esta forma, configura un concepto del Super-yo que domina a Ego pero a la vez los impulsos de Ello. A partir de estas conclusiones crea el concepto psicológico de la conciencia moral: la conciencia es la «función» de la instancia del Super-Ego; la conciencia moral constituye la causa de la destrucción de la agresividad de los instintos del hombre, únicamente necesita para ser válida la certeza y la seguridad de uno mismo, BLuM, Ernest, «Freud y la conciencia moral», ACHÄR / ZBINDEN / JUNG, vv.aa., La conciencia moral, trad. del original Das Gewissen, Rascher, Zürich, 1958, de Lucio García Ortega, Tribuna de la Revista de Occidente, 1961, pp. 227 y ss. En este sentido, los sujetos en inconsciencia actuaban como si tuvieran conciencia moral y que esto sólo se puede explicar a través de la costumbre, y pudo concluir que la conciencia sería aquél apartarse del código de las costumbres sociales, el conflicto de deberes o de modos morales que se resuelve a favor de la conciencia. 
religiosos. Si bien acepta FREUD que la masa modifica y limita la personalidad del individuo, FREUD sustenta una concepción sexual o libidinosa de la voluntad del individuo ${ }^{53}$ en la que parte de la siguiente idea: desde el nacimiento el ser humano se adapta, se forma y supervive por la identificación con su padre, lo imita, pero a la madre la ama sexualmente, y viceversa en el caso de hija, desmitificándose el complejo de la tragedia sofocliana. Este enlace se cumple también con los objetos. En el enlace o asimilación de lo amado, el yo se trasforma en el propio objeto (introyección) y se crea una lucha entre el yo objetivado y el yo persona. El yo no transformado encierra la conciencia moral ${ }^{54}$ y el objeto ocupa finalmente el ideal del yo (Ich ideal). La diferencia entre la identificación y el amor al objeto es que en el primera el yo destruye el objeto para asimilarse en el yo, modificándolo, y en el enamoramiento el objeto se dota de las propiedades del yo.

Estos enlaces -libidinosos- se aprecian de forma más clara en las relaciones religiosas ${ }^{55}$. ¿Pero entonces por qué existen lazos más fuertes que otros? Concluye que «las tendencias

53 Según FREUD, la seducción que produce un líder crea lazos afectivos más fuertes que los que se enlazan entre individuos, sin embargo no toda agrupación de hombres crea este condicionante, no en todo grupo existen lazos libidinosos cruzados entre individuos que consigan un factor determinante para la coerción encaminada a evitar la disolución o modificación, y así «no depende de la voluntad del individuo entrar o no a formar parte (...) y una vez dentro, la separación se halla sujeta a determinadas condiciones, cuyo incumplimiento es rigurosamente castigado», haciendo referencia a «masas artificiales como la Iglesia y el Ejército», FreUD, Sigmund, Psicología de las masas, $8^{\text {a }}$ reimp., Alianza Editorial, 2008, pp. 31, 37 y 38. Antes LE BoN afirmó que en la masa surgen los instintos más primitivos y violentos del ser humano, pero a la vez y en interés de la masa el individuo es capaz del mayor desinterés y sacrificio por el fin mismo de la masa o del líder con capacidad para fascinar y anular la facultad crítica lo que se consigue con el «prestigio», percatándose de la idea nietzscheana de que la Voluntad de Poder tiene el reverso de la voluntad de ser sometido, resultado que reluce con especial dramatismo en la obediencia ciega a la autoridad, esto es: la inevitabilidad, LE Bon, Gustave, Psicología de las multitudes, $28^{\mathrm{a}}$ ed., Feliz Alcan, París, 1921, pp. 17 a 19 consideraba que «(e)l más singular de los fenómenos presentados por una masa psicológica es el siguiente: cualquiera que sean los individuos que la componen y por diversos o semejantes que puedan ser su género de vida, sus ocupaciones, su carácter o su inteligencia, el solo hecho de hallarse transformados en una multitud les dota de una especie de alma colectiva. Esta alma les hace sentir, pensar y obrar de una manera por completo distinta de cómo sentiría, pensaría y obraría cada uno de ellos aisladamente (...) Sabemos hoy que un individuo puede ser transferido a un estado en el que, habiendo perdido su personalidad consciente, obedezca a todas las sugestiones del operador que se la ha hecho perder y cometa los actos más contrarios a su carácter y costumbres (...) detenidas observaciones parecen demostrar que el individuo sumido algún tiempo en el seno de una multitud activa cae pronto, a consecuencia de los efluvios que de la masa manan o por cualquier causa, aún ignorada, en un estado particular, muy semejante al estado de fascinación del hipnotizado entre las manos de su hipnotizador. Paraliza la vida cerebral del sujeto hipnotizado, ser convierte éste en esclavo de todas sus actividades inconscientes, que el hipnotizador dirige a su antojo (...) Perdidos todos sus rasgos personales, pasa a convertirse en un autómata sin voluntad».

54 FREUD, S., Psicología de las masas, op. cit., p. 47.

55 Comentaba al respecto FREUD que «(l)a distinción entre la identificación del yo y la sustitución del ideal del yo por el objeto halla una interesantísima ilustración en las dos grandes masas artificiales (...): el Ejército y la Iglesia Cristiana»; las religiones históricamente tradicionales establecen ritos para el acceso, pero a la vez sanciones ejemplares al desertor (apostasía, control a través de obligación de la confesión o la absolución premuerte). Continúa señalando que «es evidente que el soldado convierte a su superior, o sea, en último análisis, al jefe del Ejército, en un ideal; mientras que, por otro lado, se identifica con sus iguales y deduce de esta comunidad del yo las obligaciones de camaradería, o sea, el auxilio recíproco y la comunidad de bienes. Pero si intenta identificarse con el jefe, no conseguirá sino ponerse en ridículo (...) No sucede lo mismo en la Iglesia católica. Cada cristiano ama a Cristo como su ideal y se halla ligado por identificación a los demás cristianos. Pero la Iglesia exige más de él. Ha 
sexuales coartadas en su fin son las que crean entre los hombres lazos más duraderos. Pero esto se explica fácilmente por el hecho de que no son susceptibles de una satisfacción completa, mientras que las tendencias sexuales libres experimentan una debilitación extraordinaria por la descarga que tiene efecto cada vez que el fin sexual es alcanzado».

Esto lleva a concluir que el amor al objeto resulta más fuerte cuando ese objeto (ideal religioso, filosófico, cosmológico) puede transformarse al antojo del yo. La entrada de un miembro en un grupo religioso supone una explosión del yo que se modifica al criterio del objeto ideal ofertado. Mientras que en otros grupos la oferta religiosa del objeto ideal se asimila por identificación, se dota al objeto identificado en el yo partes del yo. La pertenencia a un grupo u otro marca el ángulo del horizonte de expectativas ofertado, y sobre el que se crea la mayor o menor inevitabilidad de la voluntad respecto a la conciencia. En algunos grupos -religiosos- la asimilación es plena, fuerte y coartada, el yo se modifica en el fin del objeto ideal. De aquí surge la comunidad de vida y de lealtad. El grupo garantiza que las conductas de sus miembros son válidas, están vigentes y las ratifican cual norma general.

Ya DURKHEIM ${ }^{56}$ inició la teoría de la sociedad basada en la conciencia, representación o identidad colectiva y en la solidaridad social u orgánica; ambas se sustentan en la moral, la religión y el rito; la coacción o la simple inclinación son insuficientes para fundamentar la validez de la norma, es la autoridad moral como coacción propia a la naturaleza de uno mismo la que la fundamenta. Ello viene de la constitución de una determinada norma considerada sagrada, lo sacro y posteriormente elevada y generalizada a santa. En este tránsito interviene la Sociedad con sus representaciones santas, llega el consenso, primero a través de la religión pero luego alcanza validez en las demás normas como consenso normativo. Si bien supo intuir que la conciencia colectiva se fundamenta en los procesos de socialización, acaba por justificarla en la racionalidad: la civilización -dice- es la prueba de la mayor racionalidad. Sin embargo, fue incapaz de explicar cómo se llega materialmente a dicho consenso. Su principal conclusión es que la solidaridad social diferencia los procesos del sistema social.

de identificarse con Cristo y amar a los demás cristianos como Cristo hubo de amarlos. La Iglesia exige, pues, que la disposición libidinosa creada por la formación colectiva sea complementada en dos sentidos. La identificación debe acumularse a la elección de objetos, y el amor, a la identificación. Este doble complemento sobrepasa evidentemente la constitución de la masa. Se puede ser un buen cristiano sin haber tenido jamás idea de situarse en el lugar de Cristo... El hombre, débil criatura, no puede pretender elevarse a la grandeza del alma y a la capacidad de amor de Cristo. Pero este desarrollo de la distribución de la libido en la masa es probablemente el factor en el cual funda el cristianismo su pretensión de haber conseguido una moral superior», ID., ibidem, op. cit., pp. 73 y 74.

56 DURKHEIM, Émile, La división del trabajo social, Akal, 1987; ID., Las formas elementales de la vida religiosa, Alianza Editorial, 2014; ID., El suicidio. Un estudio de Sociología, revisión traducción Sandra Chaparro, $2^{a}$ ed., Akal, 2012; ID., Sociología y filosofía, Comares, 2006. 
Aquí nace la teoría sistémica de la sociedad que desarrollará posteriormente PARSONS ${ }^{57}$, quien parte de la acción social como sistemas vivos de acción y de su relación con y en los sistemas sociales; aleja la personalidad y la cultura del ámbito de los sistemas, sin embargo no escapa de la intrincada tradición de que la acción social se suponía en su tiempo racionalmente finalista y en la que el «medio» y el «fin» seguían siendo consustanciales a la orientación de la acción social; el orden social sin atención a una razón coactiva constituye un acuerdo normativo en la contingencia de las alternativas posibles. Este fenómeno es una doble contingencia: siempre es posible y a la vez no. En este punto media una orientación cognitiva y evaluativa que supera a la mera orientación en los fines que se asienta en la cultura, en la sociedad y en cada sujeto. En este proceso cada sistema supone una variable, una diferenciación estructural.

PARSONS concluye que existen cuatro subsistemas del orden social: la cultura, la sociedad, la personalidad y el sistema comportamental, y en estos coexisten la familia, el proceso de interacción y la socialización como elementos del intercambio intersistémico (interpenetración). Entre los sistemas, el sistema de acción y los sistemas propiamente dichos, se interconectan medios de generalización o medios de control que sirven de valoración y evolución de las operaciones de los sistemas. Estos son el poder, el dinero, la influencia y el compromiso.

En definitiva, si bien PARSONS consiguió elevar al sistema como categoría primaria de estudio social, no consiguió desligarse de la tradición idealista que seguía poniendo el punto de mira en la racionalidad de la acción social. La racionalidad social seguía estando en el centro del sistema social.

Posteriormente HABERMAS desarrolló las tesis de la comunicación y de la conciencia colectiva que toma en parte de $\operatorname{MEAD}^{58}$ y que más tarde expondrá definitivamente en su obra

57 PARSOns, Talcott, Ensayos de teoría sociológica, Paidós, Buenos Aires, 1954; ID., El sistema Social, Alianza Editorial, 1998; ID., vv.aa., Hacia una teoría general de la acción, Talcott Parsons y Edward A. Shils (dir.), Ed. Kapelusz, Buenos Aires, 1968; ID., La estructura de la acción social. Estudios de teoría social, con referencia a un grupo de recientes escritores europeos, I y II, Ediciones Guadarrama, Madrid, 1968.

58 MEAD desarrolló los postulados de la comunicación social y normativa desde la perspectiva de la lingüística, a lo que denominó «behaviorismo social», aquella interacción de al menos dos elementos que convierte dicha interacción en un significado. Para esto analizó la evolución del lenguaje desde los inicios de la historia: los gestos, el grito. Concluyó que todo acto de comunicación del sujeto está previamente mediatizado por el contexto social (carácter social de la percepción) sin el cual no tendría significado, de aquí que el comportamiento y concretamente la comunicación sean una expectativa social entre los sujetos en los que se desarrolla la comunicación, se transforma la expectativa de uno con la del otro y viceversa. La internalización de la comunicación social mediante la interpretación de la comunicación de alter hace que se constituya uno mismo (self) como respuesta de ego a alter (response). Esta secuencia, a la postre, va creando comportamientos que se rigen por reglas de validez intersubjetiva que conforman expectativas de comportamiento: los roles suponen que cada uno ( $M e$ ) comunica desde la perspectiva de «otro generalizado» $(I)$. Esto resume el proceso de socialización entre sujetos, objetos y la Sociedad. Ésta se trasforma a la par que aumenta la racionalidad, y la socialización individualiza socialmente al sujeto en su propia identidad conformando la universalidad de la moral, MEAD, George Herbert, Espíritu, persona y sociedad. Desde el punto de vista del conductismo social, intr. Charles W. Morris, presentación a la ed. castellana Gino Germani, Paidós, Barcelona-Buenos Aires-México, 2009. 
Facticidad y validez. Explica que las pretensiones de validez han de ser análogas a la verdad ${ }^{59}$. Ni los imperativos ni las declaraciones de intención pueden constituir un acuerdo «racionalmente motivado» ${ }^{60}$. La validez normativa se construye cuando las expectativas de comportamiento se generalizan en el espacio y en el tiempo de un grupo social ${ }^{61}$. Después se desarrollan los actos de comunicación, que sirven para formalizar «la transmisión de saber culturalmente acumulado» ${ }^{62} \mathrm{y}$ a la vez para el cumplimiento de las normas a cada contexto social, de ahí que se instaure la socialización con los actos comunicativos, con la simultaneidad de la transmisión del saber, la integración social y la socialización que en definitiva constituye a lo que él llama «el mundo de la vida» ${ }^{63}$.

HABERMAS determina la verdad como el substrato de la validez de las normas en la racionalidad comunicativa del consenso ${ }^{64}$. Concluye que el Derecho es la culminación del interés colectivo racional y moral $^{65}$ : el sistema y el mundo de la vida se pueden concebir simultáneamente $^{66}$. En su obra Facticidad y validez sostiene que el Derecho y la moral, cuando se complementan, otorgan legitimidad a las normas. El discurso racional autónomo de cada ciudadano eleva el Derecho a válido y legítimo, la simple vigencia es insuficiente, ambas tienen que constituirse en un solo acto ${ }^{67}$. De aquí que una norma es democrática y legítima cuando todos los ciudadanos particularmente han ayudado de forma discursiva en su creación. De este modo HABERMAS se aferra a la idea de que las normas tienen que ser compatibles con los presupuestos morales aunque sean democráticas (institucionalizadas), lo que le lleva a otorgar cierta primacía al valor moral, pero entiende que hace falta además un discurso fundamentador no sólo en la aplicación sino también en la constitución de la norma, por eso reconoce que hay casos en los que una norma concreta, aunque sea válida y legítima, no puede fundamentarse para el caso, esto es, hace falta una decisión justa. Pretende salvar un hecho innegable: no todas las normas tienen ese denominado discurso racional, sino que simplemente a veces no gustan a uno

59 HABERMAS, Jürgen, Teoría de la acción comunicativa, II, Crítica de razón funcionalista, reimp. de 1992 de la $1^{\text {a }}$ ed., 1987, Taurus Humanidades, p. 43.

60 ID., ibidem, op. cit., p. 49.

61 ID., ibidem, op. cit., pp. 52 y ss.

62 ID., ibidem, op. cit., p. 93.

63 ID., ibidem, op. cit., p. 94.

64 ID., ibidem, op. cit., pp. 105 y 106. Al respecto comenta que «(l)a relación reflexiva consigo mismo funda la capacidad que tiene el actor de responder de sus actos», es su imputación, de lo que se infiere que es una «categoría práctico-moral», ID., ibidem, op. cit., p. 110.

65 ID., ibidem, op. cit., pp. 112 y ss; también comentaba MARÍn MONROY que «(l)as facultades cognitivas del orden natural faltaban al hombre primitivo, cuyo poder de objetivación (...) era casi nulo, por ser casi nula su personalidad», MARÍn MONROY, Antonio, Metasofía de la cultura. Normalismo. Lógica y Antifísica de la cultura y estudio de la cultura primitiva, ed. Hermanas Marín Padilla, Cometa, Zaragoza, 1990, p. 40.

66 HABERMAS, J., Teoría de la acción comunicativa, II, op. cit., p. 170.

67 Habermas, J., Facticidad y validez. Sobre el derecho y el Estado democrático de derecho en términos de teoría del discurso, intr. y trad. Manuel Jiménez Redondo, $4^{\mathrm{a}}$ ed. revisada, Ed. Trotta, 2005. 
u otro ni a la generalidad. Esta es la paradoja de la moral. Es fácil constituir una moral, máxime si es acorde a la generalidad, pero es imposible en todos casos adecuarse a ella. El posterior discurso moral que hace el sujeto para alegar que en verdad no se ha desvinculado de la moral es moralidad.

HABERMAS asienta la socialización de los sujetos y la autoridad moral de la normas ${ }^{68}$, en definitiva la democracia, si bien la interacción del mundo de la vida y el sistema no acaba por fundamentar por qué determinadas normas, aunque injustas desde su teoría de la mayor racionalidad del discurso autónomo, funcionan en el sistema, a veces cual norma fundamental. Pero desde que NiETZSCHE advirtió que la moral es tan transformable existe la paradoja de someter a una mayoría que la rechaza. De esto se dio cuenta LUHMANN cuando definitivamente desterró al hombre de los límites del sistema y lo situó en el lugar que pertenecía: el entorno. La moral ya no pertenece al sistema ni constituye un sistema, únicamente tiene cierta influencia en determinados momentos, pero no sustenta la operatividad de un sistema social.

\section{Introducción a la teoría de sistemas: la moral extra-sistema}

LUHMANN alcanzó a crear una descomunal teoría de los sistemas sociales, omnicomprensiva y totalizadora, en donde cada sistema viene determinado y clausurado en sus operaciones de forma autorreferencial, autopoiética y diferencial con otros sistemas o entornos; el hombre deja de ser parte del sistema para, desde la perspectiva de un observador del observador, formar parte del entorno; si bien el hombre es presupuesto de la Sociedad, lo es exclusivamente en cuanto a referencia. Configuró una teoría de la sociedad y de los sistemas sociales (parte de que hay sistemas) con un claro leitmotiv, la comunicación de sentido. Los sistemas sociales se vinculan

68 Es de destacar su teoría de la socialización, en la que desarrolla el concepto también husserliano del mundo de la vida pero desde una perspectiva que abarca la puramente fenomenológica. Dice que «(l)a situación de acción así interpretada circunscribe un ámbito de alternativas de acción abierto en vista de un tema, esto es, un ámbito de condiciones y medios para la ejecución de planes. A la situación pertenece todo aquello que se hace sentir como una restricción para las correspondientes iniciativas de acción. Mientras que el mundo de la vida, como recurso que es para la acción orientada al entendimiento, lo mantiene el actor a sus espaldas, esas restricciones que las circunstancias de la ejecución de sus planes le imponen le salen al paso como ingredientes de la situación», HABERMAS, J., Teoría de la acción comunicativa, II, op. cit., p. 191. En coherencia con su teoría de la razón funcionalista, reconoce que existen horizontes restringidos que limitan el mundo de la vida, por ejemplo las tradiciones culturales que definen todos los estados y sus historias verdaderas, ID., ibidem, op. cit., pp. 192 y ss. En concreto, señala que «(l)as estructuras simbólicas del mundo de la vida se reproducen por vía de la comunicación del saber válido, de la estabilización de la solidaridad de los grupos y de la formación de actores capaces de responder de sus acciones (...) A estos procesos de reproducción cultural, integración social y socialización corresponden los componentes estructurales del mundo de la vida que son la cultura, la sociedad y la personalidad», ID., ibidem, op. cit., p. 196. Sobre este trinomio fundamenta y desarrolla su teoría de la comunicación y los sistemas «autorregulados», superando, dice, la filosofía de la conciencia y del conocimiento. Tanto es así que llega a afirmar con toda coherencia que «(l)os actores nunca controlan por completo su situación de acción», ID., ibidem, op. cit., p. 211. 
con acciones humanas entre sí diferenciadas de otros sistemas de forma que podría decirse que existe cierto automatismo ajeno al hombre. El eje central de su pensamiento es que cada sistema social (Derecho, Política, Economía, etc.) tiene sus propias operaciones. Estas operaciones se autorrefieren (autorreferencia) pero a la vez se autoconstruyen (autopoiesis), lo que causa la diferenciación clausurada con otros sistemas o entornos.

La propiedad de cada sistema son los medios de comunicación simbólicamente generalizados: el Amor, la Verdad, el Poder, el Dinero. Estos medios de comunicación son propios de sociedades modernas o funcionalmente diferenciadas. Contienen un código positivo/negativo que articula las operaciones en el sistema: las expectativas positivas (fiables) y negativas (no fiables). Estos medios de comunicación constituyen la diferencia entre sistemas, por ejemplo, en la Política el medio de comunicación sobre el que se basa y se constituye es el Poder, de manera que todas las operaciones, en definitiva, las expectativas sociales se basan en el Poder.

Concluyó que la moral no cumple una función relevante en los sistemas sociales ${ }^{69}$. De aquí que los «sistemas psíquicos», los pensamientos del hombre, no constituyan un elemento propio de los sistemas, sino del entorno, las expectativas se orientan social y psíquicamente ${ }^{70}$, son las operaciones codificadas positivas y negativas las que se transfieren con los medios de comunicación simbólicamente generalizados de modo que «la selectividad interna del hombre, esto es, lo que constituye como unidad orgánico-psíquica, no es idéntica a la selectividad social del sistema de comunicación y transcurre de un modo enteramente distinto» ${ }^{71}$. Por eso la sociedad es comunicación, no consiste en individuos, sino en comunicaciones en una estructura (red de expectativas) que están en el lado objetivo de la «relación cognoscitiva» ${ }^{72}$. La moral ya no tiene una función propia y diferenciadora en las sociedades modernas, ni puede ser aislada al haber sido sustituida por otros medios de comunicación simbólicamente generalizados que procuran la diferenciación en el sistema. La moral se difumina en cada sistema social, en cada medio de comunicación que son los que ahora procuran la fluidez de la comunicación sin tener en cuenta la moral estrictamente, o neutralizándola, no se precisa ninguna motivación moral ${ }^{73}$. En este sentido, LUHMANN refuerza la doctrina nietzscheana de la inversión de la moral o

69 Luhmann, N., «Paradigm Lost: sobre la reflexión ética de la moral», LUHMANN, N., La moral de la sociedad, Ed. Trotta, recopilación de artículos, 2013, p. 243.

70 LUHMANN, N., «Las normas desde una perspectiva sociológica», LUHMANN, N., La moral de la sociedad, op. cit., p. 34.

71 LUHMANN, N., «Sociología de la moral», LUHMANN, N., La moral de la sociedad, op. cit., p. 81.

72 ID., ibidem, op. cit., p. 91.

73 HORSTER, Detlef, «Posfacio», LUHMANN, N., La moral de la sociedad, op. cit., p. 348. 
transvaloración de todos los valores, de manera que la moral no tiene peso determinante en la Sociedad ni en el Derecho, al menos como hace unos pocos siglos ${ }^{74}$.

En un mundo de sistemas sociales, todos debemos contar con la contingencia que suponen los otros (alter) en nuestras propias expectativas: doble contingencia. Si para LUHMANN los hombres tienen expectativas sociales, y éstas tienen contingencias, o sea, que pueden suceder de otra manera y lo imposible se puede hacer posible, en tales expectativas se han de contar con las expectativas de los otros. En esta contingencia se crea un nuevo horizonte de lo posible, aceptándolo o no: se reduce la complejidad pero se crea otra al crearse un nuevo horizonte. Aquí se inicia ya el orden social, con el sentido de la más mínima contingencia y decisión sobre la expectativa se crea un sistema que cuando se coordinan con otros posibilitan el orden social ${ }^{75}$.

La pregunta que sobresale y nos es lícito hacer es la siguiente: ¿para qué entonces la moral generalizada si bastan las expectativas sociales, las generalizadas? En armonía con LUHMANN, en cuanto se entra en el discurso de la moral, surge el «problema» de que quien la alega se ve sometido siempre a ésta. Sin embargo, seguir siempre una norma moral -también generalizadano es posible en todos los casos porque las expectativas cambian, también las sociales: esta es la paradoja de la moral. Decir que alguien ha incumplido una norma por motivos morales es hablar de nada, también en el caso de quien alega el incumplimiento de una norma moral ${ }^{76}$.

Según LuhmanN, esta confluencia de expectativas de unos y otros forman las normas de deber en la sociedad, unas veces legales, otras convencionales o morales. Las normas son las

\footnotetext{
74 Los políticos (el sistema social de la Política en la sociedad moderna) no sostienen sus decisiones en la moral, sino que en ocasiones hacen referencia al subsistema de la moral. La expectativa social no es que los políticos tomen decisiones morales sino propiamente positivas para la sociedad. Si bien la expectativa social comunica que no se espera que los políticos sean corruptos o jueguen sucio, o los deportistas se dopen desvirtuando de tal manera la política del deporte, lo que referencialmente llama al subsistema de la moral, pero no lo integra per se, aunque pueda determinarlo cuando la moral entra en la red de la estructura social a modo de expectativa, LUHMANN, N., «La honradez de los políticos y la superior amoralidad de la política», LUHMANN, N., La moral de la sociedad, op. cit., pp. 159 a 161; ID., «La ética como teoría reflexiva de la moral», LuHMANN, N., La moral de la sociedad, op. cit., pp. 309 y 310, añade que «(d)e ahí no se puede concluir que los sistemas funcionales mismos estén fundados en la moral. Más bien, es la conclusión contraria la que resulta obvia, a saber, que el medio influido de la moral cristaliza allí donde los sistemas funcionales pueden darle una función».

75 Luhmann, N., ¿Cómo es posible el orden social?, trad. Pedro Morandé Court, Herder, 2009, p. 125.

76 El sociólogo alemán explica que el Derecho opera normativamente clausurado pero cognitivamente abierto, su apertura es la condición de su clausura como en cualquier otro sistema, de aquí que la tesis de la clausura normativa «se dirige en primer lugar contra la concepción de que la moral podría tener validez de inmediato dentro del sistema jurídico»' LUHMANN, N., El derecho de la sociedad, $2^{\mathrm{a}}$ ed., Herder, 2005, pp. 133 y 134. Añade que «la distinción entre cerrado normativamente y abierto cognitivamente se practica sólo dentro del sistema (y no como circunstancia dada objetivamente). El sistema jurídico se convierte a sí mismo en ley. Por eso, la moral no tiene ninguna relevancia jurídica: ni como código (bien hecho/mal hecho; bueno/malo), ni como valoración singular (...) Ciertamente el derecho puede aceptar metas normativas preestablecidas por parte de la moral o de otras fuentes sociales. Sin embargo, esto debe tener lugar a través de una transformación explícita en derecho», ID., ibidem, op. cit., p. 141.
} 
operaciones de las expectativas de uno (ego) con las del otro (alter $)^{77}$, son expectativas y expectativas de expectativas del otro, lo que cabe esperarse, la fiabilidad: este es el fundamento de las normas ${ }^{78}$ convencionales, legales y morales. No puede aceptarse entonces que en el Sistema Social pueda darse un consenso general ni la racionalidad comunicativa en los términos antes expuestos, sino el poder de algún sistema sobre otro según el caso, esto es, porque al sistema le falta racionalidad ${ }^{79}$. Son las operaciones propias de cada sistema lo que legitima su existencia, a esto le denomina legitimación a través del procedimiento y sirve para fundamentar especialmente la legitimidad de las normas ${ }^{80}$, no una moral generalizada ni la racionalidad comunicativa. De aquí se extrae la principal conclusión contra la tradición idealista: el sistema no se fundamenta en el consenso ni en la moral generalizada.

\section{La moral como expectativa riesgosa}

LUHMANN ha criticado que exista un fundamento último de la moral ${ }^{81}:$ «Frente a KANT, puede objetarse con SADE que también el mal moral permite ser concebido como principio generalizable» ${ }^{82}$. En su opinión, las reglas que conforman la moral no nacen de los valores, si bien existen ciertas reglas morales que se refieren a valores, por ejemplo en el de la vida no existe un valor omniabarcante de la vida sino la expectativa social consensuada, cómo se respeta un bien sería el valor en todo caso. Encuentra el fundamento o «formación» de la moral en el código estima/menosprecio ${ }^{83}$, conceptos que están en su opinión libres de moralismo, no se justifican en la moral, únicamente se refieren a la reducción de la complejidad mediante la contingencia (puede ser de otra manera), por eso otros medios de comunicación han sustituido la moral como medio generalizado de comunicación simbólico ${ }^{84}$.

77 LuhmanN, N., «Las normas desde una perspectiva sociológica», op. cit., p. 34; ID., «Sociología de la moral», op. cit., pp. 96 y ss.

78 LUHMANN, N., «Las normas desde una perspectiva sociológica», op. cit., pp. 35 y ss.

79 Luhmann, N., Sistemas sociales, op. cit., p. 104. Pueden darse dos clases de expectativas, las cognitivas y las normativas. Las expectativas cognitivas y las normativas se diferencian en que con las primeras podemos aprender: por ejemplo, si esperamos algo como fiable y no se cumple, aprendemos que no se da el caso por algo, mientras que con las expectativas normativas no aprendemos o nos mostramos reacios a aprender: se da una alta fiabilidad, que si no se cumple es porque no era exigible tal expectativa.

${ }_{80}$ LummanN, N., Legitimation durch Verfahren, Luchterhand Verlag, 1969; ID., «Sistema jurídico y dogmática jurídica», trad. Ignacio de Otto Pardo, Centro de Estudios Constitucionales, Madrid, 1983.

81 LUHMANN, N., «Sociología de la moral», op. cit., pp. 57 a 77.

82 LuhmanN, N., «La ética como teoría reflexiva de la moral», op. cit., p. 299. Véase la tan nombrada obra por LUHMANN del Marqués de SADE, Justine o los infortunios de la virtud, op. cit., pp. 55 a 60.

83 LUHMANN, N., «Sociología de la moral», op. cit., p. 100; ID., «Paradigm Lost: sobre la reflexión ética de la moral», op. cit., p. 240

84 Refiere por ejemplo que el altruismo tampoco resulta fiable para ganarse la estima «aunque sólo sea porque renunciar a los propios intereses deja demasiado espacio para favorecer o perjudicar los de otros», LUHMANN, N., «Sociología de la moral», op. cit., p. 99. 
No resultará ilógico por ello que LUHMANN concluya que es ese conjunto de condiciones que se practican en un hecho determinado con estima o menosprecio lo que forma la moral de una sociedad, de manera que la moral codifica las relaciones entre ego y alter, por eso rechaza que exista un imperativo categórico o ley general ${ }^{85}$. La estima convierte un hecho en algo «normal», bueno, habitual, mientras que el menosprecio en «anormal» (incapacidad, delincuencia), por eso el código parece ser más bien lo bueno/malo (así también NIETZSCHE) frente a lo verdadero/no verdadero de las ciencias, si bien este último tiene la misma relevancia universal que el código moral $^{86}$. Esta es la razón de que la moral haya perdido una función propia, o más exactamente: la moral no tiene una comunicación propia.

De aquí resulta que en el pensamiento luhmanniano la autoría de conciencia (también incluye al autor por convicción) no tenga trascendencia jurídica per se, salvo trascendencia jurídica previa $^{87}$. Podemos sacar una importante conclusión sobre la trascendencia de la moral en el Derecho: la moral de un comportamiento no puede ser valorada por el Derecho salvo que se incurra en la contradicción de valorar moralmente un acto moral, por eso sólo cuando un acto moral tenga trascendencia previamente configurada normativamente se valora como una operación que «funciona»o no «funciona» en el Sistema. Puede haber conductas que moralmente sean rechazables (también en casos de imprudencia) que no precisan de contundencia penal. Esto se debe a que la Sociedad puede funcionar con esa operación.

La moral trata de las condiciones de estima y menosprecio entre ego y alter. Cuando ego le comunica a alter su estima o menosprecio, ego está constituyendo una comunicación a la que él mismo se está sometiendo de modo que genera obligación/vinculación, también como forma de «inclusión» en la sociedad ${ }^{88}$. En sociedades modernas, funcionales, la moral se vacía ante el desarrollo del sistema funcional ${ }^{89}$. Tanto es así que la moral es algo relativamente novedoso, se comienza a distinguir entre derecho como obligación externa y moral como obligación interna

85 LuHMANN, N., «Sociología de la moral», op. cit., p. 103; ID., «La ética económica ¿es una ética?», La moral de la sociedad, op. cit., p. 183, no lleva a ninguna instrucción de cómo actuar; ID., «¿Hay aún en nuestra sociedad normas irrenunciables?», LUHMANN, N., La moral de la sociedad, op. cit., p. 217.

86 LuHMANN, N., «La ética como teoría reflexiva de la moral», op. cit., p. 254.

87 Razona que «se encuentra el principio de la no identidad de la Constitución con las cosmovisiones sobre la sociedad y sobre el mundo: morales, ideológicas, religiosa. En Alemania este principio ejerce una atracción especial debido a la experiencia con el nacionalsocialismo: la desacreditación de la distinción entre derecho y cosmovisión que era tenida por los nazis como reliquia del Estado de derecho liberal», ID., ibidem, op. cit., p. 152.

88 LUHMANN, N., «La ética como teoría reflexiva de la moral», op. cit., pp. 258, 260 y 268.

89 ID., ibidem, op. cit., p. 269. 
desde el siglo XVIII ${ }^{90}$, significativamente desde las primeras declaraciones universales de derechos fundamentales.

No obstante, la moral puede llegar a normativizarse, siempre y cuando exista un «consenso» a la par de las expectativas de conocimiento ${ }^{91}$, de manera que la moral tendría así fiel reflejo en la

90 Luhmann, N., El derecho de la sociedad, op. cit., p. 95 y p. 209. Demuestra esta conclusión diversas consideraciones: Se dice que el Mazdeísmo o Zoroastrismo fue la primera gran religión de la historia, en la que por primera vez la ley divina habla del bien y del mal, de la recompensa y castigo divino como el cielo y el infierno o el fin del mundo, antes inclusive que el judaísmo, BERGUA, Juan B., «Zarathustra y su doctrina», El Avesta, textos relativos al Mazdeísmo o Zoroastrismo, primera de las grandes religiones, trad. Juan B. Bergua, 2a ed., 1992, pp. 6 y ss. Tal y como asevera MARÍAS, en el mundo clásico, en la polis, sus ciudadanos adoptaban una creencia común en los dioses, mediante unas leyes consuetudinarias y mediante los usos como concepción de la comunidad y de la seguridad de la vida, MARÍAS, Julián, Introducción a la Política de Aristóteles, Centro de Estudios Constitucionales, Madrid, 1970, p. 111; también advierte SOUTO PAZ que «(e)l individuo no descubre las creencias, no las crea, ni las racionaliza, pues no son simples ocurrencias, sino usos transmitidos de generación (...) Las creencias, por otra parte, no son individuales, sino comunitarias. Las creencias pertenecen a la comunidad, entre otras cosas, porque en el mundo griego la vida individual sólo puede realizarse dentro de la polis, de la ciudad», SOUTO PAZ, JA., Comunidad política y libertad de creencia, op. cit., p. 16.

En el mundo romano, las creencias concentran el eje de la política y cultura, siendo el pontífice única persona que puede mediar con el mundo divino e interpretar sus leyes. Los gobernantes reunían en su persona además del poder político el religioso. Pero a finales del Imperio Romano y comienzo del Imperio Bizantino, la propagación de la visión cristina rompió la unicidad Estado-Religión, se impuso lo que se ha denominado «dualismo cristiano». Como afirma SOUTO PAZ «(1)a singularidad de esta comunidad política no reside tanto en el hecho de su carácter teocrático, característica común a otras comunidades políticas, como la judía o la islámica, como en la presencia en el mensaje cristiano de lo que se ha denominado dualismo cristiano», ID., ibídem, op. cit., p. 23. El cristianismo aceptó las leyes del emperador en tanto no se confrontasen con las leyes divinas. Vemos como este dualismo, de separación del ámbito civil y religioso, supone el principio de la problemática en el imperio de la obligación jurídica $o$ la obligación moral si bien ésta última comprendida como sometimiento a los dictados religiosos, no estrictamente morales o personales. Este dualismo continuará durante toda la Alta Edad Media, en lo que se ha llamado «cesaropapismo», manteniéndose el conflicto entre el emperador y las autoridades religiosas por la primacía. Pero durante la Baja Edad Media con la auto proclamación del Papa y auto adjudicación de la supremacía de la potestad de éste sobre el orden civil en asuntos religiosos, confirmada más adelante en el Concordato de Worms, el dualismo cristiano se trasforma en lo que se ha denominado «hierocratismo», un falso dualismo cristiano, en donde la comunidad política y cultural se refunden. Tal falso dualismo, producirá durante toda la Edad Media, el impedimento de la propagación de la libertad de creencia y de otras libertades vinculadas, como la libertad de conciencia. Ejemplo de ello es la Inquisición y la persecución de los supuestos herejes.

El paso a la Edad Contemporánea con la Revolución Francesa de 1789, supuso la primera derrota del Régimen Absoluto y el triunfo de la Ilustración. La autonomía del individuo, el individualismo es fuente de la libertad de creencias, a raíz de la Declaración francesa de 1789 y americana de 1787. En palabras de SOUTO PAZ la libertad de creencias «se convierte así en la primera libertad especializada, reconocida en los tiempos modernos», ID., ibidem, op. cit., p. 28.

Podemos entender los fundamentos teóricos de las libertades y en concreto de la libertad de creencias desde tres planos: historicista, individualista y estatalista, FIORAVANTI, Maurizio, Los derechos fundamentales. Apuntes de Historia de las constituciones, presentación Clara Álvarez Alonso, trad. de Manuel Martínez Neira, $3^{\mathrm{a}}$ ed., Trotta, 2000 , pp. 26 y ss. Con las revoluciones del siglo XVIII, la concepción sobre los derechos fundamentales cambia a favor del individualismo (el contractualismo como pacto para el abandono del estado de naturaleza), la libertad pasa a ser una presunción. En lógica estatalista, sostener que el estado de naturaleza es bellum omnium contra omnes significa necesariamente sostener que no existe ninguna libertad y ningún derecho individual anterior al Estado, antes de la fuerza imperativa y autoritativa de las normas del Estado, únicas capaces de ordenar la sociedad», ID., ibidem, op. cit., p. 48. De los modelos expuestos podemos concluir, al igual que lo hace FIORAVANTI, que las constituciones francesa y americana parten de dos concepciones distintas de los derechos fundamentales. Con el Estado liberal la concepción francesa fue exponente del estatalismo, y la americana del individualismo ID., ibidem, op. cit., p. 97. En la actualidad vivimos una reunificación de los dos criterios constitucionales, ID., ibidem, op. cit., pp. 125 y 125.

91 LUHMANN, N., «Sociología de la moral», op. cit., p. 106. 
norma (la norma es reflejo de la expectativas morales) ${ }^{92}$. A causa de esto la libertad se interpreta como contingencia de la reducción de la complejidad, por eso no es un presupuesto sino una consecuencia de la moral, o en verdad, de toda comunicación en la elección de aceptar o no dicha comunicación: es el producto de la sociedad ${ }^{93}$.

Según LuHMANN, la moral hoy en día es insuficiente, no es un pleno medio de comunicación, necesita completarse con la «racionalidad de enlace», el «amor»y el «derecho», para adquirir cierta «influencia»o «infiltrarse», sino como sistema, sí en el sistema ${ }^{94}$. Con esta conclusión,

92 Lo llamativo es que en todos los sistemas rige una estructura o red de expectativas que a través de las comunicaciones forman códigos de orientación de la conducta. Pero es más, en todo código rige el principio de no contradicción -al que nos hemos referido ampliamente más arriba-como «parte integrante de un código simbólico que viene exigido para implementar operaciones que esquematizan de forma binaria», ID., ibidem, op. cit., p. 74. En el principio de no contradicción se cumple la elección de una de las dos partes del código del sistema, en la moral se refiere a la elección bueno/malo, estima/desprecio: orientación de la conducta con base en una disyunción. Se le corresponde con el presupuesto de la libertad, el verdadero fundamento sería la libertad misma, no en el modo de una característica del hombre sino en el efecto de la comunicación de «expectativas, normativizaciones y predicciones» que aparecen y desaparecen como la comunicación, ID., ibidem, op. cit., pp. 113 y 114.

93 LuHMANN, N., «La ética como teoría reflexiva de la moral», op. cit., pp. 314 y 315.

94 LuHMANN, N., «Sociología de la moral», op. cit., p. 118, y p. 121 en donde dice: «El derecho puede así hacerse independiente de una cobertura moral de las normas (...) el derecho a la propiedad nos asegura frente a la exigencia moral de dar y compartir»; ID., «La ética como teoría reflexiva de la moral», op. cit., p. 309. Si bien «(t)odo esto exige un considerable enfriamiento moral del derecho, no sólo donde hay materias moralmente neutrales que han de ser reguladas, como los registros oficiales o el tráfico, sino también -y justamente- en el caso de disfunciones sociales de la moral», ID., «Sociología de la moral», op. cit., p. 121. Y añade que «(p)recisamente las innovaciones morales a menudo se adentran en un terreno no consentido y aún no normativizado o han de romper (¡Antígona!) con las normas para hacer visibles niveles transformados de la integrabilidad de expectativas», ID., ibidem, op. cit., p. 100. No obstante, LUHMANN otorga cierta relevancia sistémica a la moral, si no determinante, con parte de fuerza, hasta el punto que afirma que «el derecho como la moral han de pretender validez en armonía con el orden social. No cabe duda de que, por ello, la presión moral lleva con frecuencia a la transformación del derecho, del mismo modo que, a la inversa, los cambios jurídicos influyen en el juicio moral», ID., ibidem, op. cit., op. cit., p. 122. Pero esta afirmación no es contradictoria con que la moral ha sido sustituida en la sociedad moderna por otros medios de comunicación simbólicamente generalizados, como el poder y el dinero. Tanto la moral como el Derecho se complementan o tienen capacidad para afectar del uno al otro de forma tal que se identifican, y cuando no es así, se trasforman, en ese caso por ejemplo «(l)a moral sólo puede ganar cuando se delimita frente a la racionalidad de enlace y el derecho y se retira ahí donde los equivalentes son suficientes», ID., ibidem, op. cit., pp. 122 y 123. Por lo que quien defienda el pluralismo como moral no puede afirmar a la postre que las nuevas ideas son mejores que las anteriores, ID., ibidem, op. cit., p. 128. De este modo en la Modernidad se infieren síntomas de «inmoralidad» en los sistemas funcionales, como en la economía con la búsqueda del beneficio, que parecen escapar del consenso moral, ID., «La ética como teoría reflexiva de la moral», op. cit., p. 307. Huelga comentar que LUHMANN habla de la moral como un sistema parcial (universalismo sin especificación) que tiene entradas e influencias en otros sistemas (Política, Derecho, Economía), pero no una función propia como sistema, no se diferencia de otros sistemas, ID., ibidem, op. cit., pp. 308 y ss. El valor de la moral es moralidad, pero la moral no demuestra que haya que obrarse bien o mal, sino que es una cuestión de decisión, ID., «Política, democracia, moral», Luhmann, N., La moral de la sociedad, op. cit., pp. 167 y ss. Puede rechinar la siguiente frase: «No conozco ningún lugar en el que se diga que Dios no sea ni bueno ni malo, sino que sea indiferente a la moral», ID., «La ética económica ¿es una ética?», op. cit., p. 195. Expone el caso de la hipocresía, y critica a la moral que crea que le iría mejor si no existiese hipocresía, ID., ibidem, op. cit., p. 172 y p. 176. La ética pretendía hacer del código bueno/malo una comunicación de la moral de las buenas razones, sin embargo en los sistemas se ve cada día más claramente que la ética supone una dialéctica de acercamiento de posturas, entonces, de expectativas y sus contingencias, ID., ibidem, op. cit., p. 182. Por ejemplo en la economía nadie negará que no existen muchas influencias de la moral en la organización económica moderna, no se trata de que sea justo o injusto, sino de decisiones y expectativas, ID., «La ética económica ¿es una ética?», op. cit., pp. 192 y ss. Por eso llegó a decir que no hay normas irrenunciables, al menos moralmente «puesto que esto sólo podría llevar a desacreditar moralmente una u otra opción y a exorcizar el demonio en el derecho con el Belcebú de la moral», sino más bien, concebir las normas como construcciones para 
parece afirmar que la autoría de conciencia respondería a una expectativa social que la norma no ha expresado en expectativa idéntica a una expectativa social, o no la ha comunicado al menos $^{95}$. La configuración de la moral que realiza el sociólogo alemán es una muestra clara de la libertad de conciencia como representación de una expectativa legítima de la sociedad y que efectivamente está cubierta en la norma. No de otro modo podemos entender que LUHMANN, sin otorgarle una relevancia de medio de comunicación, acepte que la moral trasfigura la norma y viceversa. La norma se identifica con la Sociedad como fiel reflejo de la misma, pero cuando la norma no se refiere a aspectos de la influencia de la moral: «(l)a moral reacciona a la complejidad de su ámbito funcional creando en sí misma posibilidades para la puesta en relación» ${ }^{96}$.

LUHMANN parece también criticar el uso que se hace al colocar un «valor»a algo, puesto que de tal modo se detiene la reflexión, la elección, a decir verdad, la libertad. Valores como la libertad, la igualdad, la justicia, la paz, la seguridad, la dignidad, el bienestar y la solidaridad no son firmes, no tienen una preeminencia sobre otros, ni se excluyen entre sí, inclusive en la «ponderación de intereses» dicha fórmula no expresa cuál es el resultado. La única norma irrenunciable sería la «autopoiesis» del sistema ${ }^{97}$. La moral produce «paradojas»o «disfunciones» que no permiten el asentamiento de un sistema propio y diferenciado de otros sistemas $^{98}$. En estos términos la libertad había sido entendida tradicionalmente como un presupuesto del juicio moral, pero no explicaba cómo. LUHMANN considera que la libertad tiene sentido en cuanto producto derivado de la comunicación ${ }^{99}$, por lo que es por él entendida como el producto de la formación de expectativas.

Entonces la moral supone una elección que busca reducir la complejidad. Pero en esta tentativa se asumen riesgos y peligros. Los riesgos los asume uno mismo, es una cuestión de «decisión» (montarse en un avión), y por tanto es una cuestión de «elección» y de «posibilidad».

las expectativas contrafácticas de manera que se mantengan cuando son decepcionadas, ID., «¿Hay aún en nuestra sociedad normas irrenunciables?», op. cit., pp. 217 y 218.

${ }_{95}$ Por eso concreta que «el mito de Antígona estiliza una situación que es excepcional. La idea de que el derecho nuevo podrá ser mejor que el antiguo es una reflexión muy tardía de una praxis introducida desde hacía mucho (...) se trata (...) de hacer extensivas las experiencias antiguas a los casos nuevos», LUHMANN, N., El derecho de la sociedad, op. cit., p. 330.

96 LUHMANN, N., «Sociología de la moral», op. cit., p. 136.

97 Luhmann, N., Sistemas Sociales, op. cit., pp. 54 y ss., y p. 56 donde dice: «En el caso de los sistemas sociales, el estado de cosas es distinto en un doble sentido: por un lado, no existe ninguna comunicación fuera del sistema de comunicación de la sociedad. Este sistema es el único que utiliza este tipo de operación, y es esta medida real y necesariamente cerrado, lo cual, por otro lado, no es válido para los otros sistemas sociales»; ID., «¿Hay aún en nuestra sociedad normas irrenunciables?», op. cit., pp. 227 a 230.

98 LUHMANN, N., «Paradigm Lost: sobre la reflexión ética de la moral», op. cit., p. 244

99 ID., ibidem, op. cit., p. 250. 
Los peligros no dependen de nosotros (la caída de un rayo) ${ }^{100}$. En la evolución tecnológica y en la organización de la sociedad moderna se ven ahora como riesgos cuestiones que antes hubieran sido tratadas como peligros, de modo que la conciencia sobre el riesgo crece a costa de la conciencia de peligro ${ }^{101}$. Los riesgos a los que se enfrenta la sociedad precisan de un acuerdo que suspenda el juicio moral ${ }^{102}$.

En conclusión, en un mundo en el que constantemente los ciudadanos estamos asumiendo riesgos con nuestras decisiones, también las morales, se han de ponderar diversos riesgos por las distintas probabilidades y ventajas, de manera que en su caso la responsabilidad por el error en la decisión sobre los riesgos se deberá plantear en la «verosimilitud» de su «evitabilidad» ${ }^{103}$ : el horizonte de expectativas y alternativas. Esta conclusión lleva al problema de la confianza ${ }^{104}$, no es una cuestión estricta de moral.

\section{IV.- Libertad, determinismo neurocientífico y psicológico en la responsabilidad penal}

En las últimas décadas la neurociencia ha puesto en duda uno de los presupuestos básicos del Derecho penal, la libertad de los ciudadanos y la responsabilidad penal por los actos construida sobre la base de la culpabilidad, en esencia, en las últimas décadas la neurociencia ha puesto en duda el tradicional concepto del libre albedrío.

El libre albedrío se ha puesto en duda con múltiples experimentos que pretenden confirmar que las decisiones del ser humano no son voluntarias, sino que parten de previos movimientos neuronales que afectan de manera inconsciente a nuestras decisiones, que a la postre, determinan nuestra voluntad y su ejecución. En otro sentido, la Física cuántica defiende un modelo de determinismo indeterminado, en el que el ser humano está siempre determinado causalmente, aunque tal multiplicidad de causas, le hace precisamente indeterminable.

100 LuHMANN, N., «Acuerdo sobre riesgos y peligros», LUHMANN, N., La moral de la sociedad, op. cit., pp. 323; ID., «La moral del riesgo y el riesgo de la moral», LuHMANN, N., La moral de la sociedad, op. cit., p. 333.

101 LuHMANN, N., «Acuerdo sobre riesgos y peligros», op. cit., pp. 323 y 324; ID., «La moral del riesgo y el riesgo de la moral», op. cit., p. 334. Al respecto resalta que los estudios empíricos han determinado que ha disminuido la confianza en la competencia de los expertos, en las organizaciones industriales y en los sistemas políticos, ID., «Acuerdo sobre riesgos y peligros», op. cit., p. 326.

102 LUHMANN, N., «Acuerdo sobre riesgos y peligros», op. cit., p. 329. Inclusive la decisión de cometer un delito supone un riesgo porque «remite al problema de la criminalización moral de la acción dispuesta al riesgo. Aquellos que se adentran en la zona de disponibilidad para el riesgo moralmente precaria pero aún no criminalizada, por ejemplo en la consolidación del aprovechamiento industrial de la energía nuclear, ¿son criminales o no? Y si antes de Chernobyl no lo eran, ¿lo son después de Chernobyl? (...) En la medida en que la opinión pública exige un juicio/condena unívoco, no será fácil implementar una especie de «teoría a varios niveles» y afirmar la distinción entre la conducta arriesgada criminal y la que sólo es moralmente rechazada, tanto menos cuando la maquinaria legislativa está a disposición», ID., «La moral del riesgo y el riesgo de la moral», op. cit., pp. 335 y 336.

103 LUHMANN, N., «La moral del riesgo y el riesgo de la moral», op. cit., p. 338.

104 ID., ibidem, op. cit., p. 341. 
Los avances científicos de las últimas décadas precisan de una nueva reformulación del Derecho penal, al menos su especial atención. A continuación vamos a desglosar las diferentes posiciones científicas con el objetivo de ver si estos avances ocasionan alguna modificación relevante en las instituciones del Derecho penal, y más concretamente, en la culpabilidad y su relación con los comportamientos criminales por motivos morales.

En las teorías sobre el libre albedrío, así también según lo expuesto en las teorías filosóficas de la libertad de la voluntad, yacen siempre las formas de comprender el mundo: las teorías deterministas e indeterministas y las teorías intermedias sobre la libertad de la voluntad. Por ejemplo, la escuela positiva italiana abogaba por el determinismo y la negación del libre albedrío $^{105}$. Las teorías ambientalistas de la criminalidad nunca llegaron a sustentarse en datos objetivos ni científicos confiables, sin perjuicio de que sirvieron para ayudar a entender la inimputabilidad.

Pues bien, entre las investigaciones neurocientíficas a destacar en las últimas décadas debemos señalar la de LIBET $^{106}$. Concluyó que los actos voluntarios son sólo aparentemente voluntarios, que provienen de una previa actividad neuronal inconsciente (sistema límbico) que determina nuestra posterior actividad de razonamiento consciente, por lo que la consciencia es una determinación neuronal. Posteriormente HAYNES ${ }^{107}$ demostró que diez segundos antes de ser conscientes de haber tomado una decisión, la actividad cerebral ya registra una actividad tal en el

105 FERRI consideraba que la consciencia de libertad es una mera ilusión por la falta de todos los datos previos, FERri, Enrico, Principii di Diritto Criminale. Delinquente e delitto, Torino, 1928; LomBroso pensaba que la apariencia del sujeto marcaba su carácter (criminalidad antropológica), LoMBRoso, Cesare, L'Uomo delinquente, $2^{\mathrm{a}}$ ed., Boca, Turín, 1870.

${ }_{106}$ Vid. y más ampliamente BALBUENA PÉREZ, David Eleuterio, Derecho penal, neurociencia y libertad. Una aproximación teórica al replanteamiento de la responsabilidad penal a propósito de las aportaciones neurocientíficas sobre el proceso mental para formación de la voluntad, Ed. Marben, Asunción, 2014, p. 29; DEMETRIO CRESPO, Eduardo, «La libertad de voluntad, investigación sobre el cerebro y responsabilidad penal. Aproximación a los fundamentos del moderno debate sobre Neurociencias y Derecho penal», InDret., 2011, p. 21 y ss; FEIJOO SÁNCHEZ, Bernardo José, «Derecho penal y Neurociencias. ¿Una relación tormentosa?», InDret., 2/2011, Barcelona, pp. 5 y ss; PARDo MiCHAEL S / PATTERSON DENNIS, «Fundamentos filosóficos del Derecho y la Neurociencia», InDret., 2/2011, p. 24. El estudio de LIBET parte de la concepción de SCHOPENHAUER sobre la determinación necesaria de libertad de voluntad, SCHOPENHAUER, A., Sobre la libertad de la voluntad, op. cit., pp. 48 y 156; de aquí también ENGISCH, Karl, La teoría de la libertad de la voluntad en la actual doctrina filosófica del Derecho Penal, $1^{\text {a }}$ ed., Ed. B de F, 2006.

107 Vid. BALBUEna PÉREZ, DE., Derecho penal, neurociencia y libertad, op. cit., p. 30. En este sentido RUBIA afirma que la libertad no sería más que una apreciación subjetiva que el ser humano se representa para poder vivir. El cerebro construye realidades que pasan a la conciencia como datos ciertos inclusive en los casos que el cerebro no puede comprender la realidad, la construye y recombina para darle realidad, RUBIA, Francisco José, «Neurociencia y libertad», Eduardo Demetrio Crespo (dir.) / Manuel Maroto Calatayud (coord.), Neurociencias y Derecho penal. Nuevas perspectivas en el ámbito de la culpabilidad y tratamiento jurídico-penal de la peligrosidad, Edisofer, Madrid, 2013, pp. 185 a 90; ID., La ficción de la libertad, Conferencia en el Congreso Internacional de Bioética, Valencia, 14 de noviembre de 2012, www.tendencias21.net, consultado el 15 de enero de 2015. Este planteamiento nos recuerda el principio de razón aristotélico basado en el principio de no contradicción. El ser humano no puede funcionar ante contradicciones, siempre tiene que escoger una y negar otra para seguir adelante en la percepción de la realidad, en el razonamiento, toma de decisiones y la dirección de la voluntad. 
mismo sentido que la decisión consciente. No sin críticas ${ }^{108}$, esto vendría a confirmar que se puede hacer una predicción de las decisiones del ser humano segundos antes de que se tomen conscientemente.

El debate del determinismo de la libertad y de la responsabilidad penal se recrudeció con el artículo de varios neurobiólogos ${ }^{109}$ que, grosso modo, esgrimen que la actividad cerebral de los motivos inconscientes, y especialmente la memoria cerebral, determinan nuestra conciencia un segundo o dos antes ${ }^{110}$. Sin embargo los datos que comprueban la Neurociencia y la Psicología son todavía insuficientes para fundamentar la «causa» o imputación de comportamientos tan complejos como los delictivos. Las investigaciones únicamente han señalado que existe actividad cerebral previa a la toma de decisiones, previa a la ejecución o que existen motivos inconscientes, por eso, la posición de la doctrinal penal más autorizada apenas ha sufrido cambios en sus postulados a este respecto.

La doctrina penal se ve obligada a concebir la libertad como presupuesto a priori de la responsabilidad penal ${ }^{111}$. En la doctrina alemana, VON LISZT ${ }^{112}$ defendió la imputabilidad como

108 Críticamente se ha combatido estos experimentos alegando que no había una deliberación libre sino condicionada por los propios experimentos, SOLER GIL, Francisco José, «Relevancia de los experimentos de Benjamin Libet y de John-Dylan Haynes para el debate en torno a la libertad humana en los procesos de decisión», Thémata, Revista de Filosofía, núm. 41, 2009, pp. 544 y 545.

109 MONYER H / RÖSLER F / Roth G / SCHEICH H / SINGER W / ELGER CE / FRIEDERICI Ad / KOCH C / LUHMANN H / VON DER MALSBURG C / MENZEL R., «Das Manifest. Elf führende Neurowissenschaftler über Gegenwart und Zukunf der Hirnforschung», Gehirn \& Geist, núm. 6, 2004, pp. 30 y ss. (trad. en RuBIA, El fantasma de la libertad, 2009, pp. 151 y ss.).

110 Vid. DEMETRIO CRESPO, E., «La libertad de voluntad», op. cit., pp. 6, 13 y 14. SingER llega a la conclusión de que la construcción de nuestros pensamientos responde a funciones cerebrales determinadas por procesos psíquicos, determinados igualmente por la experiencia que desdobla un yo construido socialmente mediante la interacción entre las personas pero distinto al «yo». En su opinión, nuestras percepciones son el resultado de procesos constructivos al igual que sucede en los animales, pero que en el caso de los seres humanos se magnifican en la interacción social entre los sujetos mediante el reconocimiento e identificación social, más ampliamente ID., ibidem, op. cit., pp. 10 y ss; BALBUENA PÉREZ, DE., Derecho penal, neurociencia y libertad. op. cit., p. 51 y ss. Similarmente, para el psicólogo PRINZ la libertad de voluntad es una producción cultural de la comunicación social que no existe científicamente, pero que sin embargo crea un mundo (instituciones) interrelacionado intuitivamente sobre la base de la libertad que posibilita la prohibición de regreso. Puesto que el sujeto se ha interaccionado bajo el presupuesto de la libertad, puede presuponerse que pudo actuar de otra manera, entonces es responsable por cuanto su interrelación se ha presupuesto libre. La percepción de los fenómenos psíquicos sólo aporta una imagen incompleta, por lo que la percepción de la libertad es una interpretación psicológica. De aquí deviene, por un lado, una realidad objetiva, y por otro, una subjetiva, como sería la libertad de la percepción, vid. DEMETRIO CRESPO, E., «La libertad de voluntad», op. cit., pp. 7 a 10.

111 Demetrio Crespo, E., «La libertad de voluntad», op. cit., pp. 30 y 31; ViVES ANTÓN, Tomás Salvador, «Neurociencia y determinismo reduccionista: una aproximación crítica», Eduardo Demetrio Crespo (dir.) / Manuel Maroto Calatayud (coord.), Neurociencias y Derecho penal. Nuevas perspectivas en el ámbito de la culpabilidad y tratamiento jurídico-penal de la peligrosidad, op. cit., pp. 219 a 233; FEIOO SÁNCHEZ, BJ., «Culpabilidad jurídicopenal y Neurociencias», Eduardo Demetrio Crespo (dir.) / Manuel Maroto Calatayud (coord.), Neurociencias y Derecho penal. Nuevas perspectivas en el ámbito de la culpabilidad y tratamiento jurídico-penal de la peligrosidad, op. cit., pp. 269 a 298; ID., «Derecho penal y Neurociencias. ¿Una relación tormentosa?», op. cit; RAMOS VÁZQUEZ, José Antonio, Ciencia, libertad y Derecho penal, (Aportaciones del determinismo y defensa de la libertad de acción como base del sistema pena), Tirant lo Blanch, Valencia, 2013; ID., «La pregunta por la libertad de acción (y una respuesta desde la filosofía del lenguaje)», Eduardo Demetrio Crespo (dir.) / Manuel Maroto Calatayud (coord.), 
la libertad de autodeterminación por el sujeto a través de motivos previos, ya que sin éstos la conducta sería un puro azar. Sin embargo, muy acertadamente JAKOBS, entre otros, se ha referido a la irrelevancia del libre albedrío ${ }^{113}$ para la culpabilidad penal, por cuanto ésta se sustenta en cuestiones ajenas a la concepción de la libertad en el Derecho. En concreto, JAKOBS se refiere a la idea de falta de fidelidad al Derecho cuando el sujeto tiene alternativas en su esfera de auto-organización para actuar de otra forma que no quebrante la norma, y en esta medida la culpabilidad no es una construcción psicológica ni neurológica, sino social ${ }^{114}$, de tal modo que la culpabilidad tiene una función preventiva, general y positiva de mantener el Sistema Social, comunicando que ciertas conductas defraudan la expectativa social de los demás, pero sobre

Neurociencias y Derecho penal. Nuevas perspectivas en el ámbito de la culpabilidad y tratamiento jurídico-penal de la peligrosidad, op. cit., pp. 137 a 160.

${ }^{112}$ LISZT, Franz von, Tratado de Derecho penal, T. II, trad. Jiménez de Asúa y Quintiliano Saldaña, $3^{\mathrm{a}}$ ed. de $20^{\mathrm{a}}$ ed. alemana, Reus, p. 389 en cuanto que la conducta humana puede ser determinada por representaciones tales como la religión, la moral y el Derecho.

113 JAKOBS, Günther, Derecho penal, Parte General, Fundamentos y teoría de la imputación, trad. Joaquín Cuello Contreras y José Luis Serrano González de Murillo, Marcial Pons, 1997, 17/23 y ss. En el mismo sentido ya se pronunció LISZT, Franz von, Tratado, T. II, op. cit., p. 389. Similarmente HIRSCH se refiere a que lo importante es que el ser humano se auto-percibe libre, por eso cualquier determinismo comprobado por la neurociencia no afecta a la responsabilidad penal. Opina que un Derecho penal basado en el determinismo daría problemas de políticacriminal y abocaría nuevamente a un Derecho penal de resultados, en el que la acreditación del abandono de la vida criminal parecería fundamento bastante para dejar de aplicar una pena o medida de seguridad o, por el contrario, a actuar excesivamente contra el reincidente, HIRSCH, Hans Joachim, «Acerca de la actual discusión alemana sobre libertad de voluntad y Derecho Penal», Eduardo Demetrio Crespo (dir.) / Manuel Maroto Calatayud (coord.), Neurociencias y Derecho penal. Nuevas perspectivas en el ámbito de la culpabilidad y tratamiento jurídico-penal de la peligrosidad, op. cit., pp. 28 y 29. En sentido similar y entendido la culpabilidad desde la propia perspectiva del autor si considera que tiene alternativas BURKHARDT, Björn, «La comprensión de la acción desde la perspectiva del agente en el derecho penal», en ALCÁCER GUIRAO, Rafael, El problema de la libertad de la acción en el Derecho Penal, Buenos Aires, 2007; en cambio, Roxin entiende la culpabilidad como la capacidad del sujeto de adecuarse a la norma o de escoger entre las conductas que no quebrantan la norma, Roxin, Claus, Derecho penal, Parte General, T. I, Fundamentos. La estructura de la teoría del delito, trad. y notas Luzón Peña / Díaz y García Conlledo / De Vicente Remesal de la $2^{a}$ ed. alemana, Civitas, 1997, pp. 791 y ss; En otro sentido, pero arribando a la misma conclusión, HASSEMER afirma que al Derecho penal sólo le interesa determinar si el sujeto es imputable o no (principio de imputación, especialmente la imputación subjetiva en cuanto que permite la valoración de grados de evitabilidad, dolo e imprudencia basados en razones sociales), HASSEMER, Winfried, «Neurociencias y culpabilidad en Derecho penal», InDret., 2/2011, pp. 8 y ss. Se presume la libertad del sujeto, ID., ibidem, op. cit., p. 9. Por tal motivo denuncia la intromisión de la neurociencia al utilizar criterios impropios del Derecho penal, ID., ibidem, op. cit., pp. 4 y ss. Comenta que la Verdad no es la misma verdad en una ciencia que en otra, o al menos cada ciencia busca una verdad distinta, y por ello una ciencia no puede entrar en otra dominándola en el objeto y en los presupuestos, bajo pena de incurrir en un «error categorial», ID., ibidem, op. cit., p. 6; en el mismo sentido FEIJOO SÁNCHEZ, BJ., «Derecho penal y Neurociencias. ¿Una relación tormentosa?», op. cit., p. 11. La Verdad que se instruye en un procedimiento penal, comenta HASSEMER, es una verdad limitada a la concurrencia de los demás derechos, la duda prima en el debate procesal con el principio in dubio pro reo y por ende las dudas sobre la responsabilidad del sujeto se construyen desde una perspectiva indeterminista del mundo en donde la culpabilidad se asienta en sus causas propias de exclusión, HASSEMER, W., «Neurociencias y culpabilidad», op. cit., p. 12. En el mismo sentido Klaus GÜNTHER, apela que la experiencia demuestra que la mayoría de personas tiene capacidad cognitiva y volitiva, es decir, presunción de normalidad, por lo que la culpabilidad puede ser impugnada, la culpabilidad tiene un sentido normativo por cuanto se presume que la mayoría de sujetos tienen poder de actuar de otra manera, el particular también, vid. DEMETRIO CRESPO, E., «La libertad de voluntad», op. cit., pp. 25 y 26.

114 Así también FeIJOO SÁNCHEZ, BJ., «Derecho penal y Neurociencias. ¿Una relación tormentosa?», op. cit., p. 28. 
todo, del propio Sistema Social. Por ende, la pena cumple la función de restablecer la defraudación generada en el Sistema: la pena lo reconstruye.

Parte de la doctrina otorga algún valor a la neurociencia en las instituciones del Derecho penal, sobre todo en la inimputabilidad y en las medidas de seguridad. Desde los postulados de la prevención general positiva se defiende la separación del Derecho penal y la neurociencia en cuanto que el primero sanciona hechos sociales, la culpabilidad sólo puede entenderse como un quebrantamiento normativo desde el presupuesto de la libertad en una sociedad democrática que acredita precisamente dicha libertad y su reconocimiento social (sistema de reconocimientos de la dignidad y el libre desarrollo de la personalidad como fundamentos de la legitimidad de las normas) ${ }^{115}$, sin embargo se reconoce que la neurociencia puede ayudar a la forma de aplicar el Derecho penal en las medidas de seguridad y en las medidas terapéuticas, por ejemplo en aquellos casos comprobados en los que la neurociencia demuestra que los tumores cerebrales condicionan altamente la conducta del sujeto, sin la cual se hubieran tratado como psicopatías y maldad sin ninguna trascendencia penal ${ }^{116}$.

Pues bien, en nuestra opinión, este sentimiento o intuición de la libertad que tenemos generalmente todos los seres humanos recuerda aquel concepto aristotélico del principio de no contradicción. El ser humano es tal porque siempre se ve obligado a elegir para contraponer una cosa a otra, de tal manera puede conformar un mundo posible: hacer posible lo imposible.

Los anteriores postulados científicos demuestran al menos que ciertas conductas pueden estar, si no predeterminadas, sí decisivamente inclinadas sin que exista por ello una solución en la inimputabilidad, sino que en nuestra opinión redundan en los postulados entre conciencia y voluntad, una cuestión estrictamente subjetiva con trascendencia social y a partir de lo social. En ocasiones la conciencia se autodetermina de tal manera que no deja resquicio alguno a una voluntad conforme a la norma. A esta singularidad se le ha tratado muchas de las veces de

115 FEIJOO SÁNCHEZ, BJ., «Derecho penal y Neurociencias. ¿Una relación tormentosa?», op. cit., pp. 38, 43 y ss.

116 BAlbuena PÉREZ, DE., Derecho penal, neurociencia y libertad, op. cit., p. 84; CANCIO MELIÁ, M., «Psicopatía y Derecho penal: algunas consideraciones introductorias», Fernández Teruelo JG / González Tascón MM / Villa Sieiro SV (Coords.), Estudios penales en homenaje al profesor Rodrigo Fabio Suárez Montes, Constitutio Criminalis Carolina, Oviedo, 2013, pp. 115 y ss., 119 y ss; DEMETRIO CRESPO, E., «La libertad de voluntad», op. cit., p. 31; de esta opinión y sobre casos concretos en FEIJOO SÁNCHEZ, BJ., «Derecho penal y Neurociencias. ¿Una relación tormentosa?», op. cit., p. 2 y ss., 40 y ss. En suma, señala FeIJOO SÁNCHEZ, «no debemos conocer si estamos determinados, sino cómo lo estamos», ID., ibidem, op. cit., p. 19. Esto sólo se puede resolver mediante un «acoplamiento estructural» entre el mundo jurídico y las ciencias, ID., ibidem, op. cit., p. 20. Comenta que «(l)as personas son unidades de imputación en la medida en la que tienen adscrita por el sistema jurídico un haz de libertades. Las ideas de KANT sobre la persona como unidad de imputación basadas en su filosofía moral se pueden traducir en términos de filosófica social. La culpabilidad no tiene que ver con la libertad en sentido metafísico, trascendente o naturalístico sino con el proceso histórico de reconocimiento social y normativo de la libertad de actuación, que conlleva necesariamente la correspondiente responsabilidad por las consecuencias de dicha libertad», ID., ibidem, op. cit., p. 44; ID., «Culpabilidad jurídico-penal y Neurociencias», op. cit., pp. 294 a 298; 
enfermedad, otras veces de determinismo neurobiológico o psicológico, sin atenderse a que el ser humano siempre se constituye como la unión entre conciencia y voluntad. Lo que habrá que determinar y trataremos de hacer en esta investigación es, qué fuerza de unión tienen y si trasciende a la responsabilidad.

\section{V.- Hacia la libertad de creencias}

\section{A. Introducción}

Tras la Segunda Guerra Mundial fue necesario proteger los más básicos derechos del hombre, para impedir sucesos tan horrendos como los acaecidos en los campos de concentración nazi. La Declaración de Derechos Humanos de 10 de diciembre de 1948 preceptúa en el art. 2.1 la libertad religiosa, y en el art. 18 desarrolla libertad de pensamiento, de conciencia y de religión, que incluye la libertad de manifestar la creencia individual y colectivamente. Años más tarde el Pacto Internacional de Derecho civiles y políticos de 1966 y diversos pactos y convenios internacionales garantizaron la libertad de pensamiento, de conciencia, de religión, creencias o convicciones.

Todas estas manifestaciones son en realidad plurales y jurídicamente determinables de la misma realidad $^{117}$. La libertad de creencias, como reducto personal, no tiene sujeción imperativa a los sistemas religiosos o filosóficos, las personas son libres para adoptar una propia creencia, a diferencia de lo que sucedía en el mundo clásico según las conclusiones que hemos alcanzado, significativamente hasta la Declaración de Virginia en 1776 y la Revolución francesa con en la Declaración de Derechos del Hombre y del Ciudadano de 1789.

Finalmente en España, tras más de un siglo de vaivenes entre la limitación y cierta tolerancia religiosa, la democracia y su máxima representación escrita en la Constitución española, tras varios borradores, recogieron en el art. 16 de la misma la libertad de conciencia. El art. $16 \mathrm{CE}$ supuso toda una novedad en materia de libertad religiosa a pesar de la aconfesionalidad del Estado, que no laicidad ni ateísmo estatal. Este artículo utiliza dos expresiones, libertad ideológica y religiosa, si bien se garantiza con esta pluralidad la misma realidad: la libertad de tener una forma de entender la vida personal o colectivamente a través de sentimientos ideológicos, filosóficos o religiosos, y la libertad de cambiar. Esta libertad es irrenunciable,

\footnotetext{
117 En este sentido SOUTO PAZ comentaba que «la libertad de creencias, que reconoce y garantiza la Declaración Universal de Derechos Humanos, en su versión de libertad de pensamiento, conciencia, religión, creencias o convicciones, se refiere (...) a ese ámbito de autonomía personal que alberga la propia concepción del mundo y de sí mismo, la propia cosmovisión, que constituye el estrato más profundo de nuestra vida, esa tierra firme en la que estamos, que nos tiene y nos sostiene», SouTo PAZ, JA., Comunidad política y libertad de creencia, op. cit., p. 14.
} 
intransferible y personal ${ }^{118}$. La fuente puede ser cualquiera, filosófica, ideológica, religiosa, ética, sin embargo con la expresión «libertad de creencias» la CE parece insistir en la no importancia de que éstas sean religiosas. A pesar de no aparecer en el art. 16 CE la expresión «libertad de conciencia», la jurisprudencia del Tribunal Constitucional ${ }^{119}$ se encargó de incluirla como una variedad más de la libertad de apreciar una propia cosmovisión y, además da sustento a otras libertades como el derecho a la educación y el derecho de expresión ${ }^{120}$.

$\mathrm{El}$ art. $16 \mathrm{CE}$ ordena la cooperación con las confesiones religiosas, que se desarrolló con la Ley Orgánica de Libertad Religiosa de 5 de julio de $1980^{121}$, pero este desarrollo se circunscribe a la libertad religiosa y no a la libertad de creencias no religiosas como por ejemplo la ideológica $^{122}$. A pesar de esta exclusión, el art. 10 de la $\mathrm{CE}^{123}$ ordena interpretar los derechos reconocidos en la constitución conforme a los tratados ratificados, sobre todo en relación al art. 18 del PIDCP que incluye la expresión «religión y convicciones de su elección».

Por nuestra parte, entendemos que tanto una como otra libertad tienen el mismo rango jurídico, ambas presuponen un poder semejante de trasformación de la conducta de las personas $^{124}$. Hay voces que consideran que la convicción política tiene menor intensidad, es

118 Como afirma Souto PAZ, «(e)ste derecho implica -según el convenio- la libertad de cambiar de religión o de convicciones. La expresión convicciones reafirma la tesis antes apuntada y la libertad de cambiar de cosmovisión (...) ratifica la idea de que el derecho que se garantiza es esa dimensión irrenunciable de la persona humana de elegir y, en su caso, cambiar la propia cosmovisión», ID., ibidem, op. cit., p. 220.

119 STS 53/1985, de 11 de abril.

120 STS 20/1990, de 15 de febrero.

121 La LOLR en su artículo 1.1 garantiza que el estado proteja la libertad religiosa y de culto; el artículo 1.2 se protege la no discriminación por motivos religiosos; en el artículo 2 se relatan los derechos fundamentales contenidos; en el artículo 3 se establecen los límites al ejercicio de tales derechos; en el artículo 4 se establece la protección jurisdiccional; y en los artículos 5, 6 y 7, se reconoce a las entidades religiosas y sus derechos.

${ }_{122}$ Así lo dice esta ley excluyendo de su ámbito, en su art. 3.2 a «las actividades, finalidades y entidades relacionadas con el estudio y experimentación de los fenómenos psíquicos o parapsicológicos o la difusión de valores humanísticos o espiritualistas u otros fines análogos ajenos a los religiosos».

${ }^{123}$ MarTíneZ-Torrón, Javier, Normas de Derecho eclesiástico, Granada, 1998, p. 73. El Tribunal Constitucional en Sentencia 78/1982 FJ $4^{\circ}$ declaró que «(l)a Constitución se inserta en un contexto internacional en materia de derechos fundamentales y libertades públicas por lo que hay que interpretar sus normas en esta materia de conformidad con la Declaración Universal de Derecho Humanos y los Tratados y Acuerdos Internacionales que menciona al respecto (...) no sólo las normas contenidas en la Constitución, sino todas las del ordenamiento relativas a los derechos fundamentales y libertades públicas que reconoce la norma constitucional».

${ }_{124}$ Como dice LABRADA RUBIO al respecto «(l)a libertad de conciencia incluye la libertad de pensamiento y la de religión; se trata de la manifestación más importante de la libertad del hombre en cuanto afecta a la facultad que más le dignifica. La dignidad de la persona humana tiene su punto culminante en la conciencia, en su capacidad cognoscible», Labrada RuBIO, Valle, Introducción a la teoría de los Derechos Humanos: Fundamento. Historia. Declaración Universal de 10 de diciembre de 1948, Editorial Civitas, $1^{a}$ ed., 1998, p. 153; también tal y como dice SOUTO PAZ «(l)os derechos reconocidos a las entidades religiosas deben extenderse también a las asociaciones ideológicas, filosóficas o éticas, expresión utilizada en los primeros borradores de la Constitución y actualmente en la Declaración adoptada por la Conferencia en el Tratado de Ámsterdam», Souto PAZ, JA., Comunidad política y libertad de creencias, op. cit., p. 256. JERICÓ también aboga por una concepción amplia del término conciencia, JERICó OJER, Leticia, El conflicto de conciencia ante el Derecho penal, La Ley, 2007, p. 74. Concluye que «por conciencia deberá entenderse aquella instancia moral perteneciente a la esfera íntima del individuo desde la cual se originan para el sujeto una serie de conocimientos, decisiones, juicios e imperativos que informan la concepción 
menos inevitable, por ser política, admite dudas, es discutible, a diferencia de la convicción en la creencia $^{125}$, sin embargo si hacemos esta distinción no se respetaría el mismo rango constitucional que ordena el art. 16. De aquí que tanto la autoría de conciencia, aquella que suele decirse que se basa en motivos de conciencia morales y/o religiosos, como la autoría por convicción que suele señalarse como aquella que obra por motivos políticos o ideológicos, no se diferencian normativamente en el ámbito constitucional. Ambos casos debemos tratarlos, en principio, como autoría que obra por motivos tan internos que conforman ineludiblemente la voluntad y el comportamiento. El tratamiento diferenciado entre uno y otro tipo de autoría vendrá de otros criterios normativos.

El Tratado de Maastricht, de 7 de febrero de 1992, en su art. F asume los derechos fundamentales del Convenio Europeo para la Protección de los Derechos Humanos y de las Libertades Fundamentales de 1950. El artículo 9 CEDH preceptúa:

«1. Toda persona tiene derecho a la libertad de cambiar de religión o de convicciones, así como la libertad de manifestar su religión o sus convicciones individual o colectivamente, en público o en privado, por medio del culto, la enseñanza, las prácticas y la observación de los ritos. 2. La libertad de manifestar su religión o sus convicciones no puede ser objeto de más restricciones que las que, previstas por la ley, constituyan medidas necesarias, en una sociedad democrática, para la seguridad pública, la protección del orden, de la salud o de la moral pública o la protección de los derechos o las libertades de los demás».

El Tratado de Ámsterdam de 2 de octubre de 1997 modificó el anterior art. F del Tratado de Maastricht que quedó reflejado en el artículo 6 de la siguiente forma:

«1. La Unión se basa en los principios de libertad, democracia, respecto de los derechos humanos y de las libertades fundamentales y el Estado de Derecho, principios que son comunes a los Estados miembros».

Y el artículo 11 del Tratado de Ámsterdam reza:

«(l)a Unión Europea respeta y no prejuzga el estatuto reconocido, en virtud del Derecho nacional, a las iglesias y las asociaciones o comunidades religiosas en los Estados miembros. La unión Europea respeta asimismo el estatuto de las organizaciones filosóficas y no confesionales».

individual del mundo y las cosas (...) Esta noción de conciencia, será perfectamente aplicable al estudiar la objeción de conciencia y el conflicto de conciencia, pues no será el término conciencia, sino las nociones de objeción y de conflicto las que permitan establecer una diferencia», ID., ibidem, op. cit., p. 75.

125 LLAMAZARES FERNÁNDEZ opina que la ideología nunca es dogmática a diferencia de la creencia, la segunda es siempre revisable y discutible, mientras que la creencia no admite duda y se basa en la relación con un ser superior, LlAmAZARES FERNÁNDEZ, Dionisio, «Sectas y Derecho fundamental de Libertad de conciencia», vv.aa., Aspectos socio-jurídicos de las sectas desde una perspectiva comparada / The Oñati Internacional Institute for the Sociology of Law, 1991, edited by Juan Goti Ordeñana, p. 135. 
Posteriormente el Consejo de Europa proclamó el día 7 de diciembre del 2000 la Carta de Derechos fundamentales de la Unión Europea, que además de regular los anteriores derechos y significativamente la libertad de educación de los hijos conforme a las convicciones religiosas, filosóficas y pedagógicas de los padres, incluyó la novedad de reconocer la objeción de conciencia «de acuerdo con las leyes nacionales que regulen su ejercicio» ${ }^{126}$.

La conclusión más importante que extraemos de lo anterior es que, aparte de las limitaciones que pueden tener los derechos referidos, la libertad de poseer y elegir creencias, en su más extenso sentido, es un derecho absoluto y quizás el único.

B. El reconocimiento de la libertad de conciencia como objeción de conciencia en nuestro ordenamiento jurídico

\section{Definición y requisitos}

Hemos estudiado que en ocasiones la conciencia y la voluntad se vinculan de tal manera que la ley jurídica no doblega la estrecha fuerza que se crea entre ellas. Estos comportamientos suelen asociarse a la objeción de conciencia como aquella manifestación concreta del comportamiento que se asienta en la libertad de conciencia. La polémica viene del reconocimiento general de la libertad de conciencia, esto es: una norma fundamental que orienta un horizonte de expectativas y manifestaciones conforme a la conciencia. Sin embargo, el Derecho neutraliza diversos comportamientos siéndole ajeno algunas de las manifestaciones de la conciencia. Aquí nace la objeción de conciencia. Esta objeción o denuncia particular del ciudadano ha alcanzado en las últimas décadas un reconocimiento mayor, fundamentalmente propiciado con la antigua prestación sustitutoria al servicio militar, pero también en otros ámbitos como el sanitario (aborto, tratamientos médico vitales, eutanasia, investigación de células madre, etc.).

Resulta problemático distinguir entre una objeción de conciencia que pretende confirmarse a través del derecho fundamental a la libertad de conciencia, y una objeción de conveniencia que parece simplemente escapar de los dictados de las leyes. Diferenciar tales supuestos es vital en nuestro ordenamiento, pues la objeción de conciencia se reconoce y se garantiza mientras que una objeción de conveniencia, aquella que suele relacionarse con el autor por convicción, se relaciona con una actitud despreciable por la sociedad.

\footnotetext{
126 Souto PAZ, JA., «Comentarios a la Carta de los Derechos Fundamentales de la Unión Europea», RPJ, Tercera época, núm. 61, 2001, pp. 63 a 85, ID., Comunidad política y libertad de creencia, op. cit., pp. 221 a 223.
} 
En tal sentido, la doctrina española mayoritaria ${ }^{127}$ considera, al igual que la jurisprudencia del TC en SS 15/1982, de 23 de abril (FJ $3^{\circ}$ ) y 53/1985 de 11 de abril (FJ 14º), y la jurisprudencia del TS en Sentencia de 15 de octubre de 1993, que la libertad de conciencia se reconoce a través de la libertad ideológica y religiosa expresamente reconocidas en el art. $16 \mathrm{CE}$, si bien estamos de acuerdo con aquella parte de la doctrina que defiende ${ }^{128}$ que estas libertades son especificaciones de la libertad de conciencia en cuanto derecho a la formación de la conciencia general. Esto es porque sin capacidad para la formación difícilmente nace la posibilidad de actuar conforme a la conciencia, sea tanto ideológica, religiosa, por convicción, filosófica, o de cualquier naturaleza.

127 CASTRO JOVER, Adoración, «La libertad de conciencia y la objeción de conciencia individual en la jurisprudencia constitucional española», La libertad religiosa y de conciencia ante la justicia constitucional, ed. Javier Martínez-Torrón, Actas del VIII Congreso Internacional de Derecho eclesiástico del Estado, Comares, Granada, 1998, op. cit., p. 140; CÁMARA VILLAR, Gregorio, «La objeción de conciencia en España como derecho fundamental y el principio de igualdad», Anuario de Derecho Público. Estudios Políticos, 2, 1989-1990, pp. 270 y ss; Cuerda RIEZU, A., El delito de aborto ante la Propuesta de Anteproyecto del nuevo Código penal, op. cit, p. 382; De Asís RoIG, Rafael, «Las tres conciencias», Ley y conciencia. Moral legalizada y moral critica en la aplicación del derecho. Edición a cargo de Gregorio Peces-Barba. Instituto de derechos humanos Bartolomé de las Casas. Universidad Carlos III de Madrid. Boletín oficial de Estado, Madrid 1993, p. 34; EsCOBAR RoCA, Guillermo, La objeción de conciencia en la Constitución española, Centro de Estudios Constitucionales, Madrid, 1993, pp. 185 y ss., y 193; ESCRIVÁ IVARS, Javier, «La objeción de conciencia al uso de determinados medios terapéuticos», La objeción de conciencia. Actas del VI Congreso Internacional de Derecho Eclesiástico del Estado, Valencia 28-30 mayo de 1992, V. Guitarte Izquierdo y J. Escrivá Ivars (Eds.), Generalitat Valenciana y Consejo General del Poder Judicial, Valencia, 1993, pp. 123 y ss; FloRES MENDOZA, Fátima, Objeción de conciencia en Derecho penal, Comares, Granada, 2001, pp. 112 y 113; GARCíA ARÁN, M., «La objeción de conciencia del médico en relación a la interrupción del embarazo», op. cit., pp. 119 y ss; GARCÍA HERRERA, Miguel Ángel, La objeción de conciencia en materia de aborto, Departamento de Sanidad, Servicio Central de Publicaciones del Gobierno Vasco, Vitoria, 1991, pp. 100 y 119; GASCÓN ABELláN, Marina, «A vueltas con la insumisión», Jueces para la Democracia, 27, 1996, p. 18; ID., Obediencia al Derecho y objeción de conciencia, $1^{a}$ ed., Centro de Estudios Constitucionales, Madrid, 1990, pp. 168 y ss., pp. 256, 271 y pp. 302 y ss; JERICó OJER, L., El conflicto de conciencia, op. cit., pp. 74 y ss. y p. 139; JIMÉNEZ VILLAREJO, José, «Objeción de conciencia e insumisión. Una aproximación desde el derecho penal», Vinculación del Juez a la ley penal, CDJ, XVII, Consejo General del Poder Judicial, Madrid, 1995, p. 245; LABRADA RUBIO, Valle, Introducción a la teoría de los Derechos Humanos, op. cit., p. 153; LLAMAZARES FERNÁNDEZ, D., Derecho de la libertad de conciencia, I, Libertad de conciencia y laicidad, $1^{\mathrm{a}}$ ed., Civitas, 1997, p. 228; MARTín SÁNCHEZ, I., El Derecho a la formación de la conciencia y su tutela penal, Tirant lo Blanch, Valencia, 2000, pp. 25 y ss; OlIVER ARAuJO, Joan, La objeción de conciencia al servicio militar, Civitas, Madrid, 1993, p. 200 y ss; PECES-BARBA, Gregorio, Derechos fundamentales, Madrid, 1983, p. 98; PÉREZ DEL VALle, C., Conciencia y Derecho penal. Límites a la eficacia del Derecho penal en comportamientos de conciencia, Comares, Granada, 1994, pp. 35 y 40; PRIETO SANCHís, Luis, «Insumisión y libertad de conciencia (A propósito de la sentencia 75/92 del Juzgado de lo Penal número 4 de Madrid de 3 de febrero de 1992», Ley y conciencia. Moral legalizada y moral crítica en la aplicación del Derecho, op. cit., p. 137; SouTO PAZ, JA., «La libertad ideológica y religiosa en la jurisprudencia constitucional», Las relaciones entre la Iglesia y el Estado. Estudios en memoria del profesor Pedro Lombardía, Madrid, 1989, p. 516; TAMARIT Sumalla, JMa ., La libertad ideológica en el Derecho penal, PPU, Barcelona, 1989, p. 41.

128 Por ejemplo MARTín SÁnCHEZ, I., El Derecho a la formación de la conciencia, op. cit., p. 22 y pp. 58 y 59 , y añade que «el derecho a la libre formación de la conciencia, en cuanto presupuesto lógico y necesario para poder elegir libremente una convicción, religiosa o no, y no como el derecho a actuar de acuerdo con unas convicciones, las cuales presuponen una conciencia formada conforme a la que se han elegido», ID., ibidem, op. cit., p. 26; MARTínEZ-TORRÓN, J., «El derecho a la libertad religiosa en la jurisprudencia en torno al Convenio Europeo de Derecho Humanos», ADEE, II, 1986, pp. 422 y ss. 
La libertad de conciencia se puede concebir -siguiendo en parte a LUHMANN- como el propio e ineludible sistema psíquico de pensamientos que conforma la conciencia, de forma que la multiplicidad de pensamientos y sentimientos constituyen un sistema autopoiético y autorreferencial cerrado $^{129}$, y su libertad el producto de dichas operaciones. Por tal motivo las influencias del entorno, como el Derecho, limitan y reestructuran la operatividad de la conciencia y por ende la voluntad, a modo de orientación de alternativas en la autonormatividad del sistema psíquico.

En este sentido, LUHMANN explicaba que el conflicto de conciencia se basa en una necesidad moral de comportamiento que infringe las normas. De esta manera, la conciencia tiene una función de «control» entre el sistema psíquico y la norma ${ }^{130}$, pero en determinados momentos la conciencia no puede institucionalizarse normativamente ni precisa de consenso pues se autonormativiza sin influjo del sistema normativo ${ }^{131}$, de aquí el conflicto. Así, la libertad de conciencia supone la institucionalización del derecho fundamental a la autonormatividad de la conciencia, en la vinculación de dicha normatividad a la norma social. La libertad de conciencia no protege la conciencia sino se protege de ella ${ }^{132}$, de modo que propone como forma de averiguar la seriedad y realidad del comportamiento de conciencia, su coherencia ${ }^{133}$. De aquí que la libertad de conciencia esté estrechamente relacionada con la dignidad humana, como todos los derechos fundamentales como institución ${ }^{134}$. Se puede concluir que algunas conductas de conflicto de conciencia se pueden basar en el miedo, pero a la vez el orden social en determinas situaciones no exige un comportamiento tan fiel a la norma. Sin embargo, en un mundo altamente normativizado, existen tantas alternativas de acción gracias a la estructura diferenciada de la sociedad, que difícilmente se llegan a situaciones en las que se deba tomar una decisión de

129 LUHMANN, N., Sistemas sociales, op. cit., pp. 236 y ss.

130 LuhManN, N., «Die Gewissensfreiheit und das Gewissen», AÖR, 90, 1965, pp. 257 a 267, también ID., «Die Gewissensfreiheit und das Gewissen», Die Ausdifferenzierung des Rechts, Frankfurt a. M., 1981, pp. 326 a 359.

131 LuhmanN, N., «Die Funktion der Gewissensfreheit im oeffentlichen Recht», Funktion des Gewissens im Recht, Frankfurt a. M., 1970, pp. 9 a 22; ID., «Das Phänomen des Gewissens und die normative Selbstbestimmung der Persönlichkeit», Franz Böckle / Erns-Wolfgang Böckenförde Hg., Naturrecht in der Kritik, Mainz, Grünewald, 1973 , pp. 223 a 243.

${ }_{132}$ LUHMANN, N., Los derechos fundamentales como institución (Aportación a la sociología política), Universidad Iberoamericana, 2010, p. 167.

133 Luhmann, N., «Die Gewissensfreiheit und das Gewissen», op. cit., pp. 281, también en ID., «Die Gewissensfreiheit und das Gewissen», op. cit., p. 356 y 357.

134 En este sentido, dice LUHMANN que «(1)a autoconciencia individual puede trasformar la confirmación social de acciones particulares, convirtiendo el éxito de autorrepresentaciones particulares en una confirmación de la propia persona en su totalidad. La auto-seguridad que de allí resulta hace posible sustituir, en mayor o menor medida, el apoyo externo en expectativas, roles e instituciones definidos con toda precisión y, en ese sentido, liberar internamente al ser humano. De esta manera, puede alcanzarse un alto grado de sujeción del miedo, aun en situaciones que no están claramente determinadas en lo social», LuHMANN, N., Los derechos fundamentales como institución, op. cit., p. 135. Y añade que «(u)n orden social que agobia estructuralmente a la personalidad individual debe, al mismo tiempo, aligerarla limitando sus exigencias», ID., ibidem, op. cit., p. 136. 
conciencia ${ }^{135}$ o decidir a favor de la propia muerte. Así, la libertad y concretamente la libertad de conciencia se refiere a «las condiciones y problemas externos de la autorrepresentación de sí mismo como personalidad individual», mientras que la dignidad se refiere a las condiciones y problemas internos ${ }^{136}$. De este modo, acertadamente, LUHMANN trata la libertad de conciencia como condición previa de la libertad religiosa, ideológica o de culto, ligada íntimamente a la dignidad, puesto que sin ésta difícilmente se puede configurar una «autorrepresentación» trascendental de comunicación particular. De aquí parten los factores de creación de la civilización de expectativas y consecuentemente la diferenciación social

Para un sector doctrinal, sólo constituiría objeción de conciencia la que no estuviera expresamente reconocida en las leyes como derecho general de la objeción de conciencia ${ }^{137}$, mientras que para otro sector, sólo sería aquella que se reconoce en el ordenamiento jurídico como objeción de conciencia legalizada ${ }^{138}$, como la objeción de conciencia al servicio militar obligatorio, la de los médicos ante el aborto y la de los profesionales de la información, es decir, excepcional. Por nuestra parte, nos posicionamos a favor de que la objeción de conciencia es un derecho general a la formación y elección de conciencia, principalmente expresado en el art. 16 $\mathrm{CE}$, que encuentra limitaciones particulares y funcionales en el comportamiento exteriorizado según la operatividad básica de la Sociedad.

La doctrina mayoritaria considera que la problemática estriba entre un conflicto de un derecho como es la objeción de conciencia y un deber que se impone por la CE y por el ordenamiento

135 ID., ibidem, op. cit., pp. 167 y 168.

136 ID., ibidem, op. cit., p. 168.

137 BAUCELLS se muestra a favor de un derecho constitucional de la dignidad de las personas como ejercicio y límite del derecho a la vida y de la libertad de conciencia, BAUCELLS I LLADós, Joan, La delincuencia por convicción, Tirant lo Blanch, Valencia, 2000, p. 215; Flores MENDOZA, F., Objeción de conciencia, op. cit., pp. 118 y 119, aunque dice que el fenómeno es excepcional; GASCÓN ABELLÁN, M., Obediencia al Derecho y objeción de conciencia, op. cit., pp. 281 y ss; NAVARRO VALls Rafael / MARTÍNEZ-TORRÓN Javier, Las objeciones de conciencia en el Derecho Español y Comparado, McGraw-Hill, Madrid, 1997, p. 12; PÉREZ DEL VAlle, C., Conciencia, op., cit., pp., 41 y ss; PRIETO SANCHÍs, L., «La objeción de conciencia», en IBÁN / PRIETO SANChís / MotILlA, Curso de Derecho eclesiástico, Madrid, 1991, p. 351; Romeo CASABONA, CMª., «El derecho a la objeción de conciencia», Héctor Gross Espiell Amicorum Liber. Persona Humana y Derecho Internacional., Vol. II, Bruylant, Bruxelles, 1997, pp. 1319 y 1320; SIERRA MuCIENTES, Sara, La objeción de conciencia sanitaria, Dykinson, Madrid, 2000, pp. 46 y ss.

138 DE LuCAS Javier / VidAL Ernesto / ANTÓN María Jesús, «Desobediencia o respeto a la conciencia», Ley y conciencia. Moral legalizada y moral critica en la aplicación del derecho, op. cit., pp. 91 y ss. y p. 111; JERICó OJER, L., El conflicto de conciencia, op. cit., p. 140; PECES-BARBA MARTíNEZ, G., «Desobediencia civil y objeción de conciencia», Anuario de Derechos Humanos, 1988-1989, p. 31; SouTO PAZ, JA., Derecho Eclesiástico del Estado. El Derecho de la libertad de ideas y creencias, $3^{\mathrm{a}}$ ed., revisada y ampliada, Marcial Pons, Madrid, 1995, p. 139. 
jurídico $^{139}$. Una opinión minoritaria considera que el conflicto puede consistir entre deberes (GÓMEZ BENÍTEZ ${ }^{140}$ ), o entre derechos y deberes (CONTRERAs MAZARIO) ${ }^{141}$.

La libertad de conciencia admite tres postulados o/y reconocimientos o/y niveles que son ampliamente admitidos por la doctrina ${ }^{142}$ : en primer lugar el derecho a formar y tener conciencia propia o colectiva; en segundo lugar, la libertad para expresarla; y en tercer lugar, la libertad de práctica o de adecuar la conducta a la conciencia. Es en este último nivel donde se crean las mayores dificultades de conciliación entre conciencia y ley, o deber moral y deber jurídico, precisamente porque en éste se aprecia una mayor amplitud del reconocimiento general a la

\footnotetext{
139 Romeo CASABona, CMª., El Derecho y la Bioética ante los límites de la vida humana, Centro de estudios Ramón Areces, 1994, p. 126.

140 GómEZ BENíTEZ considera que el conflicto es siempre de deberes, GóMEZ BENíTEZ, José Manuel, «Consideraciones sobre lo antijurídico, lo culpable y lo punible, con ocasión de conductas típicas realizadas por motivos de conciencia», Ley y conciencia. Moral legalizada y moral critica en la aplicación del derecho. Edición a cargo de Gregorio Peces-Barba. Instituto de derechos humanos Bartolomé de las Casas. Universidad Carlos III de Madrid. Boletín oficial de Estado, Madrid 1993, p. 76 y ss. En concreto dice que «del derecho de libertad de conciencia (16.1 C.E) no es deducible que la conciencia individual sea un bien jurídico protegido por el derecho penal. Del mismo modo, de la declaración constitucional del obligado respeto a la dignidad de las personas no puede deducirse que la imposición de un deber legal de actuar de determinada forma lesione la dignidad de aquellos que lo incumplen por razones de conciencia», ID., ibidem, op. cit., p. 80. El citado intenta fundamentar con ello que es posible que el quebranto de un derecho fundamental no tiene porqué acarrear una sanción penal, una sanción penal no tiene porqué acarrear un quebranto de un derecho fundamental. Por ello GóMEZ BENÍTEZ considera que se debe preservar el bien jurídico protegido pero realizando una «ponderación de deberes». Respecto al caso de la objeción de conciencia a la prestación social sustitutoria del servicio militar, el citado autor concluía que no se puede efectuar tal ponderación porque solo existe un deber: «Si reivindicamos la ausencia de necesidad de imponer una pena por causa supralegal de exclusión de punibilidad, debemos alienarnos con la teoría social de los bienes jurídicos a proteger, sobre todo en los delitos en los que el tipo es de omisión propia». Y sigue diciendo: «Como puede comprenderse fácilmente no es ajena la reivindicación de esta causa supralegal la teoría de los bienes jurídicos penalmente protegidos que busca la legitimación de su selección en el texto constitucional. Desde ella se impone que las causas de justificación, al igual que los tipos penales, deban encontrar su legitimación en los textos constitucionales. La solución, entonces, debe ser igual para las causas de exclusión de la culpabilidad, de exculpación, y de exclusión de la pena, pues no se entiende que éstas puedan o tengan que encontrar una legitimación distinta, puramente ética, moral o religiosa», ID., ibidem, op. cit., pp. 81 y 82.

${ }_{141}$ A este respecto comenta CONTRERAS MAZARIO que la objeción de conciencia «surge del contraste de deberes que conduce a un conflicto, fruto de la relación entre una norma jurídica, que prescribe una obligación, y una norma moral (...) lo que produce en el individuo un verdadero y propio conflicto interior», por lo que «la objeción de conciencia puede tener su origen tanto en un conflicto entre un deber moral y un deber jurídico como entre un derecho moral y un deber jurídico», CONTRERAS MAZARIO, José María, «La libertad de conciencia, objeción de conciencia, insumisión y Derecho (comentario a la sentencia núm. 75/92 del Juzgado de lo penal $\mathrm{n}^{\circ} .4$ de Madrid)», Ley y conciencia. Moral legalizada y moral critica en la aplicación del derecho, op. cit., p. 39. Entonces la objeción de conciencia según el referido autor es «la excepción que el Derecho consiente respecto de su cumplimiento obligatorio basada en la existencia de auténticas y profundas convicciones personales», ID., ibidem, op. cit., p. 41.

${ }^{142}$ CONTRERAS MAZARIO, JMª., «La libertad de conciencia», op. cit., p. 51; EsCOBAR RoCA, G., La objeción de conciencia, op. cit., p. 193; GASCÓN ABELlÁN, M., Obediencia al Derecho y objeción de conciencia, op. cit., pp. 256 y 271; LlamAZARES FERnÁNDEZ, D., «Derecho de la libertad de conciencia», op. cit., p. 14 y ss; MARTín SÁNCHEZ, I., El Derecho a la formación de la conciencia, op. cit., pp. 66 y 67; OLIVER ARAUJO, J., La objeción de conciencia al servicio militar, op. cit., p. 200 y ss; PÉREZ DEL VAlLE, C., Conciencia, op. cit., p. 40; SOUTO PAZ, JA., Derecho Eclesiástico, op. cit., pp. 133 y 134 y ss; ID., Comunidad política y libertad de creencias, op. cit; TAMARIT

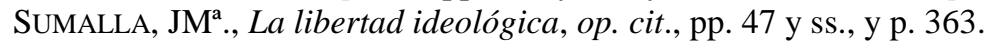


libertad de conciencia tal y como opina la doctrina mayoritaria ${ }^{143}$ y el TS en su Sentencia de 15 de octubre de $1993\left(\mathrm{FJ} \mathrm{3}^{\circ}\right)$.

Sin embargo, en estos tres niveles falta la premisa básica para formar la conciencia: el horizonte de expectativas. Sin este horizonte que puede ejemplificarse en la información y ámbito sociocultural, difícilmente existe la posibilidad de formar una conciencia libremente en cuanto que la libertad se refiere a la elección de un abanico de alternativas o posibilidades. El problema viene cuando el ordenamiento no ofrece alternativas de comportamiento, que normalmente se justifica en relación al interés del bien jurídico ${ }^{144}$.

Concretamente, los delitos de insumisión propia, impropia y sobrevenida fueron en nuestra legislación un difícil escollo que finalmente se solucionó con la derogación. El art. $30 \mathrm{CE}$ preceptúa el derecho/deber de todos de defender a España, pero se podía acoger el obligado a la regulación de la prestación sustitutoria. A este respecto, la STC 53/1985 de 11 de abril, el TC reconocía que la objeción de conciencia es un derecho vinculado a la libertad de conciencia ${ }^{145}$, mientras que en la STC 160/1987 ${ }^{146}$ que desestimaba el recurso de inconstitucionalidad contra la

143 DE Asís RoIG, R., «Las tres conciencias», op. cit., p. 34; ESCOBAR ROCA, G., La objeción de conciencia, op. cit., pp. 170 y ss; GARCÍA HERRERA, MA., La objeción de conciencia en materia de aborto, op. cit., pp. 100 y ss; GASCÓN ABELlÁN, M., «A vueltas con la insumisión», op. cit., p. 18; ID., Obediencia al Derecho y objeción de conciencia», op. cit., p. 270 y pp. 279 y ss; JIMÉNEZ VILLAREJO, J., «Objeción de conciencia e insumisión», op. cit., p. 245; MARTíneZ-TORRóN, J., «La objeción de conciencia en la jurisprudencia del Tribunal Supremo norteamericano», ADEE, I, 1985, pp. 422 y ss; MUÑOZ CONDE, Francisco, «La objeción de conciencia en Derecho penal», op. cit., p. 286; PÉreZ DEL VAlle, C., Conciencia, op. cit., pp. 41 y ss; PRIETo SANChís, L., «Insumisión y libertad de conciencia», op. cit., p. 37; RUIZ MiguEL, Alfonso, «La objeción de conciencia, en general y en deberes cívicos», Revista Española de Derecho Constitucional, mayo-agosto, 1996, p. 102; ROMEO CASABONA, CMª., «El derecho a la objeción de conciencia», op. cit., pp. 1319 y 1320; SIERRA MuCIENTES, S., La objeción de conciencia, pp. 46 y ss.

144 A este respecto comentaba MUÑ̃z CONDE que «el que las leyes no prevean alternativas que respeten la libertad de conciencia, puede deberse, sin embargo, a que la importancia del bien jurídico conculcado por decisión de conciencia es de tal magnitud que no quepa ninguna otra forma de evitar la lesión del mismo que no sea la de prohibir y sancionar en consecuencia la conducta que pueda lesionarlo. Cuando respetar la libertad de conciencia supone tanto como admitir la lesión de bienes jurídicos para la existencia del propio Estado o de su sistema político $\mathrm{u}$ orden constitucional, parece lógico que el Estado no conceda ninguna alternativa y sancione el ataque a los mismos», MuÑOZ Conde, F., «La objeción de conciencia en Derecho Penal», Política criminal y nuevo derecho Penal, Libro Homenaje a Claus Roxin, Bosch, Barcelona, 1997, pp. 281 y 282, también con el mismo título en Separata de Nueva Doctrina Penal, 1996, pp. 87 a 102.

${ }_{145}$ STC 53/1985, de 11 de abril, FJ $12^{\circ}$ se declara que "por lo que se refiere al derecho a la objeción de conciencia (cabe señalar) que existe y puede ser ejercido con independencia de que se haya dictado o no tal resolución. La objeción de conciencia forma parte del contenido del derecho fundamental a la libertad ideológica y religiosa reconocido en el art. 16.1 de la Constitución, y como ha indicado este Tribunal en diversas ocasiones, la Constitución es directamente aplicable, especialmente en materia de derechos fundamentales».

146 STC 160/1987 de 27 de octubre, y en el mismo sentido la STC 161/1987 de 27 de octubre. La primera de las sentencias también añade de forma más aclaratoria en su FJ $4^{\circ}$ que: «En una sociedad democrática, en un Estado social y democrático de Derecho, que se construye sobre un consenso mayoritario expresado libremente (...) la permisión de una conducta que se separa de la norma general e igual para todos ha de considerarse como excepcional». También declara «consiste en construir un derecho a ser declarado exento del deber general de prestar el servicio militar», como «excepción al cumplimiento de un deber general solamente permitida por el art. 30.2, en cuanto que sin ese reconocimiento constitucional no podría ejercerse el derecho, ni siquiera al amparo de la libertad ideológica o de con conciencia». Críticamente a este razonamiento por resultar contradictorio con otros 
Ley de objeción de conciencia de 26 de diciembre de 1984, señalaba que la objeción de conciencia es un derecho autónomo de la libertad de conciencia y de la religiosa. En Sentencia 60/1991 de 14 de marzo, el TC declaró que el deber que nace para todos los españoles en el art. $30 \mathrm{CE}$ es un deber constitucional de defensa militar, si bien existían hasta tres bienes jurídicos a proteger, en concreto: la defensa militar de España, la defensa nacional, y el interés a la prestación del servicio militar ${ }^{147}$.

Así pues, tenemos una objeción de conciencia excepcional que suele regularse con regulaciones alternativas, y otra «general» que nace de la libertad de conciencia del art. 16 y del art. 10 CE. Es opinión mayoritaria como dijimos, que la objeción de conciencia aunque no esté expresamente mencionada, forma parte del derecho a la libertad de conciencia del art. $16 \mathrm{CE}$. Esto nos lleva a entender que la objeción de conciencia es un derecho general pero también con innumerables excepciones (épocas de criminalización del aborto y el servicio militar). A criterio personal, entonces, la objeción de conciencia es un derecho general pero no automático por su mera alegación. Precisa valorar las circunstancias en las que se desarrolla, principalmente las circunstancias del propio sujeto que apela a este derecho y las necesidades de protección del bien jurídico. En el caso del derogado servicio miliar, la interpretación más correcta es aceptar que el art. 30.1 CE establece el deber constitucional de defensa de España, mientras que el 30.2 CE señala una alternativa sobre esta defensa, una militar como es el servicio militar, y otra que se reserva para aquellos que la conciencia impide actuar conforme a parámetros bélicos. Entonces, la regulación de una alternativa ${ }^{148}$ que no afecta a la conciencia impide concluir que pueda otorgarse alguna relevancia privilegiante al comportamiento conforme a la conciencia, y viceversa: la falta de alternativas normativas y fácticas suele ocasionar el incumplimiento de las normas por motivos de conciencia. El argumento de los objetores fue que la prestación social estaba vinculada a la defensa nacional.

de las Sentencias del TC que hacían derivar la objeción de conciencia de los médicos a la práctica abortiva del 16.1 CE, CONTRERAS MAZARIO afirma que «(e)s justamente la naturaleza excepcional de este derecho -derecho a una exención en la forma de prestación de un deber constitucional, como es el servicio militar- lo que le caracteriza como derecho constitucional autónomo, con independencia de que se derive materialmente del derecho de libertad ideológica y religiosa en cuanto que su fundamento son motivos de conciencia que favorecen esa determinada posición privilegiada», CONTRERAS MAZARIO, JMª, «La libertad de conciencia», op. cit., pp. 44 y 45.

147 FJ $5^{\circ}$ STC 60/1991 de 14 de marzo.

148 Como decía GARCía Rivas «(s)e trata, entonces, de dos modos o formas de cumplir el mismo deber de «defender a España» previsto en el apartado primero del art. 30 CE», GARCÍA RIVAS, Nicolás, «Los delitos de insumisión en la legislación española», $A D P C P, 1992$, p. 888. Bien es cierto que la polémica siguió con la interpretación del art. 6.1 de la Ley 48/84 que ordenaba que la prestación se realizara mediante actividades públicas, lo que como apuntaba GARCÍA RIVAS «no se corresponde exactamente con el fin constitucional asignado a la misma porque debe diferenciarse el apartado segundo del art. $30 \mathrm{CE}$, dedicado a una prestación social en cumplimiento del deber de defender a España, y el apartado 3, que alude a un «servicio civil» para el cumplimiento de fines de interés general que nada tiene que ver con la defensa nacional», ID., ibidem, op. cit., p. 899. 
A criterio personal, la problemática y solución debió fijarse en la concreción de la prestación del servicio, pues si se incurría en el tipo penal, la no prestación a favor de la defensa nacional, por ejemplo en la asistencia a los ancianos, revelaba la poca solidaridad de los insumisos, hecho que demostraba la convicción por no contribuir a España de ninguna forma: una decisión estrictamente de conveniencia propia del autor por convicción.

2. Límites de la libertad de manifestar y practicar las creencias: orden público, salud y seguridad públicas y moral pública

Desde los planteamientos liberales del Estado de Derecho se mantuvo una concepción absoluta de los derechos humanos, prueba de ello es el art. 17 de la Declaración de Derechos del Hombre y del Ciudadano: «La propiedad es un derecho inviolable y sagrado». Pero con la propagación de las ideas iusracionalistas, esa concepción absoluta se transformó en la consideración de que su ejercicio tiene limitaciones: respetar «el contenido esencial» ${ }^{149}$.

Los derechos fundamentales como el derecho de libertad de creencias y la libertad de conciencia, se basan en el mantenimiento y respeto máximo de la dignidad de las personas. Se ha considerado tradicionalmente que la conducta es más buena o comprensible en el autor de conciencia que la del autor por convicción, sin embargo, si tratamos la cuestión conceptual de forma normativa, deberemos desechar los conceptos de medio/fin, motivo/móvil, porque están impregnados de valoraciones morales. Una valoración normativa, en cambio, significa que los motivos de uno y otro tipo de autor, más allá del hecho, se valoran por el Sistema del Derecho como funcionales/no funcionales para la Sociedad, esto es desde la diferenciación de sistemas. Si lo funcional se vincula a la moral de la sociedad, es cuestión aparte, lo que importa al Derecho es si un hecho pertenece a su sistema, si lo puede introducir en su operatividad y en qué sentido: si lo incluye en su operatividad o lo destierra por ser cuestión de otro sistema.

Un ejemplo paradigmático de esta forma de operar del sistema normativo es el art. 3 de la LOLR. Este precepto limita la libertad de manifestación y actuación conforme a las creencias, en virtud de los derechos fundamentales y libertades públicas de los demás y el orden público protegido por la ley como expresión de la salud pública, la seguridad pública y la moralidad pública. Aquí subyace una contraorientación normativa en nuestra opinión. Por un lado se defiende la libertad de conciencia y posteriormente se limita con criterios que se fundamentan en

149 STC 11/1981, de 8 de abril, FJ $8^{\circ}$ : «constituyen el contenido esencial de un derecho subjetivo aquellas facultades o posibilidades de actuación necesarias para que el derecho sea reconocible como perteneciente al tipo descrito y sin las cuales deja de pertenecer a ese tipo y tiene que pasar a quedar comprendido en otro, desnaturalizándose, por decirlo así». Sobre las consideraciones doctrinales del contenido esencial, ampliamente RODRÍGUEZ-ARMAS, Lorenzo, Análisis del contenido esencial de los derechos fundamentales, Granada, 1996. 
valoraciones generales de la sociedad, se tiene derecho hasta que no afecte a la opinión dominante sobre lo que se considera salud pública, seguridad pública y moralidad pública. Si bien es cierto que los primeros dos límites pueden defenderse más allá de la opinión generalizada sobre éstos, es decir, por razones de funcionamiento del sistema (sin salud y seguridad pública es imposible que la Sociedad exista), en nuestra opinión supone una contraorientación normativa de importante calado refrendar la libertad de conciencia, personal, individual o colectiva/religiosa de una minoría, y por otro lado establecer un límite en función al sentimiento moral de la generalidad dominante. Esto es porque de esta contraorientación emana que por un lado se socializa a la minoría, se comunica normativamente la vigencia de la operatividad de su creencia, y con posterioridad al hecho «delictivo» se valora negativamente su ejercicio por razones de la consideración general.

Pues bien, el primero que nos ocupa como límite de manifestar creencias, son los derechos fundamentales y libertades públicas de los demás como representación del principio de «no dañar» o neminem laede que ya en su día propugnaba la Declaración francesa del Hombre y del Ciudadano en su art. 4. Es un límite general de convivencia, que por su propia virtualidad domina y articula los límites específicos del orden público, la salud o seguridad pública y la moralidad pública como ya ordena la DUDH en su art. 29.2.

Las libertades de manifestar se proyectan, como antes hemos dicho sobre otras libertades, la de conciencia, de educación y de expresión, pero con sus propios límites, a saber: la libertad de expresión tiene como límite el derecho al honor, a la intimidad y a la propia imagen ${ }^{150}$. Pues bien, el primer límite de la libertad de conciencia se considera tradicionalmente que es el orden público que se interpreta conforme al art. 9.2 CEDH antes expuesto. El orden público depende de cada tipo de configuración normativa de la sociedad, de modo que se trasforma cada vez que cambia la configuración societaria: monárquica, república, liberal, dictatorial hasta la actual democrática.

Según lo dicho, para comprender qué es el orden público como límite de la libertad de conciencia debemos analizar la salud y seguridad pública y posteriormente la moral pública.

La salud pública está comprendida en el art. 29 DUDH, que la preceptúa como «bienestar general», intrínsecamente vinculada también al concepto de seguridad pública, y según el art. 43.2 $\mathrm{CE}$ «(c)ompete a los poderes públicos organizar y tutelar la salud pública a través de medidas preventivas y de las prestaciones y servicios sanitarios». De esta manera cabe entender

150 STC 20/1981 declara que "cuando el hecho imputado a un ciudadano afecte principalmente a su libertad ideológica, su enjuiciamiento ha de ponderar y analizar también principalmente de qué manera se ha vulnerado el orden protegido por la ley». 
que la salud pública se vincula con la medicina preventiva, y la asistencia sanitaria mediante tratamiento o control al individuo o grupos de personas que por una situación concreta, pongan en peligro la salud de la población. No sólo una cuestión preventiva, sino también curativa.

En conclusión, podemos anticipar que el límite de la salud pública tiene a su vez su límite en la conciencia y voluntad individual cuando sólo afecta a quien la apela, aunque sea en casos de riesgo de salud también estrictamente personal, esto a pesar de algunas Sentencias en sentido contrario $^{151}$.

Respecto a la seguridad pública como límite a la manifestación de creencias, la STC 33/1982, de 8 de junio declaró ${ }^{152}$ tres importantes conclusiones: primera, que la seguridad pública está vinculada estrechamente con la «paz social» que ordena el art. 10.1 CE, y a la vez conectada con la misma salud pública, ya que el riesgo de la salud pública puede acarrear un riesgo para la seguridad de la población; segunda, también la seguridad individual está vinculada con la libertad individual; y tercera, que la libertad de creencias como manifestación, como fundamento de la voluntad, tiene como límite la seguridad pública entendida ésta como «orden político y de la paz social» del art. $10 \mathrm{CE}$.

De otra parte, la moral pública se ha concebido tradicionalmente como esencia del orden público estatal. Basta ver la evolución del concepto de orden público para comprobar que cambia a ritmo del sistema político, y éste a ritmo de las valoraciones sociales, o sea, a golpe de moralidad. Este límite a la libertad de creencias es aún más difícil de circunscribir en unos parámetros, pues el término moral adolece de determinación jurídica.

Ya hemos comentado las corrientes contrapuestas que existen sobre la moral como límite al ejercicio de los derechos fundamentales, es decir, entre los iusracionalistas que reivindican una moral social natural, y la concepción legalista que plantea como límite la moral social. Si aceptamos la primera nos guiaremos con base a la dignidad de las personas, mientras que si

151 Un caso de interés en nuestro ámbito de estudio es el Auto y posterior Providencia de 20 de enero de 1984, que autorizaban a los servicios sanitarios la transfusión de sangre a una Testigo de Jehová sugerida por el facultativo, debido a un parto previo, pero que por las negativas del marido se precisó para tal transfusión la autorización del Juzgado de Guardia. Tras la práctica de la transfusión la mujer murió. Este caso lo analizaremos en el capítulo tercero.

${ }_{152}$ STC 33/1982, de 8 de junio, FJ $3^{\circ}$ : la «actividad dirigida a la protección de personas y bienes (seguridad en sentido estricto) y al mantenimiento de la tranquilidad y el orden ciudadano, que son finalidades inseparables y mutuamente condicionadas (...) Afirmar esto no supone negar que una crisis sanitaria pueda amenazar la seguridad pública y justificar, en consecuencia, una intervención de las autoridades a las que corresponda su custodia. Incluso es de recordar que crisis sanitarias tales como epidemias y situaciones de contaminación graves pueden motivar la declaración de estado de alarma (Ley Orgánica 4/1981, de 1 de junio, art. 4.b). Sin llegar a semejante extremo no cabe excluir la posibilidad de que, en aras de la protección de los ciudadanos, la seguridad pública requiera tomar medidas para atajar riesgos de la salud pública cuando esas medidas vengan impuestas por razón de necesidad y urgencia, de forma que no pueda esperarse a la actuación de las autoridades normalmente competentes para afrontar esos riesgos». 
aceptamos la segunda lo determinante es la moral social, del grupo social ${ }^{153}$. Lo problemático del caso, es que el art. 3 LOLR establece como límite a la libertad de creencias, otra creencia, esto es en nuestra opinión, la moral limitada por la moral de la mayoría, por la moral pública.

El TC ${ }^{154}$ admite que el ordenamiento jurídico y la Constitución están impregnados de diversos valores éticos, que comandan e influyen en la creación de leyes; es decir, la moral pública como expresión democrática, pero también del pluralismo pues admite aquellas convicciones morales, creencias, que no choquen con la moral generalizada pero sin que se permitan cambios caprichosos y sorpresivos en la valoración de los hechos por el Derecho.

La Constitución ampara el pluralismo de creencias, y la cooperación con las confesiones y entidades de naturaleza metafísica, pero no se declara en la misma que el Estado opte por una ni otra (art. 16.3 CE «ninguna confesión tendrá carácter estatal»). En este punto consideramos que se cumple una contraorientación normativa. Parece una contradicción la de aquella gran parte de la doctrina penal que abandera la libertad de conciencia, personal, individual o colectiva/religiosa de una minoría, y por otro lado establece un límite en función del sentimiento moral de la generalidad dominante, al menos en los casos en los que este sentimiento no se ve afectado gravemente ni existe una clara disposición normativa previa ${ }^{155}$.

Por un lado, el derecho a la libertad de conciencia socializa, comunica la vigencia de la operatividad de la creencia, y posteriormente se valora negativamente su ejercicio por razones puramente morales, es decir, sin afección real en la mayoría de casos a la llamada eticidad social. Si la norma que habilita el ejercicio de la libertad de conciencia o religiosa comunica que la generalidad, la Sociedad, está de acuerdo en permitir esa libertad interna y externa, no tiene sentido posteriormente su limitación bajo el mismo argumento, máxime por una razón moral simplemente dominante y no estrictamente normativa o de funcionamiento del Sistema Social.

153 Labrada Rubio, V., Introducción a la teoría de los Derechos Humanos, op. cit., pp. 196 y 197.

154 Según Souto PAZ hay dos ocasiones en las que el TC se ha pronunciado sobre la moral como límite. En la primera ocasión el TC declara que «si se tiene en cuenta, además que la moral pública -como elemento ético común de la vida social- es susceptible de concreciones diferentes según distintas épocas y países, por lo que no es algo inmutable desde una perspectiva social. Lo que nos lleva a la conclusión de que la admisión de la moral pública como límite ha de rodearse de las garantías necesarias para evitar que un concepto ético, juridificado en cuanto es necesario un mínimo ético para la vida social, se produzca una limitación injustificada de derechos fundamentales y libertades públicas que tiene un valor central en el sistema jurídico», STC 62/1982, de 15 de octubre, FJ $3^{\circ}$ B). Mientras que en la segunda ocasión en la que pronuncia el TC sobre la moral pública como límite, dice que el matrimonio canónico «no supone la asunción por el Estado de las características y propiedades que la Iglesia católica asigna al matrimonio en su fuero propio, dado que su carácter pluralista y aconfesional el Estado no viene obligado a trasladar a la esfera jurídico-civil los principios o valores religiosos que gravan la conciencia de determinados fieles y se inserta en el orden intraeclesial», ATC 617/1984, de 31 de octubre, FJ 5, vid. SOUTO PAZ, JA., Comunidad política y libertad de creencias, op, cit., pp. 274 y ss.

155 Como afirma SOUTO PAZ y con lo que estamos de acuerdo «(l)a moralidad pública no puede ser interpretada a la luz de una moral o una ética confesional o no confesional, pues ello comportaría la quiebra del pluralismo y de la propia aconfesionalidad del Estado», SOUTO PAZ, JA., Comunidad política y libertad de creencias, op, cit., p. 275. 
La limitación se tiene que vincular a la impropiedad de la operación delictiva, si se quiere también a su motivo de conciencia o por la convicción relacionada con la impropiedad del motivo (precio, recompensa y promesa en el asesinato, motivos racistas en el delito, etc.), esto es cuando tal motivo exteriorizado pone en peligro la operatividad del Sistema Social.

\section{Obligatoriedad del deber jurídico ante el deber moral y desobediencia civil}

En el último siglo, desde el primer tercio del siglo XX hasta nuestros días, la doctrina penal ha discutido si existían diferentes categorías conceptuales entre las diversas conductas realizadas por motivos de conciencia o ideológicos, y si merecían un tratamiento penal diferenciado basado en la vinculatoriedad y obligatoriedad del deber moral antes que en el cumplimiento del deber jurídico. La mayoría de la doctrina respalda la vinculatoriedad del deber moral al deber jurídico, de lo contrario -se dice habitualmente- no podría funcionar la Sociedad si cada vez que un sujeto tiene un motivo discrepante con la ley se le eximiera de responsabilidad. Si bien también es verdad que parte de la doctrina que ha estudiado concretamente la problemática, ha encontrado motivos de comprensión con efectos privilegiantes. A decir verdad, todos los actuales postulados de la doctrina sobre la obligatoriedad del deber jurídico ante el deber moral redundan en el tradicional idealismo y racionalismo social ${ }^{156}$.

En concreto, HABERMAS parte de que no hay contradicciones en el ordenamiento jurídico, pero en determinados casos hay que salvar la aparente antinomia con la aplicación de decisiones correctas, por ejemplo en el caso del juez con un discurso estructuralmente bien argumentado. Si bien, definitivamente tiene que reconocer cierto grado de validez a la desobediencia civil cuando se pretende mejorar el derecho mediante un discurso fundamentador (en casos de crisis) ${ }^{157}$, pero cuando no se respetan los derechos fundamentales se puede justificar la desobediencia civil, como opina parte de la doctrina ${ }^{158}$ no sin crítica ${ }^{159}$.

156 ATIENZA afirma que la conciencia individual debe controlarse mediante la racionalidad, la imparcialidad, la universidad y la libertad y en consecuencia la democracia debe ser una productora de la moral dominante, que marque límites a la individual, ATIENZA, Manuel, «La filosofía del Derecho de Felipe González Vicén», El lenguaje del Derecho, Buenos Aires, 1983, p. 69; FERnÁNDEZ GARCía considera que el hombre sólo debe obedecer la ley cuando ésta sea justa, cuando ésta nazca del ejercicio legítimo contractual y cuando respete los derechos fundamentales, FERNÁNDEZ GARCÍA, Eusebio, La obediencia al Derecho, Madrid, 1987.

157 Habermas, J., Facticidad y validez, op. cit., pp. 465 y 466.

158 En el mismo sentido ACINAS comenta que «(l)a desobediencia civil, en fin, podemos concluir, supone el incumplimiento público de una ley, disposición gubernativa u orden de la autoridad, por motivos políticos y morales; pero inexorablemente no tiene por qué ser ilegal, fiel a los fundamentos constitucionales, no violenta y además dar la bienvenida a su castigo», ACINAS, Juan Claudio, «Sobre los límites de la desobediencia civil», Sistema 97, Madrid, julio, 1990, p. 111; también DE LUCAS / VIDAL / ANTÓN entienden que «de ahí que se admita casi unánimemente que la desobediencia civil debe ser castigada y que quien la practica debe aceptarlo (...) como indica HABERMAS, debe tenderse a reducir al mínimo la penalización de ese tipo de conductas», DE LUCAS J / VIDAL E / ANTÓN M ${ }^{a}$ J., «Desobediencia o respeto a la conciencia», op. cit., p. 102; en el mismo sentido JERICÓ OJER, L., El 
A este respecto, Bustos resume con la brillantez que le caracteriza los fundamentos de la doctrina: «(e)l hombre responde entonces por su comportamiento; por la conciencia de él, ése es fundamento y límite de la reacción social que se ejerce sobre él, pero esa conciencia está dada socialmente, y por eso también responde la sociedad toda (...) No se trata de un juicio a las capacidades de las personas, sino a la capacidad del Estado, en definitiva de su legitimación, para exigir esa respuesta a la persona y para ello el Estado, en los términos del art. 9.2 CE, respecto de ese individuo concreto ha de haber promovido (...) su libertad e igualdad» ${ }^{160}$.

A su vez, JERICó define la desobediencia civil como una desobediencia al Derecho o una determinada norma como en la objeción de conciencia» ${ }^{161}$. Parece incluir la desobediencia civil como una posible forma de lucha contra la vigencia de la norma, aunque admite ciertas dosis de violencia ${ }^{162}$.

conflicto de conciencia, op. cit., p. 115; ID., «La desobediencia civil: Concepto y tratamiento jurídico (A propósito del corte de carreteras para solicitar la gratuidad de la autopista A-15 y otros supuestos análogos», Revista Jurídica de Navarra, pp. 139 a 174. En contra Eusebio FERNÁNDEZ opina que «puede darse una justificación moral y política, pero no puede existir una justificación jurídica de la desobediencia civil (...) ha de reconocerse la desobediencia civil como parte constitutiva de la cultura política de una comunidad democrática desarrollada (...) la desobediencia civil no debe ser legalizada en cuanto tal (...) Por eso, la justicia penal ha de registrar y, en su caso, perseguir ese tipo de desobediencia como ilegal: pero no la debe valorar como un delito más», FERNÁNDEZ GARCÍA, E., «Conciencia y respeto al Derecho», Ley y conciencia. Moral legalizada y moral critica en la aplicación del derecho, op. cit., p. 66, cita núm. 4.

159 Por ejemplo similarmente JAKOBS refiere que la desobediencia civil consiste en la lesión de un bien jurídicopenal o infracción administrativa por motivos de ideología política normalmente, sin restar legitimidad al Estado y al Derecho de forma moderada que afecta sólo a bienes de componente público y sin que se aprecie justificación alguna, por lo que dicha opinión política como desobediencia no resulta vinculante para el Estado ni aun con un buen fin político, JAKOBS, G., $P G$, op. cit., 15/5 y ss. En concreto, recuerda JAKOBS que en el derecho alemán, el parágrafo 20, párrafos 1 a 3 de la Ley Fundamental contempla un supuesto de auxilio necesario del Estado vinculado al llamado derecho de resistencia ante una agresión culpable del ordenamiento constitucional, ID., ibidem, op. cit., 15/1 y ss; similarmente FERNÁNDEZ GARCÍA, E., «Conciencia y respeto al Derecho», Ley y conciencia. Moral legalizada y moral critica en la aplicación del derecho, op. cit., p. 66, cita núm. 4.

160 Bustos Ramírez Juan / HormazÁBAl MALARÉE Hernán, Lecciones de derecho penal, Teoría del delito, teoría del sujeto responsable y circunstancias del delito, Vol. II, Trotta, 1999, p. 337; COBO DEL ROSAL y VIVES ANTÓN distinguen claramente el concepto de obligación jurídica nacida de la propia Ley de la obligación moral. Ellas se contradicen por su misma naturaleza ya que la primera se establece de forma externa al sujeto, y la segunda por la aceptación como norma válida. En este sentido concluyen que «(l)a culpabilidad jurídica difiere de la culpabilidad moral en la misma medida en que la obligación jurídica y la moral son, por su misma naturaleza, distintas. Según el conocido criterio kantiano, la obligación moral es autónoma (esto es, depende de una norma reconocida como válida por el sujeto empírico) mientras que la obligación jurídica es heterónoma (esto es, se halla establecida por unas instancias externas a la conciencia del individuo)», COBO DEL RosAl Manuel / VIVES ANTÓN Tomás Salvador, Derecho Penal, Parte General, $5^{a}$ ed., Tirant lo Blanch, Valencia, 1999, p. 539; para Elías DíAZ existe un fundamento moral tanto para la obediencia como para la desobediencia, DíAz GARCíA, Elías, De la maldad estatal y la soberanía popular, Debate, Madrid, 1984, pp. 75 a 95; GONZÁLEZ VICÉN niega que el vínculo jurídico constituya una obligación ética, pero también admite que «la situación que provoca el juicio de conciencia es también una situación concreta e irrepetible, una constelación de fines, intereses, supuestos, implicaciones, caracterizada precisamente por su unicidad», GonZÁLEZ VICÉN, F., «La obediencia al Derecho», vv.aa., Estudios de Filosofía del Derecho, Universidad de La Laguna, 1979, pp. 388 y 389.

161 JERICÓ OJER, L., El conflicto de conciencia, op. cit., p. 115.

162 ID., ibidem, op. cit., p. 115. Sin embargo no compartimos que no exista diferencia alguna entre la desobediencia y la objeción en cuanto que el daño causado es en ambas «inesencial», ID., ibidem, op. cit., p. 119. No hay objeción alguna para incluir en la autoría de conciencia delitos de resultado inclusive en comisión por omisión, 
En conclusión, la doctrina considera que es la falta de creencia de la obligatoriedad del deber jurídico tradicionalmente la que ha fundamentado la desobediencia civil y penal, cuestión que en algunos casos plantea el debate de la legitimidad y validez de las normas y el sistema. El problema para la mayoría de la doctrina entre la obligación moral, el deber moral y el deber jurídico, no es tanto sobre la licitud de un valor moral que tenga una persona, o su posible contraposición a la obligación jurídica, sino la consecuencia que acarrea el hecho de dirigir la voluntad conforme a los valores morales cuando se incurre en el quebrantamiento de una norma. Por ende, en el problema dogmático que se plantea parece centrarse en la culpabilidad del sujeto $^{163}$.

En nuestra opinión, la problemática que plantea el autor por convicción y de conciencia no viene sólo del punto de vista dogmático del tratamiento penal, sino de una conceptualización errónea e inconstitucionalmente basada en la mayor fuerza de los motivos de conciencia, morales o religiosos respecto a los ideológicos y políticos. No obstante, la doctrina no se ha puesto de acuerdo aún hoy sobre una definición del autor por convicción y de conciencia. Hay opiniones que mezclan la moral y la religión con lo político e ideológico, y en otras ocasiones, se intercambian, pero como apuntábamos supra, en la mayoría de la doctrina penal está el pensamiento de que los motivos morales, religiosos o de conciencia poseen una inevitabilidad mayor que los estrictamente políticos o ideológicos. En este error se fundamenta la valoración estrictamente moral de que en los autores de conciencia existe algo «comprensible» o «justificado»y en los autores de conciencia una «perversidad» que fundamenta la máxima pena. Sin embargo, los motivos pueden ser tan poderosos e inevitables para la voluntad tanto en uno como en otro caso. La cuestión es si existe alternativa para la voluntad en su fin, o si el delito es un medio para un fin.

por ejemplo en el homicidio. Por eso estamos de acuerdo con ella en que tanto la desobediencia civil como en la objeción de conciencia no hay siempre una deslegitimación de la validez general de la ley sino de la puntual norma, ID., ibidem, op. cit., p. 116. Mientras que con la desobediencia se lucha o se disiente una norma puntual por considerarla injusta utilizando la publicidad (ID., ibidem, op. cit., p. 116) en la objeción de conciencia el objetor quiere una exención a su actuar sin aspirar a «influir en un cambio político o legislativo», ID., ibidem, op. cit., p. 118. No utiliza medios violentos generalmente, no precisa «ganar adhesiones a su causa», ID., ibidem, op. cit., p. 117.

163 Como señala GómEZ BENíTEZ, «la doctrina y la jurisprudencia penal dominantes hayan preferido remitir los motivos de conciencia al terreno conceptual de la culpabilidad, reafirmando, así que el delito (...) y la justificación son conceptos vinculados al contenido del Derecho, al deber general, cuya existencia o no en nada puede depender de los motivos de conciencia de las personas (...) aunque si se puede admitir su eficacia en Derecho penal, pueden fundar, en el mejor de los casos, un supuesto de excepción personal de deber general en el caso concreto, es decir, una causa de influencia, bien excluyente, bien atenuante, sobre la culpabilidad de las personas», GóMEZ BENÍTEZ, JM., «Consideraciones», op. cit., p. 72. 


\section{VI.- Trascendencia del reconocimiento de la libertad de conciencia en grupos religiosos y sectas}

\section{A. Los grupos religiosos y las sectas en la $O N U$}

La ONU escasamente ha valorado la problemática de las sectas ${ }^{164}$. Es de interés señalar que ninguna resolución de la ONU se ha pronunciado estrictamente sobre organizaciones religiosas de distinto cariz de las religiones tradicionales, salvo la Declaración sobre la eliminación de todas las formas de intolerancia y discriminación fundadas en la religión o las convicciones, de 25 de noviembre de 1981 (resolución 36/1955), y el Informe Fattah de 1996 que señaló la inocuidad de los grupos totalitarios que han sido designados como sectas «destructivas» ${ }^{165}$. Esta falta de pronunciamiento por parte de la ONU es del todo normal. Únicamente la Resolución núm. 36/1955 citada parece dedicarse en parte al ámbito de las sectas y a su problemática, defendiendo la libertad de conciencia, de religión o de convicciones y la tolerancia ${ }^{166}$.

\section{B. Resoluciones del Parlamento europeo}

El Parlamento europeo se ha pronunciado en varias ocasiones de forma más o menos contundente. A finales de los años setenta, principios de los ochenta, se suscitó el temor en parte de la población europea ante el surgimiento en nuestro continente de la asociación para la Unificación del Cristianismo Mundial del reverendo Sun Myung Moon.

Representación de ese temor es el Documento 1-2/82 de 9 de marzo que se refiere una Propuesta de resolución presentada por diputados europeos y que exponía que «(e)1 Parlamento Europeo, vivamente preocupado por los casos de problemas y las rupturas familiares provocadas por la asociación para la unificación del cristianismo mundial de Sun Myung Moon». En esta Propuesta se solicitaba al Parlamento Europeo que instase a los gobiernos nacionales a no conceder ventajas fiscales y a que realizaran una denuncia casi-masiva contra este grupo religioso. En el mismo sentido se dirigió la también la Proposición de resolución de otro diputado (Documento 1-109/82 de 13 de abril).

\footnotetext{
164 MoYAno, Antonio Luis, Sectas, la amenaza en la sombra. Cómo actúan, quiénes son y cómo defendernos, Nowtilus Frontera, Colección La puerta del misterio, 2a ed., 2002, p. 122.

165 ID., ibidem, op. cit., p. 122.

166 En su Considerando primero se proclama nuevamente el respeto a los derechos humanos y libertades fundamentales; en el segundo se proclama el principio de no discriminación y libertad de pensamiento, conciencia, religión o convicciones; en el tercero se señala que la violación de la libertad de religión ha sido uno de los peores lastres de la historia junto a la injerencia de los Estados en los asuntos internos de los demás; en el cuarto se preceptúa que «la religión o las convicciones, para quienes los profesa, constituyen uno de los elementos fundamentales de su concepción de la vida y que, por tanto, la libertad de religión o de convicciones debe ser íntegramente respetada y garantizada»; mientras que el quinto apela a la promoción de la tolerancia y de los derechos citados en cualquiera de sus dimensiones.
} 
La preocupación sobre las sectas o grupos religiosos de nuevo cuño culminó en el encargo por parte del Parlamento Europeo al eurodiputado COTTRELL de investigar y profundizar sobre el fenómeno sectario europeo. Esta investigación concluyó en el famoso Informe Cottrell (Documento 1-47/84 de 2 de abril de 1984 del Parlamento Europeo ${ }^{167}$ ). Este informe constaba de seis puntos que fueron incluidos en la definitiva Propuesta de Resolución y Exposición de Motivos que sin pretender menospreciar la libertad religiosa distinta a la tradicional, en nuestra opinión lo consiguió por la mención constante a la proliferación de grupos sectarios-religiosos como la Iglesia de la Unificación y al grupo Niños de Dios.

Tras varios debates se adoptó el concepto cambiar el término secta y de «nuevos movimientos religiosos» que figuraba en Informe Cottrell por el de «nuevas organizaciones que obran bajo la cobertura de la libertad de conciencia». La Resolución de 1984 de 22 de mayo del Parlamento Europeo elevó el informe a documento oficial europeo que en esencia versaba «sobre una acción común de los estados miembros de la Comunidad Europea en torno a diversas violaciones de la Ley cometidas por nuevas organizaciones que actúan bajo la cobertura de la libertad religiosa». El informe y la posterior Resolución europea nació de la preocupación por investigar a la Iglesia de la Unificación del reverendo Sun Myung Moon, si bien, paradójicamente, en la Exposición de Motivos de la resolución se afirmaba que el fin de este grupo no era la discriminación, ni ejercer un control abusivo de determinados grupos religiosos puestos en sospecha. Algunos autores concluyeron que en verdad con tal resolución se consiguió lo contrario ${ }^{168}$.

La Resolución consta de dos partes, una primera centrada en su Exposición de motivos que parece ser una parte informativa, y una segunda una parte sustantiva sobre medidas preventivas ante las problemáticas que suscitaban estos grupos en las familias europeas. En la primera parte se toma como base el art. 9 CEDH y el art. 220 del Tratado de Roma ${ }^{169}$. Tras una declaración de intenciones en el respeto de la libertad de conciencia, se preceptúa una serie de considerandos que dejaban asomar la desconfianza hacia estos grupos ${ }^{170}$.

\footnotetext{
167 Ampliamente y originales de este informe y documentos de Propuestas de resolución del Parlamento europeo, VidAl MANZANARES, C., El infierno de las sectas, Ediciones Mensajero, Bilbao, 1989, pp. 173 a 196.

168 Vid. MARtínez Muñoz Daniel / CARRETERo SÁEz Patricia / Alonso RAMOs Laura Ma / PERALES PiZARro Antonio / RoDRíGUEZ RuIZ Óscar, «Sectas y Derecho Internacional», Sectas y Derechos Humanos / III Congreso Interuniversitario de Derecho Eclesiástico para Estudiantes, 21-24 Abril 1994, coordina la edición M ${ }^{\mathrm{a}}$ Elena Buqueras Segura, p. 24.

169 Art. 220 TR: "Los estados miembros entablarán en tanto sea necesaria negociaciones entre sí, a fin de asegurar a favor de sus nacionales: la protección de las personas, así como el disfrute y la tutela de los derechos, en las condiciones reconocidas en cada Estado a sus propios nacionales».

170 En concreto en el Considerando A, punto b, se declara que «a la inquietud que suscitan entre los ciudadanos europeos y sus familias las actividades de ciertas organizaciones designadas como NMR» (Nuevos Movimientos Religiosos) pueden atentar contra los derechos civiles y personales a nivel mundial. No obstante se insiste en que a pesar de no poderse entrar a juzgar las bases morales, religiosas o de pensamiento que cada grupo defiende,
} 
La Resolución del Parlamento se centró en la enumeración de criterios a adoptar en formas de prevención para «el examen, inventario y valoración de las actividades de las organizaciones». Más que una medida de prevención parece una acusación que vulnera no sólo el derecho a la libertad religiosa, sino también el derecho a la presunción de inocencia de estos grupos. En concreto se menciona sorprendentemente que sólo los mayores de edad deberían formar parte de estos grupos, que se debería establecer un periodo de reflexión, que una vez se efectuara el ingreso en el grupo se debería fomentar el contacto con la familia, los amigos y su grupo social, y que estos grupos no debían interferir en grupos potenciales de captación como los estudiantes y los turistas. Lo que llama poderosamente la atención es que dicha resolución se permita dentro de un marco de libertades discriminar la forma de acceso y las relaciones sociales en estos grupos y nada se diga al respecto de las religiones tradicionales, como si en éstas no hubieran surgido hechos tanto o más perseguibles o cuando menos de estricta prevención como los ya tan famosos abusos sexuales por parte de clero católico.

Posteriormente la Resolución anima a los Estados miembros del Consejo de Europa ${ }^{171}$ a la elaboración de convenciones para garantizar la protección de los individuos susceptibles de ser agredidos de alguna forma por estas organizaciones, lo que suscitó la idea de que esta resolución no es del todo neutral, atacaba en aquel momento a un fenómeno social no realmente constatado, y si estaba constatado al menos no delimitado estrictamente, se incluyó a todo tipo grupo religioso o de creencias distinto o discrepante con las religiones tradicionales y conocidas. Por ello algún sector se decantó, muy acertadamente, por entender que el fin de esta resolución era «controlar las actuaciones de estos grupos» ${ }^{172}$. Podemos concluir con esta corriente de opinión, que en dicha resolución el contenido del derecho a la libertad religiosa se ve restringido, el

cuestiona «el carácter legal de los métodos empleados por estas asociaciones». De esta conclusión se puede apreciar una enorme desconfianza hacia las sectas o grupos religiosos no tradicionales, si bien y en nuestra opinión, creemos que en verdad la Resolución, sin decirlo, mencionaba constantemente aquellos grupos u organizaciones de tientes criminales, sin embargo desconocía qué conductas podrían ser constitutivas de delito. En los años ochenta no existía una clara idea de cuáles eran los métodos y fines criminales que algunos grupos podrían estar realizando, salvo a formulaciones genéricas por parte de la literatura especializada en torno a conductas de estafa, agresiones sexuales y de manipulación mental. Han sido necesarios décadas de estudio para poder centrar convenientemente la problemática penal, si bien la resolución europea abrió el camino al menos en el interés por escuchar aquellas personas que denunciaban abusos por parte de determinados grupos. El Parlamento Europeo hizo también hincapié en que el Consejo de Ministros promoviese el intercambio de información entre naciones, especialmente en ciertas problemáticas como la utilidad pública de estos grupos, el respeto a la ley por éstos y las consecuencias de su desprecio, las personas vulnerables de captación malintencionada y la asistencia a éstas jurídica o socialmente.

171 Particularmente se invita al Consejo de Europa «a emprender un camino común dentro de su marco», y sus Estados miembros a la elaboración de Convenciones que protejan a las personas de los daños psicológicos y psíquicos que ejercen algunas de estas organizaciones sectarias.

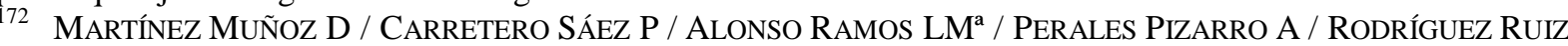
O., «Sectas y Derecho Internacional», op. cit., p. 28, afirman que esa resolución y su contenido no tienen justificación en virtud del derecho a la libertad religiosa, y menos aún en una sociedad democrática. 
control sólo parece dirigirse a estos nuevos movimientos religiosos y no a todos los grupos religiosos tradicionales ${ }^{173}$.

\section{Las resoluciones del Consejo de Europa sobre la problemática de la libertad de conciencia en las sectas}

A instancia de la Resolución del Parlamento Europeo se solicitó la actuación del Consejo de Europa y a sus Estados miembros en la elaboración de convenios de protección de los individuos, para prevenir y luchar contra las lesiones psíquicas y físicas que algunos de estos grupos sectarios realizaban a sus miembros. Desde luego que la declaración de intenciones es altamente peligrosa al tratar de forma política una cuestión que en todo caso sería estrictamente penal y de competencia de cada Estado miembro a través de sus leyes penales.

Gracias a la denuncia de la problemática por la citada resolución, se promovió la actuación del Consejo de Europa con la Moción presentada por Elmquist y otros para que se elaborara otra resolución europea sobre el tema. Finalmente se elevó la Resolución sobre libertad religiosa de fecha 6 de mayo de 1987 entre otras ${ }^{174}$, cuyo punto cuarto menciona las «infracciones de la ley provenientes de nuevas organizaciones que operan bajo la cobertura de los grupos religiosos», y cuyo punto quinto afirma que tales «limitaciones versan sobre el poder abusivo y la influencia intrusita que alguna de estas organizaciones religiosas y sectas ejercen sobre jóvenes y otras personas susceptibles de ser fácilmente influenciadas».

De tales declaraciones se resalta nuevamente la falta de control de los grupos religiosos tradicionales, lo que hizo sospechar a algún sector sobre la falta de respeto a la libertad de conciencia o religiosa. A juicio propio, la sospecha de que algunos grupos vulneraban la libertad individual es suficiente en una «sociedad del riesgo» para adoptar medidas de control, también sobre las religiones tradicionales, máxime por las denuncias que ya en aquél momento se presentaban sobre abusos sexuales y de «niños robados», si bien la problemática era y es distinta.

La Moción delegó la actuación al Comité de Asuntos Legales y otros órganos las «acciones que puedan ser apropiadas respecto de los abusos que se descubra son llevados a cabo por ciertas organizaciones o sectas». Posteriormente el día 28 de julio de 1987 se presentó por

173 ID., ibidem, op. cit., pp. 28 y 29.

174 Proposition de resolution relative à la liberté de religion présentée par M. ELMQUIST y otros, de 6 de mayo de 1987, en Documents de séance de la Asamblea Parlamentaria del Consejo de Europa, DOC 5737, Vol. II, 198788, Strasbourg, 1987. Otros informes sobre sectas tienen menor interés en el ámbito europeo. No obstante resulta peculiar la Declaración núm. 210 sobre la libertad religiosa de los Estados Miembros del Consejo de Europa de 29 de abril de 1991 (doc. 6497), en donde se preconiza la libertad de conciencia, pero a la vez se denuncia la vulneración de la libertad de conciencia por Alemania al denominar de organización criminal a la Iglesia de la Cienciología. 
Cifarelly y otros, otra Moción de Resolución ante la Asamblea del Parlamento sobre libertad religiosa, que en opinión de un sector ${ }^{175}$, es mucho más respetuosa con la libertad religiosa, al limitar el control a dos cuestiones importantes, a saber, a los Funcionarios Públicos, Educadores y otros oficiales que sugieran medidas discriminatorias en contravención de la libertad de religión y de creencias. Cabe reseñar que ninguna de las dos Mociones fue aprobada finalmente.

En nuestra opinión, la Propuesta era de importancia porque aceptaba y advertía del peligro de las técnicas de despersonalización. En concreto se decía en su punto cuarto que las «medidas como el confinamiento, la privación de comida y sueño, hacerles padecer un maltrato físico y psicológico constante, la amenaza de represalias y la interferencia con su privacidad».

Por tanto, en la primera Moción se hacía referencia expresa a las sectas u organizaciones análogas, mientras que en la segunda, en la de 28 de julio se hacía mención no expresamente a éstas sino a «los intentos de despersonalizar a la gente que profesa una religión u otro credo, viejo o nuevo, para forzar a la gente a renunciar a su religión o sus creencias». Con esta afirmación se consiguió separar la problemática entre nuevos grupos religiosos como sujetos activos de la despersonalización y antiguos o tradicionales grupos religiosos.

Mayor interés suscitó el llamado Informe Viven en el panorama sectario francés, encargado por el Primer Ministro Piere Mauroy en 1982 al diputado socialista que da nombre al mismo informe. En este, se relatan diversas medidas preventivas como el planteamiento de un sistema de laicismo abierto que permitan una mayor libertad de elección religiosa, y otras medidas asistenciales como la creación de un Juez de Familia que se dedicase a determinar si no había existido manipulación en la inserción del adepto a la secta. Pero la más importante conclusión a la que llegó el Informe Viven fue que no había necesidad de una nueva legislación específica y combativa sobre la problemática de las sectas, al menos reconocía la suficiencia de la actual legislación.

\section{Jurisprudencia europea sobre la problemática de la libertad de conciencia en los}

grupos sectarios religiosos

\section{La jurisprudencia del Tribunal Europeo de Derechos Humanos}

La Comisión Europea de Derechos Humanos tiene la potestad de admitir o no admitir a trámite los recursos planteados por grupos «sectarios». En 1968 la Iglesia de la Cienciología recurrió ante el TEDH la revocación por el Reino Unido de su única institución de enseñanza.

\footnotetext{
175 Vid. MARtínez Muñoz D / CARretero SÁEZ P / Alonso Ramos LMa / Perales Pizarro A / RodríGUEZ RUIZ O., «Sectas y Derecho Internacional», op. cit., p. 30.
} 
Reino Unido consideró que la Iglesia de la Cienciología no tenía esa cualidad, por tal motivo no admitió a trámite el recurso por entender que la administración del Reino Unido no desatendió el derecho a la libertad religiosa, aunque finalmente en 1980 se levantó la medida por la debilidad de los argumentos.

Esta clase de vulneración del derecho a la libertad de conciencia con escasos argumentos jurídicos, es una constante que no sólo se repite en la jurisprudencia europea sino ante todo en la jurisprudencia interna de los Estados miembros, se suele materializar en la negativa de la administración en la inscripción en el registro de entidades religiosas de determinadas sectas o grupos a los que se les cataloga de peligrosos pero sin argumento, prueba o indicio algunos.

Otras de las vulneraciones del derecho a la libertad de conciencia fue la realizada por Austria al denegar a la Iglesia de la Unificación del Reverendo Moon, la creación de una nueva asociación filial de ésta en continuación de una anterior declarada ilícita, aunque la nueva fue decretada lícita por sus fines en el momento de la inscripción en el correspondiente registro. En el recurso planteado ante el TEDH, la Comisión competente entendió que la denegación de inscripción de esta asociación no vulneraba el derecho a la libertad religiosa porque no se impedía a la Iglesia de la Unificación reunirse y proyectar la manifestación de sus credos, lo que para algunos era una traba al derecho a la libertad religiosa en su sentido amplio ${ }^{176}$.

En nuestra opinión, la libertad religiosa se protege más allá de la inscripción, tanto para manifestarla y/o profesarla individualmente, como colectivamente, sin embargo, la vulneración de la libertad de conciencia viene en estos casos de la discriminación o agravio comparativo en la denegación de unas sin motivo o indicio alguno y la admisión de otras.

El caso más famoso en este nivel jurisprudencial fue precisamente el admitido a trámite por la Comisión de Derecho Humanos, el caso Kokkinakis versus Grecia resuelto por la STEDH de 25 de mayo de 1993, en la que se falló a favor del recurrente Testigo de Jehová para ejercer libremente su derecho a la libertad religiosa en una variante de proselitismo que ampara la DUDH en su art. 18, y la CEDH en su art. 9. El caso versó sobre la conducta del recurrente cuando entró en el domicilio de un particular para difundir su doctrina, previa autorización del propietario, entonces resulta evidente que Grecia sancionó injustamente al testigo de Jehová, quizá impulsada por como decimos el desconocimiento o poca consideración por el ejercicio de la libertad de conciencia y de la libertad de proselitismo inherente en ésta.

176 Vid. ID., ibidem, op. cit., p. 36. 


\section{La jurisprudencia del Tribunal de Justicia de la Comunidad Europea en materia}

religiosa de grupos sectarios

Bien es cierto que no existe abundante jurisprudencia del TEDH en materia estrictamente de sectas salvo los conocidos casos que iremos señalando en su lugar en esta investigación, pero tampoco en la jurisprudencia del TJCE, porque su función no es específicamente ésta, sino la de garantizar los derechos del Tratado fundacional de la Unión Europea y de las directivas que nazcan de su seno.

El caso más famoso en la jurisprudencia del TJCE es el asunto Yvonne van Duyn contra Home Office. Versó sobre la negativa de entrada a Reino Unido a una mujer perteneciente a la Cienciología y para la cual prestaba una relación laboral que fue el motivo de denegación de entrada al considerarse por el Reino Unido de una relación peligrosa y contraproducente por motivos de orden público, ya que Cienciología estaba prohibida en aquel momento en este país. Como no podía ser de otra manera, el TJCE falló a favor de la demandante porque motivo jurídico alguno para prohibir la entrada a la demandante a pesar de su relación con un grupo prohibido.

E. Dictamen, Propuesta, Conclusiones e Informe en materia de sectas en el Pleno del

\section{Parlamento español de 1988 para instar al Gobierno a su aplicación}

El Ministro de Justicia Ledesma Bartret, en marzo de 1983, instó al Fiscal General del Estado a promover investigaciones sobre la proliferación de nuevos grupos religiosos que estaban siendo masivamente denunciados por múltiples afectados. Aunque no se materializaron tales investigaciones, en 1988, se volvió a instar al Fiscal General, esta vez con mayor suerte. En 1987, se encargó al sociólogo CANTERAS una investigación sobre las sectas en nuestro territorio para la Comisión Interministerial de la Juventud. De tal investigación nació el informe titulado «Asociación y Libertad Individual: los movimientos Religiosos Sectarios» ${ }^{177}$, en el que intervinieron, además de CANTERAS, el experto en sectas José RODRÍGUEZ y el psicólogo Álvaro RODRÍGUEZ-CARBALLEIRA. Dicho informe se centró en la captación que realizaban las sectas en un determinado grupo de mayor vulnerabilidad, los jóvenes.

La Comisión de Investigación del Parlamento español en su estudio de repercusión de las sectas en España, utilizó el criterio de «limitado arraigo social» para acotar y circunscribir el

177 Una síntesis en CANTERAS MURILlo, Andrés, «Asociacionismo y libertad individual: Los movimientos religiosos-sectarios», vv.aa., Aspectos socio-jurídicos de las sectas desde una perspectiva comparada, op. cit., pp. 55 y ss. 
polémico concepto de «secta» ${ }^{178}$. En tal investigación se propuso el adjetivo «destructivas» para calificar y diferenciar de las sectas, los grupos sectarios que parecían vulnerar determinados derechos básicos de la persona por métodos y estructuras que presumían un peligro para la sociedad. Pero la principal conclusión de dicho informe fue «la necesidad de interpretar el fenómeno religioso-sectario, como una manifestación social del creciente pluralismo ideológico religioso de tono secularizador que viene consolidándose en nuestro país y deslindando claramente del mismo la nefasta acción de algunas sectas destructivas».

Cabe reseñar, por último, que la problemática y preocupación mundial en esta materia propició la celebración del primer congreso Internacional sobre sectas, titulado «Sectas y Sociedad» ${ }^{179}$ en el año 1987, celebrado en Barcelona, e impulsado por la Asociación ProJuventud, asociación formada por familiares de adeptos y ex-adeptos cuyo cometido era luchar contra las sectas «peligrosas» bajo el auspicio del Generalitat de Catalunya.

Tanto el meritado informe como el primer congreso internacional sobre sectas en nuestro país, además claro está la Resolución del Parlamento Europeo y Mociones del Consejo de Europa de 1987, propulsaron la formación de una Comisión de investigación sobre la repercusión de las sectas en España y que culminó en la Resolución del parlamento español de $1988^{180}$.

La principal conclusión de este importante congreso fue que el fenómeno sectario problemático se puede solucionar sin reformación de la Ley ${ }^{181}$. Todo ello derivó en que el congreso internacional invitara a la creación de una Comisión Interministerial que finalmente se constituyó en 1987 gracias a los esfuerzos de María Dolores Renal y la diputada experta en sectas Pilar SALARRULlanA. Gracias también a esta última se creó una Comisión parlamentaria que señaló al Gobierno cuáles eran las directrices en materia de sectas más adecuadas ${ }^{182}$. Sin

178 Más ampliamente Motilla, Agustín, «Anexo V», Sectas y derecho en España, Editoriales de Derecho Reunidas, Madrid, 1990, pp. 119 y 120.

179 Íntegramente en AlONSO HERrERos R / MuÑIZ CALAZ B / RAMOS SUÁrEZ A / RodríGUEZ JA., «Actitud del ordenamiento español ante las sectas», Sectas y Derechos Humanos, op. cit., pp. 65 a 69.

180 Boletín oficial de las Cortes Generales, Congreso de los Diputados, III Legislatura, Serie E, 10 de marzo de 1989, núm. 174.

181 Del congreso merece especial atención las diversas propuestas planteadas: medidas dirigidas a la administración, como por ejemplo el control de la legalidad de los estatutos a través de la comparación con las reales actividades de las sectas, para evitar falsas entidades religiosas o asociaciones delictivas, y una mayor investigación en los aspectos laborales y fiscales para acreditar el ánimo de lucro desproporcional; medidas encaminadas a la modificación del régimen jurídico de las asociaciones sin ánimo de lucro; medidas de prevención y apoyo destinadas al poder judicial para informar sobre el llamado «síndrome disociativo atípico»; medidas destinadas a promover la información policial para detectar sectas delictivas; difusión de informaciones a los jóvenes en su ámbito cultural y educativo; medidas de apoyo a las posibles víctimas de procesos despersonalizadores; y medidas de tutela a menores de edad.

182 SALARRULLANA presentó dos mociones, una para la aprobación de la Resolución del Parlamento Europeo de 1984 para que se alcanzase una acción conjunta de los Estados miembros, y la de creación de Comisión de investigación del fenómeno, sobre los peligros de unas y otras sectas consideradas «peligrosas», tanto sobre las inscritas en el Registro de Entidades Religiosas, como las que adoptaban la forma jurídica de asociación civil, e 
embargo, toda la labor investigadora de la Comisión se quedó en un mero estudio sociológico, psicológico, psiquiátrico y criminológico del fenómeno sectario sin profundizar en pruebas o indicios delictivos, ni mucho menos en cómo el Derecho penal como ciencia podía ayudar a prevenir y a sancionar conductas que hasta la fecha suponía una novedad criminológica como la manipulación mental o persuasión coercitiva, y la relación con otras conductas penales tradicionales como el intrusismo profesional y la estafa.

\section{F. Problemáticas en la inscripción de grupos religiosos en el Registro de Entidades Religiosas}

Como vemos, las entidades no religiosas se protegen. El problema se circunscribe en la compresión de los términos «fines religiosos» que marca la LOLR en su art. 5, y lo complementa el art. 3.2 c) del RD 142/1981, de 9 de enero, sobre organización y funcionamiento del Registro de Entidades Religiosas. Los Tratados y Declaraciones internacionales protegen las creencias no religiosas, de modo que una interpretación extensiva de «fines religiosos» también protege las creencias a través de la Ley ${ }^{183}$.

La Dirección General de Asuntos Religiosos en sus Resoluciones de 15 de septiembre de 1983, 25 de junio de 1985, 29 de enero de 1988, 18 de abril de 1988 y 25 de enero de 1995 exige para entender «fines religiosos» de las entidades: un cuerpo doctrinal propio, una liturgia que recoja los ritos y existencia de lugares de culto, unos fines religiosos que respeten el derecho a la libertad religiosa del art. 3 de la Ley Orgánica de Libertad Religiosa, y carácter previo de un número significativo de adeptos.

La interpretación jurisprudencia sobre los términos «fines religiosos» se puede encontrar en la STS de 1 de marzo de 1994 y STS de 15 de febrero de 2001, en las que se afirma que una entidad posee fines religiosos «cuando su objetivo es agrupar a las personas para considerar en común esa doctrina, orar y predicar sobre ella, así como realizar los actos de culto que su sistema de creencias establece». Es de destacar la STC 46/2001, de 15 de febrero, que resolvió el problema de inscripción de la Iglesia de la Unificación de Moon, que había sido denegada por la

incluso en algunos casos sobre aquellas que adoptaban bajo la personalidad jurídica de sociedad mercantil, más ampliamente SAlarrullana, Pilar, Las sectas, $4^{\mathrm{a}}$ ed., Ed. Temas de hoy, Madrid, 1990, pp. 157 y ss.

183 LÓPEZ ALARCÓN, Mariano, «Dimensión orgánica de las confesiones religiosas en el Derecho español», Ius Canonicum, Vol. XX, 1980, p. 46; Souto PAZ, JA., Comunidad política y libertad de creencias, op. cit., pp. 256 y 257. Otros autores requieren para entender fines religiosos en las entidades, la creencia en un Ser Superior, por ejemplo GOTI ORDEÑANA comenta que «un fondo doctrinal que haga referencia a la divinidad, dotada de una praxis ritual y moral y de una estructura permanente con normas de organización autónoma», GOTI ORDEÑANA, Juan, Sistema de Derecho Eclesiástico, Parte Especial, San Sebastián, 1992, p. 16. 
DGAR mediante la Resolución de 22 de diciembre de 1992, al dictaminar que no cumplía ninguno de los siguientes requisitos:

«1) Creencia en la existencia de un Ser superior, trascendente o no, con el que es posible la comunicación.

2) Creencia en un conjunto de verdades doctrinales [dogmas y reglas de conducta (normas morales)], de un modo u otro derivadas de ese Ser superior. 3) Una serie de acciones rituales, individuales o colectivas (culto), que constituyen el cauce a través del cual se institucionaliza la comunicación de los fieles con el Ser superior».

Estos argumentos fueron también alegados para denegar la inscripción de otras tantas asociaciones ${ }^{184}$ de pretendidos fines religiosos. Del mismo modo, la Resolución insiste en la infracción del orden público remitiéndose al estudio del Congreso de fecha 2 de 1989, al que luego aludiéremos más extensamente, y en el que afirma que dicha asociación es una organización peligrosa para la sociedad.

La Sentencia de la Audiencia Nacional de 30 de septiembre de 1993 y la STS de 14 de julio de 1996, confirmaron la denegación por entender igualmente que dicha asociación suponía un riesgo para la sociedad. Sin embargo, STC 46/2001, de 15 de febrero acertadamente declaró que «la Administración no debe arrogarse la función de juzgar el componente religioso de las entidades solicitantes del acceso al Registro, sino que debe atenerse a constatar que, atendidos sus estatutos, objetivos y fines, no son entidades de las excluidas por el artículo 3.2 de la Ley Orgánica de Libertad Religiosa».

De otra parte, la Resolución de la DGAR de 11 de diciembre de 1983 denegó la inscripción a la Iglesia Universal de la Cienciología, en cuyo considerando tercero se argumentaba que el grupo tenía finalidades que no respetaban uno de los elementos constitutivos del orden público, en concreto la salud pública, refiriéndose a los métodos «meta-psicológicos». Dos años después, nuevamente la DGAR denegó la inscripción en la Resolución de fecha 22 de abril de 1985 a la Iglesia Ciencio-lógica de España, al argumentar en su considerando quinto que «el estudio de la mente y la curación de las enfermedades no debe separarse de la religión ni debe condenarse a campos religiosos», también en atención a la documentación presentada, referida a la obra Dianética. La ciencia moderna de la salud mental de su fundador L. Ronald HUBBARD, afectan negativamente a la salud pública. Dichas Resoluciones fueron confirmadas por las Sentencias de la Audiencia Nacional de 23 de junio de 1988 y por la Sentencia del Tribunal Supremo de 25 de junio de 1990. Posteriormente se volvió a denegar su inscripción por la Resolución de fecha 11 de febrero de 2005, sin embargo, en esta ocasión, la Sentencia de la Audiencia Nacional de 11 de

\footnotetext{
184 Ampliamente sobre las problemáticas registrales de grupos en el Registro de Entidades Religiosas, SEGLERS, Álex, «La inscripción registral de las confesiones religiosas: análisis de los requisitos legales», Revista de Administración Pública, núm. 163, enero-abril, 2004, pp. 311 a 347.
} 
octubre de 2007 estimó la inscripción por considerar que tiene «fines religiosos» ${ }^{185}$, siguiendo así las bases de la meritada STC 46/2001, de 15 de febrero.

Ha de concluirse que, efectivamente no es necesaria la inscripción en el Registro de Entidades Religiosas para asociarse en la práctica religiosa o de cualquier ámbito trascendental del ser humano, como igualmente sucede en Alemania ${ }^{186}$. No obstante, la casuística jurisprudencial y legal han ampliado el concepto de «fines religiosos» en el sentido de abarcar cualquier sentimiento o pensamiento trascendental, de forma que la agrupación de personas con una idea común trascendental y/o metafísica, puede también beneficiarse de los efectos de la inscripción registral. Así se confirma que los postulados metafísicos de la moral agrupan cualquier otro aspecto digno de protección (ideas, pensamientos, convicciones, ética, etc.) conforme al art. 16 CE.

\section{VII.- Conclusiones}

Hemos visto que tradicionalmente, con asombrosa singularidad, en el pensamiento filosófico se ha identificado la religión o el sentimiento religioso dominante en una sociedad determinada con la norma jurídica. La ley divina como moral y la ley jurídica se identificaban mutuamente representándose la una a la otra. Sin embargo, en una sociedad funcionalmente diferenciada que supera la rigidez segmentaria o jerarquizada, la moral se torna como un escollo de la libertad de conciencia. Efectivamente la moral ha dejado de tener una comunicación propia, si bien durante gran parte de la historia ha venido asociada a la religión, al sentimiento colectivo y/o divino, y no estrictamente al sentimiento individual.

En aquellos momentos de la historia en que la ley jurídica se refería a la ley divina, la actuación conforme a esta última no suponía un verdadero conflicto de conciencia, sino más bien, la suposición de que la ley jurídica se había desvinculado del imperativo divino, de modo que sólo cuando la ley jurídica se desvinculó del todo de la ley divina es cuando comenzaron a surgir verdaderos conflictos de conciencia entre el deber moral y el deber jurídico. En este

185 En concreto comenta la SAN, de 11 de octubre de 2007, en su FJ $8^{\text {a }}$ que «se desprende «prima facie» de sus estatutos, así como del cuerpo de doctrina aportado, y también del hecho de que la asociación es similar a otras que se encuentran debidamente inscritas en registros oficiales en países de nuestro entorno jurídico y social; por el contrario, no existe dato alguno que permita concluir que la demandante lleva a cabo actividades distintas de las expresadas en sus estatutos que pudieran determinar la aplicación del art. 3,2 citado». Ampliamente sobre la meritada Sentencia, FERNÁNDEZ-CORONADO, Ana, «Reflexiones en torno a la función del Registro de entidades religiosas (A propósito de la Sentencia de la Audiencia Nacional de 11 de octubre de 2007 sobre inscripción de la Iglesia de la Scientology)», Laicidad y Libertades. Escritos Jurídicos, núm. 7, 2007, páginas 389 a 402.

186 RoCA, María José, «La interpretación del concepto "fines religiosos" y la discrecionalidad administrativa», ADEE, Vol. XTV, 1998, pp. 469 y ss. 
sentido, el reconocimiento jurídico de la libertad de conciencia individual, sobre todo gracias a partir de los postulados de la autonomía de la voluntad de KANT, propició que surgieran los verdaderos conflictos de conciencia.

Desde el idealismo alemán se comparte la idea de que el fin mismo de la conciencia expresada en la voluntad es ineludible, que la fuerza de la conciencia se alinea con la voluntad, por lo que aquellos sentimientos de nuestra conciencia que no fueren un fin en sí mismo, sino un simple medio, una alternativa, a pesar de contener para el propio sujeto una cuestión inevitable, esto es la elección de una alternativa que contradice la ley jurídica contando con otras alternativas, es vista por la Sociedad como una conducta más reprochable que aquella que inevitablemente opera, al menos, bajo la creencia de que es un fin en sí mismo o una Ley universal de la naturaleza, en este caso de la conciencia moral. Desde el idealismo alemán hasta la actualidad se concibe que la posesión de alternativas y la elección de una de ellas es la demostración de libertad, entonces tendremos que convenir que la falta de alternativas supone, al menos, una forma de restricción de la libertad. En ambos casos, cuando la conciencia y la voluntad se alinean, con o sin alternativas, se autonormativiza de tal manera que hace de tal operación un imperativo o autorrepresentación inapelable de la realidad del sujeto y de su voluntad.

La crítica nietzscheana, y más recientemente luhmanniana, a esta valoración es que sigue presente la máxima kantiana y la distinción entre móvil y motivo, entre medio y fin, o dicho de otra forma, que las conductas que persiguen un fin en sí mismo suponen una analogía con el imperativo categórico, si bien, en ocasiones, errado cuando la conducta es inmoral o cuando se incurre en el delito, y que las conductas que anteponen un medio delictivo para conseguir un fin vulneran plenamente el sentimiento del imperativo categórico. De aquí surgió la posterior teoría sociológica anquilosada en la racionalidad de la acción social comunicativa, que ha seguido fundamentando el consenso normativo (la autoridad) en la moral. Por eso, con NIETZSCHE se inicia la idea de que la Sociedad y la norma realizan, paradójicament, una valoración, además de normativa, moral del hecho. Tradicionalmente se ha valorado un mismo hecho moralmente como negativo primero y positivamente después, y viceversa, lo cual significa que la valoración normativa depende, en parte, de influjos morales de la Sociedad: ¿pero esto fundamenta el orden social, el Sistema?

Con LUHMANN se concluye la primigenia concepción nietzscheana de que no existen hechos morales sino sólo interpretaciones morales de los hechos, pero ahora en la máxima: la moral no pertenece al Sistema Social sino al entorno. El sistema del Derecho no tiene operaciones morales 
sino influencias morales: basta con expectativas generalizadas. De esta manera se consigue reafirmar la propia operación clausurada del Sistema sin entradas de operaciones morales cambiantes que lo puedan poner en peligro.

De nuestra conciencia, o sea, del conocimiento, se crean alternativas de comportamiento, que son elegidas por nuestra voluntad con más o menos convicción (intensidad) en nuestra conciencia. Estas alternativas conforman un horizonte de expectativas que supone un principio para la voluntad inmaterial, y a lo que se refiere sobre todo nuestra conciencia religiosa, ideológica, política o filosófica, de modo que de este horizonte de expectativas el sujeto puede elegir tales alternativas que propician la formación de conciencia general, y particularmente religiosa o moral. Entonces, la conciencia supone una crítica del juicio que nos hace eliminar las alternativas, la complejidad, y actuar sin contradicción con nuestra representación conocida del mundo (principio de no contradicción). La conciencia en cuanto representación del horizonte de expectativas supone el primer escalón de la libertad de voluntad, que se desarrolla posteriormente con la elección de las expectativas representadas por el sujeto en todo el horizonte de posibilidades. En cuanto se cierran las alternativas y el sujeto se marca un fin, en cuanto dirige su voluntad a una de las alternativas, la conducta determinada es su fin, entonces, la libertad es el producto de esta operación. Sólo otro haz de alternativas podrá cambiar la dirección de la voluntad.

En este sentido el Derecho penal comunica a la Sociedad que diversas alternativas no son posibles bajo riesgo de una consecuencia: la sanción penal. De aquí que la elección contraria al Derecho parte de una reducción de la complejidad seleccionada previamente por el sujeto, y demuestra que el sujeto -itenía alternativas!- era libre, salvo causalidad, infortunio, o producto inevitable de la naturaleza. Sin embargo, antes de la conciencia y la representación de las cosas, para adquirir el horizonte de expectativas y conformar alternativas, falta una predisposición, también llamada Voluntad, en virtud de la cual y su intensidad, se dirige al conocimiento y a la representación de dicho horizonte, restringiéndolo, ampliándolo, seleccionándolo. De este modo, la Voluntad precondiciona la conciencia y la representación de las alternativas que a la postre, determina la crítica del juicio tanto en las elecciones morales como en las puramente materiales.

Así, existe una primera Voluntad, la que determina el horizonte de expectativas, y una segunda Voluntad que una vez toma conciencia de este horizonte, elige su concreta expectativa, y en cuanto le otorga normatividad, la ejecuta irremediablemente. La primera voluntad se refiere la capacidad natural del ser vivo, la segunda a la capacidad de elección y ejecución. Ambas voluntades pueden ser irresolubles, la primera en cuanto a la inevitable conformación de un 
horizonte de expectativas, la segunda se refiere a la elección y/o ejecución de una determinada alternativa, pero en ambas subyace el producto de la libertad, salvo que se elimine relevantemente la conformación del horizonte de expectativas que se le presentan al sujeto, y/o se restrinja la elección y la ejecución de la alternativa. De esta diferencia pueden extraerse importantes consecuencias en el Derecho penal como veremos a partir del capítulo segundo.

Hemos visto también que en la valoración de la conciencia y la voluntad se entremezcla distintas metodologías científicas, desde la filosofía metafísica, la psicología, la sociología y las neurociencias últimamente. El debate indeterminismo/determinismo nada aporta a ninguna ciencia si no son integrados estos conceptos en la semántica social. Todo está tan determinado que resulta indeterminado, o todo está indeterminado hasta el punto que se puede determinar en algún punto. Por eso el concepto de libertad es para el Sistema del Derecho penal un concepto que en la semántica social significa la aceptación por la sociedad del reconocimiento de la libertad, salvo que no se acepte, en cuyo caso, esta falta de aceptación puede venir de motivos también de la socialización (inexigibilidad), de la ciencia (falta de acción en el sonambulismo, falta de culpabilidad por las anomalías en la capacidad cognitiva y/o volitiva), o por causas político-criminales tales como la falta de merecimiento de la pena (punibilidad).

Todas las causas desde sus ciencias son verdad en cuanto se fija lo verdadero o se tiene-porverdadero, pero todas ellas consideradas a la vez adquieren un conocimiento de segundo orden: el realizado por un segundo observador. Desde una observación de segundo orden, aquella que toma en consideración las operaciones que todas las ciencias producen sobre una determinada cuestión, se puede conocer si un determinado hecho pertenece al ámbito de conocimiento concreto que se quiere aplicar. Si el Derecho penal pretende conocer si un determinado hecho puede ser valorado de alguna forma según su normativa (operatividad), ha de contar con las operaciones realizadas en otros ámbitos (sistemas), pero sólo en cuanto que esa operación es trasformada en el sentido de la operatividad del propio sistema, especialmente el mayor en el que se circunscribe: la Sociedad. De aquí que la inimputabilidad, la exigibilidad, la punibilidad y otras instituciones tradicionales del Derecho penal cuenten con la operatividad de otras ciencias, y se produzcan entradas cognitivas de otras ciencias en la propia operatividad del Derecho penal, pero trasformada a su propio sentido. Inclusive un mismo hecho para el Derecho penal puede considerarse previamente determinado o indeterminado, en función de las entradas de operaciones de otras ciencias y tipo de sociedad que se trate, sin que en uno u otro caso se reste relevancia a cada conclusión. Pero esta no es nuestra cuestión. 
El análisis del presente capítulo arroja la conclusión de que la moral no pertenece al Sistema, tampoco al subsistema del Derecho penal, por eso el consenso normativo (válido y legítimo) no se alcanza por la autoridad moral ni por la mayor racionalidad a la que alude el idealismo tradicional, sino en la contingencia de expectativas de todos, esto es: la generalidad de expectativas. Dicha generalidad depende de cada sistema. Esto no significa que no existan influencias, pero si el Derecho es tratado como moral (solidaridad mínima) se corre el peligro de que los valores que se asocian a determinados hechos sufran contradicciones/paradojas con el tiempo. Esto es precisamente lo que ha sucedido en la conceptualización de la autoría de conciencia, por convicción y con el enemigo, como si unos fueran «buenos»y otros «malos», como si unos merecieran la atenuación de la pena o la exoneración per se y otros la máxima responsabilidad.

Como ha señalado Polaino NAVARRETE, también son bienes jurídicos «los valores más firmes del orden de convivencia humana en condiciones de dignidad y progreso de la persona en sociedad», siempre y cuando exista un consenso general ${ }^{187}$. Esto desde luego es innegable, y constituye una opinión que ratifica la teoría racionalista, pero se convendrá que no todo desafío a los valores del orden social suponen un quebrantamiento tal, que merezca la intervención del Derecho penal o la mayor sanción penal. Engañar es una acción que per se no tiene mayor valor que la de una interpretación moral, de aquí que el contexto social en que se ejercita la acción de engañar, inclusive más allá de las consecuencias en un tercero, sea el medio en que dicha acción se comunica hasta el punto de alcanzar relevancia en la operatividad de la Sociedad. Por eso recuerda LUHMANN que el consenso no fundamenta la Sociedad, sino que supone una disyunción entre el comportamiento adecuado a la norma y la desviada con sus diferentes expectativas. Hay una «lógica propia del mal» que también pertenece a la sociedad en cuanto que el delincuente quiere lo prohibido ${ }^{188}$.

En nuestra opinión -y siguiendo en parte el modelo de LUHMANN-, la libertad de conciencia se puede concebir como el propio e ineludible sistema psíquico de pensamientos que conforma la conciencia, de forma que la multiplicidad de pensamientos y sentimientos constituyen un sistema autopoiético y autorreferencial cerrado que se abre, se interpenetra por la fuerza del Derecho, la autoridad, la educación, es decir, por otros sistemas. Esta interpenetración es lo que parte de la doctrina señala que hace el Derecho: orienta normativamente a los sujetos. Los límites a la

\footnotetext{
187 Polaino NaVArRete, Miguel, El bien jurídico en el Derecho penal, Anales de la Universidad de Sevilla, núm. 19, Servicio de Publicaciones, Sevilla, 1974, pp. 356.

188 LUHMANN, N., «Interacción, organización, sociedad. Aplicaciones de la teoría de sistemas», LUHMANN, N., La moral de la sociedad, op. cit., op. cit., p. 201.
} 
libertad de conciencia constituyen entonces entradas o influencias de la moral general en el sistema del Derecho, a modo de mínimos éticos, que en ocasiones producen la contraorientación normativa con la libertad de conciencia en grupos minoritarios o conciencias individuales. La libertad de conciencia no protege la conciencia sino que se protege de ella, de su propia autonormatividad, orientándola a las alternativas normativas de la Sociedad, de modo que respecto algunas conductas en conflicto de conciencia, el orden social en determinas situaciones no exige un comportamiento tan fiel a la norma, ya sea por falta de alternativas o por contraorientación manifiesta entre la previa orientación normativa y la determinada norma de conducta.

La conciencia controla la autocreación de la normatividad personal, así la conciencia tiene presente la norma social para construir la personalidad. La libertad de conciencia orienta a la conciencia en dicha normatividad, por eso la libertad de conciencia es también condición previa de la libertad religiosa, ideológica o de culto, pero a la vez informa a la conciencia sobre cómo ha de autonormativarse conforme a la norma social. De aquí que en ocasiones, cuando la norma orienta al sujeto a una determinada conducta, y después se la prohíbe llegada la situación de ejercicio, el sujeto sufre un conflicto de conciencia entre la previa orientación y la última directriz normativa, de modo que el sujeto se siente tan socializado en la conformación de su voluntad respecto a dicha orientación, que inevitablemente le lleva a desatender la norma. De esta manera, es comprensible que la objeción de conciencia es un derecho general a la formación y elección de conciencia, principalmente expresado en el art. $16 \mathrm{CE}$, que encuentra limitaciones particulares y funcionales en el comportamiento exteriorizado según la operatividad básica de la Sociedad, si bien, en determinados supuestos (antiguo servicio militar, la actual objeción al aborto, etc.), la norma establece regulaciones excepcionales de objeción de conciencia, en el sentido de determinadas alternativas de comportamiento, todo ello sin perjuicio del reconocimiento al derecho general a la objeción de conciencia que adquirirá virtualidad en función del contexto y expectativas sociales. Por eso, la libertad de conciencia admite varios niveles de ejercicio: la formación del horizonte de alternativas y expectativas, el derecho a formar y tener conciencia propia o colectiva, libertad para expresarla, y libertad de práctica o de adecuar la conducta a la conciencia. De aquí que la autoría de conciencia se relaciona con la libertad de conciencia, e íntimamente e inherentemente se relaciona con la dignidad.

La libertad de conciencia y su tratamiento penal suponen la reafirmación de la operación psíquica de la conciencia y del sentimiento religioso como expresión material de la voluntad en la conducta. Por eso, si la norma que protege este sentimiento de la voluntad no se ve alterada 
por el final resultado de ésta, el sistema normativo y social sigue funcionando. Esto no significa que no requiera de sanción. Mientras que aquellas conductas iniciadas en este sentimiento ineludible que ponen en peligro la operatividad del Sistema, se expulsan para procurar su propia operatividad. Dicho de otro modo, el Sistema Social en razón del sistema que valora las conductas más graves, el Derecho penal, «se las arregla mejor» con unas conductas criminales que con otras, especialmente con aquellas conductas que parten de un comportamiento obligatorio de conciencia cuando dicho motivo procede de la propia operatividad del sistema mayor en relación de diferenciación: el Sistema Social.

La paradoja en la que incurre la tradicional forma de interpretar el sistema normativo y social, es valorar como máxima kantiana, o sea, moralmente, una conducta moral. A esto se le puede denominar la moralidad del Sistema, cuando no aplica su propia operatividad normativa, sino una determinada influencia moral, por ejemplo al valorar positivamente los sentimientos religiosos concretos (rechazar un tratamiento vital) y posteriormente criminalizar en determinados casos especiales una conducta circunstancial e ineludible en este sentimiento. En verdad, en esta valoración el Sistema se nutre del sentimiento general de la sociedad, se nutre de moral generalizada, para valorar un hecho como si fuera normativamente, sin prestar atención a su propia operativa, aquella que le ha permitido al sujeto tener su sentimiento imprescindible. Esa forma de proceder, a la que hemos denominado moralidad del Sistema, no valora al sujeto normativamente sino moralmente, sin atender a la realidad de que no todos pueden conocer cuál es esa máxima que eleve su obrar a Ley universal, sin atender a la previa permisividad que la orientación normativa y social producen.

Esta forma de plantear la cuestión, estrictamente racionalista y que discutimos, nos lleva a concluir que diversas conductas que normalmente se han tratado de autoría de conciencia pueden valorarse con los postulados actuales del Derecho penal como autoría por convicción y viceversa, simplemente basta cambiar el hecho o su gravedad para que la valoración tradicional dogmática cambie su criterio conceptual, y esto es porque tradicionalmente se ha tratado esta problemática como un asunto de moralidad del Sistema, como «conformidad de una acción o doctrina con los preceptos de la moral» ${ }^{189}$, no de forma puramente normativa. Veremos que cuando el autor de conciencia realiza la conducta en omisión de deber de socorro no faltan voces que atenúan la responsabilidad, sin embargo cuando las circunstancias cambian, y el mismo sujeto, o sea con el mismo sentimiento ineludible de su actuar, incluso con la misma distancia de

\footnotetext{
189 Según la RAE en relación al concepto de «moralidad».
} 
su moral con la moral generalizada comete un homicidio en comisión por omisión, la valoración cambia hasta el punto de reclamar la máxima pena dentro de la extensión de la pena o se agrava.

Los ejemplos paradigmáticos que hemos podido encontrar es el de un padre testigo de Jehová que omite el deber de socorro cuando rechaza el tratamiento médico vital de trasfusión de sangre para su hijo, y otro, el del mismo padre pero con excelentes conocimientos médicos que omite llamar a las asistencias en el mismo caso. En el segundo ejemplo, la doctrina adecuadamente valora el hecho como comisión por omisión de homicidio o asesinato según los casos, incluso como un caso de autoría por convicción, o como un enemigo, y erróneamente proponen la máxima responsabilidad, sin embargo como puede verse, existe el mismo sustrato de la conciencia obligatoria de la voluntad en ambos ejemplos, sin embargo, en el primero se tiende a atenuar la pena y en el segundo a la máxima responsabilidad, y esto se debe a un reproche moral en el último y a una comprensión moral en el primero, pero no atiende a verdaderos razonamientos sistémicos y normativos, por cuanto el influjo moral, los valores sociales ya están incluidos en la norma. Esto tampoco negará que en determinadas circunstancias, especiales motivos puedan valorarse en la determinación de la pena, pero no aquellos que ya han sido tenidos en cuenta en la constitución normativa del injusto.

No obstante, en la autoría por convicción, la doctrina nunca ha encontrado motivos comprensibles. En ninguno de los casos paradigmáticos de este tipo de autoría, por ejemplo el terrorismo, se han formulado criterios de atenuación de la pena, salvo escasas excepciones (colaboración, arrepentimiento). Se piensa que, puesto que la conducta es suficientemente grave en su injusto, no puede existir motivo alguno para atenuarla, y es cierto, así es, pero esto demuestra que en la valoración negativa que impone la máxima responsabilidad se ha introducido una valoración moral que reza así: al hecho grave cometido por convicción le merece el máximo reproche penal. Esto es cierto pero no en todos los casos. Sobre estas excepciones trata, en parte, esta investigación, excepciones que confirman que la principal función del Sistema social y normativo es la autoprotección de su operatividad.

Nuestra investigación, si bien se inició con el estudio de las sectas criminales, se ha visto obligada a tratar también los conceptos y tratamiento penal de la autoría de conciencia, por convicción y el enemigo, porque tal y como desarrollaremos infra, las sectas criminales suponen casos paradigmáticos de contingencia de las tipologías criminales. La valoración sobre la que vamos a partir en esta investigación será aquella que trate de evitar cualquier tipo de operación o valoración moral en conceptos como «bien común»o «racional». De esta forma de proceder se puede criticar y exponer que, tradicionalmente se ha tratado la autoría de conciencia y por 
convicción, al enemigo y a las sectas con fundamentos paradójicamente de «moralidad», entonces, trataremos de llegar a conclusiones que estrictamente valoren las conductas criminales normativamente y sistémicamente.

Por tanto la única forma de explicar un diferente trato a dos acciones que nacen de un motivo moral, no puede ser otorgar un valor positivo o negativo a cada hecho criminal, salvo pena de incurrir en la paradoja de juzgar moralmente hechos idénticos, sino la razón es simplemente sistémica o de funcionamiento de la Sociedad. Este fenómeno de contraorientación normativa o de uso indiscriminado de la moral dominante se aprecia con mayor virulencia en las trabas, acusaciones e impedimentos a los grupos denominados tradicionalmente como sectas, pero sin argumentos, pruebas o indicios, más que la simple intuición de que cometen delitos, o al menos y de otra parte, sin atender ni prestar atención, sin investigar seriamente las denuncias de los exadeptos. Como veremos en posteriores capítulos, el Código penal criminaliza las asociaciones que utilicen la manipulación mental aunque fuere para fines lícitos, sin embargo lo que llama la atención es que ni la doctrina ni la norma penal hayan concretado a qué se refiere con la expresión manipulación mental. Los estudios e investigaciones se han quedado en un mero análisis sociológico, psicológico y criminológico, pero escasamente se ha abordado la cuestión desde el estricto ámbito penal.

La moral y la conciencia, desde un aspecto normativo, pueden constituir un asunto riesgoso como la fabricación y venta de productos, sin embargo si bien es cierto que la libertad de conciencia es sana para una sociedad democrática y plural, lo cierto es que precisa del mismo control que la fabricación y venta productos a la sociedad, por cuanto que los producto «conciencia», «moral», «religión», afectan a la más estricta formación de nuestra voluntad. La situación riesgosa de aleccionar la conciencia y la moral de otros precisa del mismo control, que no represión, que cualquier otra actividad riesgosa como los tratamientos médicos y psicológicos, máxime cuando en la conciencia religiosa o moral se inicia el principio de nuestra voluntad. 


\section{Capítulo II}

\section{AUTOR DE CONCIENCIA, AUTOR POR CONVICCIÓN \\ Y PELIGROSIDAd CRIMINAL DESESTABILIZADORA}

\section{I.- Introducción: visión criminológica}

En la evolución histórica del pensamiento filosófico y jurídico se aprecia la disyuntiva de la obligación moral y jurídica. El paradigma ofrecido desde las distintas vertientes sobre la obligatoriedad de las normas, y en concreto de las normas penales que se inmiscuyen en los valores morales de las personas, es la oposición de unos al deber jurídico-penal cuando entra en conflicto con el deber moral, mientras que para otros, el deber jurídico, o más concreto, el deber jurídico-penal, debe imponerse al moral.

Para el pensamiento escolástico que hunde sus raíces en la lógica iusnaturalista aristotélica ${ }^{190}$, si se produce un conflicto de deberes entre el jurídico y el moral de fuente divina, el segundo debe primar sobre el primero. Con el nacimiento del Estado moderno, con la transición del modelo de la sociedad feudal al modelo contractual de la Revolución francesa, la doctrina de la seguridad jurídica ganó adeptos gracias al cambio de la concepción teocentrísta a la antropocentrísta $^{191}$. Con este cambio de concepción no es la Ley divina el motor de lo jurídico, sino la razón humana. A raíz de la teoría del contrato social se agudizaron concepciones absolutistas. Concretamente KANT negó el derecho de resistencia ${ }^{192}$ aunque la norma fuera ilegítima. Junto con KAnt, Hegel, BeCARÍA, Feuerbach, Romagnosi y CARRARA fueron

190 La filosofía de ARISTÓTELES impregnó en buena medida el pensamiento de la Escuela escolástica, en particular en la justificación del hecho por motivos morales, QUINTANO RIPOLLÉS, A., «La motivación moral en el Derecho Penal», RGLJ, núm. 4, 1949, p. 394.

191 BujÁn, Javier Alejandro, Elementos de Criminología en la Realidad Social, Depalma, Buenos Aires, 1998, pp. 59 a 64.

192 Sobre la negación del derecho de resistencia en KANT, Sobre la paz perpetua, op. cit., pp. 61 y ss. El derecho de resistencia nace el en siglo XVIII con la Constitución francesa de 1789 y con la posterior de tintes jacobinos de 1793. En la primera se preceptúa que existe la posibilidad del uso de la fuerza cuando se ataque la Constitución o la ley. En tal sentido los art. 33, 34 y 35 rezan así: art. 33 «la resistencia a la opresión es la consecuencia de los demás Derechos del hombre»; art. 34 «hay opresión contra la sociedad cuando uno solo de sus miembros está oprimido. Hay opresión contra cada miembro cuando la sociedad está oprimida; "Cuando el gobierno viola los derechos del pueblo, la insurrección es, para el pueblo y para cada parte de él, el más sagrado de los derechos y el más indispensable de los deberes». LUHMANN al respecto explica que el derecho de resistencia consiste en que el derecho, por sí mismo, no garantiza la paz, sin embargo esto constituiría un contrasentido: «(p)recisamente si cada cual se remitiera a su razón natural o buscara argumentos en los materiales jurídicos impresos, entonces el derecho destruiría su propia condición de posibilidad: la paz», LuHMANN, N., El derecho de la sociedad, op. cit., p. 478. 
precursores de la Escuela clásica de la criminología que defendió el sistema del contrato social. El delito se consideraba una ruptura con el contrato ${ }^{193}$, legitimándose así la pena como retribución (teoría de la retribución de la pena), o como intimidación a la sociedad en general (teoría de la prevención general negativa). No es de extrañar entonces que la escuela clásica consideró a los autores por convicción o de conciencia auténticos corruptores del contrato social, por lo que la postura mantenida por tal escuela era la penalización máxima.

La escuela criminológica positiva, cuyos antecedentes son la fisiología de LAVATER y DELLA PORTA y la frenología de GALL, tuvo como miembros destacados a BINDING con el positivismo jurídico, a LOMBROSO ${ }^{194}$ con el positivismo materialista o antropológico, cuya obra se centró en el delincuente «nato» como aquel que tiene una forma hereditaria de delincuencia, y a FERRI y su positivismo sociológico que consideraba al autor por convicción como aquel que comete delitos políticos sociales ${ }^{195}$. Quizás por causas individuales, ambientales y psicológicas, estos delincuentes se consideraban desde estos postulados como delincuentes pasionales o emotivos que incurrían en delitos de conspiración, alta traición, violencia electoral, sedición, o inclusive homicidio, hurto, falsedad y delitos económicos, con lo que cabe concluir que el criterio que definía para esta escuela a este tipo de autores era el motivo, lo subjetivo.

La escuela criminológica positiva también tuvo entre sus miembros a GARÓFALO ${ }^{196}$ que defendía un positivismo jurídico, y a vON LISZT como fundador de la Escuela del Derecho de defensa y prevención social ${ }^{197}$, corriente que se servirá de los alegatos de la Escuela positiva para el fundamento de la teoría de la prevención especial positiva (resocialización), y que además también servirá de fundamento a la teoría de la prevención especial negativa (neutralización). Amén de ello, para la escuela positiva, los delincuentes por convicción y de conciencia debían ser tratados como «enfermos», por tal motivo únicamente se les podía aplicar un tratamiento para la recuperación social, salvo los casos imposibles en los que se aplicaría la neutralización del sujeto.

193 Buján, JA., Elementos de Criminología en la Realidad Social, op. cit., p. 79.

194 Lombroso, C., L'Uomo delinquente, op. cit.

195 FERRI, Enrico, Principii di Diritto Criminale. Delinquente e delitto, op. cit; ID., Sociologia Criminale, $4^{\mathrm{a}}$ ed., Fratelli Boca, Torino, 1900.

196 Garofalo, discípulo de LOMBRoso, afirmó que unos delincuentes lo eran por anomalías psíquicas incorregibles en la base moral: «Estos son los que cometen asesinatos por motivos puramente egoístas, sin influencia alguna de prejuicios, sin la complicidad indirecta del medio social», GAROFALO, Raffaele, Estudios criminalistas, Librería Suárez, Madrid, 1986, p. 81.

197 Para von LISZT «(e)l delito es el producto de la individualidad del autor en el momento de realizar el acto y de las condiciones ambientales que se den en ese momento» y en «(l)as causas y géneros de la criminalidad», propone la unificación de la ciencia jurídico-penal y criminológica en una misma «ciencia Conjunta del derecho Penal», LISZT, F. von, Tratado, T. II, op. cit., pp. 12 y ss. 
Por otra parte, la escuela Sociológica, en palabras de BuJÁn, considera al delincuente «como un ser normal no patológico. El comportamiento desviado es un factor necesario y útil para el equilibrio y el desarrollo sociocultural» ${ }^{198}$. Dentro de los precursores de esta teoría se incluyen WEBER y DURKHEIM (teoría sociológica), MERTON (teoría estructural funcionalista), MACKAY MACKENZI (teoría ecológica), COHEN (teoría de las subculturas criminales), SUTHERLAND ${ }^{199}$ (teoría de la asociación diferencial), SYKES y MATZA (teoría de la neutralización) ${ }^{200}$. Los últimos presentaron al autor por convicción y de conciencia como reaccionarios a la cultura dominante, son autores que pertenecen a una «contracultura» que utiliza la técnica de neutralización distinto a los individuos pertenecientes a una «subcultura» ${ }^{201}$.

Desde la perspectiva de otras Ciencias, especialmente la Criminología, la escuela del labelling aproach desarrolló postulados sobre el control social o reacción social y teorías del conflicto. Estas teorías presentaban al autor por convicción y de conciencia como unos reaccionarios sociales. Bajo estos postulados se consideraba al autor por convicción como un delincuente que reacciona frente al orden jurídico establecido en función de su ideología, religión o concepción política y por ello en contra del Poder, se consideraba que el delito era la creación del Poder para reprimir las concepciones diferentes ${ }^{202}$. Los autores más representativos de la teoría del labelling aproach (BECKER, LEMERT y TANNENBAUM ${ }^{203}$ ) defendían que el delito y el delincuente son consecuencia del Poder, de la decisión de criminalizar tales conductas, especialmente la de las clases desfavorecidas por no someterse al poder, a la cultura impuesta. En consecuencia, como hemos adelantado antes, el autor por convicción y de conciencia para esta teoría, era sujetos reaccionarios al poder establecido, a la cultura establecida y los intereses generales.

198 BujÁn, JA., Elementos de Criminología en la Realidad Social, op. cit., p. 96.

199 Sutherland, E., Principles of Criminology, 1939; ID., White Collar Crime, 1940, en donde define el delito como producto social y nos habla por primera vez del concepto del delincuente de cuello blanco.

200 SYKES y MATZA elaboraron la teoría de la neutralización. Consideran que el autor por convicción y de conciencia, en base a la Contracultura a la que pertenecen, presentan el delito como un acto lícito, como condicionado a factores externos, como lealtad al grupo, niegan el daño a la víctima y deslegitiman el poder de la autoridad.

201 Cometa al respecto BUJÁN que «(1)a Subcultura es entendida como un subsistema social para el que rigen valores, normas y símbolos propios que pueden coincidir parcialmente con la cultura superior y dominante, pero en parte diferenciada claramente de ella (...) se debe hablar siempre de subcultura y no de contracultura, en cuanto los nuevos valores o legitimaciones culturales de las prácticas ilegales no tiene fuerza política de colocarse en términos de alternatividad en relación con la cultura dominante», BUJÁN, JA., Elementos de Criminología en la Realidad Social, op. cit., p. 179.

202 HASSEMER y MUÑOZ CONDE comenta al respecto que «(1)a criminalidad no existe, sino se hace. Esta construcción de la criminalidad nada tiene que ver con los factores sino con los sujetos que tiene el poder de definir, de ahí que estas teorías sean conocidas como planteamientos definitorios o interaccionistas», HASSEMER Winfried / MUÑOZ CONDE Francisco, Introducción a la criminología y al derecho penal, Tirant lo Blanch, Valencia, 1989, p. 57.

203 BECKER, Howard S., Outsiders: Studies in the sociology of deviance, Free Press, New York, 1963; LEMERT, Edwin M., Human deviance, social problems and social control, Prentice-Hall, Englewood Cliffs, 1967; TANnenBAum, Frank, Crime and Community, C.U. Pres, New York, 1938. 
Cabe señalar la teoría de la criminalidad radical. Esta teoría fue respaldada por autores como TAYLOR, WALTON y YOUNG ${ }^{204}$. Sus hipótesis parten de entender al delincuente y al delito como reacción de las clases, de la lucha de clases, en donde el Poder impone con sus decisiones jurídicas una conducta fuera de las posibilidades de actuación de la clase desfavorecida ${ }^{205}$.

Y decía gráficamente SEELIG que dentro de la categoría de autor por convicción deben incluirse «(l)as figuras más altas de la historia de la humanidad (Antígona, Sócrates, Jesús), y también simpatizantes extraviados y fanáticos ávidos de poder» ${ }^{206}$. Afirmó que por tal categoría debe entenderse el autor que «por la convicción de que debe cometer el hecho de acuerdo con un orden normativo al que valora más altamente que el derecho estatal vigente». Este orden normativo superior según el citado autor comprende la «naturaleza política, religiosa, de honor, de ética profesional o de ética general» ${ }^{207}$.

A modo de conclusión parcial, podemos afirmar que en los inicios de la teoría de los autores que cometen delitos porque moralmente o ideológicamente lo creen necesario se desarrolló en un clima de repulsa y de combate, seguramente fundamentado por los periodos de guerra e inestabilidad política y social, de modo que todo delincuente era un peligro social, pero más aún aquellos que actuaban convencidos de la licitud de su actuar, por eso la teorías que estudiaron la problemática concluyeron que este tipo de autores criminales merecían la máxima pena y en algunos casos se les debía tratar como enfermos patológico-sociales. En los inicios de la criminología y de la ciencia penal puede concluirse que se combatió la figura de los reaccionarios al poder o por motivos de conciencia, pero verdaderamente sin hacer una diferenciación ni conceptual ni de tratamiento penal.

\section{II.- Los conceptos de autor por convicción y de conciencia en la doctrina penal}

\section{A. Introducción}

Es palpable en la historia del Derecho penal los diferentes tratamientos que han tenido aquellos que, por convicciones o conciencia, se han desvinculado habitual o puntualmente del Derecho. La dogmática penal ni se puso de acuerdo en el pasado ni mucho menos en la actualidad. La problemática parte del propio concepto de uno y otro tipo de autor. Mientras unos reconducen la solución penal a los dos tipos de autores, otros prefieren crear una diferenciación

\footnotetext{
204 TAYLOR Ian / WALTON Paul / YOUNG Jock, La nueva criminología, contribución a una teoría de la conducta desviada, II, Editorial Amorrottu, Buenos Aires, 1990, p. 176 comentan que «(1)a reacción social supera el concepto de una teoría y significa una verdadera reorientación del método de explicación de la criminalidad».

205 Más ampliamente sobre las diferentes corrientes estudiadas, HeRRERO, César, Criminología (Parte General y Especial), $2^{a}$ ed., Dykinson, Madrid, 2001; BujÁn, JA., Elementos de Criminología en la Realidad Social, op. cit.

206 SEElig, Ernest, Tratado de Criminología, trad. José María Rodríguez Devesa, Madrid 1958, p. 170.

207 ID., ibidem, op. cit., p. 169.
} 
tajante entre el autor por convicción y de conciencia, sin embargo es llamativo que quien ha estudiado la problemática habitualmente se ha centrado en uno u otro tipo de autor, por lo que en nuestra opinión la valoración se queda coja e insuficiente, o al menos no es omnicomprensiva, de aquí procede el error de no apreciar en el autor de conciencia injustos especialmente graves y en el autor por convicción conductas a las que se puede atenuar la pena y la responsabilidad e incluso eximir.

Se ha sostenido que las actuaciones nacidas de la conciencia pueden estar entre la espada y la pared, es decir, en un estado de necesidad «puro» (causa de justificación) cuando el conflicto pudiese acarrear una neurosis psíquica (TIEDEMANN ${ }^{208}$ ) y el bien salvado objetivamente tiene más peso que el otro bien jurídico afectado. También se ha defendido en la doctrina penal que en la autoría de conciencia podría apreciarse un error de prohibición sobre el estado de necesidad o sobre sus presupuestos cuando aun no habiéndose producido una neurosis psíquica, el obrar final estaba condicionado, o cuando el sujeto cree que la norma que le obliga a actuar conforme a Derecho se invalida por una apreciación valorativa del art. 16 (libertad de conciencia) o del art. $10 \mathrm{CE}$ (dignidad de la persona).

También se ha defendido que el autor de conciencia cree erróneamente que la ley jurídica está invalidada por una norma superior no jurídica sino moral. En cambio, se suele fundamentar en el autor por convicción, paradigmáticamente el terrorista, la máxima pena, e inclusive se le ha denomino «enemigo» al que sólo se le puede combatir con un derecho penal «excepcional»o especialmente combativo, o también denominado tradicionalmente por la doctrina funcionalista como «Derecho penal del enemigo». En definitiva, la doctrina penal ha diferenciado al autor de conciencia y al autor por convicción en el tratamiento penal, sin más, pero como trataremos de demostrar, esta diferenciación nada aporta a la problemática, decir que un hecho es grave y que otro hecho no lo es tanto es una conclusión meramente enunciativa en el sentido expuesto por John AUSTIN.

De forma prácticamente unánime ${ }^{209}$ la doctrina tradicionalmente ha rechazado que el autor de conciencia sea un sujeto inimputable, porque aunque tenga una presión psíquica no le constriñe su capacidad de culpabilidad en el sentido de un trastorno o alteración mental, pues si así fuera el caso, constituiría la aceptación de que el conflicto de conciencia proviene de un trastorno. En este sentido podemos estar de acuerdo que por regla general no existe impedimento para

208 Vid. JAKOBS, G., $P G$, op. cit., 21/22, nota 33a.

209 Vid. y de esta opinión FlORES MENDOZA, F., Objeción de conciencia, op. cit., p. 202; BAUCELLS I LLADÓS, J., La delincuencia por convicción, op. cit., p. 418; TAMARIT SUMALLA, JMa ., «La objeción de conciencia», CJ, 22, 1994, op. cit., p. 41. 
desestimar una causa de inimputabilidad, pero únicamente en términos generales. Efectivamente una cosa es el conflicto de conciencia y otra bien distinta la manipulación mental que provoca un conflicto de conciencia, si bien en ocasiones puede existir un trastorno a causa o por origen de un conflicto de conciencia como veremos, es este trastorno lo que permitiría la inimputabilidad y no estrictamente el conflicto de conciencia. Sin embargo, no cabe restar importancia a que también serían casos de conflicto de conciencia, en tal grado, que en determinados sujetos se afecte a su voluntad que ineludiblemente haga actuar en contra de la norma ${ }^{210}$. Si admitimos que el Derecho penal reconoce la sanción del dominio de la voluntad en el tipo de coacciones, en la autoría mediata como forma de participación, y en otras instituciones, que el trastorno provenga del conflicto de conciencia no le resta valor a que sea igualmente un caso de conflicto de conciencia.

El planteamiento puede ser interpretado desde dos perspectivas sin que se reste valor. En unos casos el conflicto de conciencia es libremente interpretado por el sujeto hasta el punto que la dejación de sus motivos de conciencia le causen un trastorno que le obliga a actuar en contra de la norma, y en otras ocasiones el conflicto de conciencia viene a causa del dominio de la voluntad por un tercero (adicción comportamental, persuasión coercitiva y obediencia ciega a la autoridad) que sitúa a la postre al sujeto en un conflicto entre la conciencia y la norma jurídica que resuelve «inevitablemente» a favor de su conciencia, si bien previamente ordenada.

En atención a esto, en primer lugar nos centraremos en los conflictos de conciencia en los denominados autores de conciencia u objetores de conciencia libremente establecida por el propio sujeto, su tratamiento penal y solución, para con ello encontrar un fundamento propio, posteriormente estudiaremos y compararemos el fundamento penal de los tradicionalmente denominados autores por convicción (por ejemplo el terrorista), y finalmente determinaremos si el «fundamento» de su tratamiento penal es el mismo o distinto.

\section{B. Primeras consideraciones doctrinales sobre el autor por convicción y de conciencia}

Entrando ya de lleno en las consideraciones doctrinales que inicialmente estudiaron el concepto de autor por convicción y de conciencia como fenómenos jurídico-penales, hemos visto supra que la concepción de autor por convicción nace posiblemente de la ciencia criminológica del siglo XIX. En tal sentido podríamos decir que tal concepción inicialmente histórica en la Criminología contiene una categoría autónoma del concepto de delincuente. HIRSCH comenta al respecto de las primeras concepciones penales sobre este tipo de autoría que «(s)e los definía

210 En contra de mi opinión Flores MendOZA, F., Objeción de conciencia, op. cit., p. 203. 
como autores cuya motivación decisiva reside en que se sienten obligados a realizar el hecho en virtud de sus convicciones éticas, religiosas o políticas ${ }^{211}$.

En la Ciencia penal fue RADBRUCH el primer autor en estudiar con detalle la noción del autor por convicción y de conciencia desde el punto de vista dogmático en su proyecto de Código penal alemán de 1922 y 1925. Para el penalista alemán, el autor por convicción y el autor de conciencia son una misma categoría, ya que la decisión de dichos autores parte de la misma motivación: «existe el íntimo y decisivo móvil de estar obligado al hecho a causa de su convicción moral, política o religiosa» ${ }^{212}$.

Pero fue a partir de los años 50 del pasado siglo XX cuando la doctrina comenzó a distinguir entre los dos tipos de autores $^{213}$, en buena parte tras el nacionalsocialismo, y particularmente en la Gran Comisión para la reforma del Derecho penal alemán de 1959 y posteriormente en la Comisión especial de reforma del Derecho penal de los años 60 en Alemania ${ }^{214}$, donde se comenzó a distinguir entre los autores de delitos políticos y el autor por convicción y de conciencia. Lo que parecía claro para los penalistas y criminólogos de la época es que la acción del autor por convicción o de conciencia se realiza evidentemente de forma razonada, es decir, estos autores realizan el hecho delictivo con conocimiento del hecho, por lo que no se les puede considerar inimputables propiamente, pero lo que no era tan claro es si la delimitación conceptual entre uno y otro tipo de autor venía de la forma de cometer el delito, de tipología de la acción u omisión. La problemática no se encuadró sólo en la teoría de los motivos ${ }^{215}$ que se circunscribe en el ámbito estricto de lo injusto, sino si podía trasladarse a la teoría de la acción y de la omisión, y si repercutía en la culpabilidad por conocimiento de lo antijurídico.

Volviendo a la cronología de la evolución del tratamiento penal del autor de conciencia y por convicción, en el Congreso de juristas alemanes celebrado en Colonia en 1926 se debatió ampliamente sobre el concepto de autor por convicción y sobre su tratamiento penal en la culpabilidad. Las siguientes páginas resumen, grosso modo, las consideraciones y debates doctrinales de algunos de los miembros del Congreso de juristas alemanes de 1926.

211 HIRSCH, Hans-Joachim, «Derecho penal y autor por convicción», trad. Patricia Laurenzo Copello, HIRSCH, HJ., Derecho Penal Obras Completas, Libro Homenaje, T. II, Rubinzal Culzoni, Buenos Aires, 2000, p. 175.

212 Vid. PÉREZ DEl VAlle, Carlos, Conciencia, op. cit., p. 58 (Congreso de juristas alemanes de 1926 en Colonia, en «Verhandlungen des Deutschen juristentag zu Köln», BD.II, Berlín und Leipzig, 1927, p. 352); BAUCELlS I LLADÓs, J., La delincuencia por convicción, op. cit., pp. 37 y ss., y pp. 44 y ss.

213 Dice HIRSCH que «(s)e impuso la opinión que los delincuentes de conciencia componen una problemática que ha de separase claramente de los demás supuestos, lo que condujo a que en las décadas posteriores el concepto de autor por convicción se entendería con frecuencia en el sentido restringido de autor por conciencia», HIRSCH, HJ., «Derecho penal y autor por convicción», op. cit., p. 173.

214 BAUCELlS I LLADÓs, J., La delincuencia por convicción, op. cit., pp. 51 y ss.

215 DíEZ RIPOLLÉS, José Luis, «La atenuante de obrar por motivos morales, altruistas o patrióticos de notoria importancia», ADPCP, 1979, p. 94 a 101. 
El debate versaba sobre la incursión de estos autores en el parágrafo 71 del proyecto de Código penal alemán, es decir, si era conveniente aplicar una pena especial y atenuada (arresto), cuestión que defendía RADBRUCH basándose en la honestidad con la que obraban algunos autores de esta tipología criminal, o seguir incluyéndolos en el parágrafo 20 del entonces Código penal alemán, que aplicaba para este tipo de autoría una pena de privación de libertad en fortaleza, paradójicamente en contra de la aludida opinión, por lo deshonesto de las convicciones que motivaban la realización del delito ${ }^{216}$.

Con motivo de la redacción del Proyecto Oficial de Código Penal alemán de 1925 y el polémico parágrafo 71, RADBRUCH consideraba que el autor por convicción es un delincuente especial por sus características psicológico-criminales, pero que no se diferenciaba, generalmente, del delincuente pasional u ocasional ${ }^{217}$. Opinaba que tal autor posee un egoísmo no común (a diferencia del delincuente común), un egoísmo de ideales sociales que concurren con motivos nobles ${ }^{218}$. El autor por convicción sigue una norma que entiende que es de mayor rango que la infringida, creyendo estar excusado ${ }^{219}$. Para RADBRUCH, hay una diferencia entre quien no conoce que está infringiendo una norma y por ello no puede ser culpable por acción dolosa futura, y quien conoce una norma jurídica y actúa con base a una norma de mayor rango como justificación, actúa en forma dolosa, por lo tanto punible. Incluso un delincuente político que asesina por convicción a una autoridad es un autor por convicción, comenta el citado penalista, de tal manera, no diferencia entre motivaciones políticas, morales o religiosas para delimitar esta clase de autoría ${ }^{220}$. El valor psicológico-criminal del autor, sobre todo su «motivo preponderante» es lo relevante. Este es uno de los elementos que ha de valorar el juez, si supo el autor del principio normativo que se lo impedía o si por el contrario lo desconocía. El autor por

216 RADBRUCH, Gustav, «El delincuente por convicción», trad. y notas José Luis Guzmán Dalbora, Universidad de Antofagasta (Chile), RECPC, núm. 7, 2005, p. 3. Publicado originalmente en la Zeitschrift für die gesamte Strafrechtswissenchaft, T. 44, 1924, págs. 34-38, el presente fue el primero de dos trabajos que Radbruch dedicó al polémico tema. El otro tiene el mismo título «DerÜberzeugungsverbrecher», Juristische Rundschau, T. 2, 1926, págs. 865 y ss.

217 RADBRUCH, G., «El delincuente por convicción», op. cit., p. 3.

218 ID., ibidem, op. cit., p. 5.

$219 \mathrm{Al}$ respecto decía RADBRUCH que «el delincuente por convicción es alguien que ni precisa ser corregido ni resulta merecedor de retribución, sino sólo uno que -rebatible o no- piensa de otra manera, un adversario del actual poderío moral, religioso o político, a quien ciertamente cabe combatir en interés de la preservación de aquél, pero al cual no se puede imponer con sensatez medidas correctivas o retributivas», ID., ibidem, op. cit., p. 4; vid. también PÉRez del VAlle, C., Conciencia, op. cit., p. 58 (Congreso de juristas alemanes de 1926 en Colonia, en «Verhandlungen des Deutschen juristentag zu Köln», BD.II, Berlín und Leipzig, 1927, p. 357).

${ }^{220}$ Precisa RADBRUCH: «Claro es que hay que extender éstos más allá del delincuente político y hacerlos abarcar al delincuente por convicción religiosa o moral. Puede resultar discutible que junto al delincuente por convicción moral hubo de nombrarse por separado, con fines ilustrativos, al delincuente por convicción política o religiosa, dado que toda convicción de un deber es, por necesidad conceptual, de índole moral y porque los campos de los deberes políticos y religiosos son sólo particulares ámbitos de acción de convicciones éticas», RADBRUCH, G., «El delincuente por convicción», op. cit., p. 4. 
convicción sería un fanático, un paranoico, o algún tipo de psicópata. No reconoce la superioridad moral del Estado, por lo que la idea de retribución de la pena no se puede cumplir, este tipo de autor es tanto o más peligroso que el común, por eso es adecuada aplicar una pena privativa de libertad fundamentada en la seguridad pública, por lo que finalmente RADBRUCH propone, para el autor por convicción, no una pena sino en verdad una medida de seguridad ${ }^{221}$.

A partir de aquí comenzaron diversas opiniones que resumidamente se pueden diferenciar entre los que defendían cierta comprensión, y por tanto una rebaja de la pena, y los que por el contrario reclamaban la máxima sanción ${ }^{222}$.

221 RADBRUCH, G., «El delincuente por convicción», op. cit., p. 3.

222 GUCKEMHEIMER partía del concepto de «motivo» de Von LISZT como particularidad psíquica que ha producido la actividad voluntaria en la conciencia del sujeto (el carácter). Toma de la idea de BINDING sobre el honor, por eso considera que el autor por convicción actúa de manera deshonesta, actúa por motivos mezquinos y egoístas, poniendo en juego un valor más importante con conciencia, sin embargo el delincuente político al actuar por convicción y poner en juego valores superiores, pero que subjetivamente considera inferiores, no actúa de manera deshonesta. Los valores importantes se determinarán por la época y la cultura, y es por ello que no se puede realizar una valoración general de cuáles son los valores de interés humano. Todo ello nos hace pensar que el citado autor consideraba que el autor de conciencia se integraba en la categoría de delincuente político, aquel que sin egoísmo realiza el hecho sin conciencia de la superioridad del ordenamiento jurídico respecto a sus ideales políticos, vid. PÉREZ Del VAlle, C., Conciencia, op. cit., pp. 54 a 57 (GUCKEMHEIMER, E., Der begriff der ehrosen Gesinnung im Strafrecht, Editorial Gente, Hamburg, 1921, en especial pp. 22, 79, 80, 84, 85, 87, 102, 103, 104, 196 y 107); KOHLRAUCH reconocía el tipo criminológico del autor por convicción de RADBRUCH y su posible disminución de culpabilidad en algunos casos, vid. ID., ibidem, op. cit., pp. 62 y 63 («Verhandlungen des Deutschen Juristentag zu Köln», op. cit., pp. 353, 354, 371 y 372). Pero en este caso se debería extender entonces a otros sujetos distinguiendo unos de otros, pero esto no le parecía adecuado, por decía que entonces habría que distinguir a los delincuentes políticos que actúan por codicia de los que por ejemplo, están convencidos de la licitud de sus actos porque se adecúan a los intereses de todos los hombres, vid. ID., ibidem, op. cit., p. 58 («Verhandlungen des Deutschen juristentag zu Köln», op. cit., p. 413). La crítica de este penalista y la mayoría de la doctrina que contradecía el parágrafo 71 del Proyecto de RADBRUCH es que quien por sus convicciones está obligado a lesionar, la aplicación de la atenuante supondría la auto-negación del derecho, vid. ID., ibidem, op. cit., p. 59; Von CALKER también en el Congreso de Juristas alemanes de 1926, determinó el concepto de autor por convicción como un autor organizado (sustracción de explosivos), pero también aquél que actúa por motivos altruistas o en beneficio del bien común (quien mata al padrastro por abusar de su madre), vid. ID., ibidem, op. cit., p. 63 («Verhandlungen des Deutschen juristentag zu Köln», op. cit., pp. 382 y 383). Por ello propone que la convicción sea el elemento diferenciador de la pena. Argumentaba que existen acciones, como la del hijo que mata a su padrastro, que proceden de convicciones no reprochables, vid. ID., ibidem, op. cit., p. 64 («Verhandlungen des Deutschen juristentag zu Köln», op. cit., pp. 380); ASCHAFFENBURG consideraba que «(e)l delito político y de convicción es dependiente de la convicción que sostiene el autor, y sólo de forma más remota su ambiente y su situación influyen en él», vid. ID., ibidem, op. cit., p. 67 («Verhandlungen des Deutschen juristentag zu Köln», op. cit., p. 398), por ello, como comenta en la actual doctrina PÉREZ DEL VALLE, este tipo de autor actúa valorando más altamente su convicción que el ordenamiento, ID., ibidem, op. cit., p. 67. Deduzco que ASCHAFFENBURG incorpora en el mismo concepto de autor por convicción a los autores que realizan el hecho delictivo tanto por motivos políticos, como religiosos, como por motivos de conciencia, morales o éticos. En otro sentido WEGNER criticó la distinción entre los dos tipos de autor por convicción que los precedentes autores tanto se habían esmerado en diferenciar: el político y no político. Bajo este argumento concluyó que es arriesgado conceder a los tipos de autor por convicción una custodia punitivamente honesta, vid. ID., ibidem, op. cit., p. 68 («Verhandlungen des Deutschen juristentag zu Köln», op. cit., pp. 410 y 411). A este respeto llama la atención la brillante frase de WEGNER: «quien no realizó el delito con caballerosidad no es un caballero», vid. ID., ibidem, op. cit., p. 67 («Verhandlungen des Deutschen juristentag zu Köln», op. cit., p. 409); NAGLER pensaba que da igual que el autor por convicción realice el hecho delictivo por causas exteriores, internas, religiosas, políticas o científicas, lo importante es la intensidad y no de donde provengan, ya que la nota común es la sobre-valoración de unas ideas, el autor por convicción conoce el Estado y el ordenamiento jurídico, ya que de otro modo no actuaría creyendo en la superioridad de sus ideas, vid. ID., ibidem, op. cit., p. 68 (NAGLER, Johannes, «Der Überzeugungsverbrecher», Der Gerichtsaal Bd. 94, 1927, p. 48). El autor por convicción es por 
En años posteriores, WELZEL sostuvo una concepción -que explicó en parte en la Gran Comisión para la reforma penal- según la cual el delincuente político debe excluirse de la categoría de «autor a conciencia» por cuanto que el primero actúa bajo la comprensión de lo éticamente correcto ${ }^{223}$. En La conciencia errada, WELZEL analiza la afirmación de RADBRUCH relativa a «si la ley injusta es obligatoria, si los injustos legales pueden poseer fuerza obligatoria», cuya clave era la percepción por el individuo de lo que es un injusto legal

tanto un delincuente habitual para NAGLER pero con estas particularidades, vid. ID., ibidem, op. cit., p. 58 (NAGLER, J., «Der Überzeugungsverbrecher», op. cit., p. 69). Podemos estar de acuerdo con NAGLER en que efectivamente uno de los elementos importantes es la intensidad de la conciencia o convicción, provenga de donde provenga, lo importante para diferenciar a estas dos clases de autoría con otra común, es que al menos realizan el hecho delictivo con pleno convencimiento de la obligatoriedad e inevitabilidad en su voluntad de obrar, por cuanto que si el propio autor no está convencido de que su actuar es correcto, o duda, nada le diferenciaría de un criminal común. De este modo, no resultará extraño que quien actúa de forma tan ineludible cometa en más ocasiones el delito, sin embargo, creemos que NAGLER en esto yerra, pues, en nuestra opinión, la habitualidad y la reincidencia, tal y como desarrollaremos más adelante, son notas más propias del autor por convicción, en el autor de conciencia el delito es algo circunstancial, difícilmente repetible porque, y adelantándonos a nuestras conclusiones, no combate directamente la norma, sino que las circunstancias que se le presentan sorpresivamente le obligan a tomar una decisión a favor de su conciencia; Erick WOLF parte del concepto kantiano de que el deber es apriorístico, es decir, la acción de la voluntad nace de la autonomía de la voluntad, de la conciencia, por eso el autor por convicción actúa no con base a la autonomía de la voluntad como principio de todo deber moral, sino de la restricción de su contenido, vid. ID., ibidem, op. cit., p. 74 (Z.St.W, Zeitschrift für die gesamte Strafrechts-wissenschaft, 46-1925, p. 294, y en Verbrechen aus Überzeugung, p. 6). Estamos de acuerdo con WOLF en esto por lo expuesto en el primer capítulo por cuanto que el autor por convicción, claramente el terrorista, no actúa creyendo que su delito, su obra, sea una máxima aplicable en todo espacio-tiempo, sino un medio, un móvil para un fin. Para Wolf la ética del Estado se contradice por la ética del individuo delincuente por convicción, por lo que para el Estado este autor es peligroso, y el problema nace de la propia obligatoriedad de las convicciones, vid. ID., ibidem, op. cit., p. 76 (Verbrechen aus Überzeugung, p. 13, y en Z.St.W, 46-1925, p. 204). En este sentido, consideramos que aquí WoLF comete un error al introducir una valoración moral, como si la moral general o mayoritaria fundamentara por sí sola la especial repulsión de la conducta del autor por convicción, sin embargo, magistralmente llega a otra conclusión cuando sobresalen determinadas circunstancias. Continúa WOLF argumentando acerca de esto que si una conducta es obligatoria moralmente, como ley moral, y este es el problema, habrá que analizar si el sujeto actúa por la ley moral y no una restricción de esta, vid. ID., ibidem, op. cit., p. 76 (Verbrechen aus Überzeugung, p. 13). WoLF entiende que el Estado debe dar un reconocimiento valorativo a determinadas convicciones individuales, vid. ID., ibidem, op. cit., p. 76 (Z.St.W, 46-1925, p. 210). Este razonamiento de WOLF es brillante en lo que ya comentamos en el primer capítulo, la ley que permite la libertad de conciencia de forma general no puede luego limitarse por una razón estrictamente de la moral de la mayoría, pues de lo contrario carecería de virtualidad la libertad de conciencia para las minorías. Su posición se centra en que existen poderes ético-sociales diferentes a los del Estado, éste no es el legislador exclusivo, esta es la razón de que se deban reconocer en alguna medida, según las circunstancias, las convicciones individuales de un grupo o de una cultura, vid. ID., ibidem, op. cit., p. 76 (Z.St.W, 46-1925, p. 217) ; con otro criterio BUDZINSKI incluyó en el concepto de autor por convicción a los autores de traición, asesinos políticos y al homicida imprudente, por ejemplo el padre miembro de secta que no reclama asistencias para su hijo, es decir, el padre que omite el auxilio a su hijo por motivos morales no actúa con dolo, ni dolo eventual, vid. ID., ibidem, op. cit., p. 58 (BUDZINSKI, Wilhelm, Der Überzeugungsverbrecher, Borna-Leipzip, 1931, pp. 26 a 28). En este sentido BUDZINSKI contradice la propuesta de RADBRUCH. Por eso el primero incluyó en el concepto de autor por convicción, además de los citados, a los objetores de conciencia, a los adventistas, tolstoyanos y nacionalsocialistas por considerar a estos últimos iban en contra de las libertades cívicas. En nuestra opinión, si bien no puedo estar de acuerdo en que el ejemplo del padre de una secta que cuando omite su deber de socorro actúa imprudentemente, sí que estoy de acuerdo en que el autor de conciencia puede cometer delitos imprudentes y de peligro, no sólo dolosos. Esto puede fundamentarse si partimos de la base de que en determinadas circunstancias al autor de conciencia se le presenta la comisión del delito sorpresivamente sin tiempo para adecuar su comportamiento a la norma, o en casos «aislamiento cultural» o de «adicción comportamental», «manipulación mental», «persuasión coercitiva» o de «obediencia a la autoridad». Sobre esta posibilidad volveremos infra.

223 Vid. JERICÓ OJER, L., El conflicto de conciencia, op. cit., p. 280. 
(culpabilidad supra-positiva), mientras que WELzEL analizó la conciencia de error sobre la base de la idea aristotélica de ignorancia universal como nunca involuntaria y por tanto reprochable, partiendo de la concepción kantiana de «la libre sumisión de la voluntad bajo la ley», de la que extrae que la intención nos da el valor ético moral material de la acción que se conecta con la moral objetiva, y entendiendo que no se pueden establecer principios de Derecho natural evidentes porque la ética está sujeta a errores, al error humano (el error como condición de la existencia humana diría yo, de forma más precisa), pero el error no excluye la culpabilidad, sólo cuando es invencible, es decir, con esfuerzo de conciencia, por lo que cuando realizamos tal esfuerzo, se puede apreciar un «el injusto legal».

WELzEL consideraba que el Derecho no es sólo el mandato de quien ostenta el poder, sino que el Derecho exige una vinculación ética para la conciencia, entendiendo que existen formas legales que son injustos legales, que no derecho, pues «si exigimos en estos casos de injusto legal la reflexión de si la orden que proviene de una autoridad y hablamos de autor culpable que no ha efectuado esta reflexión cuando podía hacerla, debemos dar otorgar también un privilegio que por motivos de conciencia cree que esa norma es un injusto legal, y que por tanto carece de fuerza obligatoria», pero tal privilegio no se puede conceder al simple actor por convicción porque éste tiene una ciega obediencia a las órdenes recibidas, es un fanático, sin que pueda hablarse de una decisión de conciencia. Sin embargo, es posible que el autor de conciencia no sea culpable por la conciencia errónea, ceguera errónea. No es de extrañar entonces que considere que el autor por convicción es responsable porque el Derecho no puede verse sometido a la validez que dé la conciencia del sujeto, en él permanece «el acento negativo de la responsabilidad, pero permanece íntegro el momento (enclavado en la decisión libre) de responsabilidad libre del autor por su decisión» ${ }^{224}$.

Podemos estar de acuerdo con WELzEL en la distinción que hace del autor por convicción y de conciencia. Efectivamente, más allá de los tipos de motivos, hay una fuerza infalible en el sujeto que actúa criminalmente, si bien la forma de explicar la diferencia de trato, entre un «injusto legal» y otro claramente ilegal, es errónea porque la fundamenta en la particularidad de que el autor de conciencia comete un error semejante al de prohibición, lo cual llevaría a que este tipo de autoría es un error en sí mismo contra la máxima kantiana, lo que pondría en duda esta misma máxima kantiana de que todos los hombres podían intuirla. De esta manera, parece estimar que

224 Welzel, Hans, Derecho penal alemán, Parte General, trad. Juan Bustos Ramírez y Yáñez Pérez a la $11^{\text {a }}$ ed. alemana de 1959, $2^{\text {a }}$ ed., Santiago de Chile, 1976, pp. 246 y 247. Al respecto las opiniones de BAUCELLS I LLADÓs, J., La delincuencia por convicción, op. cit., pp. 62 a 65; JERICÓ OJER, L., El conflicto de conciencia, op. cit., pp. 251 y ss; PÉreZ Del VAlle, C., Conciencia, op. cit., pp. 92 y 93. 
el autor de conciencia es incapaz de saber cuál es el bien, sin embargo ni desarrolla ni fundamenta cómo es posible que una persona cometa tal error, olvidando intencionadamente para no incurrir en contradicción con su doctrina finalista del dolo, que la libertad de conciencia también se dirige a las minorías, lo cual preordena $\mathrm{u}$ orienta hacia un haz de conductas vinculadas con la moral y la conciencia, es decir, la minoría que por motivos de conciencia no comete un error sobre la norma ni sobre la interpretación del bien, sino que por el contrario, con su actuar manifiestan externamente una obra propia de la voluntad unida a la internamente a la conciencia.

TAMARIT SumALLA apoya la postura de referencia, y podemos estar de acuerdo con él ${ }^{225}$ en que efectivamente el autor de conciencia, a diferencia del autor por convicción, no revela un sentimiento contra la vigencia de la norma o el contenido objetivo de la norma, y en que la razón de que tradicionalmente no se aprecie un mayor trato privilegiado al autor de conciencia es la clásica concepción de que la excepciones «personales» pueden cuestionar la validez general de la norma, sin embargo, en igual sentido que para los terroristas se aplica una mayor pena bajo el fundamento que su actuar ataca principios y valores democráticos, en el autor de conciencia que actúa también impulsado por aquella norma general de la libertad de conciencia, o sea, queriendo que se le respete un derecho fundamental que emana de la sociedad, se le puede aplicar atenuantes o incluso la exención de responsabilidad cuando las circunstancias personales y concomitantes lo procuren, sin que el Estado de Derecho y la seguridad jurídica se vean afectada, al igual que propone para los casos considerados «graves» el Derecho penal de enemigo. El fundamento en uno y en otro caso sería el mismo, por lo tanto coherente con la dogmática penal como ciencia. Lo contrario sería, como venimos diciendo, valorar el hecho moralmente.

Por otra parte, PETERS realizó una distinción más concreta de la categoría, hasta el punto de diferenciar dogmáticamente a dichos autores desde el punto de vista de la forma activa u omisiva de cometer el delito, pero según un criterio de la adecuación social de la conducta, entendiendo que el autor de conciencia incurre en un tipo omisivo, mientras que el autor por convicción en un tipo de acción. La diferenciación le sirve para establecer que en los primeros debe primar la

225 Argumenta que «por otra parte, desde esta perspectiva, podrá comprobarse en muchas ocasiones que el autor no objeta propiamente el contenido objetivo de la norma, sino tan sólo su función imperativa; no niega vigencia en abstracto del valor o del bien jurídico, sino que simplemente se ve impulsado a supeditarlo en el caso concreto a otro valor o a un objetivo que sinceramente considera prioritario y superior. Por otra parte, el reconocimiento de la presencia de un contenido valorativo en toda norma penal, introduce la posibilidad de proceder a una ponderación entre el valor objetivo que da la norma y las valoraciones individuales que concurren en cada caso, atendiendo al mandato de tolerancia impuesto por el Estado democrático de Derecho, y a la libertad y pluralismo como «valores superiores» del Ordenamiento Jurídico. Dicha ponderación es factible a partir de la concepción del bien jurídico como núcleo de la antijuricidad, pero resulta contradictoria con la construcción del injusto propio de los

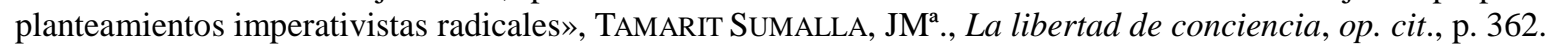


exención de pena porque su conducta es adecuada socialmente al no sobrepasar los límites del derecho la libertad de conciencia del art. 4 de la Ley Fundamental (objetores de conciencia al servicio militar e insumisos), y para los segundos propuso una ejecución especial de la pena ${ }^{226}$.

Parece claro - como bien apunta BAUCELLS- que en un inicio se concibió la autoría por convicción en relación a lo móviles políticos o religiosos. Los motivos que fueran respetables dentro de la moral de la sociedad daban lugar a algún tipo de atenuante, pero tras el nacionalsocialismo y al República de Weimar se abandonó la idea del trato privilegiante a los motivos al menos políticos ${ }^{227}$, lo que llevó a la construcción del concepto de «delincuente por conciencia ${ }^{228}$. Sin embargo, podemos decir que en estas primeras consideraciones de la doctrina penal alemana existe una constante confusión entre la autoría de conciencia y por convicción, siempre inspirada en la introducción de un valor particular por el observador científico y jurídico-penal, de modo que fundamentalmente impidió un acuerdo dogmático sobre ambas categorías conceptuales y de tratamiento. A golpe de la sociedad, a golpe de la paradójica concepción moral de la estructura normativa de la sociedad, la doctrina fue dando palos de ciego, sin apreciar que la valoración de la libertad de conciencia no puede hacerse desde la perspectiva individual o sobre la consideración de cuál es el sentir moral de la mayoría de la sociedad, porque de tal forma se incurre en el absurdo de que una norma general destinada a orientar conductas libres como la libertad de conciencia, sea valorada paradójicamente por una mayoría, lo que hace perder su sentido de Derecho fundamental, sino que sólo es posible normativamente, y más precisamente, mediante un análisis funcional de la norma y sistémico, aquel que para valorar una operación, en este caso si una conducta es delictiva o merece una atenuación, exención o agravación, utiliza sus propias operaciones, las normas en su conjunto, y no mediante la introducción de una operación que valora moralmente y no normativa y puramente el hecho.

26 Vid. PÉrez del VAlle, C., Conciencia, op. cit., p. 109; vid. Flores Mendoza, F., Objeción de conciencia, op. cit., p. 105; vid. BAUCELlS I LLADÓs, J., La delincuencia por convicción, op. cit., pp. 68 a 72 (PETERS, Karl, «Überzeugungstäter und Gewissenstäter», Zeitschrift für Hellmuth Mayer zum 70. Geburstag, Duncker \& Humblot, Berlin, 78, 1966, p. 276). Tales postulados fueron criticados por GöDAN al interpretar que la categoría de autor por convicción debe ser más amplía y neutral que la de conciencia. La «conciencia no puede entenderse como opuesta al término global «convicción»; más bien debe servir para remarcar aquellos supuestos en los que se dan unos matices fuertemente personales, de manera que habrá de enjuiciarse el comportamiento del autor que se encuentra en una situación concreta de conflicto», vid. PÉREZ DEl VAlle, C., Conciencia, op. cit., p. 109 (GöDAN, Jürgen Christoph, Die Rechtsfigur des überzeugungstäters, Duncker \& Humlot, Berlin, 1975, pp. 239 y 240).

227 BAUCELls I LLADÓS, J., La delincuencia por convicción, op. cit., pp. 81, 409 y 410.

228 ID., ibidem, op. cit., pp. 81 y 82. 


\section{Consideraciones actuales sobre el concepto de autor por convicción y de conciencia}

En la doctrina española, ya dijo en su día JIMÉNEZ DE AsÚA que dentro de la categoría de autor por convicción debe comprenderse también la del delincuente político ${ }^{229}$, siguiendo la misma línea de la doctrina penal alemana de su tiempo. En la actualidad de la dogmática penal, la diferencia entre autor por convicción y de conciencia no es ni aceptada por todos ni claramente distinguida por todos, por lo que la diferenciación jurídico-penal sigue siendo una problemática sin atisbos de solución. La razón fundamental en nuestra opinión es que la doctrina que minuciosamente ha estudiado la autoría de conciencia no se ha interesado por la de convicción y viceversa. La doctrina de antaño y la actual no distinguen entre autores por convicción, autores de conciencia y objetores de conciencia, o al menos no se ponen de acuerdo en la delimitación conceptual y tratamiento jurídico penal, y debido a ello, se produce una disparidad conceptual que no permite avanzar en la distinción jurídico-penal ${ }^{230}$ por razones que estriban en la falta de análisis de todas las categorías y su puesta en comparación: autor de conciencia, autor por convicción y el enemigo. Como hemos visto, las primeras opiniones sobre este tipo de autoría se referían sobre todo a las conductas realizadas por motivos políticos o ideológicos, sin embargo en la actualidad se está tratando de delimitar los motivos estrictamente morales de los políticos.

FLORES MENDOZA y TAMARIT SUMALla, en sus respectivos trabajos doctorales, plantean una diferencia entre unos y otros tipos de autores, sobre la base -según comenta TAMARIT SUMALLAde que el autor por convicción realiza una desobediencia al Derecho porque «se siente obligado a la comisión del delito a causa de sus creencias morales, políticas o religiosas», y por lo tanto realiza el tipo por convicción, es decir, convencido, y ello representa el motivo de su actuación delictiva ${ }^{231}$, mientras que el autor de conciencia -comenta FLORES MENDOZA- realiza el tipo delictivo por un deber ineludible, a diferencia del autor por convicción ${ }^{232}$.

En tal medida, esta autora considera oportuno dividir las categorías del autor por convicción y de conciencia en el sentido siguiente: la autoría de conciencia como categoría amplia que englobaría la desobediencia al Derecho por motivaciones ideológicas, como los supuestos de resistencia al Derecho, desobediencia civil, y éstos en oposición a la objeción de conciencia; mientras que la categoría de autoría por convicción, se restringiría excluyentemente a los que actúan sin evitabilidad de su conducta delictiva. Esta autora y el criterio doctrinal que se manifiesta en el mismo sentido realizan una división jurídico-penal con base a la intensidad de la

229 JimÉnEZ De Asúa, Luis, Tratado de Derecho penal, T. III, Losada, Buenos Aires, 1951, p. 246.

230 De la misma opinión, FloRes MeNDOZA, F., Objeción de conciencia, op. cit., pp. 34 y ss. y p. 100.

231 TAMARIT SumAlla, JMa ., La libertad ideológica, op. cit., p. 342 y ss.

232 Flores MendoZA, F., Objeción de conciencia, op. cit., p. 44. 
convicción, que en nuestra opinión debe ser rechazada totalmente por las razones expuestas supra, no podemos dejar de reconocer que las conductas de los terroristas que llegan hasta la perpetración de asesinatos en masa, no se realizan por simple capricho, sino por el irrevocable convencimiento del deber moral (terrorismo yihadista) y/o ideológico y/o político. En nada se diferencia cuantitativamente al deber moral de los objetores de conciencia o de la autoría de conciencia con la autoría por convicción.

FLORES MENDOZA realiza una división dentro de la categoría de la «decisión de conciencia» entre las conductas de conciencia «amplias», aquellas que no constituyen una verdadera decisión de conciencia ${ }^{233}$, y las «estrictas» que sí lo son. Dentro de las estrictas, plantea las «simples», aquellas en las que «el deber de conciencia que justifica la conducta no se opone a ningún deber jurídico», y que se corresponde con una decisión de conciencia de carácter intrapersonal ${ }^{234}$, es decir, el bien jurídico controvertido es de titularidad del que tiene el conflicto de conciencia. En estos últimos supuestos incluye los casos de negativa de los Testigos de Jehová a trasfusiones de sangre y los casos de enfermedad terminal en los que el sujeto desea la muerte antes de una vida ya de por sí condenada a su fin, aquellos en los que el sujeto pone fin a la vida mediante el rechazo de la iniciación del tratamiento o su continuación.

En nuestra opinión, a estos comportamientos deberíamos calificarlos de atípicos, aunque bien es cierto que tal solución no está exenta de controversia. Por tanto, para esta autora, la objeción de conciencia es sólo aquella en la que «el conflicto entre un deber moral -el deber de conciencia- y un deber jurídico, se resuelve por el objetor a favor del primero que considera de mayor valor, produciéndose de esta forma el incumplimiento del segundo ${ }^{235}$. Esta consideración es en buena parte seguida desde siempre por la mayoría de la doctrina. Está de acuerdo la referida autora en que el deber de conciencia es vivido de forma tan intensa por el sujeto que el incumplimiento supondría una grave lesión en su conciencia pero también en su propia persona $^{236}$, criterio con el que estamos de acuerdo y del que tendrá que derivar la solución a la problemática de los conflictos de conciencia.

Para Flores MendozA, la objeción de conciencia tiene un contenido «esencial» que se caracteriza por ser un comportamiento ético o moral, pero no político como la desobediencia

33 ID., ibidem, op. cit., p. 49.

234 ID., ibidem, op. cit., p. 50, siguiendo el criterio de RUIZ MIGUEL, A., «Autonomía individual y derecho a la propia vida (Un análisis filosófico-jurídico)», Revista del Centro de Estudios Constitucionales, 14, 1993, p. 135.

235 FloRes MendOZA, F., Objeción de conciencia, op. cit., p. 52.

236 ID., ibidem, op. cit., p. 57, en el mismo sentido JAKOBS, G., PG, op. cit., 20/22; OlIVER ARAUJO, J., La objeción de conciencia al servicio militar, op. cit., p. 31. 
civil o la resistencia aunque estos son respetuosos con el sistema democrático y constitucional ${ }^{237}$, por lo que supone una desobediencia de carácter moral individual ${ }^{238}$ y de carácter directo, es decir, que es necesario que el cumplimiento del deber jurídico que se objeta sea el que directamente lesiona la conciencia, por lo que sólo se rebela contra ese deber, y por eso es excepcional $^{239}$, en un conflicto directo y absoluto ${ }^{240}$.

Otro contenido al que alude la referida autora es el «no esencial» como el carácter «privado» del conflicto por cuanto sólo afecta al sujeto y a la norma jurídica. Parte de la doctrina ${ }^{241}$ rechaza esta postura al entender que siempre será pública por afectar a la autoridad representada por la norma. Asimismo otro aspecto reconocido a la objeción de conciencia es su índole «individual» ${ }^{242}$, al ser afectar la conducta al sujeto mismo, aunque en ocasiones pueda realizarse en un acto colectivo, «pacífico» ${ }^{243}$, motivo por el cual el objetor acepta el castigo como muestra de estar de acuerdo con los valores democráticos y el ordenamiento jurídico. También incluye otro criterio distintivo en la objeción de conciencia, la «interpersonalidad» del conflicto aunque con matices ${ }^{244}$. De estos postulados encuentra argumentos que le llevan a excluir la objeción de conciencia en determinados supuestos, tales como en la objeción al servicio militar (conducta de conveniencia) $^{245}$, en conflictos intrapersonales en la que los motivos son ajenos a dicha libertad $^{246}$, cuando media el consentimiento como causa de exclusión de la responsabilidad y el bien jurídico sea del titular, o sea, privado o disponible ${ }^{247}$, y en definitiva cuando existen deberes alternativos $^{248}$ que al menos uno respete la actuación conforme a conciencia.

En definitiva, la citada autora pone la clave de la objeción de conciencia en el ineludible e insalvable conflicto de conciencia resuelto a favor de la conciencia en detrimento de la norma

37 ID., ibidem, op. cit., p. 75.

ID., ibidem, op. cit., p. 73.

ID., ibidem, op. cit., p. 75.

240 ID., ibidem, op. cit., p. 76.

241 En contra EsCOBAR RoCA, G., La objeción de conciencia, op. cit., p. 50.

242 También ESCOBAR ROCA, ID., ibidem, op. cit., p. 59.

243 JAKOBS, G., $P G$, op. cit., 20/22.

244 Flores MendozA, F., Objeción de conciencia en Derecho penal, op. cit., p. 78: «En el ámbito penal habitualmente la objeción de conciencia se suele presentar como una conducta de carácter interpersonal frente a la conducta de conciencia simple, que suele ser de carácter intrapersonal. No obstante, de la misma forma que existen supuestos de comportamiento de conciencia simple de carácter interpersonal cuando se trata de bienes jurídicos individuales de carácter disponibles, de igual forma pueden existir supuestos de objeción de conciencia intrapersonal, cuando a pesar de que igualmente el bien jurídico es de carácter individual, por decisión estatal no es disponible».

245 ID., ibidem, op. cit., p. 80.

246 ID., ibidem, op. cit., pp. 82 y 83, especialmente p. 84 .

247 ID., ibidem, op. cit., p. 86.

248 ID., ibidem, op. cit., pp. 91 a 96. 
jurídica, lo que le lleva a considerar que dichos autores sólo pueden actuar dolosamente $e$ improbablemente por imprudencia ${ }^{249}$.

Un ejemplo claro de separación conceptual entre autor por convicción y de conciencia es la argumentación de ZAFFARONI que señala al «(a)utor por convicción al que solo es un objetor de la norma y autor por conciencia o por conciencia disidente al que incumple la norma por sentirlo como un deber de conciencia» ${ }^{250}$.

Otra definición, diferente a la de cualquier otro citado previamente, se sustenta por JAKOBS, al incluir en el mismo concepto de autor por convicción al de conciencia, pero estableciendo una graduación en el concepto de convicción, de autor por convicción duro y blando. El citado penalista señala que «en el autor por convicción duro (autores por motivos de conciencia o, mejor, autores en conflicto - Konflikttäter) ... el conflicto entre convicción y Derecho es irresoluble, si no hace caso a su convicción daña a su persona» ${ }^{251}$. Mientras que autor por convicción blando estaría constituido, según JAKOBS, por aquellos «que cometen delitos, desde luego sin considerarse imperativamente obligados a hacer valer el orden mejor según su parecer $^{252}$. JAKOBS acierta en distinguir no tanto una diferencia cuantitativa de la inevitabilidad del conflicto, sino estrictamente cualitativa, o en cuanto alcanzo a comprender hasta aquí, tanto el autor de conciencia (por ejemplo, el testigo de Jehová que omite el deber de socorro a su hijo), como el autor por convicción «duro», en este caso el terrorista, actúan de forma ineludible, sin embargo, en JAKOBS subyace la idea novedosa de que en este último caso también entrarían los autores que como el cazador que furtivamente caza fuera de los periodos de veda, no actúa obligatoriamente por un imperativo moral, sino en un convencimiento propio y particular.

Otra definición diametralmente opuesta a su vez a la de JAKOBS es sustentada por HIRSCH. Este penalista argumenta que el autor por convicción «no se encuentra en un conflicto de conciencia sino que simplemente lo motiva la justicia material de su decisión. Actúa por pura convicción, es decir, motivado por la conciencia del deber pero sin obligación perentoria

249 ID., ibidem, op. cit., p. 100.

250 ZafFAroni Eugenio Raúl / Alagia Alejandro / SLOKAR Alejandro, Derecho penal, Parte general, $2^{\mathrm{a}}$ ed., Ediar, Buenos Aires, 2002, p. 737. Explica que «en el llamado autor por conciencia o por conciencia disidente se reactualiza el drama de Antígona, en el conflicto entre el imperativo de la ética individual y los valores objetivados jurídicamente, de tal magnitud que no podría actuar contra aquel sin una seria necesidad de conciencia moral, lo que a veces ocurre en la delincuencia por causas políticas y por convicción religiosa», ID., ibidem, Derecho penal, Parte general, op. cit., pp. 678 y 679.

251 JAKOBS, G., PG, op. cit., 20/20 a 20/22. En la misma línea el profesor Klaus TIEDEMANN puesto que «tras un hecho contrario a la conciencia, en la vergüenza que siente el convencido, ello sería consecuencia de una neurosis compulsiva», vid. ID., ibidem, op, cit., nota 21/22, píe de página 33a.

252 ID., ibidem, op. cit., 20/21; le sigue en la distinción de tipos de autores por convicción SANTA RITA TAMÉS, Gilberto, El delito de organización terrorista: un modelo de Derecho penal del enemigo. Análisis desde la perspectiva de la imputación objetiva, pról. Miguel Polaino-Orts, Bosch, 2015, pp. 568 a 570. 
derivada de la vivencia interna resultante de la contradicción entre lo bueno y lo malo. Se trata sobre todo de motivos políticos existenciales que se experimentan subjetivamente como deberes de actuar» ${ }^{253}$.

Por otro lado, Tribunal Constitucional alemán denominó autor por convicción a lo que JAKOBS llama autor por convicción duro, o ZAFFARONI designa como autor de conciencia. El citado Tribunal incluye en la categoría de autor de conciencia al autor por convicción como un subtipo, y al que define como aquel en el que «toda decisión ética sería, es decir orientada a las categorías de lo bueno y lo malo (...) que el individuo experimenta internamente en una determinada situación como forzosa e incondicionalmente obligatoria para el de modo que no podría actuar en contra de ella sin un grave conflicto de conciencia» ${ }^{254}$.

En otro sentido, y en la doctrina española, MIR PUIG considera que dentro del concepto de autor por convicción se deben incluir los citados autores de conciencia: «Este es el caso del llamado «delincuente por convicción», que, generalmente por motivos religiosos o políticos, no experimenta sentimiento de culpabilidad pese a conocer el significado jurídico de su hecho» ${ }^{255}$. Entre ese tipo de delincuentes incluye los miembros de las confesiones religiosas, como los Testigos de Jehová que difieren con las obligaciones jurídicas en el caso de la transfusión de sangre y con base a sus valores religiosos, a los insumisos y a los terroristas. Como se puede apreciar en la teoría de MIR PUIG, su concepto abarca a todo tipo de autores por motivos morales, desde aquellos que aunque «civilizados» se oponen en alguna cuestión al ordenamiento por motivos morales, pero también incluye a los sujetos incivilizados como los terroristas, que sin piedad contradicen no sólo una norma penal, sino que atacan al ente democrático y moral de la sociedad.

RODRÍGUEZ DEVESA y GÓMEZ SERRANO ${ }^{256}$ tampoco diferenciaron entre autor por convicción y de conciencia. Siguió esta misma línea CEREzo MIR, quien incluyó en el mismo concepto de autor por convicción al de conciencia: «En el autor por convicción, por ejemplo, el insumiso (...) o el padre testigo de Jehová que rechaza, por sus creencias religiosas que se le haga una transfusión de sangre a su hijo menor de edad (...) no hay culpabilidad moral, pero sí culpabilidad jurídica», de manera que por la aplicación del principio de alternatividad, se

253 HIRSCH, HJ., «Derecho penal y autor por convicción», op. cit., p. 197.

254 BverfG, 12, pp. 46 y ss.

255 MIR PUIG, Santiago, Derecho penal, Parte general, $5^{\text {a }}$ ed., Reppetor, Barcelona, 1998, p. 546.

256 Rodríguez DeVESA José María / SERRANo GómeZ Alfonso, Derecho penal, Parte general, 17 ed., Dykinson, Madrid, 1994, pp. 440 y 441. 
aplicará el delito de homicidio en comisión por omisión, en detrimento de la omisión del deber de socorro $^{257}$.

Bajo otros presupuestos, BAUCELLS concibe al delincuente por convicción «como un tipo de autor genérico cuya motivación es impulsada por la convicción de que debe cometer el hecho de acuerdo con un orden normativo que valora más altamente que el Derecho estatal vigente. Este orden de normas puede ser político, religioso o ético. Mientras el delito político se definiría por la finalidad política de la acción, el delito por convicción se caracterizaría por la motivación política ${ }^{258}$. Estamos de acuerdo con BAUCELLS en que no se puede hacer una distinción de la convicción y de la conciencia en los motivos, pues los políticos, ideológicos, religiosos e inclusive filosóficos pueden tener un peso igualmente trascendental, o sea, forzosamente en la dirección externa de la voluntad, la conducta.

Sin embargo, utilizando sesgadamente la doctrina kantiana del imperativo categórico (ley moral universal) BAUCELLS relega la categoría conceptual de «actuación por conciencia» en el fundamento de que en éste existe un deber moral que procede de un imperativo categórico, a la vez, sustentado en la autonomía y en la humanidad, a diferencia de quien actúa especialmente motivado por un imperativo hipotético, por un propósito interesado que igualmente permite la relevancia ética y jurídica porque el ordenamiento jurídico reconoce criterios de racionalidad ética (autonomía y humanidad) reconocidos en el art. 10.2 CE al respecto de la dignidad, y en el art. 9.1 CE en relación a la vigencia general de las norma ${ }^{259}$. De tal forma delimita el concepto de autor por convicción y de conciencia con base a la distinción del imperativo categórico ${ }^{260}$, como sí unas conductas representasen un «deber moral» ${ }^{261}$ universal amparado en el art. $30.2 \mathrm{CE}$ como objeción de conciencia, mientras que otras fueran simples convicciones que no alcanzan dicho valor pero que igualmente pueden merecer un tratamiento privilegiado amparado en el art. $16 \mathrm{CE}$ mediante la libertad de convicciones ${ }^{262}$, de lo cual extrae repercusiones privilegiantes o no según si la conducta incumple deberes individuales, colectivos o afectan a un bien jurídico. El incumplimiento de los deberes individuales puede aceptar ciertas formas de atipicidad, mientras que los restantes a ciertas categorías del delito y la determinación de la pena ${ }^{263}$.

257 Cerezo Mir, José, Curso de Derecho penal español. Parte general, III, Teoría jurídica del delito/2, $5^{\mathrm{a}}$ reimp. 2005, de la $1^{\text {a }}$ ed. 2001, Tecnos, p. 35 y nota núm. 91, si bien también admite la atenuante analógica o muy cualificada de arrebato u obcecación, ID., ibidem, op. cit., p. 37; CEREZO MIR, J., Derecho penal, Parte general, Lecciones, (26-40), $2^{\mathrm{a}}$ ed., 2000, UNED, pp. 31 a 33.

258 BAUCELlS I LLADÓS, J., La delincuencia por convicción, op. cit., p. 409.

259 ID., ibidem, op. cit., pp. 410 y 411.

260 Críticamente JERICÓ OJER, L., El conflicto de conciencia, op. cit., pp. 214 y ss.

261 BAUCELls I LLADÓS, J., La delincuencia por convicción, op. cit., pp. 412.

262 ID., ibidem, op. cit., pp. 412, 413.

263 ID., ibidem, op. cit., pp. 412 y 413. 
Más recientemente, JERICó opta por un concepción amplia del término conciencia ${ }^{264}$ pero reconoce que dificulta la distinción con el término «convicción» que lo relega al ámbito del conflicto de conciencia (decisión de conciencia/decisión por convicción), de tal modo que la decisión de conciencia, a diferencia, genera una obligación imperativa (conflicto irresoluble) que en caso de incumplirse afecta gravemente a la dignidad y a la personalidad. Aquí apunta ya a una solución jurídico-penal en la institución de la inexigibilidad de la conducta ${ }^{265}$, mientras que el mandado de convicción no participa de la obligatoriedad interna ${ }^{266}$. En este sentido, diferencia la objeción de conciencia como «un incumplimiento de una norma jurídica motivada por la colisión entre dogmas y reflexiones más íntimos del sujeto afectado y lo exigido por aquélla ${ }^{267}$ (...) La necesidad de que exista cierto deber interno es lo que permite que el Estado acceda a que los ciudadanos incumplan determinadas normas, en principio de obligado cumplimiento, no por cualquier motivo, sino por consideraciones que estas motivaciones merecen ser atendidas o respetadas ${ }^{268}$

Precisa que la objeción de conciencia se produce por la colisión entre un deber moral y un deber jurídico, por lo que «carece de sentido aludir a aquélla cuando no existe un deber jurídico», o cuando se acata la norma ${ }^{269}$, deber o derecho según las posiciones de cumplimento o amparo y según los $\operatorname{casos}^{270}$, de tal manera que si existe algún tratamiento privilegiante en la objeción de conciencia es porque en definitiva algún derecho hay, a pesar de que se incumpla un deber jurídico. Admite que las motivaciones políticas se releguen, en la mayoría de las ocasiones, a la autoría por convicción pero no renuncia a que en determinadas ocasiones exista un conflicto de conciencia como en los casos de movimientos fundamentalistas en los que se mezclan motivaciones religiosas $^{271}$, pero rechaza que su actuar sea imperativamente inevitable ${ }^{272}$, por lo que parece relegar la decisión o conflicto de conciencia a un fundamento religioso irresoluble ${ }^{273}$,

264 JERICÓ OJER, L., El conflicto de conciencia, op. cit., p. 77.

265 ID., ibidem, op. cit., pp. 404 y 622 y ss.

266 ID., ibidem, op. cit., p. 77.

267 ID., ibidem, op. cit., p. 93.

268 ID., ibidem, op. cit., p. 94. Concluye que «la objeción de conciencia excede de la oposición a la ley por un deber precedente exclusivamente de la conciencia (en un sentido restringido), puesto que es admisible que el Estado, al amparo de la objeción de conciencia, tolere ciertos comportamiento disidentes que no proceden estrictamente del ámbito de la conciencia (...) Será, precisamente, la intensidad del deber la que nos sitúe en otro plano completamente diferente, concretamente en el del conflicto de conciencia, pues para entender que un sujeto se halla en un conflicto de conciencia, se deberá exigir que el deber interno sea un imperativo de tal intensidad que, en caso de no seguirlo, ocasione lesiones irreversiblemente en su dignidad personal, desvalor que en ningún momento es exigido en la objeción de conciencia», ID., ibidem, op. cit., p. 95.

269 ID., ibidem, op. cit., p. 152.

270 ID., ibidem, op. cit., p. 155.

271 ID., ibidem, op. cit., pp. 184 y 185.

272 ID., ibidem, op. cit., p. 217.

273 ID., ibidem, op. cit., p. 186. 
si bien acertadamente desautoriza que el Estado pueda considerar unas u otras concepciones como mejores o peores, malas o buenas ${ }^{274}$. Finalmente concluye que los conflictos de conciencia o la objeción de conciencia pueden manifestarse tanto con una acción o una omisión, pero admite que en la mayoría de casos aparece cuando existe un deber de acción y el deber interno del sujeto obliga a abstenerse ${ }^{275}$.

Pues bien, como ha fundamentado SÁNCHEZ-VERA ${ }^{276}$, no pueden compartirse aquellos criterios que, como el de JERICó, arguyen que la mayoría de los deberes jurídicos son de naturaleza prohibitiva, que exigen abstenerse, y esto porque se desnaturalizan o no se contemplan los llamados delitos de infracción de deber, tanta prohibición existe en no matar por acción como por omisión en el caso del padre que no asiste a su hijo en una situación de desamparo, lo que ocurre es que los mandatos de prohibición, todos en verdad, no especifican cómo cumplir la norma, a diferencia de los delitos de infracción de deber que se refieren a normas de flanqueo que los sujetos deben conocer en principio. Dependerá de la configuración normativa de las circunstancias, que en ocasiones ordenará una acción o una omisión, sin que esta configuración, en nuestra opinión, distinga la autoría de conciencia y por convicción.

Finalmente JERICó diferencia el autor de conciencia y por convicción en la premisa de una decisión de conciencia o por convicción pero sin establecer una frontera rígida. Fundamenta la diferencia en la «obligación inexcusable» que con mayor facilidad aparece en los motivos religiosos que tiene el autor de conciencia, lo cual le genera el grave conflicto de atentar contra su dignidad y persona ${ }^{277}$, mientras el autor por convicción «puede considerar que su hecho es también obligatorio, pero en ningún caso sufre un conflicto interno si no lleva a cabo un comportamiento que es acorde a su convicción. Es precisamente el carácter de vinculación interna y de inexcusabilidad del imperativo de conciencia lo que permite plantear un posible tratamiento jurídico diferenciado del sujeto que actúa por conflicto de conciencia» ${ }^{278}$.

En nuestra opinión, basta considerar los motivos de algunos terroristas para darse cuenta que no existe en éstos un conflicto puro, sino lucha por convicción, una conducta inevitable que lógicamente tiene mayor o menor intensidad, al igual que en cualquier autor de conciencia con un conflicto entre el deber jurídico y el deber/derecho moral.

74 ID., ibidem, op. cit., p. 193.

275 ID., ibidem, op. cit., pp. 184 y 185.

276 SÁNCHEZ-VERA, Javier, Delito de infracción de deber y participación delictiva, presentación Enrique Bacigalupo, pról. Günther Jakobs, Marcial Pons, Barcelona, 2002, pp. 83 y ss.

277 JERICÓ OJER, L., El conflicto de conciencia, op. cit., p. 289.

278 ID., ibidem, op. cit., p. 459. 


\section{D. ¿El autor de conciencia y por convicción culposos?: Reflexiones sobre la posibilidad}

jurídico-penal de un autor por convicción o de conciencia imprudente

Cabe plantearse si dentro de las categorías conceptuales de autorías por convicción y de conciencia en algunos casos actúan imprudentemente. Esta cuestión apenas ha sido debatida por la doctrina porque el presupuesto principal ha sido siempre que ambos actúan dolosamente.

Sin embargo, hay quienes plantearon la posibilidad de la comisión imprudente en algunos casos, por ejemplo, en la doctrina alemana se suscitaron esta posibilidad EBERT y BUDZINSKI ${ }^{279}$. Este último autor propone el siguiente ejemplo: el médico que atropella a un peatón al socorrer a un menor de edad que niega posteriormente el auxilio. Este caso podía ser resulto en su época mediante el delito imprudente, pero en la actualidad, la práctica totalidad de la doctrina abogaría por un delito de omisión del deber de socorro agravado, el cual si bien no precisa del dolo sino de la injerencia precedente, se concibe como un delito de omisión pura agravada o de peligro en el que es indiferente si la omisión exigida normativamente se realiza por imprudencia o dolo. No obstante, el ejemplo de BUDZINSKI reconducido al delito de omisión del deber de socorro agravado, puede adoptar los presupuestos de la comisión imprudente o en su caso dolosa pero al sancionarse como delito de peligro, no cabe dudar que el fundamento de punibilidad es ajeno a la conciencia o convicción.

A este respecto, se hace necesario recordar que dentro de la imprudencia habría que diferenciar la imprudencia consciente o con representación (negligentia), de la imprudencia inconsciente o sin representación (luxuria). En la primera el sujeto prevé el resultado, pero confía en evitarlo, y en la segunda el sujeto ni prevé la posibilidad del resultado, a pesar de poder haberlo previsto. Así, la imprudencia plantea terribles problemas de delimitación, en concreto, la imprudencia consciente con el dolo eventual ya que éste suele concebirse como la representación y aceptación probable del resultado delictivo, pero a la vez, plantea también problemas de la delimitación de la culpa inconsciente con caso fortuito en sucesos imprevisibles humanamente («no hay pena sin dolo o imprudencia»).

La distinción entre dolo eventual e imprudencia consciente precisa previamente diferenciar varias teorías. La «teoría de la probabilidad» considera que será dolosa eventual una conducta si el autor se ha representado el resultado como probable, e imprudente si sólo se lo representa como posible. Mientras que en la «teoría del consentimiento» se requiere además de la

279 Vid. Flores MendoZA, F., Objeción de conciencia en Derecho penal, op. cit., p. 100 nota (respectivamente EBERT, Udo, Der Überzeugungstäter in der neueren Rechtsentwicklung, Duncker \& Humblot, Berlín, 1975, p. 9; BUDZINSKI, W., Der Überzeugnungstäter, op. cit., p. 28); FlORES MENDOZA comenta que el autor de conciencia actúa dolosamente e improbablemente por imprudencia, ID., ibidem, op. cit., p. 100. 
representación del resultado como probable, que el resultado sea asumido, aceptado por el sujeto. En este punto, conviene recordar la teoría de LAURENZO COPELlo de que, aun partiendo de las teorías del conocimiento, la culpa consciente encierra un error de tipo sobre la evaluación del dato objetivo de que el peligro se manifestará en su propia acción, a pesar de reconocer el peligro genérico $^{280}$, de modo que en los delitos de peligro, se identifica de mejor manera la culpa consciente que el dolo de peligro, como una tentativa imprudente de delito de resultado, o dicho de otra manera, existe identidad estructural entre el dolo de peligro y la imprudencia consciente $^{281}$.

De otra parte, la teoría hipotética del consentimiento considera que será doloso eventual si el sujeto ante un juicio hipotético sobre lo que hubiese hecho, se representa el resultado como seguro e igualmente actúa, mientras que será imprudente si hubiese desistido ${ }^{282}$.

Un caso que puede generar dudas o convencer sobre la posibilidad de la conducta imprudente en la autoría de conciencia o por convicción, es aquél suscitado en la Audiencia Provincial de Alicante de 12 abril de $2003^{283}$ rec. 26-2003, sobre el fallecimiento causado por dos afiliados al grupo Osho Commune Internacional, filial de la organización religiosa Osho Rajneesh, y que versa sobre la práctica «terapéutica» denominada «niño interior» ${ }^{284}$.

Esta técnica fundamentalmente era utilizada por el grupo en cuestión como medida de desarrollo personal. A la víctima se le hizo retroceder en el tiempo hasta el momento del claustro materno. Se representaba la gestación mediante el posicionamiento fetal y envolviendo al sujeto en una manta, y producir durante unos segundo las ausencia de respiración. En el caso en cuestión, los acusados forzaron la imposibilidad de parto del ficticio feto, repitiendo la operación hasta en dos ocasiones, a pesar de que ya antes de la primera de las representaciones/sesiones la víctima que, siempre «voluntariamente» se sometió a ésta técnica, sintió síntomas de asfixia.

280 Laurenzo Copello, Patricia, Dolo y conocimiento, Tirant lo Blanch, Valencia, 1999, pp. 288 y ss. toma el criterio de STRATENWERTH, Gunther, «Dolus eventuales und bewusste Farhlässigkeit», ZStW, núm. 71, 1959, p. 59.

281 LAURenzo Copello, P., Dolo y conocimiento, op. cit., pp. 294 a 307.

282 Ampliamente ID., ibidem, op. cit; CORCOY BIDASOLO, Mirentxu, El delito imprudente. Criterios de imputación del resultado, $1^{\mathrm{a}}$ ed., PPU, Barcelona, 1989, pp. 270 y ss.

283 SAP de Alicante, Sección 3a , de 12 abril de 200, rec. 26-2003, procedente del recurso de apelación de la sentencia núm. 406/02, de fecha 10 septiembre, dictada por el Juzgado de lo Penal núm. 1 de Benidorm, en su Juicio Oral núm. 24/02, correspondiente al Procedimiento Abreviado núm. 76/00 del Juzgado de Instrucción núm. 5 de Benidorm

284 La técnica del «niño interior» consiste «en ponerse, quien va a realizarlo, en el suelo en posición fetal y se tapa enteramente con una manta, y los demás participes se colocan encima al objeto de hacer una presión con los cuerpos, todo ello con el fin de que la persona que se encuentre en posición fetal ejerza fuerza suficiente para poder aguantar tal presión y así poder liberar los patrones de conducta innatos en sí mismos. Durante dicha práctica se tienen dificultades respiratorias. Así lo manifiesta la acusada que resultó absuelta, Constanza, y así lo describe la apelante Raquel quien afirma que el corazón parece dejar de latir, siendo como un gran desmayo, y cuando uno vuelve es un gozo», FJ $3^{\circ}$ SAP de Alicante, Sección 3ª de 12 abril de 2003. 
Durante la segunda sesión, la víctima volvió a someterse, pero con el fatal resultado de la muerte por asfixia mecánica por comprensión realizada por los demás miembros.

La Sentencia considera probado la relación causal entre la acción de los sujetos intervinientes y la muerte de la víctima como fundamento de la imputación objetiva pero a título de imprudencia $^{285}$. Lo que no resuelve la Sentencia son dos cuestiones que especialmente nos interesan: la diferenciación entre culpa consciente e inconsciente y su delimitación en el caso concreto con el dolo eventual; y en consecuencia y en especial importancia, la repercusión de la motivación de conciencia en la responsabilidad penal.

La Sentencia es correcta en cuanto a la conclusión de la comisión imprudente, si bien parte de la doctrina, aquellos que defienden la teoría de la probabilidad, concluirían que el caso refiere una conducta dolosa, al menos eventual. Sin embargo, debemos analizar qué relevancia tiene la técnica «terapéutica» del «niño interior» en la conciencia religiosa de autores. Hemos defendido que la libertad de conciencia engloba una serie de manifestaciones, entre las que se pueden incluir el proselitismo y medidas tendentes a obtener la salvación o el mejoramiento personal ya sea religioso, ideológico o filosófico. Es claro que ninguna normativa prohibió a este grupo la técnica del «niño interior», si bien parece ser estaba ampliamente reconocida no sólo en este grupo religioso, sino también en técnicas terapéuticas que en este caso en concreto no está regulada normativamente ni limitada a una profesión en concreto. En este sentido, no encontramos norma alguna que prohíba a un grupo de personas realizar esta técnica u otras semejantes para el mejoramiento personal, máxime cuando no está limitada a prescripción médica ni psiquiátrica con farmacología. Así pues, la conducta realizada por los autores exclusivamente suponía un «riesgo permitido» en el que la víctima se auto-colocó (autopuesta en peligro) por medio de su consentimiento a la aplicación de la medida, por lo que concurre una situación riesgosa en comunidad o concurrencia de culpas, en la que evidentemente no se pretendió el resultado de muerte pero que se podía conscientemente conocer porque la víctima ya había tenido en la primera sesión síntoma de asfixia por lo que no se puede negar la probabilidad del resultado. Sin embargo, dicho resultado ni se quería ni se aceptaba por los autores, al igual que sucede en el clásico caso de los padres testigos de Jehová que omiten el deber de socorro. La diferencia en este caso es puramente normativa al tratarse de un delito de resultado, sin embargo,

285 Dice la Sentencia en cuestión que «(e)n definitiva y según los criterios de imputación objetiva, no solo existe una relación causal de índole natural entre la muerte de María Esther y la acción de los apelantes, sino que se puede imputar objetivamente a estos últimos la muerte de aquella ya que realizaron los actos necesarios que pusieron en peligro la vida de la fallecida. Estos actos eran además adecuados para poner en peligro la vida de las personas que se sometían a este ejercicio dado que por las declaraciones, a las que ya se ha hecho referencia, se alcanzaban situaciones de desvanecimiento y desmayo, indudablemente originados por la ausencia suficiente de oxígeno», FJ $5^{\circ}$ SAP de Alicante, Sección 3 ${ }^{\text {a }}$, de 12 abril de 2003. 
al igual que en la omisión del deber de socorro, el dolo es indiferente cuando la conducta de la propia víctima o el hecho riesgoso no competen a los autores del resultado. También puede haber un resultado material en la omisión del deber de socorro no punible.

Por otro lado, podemos reseñar también el caso de Anneliese Michel ${ }^{286}$, nacida en 1952 en Alemania, que empezó a padecer una serie de convulsiones, ataques, y visiones de rostros demoníacos que los médicos diagnosticaron como epilepsia. La afectada aseguró que la medicina sería incapaz de aliviar su sufrimiento porque estaba poseída, por lo que requirió la ayuda de la Iglesia Católica que finalmente accedió a tratar a la joven mediante varios exorcismos. El obispo de Würzburg, en septiembre de 1975 designó a dos sacerdotes realizar el exorcismo. Finalmente a consecuencia de una neumonía, la fiebre alta y la desnutrición que arrastraba, la joven murió.

El caso fue llevado a juicio. Se acusó al padre de la fallecida y a los dos exorcistas de homicidio negligente, y tras dos años de pleito, el jurado fallo a favor de la tesis planteada por los fiscales y psiquiatras, que Anneliese había muerto a consecuencia de la desnutrición, producida a consecuencia de dejar de tomar la medicación recetada por los servicios médicos, y que finalmente también degeneró en psicosis. Se condenó a los imputados como culpables de un homicidio involuntario, con la pena de seis meses de cárcel, pero con libertad condicional. Finalmente la Conferencia Episcopal alemana, se desvinculó del proceder de los exorcistas, concluyendo que la joven no estaba realmente poseída.

En ambos casos la autopuesta en peligro de la víctima hace más evidente que los autores no consintieron el resultado, no lo aceptaron, a pesar de representarse una, digamos, alta probabilidad del resultado. Entonces, puesto que la medida «terapéutica» o de «desarrollo personal» se fundamentaba en una decisión de conciencia, en este caso religiosa, no hay impedimento alguno para sostener la posibilidad de una autoría de conciencia imprudente.

Sin embargo esta conclusión de la autoría de conciencia imprudente puede desmentirse con otros argumentos. ¿Cabe hablar de actio libera in causa (alic) en las conductas típicas imprudentes realizadas por el autor de conciencia? En nuestra opinión, y adelantando nuestra conclusión, sí es posible si partimos del modelo de acción típica de la actio libera in causa.

La responsabilidad atribuida a título de imprudencia en el caso del «niño interior» antes citado, parte de la admisión de la imprudencia consciente pues de la relación causal se advierte la objetiva probabilidad del resultado de muerte. Los sujetos que llevaron a cabo la práctica eran conocedores, no ya por sus conocimientos superiores sobre técnicas de desarrollo personal a

286 Goodman, Felicitas D., The Exorcism of Anneliese Michel, Wipf \& Stock Publishers, 2005. 
título personal, sino como personas y por la asfixia de la primera sesión, que la presión ejercida podría causar la muerte de la víctima, es decir, eran conocedores objetivamente que tal práctica podría causar la muerte por asfixia. Si ésta no fue querida, no fue dolosa, sin embargo lo cierto es que fue previsible el resultado, por lo que le era exigible la observancia del cuidado objetivamente debido, no en posición de garante, pues esta técnica no precisa de un título oficial determinado, y aunque la conducta aumenta el peligro (injerencia), la víctima voluntariamente lo acepta. La creencia moral sobre esta técnica de desarrollo personal, en tanto en cuanto creencia querida y voluntariamente ejercitada, es la causa principal de la inobservancia del cuidado objetivamente debido, o dicho de otro modo, la imputación a título de imprudencia viene causada de una conducta previa lícita, querida y voluntariamente materializada, como es la propia convicción moral en la técnica de desarrollo personal, además de que viene aceptada por la víctima, aun conociendo el riesgo que la primera sesión le facilitó.

De tal suerte, un error volitivo por la indiferencia en conocer que esta técnica es peligrosa produce la inobservancia del cuidado objetivamente debido. Se produce, entonces, la indiferencia al Derecho, que en nuestra opinión, y en estos casos, produce una indiferencia en lo normativo del deber de observancia del cuidado objetivamente debido. Los errores cognitivos que producen errores volitivos pueden ser perdonables en virtud del art. 14 del CP, pero los errores volitivos que producen errores cognitivos no son perdonables cuando el error cognitivo es a título de imprudencia en grado alto.

Sin embargo piénsese en otro caso hipotético. Un sujeto acude a una cita con una espiritista. El sujeto cree en estas concepciones cosmológicas del destino. En esta cita, la pitonisa le comenta que va a morir de un cáncer, exactamente en el término de un año. El sujeto sale convencido de la cita de que su destino está cerrado y sentenciado, y haciendo caso de sus fuertes convicciones que tiene sobre el destino predeterminado que le ha comentado la espiritista, coge el coche haciendo caso omiso de las reglas circulatorias, poniendo en grave peligro la seguridad personal de los demás, produciéndose finalmente un accidente con resultado de muerte por imprudencia grave. Entonces, ¿cabe responsabilizar al sujeto a título de imprudencia, o a título de doloso? ¿Cabe, por tanto, hablar de autoría por de conciencia o por convicción imprudente en este caso? Entendemos que sí, siempre y cuando la inobservancia del cuidado exigido provenga precisamente de una convicción moral que es la que de modo directo causa la inobservancia, sin embargo, tal postulado puede transformarse en una imputación a título doloso, al igual que en el caso del «niño interior» utilizando los criterios de la actio libera in causa en cuanto que la falta de cuidado al venir de una convicción moral, o sea, con 
conocimiento, puede retrotraerse la imputación a dicho estado, haciendo a la conducta final responsable a título dolo en todo el devenir de la conducta.

Por ahora dejamos sentada esta problemática que ha sido poco debatida por la doctrina, al menos desde luego en la autoría de conciencia y por convicción. Si bien, hemos podido llegar a la conclusión de poder apreciar dogmáticamente la imprudencia. Volveremos sobre dicha problemática.

\section{E. Conclusiones parciales}

Lo que es evidente es que existe un galimatías conceptual en la doctrina desde los inicios del debate conceptual que sólo puede resultar fructífero tras el análisis del tratamiento penal de cada una de las conductas en las que un sujeto apela a un motivo «inmaterial», ya sea religioso, político, ideológico o filosófico, según lo expuesto supra. El tratamiento penal diferenciado, pero puesto en comparación del autor por convicción, autor de conciencia y del enemigo, puede resultar beneficioso para comprender en su totalidad la problemática.

Tradicionalmente se ha diferenciado al autor de conciencia y por convicción en un sentido que nos parece estrictamente acorde a la moralidad de la sociedad. El primero como aquél que tiene motivos «buenos», «comprensibles», o acordes a la sociedad y la moral de la mayoría de su tiempo; mientras que el segundo como aquél que por «conveniencia» ataca al Estado y a la Sociedad. Esta diferenciación llevó a algunos autores a distinguir los conceptos en la dinámica criminal y en la forma de comisión: omisiva en los autores de conciencia, comisiva en los autores por convicción, por eso también tradicionalmente se ha tratado la desobediencia civil como una forma de autoría por convicción.

En este contexto se ha se eliminar de la conceptualización y del tratamiento el influjo determinante de la moralidad, de modo que la observación de estas tipologías criminales no se determine exclusivamente en conceptos morales de la generalidad, sino de fundamentos estrictamente normativos. Así, desde este tipo de observación de la fenomenología criminal, se pueden plantear concepciones basadas en la funcionalidad criminal y sistémica, de forma tal que la consideración moral sobre lo «comprensible» o la «conveniencia», es decir, sobre lo más o menos «bueno», o lo más o menos «malo», se traslada a una operación estrictamente funcional en relación a la continuidad de la operatividad de la Sociedad.

Dicho esto, utilizando esta forma de observación, la conceptualización de la autoría de conciencia y por convicción sería la siguiente: el autor de conciencia obra con una conexión ineludible entre los pensamientos (sistema psíquico), la conciencia y voluntad, donde la 
conciencia, si bien normalmente controladora de la voluntad, se ve influenciada por la comunicación normativa del Derecho a la libertad de conciencia, de tal modo que se autonormativiza utilizando la orientación de conductas que comunica la libertad de conciencia; así, el delito, para el autor de conciencia, es el único medio para alcanzar el fin de protección del derecho a la libertad de conciencia, no existen más alternativas normativas, o las que existieren son incapaces de orientar al sujeto debido a socialización que ha provocado el Derecho a la libertad de conciencia; pero además, con su conducta no pretende comunicar a la sociedad que la norma no está vigente, sino reafirmar su autonormatividad que ha sido orientada por el Derecho a la libertad de conciencia. Si bien la conducta del autor de conciencia niega el contenido material de la norma quebrantada, dicha comunicación negativa es bilateral, o dicho de otro modo, el autor de conciencia realiza con su conducta una comunicación cara a cara entre el propio sujeto y la norma, expresándole que no le es vinculante o no está vigente para él la norma, y en este caso excepcionalmente concreto. Dicha comunicación es estrictamente bilateral y no contiene la expresión de sentido de comunicar su actitud a toda la Sociedad y sus componentes, ni contra el Sistema.

Por eso, si bien hay que otorgar la razón a planteamientos como los de GRACIA MARTÍn que se refieren a que también en la autoría de conciencia, como en la autoría por convicción, se defrauda el compromiso ético individual con el orden jurídico de la comunidad, y que se vulnera el compromiso de renuncia a los particulares deberes de conciencia ${ }^{287}$, más cierto es que dicha defraudación no se realiza en aprovechamiento del Sistema, cuestión que también acierta a ver GRACIA MARTín en el caso de la autoría por convicción, sino que pretende reafirmar el Derecho a la libertad de conciencia, de manera que la inevitabilidad de su conducta, a nuestro juicio, se debe fundamentalmente a la orientación normativa previamente realizada por el Sistema social y normativo que comunica al sujeto dicha libertad sin plantear/comunicar/orientar de forma clara alternativas normativas.

Por el contrario, el autor por convicción ataca el contenido material de la norma, pero a la vez la vigencia general de la configuración normativa de la sociedad, en mayor o menor medida. El delito se presenta en el autor por convicción, si bien también inevitable en la conexión entre su sistema de pensamientos, la conciencia ideológica o política o moral, y la norma, no existe influjo ninguno del Sistema en ese modo de obrar, el delito se realiza como «elección» entre otras alternativas que le plantea el Sistema, por ejemplo, para cazar fuera de los periodos de

\footnotetext{
287 GRACIA Martín, Luis, Fundamentos de dogmática penal. Una introducción a la concepción finalista de la responsabilidad penal, Atelier, 2006, p. 148.
} 
veda, al autor por convicción le basta instar a la administración sobre la superpoblación de alguna especie, y plantear las solicitudes, y en su caso, los recursos administrativos y judiciales correspondientes, o en el caso del terrorista, puede iniciar un proceso organizado y democrático de oposición al Sistema.

Amén de esto, no existe ninguna diferencia entre ambas tipologías en cuanto a la intensidad, energía o fuerza del contenido del motivo. En ambos pueden suscitarse sentimientos de conciencia moral, ideológico, político o filosófico, sin que afecte a su conceptualización, puesto cada uno de estos sentimientos tienen el mismo rango de protección constitucional.

Según la concepción kantiana, y que -como veremos infra- utiliza parte de la doctrina, el delito en el autor por convicción es un medio o móvil para un fin, mientras que en el autor de conciencia el delito es un fin inevitable. El especial reproche penal en el autor por convicción, entonces, subyace, desde esta perspectiva moralizante, en que un medio nunca supone un fin en sí mismo, ni una Ley Universal. Sin embargo, desde una observación estrictamente funcionalista y normativista, el autor por convicción reafirma su culpabilidad porque dispone de claras alternativas normativas de comportamiento, sin embargo, la elección del delito se forma en su conciencia como inevitable a pesar de existir alternativas lícitas, de modo tal que dicha inevitabilidad supone un peligro objetivo para la operatividad del Sistema social, porque la norma ha sido incapaz de orientarle en un comportamiento adecuado al Sistema a pesar de las alternativas normativas de comportamiento ofrecidas, por eso el delito en su caso comunica que el contenido de la norma y además las alternativas que le ofrece el sistema normativo, no le son vinculantes en ese determinado momento de elección, de aquí que no sólo ataque el contenido material de la norma que defrauda, sino todo el Sistema en mayor o menor medida. En definitiva, la inevitabilidad de su delito supone un peligro para el Sistema normativo y social.

LUHMANN explicaba que el conflicto de conciencia se basa en una necesidad moral de comportamiento que infringe las normas. De esta manera, la conciencia -para el citado sociólogo- tiene una función de «control» entre el sistema psíquico y la norma ${ }^{288}$, pero en determinados momentos la conciencia no puede institucionalizarse normativamente ni precisa de consenso pues se autonormativiza sin influjo del sistema normativo ${ }^{289}$, de aquí el conflicto. Sin embargo, en nuestra opinión, la diferencia fundamental entre ambas tipologías desde el modo de observación sistémico - de segundo orden- que proponemos, es que mientras el autor de

\footnotetext{
288 LuhMANN, N., «Die Gewissensfreiheit und das Gewissen», op. cit., pp. 257 a 267, también en ID., «Die Gewissensfreiheit und das Gewissen», op. cit., pp. 326 a 359.

289 LuhmanN, N., «Die Funktion der Gewissensfreheit im oeffentlichen Recht», op. cit., pp. 9 a 22; ID., «Das Phänomen des Gewissens und die normative Selbstbestimmung der Persönlichkeit», op. cit., pp. 223 a 243.
} 
conciencia muestra una actitud defensiva sin negar la vigencia de la norma para los demás, y de aquí viene que tenga un «conflicto» entre su conciencia y la norma, de tal modo que en verdad «sí» que existe orientación del Sistema normativo, en este caso, la previa orientación normativa que ha llevado al sujeto a formarse y ejercitar la libertad de conciencia; el autor por convicción muestra una actitud de «lucha» en mayor o menor medida contra la norma, y de «aprovechamiento» del Sistema, de aquí que se pueda concluir que el autor por convicción no sufre ningún «conflicto».

Lo anterior explica que el autor de conciencia suele adoptar una actitud pasiva ante la obligatoriedad de la norma, y que el autor por convicción adopta una actitud combativa y aprovechacionista, y por lo tanto, resuelva su elección de forma activa, sin embargo, ha de aclararse ya en este punto que la forma de comisión sólo revela un dato estadístico en ambos supuestos, puesto que la forma de comisión del delito puede alterarse, intercambiarse, según las circunstancias organizativas del delito, el ámbito de competencia, y el contenido de la norma. Sobre esto volveremos en el capítulo tercero.

\section{III.- Tratamiento penal del autor de conciencia}

A. Introducción: máxima responsabilidad de la autoría de conciencia y por convicción

Concretar la solución jurídico-penal del autor por convicción y de conciencia pasa por revisar las categorías dogmáticas. En verdad, cuando se trata la problemática del autor de conciencia y por convicción se está planteando toda la teoría jurídica del delito o toda la ciencia penal. En ambos casos, no hay limitaciones en el análisis de la problemática más que la amplia revisión dogmática de todas las instituciones jurídico-penales pero no en el delincuente común, sino en la especial categoría criminal del autor de conciencia y por convicción, e inclusive en el «enemigo», lo que exige una descomunal revisión científica impropia de una tesis, sin embargo, como ya hemos expuesto, la problemática sólo puede resolverse si confrontamos cada tipo de autoría.

Este descomunal trabajo se puede apreciar en aquellos estudios que han analizado minuciosamente la autoría de conciencia, obligados a revisar cada institución jurídico-penal, pues en la tradición científica se ha resuelto la problemática, podríamos decir, en cada una de las instituciones. Lo mismo sucede, si bien de manera más relajada, en los estudios de la autoría por convicción, o más propiamente en los estudios penales sobre el terrorismo. Y escasamente, por no decir en absoluto, en los trabajos sobre el «enemigo», lo que en nuestra opinión pone de manifiesto la conveniencia de confrontar cada tipo de autoría, más la del enemigo con la 
anteriores pues no podemos despreciar la idea de un enemigo-autor por convicción que por razones de déficit de socialización que recuerdan la obediencia ciega y debida, comete delitos altamente penados, por ejemplo algunos supuestos criminales en el Tercer Reich.

Dejando a un lado que las categorías tipológicas del autor de conciencia, por convicción, y el enemigo parten de la premisa básica de que tales conductas típicas son dolosas, el debate principal y más arduo de la doctrina se encuentra dividida entre aquellos que consideran que el autor por convicción y de conciencia realizan el tipo penal culpablemente, sin posibilidad de atenuante o exculpación, y en algunos casos se plantea exclusivamente una pena menor o mayor en virtud de los motivos y/o exigencia de la conducta en el caso concreto, o sea, una mera cuestión de determinación de la pena ${ }^{290}$, y aquellos otros que consideran que la diferencia entre uno y otro parte de que el autor de conciencia comete un error de prohibición, o la conducta ordenada le era inexigible.

Así pues, en la doctrina española tradicionalmente mayoritaria considera que el autor por convicción y de conciencia actúan culpablemente ${ }^{291}$, es decir, no se les puede excluir la culpabilidad jurídica, aunque muchos defienden criterios de exención o atenuación.

Por otro lado, se ha indicado ${ }^{292}$ que el autor por convicción, refiriéndose a los Testigos de Jehová y a los insumisos, no tiene culpabilidad moral, pero sí jurídica. El autor de conciencia

290 Muñoz Conde, F., El error en Derecho Penal, Tirant lo Blanch, Valencia, 1989, p. 90, cita núm. 127.

291 Cerezo MIR, J., Curso de Derecho penal español. Parte general, III/2, op. cit., p. 35 y nota núm. 91, si bien también admite la atenuante analógica o muy cualificada de arrebato u obcecación, ID., ibidem, op. cit., p. 37; CERezo Mir, J., Derecho penal, Parte general, Lecciones, (26-40), op. cit., pp. 31 a 33; CoBo DEL RoSAL M / VIVES ANTÓN TS., PG, op. cit., pp. 557 a 559; CóRDOBA RODA se muestra en la misma línea que la mayoritaria doctrina penal española, pero creemos que comete un error al fundamentar la culpabilidad jurídica al decir que «el motivo será moral en cuanto merezca la consideración de valioso desde el punto de vista de la ética social vigente en el momento del hecho», CóRdobA RodA, Juan, Culpabilidad y pena, Bosch, 1997, p. 31; GRACIA MARTíN, L., Fundamentos de dogmática penal, op. cit., pp. 135 y ss; MIR PUIG, S., PG, op. cit., pp. 546 y 547; QUINTERO Olivares, Gonzalo, Parte General del Derecho penal, colaboración de Fermín Morales Prats, $1^{\mathrm{a}}$ ed., Aranzadi, 2005, pp. 433 y 542; RODríGUEZ DEVESA JM ${ }^{\text {a }}$ SERRANo GóMEZ A., PG, op. cit., pp. 440 y 441; SAINZ CANTERO, José Antonio., Lecciones de Derecho penal, Parte general, Culpabilidad, punibilidad, formas de aparición, III, $2^{\mathrm{a}}$ ed., Bosch, Barcelona, p. 18, En concreto, en la misma línea que los precedentes penalistas, SAINZ CANTERO considera que la culpabilidad jurídica se aprecia inevitablemente en los autores de conciencia, al estimar que éstos actúan dolosamente. Esta conclusión viene motivada en la doctrina causalísta que defendía que el dolo se integraba en la culpabilidad, el dolo está integrado por el conocimiento de los hechos constitutivos del tipo, tanto normativos como descriptivos, por la voluntad de realización de los hechos típicos y el conocimiento actual y real de la antijuricidad; es por ello entendible que para el citado penalista el autor por convicción o de conciencia actúan culpablemente. Pero posteriormente SAINZ CANTERO argumenta que «(l)a pena justa debe estar fundamentada en la culpabilidad del sujeto y ajustarse a ella en su medida. Esto no es obstáculo para aceptar que para la imposición de la pena no debe bastar al ordenamiento jurídico con que el sujeto sea culpable; la pena además debe ser necesaria para la prevención general y la especial. En atención a esa necesidad, la pena a imponer puede ser inferior a la que resultaría de la medida de la culpabilidad, e incluso puede dejarse de imponer», por lo que de alguna manera aceptaba algún tipo de atenuación de la pena según los casos y en determinadas circunstancias de la autoría de conciencia o por convicción, cuando las motivaciones con la que se realizaba el hecho delictivo, pueden dar lugar a la inexigibilidad de la conducta adecuada a la norma; TORÍO LÓPEZ, Ángel, «Indicaciones metódicas sobre el concepto material de culpabilidad», $C P C$, núm. 36, 1988, p. 761.

${ }_{292}$ MuÑoz CONDE, F., Teoría general del delito, $3^{\mathrm{a}}$ ed., Tirant lo Blanch, Valencia, 2004, pp. 177 y 178. 
afecta a los bienes jurídicos esenciales de la víctima como la vida, la integridad física, aun con la participación de la víctima, no invalidaría la culpabilidad jurídica del autor de conciencia. Si bien se puede estar de acuerdo con este tipo de argumentos, creemos que falta precisar que en verdad, la libertad de conciencia, según lo expuesto, no puede depender de la moral/conciencia de la mayoría, bajo pena de incurrir en contraorientación normativa.

COBO DEL ROSAL y VIVES ANTÓN consideran que la democracia como creadora final de las normas jurídicas debe ser protegida respecto de los ataques procedentes de individuos que difieren moralmente de la construcción jurídica ${ }^{293}$. Se interpreta de sus palabras que definen el problema de los autores por convicción y de conciencia como una problemática estricta de la culpabilidad, pero que en función del principio de culpabilidad la pena se gradúa en mayor o menor medida sin que exista un fundamento jurídico de atenuación, actúan con conocimiento actual de la antijuricidad y el comportamiento jurídico les es exigible ${ }^{294}$.

En la misma línea, TORío LÓPEZ, en uno de sus estudios sobre el concepto material de culpabilidad, considera que el autor por convicción y de conciencia tienen conciencia potencial o real de la antijuricidad, por lo que aunque realicen el hecho «cediendo a instancias o imperativos de conciencia», es suficiente la culpabilidad jurídica para penar. La culpabilidad moral es innecesaria para la atribución de la responsabilidad penal, porque de lo contrario, si así fuere, el campo de la institución de la inexigibilidad sería demasiado amplio, es decir, según él mismo comenta «se proporcionaría la base para un excesivo número de absoluciones» ${ }^{295}$.

293 Bajo este postulado afirman que «(e)n un sistema democrático el individuo participa en el proceso de elaboración de las normas. Pero, inevitablemente, ha de obedecer los mandatos de la legislación, adoptada por la mayoría, aun cuando sean contrarios a su particular modo de sentir. La infracción del deber jurídico dimanante de dichos mandatos puede ser moralmente irreprochable, e incluso valiosa, sin embargo, es suficiente para afirmar la culpabilidad jurídica. Mantener lo contrario supondría una lamentable confusión entre Derecho y Moral, con todos los peligros que ellos comportan», COBo Del RoSAL M / ViVES ANTón TS., PG, op. cit., pp. 539 y ss. Con dicho argumento concluyen que «(e)n tales circunstancias no cabe dejar de imponer la pena por el hecho de que el sujeto no pueda, en conciencia- dado que no comparte los valores del Estado democrático-, determinarse de acuerdo con las normas», ID., ibidem, op. cit., p. 538. Y finalmente comentan que «(t)oda concepción de la culpabilidad que la configure como juicio sobre la persona traspasa los límites propios del Derecho penal para invadir los de la Moral», ID., ibidem, op. cit., p. 537.

294 COBO Del Rosal M / Vives Antón TS., PG, op. cit., p. 688 cita núm. 7: «(1)a concepción de la no exigibilidad desde perspectivas eticistas, cual las que adopta Freundenthal, coindice a una confusión entre la culpabilidad jurídica y la culpabilidad moral. Ciertamente, negando relevancia, a la hora de determinar la exigibilidad o inexigibilidad del comportamiento adecuado a la norma, a factores extra-jurídicos, puede, en el seno de sociedades donde la regla es la desigualdad material de sus miembros, incurrirse en el defecto ético de aplicar por igual la pena a hombres de los que se exige una capacidad de resistencia desmesurada y a hombres a los que el comportamiento del deber jurídico les resulta, a la vez, demasiado fácil (...) Un tal defecto ético pondría de manifiesto la injusticia del sistema jurídico, pero tal injusticia de base no puede subsanarse en la fase aplicativa, sino que, en la medida en que existe (y en todos los sistemas existe en alguna medida), constituye una llamada a la reforma».

295 En concreto afirma que «(l)a conciencia, potencial o real, de la antijuricidad es así elemento central, nuclear, de la culpabilidad», que «culpabilidad penal es culpabilidad jurídica, no culpabilidad moral. Paralelamente, no deja de existir culpabilidad porque el autor realice el hecho cediendo a instancias o imperativos de conciencia (autor por 
Asimismo Rodríguez Devesa y Gómez SERRANo también defendieron la total culpabilidad de la autoría de conciencia y por convicción. Consideraban que la culpabilidad radica en la normatividad, es decir, en «módulos jurídicos», más aún cuando un sujeto realiza una acción típica y antijurídica sin causas de exclusión de la culpabilidad ${ }^{296}$. En todo caso parece que defienden que los motivos morales sólo podrían destinarse para la medición de la pena y no como rebaja significativa o exención de la responsabilidad ${ }^{297}$.

GRACIA MARTín alude al autor por convicción y al autor de conciencia como aquel que «se forma un sistema ético-individual contrario al orden ético-social lo hace de modo autónomo y responsable» ${ }^{298}$. La premisa para comprender la culpabilidad del autor por convicción, para este penalista, es entender que el Derecho penal tiene por contenido «valores ético-sociales de acción», son obligaciones que se definen como «valores de resultado» necesarios en el contrato social $^{299}$, incluso cuando el Derecho es injusto, es obligatorio mientras conserve su vigencia puesto que el sujeto tiene la posibilidad de derogarla a través del proceso de inconstitucionalidad de la norma ${ }^{300}$, de manera que el autor por convicción no plantea una problemática distinta a los casos de error sobre la validez de la norma, sino que no le otorga fuerza vinculante a la norma ético-social «y la infringe porque eleva a motivo de su acción su propia norma ética individual» ${ }^{301}$. En concreto, diferencia entre el autor por convicción, aquel como el terrorista, y el autor que actúa bajo motivos de conciencia, como el Testigo de Jehová que se opone a la trasfusión de sangre de su hijo, es decir, que se opone a la norma en «contextos selectivos», no como imperativo categórico, por eso los casos de autoría de conciencia son de colisión de

conciencia, delincuente por convicción), dado que para la existencia de la culpabilidad es suficiente la conciencia de antijuricidad». Y sigue diciendo en cuanto a la culpabilidad material que «(e)n tercer lugar, requiere la culpabilidad que en la situación concreta pudiera exigirse del sujeto, según una apreciación valorativa, un comportamiento diverso del realizado. Esta inexigibilidad de una conducta diversa, falta la culpabilidad (...) Pero desde este plano valorativo, se ha producido un deslizamiento al utilitario, al afirmarse que de admitir dicho criterio se originaría un reblandecimiento de la prohibición jurídica, o parafraseando una afirmación referente a un campo correlativo, se proporcionaría la base para un excesivo número de absoluciones», TORíO LÓPEZ, Ángel, «Indicaciones metódicas sobre el concepto material de culpabilidad», op. cit., pp. 760 y 761 ,

296 Concluyen que «(p)or ello, no es obstáculo, para que sea considerado culpable el sujeto, la ceguera para los valores jurídicos, la hostilidad al derecho, ni que el acto responda a profundas convicciones sobre lo justo y lo injusto, divergentes de las valoraciones del ordenamiento jurídico. Todos estos factores son seguramente de gran peso en la determinación de la culpabilidad desde el punto de vista religioso o ético, no desde el punto de vista jurídico. La tienen para la crítica del derecho positivo y una adecuada política criminal, así como en la medida de la pena», RODRÍGUEZ DEVESA JMa / SERRANO GóMEZ A., PG, op. cit., pp. 440 y 441.

${ }_{297}$ Porque «(t)odas las teorías quiebran -en clara alusión a las teorías que atenúan o incluso eximen de pena con base exclusivamente moralista- cuando se enfrentan con el derecho positivo», ID., ibidem, op. cit, p. 440, cita núm. 62.

298 Gracia Martín, L., Fundamentos de Dogmática penal, op. cit., p. 136.

299 ID., ibidem, op. cit., p. 141.

300 ID., ibidem, op. cit., pp. 143 y 144.

301 ID., ibidem, op. cit., p. 144. Previamente también hablaron de culpabilidad «ético-social», WELZEL, Hans, Derecho penal alemán, op. cit., pp. 211 y ss; MAURACH, Reinhart, Tratado de Derecho penal, II, trad. Juan Córdoba Roda, pról. Octavio Pérez Vitoria Moreno, Ariel, Barcelona, 1962, pp. 79 y 80. 
deberes éticos individuales ${ }^{302}$ en los que el sujeto pretende volver al estado de naturaleza imponiendo la fuerza de sus sistema de acción ${ }^{303}$. De esta forma de imponer el autor su propio sistema ético individual, GRACIA MARTíN extrae su capacidad y por ende su culpabilidad, lo que le distingue de los inimputables ${ }^{304}$. El autor de conciencia vulnera su compromiso ético individual con el orden jurídico de la comunidad, vulnera su compromiso de renuncia a sus particulares deberes de conciencia ${ }^{305}$.

Sin embargo, cuando el citado autor contrapone al autor de conciencia con el autor por convicción, reconoce que éste último no se siente desvinculado internamente de la obligación de la norma ético-social de no matar, sino que sólo en contextos selectivos y discriminatorios se desvincula, pero de forma general la tiene por obligatoria ${ }^{306}$. Expuesta así la problemática, parece que GRACIA MARTín llega a confundir ambas categorías sobre las que previamente ha querido distinguir. Si bien el argumento es intachable en cuanto que tampoco el terrorista considera la acción de «matar» como una norma universal vinculante, aclara que el autor por convicción a pesar de no sentir en ese concreto contexto selectivo la norma ético-social, se aprovecha de ella, la utiliza en su propio beneficio (por ejemplo el defraudador de tributos por convicción, sigue utilizando los resultados en los que se invierten los tributos de los demás), lo cual significa un reconocimiento al sistema normativo, de modo que su culpabilidad es «máxima» ${ }^{307}$. Tanto es así que en caso de que el sujeto crea que la norma es injusta, el sistema le plantea vías de revisión que no ha utilizado ${ }^{308}$. Así la infracción normativa siempre tiene como base la infracción de una norma jurídica de base ético-social reconducible a la vez a la infracción de una norma ético-individual, «de un deber interno vinculante en virtud del compromiso ético del sujeto con un determinado orden objetivo» ${ }^{309}$, de manera que -para GRACIA MARTíN- la culpabilidad jurídica se equipara a la culpabilidad moral ${ }^{310}$, y de esta forma resuelve magistralmente la tradicional desvinculación doctrinal entre culpabilidad jurídica y moral.

Respecto del pensamiento de GRACIA MARTín, podemos estar de acuerdo exclusivamente en las razones expuestas y tratamiento del autor por convicción. Es verdad que este autor no pretende imponer su conducta en todo espacio tiempo, ni como imperativo categórico, sin

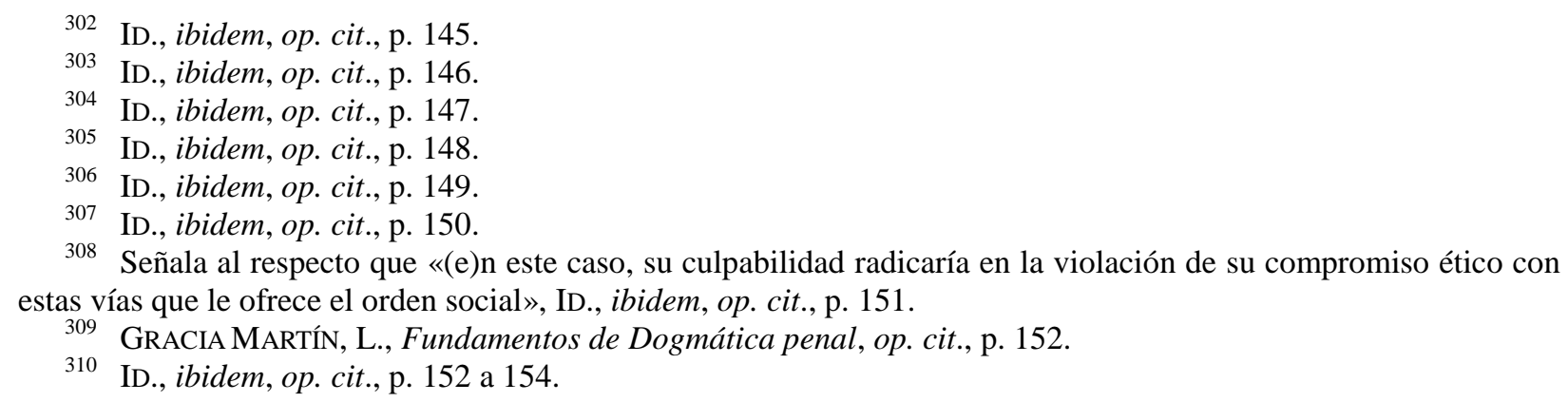

310 ID., ibidem, op. cit., p. 152 a 154. 
embargo, esta afirmación no se comprende diferencialmente en el autor de conciencia, únicamente explica el citado penalista que en un contexto selectivo desautoriza la norma, lo cual también sucede en el autor por convicción, inclusive ambos renuncian al compromiso ético previamente acordado con el sistema normativo, lo cual supone una contradicción manifiesta. Si bien el citado autor fundamenta excelentemente desde su concepción finalista la máxima responsabilidad de ambos autores, no se entiende qué diferencia conceptual y normativa existiría entre el terrorista como autor por convicción y el Testigo de Jehová como autor de conciencia. Si bien, cabe destacar que el citado penalista otorga cierta relevancia a la norma ética-individual para la determinación del grado de socialización o integración ético-social del individuo en el sentido expuesto por TORío sobre «las posibilidades y capacidades del autor concreto tomado en cuenta su formación, profesión, educación, posibilidades económicas, situación familiar, para enjuiciar en tal sentido concreto la conexión personal real existente entre él y el hecho tipificado como delito», tomando en cuenta «las relaciones sociales del autor», de modo que gradúe la necesidad de la pena en función de esa prevención especial ${ }^{311}$, de manera que «(s)i la sociedad no ha proporcionado al individuo los instrumentos que precisa como condición de la posibilidad de cumplimiento de las obligaciones que tienen su fuente en el contrato social, entonces no podrá exigirle una plena responsabilidad por su incumplimiento y esto deberá reflejarse en la medida de la pena que pueda serle impuesta, la cual, según los casos, podrá quedar incluso excluida» ${ }^{312}$. Entonces, parece claro que GRACIA MARTín reconoce supuestos excepcionales con base a la exigibilidad cuya trascendencia repercute en la culpabilidad y finalmente en la pena, si bien, ni él ni la doctrina que aboga por la máxima culpabilidad entran en la casuística excepcional, de modo que sigue sin resolverse cuáles son «las relaciones sociales del autor» que pueden excluir la culpabilidad y la pena.

Este tipo de argumentos se repiten en la mayoría de la doctrina española y alemana que abogan por la culpabilidad de los autores de conciencia y por convicción, si bien, y según lo expuesto, el mismo reproche moralista que hace al autor de conciencia y por convicción que se defiende alegando sus motivaciones morales o ideológicas, puede realizarse a esta parte de la doctrina.

De otra parte, veremos infra que la doctrina minoritaria española considera que pueden existir casos en los que se excluya la tipicidad o la antijuricidad como causa de justificación ya sea

\footnotetext{
311 Vid. ID., ibidem, op. cit., p. 152 a 154 (TORÍ́ LÓPEZ, A., «El concepto individual de culpabilidad», $A D C P C$, 1985, pp. 299 y 300).

312 ID., ibidem, op. cit., p. 198.
} 
porque exista una causa de atenuación por eximentes completas o incompletas, o una causa de exculpación por miedo insuperable o estado de necesidad exculpante.

La doctrina alemana también se ha decantado tradicional y mayoritariamente a favor de la culpabilidad jurídica de los autores de conciencia y por convicción, si bien, como veremos, existe un amplio sector que también tradicionalmente ha encontrado argumentos dogmáticos a favor de algún tipo de exención de la responsabilidad penal.

Aquí ya podemos sacar ya una primera aproximación a la problemática del autor por convicción y de conciencia: aun en los casos de presupuesta culpabilidad, incluso máxima, en ciertos casos habrá que examinar aquellos elementos ambientales, sociales, culturales, educativos, o de otra índole que hayan podido modificar en cierta manera la capacidad de obrar conforme a la norma, de manera que algunos «déficits» externos a la propia capacidad inherente de entender y obrar del sujeto, pueden modular su culpabilidad. Sobre esto volveremos al tratar los «déficits de socialización».

Merece destacar también entre la doctrina penal alemana que defiende la culpabilidad de esta tipología criminal bajo mandatos de conciencia a WESSELS ${ }^{313}$, SCHMIDHÄUSER $^{314}, \mathrm{ZIPF}^{315}$, Bockelmann, Heinitz y MAURACH. En particular, BoCKELMANn se muestra totalmente firme en no aceptar ningún tipo de atenuación bajo el argumento que si se aceptase que el peso de las convicciones puede atenuar la culpabilidad y la pena, deberíamos ser más indulgentes con los líderes revolucionarios ${ }^{316}$. En el mismo sentido también se muestra HEINITZ cuando añade que una atenuación sería «un signo del debilitamiento de nuestro Derecho y de nuestra democracia» ${ }^{317}$. Sin embargo otros autores, aunque defendiendo la culpabilidad, admiten alguna posibilidad de atenuar la culpabilidad y la pena. De tal suerte MAURACH consideraba que la conducta basada en la conciencia y que incurre en algún tipo penal, puede tener algún problema en la interpretación de los elementos del tipo, o de requisitos de las causa de justificación o de la exigibilidad de la conducta, si bien reconoce que su culpabilidad jurídico-penal proviene de la

\footnotetext{
313 Wessels, Johannes, Derecho penal, Parte general, trad. Conrado A. Finzi, de la $6^{\text {a }}$ ed. alemana de 1976, Depalma, Buenos Aires, 1980, pp. 111 y 112.

314 SCHMIDHÄUSER, Eberhard, Strafrecht Teil, Lehrbuch, 2, neubearbeitete Auflage, J.C.B. Mohr, Paul Siebeck, Tubinga, 1975, pp. 425 y ss.

${ }_{315}$ ZIPF, Heinz, Introducción a la política criminal, Edersa, 1979, pp. 50 y 51.

316 BOCKELMANN, Paul, «Zur problematik der Sonderbehandlung von überzeugungsverbrecher», Festschrift für Welzel, Berlin, 1974, p. 551, especialmente dice que en el caso de admitirse la atenuación «deberían admitirse como resoluciones fundadas en principios morales también las opciones más miserables, en la medida en que sean sentidas personalmente como obligatorias de modo absoluto», ID., ibidem, op. cit., p. 552.

317 HeINITZ, Ernst, «Der überzeugung-stäter im Strafrecht», ZStW, 1966, núm. 78, pp. 622 y 637.
} 
culpabilidad «ético-social», lo que fundamenta en algunos casos una «custodia honesta» en contra de una «pena deshonrosa» 318 .

Con la Sentencia del Tribunal Federal alemán de 19 de octubre del año 1971, que excluyó de responsabilidad penal a un Testigo de Jehová por no apreciar el delito de omisión del deber de socorro, el Tribunal argumentó para excluir la imputación objetiva que al acusado sólo se le permitía revisar argumentos jurídico-constitucionales, y no los elementos del tipo, en este caso, el deber concreto en la situación concreta de peligro. Tras esta Sentencia, vino una numerosísima doctrina sobre la problemática del autor de conciencia que revisó con mayor esmero la problemática.

\section{B. La objeción de conciencia en la tipicidad}

Parte de la doctrina minoritaria que defiende algún tipo de privilegio, atenuación o exención de la responsabilidad, ha encontrado, si bien también es minoritaria esta doctrina, causas de atipicidad en los casos prototípicos del autor de conciencia. En esta orientación se encuadra BAUCELLS, quien delimita el concepto de autor por convicción y de conciencia con base a la distinción del imperativo categórico, si bien incluye en el término conciencia en el de convicción $^{319}$. Unas conductas representan un «deber moral» ${ }^{320}$ universal amparado en el art. 30.2 CE como objeción de conciencia, mientras que otras son simples convicciones que no alcanzan dicho valor pero que igualmente pueden merecer un tratamiento privilegiado amparado en el art. $16 \mathrm{CE}$ mediante la libertad de convicciones ${ }^{321}$, de lo cual extrae repercusiones privilegiantes, o no, según si la conducta incumple deberes individuales, colectivos o cuyo incumplimiento afecte a un bien jurídico ${ }^{322}$, si bien considera que el conflicto siempre es de intereses $^{323}$. El incumplimiento de los deberes individuales puede aceptar ciertas formas de atipicidad, mientras que los restantes a ciertas categorías del delito y a la determinación de la pena $^{324}$.

Sin embargo, no podemos estar de acuerdo con Baucells cuando fundamenta que la atipicidad de incumplimientos individuales procede del mero incumplimiento de un deber genérico, como por ejemplo en la omisión del deber de socorro, distinto al deber específico del cumplimento en

318 MAURACH, R., Tratado, II, op. cit., pp. 79 y 80, y p. 159.

319 BAUCELls I Lladós, J., La delincuencia por convicción, op. cit., pp. 161 y 162. Antes TAMARIT Sumalla, $\mathrm{JM}^{\mathrm{a}}$., La libertad ideológica, op. cit., p. 415.

320 BAUCELls I LLADÓs, J., La delincuencia por convicción, op. cit., pp. 134 a 142, y p. 412.

${ }^{321}$ ID., ibidem, op. cit., p. 139, pp. 412 y 413.

322 ID., ibidem, op. cit., pp. 211 y ss.

323 ID., ibidem, op. cit., p. 213

324 ID., ibidem, op. cit., pp. 412 y 413. 
su día del servicio militar, pues si bien estamos de acuerdo en la atipicidad en muchos de los casos cuando aun a pesar del peligro y del desamparo el sujeto en tal estado no permite ni autoriza al tercero omitente, dicha fundamentación no se sustenta tanto en el incumplimiento de un deber específico, sino en que efectivamente no hay deber alguno de actuar, por lo que no entra en conflicto la conciencia con la norma. La norma no exige nada y entonces no puede surgir ni conflicto ni imputación objetiva.

En opinión de BAUCELLS ${ }^{325}$, los incumplimientos de deberes en relación a derechos individuales «sin tipificación penal expresa», son casos de atipicidad, por ejemplo «la omisión del deber de socorro de la madre, cuya vida corre grave peligro, por parte del médico en un supuesto de aborto terapéutico libremente decidido por ella y del médico o pariente que, ante esa misma libre decisión del paciente, se niega a consentir una trasfusión de sangre para salvar su vida». Considera que son supuestos en donde el sujeto incumple un deber (delitos de infracción de deber, o de omisión del deber de socorro de los arts. 195 y 196 CP) pero a la vez, la víctima, ejercita un derecho que otorga la Ley General de Sanidad en la autopuesta en peligro libremente asumida por ésta que se basa en la consideración del respeto a la dignidad, y por ende el comportamiento es atípico ${ }^{326}$.

Sin embargo, consideramos que la opinión del autor en referencia no es adecuada, al menos en su tratamiento sistemático, por cuanto si tal como él mismo afirma «la decisión del paciente fuera tomada por conciencia como por simple convicción tendría la misma relevancia, en la medida en que ambas serían decisiones tomadas libre y responsablemente», entonces, no cabe hablar ni de conflicto de conciencia ni de objeción de conciencia, el ordenamiento jurídico ni pregunta ni le interesan los motivos para apreciar la atipicidad ${ }^{327}$, es más la «víctima» o el paciente no tiene que exponer los motivos del rechazo.

En un sentido similar, SILVA SÁNCHEZ acepta la inexigibilidad de otra conducta en la autoría de conciencia. Afirma que no se le puede obligar al padre perder sus valores espirituales, es más, no se encuentra en posición de garante, por lo que la inexigibilidad no es una causa de justificación ni de exculpación sino que supone ya, desde el principio, la atipicidad ${ }^{328}$. Por eso, no es de extrañar, que admita cierta relevancia del principio de inexigibilidad en la delimitación de las clases de posición de garante y su alcance ${ }^{329}$.

ID., ibidem, op. cit., p. 225 y ss.

326 BAUCELlS I LLADÓs, J., La delincuencia por convicción, op. cit., p. 233.

327 En el mismo sentido, FLORES MENDOZA, F., Objeción de conciencia, op. cit., pp. 82 y ss.

328 SILVA SÁNCHEZ, Jesús-María, «La responsabilidad penal del médico por omisión», La Ley, 1987, T. I, pp. 955 y ss.

${ }_{329}$ Silva SÁNCheZ, J-Mª ., El delito de omisión. Concepto y sistemas, Bosch, Barcelona, 1986, p. 307 y ss. 
En la década de los sesenta, en Alemania, PETERs ya expuso que estos comportamientos atípicos por ser adecuados socialmente, entendiendo que el autor de conciencia incurre en un tipo omisivo por lo que debe primar la exención de pena, su conducta es adecuada socialmente al no sobrepasar los límites del derecho la libertad de conciencia del art. 4 de la Ley Fundamental (objetores de conciencia al servicio militar e insumisos). Concluyó que la conducta no se subsume en ningún tipo penal ${ }^{330}$.

Por otro lado, RoxiN ${ }^{331}$ expone que si el sujeto realiza una conducta que alternativamente permite la norma, la conducta es atípica en aquellos supuestos de omisión, matizando que distingue los supuestos de deber sin quitar legitimidad al Estado y sus principios rectores, considera que se apreciaría una situación de conflicto en aquellas ocasiones en las que el ejercicio de la libertad de conciencia se amparaba en la Ley Fundamental alemán (art. 4) por medio de una causa de exclusión de la pena, más que la atipicidad de la conducta. Si se exige algún tipo de deber, la conducta siempre tendrá que ser típica. En estos casos sólo podría plantearse la exclusión de la pena salvo en casos que afecten a bienes jurídicos privados ante la vida. En casos de padres que dejan morir a su hijo o el del médico que deja morir a la embarazada por oposición de conciencia al aborto no cabría excluir la pena, pero sí en aquellos casos contra derechos privados y en terminadas circunstancias ${ }^{332}$. El art. 4 de la Ley Fundamental rompe con la teoría de la responsabilidad penal porque fundamenta la imposición de las penas en criterios de prevención, por lo que aun perpetrándose el delito, es posible que no merezca imponerse una pena por ser soportable tal conducta desde este prisma preventivo ${ }^{333} 334$.

Estamos parcialmente de acuerdo con Roxin en la conclusión final de que en determinadas circunstancias como la de los padres que dejan morir a su hijo o el del médico que deja morir a la embarazada por oposición de conciencia al aborto, no cabría excluir la pena pero pueden existir motivos tan ineludibles, que sin causa de una enfermedad mental lleven al sujeto al obrar contra

330 Vid. PÉrez Del VAlle, C., Conciencia, op. cit., p. 109; vid. también Flores MendozA, F., Objeción de conciencia, op. cit., p. 105; vid. BAUCELls I LLADÓs, J., La delincuencia por convicción, op. cit., pp. 68 a 72 ; vid. también en JERICÓ OJER, L., El conflicto de conciencia, op. cit., pp. 294 y ss. (PETERS, K., «Überzeugungstäter und Gewissenstäter», op. cit., p. 276).

331 Vid. JERICÓ OJER, L., El conflicto de conciencia, op. cit., pp. 295 y 296 (RoXIN, C., «Die Gewissenstat als Strafbefreiungsgrund», Rechtstaat und Menschenwürde-Festschrift für Werner Maihofer, Vittorio Klostermann, Frankfurt am Main, 1988, pp. 404 y ss).

332 Vid. PÉREZ Del VAlle, C., Conciencia, op. cit., p. 250 y 251 (RoXIN, C., «Die Gewissenstat als Strafbefreiungsgrund», op. cit., pp. 400 y 401).

333 Vid. ID., ibidem, op. cit., p. 250 y 251 (RoxIN, C., «Die Gewissenstat als Strafbefreiungsgrund», op. cit., pp. 410 y 411

334 En relación al insumiso, Roxin, C., “"Culpabilidad” y "Responsabilidad” como categorías sistemáticas jurídico-penales», RoxIN, C., Culpabilidad y prevención en Derecho penal, trad. intr. y notas Francisco Muñoz Conde, Reus, Madrid, 1981, pp. 57 y ss; HASSEMER W / MuÑoz CONDE F., Política criminal y sistema del Derecho penal, trad. Francisco Muñoz Conde, Barcelona, 1972, p. 67. 
la norma. Esta razón es en nuestra opinión una cuestión a debatir en la culpabilidad y más concretamente en la inexigibilidad. En estos casos el sujeto tiene un déficit de socialización, en otros casos, la norma que comunica que tiene libertad de conciencia ha permitido -comunicadoel ejercicio habitual de sus creencias, sin embargo otra norma (el deber de actuar o de socorro) irrumpe sorpresivamente en la cotidianidad del sujeto mediando circunstancias imprevistas cuando el sujeto está socializado conforme a un actuar inevitable. Si bien en aquellos casos que la norma, concretamente la norma de deber, permita un comportamiento alternativo, estamos de acuerdo en que el comportamiento será atípico, en estos casos se obvia la intranscendencia del motivo de conciencia en el tratamiento penal de estos últimos casos, y centra el debate en la naturaleza del bien jurídico en peligro (vida, integridad, libertad) y la disponibilidad del bien o renunciabilidad del derecho. El consentimiento de la víctima puede jugar un papel en la tipicidad, en la antijuricidad y en la culpabilidad, pero en estos casos el motivo es indiferente para el tratamiento penal cuando existe consentimiento o autopuesta en peligro de la víctima/paciente.

JERICó se ha mostrado crítica en el tratamiento del conflicto de conciencia como causa de atipicidad. Si bien sostiene que «con independencia de la mayor frecuencia de comportamientos de abstención, la afección del bien jurídico puede llevarse a cabo de igual modo tanto por una conducta activa como por una abstención no debida. De ahí que, en caso de que la adecuación social tenga algún sentido en los conflictos de conciencia, pueda predicarse tanto de conductas activas como omisivas (...) pero mantienen la ilicitud en el ordenamiento jurídico general» ${ }^{335}$, con lo que se muestran parcialmente conforme con los postulados propuestos por RoXIN en cuanto a que una conducta alternativa neutral permitida sería una causa de atipicidad, no así cuando el sujeto no realiza ni la conducta alternativa, en cuyo caso, tendría trascendencia en la culpabilidad $^{336}$. A pesar de rechazar correctamente el fundamento de la adecuación social, JERICó apela a otro argumento como posible factor de atipicidad: el principio de tolerancia ${ }^{337}$. Este razonamiento no hace más que cambiar un concepto volátil y moldeable por otro igualmente discutible.

La principal aportación de Roxin a la problemática del autor de conciencia estriba en que, al igual que en otras problemáticas, la realización de una conducta alternativa expresamente designada por la norma, o en su caso, neutral pero que alternativamente se corresponde con el mandato de deber de la norma, resuelve con brillantez algunos casos a los que habitualmente se

335 JERICÓ OJER, L., El conflicto de conciencia, op. cit., p. 299.

336 ID., ibidem, op. cit., p. 301.

337 ID., ibidem, op. cit., p. 300. 
ha reconducido la autoría de conciencia, por ejemplo la omisión del deber de socorro de los Testigos de Jehová, si bien el fundamento no proviene exclusivamente del ejercicio de la libertad religiosa o de conciencia, puesto que la norma no exige cuando se rechaza un tratamiento alegar los motivos, y en el mismo sentido, tampoco cuando el padre omite el deber de socorro, si bien, se criminaliza sin más, pero en caso de que el autor adopte una conducta alternativa, sirva el ejemplo del padre que lleva a su hijo al hospital, la falta de consentimiento del tratamiento de trasfusión de sangre, en nuestra opinión, no es un presupuesto objetivo de la omisión del deber de socorro, pues previamente el padre ya ha hecho todo lo necesario para que otros garantes, en este caso, los facultativos, entren la competencia de salvamento, ajena ya a la actuación del padre puesto que si existe peligro para la vida del menor, el deber de actuación de los médicos es ajeno al consentimiento de los padres. Sirva también de ejemplo, el amigo que lleva a un menor sin familia, en este caso, no se dudaría que los directamente obligados a socorrer son los facultativos que entrar en el campo de la posibilidad de salvamento, nadie en caso de urgencia defendería que al faltar el consentimiento paterno no existe el deber de actuar de los facultativos, por lo que el motivo por el que omite el consentimiento el padre es ajeno a la imputación objetiva cuando ya ha realizado una conducta que asegura el deber de salvación por otros. Los Testigos de Jehová, hábilmente, no rechazan el tratamiento para su hijo taxativamente por norma general, de manera que se imponga una decisión de conciencia, sino que por regla general «omiten» el consentimiento activo de tratamiento. No obstante, pensamos que el rechazo expreso del tratamiento también es impune por atipicidad, y con ajenidad del motivo, cuando se desarrolla una conducta suficiente de salvamento. Al igual que sucede en el simple ciudadano que acciona una conducta de salvamento en un accidentado, no se le exige una total responsabilidad sobre el resultado, o sea, que su deber termina cuando llama a las asistencias. En el caso de los padres, si bien existe una vinculación institucional mayor, la paterno-filial, ésta no puede exigirse desproporcionadamente con un consentimiento expreso a una situación de urgencia que los facultativos en caso de inconsciencia del menor o inclusive conciencia tienen el deber de actuar cuando existe peligro para la vida, como si el consentimiento modificase normativamente y materialmente la situación.

No obstante y como expondremos infra, existe un argumento dogmáticamente mejor: la falta de consentimiento como omisión del deber de socorro por motivos de conciencia obligatorios, está amparada por una causa de estado de necesidad exculpante en determinados casos especiales. 


\section{La objeción de conciencia en la antijuricidad}

\section{Introducción}

Otra parte de la doctrina defiende que la exclusión de la antijuricidad en el autor de conciencia se fundamentada en algunas de las causas de justificación que se encuentran en el art. 20 del CP. En concreto, estudiaremos la causa de legítima defensa del art. 20.4º , la de estado de necesidad del $20.5^{\circ}$, la de obrar en cumplimiento de un deber o ejercicio legítimo de un derecho, oficio o cargo del art. $20.7^{\circ}$, y el consentimiento del titular del bien jurídico protegido en el art. 156 CP. No obstante conviene antes centrar la problemática sobre la trascendencia jurídico-penal de la exclusión de la antijuricidad.

Existen dos posiciones contrapuestas en cuanto a la relación del tipo y sus elementos con la ausencia de antijuricidad. Para la teoría tradicional, la ausencia de antijuricidad no conlleva la desaparición de la tipicidad ${ }^{338}$, pues la conducta sería típica aunque justificada, mientras que la «teoría de los elementos negativos del tipo» ${ }^{339}$ considera que la ausencia de antijuricidad o las causas de justificación eliminan la tipicidad. Nosotros nos posicionamos a favor de la primera teoría. En nuestra opinión el tipo únicamente describe los elementos positivos del hecho antijurídico, es decir, por sí solo el tipo es incapaz de determinar la antijuricidad total, falta comprobar la parte negativa que se completa con la ausencia de causas de justificación.

Lo cierto es que la doctrina no se pone de acuerdo sobre el fundamento de la justificación penal. De una parte se alegan varios fundamentos, de otra un único fundamento ${ }^{340}$.

La cuestión a debatir en el ámbito de nuestro estudio es si puede apreciarse un estado de necesidad justificante (art. 20.5 $\mathrm{CP}$ ) como colisión de bienes y entendido el concepto bien como un desvalor de resultado, o de males como afección en el desvalor de la acción ${ }^{341}$, o si por el contrario se trata del ejercicio legítimo de un derecho $\left(20.7^{\circ} \mathrm{CP}\right)$. Pues bien, en primer lugar analizaremos el consentimiento de la víctima como posible causa de atipicidad o de justificación con el objetivo de comprobar si aquí se resuelve parte de la problemática del autor de conciencia como defienden ROXIN y BAUCELLS, entre otros, y posteriormente analizaremos las causas justificación del art. 20 CP con la misma finalidad.

Polaino Navarrete, M., Lecciones de Derecho penal, Parte General, T. II, Tecnos, 2013, p. 145.

339 MIR PUIG, S., PG, op. cit., p. 418.

340 CARBONELl MATEU, Juan Carlos, La justificación penal. Fundamento, naturaleza y fuentes, Edersa, Madrid, 1982 , p. 22 a 24

${ }^{341}$ BAUCELLS I LLADÓs, J., La delincuencia por convicción, op. cit., p. 184. 


\section{Problemática del consentimiento como causa de atipicidad o de justificación en la}

conducta del autor de conciencia

En algunos casos, el consentimiento de la víctima puede excluir la responsabilidad penal, atenuarla o justificar una conducta en principio criminal más allá de si los motivos de la conducta son de conciencia.

En primer lugar, si concurre el consentimiento válido en los delitos contra la libertad, o en los delitos de detenciones ilegales, o en las coacciones, o en el allanamiento de morada, no se produce la lesión, pues el consentimiento expresa un «acuerdo», «asentimiento» o «conformidad (Einverständnis) -así lo denomina la doctrina alemana- para defender en estos supuestos la atipicidad en la que se ha llamado teoría unitaria del consentimiento $^{342}$. Claro está que, si el consentimiento está viciado, éste no tendrá el efecto de eliminar la lesión.

En segundo lugar, en los delitos contra la integridad física o en aquellos casos en los que el consentimiento es expresión del «libre desarrollo de la personalidad» que ampara el art. 10 de la CE, cuando no está justificado por un estado de necesidad o la legítima defensa, el consentimiento de la víctima no elimina la lesión producida, sino que puede atenuar la pena cuando el consentimiento no esté viciado o no provenga de menor o incapaz, pero en las operaciones quirúrgicas parece ser que el consentimiento excluye la antijuricidad, pues el consentimiento expresa «la libertad de desarrollo personal». Este segundo tipo de consentimiento constituye un verdadero consentimiento, aunque hay que decir que esta distinción terminológica de la doctrina alemana no es seguida por la doctrina española que utiliza en los dos casos el término «consentimiento».

Por nuestra parte nos decantamos por la terminología adoptada en la doctrina alemana. El «acuerdo» entre «víctima» $\mathrm{y}$ «autor» expresa de forma más precisa la falta de lesión en el bien privado y la tipicidad, mientras que el «consentimiento» se refiere una causa de justificación ${ }^{343}$. Piénsese que cuando un médico produce una lesión en un tratamiento quirúrgico obra bajo el consentimiento del lesionado, y esto excluye la antijuricidad en virtud de la eximente de ejercicio legítimo de un derecho.

En los delitos contra la vida humana, el consentimiento no acarrea una justificación. En nuestro Derecho el derecho a la vida es en principio «irrenunciable» e «indisponible», si bien defenderemos lo contrario infra. En algunos casos extremos, como en los de inducción al suicidio del art. 143.1 CP, los de cooperación al mismo del art. 143.2 CP, los de cooperación al

342 RoxIN, C., $P G$, I, op. cit., p. 516.

343 En el mismo sentido la doctrina dominante, en concreto CoBo Del Rosal M / Vives AnTón TS., PG, op. cit., p. 375; MIR PUIG, S., PG, op cit., p. 520. 
atenúa la pena respecto a las formas básicas de homicidio, con el consentimiento se expresa un interés privadísimo que de lege lata no puede eximir pero sí atenuar por razones humanitarias y/o de política criminal. Mientras que en los delitos de aborto, el consentimiento de la embarazada sirve para atenuar la pena. Los requisitos que se exigen para apreciar un consentimiento válido con efecto jurídico-penal son los siguientes:

En primer lugar, que exista «capacidad natural de discernir que le permita advertir el significado y consecuencias esenciales de su consentimiento» ${ }^{344}$, sin ser necesario la capacidad jurídico-civil. Bien es cierto que en algunos delitos se restringe el consentimiento válido, como en los delitos de abusos sexuales. En segundo lugar, hoy la doctrina dominante considera que basta con que sea reconocible la voluntad del sujeto por algún medio para apreciar el consentimiento. Se ha impuesto la teoría de la dirección intermedia de la voluntad sobre la teoría de la declaración que exigía la manifestación externa, pero también se ha impuesto sobre la teoría de la dirección que pedía únicamente la conformidad interna del sujeto. En realidad, la teoría de la dirección intermedia resuelve mejor los problemas prácticos en los que el consentimiento está en duda.

En nuestra opinión, la voluntad sigue siendo voluntad a pesar de que no existan medios actuales y materiales para reconocerla, como en los casos en los que el sujeto esté inconsciente pero existe una presunción con probabilidad ex ante, es decir, consentimiento presunto de que el afectado hubiera consentido. Algo parecido sucede en los casos prácticos de testamento vital, en la eutanasia, en los que la declaración escrita para realizar una eutanasia lícita o ilícita (art. 143.4 $\mathrm{CP}$ ) en nuestra opinión tiene validez. Bien es cierto que en los arts. 155 y $156 \mathrm{CP}$ y en las indicaciones legales para el aborto del art. 417 bis de CPd, se exige que éste se manifieste expresamente, por lo que en estos casos no podrá aceptarse la teoría de la dirección intermedia de la voluntad, pero nada impide que pueda aceptarse en los casos de eutanasia y en otros. De esta manera podemos concluir que el consentimiento válido es aquel que en el que además de concurrir los requisitos comentados, además no contiene vicios de la voluntad. Por ello, la coacción excluye el consentimiento, mientras que el error en el consentimiento cuando haya sido afectado de forma cualitativa y cuantitativamente suficientes será inválido. Bajo dicho argumento el consentimiento viciado, en principio, no podrá tener efectos jurídico-penales favorables. Aquí entra la problemática del error en los motivos del comportamiento conforme a la mora, cuestión sobre lo que volveremos infra.

344 MIR PUIG, S., PG, op. cit., p. 526. 
El efecto del consentimiento o de la petición servirá para apreciar en algunos casos una eximente incompleta de inexigibilidad de otra conducta, o atenuante analógica del art. $21.7^{\mathrm{a}} \mathrm{CP}$ bajo el fundamento de la disminución del desvalor de la acción (por motivos acordes a los motivos de la esfera de organización del tercero), y del resultado, en cuanto que se obra en un claro beneficio del tercero: hacer efectiva la conciencia o la libertad de conciencia.

En este sentido, FlORES MENDOZA ${ }^{345}$ rechaza que el consentimiento pueda ser una causa de justificación por su inoperatividad en la objeción de conciencia. Aunque el bien jurídico de la vida y la libertad pueden ser disponibles, dicha disponibilidad cede frente a los intereses del Estado en la protección de dichos bienes, excepto en los bienes jurídicos privados como en los delitos de injurias, daños y en supuestos de lesiones (art. 156 CP).

\section{La objeción de conciencian como legítima defensa del art. $20.4^{\circ} \mathrm{CP}$}

\section{1) Requisitos}

La legítima defensa tiene su fundamento en la defensa de bienes jurídicos individuales, y no en bienes colectivos. El precepto nos habla de defensa de bienes o derechos propios o ajenos. En Alemania en concreto, la legítima defensa se denomina «defensa necesaria» (Notwehr) lo que la conecta con el estado de necesidad como un derecho de necesidad ${ }^{346}$.

El requisito esencial para apreciar la legítima defensa es la existencia de una agresión que sea ilegítima, ya sea una agresión física o dirigida contra bienes inmateriales como la honestidad o el honor, pero esto no quiere decir que no se exija que la agresión deba tener un carácter de fuerza. No es necesario que la agresión ilegítima se realice materialmente con una lesión, únicamente es necesario el intento posible, es decir, que sea un intento idóneo. También se exige que provenga de un acto humano. La agresión debe ser antijurídica. No necesario que el autor sea culpable de la agresión, pues el ataque ilegítimo puede provenir también de un demente ${ }^{347}$. La agresión ilegítima ha de ser actual, por ello se exige que la agresión sea próxima y que el peligro no haya desaparecido, salvo que se vaya a repetir de forma inminente ${ }^{348}$.

El segundo requisito de la legítima defensa es la defensa necesaria desde un punto de vista general, pero también necesaria en proporción a los medios defensivos que se emplean ${ }^{349}$.

345 FloRes MENDOZA, F., Objeción de conciencia, op. cit., pp. 188 y 189.

346 Vid. Polaino NaVArRete, M., Lecciones de Derecho penal, Parte general, T. II, op. cit., p. 153.

347 Acoge un criterio mixto de ilegitimidad del ataque como contrariedad a Derecho, en sentido estricto contra el Derecho penal y en sentido amplio contra el Ordenamiento jurídico, Polaino NaVArReTE, M., Lecciones de Derecho penal, Parte general, T. II, op. cit., p. 148.

348 ID., ibidem, op. cit., p. 147.

349 Comenta POLAINO NAVARRETE al respecto que «al propio medio necesario: racional es el último medio disponible», ID., ibidem, op. cit., p. 150. 
La falta de algunos de estos requisitos causará la inaplicabilidad de la legítima defensa completa y habría el debate de la aplicabilidad de la causa incompleta.

Por último, parece evidente que la expresión del tipo «el que obre en defensa de» integra el elemento subjetivo de realizar los elementos objetivos de la legítima defensa. Seguimos en este punto la doctrina ${ }^{350}$ que requiere junto al elemento objetivo el elemento subjetivo del ánimo de defensa. Al ser el elemento subjetivo un elemento no esencial, su falta constituye por consiguiente la eximente incompleta. La «falta de provocación suficiente» requiere que para que exista provocación suficiente ha de ser intencional, es decir, con el propósito de defenderse posteriormente esgrimiendo la legítima defensa.

Podemos concluir anticipadamente que el requisito esencial de «agresión ilegítima» no se aprecia en la casuística de los autores de conciencia y por convicción ${ }^{351}$. Ambos autores conocen y tienen voluntad de cometer el hecho antijurídico. En la autoría de conciencia no se aprecia una agresión ilegítima a su persona o a derechos propios o ajenos (debatible es el caso del aborto ético), sino que su problemática parte normalmente del conflicto de intereses jurídicos ${ }^{352}$. Esta conclusión no excluye la apreciación de una agresión ilegítima dirigida a la producción de una lesión jurídica ${ }^{353}$. Esta es la cuestión problemática, si bien ni la doctrina ni la jurisprudencia han aplicado esta causa propiamente en la casuística de los autores de conciencia y por convicción.

\section{2) Jurisprudencia}

Son escasas las Sentencias que se ha pronunciado sobre la posibilidad de apreciar la causa de justificación de la legítima defensa en la autoría de conciencia.

Escuetamente, sólo hemos encontrado las interesantes Sentencias 37, 38 y 39 del Juzgado de lo penal núm. 1 de Albacete, entre otras ${ }^{354}$, sobre la insumisión propia (negativa a realizar la prestación social sustitutoria), en las que se alegaba por los acusados la eximente de legítima defensa y cumplimiento de un deber. Las Sentencias argumentan que los acusados hicieron caso omiso «del requerimiento», expresaron la «voluntad patente y decidida de incumplir el deber impuesto por la norma». Refieren las Sentencias, acertadamente, que el sujeto ya ejerció su

350 ID., ibidem, op. cit., p. 152.

351 GARCÍA RIVAS, N., «Los delitos de insumisión en la legislación española», op. cit., p. 907.

352 MARTínEZ-TORRÓN, J., «La objeción de conciencia en la jurisprudencia del Tribunal Supremo norteamericano», op. cit., pp. 395 a 458.

353 Cerezo Mir, J., Derecho penal, Parte general, II, Teoría jurídica del delito, $2^{\mathrm{a}}$ reimp. 2000, de la $6^{\mathrm{a}}$ ed. 1998, Tecnos, pp. 212 y ss; MIR PUIG, S., PG, op. cit., p. p. 432; POlaINO NAVARreTE, M., Lecciones de Derecho penal, Parte general, T. II, op. cit., p. 148.

354 En el mismo sentido también las Sentencias 30, 31 y 32 de 1 de febrero del Juzgado núm. 2 de Albacete. 
derecho para eximirse de la obligación de prestar el servicio militar, por lo que se debió realizar la alternativa que se ofrecía con la prestación sustitutoria

La asociación de objetores de conciencia se mostró contraria a dichos argumentos, explicó que los requerimientos que se establecieron normativamente a los objetores para la prestación sustitutoria estaban anulados por la STS de 12 de enero de 1990. Este fue el argumento del Juzgado de lo Penal de Salamanca en la Sentencia 104/1990, de 6 de marzo, para llevar el debate a un error de prohibición. El Magistrado consideró inexistente la causa de justificación ${ }^{355}$. Pero más adelante en la Sentencia se cambia de rumbo para apreciar un error en los presupuestos de una causa de justificación ${ }^{356}$.

En nuestra opinión, el razonamiento de la Sentencia no es incorrecto pero tampoco es aplicable al caso concreto. El objetor no probó su conciencia discrepante, simplemente alegó su conciencia. Como razona la STS de 26 de mayo de 1987, «si bien es difícil determinar la existencia o no de error, por pertenecer al arcano íntimo de la conciencia de cada individuo, sin embargo, no puede bastar su mera alegación» ${ }^{357}$. GARCÍA RIVAS señaló que el caso en cuestión no es supuesto de error, «sino frente a la creencia de que la normativa que regula el cumplimiento de la PSS es inconstitucional, cosa bien distinta» ${ }^{358}$.

El objetor total o insumiso despreciaba al ordenamiento y a los valores y principios mínimos. Esto es porque a pesar de que la norma le ofrecía una conducta alternativa, omitía ésta, ya no por razones de conciencia contra el hecho de defender al país, sino por desvinculación total al deber de solidaridad general al Sistema. El insumiso total era un autor por convicción.

\section{La objeción de conciencia como estado de necesidad justificante}

1) Requisitos

La gran diferencia entre la legítima defensa y el estado de necesidad estriba en que la primera únicamente se permite la defensa cuando haya una agresión ilegítima (antijurídica), mientras que en el estado de necesidad se permite agredir o defender los intereses aun faltando la agresión ilegítima. En el estado de necesidad los dos sujetos «combatientes» obran lícitamente. El estado

\footnotetext{
355 Afirma que «el criterio ponderativo de intereses contenido en las Sentencias del Tribunal Constitucional 160 y 161/87 impiden dar relevancia de causa de justificación al ejercicio de la libertad ideológica realizado por el inculpado», FJ $12^{\circ}$ de la Sentencia del Juzgado de lo Penal de Salamanca 104/1990 de 6 de marzo.

356 El Magistrado razonaba que el sujeto «se encuentra de pleno en un supuesto de extralimitación de las causas de justificación o creencia de obrar lícitamente, de obvia naturaleza vencible», FJ $12^{\circ}$ de la Sentencia del Juzgado de lo Penal de Salamanca 104/1990 de 6 de marzo.

357 También en este sentido FlORES MendOZA, F. Objeción de conciencia, op. cit., 81; JerICó OJER, L., El conflicto de conciencia, op. cit., p. 199.

358 GARCÍA RIVAS, N., «Los delitos de insumisión en la legislación española», op. cit., p. 909.
} 
de necesidad puede ser por colisión de deberes o de intereses (derechos). Por ello en el estado de necesidad justificante la ponderación de la colisión es la clave para resolver estas situaciones a diferencia del estado de necesidad exculpante.

El fundamento de esta causa de justificación suele ser aquel que defiende la teoría de la diferenciación. Esta teoría defendida por parte de la doctrina ${ }^{359}$ diferencia entre el estado de necesidad justificante y disculpante (exculpante). El primero sería aquél cuyo fundamento parte de la justificación de la protección del interés objetivo más importante, mientras que el estado de necesidad disculpante parte de casos en los que el interés que se protege por el autor es levemente inferior al lesionado (ponderación de bienes), de tal forma que la objetividad desaparece en estos casos, cosa que hace a este estado de necesidad no ser una causa de justificación sino una causa de exclusión de la culpabilidad, mientras que los casos en los que el mal causado sea igual que el que se trata de evitar, es decir, no es mayor, el estado de necesidad se considera disculpante (causa de exculpación). Amén de ello, parte de la doctrina española considera aplicable la eximente de estado de necesidad exculpante dentro del art. $20.5^{\circ} \mathrm{CP}$.

Por otro lado, parte de la doctrina en la que se encuadra POLAINO NAVARRETE entre otros ${ }^{360}$, defiende la llamada «teoría de la unidad» por la que se postula que el estado de necesidad justificante también englobaría conflictos de bienes iguales, puesto que no se excluye que «el mal causado no sea mayor que el que se trata de evitar». Si bien matiza que «(e)l estado de necesidad subjetivo excluye la culpabilidad, a diferencia del estado de necesidad objetivo que justifica la conducta (...) El estado de necesidad subjetivo afronta la alternativa de acciones lesivas de bienes jurídicos de igual valor (...) en que no se puede justificar una a costa de la otra sino sólo exculpar la lesión de uno de ellos ante la imposibilidad de salvaguardar ambos» ${ }^{361}$.

Por nuestra parte, consideramos que el art. $20.5^{\circ} \mathrm{CP}$ recoge dos tipos de eximentes, justificadora y disculpante. Debe restringirse el campo justificante del estado de necesidad, pues

359 Entre los que podemos incluir a COBO Del RosAl M / ViVES ANTÓn TS., PG, op. cit., pp. 492 y ss; JAKOBS, PG, op. cit., 7/104; ROMEO CASABONA, CMa ${ }^{\mathrm{a}}$, El médico y el Derecho penal. La actividad curativa (Licitud y responsabilidad penal), Bosch, Barcelona, 1981, pp. 300 y ss. Aceptan las eximentes por analogía BACIGALUPO, E., «La rigurosa aplicación de la ley según el artículo $2^{\circ} \mathrm{CP}$, Vinculación del juez a la ley penal, CDJ, XVIII, Consejo General del Poder Judicial, 1995, pp. 126 y ss; FloRES MENDOZA, F., Objeción de conciencia, op. cit., pp. 245 y ss; Gracia MARTín, L., «El "iter criminis”, El Código Penal Español de 1995, El sistema de responsabilidad en el nuevo Código penal», CDJ, XXVII, Escuela Judicial y Consejo General del Poder Judicial, Madrid, 1996, pp. 267 y ss.

360 Polaino NaVArrete, M., Lecciones de Derecho penal, Parte general, T. II, op. cit., p. 154; JerICó OJER, L., El conflicto de conciencia, op. cit., pp. 412 y ss., considera que nuestro CP no recoge el estado de necesidad disculpante aunque se produzca entre intereses iguales; LuZÓN PEÑA, Diego-Manuel, Curso de Derecho penal, Parte general, I, Universitas, 1996, p. 621; MIR PUIG, S., PG, op. cit., pp. 458 y 459 opina que el campo del estado de necesidad justificante es demasiado grande, mientras que el campo del disculpante en ocasiones es demasiado amplio, y otras veces muy restringido, por lo que propone que el estado de necesidad disculpante se reserve para la eximente de miedo insuperable del art. $20.6^{\circ} \mathrm{CP}$, o cuando este miedo sea insuficiente por la atenuante analógica.

361 Polaino NaVArRete, M., Lecciones de Derecho penal, Parte general, T. II, op. cit., p. 174. 
la letra del artículo no nos habla de que el bien salvado sea igual o mayor que al que se enfrenta, sino de que el valor del «mal» causado no sea mayor que el que se evita, es decir, la ponderación debe ser objetiva en todos los casos, mientras que en el estado de necesidad disculpante la ponderación tiene en cuenta la circunstancias subjetivas del sujeto sobre el valor del mal, y por ello estaríamos no en el campo de la antijuricidad sino en el de la culpabilidad. Sobre esta consideración volveremos con más detalle cuando tratemos el estado de necesidad exculpante.

El primer requisito del estado de necesidad exige un elemento objetivo esencial: el «estado de necesidad». También que haya un peligro de un mal propio o ajeno y que por lo tanto exista necesidad de lesionar un bien jurídico de tercero o de incumplir un deber. Se exige entonces el conocimiento de esa necesidad, aunque de forma no esencial. El peligro ha de tener una probabilidad, en principio, inminente y actual. El peligro es un elemento esencial, no así la inminencia, cuya falta ha sido admitida en algunas ocasiones como eximente incompleta. El concepto de mal no puede quedar en un concepto simplemente valorativo. En nuestra opinión sólo puede entenderse como mal el jurídico y objetivable, un mal reconocido como tal por el ordenamiento jurídico. El mal que se trata de evitar puede ser propio o ajeno. Si es ajeno, el autor del mal obra en auxilio necesario de un tercero. Esto plantea la posibilidad de la colisión de deberes.

El segundo requisito que se exige en esta causa de justificación es la necesidad de carácter absoluto de lesionar un bien jurídico de otra persona o la necesidad absoluta de incumplir un deber, esto es, que no haya otra forma de actuación menos lesiva para evitar el mal. De aquí que el concepto «males» pueda incluir intereses jurídicos o deberes jurídicos, por ejemplo omitiendo una conducta.

Se exige también un elemento subjetivo en el conocimiento del estado de necesidad, sin perjuicio de otros elementos subjetivos o motivaciones de la acción (por ejemplo, odio). Su falta puede llevar también a considerar a la acción como imprudente.

La mayor problemática está en determinar el alcance de la expresión «el mal causado no sea mayor que el que se trata de evitar». En nuestra opinión no se han de ponderar los bienes jurídicos en juego, sino el peligro de males jurídicos y la forma en que se lesionan ${ }^{362}$.

El tercer requisito del estado de necesidad justificante exige que la situación de necesidad no haya sido provocada intencionadamente por el sujeto en caso de intereses propios, ni por el sujeto auxiliador en caso de bienes ajenos, por lo que si se causa el peligro desaparece

362 MIR PUIG, S., PG, op. cit., p. 471 comenta que «cuando en situación de necesidad se lesione un bien jurídico igual que el que el que se salva, podrá ser mayor el mal causado (porque éste encierra la perturbación inherente a la realización del hecho típico) que el evitado (que generalmente sólo consistirá en la lesión del bien impedida». 
automáticamente tal requisito. El fundamento para esta conclusión estriba en la equiparación con la doctrina de la actio libera in causa en su modelo de acción típica imprudente.

El cuarto y último requisito se refiere a que el necesitado no tenga por razón de su cargo u oficio obligación de sacrificarse. Diversas profesiones o cargos obligan a sacrificarse en determinadas situaciones. Se exige que la obligación sea concreta y no genérica. No puede aplicarse la eximente cuando el agente lesiona al necesitado para evitar un mal que por su profesión debe soportar.

\section{2) Doctrina a favor}

Son pocos los autores que defiende una causa de justificación de estado de necesidad en casos de conflicto de conciencia, aunque como veremos más abajo, la jurisprudencia si bien también la ha rechazado de plano, en algunos casos concretos la ha aceptado.

De los que abogan por la contemplación de una causa de justificación, ROMEO CASABONA ${ }^{363}$ opina que puede aplicarse una disminución de lo injusto por la ponderación del art. $16 \mathrm{CE}$ (libertad ideológica y religiosa) y el deber de actuar en los delitos de omisión como ejercicio legítimo de un derecho (causa de justificación). La conducta del insumiso es omisiva genuinamente, según estima el autor citado ${ }^{364}$.

Con otra fundamentación, BAUCELLS propone otros dos casos diferenciados en su tratamiento: incumplimientos colectivos y los que afectan materialmente a un bien jurídico. Acepta un tratamiento justificante por disminución del desvalor de la acción y del resultado en relación al menor quebrantamiento de los derechos de los demás, la dignidad, y los valores del ordenamiento $^{365}$ que ampara incluso las eximentes incompletas de estado de necesidad y la analógica $^{366}$. En los casos de incumplimiento de deberes contra bienes jurídicos colectivos, la objeción de conciencia cuando actúe conformando la conducta a otra alternativa legal permiten la justificación penal al no afectar a los valores del ordenamiento, esto según un criterio de ponderación de intereses ${ }^{367}$, mientras que cuando se lesione -materialmente- un bien jurídico, según los casos también, se permitirá una justificación penal, por ejemplo en los casos de la interrupción de una trasfusión de sangre mediante la retirada del catéter causando la muerte porque con tal conducta está obrando conforme a la libertad de conciencia de la víctima.

\footnotetext{
363 RomeO CASABONA, CM${ }^{\mathrm{a}}$., «El derecho a la objeción de conciencia», op. cit., pp. 1311, 1319, 1325 y 1326.

36 RomeO CASABONA, CM ${ }^{\mathrm{a}}$, El derecho y la Bioética ante los límites, op. cit., p. 126.

365 BAUCELls I LLADÓs, J., La delincuencia por convicción, op. cit., pp. 214 y ss. y pp. 414 y 415.

366 ID., ibidem, op. cit., p. 420.

367 ID., ibidem, op. cit., p. 415.
} 
De lo anterior extrae BAUCELLS dos tipos de causas de justificación. Una basada en un derecho objetivo ${ }^{368}$ referida a la salvaguarda de la libertad de conciencia mediante la aplicación de un estado de necesidad justificante $\left(20.5^{\circ} \mathrm{CP}\right)$, y otra mediante la salvaguarda de un derecho subjetivo como ejercicio legítimo de un derecho ${ }^{369}$ del art. $20.7^{\circ} \mathrm{CP}$ dentro de una debida ponderación de intereses ${ }^{370}:$ «por ejemplo, del ejercicio del derecho a la objeción de conciencia al servicio militar según procedimiento previsto» ${ }^{371}$. Pero en algunos casos, dichos intereses no tienen tal efecto justificante, porque no están contemplados en el Código penal. Por eso el citado autor apela a la meritada distinción entre incumplimiento de deberes que afectan al colectivo y los que afectan a un bien jurídico protegido por el Código penal. Los primeros, al referirse a delitos de deber, no permiten la justificación como ejercicio legítimo de un derecho, a diferencia de los segundos, pero sí en algunos casos el estado de necesidad justificante ${ }^{372}$. No obstante, BAUCELLS defiende un error de prohibición fundamentado en que algunos desconocimientos inevitables proceden de la inexigibilidad del conocimiento.

También TAMARIT SUMALLA ${ }^{373}$ apuesta por el estado de necesidad justificante en la autoría de conciencia, pero en la causa incompleta de la atenuante analógica en relación con el $1^{\mathrm{o}}$ requisito del estado de necesidad. En otros casos propone la justificación en el caso de que no se ponga en peligro el bien jurídico como en el abandono de la mesa electoral. Otros autores, como RuIZ MigUEL $^{374}$, siguen este criterio de la falta de lesión o peligrosidad para el bien jurídico.

Más recientemente, LUZÓN PEÑA ha llegado a la misma conclusión. Considera que la actuación de conciencia estaría justificada en los delitos omisivos por razón del ejercicio de los derechos fundamentales constitucionalmente reconocidos de la libertad de conciencia o de objeción de conciencia. Argumenta que tales derechos tienen admisión y regulación legal expresa en el art. 30.2 CE como en los anteriores supuestos del servicio militar ${ }^{375}$, otras veces con final reconocimiento legal como en los casos de objeción de conciencia al aborto aunque «ciertamente parcial y restringida, pues no se extiende al médico-sanitario que se niegue a dar información u otra ayuda indirecta a la práctica del aborto ni tampoco al personal farmacéutico

368 ID., ibidem, op. cit., pp. 156 y ss. y p. 416. En sentido similar MARTínEZ-TORRÓN, J., «Ley del jurado y objeción de conciencia», REDC, 48, 1996, pp. 124 y ss. y 137 y ss.

369 BAUCELls I LLADÓs, J., La delincuencia por convicción, op. cit., pp. 155 y ss. y p. 416.

370 Críticamente JERICÓ OJER, L., El conflicto de conciencia, op. cit., p. 330, entiende que la ubicación en la antijuricidad es incorrecta y que la culpabilidad ofrece más posibilidades de tratamiento.

371 BAUCELls I LLADÓs, J., La delincuencia por convicción, op. cit., p. 185.

372 ID., ibidem, op. cit., pp. 417.

373 TAMARIT SUMALLA, JMa ., La libertad ideológica, op. cit., pp. 416 y 438 ss; ID., La objeción de conciencia, op. cit., p. 4 y 40.

374 RuIZ Miguel, A., «La objeción de conciencia», op. cit., p. 117.

375 LUZÓN PEÑA, D-M., «Actuación en conciencia y objeción de conciencia como causa de justificación y como causa de exculpación frente a la punición del delincuente por convicción», InDret., 1/2013, p. 5. 
en relación con la dispensación de medicamentos abortivos» ${ }^{376}$, salvo que exista una negativa al aborto que por otro lado incurriría no ya en el art. $196 \mathrm{CP}$ sino en el art. $412 \mathrm{CP}^{377}$. En otros supuestos reconoce su admisión utilizando el criterio de una ponderación de intereses (se refiere a los casos de negativa a mesas electorales, objeción fiscal en gastos militares, a formar parte del Tribunal del Jurado, negativa de Jueces y Funcionarios a alguna obligación como la autorización del matrimonio homosexual ${ }^{378}$ ).

En tal sentido, LUZÓN PEÑA reconoce que la regulación específica de la objeción de conciencia no limita una aplicación más general de la objeción de conciencia en el art. $16 \mathrm{CE}$ aunque con las limitaciones del orden público como «orden del conjunto de valores jurídicos», que el art. 3.1 de la LOLR también establece ${ }^{379}$, se requiere una ponderación de intereses en el conflicto en relación a intereses jurídicamente superiores, lo que depende de las circunstancias $^{380}$. Por tal motivo, admite la justificación en delitos de omisión propia siempre que no afecte a bienes jurídico como la vida y la integridad ${ }^{381}$ ni cuando pesa más la actuación exigida que la salvaguarda de la libertad de conciencia ${ }^{382}$. De esta manera, no admite la objeción de conciencia en los de delitos comisión, y esto es porque considera que en los delitos de omisión se criminalizan hechos «mucho menos graves» pues «sólo implican la no realización de actividades positivas de prestación o fomento» en relación a bienes jurídicos, lo que justifica, según su criterio, la ponderación a favor de la libertad de conciencia ${ }^{383}$, mientras que en los segundos, los delitos de comisión, se atacan bienes jurídicos ajenos y en los que se crea un cambio de situación, como sería el caso de impedir activamente una trasfusión de sangre. Esta opinión la fundamenta no sólo por la posición de garante, sino también porque se impide un curso causal salvador ${ }^{384}$ que infringe deberes de abstención. No obstante, admite la aplicación de una causa de exculpación basada en la inexigibilidad de otra conducta en casos de conflicto extremo $^{385}$.

No podemos en este punto estar de acuerdo con LUZÓN PEÑA, por entender que discrimina la atención o la exención de la responsabilidad penal en el mero argumento de la forma de comisión y en los bienes jurídicos en juego, como si la forma de comisión fuera el coto privado de unas

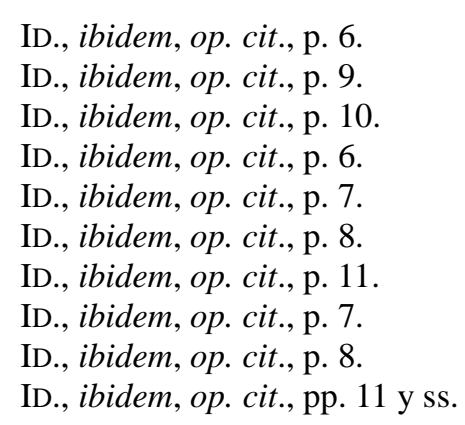


causas de atenuación o de exención particularmente designada en cada supuesto, pero es que además su consideración de atender a los bienes jurídicos tampoco excluye per se la posibilidad de apreciar una causa privilegiante o exonerante, salvo que interpretemos que los bienes jurídicos son la exclusiva función que tiene la norma penal de protección.

Otros autores, como SHULTE y TRÄGER ${ }^{386}$, en su día admitieron una causa de justificación sustentada en el estado de necesidad justificante. El fundamento que encontraron, en esencia, es la evitación por el objetor de conciencia o autor de conciencia de un peligro de un bien jurídico propio o de tercero, en este caso la libertad de conciencia, como mal grave que se representa de forma inevitable sin una lesión supuestamente menor de otro bien jurídico. Dicha amenaza es absoluta, no existe otra manera de evitar la lesión de la conciencia sino es quebrantando la norma, no hay otra «alternativa», por eso, ni rechazan ni niegan la vigencia de la obligatoriedad del deber jurídico o la norma. Este tipo de autor rechaza adecuar su comportamiento a los dictados de la norma por motivos de conciencia, de lo que deviene -como afirma FloRES MENDOZA- otorgándoles en parte la razón- que la amenaza del mal no es ajena al objetor sino que procede de él mismo, su origen es de procedencia endógena como en el síndrome de abstinencia por drogas o alcohol, o en las enfermedades terminales, por lo que «el deber jurídicopenal que desobedece es exactamente el mismo, cuya obediencia rechaza su conciencia» ${ }^{387}$. Así las cosas, y siguiendo al autor citado, quien rechaza un tratamiento médico, una trasfusión, no está obrando mediante una causa de justificación de estado de necesidad, el comportamiento es conforme a Derecho, es atípico, es decir, no existe la amenaza de un mal en sentido jurídico, en todo caso, sería un mal subjetivamente apreciado por el sujeto, nada más ${ }^{388}$.

En sentido similar, SíLVA DíAs ${ }^{389}$, amparándose en el art. 41.6 de la Constitución portuguesa sobre el derecho a la objeción de conciencia al servicio militar considera que el reconocimiento legal de una «alternativa» no puede significar en caso de incumplimiento un peor trato jurídico que antes de la regulación de la alternativa legal.

\footnotetext{
386 Vid. Flores MendOZA, F., Objeción de conciencia, op. cit., p. 180 (SHUlTE Reiner / TrÄGER Ernst, «Gewissen im Strafprozess. Eine Rehtsprechungübersicht», 25 Jahre Bundesgerichtstshof, coord. Gerda KrügerNieland, C.H. Beck, München, 1975, p. 263).

387 Flores MeNDOZA, F., Objeción de conciencia, op. cit., pp. 172 y 173.

388 ID., ibidem, op. cit., pp. 175.

389 Sílva DíAs, Augusta, A relevância jurídico-penal das decisoes de consciência, Livraria Almedina, Coimbra, 1986, pp. 109 y ss.
} 
Vemos claramente que la mayoría de la doctrina que aboga por una causa de justificación en la autoría de conciencia la fundamentan por la apreciación del «principio de ponderación de intereses» ${ }^{390}$, y en otros casos en la relevancia de un comportamiento alternativo.

La crítica ${ }^{391}$ a la apreciación de un estado de necesidad justificante a causa de la presión psicológica en los conflictos de conciencia defiende que precisamente dicha presión, al ser externa, afecta al instinto propio de conversación vital, lo que excluye el conflicto de conciencia, es decir, no constituye un mal en sentido jurídico la perdida de la vida «eterna» por lo que si bien la presión psicológica puede ser lo suficientemente intensa para concebir que existe una situación de necesidad, no así la disminución del injusto al faltar la afección al bien jurídico de la vida física. Pero claro, lo que se plantea es que la afección pueda ser a la integridad psíquica como derecho y bien jurídico.

También JERICÓ ${ }^{392}$, a pesar de reconocer que en los conflictos de conciencia «el cumplimiento del deber jurídico ocasiona en el sujeto afectado un peligro o bien para su propia personalidad y dignidad», concluye que desde una perspectiva objetiva, un hombre medio ideal en una situación similar no consideraría que el peligro «sea de tanta intensidad que le obliga a actuar para preservar un bien jurídico», pero además añade que el mal que amenaza, el peligro, no es jurídico sino subjetivo en los casos de la creencia de la pérdida de la vida eterna, pero cuando lo que se cree que puede perderse es precisamente la libertad de conciencia como derecho, no le queda más remedio que aceptar que dicho mal sea jurídico -como también acaba reconociéndolo FLORES MENDOZA ${ }^{393}$-, si bien, si se admite que la libertad de conciencia como mal jurídico cuando pueda ser amenaza, se habrá de admitir igualmente que la consecuencias de dicha libertad, y precisamente el respeto a dicha libertad englobaría la creencia en concreto, en este caso, la creencia en la vida eterna, sería un mal jurídico. Además no es del todo disparatada o supersticiosa por cuanto pocos ateos categóricos, agnósticos o exceptivos hay, habrá que admitir que ese tipo de creencias proceden de una tradición históricamente instaurada en todas clases de sociedades, por lo que puede considerase un mal jurídico inherente a la libertad de conciencia como contenido de la misma, por cuanto la libertad de conciencia exclusivamente formal, sería una nada en el ordenamiento jurídico.

\footnotetext{
390 BAUCELls i Lladós, J., La delincuencia por convicción, op. cit., pp. 184 y 185; PÉREZ DEL VALLE, C., Conciencia, op. cit., pp. 219 y ss. y 305.

391 FlORES MENDOZA, F., Objeción de conciencia, op. cit., pp. 232, 233, 235 y 236, dicha autora también señala en esta dirección a BOOP, Ulrich, Der Gewissenstäter und das Grundrecht der Gewissensfreheit, Freiburger Rechts und Staatswissenschaftliche Abhandlungen, Band 38, C.F. Müller Juristischer Verlag, Karlsruhe, 1974, pp. 246 y ss; también críticamente JERICÓ OJER, L., El conflicto de conciencia, op. cit., pp. 326 y ss.

392 JERICÓ OJER, L., El conflicto de conciencia, op. cit., pp. 341 y 342.

393 FloRES MENDOZA, F., Objeción de conciencia, op. cit., pp. 169 y ss., y pp. 176 y ss.
} 
Lo que no constituye un mal es que la trasfusión de sangre condene sin vida eterna. Dicha disposición es manifiestamente interpretable, lo cual no niega que la libertad de conciencia no ampare las creencias. Lo que sucede es que todo derecho tiene límites, y estos límites los pone el Derecho en apreciaciones que se toman o se tienen-como-verdaderas o fijas. En un Estado que amparase la creencia en el más allá la discusión no existiría, pero un Derecho que organiza libertades de creencias de toda índole, ha de fijar (tener-como verdadero) sólo aquellas cuestiones constatables, como serían algunos casos de miedo insuperable ante la creencia de la pérdida de la vida eterna. En estos casos, una pericial en su caso, podría constatar la alteración psicológica que efectivamente diera lugar a un daño psicológico, pero como veremos infra, no sucede frecuentemente y son raros los casos, por no decir que sólo hemos encontrado uno: un menor de edad que ante una transfusión de sangre se negó airadamente por un miedo irresistible a la pérdida de la vida eterna.

JERICÓ argumenta que será más fácil justificar motivaciones que provengan de un conflicto de conciencia cuando el sujeto omita una conducta debida, o un deber de carácter fungible o cuando se lesionen bienes jurídicos supraindividuales, pero habrá que ver caso por caso para comprobar la ponderación de intereses en juego ${ }^{394}$. Admite que los límites de la ponderación de intereses en el conflicto están en el orden público como exigencia de los valores del ordenamiento jurídico. La autora razona que la libertad de ideología garantiza la formación de ideas pero sin vinculación a un deber, mientras que la libertad de conciencia ampara el conflicto y la intensidad que se pueda generar ${ }^{395}$, puesto que «no lo es lo mismo que el sujeto actúe para evitar un grave conflicto para su conciencia a que lo haga porque está convencido de ello». Lo anterior le permite concluir que «(1)a libertad de conciencia goza de mayor protección que la mera actuación por convicción y esto debe tener trascendencia en el juicio de ponderación» ${ }^{396}$, pero referíamos más arriba que la autora se ve abocada a negar la posibilidad de un estado de necesidad justificante por faltar un peligro objetivo atendiendo al criterio del hombre medio ideal, lo cual llama la atención porque se niega ese valor superior al que se refiere la citada con la libertad de conciencia en protección de la dignidad y personalidad, lo que le obliga a negar el carácter de mal jurídico según ese criterio de hombre medio ideal al faltar un carácter objetivo y general, sin embargo la confusión en la que incurriría el sujeto permitiría apreciar la eximente

394 JERICÓ OJER, L., El conflicto de conciencia, op. cit., pp. 460 y 461.

395 ID., ibidem, op. cit., p. 460.

396 ID., ibidem, op. cit., p. 461. 
incompleta al faltar los requisitos «inesenciales» de subsidiariedad y proporcionalidad en la lesión del bien jurídico pero en verdad considera que faltan los requisitos esenciales ${ }^{397}$.

Dicho lo cual, estamos de acuerdo en no admitir la creencia como una amenaza de un mal jurídico, salvo en los casos en los que afecte palpablemente a la integridad psicológica, al igual que sucede en determinadas circunstancias del aborto en periodos de criminalización.

\section{3) Jurisprudencia}

La Sentencia 75/1992 $2^{398}$ del Juzgado de lo Penal núm. 4 de Madrid, de 3 de febrero de 1992, estimó la concurrencia de causa de justificación que hacía desaparecer la antijuricidad por estado de necesidad en el caso de un insumiso a la prestación social sustitutoria.

La Sentencia en cuestión señala sobre el controvertido bien jurídico que «(s)i se estima que lo es la prestación social en sí misma, esto es, considerada como una actividad, sucede que su carácter obligatorio se contradice frontalmente con la solidaridad, esencialmente voluntaria, que la fundamenta». Todo el razonamiento de la Sentencia gira sobre la apreciación de que el sujeto no es estrictamente insolidario, para estimar así que se está produciendo un mal jurídico sobre el superior al mal que el sujeto crea, y cabe entonces el estado de necesidad. Pero el razonamiento anterior decae desde el principio, no es la prestación sustitutoria el bien jurídico ni la solidaridad lo que lo fundamenta, sino que es la defensa nacional concretada en la defensa civil, por lo que la prestación sustitutoria como garantía de excepción al deber general de defensa militar, como garantía de la conciencia, no puede ser en sí misma un mal jurídico, se reconoce como la expresión material de un bien jurídico, como instrumento de él ${ }^{399}$.

397 ID., ibidem, op. cit., p. 463.

398 Sentencia 75/92 del Juzgado de lo Penal, núm. 4, de Madrid de 3 de febrero de 1992. En la Sentencia 270/1992 de 20 de mayo, del Juzgado de lo penal núm. 25 de Madrid, el Juez desarrolla un fundamento contrario del utilizado en la Sentencia 75/92 anteriormente analizada y que muestra la opinión de la doctrina mayoritaria. El acusado objeta a la prestación social sustitutoria también, por reproducir ésta los esquemas militares. Se argumenta que el estado de necesidad que se trata de verificar no es tal, ya que el mal que se trata de evitar tiene que ser objetivo para todo el mundo, es decir, «no bastando con que merezca tal calificación desde el punto de vista individual del sujeto activo (STS de diciembre de 1949, 29 de mayo de 1968)». En definitiva dice la referida Sentencia, FJ 30: «lo expuesto lleva a dos consideraciones: 1- Que la prestación social sustitutoria no es una sanción ni reproduce los esquemas o funciones del servicio militar, por lo que las convicciones del tipo moral, religioso, éticas o filosóficas incompatibles con las actividades militares que llevan al legislador a reconocer el derecho de objeción de conciencia al acusado, no son válidas para pretender incumplir el servicio social sustitutorio al ser prestaciones totalmente diferentes y de exclusivo matiz social la última. 2- Que la valoración de la prestación social sustitutoria a nivel constitucional y legislativo es positiva, por lo que desde estos puntos de vista, únicos que vinculan a este juzgado, no puede nunca constituir un mal a efectos del 8.7 del Código Penal que ponga en peligro los bienes o derechos de los ciudadanos».

${ }^{399}$ Comenta GARCÍA RIVAS que «(e)l cumplimiento de la PSS no puede representar un mal jurídico desde el momento en que se reconoce constitucionalmente para aquellos que ejercen su derecho fundamental a la objeción de conciencia», GARCíA RIVAS, N., «Los delitos de insumisión en la legislación española», op. cit., p. 914; DE Asís comenta sobre la Sentencia 75/1992 que «el juez trata de dar una justificación jurídica a algo que considera como 
Parece que el Juez se basó en su personal libertad de conciencia para no fallar en contra, pero bien es cierto que esta actuación no es posible cuando pudo y tuvo tiempo de pedir la inhibición al caso en concreto, es decir, con la abstención debidamente motivada ( 221 de la LOPJ ${ }^{400}$. Por eso la prestación social sustitutoria no se podía eludir, pues es la «consecuencia jurídica que la constitución permite deducir del ejercicio del derecho de objeción de conciencia al servicio militar», como acertadamente manifiesta CONTRERAS ${ }^{401}$.

No se puede aplicar un estado de necesidad con base a convicciones morales en estos casos ${ }^{402}$, ya que la objeción de conciencia se plasma y se garantizaba con la prestación sustitutoria, máxime cuando ésta es la sustitución de la defensa militar, una alternativa neutra, de modo que la conducta criminal ya no era «ineludible», es más, se estará de acuerdo en que nadie puede

desobediencia civil, y ésta por definición, es ilegal. Incluso cuando el juez se plantea el significado de la desobediencia civil expone las características que la doctrina ha identificado como propios de ella, entre los cuales está, no olvidemos, su carácter ilegal (...) Esto es independiente de que las trasgresiones al derecho puedan, en determinadas casos, ser castigadas con penas menores; de que pueda haber razones morales para desobedecer; y de que, a través de la objeción de conciencia, que si se le puede dar un fundamento jurídico, se hubiera llegado a una solución similar», DE ASÍs RoIG, R., «Las tres conciencias», op. cit., p. 25.

400 Como dice DE Asís «(p)odría así el juez argumentar que posee un interés directo o indirecto en la causa, al estar en conciencia en desacuerdo con el sentido de la norma», DE Asís ROIG, R., «Las tres conciencias», op. cit., p. 29. Añade acertadamente que «la conciencia social de un Estado democrático impide también con carácter necesario el que éste, a través del Ordenamiento Jurídico, facilite ciertas formas de «desobediencia civil» mediante el reconocimiento de la objeción de conciencia (...) tradicionalmente se aduce para la justificación del servicio militar obligatorio razones como la defensa a la patria, mientras que para la realización de la prestación social sustitutoria las de solidaridad. En cambio, la normativa sobre esta última no parece atender a este fundamento, sino que se relaciona con la primera», ID., ibidem, op. cit., p. 33; CONTRERAS ha señalado que «lo que pretende el demandado es algo radicalmente distinto: «no es obtener el reconocimiento de la incompatibilidad entre los mandatos de su conciencia y su participación en actividades militares (...) sino lograr sobre la base de convicciones personales profundas la trasformación del modelo de Ejército, que debería pasar a estar configurado como un servicio profesional», CONTRERAS MAZARIO, JMª ., «La libertad de conciencia», op. cit., p. 46 y 47. El Juez aplica el estado de necesidad, con lo que está reconociendo la objeción de conciencia a la prestación social sustitutoria. Con ese actuar, dice CONTRERAS en el mismo sentido que DE Asís, el Juez está «situando en lugar preferente sus propias convicciones personales frente a los intereses generales y a las obligaciones que le impone el Derecho vigente», CONTRERAS MAZARIO, JMª ., «La libertad de conciencia», op. cit., 47.

401 CONTRERAS MAZARIO, JM ${ }^{\text {a., }, ~ « L a ~ l i b e r t a d ~ d e ~ c o n c i e n c i a », ~ o p . ~ c i t ., ~ p . ~ 48 ; ~ S e g u ́ n ~ e ́ s t e, ~ e l ~ p r o b l e m a ~ v e n i ́ a ~ d e ~ l a ~}$ expresión «régimen análogo» de la Ley 48/1984 «como un supuesto de asimilación entre uno y otro servicio que desvirtúa el contenido del derecho a la objeción de conciencia, en la medida en que se somete al objetor "a un régimen militar al que precisamente objeta por razones de conciencia”», ID., ibidem, op. cit., p. 49, nota 65.

402 MuÑOZ CONDE señala que «(t)ampoco creo que sea aplicable (...) un estado de necesidad, tan generosamente regulada en nuestro Código (...) Ciertamente, podemos encontrarnos aquí con una situación de necesidad motivada por la colisión de dos bienes jurídicos: por un lado, la libertad de conciencia del insumiso a rechazar no sólo el servicio militar obligatorio, sino también el servicio civil sustitutorio, regulado por lo demás de forma bastante ruin y casi punitiva; por otro, el interés del Estado en asegurar la prestación de servicios sociales en beneficio de la colectividad, bien sea a través del servicio de armas, bien a través de cualquier otro tipo de actividad sustitutoria del militar, pero reglamentada por el propio Estado tanto en su extensión, como en la forma de su prestación. El principio de ponderación de intereses, conforme al cual se suelen resolver los casos de colisión entre dos bienes jurídicos, característicos del estado de necesidad, no ayuda mucho en la solución de este problema, al tratarse la libertad de conciencia de un bien jurídico difícil de precisar y, por tanto, difícilmente comparable o ponderable con otros bienes también protegidos jurídicamente y de más precisa delimitación», pero finalmente añade que «(c)onceder a toda costa prioridad jurídica a la libertad de conciencia puede llevar a imprevisibles consecuencias tanto en este como en otros ámbitos, como el fiscal, electoral, etc., si no se precisan las razones en las que se basa esa prioridad», MuÑOZ CONDE, F., «La objeción de conciencia en Derecho penal», op. cit., pp. 286 y 287. 
considerar que prestar ayuda a los ancianos, por ejemplo, es un mal jurídico que atenta contra la conciencia o la libertad de conciencia del art. $16 \mathrm{CE}$. Los que fueron llamados a prestar sus servicios a España tuvieron la oportunidad ya con la objeción de conciencia de hacerla salvaguardar, esto es, realizar una conducta alternativa que respetaba la conciencia ${ }^{403}$. Por lo tanto, concordamos con la opinión de CONTRERAS cuando explica que el problema viene de la confusión del juez al asimilar la objeción de conciencia del art. 30.2 CE como objeción también para la prestación sustitutoria con base al art. 16.1 CE, es decir, asimilar la objeción de conciencia con la desobediencia civil ${ }^{404}$, pues tal asimilación vulnera la solidaridad y el interés general de todos en un sistema social constitucional.

La STS de 5 diciembre de $1997^{405}$ configuró gráficamente la imposibilidad de apreciar un estado de necesidad ni aun en su vertiente incompleta, pero el razonamiento jurídico nos parece poco contundente. Argumenta el TS que «el requisito fundamental es que exista mayor o igual mal en peligro que se trata de evitar que en el mal causado» ${ }^{406}$. El criterio utilizado por el TS es más de «conveniencia» que de un verdadero argumento jurídico-penal ${ }^{407}$. El TS en verdad se basa en el peligro que desentrañaría esta aplicación, relativizaría los mandatos legales. Vemos como tales argumentos son escasos e insuficientes para fundamentar una condena, no se motiva con la suficiente claridad el entramado jurídico-penal de la culpabilidad al menos. Esa comparación de bienes, que son, no lo olvidemos derechos, es una mala técnica argumentativa de la condena a estos sujetos de conciencia, no es la comparación de bienes, sino de males jurídicos en juego lo que fundamentaría en todo caso el estado de necesidad justificante. Esta es una constante en la línea jurisprudencial del TS que muestra el escaso interés por las minorías de conciencia o religiosas.

El Tribunal Supremo en la tan repetida Sentencia 704/1997, de 18 mayo, como fundamento jurisprudencial de la culpabilidad en estos casos, indicó acertadamente que no es la ponderación de bienes jurídicos en juego el elemento decantador, pues como hemos afirmado los derechos

${ }^{403}$ CONTRERAS MAZARIO, JM ${ }^{\mathrm{a}}$., «La libertad de conciencia», op. cit., p. 52, nota 73.

404 ID., ibidem, op. cit., p. 52.

405 STS, de 5 diciembre de 1997, rec. 20311997.

406 FJ $1^{\circ}$ de la STS, de 5 de diciembre de 1997.

407 El FJ $3^{\circ}$ de la STS, de 5 de diciembre de 1997 comenta que «por cuanto la audiencia no ha aplicado una causa de justificación, sino de inculpabilidad que sería aproximable a la causa supralegal de inexigibilidad de conducta distinta. No es en principio y con carácter general inadecuada la construcción del Tribunal de instancia porque desde una perspectiva dogmática, la explicación del problema del autor por convicción o del autor de conciencia ha pasado con frecuencia por esta idea de la exigibilidad, pero es necesario aquí recordar la relevancia que, en las omisiones propias, se ha atribuido por la doctrina a este elemento como integrante de su propia tipicidad, especialmente en la omisión del auxilio; mas ello en la aplicación concreta al caso que se decide resulta inviable». En el mismo sentido pero en la inaplicación de una atenuante analógica de estado de necesidad del art. $8.7^{\circ}$ en relación al $9.1^{\circ}$ del CPd que sí aplicaron las respectivas Audiencias Provinciales, véase por ejemplo la STS, de 3 julio de 1997, rec. 2-1997, que dimana de la SAP Madrid, de 22 de noviembre de 1996. 
fundamentales no tienen rango entre sí. El art. 30.2 CE establece una excepción a un obligación general que no entra en conflicto con la libertad de conciencia del art. 16, precisamente por la excepción o alternatividad neutral que se concede para realizar otro servicio que no entraña problemas de conciencia ${ }^{408}$.

Otras sentencias del TS, como la STS de 26 de octubre de 1998 (rec. 1693/97), se limitan a invocar sentencias del TC, en concreto la Sentencia 55/1996, de 28 de marzo, en la que se declara que «so pena de vaciar de contenido los mandatos legales, el derecho a la libertad ideológica reconocido en el art. 16 de la CE no resulta por sí solo suficiente para eximir a los ciudadanos por motivos de conciencia del cumplimiento de deberes legalmente establecidos» ${ }^{409}$.

De otra parte, sobre la posible apreciación de una eximente incompleta de estado de necesidad, la STS de 11 junio de $1998^{410}$ entiende igualmente que no existe tal conflicto jurídico, aunque sí de conciencia, cosa que no permite prever el elemento esencial del estado de necesidad que es la premisa básica de un conflicto de bienes jurídicos. Como ya hemos comentado, la negativa al servicio militar estaba amparada por la excepción alternativa del $30.2 \mathrm{CE}$, lo cual respetaba los motivos de conciencia anti-militares, pero por ende se subsume la conducta en la obligación de realizar la prestación social sustitutoria, que si bien tiene un régimen análogo, esto no quiere decir semejante al militarista del servicio militar, con lo cual, no existe un conflicto de bienes jurídicos, a no ser que el sujeto activo no la realice por su falta de solidaridad, cosa que el ordenamiento no permitía ni amparaba.

La STS de 21 marzo de 1998 (rec. 2405-1997) se desvincula de la línea jurisprudencial firmemente adoptada. En ella se confirma la aplicación de una atenuante analógica muy cualificada de estado de necesidad por la Sentencia de la AP de Madrid de 9 junio de 1997 dictó sentencia. El TS desestima el recurso por entender que no era arbitraria la decisión de aplicar una proporcionalidad de la pena a un caso estricto de culpabilidad disminuida levemente. El TS señala al respecto que no puede entrar a valorar el caso, sólo cuando se haya aplicado un fin de la pena inadmisible o «haya tenido en consideración factores de la individualización incorrectos o

408 Señala la Sentencia que «el derecho a la libertad ideológica reconocido en el artículo 16 de la Constitución española no resulta suficiente para eximir a los ciudadanos por motivos de conciencia del cumplimiento de deberes legalmente establecidos, con el riesgo aparejado de relativizar los mandatos legales». En el mismo sentido SSTS núm. 948/1997, de 30 junio, y el FJ $3^{\circ}$ de STS, de 29 mayo de 2000 (rec. 4406-1998), donde se dice «(e)ste Alto Tribunal --al examinar otro caso similar al presente-- ha declarado que (...) el dato fáctico esencial (...) de que (el acusado) no solo se negó al cumplimiento del servicio militar sino también a la prestación social sustitutoria determina que la conducta no pueda verse disminuida en su antijuridicidad ni en su culpabilidad como justamente ha subrayado la jurisprudencia de este Tribunal Supremo»

409 En el mismo sentido al del TC se muestra el FJ $1^{\text {o }}$ de STS, de 24 de enero de 1999 (rec. 3233-1997), procedente de SAP de Madrid, de 9 de junio de 1997.

${ }^{410}$ FJ $3^{\circ}$ de STS, de 11 junio de 1998 (rec. 3997-1997), que dimana de la SAP Madrid, de 9 de diciembre de 1996. 
haya establecido una cantidad de pena manifiestamente arbitraria» ${ }^{411}$. La Sentencia se apoya en la línea jurisprudencial que entiende que la atenuante analógica del actual art. 21.7 $\mathrm{CP}$ es una «cláusula general de individualización de la pena» ${ }^{412}$ permite la disminución de la pena en casos de leve disminución de la culpabilidad en el caso concreto.

En nuestra opinión, esta atenuante no sólo debe ser aplicada por la leve disminución de la imputación subjetiva, sino también en casos de disminución de la gravedad del injusto de acto o de resultado y en casos de disminución de la propia necesidad de la pena, como en los supuestos de los arts. $21.4^{\mathrm{a}}$ y $5^{\mathrm{a}} \mathrm{CP}$, en los que debe aplicarse la atenuante por disminución del injusto de acto o de resultado. Los argumentos dados por la sentencia en análisis se remiten a criterios cuantitativos materiales de vulneración del bien jurídico protegido de la defensa nacional.

La STS de 26 septiembre $1997^{413}$ reconoce tales deberes relativos al servicio militar como propios del acusado, pero, por el mencionado conflicto con sus creencias pacifistas, y considerando que penalmente éstas habrían de tener una eficacia de atenuación de la responsabilidad por llevar consigo una menor culpabilidad, en comparación con la conducta de quienes pueden incurrir en esos mismos delitos por motivos egoístas o simplemente por capricho, apreció tal circunstancia atenuante y, además, con el carácter muy cualificado antes referido, lo que supuso una sensible reducción de las penas.

Cuestión bien distinta son los casos en los que se plantea una problemática en cuanto a la atipicidad de la conducta cuando el sujeto activo solicita su declaración de objetor de conciencia en el mismo día de incorporación a filas, o los casos en los que la Comisión de Objeción de conciencia no responde en plazo a la negativa escrita del sujeto por motivos de conciencia. Esta problemática debe ser reconducida a la atipicidad del delito ya derogado de negativa o falta de incorporación al servicio militar, cuestión que no exime del cumplimiento de la prestación social sustitutoria.

El último de los problemas que se plantearon en estos ilícitos fue la retroactividad de las leyes penales en beneficio del reo y la aplicación vigente más favorable como así fue por la progresiva despenalización de estos ilícitos, desde una primera derogación de la pena de privación de libertad, con lo que únicamente se sancionaba con la pena de inhabilitación especial, y finalmente con la absoluta derogación de todas las sanciones penales por la creación del cuerpo militar profesionalizado.

La Sentencia de la Audiencia Provincial de Jaén, de 7 abril de 1997, aplicó una eximente

411 FJ Único penúltimo párrafo de la STS, 21 de marzo de 1998.

412 STS, de 22 de marzo de 1998.

413 FJ $2^{\circ}$ de STS, de 26 sep. 1997 (rec. 403-1997), procedente de SAP Madrid, de 4 diciembre de 1996. 
incompleta del llamado estado de necesidad «económico», porque al tiempo de la consumación del delito la familia del sujeto activo no tenía más sustento que la posibilidad laboral y por tanto económica de éste, que inclusive en aquel tiempo estaba desempleado. En el caso se vislumbran dos motivaciones delictivas, una por motivos de conciencia, y otra por motivos económico. La segunda no pertenece estrictamente a nuestro estudio por lo que la desecharemos, sin antes resaltar que el peligro de económico-social de la familia, en tanto peligro a esos bienes jurídicos a proteger, merecen en nuestra opinión una atenuante analógica del miedo insuperable pero no viene a causa directa de un conflicto de conciencia.

En conclusión, los casos de insumisión podemos anticipadamente concluir no se corresponden con la tipología del autor de conciencia. Representan comportamientos con una actitud recalcitrante: la existencia de alternativas normativas despoja de argumentos los iníciales de conciencia. Sólo se puede definir su actuar como una simple y mera decisión de conveniencia, y en casos especiales de lucha contra el ordenamiento jurídico, lo que constituye un claro presupuesto de la autoría por convicción o de enemistad a pesar de realizarse en omisión.

En todos los estados democráticos suelen existir medidas de solidaridad a favor de la sociedad que, particular y personalmente los ciudadanos han de sufragar, de lo que deviene que la Sociedad es un Sistema reglado por la confianza en las expectativas. La confianza no se apoya en criterios estrictamente morales, sino en argumentos de funcionamiento del sistema normativo y de convivencia. Si se quiere, en todo caso, la solidaridad únicamente supondría una influencia moral -en el sentido expresado por LUHMANN- en el sistema normativo, pero no determina la operación sobre la decisión de establecer la solidaridad general. En esta decisión prima la clausura operativa de la operación en donde la moral supondría un argumento más. Piénsese por ejemplo que también en estados dictatoriales o totalitarios existe ese deber de solidaridad general de los ciudadanos en determinadas materias, y sin embargo el criterio también subyace en la propia operatividad del Sistema. Si estuviera basado en razones estrictamente morales llevarían a la desintegración del sistema dictatorial, que se confrontaría con el respeto de las libertades vulneradas propiamente en estos estados.

\section{La objeción de conciencia como ejercicio legítimo de un derecho}

Los casos de autoría por convicción y de conciencia parten del conocimiento y voluntad de realizar el hecho antijurídico, por lo que en principio tampoco se apreciará esta causa de justificación en esta problemática. Las anteriores justificaciones pueden ser defendidas en algunos casos aunque sólo sea como eximente incompleta, excepto la eximente de legítima 
defensa del art. $20.4^{\circ} \mathrm{CP}$. Lógicamente la conducta que incurre en un injusto puede estar justificada por legítima defensa o estado de necesidad, y añadirse el convencimiento moral de actuar correctamente. En estos casos se equipararía el deber y la justificación jurídica con el deber y justificación moral. No de otro modo se puede entender que quienes tienen la posibilidad de defenderse a sí mismos o defender a un tercero ante un ataque ilegítimo, o quienes se defienden a sí mismos o defienden a terceros en un estado de necesidad actúen así.

En la causa de justificación de cumplimiento de un deber esta equiparación en la psique del autor de conciencia entre deber moral y jurídico no se cumple. El sujeto que cumple un deber puede estar en desacuerdo moral con ese deber jurídico que el Derecho le exige, por tanto si se asemeja la motivación del deber moral con el propio deber jurídico, no existirá un conflicto de conciencia tal como ya ha apuntado parte de la doctrina ${ }^{414}$. En estos casos se excluye esta causa de justificación de nuestro ámbito de estudio.

Esto mismo no se cumple respecto a la eximente de ejercicio legítimo de un derecho. El sujeto no tiene obligación jurídica de actuar u omitir, aunque si ejercita este derecho, lógicamente y normalmente, lo hará porque moralmente lo cree correcto.

Se ha entendido que «a primera vista, parece que cuando la objeción es fundada podría admitirse la causa de justificación de ejercicio legítimo de un derecho prevista en el num. 9 del artículo 8 del Código penal»-ahora 20.7. - , «por cuanto la libertad de conciencia es un derecho fundamental reconocido como tal en el artículo 16 de la Constitución, carácter del que carece el deber de prestar el servicio militar obligatorio o la alternativa civil prevista en el artículo 30.3 de la Constitución. Sin embargo, no puede ignorarse que este planteamiento lleva demasiado lejos, no sólo en este ámbito, sino también en otros más fundamentales, la importancia de la libertad de conciencia como derecho oponible o incluso superior a otros derechos. Una cosa es que el Estado respete la libertad de conciencia individual y otra distinta es que la respete hasta el punto de hacer suya la decisión de conciencia individual contraria a sus leyes, dejando condicionada su aplicación a la aceptación de las mismas por parte del individuo ${ }^{415}{ }$.

414 Véase sobre la causa de justificación de cumplimiento de un deber, POLAINO NAVARRETE, M., Lecciones de

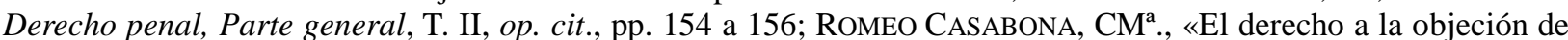
conciencia», op. cit., p. 1310; CEREZO MIR, J., Curso de Derecho penal español, Parte general, II, op. cit., pp. 290; Cuerda Riezu, A., La colisión de deberes en Derecho Penal, Tecnos, Madrid, 1984, pp. 72, 83 y ss., y 254 y ss; CARBOnell MATEU, JC, La justificación penal, op. cit., p. 157; GARCÍA RIVAS, N., «Los delitos de insumisión en la legislación española», op. cit., p. 907.

415 MuÑoz Conde, F., «La objeción de conciencia en Derecho penal», op. cit., p. 286, añade: «(u)na tal pretensión estaría en contradicción con la propia esencia del Derecho, como conjunto de normas objetivas de validez general». 
Por otro lado, PÉREZ DEL VAlle mantiene una diferenciación conceptual de autor por convicción y de conciencia en esta causa de justificación ${ }^{416}$. Considera que puede aplicarse una causa de justificación de ejercicio legítimo de un derecho en el autor de conciencia al faltar la responsabilidad por el hecho por disminución de lo injusto, el desvalor de la acción y el desvalor del resultado. Esta conclusión la fundamenta en la irradiación del art. 16 C.E del que extrae un conflicto de intereses jurídicos entre este derecho y la norma jurídica que se pretende quebrantar $^{417}$. También defienden una causa de justificación por ejercicio legítimo de un derecho QUINTANO RIPOLLÉS $^{418}$ y RUIZ MigueL ${ }^{419}$, para éste último bastaría la simple acreditación de la pertenencia a una determinada confesión religiosa para cumplir la justificación.

La crítica a la causa de justificación como ejercicio legítimo de un derecho, tal y como ha expuesto FlORES MENDOZA, discrepando de la de la mayoría de la doctrina que rechaza esta justificación por motivos de conciencia porque llevaría a que la norma perdiera fuerza obligatoria, es que sería «un contrasentido que se reconozca la libertad de conciencia y que al mismo tiempo se le niegue eficacia en el Derecho penal (...) La explicación puede hallarse en el hecho de que todas ellas, -también el estado de necesidad y la legítima defensa- están basadas en una situación objetiva, como es la necesidad de cumplir con un deber con un deber jurídico, ejercer un oficio o cargo, un estado de necesidad, una agresión ilegítima, mientras que aquí nos encontramos con una situación subjetiva (el conflicto de conciencia)» ${ }^{420}$. Así, la postura de PÉREZ DEL VALLE permitiría la exclusión de la responsabilidad penal en todos los conflictos de conciencia, en todos los objetores existe una intensidad del conflicto que puede llevar a la destrucción de la personalidad ${ }^{421}$ y el peligro de la falta de obligatoriedad de la Ley, del fin de la protección de la norma y la imposibilidad de aplicar una medida de seguridad ${ }^{422}$.

De otra parte, se admiten dos tipos de causas de justificación, una basada en un derecho objetivo $^{423}$ en el estado de necesidad justificante $\left(20.5^{\circ} \mathrm{CP}\right)$, y otra mediante la salvaguarda de un

416 PÉREZ DEL VAlle, C., Conciencia, op. cit., pp. 110 y 114.

417 ID., ibidem, op. cit., pp. 219, 284 y 294, y sobre la responsabilidad por el hecho véase p. 46. Críticamente Flores MendozA, F., Objeción de conciencia, op. cit., p. 185, pero parece atribuir a este autor que defienda una eximente de estado de necesidad, cuando en nuestra opinión defiende una causa de ejercicio legítimo de un derecho; también críticamente JERICÓ OIER, L., El conflicto de conciencia, op. cit., p. 326.

418 Quintano RIPOLlÉS, A., «La objeción de conciencia ante el Derecho penal», Estudios penales, Homenaje a R. P. Julián Pereda, Universidad de Deusto, Bilbao, 1965, pp. 613 y ss.

419 RuIZ Miguel, A, «La objeción de conciencia», op. cit., p. 114.

420 FlORES MENDOZA, F., Objeción de conciencia, op. cit., p. 160.

421 ID., ibidem, op. cit., pp. 303 a 305.

422 ID., ibidem, op. cit., p. 305; apela a la superioridad moral-ética del Estado respecto a la conciencia individual NolL, P., «Der überzeugungstäter im Strafrecht. Zugleich einen Auseinandersetzung mit Gustav Radbruchs rechtsphilosophischem relativismus», ZStW, 78, 1966, Walter de Gruyter \& co. Berlin, 1966, p. 658 (vid. BAUCELLS I LLADÓS, J., La delincuencia por convicción, op. cit., p. 189).

${ }^{423}$ BAUCELls I LLADÓs, J., La delincuencia por convicción, op. cit., pp. 156 y ss. y p. 416. 
derecho subjetivo ${ }^{424}$ amparada en el ejercicio legítimo de un derecho del art. $20.7^{\circ} \mathrm{CP}$ aplicando un debida ponderación de intereses ${ }^{425}$ «por ejemplo, del ejercicio del derecho a la objeción de conciencia al servicio militar según procedimiento previsto» ${ }^{426}$, pero en admite que algunos casos, dichos intereses no tienen tal efecto justificante por no estar contemplados en el Código penal. Por eso, se apela a la meritada distinción entre incumplimiento de deberes que afectan al colectivo y los que afectan a un bien jurídico protegido por el Código penal. Los primeros al referirse a delitos de deber no permite la justificación como ejercicio legítimo de un derecho a diferencia de los segundos, pero sí en algunos casos el estado de necesidad justificante ${ }^{427}$.

Según los postulados a los que hemos llegado, el autor de conciencia en determinadas ocasiones no comete injusto alguno cuando afecta a bienes personales, independientemente del motivo alegado, lo que excluye la problemática de la autoría de conciencia, sin embargo cuando la afección se produce en intereses colectivos o de terceros no consideramos que la conducta esté justifica, tampoco por el ejercicio legítimo de un derecho. Esto se debe a que si bien el autor obra en ejercicio de un derecho, se desconoce objetivamente qué entidad se pretende proteger, en otros casos, si afecta de forma tan grave a su integridad psíquica. Efectivamente el autor de conciencia está ejercitando un derecho, pero al desconocerse qué trascendencia objetiva tiene ese derecho, según los postulados antes señalados de la naturaleza de la antijuricidad, ni tan siquiera puede plantearse un debate en la ponderación. En nuestra opinión el tipo únicamente describe los elementos positivos del hecho antijurídico, es decir, por sí sólo el tipo es incapaz de determinar la antijuricidad, pues hace falta comprobar la parte negativa que se completa con la ausencia de causas de justificación. Por ello, la existencia de causas de justificación excluye la antijuricidad, lo que precisa concretar objetivamente cuál es el quebranto objetivo-normativo. La referencia genérica al ejercicio legítimo de un derecho sólo reconduce la problemática a la valoración estrictamente subjetiva, o sea, de conciencia, por el propio sujeto, lo que supone una cuestión a debatir en la culpabilidad, o anticipándonos a nuestra conclusión, si la norma ha sido capaz de orientar al sujeto, o si el sujeto ha sido capaz de orientarse conforme a la norma, pero a esta valoración le es ajena la parte objetiva, porque el autor de conciencia si bien apela a un derecho, la libertad de conciencia, al hacerlo de forma tan genérica, está reclamando una conexión irremediable entre conciencia y voluntad. Esta conexión la realiza el sujeto de forma estrictamente subjetiva, lo que impide valorarse la problemática del contenido del derecho de

424 ID., ibidem, op. cit., pp. 155 y ss. y p. 416.

425 Críticamente JERICÓ OJER, L., El conflicto de conciencia, op. cit., p. 330, considera que la ubicación en la antijuricidad es incorrecta y que la culpabilidad ofrece más posibilidades de tratamiento.

426 BAUCELlS I LLADÓs, J., La delincuencia por convicción, op. cit., p. 185.

427 ID., ibidem, op. cit., pp. 417. 
forma objetiva y por ende más allá de la antijuricidad. Entonces lo que al Derecho le es legítimo valorar es si la conexión subjetiva entre conciencia y voluntad es de tal forma tan ineludible que precisa un debate en la institución de la culpabilidad, en la que el Derecho viene a fiscalizar tal subjetiva inevitabilidad y por qué se ha producido esta situación, si por culpa del sujeto o por culpa de la norma: por falta de comunicación o de socialización de la norma quebrantada.

\section{El error de prohibición en la objeción de conciencia}

El error de prohibición que preceptúa el art. $14 \mathrm{CP}$ rompe con el axioma jurídico general error iuris nocet. En España dos penalistas defienden la posible aplicación de un error de prohibición en determinados conflictos de conciencia.

\section{1) Doctrina a favor}

En un primer momento se propuso un concepto material de culpabilidad basado en la participación en los bienes jurídicos por las normas penales, en el sentido que quien no participa en la protección de esos bienes no puede ser motivado por la norma que los protege, defendiéndose que el autor por convicción no actuaba culpablemente ${ }^{428}$. Sin embargo, tras la introducción en el CP del error de prohibición, se pasa a estimar que «(e)l error de prohibición no es, pues, una estructura cuya relevancia se admita sin más. Incluso en algunos casos límite en los que el sujeto conoce el alcance de la norma jurídica pero no la reconoce como vinculante por discrepancia con el sistema jurídico oficialmente vigente (delincuente por convicción), esta discrepancia deja de tener relevancia por no poder permitirse el Estado el lujo de hacer depender la vigencia de sus normas de la aceptación y el reconocimiento de los ciudadanos (...) Los casos de ceguera jurídica o de enemistad o indiferencia al Derecho ${ }^{429}$, no son normalmente casos de error vencible de prohibición, sino actuaciones plenas de conciencia de la antijuricidad» ${ }^{430}$. Mientras que el autor de conciencia sería aquel que por «creencia errónea» y «creencia

\footnotetext{
428 MuÑOZ CONDE, F., «El principio de culpabilidad», Jornadas de profesores de Derecho penal, Universidad de Santiago de Compostela, 1976, p. 231.

429 Sobre el concepto de «ceguera jurídica o enemistad hacia el Derecho», MEZGER, Edmund, Moderne Wege der Strafrechtsdogmatik, Berlín-Munich, 1950, p. 43, en donde MEZGER, incluye en el dolo la enemistad hacia el Derecho como conocimiento actual de la antijuricidad, al mostrar el delincuente indiferencia o desprecio a los valores más elementales, y mostrando así, la culpabilidad del sujeto no sólo por el hecho, sino también por su actitud durante toda la vida (culpabilidad por la conducción de vida), MEZGER, E., Moderne Wege der Strafrechtsdogmatik, op. cit., p. 45. WELzEL consideraba que el error sobre la validez de una norma penal o error de validez, «es una variedad del error de prohibición», Welzel, Hans, El nuevo sistema del Derecho Penal, Una introducción a la doctrina de la acción finalista, trad. José Cerezo Mir, Ariel, Barcelona, 1964, p. 120. Más ampliamente LUZÓN DOMINGO, Manuel, Tratado de la culpabilidad y de la culpa penal, Ed. Hispano-Europa, Barcelona 1960.

430 MuÑoz Conde, F., El error en Derecho Penal, op. cit., p. 48.
} 
diferente» ${ }^{431}$, comete un error sobre la validez de la norma (error de prohibición), pues conociendo la norma jurídica que incumple considera que debe ser incumplida porque existe una norma superior.

En sí, el autor por convicción es por «creencia discrepante» al ordenamiento jurídico, y el autor de conciencia por «creencia errónea» o «creencia diferente». Pero la concepción de este penalista se ve sensiblemente mermada tras el rechazado por parte del Tribunal Supremo de la aplicación del error de prohibición en el autor de conciencia, concretamente en las Sentencias de 25 de enero de 1999 (A. 283), y 12 de marzo de 1999 (A. 1438), aunque en la Sentencia de 21 de julio de 1993 (A. 6335), el TS admite alguna posibilidad de aplicar la atenuante analógica de arrebato u obcecación del $21.3^{\mathrm{a}} \mathrm{CP}$ en relación $21.6^{\mathrm{a}} \mathrm{CP}$, en el delito de colaboración con banda armada por motivos de conciencia, pero no la aplica por «motivos prácticos». Esta posibilidad de atenuación analógica fundamentada en el arrebato u obcecación, rompe con la posibilidad de tratar la autoría de conciencia en el error de prohibición. Si existe tal arrebato u obcecación es porque el sujeto conoce primacía normativa, si bien por determinadas circunstancias subjetivas el sujeto de forma irresistible en su voluntad se ve obligado a quebrantar la norma.

Sin embargo, la aludida teoría ${ }^{432}$ considera -en contra la doctrina mayoritaria ${ }^{433}$ - aplicable una atenuación o exención de la responsabilidad en virtud de un error de prohibición para los casos de autor de conciencia salvo en delitos de sangre y otros graves, y ningún tipo de atenuación o exención para el autor por convicción; no cabe ni la atenuación cuando se ponga en peligro la vida, la integridad física, la libertad y la propiedad pues «no se puede dar ninguna relevancia a la decisión de conciencia que los ataque, ya que dichos bienes jurídicos son más importantes que la libertad de conciencia y son indisponibles para el desarrollo de los demás ciudadanos», si bien también admite una posible eximente de estado de necesidad basada en una

431 ID., ibidem, op. cit., p. 69; crítico GRACIA MARTín, L., Fundamentos de dogmática penal, op. cit., p. 142 y pp. 154 a 158; también en contra OCTAVIO DE TOLEDO Y UBIETO Emilio / HuERTA TOCILDO Susana, Derecho penal, Parte general, Teoría jurídica del delito, $2^{\mathrm{a}}$ ed., corregida y aumentada, Rafael Castellanos (Edit.), p. 313.

${ }^{432}$ Muñoz CONDE, F., «La objeción de conciencia en Derecho Penal», op. cit., pp. 292 y ss., en donde considera aplicable un error de prohibición por el párrafo $3^{\circ}$ del art. $6^{\circ}$. Bis. a) del derogado Código Penal, ahora párrafo tercero del art. 14 del nuevo Código del 95; ID., El error en Derecho Penal, op. cit., distingue entre autor por convicción como aquél que desvalora el ordenamiento con conocimiento de la antijuricidad, y el autor de conciencia que por creencia disidente comete un error de prohibición; ID., Teoría general del delito, op. cit., pp. 177 y 178 , en donde elimina la atenuación cuando se ponga en peligro la vida, la integridad física, la libertad y la propiedad: «no se puede dar ninguna relevancia a la decisión de conciencia que los ataque, ya que dichos bienes jurídicos son más importantes que la libertad de conciencia y son indisponibles para el desarrollo de los demás ciudadanos...». Ejemplos de ello sería cuando se deja morir a una mujer desangrándose tras un aborto ilegal, en donde no cabe ni la atenuación, pero continúa diciendo: «Sin embargo, incluso respecto a la vida la solución puede variar si, por ejemplo, la muerte se produce para evitar graves dolores a un moribundo aquejado de una enfermedad irreversible en fase terminal y el paciente está de acuerdo en ello».

433 Vid. Flores MENDOZA, F., Objeción de conciencia, op. cit., p. 212, nota 53. 
causa de inexigibilidad exculpante en algunos $\operatorname{casos}^{434}$ : el autor por convicción es tal por «creencia discrepante» al ordenamiento jurídico, mientras que el autor de conciencia es tal únicamente por «creencia diferente» ${ }^{435}$ (...) Los casos de ceguera jurídica o de enemistad o indiferencia al Derecho, no son normalmente casos de error vencible de prohibición, sino actuaciones plenas de conciencia de la antijuricidad» ${ }^{436}$.

Se ha defendido la aplicación del error de prohibición en los conflictos de conciencia, aunque muy excepcionalmente, acomodando la categoría de culpabilidad a un concepto material sustentado en las normas constitucionales del Estado democrático y de derecho y en el principio de igualdad, rechazando las causas de inimputabilidad en la autoría de conciencia y por convicción y las causas de exclusión de la culpabilidad como el estado de necesidad disculpante, al entender que el conflicto no es en cuanto a males sino de intereses ${ }^{437}$; considera desde una concepción material de la culpabilidad que estos casos pueden acogerse a un error de prohibición sobre la validez y sobre la permisión en los límites de una causa de justificación, pero desde la perspectiva de que dicho error (vencible/ invencible) parte de un binomio de conocimiento/ desconocimiento. Cuando la motivación venga del respeto a la autonomía y universalidad se fundamenta un desconocimiento inexigible ${ }^{438}$.

En Alemania, hace años, Peters, Rudolphi, Armin Kaufmann, Arthur Kaufmann, TIEDEMANN y otros autores como Sax, SCHULTE y TRÄGER ${ }^{439}$ también aceptaron la posibilidad de un error de prohibición en tales conductas. En concreto, PETERS ${ }^{440}$ afirmaba que si bien el autor de conciencia conoce la norma, no le concede el valor de obligatoriedad al entender que la norma moral es superior, fundamento que viene respaldado por la propia Ley Fundamental alemana. RUDOLPHI ${ }^{441}$ admitía en determinados supuestos un error sobre la validez de la norma,

434 MuÑoz CONDE, F., «La objeción de conciencia en Derecho Penal», op. cit., p. 287, de manera que «ha de admitirse la objeción de conciencia al servicio militar, cuando se presta voluntariamente un servicio civil social sustitutorio en la forma prevista legalmente. El problema de la «insumisión total», tanto al servicio militar, como al sustitutorio, no debe, por tanto, ser tratado en este apartado, por más que ya advirtamos que la fórmula alternativa que prevé la actual ley española para estos casos no sea la más conveniente para solucionarlos, y, por tanto, no esté exenta de objeciones. Precisamente, y no está de más decirlo ya en este momento, la imposición obligatoria del servicio militar, sin alternativas civiles o sociales al mismo, característica del sistema de la dictadura franquista, motivó en nuestro país las primeras condenas por estos hechos, que revelaban más las peculiaridades de un Estado totalitario que el carácter delictivo de los hechos en sí», ID., ibidem, op. cit., pp. 292 y ss.

435 Vid. MUÑOZ CONDE, F., El error en Derecho Penal, op. cit., p. 69.

436 ID., ibidem, op. cit., p. 48.

437 BAUCELlS I LLADÓS, J., La delincuencia por convicción, op. cit., pp. 418 y 419.

438 ID., ibidem, op. cit., pp. 419 y 420.

439 Vid. PÉREZ DEL VAlle, C., Conciencia, op. cit., p. 237.

440 Vid. ID., ibidem, op. cit., p. 236 (PETERS, K., «Überzeugungstäter im Strafrecht», Zeitschrift für die Gesamte Strafrechtswissenschaft, 78, 1966, p. 279, nota 271).

441 Vid. Flores MENDOZA, F., Objeción de conciencia, op. cit., 215 y ss; vid. JeRICó OJER, L., El conflicto de conciencia, op. cit., p. 381 y 382 (RUDOLPHI, Hans-Joachim, Unrechtsbewusstsein, Verbotsirrtum und Vermeidbarkeit des Verbotsirrtums, 1969, pp. 188 a 190). 
pero por regla general no sería admisible cuando existe un conflicto de conciencia en el que el sujeto conoce la validez de la norma porque si fuera así trasformaría al ordenamiento jurídico en una cuestión moral. Armin KAUFMANN ${ }^{442}$ concluyó que quien está convencido de que una norma no le es vinculante, desconoce su fuerza jurídica y vigencia, mientras que Arthur KAUFMANN ${ }^{443}$ admite la posibilidad de que en las conductas basadas en conciencia no haya ni culpabilidad jurídica ni moral, y de manera similar TIEDEMANN ${ }^{444}$ condiciona la validez de una norma jurídica al reconocimiento de ésta por parte de sus finalmente obligados, por lo que el «autor por convicción» no estaría sujeto a obligación jurídica, ya que éste no la considera vinculante ni obligatoria.

También SílVA DíAs ${ }^{445}$ en Portugal considera aplicable un error de prohibición sobre la ilicitud amparado en el art. 17 de la Constitución portuguesa en el prototípico caso de un testigo de Jehová que no socorre a un accidentado porque considera que no está obligado por su conciencia.

En conformidad con la doctrina mayoritaria, FLORES MENDOZA ${ }^{446}$ rechaza la apreciación del error de prohibición sobre la existencia de la norma por cuanto si comete un error sobre la validez de la norma ello supone la falta de conciencia y por ende no es un conflicto de conciencia. El autor de conciencia precisamente conoce la norma y su validez, si bien le otorga un rango inferior, y este parece ser el conflicto de conciencia que aprecia parte de la doctrina como fundamento de irresponsabilidad por error de prohibición invencible. Sin embargo dicha penalista admite que en algunos casos puede apreciarse un error de prohibición cuando el objetor «se equivoque en el presupuesto que da lugar a una causa de inculpabilidad (...) su apreciación es ajena a la motivación de conciencia (...) y no al conflicto de conciencia que vive el objetor».

También JERICÓ ${ }^{447}$ concluye que si estamos ante un conflicto no puede haber error de validez aunque «por diversas razones, la considera nula, razones, que por otro lado, deben estar

442 Vid. Pérez del Valle, C., Conciencia, op. cit., p. 236; vid. también en Flores Mendoza, F., Objeción de conciencia, op. cit., 215, nota 61; vid. JERICÓ OJER, L., El conflicto de conciencia, op. cit., p. 381 (KAUFMANN, A., «Die Dogmatik im Alternativ-Entwurf», ZstW, 80, 1968, op. cit., pp. 34 y ss; ID., «Die Dogmatik im AlternativEntwurf», Strafrechtsdogmatik zwischen Sein und Wert, Carl Heymanns Verlag, Köln, 1982, colección de artículos, pp. 234 y 235$)$.

443 Vid. Flores MendozA, F., Objeción de conciencia, op. cit., 215, nota 61 (KAUFMANN, Arthur, Das Schuldprinzip. Eine strafrechtlich-rechtsphilosophische, Carl Winter, Heidelberg, 1961, pp. 139 y ss.).

444 Vid. TAMARIT SUMAlla, JMa., La libertad ideológica, op. cit., pp. 358 y 359; vid. también en FLORES MENDOZA, F., Objeción de conciencia, op. cit., 215, nota 61 (TIEDEMANN, Klaus, «Zur legislatorischen Behandlung des Verbotirrtums im Ordnungswidriegkeiten- und Steuerstrafrecht», Zeitschrift für die gesamte Strafrechtswissenschaft, 81, 1969, p. 873 y nota 11).

445 SílVA DíAS, A., A relevância jurídico-penal das decisoes de consciência, op. cit., p. 146.

446 Flores MendozA, F., Objeción de conciencia, op. cit., pp. 212 y ss. y 235; SANTA RitA, G., El delito de organización terrorista, op. cit., pp. 558 y ss.

447 JERICÓ OJER, L., El conflicto de conciencia, op. cit., p. 391. 
reconocidas por el propio ordenamiento jurídico» ${ }^{448}$; si bien admite la posibilidad de un error indirecto sobre el alcance de una causa de justificación con relación a la libertad de conciencia, por ejemplo, excepcionalmente en aquellos casos en los que se introduce una norma nueva en el ordenamiento y sobre la que no hay pronunciamiento alguno por parte de la doctrina o la jurisprudencia, aunque serían independientes del conflicto de conciencia por cuanto que dicho error proviene de otra causa, no en sí mismo del conflicto.

Críticamente podemos concluir que no existe conflicto de conciencia en el error de prohibición sobre la permisión, sino más bien de un error genuino y ajeno a la conciencia, salvo que dicho error venga causado directamente por la creencia de que el deber moral está jurídicamente por encima de otra norma de deber. Estos últimos casos serían una excepción, tal y como considera parte de la doctrina, si bien, y como expondremos más abajo al tratar la problemática en la culpabilidad, el autor de conciencia ni tan siquiera está valorando su conciencia por encima de la norma, sino que actúa subjetivamente de forma inevitable, es decir, conoce que la norma jurídica está por encima de su caso en concreto, pero actúa de forma ineludible, por eso el conflicto en verdad no es tanto entre derechos objetivamente puestos en valoración objetiva, ni sobre la interpretación de qué rango tienen, ni existe error en dicha interpretación, sino un conflicto del sujeto consigo mismo, que quiere cumplir la norma jurídica, pero que subjetivamente se ve obligado de forma infalible a quebrantarla. La problemática estriba en la culpabilidad, si el sujeto es culpable de dicha subjetividad inevitable, o sea, si fue capaz de orientarse conforme a la norma, o si la norma no fue capaz de orientarle por un déficit de comunicación atribuible a la propia norma, lo que consideramos que es un déficit de socialización de la norma en su capacidad normativa de orientar, o si el sujeto estaba socializado de tal forma que le impedía actuar conforme a la norma.

\section{2) Jurisprudencia}

En España el error de prohibición en los conflictos de conciencia ha sido planteado en varias ocasiones en los delitos electorales realizados por sobre todo por Testigos de Jehová. El art. 143 de la Ley Orgánica 5/1985, de 19 de junio, del Régimen Electoral General, preceptúa:

«(E)l Presidente y los Vocales de las Mesas Electorales así como sus respectivos suplentes que dejen de concurrir o desempeñar sus funciones, las abandonen sin causa legítima o incumplan sin causa justificada las obligaciones de excusa o aviso previo que les impone esta Ley, incurrirán en la pena de arresto mayor y multa de 30.000 a 300.000 pesetas».

448 ID., ibidem, op. cit., p. 393. 
La sanción penal se basa en la obligación que se establece para determinadas personas en el artículo 27 de la citada Ley cuando preceptúa que «los cargos de Presidente y Vocal de las Mesas Electorales son obligatorios». El artículo también establece causas de justificación pero a una condición previa: a la efectiva comunicación del aviso previo o excusa.

La participación en una mesa electoral es un «deber cívico, de carácter general y exigible», que precisamente nace de la propia configuración de nuestra Nación, es decir, como «Estado social y democrático de Derecho» (art. 1.1 CE). Precisamente la pertenencia de los sujetos a las normas de un país, hace comulgar con el ordenamiento jurídico de éste, pero no con los principios básicos, el bien jurídico protegido no es la misma democracia, sino la neutralidad política $^{449}$. Si la conciencia de los Testigos de Jehová impide participar en procesos políticos, precisamente por su neutralidad política, es ilógica una negativa a esa participación, cuando precisamente lo que se trata de proteger es esa misma neutralidad política. La jurisprudencia española ha sido tajante y en la mayoría de los casos ha condenado estas conductas.

En tal medida confluyen en estos casos dos aspectos a proteger, a saber, la libertad de conciencia o libertad de creencias y su efectiva materialización en la vida social y la salvaguarda de la «neutralidad política en los procesos de formación democráticos».

No obstante, la Sentencia de la Audiencia Provincial de Barcelona, de 19 de abril de 1993, aprecia la concurrencia de un error de prohibición invencible sobre una causa de justificación de estado de necesidad putativo. Aunque la Audiencia Provincial considera que no existe un conflicto entre los bienes jurídicos en controversia, a saber, neutralidad política en la formación democrática, y la libertad de conciencia, considera la imposibilidad por parte del sujeto activo de conocer la fuerza de la obligación normativa, es decir, creyendo actuar bajo un estado de necesidad que no reúne los elementos objetivos por tratarse una causa de justificación inexistente en nuestro ordenamiento jurídico (en concreto, el llamado estado de necesidad putativo). De sus palabras se extrae que esta imposibilidad o apreciación errónea iuris nace del propio conflicto moral del sujeto activo del delito ${ }^{450}$.

449 TAMARIT Sumalla, JMa ., La libertad ideológica, op. cit., pp. 358 y 359; vid. también en FLORES MENDOZA, F., Objeción de conciencia, op. cit., 215, nota 61 (TIEDEMANN, Klaus, «Zur legislatorischen Behandlung des Verbotirrtums im Ordnungswidriegkeiten- und Steuerstrafrecht», op. cit., p. 873 y nota 11).

450 En concreto la referida Sentencia fundamenta su decisión en que «los móviles religiosos no son por sí solos suficientes para eliminar el dolo, es de observar que la acusada no tuvo pleno conocimiento de su significación antijurídica, por creer erróneamente que concurrían en su acción los presupuestos de una causa de justificación, no prevista realmente en el ordenamiento jurídico; se da, pues, un error de prohibición, de carácter invencible, pues el sujeto activo se creía amparado por un estado de necesidad putativo, al ser el conflicto de bienes sólo aparente, dado que, pese a la estimación errónea de la acusada, las exigencias religiosas no podían en realidad ser en el caso objeto de protección o servir de justificación, cuando del cumplimiento de un deber legal se trataba, sin que cupiera 
En nuestra opinión -y en contra del criterio sustentado en dicha Sentencia-, la moral o las convicciones morales no afectan en sí mismas al intelecto, ni mucho menos al acceso $u$ oportunidad de conocimiento de la obligación normativa. Toda condición social puede ayudar en mayor o menor medida a la formación intelectual, social y cultural de sujeto, pero no cabe por esto concluir que la libre decisión moral afecta por sí misma al intelecto.

La Sentencia de Tribunal Supremo de 15 octubre 1993 declara haber lugar el recurso de casación contra la sentencia absolutoria de instancia que apreció el error de prohibición ${ }^{451}$. Los hechos son semejantes a los casos ya citados, es decir, desestimación por la Junta Electora de motivo de conciencia alegado por pertenencia al citado grupo religioso, e incomparecencia a la constitución de la Mesa Electoral. El Tribunal Supremo, en armonía a su línea jurisprudencial argumentó la estimación del recurso, y por tanto la culpabilidad del sujeto activo, en el previo conocimiento de la obligación normativa y en la falta de conflicto jurídico entre el bien jurídico protegido, la neutralidad política y la libertad de conciencia del art. $16 \mathrm{CE}^{452}$. Esta es la constante argumentativa que se va a repetir a lo largo de las sentencias que se han pronunciado sobre esta problemática.

En otras ocasiones, el motivo alegado del error de prohibición se intenta sustentar por el desconocimiento del sujeto activo de que el incumplimiento normativo lleva aparejada una sanción penal. Sobre este aspecto nos interesa si el desconocimiento es causa suficiente para la aplicación de un error de prohibición. Al respecto se pronuncian las Sentencias del Tribunal Supremo de 23 y 30 de diciembre de 1992, de 30 de marzo y 15 de octubre de 1993, y de 27diciembre de 1994. En concreto la última Sentencia citada dice al respecto que «el alcance de tal conciencia o conocimiento de estar obrando ilícitamente no exige el exacto saber del contenido concreto del tipo infringido».

Un caso de especial interés es aquél en el que se alega la imposibilidad física de permanecer en la Mesa Electoral por causa de conciencia. La Sentencia del TS desestima el recurso de casación por falta de prueba de que la pertenencia podría producir «unas desfavorables consecuencias físicas o psíquicas, pero además, tampoco es válida como excusa (...) para

exigir a la acusada conducta distinta a la realizada; procede, conforme a lo dispuesto en el art. 6 bis a) CP, la exoneración de responsabilidad criminal y, en consecuencia, la libre absolución de la acusada».

451 STS, de 15 de octubre de 1993.

452 FJ $7{ }^{\circ}$ STS, de 14 diciembre de 1994: «(e)l acusado fue noticioso, y él mismo lo confirma, de la inoperatividad de la excusa aducida y denegación de su instancia. Su actuar viene presidido por aquel dolo necesario para la configuración penal de una conducta. Tuvo conciencia de la significación antijurídica de su proceder y voluntad decidida de llevarlo a la práctica. El dolo, entendido tradicionalmente como «intención maliciosa» 
excluir la punibilidad el alegar motivos de conciencia» ${ }^{453}$. Lo interesante del caso en cuestión, es determinar la responsabilidad en caso de haberse acreditado la imposibilidad física o psíquica de permanecer tantas horas realizando las funciones propias. Si así fuere, existiría en nuestra opinión un peligro de quebrantamiento de un bien jurídico protegido como sería la integridad física o psíquica, que aplicado al caso entraría en controversia con el bien jurídico de «neutralidad política durante la formación democrática». Tendría que analizarse en qué forma y en qué magnitud se constituye el peligro que produciría un mal jurídico, y en qué medida se lesionaría a éste último.

La única sentencia del Tribunal Supremo que absolvió a los imputados por apreciación de un error de prohibición es la de 29 de septiembre 1993, rec. 759-1993. El Tribunal de primera instancia absolvió a los acusados por un delito electoral por incomparecencia en la Mesa Electoral, y el Tribunal Supremo desestimó el recurso interpuesto por el Ministerio Fiscal por la concurrencia de un error de prohibición ${ }^{454}$. El Supremo se basó en una Sentencia de años antes, la de 30 de enero de 1979, en la que en hechos análogos absolvió a los imputados ${ }^{455}$.

Todo lo anterior salvo la anterior sentencia demuestra la total culpabilidad de los miembros de grupos religiosos que aducen el motivo de conciencia para incumplir la norma electoral. Dicho incumplimiento, no es realmente grave, y sin bien ataca de manera indirecta el buen funcionamiento de un valor democrático, el ejercicio del derecho al voto de los demás ciudadanos, lo cierto es que el ataque a la neutralidad política no se ve afectada materialmente, puesto que dicha omisión no causa por sí misma la imposibilidad de que los ciudadanos ejerciten su derecho, como sería el caso de atentar o impedir activamente la celebración del voto, de lo que deviene que pueda concluirse que estas conductas son propias del autor de conciencia, a diferencia del autor por convicción, que en el mismo caso más que negarse a comparecer, impediría el ejercicio al voto, lo que sí quebrantaría de manera grave y seria, ya no la neutralidad política, sino la funcionalidad de la democracia.

453 FJ Único STS, de 30 de septiembre de 1994.

454 Comenta el Tribunal Supremo que «en definitiva, el hecho realizado por los acusados está tipificado en la Ley Electoral como delito, pero, aplicando el sistema culpabilístico que impera en nuestro Ordenamiento penal, se estima que la infracción penal no existió. En efecto, los acusados estimaron que con su comportamiento ejercitaban su libertad religiosa e ideológica y que, atendida la condición de ésta como derecho fundamental, habría de prevalecer sobre la que establecía la Ley Electoral. Ello no es así, pero no cabe duda de que la reflexión que precedió a la negativa, y que fue aceptada por el juzgador de instancia, era aceptable», FJ $6^{\circ}$ STS, de 29 de septiembre de 1993, rec. 759-1993.

455 FJ $5^{\circ}$ STS, de 29 de septiembre de 1993, rec. 759-1993. 


\section{Objeción de conciencia en la culpabilidad}

\section{Postulados doctrinales sobre el concepto material y formal de culpabilidad}

Es acertada la consideración que afirma que la mayoría de la doctrina que se ha ocupado sobre la autoría de conciencia encuentra soluciones en la institución de la culpabilidad ${ }^{456}$, aunque dicha conclusión ha de ser matizada porque quienes encuentran algún efecto privilegiante en la culpabilidad, como no podía ser de otro modo, utilizan fundamentos amparados en otras instituciones o normas, si bien, en todas estas posturas está como determinante la concepción que se trate sobre el concepto de culpabilidad.

Como dice MIR PUIG, es más correcto utilizar la terminología «imputación personal» en vez del término «culpabilidad» que fue utilizado por VON LISZT y por la doctrina posterior ${ }^{457}$. La «concepción psicológica de la culpabilidad» de VON LISZT parte de entender la culpabilidad como «la relación subjetiva entre el acto y el autor» ${ }^{458}$. Se entendía que el dolo y la imprudencia como dos especies de culpabilidad. El dolo se concebía como la clase más perfecta de culpabilidad al existir una relación psicológica más completa entre el hecho delictivo y el autor, mientras que la imprudencia evidenciaba una relación más imperfecta de lo psicológico y el hecho. Pero estos planteamientos no pudieron explicar la «culpa inconsciente», ni por qué en algunas causas de exculpación aparece el dolo. VON LISZT, adoptando el criterio de VON OTTINGEN, recordaba que el fin de la pena en algunas ocasiones tiene restricciones en la relación de la culpabilidad con la Sociedad ${ }^{459}$.

La teoría normativa de la culpabilidad, fundamentalmente tras las aportaciones de GoldSCHIMIDT, Freudentahl y FrANK, consideraba que la culpabilidad es un juicio de reproche en la voluntad defectuosa. El dolo y la imprudencia representaban esa voluntad. Entonces, si no se apreciaba ninguna causa de exculpación como el estado de necesidad disculpante o el miedo insuperable, se completaba totalmente la reprochabilidad. Pero el fallo de esta teoría fue mantener el concepto psicológico del hecho, no abandonó el concepto causal de la acción.

456 BAUCELls I Lladós, J., La delincuencia por convicción, op. cit., p. 312.

457 MIR PUIG, S., PG, op. cit., p. 539, y nota núm. 1, dice que «la expresión imputación personal tiene la ventaja de que deja más claro que en esta segunda parte de la teoría del delito se trata de atribuir (imputar) el desvalor del hecho penalmente antijurídico a su autor: no se castiga una «culpabilidad» del sujeto, sino que sólo se exige el hecho penalmente antijurídico, lo único que el Derecho desea prevenir (si puede), sea imputable penalmente a su autor (...) Según esto la imputación personal no añade al injusto penal ningún objeto específico de desvalor que contribuya a fundar la pena, como, sin embargo, pretende la teoría de la "actitud interna"».

458 LISZT, F. von, Tratado, II, op. cit., p. 388.

459 ID., ibidem, op. cit., pp. 29 y 30: «el conocimiento de que el crimen tiene su raíz profunda en las circunstancias sociales, evitará la exageración de la idea finalista. La convicción de la "culpa colectiva de la Sociedad (...) trazará los límites de la actividad punitiva del Estado». 
La concepción normativa pura de la teoría finalista consiguió desvincularse de estos presupuestos causales y establecer que el objeto de reprochabilidad se centra en el injusto, mientras que la culpabilidad se refiere a las circunstancias que permiten atribuir personalmente la concurrencia de injustos. De esta manera, la imputabilidad era la incapacidad de culpabilidad; el dolo se entendía como «dolo natural», lo que sitúa al sujeto en lo injusto; mientras que el dolus malus pertenecía a la culpabilidad, porque este dolo se consideraba que suponía el conocimiento de la antijuricidad o la posibilidad de conocimiento. Entonces la falta de la posibilidad de conocimiento, según la teoría finalista, no elimina la conducta dolosa, es decir, no elimina el «dolo natural», sino que supone la exclusión de la culpabilidad por un error de prohibición invencible, pero si es vencible supone una atenuación de dicha culpabilidad.

Visto lo anterior, nuestra posición parte de considerar la culpabilidad como «atribuibilidad personal»o «imputación personal» de lo injusto. Partimos de una concepción normativa de la culpabilidad, pero asumiendo también un fundamento material distinto. El fundamento material de la culpabilidad no puede hallarse en la doctrina del libre albedrío, ni en el «poder actuar de otro modo», como afirmaba ENGISCH. Ni se puede demostrar científicamente que el hombre se mueva por causas libres, no naturales, ni lo contrario, los factores naturales pueden determinar la conducta de alguna manera en muchas situaciones.

La teoría de la motivación de la norma ${ }^{460}$ defiende que el principio material de culpabilidad no se puede fundamentar en la metafísica posibilidad de actuar de otro modo. La norma tiene capacidad para motivar a los sujetos para adecuar el comportamiento conforme al Derecho. La culpabilidad se refiere a la falta de motivación atribuible al sujeto

Por nuestra parte, y a diferencia de la teoría de la motivación de la norma, el fundamento material de la culpabilidad es la falta de orientación funcional a la norma atribuible al sujeto. La atribuibilidad de lo injusto del hecho es la capacidad del sujeto de adecuarse/orientarse a los dictados de la norma otorgándole mediante su actuar validez, pero también de la capacidad de la norma de comunicar dicha orientación comportamental. En este sentido aceptamos parcialmente

\footnotetext{
460 Esta teoría procede de los planteamientos de Roxin en cuanto que la culpabilidad es el límite de la pena, pero no la fundamenta per se, sino que la culpabilidad exclusivamente limita la determinación de la pena. RoxIN, C., $P G$, I., op. cit., pp. 813 y ss; ID., «Qué queda de la culpabilidad en Derecho penal», trad. Jesús-María Silva Sánchez, $C P C, 30,1986$, pp. 688 y ss; le siguen GARCÍA ARÁN, M., «Culpabilidad, legitimación y proceso», ADPCP, 1988, p. 86; GIMBERNAT, E., «El sistema del Derecho penal en la actualidad», Estudios de Derecho penal, op. cit., p. 174 y ss; GonZÁLEZ MATEOS, JC., «Esencia de la norma penal y antijuricidad de la tentativa», Anuario de la Facultad de Derecho, Band, 18, Universidad Extremadura, Cáceres, 2000, p. 194 y ss; MIR PUIG, S., PG, op. cit., p. 551; ID., Introducción a las bases del Derecho penal: concepto y método, $2^{\mathrm{a}}$ ed. Reimp., 2003 de la $1^{\mathrm{a}}$ ed. 1976 , Bosch, Montevideo, pp. 56 y ss; MUÑOZ CONDE, F., «El principio de culpabilidad», op. cit., pp. 229 y ss; ID., Introducción al Derecho penal, op. cit., pp. 50 y ss; ID., «Introducción», RoXIN, C., Culpabilidad y prevención en Derecho penal, op. cit., p 23; MuÑOZ CONDE Francisco / GARCÍA ARÁN Mercedes, Derecho penal, Parte general, $6^{\mathrm{a}}$ ed. revisada y puesta al día, Tirant lo Blanch, Valencia, 2004, p. 357 y ss.
} 
los postulados de JAKOBS sobre el concepto funcional de culpabilidad como reproche normativo. Nuestra aportación estriba en que la norma, cuya función es la comunicación de la orientación de conductas, ha de ser capaz también de identificarse con la toda la Sociedad. El reproche normativo también puede atribuirse a la propia norma. En ocasiones a ésta le es reprochable un déficit de comunicación, que habilita al sujeto a comportarse en una orientación discrepante. En determinadas circunstancias la norma sufre un déficit de comunicación que se puede calificar de contraorientación normativa cuando el ejercicio de la libertad de conciencia viene refrendada no sólo por la norma general, sino en muchas ocasiones por la permisividad normativa (inscripción de la confesión en el correspondiente registro) o por la Sociedad cuando acepta determinadas conductas de forma consuetudinaria), de forma tal que la contraorientación normativa se produce cuando de forma subrepticia y sorpresiva otra norma obliga a comportarse en contra de la permisividad (riesgo permitido) pero en un momento en el que el sujeto se ha socializado conforme a dicha permisividad, por lo que el quebrantamiento normativo procede de un déficit de comunicación atribuible a la norma que impide hacer responsable al sujeto. La culpa de dicho quebrantamiento es de la norma que ha permitido que el sujeto conecte subjetivamente su conciencia y su voluntad de forma ineludible.

En este sentido, la culpabilidad es la falta de fidelidad al Derecho cuando existen alternativas en la esfera de auto-organización para actuar de otra forma que no quebrante la norma. En esta medida la culpabilidad no es una construcción psicológica ni neurológica sino social, de tal modo que la culpabilidad tiene una función preventiva, general y positiva de mantener el Sistema Social. La culpabilidad es el reproche normativo por defraudación de la expectativa social que se identifica con la norma. El reproche comunica que ciertas conductas defraudan la expectativa social de los demás pero más Sistema Social ${ }^{461}$. De esta manera, la pena cumple la función de restablecer la defraudación generada en el Sistema, la pena reconstruye de facto el quebrantamiento de la vigencia de la norma.

Por eso, cuando la norma no se identifica con la sociedad, o no responde a parte de la sociedad, o habilita previamente a parte de la sociedad a adecuar la conducta de una determinada manera, no puede posteriormente exigir una determinada conducta contradictoria con la previa habilitación. Podría decirse que existen argumentos que fundamentarían esta conclusión con base a la teoría de la «prohibición de regreso», si bien, como el sujeto se ampara en una motivación estrictamente subjetiva en la conexión entre conciencia y voluntad, la contraorientación no es

\footnotetext{
461 JAKOBS, G., Sociedad, norma y persona en una teoría de un Derecho penal funcional, trad. Manuel Cancio Meliá y Bernardo Feijoo Sánchez, Civitas, Madrid, 1996, p. 63.
} 
puramente objetiva entre las normas en conflicto, sino puramente subjetiva. Efectivamente ambas normas coexisten en el mismo tiempo, la que habilitó al sujeto a ejercitar su voluntad conforme a su conciencia y la que por ejemplo le obliga a socorrer, sin embargo al presentarse la obligatoriedad normativa de forma sorpresiva, esto es, el peligro del tercero viene sin previo aviso, sino que las circunstancias de dicho peligro se presentan sorpresivamente, el sujeto aun conociendo que ha de conformar su conducta a esa norma que se le ha presentado, no puede por esa previa socialización de la norma en el ejercicio de la libertad de conciencia, lo que constituye a la postre que la segunda norma que entra en conflicto no pueda orientar al sujeto por un déficit de comunicación entre la previa socialización y las concretas circunstancias presentadas sorpresivamente.

Dicho lo cual, no aceptamos - como hace MIR PUIG- que lo responsable penalmente viene a causa de que el sujeto «pudo ser (pasiva) y fue motivado normalmente», es decir, no aceptamos que «la capacidad pasiva de ser influido (normalmente) por las normas» ${ }^{462}$ sea el fundamento material de la culpabilidad, sino la capacidad propia del sujeto de orientarse a sí mismo para actuar conforme a la orientación que propone la norma como expectativa social, pero entendida esa capacidad como la capacidad que a todo hombre, en cuanto persona, le es exigida por el Derecho en un espacio y tiempo determinado. Y viceversa, la capacidad de la norma de orientar y comunicar conductas.

En nuestra opinión, el Derecho sólo puede pedir aquello que todos los hombres pueden hacer, en este sentido, tampoco al hombre se le puede exigir «ser» ni «tener» conocimientos de un «hombre medio». La cuestión inicial es si en la autoría de conciencia y en la autoría por convicción existe un déficit de fidelidad a la norma que proceda de causas cognitivas y/o volitivas del sujeto (déficit psicológico de comprender el sentido de la norma o determinarse conforme a esa comprensión ${ }^{463}$ ), cuestión bien distinta de un déficit de socialización atribuido a la propia norma o al conjunto del ordenamiento jurídico, o atribuible a un tercero que causa un déficit de socialización al autor. Ambos casos los trataremos más adelante.

\section{Introducción a las causas de inimputabilidad}

El propósito de las siguientes líneas es dilucidar si el autor de conciencia puede acogerse a alguna de las causas de inimputabilidad que recoge nuestro $\mathrm{CP}$, es decir, si estos autores pueden ser, por ejemplo, enfermos mentales, cosa que ya anticipadamente podemos concluir que

462 MIR PUIG, S., $P G$, op. cit., p. 557.

${ }^{463}$ Polaino Navarrete, M., Lecciones de Derecho penal, Parte General, T. II, op. cit., p. 157. 
difícilmente podrá ser si el presupuesto básico del que partimos es que estos autores conocen y tienen voluntad de realizar los hechos antijurídicos, sin embargo, si el sujeto sufre un déficit de socialización que a la postre le causa una enfermedad, debemos debatir si sigue presentando los presupuestos de que en su actuar, aun causado por una enfermedad, existen motivos de conciencia.

Por eso, y como veremos, habrá que plantearse la posibilidad de que algunos terroristas o líderes de sectas o miembros de ellas sean autores inimputables o semi-imputables por causa de un «lavado de cerebro», «manipulación mental», «adicción comportamental», o si estas causas son sólo déficit de socialización como formas de «aislamiento cultural» o de «obediencia ciega a la autoridad», y qué trascendencia jurídico penal tiene en su tratamiento, sin que sea preciso que este déficit se le catalogue como enfermedad.

Según la doctrina dominante la imputabilidad es la capacidad de comprender lo injusto del hecho, y la capacidad que tiene el sujeto de dirigir su obrar conforme a lo que entiende como hecho ilícito ${ }^{464}$, por lo que el presupuesto básico del que parte nuestro Derecho penal, y en concreto la teoría sobre la culpabilidad, es el libre albedrío. Sin este presupuesto según las conclusiones a las que hemos llegado en el primer capítulo, cuyo fundamento es la intuición/sentimiento de libertad psíquicamente hablando, o el producto de la operación en la elección de expectativa desde un punto de vista sistémico, el sujeto es un elemento más de la naturaleza, una causa y consecuencia natural más.

En nuestro Código Penal se recoge de forma completa en los apartados primero y segundo del art. 20, y de forma incompleta en el art. $21.1^{\mathrm{a}}, 2^{\mathrm{a}}$ y $3^{\mathrm{a}} \mathrm{CP}$ las causas de inimputabilidad, aunque la minoría de edad del art. $19 \mathrm{CP}$, y la eximente del art. $20.3^{\circ} \mathrm{CP}$, también tienen parte de los componentes normativos de las dos primeras.

Se suele exigir para apreciar la inimputabilidad, la plena -no absoluta-, perturbación de las facultades intelectivas para conocer la antijuricidad, o perturbación plena de la voluntad para adecuarse al conocimiento de la antijuricidad. Entonces la imputabilidad debe referirse a la capacidad personal del sujeto para orientarse conforme a la norma. El inimputable es incapaz, cognitiva y/o volitivamente, de orientar su comprensión y dirigir su voluntad conforme a ella. En caso contrario, si el sujeto no puede orientarse conforme al Derecho cuando la norma entra en su radio de acción con pleno sentido comunicativo, a pesar de tener capacidad para cumplirla, en estas ocasiones podemos hablar de «creencia discrepante ante el Derecho», o en otros casos

\footnotetext{
464 JeSCHECK Hans-Heinrich / WeIGEND Thomas, Tratado de Derecho penal, Parte General, $5^{\mathrm{a}}$ ed., ampliada y renovada, trad. Miguel Olmedo Cardenete, Granada, 2002, 40, I y ss; POLAINO NAVARrete, M., Lecciones de Derecho penal, Parte General, T. II, op. cit., pp. 159 y ss.
} 
podemos hablar de «error de prohibición» cuando la norma no alcanza el radio de conocimiento del sujeto en grado de evitabilidad o inevitabilidad. La imputabilidad es entonces distinta de las causas de exculpación. En éstas la falta de orientación normativa del sujeto proviene de causas también exógenas al sujeto, y no exclusivamente sus circunstancias internas como en las causas de inimputabilidad.

Téngase en cuenta entonces que la inimputabilidad no es en esencia una ausencia total y absoluta de lo intelectivo y/o volitivo del sujeto activo durante la comisión del delito, sino una anormalidad o déficit físico y/o psicológico del sujeto. Si la inimputabilidad se basará en la ausencia absoluta de las cualidades humanas, estaríamos hablando de una causa natural, y por lo tanto no de culpabilidad o capacidad de atribuibilidad personal, sino de atipicidad por suponer la falta de acción humana (ausencia de acción) ${ }^{465}$.

\section{La anomalía o alteración psíquica del art. $20.1^{\circ} \mathrm{CP}$}

Las anomalías o alteraciones psíquicas que tradicionalmente recoge la ciencia médica son las psicosis, las oligofrenias, las neurosis y las psicopatías. La transcendencia de estas enfermedades en la responsabilidad penal es variada, lo que precisa detenernos en su relación con la autoría de conciencia y por convicción.

$\mathrm{El}$ art. $20.1^{\circ} \mathrm{CP}$ establece que están exentos de responsabilidad criminal «el que al tiempo de cometer la infracción penal, a causa de cualquier anomalía o alteración psíquica, no pueda comprender la ilicitud del hecho o actuar conforme a esa comprensión», por lo que esa alteración o anomalía no tiene por qué ser permanente, sólo se exige que concurra en el momento de cometer la infracción penal. El segundo párrafo aclara más todavía esto último: «El trastorno transitorio no eximirá de pena cuando hubiese sido provocado por el sujeto con el propósito de cometer el delito o hubiera previsto o debido prever su comisión».

Dicho esto, la inimputabilidad en nuestro CP ha seguido una fórmula mixta ${ }^{466}$ para apreciar la incapacidad, como son las anomalías psiquiátricas o biológicas y la anomalía psicológica. Esto quiere decir que sólo se apreciará la inimputabilidad o la semi-imputabilidad de la responsabilidad penal cuando el sujeto tenga una anomalía psiquiátrica (fórmula psiquiátrica) en el momento del delito y le haya afectado significativamente en su conducta (fórmula psicológica).

\footnotetext{
465 Polaino NaVARReTe, M., Lecciones de Derecho penal, Parte general, T. II, op. cit., pp. 121 y ss., y p. 171.

466 ID., ibidem, op. cit., p. 169.
} 
En nuestra opinión, la psicosis ${ }^{467}$ no es una causa que se presente en la autoría de conciencia ni en la autoría por convicción. Esto es porque tanto el autor de conciencia como el autor por convicción obran consciente y voluntariamente, aunque sea de forma infalible, lo que posibilita la conducta imprudente o de peligro, por lo que se descarta la posibilidad de que no comprendan lo ilícito. Sin embargo, en cuanto al otro presupuesto de la psicosis, el que se refiere a que no pueda el sujeto actuar conforme a tal comprensión se plantean mayores problemas. En este caso, es verdad que el autor de conciencia y el autor por convicción actúan de forma ineludible, sin embargo por la evidente conexión entre la conciencia moral/religiosa/ideológica y la voluntad, no puede apreciarse la parte somática ni la transformación de las leyes físicas (alucinaciones) ni de la conciencia, salvo los casos más graves que estudiaremos de «manipulación mental»o «persuasión coercitiva». Tampoco se aprecian fases lúcidas que motiven la eximente incompleta en la autoría de conciencia y en la autoría por convicción, salvo los casos asociados a la «manipulación mental» $\mathrm{o}$ «persuasión coercitiva» que estudiaremos.

En nuestra opinión, la oligofrenia ${ }^{468}$ no es un presupuesto ni tan siquiera hipotéticamente tratado de la autoría de conciencia y por convicción.

Las neurosis suelen apreciarse como trastornos transitorios del art. $20.1^{\circ}$ segundo párrafo del $\mathrm{CP}$, y en casos de obsesión irresistible. La neurosis es una respuesta psíquica fuera de lo normal en situaciones normales que puede llevar al sujeto que la sufre a tal estado de angustia y ansiedad que no puede evitar obrar de otra forma. Esta ansiedad y angustia aparecen en la autoría de conciencia, no así en la autoría por convicción (terroristas) por cuanto en la primera el autor no

467 La psicosis es una enfermedad mental que se caracteriza por tener una base somática y una transformación de las leyes físicas (alucinaciones). Las psicosis se dividen en por un lado en endógenas (nacen del propio organismo del enfermo), como la esquizofrenia, la paranoia, la psicosis maníaco-depresiva y la epilepsias, y de otra parte en exógenas (nacen factores externos) como las toxifrenias (nacen de intoxicaciones de drogas o alcohol, entre las que se encuentra especialmente la embriaguez patológica), las psicosis traumáticas y las psicosis sifilíticas (nacen de traumatismo o infecciones respectivamente), y las psicosis de demencias seniles y preseniles (nacen de deficiencias mentales producidas por la edad normalmente), ID., ibidem, op. cit., pp. 170 y 171 . Así pues, en cuanto a la psicosis, ésta puede llevar al sujeto a no comprender lo ilícito del hecho o, a no poder actuar conforme a tal comprensión, con lo que el sujeto será inimputable si la intensidad de la anomalía en el momento de la comisión es plena en cualquiera de los dos presupuestos, intelectual o volitivo (STS, de 3 de mayo de 1995 en casos de esquizofrenia, por ejemplo), mientras que en los casos en los que no se aprecie la plena intensidad, se apreciará la eximente incompleta en virtud del art. 21.1 ${ }^{\text {a }}$ CP. Por otro lado, como bien describen las SSTS, de 27 de marzo de 1989, y de 24 de marzo de 1992, la psicosis maníaco-depresiva y la epilepsia plantean la problemática de los intervalos lúcidos (aura epiléptica y estados crepusculares). En estas sentencias se establece que si durante el ataque se aprecian intervalos lúcidos, no será posible la eximente completa sino la incompleta.

468 La oligofrenia es una deficiencia del grado de la inteligencia. Se divide en varias vertientes, a saber: la debilidad mental (oligofrenia leve), la imbecilidad (oligofrenia media) y la idiocia (oligofrenia profunda). Por otro lado, y respecto a la oligofrenia, sólo se considera como causa de inimputabilidad cuando es profunda como en los casos de imbecilidad e idiocia. En los casos de debilidad mental se suele apreciar la eximente incompleta del art. $21.1^{\text {a }} \mathrm{CP}$, o si tiene una intensidad más leve se suele apreciar la atenuante analógica de art. 21.7 ${ }^{\mathrm{a}} \mathrm{CP}$. En cambio, la torpeza mental, al ser un estado entre la normalidad intelectual y la debilidad mental, no se aprecia ni siquiera la atenuante. 
desea quebrantar la norma, sino que se ve obligado a hacerlo para obrar según su personalidad pero ante una situación anormal como es el conflicto de desear cumplir la norma jurídica. Si bien la situación es irresistible no proviene de una situación normal, sino precisamente de conflicto anormal, hasta el punto que el autor de conciencia no desea que su obrar, su delito, sea una norma aplicable a los demás, sino estrictamente particular, de conciencia, por eso la situación es objetivamente anormal también porque no se pretende atacar la vigencia de la norma, sino su aplicabilidad a un caso particular de conciencia.

De otra parte, tradicionalmente la psicopatía ${ }^{469}$ se ha tratado como enfermedad moral, por eso no se reconoce trascendencia penal alguna en la culpabilidad. Por esta equiparación con enfermos morales, los psicópatas se han vinculado tradicionalmente con los autores por convicción, si bien la psicopatía únicamente se aprecia en un porcentaje ínfimo, por lo que no pude equipararse la autoría por convicción y psicopatía. La jurisprudencia del TS acierta al no eximir ni atenuar por tal causa, salvo en casos en que la psicopatía vaya acompañada de otra enfermedad. No obstante, cuando los comportamientos psicopáticos tienen manifestaciones graves, o concurren con la debilidad mental, la neurosis y otros trastornos cerebrales, de modo que afectan a la inteligencia o a la voluntad, pueden repercutir en la imputabilidad. Algunos casos de autoría por convicción, como los terroristas y algunos líderes de sectas, son claros ejemplos de psicopatías sin concurrencia de otra enfermedad ${ }^{470}$.

Amén de ello, no podemos definir la moral como ente digno de calificarse con los parámetros propios de una enfermedad aunque el comportamiento fuere extremadamente inmoral. No obstante, hay casos a los que hemos denominado de déficit de socialización que a causa de una adicción comportamental, manipulación mental, persuasión coercitiva u obediencia ciega a la autoridad, similares al «aislamiento cultural», que en su máxima gravedad pueden producir trastornos mentales que fundamenten un actuar criminal y al que podría aplicársele las circunstancias exonerantes del art. 20 y 21 CP. En este sentido, la problemática real sobre las posibles causas de inimputabilidad vendrá no cuando se constriña o se domine el ejercicio de la libertad de voluntad de actuar en general y especialmente de la configuración religiosa o de la conciencia, sino si se causa un trastorno o anomalía psíquica.

\footnotetext{
469 Las psicopatías son anomalías en el carácter, es decir, en el modo de ser, en la personalidad. Lo característico de los psicópatas es que son unos enfermos o locos morales, capaces de realizar crímenes horrendos sin el más mínimo remordimiento.

${ }^{470}$ GAUPP sostuvo que el autor por convicción es un fanático en ámbito político o religioso con posible psicopatía, esquizofrenia y rigidez afectiva, al que se le debe aplicar un tratamiento psicoterapéutico, vid. BAUCELLS I LLADÓs, J., La delincuencia por convicción, op. cit., p. 331 (GAUPP, R., «Der überzeugungsverbrecher», Monatsschrift für kriminalpsychologie und Strafrechtsreform, Carl Winters Universitätsbuchhandlung, Heidelberg, 1926, pp. 398 y 399).
} 


\section{El trastorno mental transitorio del art. $20.1^{\circ}$ segundo párrafo y del art. $20.2^{\circ}$ del CP en}

los conflictos de conciencia

Como ya hemos mencionado en anteriores líneas, el trastorno mental transitorio como causa de inimputabilidad viene regulado en el segundo de los párrafos del art. $20.1^{\circ} \mathrm{CP}$, pero en el siguiente número se aducen dos causas específicas. Según este precepto, están exentos de responsabilidad criminal «el que al tiempo de cometer la infracción penal se halle en estado de intoxicación plena por el consumo de bebidas alcohólicas, drogas tóxicas, estupefacientes, sustancias psicotrópicas u otras que produzcan efectos análogos, siempre que no haya sido buscado con el propósito de cometerla o no se hubiese previsto o debido prever su comisión, o se halle bajo la influencia de un síndrome de abstinencia, a causa de su dependencia de tales sustancias, que le impida comprender la ilicitud del hecho o actuar conforme a esa comprensión». Así pues, no sólo una enfermedad mental transitoria que determine en el sujeto la comisión de un delito es una enfermedad transitoria, sino también aquellas que provienen de causas externas (exógenas), como las drogas o el propio síndrome de abstinencia, ya que el elemento fundamental de la eximente de trastorno mental transitorio, la transitoriedad, se puede cumplir por estas causas exógenas o endógenas. Para que exima ha de producir el efecto de una anomalía o alteración psíquica durante la comisión delictiva: el trastorno tiene un límite temporal y causal.

En nuestra opinión, no se exige la base patológica porque no viene expresamente recogida en la letra del precepto. Especialmente la intoxicación por alcohol, drogas u otras sustancias estupefacientes plantea la problemática del grado o intensidad en la anulación de la conciencia y/o voluntad, y de las conductas pre-ordenados, las voluntarias, culposas ofortuitas con las que se llega a tales estados de intoxicación. Por eso, una problemática de la autoría de conciencia o por convicción es aquella que el autor la haya «buscado con el propósito de cometerla o no se hubiese previsto o debido prever su comisión». Aquí entramos en la problemática de la actio libera in causa, si al autor le era exigible evitar la irrogación de un riesgo en la conexión tan íntima e ineludible de la conciencia con la voluntad.

No cabe plantear aquí problemática más que la consideración de que la asunción de la conciencia religiosa/moral o ideológica supone un elección siempre riesgosa, pero de los riesgos catalogados como «permitidos» en Derecho, amparados por el derecho fundamental a la libertad de conciencia, de tal manera no se puede retrotraer la imputación de la culpabilidad, aun en los prototípicos casos de arrebato u obcecación, al momento en el cual se asume una conciencia 
moral determinada, por mucho que se conozca que a la postre puede suscitar una situación, por ejemplo de peligro para la vida, como en los casos de omisión del deber de socorro. Esto se debe fundamentalmente a que en la autoría de conciencia y por convicción en principio no se aprecian trastornos ni enfermedades mentales, salvo los casos graves que debatiremos infra de «adicción comportamental», «manipulación mental», «persuasión coercitiva», y «obediencia ciega a la autoridad», que den como consecuencia un trastorno o enfermedad que cause a la postre la exoneración o disminución de la responsabilidad, o en cuyo defecto, si estas circunstancias personales pueden haber sido buscadas o exigible su evitación, de modo que se retrotraiga la imputación subjetiva. Sobre esto volveremos, si bien, como decimos, en principio estos casos serían excepcionales.

En este sentido, la mayoría de la doctrina ${ }^{471}$ ha rechazado la aplicación de una causa de inimputabilidad en el conflicto de conciencia. Así, BAUCELLS ${ }^{472}$ admite la posibilidad de ciertas neurosis obsesivas, el fanatismo y la esquizofrenia como posible causa de trastorno mental en determinados casos. Considera es posible aplicar la eximente de alteración psíquica en casos de sujetos que desde su infancia están sometidos a un determinado contexto cultural y de valores que impiden acceder a las normas culturales de la sociedad ${ }^{473}$.

JERICó le opone la objeción crítica de que estos casos se reconducirían a los de error de prohibición «ya que el hecho de que el sujeto se encuentre aislado de lo considerado socialmente normal no afecta a su capacidad biológica para conocer la norma, sino al hecho de que desconozca la norma jurídica imperante en dicha sociedad» ${ }^{474}$. Sin embargo, JERICó admite que, en casos de sectas fanáticas el adepto pueda tener afectada su capacidad de culpabilidad, «su comprensión acerca de lo ilícito de su hecho y la actuación conforme a dicha comprensión» ${ }^{475}$, si bien no lo atribuye a un conflicto de conciencia sino a la misma alteración psíquica aunque existen casos que podrían venir de dicho conflicto.

TAMARIT SUMALlA ${ }^{476}$ critica la aplicación del arrebato y obcecación en determinadas circunstancias como en el caso recogido por la STS de 27 de marzo de 1990 en el que se condena por homicidio doloso a un Testigo de Jehová por desconectar el catéter durante la trasfusión de sangre, puesto que no es admisible en un Estado de Derecho tratar a los sujetos creyentes como

471 BAUCElls i Lladós, J., La delincuencia por convicción, op. cit., pp. 335 y ss; FlORES MeNDOZA, F., Objeción de conciencia, op. cit., pp. 202 a 204; JERICÓ OJER, L., El conflicto de conciencia, op. cit., pp. 370 a 374, y pp. 463 y 464; TAMARIT SUMALLA, JM ${ }^{\mathrm{a}}$., «La objeción de conciencia», op. cit., p. 41.

472 BAUCELls I LLADÓs, J., La delincuencia por convicción, op. cit., pp. 335 y ss.

473 ID., ibidem, op. cit., pp. 335 y 336.

474 JERICÓ OJER, L., El conflicto de conciencia, op. cit., pp. 371 y 463.

475 ID., ibidem, op. cit., p. 371.

476 TAMARIT SUMALlA, JMa ., «La objeción de conciencia», op. cit., p. 41. 
obcecados. JERICÓ ${ }^{477}$ comenta al respecto que si se ampara la libertad de conciencia, a la postre no puede ser tratada como una anomalía psíquica, lo que implicaría una especie de superioridad moral del Estado ante determinadas conductas realizadas por conciencia.

LUZÓN PEÑA, si bien considera que el autor por convicción merece el máximo reproche penal por su peligrosidad y por su enfrentamiento «total» con el ordenamiento jurídico, sin embargo admite que en casos «muy excepcionales» la situación psicológica de fanatismo del autor por convicción puede ser «anormal», y expone el caso de los lavados de cerebro en los que existe una anomalía psíquica o de trastorno mental transitorio que excluya la culpabilidad por inimputabilidad que fundamenta la aplicación de medidas de seguridad por la peligrosidad que demuestra $^{478}$.

De manera similar, FloRES MENDOZA ${ }^{479}$ considera aplicable la eximente de alteración o anomalía psíquica en un sujeto obligado a los dictados de una conciencia cuando llega al fanatismo o a la neurosis o a la patología, con lo que estamos de acuerdo, lo cual tampoco niega, como bien ha apuntado JERICÓ, que dicha alteración llegue a fijar siempre una conciencia y valores considerados supremos que originen a la postre un conflicto de conciencia de obligado cumplimiento. En este sentido niega que en estos casos se pueda hablar de verdadero conflicto de conciencia porque se aplicaría la inimputabilidad.

Con este último argumento, empero, no podemos estar de acuerdo según lo visto. Quien llega con una previa dolencia o alteración a una secta, y su dolencia se incrementa, inclusive por causa ajena o de tercero, puede igualmente desarrollar una prelación de valores que a la postre le hagan actuar contra la norma sin tener ya anomalía psíquica alguna, o dicho de otro modo, si bien la doctrina mayoritaria niega la aplicación de la eximente o la atenuación por causas de alteración mental o anomalía psíquica o enfermedad mental, parte de la doctrina que se ha interesado especialmente sobre el tema de la autoría de conciencia y por convicción -así, BAUCELLS, Jericó, Flores Mendoza, Luzón PeÑa y TAMARit Sumalla- aceptan la posibilidad que en ciertos circunstancias de fanatismo y/o de contexto cultural desde la infancia, se reproduzca una alteración psíquica tan relevante que produzca el conflicto de conciencia que estamos estudiando. Espero demostrar que si bien esta conclusión es acertada, le falta una mayor argumentación. La posibilidad de exención o atenuación de la responsabilidad criminal puede también fundamentarse sin irrogar el alcance normativo de las causas de inimputabilidad, sino más bien especialmente en la inexigibilidad. Esto es porque la causación de un trastorno o

477 JERICÓ OJER, L., El conflicto de conciencia, op. cit., pp. 370 a 374.

478 LUZÓN PEÑA, D-M., «Actuación en conciencia», op. cit., p. 15.

479 Flores MendOZA, F., Objeción de conciencia, op. cit., pp. 203 y 204. 
anomalía psíquica constituye, por un lado, la consecuencia de la gravedad en la que se ha desarrollado el fanatismo y/o el contexto cultural del sujeto desde la infancia, o sea, una lesión psíquica que fundamenta luego el conflicto de conciencia o la convicción, o por otro lado, una circunstancia que se produce antes o durante el fanatismo y/o el contexto cultural sin que éstos haya mediado o intervenido en dicha causación.

5. La alteración de la percepción del art. $20.3^{\circ}$ del CP, como imposible eximente en los autores por convicción y de conciencia

Preceptúa el art. 20.3 $\mathrm{CP}$ que está exento de responsabilidad criminal «el que, por sufrir alteraciones en la percepción desde el nacimiento o desde la infancia, tenga alterada gravemente la conciencia de la realidad». Esta eximente supone un déficit de conciencia o sensorial que podría haber sido suplida por la fórmula «cualquier anomalía» psíquica del art. $20.1^{\circ} \mathrm{CP}$, como acertadamente recuerda POLAINO NAVARRETE ${ }^{480}$, si bien no toda falta de percepción es pretexto para la inimputabilidad, por ejemplo, un homicidio puede ser cometido por un ciego. El precedente legislativo eximía a los sordomudos de nacimiento o desde la infancia que carecieren «en absoluto» de instrucción, por lo que en la actualidad no hay motivo para dejarles fuera de la eximente a pesar de que no se les nombren.

El requisito normativo esencial es que la alteración de la percepción sea desde el nacimiento o la infancia, con esto se exige en verdad que provenga de una causa endógena, y que afecte tan intensamente en la conciencia de la realidad o a los sentidos que haga al sujeto dirigir su voluntad a realizar lo ilícito, el sujeto no puede orientarse conforme a la norma. El sordomudo desde el nacimiento, por lo general, no tiene posibilidades de conocer la norma, es un incomunicado psíquico, lo que le afecta en la falta de capacidad de recibir la comunicación material de la norma. Por ejemplo, si un ciego ayuda activamente en la ejecución de un suicidio (autor de conciencia), o un terrorista también invidente (autor por convicción) coloca una bomba en los bajos de un coche, no existe criterio jurídico para eximir de responsabilidad, pues la alteración de percepción en estos dos casos no conlleva una alteración grave de la conciencia de la realidad normativa en ese espacio-tiempo.

En la doctrina española, únicamente TAMARIT SuMALLA ${ }^{481}$ acepta la posibilidad de una atenuante de esta clase en «supuestos de aislamiento cultural» que impida valorar al sujeto las

480 Polaino NaVarrete, M., Lecciones de Derecho penal, Parte general, T. II, op. cit., pp. 172 y 173.

481 TAMARIT SUMALLA, JMª., «Libertad de conciencia y responsabilidad penal: relevancia de los motivos de conciencia en la valoración de la antijuricidad y culpabilidad», Laicidad y Libertades. Escritos Jurídicos, 1, 2001, pp. 397 y ss. 
circunstancias por el lejano conocimiento de los valores de una sociedad. De tal manera, este penalista utiliza un concepto, demasiado amplio y lejano del término «percepción» en relación a los elementos exigidos en la eximente que exclusivamente se centran en la alteración de la percepción desde el nacimiento o la infancia ${ }^{482}$. En este sentido, el precepto no habla ni implícitamente de «aislamiento cultural».

FLORES MENDOZA se ha mostrado tajantemente contraria a la concurrencia de algún tipo de alteración mental o anomalía tanto de los arts. $20.1^{\circ}, 2^{\circ}$ y $3^{\circ}$ como del $21.3^{\mathrm{a}} \mathrm{CP}$ sin perjuicio de que existan casos excepcionales «(p)ero en tales circunstancias será la exclusión o disminución de la capacidad de culpabilidad la que excluirá o disminuirá la pena, y no los motivos de conciencia. Incluso sería discutible (...) que en estos casos se hablara de conflicto de conciencia en sentido estricto y, por tanto, de objeción de conciencia» ${ }^{483}$ y porque la causa, según doctrina y jurisprudencia mayoritaria, han de ser externas ${ }^{484}$. Pero a la vez aboga por la apreciación de la atenuante analógica en casos excepcionales cuando el fundamento sea el mismo que una de las causas de exención de la responsabilidad, inclusive afirma que se podría apreciar la atenuante muy cualificada rebajando la pena en uno o dos grados ${ }^{485}$.

En nuestra opinión, el aislamiento cultural no sería una causa de exención o disminución de la imputación subjetiva en el sentido expuesto por esta circunstancia sino de inexigibilidad o estado de necesidad exculpante, en aquellos supuestos que sin llegar a suponer una alteración de la percepción o anomalía de la realidad propician en el sujeto un déficit de socialización atribuido al contexto cultural, a la autoridad o a la norma totalitaria y autoritaria. Ejemplo paradigmático de estos casos serían el de algunos jóvenes nazis y miembros de sectas criminales totalitarias y autoritarias o que por dinámicas comportamentales hayan nacido en el seno de la organización o lleven muchos años aislados de un contexto democrático.

\section{Breve referencia a la minoría de edad en los autores de conciencia}

En la problemática de la objeción de conciencia no hay impedimento para que un menor de edad sea sujeto de un conflicto de conciencia cuando le afecte una situación especial y sorpresiva

482 En el mismo sentido JERICÓ OJER, L., El conflicto de conciencia, op. cit., pp. 373 y 374, alude a que el conflicto de conciencia es mucho más que un aislamiento cultural que llevarían al error de prohibición o incluso a la inimputabilidad, sino es una situación extrema en la que el sujeto obra inevitablemente de tal forma.

483 FlORES MENDOZA, F., Objeción de conciencia, op. cit., p. 279 nota 273.

484 ID., ibidem, op. cit., pp. 279 y 280 y nota núm. 275.

485 ID., ibidem, op. cit., p. 280; en el mismo sentido TAMARIT SUMALLA, JMª ., «La objeción de conciencia», op. cit., p. 40; CERezo MIR, J., Curso de Derecho Penal Español. Parte General, III/2, op. cit., op. cit., p. 37; ID., Derecho Penal, Parte General, Lecciones, (26-40), op. cit., p. 33. 
que haga rechazar un tratamiento médico por motivos de conciencia ${ }^{486}$. En estos casos se puede suscitar el art. 162.1 CC por «actos relativos a derechos de la personalidad (...) de acuerdo con las Leyes y con sus condiciones de madurez, pueda realizar por sí mismo». Sin embargo, el debate jurídico está en determinar precisamente ese grado de madurez, cuestión que parece sólo resoluble mediante una pericial médico-forense y dependiendo del caso, pero que igualmente entraña problemática en la imputación subjetiva en la colisión de deberes de los padres o representantes legales en casos en los que el menor se niega al tratamiento y los padres también.

Por otro lado, desde la perspectiva de la autoría por convicción, el art. 19 de nuestro CP realiza una división penal entre sujetos y tiene la intención de crear una protección penal para el menor de dieciocho años, partiendo de la «presunción»-discutible- de que el menor no es en realidad un inimputable, sino un semi-imputable, es decir, sujetos que no tienen una conciencia y voluntad plena, pero que pueden llegar a tenerla ${ }^{487}$.

De tal suerte, los menores de edad podrán ser autores por convicción, como algunos jóvenes pertenecientes a grupos juveniles vinculados con la lucha del terrorismo, como lo era Jarrai, o autores de conciencia según lo referido supra. En este último caso, la libertad de conciencia es un bien personalísimo e indisponible que no se fija naturalmente en un momento concreto de la vida, sino que puede aparecer a edades por debajo de la mayoría de edad legal o antes de la emancipación (arts. 317, 320, y 46 CC), pero por razones de política criminal, la ley entiende que existe la presunción de que su grado de conciencia y voluntad no es del todo pleno, lo que acarrea que la Ley de Responsabilidad Penal del Menor haya establecido unas medidas de seguridad proporcionales a esa presunción de cierta madurez (presunción favorable al reo) de semi-imputabilidad para frenar la criminalidad del menor. En tal sentido los menores también pueden ser autores de conciencia o por convicción puesto que la Ley del menor sólo otorga un beneficio presunto, y dicha presunción no está eximiendo de la aplicación de una sanción que si bien no es conceptualmente punitiva, sí que restringe los derechos del menor, salvo en aquellos casos de menores por minoría de edad infra ley de responsabilidad penal del menor.

486 JERICÓ OJER, L., El conflicto de conciencia, op. cit., pp. 205 y ss.

487 Señala MIR PUIG que «(e)l CP de 1995 hace coincidir la mayoría de edad penal con la civil (18 años), pero admite que los menores de tal edad puedan responder «con arreglo a lo dispuesto en la ley penal juvenil y del menor. Puede verse aquí un cambio de tendencia, hacia alguna clase de responsabilidad penal del menor que sea mayor de cierta edad», MIR PUIG, S., PG, op. cit., p. 609. 


\section{E. La objeción de conciencia como causa de exculpación}

\section{Introducción: el principio de inexigibilidad y las causas de exculpación}

La inexigibilidad de conducta conforme a Derecho se ha constituido en nuestro ordenamiento en un principio general ${ }^{488}$, por lo que en la mayoría de las ocasiones habrá que buscar las causas de inexigibilidad más allá del Derecho penal.

A través de la teoría psicológica de la culpabilidad no se podía explicar cómo en las causas de exculpación, por ejemplo en el miedo insuperable, hubiese dolo y a la vez existieran argumentos para eximir de responsabilidad. Fue la teoría normativa de la culpabilidad de FRANK $^{489}$, que explicó que en la inimputabilidad podían concurrir el dolo o la imprudencia. Este nuevo postulado dogmático posibilitó el inicio de la teoría de la inexigibilidad.

En concreto, GOLDSCHIMDT ${ }^{490}$ llegó a la conclusión de que las normas de deber se dirigen a motivar lo interno del sujeto y por lo tanto se sitúan en la culpabilidad, mientras que las normas prohibitivas se dirigen al comportamiento externo, y por lo tanto se sitúan en la institución de la antijuricidad. Con este razonamiento consiguió fundamentar la ubicación del estado de necesidad exculpante en la culpabilidad. Pero fue FreudenthaL ${ }^{491}$ quien llegó a la conclusión de que la inexigibilidad es una causa de exculpación por razón de una causa supralegal. La inexigibilidad, según FREUDENTHAL, excluye la culpabilidad por razones que van más allá de las eximentes, principalmente por la «presión psíquica» externa. Este postulado fue criticado por la doctrina porque conlleva una confusión entre el Derecho y la ética, por tal motivo le ha tachado de ser una «solución psicologizante» ${ }^{492}$.

488 Vid. Flores MendOZA, F., Objeción de conciencia, op. cit., pp. 191 y 192. En la española CUERDA RIEZU, A., «Sobre el concurso entre causas de justificación», Causas de Justificación y de atipicidad en Derecho Penal, Diego-Manuel Luzón Peña y Santiago Mir Puig (Coord.), Aranzadi, Pamplona, 1995, pp. 226 y ss. 234 y ss. p. y 242; AGUADO CORREA, Teresa, Inexigibilidad de otra conducta en derecho penal, Comares, Granada, 2004, pp. 5 y pp. 39 y ss.

489 Vid. AgUAdO CORREA, Teresa, Inexigibilidad, op. cit., pp. 9 y ss. (FrANK, Reinhard, «Über den Aufbau des Schuldbegriffs», Festgabe für die Juristische Facultät der Universitat Giessen, Giessen, 1907, pp. 4, 7, 13 y 14).

490 GoldschmidT, James, La concepción normativa de la culpabilidad, trad. M. de Goldschmidt y Ricardo Núñez, Buenos Aires, 1943, pp. 38 y ss; aunque anteriormente ID., «Der Notstand, ein Schuldproblem», ÖstZStr, 1913; ID., «Normativer Schuldbegriff», Festgabe für Reinhar von Frank, Band I, Tübingen; véase al respecto, SAINZ CANTERO, JA., «El desenvolvimiento histórico-dogmático del principio de "no exigibilidad"», ADPCP, 1960, 419 y ss; ID., La exigibilidad de conducta adecuada a la norma en Derecho Penal, Universidad de Granada, Granada, 1965, pp. 7 y ss.

491 Vid. Aguado Correa, T., Inexigibilidad, op. cit., pp. 14 y ss; vid. también en BAUCELls I LLADÓs, J., La delincuencia por convicción, op. cit., p. 304 (FREUDENTHAL, Berthol, Schuld und Vorwurf im geltenden Strafrecht, Tübingen, 1922).

492 JAKOBS, G., PG, op. cit., 20/1; críticamente también MARTín LORENZO, María, La exculpación penal. Bases para una atribución legítima de la responsabilidad penal, Tirant lo Blanch, Valencia, 2009, p. 61 a 64, puesto que estas teorías exclusivamente resaltan su efecto de la angustia o del miedo en las amenazas a la vida, margina las puestas en peligro de la integridad corporal, la libertad y otros bienes, no resaltan la distinción entre el estado necesidad e inimputabilidad, ni demuestran la obligación de soportar diversos peligros, ni explican en materia de error el estado de necesidad putativo. 
Posteriormente cobró fuerza la inexigibilidad como un principio estrictamente normativo, de tal manera se empezó a abandonar la idea de que la inexigibilidad dependía de si el sujeto está afectado por diversas circunstancias. Este cambio supuso el inicio de las teorías normativas ${ }^{493}$. La variante normativa de las teorías subjetivas tienen también en contra la indeterminación del criterio de ciudadano normal o del poder medio para fundamentar las causas legales de exculpación ${ }^{494}$.

Por otro lado, VARONA GÓMEZ ${ }^{495}$, desde la perspectiva personal del autor, sostiene que este principio tiene la misma trascendencia que cualquier otro principio jurídico penal. En su estudio sobre el miedo insuperable fundamenta la inexigibilidad o «razonabilidad» ${ }^{496}$ en que la posibilidad del sujeto de obrar conforme al derecho está disminuida, se limita su voluntad o libertad de elección, por lo que el Derecho ha de reafirmar su libertad con la falta de pena ${ }^{497}$, argumento que le lleva a ubicar la inexigibilidad en la culpabilidad ${ }^{498}$.

De otra parte, AGUADO CORREA ${ }^{499}$ considera que la inexigibilidad es un principio general del ordenamiento jurídico, fundamentado por su relación con el valor de justicia, la dignidad de la

En la evolución histórica de la inexigibilidad puede destacarse la interesante propuesta de HENKEL, que aunque prosiguió con una argumentación psicologizante al fundamentar la exención en el instinto de autoconservación, definió la inexigibilidad como un principio regulativo de la tipicidad sobre todo en los delitos culposos, en los de omisión propia y comisión por omisión, en la antijuricidad y la culpabilidad, en el sentido de que la inexigibilidad delimita los deberes en cada situación mediante el principio de confianza, de buena fe y buenas costumbres, vid. Aguado Correa, T., Inexigibilidad, op. cit., pp. 24 a 33 y pp. 64 y 65; vid. también, MARTín LORENZO, M., La exculpación penal, op. cit., p. 64, nota 47 (HENKEL, Heinrich, «Zumutbarkeit und Unzumutbarkeit als regulatives Prinzip», Festschrift für Mezger zum 70. Geburtstag, München, Berlin, 1954, pp. 249 y ss.). Gracias a las aportaciones de HENKEL parece que se acepta por la doctrina la transcendencia de este principio en todo el Derecho. Para tal delimitación utilizó un criterio mixto subjetivo-objetivo; el subjetivo sirve para modular la culpabilidad, el objetivo para establecer la exigencia en la tipicidad y en la antijuricidad. Sin embargo su intuitiva formulación perdió fuerza argumentativa, en nuestra opinión, por delegar al Juez la tarea de determinar el grado de exigibilidad en cada categoría en el caso en concreto, como si este principio escapara de la dogmática penal, si bien, Vid. Aguado Correa, T., Inexigibilidad, op. cit., p. 31.

493 En concreto FRELLESEN consideraba que el problema de la inexigibilidad tiene relación con cada delito de la parte especial porque delito y culpabilidad están unidos, máxime aún en la delimitación del deber de cuidado y la posición de garante, vid. AgUADO CORREA, T., Inexigibilidad, op. cit., pp. 35 y ss. (FrELlESEN, Peter, Die Zumutbarkeit der Hilfeleistung, Frankfurt a. Main, 1980, pp. 90 y ss). Estos postulados actualmente los comparten MAQUEDA ABREU, María Luisa, «Exigibilidad y derecho a no declararse culpable», ADPCP, 1991, pp. 33 y ss., configura la inexigibilidad en el derecho a no confesarse culpable o a no declarar contra uno mismo en casos de incumplimiento del deber de socorro o por no denunciar un delito en virtud del art. 24.2 CE; BAUCELLS I LLADÓs, J., La delincuencia por convicción, op. cit., pp. 311 y ss., como principio constitucional relacionado con la dignidad, el derecho al libre desarrollo de la personalidad y la igualdad, lo que le sirve para apreciar una disminución de la culpabilidad en el autor de conciencia en determinados casos.

494 MARTÍn LORENZO, M., La exculpación penal, op. cit., pp. 66 y 67.

495 VARONA GÓMEZ, Daniel, El miedo insuperable: una reconstrucción de la exigibilidad desde una teoría de la justicia, Comares, Granada, 2000, pp. 115 y ss.

496 ID., ibidem, op. cit., pp. 52 y ss.

497 ID., ibidem, op. cit., p. 57.

498 ID., ibidem, op. cit., p. 121.

499 AGUADO CORREA, T., Inexigibilidad, op. cit., pp. 39 y ss., fundamento que también lo encuentra respaldado en las SSTC 62/1982, de 15 de octubre y 53/1985, si bien en contra de esta última sentencia, que es la única vez que hasta el momento el TC se había pronunciado sobre la inexigibilidad, no considera que pueda relacionarse con el 
persona y los derechos fundamentales, y en este destaca ${ }^{500}$ las SSTS de 24 de junio y 28 de octubre de 1991, en las que se declara que los Jueces y Tribunales deben tener en cuenta para fijar la culpabilidad por el hecho tanto la gravedad del injusto, como las mayor o menor exigibilidad del cumplimiento de la norma, y el disvalor ético social de los motivos que impulsaron a actuar.

En nuestra opinión, la inexigibilidad de conducta conforme a Derecho no es la ausencia de obligación jurídica o de prohibición, sino la institución jurídico-penal que valora la situación determinada que lleva al sujeto a no orientarse por la norma y que fundamenta en consecuencia la renuncia de la punición en causas individuales ${ }^{501}$ y de entorno, a diferencia de las causas de exclusión de la culpabilidad (inimputabilidad). La inexigibilidad es una causa de exculpación que procede del principio de culpabilidad. Si bien hay que admitir que la inexigibilidad acaece como fundamento tradicional de la legitimidad de las normas y de la imputación de la tipicidad, por ejemplo en la doctrina española en la exención de responsabilidad a los funcionarios que no cumplen órdenes nulas del art. $410.2 \mathrm{CP}^{502}$, y en la doctrina alemana en relación al deber de espera cuando existe peligro de persecución delictiva en la omisión de socorro agravada, o que modula la culpabilidad en los delitos dolosos e imprudentes ${ }^{503}$, incluso un sector la defiende como un principio general del Derecho ${ }^{504}$.

Hay voces también que argumentan que la inexigibilidad se fundamenta en el principio de igualdad recogido en la $\mathrm{CE}$ en relación a la individualización de la pena respecto a la

principio de proporcionalidad, aunque admite semejanzas e interdependencia por el valor de justicia a la hora de tipificar por el legislador en la proporcionalidad abstracta y concreta, si bien la proporcionalidad se refiere al «desequilibrio patente y excesivo entre sanción y la finalidad de la norma (...) desde un punto de vista de relación medio-fin; la exigibilidad enjuicia un deber de comportarse teniendo en cuenta la situación personal del afectado, es un límite de los deberes jurídicos de comportamiento de los ciudadanos», ID., ibidem, op. cit., p. 44. Aunque admite esa interdependencia porque «si la conducta no es exigible en abstracto, la pena no es proporcionada en abstracto si la conducta no es exigible al sujeto concreto la pena no es proporcionada en concreto», ID., ibidem, op. cit., p. 47; véase también al respecto la relación del principio de proporcionalidad, ID., El principio de proporcionalidad de Derecho penal, Ed. Edersa, Madrid, 1999.

500 Vid. AguAdo CORREA, T., Inexigibilidad, op. cit., p. 46, si bien lo toma de ZUGALDía EsPinAR, José Miguel, «El principio de culpabilidad en la reciente jurisprudencia del Tribunal Supremo», Estudios de Jurisprudencia, Revista Colex, Madrid, 1992, p. 67.

501 PERRÓN, Walter, «Justificación y exclusión de la culpabilidad a la luz del Derecho comparado (con especial consideración al Derecho penal español)», trad. Silva Sánchez, ADPCP, 1988, p. 142 concluye que «las causas de exclusión de la culpabilidad constituyen simplemente una forma especial de renuncia a la sanción penal que toma como fundamento la individualidad del autor»; POLAINO NAVARRETE, M., El delito de detención ilegal, Aranzadi, Pamplona, 1982, pp. 173 y ss.

502 LUZÓN PEÑA, D-M., Curso de Derecho penal, Parte General, I, op. cit., p. 569.

503 COBo Del Rosal M / Vives AnTón TS., PG, op. cit., pp. 619 y ss.

504 BAUCELls I Lladós, J., La delincuencia por convicción, op. cit., p. 310; GARCía ARÁN, M., «Culpabilidad, legitimación y proceso», op. cit., p. 101; RoXIN, C., "“Culpabilidad" y "Responsabilidad" como categorías sistemáticas jurídico-penales», op. cit., p. 60; SAINZ CANTERO, JA., La exigibilidad de otra conducta adecuada a la norma en Derecho penal, op. cit., pp. 94 y ss; TAMARIT SUMALLA, JM"., La libertad ideológica, op. cit., p. 422. 
culpabilidad $^{505}$. Si bien críticamente la doctrina mayoritaria no considera que la inexigibilidad sea una causa supralegal de exculpación ${ }^{506}$.

También existen argumentos que ubican la relevancia del principio de inexigibilidad en la antijuricidad, y concretamente en la legítima defensa excesiva extensiva ${ }^{507}$, si bien en la intensiva hay quienes aceptan la posibilidad de apreciar la eximente de miedo insuperable completa o incompleta si se aceptan los postulados de la doble disminución de la culpabilidad como sucede taxativamente en Alemania ${ }^{508}$. No obstante, puesto que hemos concluido supra que no existen argumentos de aplicación de la legítima defensa en el autor de conciencia ni por convicción, no nos detendremos en un análisis más esmerado en la posible concurrencia de otras eximentes en caso de legítima defensa incompleta. Y también hay quienes fundamentan la

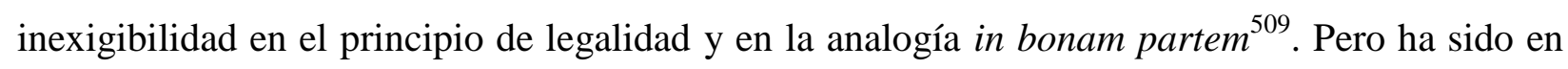
los delitos de omisión propia o pura y en los de comisión por omisión o de omisión impropia, donde la doctrina y la jurisprudencia han admitido que la exigibilidad o inexigibilidad alcanza mayor relevancia jurídico-penal ${ }^{510}$. Sobre la relevancia de la inexigibilidad volveremos

505 BAUCElls i Lladós, J., La delincuencia por convicción, op. cit., pp. 297 a 301 en cuanto que el principio de igualdad permite valorar la edad, condiciones familiares, sociales, educación, y circunstancias de la acción, explica mejor las causas de inimputabilidad del art. 20.1, 2 y 3 que los criterios médicos o psicológicos, y también fundamenta mejor los supuestos de estado de necesidad exculpante, el miedo insuperable; GARCÍA ARÁN, M., «Culpabilidad, legitimación y proceso», op. cit., p. 95.

${ }_{506}$ Ampliamente SAINZ CANTERO, JA., «Las causas de inculpabilidad en el Código penal español (El principio de no exigibilidad)», RGLJ, 1963, pp. 27 y ss.

507 IGLESIAS RíO, Miguel Ángel, Fundamento y requisitos estructurales de la legítima defensa. Consideración especial a las restricciones ético-sociales, Comares, Granada, 1999, pp. 376 y ss., no en casos de exceso intensivo sino sólo extensiva; AGUAdo CORREA, T., Inexigibilidad, op. cit., p. 80 en casos que no se permita apreciar la eximente completa.

508 Aguado Correa, T., Inexigibilidad, op. cit., p. 884 y 85, si bien para apreciar la completa de miedo insuperable requiere «cierta intensidad no bastando con la alteración del ánimo propio de los casos de legítima defensa, ya que en este último caso procedería apreciar únicamente la eximente incompleta de legítima defensa, o incluso la eximente completa de legítima defensa, en atención a consideraciones de inexigibilidad».

509 BAUCELlS I LLADÓs, J., La delincuencia por convicción, op. cit., p. 308; MIR PUIG, S., «Introducción a las bases», op. cit., p. 319; especialmente FlORES MENDOZA, F., Objeción de conciencia, op. cit., p. 257 en la aplicación analógica de las eximentes relacionadas con la inexigibilidad.

510 En los delitos de omisión propia se suele decir que resulta menos grave dicha omisión que en el mandato de acción cuando la omisión trata de salvaguardar intereses propios. Sin embargo, esto no es del todo cierto, por cuanto la obligación de actuar en los delitos de omisión propia o pura se refiere normalmente a un deber de protección o de seguridad o salvamento que trasciende los intereses propios, salvo cuando exista conflicto con las habituales cláusulas «sin riesgo propio o ni de terceros» o «sin riesgo propio o ajeno» de los arts. 195 y ss. CP en la omisión del deber de socorro pura y agravada, y del $450 \mathrm{CP}$ en relación al deber de impedir delitos o promover su persecución. Mientras que en los delitos de comisión por omisión, parte de la doctrina (JAKOBS, G., PG, op. cit., 29/96 a 20/99; JESCHECK HH / WEIGEND T., Tratado, op. cit., 58, II, según la «comprensión natural de las cosas», y 58, III; MAURACH, R., Tratado, II, op. cit., pp. 279 y ss.) en contra de la opinión mayoritaria (vid. AGUADO CORREA, T., Inexigibilidad, op. cit., pp. 183 y ss., si bien, la referida autora explica que la doctrina está repartida entre los que atribuyen a la inexigibilidad relevancia en la tipicidad como límite del deber de protección del bien jurídico, los que se la dan en la justificación, y los que se la otorgan en la culpabilidad apelan a la presión de la motivación como afección al deber) niega que exista una mayor intensidad de la exigencia en los delitos de comisión precisamente por la «cláusula de correspondencia» entre omisión y acción, y porque la posición de garante también se da, es decir, se da el deber de protección de la institución, de tal manera que defienden, muy acertadamente, que no se exige un 
específicamente en el capítulo siguiente, al tratar las conductas del autor de conciencia y por convicción en los delitos de omisión y comisión por omisión.

En nuestra opinión, se ha de dotar de su correspondiente ámbito en las causas especiales a las que se enfrentan las personas. Según los postulados que hemos ido fijando, el Derecho penal tradicionalmente ha exigido comportamientos en ocasiones exquisitos conforme a la norma sin dejar recodo alguno a la comprensión de ciertas conductas que según las circunstancias ineludiblemente llevan al autor a quebrantar la norma. Se ha dicho al respecto que el Derecho no puede exigir comportamientos heroicos. Por ello la inexigibilidad encuentra su fundamento más allá de las eximentes legales. El sujeto puede actuar conforme a Derecho, pero su especial situación provoca una merma de orientación conforme a la norma, de tal manera que la inexigibilidad no es una ausencia total de culpabilidad, sino una disminución significativa del poder obrar de otra manera. Es por ello que las causas de exculpación son, terminológica y estrictamente hablando una disculpa especial del Derecho.

Sin embargo, tradicionalmente la doctrina y la jurisprudencia apenas han dejado margen de aplicación a la inexigibilidad y concretamente a las causas de exculpación. Esto se debe en nuestra opinión a la crítica de que el Derecho penal deber comunicar a la sociedad la seguridad jurídica de que las normas son de obligado cumplimiento para todos y en todo su tiempo de vigencia. Recuérdese que supra comentábamos que la doctrina explicaba la culpabilidad del autor de conciencia y por convicción en la inseguridad jurídica que supondría la exención de responsabilidad o la disminución de la pena de aquellas conductas criminales que se dicen amparar en la libertad de conciencia. Este fundamento se ampara en la seguridad jurídica, de tal modo que no vemos impedimento alguno que se aplique a la inversa, cuando una conducta no quebranta la seguridad jurídica en atención a las particulares y especiales circunstancias del caso (déficit de socialización atribuido a tercero), se puede eximir de pena o disminuirse sin que se vea afectada la seguridad jurídica, sino al contrario, se reafirma la vigencia de la norma porque su función, como veremos más abajo, no es sólo la de penar, sino la de no penar cuando su vigencia no se vea afectada. La falta de pena como función también de la vigencia de la norma se ve claramente en la inimputabilidad, pero especialmente en nuestra opinión en casos paradigmáticos del autor de conciencia y por convicción, inclusive en la autoría denominada

mayor deber, sino que la protección que se refiere en la comisión por omisión se fundamenta en una institución mayor, no una mayor exigencia. En este sentido, parte de la doctrina afirma que únicamente podrá haber alguna graduación de la exigibilidad en el estado de necesidad exculpante, JAKOBS, G., PG, op. cit., 29/98. Críticamente Aguado Correa, T., Inexigibilidad, op. cit., p. 182. 
enemiga, pero bajo argumentos apoyados en las causas de exculpación inherentemente fundamentados en el principio de inexigibilidad.

Como ya expusimos supra al tratar el estado de necesidad justificante, la teoría de la diferenciación, defendida por parte de la doctrina ${ }^{511}$ distingue entre el estado de necesidad justificante y disculpante (exculpante). El primero sería aquél cuyo fundamento parte de la justificación de la protección del interés objetivo más importante, mientras que el estado de necesidad disculpante se relega a casos en los que el interés que se protege es levemente inferior al lesionado o igual (ponderación de bienes), por lo que la objetividad desaparece en estos casos y hace a este estado de necesidad no ser causa de justificación sino de exclusión de la culpabilidad.

Pero esta opinión ha sido desmentida parcialmente por parte de un sector minoritario de la doctrina. Concretamente MIR PUIG ${ }^{512}$ considera que el campo del estado de necesidad justificante es demasiado grande, mientras que el campo del disculpante en ocasiones puede ser demasiado amplio, y otras veces muy restringido, por lo que propone que el estado de necesidad disculpante se reserve únicamente para la eximente de miedo insuperable del art. $20.6^{\circ} \mathrm{CP}$, o cuando este miedo sea insuficiente por la atenuante analógica.

Por el contrario y críticamente, parte de la doctrina ${ }^{513}$-entre la que se encuadra POLAINO NAVARRETE- defiende la llamada «teoría de la unidad», que estima que el estado de necesidad justificante también englobaría conflictos de bienes iguales puesto que no se excluye que «el mal causado no sea mayor que el que se trata de evitar», no existe impedimento en que el principio de inexigibilidad tenga relevancia en la justificación (STC 53/1985). Se sostiene por los detractores de la teoría de la diferenciación que ésta tiene sentido en la regulación alemana en la que se distingue en entre estado de necesidad justificante y disculpante en el parágrafo 35 StGB, máxime en cuanto que el inciso 1.2 del parágrafo 35 StGB excluye de su aplicación a quien tiene obligación de soportar el peligro que haya causado o por su especial situación jurídica. Esta

511 Entre los que podemos incluir a COBo Del Rosal M / VIVES ANTÓN TS., PG, op. cit., pp. 492 y ss; CueRDA ARNAU, María Luisa, El miedo insuperable. Su delimitación frente al estado de necesidad, Tirant lo Blanch, Universitat de Valencia, Valencia, 1997, p. 203; JAKOBS, PG, op. cit., 7/104 y 20/1 y ss; LUZÓN PEÑA, D-M., Curso de Derecho penal, Parte General, I, op. cit., p. 560; Romeo CASABONA, CM ${ }^{\mathrm{a}}$., El médico y el Derecho penal, op. cit., pp. 300 y ss; SAINZ CANTERO, JA., «Las causas de inculpabilidad en el Código penal español (El principio de no exigibilidad)», op. cit., p. 12.

512 MIR PUIG, S., $P G$, op. cit., pp. 458 y 459.

513 Aguado Correa, T., Inexigibilidad, op. cit., p. 94; Gimbernat, Enrique, «El estado de necesidad: un problema de antijuricidad», Estudios de Derecho penal, $3^{a}$ ed., Tecnos, 1990, pp. 218 y ss; GómEZ BENíTEZ, JM., Teoría jurídica del delito. Derecho penal, Parte general, Madrid, 1984, p. 379; LuZÓN PEÑA, D-M., Curso de Derecho penal. Parte general, op. cit., p. 650; POlaino NAVARReTe, M., Lecciones de Derecho penal, Parte general, T. II, op. cit., p. 154; ROPERO CARRASCO, Julia, La provocación del estado de necesidad en Derecho penal. Provocación de situaciones de riesgo en el tráfico automovilístico y otros estados de conflicto, Comares, Gramada, 2002, pp. 263 y ss. 
teoría defiende que el principio de exigibilidad es otra cara de la moneda, por eso se aprecia en los elementos del estado de necesidad justificante, especialmente en la falta de provocación intencionada $^{514}$, como la prevista en el parágrafo 34 StGB, y en la circunstancia referida a que el necesitado no tenga por su oficio o cargo, obligación de sacrificarse como supuesto de exigibilidad especial $^{515}$.

Sin embargo, otra parte de la doctrina ${ }^{516}$ ha fundamentado el estado de necesidad exculpante (o disculpante en la terminología alemana cuando se aprecia disminución de la culpabilidad) por una doble disminución de la culpabilidad. De una parte la disminución del injusto en dos sentidos, uno por un menor desvalor de la acción al tratar el autor de salvaguardar un bien jurídico, y otro por conseguir dicha salvación. Y de otra, la disminución de la culpabilidad porque tal acción viene reflejada en la presión anímica o disminución de la capacidad de obrar conforme a Derecho en todas las situaciones que llevan a que el sujeto decida a favor del instinto de conservación, no se anula la capacidad de decisión, sino que se compromete por las circunstancias, si bien, entre sus partidarios se discute qué disminución tiene mayor relevancia, si la del injusto que después afecta consecuentemente a la culpabilidad (RUDOLPHI) o si la culpabilidad se refleja en el injusto (LENCKNER/PERRON), si bien todos coinciden en la disminución del desvalor de la acción e introducen argumentos preventivos acerca de la falta de necesidad de la pena ${ }^{517}$.

\footnotetext{
514 AguAdo CORREA, T., Inexigibilidad, op. cit., p. 113 puesto que «el segundo requisito previsto en el art. 20.5 $\mathrm{CP}$ no es más que una exención a la inexigibilidad general, y a la consiguiente exención de responsabilidad criminal, cuyo fundamento es una exigibilidad especial reclamable al sujeto que ha provocado intencionadamente la situación de necesidad (...) se le exige el sacrificio de sus intereses»; críticamente en cuanto que no entra la inexigibilidad en el estado de necesidad al tratarlo siempre de forma justificante, ROPERO CARRASCO, J., La provocación del estado de necesidad en Derecho penal, op. cit., p. 266.

515 Aguado Correa, T., Inexigibilidad, op. cit., p. 114 y 115; LuZÓn PEÑA, M-D., Curso de Derecho penal, Parte general, I, op. cit., p. 632; SILVA SÁNCHEZ, J-M ${ }^{\mathrm{a}}$., «Sobre el estado de necesidad en Derecho penal español», ADPCP, 1982, p. 687.

516 Cerezo MIR, J., Curso de Derecho Penal Español, II, op. cit., p. 272 y 273; ID., «El delito como acción culpable», Carlos María Romeo Casabona (ed.), Dogmática penal, Política Criminal y Criminología en evolución, La Laguna, 1997, p. 48; Cuello Contreras, Joaquín, Derecho penal español, Parte general. Nociones introductorias, Teoría del delito, $3^{\mathrm{a}}$ ed., Madrid, 2002, pp. 1127 y ss; FlORES MENDOZA, F., Objeción de conciencia, op. cit., pp. 246 y ss; PÉREZ Del VAlle, C., Conciencia, op. cit., pp. 284 y ss; Silva SÁnCHEZ, J-Ma, Aproximación al Derecho penal contemporáneo, $1^{a}$ ed., Bosch, 1992, p. 414. Bibliografía alemana a favor, principalmente Kaufmann, Armin, Dogmática de los delitos de omisión, trad. Joaquín Cuello Contreras, José Luis Serrano González de Murillo (Edit.), Marcial Pons, 2006, pp. 166 y ss., originalmente en alemán Die Dogmatik der Unterlassungsdelikte, Göttingen, 1959; Welzel, H., Derecho penal alemán, op. cit., pp. 248 y ss. situó la inexigibilidad como causa de exculpación por disminución del poder obrar de otro modo, es decir, como una disminución de la imputabilidad, pero a la vez como disminución del injusto de la acción por ir dirigida a salvar un bien jurídico.

${ }_{517}$ Vid. y más ampliamente MARTín LORENZO, M., La exculpación penal, pp. 76 y ss. y pp. 91 y ss.
} 
Se ha criticado que no tiene por qué llegarse a salvar el bien por el autor, no siempre se aprecia una disminución del desvalor del resultado ${ }^{518}$, ni siempre existe una voluntad de preservación o al menos se compensa con el resultado delictivo ${ }^{519}$, lo que ha llevado a criticar que, efectivamente, también puede existir voluntad de preservar otros bienes como el patrimonial $^{520}$, ni casan bien dichos postulados en los casos de exigencia especial por la posición jurídica del autor o cuando es éste mismo quien crea el peligro.

Existen también varias concepciones sobre la exculpación que parten de planteamientos filosóficos: en el respeto a la oportunidad de vivir que debe conceder el Estado absteniéndose a condenar $^{521}$.

En la doctrina española tiene cierta fuerza la postura de la teoría de la motivación de la norma. Esta teoría defiende que el estado de necesidad exculpante y en verdad todas las causas de exculpación, se deben a la falta de motivación o anormalidad de motivación no en el propio sujeto sino a causa de las circunstancias, lo que hace a este sector tener que utilizar el criterio del «hombre medio» u otros criterios similares para delimitar los casos de falta de motivación, lo cual es claramente criticable ${ }^{522}$.

GiMBERnAT se desmarca de los anteriores postulados. Considera que las casusas de exculpación pertenecen a la antijuricidad ${ }^{523}$. Tanto el miedo insuperable como el estado de necesidad exculpante en conflictos de intereses de igual rango ${ }^{524}$ serían causas de justificación. Esto se debe a su concepción sobre la culpabilidad que se basa en la capacidad de «ser motivado por la norma», por lo que si lo es, su conducta no puede exculparse sino justificarse.

Por otro lado, SILVA SÁNCHEZ ${ }^{525}$ propone un tratamiento de la inexigibilidad en el estado de necesidad. Relega el estado de necesidad exculpante, si bien, incluido en el art. $20.5^{\circ} \mathrm{CP}$ en casos

518 JAKOBS, G., PG, op. cit., 20/3; MARTín LOREnZO, M., La exculpación penal, pp. 83 y ss.

519 JAKOBS, G., $P G$, op. cit., 20/3, máxime cuando la disminución del injusto no es tan siquiera una causa de atenuación de la culpabilidad; MARTín LORENZO, M., La exculpación penal, pp. 86 y ss.

520 JAKOBS, G., PG, op. cit., 20/1 y ss; MARTín LORENZO, M., La exculpación penal, op. cit., p. 89.

521 BERNSMANN, Klaus, Entschuldigung durch Notstand: Studien zu $\$ 35$ StGB, Carl Heymanns, 1989, pp. 320 y 330 (vid., MARTín LORENZO, M., La exculpación, op. cit., p. 171 y 173, críticamente ella misma comenta que su propuesta no alcanza a la salvaguarda de otros bienes como la pérdida de miembros, ID., ibidem, op. cit., p. 183).

522 Llama la atención que la mayor parte de la doctrina siga utilizando el criterio del «hombre medio» para modular la exigibilidad en una u otra categoría del delito. Este criterio es claramente superfluo por cuanto deja impunes conductas que si bien están por debajo de ese criterio, o sea, una conducta que un hombre medio le parecería «insuperable», no se entiende qué factor ha de concurrir para no imputar objetiva o subjetivamente a un sujeto que comete una conducta que para él era claramente superable como sujeto racional.

523 GIMBernat, E., Introducción a la Parte general del Derecho penal español, Universidad Complutense, Madrid, 1979, op. cit., p. 66; ID., «El estado de necesidad: un problema de antijuricidad», op. cit., pp. 218 y ss; Similarmente, Cuerda RIEZU, A., La colisión de deberes en Derecho Penal, op. cit., p. 253; GóMEZ BENÍTEZ, JM., Teoría jurídica del delito, op. cit., pp. 436 y ss.

524 GIMBERNAT, E., «Estado de necesidad: un problema de antijuricidad», op. cit., pp. 220 y ss.

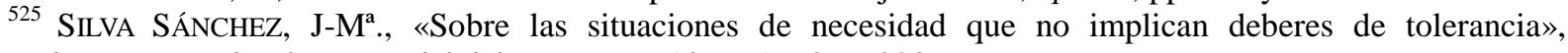
Consideraciones sobre la teoría del delito, Buenos Aires, 1998, p. 223. 
de conflicto en el que se salva un bien de mayor valor pero no relevantemente mucho mayor, o en casos de bienes de igualdad entidad, a casos de exculpación cuyo fundamento estriba en situaciones que no generan deberes de tolerancia, no se fundamentan en la intensidad del conflicto puesto que también se aprecia en los trastornos transitorios ${ }^{526}$, sino por ser adecuados a la situación, por ser de «utilidad social» ${ }^{527}$. Su concepción fundamenta la exención de la pena por razones sociales o utilidad-social del acto $^{528}$, si bien en casos de salvaguarda de un bien no menor pero lesionando uno no relevantemente mayor, considera que existe responsabilidad por $\operatorname{organización}^{529}$ al que se le puede aplicar una amplia atenuación ${ }^{530}$. Así, lleva al estado de necesidad justificante los casos en los que se salvaguarda un bien relevantemente mayor. Su propuesta intenta ser claramente objetiva, si bien en la valoración de qué es una conducta con utilidad social o en la interpretación del término «relevantemente», se ve obligado a incurrir en el subjetivismo propio en el que todas las doctrinas se ven abocadas a caer al valorar los conflictos $\mathrm{y}$, si bien pretende escapar de los postulados de la intensidad de motivo, le otorga cierta importancia, pero sólo a los efectos de construir la consideración sobre la utilidad social del acto en función al nivel de compromiso de abstención ante los terceros en la interacción social (responsabilidad por organización). De tal modo que acepta ${ }^{531}$ la inexigibilidad de otra conducta en la autoría de conciencia. Sin embargo, su tratamiento lleva a otra conclusión, no se le puede obligar al padre a perder sus valores espirituales, en verdad, no se encuentra en posición de garante, por lo que la inexigibilidad no es una causa de justificación sino que supone ya desde el principio la atipicidad.

Más recientemente, MARTín LORENZO propone ubicar la inexigibilidad o causas de exculpación en la culpabilidad. La valoración se realiza en un primer plano en el sujeto y sobre su decisión jurídica sin considerar a otros sujetos que intervienen en el conflicto, mientras que en la antijuricidad «el ordenamiento se relaciona con la totalidad de los destinatarios de sus normas» ${ }^{532}$. De tal modo, pero sirviéndose de la distinción de JAKOBS ${ }^{533}$ entre motivos jurídicamente «buenos»o «bien fundados», que sirven para justificar conductas en principio prohibidas y motivos jurídicamente «comprensibles» que llevan a fundar la exculpación, en su

\footnotetext{
526 SILVA SÁNCHEZ, J-Mª ., «Sobre las situaciones de necesidad que no implican deberes de tolerancia», op. cit.,

ID., ibidem, op. cit., p. 248.

528 ID., ibidem, op. cit., pp. 251 y 252.

529 ID., ibidem, op. cit., p. 253.

530 ID., ibidem, op. cit., p. 256 y 257.

531 SILVA SÁNCHEZ, J-Ma ., «La responsabilidad penal del médico por omisión», op. cit., pp. 955 y ss.

532 MARTín LORENZO, M., La exculpación penal, op. cit., pp. 273 y 274.

533 JAKOBS, G., $P G$, op. cit., 11/1 y 21/20.
} p. 246 . 
opinión, la afección psíquica o la indulgencia o compasión punitiva del Estado -que achaca a la prevención general positiva- no son fuentes de la comprensión exculpatoria ${ }^{534}$, sino que es el valor del motivo en el contexto el que puede hacer comprensible (entendible/alcanzable) la conducta del autor por la injusticia de la sanción ${ }^{535}$, aquellos vinculados al sistema liberaldemocrático. Éste se refiere a un sistema de decisiones de todos los ciudadanos en la creación de normas y tiene su mayor expresión jurídico-penal en la concepción sobre la culpabilidad y las normas sobre las causas de exculpación.

MARTÍN LORENZO, para llegar a tal conclusión, se apoya en la obra de Facticidad y validez de HABERMAS, para quien la validez de las normas se produce por los discursos racionales sobre el asentimiento de los ciudadanos, lo que constituye un principio democrático de la validez e irradiación normativa. Se apoya también en las consideraciones de GÜNTER en su obra Strafrechliche Verantwortlichkeit sobre la vinculación de la culpabilidad con la legitimación democrática de las normas que proviene de los ciudadanos como personas racionales con «capacidad deliberativa» para argumentar y mantener sus pretensiones pero a la vez para ceder ante otras razones como comunicación, dialogo entre persona y Derecho ${ }^{536}$. Esto constituiría una razón «comprensible» intersubjetivamente aceptada entre «ese» sujeto-autor y «ese» sujetovíctima, no en la ubicuidad de un cualquiera ${ }^{537}$.

La ratio de la exculpación la sitúa en dos argumentos. De una parte en el peligro existente en la conservación del carácter de la persona deliberativa: si no actuase de tal manera perdería su capacidad crítica en el futuro para no frustrar la expectativa normativa de comportamiento

534 MARTín LORENZO, M., La exculpación penal, op. cit., pp. 279 y ss.

535 ID., ibidem, op. cit., p. 284: «pues aun cuando no tenga buenos motivos para ello, sí los tiene comprensibles (...) no todos los motivos (...) exculpan».

536 ID., ibidem, op. cit., pp. 285 a 293. Por eso en el juicio de culpabilidad se relacionada el «doble rol de autor y destinatario de la norma, pero la conexión no reside en el contenido del juicio, que el autor hubiera podido cumplir la norma por conocer sus razones legitimadoras, sino que lo que fundamenta el reproche es que en su posición el autor hubiera podido cumplir la norma como destinatario con libertad de actuación y autonomía privada, la misma que empleó en su rol de ciudadano», ID., ibidem, op. cit., p. 295. La referida autora considera que la participación del ciudadano en la creación de normas fundamenta su capacidad y legitimidad deliberativa sobre la norma cuando es el específico destinatario, de tal manera se refuerza la idea que las personas son libres, iguales y responsables, sin embargo se ve abocada a otorgar valor jurídico a los motivos del autor, no es lo mismo no prestar socorro por motivos racistas o por tener una cita amorosa, ID., ibidem, op. cit., pp. 299 y 300. Por eso afirma que «(e)1 carácter democrático supone dos reglas: una primera, las razones importan, de modo que no puede hurtarse a nadie la posibilidad de exponerlas; una segunda, las razones deben importar a todos y cada uno de los sujetos para convertirse en razones jurídicas (...) pero esas razones sólo lograrán exculpar si son importantes para todos en el sentido pretendido por su defensor, que no es otro que el de excluir el reproche por su acción antijurídica», lo que constituye un claro reconocimiento del criterio delimitador cuando cualquier otro en la misma posición hubiese actuado de esa misma forma, pero ahora valorado desde el binomio democracia y culpabilidad, ID., ibidem, op. cit., pp. 302 y 303. La fórmula es: «cuando esas razones sean también importantes para el sujeto frente al que se hacen valer», ID., ibidem, op. cit., p. 309.

537 ID., ibidem, op. cit., p. 317. 
conforme a dicha capacidad ${ }^{538}$. De otra, en la ausencia de coacción o en la autodeterminación, para que el sujeto se exprese libremente, por eso el actuar en tales casos siempre viene acompañado de miedo, que es en esencia el efecto exonerador ${ }^{539}$. De esta manera, se ve abocada a reconocer importancia al planteamiento de JAKOBS sobre que la impunidad se fundamenta en «reacciones adecuadas a la situación», sin embargo la autora lo traslada al valor del motivo ${ }^{540}$.

Así exige en conclusión los siguientes requisitos normativos para apreciar una causa de exculpación: una mínima gravedad de la situación inicial; una probabilidad de peligro ${ }^{541}$; un mal sin límites en el catálogo de bienes (también patrimoniales) ${ }^{542}$ cuya procedencia puede ser típica o natural (catástrofe $)^{543}$; ajenidad del autor respecto a la situación exculpante pero no para mejorar su posición sino para conservarla ${ }^{544}$; necesidad o amenaza y una acción ex ante idónea para repelerla con el fin de conservar la vida, la integridad o la libertad u otros bienes (libertad sexual, honor, patrimonio) pero en razón de proteger la capacidad deliberativa que constituye el mínimo de gravedad cuando fuere «irreparable» ${ }^{545}$; falta de provocación en la exculpación ${ }^{546}$, sin obligación de sacrificarse ${ }^{547}$; proporcionalidad porque no se puede ocasionar un daño relevantemente mayor ${ }^{548}$; y por último la necesidad de una pena que como fuente originaria de la culpabilidad incluye la perspectiva del «propio autor» ${ }^{549}$, por lo que no son comprensibles los motivos de un policía que en un asalto emplea a un civil como escudo, esta falta de comprensión deviene de un motivo normativo, la obligación de sacrificio ${ }^{550}$.

538 ID., ibidem, op. cit., pp. 325 a 327 y pp. 414 a 417, si bien admite que un motivo comprensible no excluye otros motivos que hagan variar el juicio, ID., ibidem, op. cit., p. 416.

539 ID., ibidem, op. cit., p. 328 a 330.

540 ID., ibidem, op. cit., p. 332; sobre la referencia a JAKOBS, G., PG, op. cit., 20/4.

541 MARTín LORENZO, M., La exculpación penal, op. cit., p. 334 y pp. 417 y 418.

542 ID., ibidem, op. cit., p. 422.

543 ID., ibidem, op. cit., pp. 419 y 420

544 ID., ibidem, op. cit., p. 423.

545 ID., ibidem, op. cit., pp. 424 y 425 y pp. 450 a 452, si bien reconoce que normalmente esa gravedad vendrá del rango existencial, ID., ibidem, op. cit., p. 431.

546 ID., ibidem, op. cit., pp. 434 a 439, va a depender de si el sujeto causó dolosa o imprudentemente la situación de peligro, o si la buscó, por lo que la falta de provocación no pertenece a la antijuricidad puesto que aun existiendo provocación se podría apelar a la justificación, sin embargo en la exculpación es un requisito sine qua non de que no sea responsable de dicha falta, inclusive en los deberes de aseguramiento y de posición de garante en casos de injerencia, porque no puede esperar comprensión si pone en peligro sus propios bienes. Pone el ejemplo del excursionista mal equipado que ante una tormenta arrebata la chaqueta a otro para evitar congelarse, pero en casos de acción previa imprudente se podrá aplicar una exención exculpante incompleta. Concluye entonces que no podrá aplicarse la exculpación completa en caso de que el sujeto reúna la condición de provocador, necesitado y agente, ID., ibidem, op. cit., p. 441; similarmente pero siguiendo la teoría de la actio illicita in causa ROPERO CARRASCO, J., La provocación del estado de necesidad en Derecho penal, op. cit., pp. 491 y 492.

547 MARTín LORENZO, M., La exculpación penal, op. cit., p. 444 y 445.

548 ID., ibidem, op. cit., p. 340 y 341, y pp. 453 a 455, parece acoger la tesis de Silva Sánchez,

549 ID., ibidem, op. cit., p. 443.

550 ID., ibidem, op. cit., p. 349, pero con el límite de la alta probabilidad de muerte. Si bien explica que existe una diferencia entre la falta de provocación, cuyo fundamento está en la causación de un peligro, y la obligación de sacrificarse, que está en un deber previamente configurado al peligro, ID., ibidem, op. cit., pp. 446 y ss. 
Sobre el elemento subjetivo «para evitar un mal», la referida autora critica que la teoría dualista no se ha preocupado por esta distinción, considera que no existe equiparación entre el elemento subjetivo en el estado de necesidad justificante y el exculpante, por cuanto en el primero la acción es conforme a Derecho, y el segundo se fundamenta en el valor de la acción referido a sus consecuencias y al valor del motivo, es decir, que además de conocer el mal, el fin sea la salvaguarda del bien en peligro ${ }^{551}$.

Llama la atención que explique que en el caso hipotético de que el autor obre sin ánimo de defensa, por convicción, habría que condenar, si bien acepta la compatibilidad con otros motivos (particulares como el reconocimiento social o el deseo de ser nombrado heredero) además del defensivo, por lo que si no existe motivo no podrá ser comprensible y por ende no se exonerará ${ }^{552}$.

Con tales argumentos considera que el art. $20.5^{\circ} \mathrm{CP}$ en caso de conflicto de bienes iguales desborda los límites de la justificación porque se refiere a casos de exculpación. En su opinión, el inductor, el cooperador y el cómplice están exentos no por las reglas de la accesoriedad, sino porque la conducta entra de modo directo en la circunstancia exoneradora ${ }^{553}$ como vínculo especial entre autor y sujeto en la amenaza de sus bienes en proximidad (por ejemplo la familia o parientes), siempre y cuando exista relación y conocimiento de dicha proximidad ${ }^{554}$.

Dicho todo lo cual, podemos concluir que hay un acuerdo amplio por parte de la doctrina en otorgar a la inexigibilidad relevancia penal ubicada en la institución de la culpabilidad, si bien y paradójicamente, sólo existe reconocimiento -casi unánime por parte de la doctrina, no por la jurisprudencia del Tribunal Supremo- en que el miedo insuperable sería una causa de exculpación fundamentada en la inexigibilidad.

1) Doctrina a favor de aplicar el estado de necesidad exculpante en la autoría de conciencia

Parte de la doctrina española ${ }^{55}$ considera aplicable la eximente de estado de necesidad exculpante dentro del art. $20.5^{\circ} \mathrm{CP}$. Y por esta vía reconoce cierta solución de la problemática del autor de conciencia en el estado de necesidad exculpante.

551 ID., ibidem, op. cit., pp. 457 y 458.

552 ID., ibidem, op. cit., pp. 459 y 450.

553 ID., ibidem, op. cit., pp. 394 y 395.

554 ID., ibidem, op. cit., pp. 429 a 431.

555 Cobo Del Rosal M / Vives Antón TS., PG, op. cit., pp. 492 y ss; JAKOBS, PG, op. cit., 7/104; acertadamente POLAINO NAVARRETE explica que «(e)l estado de necesidad subjetivo excluye la culpabilidad, a diferencia del estado de necesidad objetivo que justifica la conducta (...) El estado de necesidad subjetivo afronta la alternativa de acciones lesivas de bienes jurídicos de igual valor (...) en que no se puede justificar una a costa de la otra sino sólo exculpar la lesión de uno de ellos ante la imposibilidad de salvaguardar ambos», POLAINO NAVArRete, M., Lecciones de Derecho penal, Parte general, T. II, op. cit., p. 174; RoMEO CASABONA, CMa., El 
En la doctrina alemana, ya en su tiempo GALLAS ${ }^{556}$ admitió que en una colisión de deberes como en el conflicto de conciencia podría plantearse una causa de estado de necesidad no justificante, sino exculpante. De forma más tajante, VON BURSKI ${ }^{557}$ consideraba que los casos de conducta basada en la conciencia como la de los testigos de Jehová que se niegan a una transfusión de sangre, son conforme al Derecho. Considera que este tipo de conductas están adecuadas a la libertad de conciencia de la Ley Fundamental, por lo que estaríamos ante un estado de necesidad exculpante.

Por su parte, HIRSCH acepta la posibilidad de que no exista antijuricidad en la autoría de conciencia por mor del derecho de libertad de conciencia del art. 4 de la Ley Fundamental. Considera también que la culpabilidad quedaría disminuida por debajo de los umbrales de exigencia por una causa de estado de necesidad exculpante y por lo tanto la pena no se debe $\operatorname{aplicar}^{558}$.

A su vez, STRATENWERTH ${ }^{559}$ admite, según los casos, la posibilidad de aplicar la analogía del estado de necesidad que disminuiría la culpabilidad. Considera que no toda conducta de motivos de conciencia es irreprochable, sólo aquellas que se basen en una situación de coacción personal del autor «tan cercana a su personalidad» (mandatos de conciencia elementales), por lo que no cabe la exclusión de la culpabilidad en base al art. 4 de la Ley Fundamental, salvo «si la infracción de las convicciones de conciencia que el derecho exige en el caso concreto del autor, dadas las circunstancias, también en miras a la clase y gravedad del hecho cometido en estado de necesidad, resulta tan grave que debe considerarse inexigible», y en casos del límite de proporcionalidad del estado de necesidad de conciencia del parágrafo 35 , apartado I. $2 \mathrm{StGB}^{560}$.

médico y el Derecho penal. La actividad curativa (Licitud y responsabilidad penal), Bosch, Barcelona, 1981, pp. $300 \mathrm{y}$ ss.

556 Vid. PÉrez del Valle, C., Conciencia, op. cit., pp. 169; vid. también vid. en Flores Mendoza, F., Objeción de conciencia, op. cit., 183.

557 Vid. FloRES MENDOZA, F., Objeción de conciencia, op. cit., 159 y 234; vid. también BAUCELLS I LLADÓs, J., La delincuencia por convicción, op. cit., pp. 234 a 236, y pp. 334, 335, y 338, (BURSKI, Ulrich von, Die Zeugen Jehovas, die Gewissensfreiheit und das Strafrecht, Inagural-Disertation zum Erlangung der Doktorwürde der Rechts und Staatswissenschaftlichen Fakultät der Albert Ludwigs, Universität zu Freiburg im Breisgau, 1970, p. 88 y ss. y 108 y ss.).

${ }_{558}$ Vid. BAUCELlS I LLADÓs, J., La delincuencia por convicción, op. cit., pp. 348 y 349 (HIRSCH, HJ., Strafrecht und Überzeugungstäter, Walter de Gruyter, Berlin/Nueva York, 1996, pp. 11 ss. 21 y ss. y 34 y35).

559 Stratenwerth, G., Derecho penal, Parte general I. El hecho punible, trad. Manuel Cancio Meliá y Marcelo A. SANCINETTI, Thomson, 2005, pp. 269 y ss.

560 ID., ibidem, op. cit., p. 271. A favor de esta perspectiva BAUCELLS, se centra en la protección de la libertad de conciencia y en su consecuencia en el libre desarrollo de la personalidad «sin recurrir a otros valores no reconocidos constitucionalmente (...) respetan el principio de igualdad ante la ley reconocido en el artículo 3.3 GG (...) su propuesta permite desarrollar el efecto irradiante que la libertad de conciencia debe tener en la inexigibilidad permitiendo superar el concepto psicológico de culpabilidad», BAUCELLS I LLADÓs, J., La delincuencia por convicción, op. cit., p. 343. También porque la postura de STRATENWERTH «permite superar la crítica a la inseguridad jurídica ofrecida por POMPE en el sentido de que sólo el legislador podía ofrecer mecanismos 
RoXIN distingue al igual que nuestros postulados, entre autor por convicción y autor por motivos de conciencia (hechos de conciencia/hechos de convicción). Admite que en la conducta del autor de conciencia, en algunos casos, pueda apreciarse la irresponsabilidad en virtud de un estado de necesidad supra-legal disculpante que bien puede situarse en una causa de inexigibilidad, basándose en el art. 4 de la Ley Fundamental que proclama la libertad de conciencia $^{561}$, pero es que además la pena sería innecesaria desde el punto de vista de su función preventiva. Para dicha postura, crea una institución jurídica a la que denomina «responsabilidad» o «reprochabilidad» (si bien ya MAURACH fundamentó esta institución), situada sistemáticamente después de la institución de la culpabilidad, que viene a fundamentar la punibilidad de la conducta desde criterios preventivos generales y especiales, es decir, por falta de necesidad de imponer una pena en casos concretos y bajo la causa legal de los art. 33 y 35 StGB. Pero lo más interesante que al respecto plantea RoxIN es la posibilidad de apreciar atipicidad en la conducta, como ya explicamos supra, cuando el propio Estado tiene medios para no afectar a esta libertad de conciencia, se refiere a la alternativa de comportamiento o legal, por ejemplo, cuando los padres omiten el consentimiento a la trasfusión de su hijo, pero a la vez existe la acción del médico que actuaría bajo un estado de necesidad justificante ${ }^{562}$.

Sin quitar legitimidad al Estado y sus principios rectores, RoxIN considera que en ocasiones la libertad de conciencia de la Ley Fundamental puede ampararse una causa de exclusión de la pena más que en la atipicidad de la conducta, en el sentido de que si se exige algún tipo de deber, es que la conducta es típica, por lo que sólo podría plantearse la posibilidad de la exclusión de la pena, salvo en casos que afecten a bienes jurídicos privados relacionados con la vida, por ejemplo, los padres que dejan morir a su hijo o el del médico que deja morir a la embarazada por oposición de conciencia al aborto. En estos últimos casos no cabría excluir la pena, pero sí en aquellos casos contra derechos privados y en terminadas circunstancias ${ }^{563}$. Para RoXIN, el art. 4

exculpatorios para las decisiones en conciencia (...) no creo que posiciones como las de STRATENWERTH fuercen en absoluto el sentido gramatical del párrafo 35», ID., ibidem, op. cit., p. 344. Y añade que «si la introducción en el párrafo 35 StGB del término «libertad», en 1975 se justificó por poseer un rango similar al de la integridad física o la vida, no se entiende por qué no puede extenderse analógicamente a la salvaguarda de la libertad de conciencia si ésta (...) está garantizada en la Constitución como íntimamente vinculado con la dignidad y la personalidad humanas», ID., ibidem, op. cit., p. 345. De tal modo BAUCELLS acude a estos postulados para sostener junto a STRATENWERTH la disminución de la culpabilidad derivada del injusto que se tendrán en cuenta en el parágrafo 35 StGB. Críticamente en relación al efecto extensivo analógico de la «libertad», RoxIN, C., PG, I, op. cit., p. 905.

561 RoXIN, C., PG, I, op. cit., pp. 942 ss. y pp. 949 ss; ID., “"Culpabilidad” y "Responsabilidad” como categorías sistemáticas jurídico-penales», op. cit., p. 91.

562 Roxin, C., PG, I, pp. 945, núm. 109, 949 y 950, núm. 120; también ID., «Die Gewissenstat als Strafbefreiungsgrund», op. cit., pp. 398 y ss., (vid. PÉREZ DEL VALlE, C., Conciencia, op. cit., p. 249).

563 Vid. PÉREZ Del VAlle, C., Conciencia, op. cit., p. 250 y 251; vid. BAUCELlS I Lladós, J., La delincuencia por convicción, op. cit., pp. 323 y 324 (RoXIN, C., «Die Gewissenstat als Strafbefreiungsgrund», op. cit., pp. 400 y 401). 
de la Ley Fundamental rompe con la teoría de la responsabilidad penal porque fundamenta la imposición de las penas en criterios de prevención, por lo que aun perpetrándose el delito, es posible que no merezca ser impuesta una pena por ser soportable tal conducta desde este prisma preventivo, siempre y cuando no quebrante los principios constitucionales, o se afecte a las seguridad del estado o derechos fundamentales de terceros ${ }^{564} 565$.

En la doctrina española, MIR PUIG, con su concepto amplio de autor por convicción, considera que la imputación personal (la culpabilidad) de este tipo de autores se basa, en que estos realizan el hecho dolosamente y con conocimiento de la antijuricidad, y que el conocimiento o la creencia de que la conducta «no merece ser antijurídica», no pertenecen a la imputación personal ya que tales creencias diferentes (elementos subjetivos) pertenecen al tipo de lo injusto. Es así como diferencia entre la obligación moral y jurídica, siendo ésta última portadora de la culpabilidad jurídica $^{566}$.

Tras esta argumentación, finalmente MIR PUIG deja la puerta abierta para exculpar (disculpar) o justificar casos de estado de necesidad, en virtud de su concepto material de culpabilidad basado en la «capacidad normal de motivación» como «capacidad pasiva de ser influido (normalmente) por las normas (...) porque pudo ser (en pasiva) y fue motivado normalmente» ${ }^{567}$ en algunos supuestos de omisión del deber de socorro por el Testigos de Jehová o en los casos de insumisión, aunque como se desprende de sus palabras esto sería ajeno a la propiedad conceptual jurídico-penal del autor por convicción ${ }^{568}$.

564 Vid. PÉrez del Valle, C., Conciencia, op. cit., p. 250 y 251; vid. Jericó OJer, L., El conflicto de conciencia, op. cit., pp. 434 a 437, críticamente le reprocha que ubique la falta de necesidad de la pena en una sola categoría y no en ámbitos diferentes de la teoría del delito, ID., op. cit p. 439 (RoXIN, C., «Die Gewissenstat als Strafbefreiungsgrund», op. cit., pp. 410 y 411.

565 En relación al insumiso RoXIN, C., "Culpabilidad” y "Responsabilidad” como categorías sistemáticas jurídico-penales», op. cit., pp. 57 y ss; HASSEMER W / MuÑOz CONDE F., Política criminal y sistema del Derecho penal, op. cit., p. 67.

566 Así advierte que «(1)a imputación personal jurídico-penal no requiere, pues, un sentimiento ético ni psicológico, no es culpabilidad de conciencia. Si no es suficiente una culpabilidad moral sin imputación jurídicopenal, sí basta la imputación jurídico-penal aunque no vaya acompañada del sentimiento de culpabilidad moral. De ahí que no deba confundirse el conocimiento de la antijuricidad, necesario para la imputación personal, con la creencia del sujeto de que su conducta no merece ser antijurídica», MIR PUIG, S., PG, op. cit., op. cit., p. 546; también MUÑOZ CONDE considera que existen menos dificultades «en admitir en algunos casos de realización, por razones de conciencia, de un tipo delictivo, no amparado por una causa de justificación, la existencia de una causa de exculpación o de exclusión de la culpabilidad. Desde este punto de vista, puede, por ejemplo, admitirse el estado de necesidad en su vertiente de causa de exculpación, lo que, sin embargo, supondría que la eximente $7^{\mathrm{a}}$ del artículo 8 de nuestro Código penal», ahora $20.5^{\circ} \mathrm{CP}$, «puede tener también este carácter, lo que algunos discutimos, y, en todo caso, obligaría a una ponderación y comparación entre dos bienes jurídicos difícilmente comparables», MUÑOZ CONDE, F., «La objeción de conciencia en Derecho penal», op. cit., p. 287; similarmente con este último BAUCELLS I LLADÓs, J., La delincuencia por convicción, op. cit., pp. 352 y ss.

567 MIR PUIG, S., PG, op. cit., p. 557.

568 ID., ibidem, op. cit., p. 547. 
PÉREZ DEL VALLE ${ }^{569}$ propone otra institución de la teoría del delito, la «responsabilidad por el hecho», similar a la de «responsabilidad» de RoxIN, pero ubicada en el estado de necesidad disculpante o exculpante como fundamento de un menor desvalor de la acción por el efecto irradiante del derecho a la libertad de conciencia del art. 16 CP como causa legal de exclusión de la pena, que se sustenta en el ejercicio legítimo de un derecho, y amparada doctrinalmente en un menor desvalor del resultado, porque el autor de conciencia, con el quebrantamiento de la norma, salvaguarda su propia conciencia, es decir, fundamenta un menor del desvalor de lo injusto ${ }^{570}$. Por eso, no descarta la aplicación de una atenuante de eximente incompleta de dicho ejercicio legítimo de un derecho o estado de necesidad exculpante ${ }^{571}$.

Expone que en el caso de no realizarse el traslado de un menor, sin madurez suficiente para decidir, o incapaz, o inconsciente, al centro hospitalario, o en caso de no avisarse a los servicios sanitarios, considera que aquí sí que existe un verdadero caso problemático. Centra la solución en la existencia de una «fuerza psíquica» que hace «inexigible» la conducta adecuada a derecho ${ }^{572}$, y concluye que en la mayoría de casos se aprecia esa disminución lo que lleva a una atenuación de la pena muy cualificada ${ }^{573}$. En este sentido el meritado penalista opina que existe mayor exigencia en los deberes de actuar que en los de omisión. En los delitos de omisión el nivel de inexigibilidad jurídica es superior precisamente por la mayor exigencia en el deber de actuar activamente, lo que fundamenta un menor desvalor de lo injusto y por lo tanto de la pena $^{574}$, sin embargo, en un artículo posterior reconoció que el fundamento de dicha disminución no es la diferencia de dificultad entre los tipos de acción o de omisión, sino las propias circunstancia del autor de conciencia ${ }^{575}$. También Flores MENDOZA acepta en determinados casos de objeción de conciencia la aplicación de un estado de necesidad disculpante mediante la aplicación analógica $^{576}$.

69 Pérez del VAlle, C., Conciencia, op. cit., pp. 284 y ss.

570 ID., ibidem, op. cit., p. 294.

571 ID., ibidem, op. cit., pp. 299 y 301.

572 ID., ibidem, op. cit., p. 262; TAMARIT SUMALLA, JMª., La libertad ideológica, op. cit., pp. 438 a 441, y 460 y ss.

573 PÉReZ Del Valle, C., Conciencia, op. cit., p. 316. Lo explica de la siguiente manera: «El conflicto de conciencia de los padres en esa omisión del deber de auxilio puede determinar una disminución de lo ilícito que, sin embargo, difícilmente puede excluir la pena, pues no se han agotado todas las alternativas que ofrece el orden jurídico. Una vez en el centro hospitalario, el tratamiento puede ser diverso del que se iba a rechazar y si, en cualquier caso, sólo se ofrece aquel como alternativa de salvación, la negativa al tratamiento propuesto no será típica, como se ha visto. Por lo tanto, la disminución de lo ilícito sólo será relevante para hacer desaparecer la pena si la correspondiente disminución del desvalor de acción fuese de consideración suficiente. Ello sucederá si los padres tuviesen la absoluta seguridad de que el único tratamiento de salvación es el que se va a rechazar y que cualquier otra posibilidad está descartada».

574 ID., ibidem, op. cit., p. 303.

575 PÉREZ Del VALLE, C., «La discusión actual sobre la delincuencia por convicción», CPC, 71, 2001, p. 374.

576 FloRes MeNDOZA, F., Objeción de conciencia, op. cit., pp. 245 y ss. 


\section{2) Doctrina a favor del principio de inexigibilidad de otra conducta en la autoría de}

\section{conciencia}

¿Es posible apreciar en el autor por convicción y de conciencia una disculpa de la conducta típica y antijurídica en la que han incurrido? En primera instancia, parece ser que en el autor por convicción, tal y como lo hemos conceptualizado en esta investigación, no se puede apreciar una causa de disculpa del Derecho, pues por ejemplo el terrorista «lucha» activamente contra el Derecho, contra la sociedad, contra la paz y el orden establecido democráticamente. Sin embargo, en la autoría de conciencia, la parte de la doctrina que ha estudiado la problemática, ha encontrado argumentos a favor de la inexigibilidad.

En la doctrina alemana, en este sentido MEZGER ${ }^{577}$ afirmaba que «la especial causa «supralegal» (de exclusión de la culpabilidad) de la no exigibilidad es también derecho reconocido en el ámbito de la conducta dolosa», lo cual tiene sentido en la autoría por convicción, respecto a la existencia de un deber jurídico-privado, como causa de exclusión de la culpabilidad.

EBERT consideraba que «la misión del artículo 4.1 de la Ley Fundamental es necesariamente preservar a los individuos ante la fuerza de la conciencia estatal» ${ }^{578}$. Utilizó para la exculpación, no el criterio moral como hacía en algunos casos Noll, sino el estricto ámbito jurídico. La comprensión en sus justos términos del principio de culpabilidad se excluye en el autor de conciencia. Éste actúa impulsado por una fuerza psíquica que le imposibilita actuar conforme a Derecho $^{579}$; sin embargo, la falta de culpabilidad -según el citado autor- viene determinada en el reconocimiento jurídico de la libertad de conciencia que le ampara actuar según la conciencia y que especialmente se recoge en una causa de inexigibilidad ${ }^{580}$. El estado de necesidad exculpante (disculpante) que preceptúa el parágrafo 35 a diferencia del 34 StGB que preceptúa el estado de necesidad justificante - la diferencia de los dos estados de necesidad es que el primero versa sobre casos en los que el mal causado ha sido igual al que se trataba de evitar, mientras que en justificante el mal causado debe ser menor al que se trataba de evitar- o la analogía o el ámbito

577 MezGer, E., Tratado de Derecho penal, T. II, trad. de la $2^{\text {a }}$ ed. alemana de 1933 y notas al Derecho penal español por José Arturo Rodríguez Muñoz y Antonio Quintano Ripollés, $3^{\text {a }}$ ed. adicionada, y puesta al día, Madrid, 1957, p. 221.

578 Vid. TAMARIT SUMALla, JMa ., La libertad ideológica, op. cit., p. 393 (EBERT, U., Der Überzeugungstäter in der neueren Rechtsentwicklung, op. cit., p. 60).

579 Vid. PÉREZ Del VAlle, C., Conciencia, op. cit., pp. 242 y 243 (EBERT, U., Der Überzeugungstäter in der neueren Rechtsentwicklung, op. cit., p. 60 y 61).

580 Vid. PÉrez Del VAlle, C., Conciencia, op. cit., pp. 242 y 243; vid. Flores Mendoza, F., Objeción de conciencia, op. cit., p. 207, (EBERT, U., Der Überzeugungstäter in der neueren Rechtsentwicklung, op. cit., p. 64). 
supralegal, son fuentes de interpretaciones a favor de la conducta bajo mandatos de conciencia. En este sentido, PETERS consideraba que se puede aplicar la analogía en virtud del antiguo parágrafo 51 del Código penal alemán (ahora parágrafo 35 StGB) como causa de estado de necesidad exculpante, pues la pérdida de la vida eterna para los autores de conciencia o de motivos religiosos es la perdida de la vida terrenal de ahora ${ }^{581}$. Sin embargo, como bien recuerda FLORES MENDOZA $^{582}$, la protección normativa de la vida no se refiere a la vida «eterna», sino a la física.

BooP $^{583}$ introdujo el llamado «principio de tolerancia» en la limitación de la libertad de conciencia sobre la medida de otorgar dos niveles de protección, uno primario referido a la esfera de la libertad, y otro secundario sobre los hechos no autorizados. Así, puesto que la pena supone el reproche estatal sobre la culpabilidad, en los casos de padres que niegan el consentimiento para la trasfusión de sangre, si bien existe una limitación del derecho a la libertad de conciencia, la falta de culpabilidad hace innecesaria la aplicación de una pena en atención al principio de tolerancia de la Ley Fundamental.

RUDOLPHI $^{584}$ apeló a la inexigibilidad a causa de la libertad de actuar conforme a la conciencia porque la Ley Fundamental habilita a actuar exteriormente conforme la conciencia interna, cuyo único límite sería la afección a terceros. El Derecho penal -según expone RUDOLPHI- también debe asegurar la esfera de libertad de los ciudadanos, por lo que debe tolerar, excepcionalmente, ciertas conductas y no restringirlas penalmente. El derecho penal tan sólo debe establecer un mínimo ético que si no es rebasado por el autor de conciencia se le puede aplicar una causa de exclusión de la pena, es decir, una causa de exculpación que deriva del art. 4 de la Ley Fundamental porque falta en verdad el reproche estrictamente penal. RUDOLPHI admite que si bien no se elimina totalmente la culpabilidad, existe una doble disminución, por un lado del injusto porque el sujeto trata de salvar su personalidad, lo que fundamenta un menor desvalor

581 Vid. TAmarit Sumalla, JMª ., La libertad ideológica, op. cit., p. 406; vid. también Flores MendOZA, F., Objeción de conciencia, op. cit., p. 206, mantiene que PETERS en verdad no considera que el conflicto de conciencia se identifique con supuestos patológicos de inimputabilidad; vid. también BAUCELLS I LLADós, J., La delincuencia por convicción, op. cit., pp. 332, 333, y 337 (PETERS, K., Das Gewissen aus rechtlicher psycologischer und teologischer Sicht, I, Peters (Hrsg), Evangelischer Akademie, Mülheim a. d. Ruhr, 1974, p. 12, ID., «Überzeugungstäter und Gewissenstäter», op. cit., p. 278 y ss., nota 70).

582 Flores MENDOZA, F., Objeción de conciencia, op. cit., p. 232 y ss.

583 Vid. PÉreZ Del VAlle, C., Conciencia, op. cit., pp. 241y 242; vid. BAUCELls I Lladós, J., La delincuencia por convicción, op. cit., pp. 236 y 237, y pp. 322 y 323; vid. JERICó OJER, L., El conflicto de conciencia, op. cit., pp. 433 y 434, críticamente en p. 438 (BoOP, U., Der Gewissenstäter und das Grundrecht der Gewissensfreheit, op. cit., pp. 182 a 185 , y 210 y ss).

584 Vid. PÉrez Del VAlle, C., Conciencia, op. cit., p. 224 y 248; vid. Jericó OJer, L., El conflicto de conciencia, op. cit., pp. 431 a 433; vid., BAUCELLS I LLADÓs, J., La delincuencia por convicción, op. cit., pp. 318 a 320; (RUdOLPHI, H-J., «Die Bedeutung eines Gewissenentsscheides für das Strafrecht», Festschrift für Hans Welzel, 1974 , pp. 605 y ss.). 
del resultado, y por otro de la culpabilidad porque el sujeto ha tenido dificultad de motivarse conforme a la norma, lo cual hace innecesaria la pena, en definitiva porque otras medidas pueden servir en orden a mantener la protección social.

De otra parte, Noll consideraba que «las normas jurídicas están fundadas moralmente en la medida en que protegen bienes jurídicos» ${ }^{585}$, por lo que si se incurre en un tipo penal se ha descuidado un deber moral. En este sentido el autor por convicción, al no reconocer la norma, no se le puede reprochar moralmente el quebrantamiento, y de aquí que tampoco jurídicamente en aquellos casos en los que los bienes jurídicos sean cambiantes respecto al orden moral y social, como el orden político ${ }^{586}$.

LÜCKE $^{587}$ abogó por una causa supralegal de exclusión de la culpabilidad de carácter general en virtud del art. 242 CC alemán que parece garantizar una causa de inexigibilidad, mientras que WITTIG $^{588}$ la fundamenta en una causa supralegal basada en el principio de nulla poena sine culpa.

Por último, también podemos incluir en este apartado a RoXIN como defensor de una causa de inexigibilidad en razón de la supralegal del art. 4 de la Ley Fundamental, si bien no la llega a fundamentar en esencia en ésta. Su idea sobre las causas de exculpación se sostiene en la «responsabilidad» que se refiere a una categoría, como dijimos, entre la culpabilidad y necesidad preventiva de la pena. Según Roxin, en las causas de exculpación emergen los argumentos preventivos, por ejemplo en casos especiales cuando el sujeto está socializado y el delito es algo extraordinario y por un menor desvalor del injusto cuando la salvación de sus bienes incide en la idea de improbabilidad de reincidencia. Con la prevención general argumenta que no hace falta intimidar, si bien hay culpabilidad lo que falta en estos casos son argumentos de punibilidad ${ }^{589}$.

En la doctrina española, TAMARIT SUMALLA ${ }^{590}$ considera que en algunos casos se puede aplicar una causa de exculpación por inexigibilidad de otra conducta. Una cuestión importante que bien predijo $^{591}$, en relación a los objetores de conciencia al servicio militar, es que una política militar, acompañada del respaldo constitucional del art. $30.1 \mathrm{CE}$, se verían, y así se vio,

585 Vid. BAUCElls I Lladós, J., La delincuencia por convicción, op. cit., 314 (Noll, P., «Der überzeugungstäter», op. cit., p. 644).

586 Vid. ID., ibidem, op. cit., p. 314 (NoLL, P «Der überzeugungstäter», op. cit., p. 653).

587 Vid. FloRES MENDOZA, F., Objeción de conciencia, op. cit., 257.

588 Vid. ID., ibidem, op. cit., 259.

589 RoXIN, C., PG, I, op. cit., pp. 942 ss. y pp. 949 ss; ID., «Culpabilidad, prevención y responsabilidad en Derecho penal», RoxIN, C., Culpabilidad y prevención en Derecho penal, op. cit., p. 152; ID., «"Culpabilidad” y "Responsabilidad" como categorías sistemáticas jurídico-penales», op. cit., pp. 57 y ss.

590 TAMARIT SUMALLA, JM ${ }^{\mathrm{a}}$., La libertad ideológica, op. cit., pp. 422 y ss. y especialmente p. 430, aunque en un trabajo posterior parece rechazarlo, ID., «La objeción de conciencia», op. cit, p. 39.

591 TAMARIT SUMALla, JM ${ }^{\mathrm{a}}$, La libertad ideológica, op. cit., p. 450. 
comprometidos por la masiva avalancha de objetores e insumisos. Esto fue síntoma claro de un cambio de valores de la sociedad en los años noventa, por ello no tardó el legislador en dar el respaldo necesario acorde a esos nuevos valores con la supresión progresiva del servicio militar obligatorio y la entrada del Ejercito Militar Profesional. El final del servicio militar obligatorio ha demostrado con el tiempo que la pena para los insumisos era innecesaria, aunque sí antijurídica y culpable ${ }^{592}$.

Por otro lado, otros autores como Bustos consideran que la «creencia diferente» afecta a la culpabilidad $^{593}$. De alguna manera parece sostener que la inexigibilidad afecta al juicio de la culpabilidad, sin embargo, este mismo autor comentaba que «(n)o se trata de un juicio a las capacidades de las personas, sino a la capacidad del Estado, en definitiva de su legitimación, para exigir esa respuesta a la persona y para ello el Estado, en los términos del art. 9.2 CE, respecto de ese individuo concreto ha de haber promovido (...) su libertad e igualdad ${ }^{594}$. En este sentido, si bien tal criterio se fundamentaba en la ética-social de la norma y su deber de cumplimiento en este sentido, también se extrae de sus argumentos que la norma y su legitimación han de identificarse con ética-social, lo que pretexta una conducta conforme a la norma cuando ésta, o sea, la capacidad del Estado, no se legitima con la identificación de la sociedad. Por ello, podemos concluir que en esta tesis se fundamenta el principio de inexigibilidad en base a la legitimidad de las normas, de tal modo que en ocasiones a los ciudadanos no les sería exigible un comportamiento conforme a la norma cuando no está legitimada sistémicamente ${ }^{595}$.

Otros autores, como GómEZ BENÍTEZ ${ }^{596}$, aplican una causa supralegal de exclusión de la punibilidad en virtud de las normas constitucionales relativas a los fines de la pena, en este caso, cuando la pena no sea necesaria en función de las determinadas circunstancias del sujeto.

\footnotetext{
592 No es desacertada la opinión de TAMARIT SUMALLA cuando dice que «(l)a preocupación por imponer más pena que la necesaria, la falta de otra finalidad de la pena que no sea la mera prevención general, así como la conveniencia de evitar la conflictividad social planteada por la proliferación de presos de conciencia, son factores que (...) van a determinar probablemente el recurso a diversos mecanismos que eviten la imposición de la pena, o bien la reduzcan o atenúen en lo posible el rigor de su cumplimiento», ID., ibidem, op. cit., p. 456.

593 Bustos RamíRez, J., Control Social y sistema penal, PPU, 1987, op. cit., p. 360; Bustos RAMíREZ J / HormazÁBAl MalarÉE H., Lecciones de Derecho penal, op. cit., pp. 311 a 337.

594 Bustos RAMíREZ, J., Control Social y sistema penal, op. cit., p. 337.

595 Sin embargo, si bien sus conclusiones fundamentarían la exoneración del autor de conciencia por causa de inexigibilidad, la determinación que hace sobre la ética-social incurre en la contradicción de aplicar las normas en el sentido de la moral pública dominante, dejando de lado y por lo tanto sin aplicación el principio de inexigibilidad, en aquellas conductas basadas en una conciencia moral minoritaria, opuesta o discrepante de la dominante, por lo que sus postulados de inexigibilidad sólo se aplicarían a las conductas de conciencia tradicionalmente preestablecidas en la moral dominante, con lo que en verdad se redunda en la idea de que la autoría de conciencia es sólo aquella que es «comprensible» en la ética-social dominante, y no aquélla que por su especialidad discrepa.

596 GÓMEZ BENÍTEZ, JM., «Consideraciones», op. cit., pp. 78 a 80.
} 
Aunque también admite ${ }^{597}$ la aplicación de un estado de necesidad exculpante cuando existe un conflicto entre el derecho a la libertad de conciencia y el deber jurídico, más exactamente, cuando entra en conflicto el deber moral y el deber jurídico.

También BAUCELLS se ha mostrado partidario del efecto irradiante de las libertades de convicción y de conciencia en el juicio de «inexigibilidad», sin que sea necesario recurrir a otras categorías del delito fuera de la culpabilidad para dotar de eficacia a la inexigibilidad ${ }^{598}$. Esta conclusión la sostiene en un criterio teleológico-constitucional de la culpabilidad, concretamente en los principios de igualdad, legalidad y dignidad humana ${ }^{599}$. Concluye que no se está amparando en una causa supralegal de inexigibilidad ni de la aplicación analógica, sino del análisis del efecto irradiante de la garantía constitucional de esas libertades que encuentran su acomodo en las causas legales de exculpación ${ }^{600}$. Lo decisivo será la situación de inexigibilidad, mientras que la disminución del ilícito servirá de limitación preventiva. En este último caso, comenta que «será más fácil aceptar socialmente la exclusión de la pena si la conducta salvaguarda un bien reconocido por el ordenamiento jurídico». De este modo, se faculta la aplicación del estado de necesidad exculpante con base a los arts. 16 y $30 \mathrm{CE}$, si bien se reconoce que es insalvable la crítica de que estaríamos ante bienes difícilmente comparables: «(s)erá difícil imaginar un conflicto de conciencia que lleve al sujeto a lesionar la libertad de conciencia de otros». Puesto que el art. $20.5^{\circ} \mathrm{CP}$ se refiere a conflicto de intereses, no tanto de males, será difícil mantener que puede mantenerse en este precepto el estado de necesidad exculpante ${ }^{601}$.

597 ID., ibidem, op. cit., pp. 75. Críticamente FlORES MENDOZA, F., Objeción de conciencia, op. cit., p. 183 por cuanto considera que de un derecho a la libertad de conciencia no se deriva siempre un deber jurídico o moral, habría siempre un conflicto de conciencia aunque no estuviera amparada en una norma o derecho; también críticamente BAUCELLS I LLADós, J., La delincuencia por convicción, op. cit., p. 326 al afirmar que no entiende por qué «si exige como condición que no se interfiera en esferas jurídicas ajenas, no puede encontrar una solución en el ámbito del injusto».

598 BAUCELlS I LLADÓs, J., La delincuencia por convicción, op. cit., pp. 325 y 326, su planteamiento se inspira en las consideraciones de WITTIG y LÜCKE sobre el fundamento constitucional de la causa de inexigibilidad como casusa supralegal de exclusión de la culpabilidad (WITTIG, Peter, «Der übergesetzliche Schuldausschliessungsgrund der Zumutbarkeit in verfassungsrechtlicher Sicht», JZ, 1969, pp. 546 y ss; LÜCKE, Jörg, «Die Grundsätze der Verhältnismässigkeit und der Zumutbarkeit», DÖV, 1974, pp. 769 y ss).

599 De modo tal que «deberá analizarse hasta qué punto la garantía constitucional de actuar de acuerdo con las propias convicciones o conciencia sin que el sujeto deba verse coaccionado por una pena permite excluir la culpabilidad del sujeto (...) Se tratará más bien de respetar los límites del efecto irradiante que esas libertades, como derecho objetivo, tiene en la culpabilidad, que no son otros que los establecidos por el legislador, de acuerdo con el contenido de los principios constitucionales aludidos, en la concreta regulación legal de las causas de exclusión de la culpabilidad», BAUCELLS I LLADÓs, J., La delincuencia por convicción, op. cit., p. 327.

600 ID., ibidem, op. cit., p. 329.

601 ID., ibidem, op. cit., p. 356 y 357. 
Más recientemente, LUZÓN PEÑA ${ }^{602}$ admite que en los casos extremos y en determinadas circunstancias, la «actuación de conciencia» puede verse afectada por un conflicto interno (psíquico, motivacional) que impida fácticamente al sujeto su «accesibilidad normativa» para motivarse conforme a la norma. Esta situación fundamentaría la exculpación por una causa supralegal basada en el principio de inexigibilidad penal individual o subjetiva o «si se prefiere analógica con las causas de exculpación legalmente admitidas», siempre que se den dos requisitos: por un lado que la valoración normativa no se oponga a ello, y por otro y excepcionalmente que «se dé el dato adicional de que esa actuación en conciencia no implique peligro de repetición reiterada y por ello no resulte penalmente intolerable desde el punto de vista preventivo (el criterio normativo en este supuesto coincide, como se ve, con el criterio de RoxIN de excluir la responsabilidad cuando la punición no es necesaria a efectos de prevención general ni especial)» ${ }^{603}$. Admite también que en casos en los que la presión motivacional no es tan intensa o en casos en los que aun que sea extremo el conflicto no es «normativamente comprensible tal conflicto», o cuando existe una «valoración negativa a efectos preventivos por el peligro de repetición de ese conflicto», se podrá disminuirse por una exculpación parcial en virtud de una atenuante analógica incluso muy cualificada del art. 66.1.2 $2^{\mathrm{a}} \mathrm{CP}$, no así por una causa incompleta del art. $21.1^{\mathrm{a}} \mathrm{CP}$ que -según su opinión- no se contempla en la inexigibilidad $^{604}$.

De esta manera, el citado penalista otorga al autor de conciencia cierto trato privilegiante con la aplicación vista más arriba de una causa de justificación basada fundamentalmente en el art. $16 \mathrm{CE}$, y en otras ocasiones cuando no se aprecie ésta, la exculpación penal o atenuación de la pena por una mayor o menor inexigibilidad de la conducta conforme a la norma, significando de esta manera el distinto tratamiento penal entre el autor de conciencia y el autor por convicción. El autor por convicción no comparte el fundamento de la norma, por eso internamente no la respeta, cree que actúa correctamente por una ideología contraria a las normas jurídicas vigentes, lo que parece causar su comportamiento delictivo como en los terroristas, en ciertos miembros de sectas criminales, fanáticos, grupos antisemitas, mafias y bandas organizadas, sin embargo admite que en casos de fanatismo político, religioso o ideológico su conducta se deba a un conflicto «insalvable» para su conciencia ética, pero en la mayoría de casos el autor es capaz de motivarse por la norma, por eso evita ser castigado, incluso en los casos de terrorismo yihadista

62 LUZÓN PEÑA, D-M., «Actuación en conciencia», op. cit., pp. 11 y ss.

${ }^{603}$ ID., ibidem, op. cit., pp. 12 y 13 (cursiva del autor), como sería el caso de la objeción de conciencia fiscal en gastos militares, en los que habría una alta probabilidad de que se volviera a repetir el conflicto, lo que en su caso impediría una exculpación total en el segundo delito.

${ }^{604}$ ID., ibidem, op. cit., pp. 13 y 14. 
el autor aunque no tiene miedo a la pena porque busca su inmolación en muchos casos, igualmente teme ser capturado y sufrir la pena. De esta manera concluye que el autor por convicción merece el máximo reproche penal por su peligrosidad y por su enfrentamiento «total» con el ordenamiento jurídico, sin embargo admite que en casos muy excepcionales la situación psicológica del autor por convicción puede ser «anormal», y expone el caso de los lavados de cerebro en los que existe una anomalía psíquica o de trastorno mental transitorio que excluya la culpabilidad por inimputabilidad que fundamenta la aplicación de medidas de seguridad por la peligrosidad que demuestra ${ }^{605}$.

De otra parte, la solución que propone JERICó es privilegiante por razones de inexigibilidad, al menos en casos de bienes jurídicos menos importantes ${ }^{606}$, según los casos ${ }^{607}$. No acabamos de entender qué relevancia tiene la conclusión de la autora de que en la mayoría de supuestos de conflicto de conciencia, las normas obligan a un comportamiento positivo para proteger bienes supraindividuales ${ }^{608}$.

Dicha conclusión nos parece incoherente con los postulados de la vigencia de la norma. Toda norma tiene igual fuerza vinculante siempre y cuando tenga legitimidad y no realice cierta contraorientación. De esa manera no podemos estar de acuerdo en que según la afección al bien jurídico exista más o menos fuerza vinculante, porque la referencia al bien digno de protección tiene su transcendencia en la pena, no en la fuerza vinculante y en la vigencia de la norma.

\section{El miedo insuperable como causa de exclusión de la culpabilidad en los autores de} conciencia

\section{1) Introducción}

$\mathrm{El}$ art. $20.6^{\circ} \mathrm{CP}$ preceptúa que está exento de responsabilidad criminal «el que obre impulsado por miedo insuperable». Si el sujeto obra por la acción material irresistible de un tercero (fuerza) se apreciaría una coacción, lo que eliminaría el comportamiento humano, por lo que no es esto lo que parece decir el apartado sexto, sino que el sujeto obre por un temor, por una amenaza de un mal. Así, desde la aparición de la nueva redacción por la que se excluyó el requisito de que los males fueran de la misma entidad, iguales, la doctrina viene sosteniendo que esta causa supone

${ }^{605}$ ID., ibidem, op. cit., pp. 14 y 15.

606 JERICÓ OJER, L., El conflicto de conciencia, op. cit., p. 438, y pp. 464 y ss.

607 ID., ibidem, op. cit., p. 155.

${ }^{608}$ Señala que «(a)l no afectar el conflicto a bienes jurídicos más importantes, parece más entendible que en aquellos supuestos anteriormente mencionados sea menos exigible que el sujeto se comporte conforme a lo establecido por la norma, debido precisamente a la menor entidad de los bienes jurídicos protegidos», ID., ibidem, op. cit., p. 464. 
una eximente supletoria a las demás ${ }^{609}$, por ejemplo para apreciar la exoneración en caso de exceso intensivo de legítima defensa como ya hemos apuntado.

La doctrina mayoritaria ubica en la culpabilidad la aplicación de una causa de exculpación basada en el miedo insuperable, si bien no se pone de acuerdo si es una causa de inexigibilidad, mayoritariamente aceptada por la doctrina ${ }^{610}$, o por el contrario es una causa inimputabilidad, aunque hay quienes, como GIMBERNAT ORDEIG ${ }^{611}$, se aferran a la idea de que es una causa de justificación como ya expusimos.

En nuestra opinión, y siguiendo a la doctrina mayoritaria, el miedo insuperable se integra en la categoría de la culpabilidad por inexigibilidad porque supone una merma significativa de la capacidad del sujeto para orientarse conforme a la norma en atención a una especial situación ${ }^{612}$, esto es, por una causa externa y no interna que supondría una causa de inimputabilidad como defiende parte de la doctrina y la jurisprudencia del Tribunal Supremo reiteradamente ${ }^{613}$, si bien a partir del año 2002 la jurisprudencia empieza a contemplar el fundamento de la inexigibilidad $^{614}$.

609 Cerezo MiR, J., Curso de Derecho penal español. Parte general, III/2, p. 144 ; COBO DeL RosAL M / VIVES AnTON TS., PG, op. cit., p. 697; CUERDA ARnAU, ML., «Comentario al art. 20.5 ${ }^{\circ}$ CP», coord. VIVES ANTÓN, Comentarios al Código penal de 1995, T. I, Valencia, 1996, pp. 164 y 165; VARONA GómEZ, D., El miedo insuperable, op. cit., pp. 293 y ss.

610 Cerezo MIR, J., Derecho penal, Parte general, Lecciones, op. cit., p. 130 ; ID., Curso de Derecho penal español, Parte general, III/2, op. cit., p. 140; DíAZ PALOS, Fernando, «Miedo insuperable», Nueva Enciclopedia Jurídica Seix, T. XVI, Barcelona, 1978, pp. 347 y ss; CoBo Del RoSAL M / VIVES ANTÓN TS., PG, op. cit., pp. 698; CUERDA ARNAU, MáL., El miedo insuperable, op. cit., p. 80; HiguERA GuIMERÁ, JF., La eximente de miedo insuperable en el Derecho penal común y militar español, Bosch, Barcelona, 1991, pp. 81 a 85 y p. 214; JERICO OJER, L., El conflicto de conciencia, op., cit., p. 413; MIR PUIG, S., PG, op. cit., pp. 622; PEREZ DEL VALLE, C., Conciencia, op. cit., p. 275; SAINZ CANTERO, JA., La exigibilidad de conducta adecuada la norma en Derecho penal, op. cit., pp. 47 y 134 ; VARONA GÓMEZ, D., El miedo insuperable, op. cit., pp. 123 y ss.

611 GIMBERnAT, E., Introducción a la Parte general del Derecho penal español, op. cit., pp. 66 y ss; similarmente, CUERDA RIEZU, A., La colisión de deberes en Derecho penal, op. cit., p. 253; GÓMEZ BENÍTEZ, JM., Teoría jurídica del delito, op. cit., pp. 436 y ss.

612 Cerezo Mir, J., Curso de Derecho penal español, Parte general, III/2 op. cit., p. 140; CUERDA ARNAU, MaL., El miedo insuperable, op. cit., p. 82; HigUERA GUIMERÁ, JF., La eximente de miedo insuperable, op. cit., pp. 118 y ss; MIR PUIG, S., PG, op. cit., p. 623; VARONA GÓMEZ, D., El miedo insuperable, op. cit., p. 122.

613 En la jurisprudencia, por ejemplo las SSTS, de 20 de septiembre de 1995 y de 25 de diciembre del mismo año y STS, de 26 de abril de 1999, entienden que el miedo insuperable es una causa de inimputabilidad de similar naturaleza a la del trastorno mental transitorio. También más recientemente la STS 172/2003, de 6 de febrero de 2003 Esto en opinión de MIR PUIG constituiría un sinsentido pues «se vendría a convertir la eximente de miedo insuperable en una inútil modalidad de trastorno transitorio, que ya produce el mismo efecto según el art. 20.1. ${ }^{\circ}{ }$, MIR PUIG, S., PG, op. cit., p. 622. Recuerda que «(n)o se trata de que el sujeto pierda su lucidez mental y sea excluida su imputabilidad, sino de que se halla sometido a la amenaza de un mal intersubjetivamente insuperable, esto es, que el hombre medio no superaría, por mucho que siga teniendo clara su conciencia y sea dueño de su voluntad. Ello basta para que concurra un «miedo insuperable», ID., ibidem op. cit., p. 623. Anteriormente el TS incluso apreció que el miedo insuperable era una causa de ausencia de acción en la STS, de 26 de octubre de 1982.

614 STS de 13 de diciembre de 2002. Más ampliamente al respecto de la jurisprudencia del TS, AGUADO CORREA, T., Inexigibilidad, op. cit., pp. 130 a 138. 


\section{2) Requisitos del miedo insuperable}

Si como decimos basta para la apreciación de la eximente un temor insuperable provocado por la amenaza de un mal, debería aplicarse a los autores de conciencia, sin embargo, como FLORES MENDOZA ${ }^{615}$ advierte con razón, al requerirse que dicho miedo provenga de una causa exógena, no parece posible que se pueda aplicar al autor de conciencia ya que en este el miedo viene precisamente de sus propias convicciones, ni se aprecia en su conflicto un mal en sentido jurídico.

Sin embargo, en nuestra opinión, no es necesario que el mal sea real, basta que exista el efecto psicológico de un temor ${ }^{616}$, pues ya no se exige «un mal mayor» como así lo exigía el anterior precepto derogado del miedo insuperable, lo que habla a favor de considerar esta eximente como una causa de inexigibilidad inclusive supletoria en casos de exceso extensivo o intensivo de legítima defensa o estado de necesidad ${ }^{617}$. En este sentido, será el grado de miedo que sufra el sujeto lo relevante, no en tanto a la insuperabilidad del miedo, cuestión que sería del todo psicologizante, sino como acuerdo del ordenamiento en no poder exigir al sujeto adecuar su conducta conforme a Derecho en ese caso en concreto ${ }^{618}$.

El Tribunal Supremo exige que el miedo sea de tal intensidad que el «hombre medio», es decir, «el común de los hombres» no lo pudiese resistir. Sin embargo, me parece que el recurso constante al «hombre medio» ${ }^{619}$ es erróneo para valorar el miedo, algo que no ha de ser valorado subjetivamente, sino normativamente por un déficit de socialización causado por las circunstancias del caso ${ }^{620}$, aunque otros utilizan el criterio personal y subjetivo para determinar si el miedo es insuperable ${ }^{621}$. Así pues, verificado en el sujeto tiene un temor que por sus circunstancias no haya podido superar, habrá que examinar si ex ante, pero exigiendo una mínima racionalidad del miedo, existe una anormalidad de capacidad de orientarse conforme a la norma.

\footnotetext{
615 Flores MendozA, F. Objeción de conciencia, op. cit., pp. 250 y 251; también Higuera GuIMERÁ, JF., La eximente de miedo insuperable, op. cit., pp. 121 y ss.

616 Parece sostener también esto Polaino NAVARrete, M., Lecciones de Derecho penal, Parte General, T. II, op. cit., p. 175; HIGUERA GUIMERÁ, JF., La eximente de miedo insuperable, op. cit., p. 216 y 217 habla de vis compulsiva.

617 Aguado CoRrea, T., Inexigibilidad, op. cit., p. 138.

618 ID., ibidem, op. cit., p. 139; CUERDA ARNAU, Mª., El miedo insuperable, op. cit., p. 81; VARONA GÓMEZ, D., El miedo insuperable, op. cit., p. 76.

619 Tampoco acepta el criterio del «hombre medio» en el miedo insuperable VARONA GómEZ, D., El miedo insuperable, op. cit., pp. 159 y ss.

620 También críticamente CUERDA ARNAU, M Ma L., El miedo insuperable, op. cit., pp. 111, si bien no desecha la utilización del criterio del hombre medio, apuesta por utilizar otros criterios.

621 Higuera GUIMERÁ, JF., La eximente de miedo insuperable, op. cit., p. 125.
} 
Si partimos de los mismos presupuestos de la doctrina que defiende el concepto de «hombre medio» como criterio objetivo pero sin desperdiciar las cualidades del sujeto, podría legitimar la concurrencia de éste en conductas típicamente dolosas y antijurídicas del autor por convicción como el terrorista. Imaginemos a un sujeto de esta índole que tiene miedo a que el nuevo presidente de la nación cambie la configuración económica de la capitalista a la comunista, porque así se puede llegar a deducir de las palabras del mismo o de su programa electoral finalmente reconocido democráticamente. Este miedo puede causar una contrariedad o conflicto con sus circunstancias o condiciones personales físicas y mentales, como es la ideología propia que tiene el sujeto y su grado de implantación en sus valores, que le lleve a ejecutar el atentado por un miedo insuperable. Pero este miedo insuperable o inevitable subjetivamente -como defiende Higuera GUIMERÁ ${ }^{622}$ - puede considerarse como tal, subjetivamente el sujeto así lo aprecia. Por nuestra parte, admitirlo sería un sin sentido, porque se legitimaría que cualquier convicción personal ya fuese moral, religiosa, política o filosófica, que tuviera una entidad suficiente en el sujeto, llevaría también conforme al criterio de «hombre medio», a eximir de responsabilidad.

Dicho lo cual, efectivamente, el Derecho tampoco puede depender de las apreciaciones subjetivas por intensas o ineludibles que fueren como en el miedo insuperable, sino de razones estrictamente normativas. A este respeto, recuérdese que si bien defendemos un fundamento de exoneración o disminución de la responsabilidad en el autor de conciencia por la estrecha conexión entre conciencia y voluntad, hemos explicado que normativamente existe en algunos casos un déficit de socialización en el sujeto por culpa de la norma o atribuible a la norma, o déficit de comunicación o contraorientación normativa que provoca ese factor inevitable. Por eso para apreciar la causa de miedo insuperable hay que analizar la entidad del mal y su naturaleza.

Por regla general, el mal que amenaza ha de ser grave e inminente ${ }^{623}$, al igual que en el estado de necesidad, pero se discute si basta un miedo real, al menos en la conciencia del sujeto (imaginario) como parte de la doctrina defiende ${ }^{624}$, o necesariamente ha de tener realidad en el mundo exterior ${ }^{625}$. Sin embargo en nuestra opinión, y siguiendo la doctrina mayoritaria, lo

${ }^{622}$ ID., ibidem, op. cit., pp. 128 y ss. y p. 217.

623 Discute la inminencia HIGUERA GUIMERÁ, JF., La eximente de miedo insuperable, op. cit., p. 121.

${ }^{624}$ Cobo Del Rosal M / Vives Anton, TS., PG, op. cit., p. 700, nota núm. 48; Higuera Guimerá, JF., La eximente de miedo insuperable, op. cit., p. 217 si bien en estos casos los trata como error; JERICO OJER, L., El conflicto de conciencia, op. cit., p. 424.

${ }^{625}$ Higuera GUIMERÁ, JF., La eximente de miedo insuperable, op. cit., pp. 123 y pp. 216 y 217; VARONA GÓMEZ, D., El miedo insuperable, op. cit., pp. 184 y ss. 
importante para aceptar casos de miedo insuperable es que el mal ha de ser jurídico ${ }^{626} \mathrm{y}-$ como muy acertadamente explica PoLAINO NAVARRETE- «(e)l miedo se funda en la relevancia social que lo determina (por ejemplo: el temor a sufrir un allanamiento de morada o una agresión personal, y no a percibir el recibo mensual del alquiler de un apartamento)» ${ }^{627}$. De esta manera, defendemos que esa entidad del mal se ha de poner en relación con el valor normativo, esto es que sea jurídico y tenga cierta importancia en el caso concreto en el acervo social, de lo contrario bastaría con un miedo insuperable en la pérdida de la vida eterna para quebrantar la norma. Este valor no es jurídico, se desconoce en el acervo social esa trascendencia, sin embargo se puede amparar en la libertad de obrar conforme a la conciencia cuando el sujeto afecta a sus propios bienes, y en otros casos cuando afecta a los del tercero, no por dicho trascendencia eterna, sino como hemos anunciado, por déficit de socialización atribuido a la norma, por disminución relevante o falta de la comunicación o contraorientación normativa.

VARONA GÓMEZ explica que la insuficiente redacción del art. 20.6 $\mathrm{CP}$ impulsa a interpretar el «miedo insuperable» en aquellos casos en los que el mal realizado es mayor que el que se trata de salvar, como defiende la más reciente doctrina ${ }^{628}$ en relación a la entidad de un «mal amenazante» real con la «acción salvadora» de una amplia categoría de bienes ${ }^{629}$, cuyo sujeto o alguien muy cercano afectivamente ${ }^{630}$ actúa proporcionalmente y sin obligación de tolerar peligros $^{631}$. El específico campo de la exculpación que adopta VARONA le hace relegar todas las situaciones del estado de necesidad al justificante ${ }^{632}$.

MARTín LORENZO critica la «eficacia psíquica cuantitativa» del miedo insuperable porque también otras pasiones como el odio, los celos y la furia tienen esa eficacia intensa en la conducta, pero no son exoneradoras, por lo que aboga por un criterio del miedo cualitativo en relación al ánimo de conservación o subsistencia de la capacidad de autodeterminación o capacidad deliberativa, que en esencia constituye el motivo comprensible ${ }^{633}$. Parece defender su

626 CUerda Arnau, Mál, El miedo insuperable, op. cit., p. 114; Higuera GuIMERÁ, JF., La eximente de miedo insuperable, op. cit., pp. 121 y ss; POLAINO NAVARRETE, M., Lecciones de Derecho penal, Parte General, T. II, op. cit., p. 175. No contempla la necesidad de un mal no juridico, Flores MENDOZA, F., Objeción de conciencia, op. cit., p. 253.

${ }_{627}$ Polaino NaVArrete, M., Lecciones de Derecho penal, Parte general, T. II, op. cit., p. 175.

628 VARONA GÓMEZ, D., El miedo insuperable, op. cit., p. 122; MARTín LORENZO, M., La exculpación, op. cit., p. 491, por lo que no puede ser una causa de justificación.

${ }^{629}$ También Higuera GuIMERÁ, JF., La eximente de miedo insuperable, op. cit., p. 217 sobre la vida, la integridad física, libertad, propiedad y honor, pues, el CP no hace ninguna indicación.

630 VARONA GÓMEZ, D., El miedo insuperable, op. cit., p. 263.

631 ID., ibidem, op. cit., pp. 184 y ss.

632 ID., ibidem, op. cit., p. 332.

633 Martín Lorenzo, M., La exculpación, op. cit., pp. 505 a 511. Pues «(m)ientras que en el estado de necesidad la conducta se exculpa porque se comprende el motivo del sujeto, asegurar su continuidad como partícipe; la exclusión de responsabilidad atenta al miedo no entra a valorar el contenido del motivo, sino su efecto anulador 
aplicación como causa de exculpación en una amplia categoría de bienes, pudiendo proceder el mal de cualquier fuente, humana o no, real o irreal pero que al menos atente a un bien entendido como jurídico pero sin que se precise que sea típico ${ }^{634}$. A la vez, critica la enorme construcción doctrinal y la jurisprudencia que parecen restringir el campo de acción de la eximente a situaciones discrecionales del autor, por eso concluye que la eximente sólo viene configurada en el art. $20.6^{\circ} \mathrm{CP}$ por un miedo que ha de ser insuperable $\mathrm{e}^{635}$, entendido como motivo «comprensible» en relación a la merma de la «capacidad deliberativa» de la persona. Con ello quiere significar que al constituirse como una cláusula supletoria de otras eximentes, su función es la de una cláusula general de inexigibilidad que se articula en el miedo como insuperabilidad, lo que significa «presencia insuficiente de motivos para eximir por otras circunstancias, pero no absoluta inexistencia», por eso, a falta de una regulación más depurada se constituye como la más indeterminada en configuración normativa de las eximentes ${ }^{636}$.

Dicho lo cual, parte de la doctrina acepta la eximente incompleta cuando el miedo no sea suficientemente intenso, es decir, superable ${ }^{637}$. El miedo es graduable en su efectos, por lo que es posible otorgar relevancia jurídica al pleno bloqueo mental o pánico que cause la involuntariedad o incapacidad psíquica de la acción en vez de una causa de inculpabilidad ${ }^{638}$.

\section{3) Doctrina a favor de la aplicación del miedo insuperable en la autoría de conciencia}

Es escasa la doctrina que se ha pronunciado a favor del miedo insuperable en la autoría de conciencia, si bien los argumentos que se han manejado en relación a los requisitos y fundamentos de la inexigibilidad dan cierta coherencia a esta solución.

JIMÉNEZ DÍAZ ${ }^{639}$ se muestra a favor de apreciar dicha circunstancia en la autoría de conciencia en la prestación sustitutoria de los Testigos de Jehová que por miedo a la pérdida de la vida eterna quebrantan la norma. Este autor fundamenta la insuperabilidad del miedo en que todos los testigos de Jehová, en la misma situación, obran quebrantando la norma. De esta manera, JIMÉNEZ DíAZ utiliza un criterio de hombre medio objetivo-subjetivo primando más en este caso la credibilidad del carácter subjetivo, pero cómo decíamos, no constituye un mal jurídico este

de las condiciones mínimas para hablar de una toma de postura crítica. En el estado de necesidad se valora positivamente el motivo y por eso se comprende, aquí se valora directamente la presencia de miedo como excluyente del reproche, no por su evaluación positiva, sino por su carácter invalidante», ID., ibidem, op. cit., p. 511.

634 ID., ibidem, op. cit., p. 493 y ss.

635 ID., ibidem, op. cit., pp. 496 y ss.

636 ID., ibidem, op. cit., pp. 501 y 502, y pp. 513 y 514.

637 Higuera GuIMERÁ, JF., La eximente de miedo insuperable, op. cit., pp. $131 \mathrm{y}$ ss.

638 Polaino Navarrete, M., Lecciones de Derecho penal, Parte General, T. II, op. cit., p. 175.

639 JimÉnEZ DíAZ, María José, Delitos relativos a la prestación social sustitutoria. Su problemática aplicación, II Parte, $C P C, 55,1995$ pp. 79 a 84. 
miedo. Acierta en intuir que la conducta, en este caso, de los Testigos de Jehová, por regla general tiende a quebrantar la norma, si bien relaciona este hecho incorrectamente, a nuestro modo de ver, con la insuperabilidad del miedo, sin embargo este es sólo un indicio de que el comportamiento es ineludible, por lo tanto se puede confundir o aplicar también para el estado de necesidad exculpante. La clave en esta circunstancia exonerante es que el miedo sea jurídico, por lo que consideramos que con este criterio no se acaba de explicar convenientemente que para esto es necesario averiguar en qué medida el fin de la conducta está relacionado con la salvación de otra norma de tal modo, que desde aquí se analice si es insuperable dicho miedo. La clave está en que en la autoría de conciencia la conexión de la conciencia y la voluntad de forma tan irresistible no está en un miedo, algo que inevitablemente llama a lo psicológico, sino al hecho cierto que demostramos en el primer capítulo de esta investigación que es que la conciencia y la voluntad, máxime en la configuración moral/religiosa o ideológica, fundamentan al ser humano en cuanto persona libre, de modo que lo ineludible no se refiere al miedo, sino al obrar libremente, lo que significa «necesariamente», de aquí que se haya elevado a Ley Fundamental el derecho a la libertad de conciencia, y amén de esto, que en la valoración de este tipo de conductas tengamos que renunciar al valor psicológico o moralizante a favor de otro estrictamente normativo.

En el mismo sentido al expuesto por JiMÉNEZ DíAZ se ha pronunciado TAMARIT SUMALLA ${ }^{640}$ en cuanto que el sujeto, en los casos de conciencia, tiene una angustia moral insuperable. De aquí que admita la eximente incompleta en caso de que el miedo sea superable. Para apreciar dicha insuperabilidad se basa en el criterio del «hombre medio», pero no en el criterio estrictamente objetivo, sino mixto, al considerar también las cualidades y percepciones de sujeto. De esta manera, concluye que en el caso del médico que realiza la trasfusión de sangre aun sin consentimiento del testigo de Jehová, existiría un estado anímico notablemente afectado por el temor de traicionar su conciencia.

En sentido similar, CORCOY BIDASOLO ${ }^{641}$ se ha mostrado partidaria de esta eximente al apreciar que quien está convencido de su deber puede sentir un miedo tan insuperable que le impulse a quebrantar la norma.

FLORES MENDOZA $^{642}$ se ha mostrado contraria a apreciar el miedo insuperable en la autoría de conciencia. Considera que la falta de un mal en sentido jurídico no procede del exterior, sino de la misma conciencia del sujeto.

640 TAMARIT SUMALla, JMa., La libertad ideológica, op. cit., pp. 436 y ss.

${ }^{641}$ Corcoy Bidasolo, M., «Problemas jurídico-penales de la objeción de conciencia en el ámbito de las actividades sanitarias», Estudios de Bioética y Derecho, 2000, p. 81. 
En cambio, JERICó ${ }^{643}$ considera que lo relevante para apreciar esta causa es el proceso de anormalidad en la motivación. De aquí deduce que puede suceder tanto en un miedo real como irreal puesto que la eximente no hace referencia alguna al mal ni se precisa por tanto que sea un mal de carácter jurídico, y puesto que esta eximente se ubica en la culpabilidad no se precisa que la causa de anormalidad provenga exclusivamente del exterior. Así la cuestión de la insuperabilidad dicha autora la valora desde la perpestiva subjetiva-individual, es decir, de las circunstancias particulares del sujeto, por lo que desde el punto de vista teoríco podría apreciarse esta causa en los conflictos de conciencia, y en consecuencia, cuando el miedo sea superable, podrá apreciarse la eximente incompleta, si fuere fácilmente superable se aplicaría la atenuante analógica, lo que hará - comenta la autora- que se deba contar con periciales exhaustivas ${ }^{644}$.

Tal y como anunciábamos antes, el criterio de la insuperabilidad psicológica no se presenta en la autoría de conciencia. La conexión de la conciencia y la voluntad, de forma tan estrecha, no está en un miedo, algo que inevitablemente es psicológico, sino al hecho cierto de que la conciencia y la voluntad, máxime en la configuración moral/religiosa o ideológica, fundamentan al ser humano en cuanto persona libre. Lo ineludible no se refiere al miedo, sino al obrar que necesariamente se dirige a quebrantar la norma, y de aquí que se haya elevado a norma fundamental el derecho a la libertad de conciencia. La valoración de este tipo de conductas como el miedo insuperable, y más concretamente en la autoría de conciencia, tradicionalmente otorgan un valor normativo a lo psicológico, lo que redunda no sólo en una perspectiva moral, sino también confusa con la inimputabilidad, por lo que a nuestro modo de entender la autoría de conciencia, según los postulados normativos que hemos ido desarrollando, no es defendible desde la eximente del miedo insuperable.

\section{F. Doctrina a favor de la falta de merecimiento de una pena o su disminución en la autoría} de conciencia

\section{Introducción}

Una institución jurídico-penal un tanto olvidada por los Jueces y Tribunales españoles es la punibilidad. Quizá la tradición dogmática universitaria que ha formado a nuestros jueces y magistrados no puso especial atención a la institución de la punibilidad sino más bien como categoría externa al estricto ámbito de la teoría jurídica del delito, relegándola a la política

${ }^{642}$ Flores Mendoza, F., Objeción de conciencia, op. cit., pp. 248 y ss; JeRICó OJER, L., El conflicto de conciencia, op. cit., pp. 423 y ss.

${ }^{643}$ JERICÓ OJER, L., El conflicto de conciencia, op. cit., pp. 424 y 465.

${ }^{644}$ ID., ibidem, pp. 425 y 426 , y pp. 455 y 465. 
criminal o consecuencia jurídica del delito, y otras veces como penalidad, cuando en verdad no faltaban voces -como la de ROXIN y JAKOBS entre otros, y que de modo singular pone de manifiesto PolAino NAVARRETE ${ }^{645}$ ( $\ll$ sin la punibilidad no se produce delito en sentido estricto»)- que defienden desde hace tiempo que la punibilidad es una categoría más de la teoría jurídica del delito que equivale a la necesidad, merecimiento e idoneidad de una pena tras la comisión de un hecho típico, antijurídico y culpable. El fundamento de la punibilidad constituye que la conducta sea precisamente idónea o relevante, mientras que la penalidad se refiere a la consecuencia jurídica del delito y a la política criminal. En este sentido, POLAINO NAVARRETE ${ }^{646}$ incluye dentro de la punibilidad los delitos perseguibles de parte, la ausencia de punibilidad -que divide en la irrelevante incidencia en el bien jurídico protegido y la ausencia de condiciones objetivas de punibilidad-, las excusas absolutorias, y la ausencia de penalidad.

Sin embargo, en nuestra opinión, la punibilidad supone una categoría vinculada a la expresión comunicante de la norma con el sujeto, de manera tal que si el sujeto comete una conducta inidónea per se decae el fundamento de «imputación objetiva» del delito. La mayor o menor idoneidad de la conducta para quebrantar la norma más que el bien jurídico protegido en sí mismo, gradúa a la postre el merecimiento de la pena y parte de su necesidad, de tal manera que la penalidad se refiere entonces con mayor propiedad a la consecuencia del tratamiento proporcional de la pena en relación al quebrantamiento de la norma.

Más allá de esta reformulación de la institución de la punibilidad, cuya consecuencia podrá apreciarse en próximos capítulos cuando hablemos de la imputación objetiva de la tentativa inidónea de persuasión coercitiva, lo cierto es que parte de la doctrina que ha estudiado la problemática de la autoría de conciencia y por convicción ha encontrado argumentos plausibles de falta de merecimiento de pena o de reprochabilidad punitiva, si bien, en muchas ocasiones, ligados a fundamentos que disminuyen la culpabilidad con base a la irradiación del derecho fundamental a la libertad de conciencia, como causa supralegal, o al principio de inexigibilidad.

\footnotetext{
645 Polaino Navarrete, M., Lecciones de Derecho penal, Parte general, T. II, op. cit., p. 181, si bien reconoce la conexión «entre los criterios dogmáticos fundamentadores de la sanción penal y las exigencias político-criminales de prevención general y de prevención especial a cuya consecución ha de tener la misma (...) con los fines propios del sistema», ID., ibidem, op. cit., p. 182.

${ }^{646}$ ID., ibidem, op. cit., pp. 184 a 188.
} 


\section{Postulados doctrinales}

Parte de la doctrina española ${ }^{647}$ aboga por otorgar al conflicto de conciencia relevancia en la determinación de la pena. En concreto, FLORES MENDOZA considera que en casos concretos y excepcionales, cuando la conducta esté sancionada con pena privativa de libertad y por motivos de falta de necesidad preventiva general y especial, la falta de proporcionalidad de una pena de prisión en la rehabilitación y resocialización del sujeto o en virtud del principio de tolerancia por el efecto irradiante de la libertad de conciencia, serían fundamento para no sólo para la disminución de la pena amparada por una atenuante analógica inclusive como muy cualificada, sino también para la suspensión de la pena o su sustitución por otras alternativas ${ }^{648}$.

GÓMEZ BENítez ${ }^{649}$ aprecia que no existe necesidad de penar en estos casos, y propone la exclusión de la pena por motivos de ponderación según las concretas circunstancias, cuando no se afecte a derechos de terceros, y cuando la conducta esté motivada por un conflicto de conciencia que fundamente su conducta para salvaguardar precisamente su conciencia. A causa de esto, el meritado penalista no defiende una causa de general de exclusión de la pena porque esto avalaría la idea de que todo derecho fundamental protege en todo caso un bien jurídico, por eso apela a que en cada caso concreto se realice una ponderación. Su postura es criticable porque no concreta los criterios normativos para realizar esa ponderación.

Parte de la doctrina alemana más autorizada otorga cierta relevancia al conflicto de conciencia en la determinación de la pena ${ }^{650}$ con fundamento en el parágrafo 46 del StGB $^{651}$. Este precepto

647 BAuCElls i Lladós, J., La delincuencia por convicción, op. cit., pp. 301 y 302; CEREZO Mir, J., Derecho Penal, Parte General, Lecciones, op. cit., p. 35; ID., Curso de Derecho Penal español, Parte General, III/2, op. cit., p. 37; Flores MendozA, F., Objeción de conciencia, op. cit., pp. 282 a 284; GóMEZ BENÍTEZ, JM., «Consideraciones», op. cit., pp. 78 y ss. y p. 82; PÉREZ DEL VALle, C., Conciencia, op. cit., pp. 284 y ss; ROMEO CASABONA, CMa ${ }^{\mathrm{a}}$, «La objeción de conciencia en la praxis médica», La libertad ideológica y derecho a no ser discriminado (I), Escuela Judicial y Consejo General del Poder Judicial, Madrid, 1996, p. 79; TAMARIT SUMALLA, $\mathrm{JM}^{\mathrm{a}}$., La libertad ideológica, op. cit., p. 438 ss; ID., «La objeción de conciencia», op. cit., p. 40.

648 Flores MendozA, F., Objeción de conciencia, op. cit., pp. 280 a 284.

649 GÓMEZ BeníteZ, JM., «Consideraciones», op. cit., pp. 78 y ss. y p. 82.

650 Vid. JERICÓ OJER, L., El conflicto de conciencia, op. cit., p. 439, nota núm. 509 (especialmente, BoOP, U., Der Gewissenstäter und das Grundrecht der Gewissensfreheit, op. cit., pp. 252 y ss; EBERT, U., Der Überzeugungstäter in der neueren Rechtsentwicklung, op. cit., p. 71; JESCHECK HH / WEIGEND T., Tratado, op. cit., 37, II; RUDOLPHI, Hans-Joachim, Welzel-FS, 1974, op. cit, p. 633; SCHÜNEMANN, Bernd, «Die deutschsprachige Strafrechtswissenschaft nach der Strafrechtsreform im Spiegel des Leipziger Kommentars und des Wiener Kommentars», GA, 1986, p. 308). A favor de una pena especial, BUDZINSKI, W., Der Überzeugungsverbrecher, op. cit., pp. 47 y ss; GREFFENIUS, Gunter, Der Täter aus Überzeugung und der Täter aus Gewissensnot, Kriminologische Schriftenreihe aus der Deutschen Kriminologischen Gessellschaft, Hamburg, 1969, pp. 75 y ss. (vid. JERICó OJER, L., El conflicto de conciencia, op. cit., p. 440, nota núm. 510). SCHÜNEMANN se muestra favorable a una disminución de la pena en los conflictos de conciencia en los delincuentes políticos que actúan bajo motivos altruistas por menor capacidad de motivación conforme a la norma, pero en casos de terrorismo fanático aboga por una medida de seguridad. Con esta diferenciación de tratamiento creemos que el referido penalista diferencia al autor de conciencia y al autor por convicción en su tratamiento penal, sin restar importancia a los motivos de uno y otro sino que les otorga relevancia en la pena, y esto porque que en la determinación de la pena han de tomarse en consideración aquellas circunstancias que no se aprecian en la imputación del delito, unas veces 
- como ha señalado acertadamente BAUCELLS ${ }^{652}$ - sirve tanto para atenuar como para agravar por criterios generales o especiales, y se aplicaría tanto en el autor de conciencia o como en el autor por convicción en la determinación de la pena y según los casos.

Es necesario advertir en este sentido llama la atención que en la regulación penal española no exista un precepto tan preciso como el parágrafo $46 \mathrm{StGB}$, de modo en que los Jueces y Tribunales puedan valorar con mayor criterio normativo la determinación de la pena. Es una constante en nuestra jurisprudencia no apreciar más circunstancias que la falta de antecedentes penales y denuncias previas para fundamentar una pena en su límite mínimo, sin embargo, se encuentran todo tipo de argumentos para agravar hasta el límite máximo. Esto se debe al criterio del TC que únicamente exige una depurada motivación en la determinación máxima de la pena, y no cuando se aplica en su límite mínimo, si bien, como puede apreciarse en el parágrafo 46 StGB, «los móviles y los fines del sujeto, la actitud interna que se deduce del hecho y la voluntad con la que se realizó el hecho, la medida del incumplimiento del deber, el modo de ejecución y los efectos culpables del hecho», son relevantes a la hora de determinar la pena. Estos criterios de valoración si fueran regulados expresamente en España acabarían, o al menos ayudarían, a solucionar muchas de las problemáticas surgidas tanto en los delitos cometidos por autores de conciencia como los cometidos por los autores por convicción e inclusive enemigos, en el sentido de que tanto en unos como en otros, se puede apreciar circunstancias que lleven a determinar la pena en su límite mínimo o máximo, sin atender exclusivamente a la gravedad del hecho que por otro lado ya viene marcada en la extensión de la pena, por lo que los Jueces y Tribunales estarían obligados a motivar exquisitamente la determinación de la pena en las circunstancias del autor, aun a pesar de la valoración del hecho. Según este criterio, no vemos impedimento legal tampoco en España según el precepto 65 del CP ( «Las circunstancias agravantes o atenuantes que consistan en cualquier causa de naturaleza personal agravarán o atenuarán la responsabilidad sólo de aquéllos en quienes concurran») en relación con el art. 72

para rebajar o penar al mínimo, otras para penar con el límite máximo por motivos especialmente recalcitrantes, SchünemanN, B., «Politisch motivierte Kriminalität», Politisch motivierte Kriminalität- echte Kriminalität? Schriftenreihe des Instituts für Konflikforschung, 4, W. De Boor (Hrsg.), S. Karger, Basel/München, 1978, pp. 170 y ss (vid. JERICÓ OJER, L., El conflicto de conciencia, op. cit., p. 441, y nota 514).

65146 del StGB: «1. La culpabilidad del autor es el fundamento de la medición de la pena. Se deberán considerar los efectos esperables de la pena para la vida futura del autor en la sociedad. 2. En la medición de la pena el tribunal ponderará las circunstancias favorables y contrarias al autor. Con este fin se contemplarán particularmente: los móviles y los fines del sujeto, la actitud interna que se deduce del hecho y la voluntad con la que se realizó el hecho, la medida del incumplimiento del deber, el modo de ejecución y los efectos culpables del hecho, los antecedentes del sujeto, su situación personal y económica, así como su comportamiento postdelictivo, especialmente sus esfuerzos por reparar el daño, así como los esfuerzos del sujeto para alcanzar una compensación con el perjudicado. 3. Las circunstancias que sean ya elementos del tipo legal no pueden ser tenidas en cuenta».

652 BAUCELlS I LLADÓs, J., La delincuencia por convicción, op. cit., p. 389. 
CP («Los jueces y tribunales, en la aplicación de la pena, con arreglo a las normas contenidas en este capítulo, razonarán en la sentencia el grado y extensión concreta de la impuesta») para que en casos excepcionales, que estudiaremos en breve se pueda llevar la determinación de la pena en el autor por convicción e inclusive en el enemigo al límite mínimo, y viceversa, al límite máximo en conductas tradicionalmente entendidas de autoría de conciencia, sin que suponga ninguna contradicción conceptual, sino precisamente el reforzamiento de que en tales categorías conceptuales el Derecho penal ha de operar normativa y no moralmente.

No obstante estos mismos criterios normativos del StGB han servido a parte de la doctrina para fundamentar la exención de la responsabilidad penal o su disminución.

Ya en su día Welzel ${ }^{653}$ consideraba que en los casos de delitos cometidos por conciencia se elimina la parte negativa de lo reprochable y esto debía tener un reflejo en la pena. Y también MEZGER $^{654}$ anteriormente afirmaba que la convicción podía ser una circunstancia que atenuase la pena. Recuérdese que RADBRUCH defendió la incursión de estos autores en el parágrafo 71 del proyecto de Código penal alemán mediante la aplicación una pena especial y atenuada (arresto), con base a la honestidad con la que obraban en algunos casos ${ }^{655}$. En un sentido similar pero innovador, ya comentamos más arriba que Roxin considera que el art. 4 de la Ley Fundamental rompe con la teoría de la responsabilidad penal porque fundamenta la imposición de las penas en criterios de prevención, por lo que aun perpetrándose el delito, no merezca ser impuesta una pena por ser soportable tal conducta desde este prisma preventivo (falta de responsabilidad/ reprochabilidad) ${ }^{656}$.

BAUCELLS considera, desde una concepción teleológico-constitucional de la pena en relación a la afección del bien jurídico, que la pena no puede basarse en consideraciones preventivas ni psicológicas ni sociales, sino respecto a principios y garantías constitucionales que limitan la orientación preventiva de la pena ${ }^{657}$. Por ello aboga por la reducción de la pena en la atenuante analógica respecto al art. $21.3^{\mathrm{a}} \mathrm{CP}$ de arrebato u obcecación o estímulos poderosos, y en otras ocasiones respecto al estado de necesidad ${ }^{658}$. Asimismo fundamenta la una menor pena no por motivos de prevención general, porque en su opinión supondría la instrumentalización del sujeto,

653 Welzel, H., Derecho penal alemán, op. cit., pp. 246 y 247.

654 Mezger, E., Tratado, II, op. cit., pp. 403 y 404, y pp. 417 y ss.

655 RADBRUCH, G., «El delincuente por convicción», op. cit., pp. 3 y ss; vid. también PÉREZ DEL VALLE, C., Conciencia, op. cit., p. 58 («Verhandlungen des Deutschen juristentag zu Köln», op. cit., pp. 357 y ss.).

656 Vid. PÉrez Del VAlle, C., Conciencia, op. cit., p. 250 y 251; vid. también Flores MENDOZA, F., Objeción de conciencia, op. cit., pp. 285 a 290. (RoxIN, C., «Die Gewissenstat als Strafbefreiungsgrund», op. cit., pp. 410 y 411.

657 BAUCELls i Lladós, J., La delincuencia por convicción, op. cit., pp. 301 y 302.

658 ID., ibidem, op. cit., p. 407. 
sino por criterios especiales para evitar otro delito. De esta manera defiende que la pena tiene que ser socializadora ${ }^{659}$.

Con buen criterio, confiere efectividad al parágrafo 46.2 StGB en la determinación de la pena del autor de conciencia o por convicción en la «voluntad empleada en el hecho», de manera que la fuerza de la convicción es un criterio que puede rebajar la pena, y a la vez, dicho precepto concilia mejor la concepción normativa de la culpabilidad en la relevancia constitucional de las actuaciones por convicción o de conciencia. En opinión de este autor, para nada desencaminada pero a la que le falta en nuestra opinión concreción normativa, «tendrá relevancia, en cambio, la distinción (...) en la teoría racional de los actos morales. La distinción que merezca tratamiento atenuante no reside tanto en el carácter de deber es decir, en "la voluntad expresada en el hecho", o en «la medida a la contrariedad del deber» sino en que se respete en la decisión el principio de humanidad y autonomía de la voluntad, es decir, en los «objetivos» y «en el modo de ejecución del hecho» ${ }^{660}$.

Precisamente la forma de ejecutar el hecho y el injusto en que se incurre, a nuestro modo de ver, no respeta ese principio de humanidad y autonomía de la voluntad, al que alude BAUCELLS, lo que lleva tradicionalmente a legislar tipos altamente penados, sin embargo repárese que en el terrorismo yihadista con claras connotaciones religiosas, por mucho conflicto o debate moral o racionalidad que el sujeto aplique en su obrar, resulta que en determinadas ocasiones excepcionales, las connotaciones religiosas forzosas y el aislamiento cultural desde la infancia, motivarían en igual medida la rebaja de la pena que la que se fundamenta en la autoría de conciencia. Resulta además necesario estudiar las bases normativas que distingan al autor de conciencia del autor por convicción y el enemigo, desde una perspectiva normativa y funcionalista, dejando de lado la fuerza de la conciencia, la convicción o mero convencimiento, o la racionalidad en la organización del injusto, puesto que en todas las tipologías de autoría estudiadas se nos presentan con la misma intensidad.

De otra parte, JERICó ${ }^{661}$, siguiendo los postulados de la teoría del límite máximo de LUZÓN PEÑA, defiende la disminución de la pena en su límite mínimo en aplicación del art. 66 CP cuando las circunstancias personales lo aconsejen. Se refiere a criterios de prevención especial, e incluso en casos en los que dichas circunstancias sean sumamente favorables aplicar la atenuante analógica por no existir necesidad de aplicación de la pena, y en otros casos la sustitución de la

659 ID., ibidem, op. cit., pp. 401 y ss. Crítica FloREs MendozA, F., Objeción de conciencia, op. cit., pp. 282 y SS.

660 BAUCELLS I LLADÓS, J., La delincuencia por convicción, op. cit., p. 390.

661 JERICÓ OJER, L., El conflicto de conciencia, op. cit., pp. 456 y ss. y p. 467. 
pena cuando los artículos del CP lo permitan, por lo que en casos de omisión del deber de socorro no se podría aplicar la sustitución porque las penas ya contemplan la de multa y la inhabilitación. En el mismo sentido afirma la citada autora que no podrán sustituirse las penas por delitos contra la vida o la integridad al superarse en estos la pena de dos años, pero sí en casos de causación o cooperación activa con actos necesarios y directos a la muerte de otros sujetos del art. 143.4 CP. En nuestra opinión, yerra al respecto JERICó, puesto que la pena a la que se refieren los arts. 80 y $88 \mathrm{CP}$ (éste último ahora derogado ${ }^{662}$ ) es la impuesta por el Juez o Tribunal, por lo que en verdad eran la mayoría de los casos en los que se podía aplicar igualmente la sustitución.

Siguiendo esta teoría, en casos de mayor gravedad de lo injusto se deberá aumentar la pena a su límite máximo, lo que en nuestra opinión deja sin sentido la aplicación del art. 65 y ss. CP en la autoría por convicción en la determinación de la pena en un límite mínimo. En definitiva, este postulado incurre en contradicción por el mero hecho de no aplicar el límite mínimo en injustos de extrema gravedad, de modo que parece basar el límite máximo en el mismo fundamento de imputación objetiva del delito en contra, entonces, del sentido de los arts. 65 y ss. CP.

De esta forma, LUZÓN PEÑA admite que en casos en los que la presión motivacional no es tan intensa o en casos en los que aunque sea extremo el conflicto y no sea «normativamente comprensible tal conflicto», o cuando exista una «valoración negativa a efectos preventivos por el peligro de repetición de ese conflicto» ${ }^{663}$, podrá disminuirse por una exculpación parcial en virtud de una atenuante analógica incluso muy cualificada del art. 66.1.2 $\mathrm{a}$ CP, no así por una causa incompleta del art. $21.1^{\text {a }} \mathrm{CP}$ que no contempla la inexigibilidad ${ }^{664}$. Entendemos esta conclusión rompe con aquella otra que se decía del límite máximo basado en la gravedad del injusto, de manera que el fundamento que ahora se esgrime para imponer el límite mínimo nuevamente se basa exclusivamente en la menor gravedad del hecho, de manera que en verdad no tiene cabida en esta argumentación las especiales circunstancias del sujeto que le han llevado a obrar.

662 Con la reforma del Código penal por la Ley $1 / 2015$, de 30 de marzo, se deroga el art. 88 CP que tradicionalmente regulaba el régimen de la sustitución de las penas. Se mantiene la sustitución de las penas privativas de libertad, pero como una «modalidad de suspensión», mediante el pago de multa y/o la realización de trabajos en beneficio de la comunidad regulado ahora en el art. $84 \mathrm{CP}$.

663 Expone un ejemplo en el que el miembro de una confesión religiosa en su día de descanso semanal ordenado por el mandato de su religión, se niega a llevar a un enfermo, herido o accidentado muy grave, que a diferencia del Testigo de Jehová que no consiente la trasfusión, esa situación puede tener mayor frecuencia si tiene vinculación laboral, LUZÓN PEÑA, D-M., «Actuación en conciencia», op. cit., p. 13.

664 ID., ibidem, op. cit., pp. 13 y 14. 
Como bien recuerda Flores MENDOZA, gran parte de la doctrina alemana admite el concurso de causas de justificación, y minoritariamente en la española cuando concurran en un mismo hechos los elementos esenciales de dos o más causas de justificación. La trascendencia de este criterio redunda en la idea de que en la doctrina española todavía no se ha tenido en cuenta que las especiales circunstancias del autor de conciencia, por convicción y enemigo, fundamentan la aplicación no sólo de una, sino de varias posibles circunstancias exonerantes, disminutivas o agravantes más allá del hecho en que se incurra.

\section{G. La doctrina jurisprudencial alemana}

El Tribunal Constitucional Federal Alemán, en la Sentencia de 20 de diciembre de 1960, definió la decisión de conciencia como «toda decisión seria de carácter moral, es decir, orientada en las categorías del «bien»y del «mal», que el individuo experimenta internamente en una determinada situación como vinculante e incondicionalmente obligatoria, de tal forma que no podría actuar contra ella sin violentar seriamente su conciencia» ${ }^{665}$. Esta definición es seguida y admitida por buena parte de la doctrina alemana ${ }^{666}$ y más escasamente por la doctrina española ${ }^{667}$ como ya hemos podido estudiar.

Este Tribunal ha venido negando cualquier clase de atenuación de la culpabilidad o de la pena en los casos de no prestación del servicio civil sustitutorio. Entiende que la Constitución ya ha regulado la salvaguarda de la conciencia en relación al servicio militar con la prestación sustitutoria. Pero en otros supuestos el mismo Tribunal deja una puerta abierta. Así, en la Sentencia de 19 de octubre de 1971, estimó que el recurrente no había incurrido en el delito de omisión del deber de socorro cuando su mujer tras sufrir una hemorragia por un parto, se negó a una transfusión de sangre que le hubiese salvado su vida en virtud de su conciencia y estatuto de Testigo de Jehová, pues una conducta conforme a la norma hubiera supuesto la trasfusión de sangre y en su consecuencia la contaminación del alma de por vida, y tras la vida.

Como afirma TAMARIT Sumalla, el Tribunal entendió «que la condena trasgredía la libertad de conciencia, que comprende el derecho a adecuar el comportamiento global de la persona a los

665 BVerfG 12, 45 (54).

666 En la doctrina alemana, JAKOBS, G., $P G$, op. cit., 20/22; RoXIN, C., «Otras causas de justificación y exculpación», Justificación y exculpación en Derecho penal, coloquio hispano-alemán, Edit. Albin Eser / Enrique Gimbernat / Walter Perrón, Madrid, 1995, p. 230; JeSCHECK H-H / Weigend, T., Tratado, op. cit., 41, I 3 a); críticamente TIEDEMANN, Paul, «Der Gewissensbegriff in der höchstrichterlichen Rechtsssprechung», DöV. Heft 2 W Kohlhammer GmbH. Stuttgart, 1984, p. 62, al referirse a que en un Estado democrático está basado en la racionalidad, no en la fuerza interna incondicional (vid. ult. loc. BAUCELLS I LLADÓs, J., La delincuencia por convicción, op. cit., p. 66).

667 MUÑOz CONDE, F., «La objeción de conciencia en Derecho penal», op. cit., p. 279, pp. 279 a 294; ROMEO CASABONA, $\mathrm{CM}^{\mathrm{a}}$., «El derecho a la objeción de conciencia», op. cit., p. 1308. 
imperativos de conciencia» ${ }^{668}$. Los razonamientos para llegar a tal conclusión por la Sentencia, que bien puede decirse abrieron una puerta en pro de la libertad de conciencia, fueron: la esencia de límites expresos del derecho de libertad de conciencia del art. 4 de la Ley Fundamental; eso da un efecto de irradiación al art. 4 en el ámbito penal en caso de incurrirse en algún tipo; «el conflicto existente entre un bien jurídico basado en las convicciones generales y un mandato individual de conciencia lleva al autor a un «apuro espiritual», por lo que en caso de penalizarse la conducta la pena «se presentaría como una reacción social exagerada y por ello lesiva de su dignidad humana (...), la pena no sería, para tales casos, bajo ninguna de sus dimensiones retribución, prevención, resocialización- una sanción adecuada». Considera ${ }^{669}$ que el error de la meritada Sentencia es no haber utilizado elementos de la dogmática jurídico-penal, sino únicamente argumentos jurídico-constitucionales.

Sin embargo, y por otro lado, en el Tribunal Supremo alemán, si bien asimiló la autoría por convicción a un motivo respetable, sus resoluciones parecen contradictorias. Por ejemplo en la Sentencia del BGHSt 2, 208 considera que el mismo autor por convicción señala su culpabilidad cuando antepone sus valores al establecido por la comunidad. La BGHSt declaró que «quien vive en una sociedad debe respetar la validez del Derecho vigente incluso en contra de sí mismo», y en BGHSt 4,1 (5) sobre un caso prohibición de encuestas declaró que las convicciones políticas no merecían consideración, sin embargo en la BGHSt 8, 162 (163) se declaró que «el valor ético de una conducta y una convicción respetable podría fundamentar una reducción de la culpabilidad» ${ }^{670}$.

668 TAMARit Sumalla, JMª ., La libertad ideológica, op. cit, p. 368.

669 ID., ibidem, op. cit., p. 371. Comenta GÓMEZ BENÍTEZ que la «sentencia del Tribunal Constitucional alemán de 19 de octubre de 1971 fundamentó la impunidad por inculpabilidad del autor de un delito de denegación de auxilio, de la siguiente manera (...) Si bien objetivamente y conforme a las concepciones valorativas dominantes de modo general en la sociedad se debe desaprobar esta decisión, (...) ya no es tan reprochable como para que estuviera justificado proceder contra el autor con el arma más terrible de que dispone la sociedad, es decir, el Derecho penal. Ante un caso como éste la pena criminal, con independencia de su cuantía, no es una sanción adecuada en ningún aspecto (retribución, prevención o resocialización del autor) ... el Derecho penal debe retirarse cuando el concreto conflicto entre un deber jurídico existente según la consideración general y un mandato de la conciencia produce una aflicción al autor, frente al cual la imposibilidad de una pena se presentaría como reacción social desproporcionada y por ello lesiva de su dignidad», GÓMEZ BENíteZ, JM., «Consideraciones», op. cit., p. 77.

${ }_{670} \mathrm{Vid}$. BAUCELLS I LLADÓs, J., La delincuencia por convicción, op. cit., p. 61. 


\section{IV.- Especial referencia a los planteamientos del funcionalismo normativo: déficit de socialización}

A. Introducción al funcionalismo normativo: sociedad, norma y personas

La concepción funcionalista del Derecho penal, también denominada funcionalismo normativo, nace de los planteamientos dogmáticos de JAKOBS, si bien con claras influencias de la teoría de los sistemas sociales de LUHMANN ${ }^{671}$.

JAKOBS concibe la sociedad como un acuerdo normativo ${ }^{672}$ que articula la orientación de los comportamientos humanos y las expectativas sociales más allá de una simple posibilidad de una expectativa personal ${ }^{673}$. Esta es la razón de que en el funcionalismo normativo la norma tiene vigencia en el contenido prescriptivo, la norma viene a cubrir una necesidad real de la sociedad. Así, la legitimidad de una norma viene de su realidad social, o -como dice POLAINO-ORTS- «el mundo normativo no puede existir si no es real. Y no es real si no es realizable (...) Una norma ha de contar siempre con una cimentación cognitiva» ${ }^{674}$, es decir, una corroboración real o socialmente realizable, lo que hace que la norma suponga la institucionalización de las expectativas sociales.

En este sentido, el quebrantamiento de la norma puede ser algo puntual por una comunicación defectuosa por parte del ciudadano, por eso el ordenamiento jurídico le impone una pena que resulta proporcional en la confianza de que dicho quebrantamiento ha sido puntual, es decir, se le trata como «persona», no en sentido ontológico sino normativo ${ }^{675}$, con derechos y obligaciones

\footnotetext{
671 Principalmente LuHMANN, N., El derecho de la sociedad, op. cit; ID., Sistemas sociales, op. cit.; ID., La sociedad de la sociedad, Herder, 2007.

672 JAKOBS, G., Sociedad, norma y persona en una teoría de un Derecho penal funcional, op. cit., pp. 25 y ss; véase también POLAINO-ORTS, M., Funcionalismo normativo. Bases dogmáticas para el nuevo Sistema de Justicia penal, Fundamentos y Función del Derecho penal, T. I, Centro de Estudios Superiores en Ciencias Jurídicas y Criminológicas (CESCIJUC), $1^{\text {a }}$ ed. 2014, México, pp. 66 y ss.

673 POLAINO-ORTS, M., Funcionalismo normativo, op. cit., p. 86; PIÑA RoCHEFORT, JI., Rol Social y sistema de imputación. Una aproximación sociológica a la función del derecho penal, pról. J-M ${ }^{a}$ Silva Sánchez, Bosch, Barcelona, 2005, p. 233; LuHMANN, N., «¿Hay aún en nuestra sociedad normas irrenunciables?», op. cit., pp. 217 y 218.

674 POlAINO-ORTS, M., Funcionalismo normativo, op. cit., p. 69; PIÑA RoCHEFORT, JI., Rol social y sistema de imputación, op. cit., p. 214 comenta que «(1)a función del derecho es la estabilización de las expectativas normativas por medio de la regulación de la generalización temporal, objetiva y social».

675 Hegel, GWF., Fundamentos de la filosófica del Derecho, op. cit., 36, p. 178: «La personalidad contiene en general la capacidad jurídica y constituye el concepto y el fundamento también abstracto del derecho abstracto y por ello formal. El precepto jurídico reza, por ende: Sé persona y respeta a los demás como personas»; JAKOBS, G., «La idea de la normativización en la dogmática jurídico-penal», trad. Manuel Cancio Meliá del manuscrito Die Idee der Normativierung in der Strafrechtsdogmatik, JAKOBS, G., Sobre la normativización de dogmática jurídico-penal, op. cit., pp. 18 y ss; PIÑA ROCHEFORT, JI., Rol social y sistema de imputación, op. cit., pp. 279 y ss; PÉREZ DEL VALLE, C., «La persona del Derecho penal en la filosófica de Hegel», Dogmática y Ley penal. Libro Homenaje a Enrique Bacigalupo, T. I, Jacobo López Barja de Quiroga y José Miguel Zugaldía Espinar (coords.), Instituto Universitario de Investigaciones Ortega y Gasset, Marcial Pons, Madrid-Barcelona, 2004, pp. 605 y ss; POLAINO-ORTS, M., Funcionalismo normativo, op. cit., pp. 110 y ss; PIÑA ROCHEFORT, JI., Rol social y sistema de imputación, op. cit., p.
} 
dentro del marco de la Sociedad, de manera que es la persona el destinatario de la norma como elemento autorreferencial de la misma. Sin embargo, en otras ocasiones, hay ciudadanos que presentan una «autoexclusión social» que comunica un «déficit general de garantía cognitiva» de tal manera que se desconecta del «acuerdo normativo in totum, atentando contra las «normas de flanqueo» de la sociedad, con lo cual se autoexcluye del sistema social se «despersonaliza» (...) siendo combatido como enemigo», como atinadamente recuerda POLAINO-ORTS ${ }^{676}$.

LUHMANN ya explicó esta identidad norma/sociedad y sus repercusiones en el sistema jurídico-penal de la siguiente manera: «también el delincuente, lleva una existencia en la sociedad; y no solo en virtud de que oculte su acción teniendo en cuenta la norma y la policía, sino por el hecho de que quiere lo prohibido. Hay una lógica propia del mal que pertenece a la sociedad y que no se sitúa fuera de sus fronteras. Por consiguiente, el consenso en las normas no puede ser fundamento del sistema de la sociedad, sino sólo la disyunción entre el comportamiento conforme a la norma y el comportamiento desviado, con su correspondiente diferenciación de expectativas y reacciones» ${ }^{677}$.

La norma alcanza su realidad cuando se dirige a sujetos idóneos, entonces, a personas normativamente hablando, por lo que no es de extrañar que la función de la norma sea «normativa»y «fáctica», normativa en cuanto que institucionaliza las expectativas sociales a las que responde la Sociedad, y fáctica en relación a la realidad de la seguridad cognitiva en el cumplimiento de la norma y de su capacidad de orientar conductas: ser un foco o faro de guía ${ }^{678}$. Por ejemplo, los ciudadanos pueden estar seguros de que su vida no está amenazada por terceros, si bien, como bien ha resaltado CARO JOHN, los ciudadanos han de aportar en su esfera de organización libre un plus de seguridad que supla el déficit de protección normativa asegurando sus puertas ${ }^{679}$, aunque también con comportamientos que no pongan en peligro sus vidas bajo la amenaza o imputación de una autopuesta en peligro.

Asimismo la norma también tiene un aspecto «formal» 0 «apariencia externa reconocible», o sea, que el ciudadano la reconozca como norma, y otro aspecto «material», aquel en el que el ciudadano conoce y tiene la confianza de que su expectativa social va a ser cumplida, si bien

276 refiere que «ser persona» es el rol más general del individuo, y pp. 278 y 279 dice que «el individuo jamás forma parte de la sociedad si no es como persona», el rol más básico.

676 POLAINO-ORTS, M., Funcionalismo normativo, op. cit., p. 72.

677 LUHMANN, N., «Interacción, organización, sociedad. Aplicaciones de la teoría de sistemas», op. cit., p. 201.

678 POLAINO-ORTS, M., Funcionalismo normativo, op. cit., p. 94 y pp. 100 a 103.

679 CARO JoHn, José Antonio, «Derecho penal del enemigo: garantía estatal de una Libertad real del ciudadano. Una glosa a Miguel Polaino-Orts», RPDJP, núm. 7, Instituto Peruano de Ciencias Penales, Grijley, Lima, 2006, p. 642 . 
también reconoce que es mejor asegurar sus puertas ${ }^{680}$. Sin embargo, hay normas que al faltarles la realidad fáctica o expectativa social, son inidóneas para comunicar y orientar la conducta de los ciudadanos. En otros casos la institucionalización de expectativas es «contradictoria» o no está mayoritariamente refrendada (casos como el aborto), lo que, en opinión de POLAINO-ORTS, pasa por una solución de institucionalización de mínimos, si bien en casos de «diversidad cultural» la norma «ha de reflejar (...) todas las expectativas de la Sociedad, las de las mayorías y las de la minoría» por lo que «(m)ientras ello no suceda el espejo estará desenfocado, la norma será incompleta y, por tanto, manipulada» ${ }^{681}$.

Amén de ello, existen normas que crean déficits de socialización, confusión o contraorientación orientativa. En estos casos, en nuestra opinión, el déficit proviene de la propia norma o del conjunto de normas aplicables a un determinado supuesto, de modo que a la Sociedad no le llega en plenitud la expresión de sentido de la norma, y en otras ocasiones son las minorías las que sufren ese déficit de orientación: la comunicación no llega o es defectuosa porque la norma no supone un «espejo» de su realidad social ${ }^{682}$.

Tales son los casos de autoría de conciencia en su mayoría, y algunos casos de autor por convicción. Si la expectativa social es el contenido de la norma jurídica, pero a la vez la provee de sentido, y en la condición de su vigencia existe una vinculación «exacta y puntual, irrenunciable y directísima entre la norma y la Sociedad» ${ }^{683}$, según manifiesta POLAINO-ORTS, podemos concluir que cuando no exista tal correspondencia en toda su descripción autorreferencial y autopoiética, la norma no forma parte de la sociedad o contiene un déficit de comunicación que deberá ser suplido por otras normas, pero cuando esto no sea posible, el

680 POLAINO-ORTS, M., Funcionalismo normativo, op. cit., p. 84 y p. 132. Al respecto PIÑA ROCHEFORT que el aspecto formal es la «legitimidad formal», como el principio de legalidad y sus derivaciones como el debido proceso, el principio de ejecución de las sanciones; mientras que la «legitimidad material» consistiría en normas de construcción dogmática, los bienes jurídicos, la subsidiariedad, la fragmentariedad, la «humanidad de las penas», la proporcionalidad, el principio de igualdad, y especialmente el principio de culpabilidad, PIÑA ROCHEFORT, JI., Rol social y sistema de imputación, op. cit., p. 304, y ampliamente pp. 312 a 343.

681 POlAINO-ORTS, M., Funcionalismo normativo, op. cit., pp. 104 y 105. Similarmente PIÑA ROCHEFORT comenta que «si la sociedad ha diferenciado un sistema cuya función es mantener estables ciertas expectativas sociales, dicho sistema operará (y, en definitiva, existirá) legítimamente, siempre que su operación se oriente al desempeño de dicha función. Cualquier camino diverso que siga la operación del sistema, redunda inmediatamente en la pérdida de su legitimidad», PIÑA ROCHEFORT, JI., Rol social y sistema de imputación, op. cit., p. 301. Por eso, añade que «el sistema del Derecho incluso debe estabilizar expectativas que se le dirigen a él mismo, pues el sistema que lo ha diferenciado ha estimado que dichas expectativas son fundamentales para la normal operación del sistema (...) si la legitimidad del sistema jurídico pende de que se mantenga fiel al cumplimiento de su función, éste no sólo deberá mantener estabilizadas las expectativas dirigidas a otros partícipes de la operación, sino que deberá mantener estabilizadas también las que se le dirigen a él mismo», ID., ibidem, op. cit., p. 303.

682 A este respecto se refiere POLAINO-ORTS en aquellos casos de adulterio y amancebamiento castigados por el CPd vigente hasta 1977, en los que los jueces y Tribunales no llegaban a condenar porque la norma ya no cumplía la realidad social de los españoles, POLAINO-ORTS, M., Funcionalismo normativo, op. cit., pp. 96 y ss.

683 ID., ibidem, op. cit., p. 86. 
quebrantamiento de la norma debido a la incapacidad o déficit de orientación o comunicación del sentido material de la norma, posibilitará un tratamiento privilegiado al quebrantador de la norma.

De esta manera es concebido el delito como una comunicación perfecta del autor a la Sociedad, si bien su contenido es defectuoso, dicha comunicación no lo es. Así para una defraudación de la expectativa normativa hace falta que los tres postulados de la comunicación se cumplan: la información, la notificación al ordenamiento jurídico, y el acto de entenderlo como injusto ${ }^{684}$ para modular el comportamiento futuro. En algunos casos en el autor de conciencia, la conducta no llega a notificar al ordenamiento jurídico la expresión de sentido ${ }^{685}$, por eso no se comprende como injusta, sino atípica, si bien a estos casos le son ajenos el motivo. Por eso decíamos que no sería una problemática estrictamente hablando del autor de conciencia. En otros casos se exonera/exculpa o se fundamenta una atenuación por debajo del límite mínimo. Sin embargo, la norma no ha podido comunicar su contenido al sujeto por un déficit de comunicación o contraorientación normativa, lo que en nuestra opinión supone una causa de exculpación como vamos a desarrollar.

Trasladando los postulados expuestos al autor de conciencia, el conflicto que sufre entre el deber jurídico y el deber moral se debe a un reconocimiento explícito de la norma a la libertad de conciencia en la Constitución española, pero más especialmente en los supuestos de la legalización de la doctrina y ritual de una confesión religiosa debidamente inscrita en el Registro de Entidades Religiosas gracias a los filtros que la normativa registral establece. En estos últimos

684 PIÑA ROCHEFORT, JI., Rol social y sistema de imputación, op. cit., pp. 235 y ss

685 ID., ibidem, op. cit., p. 237, comenta que «cuando un terrorista queda severamente mutilado por la manipulación de un artefacto explosivo, el mensaje que recibe el sistema social es «no se debe manipular artefactos explosivos» y no se requiere ninguna pena para ello (...)». Si bien no estoy de acuerdo en este último punto, la pena correspondería con los correspondientes delitos de posesión, se crea una peligrosidad que fundamenta la validez de la punibilidad, creemos que el referido autor quiere decir que no es aceptada por la sociedad como una acto orientador de conductas positivas en el sentido de «manipule artefactos para dañarse», ni como una conducta de fiel reflejo de un acto terrorista en la finalidad que perseguiría si se hubiese colocado bajo un vehículo. De tal modo adquiere sentido su siguiente aclaración: «No debe olvidarse que toda infracción a la norma le niega su vigencia sólo normativamente, no cognitivamente. De hecho, muchas veces se observan infracciones a la norma sin que la vigencia de ésta sufra una defraudación cognitiva. La pregunta a la que esto conduce es, en definitiva: si la comunicación del infractor no llega a destino ¿por qué debe el sistema social seguir comunicando acerca de ella (imponiendo una pena)?». De tal manera contradice a JAKOBS, al que le reprocha que sólo se fije en la expresión de sentido de que la norma carece de vigencia o validez, para PIÑA ROCHEFORT, creemos que acertadamente, hace falta el entendimiento como orientador de conductas por el delito, para tal distinción se basa en la diferencia expuesta por SEARLE entre hecho brutos y hechos institucionales, los primeros son físicos o biológicos, mientras que los institucionales están en el interior de las instituciones humanas, de forma que la expresión de sentido, parece ser un hecho bruto, pero al debatirse en el sistema propio del derecho penal, la expresión de sentido es un hecho institucional, ya que el hecho de matar se procesa en el código justo/injusto no como un hecho bruto (análogo al neutral) sino como una expresión contraria a la normatividad social, por lo que concluye que la diferencia entre comunicación y expresión en el sistema jurídico-penal se hace irrelevante ID., ibidem, op. cit., pp. 238 a 241. 
supuestos la norma comunica, más si cabe, la vigencia normativa y fáctica de esas determinadas creencias, por eso cuando llega el conflicto de conciencia no existe una merma de la capacidad cognitiva del ciudadano sino una contraorientación insalvable entre la norma que habilita el ejercicio de tales creencias y la norma que obliga a una conducta contradictoria con la primera. De hecho, el sujeto no sufre un déficit de motivación, sino todo lo contrario, la norma le habilita para orientar su conducta en tal sentido, mientras que otra norma, por ejemplo, el deber de no omitir el socorro le restringe muy especialmente la conducta conforme a su conciencia, lo que hace nacer el conflicto no por un déficit cognitivo del sujeto sino por un déficit de comunicación normativo o contraorientación normativa que, en nuestra opinión, fundamenta la aplicación de una causa de exculpación. La norma ha permitido (riesgo permitido) que el sujeto conecte de forma ineludible su conciencia y voluntad, de manera que si en dicha conexión se fundamenta el motivo de su actuar, la responsabilidad subyace de la norma, de tal manera que no puede responsabilizar al sujeto ${ }^{686}$.

En los casos paradigmáticos del autor de conciencia no estamos ante una merma de la capacidad del sujeto sino de la realidad fáctico-social de la norma, de contenido material, que hace inexigible la conducta del sujeto conforme a la norma circunstancial y sorpresiva que le ordena actuar. La norma que habilita y reconoce la expectativa social, en este caso una expectativa de conciencia minoritaria, de orientar su conducta legítimamente se ve paralizada de «sopetón», sorpresivamente, por otra norma cuando durante años la primera norma ha reconocido su actuar. Si bien es cierto que el sujeto conocía también la norma de velar y salvaguardar los derechos del menor, o generalmente de actuar solidariamente, la permisividad social de su actuar, inclusive permitiendo la educación al menor con los valores de su propia conciencia, se ve paralizada normativamente por otra norma en un supuesto especialísimo a pesar de que el sujeto ha sido orientado en esa permisividad, por lo que no podemos estar de acuerdo con esos postulados que defienden que la norma motiva las conductas, sino que las guían en un horizonte de permisividad en la organización de sus conducta.

El comportamiento del autor de conciencia si bien tiene una expresión de sentido no orienta conductas a la sociedad por su especialidad, a diferencia del autor por convicción, que con su actuar expresa sentido y tiene la fuerza de hacerse entender para orientar la conducta en otros

\footnotetext{
686 Cabe invocar el argumento de PIÑA ROCHEFORT: «El rol social es recibido como cognición en el sistema de imputación. Dicho rol presenta dos dimensiones, una dimensión externa, en virtud de la que la conducta prohibida se determina mediante un baremo objetivo construido socialmente y una dimensión interna que se encarna en la relación subjetiva del destinatario con su rol. En la dimensión externa, esto es, en la determinación del contenido del rol (y la determinación de las conductas que le están prohibidas) el sistema de imputación no puede alterar el contenido del rol social sin que la sociedad entre en contradicción consigo misma», ID., ibidem, op. cit., p. 299.
} 
positiva (siguiendo dicha conducta) o negativamente (miedo). En los ataques claros a la norma, muchas veces graves, el autor por convicción no se plantea un conflicto, sino que trata de imponer su expectativa desautorizando a la norma misma, no existe otra norma que comunique la permisividad de delito, tan solo el fin que persigue el autor por convicción, que puede ser licito o ilícito. Sin embargo, la elección de su expectativa pasa por utilizar un medio delictivo (móvil) que por ser innecesario o simplemente alternativo para el fin, supone un mayor reproche penal puesto que pudo activar otro medio para lograr tal fin. Aunque su conducta sea también inevitable por motivos de conciencia/ideológicos o morales, la alternatividad de su conducta criminal demuestra el mayor reproche penal al ser innecesario, o dicho de otra manera, pudo actuar conforme a Derecho para conseguir el mismo fin.

Pero hay que destacar casos especiales del autor por convicción en los que también el sujeto sufre un déficit de socialización atribuido a la norma o a un tercero.

\section{B. Función de la norma penal: Prevención general positiva y motivación de la norma} versus norma como orientación de conductas y mantenimiento del sistema

Los anteriores postulados han de ser corroborados con argumentos que avalen la función de la norma pues la utilización de unos y otros llevarán a conclusiones distintas. Decíamos que la norma supone un faro de guía o un foco que hace permisible la esfera de organización libre del sujeto en ese determinado horizonte que señala el faro. Este es el fundamento que inutiliza los postulados de algunos autores de la doctrina ${ }^{687}$ que se refiere a que la norma tiene una función motivadora del ciudadano en la psique, sin embargo dicha motivación sólo cumple una parte negativa, la que advierte al ciudadano de que determinadas conductas están sancionadas, con lo que se cumple a través de la pena «determinada esperanza de psicología social o individual»o fines preventivos como la reinserción, como recuerda POLAINO-ORTS, «con independencia de la realización de tales esperanzas la pena ya ha cumplido su cometido estabilizador» ${ }^{688}$.

El postulado de la prevención general nada aporta al fundamento de legitimidad de la norma ni explica por qué los ciudadanos habitualmente actúan en una esfera de libertad de organización normativamente permitida. Esto se debe a que se obvia que la norma sirve al ciudadano de modo

687 Cerezo MIR, J., Curso de Derecho penal español, Parte general, III/2, op. cit., pp. 40 y ss; COBO DEL Rosal M / VIVES ANTÓn TS., PG, op. cit., pp. 57 y ss; MIR PUIG, S., Introducción a las bases del Derecho penal: concepto y método, Montevideo, Bosch, 2003, $2^{\text {a }}$ ed. reimp., $1^{\text {a }}$ ed. 1976, pp. 56 y ss; GIMBERNAT, E., «El sistema del Derecho penal en actualidad», Estudios de Derecho penal, op. cit., p. 74 y ss; GonZÁlEZ MATEOS, José Carlos, «Esencia de la norma penal y antijuricidad de la tentativa», Anuario de la Facultad de Derecho, Band, 18, Universidad Extremadura, Cáceres, 2000, p. 194 y ss; MuÑOZ CondE, F., Introducción al Derecho penal, Bosch, Barcelona, 1975, pp. 50 y ss.

688 POlAINO-ORTs, M., Funcionalismo normativo, op. cit., p. 129. 
tal que cumple las expectativas de estos tanto en un aspecto positivo como es la orientación de una conducta permitida en un haz u horizonte de posibilidades de organización, de otra, en su parte negativa, comunicando qué conducta no puede hacer ni éste ni otros terceros contra él. Por eso se dice desde la doctrina del funcionalismo normativo ${ }^{689}$ que la norma es la misma vigencia y la validez materializada e institucionalizada de las expectativas sociales ${ }^{690}$, se identifica con la Sociedad y cumple de tal modo una engranaje fundamental en el mantenimiento del sistema ${ }^{691}$ que se auto-llama y se auto-construye a sí misma por cuanto es la propia Sociedad la que se identifica con la norma, además tiene especial transcendencia en la comprensión de que la tentativita es ya en sí misma un injusto. Por eso los postulados de la función motivadora de la

689 JAKOBS, G., ¿Cómo protege el Derecho penal y qué es lo que protege? Contradicción y prevención; protección de bienes jurídicos y protección de la vigencia de la norma», trad. Manuel Cancio Meliá, JAKOBS, G., Sobre la normativización de dogmática jurídico-penal, op. cit., pp. 50 y 51; BERZ, Ulrich, Formelle Tatbestandsverwirklichung und materieller Rechtsgüterschutz, Eine Untersuchung zu den Gefährdung- und Unternehmensdelikten, 1986, pp. 32; KINDHÄUSER, Urs, Gefährdung als Straftat, Frankfurt, 1989; LESCH, Heiko Hartmunt, Das Problem Der sukzessiven Beihilfe, Frankfurt am Main, New York, P. Lang, 1992; MüssIG, Bernd, «Desmaterialización del bien jurídico y de la política criminal. Sobre las perspectivas y los fundamentos de una teoría crítica del bien jurídico hacia el sistema», CDJP, 2001, II, pp. 229 y ss; MYLONOPOULOS, Christos, Über das Verhältnis vom Handlungs-und Erfolgsunwert im Strafrecht. Eine Studie zur Entwicklung der personale Unrechtslehren, Köln, Berlin, Bonn, München, 1981, pp. 84 y ss; NIEPOTH, Bukhard, Der untaugliche Versuch beim unechten Unterlassungsdelikt, Frankfurt a. M., 1994, pp. 113 y ss; SAX, Walter, «Tatbestand und Rechtsgutsverletzung», JuS, III, 1976, pp. 429 y ss; VEHLING, Karl-Heinz, «Abgrenzung von Vorbereitung und Versuch», Schriften zum Strafrecht und Strafprozeßrecht, 4, Peter Lang, Frankfurt am Main, Bern, New York, Paris, 1991; ZACZYK, Rainer, Das Unrecht der Versuchten Tat, Duncker \& Humblot GmbH, Berlin, 1989. En España, aunque a favor de la compatibilidad de ambas tutelas, POLAINO NAVARRETE, Derecho penal, Parte general, T. II, Teoría jurídica del delito, Vol. I, Bosch, Barcelona, 2000, pp. 546 y ss., donde afirma que la tentativa es una «consumación anticipada» pero legítima; ID., Derecho penal, Parte general, I, $5^{\text {a }}$ ed., colaboración de Miguel Polaino-Orts, Bosch, 2004, pp. 151 y 152; ID., «El injusto de la tentativa en el ejemplo de los delitos de mera actividad y de omisión pura. Sobre el concepto jurídico-penal de resultado», RPJ, núm. 72, 2003, pp. 59 a 88, también en Bogotá, Universidad Externado de Colombia. 2004; ID., «Injusto de la tentativa y vigencia de la norma desde una perspectiva penal funcionalista», El Pensamiento filosófico y jurídico-penal de Günther Jakobs, México D.F., Flores Editor y Distribuidor, S.A. de C.V., 2007, p. 711; siguiendo una línea más ortodoxa, POLAINO-ORTS, M., Derecho penal del enemigo. Desmitificación del concepto, pról. Günther Jakobs, revisado por Miguel Polaino Navarrete, Grijley, Lima, 2006, pp. 27 y ss; ID., Derecho penal del enemigo. Fundamentos, potencial de sentido y límites de vigencia, pról. Günther Jakobs, Bosch, Barcelona, 2009, pp. 47 y ss., y 305 y ss., y pp. 319 y ss; ID., Lo verdadero y lo falso en el Derecho penal del enemigo, pról. Günther Jakobs, Grijley, Lima, 2009; PIÑA ROCHEFORT, JI., Rol social y sistema de imputación, op. cit., p. 305 y ss; REY SAFINZ, Luis Carlos, Tentativa jurídico-penal: acercamiento al tratamiento doctrinal del fundamento de los criterios de imputación entre naturalismo y normativismo, Dykinson, Madrid, 2001, pp. 100 y ss; SANTA RITA, G., El delito de organización terrorista, op. cit., p. 247 y pp. 285 y ss.

690 Si bien el funcionalismo de JAKOBS (también Niklas LUHMANN) se postula más cercano a que la norma cumple una función de orientación de conductas que una institucionalización de expectativas sociales, vid. y afirmando que dicha contraposición no es convincente y que son compatibles ambas tutelas, porque la norma no es un «mecanismo imperativo», sino «constituye un modelo de orientación de social, al plasmarse en él las expectativas socialmente protegibles», Polaino NaVArRete, M., Acción, omisión y sujetos en la Teoría del delito. (De la posición de garante a la responsabilidad penal de las personas jurídicas), Grijley, Perú, 2009, p. 55 y ss.

691 POlAINO-ORTS, M., Funcionalismo normativo, op. cit., p. 132; PIÑA RoCHEFORT, JI., Rol social y sistema de imputación, op. cit., pp. 233 y ss., y propio de todos los demás ámbitos del derecho. Comenta acertadamente que «(t)odas las estructuras del sistema forman parte del entramado por medio del que dicha función se alcanza. Esto quiere decir que no sólo mediante aquellas estructuras por las que se enlazan sanciones penales se orienta al cumplimiento de dicha función, sino también las estructuras en virtud de las cuales se exonera de responsabilidad y, en un nivel diferente, las estructuras de legitimidad», PIÑA ROCHEFORT, JI., Rol social y sistema de imputación, op. cit., p. 262, y sobre la (auto) legitimación del sistema de imputación ID. ibidem, op. cit., pp. 301 y ss. 
norma están cojos o sin respuesta cuando la realidad social muestra la comisión de delitos o, en nuestro caso, son incapaces de explicar la autoría de conciencia y por convicción, la habitualidad y reincidencia, o la conducta de los que adoptan un modo de vida criminal, como espléndidamente ha refutado PolAino NAVARRETE ${ }^{692}$.

En conclusión, no es cierto que el funcionalismo normativo suponga un postulado per se de criterios de prevención general positiva, sino que va mucho más allá o engloba no sólo esta concepción del Derecho penal de manera que en verdad no trata de alcanzar algo con la pena ${ }^{693}$, pues al equiparar la pena a la vigencia de la norma, ésta adquiere ya toda la expresión de sentido comunicativo y autorreferencial con la misma vigencia normativa, sin esperar a que una pena la confirme. La pena sólo repara la comunicación concreta que el autor crea con su actuar, también cuando no se pena se cumple la función estabilizadora de la norma, también se cumplen ciertas expectativas no penando, por ejemplo, así sucede en las causas de exculpación o inimputabilidad, en casos de minoría de edad, el error de prohibición invencible, estado de necesidad exculpante y en el miedo insuperable ${ }^{694}$.

JAKOBS argumenta que el delito no es quebranto del bien jurídico sino defraudación de la expectativa normativa (Enttäuschung der normativen Erwartung), lesión de deber. No es el hecho material lo que comunica la negación de la norma, sino lo «simbólico» ${ }^{695}$ del acto, su expresión comunicante, lo que se toma por el raciocinio de los sujetos como social y comunicativamente relevante ${ }^{696}$. Por eso, la teoría funcionalista entiende la norma como subsistema funcional del ordenamiento, asegura las expectativas normativas de los ciudadanos hasta el extremo de entender que la defraudación de la norma de flanqueo -aquella que es protectora de la principal- es ya un injusto, porque ciertas conductas preparatorias y la tentativa en general son «funcionales» para el mantenimiento del sistema.

\footnotetext{
692 Polaino NaVArrete, M., Derecho penal, Parte general, T. I, op. cit., p. 190; también PolainO-OrTS, M., Funcionalismo normativo, op. cit., p. 106 y ss.

693 JAKOBS, G., «Sobre la teoría de la pena», trad. Manuel Cancio Meliá, JAKOBS, G., Bases para una teoría funcional del Derecho penal, trad. Cancio Meliá / Feijoo Sánchez / Peñaranda Ramos / SANCINETTI / Suárez González, presentación Dino Carlos Caro Coria, $1^{a}$ ed., Palestra Editores, Lima, 2000, pp. 59 y ss., también con el mismo título en Cuadernos de conferencias y artículos, trad. Manuel Cancio Meliá, núm. 16, Centro de Investigaciones de Derecho Penal y Filosofía del Derecho, Universidad Externado de Colombia, Bogotá, 1999, p. 33; LESCH, HH., «La función de la pena», trad. Javier Sánchez-Vera, Cuadernos Luis Jiménez de Asúa, núm. 4, Dykinson, Madrid, 1999, pp. 45 y ss; POLAINO-ORTS, M., Funcionalismo normativo, op. cit., pp. 136 y 137 ; PIÑA ROCHEFORT, JI., Rol social y sistema de imputación, op. cit., p. 227 parágrafo 119, y pp. 306 y ss; SANTA RITA, G., El delito de organización terrorista, op. cit., p. 247 y pp. 285 y ss.

694 Excelente argumento al respecto PIÑA ROCHEFORT, JI., Rol social y sistema de imputación, op. cit., p. 330 y ss.

695 Al respecto LESCH, HH., Das Problem Der sukzessiven Beihilfe, op. cit., p. 256.

696 VeHLING, K-H., «Abgrenzung von Vorbereitung und Versuch», op. cit., p. 130.
} 


\section{Bienes jurídicos o quebrantamiento normativo y vigencia de la norma}

Los anteriores postulados tienen su máxima relevancia y significado en la negación de que el Derecho penal proteja «funcionalmente» bienes jurídicos tal y como defiende gran parte de la doctrina ${ }^{697}$ bajo el argumento de que el Derecho penal protege las estructuras lógico-objetivas de lo ontológico, como por ejemplo la vida y la libertad, sino que por parte del funcionalismo se defiende que esta protección sería una consecuencia accesoria. El derecho no puede proteger la vida como razón ontológica sino cuando adquiere relevancia social, en un determinado contexto social y en determinadas expectativas sociales, lo que confirma que el Derecho penal tiene como función la vigencia de la norma y su identidad en la Sociedad.

Algunos autores - como POLAINO NAVARRETE ${ }^{698}$ - compatibilizan ambas tutelas, y por eso reconoce que JAKOBS ha sabido diferenciar entre lesiones a bienes y lesiones a bienes jurídicos: «es la norma penal la que crea o reconoce una necesidad, un merecimiento de tutela penal a determinados bienes frente a determinados ataques: a partir de ahí, esos bienes naturales pasan a ser bienes jurídicos» ${ }^{699}$. Para Polaino NAVARRETE, la secuencia delito-pena no se agota en la «autovigencia» de la norma, sino que el bien jurídico tiene un aspecto positivo en dicha secuencia que también alcanza esa intensidad de tutela preventiva comunicando al autor que su acción lesiva de «esos concretos bienes jurídicos no será gratuita, y del mismo modo, la protección penal de esos bienes no será en vano» ${ }^{700}$, por eso concluye que la vigencia de la norma no desplaza al bien jurídico a un segundo plano, el Derecho penal no tiene la tarea de impedir resultados lesivos, sería irreal y utópico, sino de seleccionar bienes y valores jurídicos que merecen protección, los bienes jurídicos ${ }^{701}$, de manera que la protección de bienes jurídicos es el contenido y la prevención de delitos, el fin ${ }^{702}$. De esta manera, el referido penalista, con brillantez, aboga por una relación entre bien jurídico y vigencia de la norma como medio-fin en la que la norma no tiene una función autoprotectora, sino de salvaguardar «inmediatamente» los bienes y valores relacionados con ella, y de esa forma se protege «mediatamente» la vigencia de la norma ${ }^{703}$. Creemos que de esta manera POLAINO NAVARRETE explica convenientemente la compatibilidad de ambas tutelas sin mermar la función de ninguna de ellas.

697 Polaino NaVArrete, M., El bien jurídico en Derecho penal, op. cit; ID., Derecho penal, Parte general, T II, Teoría jurídica del delito, Vol. I, Bosch, Barcelona, 2000; SANTA RITA, G., El delito de organización terrorista, op. cit., p. 247 y pp. 285 y ss.

${ }^{698}$ Polaino NaVArRete, M., Acción, omisión y sujetos en la Teoría del delito, op. cit., pp. 160 y 161 , y 165 y 166; SANTA RiTA, G., El delito de organización terrorista, op. cit., p. 247.

${ }_{699}$ Polaino NaVArRete, M., Acción, omisión y sujetos en la Teoría del delito, op. cit., pp. 160 y 161.

700 ID., ibidem, op. cit., pp. 162 y 163.

701 ID., ibidem, op. cit., pp. 164 y 165.

702 ID., ibidem, op. cit., p. 166.

703 ID., ibidem, op. cit., p. 168. 
Si utilizamos esta argumentación en la autoría de conciencia y por convicción podremos concluir que entre ambas no existe más diferencia que el sentido comunicativo de quebrantamiento de la vigencia de la norma, o sea, el grado en el que «mediatamente» se ataca la vigencia de la norma. Según lo expuesto, que en el autoría de conciencia no se trata de atacar la vigencia de la norma, muy a pesar del quebrantamiento del bien jurídico, y en el autor por convicción se ataca la vigencia general de la norma, de suerte que en ambos puede acaecer un menor o mayor quebrantamiento del bien jurídico, o con otras palabras, en ambas autorías se puede incurrir en tipos penales dignos de mayor o menor protección, si bien, la diferencia estriba en la expresión de atacar la vigencia general de la norma o no, cuestión que si bien no modula la gravedad ni el delito imputable, sí la culpabilidad.

Si analizáramos el problema inversamente, esto es, analizando primero el ataque a la vigencia de la norma y después el quebranto al bien jurídico, incurriríamos en el error de analizar la conducta moralmente. Si bien el funcionalismo explica convenientemente que la tentativa ya supone un quebrantamiento de la vigencia de la norma, este planteamiento ha de servirse de la relación con el bien jurídico para explicar su ubicación sistemática, de manera que sólo analizando en primer lugar cuál es el bien jurídico quebrantado en relación «mediata» a la contradicción con la vigencia de norma, se puede comprender además de la ubicación sistemática del quebrantamiento en el Código penal, la determinación de la pena.

Prueba de esto es que el mismo JAKOBS reconoce que la consumación de los tipos especiales han de comprenderse en relación con la parte general pero también en cuanto a su afección. Esto -dice JAKOBS- se ve claramente en la relación de la consumación entre los delitos de posesión, coacciones, y generalmente en los delitos contra las personas ${ }^{704}$. Con palabras simples, el autor de conciencia si bien puede incurrir en un bien jurídico digno de la más alta protección, en su motivación «mediatamente» no se rompe la vigencia de la norma. Por el contrario, en el autor por convicción, a pesar de atacar en determinadas situaciones un bien jurídico digno de menor protección penal, con su motivación se ataca «mediatamente» la vigencia general de la norma, lo que fundamenta en la culpabilidad la mayor reprochabilidad. Entonces, no es cierto que a mayor quebrantamiento del bien (mayor injusto) exista «mediatamente» un mayor quebrantamiento de

\footnotetext{
704 En concreto señala que «el derecho de la persona a no ser desorientado está lesionado por completo cuando ésta está desorientada. Si para la consumación formal (típica) debería exigirse más es otra cuestión», JAKOBS, G., «Consumación material en los delitos contra la persona. Al mismo tiempo, una contribución a la generalización de la parte especial», trad. Sergi Cardenal Montraveta, revisada por Manuel Cancio Meliá, RECPC, núm. 04-13, 2002, p. 8, el original apareció en Schünemann / Achenbach / Bottke / Haffke / Rudolphi (eds.), Festschrift für Claus Roxin zum 70. Geburstag, am 15. Mai 2001, 2001, pp. 793 a 810. Y añade que «(t)ambién después del engaño o de la aplicación de violencia, o de una amenaza está completa la lesión del Derecho y, por lo tanto, se da la consumación», ID., ibidem, op. cit., p. 11.
} 
la vigencia de la norma, y viceversa, si no que en el autor de conciencia, por convicción y en el enemigo, la relación proporcional y medial «bien-vigencia», se rompe en determinadas circunstancias por motivo de la especialidad.

\section{Déficit de socialización}

Expuesto todo lo anterior, se hacen más compresibles los postulados del funcionalismo normativo en relación al eje triangular: Norma, Sociedad y Persona. Esta forma de comprender la realidad jurídico-penal adquiere especial relevancia en las instituciones de la teoría jurídica del delito y más concretamente en la institución de la culpabilidad y en la exculpación.

Recuérdese que decíamos supra que también cuando no se pena se cumple la función estabilizadora de la norma, también se cumplen ciertas expectativas no penando, por ejemplo, así sucede en las causas de exculpación o inimputabilidad, en casos de minoría de edad, el error de prohibición invencible, estado de necesidad exculpante, y en el miedo insuperable ${ }^{705}$. De tal manera adquiere sentido que se comprenda el principio de culpabilidad en cuanto función de la norma, y por ende una estructura de legitimación de la norma, es decir, la norma no puede orientarse y orientar conductas que no tienen fiel reflejo en la sociedad, por eso el sistema jurídico también debe mantener vigentes expectativas que comunica la sociedad.

Esto sucede principalmente en dos casos, de una parte, en la legitimidad formal de la norma, aquellos casos de validez de la norma mediante el principio de legalidad y su identificación con la sociedad (no pueden instaurarse leyes imposibles de realizar), de otra, la culpabilidad como estructura por la que -como bien comenta PIÑA ROCHEFORT- «se estabilizan expectativas dirigidas al sistema jurídico-penal» ${ }^{706}$, o dicho más específicamente, y en nuestra opinión, nadie espera ser reprimido cuando salva su vida a costa de otro. A esto se le denomina comúnmente un estado de necesidad exculpante, por eso explicábamos que el estado de necesidad justificante sólo se aprecia en aquellos casos en los que se evita un mal mayor que el que se produce, relegando el estado de necesidad exculpante en aquellos casos en los que se identifican normativamente los males en conflicto, o se salva un mal menor, levemente o mucho menor, que el producido (teoría de la diferenciación).

En este sentido debemos aclarar que en el conflicto de males jurídicos de mismo rango, el análisis que hace el sujeto ante dicho conflicto lo conoce como «ausencia de derecho». Así, no parece problemático mantener -con JAKOBS- que entre dos deberes del mismo rango no existen «máximas jurídicamente vinculantes», de manera que se trata de un ámbito «exento de

705 Ampliamente al respecto PIÑA ROCHEFORT, JI., Rol social y sistema de imputación, op. cit., pp. 330 y ss.

706 ID., ibidem, op. cit., p. 333. 
derecho» ${ }^{707}$. Ante dicha situación el sujeto está en un «estado de naturaleza», trata de proteger su vida aun en perjuicio de otro. Por eso, el sistema-jurídico penal no puede entrar a valorar dicha conducta, aunque a esta falta de valoración se le ha puesto un nombre en la doctrina penal: causa de exculpación. Sin embargo, esto simplemente significa que «no hay norma». La «ausencia de norma» es la expectativa social de que el sistema jurídico-penal no entre a valorar esa conducta. ¿Por qué en esa situación debería un sujeto pensar que la norma le ampara, o razonar en pocos segundos qué espera el Derecho de él? El sistema no espera nada, tan poco valorable sería una conducta de autoprotección de la vida, como conformarse con la muerte a favor de la vida del otro. Pero la dogmática penal en cuanto razonamiento de dicha conducta le ha otorgado un nombre institucional, la exculpación, no valora esta conducta en verdad, sino aquéllas que sin llegar a exculpase completamente, se le otorga cierta importancia o relevancia en cuanto expectativa social dirigida al sistema. A esta cierta relevancia normativa se le denomina eximente incompleta, o motivo de atenuación de la pena. En conclusión, el conflicto de males de mismo rango supone la «ausencia de derecho», en verdad, la identidad de la expectativa normativa con la libertad ${ }^{708}$ : ;Usted Derecho, aquí no puede valorar mi libertad, ni positiva ni negativamente!

Sin embargo, cuando el mal causado es mayor levemente o mucho mayor que el que se evita, en determinadas ocasiones, como en la autoría de conciencia, por convicción o el enemigo, se produce un déficit de socialización, unas veces a causa del déficit de comunicación de la norma (o por contraorientación normativa), otras atribuible a tercero, que de igual modo fundamenta la exculpación completa a pesar de causarse significativamente un mal mayor que el que se evita.

La persona supone un rol básico de derechos y obligaciones, dícese libertad, pero como individuo que es, también supone un sistema psíquico que forma parte del entorno de otros sistemas, del penal, en ambos se produce una interpenetración sistema/entorno mediante energías o reacciones que como ya dijimos se nutren uno y otros hasta acoplarse ${ }^{709}$.

707 JAKOBS, G., $P G$, op. cit., 15/7, y nota 11, en el mismo sentido nombra a KAUFMANN, Arthur, «Rechtsfreier Raum und eigenverantwortliche Entscheidung», Maurach-Festschrift, Karlsruhe 1972, pp. 327 y ss. y pp. 336 y ss; BLEI, Hermann, Strafrecht, T. I, Allgemeiner Teil, 18 ed., 1983, 63 II; críticamente por lo superfluo del ámbito exento de Derecho, nombra a HIRSCH, HJ., «Strafrecht und rechtsfreier Raum», Bockelmann-Festschrift, München 1979 , S. 89, pp. 89 y ss.

708 También así similarmente PIÑA ROCHEFORT, JI., Rol social y sistema de imputación, op. cit., p. 335.

709 Como bien alcanza a explicar sencillamente PIÑA ROCHEFORT: «(e)ste recubrimiento tiene dos dimensiones. Una eminentemente social: la tipificación, asignación y comunicación de las expectativas que conforman el rol. La segunda es de carácter psicológico-social y coincide con el proceso de socialización. En ella se produce (en calidad de proceso) la incorporación del rol como sistema de expectativa orientadoras de conductas del portador del rol (...) se produce porque la relación interna rol-individuo no lo deja indemne, simplemente orientando su conducta (...) Sólo mediante ella el individuo descubre lo que se ha llamado el yo-en-la-sociedad (...) de modo que en la situación típica se combinen espontáneamente una disposición de sentimientos, aspiraciones y la propia representación del tol. Esto no sólo permite la perfecta compatibilidad de la «enrolización» de la acción humana con la espontaneidad individual de la acción, sino que hace que la primera presuponga la segunda. En el proceso de socialización serán 
De este modo, PIÑA ROCHEFORT expone que en el error de prohibición invencible sucede una defraudación de una expectativa, pero sin embargo se mantiene la vigencia de la norma sin mediación de una pena contrafáctica porque el fallo se debe al proceso de internalización del rol: «la expectativa estaba mal dirigida por existir un fallo comunicativo» ${ }^{710}$.

Esto es lo que parece suceder en el autor de conciencia, máxime en los delitos de omisión pura, el sujeto no se ha «enrolizado», si bien y en nuestra opinión, esta falta de socialización no se debe al propio sujeto sino al ordenamiento jurídico que lo ha socializado conductivamente en otra dirección, por eso después o no se puede penar porque la conducta es atípica, o puede exculparse porque el fallo procede no ya del sujeto sino de una socialización de la norma, o dicho de otro modo, se puede atribuir la responsabilidad no al sujeto sino al sistema jurídico, de suerte que merezca la exculpación, si bien en conductas en las que existe un deber de sacrificio sólo quepa una rebaja de la pena.

Consideramos que en los primeros casos el sistema opera disfuncionalmente como reverso de la responsabilidad criminal. En los casos por lo general de autoría de conciencia la norma defrauda al rol porque en la determinación de la conducta prohibida no se puede exceder el límite que el propio sistema ha atribuido al rol, negando la culpabilidad, lo que parece significar una contradicción de la propia sociedad, sin embargo lo que en verdad aparece es la contraorientación de la norma con la Sociedad, esto es la falta de identidad entre norma y Sociedad ${ }^{711}$.

La exculpación por inexigibilidad no sólo se asienta en la incapacidad del sujeto para orientarse conforme a la norma en el sentido de la inimputabilidad, sino que existen otras causas reprochables a la misma norma cuando entra en contraorientación con la Sociedad, o en causas basadas en déficits de socialización en el autor pero cuyo comportamiento está «socialmente adecuado» ${ }^{712}$. JAKOBS y parte de la doctrina funcionalista configuran la exculpación no en cuanto

internalizadas determinadas expectativas de rol y modelos de conducta, de modo que éstas se harán evidentes para el individuo como normas, que se orientará según ellas. Con esto se diferencia un mecanismo interno del control, que se dona cuando la conducta se desvíe del rol internalizado (y se percibe como contradicción). Cuando estos mecanismos internos no son suficientes para mantener la conducta en el ámbito de lo permitido, se aplican mecanismos externos (sociales), sea la explicación de la defraudación o el enlace de una sanción», ID., ibidem, op. cit., pp. 282 y 283.

${ }_{710}$ ID., ibidem, op. cit., p. 284. Por eso concluye que «la determinación de la conducta prohibida mediante el rol consiste en un baremo objetivo construido socialmente (...) Es el propio sistema el que, al momento de explicar la defraudación, determina qué explicaciones le resultan válidas (declarando qué defraudaciones no son capaces de violentar la norma) y cuáles no (enlazando un tratamiento de reestabilización de la norma)», todo en función del momento histórico-social, ID., ibidem, op. cit., p. 285. Pone el ejemplo que en sociedades de carencia institucionalizada de alimentos no pueda apreciarse el estado de necesidad exculpante, ID., ibidem, op. cit., p. 286.

711 Utilizo la argumentación de PIÑA ROCHEFORT, ID., ibidem, op. cit., p. 287.

712 JakoBs, G., PG, op. cit., 20/4. En la misma línea Müssig, B., «Comentario al 35 StGB», Bernd von Heintschel-Heinergg (redactor), Münchener Kommentar zum Strafgesetzbuch, Vol. 1, 1-51 StGB, München, 2003, 
al fin de la prevención general positiva, sino fundamentada, tal y como expusimos supra, en el sentido de que la pena adquiere ya toda la expresión de sentido comunicativo y autorreferencial con la vigencia normativa, de tal manera que la vigencia normativa no precisa que se confirme con la pena; la pena sólo repara la comunicación concreta que el autor crea con su actuar, por lo que podemos concluir que en determinadas ocasiones, especialmente en el estado de necesidad exculpante, el fundamento de la atenuación o de la exculpación no reside fundamentalmente en criterios preventivo generales positivos, ni mucho menos en el mayor o menor quebranto del bien jurídico, postura que mantiene la doctrina tradicional ${ }^{713}$ cuando explica la menor responsabilidad del autor de conciencia en el menor injusto, y la mayor responsabilidad del autor por convicción y en el enemigo en el mayor injusto, sino en la idea de la falta de quebrantamiento de la vigencia de la norma que en determinadas situaciones pueden crearse tanto en una como en otra tipología criminal.

No obstante, JAKOBS limita y en parte niega la aplicación del estado de necesidad exculpante cuando existan deberes institucionales o por organización ${ }^{714}$. En este sentido, parece defender que tanto en los deberes institucionales como en los deberes que generan responsabilidad por organización se quebranta una expectativa social que no puede ceder ante una expectativa social atribuida o asumida por el autor, o por una conducta previa antijurídica (hay que matizar que no toda conducta antijurídica produce un deber de soportar el todo, sino el riesgo desencadenado del

35, 3-4; TIMPE, Gerhard, Strafmilderungen des Allgemeinen Teils des StGB und das Doppelverwertungsverbot. Untersuchungen zu des 23 Abs. 2, 13 Abs.2, 17 Satz 2, 35 Abs. 1 Satz 2 und 46 Abs. 3 StGB, Berlin, 1983, pp. 297 y ss (vid. estos dos últimos en MARTín LORENZO, M., La exculpación, op. cit., p. 116 y nota 239). Podemos incluir también en esta línea a PAWLIK, que desde formulaciones hegelianas, considera que el fundamento de la exculpación el estado de necesidad es el reconocimiento del concepto de «persona» a diferencia del concepto de «individuo», así que en casos de estado de necesidad de bienes iguales el «individuo» puede reclamar su existencia como sujeto en su plan de vida, con lo que perece decir, en nuestra opinión, que en determinados casos no existe derecho, sino fuerzas o el estado de naturaleza, PAWLIK, Michael, «Una teoría del estado de necesidad exculpante. Bases filosófico-jurídicas y configuración dogmática», InDret, 10/2015, pp. 13 y ss., versión originalmente en alemán ID., «Eine Theorie des entschuldigenden Notstandes: Recchtsphilosophische Grundlagen und dogmatische Ausgestaltung», JRE, 11, 2003, pp. 302 y 303.

${ }_{713} \mathrm{Al}$ respecto, MARTíN LORENZO critica que la teoría funcionalista se limita a describir que la ley opta por una solución al margen del autor. En concreto dice que «en este punto, su referencia constante al criterio de la prevención general positiva como fin de la pena - la no existencia de defraudación de la confianza general en la vigencia de las normas- adolece de la imprecisión propia de los conceptos inferidos de la sociología. A la objeción de su imposibilidad de comprobación empírica, tratándose de una teoría consecuencialista, se suma el obstáculo de la vaguedad del criterio no falsable empíricamente de la necesidad de confirmación de la norma», MARTíN LORENZO, M., La exculpación, op. cit., pp. 126 y ss. Además critica el argumento que utiliza el funcionalismo para motivar la exoneración: que el hecho es inusual, excepcional. Le parece a esta penalista que no es un fundamento convincente porque serviría para exculpar a quien ha cometido un homicidio contra un tatarabuelo, ID., ibidem, op. cit., pp. 129 y 130. Sin embargo, no podemos estar de acuerdo con ésta, porque se sirve del argumento del «motivo comprensible» en relación a la «capacidad deliberativa» para fundamentar la exculpación, lo que supone un fundamento que valora moralmente y no normativamente las causas de esta índole. Su planteamiento no explicaría por qué en el autor por convicción, cuyos fines pueden ser legítimos, el delito no merece la exculpación cuando su actuar es tan ineludible y deliberativo en ocasiones como en el autor de conciencia.

714 JAKOBS, G., PG, op. cit., 20/13. 
comportamiento antijurídico). Efectivamente, en parte tiene razón JAKOBS, en el sentido de que no se podría aplicar una causa de exculpación en aquellos casos en los que el sujeto tiene un deber institucional de salvaguardar, por ejemplo, parece inferirse que el padre testigo de Jehová no puede esgrimir un estado de necesidad exculpante cuando el deber le ordena actuar en protección de su hijo, ni cuando el sujeto ha asumido el riesgo o lo ha creado. Estamos de acuerdo en esto, pero como decimos, existen casos excepcionales en los que de igual forma existe la conexión ineludible entre conciencia y voluntad, cuestión que es ajena al deber y al quebrantamiento normativo tanto en el autor de conciencia, el de convicción y en el enemigo. Con un ejemplo, el padre Testigo de Jehová que no llama a las asistencias médicas y deja morir a su hijo, tiene un deber institucionalizado que le ordena actuar, si bien en caso de que por sus altos conocimientos médicos sabe su hijo necesita una trasfusión de sangre para salvar su vida, también obra bajo un motivo irresistible de conciencia en igual relación que en la omisión del deber de socorro, si bien por déficit de socialización atribuido a la norma, su omisión equivale a la acción de matar y por ende se le responsabiliza por ese mayor deber de actuar, o por su recalcitrante omisión, como una acción de matar por un injusto mayor que el que simplemente omite el consentimiento, sin embargo, en ambos casos, y en nuestra opinión, existe una causa de exculpación que puede graduarse en función de la mayor exigencia normativa, ajena ya al injusto. De la misma manera, en los deberes que generan responsabilidad por organización, está claro que el sujeto ha asumido (asunción) o ha creado un riesgo mayor del que es competente (injerencia), de modo que su omisión puede distribuirse sistemáticamente en uno u otro injusto, pero de igual forma que en el ejemplo anterior, la culpabilidad se puede graduar en función del binomio exigencia normativa-inexigencia subjetivonormativa. La primera, como se puede inferir postula el injusto objetivo, la segunda, articula la inexigibilidad de la conducta en relación a las especialidades motivacionales en relación a un posible déficit de comunicación atribuible a la norma o a un tercero, de modo que si bien al sujeto le era exigible actuar conforme al grado de exigencia que el mismo había asumido o en función del riesgo creado, posteriormente se tenga en cuenta en la culpabilidad que su omisión vino causada en mayor o menor medida en el déficit de socialización atribuido a la norma o a un tercero.

A este respecto creemos que sirve de referencia el siguiente argumento de JAKOBS: «(n)o existe diferencia alguna de las modalidades de explicación entre la comisión y la omisión, y tal diferencia no se podría mantener en el ámbito de la competencia organizativa debido a la intercambiabilidad del hacer y del omitir. Naturalmente, los supuestos de falta de responsabilidad por la situación serán a menudo los de omisión. Además, la situación de 
conflicto surgirá antes en los deberes de obrar que en los deberes de omitir, pues la manifestación de la propia persona mediante una acción (es decir, mediante la observancia de un mandato) será con frecuencia más inequívoca que la realizada mediante omisión (es decir, mediante observancia de prohibiciones); sobre todo, el ámbito en el que a pesar de la causalidad no se imputa un resultado a una acción es más reducido en la práctica que aquel en que, a pesar de la capacidad para evitar el resultado por medio de la acción, no se produce la imputación del resultado» ${ }^{715}$. De tal manera, no vemos impedimento en aplicar el estado de necesidad exculpante en supuestos de responsabilidad institucional o por organización.

A este criterio de la exigencia, JAKOBS también suma la diferencia entre la importancia e imposibilidad de sustitución del bien que se trata de proteger en el estado de necesidad exculpante. De tal manera, abarca bienes no sólo referidos a la vida y a la salud en casos de pérdida de miembros, sino también patrimoniales ${ }^{716}$, sin embargo y en nuestra opinión, esta conclusión también es ajena a la autoría de conciencia, por convicción y en el enemigo, por cuanto que esa limitación referida a la importancia o imposibilidad de sustitución sólo se refiere a un mayor quebrantamiento normativo en relación al bien jurídico, no en sí mismo al quebrantamiento de la vigencia de la norma que se refiere a la culpabilidad, de lo que deviene que pueda apreciarse una causa de exculpación a pesar de que el injusto sea de tal entidad que no pueda ser reparado. En estos casos, cobra importancia la autoría de conciencia, por convicción y el enemigo, como sujetos que independientemente del injusto subyace una motivación que modula en mayor o menor medida la culpabilidad. No podemos constantemente referirnos al injusto para con él mismo fundamentar la culpabilidad bajo pena de incurrir en no dejar espacio a las causas de exculpación.

No obstante, JАKOBS -partiendo de su concepto funcional de culpabilidad-considera que en los casos de autor por convicción «duro», es decir, en casos de hechos delictivos cometidos con base a una necesidad imperiosa de satisfacer un conflicto, propone la exclusión de la culpabilidad en virtud de la categoría dogmática de la inexigibilidad de otra conducta, es decir, el auténtico autor por convicción no puede resolver la situación imperiosa de otra forma que no sea contraria al tipo penal. En la mayoría de los casos de actuaciones delictivas por convicción se quebrantará el ordenamiento jurídico con total culpabilidad, pero en otras -según JAKOBS- no existirá al menos una culpabilidad total, por un déficit total o parcial de socialización, que impide

715 ID., ibidem, op. cit., 20/27.

716 ID., ibidem, op. cit., 17/14. 
al autor adecuar su comportamiento a la norma ${ }^{717}$. De tal manera, a pesar de haber defendido que las causas de exculpación no tendrían aplicación en supuestos de mayor exigencia normativa (deberes de responsabilidad institucional $\mathrm{y}$ deberes que generan responsabilidad por organización), encuentra casos excepcionales en la autoría por convicción, si bien cabe matizar que en JAKOBS la autoría por convicción se refiere tanto a supuestos de autoría de conciencia como los supuestos que en esta investigación hemos catalogado de autoría por convicción, por la exclusiva diferencia entre ambos, que nuestro autor por convicción -para JAKOBS, tal y como defendemos también nosotros- no actúa en verdad por un motivo ineludible, sino por un «móvil» que se piensa por el sujeto que es obligatorio, lo que sucede es que en el sujeto dicha inevitabilidad tiene un factor de mayor reprochabilidad porque únicamente supone un medio para un fin que puede ser lícito o ilícito, pero al suponer un medio se presenta como una elección alternativa que ha apostado por el delito para conseguir ese fin, cuestión que comunica que existía otro medio lícito para actuar, el motivo ineludible normativamente no es tal, sino especialmente recalcitrante, a diferencia del autor de conciencia, en el que el delito es en sí mismo una cuestión inevitable al no existir normativamente alternativa alguna. Tanto es así que el propio JAKOBS admite que no se puede distinguir entre convicciones auténticas y las meras ideologías «lo que no significa que sea irrelevante el contenido de la convicción, pues el que el autor sea o no responsable del conflicto (y en qué medida) depende de las posibilidades de desplazarlo a otros sistemas. Las posibilidades, a su vez, se rigen por la medida en la que el conflicto puede dañar al orden normativo. El que se pueda mantener a favor del sectario esotérico lo que surte efecto inculpatorio sobre el terrorista agresivo, es decir, la inquebrantabilidad de la convicción, constituye una señal inequívoca a favor de la naturaleza funcional del concepto de culpabilidad, y no ha de ocultarse vergonzantemente, sino desplegarse abiertamente» $^{718}$.

Recuérdese que el citado penalista señalaba a este respecto que en el autor por convicción «duro» el conflicto entre convicción y Derecho es «irresoluble, si no hace caso a su convicción daña a su persona» ${ }^{719}$, mientras que autor por convicción blando sería - para JAKOBS- aquellos sujetos que no se consideran imperativamente obligados a hacer valer el orden mejor según su parecer $^{720}$. Como dijimos, en nuestra opinión, JAKOBS acierta en distinguir no tanto una

717 ID., ibidem, op. cit., 20/23.

718 ID., ibidem, op. cit., 20/22.

719 ID., ibidem, op. cit., 20/20 a 20/22. En la misma línea Klaus TIEDEMANN puesto que «tras un hecho contrario a la conciencia, en la vergüenza que siente el convenido, ello sería consecuencia de una neurosis compulsiva», vid. JAKOBS, G., $P G$, op, cit., nota 21/22, nota 33a.

720 ID., ibidem, op. cit., 20/21. 
diferencia cuantitativa de la inevitabilidad del conflicto, sino estrictamente cualitativa, o en cuanto alcanzo a comprender hasta aquí, tanto el autor de conciencia (por ejemplo el Testigo de Jehová que omite el deber de socorro a su hijo), como el autor por convicción «duro», en este caso el terrorista, actúan de forma ineludible; sin embargo, en JAKOBS está la idea novedosa y clara de que en este último caso también entrarían los autores como el cazador que furtivamente caza fuera de los periodos de veda, no actúa obligatoriamente por un imperativo moral, sino por un convencimiento propio y particular.

Uno de los fundamentos que encuentra JAKOBS para tales planteamientos, lo encontramos en una de sus conferencias cuando afirma que «(l)a argumentación respecto al autor por convicción debe ser muy próxima; en su caso, no puede hablarse de una exculpación plena, pero dependiendo del contexto sí de una disminución de la culpabilidad. En este ámbito, no es lo mismo que un miembro de una determinada confesión religiosa, por lo demás, un sujeto plenamente integrado, en una situación puntual no cumpla con sus deberes por su fe, que un terrorista combata globalmente al Estado por sus convicciones - no necesariamente de menor calado que la fe- políticas. Aquello que en el caso del primero puede ser considerado con indulgencia en cuanto conflicto de conciencia, se le atribuye como causa de agravación, en cuanto actitud recalcitrante, al segundo: precisamente, el actuar por convicción. La decisión no depende primeramente de la medida del conflicto individual en el autor-del peso de su convicción-, sino de la posibilidad de representar el hecho como amenazante, no susceptible de generalización, o como hecho peligroso» ${ }^{721}$, entonces «se trata de averiguar si el autor, al no poder compaginar su convicción y el ordenamiento jurídico, manifiesta, desde el punto de vista del ordenamiento, un déficit de socialización, y por eso cabe exculparlo cuando este hallazgo -de forma paralela a la situación de capacidad de culpabilidad o en error de prohibición en ámbito central- se puede explicar al margen del autor sin merma para el ordenamiento jurídico (...) las posibilidades (de que el autor sea responsable o no del conflicto) se rigen por la medida en que el conflicto pueda dañar al orden normativo». Esta última afirmación creemos que supone el punto decisivo en la diferenciación de trato entre ambas tipologías criminales, en el sentido de que en el autor por convicción como el terrorista está la comunicación de la negación de la vigencia de la norma, que hace de su actuar una operación asistémica o disfuncional en el Sistema Social, si bien, como venimos defendiendo, también en esta clase de autoría no hay impedimento para apreciar una causa de exculpación que exonere la responsabilidad o la disminuya.

721 JAKOBS, G., «El lado subjetivo del hecho», trad. Manuel Cancio Meliá del manuscrito «Die subjektive Tatseite», JAKOBS, G., Sobre la normativización de la dogmática jurídico-penal, trad. Manuel Cancio Meliá y Bernardo José Feijoo Sánchez, $1^{\text {a }}$ ed., Thomson Civitas 2003, p. 98. 
El criterio de JAKOBS ha sido seriamente criticado por BAUCELLS al considerar que se pretende fundamentar el juicio de culpabilidad en la «motivación desleal al Derecho, puesto que implica deber de fidelidad al mismo», lo que en su opinión es poco garantista ${ }^{722}$. Si bien es de tener en cuenta que JAKOBS no se refiere tan solo a la fidelidad al derecho, sino que su actuar suponga una operación que ponga en peligro el Sistema Social.

De lo dicho por JAKOBS cabe extraer tres conclusiones importantes sobre su concepción y solución a la problemática que nacen de su pensamiento: primera, que el peso de las convicciones no juega el papel de la graduación de la culpabilidad en cuanto a la exigibilidad de la conducta adecuada a la norma; segunda, que el citado autor considera más culpable el comportamiento del terrorista (autor por convicción) por el peligro que supone para el sistema, a lo que añado anticipándome al posterior apartado que precisamente lo peligroso no es sólo su actuar disfuncional, sino también las convicciones en que el medio-injusto es ineludible para un fin que puede ser lícito o no; y tercera, que un factor que agrava la culpabilidad es el incremento de lo injusto por medio de la peligrosidad que supone la convicción, además de la disfunción o negación de la vigencia de la norma que comunica, por lo que adquiere coherencia que en el prototípico autor de conciencia existan argumentos normativos de exención de la responsabilidad o disminución porque este tipo de autor no pretende comunicar la negación del contenido de la norma: «no es lo mismo que un miembro de una determinada confesión religiosa, por lo demás, un sujeto plenamente integrado, en una situación puntual no cumpla con sus deberes por su fe, que un terrorista combata globalmente al Estado por sus convicciones - no necesariamente de menor calado que la fe- políticas» ${ }^{723}$.

Dicho esto, cobra mayor sentido que JАKOBS considere la aplicación de la causa de inexigibilidad en supuestos excepcionalísimos cuando no se afecte a la vigencia del ordenamiento jurídico aunque el conflicto sea tan irresoluble e imperioso y a pesar del quebrantamiento de la norma ${ }^{724}$, pero también en los casos de las excusas putativas por presión motivacional real ${ }^{725}$. Por eso, aprecia tres posibilidades de atenuación que vamos a analizar a continuación.

i. Por un lado, cuando el autor infrinja una norma pero no se afecte a su propia vigencia, o cuando a pesar de la infracción el autor reconozca la vigencia de la norma, por ejemplo en el

722 BAUCELls I LLADÓS, J., La delincuencia por convicción, op. cit., 316.

723 JAKOBS, G., «El lado subjetivo del hecho», op. cit., p. 98.

724 JAKOBS, G., $P G$, op. cit., 20/24

725 ID., ibidem, op. cit., 17/81 y ss. 
supuesto del médico que inyecta un líquido letal a un enfermo terminal amigo por petición de éste hacía tiempo.

ii. Por otro lado, en los casos de déficit de socialización del autor, cuando dicho déficit es atribuible a terceros, por ejemplo cuando haya sido educado incorrectamente o inducido a situaciones de fragilidad comprensible. En este sentido, expone el caso de una persona de veintiún años educada en el totalitarismo durante la Segunda Guerra Mundial, que se considera obligada a actuar en el exterminio judío. En estos casos reconoce una exculpación al menos parcial.

iii. Y por último, aunque parcialmente, cuando el sujeto ante un deber institucional no dispone de alternativa de organización de dicha institución pero en la que la organización no viene informada por el deber. Sobre esta conclusión, expone la negativa de un médico al aborto, en la que si bien el médico tiene un deber de actuar institucionalizado tiene la oportunidad de organizar dicho deber de tal manera que elimine la posición de garante, sin afectar a la norma ni crear un daño, como por ejemplo en los casos de los padres testigos de Jehová que rechazan la asistencia vital para el hijo menor de edad, acepta una posible exculpación plena o parcial en virtud de la configuración de la organización previa al daño. Acepta también que cuando la víctima consiente la reducción de su protección, como por ejemplo el caso de quien conoce que su pareja rechaza la trasfusión, y llegado el día, y ante la imposibilidad de negarse el necesitado, no consiente la asistencia médica ${ }^{726}$.

Sin embargo SANTA RITA, a pesar de acoger los fundamentos esenciales funcionalistas, comenta que «la convicción en un grado fundamentalista no puede ser consentido por el sistema comunicativo porque ello implicaría la negación misma del sistema de expectativas» ${ }^{727}$, esto es, «no pueden existir operaciones estatales contrafácticas con elevado nivel comunicativo (...) en una sociedad comunicativa es imposible considerar la convicción terrorista como valor

\footnotetext{
726 ID., ibidem, op. cit., 20/24; si bien lo niega en casos de terroristas y revolucionarios ID., «Conocimiento y desconocimiento de la norma», trad. Marcelo A. Sancinetti, JAKOBS Günther / STRUENSEE Eberhard / SANCINETTI, Marcelo A., Problemas capitales del Derecho penal moderno. Libro Homenaje a Hans Welzel, Hamurabi, Buenos Aires, 1998, pp. 57 a 80; admite ciertos grados de socialización si bien en casos muy concretos SANTA RITA, G., El delito de organización terrorista, op. cit., pp. 554 y ss. Critica JERICó que el primero de los postulados es demasiado amplio y sucede en casi todos los casos de conflicto de conciencia. El supuesto de déficit de socialización, en su opinión se reconduciría a los supuestos de error de prohibición sobre los límites de una cauda de justificación, aunque acepta que el sujeto crea que es justificable la aniquilación. En los supuestos de omisión del deber institucional, opina que no es necesario acudir a la inexigibilidad, sino a la atipicidad. Considera que las normas que obligan a un comportamiento positivo en protección de bienes jurídicos supraindividuales no tienen tanta relevancia como en la de bienes jurídicos individuales, con lo que no estamos de acuerdo, JeriCó OJER, L., El conflicto de conciencia, op. cit., pp. 402 a 404.

727 SANTA RITA, G., El delito de organización terrorista, op. cit., p. 569.
} 
axiológico que autorice la inexigibilidad de otra conducta ${ }^{728}$. De esta manera se desmarca de los postulados de JAKOBS, cuestión que nos parece criticable, como desarrollaremos infra, a pesar de su intachable razonamiento.

JAKOBS considera que los defectos cognitivos son en principio perdonables y los defectos volitivos son imperdonables, pero los defectos cognitivos que se basan en la indiferencia, es decir, en un defecto volitivo, son también imperdonables ${ }^{729}$. Vemos cómo en este último sentido JAKOBS vincula necesariamente el defecto cognitivo sobre la norma en motivos con defecto volito imperdonable, como la indiferencia cuando dentro de las alternativas para conseguir un fin que puede ser lícito, elige el delito como medio. Este sería el caso del terrorista, que comete un defecto volitivo imperdonable, o defecto cognitivo basado en un defecto volitivo (indiferencia) también imperdonable ${ }^{730}$. Sin embargo, el autor de conciencia incurre en un error cognitivo sobre la obligatoriedad de la norma amparado por defecto volitivo atribuible a la norma o a un tercero, no en sí mismo a un error propio, y en determinados casos, también el autor por convicciónterrorista con déficit de socialización, puede verse una exoneración o disminución de la culpabilidad. Con los postulados de JAKOBS estamos de acuerdo, si bien estimamos que precisan de ulterior desarrollo.

\section{V.- Proposiciones conclusivas: vinculación del autor por convicción y el enemigo, y su diferenciación con el autor de conciencia y el delincuente habitual}

\section{A. Autor de conciencia}

Como ya hemos indicado, en el autor de conciencia existe una conexión fatal entre conciencia y moral del que surge el conflicto entre conciencia y norma, o más exactamente entre el influjo y

728 ID., ibidem, op. cit., p. 570.

729 JAKOBS, G., «El lado subjetivo del hecho», op. cit., p. 99. JAKOBS dice textualmente «que en un déficit cognitivo puede resultar exonerante, dicho con mayor exactitud: que se atenúa la pena en caso de concurrir un error evitable. Ahora bien, las personas no se ocupan en absoluto por interés propio de la obtención de una voluntad de observancia de la norma, como hecho delictivo. No se puede vivir en contra de la naturaleza, de la lógica, de las matemáticas, al menos no de modo planificado; pero sí en contra del ordenamiento jurídico», ID., ibidem, op. cit., p. 87. Así pues, JAKOBS atribuye el defecto cognitivo a la naturaleza, es decir, el autor por convicción (autor de conciencia según la terminología seguida en esta obra) en los casos por ejemplo, de testigos de Jehová, estos caen en un defecto de apreciación de la norma que hace en principio «inexigible» su conducta, mientras que los terroristas, caen en un defecto propiciado por la indiferencia, cuestión no atribuible a la naturaleza. Es entonces la naturaleza para JAKOBS, ente inamovible, perpetuo, al menos con vocación de durabilidad, que puede afectar al autor en su voluntad y desvinculación con la norma, JAKOBS, G., PG, op. cit., 20/20 y ss., y sobre los defectos cognitivos y volitivos, ID., «Sobre el tratamiento de los defectos volitivos y de los defectos cognitivos», trad. Carlos J. Suárez González, JAKOBS, G., Estudios de Derecho penal, 1ª ed., Civitas, Madrid, 1997, pp. 127 y ss.

730 En este sentido también SANTA RITA, G., El delito de organización terrorista, op. cit., pp. 540 a 547 , y pp. 548 a 561. Gráficamente comenta que «en el Derecho penal del enemigo no existe cabida para defectos cognitivos», ID., ibidem, op. cit., p. 551. Si bien admite grados de socialización que pueden verse en sujetos muy concretos, ID., ibidem, op. cit., p. 554. 
orientación normativa del Derecho a la libertad de conciencia y la norma concreta. El autor de conciencia no ataca el contenido material de la norma, ni pretende negar la vigencia de la norma ni la vigencia general del sistema normativo ni social, no objeta estrictamente el contenido objetivo de la norma, sino la exclusiva obligación hacia él dirigida por considerar que otro valor tiene mayor fuerza. El autor de conciencia y el objetor luchan puntualmente contra una norma por motivos ideológicos, políticos o morales, sin pretender subjetivamente afectar a la vigencia de la norma ni a todo el ordenamiento jurídico. El autor de conciencia desoye la norma, no con el fin de instaurar su conducta para los demás, sino la desatiende por sí y para sí, por eso normalmente las conductas que suele realizar son delitos de omisión simple (omisión del deber de socorro, objeción de conciencia), y en otras ocasiones, actúa adecuando su comportamiento a la esfera de libertad de un tercero (eutanasia), pero sin que exista impedimento alguno para comportamientos activos o en comisión por omisión cuando las circunstancias lleven a obrar en este sentido. Desatiende puntual, circunstancial e individualmente la norma, pero para sí mismo, por eso le es suficiente organizar el delito con la falta de comportamiento acorde a la norma, pero este dato es simplemente estadístico.

En determinadas circunstancias el contenido material de la norma que le ordena realizar u omitir alguna conducta se le presenta sorpresivamente por mor de las especiales circunstancias, de manera que el sujeto sufre un déficit de socialización que no procede de capacidades inherentes de la conciencia y la voluntad del sujeto (endógenas), sino de causas exógenas atribuidas a la norma, es la misma norma la que sufre un déficit de comunicación que se produce en la contraorientación con la norma que habilita y orienta al sujeto en el ejercicio del Derecho a la libertad de conciencia.

Concretamente, la norma que quebranta el autor de conciencia no le es vinculante por la incapacidad de comunicar el contenido de la misma y de socializar al sujeto en una determinada orientación comportamental. Si bien la norma incumplida está vigente, su contenido material se activa cuando la norma previa - la libertad de conciencia- ya ha socializado al sujeto a crearse un horizonte de expectativas, a formarse una conciencia determinada, a manifestarla y a ejercitarla sin que «hasta la fecha» ninguna otra norma haya determinado sus límites normativos con tanta intensidad. La socialización de la libertad de conciencia, en su especial caso, ha sido tan intensa, que la socialización de la norma que finalmente se quebranta es tan escasa que es incapaz de orientar al sujeto. Su activación, el deber, se produce tan tardíamente que es incapaz de comunicar su obligatoriedad en ese momento. 
A esta circunstancia le podemos denominar contraorientación normativa, en el sentido de que la norma incumplida es incapaz de orientar al sujeto (interpenetar en el sistema psíquico) por una previa orientación normativa más intensa y que produce un déficit de comunicación que elimina o disminuye la culpabilidad del sujeto por una escasa exigibilidad normativa. El resultado de esto significa que en determinadas ocasiones el sistema jurídico precise interpretar su operatividad en función de las especiales circunstancias sociales y comunicativas de cada hecho criminal - como recuerda LUHMANN ${ }^{731}$-, de forma que se rompa con el anquilosado sistema germánico del Derecho basado en el angosto positivismo y en el Derecho penal de las tradicionales instituciones progresivas de la tipicidad, antijuricidad, culpabilidad y punibilidad. Amén de ello, la exigibilidad e inexigibilidad de las conductas precisan de un recodo institucional basado en la moldeabilidad de las circunstancias sociales y normativas del injusto.

Así, el sujeto en estas circunstancias no puede adecuar su voluntad conforme a la norma porque en ocasiones de especial intensidad sufre un déficit de socialización atribuido a la contraorientación normativa con la libertad de conciencia, y a la previa socialización de ésta. Factores generales como el tiempo, y especiales como el ámbito concreto de socialización («aislamiento cultural», «adicción comportamental», «manipulación mental»o «persuasión coercitiva» $\mathrm{u}$ «obediencia ciega a la autoridad») facultará para aplicar, siendo coherentes, la eximente exculpante incompleta del art. $20.5^{\circ} \mathrm{CP}$.

\section{B. Autor por convicción}

El autor por convicción se ha conceptualizado tradicionalmente como aquel sujeto que otorga licitud moral al delito por algún motivo asociado a su fuero interno, normalmente a convicciones políticas. Se tiende a decir que el autor por convicción incurre en delitos de extrema gravedad, en los que el desvalor de la acción y del resultado son mayores que en los casos del autor de conciencia (criterio cuantitativo), sin embargo, puestos en confrontación uno y otro, esta

\footnotetext{
731 Resulta interesante a este respecto algunas anotaciones de LUHMANN sobre la evolución del sistema jurídico, nos sirven para concretar más la cuestión sobre la relevancia de la operatividad del Sistema en el tratamiento de los casos especiales de la criminalidad: «Desde la perspectiva del derecho, en esta forma de innovación a través de la comprensión de los defectos, se incluye la legislación. Se percibe una anomalía. Entonces surge la pregunta: ¿Se puede remediar sin cambiar el derecho, o sólo cambiándolo? Esta «consideración de las desventajas inevitables» (mischief rule) sigue vigente en el Common Law, al menos como máxima de interpretación. Esta regla exige que se considere el derecho como sistema, como totalidad de soluciones aplicadas de manera consistente y que se seleccione una para el problema existente; que en la interpretación de la ley se suponga que el legislador quería proceder de una cierta manera y que, en el caso de que no se pudiera encontrar ninguna regla, el juez introduzca una que sea adecuada al caso y que se pueda generalizar. En este sentido, el derecho vigente se impulsa a sí mismo hacia la innovación, pero también a conservar la estabilidad = consistencia = justicia», LUHMANN, N., El derecho de la sociedad, op. cit., p. 339.
} 


\title{
conclusión es únicamente estadística o de moralidad del observador ${ }^{732}$. El autor por convicción
}

\author{
comunica que no le es vinculante la norma, que no está vigente, no otorga en ciertos puntos
}

732 La atenuación del reproche penal y de la seguridad cognitiva-normativa en el cese de la convicción subjetiva y en la desvinculación al grupo terrorista constatan la idea de que la convicción del terrorista, en este caso, supone subjetivamente, pero a la vez, objetivamente, el cese o disminución del foco de peligro, y viceversa, la agravación, el adelantamiento de la barrera punitiva, o la creación de nuevos tipos altamente penados, se fundamentan subjetivamente en la convicción del autor en los medios/móviles y fines y en la conexión ineludible entre conciencia y voluntad, que posteriormente, y de forma objetiva, se comunica por la voluntad a través del delito a la sociedad. Así, cuando se abandona dicha convicción, el sujeto comienza a mostrar cierto grado de confiabilidad que le devuelve a Derecho penal del ciudadano mediante la aplicación de un trato más benigno y proporcionado a su nueva condición.

Dicho todo lo cual, no hay impedimento alguno, sino la constatación de la vinculación estrecha entre los postulados del Derecho penal del enemigo y la tradicional concepción de la autoría por convicción. Baste reseñar que en las primeras concepciones sobre la autoría por convicción, tanto la jurisprudencia como la doctrina penal alemana y española vincularon, y siguen haciéndolo, al autor por convicción con los delitos políticos, si bien, después el análisis realizado podemos concluir que la vinculación entre ambas fenomenologías criminales es más estrecha de lo que podía pensarse, hasta el punto que no puede concebirse un enemigo sin convicción ya sea manifestada dolosa o imprudentemente. Dicho de otro modo, las propuestas legislativas contra el enemigo tratan de paliar, reparar y socializar la convicción con la que actúa el enemigo.

Por eso el art. 90.8 CP ofrece la oportunidad al terrorista y a otros miembros de organizaciones criminales de acceder a la libertad condicional si cesan en la actividad mediante «signos inequívocos» como el arrepentimiento, «lo que podrá acreditarse mediante una declaración expresa de repudio de sus actividades delictivas y de abandono de la violencia y una petición expresa de perdón a las víctimas de su delito», y con la colaboración activa en persecución de la organización de manera que sólo así normativamente se comprende que el sujeto ofrece garantías de seguridad cognitiva, no a modo de premio, sino como bien apunta POLAINO-ORTS bajo el fundamento del «justo tratamiento como persona en Derecho a quien merece dicha personalidad jurídica por su ejercicio y fomento activo de respeto de los derechos fundamentales», porque «jdejar de ser terrorista es la obligación objetiva y extrema más apremiante de todo ciudadano!», POLAINO-ORTS, M., Derecho penal del enemigo. Fundamentos, op. cit., p. 258.

Desde estos planteamientos, podemos fundamentar que en la autoría por convicción, también en el enemigo, no existen impedimentos para apreciar circunstancias atenuantes cuando se exprese cierto grado de confiabilidad en las normas integrantes de la estructura social, de suerte que si bien, y como hemos visto supra, no existen motivos para apreciar la legítima defensa ni el estado de necesidad justificante en la autoría por convicción, salvo en los excepcionales casos señalados, habrá que examinar si ese cierto grado de confiabilidad que en ocasiones demuestra el terrorista tras el hecho puede apreciarse en alguna forma durante el hecho, o si el «aislamiento cultural» y otras circunstancias tales como la «adicción comportamental», la «manipulación mental» o «persuasión coercitiva» y la «obediencia ciega a la autoridad», que se aprecian en el autor de conciencia, también pueden aplicarse en el autor por convicción y en el enemigo con el mismo resultado en el estado de necesidad exculpante. En nuestra opinión, no habrá impedimento alguno siempre que tales circunstancias tengan la suficiente intensidad al igual que sucede en la autoría de conciencia, con la salvedad de que en la autoría por convicción no se aprecia ningún déficit de comunicación atribuido a la norma sobre la que se juzga su atribución, sino en casos muy aislados, sobre la norma o autoridad de otro Estado o grupo criminal, y los anteriores en casos muy excepcionales.

De otra parte, sobre las circunstancias que incrementan lo injusto, no es difícil imaginar que pueden concurrir agravantes genéricas y específicas o accidentales en las conductas de aquellos sujetos que combaten la vigencia de la norma como el autor por convicción y el enemigo. Hemos visto que tradicionalmente en la doctrina que se ha ocupado en el tema se diferencia al autor de conciencia y por convicción en la gravedad del delito, lo que supone también que en unos y otros subyacen motivos de atenuación para el primero y de agravación en el segundo. Sin embargo, también hemos visto que existen motivos de atenuación en la autoría por convicción terrorista cuando se ofrece cierta garantía de confiabilidad. De este modo, no creemos que la concurrencia de una mayor gravedad, y por lo tanto la apreciación de circunstancias agravantes fundamente por sí solas la distinción entre autoría por convicción y de conciencia, y por tanto tampoco las atenuantes serán una cuestión exclusiva de la autoría de conciencia, y esto es por lo siguiente.

Por la peligrosidad del hecho en cuanto a la facilidad de comisión por los medios y procedimientos utilizados, la alevosía también se pueda apreciar en delitos de agresiones a adeptos, abusos sexuales a niños, e incluso podríamos aplicar la agravante en situaciones de inferioridad psicológica del sujeto que pone menor resistencia en la aplicación de técnicas de manipulación o persuasión coercitiva, cuando el consentimiento está viciado por dicha alevosía, o una vez ya aplicadas y mermadas las facultades volitivas y/o cognitivas del sujeto se le ordena suicidarse. Sin embargo, la alevosía es una circunstancia simplemente indiciaria de la conceptualización del 
vigencia a la configuración normativa de la sociedad. De aquí viene la fundamentación normativa de la máxima culpabilidad que normalmente se presenta en la autoría por convicción.

Sin embargo, el autor por convicción también realiza injustos de escasa gravedad, y en él también pueden aparecer motivos de atenuación y conducta omisivas. Tampoco existe una diferencia relevante entre autoría de conciencia y por convicción en el ataque a bienes supraindividuales o personales. Los ataques a bienes personales pueden elevarse -interpretarse funcionalmente- a un ataque al Sistema (terrorismo contra los bienes personales) y viceversa, de modo que la actitud del sujeto se presenta como un influjo moralizante del hecho que el Sistema valora en la propia operatividad y funcionalidad, unas veces sancionando pero pudiendo funcionar con el hecho (autoría de conciencia y autoría por convicción «blanda»), otras excluyéndolo (autoría por convicción enemiga).

De esta manera podemos encontrar ya una diferencia funcional entre ambas tipologías: aquella en la que los autores de conciencia no deslegitiman la vigencia de la norma, y por ende el delito no supone un quebrantamiento de la configuración normativa de la sociedad y del Sistema

autor por convicción pero que puede aparecer en el ejemplo que hemos subrayado del autor de conciencia, cuando el padre testigo de Jehová no avisa a las asistencias médicas por conocer, gracias a sus altos conocimientos médicos, que el menor precisará de una trasfusión de sangre, de manera que sólo dejando de avisar a las asistencias y/o no llevando al menor al hospital, puede cumplir su mandato de conciencia. La alevosía es una cuestión circunstancial ajena al motivo de conciencia.

Por otro lado, el abuso de superioridad se basa en la desigualdad de fuerzas entre los sujetos buscada especialmente por la edad, la ascendencia moral, la superioridad jerárquica o el rol social que representa. Del mismo modo, el abuso de confianza genera mayor facilidad en la ejecución del delito. No resultará ilógico concluir que la superioridad moral o jerárquica del rol de un líder de una secta pueda concurrir en la ejecución del delito. Sin embargo, también esta circunstancia se aprecia tanto en conductas de conciencia como por convicción. Por ejemplo, ante la comisión de un mismo tipo delictivo como pudiera ser la inducción al suicidio del 143.1 CP, el abuso de confianza o abuso de superioridad para influir en que la víctima decida suicidarse, y con el fin de cobrar una herencia, configura una conducta propia del autor por convicción, mientras que en casos de autoría de conciencia, se podría pasar a casos de ayuda al suicidio o eutanasia sólo en el caso en que el autor y víctima acuerden la ejecución.

La circunstancia agravante de "prevalerse del carácter público que tenga el culpable» del art. $22.7^{\mathrm{a}} \mathrm{CP}$, también puede apreciarse en el autor de conciencia, por ejemplo en el médico abortista o en el médico que se niega a practicarlos. Otras de las circunstancias como el disfraz, el tiempo y lugar son ajenas a la causa del conflicto de conciencia o meramente estadísticas en el autor por convicción o enemigo. Y el ensañamiento puede aparecer en las diversas tipologías dependiendo de las circunstancias. En el caso del padre con conocimientos especiales de medicina, se puede presentar un sufrimiento innecesario en el menor que no remedia el padre sin que varíe su conceptualización.

Entre las circunstancias agravantes más subjetivas, el precio, la recompensa, o la promesa del art. $22.3^{\mathrm{a}} \mathrm{CP}$ suele considerarse que suponen una especial perversión moral del sujeto que grava el reproche de culpabilidad normativa por el desvalor de los «móviles abyectos» que deja inalterado el injusto típico, y la de obrar impulsado por motivos discriminatorios del art. 22.4 $\mathrm{CP}$, cuyo fundamento también contiene «móviles abyectos», incrementa el reproche de culpabilidad, revela una mayor convicción en el delito, una actitud indigna, deshumanizada y claramente combativa contra la configuración normativa de la Sociedad. Sólo en estas dos circunstancias se podría concluir que son propiamente del autor por convicción y del enemigo, sin embargo no son esenciales. Esto se debe a una clara influencia moralizante de la Sociedad en la operatividad del subsistema de Derecho penal.

A modo de conclusión si bien estadísticamente las circunstancias agravatorias que incrementan lo injusto y/o la culpabilidad suelen concurren en la autoría por convicción y en el enemigo, no fundamentan por sí solas la conceptualización de estas tipologías criminales. 
Social, y aquella otra por la que el autor por convicción niega la vigencia del contenido material de la norma comunicando a la sociedad que no está vigente.

De otra parte, cabe la posibilidad de que la autoría por convicción, al igual que la de conciencia, también se extienda a determinados casos de delitos imprudentes. En este sentido hemos afirmado que no sorprenderá que quien olvida un conocimiento exigible normativamente o actúa sin el cuidado debido de forma consciente o inconscientemente aunque no se represente una probabilidad del quebrantamiento de la norma, ese olvidar o esa falta de cuidado pueden partir de una previa convicción que causa el déficit cognitivo y a la postre el déficit volitivo.

Así las cosas, los delitos de peligro, aquellos en los que no se valora estrictamente el dolo ni la culpa, sino la puesta en peligro de un determinado bien, o sea, la expectativa social, pueden ser causados a consecuencia de un déficit cognitivo de desatención, ceguera o falta de fidelidad irrespetuosa a la norma. Por ejemplo, aquellos casos de conductores que ingieren alcohol superando la tasa objetiva de punibilidad o que tienen una merma de las facultades para la conducción, demuestran una indiferencia a la norma que se puede asociar a la convicción de que la norma no le es vinculante, de modo que se omite el cuidado normativamente exigible. No de otro modo se puede explicar muchos de los casos de sujetos a los que se les aplica la reincidencia en delitos contra la seguridad del tráfico rodado, al crear una inseguridad cognitiva en los demás ciudadanos.

En este sentido, no han faltado voces que han asociado la autoría de los delitos contra el tráfico rodado a la categoría conceptual de «enemigo», y dichas normas como prototípicas de «Derecho penal del enemigo» ${ }^{733}$. POLAINO-ORTS ha resaltado brillantemente que el conductor en ocasiones

733 El concepto de «Derecho penal del enemigo» fue introducido por JAKOBS para designar a un individuo que mediante su comportamiento habitual, su ocupación profesional, o principalmente por su vinculación a una organización, abandona el Derecho de un modo supuestamente duradero y no solo de manera accidental, JAKOBS G., «Criminalización en el estado previo a la lesión de un bien jurídico», trad. Enrique Peñaranda Ramos, JAKOBS, G., Estudios de Derecho penal, op. cit., pp. 293 y ss; ID., «Derecho penal del ciudadano y Derecho penal del enemigo», trad. Manuel Cancio Meliá del manuscrito en alemán «Bürgerstrafrecht und Feindstrafrecht», JAKOBS Günther / Cancio Melí Manuel, Derecho penal del enemigo, $1^{\text {a }}$ ed., Thomson Civitas, 2003, pp. 19 y ss. y pp. 39 y ss. Se caracteriza como dice JAKOBS por una «defensa también frente a agresiones futuras», ID., «La ciencia del Derecho penal ante las exigencias del presente», trad. Teresa Manso Porto, JAKOBS, G., Dogmática de Derecho penal y la configuración normativa de la sociedad, $1^{a}$ ed., Thomson Civitas, 2004, pp. 43 a 45. Más concretamente JAKOBS considera que «(q)uien no puede adquirir derechos ni soportar la carga de deberes no es persona, sino que está excluido», ID., «Personalidad y exclusión en Derecho penal», trad. Teresa Manso Porto, JAKOBS, G., Dogmática de Derecho penal y la configuración normativa de la sociedad, op. cit., p. 71, también en Courakis ed., Die Strafrechtwissenschaft im 21. Jahrhundert, Festschrift für Dionysios Spinellis, T. 1, 2001. De este modo concluye que la «persona es algo distinto de un ser humano, un individuo humano; éste es el resultado de procesos naturales, aquélla un producto social (de lo contrario nunca podría haber habido esclavos, y no podrían existir las personas jurídicas», ID., «La idea de la normativización en la dogmática jurídico-penal», op. cit., p. 21; ID., «Personalidad y exclusión en Derecho penal», op. cit., 66 y ss. Este binomio entre Derecho penal del ciudadano y del enemigo rivaliza entre un estatus persona (ciudadano) y otro de no-persona (no-ciudadano/enemigo), que se ve reflejado en una legislación de lucha, pero siempre sin perjuicio de los Derechos humanos elementales, JAKOBS G., «Derecho 
penal del ciudadano y Derecho penal del enemigo», op. cit., p. 35 y 36; ID., «Personalidad y exclusión en Derecho penal», op. cit., pp. 72 y 73; ID., «La idea de la normativización en la dogmática jurídico-penal», op, cit., p. 21. También sobre el tema persona-ciudadano y enemigo-individuo, además de los ya citados LUHMANN, N., «La forma "persona"», LuHMann, N., Complejidad y modernidad: De la unidad a la diferencia, Trotta, ed. y trad. Josetxo Berian y José María García Blanco, 1998, pp. 231 y ss., originariamente "Die "Form Person"», Soziologische Ausklärung, 1985, pp. 142 y ss. El enemigo se autoexcluye de la forma persona, pasa a ser no-persona, si bien no deja de ser individuo o ser humano. El concepto de persona en LUHMANN trasciende del sistema psíquico (pensamientos) como nexo de unión con los demás sistemas. Esta es una operación de doble contingencia entre sistema psíquico y otro sistema social, por eso la forma persona no es un sistema, LUHMANN, N., «La forma "persona"», op. cit., pp. 236 y 238. De aquí una importante conclusión. Puesto que la relación entre los pensamientos (sistema psíquico) y el sistema social, en nuestro ámbito de estudio el subsistema del Derecho penal, sucede que entre ambos sistemas la forma persona produce un «acoplamiento estructural» entre ambos de modo que proporciona interpenetraciones del primero en el segundo e irritaciones, ID., "La forma "persona”», op. cit., p. 242. La interpenetración significa que la conducta realizada por la persona es procesada por el Derecho penal de manera conforme a Derecho/disconforme a Derecho, o más exactamente con el código justo/injusto en la terminología luhmanniana, si bien para ser aún más exactos deberíamos de hablar de no punible/punible. Así, la persona, obre justa o injustamente se adeuda a una operación/comportamiento que el sistema social puede procesar como parte de su existencia y funcionalidad, lo que en términos de LUHMANN podemos conceptualizar como «inclusión» ( se puede tolerar no sin consecuencias!), por eso cuando una conducta pone en riesgo la operatividad del Sistema Social, el subsistema del Derecho penal la rechaza de tal manera que observa dicha conducta con la forma «nopersona», y tenga que excluirla («exclusión»), ID., «Inclusión y exclusión», LuHMANN, N., Complejidad y modernidad, op. cit., pp. 167 y ss. De aquí el Derecho penal del enemigo sea un subsistema normativo de exclusión de comportamiento del Derecho penal del ciudadano, pero a la vez de inclusión en la operatividad normativa del Derecho penal del enemigo. Gráficamente LUHMANN razona que la «exclusión, puede significar, de nuevo, el cambio de subsistema», ID., «Inclusión y exclusión», op. cit., pp. 174. Similarmente y basándose en sus argumentaciones que relaciona con el delito de organización terrorista SANTA RITA, G., El delito de organización terrorista, op. cit., pp. 528 a 540.

La tradición histórica-filosófica ha tratado el concepto de enemigo, cuestión que ha sido estudiada y analizada ampliamente por POLAINO-ORTS. Especialmente nombra a RoUSSEAU, FICHTE, HOBBES, KANT, von LISZT y Hegel entre otros. Polaino-Orts, M., Derecho penal del enemigo. Fundamentos, op. cit., pp. 83 a 139 (Rousseau, JJ., El contrato social, op. cit., pp. 34 y 35; FICHTE, JG., Fundamentos del Derecho natural según los principios de la doctrina de la ciencia, trad. José Luis Villacañas Berlanga, Manuel Ramos Valera y Faustino Oncina Coves, Centro de Estudios Constitucionales, Madrid, 1994, pp. 257 a 272 y pp. 316 y 325; HoBBES, T., Del ciudadano y Leviatán, op. cit; KANT, I., Sobre la paz perpetua, op. cit., p. 10; HEGEL, GWF., Fundamentos de la filosofía del Derecho, op. cit., pp. 175 a 178 y pp. 322 y 323).

Es importante incidir en que no se produce una auto-exclusión absoluta tal y como comenta JAKOBS, JAKOBS, G., «Personalidad y exclusión en Derecho penal», op. cit., pp. 55 y 56. También en el mismo sentido LuHMANN comenta que «no hay ninguna exclusión de personas de la sociedad. En la medida en que alguien participa en la comunicación, aunque sea en prisión o en el escondite de unos terroristas, participa en la sociedad. Y justamente es típico de los terroristas que le den valor a esta participación. Dejan una nota en el lugar en donde han actuado o envían una cuanta de «reconocimiento» donde comunican que han sido ellos», LUHMANN, N., «La ética como teoría reflexiva de la moral», op. cit., p. 260. Y recuerda que habla aquí de personas (Personen), en cuanto destinatarios del proceso comunicativo, ID., ibidem, op. cit., p. 260, nota 11. En este sentido, el Derecho penal del ciudadano mantiene la vigencia de la norma, mientras que el Derecho penal del enemigo combate los peligros que generan los enemigos. El enemigo se aparta y renuncia, consciente y voluntariamente del Derecho del ciudadano, pero a su vez, lo aprovecha para llevar a cabo sus fines delictivos. Entonces, el Derecho penal del enemigo es una confirmación de la garantía que el ciudadano tiene en la garantía de la seguridad cognitiva y personal.

Estamos de acuerdo con POLAINO-ORTS que el Derecho penal del enemigo restabiliza la imposibilidad de una razonable confiabilidad en las normas jurídicas que provoca el enemigo, restaura la incapacitación normativa de orientar conductas que ocasiona el enemigo, y produce el aseguramiento legal-estatal de las condiciones sociales de vigencia del Derecho en adecuada proporcionalidad al foco de peligro objetivo que produce el enemigo, Polaino-OrTs, M., Derecho penal del enemigo. Fundamentos, op. cit., pp. 243 y ss. Le sigue en este aspecto SANTA RITA, SANTA RITA, G., El delito de organización terrorista, op. cit., pp. 533 y ss. De este modo, POLAINO-ORTS neutraliza el falso mito de que el Derecho penal del enemigo constituye un conjunto de normas ilegítimas per se, que legitima regímenes autoritarios, o que prescinde del principio del acto, POLAINo-OrTs, M., Derecho penal del enemigo. Fundamentos, op. cit., pp. 551 y ss. y pp. 604 y ss. Esto porque el principal postulado del Derecho penal del enemigo, tal como ha puesto de manifiesto POLAINO-ORTS es que exista al menos un peligro objetivo para la seguridad cognitiva de los ciudadanos en la vigencia del ordenamiento jurídico y del sistema social, de manera que 
sólo cuando aparezca este foco de peligro con intensidad constatada, se active un entramado normativo adecuado y proporcional para su represión. Ampliamente y redundando constantemente esta tesis ID., ibidem, op. cit., pp. 243 a 254. De aquí que la categoría normativa de enemigo, como muy acertadamente ha señalado POLAINO-ORTS es: «personal» en cuanto que sólo se imputa al sujeto que incurre en los presupuestos; «disponible» porque la categoría está disponible en su ámbito jurídico; «retornativa» porque se refiere a la posibilidad de volver a ella inclusive tras el cumplimiento de la pena (pena de alejamiento incluso tras haberse cumplido la pena privativa de libertad); «relativa» y «valorística» por la multitud de ámbitos de asimilación personal de la categoría y por la función de la convicción; «potestativa» en cuanto poder de la voluntad libre del sujeto; y «proporcional» en cuanto a lo objetivo de los principios del hecho, de tipicidad, de ofensividad, pero también referida a la peligrosidad y a la culpabilidad (imputación subjetiva). Más ampliamente ID., ibidem, op. cit., pp. 170 a 192; ID., Derecho penal del enemigo. Desmitificación de un concepto, op. cit., pp. 272 y 273.

Otra de las características que aprecia JAKOBS en el enemigo es el empleo abusivo de la norma y de legalidad del Estado para defenderse en caso de ser procesado, el enemigo sale conscientemente del Derecho del ciudadano aprovechando posterior y conscientemente el Derecho penal del ciudadano, de manera que el Derecho penal del enemigo es una confirmación de la garantía para el ciudadano o garantía de la seguridad cognitiva y personal para cada miembro de la sociedad. JAKOBS a consecuencia de esta idea, afirma que el comportamiento «personal» del enemigo defrauda de manera duradera la vigencia de la norma, y esto hace disminuir la disposición de tratar a este delincuente como «persona». Se rivaliza entre un status de persona (ciudadano) y otro de no-persona (nociudadano), que se ve reflejado en el legislador mediante una legislación de lucha. Entonces, no debemos sorprendernos, según comenta JAKOBS, de que si incluimos al enemigo en el concepto normal de ciudadano como delincuente, se mezclen conceptos de guerra y proceso penal.

Críticamente no falta quien ha calificado a las actuales leyes que se asocian al Derecho penal del enemigo como Derecho penal excepcional, contrario a los principios liberales del Estado de Derecho y derechos fundamentales reconocidos en las constituciones y Declaraciones internacionales de derechos humanos. Para este penalista, este Derecho penal excepcional afecta a principios como el de proporcionalidad, legalidad y culpabilidad, también a los principios procesales-constitucionales, como el principio de inocencia y debido proceso, MUÑOZ CONDE, F., «De nuevo sobre el "Derecho penal del enemigo"», RP, núm. 16, La Ley, 2005, pp. 123. MUÑOZ CONDE también ha calificado al Derecho penal del enemigo como aquel «Derecho penal de autor» que trascendió durante el nacionalsocialismo para castigar no en función del hecho cometido, sino por la perversión, tendencia o peligrosidad del autor, ID., ibidem, op. cit., pp. 126. MUÑOZ CONDE junto con HASSEMER califican a este fenómeno legislativo de políticas criminales de «tolerancia cero», ID., ibidem, op. cit., pp. 126; HASSEMER W / MUÑOZ CONDE F., Introducción a la Criminología, Tirant lo Blanch, Valencia, 2002, pp. 328 y ss. No obstante, a decir verdad, gran parte de la doctrina alemana y española está en contra del Derecho penal del enemigo.

Nuestro Código penal en 1995 introdujo los delitos relativos al fenómeno del terrorista para el magno intento de luchar contra los nuevos fenómenos delictivos. En el año 2003 se proclamaron infinidad de disposiciones relativas al emergente ámbito del Derecho penal del enemigo, en concreto y principalmente la Ley Orgánica 15/2003 de 25 de noviembre sobre violencia de género. Mayoritariamente la doctrina científica especializada en el tema está de acuerdo en señalar que las características principales del Derecho penal del enemigo son las siguientes: $1^{\circ}$ la anticipación de la punibilidad; $2^{\circ}$ el cambio de la perspectiva del hecho producido por otra basada en la probabilidad del hecho que se va a producir (delitos de organización); $3^{\circ}$ la agravación de las penas como por ejemplo en los delitos de blanqueo de capitales, narcotráfico, defraudaciones a Hacienda, en los delitos contra los derechos de los ciudadanos extranjeros; $4^{\circ}$ algunos señalan la «supresión de garantías procesales, donde la incomunicación del procesado constituye actualmente el ejemplo clásico» (JAKOBS, G., «La ciencia del Derecho penal ante las exigencias del presente», op. cit., pp. 43 y 44) especialmente la incomunicación del terrorista durante la detención sin derecho a un abogado de confianza, y la ampliación del plazo de detención, o la punición de los actos preparatorios; $5^{\circ}$ la Ley 1/2004 sobre violencia de género; $6^{\circ}$ la modificación del régimen general de la prisión provisional en cuanto a la duración y modificación de los fines de la prisión (art. 503 LECrim); $7^{\circ}$ la orden de alejamiento (arts. 544 bis y 544 ter LECrim); $8^{\circ}$ la agravación de las medidas penitenciarias de la Ley Orgánica 1/2004; además de endurecerse la consecución de grados penitenciarios, los permisos y la admisión de la libertad condicional; y $9^{\circ}$ recientemente Ley Orgánica 1/2015, de 30 de marzo, por la que se modifica la LO 10/1995, de 23 de noviembre, del Código Penal (BOE 31 marzo) instaura la pena de prisión permanente revisable, que según su Exposición de Motivos, podrá aplicarse en los «asesinatos especialmente graves, homicidio del Jefe del Estado o de su heredero, de Jefes de Estado extranjeros y en los supuestos más graves de genocidio o de crímenes de lesa humanidad-en los que está justificada una respuesta extraordinaria mediante la imposición de una pena de prisión de duración indeterminada (prisión permanente), si bien sujeta a un régimen de revisión». Con la reforma del Código penal por la Ley 1/2015, de 30 de marzo que establece en el art. 570 bis CP el concepto de organización criminal y en el art. 570 ter CP el concepto de grupo criminal, si bien en la LO 2/2015, de 30 de marzo, se incluye una nueva definición de organización terrorista en el art. $573 \mathrm{CP}$, relacionado con varios fines que resuelve la 
se comporta como un enemigo y el vehículo como su arma. En este sentido, el referido penalista destaca que el legislador no trata al rol de conductor como una persona autorresponsable de las competencias en la conducción sino como una fuente de peligro en el binomio conductor/vehículo de modo que en ocasiones, cuando se incurre en delitos contra el tráfico rodado, el conductor, «su personalidad se ha visto degradada (...) por mor de su peligrosidad (...) a mayor peligro creado por el agente mayor represión penal frente a él» ${ }^{734}$

El fundamento de la punibilidad, incluso agravada respecto a otras conductas similares, estriba en la «falta de seguridad cognitiva», o sea, de una «fuente de peligro» que representa un sujeto al volante para los terceros que concurran y para la Sociedad, que ve que dicha conducta tarde o temprano afectará a cualquier ciudadano. La Sociedad precisa de la adecuada «cimentación cognitiva» en una norma que oriente al ciudadano a que no conduzca si bebe, o si bebe vuelva por otros medios a su destino, de tal forma que la norma entre en la «heteroadministración» de una esfera que en principio pertenecía a la libre organización del sujeto, pero que se precisa su intervención normativa para cimentar cognitivamente en los ciudadanos dosis de seguridad ${ }^{735}$.

Podemos concluir que más allá de la criminalización de ciertas conductas peligrosas, en el tráfico rodado sobresalen ciertos autores que ejemplifican su irrespetuosidad a la norma adoptando un «modo de conducción» altamente peligroso cuando superan la tasa objetiva de punibilidad o tienen síntomas evidentes de tener mermadas las facultades para la conducción, de tal manera que la desnaturalización del requisito del dolo o la imprudencia en estos delitos, o más bien reconducidos a «tentativas imprudentes» confirma que el sujeto actúa en muchas de las ocasiones con dolo eventual (aplicación de la alic) o con imprudencia consciente, lo que supone

indefinición hasta la fecha existente: " $1^{a}$ subvertir el orden constitucional, o suprimir o desestabilizar gravemente el funcionamiento de las instituciones políticas o de las estructuras económicas o sociales del Estado, u obligar a los poderes públicos a realizar un acto o a abstenerse de hacerlo. $2{ }^{a}$ Alterar gravemente la paz pública. 3. ${ }^{a}$ Desestabilizar gravemente el funcionamiento de una organización internacional. 4. ${ }^{a}$ Provocar un estado de terror en la población o en una parte de ella». El fundamento de estas medidas vienen del binomio inseguridad/riesgo que provocan conscientemente estos individuos tanto en la confianza de los ciudadanos en la vigencia de la norma (inseguridad cognitiva sobre la norma), como sobre la capacidad de la norma orientar las conductas de los miembros de la sociedad, y de comunicar la seguridad personal e intimista de los ciudadanos sobre sus derechos.

Las causas del creciente ámbito del Derecho penal del enemigo las imputa JAKOBS ya no solo a la globalización, sino también a «(u)na sociedad que ha perdido el respaldo tanto de una religión conforme al Estado como de la familia, y en la cual la nacionalidad es entendida como una característica accidental, le concede al individuo un gran número de posibilidades de construir su identidad al margen del Derecho o, al menos, más de las que podría ofrecer una sociedad de vínculos más fuertes», JAKOBS, G., «La ciencia del Derecho penal ante las exigencias del presente», op. cit., p. 45.

734 Polaino-OrTs, M., Derecho penal del enemigo. Fundamentos, op. cit., p. 484.

735 ID., ibidem, op. cit., pp. 485 y 486. Críticamente muchas de las medidas adoptadas en relación a los delitos de tráfico rodado son desproporcionadas y no suponen peligro alguno tal y como ha denunciado POLAINO-ORTS en relación a la medida de retirada de carnet a quien se niega a someterse a las pruebas de alcoholemia, entre otros supuestos, pues en su opinión constituye un Derecho penal del enemigo «indiscriminado y mal aplicado», ID., ibidem, op. cit., p. 487 y 488; y añade que el legislador ha creado «más enemigos de los que realmente hay», ID., ibidem, op. cit., p. 489. 
que la autoría por convicción también puede desplegarse en este tipo de delitos, como una especificidad del «enemigo»y las normas asociadas a las conductas especialmente desestabilizadoras de la seguridad cognitiva de los ciudadanos en el sistema social.

\section{Concepto normativo de enemigo}

Si el autor por convicción lo es por la creencia de la licitud moral, política o ideológica del delito, normalmente como medio o móvil del fin, no resultara irracional considerar que es precisamente esa convicción lo que califica subjetivamente al enemigo, ya sea manifestada de forma dolosa, imprudente o con un comportamiento peligroso. Esto significa que todo enemigo es un autor por convicción, sin embargo, no todo autor por convicción es un enemigo de la seguridad del sistema.

Por ejemplo, el autor por convicción al que JAKOBS ${ }^{736}$ denomina «blando», el cazador que furtivamente caza fuera de los periodos de veda, en nuestra opinión no puede considerarse un enemigo puesto que no representa una amenaza para la seguridad cognitiva de los ciudadanos en el Sistema, salvo que por la habitualidad y otras circunstancias suponga un peligro concreto para la fauna, por ejemplo. Claro está que si nuestro cazador atenta contra una realidad medioambiental de sumo interés para la sociedad como por ejemplo sería la caza continuada de una especie en peligro de extinción que amenazara su existencia, tal conducta puede provocar esa inseguridad a la que nos referimos, al que JAKOBS llama autor por convicción «duro». Por ejemplo también, estaremos de acuerdo que el médico que realizase un aborto en periodos de criminalización no supone un peligro objetivo para la convivencia, sino sólo si esta convicción se lleva al extremo de ejecutarla de forma habitual, organizada, masiva y/o continuada, aunque fuere por motivos morales. En estos casos el sujeto se auto-excluye del Sistema, representa una operación ajena a éste, un entorno enemigo, que sólo puede valorarse con las operaciones y reglas de otro sistema acorde a esa operatividad: el subsistema del Derecho penal del enemigo.

El enemigo es un autor por convicción, combate el orden sociopolítico y normativo, al ordenamiento jurídico en sí mismo y la configuración normativa de la sociedad. Considera que el orden establecido ataca sus propias normas políticas e ideológicas o morales. No sufre en puridad ningún conflicto de conciencia, lo que no resta que su delito sea tan ineludible como en el autor de conciencia. Pretende instaurar para todos una configuración normativa de la sociedad adecuada a sus ideales, credos o moral, y esto sólo se puede realizar de forma normalmente

736 JAKOBS, G., $P G$, op. cit., 20/20 a 22. 
activa, si bien, esto es sólo un dato meramente estadístico que depende de la configuración y circunstancias que se presenta, de la organización del delito y de la competencia del autor.

Dicho esto, si un enemigo del Estado, del orden, se califica así por su lucha continua, habitual, e incluso profesional, a diferencia del ciudadano, debemos considerar también que el enemigo es un auténtico autor por convicción, en virtud de la peligrosidad que representa el enemigo, y entendiendo por «peligrosidad» la inseguridad cognitiva sobre la validez de la norma y la inseguridad personal que trasmite a la sociedad.

Sin embargo, no toda convicción en el delito merece una respuesta penal diferenciada cuando del hecho y aptitud subjetiva del autor se desprenda condicionantes de la propia operatividad del Sistema: el Sistema se las arregla mejor con conductas que ya ha procesado anteriormente como posibles, que con aquellas que ponen en peligro su propia operatividad al no estar comprendidas en su complejidad u horizonte de expectativas. Esta vinculación que hemos expuesto ha sido posible gracias a la confrontación de una y otra fenomenología criminal. De la misma manera, sólo mediante esta confrontación podemos llegar a conclusiones bien fundadas de las tres categorías prototípicas asociadas a la criminalidad moral.

La fuerza de la convicción, cuantitativamente hablando, no aporta nada a la distinción entre enemigo, autor por convicción y de conciencia, sin embargo sí fundamenta cualitativamente, o mejor sistémicamente en el enemigo su estatus de no persona y la peligrosidad objetiva para el sistema normativo y social.

Las organizaciones criminales constituyen casos paradigmáticos del Derecho penal del enemigo y de la autoría por convicción, si bien y especialmente en las sectas criminales también concurre la autoría de conciencia como veremos. En las sectas criminales coexisten los tres supuestos de autoría moral.

\section{Criterio funcional de delimitación de las indicadas categorías: el sentido de la}

comunicación del hecho delictivo y la alternatividad de comportamiento

Las razones que sirven tanto para diferenciar conceptualmente como normativamente son funcionales (no estrictamente cualitativas), o dicho de otro modo, se parte de distinguir si la conducta supone una operación propia del Sistema social y de la configuración normativa o no. De aquí estriba que una misma conducta, en este contexto, una operación, ya sea de conciencia o por convicción enemiga, tenga funcionalmente distintas posibilidades para el Sistema. Esto significa que por un lado se impute objetivamente el delito, por otro lado, se valore la gravedad, y por otro la culpabilidad, y en su caso, el merecimiento de la pena, de modo que una conducta 
altamente penada pueda eximirse y otra más levemente penada merezca la máxima culpabilidad. Pero todo esto depende de la valoración que se haga en la propia subsistencia y operatividad del Sistema en su diferenciación.

De una parte, puede haber conductas que por su escasa gravedad para el Sistema se conceptualicen como autoría por convicción (el furtivo), y un cambio de las circunstancias haga que se criminalice altamente (peligro de extinción de una especie) o, por el contrario, que conductas altamente penadas no supongan un peligro para el sistema normativo y social. Es por eso que en estas tipologías criminales se aprecia la posibilidad de aplicar el estado de necesidad exculpante cuando se presentan diversas circunstancias de índole particular, grosso modo, circunstancias sociales con las que cuenta el Sistema: el «aislamiento cultural» o el «déficit de socialización» atribuido a la norma o a tercero.

También hemos podido comprobar que la estrecha relación entre autor por convicción y enemigo hace de la convicción un postulado más del enemigo. La convicción injusta es la desatención de la alternatividad de otra conducta que la norma propone. De aquí que la operación que realiza el autor por convicción, según los casos, sea altamente peligrosa para el Sistema. Si bien, como hemos explicado, puede haber conductas por convicción que a pesar de desatender una orientación alternativa de la norma para conseguir el mismo fin, no suponga un peligro para el Sistema tan intenso que ponga en peligro la vigencia del mismo, como sucede en generalmente en las conductas del enemigo, sino que el Sistema cuenta con tal defraudación y permite, no sin sanción, su operatividad porque ya ha sido procesada en el Sistema: estos son los casos de autoría por convicción «blanda», tan cercana a la convicción de cualquier otro delito que el Sistema asemeja en su operatividad.

De aquí también que hayamos podido concluir que no todo autor por convicción es también un enemigo, pero sí que en todo enemigo se presente una convicción injusta, inclusive en delitos de peligro o imprudentes. El quantum de la extensión de la pena y el injusto perpetrado sólo representan la valoración que hace el Sistema de un determinado bien jurídico en relación a la subsistencia del Sistema, pero es incapaz de explicar por sí sólo por qué conductas levemente penadas (por ejemplo los delitos de conducción bajo los efectos del alcohol o superando la tasa objetiva de punibilidad) pueden representar un peligro para la seguridad cognitiva de los ciudadanos en el Sistema normativo y social que merezcan un mayor reproche en «comparación» con otros delitos que atacan el mismo bien jurídico. La razón entonces es la peligrosidad o amenaza objetiva a la subsistencia y seguridad de las operaciones del Sistema. 
Normalmente, el ordenamiento jurídico ofrece medidas alternativas para que los ciudadanos puedan compaginar su conducta y su identidad personal, pero cuando una determinada convicción o conciencia chocan frontalmente con toda posibilidad de adecuar el comportamiento a la norma, surge cierto conflicto. En estos casos, el enemigo tratará de combatir todas las alternativas porque todas ellas chocan con su convicción, con su configuración interna, mientras que en el caso del autor de conciencia no se combate la vigencia de la norma, o en otras ocasiones, se adecúa el comportamiento a la esfera de organización de libertad de un tercero (eutanasia). No instaura su norma para los demás, sino que la única forma que tiene para adecuar su conducta a su identidad y a su configuración interna es, al menos, omitir el deber de actuar, o adecuarla a la esfera de libertad de un tercero. Su conducta se trata de una operación o influjo del propio Sistema o atribuible a tercero, que postula la aplicación del estado de necesidad exculpante al introducirse en la conducta del sujeto operaciones del propio Sistema, ya sea atribuible a éste o a un tercero. Así, la convicción que igualmente demuestra el autor de conciencia y el objetor no supone una diferencia normativa per se entre éstos y el enemigo, sino la defraudación de las alternativas normativas que ofrece el Sistema.

Amén de ésta y anteriores consideraciones, si efectuamos nuevamente una valoración de la fenomenología criminal del autor por convicción-enemigo, estrictamente normativa y apoyada en la subsistencia del Sistema normativo y social, su tratamiento y las normas asociadas a éste, constatan nuevamente la idea de que no podemos tratar este ámbito con criterios morales en el sentido bueno/malo, bien/mal, atenuación o exoneración/máxima culpabilidad sino en la propia operatividad del Sistema. Así, tampoco habrá impedimento dogmático alguno en postular que también en la autoría por convicción-enemiga se pueda aplicar la disminución de la responsabilidad criminal, e inclusive la exoneración, cuando de las circunstancias subjetivas y concomitantes se aprecie cierto y relevante «déficit de socialización» atribuido a tercero, que comunique al Sistema objetivamente su propia excepcionalidad, de modo que tales circunstancias al ser estrictamente sociales se tengan en cuenta por el Sistema como operaciones de su propia complejidad. El Sistema, a pesar de procesar el hecho negativamente atendiendo a las circunstancias sociales que han afectado al sujeto al ser operaciones propias del Sistema, las añade al hecho criminal en el sentido de admitir que supone una consecuencia de su propia operatividad, de modo que ha de restarle reprochabilidad: la conducta debida no era del todo exigible al estar condicionada por operaciones propias del Sistema.

Si entre autor por convicción y de conciencia no existe una diferencia cuantitativa de la fuerza de la convicción, efectivamente, la distinción entre ambos es otra: una diferencia cualitativa en 
el valor que el Sistema diferencialmente otorga al motivo del delito y al sentido de la comunicación. Esto supone un criterio funcional. De aquí que tenga razón LUHMANN cuando considera que «la comprensión de los motivos -se refiere a los motivos de un comportamientoayuda retrospectivamente a reconocer si una acción ha ocurrido» ${ }^{737}$, y de tal modo, si ha ocurrido en el Sistema, si lo afecta, o si por el contrario se ha de dejar fuera del Sistema, en nuestro caso, si ha ocurrido y por lo tanto pertenece al sistema penal, sí es reprochable, sí es injusto, o en el caso de que sea justo concluir que no pertenece al sistema. Sin embargo en esta operación aparacen de vez en cuando paradojas en el sistema, con las que tiene que convivir reconociéndolas como propias de su operatividad o interferencias de terceros: estas son los déficits de comunicación normativa o los déficits atribuidos a tereceros. Así las cosas, la diferencia fundamental entre autoría de conciencia, por convicción y el enemigo es funcional, esto es, sistémica.

Lo analizado hasta ahora se ha limitado a estudiar la fenomenología y responsabilidad de las tipologías criminales por motivos generalmente morales desde el presupuesto de la libertad de sus conductas, sin interferencia de terceros y que en el siguiente capítulo analizaremos en casos particulares. En los capítulos del cuarto al octavo analizaremos las mismas tipologías desde el presupuesto de la interferencia imputable de tercero como conductas «coaccionadas» y a las que nos hemos referido como déficit de socialización atribuido a tercero, siendo el caso de las sectas criminales el caso paradigmámtico en el que confluyen todos ellos.

\section{E. Delincuente habitual: determinación de tipologías}

Tras lo dicho, viene la pregunta de qué diferencia normativa existe entre el delincuente habitual y el autor de conciencia. La respuesta según lo previamente establecido puede ser la siguiente. El primero no pretende instaurar un orden, sino desatender la norma como forma de vida. Conoce que su actuar es injusto y acepta sus consecuencias, o al menos le parece lógico soportarlas porque no le resta validez a la configuración normativa de la sociedad, quiere aprovecharse del delito con más o menos conciencia. Por eso el delincuente habitual puede cometer el delito dolosa o imprudentemente. Nadie negará que quien habitualmente incurre en el delito de conducir bajo los efectos del alcohol no pretende instaurar la negación de la norma para los demás, pero tampoco para sí mismo, porque en definitiva es conocedor que él también puede ser la víctima de las frecuentes consecuencias de conducir ebrio al volante, los accidentes mortales. Y nadie afirmará que el ladrón habitual quiera ser víctima de un robo. A causa de esto,

\footnotetext{
737 Luhmann, N., Poder, $1^{\text {a }}$ reimp. 2005 de la $1^{\text {a }}$ ed. 1995, Anthropos, pp. 30 y 31.
} 
es lógico pensar que el delincuente habitual, puede tener más o menos convicción en su actuar, por lo que según el grado al que haya alcanzado esa habitualidad, se expresará su convicción y su inclusión en la autoría por convicción, que a la vez, según el peligro objetivo constatado, quebranta de forma más seria y objetiva la configuración normativa de la sociedad, y su elevación a la categoría de enemigo.

De este modo, podemos también concluir que no todo delincuente habitual puede ser tratado como un enemigo, y aunque bien es cierto que se le aplican los postulados antes vistos del Derecho penal del enemigo, la intensidad de su aplicación, no se negará, es tan mínima en comparación con la reincidencia y la multirreincidencia que pierde fuerza la aplicación de los postulados del Derecho penal del enemigo, o según dirían sus defensores, se aplica de forma proporcional al peligro objetivo causado, si bien podemos concluir que en esta leve aplicación se difuminan los presupuestos del Derecho penal del enemigo, entre la simple delincuencia habitual y la autoría por convicción «blanda».

En este sentido, el autor de conciencia, a diferencia del delincuente habitual, si bien no niega la virtualidad de la vigencia de la norma, sí antepone una norma configurada en su interior que le ha permitido la norma previamente (socialización) o a causa de un tercero; mientras que el delincuente habitual opta por la desatención de la alternatividad que le otorga la norma, con o sin convicción. En toda lógica, aquellos grupos y organizaciones que atacan los más elementales derechos fundamentales de la persona y de la sociedad pueden calificarse como enemigos, y son a los que por definición les son aplicables los postulados del Derecho penal del enemigo antes descrito.

De otra parte, no resultará ilógico concluir que la fundamental diferencia entre un delincuente habitual $^{738}$ y un enemigo es en realidad la pura convicción que éste último tiene en que su actuar

\footnotetext{
738 La delincuencia habitual supone una categoría normativa presupuesta de la agravación por reincidencia del art. $94 \mathrm{CP}$ al considerarse la habitualidad «(a) los efectos previstos en la sección $2^{a}$ de este capítulo, se consideraran reos habituales los que hubieren cometido tres o más delitos de los comprendidos en un mismo capítulo, en un plazo no superior a cinco años, y hayan sido condenado por ello».

Dicho precepto impide entonces que el reo habitual acceda a los privilegios de la sustitución de la pena del art. $84 \mathrm{CP}$ y a la suspensión del art. $80 \mathrm{CP}$, lo que por cierto no guarda relación con la agravante genérica de reincidencia del art. $22.8^{\mathrm{a}} \mathrm{CP}$ por la que sólo se exige dos hechos delictivos. Dicha habitualidad se circunscribe en la comisión de hechos delictivos previstos en el mismo capítulo, o sea, de análoga naturaleza en principio -aunque bien es conocida la infortunada ubicación de algunos tipos- y de similar especialización y peligrosidad criminal que expone la Exposición de Motivos de la LO 11/2003 y que finalmente se agravó, y que se mantiene por la Ley 1/2015, de 30 de marzo, de reforma del Código penal.

De tal manera la habitualidad en el delito pasado permite aventurar la mayor probabilidad de delito futuro, su peligrosidad y por ende la convicción en el delito, por grave que sea, GUISASOLA LERMA, Cristina, Reincidencia y delincuencia habitual (regulación legal, balance crítico y propuesta de lege ferenda), Tirant lo Blanch, 2008, pp. 98 y 99. En esta medida, la gravedad o el tipo de delito no es el fundamento de agravación. Recuérdese al respecto la vigencia de la reincidencia y multirreincidencia en las faltas que pasó a considerarse delito, la agravación de la violencia de género, el delito continuado y el delito masa. El fundamento no está tampoco en el concepto de
} 
criminal es lícito y necesario para un fin subjetivamente lícito aplicable a su espacio y tiempo y a toda la sociedad, mientras que el que es sólo un delincuente habitual no tiene que actuar por motivos morales, políticos o ideológicos, y si bien con su actuar comunica siempre, de algún modo, subjetivamente, que la norma no está vigente, no es intención del delincuente habitual derogarla objetivamente, ni combatirla, sino exclusivamente desoírla sin cuestionar objetivamente su validez. De este modo, un delincuente habitual, puede ser un autor por convicción (por motivos ideológicos, morales, etc.) y a la vez no suponer una peligrosidad objetiva tal que lo eleve a la categoría de enemigo.

\section{F. Fundamentos generales del tratamiento penal del autor de conciencia y por convicción \\ 1. Déficit de comunicación/socialización en el autor de conciencia atribuido a la norma}

En la autoría de conciencia se han planteados soluciones desde la atipicidad a la falta de merecimiento de una pena. Al respecto GRACIA MARTín aboga por la máxima culpabilidad del autor por convicción y de conciencia, y reconoce que diversos factores sociales no asociados a la

habitualidad, sino en nuestra opinión en la peligrosidad, la cual se constata cuando se perpetran varios delitos de análoga naturaleza.

Lejos de entrar a valorar la constitucionalidad de la reincidencia -admitida por STC 150/191, de 4 de julio- de tales preceptos en relación al principio de «prohibición de exceso», o del ne bis in idem, lo cierto es que la habitualidad no puede compararse con el anterior denominado concepto de Derecho penal de autor o por conducción de vida o culpabilidad por habitualidad como parece sostiene GUISASOLA (ID., ibidem, op. cit., p. 101 y 102), a pesar de sostener igualmente que la habitualidad supone una exigencia de tipicidad del «delito habitual» (ID., ibidem, op. cit., p. 108) y reconozca que «una actitud de mayor desprecio y rebeldía» pero sin que sea fundamento para agravar la pena (ID., ibidem, op. cit., pp. 63 y 69). Nadie negará que el autor ha quebrantado varias veces normas similares, lo que incide en la idea de que ha comunicado sobradamente su voluntad contraria al Derecho. En este sentido POLAINO-ORTS define la reincidencia y la habitualidad delictiva como formas fenomenológicas del «Derecho penal del enemigo» por considerar, acertadamente, que tales conductas suponen un mayor desvalor del injusto, «un factor de desestabilización tal que impide que los ciudadanos afectados puedan confiar tranquilamente en la vigencia de la norma» (POLAINO-ORTS, M., Derecho penal del enemigo. Fundamentos, op. cit., p. 204), a diferencia del sujeto que comete un solo hecho aislado desestabiliza la vigencia de la norma cuantitativamente en menor proporción, lo que legitima la constitucionalidad de tales normas acorde a «las circunstancias de peligrosidad acreditadas». Estas circunstancias merecen una respuesta tanto más reafirmadora de la reacción penal ante dicha mayor inseguridad normativa, de tal manera que no se quebranta el principio de proporcionalidad ni de culpabilidad ni cae en el Derecho penal de autor ni de voluntad, ID., ibidem, op. cit., pp. 209 y ss.

De la misma manera, cuando el fundamento de la actuación delictiva muestre cierta confiabilidad, más allá del tipo criminal en que haya incurrido, de su gravedad, la habitualidad, o la reincidencia, se pueden encontrar otros argumentos ubicados en la culpabilidad que fundamenten que, si bien la gravedad lleve a aplicar un delito altamente penado, las circunstancias que han llevado al sujeto a actuar, atenúen o eximan de responsabilidad, tales como las mencionadas en el autor de conciencia, sin que se incurra en ninguna contradicción dogmática, sino que por el contrario se adquiera mayor coherencia, al ubicar la problemática de ambas tipologías criminales en la culpabilidad. Como hemos resuelto, la gravedad del hecho, y por ende la imputación del delito es algo circunstancial, si bien por norma general la motivación de cada tipo de autor normalmente llevará al de conciencia a cometer delitos menos graves y en omisión, mientras que el autor por convicción que fundamentalmente se diferencia en la comisión activa por la cual expresa su actitud de lucha contra la vigencia de la norma y del sistema, le llevará a cometer injustos más graves, si bien como veremos más abajo, en los delitos políticos, el autor por convicción también puede actuar de forma omisiva, o incurrir en injustos de menor importancia, por lo que decae esta diferencia dogmática ubicada en el tipo y forma activa u omisiva de comisión. 
capacidad inherente de comprender y obrar (inimputabilidad), pueden hacer menos exigible la conducta y tener trascendencia en la culpabilidad y en la pena ${ }^{739}$.

Según lo expuesto, en los casos de conflicto entre bienes personales y disponibles, por ejemplo en el prototípico caso de rechazo de un tratamiento médico vital, el motivo de conciencia es ajeno a dicha situación. Sin embargo, cuando el conflicto es entre un tercero o una norma de protección colectiva, la solución -según lo expuesto- no puede justificarse en ninguna causa de las que ampara el art. $20 \mathrm{CP}$, salvo que no exista conflicto, sino exclusivamente el derecho o norma que ampara la decisión, pero en la que el motivo de conciencia sigue siendo ajeno.

En nuestra opinión, el art. $20.5^{\circ} \mathrm{CP}$ recoge dos tipos de eximentes: justificadora y disculpante. Por un lado, el precepto nos habla del auxilio necesario a terceros, de que los bienes jurídicos no tienen por qué ser personalísimos (caben los patrimoniales como ha denunciado parte de la doctrina $^{740}$ ) y de la ponderación objetiva del valor que tienen los males en juego. Por otro, debe restringirse el campo justificante del estado de necesidad, pues la letra del artículo no nos habla de que el bien salvado sea igual o mayor que al que se enfrenta, sino de que el valor del «mal» causado no sea mayor que el que se evita, es decir, la ponderación debe ser objetiva en todos los casos, mientras que en el estado de necesidad disculpante la ponderación tiene en cuenta la circunstancias subjetivas del sujeto, y por ello estaríamos - no en el campo de la antijuricidadsino en el de la culpabilidad. En este sentido, muy acertadamente MONTIEL, de forma gráfica, ha concluido que conforme se superan los juicios de imputación fáctica y normativa existe mayor recelo por parte de la doctrina y de la jurisprudencia a aplicar causas de exculpación o de impunidad. Esto se debe, como bien advierte, a la tendencia de prohibición de analogía in bonam partem $^{741}$. Sin embargo, hay que convenir con HRUSCHKA ${ }^{742}$ que la imputación de la culpabilidad también supone una imputación ordinaria, si bien de segundo nivel, con el mismo valor normativo que la de primer nivel o imputatio facti.

En este sentido consideramos que el conflicto entre males iguales pertenece al estado de necesidad disculpante por mor de una situación que es valorada por el sujeto como «ausencia de derecho» ${ }^{743}$, y si bien tradicionalmente la comparación de bienes iguales se ha considerado una situación justificante, si lo tratamos como males jurídicos, la consecuencia de perder la vida para

739 Gracia MarTín, L., Fundamentos de Dogmática penal, op. cit., p. 198.

740 JAKOBS, G., PG, op. cit., 20/1 y ss.

741 MonTIEL, Juan Pablo, «Regulaciones de excepción y prohibición de analogía», InDret, 3/2013, pp. 16 a 23.

${ }^{742}$ HRUSCHKA, Joachim, «Reglas de comportamiento y reglas de imputación», HRUSCHKA, J., Imputación y Derecho penal. Estudios sobre la teoría de la imputación, ed. Pablo Sánchez-Ostiz, pról. J-Mª Silva Sánchez, 1ª ed., 2005 , pp. 27 a 40.

${ }_{743}$ JAKOBS, G., $P G$, op. cit., 15/7, y nota 11. 
el autor es siempre un mal mayor que mantener la vida aunque sea gravemente herido, de tal modo que la valoración en estos casos ex ante es estrictamente subjetiva y personal, el sujeto actúa no por considerar que tiene derecho a conservar su vida ante una situación de necesidad con un tercero, sino que el Derecho ex post lo valora como una cuestión de bienes objetivos.

Sin embargo esta valoración, aquella que ex post le otorgaría una causa de justificación, no orienta al sujeto ni le comunica nada en absoluto ex ante. Si fuera así, el autor valoraría objetivamente la situación entre bienes en juego, como si tuviera que ceder su vida ante la vida de otro, no hallaría razón alguna para quebrantar la vida de otro. Objetivamente el derecho no da razón alguna para que ante una necesidad extrema la vida del autor valga más que la de otro. Ambas son importantes hasta el punto que el ordenamiento impone el deber de socorro en caso de dos accidentados en peligro de muerte pero pueden ayudar. Como se valoran ambas vidas o ambas integridades físicas por igual, la razón de exoneración no procede de la igualdad de bienes jurídicos como sucede en la legítima defensa. En ésta subyace el fundamento de la agresión ilegítima, o sea, la intromisión culpable del tercero en la esfera de derechos del autor, por lo que la razón normativa del estado de necesidad, al faltar la agresión ilegítima, no es la comparación de bienes, sino de males subjetivamente valorados ex ante, o las consecuencias de no actuar ante una necesidad.

La razón de que la mayoría de la doctrina relegue al estado de necesidad exculpante la confrontación de bienes desiguales en que se salva uno de menor protección es la valoración subjetiva del autor, que por las circunstancias se hace comprensible lo injusto por el Derecho. De este modo, la doctrina reconoce que el sujeto valora más altamente su integridad que la vida de un tercero, por lo que la misma razón hay cuando el sujeto actúa salvando su vida en perjuicio de la vida de otro. Dicha valoración es estrictamente subjetiva, hasta el punto que la misma solución jurídica se encuentra en caso de que sea el tercero el que salve su vida.

Esto demuestra, en nuestra opinión, que en conflicto de males iguales no existe norma jurídica, sino que se hace comprensible el actuar de cada uno de los sujetos. El Derecho no puede entrar a valorar la situación, ni comunicando a uno ni a otro un derecho mayor, por lo que en esta confrontación de males iguales se determina la «ausencia de derecho», un estado de naturaleza en la ley del más listo y/o fuerte. La valoración es estrictamente de males subjetivamente comprendidos, hasta el punto que el Derecho no entra a valorar una conducta pasiva de aquel al que se le trata de matar porque se reconocen las autopuestas en peligro o, en verdad, la disponibilidad de la vida. En casos de males iguales la valoración es del todo subjetiva, del 
propio sujeto, lo que lleva al estado de necesidad disculpante. Además el art. $20.5^{\circ} \mathrm{CP}$ expresamente no se excluye que «el mal causado no sea mayor que el que se trata de evitar».

Así las cosas, la razón de exoneración es estrictamente normativa y funcional en nuestra propuesta del estado de necesidad exculpante de casos especiales de autor de conciencia. En su caso, el conflicto entre males iguales, pero también desiguales, en el que el mal causado es mayor que el que se trata de evitar, hay no una razón normativa de ponderación de bienes o males, sino una contraorientación normativa entre la norma que habilita al sujeto a ejercitar su conciencia en una determinada dirección y la norma que obliga cuando se activa su vigencia material. El campo de acción de la segunda norma, aquella sobre la que se debate la tipicidad de la conducta, es de obligado cumplimiento, sin embargo en la confrontación de la primera norma, aquella que ha socializado intensamente al sujeto en unas determinadas orientaciones de conducta, y la segunda norma, aparece una situación crítica y sorpresiva, inesperada, que confronta un derecho jurídico (el moral) con otro, de manera que la socialización intensa y continuada de la primera norma impide al sujeto en la situación obrar conforme a la segunda norma. En este punto ésta es incapaz de socializar al sujeto en una determinada orientación de la conducta, al sujeto ya le es imposible desvincularse de la conexión entre conciencia y voluntad permitida intensamente por la primera.

Por ejemplo, sobre el conflicto entre dos males de distinto valor, el padre Testigo de Jehová que por sus altos conocimientos médicos sabe que su hijo precisa una trasfusión y que omite su actuar (no avisa a las asistencias médicas o no lleva al menor al hospital) generando una responsabilidad que si bien es omisiva, al tratarse de una situación de garantía de institución que normativamente se le ha dado mayor importancia, estaremos ante una comisión por omisión de homicidio. Si bien, nada impide hablar de autoría de conciencia, porque el motivo de la omisión es el mismo que en los casos paradigmáticos de omisión del deber de socorro. Cambia una circunstancia en la que subyace con igual intensidad la inevitabilidad de obrar conforme a la conciencia. De este modo, la causa de la conexión entre conciencia y voluntad viene del riesgo permitido por la norma fundamental del derecho a la libertad de conciencia. Lo que sucede es que la segunda norma se activa materialmente en la circunstancia del peligro, la obligación de actuar nace sorpresivamente (el menor precisa con urgencia una trasfusión de sangre por un accidente doméstico), sin embargo en comparación con el prototípico caso de la omisión del deber de socorro por falta de consentimiento o rechazo a la trasfusión por los padres, se une un conocimiento especial que si bien no es ajeno a la institución paterno-filial, sí que impide al sujeto obrar en el sentido de avisar a las asistencias o llevar al menor al hospital, pues conoce 
que en tales casos su falta de consentimiento no impediría la actuación médica al concurrir igualmente la situación de peligro vital. En este caso, la omisión equivale a una acción de matar, que por la exigencia normativa se trasforma la situación en un injusto mayor, pero la valoración de los motivos de conciencia ineludibles en unión a la socialización intensa de la norma que habilita la libertad de conciencia lleva a la fundamentación del estado de necesidad exculpante, del modo antes descrito: el Sistema reconoce que en ese comportamiento existen operaciones atribuidas al propio Sistema o a un tercero, con las que ha contado previamente en su propia funcionalidad.

En la omisión del deber de socorro pura o propia, el deber de actuar, en este caso, la falta de consentimiento no se eleva a una omisión que equivale a una acción porque interviene la presencia de los facultativos, que tienen el mismo deber pero específicamente referido al salvamento mediante la aplicación de una transfusión de sangre, pero que de igual modo fundamenta la aplicación del estado de necesidad exculpante a pesar de la descompensación de males en juego (libertad de conciencia y evitación del peligro como deber de solidaridad).

La cuestión a resolver tras esta conclusión es qué intensidad ha tenido la contraorientación normativa que ha producido el déficit de socialización en el sujeto a consecuencia, en verdad, que dicha contraorientación supone un déficit de socialización de la segunda norma (deber de actuar). Para ello habrá que analizar las circunstancias de cada caso, sin que la imputación del injusto ocupe un lugar determinante en la valoración ni de la exculpación ni de su graduación, esto porque dicha exigencia normativa ya se valora en la imputación del injusto, por lo que la exigencia referida ahora a la valoración se referirá a qué grado de exigencia tiene el sujeto de romper la conexión inevitable entre conciencia y voluntad, para lo cual habrá que analizar las circunstancias concretas y concomitantes entre las que se desenvuelve esa conexión permitida por la primera norma y la sorpresividad de la activación normativa material de la segunda norma $^{744}$.

\footnotetext{
744 Esta idea no es del todo novedosa, por cuanto ya DARIES diferenció entre status necessitatis simplicis y status necessitatis cum adiunctione, con un criterio de distinción que gráficamente HRUSCHKA resume así: «habría un primer grupo de casos para los cuales el hecho en situación de necesidad, aunque infrinja una determinada ley, concuerda con dicho principio superior. En el otro grupo estarían los casos en los que el hecho en situación de necesidad contradice también el principio superior. En los primeros casos se trataría de una excepción, que se permite el autor de la regla de la ley infringida una «exceptio secundum leges instituta», es decir, una excepción conforme al sistema de las leyes. En cambio, en los segundos casos se trata de una «exceptio contra leges instituta», esto es, una excepción contraria al sistema de las leyes», HRUSCHKA, J., «Causas de justificación y causas de exculpación: La tabla de Carnéades en la doctrina de Gentz y Kant», HRUSCHKA, J., Imputación y Derecho penal, op. cit., p. 95 (DARIES, Joachim Georg, Observationes Iuris Naturalis, Socialis et Gentium, 1789, Vol. II, XX-XXII).

En opinión de HRUSCHKA, también KANT llegó a similares conclusiones pero con una argumentación distinta que se basa en la propia conciencia del autor. Al respecto comenta el primero que -para KANT- «una exculpación es una exposición de argumentos que sólo tienen validez ante el forum externum pero no ante el forum internum, es
} 
De otra parte, en la comprensión de esta excepción o déficit de comunicación normativo puede ayudar la temporalidad entre ejercicio de la primera y la activación de la segunda norma en relación al aislamiento cultural del autor, al grado de manipulación mental o persuasión coercitiva realizada por un tercero, a la adicción comportamental a una dinámica grupal, y al grado de obediencia a una autoridad o norma religiosa y de conciencia, en definitiva a la cotidianidad del ejercicio de la libertad de conciencia puesta en relación con el deber de actuar.

De esta manera, podemos solucionar la diferencia entre el deber puramente formal de la norma, aquel conocimiento que el sujeto tiene sobre la vigencia de la norma, es decir, el sujeto conoce que hay un deber normativo de proteger la vida de los hijos menores de edad concurrente con la vigencia normativa del ejercicio de la libertad de conciencia y la activación de ese deber materialmente (activación material e intersubjetiva de la vigencia de la norma y el estricto sujeto). En aquellos casos en los que apenas existe tiempo entre la adopción y ejercicio de un determinado motivo de conciencia, y la situación en la que se activa la norma de deber, la contraorientación normativa es menor por falta de tiempo en la socialización del sujeto por la primera norma, de modo que la segunda norma tiene capacidad de orientar la conducta del sujeto, por lo que escasamente se podrá fundamentar ni la exculpación plena, salvo que exista un déficit de socialización atribuible a tercero que haya generado tal intensidad, que exista la misma conexión inevitable entre conciencia y voluntad.

Recuérdese que supra decíamos que también cuando no se pena se cumple la función estabilizadora de la norma: se cumplen ciertas expectativas no penando. Esto sucede principalmente en dos casos. De una parte, en la legitimidad formal de la norma, aquellos casos de validez de la norma mediante el principio de legalidad y su identificación con la sociedad (no pueden instaurarse leyes imposibles de realizar), de otra, la culpabilidad como estructura por la que -como bien comenta PIÑA ROCHEFORT- «se estabilizan expectativas dirigidas al sistema jurídico-penal» ${ }^{745}$. A esto se le denomina comúnmente un estado de necesidad exculpante, por eso lo explicábamos así supra.

decir, ante la propia conciencia del autor, quien «debe juzgar como injusto» su hecho, lo mismo antes que después (...) Pero si una situación acontece de modo que ya no puede alcanzarse este fin esencial de la amenaza de pena, entonces -como afirma KANT- (...) es «incongruente» intentar lograr con el juicio al autor lo que ni tan sólo la ley penal con toda su fuerza ha impedido antes», HRUSCHKA, J., «Causas de justificación y causas de exculpación», op. cit., p. 98 (KANT., I., «Über den Gemeinspruch: Das mag in der Theorie richtig sein, taugt aber nicht für die Praxis», Berlinische Monatsschrift, Vol. 22, 1793, pp. 201 y ss.). Si bien no estamos del todo de acuerdo con la explicación de KANT, tanto en éste como en DARIES existe una argumentación que alcanza a la propia operatividad del Sistema, ya sea por falta de fuerza de la ley, o por cierta concordancia con el principio superior, respectivamente.

745 PIÑA ROCHEFORT, JI., Rol social y sistema de imputación, op. cit., p. 333. 
En el estado de necesidad exculpante, en aquellos casos en los que se identifican normativamente los males en conflicto, o se salva un mal levemente menor o mucho menor que el producido, el sujeto está en un estado de naturaleza, trata de proteger su vida aun en perjuicio de otro. Por eso el sistema-jurídico penal no puede entrar a valorar dicha conducta, aunque a esta falta de valoración se le ha puesto en la doctrina penal el nombre de causa de exculpación: ¡Usted Derecho, no puede valorar mi libertad, ni positiva ni negativamente! Sin embargo, cuando el mal causado es mayor levemente o mucho mayor que el que se evita, en determinadas ocasiones como en la autoría de conciencia, por convicción o en el enemigo, se puede produce un déficit de socialización, unas veces a causa del déficit de comunicación de la norma (o por contraorientación normativa), otras veces atribuible a tercero, que de igual modo fundamenta la exculpación completa a pesar de causarse significativamente un mal mayor que el que se evita. Esto se debe a que en el obrar del autor se han introducido operaciones con las que cuenta el Sistema, ya sea atribuible directamente a éste o a un tercero. En ambos casos, el Sistema ha contabilizado esta posibilidad en su propia operatividad, lo que reafirma la idea de que dicho comportamiento se ajusta en mejor medida al Sistema que aquellas otras que lo combaten directamente, lo que significa que no existe más que el aprovechamiento de los recursos del Sistema, cual parásito: por eso su exclusión.

En el autor de conciencia, máxime en los delitos de omisión pura, el sujeto no se ha «enrolizado». Esta falta de socialización no se debe al propio sujeto sino al ordenamiento jurídico que lo ha socializado conductivamente en otra dirección, por eso después, o no se puede penar porque la conducta es atípica, o puede exculparse porque el fallo procede no ya del sujeto sino de una contraorientación de la socialización de la norma. Dicho de otro modo, se puede atribuir la responsabilidad al Sistema jurídico y social, de suerte que merezca la exculpación por formar parte de la propia operatividad total del Sistema. La norma defrauda al rol del sujeto porque en la determinación de la conducta prohibida no se puede exceder el límite que el propio Sistema ha atribuido al rol, negando la culpabilidad, lo que parecería significar una contraorientación de la propia Sociedad, sin embargo lo que en verdad se produce es la contraorientación de la norma con la Sociedad, o falta de identidad entre norma y Sociedad.

En el autor de conciencia sucede que, si bien el ciudadano debe prever las decisiones que adopta el sistema del derecho, en ocasiones el sistema jurídico no puede adoptar decisiones con base a la previsión que haga sobre las consecuencias de otras de sus decisiones. La exculpación por inexigibilidad no sólo se asienta en la incapacidad del sujeto para orientarse conforme a la norma en el sentido de la inimputabilidad, sino que existen otras causas reprochables a la misma 
norma cuando entra en contraorientación con la Sociedad, o en causas basadas en déficits de socialización en el autor pero cuyo comportamiento está socialmente adecuado. La limitación que hace JAKOBS a la aplicación del estado de necesidad exculpante, cuando existen deberes institucionales o por organización ${ }^{746}$, tiene la excepción de la autoría de conciencia, gráficamente representada en la intercambiabilidad de la acción y la omisión ${ }^{747}$. De tal manera, no vemos impedimento en aplicar el estado de necesidad exculpante en supuestos de responsabilidad institucional o por organización, que además de en la autoría de conciencia, también en la autoría por convicción y en el enemigo. En este sentido, también JAKOBS diferencia, en verdad, al autor de conciencia y por convicción en la posibilidad de que se represente el hecho como amenazante, no susceptible de generalización, o como hecho peligroso ${ }^{748}$, en definitiva, se rige por la medida en que el conflicto pueda dañar al orden normativo ${ }^{749}$. Así no hay impedimento en que se aplique tanto a conductas de responsabilidad institucional, por organización, o en el autor por convicción o en el enemigo, también en el de conciencia en supuestos especiales, tales como el déficit de socialización del autor, cuando dicho déficit es atribuible a terceros, por ejemplo cuando haya sido educado incorrectamente o inducido a situaciones de fragilidad comprensibles («aislamiento cultural» / «obediencia ciega a la autoridad»).

Sin embargo, JAKOBS también fundamenta la exculpación plena o parcial, cuando el sujeto, ante un deber institucional no dispone de alternativa de organización de dicha institución pero en la que la organización no viene informada por el deber (recuérdese al respecto el ejemplo que expone: la negativa de un médico al aborto, en la que si bien el médico tiene un deber de actuar institucionalizado tiene la oportunidad de organizar dicho deber de tal manera que elimine la posición de garante, sin afectar a la norma ni crear un daño, como por ejemplo en los casos de los padres testigos de Jehová que rechazan la asistencia vital para el hijo menor de edad), y acepta una posible exculpación plena o parcial en virtud de la configuración de la organización previa al daño. Acepta también que cuando la víctima consiente la reducción de su protección, como por ejemplo el caso de quien conoce que su pareja rechaza la trasfusión, y llegado el día, y ante la imposibilidad de negarse el necesitado, no consiente la asistencia médica ${ }^{750}$.

En nuestra opinión, estas situaciones a las que se refiere JAKOBS, por falta de información sobre la alternatividad de la conducta, se explicarían por el déficit de comunicación/socialización atribuido a la norma, sin que sea necesario referirse en todo

746 JAKOBS, G., PG, op. cit., 20/13.

747 ID., ibidem, op. cit., 20/27.

748 JAKOBS, G., «El lado subjetivo del hecho», op. cit., p. 98.

749 JAKOBS, G., $P G$, op. cit., 20/22.

750 ID., ibidem, op. cit., 20/24. 
momento a la falta de alternativa de organización por falta de información de la forma de organización en el deber.

Es cierto que hemos fundamentado la autoría por convicción, y especialmente el enemigo, en el desprecio de las conductas alternativas que ofrece el Sistema, sin embargo, la falta de información de alternativas a la que se refiere JАKOBS en el contenido del deber viene motivada por la socialización previa que realiza la norma fundamental del libre ejercicio del derecho a la libertad de conciencia, de manera que la falta de alternativa en el cumplimiento del deber viene causada por la sorpresividad de la activación del contenido material de la norma, no porque ésta no informe o no tenga el deber de informar además cómo debe el sujeto adecuar su comportamiento. Si bien es cierto que una menor información de la norma en los deberes de actuar, supone una mayor contraorientación normativa respecto a la norma que previamente ha socializado al sujeto en el ejercicio de la libertad de conciencia.

Todas estas situaciones redundan en el déficit de comunicación/socialización de la norma: la falta de alternatividad o de información normativa sobre la alternatividad, viene producida por la contraorientación normativa que supone la cimentación cognitiva de una orientación normativa que la norma previa ha permitido, y por la que se ha socializado normativamente el sujeto. En conclusión, la principal diferencia que distingue al autor de convicción o enemigo con el de conciencia, bajo el presupuesto de una conducta libre, radica en las alternativas sociales y normativas de que dipone el primero y carece el segundo.

2. Déficit de socialización del autor de conciencia, del autor por convicción y del enemigo atribuido a tercero

Las circunstancias que hemos señalado referentes a «aislamiento cultural», «adicción comportamental», «manipulación mental» o «persuasión coercitiva» y «obediencia a la autoridad», redundan todas en el déficit de socialización del autor atribuible a terceros, concretamente a las situaciones de educación incorrecta o inducción a situaciones de fragilidad comprensibles a las que se refería JAKOBS.

En concreto, el aislamiento cultural se refiere a situaciones en las que el sujeto está alejado de la Sociedad y su Sistema, sin contacto con el mundo normativo y el sistema social. Sirva el ejemplo de algunos grupos religiosos que se apartan de la sociedad y habitan en poblados, lugares campestres, etc., o en situaciones de clausura religiosa en monasterios aunque sea en áreas urbanas. Se suele utilizar por parte de la doctrina el concepto de aislamiento cultural también en situaciones de error de prohibición vencible o invencible en relación a extranjeros 
que proceden de culturas menos desarrolladas y llegan a sociedades altamente normativizadas. Por último, también el aislamiento cultural se puede referir a sociedades normativizadas pero dictatoriales o totalitarias que provocan en el sujeto una socialización criminal desde la niñez o la juventud como lo acontecido con algunos jóvenes nazis en el Tercer Reich. Como puede apreciarse, el aislamiento cultural evoca la desocialización respecto a culturas altamente diferenciadas.

La adicción comportamental suele relacionarse a problemas de conducta compulsiva relacionada al juego y a las drogas, si bien también puede referirse especialmente a situaciones de adoctrinamiento totalitario o a dinámicas grupales que estimulan al sujeto a una rápida satisfacción de sus carencias a través de comportamientos relacionados con la voluntad de un tercero, o de un grupo, que representa una autoridad o estímulo que sacia las expectativas más básicas del sujeto, a la vez que le impide o dificulta la elección de otras. La adicción comportamental se ha relacionado con las conductas de miembros de grupos religiosos sectarios, y por ende, muchas de las veces a situaciones de aislamiento cultural.

La manipulación mental, o tradicionalmente denominada lavado de cerebro, se relaciona por la psicología más combativa a procesos o técnicas fisiológicas y/o psicológicas de anular o disminuir la capacidad de voluntad. Por nuestra parte hemos preferido otra terminología, según explicaremos en el capítulo cuarto, que se adecúa mejor a la realidad de las consecuencias del uso de estas técnicas: persuasión coercitiva. En ésta, el sujeto, sin perder su capacidad de voluntad natural, disminuye su capacidad de voluntad en relación a su capacidad de elegir otras expectativas, el horizonte de expectativas está muy restringido y/o condicionado a la elección de una expectativa contra la norma, si bien entre la adicción comportamental y la persuasión coercitiva está la diferencia de que la primera puede proceder también de causas propias del sujeto como en cualquier adicción, y la segunda suele proceder de la actividad de un tercero o grupo.

Por último, la obediencia a la autoridad se relaciona con conducta voluntarias de sumisión a una autoridad que pueden adoptar la forma de orden, palabra, doctrina, norma jurídica o de dinámica comportamental de un grupo de personas determinado a los que se les asocia el rol de autoridad o poder, de tal forma que el sujeto disminuye su capacidad crítica. La obediencia puede llegar a ser ciega en contextos de aislamiento cultural, de adicción comportamenal, etc. La forma más grave y representativa de la obediencia ciega evoca algunas conductas de ciudadanos alemanes durante el Tercer Reich. 
De esta manera, estas circunstancias tienen el denominador común de producir en el sujeto la incapacidad de orientarse conforme a la norma, de tal modo que producen el déficit de socialización, si bien en estos casos el déficit es atribuible a un tercero. En contra de la opinión de parte de la doctrina que se ha ocupado sobre el tema, no creemos que estas circunstancias -la doctrina se refería normalmente a fanáticos, a situaciones de aislamiento cultural, y a las sectaslleven siempre y per se a un trastorno mental de modo que la solución al problema venga exclusivamente de la inimputabilidad del autor por el delito, o a una lesión psicológica que motivase una explicación en la autoría mediata, porque consideramos que estas situaciones se pueden dar de tal forma que exclusivamente produzcan un déficit de socialización, mientras que la lesión psicológica será únicamente una consecuencia de la gravedad del déficit de socialización.

No obstante, la atribución a un tercero de este déficit de socialización supone, en nuestra opinión, un delito de coacciones al que podemos denominar especialmente de "persuasión coercitiva», pero cuya peligrosidad y gravedad no vienen recogidas en el injusto de coacciones de forma clara. Estos déficits de socialización atribuidos a tercero pueden concurrir en las organizaciones criminales, especialmente en las sectas criminales, donde coexisten de manera muy acusada las tres tipologías criminales. De este modo, en el capítulo quinto y siguientes, abordaremos, tras unas nociones criminológicas de las sectas en el capítulo cuarto, la descripción y tratamiento penal al que llevan estas circunstancias que producen el déficit de socialización en la autoría de conciencia, por convicción y en el enemigo, y en su consecuencia, la posibilidad de aplicación de la eximente de estado de necesidad exculpante. Podemos anticipar también que en todas las tipologías puede concurrir el déficit de socialización atribuido a tercero, de tal manera que la dinámica criminal alcanza relevantes consecuencias en el tratamiento penal del delito de organización o sistémico, en la coautoría y en la autoría mediata de aparatos de poder organizados.

De aquí que no podamos estar de acuerdo con el criterio de SANTA RITA, que no deja espacio alguno a la inexigibilidad en casos de convicción ${ }^{751}$ (o conciencia/«exóticos»), excluyendo casos objetivamente constatados de déficit de socialización. La forma de categorizar al enemigoterrorista que emplea le hace confundir comunicación con dolo. El Derecho penal de enemigo combate focos de peligro, de forma que al Sistema Social y concretamente al de expectativas, le es indiferente que las operaciones se realicen dolosa o imprudentemente, o supongan delitos de peligro como los de posesión. También conductas imprudentes o despreocupadas pueden poner

751 SANTA RiTA, G., El delito de organización terrorista, op. cit., pp. 569 y 570. 
en peligro al Sistema, y de aquí que POLAINO-ORTS ${ }^{752}$ haya incluido que diversas normas como los delitos de posesión, contra el tráfico vial, la reincidencia y la habitualidad están dentro del Derecho penal del enemigo, a pesar de reconocer SANTA RITA ${ }^{753}$ que la posesión de armas o instrumentos peligrosos aumenta la gravedad, si bien se refiere exclusivamente a los delitos de organización terrorista.

No podemos compartir los criterios que, normalmente desde la doctrina funcionalista, niegan la compatibilización del concepto de enemigo y por tanto la virtualidad del Derecho penal del enemigo, en aquellos sujetos que actúan, si bien con enemistad manifiesta, bajo causas de inexigibilidad por déficit de socialización, y esto es porque la enemistad no versa sobre la disposición exclusivamente subjetiva del sujeto, sino que trasciende objetivamente en su comportamiento como ataque o peligrosidad al Sistema Social, lo que también es trasladable en iguales términos al de autor de conciencia y al autor por convicción. De aquí viene el fundamento de la contingencia de la comisión imprudente o estrictamente peligrosa de todas las tipologías referidas con las salvedades hechas.

\section{G. Fundamentos especiales del déficit de socialización del autor de conciencia atribuido}

a la norma: reformulación de los requisitos del estado de necesidad exculpante

En nuestra opinión, el estado de necesidad exculpante que se puede apreciar por el déficit de socialización atribuido a la norma modifica los requisitos que tradicionalmente exige la doctrina mayoritaria. Esto se debe a que el déficit normativo particular que se produce en el sujeto relaja o modifica las exigencias normativas del estado de necesidad exculpante.

\section{La gravedad}

La gravedad se exige en la probabilidad de peligro para el sujeto. Esto significa que el sujeto conoce que se va a producir una alta probabilidad de un perjuicio para algún bien jurídico, pero a la vez cuál es el mal que se va a producir. En nuestro ámbito de estudio, el sujeto puede conocer que se va a afectar a su libertad de conciencia pero de forma tan insignificante (por ejemplo pagar impuestos que conoce que en alguna parte van destinados a sufragar presupuestos armamentísticos) que no le afecte en su conciencia. Este postulado, habitualmente aceptado por la doctrina, se ve relajado o modificado en la autoría de conciencia o por convicción imprudente. Es posible que el autor, a causa de ese déficit atribuido a la norma, o a un tercero, no conozca

\footnotetext{
752 Polaino-OrTs., M., Derecho penal del enemigo. Fundamentos, op. cit., pp. 200 y ss. pp. 355 y ss. pp. 482 y SS.

753 SANTA RITA, G., Los delitos de organización terrorista, op. cit., p. 218.
} 
dicha probabilidad pero obre conforme a conciencia incurriendo en el delito imprudentemente o en delitos de peligro según hemos explicado supra.

También la situación de necesidad exculpante se puede dar en casos que no sólo se refieren a conservar la posición o el bien jurídico, en contra de la opinión de gran parte de la doctrina ${ }^{754}$, sino también en aquellas situaciones en las que dolosamente se pretende mejorar la posición o el bien jurídico. Estos últimos casos se pueden comprobar, especialmente, en la autoría de conciencia, por convicción y en el enemigo, cuando por un déficit de socialización atribuido a un tercero el autor está obligado a mejorar su posición por orden, mandato o adecuación a la dinámica criminal de la organización. Sin embargo en el autor de conciencia que obra con el fin de mejorar su situación, no se le puede comprender un déficit de comunicación/socialización atribuido a la norma, puesto que su límite está en que el sujeto no aproveche dicho déficit para mejorar su situación, de lo contrario no podríamos haber concluido que la norma le había socializado previamente. Si la mejora, habrá que comprobar si su conducta viene a causa de un déficit de socialización atribuido a un tercero o a él mismo.

\section{El mal}

El mal puede producirse, en nuestra opinión, en un amplio catálogo de bienes, si bien en el autor de conciencia, autor por convicción y en el enemigo, todos los males se refieren al derecho de la libertad de conciencia, ideológica, política o, en definitiva, a la moral. La procedencia del mal puede ser típica o natural, pero en todo caso real, en caso contrario, si falta la realidad del mal, estaríamos ante un miedo insuperable u otra circunstancia.

Según lo expuesto, la situación de necesidad ha podido ser provocada culpablemente por el autor de conciencia que tiene un déficit de comunicación atribuible a la norma en aquellos casos de responsabilidad por organización en la creación de un riesgo o elevación de un riesgo antijurídico, también en la responsabilidad institucional, incluso dolosamente. De igual modo, tampoco se exige la obligación de sacrificarse. En este sentido, el déficit produce también conductas dolosa o imprudentemente provocadas.

En los supuestos de autor de conciencia, por convicción y en el enemigo que sufren un déficit de socialización atribuido a la norma (o a tercero), no se precisa la falta de provocación en la exculpación, o la falta de obligación de sacrificarse que en coherencia se exige generalmente en el estado de necesidad exculpante, puesto que la situación de déficit de la norma ocasiona directamente situaciones de provocación por el autor, o la inobservancia del deber de sacrificarse

\footnotetext{
754 MARTín LOREnZO, M., La exculpación penal, op. cit., p. 423.
} 
o su doloso o imprudente incumplimiento. Entonces, como ya concluimos, tampoco se exige la proporcionalidad de los males, o aquel axioma de que no se puede ocasionar un daño relevantemente mayor como exige la doctrina en supuestos generales ${ }^{755}$.

Se precisa también que la conducta se adecúe a la necesidad o la amenaza de forma ex ante e idónea para repelerlas con el fin de conservar la vida, la integridad o la libertad de conciencia en nuestro caso, aunque también es posible en otros bienes como los patrimoniales. De tal manera que la especialidad que se produce en la autoría de conciencia con déficit normativo es que la necesidad no se refiere a la «irreparabilidad» ${ }^{756}$ del bien o del derecho, o a su «importancia o insustituabilidad $^{757}$, sino exclusivamente a la conexión ineludible entre conciencia y voluntad que la norma ha permitido mediante la socialización.

\section{Subjetividad}

Sobre el elemento subjetivo «para evitar un mal», al igual que parte de la doctrina, consideramos que no existe equiparación entre el elemento subjetivo en el estado de necesidad justificante y el exculpante, máxime en las situaciones especiales de la autoría de conciencia, por convicción y en las del enemigo, por un lado, por la conexión irresistible entre conciencia y voluntad, por otro lado, por el déficit normativo o de socialización.

\section{Punibilidad}

De todo lo anterior se fundamenta la falta de necesidad de una pena cuando exista un grado tan intenso de déficit normativo y de socialización. En el caso del déficit de comunicación/socialización normativo del autor de conciencia, la pena no respondería a criterios de socialización por cuanto el autor de conciencia obra a causa de una previa socialización normativa. El sujeto ya está socializado.

Por el contrario, en situaciones de déficits plenos de socialización atribuido a un tercero, la pena será incapaz de resocializar al sujeto por cuanto el sujeto es incapaz de comprender el

\footnotetext{
755 En el ejemplo que expone MARTín LORENZO de que en los motivos de un policía, que en un asalto emplea a un civil como escudo, no existen motivos de comprensión, la obligación de sacrificio es correcta cuando no interviene un déficit de socialización atribuido a la norma, ID., ibidem, op. cit., p. 349, pero con el límite de la alta probabilidad de muerte. Si bien explica que existe una diferencia entre la falta de provocación, cuyo fundamento está en la causación de un peligro, y la obligación de sacrificarse, que está en un deber previamente configurado al peligro, ID., ibidem, op. cit., pp. 446 y ss.

756 ID., ibidem, op. cit., pp. 424 y 425 y pp. 450 a 452, si bien reconoce que normalmente esa gravedad vendrá del rango existencial, ID., ibidem, op. cit., p. 431.

757 JAKOBS, G., $P G$, op. cit., 17/14.
} 
significado de la pena. En estos casos, parece lógico aplicar una medida de seguridad resocializante adecuada a la intensidad y tipo de desocialización.

En todos los casos en los que el déficit no sea tan intenso y claro que justifique el estado de necesidad exculpante completo, sino el incompleto, de igual manera parece lógico concluir que una pena no tendría sentido resocializador en el sujeto, y si una medida de seguridad proporcional a dicha intensidad semi-plena. 


\section{Capítulo III}

\section{CONFLiCTOS DE CONCIENCIA PARTICULARES EN SECTAS}

\section{I.- La problemática del derecho a la muerte}

\section{A. Introducción: La ética médica como presupuesto previo al conflicto moral}

No podemos olvidar en este tipo de investigación relacionada con la moral las cuestiones éticas y los derechos de los pacientes en los tratamientos médicos. Comenzamos dando algunas nociones introductorias para la mejor comprensión de lo que luego analizaremos: los conflictos morales y jurídicos en el ámbito sanitario y la libertad de la voluntad en supuestos límite.

¿Qué es la ética médica? Desde antigüedad la actuación médica se rigió por los principios de paternalismo, de beneficencia y no maleficencia (primun non nocere) y en buena medida por el juramento hipocrático y el Código deontológico de la profesión médica, pero pasada la mitad del siglo XX, y en concreto desde los años setenta en que aparece la bioética, el cambio se produjo de forma drástica. En concreto, el orden jerárquico de los principios que rigen la actuación del médico en su actividad profesional, en opinión de la mayor parte de la doctrina actual, son el principio de justicia, al que se vincula el principio de no maleficencia, el principio de autonomía del paciente de raíz kantiana (contrapuesto al paternalismo o principio de intervención) y por último el principio de beneficencia. El reconocimiento de estos principios, que se reflejan finalmente en los derechos del paciente y del médico, son en definitiva el reconocimiento de la dignidad de la persona. Este reconocimiento de la dignidad lleva a constatar, a la vez, el reconocimiento de la libertad de conciencia al estar estrechamente vinculada a la dignidad.

Desde el reconocimiento de los derechos fundamentales de primera, segunda y tercera generación, se concibe la dignidad como derecho vinculado al derecho de la libertad de conciencia. Esto muestra la sensibilización y apogeo de lo que yo entiendo como uno de los derechos más importantes, la libertad de conciencia, y sobre el que gira nuestra voluntad de obrar en general.

El principio de autonomía corresponde a la manifestación jurídica de la voluntad de actuar en general, del que se deriva el consentimiento informado al que tiene derecho el paciente, en los tratamientos médicos, como constatación de su dignidad. Si bien este principio rige en cualquier 
otro ámbito, tradicionalmente se ha limitado por intereses generales, cuando afecta a la autonomía de la voluntad de otra persona. Sin embargo, como veremos en este capítulo, la mayoría de las veces no existe más fundamento de limitación que la interpretación moralista de los derechos conforme al sentir general, lo que en nuestra opinión se contradice con una interpretación estrictamente normativa. Esto se podrá ver en los casos de «autopuestas en peligro» $\mathrm{y}$ en «auxilio al suicidio» o «eutanasia», en los que aún hoy parece imperar en nuestra opinión una injustificada restricción del principio de autonomía de la voluntad, y por eso suponen casos tradicionalmente vinculados a la autoría de conciencia, y en otras, a la autoría por convicción o al enemigo.

\section{B. La vida y su calidad: en busca de la «paradoja de la moral universal»}

De los principios de justicia, no maleficencia, autonomía y beneficencia, que hemos visto como principios éticos de la actuación médica anteriormente, se desliga el valor excepcional de la vida y dignidad de la persona. Así pues, en materia de tratamientos médicos, aborto y eutanasia, es decir, sobre el valor de la vida y la muerte, y en muchas otras cuestiones, se contraponen dos postulados morales que tienen trascendencia penal.

En primer lugar, el postulado moral de la santidad de la vida, idea de procedencia judeocristina, se puede sintetizar -en opinión de ROMEO CASABONA- en que «este principio se vincula a una concepción biológica de la vida humana (...) como un proceso vital o físico-biológico, sin consideración a posibles deficiencias físicas ni a las concretas funciones o capacidades específicamente humanas, y es el que por lo general sirve (o ha servido hasta el presente) de referencia principal o exclusiva al Derecho» ${ }^{758}$. Es entonces, la santidad de la vida, esa postura que sacraliza la vida por encima de cualquier situación, siempre y cuando exista la vida misma, y adopta ante el aborto y ante la eutanasia un total rechazo.

Por otro lado, el principio de calidad de la vida «parte de que aquélla es un valor relativo (aunque susceptible de objetivación), y como tal sólo existe mientras se mantenga en la persona un cierto nivel de «calidad» ... no excluida a priori de toda ponderación de intereses, centrados en la capacidad del individuo de sostener autoexperiencia y relación o comunicación con los demás, o de asumir los propios actos» ${ }^{759}$.

Tradicional y erróneamente las legislaciones han tratado de plasmar una moral universal, cuyo resultado es la DUDH y su art. 29.2: «asegurar el reconocimiento y el respeto de los

\footnotetext{
758 Romeo CASABONA, CMa , El Derecho y la Bioética, op. cit., p. 40 y 41.

759 ID., ibidem, op. cit., p. 41.
} 
derechos y libertades de los demás y de satisfacer las justas exigencias de la moral, del orden público». Se introduce la moral pública como moral universal, por eso, erróneamente, se ha interpretado como un límite de derechos y libertades, de lo que deviene aquella contraorientación normativa y de observación, a la que aludíamos en los anteriores capítulos.

Consideramos que aunque la vieja fórmula kantiana que dice «obra sólo según una máxima tal que puedas querer al mismo tiempo se torne ley universal» es cierta, en cuanto que entiende el Derecho como libertad, dicho postulado se utiliza incorrectamente y por muchos, para otorgar mayor valor a la vida que a la libertad de decisión, como si la vida en sí misma fuere una ley universal de la naturaleza o un deber de todas las cosas.

Empero, poca libertad tendría el ser humano si en los asuntos que exclusivamente a él le atañen se aplicase el valor considerado por la mayoría. En este caso, tanto en la eutanasia como en el aborto, el debate no se puede centrar sobre qué valor tiene la vida, sino qué valor y fuerza tiene la libertad del ser humano como expectativa legítima. Si bien en la eutanasia se puede defender, desde esta postura que planteamos acorde al principio de autonomía de la voluntad y a la libertad de conciencia y de actuar en general, que existe el derecho a decidir sobre la propia muerte porque de forma clara no se afecta directamente a ningún tercero, el debate es estrictamente moral, se centra en la disponibilidad de la propia vida, como si esto fuera debatible normativamente.

En el caso del aborto, el debate se recrudece porque interviene un tercero, el pre-embrión, embrión o feto. Dispone el art. 15 CE, en concordancia al art. 3 DUDH y otras Declaraciones, que «todos tienen derecho a la vida», pero la vida es un derecho que no se protege de forma absoluta. También significativo es la vinculación que hace el TC en Sentencia 53/1985, de 11 de abril, FJ $3^{\circ}$, donde declaraba que el derecho a la vida es la proyección un valor superior del ordenamiento jurídico como es la vida humana, conectado estrechamente con el valor jurídico de la dignidad de las personas.

Cabe destacar, a la vez que criticar, que finalmente el TC consideró ese «todos» del art. $15 \mathrm{CE}$ parcialmente aplicable al nasciturus. Aunque no le reconoce el derecho a la vida ni que la titularidad sea de éste, sí que reconoce que el bien jurídico que encarna es digno de protección ${ }^{760}$.

760 Como dice SouTO PAZ, «(e)1 TC no encuentra ningún argumento, ni en el Derecho español ni en el Derecho comparado, para afirmar tal cosa», SoUTO PAZ, JA., Comunidad política y libertad de creencias, op. cit., p. 356; o como dice ROMEO CASABONA, al rechazar el TC que «el nasciturus tenga derecho fundamental a la vida, que sea titular del mismo; ese "todos" parece incluirle, pero no es suficiente para acreditarle el "derecho" fundamental. Sin embargo, si la "vida" humana constituye un valor fundamental protegido constitucionalmente y, como dice el TC, el nasciturus encarna tal valor, es lógico que se extienda también a él -al valor que encarna- el ámbito de protección constitucional», Romeo CASABONA, CM ${ }^{\mathrm{a}}$., El Derecho y la Bioética, op. cit., p. 87. 
En nuestra opinión, el razonamiento del TC parece más bien una intuición o al menos parece ese deber ser moral idealista que se ha prolongado a lo largo del tiempo. En estos casos ha de primar el valor de la libertad en tanto que la potencialidad que supone la concepción de una vida cede ante una expectativa legítima. Lo contrario significa una contraorientación normativa por la aplicación de una interpretación moralista particular aunque esté generalizada. Con esta forma incorrecta o moralista de valorar, en el caso del aborto, se otorga mayor libertad a la potencialidad de una vida. La expectativa no es del nasciturus sino es una expectativa del padre sobre la expectativa de este. Una vida que aún no es libre no tiene expectativas. La libertad es el producto de la elección de un horizonte de las expectativas legítimas, no de la simple suma de expectativas particulares. Por eso la legitimidad procede de la estructura de la expectativa en el Sistema, si esa expectativa se adecúa al procedimiento del Sistema: en este caso si la expectativa del padre es la única aplicable al caso. La expectativa de una expectativa de una expectativa constituiría la paradoja de la moral, aquella que no se puede siempre cumplir.

\section{El consentimiento informado y el derecho a no consentir un tratamiento médico vital por} su titular o para tercero

El consentimiento informado ${ }^{761}$ es un derecho y principio regulador de la actividad médica, que nace del principio de autonomía. Tiene sus precedentes en las normas de experimentación con seres humanos del Tercer Reich del año 1931. Tras la Segunda Guerra Mundial, y tras los Juicios de Núremberg, el Código del mismo nombre de 1949 proclamó la necesidad del consentimiento informado del paciente para la experimentación humana, cuya trascendencia se vio prontamente en todas las regulaciones.

El fundamento del consentimiento informado en la actuación médica, como ya expuso Arthur KAUFMANN $^{762}$ es el deber de explicación suficiente para cumplir con ello el mandato de la libertad del ser humano o autodeterminación, de tal manera -y como exponen POLAINO-LORENTE y POLAINO NAVARRETE- que «(l)a omisión del deber de aclaración médica sobre los extremos de las consecuencias peligrosas que pueden derivarse para el sujeto del tratamiento concreto, en consideración a las peculiares características del paciente singular, permite determinar la

\footnotetext{
761 Muy ampliamente sobre la evolución histórica y filosófica y plasmación normativa, SIMÓN, Pablo, El consentimiento informado. Historia, teoría y práctica, Ed. Triacastela, Madrid, 2000.

762 Vid. Polaino-Lorente Aquilino / Polaino NAVARRete Miguel, «Dimensiones Psicológico-Psiquiátrica y Jurídico-Penal en el ejercicio de la sofrología», Revista de Estudios Penitenciales, núm. 204 a 207, 1974, p. 34.
} 
responsabilidad penal del médico por un delito contra la vida o la salud o contra la libertad individual» ${ }^{763}$.

Esto es, en esencia, el consentimiento informado, la información completa y comprensible de los extremos controvertidos en los que se encuentra el paciente, para que pueda formar una decisión de forma libre y consciente. La trascendencia del derecho al consentimiento informado tiene especial interés, en su forma negativa de rechazo de un tratamiento médico vital, y en la configuración típica del deber de los padres de consentir un tratamiento vital para el hijo menor. Por nuestra parte, concluimos con parte de la doctrina ${ }^{764}$ que aquellas situaciones en las que existe el derecho a rechazar un tratamiento, éstas son las que afectan al propio sujeto, no pueden considerarse verdaderos conflictos de conciencia porque no existe obligación jurídica alguna de soportar un tratamiento vital que vulnere la integridad física, ni se exige normativamente apelar al motivo de conciencia, sino que es intranscendente por cuanto se reconoce el principio de autonomía del paciente. Sin embargo, hay determinadas situaciones límite, que conviene aclarar, como aquellas en las que el paciente está inconsciente, o es un menor, y parece trasladarse normativamente el deber de consentir, cuya falta polemiza la imputación del delito de omisión del deber de socorro.

En España, el consentimiento informado se reguló por primera vez en la Ley General de Sanidad 14/1986, de 25 de abril, aunque la Ley 41/2002 de 14 de noviembre, básica reguladora de la autonomía del paciente y de derechos y obligaciones en materia de información y documentación clínica, lo reguló más ampliamente en los arts. 8, 9 y 10.

El precepto 10.5 de la LGS, en su vigencia de 1986, regulaba el derecho de elección del paciente, mientras que el derecho que consistía en la posibilidad de rechazar un tratamiento médico se articulaba en el art. 10.9 de la misma ley, excepto en los casos que señalaba el art. 10.6: a) cuando suponga la no intervención un riesgo para la salud pública, con lo que su consentimiento es innecesario; b) no teniendo capacidad para decidir (minoría de edad o incapacidad), trasladándose la decisión a familiares y allegados, con lo que su consentimiento no es válido; c) cuando exista peligro de lesiones irreversibles o de muerte, con lo que el rechazo no se torna necesario, pues existe obligación de actuar por los servicios médicos o terceros.

Con esta normativa, se podían sustentar dos interpretaciones de los apartados 9 y 6 del art. 10, conforme explicaba ROMEO CASABONA:

763 ID., ibidem, op. cit., p. 36.

764 BAUCELls i LlADÓs, J., La delincuencia por convicción, op. cit., p. 223 y ss; sin exigir un motivo de conciencia, Flores MendozA, F., Objeción de conciencia, op. cit., pp. 33 y ss; JeRICó OJER, L., El conflicto de conciencia, op. cit., p. 300. 
Primera: «a) es necesario el consentimiento previo del paciente para iniciar cualquier tratamiento; b) aquél -el consentimiento- no es necesario en casos de urgencia, etc., porque no es preciso esperar a que el paciente (o sus familiares) se halle en condiciones de poder consentir; c) el paciente tiene derecho a rechazar un tratamiento; d) el paciente no tiene derecho a negarse al tratamiento en los supuestos de la conclusión b)», es decir, en los casos del apartado 6 del art. 10, «sino tan sólo cuando no haya urgencias y permitan demoras (...); estos supuestos constituyen supuestos por lo general poco vinculados con la eutanasia, con el deseo de morir del paciente para terminar con sus sufrimientos» ${ }^{765}$. Conforme a esta interpretación, no se permite que las personas pongan en peligro su vida, al menos cuando no exista tiempo para demoras.

Una segunda interpretación sería aquella que interpretaba el art. 10.9 de la LGS sólo referente a casos de inconsciencia o sin capacidad para decidir, como en casos de Alzheimer, por lo que el sujeto tendría derecho a poner su vida en peligro cuando tuviera capacidad de decidir y estuviera consciente a la hora de emitir tal declaración.

Apoyamos la segunda de las interpretaciones, tal y como lo hacía la doctrina mayoritaria ${ }^{766}$, pues si el hombre es libre cuando tiene raciocinio para decidir y actuar, sólo cuando tiene sus capacidades mentales en estado normal para discernir puede ejercitar su libertad libremente.

En la famosa Sentencia del TC sobre la huelga de hambre de los presos del grupo GRAPO (STC de 27 de junio de 1990, FJ núm. 7), el TC declaró que «(u)na cosa es la decisión de quien asume el riesgo de morir en un acto de voluntad que sólo a él afecta, en cuyo caso podría sostenerse la ilicitud de la asistencia médica obligatoria o de cualquier otro impedimento a la realización de esa voluntad», y otra cosa es la decisión de quienes se hallan sometidos en el seno de una relación especial penitenciaria. Aquí el TC diferenciaba el ámbito penitenciario del sanitario. En el penitenciario, la administración está obligada a asistir a los sujetos que ponen en peligro su vida. Pero en el ámbito sanitario, los sujetos tienen derecho a poner en peligro manifiesto y grave su propia vida, para hacer efectivo el derecho a rechazar un tratamiento

765 Romeo Casabona, CMª, El Derecho y la Bioética, op. cit., p. 438, afirma que «si bien es cierto que evidencia una defectuosa técnica legislativa y, en cualquier caso, una remisión innecesaria, es la única interpretación admisible secundum constitutionen, dándole, al mismo tiempo un sentido razonable al citado art. 10 núm. 9 de la LGS; de lo contrario, habría que entender inconstitucional la LGS conforme a la primera interpretación». En el mismo sentido «se puede afirmar que el paciente adulto y mentalmente sano tiene, en principio, la libertad de negarse a todo tratamiento, consecuente de una decisión, seria y responsable, incluso aunque al rechazarlo ponga en peligro su vida hasta el punto de sobrevenirle la muerte», ID., ibidem, p. 439.

766 Flores MendozA, F., Objeción de conciencia, op. cit., pp. 341, 346 a 349; RoMEO CASABONA, CM ${ }^{\mathrm{a}}$, El Derecho y la Bioética, op. cit., p. 434; RuIZ Miguel, A., «Autonomía individual y derecho a la propia vida», op. cit., p. 136. En otro sentido, DíEZ RIPOLLÉS afirmaba que bastaría una situación de urgencia, como la falta de tiempo para explicar las alternativas e informar, para limitar el derecho de consentimiento del paciente, DíEZ RIPOLLÉS, JL., «La huelga de hambre en el ámbito penitenciario», $C P C, 30,1986$, p. 623, nota 72. 
médico, cosa que no elimina el deber de terceros o de los facultativos de actuar en auxilio en casos de inconsciencia y falta de declaración del paciente.

El TC, en la Sentencia núm. 120/1990, de 27 de junio, refiriéndose al caso de la huelga de hambre mantenida en las prisiones por parte del grupo GRAPO, declaró taxativamente que «no es posible admitir que la Constitución garantice en su art. 15 el derecho a la propia muerte, y, por consiguiente, carece de apoyo constitucional la pretensión de que la asistencia médica coactiva es contraria a ese derecho constitucionalmente existente» ${ }^{767}$.

El problema que plantea el caso de huelga de hambre por estos presos viene en determinar cuándo se produce el estado de peligro manifiesto y grave de muerte, para que la intervención sobre ellos no vulnere otro derecho fundamental como es la integridad física. Según el TC, será lícito actuar para salvar la vida cuando la falta de alimentos que provoca la huelga de hambre llegue a un estado tal que verifique el peligro manifiesto. Este peligro y licitud de la intervención, puede ser como criterio indicativo, el inicio de la inconsciencia del sujeto, aunque bien es cierto que sólo es un criterio indicativo del riesgo vital. Este será el momento en el que se permitirá un tratamiento sobre personas sujetas a esta relación especial con la administración, que no vulnere el derecho a la integridad física. No olvidemos que a pesar de esta relación de sujeción, la privación de algunos derechos fundamentales que acarrea el contenido del fallo condenatorio por el que se ordena la prisión, no puede afectar a derechos fundamentales como la integridad física, en virtud del art. 25 de la CE, porque supondría, en alguna medida, una pena inhumana. Por ello mismo, el mejor -y quizás único- tratamiento médico posible, que no vulnere la integridad física es la inyección intravenosa cuando el sujeto esté inconsciente.

La Ley 41/2002, de 14 de noviembre, básica reguladora de la autonomía del paciente y de derechos y obligaciones en materia de información y documentación clínica, reguló más ampliamente en los artículos 8, 9 y 10 el derecho al consentimiento informado, y al rechazo de un tratamiento médico.

767 FJ $7^{\circ}$ STC 120/1990, de 27 de junio. El FJ $6^{\circ}$ lo desarrolla así: «(l)a cuestión consiste en determinar, desde la perspectiva de los referidos derechos fundamentales, la licitud constitucional de una resolución judicial que ordena a la Administración Penitenciaria dar asistencia médica obligatoria y en especial alimentar, incluso contra su voluntad, a los recurrentes cuando, como consecuencia de la huelga de hambre que persiguen, se vea en peligro su vida, aunque excluyendo en todo caso la alimentación por vía bucal mientras se mantengan conscientes (...) Tiene, por consiguiente, el derecho a la vida un contenido de protección positiva que impide configurarlo como un derecho de libertad que incluya el derecho a la propia muerte. Ello ni impide, sin embargo, reconocer que, siendo la vida un bien de la persona que se integra en el círculo de su libertad, pueda aquélla de forma fáctica disponer sobre su propia muerte, pero esta disposición constituye una manifestación del agere licere, en cuanto que la privación de la vida propia o la aceptación de la propia muerte es un acto que la ley no prohíbe y no, en ningún modo, un derecho subjetivo que implique la posibilidad de merecer el apoyo del poder público para vencer la resistencia que se oponga a la voluntad de morir, ni mucho menos, un derecho subjetivo de carácter fundamental en el que esta posibilidad se extienda incluso a la resistencia del legislador, que no puede reducir el contenido esencial del derecho». 
Concretamente el art. 8.2 de la Ley 41/2002, de 14 de noviembre, establece:

«(e)l consentimiento será verbal por regla general. Sin embargo, se prestará por escrito en los casos siguientes: intervención quirúrgica, procedimientos diagnósticos y terapéuticos invasores y, en general, aplicación de procedimientos que suponen riesgos o inconvenientes de notoria y previsible repercusión negativa sobre la salud del paciente».

Sin embargo, el art. 9.2 establece los límites del consentimiento informado:

«Los facultativos podrán llevar a cabo las intervenciones clínicas indispensables en favor de la salud del paciente, sin necesidad de contar con su consentimiento, en los siguientes casos: a) Cuando existe riesgo para la salud pública a causa de razones sanitarias establecidas por la Ley. En todo caso, una vez adoptadas las medidas pertinentes, de conformidad con lo establecido en la Ley Orgánica 3/1986, se comunicarán a la autoridad judicial en el plazo máximo de 24 horas siempre que dispongan el internamiento obligatorio de personas. b) Cuando existe riesgo inmediato grave para la integridad física o psíquica del enfermo y no es posible conseguir su autorización, consultando, cuando las circunstancias lo permitan, a sus familiares o a las personas vinculadas de hecho a él».

Y el artículo 9.3 preceptúa los límites del consentimiento por representación:

«Se otorgará el consentimiento por representación en los siguientes supuestos: a) Cuando el paciente no sea capaz de tomar decisiones, a criterio del médico responsable de la asistencia, o su estado físico o psíquico no le permita hacerse cargo de su situación. Si el paciente carece de representante legal, el consentimiento lo prestarán las personas vinculadas a él por razones familiares o de hecho; b) Cuando el paciente esté incapacitado legalmente; c) Cuando el paciente menor de edad no sea capaz intelectual ni emocionalmente de comprender el alcance de la intervención».

En este último caso, el consentimiento lo dará el representante legal del menor después de haber escuchado su opinión si tiene doce años cumplidos, pero no en el sentido de la propia opinión del representante o persona vinculada, sino en el sentido de expresar cuál sería la voluntad del menor o del inconsciente, como bien acierta a resaltar JERICÓ ${ }^{768}$.

Así las cosas, no encontramos argumento normativo alguno que vincule una obligación normativa de los padres, que ante una situación de riesgo vital del menor, se precise el consentimiento. Repárese que ante una situación grave en la que no sea posible conseguir la autorización, existe el deber médico de intervenir, lo que en nuestra opinión se puede identificar con la negativa de los padres. De tal modo que el mismo efecto jurídico trasciende tanto de la imposibilidad de recabar el consentimiento por ausencia de los padres, como de la negativa, en ambos casos, existe el deber de actuar de los facultativos. Tanto es así que los padres pueden alegar, que el menor no desearía dicha intervención, si tiene doce años de edad.

768 JERICÓ OJER, L., El conflicto de conciencia, op. cit., p. 526. 
Del mismo modo, cuando se trate de menores no incapaces, ni incapacitados, pero emancipados, o con dieciséis años cumplidos, no cabe aplicar el consentimiento por representación. Sin embargo, en caso de grave riesgo, según el criterio del facultativo, los padres serán informados y su opinión será tenida en cuenta para la toma de la decisión correspondiente. De este modo consideramos que se eliminan las problemáticas que existían antaño, que en caso de menores de edad que pueden prestar ellos mismos el consentimiento o el rechazo, se elimina, o mejor expresado, no se inicia, el deber de garante de los padres, cuando los servicios médicos entran en el campo de acción.

De otra parte, las previsiones de la LGS han sido sustituidas por la Ley de Autonomía del Paciente, de mayo de 2003, que en su art. 2, apartados 3 y 4 se deriva el derecho del paciente a la elección del tratamiento. El art. 2.3 LAP preceptúa:

«El paciente o usuario tiene derecho a decidir libremente, después de recibir la información adecuada, entre las opciones clínicas disponibles». Y el art. 2.4: «Todo paciente o usuario tiene derecho a negarse al tratamiento, excepto en los casos determinados en la Ley. Su negativa al tratamiento constará por escrito».

En tal sentido se reconoce en nuestra legislación no sólo la autonomía del paciente mayor de edad, sino también la del menor de edad cuando sea capaz intelectual y emocionalmente de comprender el alcance de la intervención, o dicho de otro modo, y en lo que respecta a nuestro estudio, el menor de edad por motivos religiosos o los que fueren, tiene derecho a negarse a determinada intervención siempre que sea capaz intelectual y emocionalmente de comprender el alcance de dicha intervención ${ }^{769}$, de tal manera que con dicha fórmula se resolvieron los problemas que generaba la LGS en su vigencia de 1986, que no otorgada dicha autonomía al menor de edad. Así, al menor emancipado se le reconoce la autonomía de su decisión, inclusive aunque no hubiera adquirido dicha emancipación, esto es, constituye una presunción iuris tantum $^{770}$.

Sin embargo, la verdadera problemática actual surge cuando el menor de edad no tiene la suficiente capacidad de decisión, por ejemplo un menor de doce años. En estos casos, se traslada el consentimiento a la representación paterna, que si fuere denegado puede hacerla incurrir en un delito de omisión del deber de socorro. En la actualidad, la LAP prevé esos supuestos en el art.

\footnotetext{
769 También en este sentido Gómez Rivero, María del Carmen, La responsabilidad penal del médico, Tirant lo Blanch, Valencia, 2003, pp. 191 y ss; JERICÓ OJER, L., El conflicto de conciencia, op. cit., p. 205.

770 JAKOBS, G., PG, op. cit., 29/70 nota 141; JERICÓ OJER, L., El conflicto de conciencia, op. cit., pp. 528 y 529 ; PÉReZ Del VAlle, C., Conciencia, op. cit., pp. 315 y 316, comenta que «si el menor tiene capacidad natural de asumir convicciones morales y de emitir juicios de conciencia con arreglo a estas convicciones, debe estarse a su voluntad», y añade «que en estos supuestos, cuando quien rechaza el tratamiento es un adulto o un menor con capacidad natural para negar su consentimiento, no existe deber de actuar por parte del médico, porque éste nunca asumió la posición de garante respecto al resultado lesivo», ID., ibidem, op. cit., p. 315.
} 
9.3, exigiendo el consentimiento por representación cuando el paciente no sea capaz de tomar decisiones por su estado físico o mental y, en el caso de que no tuviere representante legal, podrán prestar consentimiento las personas vinculadas a él por razones familiares o de hecho. Así también, cuando el paciente esté incapacitado legalmente, o cuando el paciente sea menor de edad y no sea capaz intelectualmente ni emocionalmente de comprender el alcance de la intervención.

Estos serían los únicos casos de controversia jurídica, cuando concurre un deber normativo de protección sobre un tercero, y a los que nos hemos referido que podría aplicarse, en nuestra opinión, un estado de necesidad exculpante por déficit de comunicación/socialización normativa. Si bien, como ya expusimos en el anterior capítulo, otros sectores doctrinales lo resuelven en la atipicidad, la antijuricidad, u otros motivos de inculpabilidad o exculpación, y sobre los que volveremos al tratar pormenorizadamente el delito de omisión de deber de socorro, la omisión agravada y sus límites con el delito de homicidio en comisión por omisión.

La falta de consentimiento exigido normativamente permitirá que el médico, o Juez, actúen, según considera parte de la doctrina, bajo una causa de justificación de estado de necesidad ${ }^{771}$, sin embargo, no puedo estar de acuerdo con este planteamiento, porque quien actúa por un estado de necesidad quebranta ya el tipo, por lo que si no actúa incurriría en un delito de omisión del deber de socorro, u homicidio en comisión por omisión ${ }^{772}$, lo cual es contradictorio, puesto que quien tiene del deber de actuar no comete un injusto que luego se justifique. En tal medida, hay que mostrar concordancia con lo manifestado por PÉREZ DEL VALLE: «En otro caso, y sólo si la única intervención de salvación posible es la rechazada por las convicciones de los padres (...) al juez se la atribuye el poder de actuar autorizando la intervención, al personal sanitario y al propio juez se les carga, cuanto menos con el deber de auxilio, sino con un deber derivado de una posición de garante de carácter institucional» ${ }^{773}$ (...) «el médico tendría la posibilidad de actuar justificadamente a través del consentimiento presunto. Es decir, allí no podría fundarse un deber de garantía de los padres respecto a la evitación del resultado, puesto que otros órganos sociales asumen la responsabilidad y no cabe sostener la tipicidad de la omisión de quien no tiene capacidad para actuar» ${ }^{774}$. De esta manera, habrá que distinguir normativamente qué deber tiene cada sujeto en cada momento, y en su caso, cuando nace el deber de actuar para distinguir en qué imputación objetiva se incurre, si en una responsabilidad por organización o institucional, puesto

771 JERICÓ OJER, L., El conflicto de conciencia, op. cit., pp. 564 y 565.

772 ID., ibidem, op. cit., p. 565.

773 Pérez del VAlle, C., Conciencia, op. cit., pp. 315 y 316.

774 ID., ibidem, op. cit., p. 316. 
que tanto padres como facultativos desarrollan funciones institucionales, pero según preceptúan los arts. 195 y 196 CP, en ocasiones el deber no se refiere a la evitación de un resultado material, ni a un deber institucional, sino a un deber de organización de simple actividad.

Mostramos asimismo conformidad con JERICÓ y otros como JAKOBS y ROXIN ${ }^{775}$, mientras haya alternativas de sustituir la voluntad de los padres, tales como la del médico o Juez, no se incurrirá en ningún tipo, bastando con que los padres lleven al menor al hospital, momento en que se trasladará la esfera de organización al médico o juez. Sin embargo, cuando no existe alternativa (JERICÓ pone como ejemplo la negativa de los padres al traslado del menor al hospital, ejemplo con el que no estamos de acuerdo porque efectivamente la misma alternativa existe si se llama a los servicios médicos), la falta de traslado (o comunicación al Juez o asistencias médicas), en caso de claro peligro de muerte, refiere la autora, deberá sancionarse la omisión como equivalencia a la causación de la muerte, o las lesiones, y en casos de omisión pura (no aclara cuáles), en virtud de la mayor penalidad del art. $226 \mathrm{CP}$ respecto del art. $195 \mathrm{CP}$, en aplicación del concurso de leyes, se decanta por el primero aunque considera más adecuada la comisión por omisión. Si bien, en estos casos, la aludida autora aprecia una causa de exculpación por inexigibilidad de miedo insuperable, siempre que se acredite el sentimiento de miedo o temor, que impulsa la inevitabilidad de la conducta penal, y en casos de menor intensidad o superabilidad del miedo, bajo una motivación análoga o por mero convencimiento que no conflicto, aplicar la atenuante analógica ${ }^{776}$.

Dicho esto, en nuestra opinión, la fórmula propuesta por RoXIN nos parece adecuada. El rechazo expreso del tratamiento, o la falta de consentimiento, también es impune por atipicidad, con ajenidad del motivo, cuando se desarrolla una conducta suficiente de salvamento. Al igual que sucede en el simple ciudadano que acciona una conducta de salvamento en un accidentado, no se le exige una total responsabilidad sobre el resultado, o sea, que su deber termina cuando llama a las asistencias. En el caso de los padres, si bien existe una vinculación institucional mayor, la paterno-filial, ésta no puede exigirse desproporcionadamente mediante un consentimiento expreso a una situación de urgencia que los facultativos en caso de inconsciencia del menor, o inclusive conciencia, tienen el deber de actuar, cuando existe peligro para la vida, como si el consentimiento modificase normativamente y materialmente la situación.

775 JERICÓ OJER, L., El conflicto de conciencia, op. cit., pp. 299 y ss., y pp. 565 y 567; JAKOBS, G., PG, op. cit., pp. 20/24 y ss; RoXIN, C., «Die Gewissenstat als Strafbefreiungsgrund», op. cit., pp. 404 y ss. (vid. JERICÓ OJER, L., El conflicto de conciencia, op. cit., pp. 295 y 296); PÉREZ DEL VALLE, C., Conciencia, op. cit., pp. 314 y ss.

776 JERICÓ OJER, L., El conflicto de conciencia, op. cit., pp. 299 y ss., y p. 566. 
Por otro lado, la actual LAP, en su art. 9.2, limita la libertad de negarse al tratamiento médico o de prescindir del consentimiento cuando exista riesgo para la salud pública, o cuando no se pueda obtener el consentimiento, previa consulta a sus familiares o personas vinculadas al sujeto respectivamente, lo que redunda en las limitaciones estudiadas en el capítulo segundo. En este sentido, no cabe duda que si el sujeto deniega el tratamiento y, posteriormente cae en una situación de inconsciencia, aunque devenga en ese estado el peligro de muerte, sería fraudulento aprovecharse de tal situación para aplicar el tratamiento, si bien lo prohíbe expresamente el art. 11 LAP. Sin embargo, en casos de inconsciencia y que se desconozca la voluntad, consideramos que se debe de aplicar el «consentimiento presunto»o «presunción de vida» ${ }^{777}$ cuando haya riesgo, no sólo sobre la vida, sino que también sería correcta la intervención con un riesgo de lesiones irreversibles ${ }^{778}$, aunque en caso de duda habrá que realizar una ponderación de intereses -como dice GÓMEZ RIVERO ${ }^{779}$ - y acudir a comités técnicos de evaluación, o en última instancia, al auxilio judicial que es la más común en caso de serias dudas, recabar el auxilio judicial, aunque en nuestra opinión también es habitual que los médicos realicen consulta al juez de guardia para sentir el apoyado judicial.

\section{La conciencia ante el valor de la muerte: el bien jurídico de la vida y el derecho al} suicidio

Comentaba SCHOPENHAUER que «nacimiento y muerte pertenecen igualmente a la vida y se contraponen $^{780}$ (...) Si le concediesen al hombre una vida eterna, la rigidez inmutable de su carácter y los estrechos límites de su inteligencia le parecerían a la larga tan monótonos y le inspirarían un disgusto tan grande, que para verse libre de ellos concluiría por preferir la nada (...) Exigir la inmortalidad del individuo es querer perpetuar un error hasta el infinito» ${ }^{781}$. El citado filósofo es de quienes se ha ocupado de la legitimidad moral del suicidio, quien mejor la fundamentó. La cosa en sí, lo a priori kantiano es la voluntad, por eso lo injusto es la negación

777 BUENO ARÚs, F., «El rechazo del tratamiento en el ámbito hospitalario», AP, T. I, núm. 31, 1991, p. 404; DíEZ RIPOLLÉS José Luis / GRACIA MARTín Luis, Delitos contra bienes jurídicos fundamentales. Vida humana independiente y libertad, Tirant lo Blanch, Valencia, 1993, pp. 257 y ss; JAKOBS, G., «La interrupción del tratamiento a solicitud del paciente y el parágrafo 216 StGB (homicidio a petición de la víctima)», trad. Manuel Cancio Meliá, JaKoBS, G., Estudios de Derecho penal, op. cit., pp. 413 y ss; KAUfMANn, Arthur, «¿Relativización de la protección jurídica de la vida?», trad. Silva Sánchez, $C P C$, núm. 31, 1987, pp. 48 y ss. En este sentido JERICó OJER, L., El conflicto de conciencia, op., p. 524.

778 JeRICÓ OJER, L., El conflicto de conciencia, op. cit., p. 523; ROMEO CASABONA, CMa ., El médico y el Derecho penal, op. cit., p. 366; TAMARIT SUMALLA, JMa ., La libertad ideológica, op. cit., p. 427.

779 GÓMEZ RIVERO, M ${ }^{\mathrm{a}} \mathrm{C}$, La responsabilidad penal del médico, op. cit., pp. 176 y ss; JERICÓ OJER, L., El conflicto de conciencia, op. cit, pp. 526 y 529.

780 SCHOPENHAUER, A., El amor, las mujeres y la muerte, op. cit., p. 107.

781 ID., ibidem, op. cit., p. 108. 
positiva de la voluntad de otro y el Derecho es la negación de lo injusto. De este modo, el suicidio es la negación de la voluntad de vivir (principium individuationis), pero por haber adquirido el conocimiento de la cosa en sí, la voluntad antes del conocimiento del fenómeno, de manera que ante tal situación, se «aquieta» la voluntad, se llega a una renuncia voluntaria y al «aniquilamiento» de la voluntad ${ }^{782}$. El suicida ama la vida, pero no acepta las condiciones en que se le ofrece, no renuncia a la voluntad de vivir, sino a la vida en sí misma, por esto obra conforme a la cosa en sí: la voluntad en $\operatorname{sil}^{783}$.

En este sentido, no extrañará que existan voces a favor de la libertad del ser humano en la disponibilidad de su vida y de su muerte como una cuestión pura y en sí misma de la voluntad, o dicho de otro modo, cuando la voluntad no hace mal a otro (deber negativo, neminem laede).

De esto proviene que la doctrina opina que la imposición de un tratamiento médico sin el consentimiento del paciente, constituiría un delito de coacciones ${ }^{784}$, aunque en nuestra opinión, y de otra parte de la doctrina, se incurriría en un delito de lesiones ${ }^{785}$, aunque según los casos, podría aplicarse el concurso con el delito contra el sentimiento religioso del art. $522 \mathrm{CP}^{786}$ si la negativa fuera motivada por motivos de conciencia. En nuestra opinión, en estos casos no sería apreciable, de ningún modo, una causa de justificación del tipo que sea $^{787}$, si bien se plantean problemas de error de prohibición ${ }^{788}$, o -como explica TAMARIT SUMALLA ${ }^{789}$ - de miedo

782 SCHOPENHAUER, A., El mundo como voluntad y representación, T. I, op. cit., Libro IV, 68 y 69, pp. 525 y ss. y pp. 550 y ss.

783 ID., ibidem, op. cit., Libro IV, 69, p. 550.

784 BAUCELls I LLADÓs, J., La delincuencia por convicción, op. cit., p. 231; CASTRO JOVER, Adoración, «La libertad de conciencia y la objeción de conciencia individual», op. cit., p. 175; CERVELLÓ DONDERIS, Vicenta, El delito de coacciones en el Código penal de 1995, Tirant lo Blanch, Valencia, 1999, pp. 83 y 84 aplica el principio de especialidad en relación al de coacciones y al delito del art. $522 \mathrm{CP}$ a favor del primero; FLORES MENDOZA, F., Objeción de conciencia, op. cit., pp. 431 y ss; GÓMEZ RIVERO, $\mathrm{M}^{\mathrm{a}} \mathrm{C}$., La responsabilidad penal del médico, op. cit., p. 206; Higuera GuIMERÁ, JF., El delito de coacciones, pról. José Cerezo Mir, $2^{\mathrm{a}}$ ed., revisada y ampliada, Bosch, 1983, p. 219; con matices y sin descartar el delito de lesiones JERICó OJER, L., El conflicto de conciencia, op. cit., p. 530; Romeo CASABOna, CMa ., El médico y el Derecho penal, op. cit., p. 357; TAMARIT Sumalla, JM ${ }^{\mathrm{a}}$, La libertad ideológica, op. cit., p. 427.

785 GÓMEZ BeníteZ, JM., Teoría jurídica del delito, op. cit., p. 395.

786 CEREZO MIR, J., «La eximente de obrar en cumplimiento de un deber o en el ejercicio legítimo de un derecho, oficio o cargo», $A D P C P, 1987$, p. 277. Críticamente a esta postura se ha sostenido que la intervención no impide al paciente practicar actos propios de creencias o profesar, ROMEO CASABONA CM ${ }^{\mathrm{a}}$, El médico y el Derecho penal, op. cit., p. 382; JERICÓ OJER, L., El conflicto de conciencia, op. cit., p. 530.

${ }_{787}$ CEREZO MIR, J., «La eximente de obrar en cumplimiento de un deber», op. cit., pp. 277 y ss; CASTRO JOVER, A., «La libertad de conciencia y la objeción de conciencia individual», op. cit., pp. 181 y ss; ESCOBAR ROCA, G., La objeción de conciencia, op. cit., p. 359; GÓMEZ RIVERO, $\mathrm{M}^{\mathrm{a}} \mathrm{C} .$, La responsabilidad penal del médico, op. cit., pp. 206 y ss; JERICó OJER, L., El conflicto de conciencia, op. cit., p. 531; ROMEO CASABONA, CMa ., El médico y el Derecho penal, op. cit., p. 382; TAMARIT SUMALlA, JMa., La libertad ideológica, op. cit., pp. 437 y ss. En su día, contrariamente, el Tribunal Supremo aplicó una eximente de estado de necesidad y de ejercicio legítimo de un derecho en la trasfusión de sangre no consentida por un Testigo de Jehová, Auto TS de 22 de diciembre de 1983.

788 Excepcionalmente en algún caso, JERICÓ OJER, L., El conflicto de conciencia, op. cit., p. 532

789 TAMARIT Sumalla, JM ${ }^{a}$., La libertad ideológica, op. cit., pp. 436 y ss; JeRICó OJER, L., El conflicto de conciencia, op. cit., pp. 532 y 533. 
insuperable debido a la angustia de ver morir, aunque estos supuestos serían casos excepcionales, y que conforme ya explicamos no serían supuestos de motivos de conciencia.

Hay que señalar que el TEDH ha rechazado el derecho a la muerte ${ }^{790}$, y la doctrina del Tribunal Constitucional considera que el derecho a la vida es «la proyección de un valor superior del ordenamiento jurídico constitucional» ${ }^{791}$. A pesar de los votos particulares como el de TOMÁS Y VALIENTE que desmienten esta conclusión razonadamente ${ }^{792}$, el TC en la Sentencia núm. 120/1990 de 27 de junio sobre el caso de alimentación forzosa a presos del GRAPO en huelga de hambre, declaró que no se garantiza el derecho a la propia muerte ${ }^{793}$.

A este respecto, JERICó considera que si bien la conducta de autopuesta en peligro de un paciente que se niega a un tratamiento médico está amparada por el derecho de libre autodeterminación, por cuanto que por ejemplo, en el ámbito sanitario «ni el médico tiene un deber jurídico de prolongar la vida del paciente contra su voluntad, ni existe un deber jurídico por parte del paciente de continuar con su vida», lo que niega que exista, en verdad, un conflicto de conciencia u objeción de conciencia, al existir un derecho del paciente a rechazar un tratamiento médico amparado por la Ley de Autonomía del Paciente ${ }^{794}$, sin embargo en el ámbito penitenciario no ocurre igual $^{795}$.

Estamos de acuerdo en que en el ámbito penitenciario no se aplican los mismos criterios. Ese deber de garantía del Estado frente a los ciudadanos no es un derecho que parezca imponerse ante el derecho a la muerte, sino que precisamente para otorgar valor al derecho a la muerte, antes el Estado debe comunicar que la norma quebrantada por el preso está vigente mediante la pena, y tras dicha comunicación, que dura el tiempo al que el reo ha sido condenado, es cuando ya en libertad, pueda hacer ejercicio de un derecho «fáctico» de poner fin a su vida. Entonces, no es que se vete su derecho, o no tenga, sino que se relega temporalmente, o se le suspende, por lo

790 TEDH, 4 4 sección, affaire «Pretty c/ The United Kingdom», del 29 de abril de 2002, trad. y comentarios Gustavo E. ABOso, Revista de Derecho penal, 2002-1, «Delitos culposos I», dir. Edgar Alberto Donna, Rubinzal Culzoni, 2002, pp. 383 y ss., vid. ABoso, Gustavo Eduardo, Los límites de la autoría mediata, B de F 2012, pp. 145.

791 STC 53/1985 FJ $3^{\circ}$.

792 Véase Voto Particular del Magistrado Francisco TOMÁs Y VALIENTE en la STC 53/1985.

793 STC 120/1990 de 27 de junio, FJ $7^{\circ}$.

794 JERICÓ OJER, L., El conflicto de conciencia, op. cit., pp. 486 y 487.

795 Comenta que «(s)i el estado no dispone de recursos más idóneos para castigar la comisión de delitos que el de la privación de libertad, entendida ésta como bien jurídico fundamental, desde una posición garantista, se le debe exigir no sólo que proteja dicho bien, sino también el sustrato del mismo que no es otro que la vida del recluso. No es, por lo tanto, la existencia de un deber de sujeción especial del interno frente a la Administración la que debe facultar la intervención, sino el deber de garantía del Estado frente a los ciudadanos, puesto que no ha sido capaz de emplear medios menos lesivos para castigar su conducta», JERICó OJER, L., El conflicto de conciencia, op. cit., pp. 303 y 492. 
que la problemática se centra en si existe disponibilidad de la vida en relación con el art. $15 \mathrm{CE}$ como acertadamente expone y defiende parte de la doctrina ${ }^{796}$.

En opinión de POLAINO-ORTs ${ }^{797}$, con la que convergemos, y en armonía con la del Voto Particular del Magistrado LEGUINA VILLA ${ }^{798}$ en la meritada Sentencia del TC 12/1990, la gestión de la vida es un acto libre pero también personalísimo, hasta el punto que la cooperación en el suicidio no debería ser punible por cuanto si aceptamos que la vida es un derecho personalísimo y estrictamente disponible para el propio sujeto, la cooperación al suicidio no puede ser punible porque absurdamente sería un «suicidio en autoría mediata», tal y como refiere JAKOBS ${ }^{799}$, quien al respecto comenta que «i(c)ómo van a poder surgir deberes del médico, contra la voluntad del paciente, a partir de una relación de tratamiento que el paciente puede rescindir sin alegación de causa alguna en cualquier momento, y limita en su contenido (no se confió la vigilancia de decisiones suicidas? (...) es inadmisible presumir como algo cierto en la víctima el carácter pasajero de la voluntad de quitarse la vida tan sólo porque podría ser así. Siempre que la víctima manifieste de modo responsable que quiere morir, el riesgo de error va en perjuicio suyo» ${ }^{800}$.

\footnotetext{
796 CARBOnell Mateu, JC., «Libre desarrollo de la personalidad y delitos contra la vida. Dos cuestiones: suicidio y aborto», CPC, 45, 1991, p. 667; FLORES MENDOZA, F., Objeción de conciencia, op. cit., pp. 468 y ss; GARCÍA ÁlVAREZ, La puesta en peligro de la vida y/o integridad física asumida voluntariamente por su titular, Tirant lo Blanch, Valencia, 1999, op. cit., p. 497; JERICÓ OJER, L., El conflicto de conciencia, op. cit., pp. 487 a 492 , lo fundamenta en el respeto a la dignidad y libre desarrollo de la personalidad del art. 10 CE; POLAINO-ORTS, Miguel, vv.aa., Lecciones de Derecho Penal, Parte Especial, T. I, Dir. Miguel Polaino Navarrete, Tecnos, 2010, pp. 66,74 y 75 .

797 Polaino-Orts, M., vv.aa., Lecciones de Derecho Penal, Parte Especial, T. I, op. cit., pp. 66, 74 y 75; BAUCELLS está a favor de un derecho constitucional de la dignidad de las personas como ejercicio y límite del derecho a la vida y de la libertad de conciencia, en cuanto que la objeción de conciencia no puede suponer un peligro ni quebranto a la vida de terceros, por ejemplo en el caso de un médico que decide salvar la vida del feto antes de la vida de la madre contra su voluntad, BAUCELLS I LLADÓs, J., La delincuencia por convicción, op. cit., p. 215.

798 En dicho Voto Particular se manifestaba el Magistrado LEGUINA VILLA: «(n)o estando en juego derechos fundamentales de terceras personas, ni bienes o valores constitucionales que sea necesario preservar a toda costa, ninguna relación de supremacía especial -tampoco la penitenciaria- puede justificar una coacción como la que ahora se denuncia que, aun cuando dirigida a cuidar la salud o a salvar la vida de quienes la soportan, afecta al núcleo esencial de la libertad personal y de la autonomía de la voluntad del individuo, consistente en tomar por sí solo las decisiones que mejor convengan a uno mismo, sin daño o menoscabo de los demás».

799 JAKOBS, G., «La autoría mediata con instrumentos que actúan por error como problema de imputación objetiva», trad. Manuel Cancio Meliá, JAKOBS, G., Bases para una teoría funcional del Derecho penal, op. cit., pp. 249 a 268, también con el mismo título en Cuadernos de Conferencias y Artículos, núm. 15, Universidad Externado de Colombia, $1^{a}$ ed., Bogotá, 1996; ID., «La organización de autolesión y heterolesión, especialmente en caso de muerte», JAKOBS, G., Estudios de Derecho penal, op. cit., pp. 404 y ss; en el mismo sentido POLAINO-ORTS, M., vv.aa., Lecciones de Derecho Penal, Parte Especial, T. I, op. cit., p. 68.

${ }_{800}$ JAKOBS, G., $P G$, op. cit., 29/70, nota 141.
} 


\section{E. La eutanasia activa}

\section{El «auxilio al suicidio» y la punibilidad de la acción de impedir un suicidio}

La palabra eutanasia proviene del griego eu que quiere decir «bueno», y de thanatos, que quiere decir «muerte», por lo que la eutanasia es «la buena muerte», o también la «muerte sin dolor».

Así las cosas, nuestro Derecho penal prohíbe la eutanasia activa directa (art. 143.4 CP) en principio, y en todos los casos (también en la mayoría de los países de nuestro entorno, por ejemplo en Alemania en su Código penal, parágrafo 216, se denomina «auxilio al suicidio» o «ayuda a morir», y en algunos casos se permite en Bélgica, Holanda y Luxemburgo), lo que normativamente impide hablar de un derecho de disponibilidad jurídica de la propia vida en todos los supuestos ${ }^{801}$, si bien, y como hemos expuesto supra, se puede admitir un derecho a la autopuesta en peligro de la vida, y en determinadas situaciones aceptarse por el ordenamiento jurídico la muerte cuando existe conflicto con otros derechos del particular (rechazo de tratamiento médico vitales). También se prohíbe la eutanasia eugenésica o socio-económica ${ }^{802}$.

Sin embargo, y de aquí surge la problemática, no se prohíbe ${ }^{803}$ en España la eutanasia directa pasiva y la eutanasia indirecta pasiva en algunos casos, al igual que en la mayoría de los países de nuestro entorno.

La eutanasia activa indirecta no es punible, en nuestra opinión, en muchos casos en nuestro ordenamiento, pues la intencionalidad no es acortar la vida, sino aliviar el sufrimiento, por lo que el dolo de homicidio activo desaparece automáticamente. Esta clase de eutanasia es la que realizan los médicos cuando suministran sustancias que reducen el dolor pero a la vez acortan la vida. Un gran sector cristiano se decante a favor de esta clase de eutanasia y no de otras.

Sin embargo, GIMBERNAT considera que se aprecia en estos casos dolo eventual aunque amparado por una causa de justificación de estado de necesidad ${ }^{804}$ de salvaguarda de derechos de la personalidad, dignidad y prohibición de tratos inhumanos, pero la mayoría de la doctrina

801 JERICÓ OJER, L., El conflicto de conciencia, op. cit., p. 490.

802 Por todos es conocida la filosofía de PlATÓn, que en algunos puntos de La República, recomendó la eutanasia del recién nacido (y otros sujetos nada esenciales para el funcionamiento económico del Estado), cuando nazcan con graves deformaciones para evitar así las cargas económicas al Estado. Más recientemente el nacionalsocialismo defendió la eutanasia de recién nacidos, enfermos terminales, oligofrénicos, personas con parálisis cerebral o de los inconscientes, para descargar de alguna forma la obligación económica del Estado.

803 GARCÍA Álvarez, P., La puesta en peligro, op. cit., p. 219; GÓMEZ RIVERO, Mª., La responsabilidad penal del médico, op. cit., pp. 536 y ss; POLAINo-OrTs, M., vv.aa., Lecciones de Derecho Penal, Parte Especial, T. I, op. cit., pp. 66, 74 y 75.

GimbernAt, E., «Eutanasia y Derecho Penal», Estudios de Derecho penal, op. cit., pp. 52 y ss; también en sentido similar, JERICó OJER, L., El conflicto de conciencia, op. cit., p. 530; MuÑOz CONDE, F., Derecho Penal, Parte Especial, $15^{\text {a }}$ ed. revisada y puesta al día, Tirant lo Blanch, Valencia, 2004, p. 76; VALLE MuÑIZ, José Manuel, «Relevancia jurídico-penal de la eutanasia», CPC, 37, 1989, p. 179. 
rechaza tal hipótesis, porque el sujeto activo no conoce la causalidad entre el alivio del dolor y el adelantamiento de la muerte, con lo que estamos totalmente de acuerdo, ya que el sujeto activo no puede determinarla - como bien señala ROMEO CASABONA ${ }^{805}$ - o no se puede determinar exacta ni temporalmente, lo que hace a la conducta que produce la muerte, ni dolosa ni imprudente, sino «fortuita», mientras que el alivio del dolor no puede ser considerado una figura delictiva antijurídica si se cuenta con el consentimiento de la familia o representante legal en tales casos.

Si faltase el consentimiento porque la familia no está presente, o se desconoce su existencia o localización, el médico que suministrase opiáceos con el fin de mitigar un dolor inhumano e insufrible, que a la larga causaran la muerte del paciente involuntariamente, actuaría atípicamente, no bajo una causa de justificación de cumplimiento de un deber, ya que la acción es inherente a la práctica médica del alivio del sufrimiento humano según el principio de beneficencia y no maleficencia que rigen en la actuación médica, a la vez que el paciente consiente dicha acción. El sujeto, en este caso, tiene derecho a que se le practique el tratamiento que él crea más conveniente, incluso negarse a recibirlo, aun a pesar de que ello conlleve dolores inhumanos, por lo que el médico nunca actuaría en cumplimento de un deber en caso de realizar la acción de mitigar el dolor con sustancias que acortan la vida con expreso consentimiento del paciente, porque si su acción estuviera justificada, habría que admitir, paradójicamente, que también lo estaría en contra de la voluntad del paciente, o al menos la eximente incompleta.

Así las cosas, sobre la posibilidad de homicidio imprudente, consideramos que no cabe la imprudencia leve ni grave ${ }^{806}$. Por lo tanto, y sobre lo que respecta a esta investigación y a la línea que seguimos, no podemos decir que tales conductas médicas puedan resultar propias ni similares de la conducta del autor de conciencia, porque el mismo ordenamiento las respalda y porque el motivo de conciencia es ajeno al tratamiento y a las conclusiones a las que se llegan.

Aquí interesa, entonces, la problemática que se suscita es la punibilidad de la acción de impedir un suicidio, por cuanto si como hemos manifestado la vida constituye un bien disponible, la intromisión de un tercero que frustre el suicidio podría considerarse paradójicamente un delito de coacciones, o según los casos, de un delito de lesiones cuando quien actúa es por ejemplo un médico mediante un tratamiento, y según los casos, también en

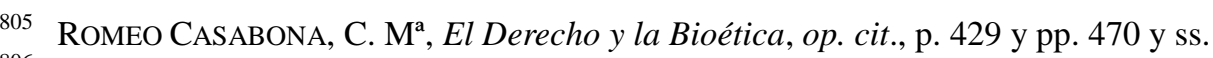

806 ROMEO CASABONA decía que «(d)e todos modos, le asiste razón a la opinión de que todo este diverso entramado jurídico genera inseguridad jurídica al médico, partiendo de que, no obstante, los criterios coincidan en el resultado de licitud, pero han podido motivar al mismo tiempo reservas injustificadas sobre el empleo de opiáceos para mitigar el dolor», ROMEO CASABONA, CMa , ID. ibidem, op. cit., pp. 430 y 431. 
concurso con un delito del art. $522 \mathrm{CP}$, si el sujeto deniega un tratamiento por motivos de conciencia.

Sobre este respecto, CUEllo CALÓN ${ }^{807}$ consideraba que no es punible impedir por coacción la perpetración de un suicidio, bajo el argumento de que existe la tipificación del «auxilio al suicidio», por lo que sería incoherente criminalizar la acción de impedir un suicidio. Otros autores, como MIR PUIG ${ }^{808}$, consideran punible esta acción como una figura de coacción, pero en la que media una causa de justificación de estado de necesidad y porque media un «límite tácito», el principio de insignificancia y la adeucación social.

En este sentido, GARCÍA ÁLVAREZ considera que la no evitación de un suicidio (con dominio del hecho del suicida-autor, o éste utilizando a un instrumento o con el común acuerdo con tercero lo que constituye una «autolesión» ${ }^{809}$ ) constituiría un delito de omisión del deber de socorro por incumplimiento del mandato de solidaridad mínima, o en determinados casos, un delito de homicidio si existe la posición de garante ${ }^{810}$. Considera que sólo podrá existir homicidio consentido (heterolesión consentida) cuando el titular del bien quiere ponerle fin pero en la que interviene un tercero con dominio del hecho ${ }^{811}$. Por eso la intervención en la autolesión no siempre es impune, puede incurrir en el art. $143 \mathrm{CP}^{812}$ cuando el tercero interviniente tiene el dominio del hecho aunque sí existe autoderminación positiva del titular del bien se reconducirá al art. $143.3 \mathrm{CP}^{813}$. Amén de ello, concluye que tanto en el auxilio ejecutivo al suicidio ajeno como en el homicidio consentido, recibirán el mismo tratamiento siempre que exista la autodeterminación positiva del sujeto, aunque el tercero interviniente tenga el dominio del hecho, por eso considera que es indiferente la calificación de contribución a una autolesión o heterolesión consentida ${ }^{814}$.

\footnotetext{
807 Cuello Calón, E., Derecho penal, Parte Especial, T. II. 14 ${ }^{\mathrm{a}}$ ed., revisada y puesta al día por Cesar Camargo Hernández, Barcelona, 1975, p. 811.

808 MIR PUIG, S., «El delito de coacciones en el Código penal», ADPCP, T. XXX, núm. 2, Madrid, 1977, pp. 299 a 301. Anteriormente WELZEL fundamentó la impunidad por la adecuación social que representa la acción de impedir un suicidio, Welzel, H., Derecho penal alemán, op. cit., pp. 83 y ss. Contrariamente FERRER SAMA planteaba la posibilidad de introducir el delito de omisión del deber de socorro en caso de no impedir un suicidio, puesto que el sujeto que intenta suicidarse se hallaría en un peligro inminente para su vida, por lo que el impedimento sería lícito, Ferrer SAMA, Antonio, Comentarios al Código penal, T. IV, Murcia, 1956, p. 268.

809 García Álvarez, P., La puesta en peligro, op. cit., p. 203.

810 ID., ibidem, op. cit., p. 204: «Habrá autoría mediata de homicidio o asesinato, en vez de una conducta de participación en un suicidio ajeno, cuando, aunque sea el propio titular del bien jurídico afectado el que realice la conducta mortal, el tercero haya hecho que ponga términos a su vida un incapaz de comprensión o juicio, ya sea por razones de edad o de enfermedad mental; o una persona a la que haya sumido en un estado de necesidad o privado de la libertad de voluntad o de la capacidad necesaria para comprender el alcance de su conducta, ya sea mediante engaños, coacciones o amenazas, o cuyo error o estado de necesidad haya utilizado a tales efectos».

811 ID., ibidem, op. cit., pp. 203 y 246.

812 ID., ibidem, op. cit., pp. 246.

813 ID., ibidem, op. cit., pp. 246 y 247.

814 ID., ibidem, op. cit., pp. 247.
} 
Sin embargo, no puede hablarse de suicidio cuando un enfermo rechaza un tratamiento porque quiere vivir pero no a toda costa, es el propio titular del bien el que determina la conducta de riesgo, son autopuestas en peligro, por eso concluye que «sólo puede admitirse un tratamiento no consentido por el paciente si éste no está capacitado, por hallarse inconsciente, para adoptar una decisión, y si por la urgencia de la situación, no puede esperarse a que éste se recupere (...) las negativas a tratamiento sólo han de admitirse si proceden del propio titular del bien jurídico y no, por tanto, si son negativas de representantes legales o tutores cuando el enfermo sea menor de edad o un incapaz» ${ }^{815}$.

El concepto normativo «desamparo» parece no cumplirse en los casos de intento de suicidio $^{816}$. Compartimos la opinión -muy acertadamente fundamentada- de POLAINO-ORTS, quien se ha pronunciado rechazando cualquier tipo de responsabilidad en la no evitación de la muerte suicida por cuanto supondría imponer a los ciudadanos «deberes excedentes de su rol y convertirlos en controladores de ámbitos de organización ajenos» ${ }^{817}$, por lo que debe excluirse cualquier tipo de «heteroadministración» por un tercero en la esfera de libertad de los ciudadanos.

JAKOBS considera que la diferencia entre autolesión y heterolesión consentida viene marcada por el parágrafo $216 \mathrm{StGB}^{818}$, porque en este precepto algunas participaciones de autolesión (o autopuesta en peligro) son tratadas como heterolesión (heteropuesta en peligro), como en el homicidio a petición, y no como mera participación en el suicidio, lo que fundamenta que quien

815 ID., ibidem, op. cit., p. 557, y pp. 575 y ss.

816 Higuera GUIMERÁ opina que «el suicidio en el Derecho español es una conducta no lícita penal, pero sí ilícita, desde el momento en que se castiga el auxilio y la inducción al suicidio, siendo pues un acto ilícito, no podrá castigarse la conducta coactiva de impedir la perpetración del suicidio, pues se impide hacer lo que la ley prohíbe... no precisando acudir a la causa de justificación», HIGUERA GUIMERÁ, JF., El delito de coacciones, op. cit., p. 158.

817 Polaino-Orts, M., vv.aa., Lecciones de Derecho penal, Parte especial, T. I, p. 74. En el mismo sentido JERICó niega la posibilidad de incriminar al médico que omite el tratamiento por un delito de cooperación necesaria omisiva al suicidio del art. 143.2 CP, puesto que el propio precepto parece imponer una conducta activa de cooperación, además el paciente tiene derecho a rechazar el tratamiento por lo que no es equiparable la negativa a recibir un tratamiento y la conducta suicida, y por tanto niega también la posibilidad del homicidio en comisión por omisión porque tal rechazo ya elimina la posición de garante y porque no se corresponde dicha omisión con una acción propia de matar, JERICÓ OJER, L., El conflicto de conciencia, op. cit., pp. 534 a 536.

818 ALDONEY comenta sobre la regulación alemana que «(l)a interpretación accesoria en forma de complicidad respecto de un suicidio no constituye una conducta punible en el ordenamiento jurídico alemán, ya que el hecho principal del cual depende no se encuentra tipificado», pero un «problema se plantea la delimitación entre una conducta meramente auxiliadora y una dominadora del acontecer. Para tal efecto, la doctrina dominante atiende a quien posee el dominio del último acto». Entonces se deberá de calificar como cooperación necesaria, y no como mero auxilio. Mientras que una contribución insignificante como mera complicidad. En los casos de no intervenir en casos de suicidio, se reconoce mayoritariamente una omisión del deber de socorro del parágrafo 323 c del CP alemán, ALDONEY RAMíREZ, Rodrigo, «Tratamiento jurídico penal de la eutanasia», Revista Penal, La ley, núm. 16, p. 172. 
actúa en último lugar no siempre tiene el dominio del hecho a pesar de tomar la decisión ${ }^{819}$, por eso, dicho criterio es algo naturalístico, no diferencia entre suicidio y homicidio, sino lo que ocurra a continuación es su propio hecho, el que actúa en último lugar no es el garante, sino sólo es garante el que tiene el deber de evitación y actúa de propia mano ${ }^{820}$, por eso, el garante, lo es tanto en los delitos de comisión por omisión como en los comisivos. La cuestión no es quién realiza el último acto, o si existe posibilidad de evitación, sino el deber de evitar una posibilidad de evitación ${ }^{821}$. Por eso es preciso saber cuándo nace la competencia del obligado y sobre qué se es competente ${ }^{822}$.

De este modo concluye que sólo habrá heterolesión si la competencia del tercero viene después de la de la víctima ${ }^{823}$, entonces la autopuesta en peligro, o autolesión, surge cuando el sujeto pone él mismo en riesgo sus bienes, o simultáneamente con un tercero, bastando que el primero pueda sustraerse de los efectos cuando lo desee, o cuando el riesgo proceda del tercero, omite salvarse, teniendo capacidad para ello, puesto que en tales casos existe dominio de la decisión por el sujeto salvo excepciones ${ }^{824}$.

Entonces, sobre la ayuda activa a morir, con petición del interesado, que se establece penalmente en el parágrafo 216 StGB, JAKOBS ${ }^{825}$ considera que este artículo sólo debería contemplar las muertes irracionales, porque en los demás casos activos, debería de respetarse la

\footnotetext{
819 JAKOBS, G., «La organización de autolesión y heterolesión, especialmente en caso de muerte», op. cit., pp. 396 y ss.

${ }^{820}$ ID., ibidem, op. cit., p. 399; críticamente al respecto pero resaltando el beneficio de equiparar autolesión y autopuesta en peligro para comprender el suicidio como autoría, y la heterolesión y heteropuesta en peligro consentida, GARCÍA ÁlVAREZ, P., La puesta en peligro, op. cit., pp. 80 y ss. y 91 y ss. respectivamente.

821 JAKOBS, G., «La organización de autolesión y heterolesión, especialmente en caso de muerte», op. cit., p. 400 .

822 ID., ibidem, op. cit., pp. 400 y 401; ID., «La competencia por organización en el delito de omisión. Consideraciones sobre la superficialidad de la distinción entre comisión y omisión», trad. Enrique Peñaranda Ramos, JAKOBS., G., Estudios de Derecho penal, op. cit., p. 359 y ss.

823 ID., ibidem, op. cit., p. 403. Críticamente GARCÍA ÁLVAREZ considera que «siempre que sea el tercero el que actúe creando un riesgo, es él el garante de que tal riesgo no se realice y, por tanto, actuará en último lugar, con lo que volvemos a encontrarnos en el punto de partida», y conocedor JAKOBS de esto, por eso introduce que no existe responsabilidad cuando el tercero interviene en último lugar con posición de garante y el titular del bien omite la salvación o su protección, por eso concluye que no consigue una distinción nítida entre autolesiones y heterolesiones consentidas, GARCÍA ÁlvAREZ, P., La puesta en peligro, op. cit., pp. 83 y 84; además le critica en que utilizando los criterios generales de autoría y participación no lo haga el parágrafo 216 StGB, ID., ibidem, op. cit., p. 89.

824 A esta regla JAKOBS excepciona los supuestos de autoría mediata, en los que el sujeto desconoce el riesgo (autoría mediata con instrumento cuasi no doloso), en los que se obliga por el tercero a sacrificar otros bienes para salvar otros (autoría mediata con instrumento cuasi justificante), y en los que la víctima es un enfermo mental o menor de edad (autoría mediata con instrumento cuasi inculpable), JAKOBS, G., «La organización de autolesión y heterolesión, especialmente en caso de muerte», op. cit., pp. 404 y ss.

825 JAKOBS, G., «Sobre el injusto del suicidio y del homicidio a petición. Estudio sobre la relación entre juricidad y eticidad», trad. Manuel Cancio Meliá, JAKOBS, G., Bases para una teoría funcional, op. cit., pp. 345 y ss; ID., Suicidio, eutanasia y Derecho penal, pról. Francisco Muñoz Conde, trad. Francisco Muñoz Conde y Patricia García Álvarez, Tirant lo Blanch, Valencia, 1999, pp. 25 y ss.
} 
autodeterminación del sujeto, como igualmente sucede en los demás casos de eutanasia pasiva o indirecta.

Lo que parece claro es que sí que hay un derecho a la autopuesta en peligro de la vida ${ }^{826}$, lo que fundamenta la falta de desamparo en la omisión del deber de socorro, por lo que hasta que no se afectara objetivamente a la vida, la acción de puesta en peligro estaría permitida, como por ejemplo sucede en el boxeo y otros deportes de alto riesgo y en las huelgas de hambre. Así, la participación en la puesta en peligro es impune, e inclusive, conforme considera parte de la doctrina podríamos señalar que no corresponde, en verdad, a una acción de suicidio ${ }^{827}$, sino a la decisión de no vivir de cualquier modo.

\section{El fundamento de la atenuante de la eutanasia del art. 143.4 CP}

El tipo requiere que la conducta del sujeto activo sea de causación o de cooperación necesaria activa directa o indirecta para la muerte. Pero fundamentalmente para apreciar la atenuante se exige también la petición expresa, seria e inequívoca, y que la víctima sufra una enfermedad grave que conduzca necesariamente a su muerte, o que produzca graves padecimientos permanentes y difíciles de soportar. Vemos lógicamente que esta forma, que algunos han denominado de homicidio, en verdad es una conducta eutanásica. Se atenúa la pena sensiblemente, en uno o dos grados, según se incurra en la conducta típica del apartado 2 o 3 , es decir, en la cooperación necesaria sin resultado de muerte, o en caso de que se causare la muerte respectivamente.

La razón de la atenuante, en este caso, nace primordialmente de un motivo muy especial, del especial elemento subjetivo del tipo, que incide fundamentalmente en la culpabilidad. La conducta se realiza por móvil humanitario, o también llamado altruista, solidario, compasivo o piadoso (mercy killing) ${ }^{828}$. Pero la casuística constata que esto no es así normalmente, pues en

826 En el mismo sentido Gómez RIVERo, Mª C., La responsabilidad penal del médico, op. cit., pp. 202 y ss; JERICó OJER, L., El conflicto de conciencia, op. cit., pp. 490 y 491; FlORES MENDOZA, F., Objeción de conciencia,

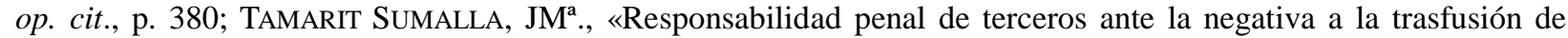
sangre de Testigo de Jehová menor de edad con resultado de muerte», Revista Actualidad Jurídica Aranzadi, núm. 325,1998, p. 2.

827 En el mismo sentido GARCía ÁlvareZ, P., La puesta en peligro, op. cit., pp. 544 y ss; GÓMEZ RIVERO, Mª., La responsabilidad penal del médico, op. cit., pp. 202 y ss; TAMARIT SUMALLA, JM ${ }^{\mathrm{a}}$, La libertad ideológica, op. cit., p. 425. Contrariamente ROMEO CASABONA, CMa., El médico y el Derecho penal, op. cit., p. 375; FLORES MENDOZA, F., Objeción de conciencia, op. cit., pp. 376 y ss.

${ }_{228} \mathrm{Al}$ respecto sostiene ROMEO CASABONA que «(e)l fundamento de esta disminución de la pena se basa, bien en la disminución pasajera de las facultades mentales del que actúa, debido a las alteraciones anímicas y emocionales que experimenta como consecuencia de los padecimientos del enfermo», refiriéndose entonces el citado autor, a la atenuante de arrebato u obcecación del ahora art. $21.3^{\mathrm{a}} \mathrm{CP}$, «principalmente cuando se trate de familiares, amigos y otros allegados, bien en su motivación puramente altruista, si la perturbación anímica no es significativa (p. ej., un médico o enfermera), lo que permitiría aplicar una atenuante por analogía», ROMEO 
otras ocasiones se acaba con la vida de un sujeto en virtud de otros móviles o motivos, como por ejemplo, para dejar libre los aparatos que le permitían tener vida, en claro beneficio de terceros con probabilidad más alta de vivir (muerte eliminadora), o por razones económicas, como en algunos casos en los que las familias sufren una carga económica muy pesada que puede llevar a decidir interrumpir el tratamiento, gracias al consentimiento que prestan, en sustitución del consentimiento del paciente cuando no está capacitado en sus facultades, o está inconsciente. Esta eutanasia es la llamada eutanasia económica.

En otras ocasiones, el móvil (motivo) humanitario, se enmarca en la llamada eutanasia eugenésica, que consiste en la muerte de sujetos portadores de enfermedades genéticas en la fase de gestación, conducta que actualmente permite el ordenamiento jurídico. Esta conducta constata que en la eutanasia el verdadero fundamento de la atenuación no sea propiamente el fin humanitario y solidario que también, pero de manera especial, se exige en el art. 143.4 CP.

La confrontación de ambas regulaciones nos hace pensar que nuestro fundamento, antes expuesto, sobre la paradoja de la moral universal, y que se argumentaba en el ejercicio de la libertad humana como expectativa legítima, subyace en las conductas del art. $143 \mathrm{CP}$, lo que fundamenta no ya la atenuación de la pena, sino de lege ferenda la descriminalización. De lo contrario se incurre en una contraorientación normativa a causa de una concepción estrictamente moralista, puesto que por un lado, se otorga relevante sensibilidad jurídica a la decisión de unos padres que no desean tener un hijo con graves malformaciones, cuyo fundamento se dice que es humanitario, pero a su vez y paradójicamente, no se reconoce el derecho a la muerte y la impunidad del cooperador cuando hay, tanto o más motivos humanitarios. Dicha contraorientación normativa viene de una anquilosada tradición moralista sobre la indisponibilidad de la vida, que por otro lado en otras partes del ordenamiento, no queda más remedio que reconocer (autopuestas en peligro, rechazo de tratamiento vitales, etc.), pero constata que el fundamento es estrictamente moralista y no normativo, como aquel que por nuestra parte planteábamos con la fundamentación de que las conductas libres racionales, aquellas ineludibles sobre bienes personales, no afectan ni tienen repercusión alguna en el Sistema, sino que en todo caso confirman la configuración normativa de la Sociedad en aquel derecho a la libertad de conciencia refrendado por la norma, y que no puede, a la postre, bajo pena de contraorientación normativa, interpretarse conforme a la moral pública o de una

CASABONA, CM ${ }^{\mathrm{a}}$, El Derecho y la Bioética, op. cit., p. 472; ID., «La objeción de conciencia en la praxis médica», op. cit., pp. 69 y ss; en el mismo sentido CÁMARA VILLAR, G., La objeción de conciencia al servicio militar: (las dimensiones constitucionales del problema, Civitas, Madrid, 1991, p. 31; Flores MENDOZA, F., Objeción de conciencia, op. cit., pp. 333 y 334. 
mayoría. De tal modo, la decisión sobre la propia muerte, libre, espontánea y voluntaria, como la participación, suponen una conducta/operación confirmatoria del Sistema al otorgarle vigencia.

Así, el elemento que caracteriza a este tipo penal y que atenúa lo injusto, además de ese motivo que se dice ser humanitario, es el consentimiento expreso, serio y libre, o más que el consentimiento, la «petición» del suicida, pues es una oferta del interesado, y no una oferta de suicidio por parte del sujeto activo que fuera aceptada posteriormente por el interesado.

Pues bien, la petición plantea numerosos problemas. No es lo mismo la petición expresa, seria, libre, e inequívoca y actual, que la petición formulada bajo las mismas condiciones pero con anterioridad suficiente como para dudar sobre cuál sería en la actualidad la decisión/voluntad del paciente. El debate se centra en el denominado testamento eutanásico o biológico, o vital, que en algunas ocasiones se formaliza para cuando llegado el momento de no poderse prestar la petición, se autoriza, en un momento de capacidad anterior, la voluntad de auxilio eutanásico, pero quizás, y este es el problema, ante la vivencia de tal situación dramática, el instinto de supervivencia innato en el ser humano, la voluntad y el deseo, podrían cambiar en tales situaciones extremas, lo que plantea problemas de validez normativa del testamento vital. También plantea problemas la inconsciencia del sujeto, que sin esa formulación testamentaria, se desconoce a ciencia cierta su voluntad. Y en la misma problemática estaríamos en casos de capacidad disminuida, semi-inconsciencia, o en casos de minoría de edad sin clara capacidad o madurez o recién nacidos.

El problema ético de estas situaciones para muchos no es el mismo en la eutanasia de un sujeto que ha cumplido las expectativas de su vida (hombre de la tercera edad), que en un adolescente que está en proceso de conseguir las ciertas expectativas y con un horizonte de posibilidades bastante amplio, o en un recién nacido que sólo tiene posibilidades. Estas diferencias, además de los niveles de conciencia, o la validez de la petición formulada anteriormente a la situación angustiosa (testamento eutanásico ${ }^{829}$ ), son problemas estrictamente de libertad. Si la libertad y la conciencia del sujeto constituyen su dignidad, y si sumamos que la voluntad humana nace del razonamiento, tenderemos que convenir que aquellas conductas que afectan al propio sujeto son el producto de su libertad, y así, de la elección de expectativas en un horizonte de posibilidades que no afectan a terceros. En este sentido no habrá inconveniente tampoco en admitir que un menor de edad, con suficiente madurez, pida a un tercero su muerte cuando concurran las circunstancias del art. $143 \mathrm{CP}$, si bien con este argumento estamos

\footnotetext{
${ }^{829}$ En la mayoría de los estados miembros de los EEUU se regula el «testamento eutanásico». Fue el Estado de California, el primero, en 1976, en promulgar la ley de «Natural Death».
} 
nuevamente fundamentando la descriminalización de lege ferenda, por cuanto su conducta igualmente confirma la vigencia de la configuración normativa del Sistema y de la Sociedad. De todo lo cual se puede deducir que la declaración de la voluntad, seria, libre, madura y espontánea en un testamento vital, o cuando se tenga noticia cierta, tenga la misma validez jurídica que una emitida al momento del riesgo vital, salvo que tratemos a los sujetos como incapaces y personas no libres, o dicho de otro modo, se valore la voluntad manifestada anteriormente de forma estrictamente moralista.

Parte de la doctrina encuentra el fundamento normativo de la atenuación de estas conductas en la atenuante analógica del art. $21.7^{\mathrm{a}} \mathrm{CP}$, por la merma de facultades volitivas que representa el estado pasional de arrebato u obcecación del art. $21.3^{\mathrm{a}} \mathrm{CP}$, como defiende ROMEO CASABONA ${ }^{830}$, que apela a que en casos de conflicto de conciencia sería aplicable una atenuación de la pena, más aun de la contenida en el mismo precepto, por disminución de las facultades mentales, lo que haría posible incluso la atenuante analógica o incluso de forma muy cualificada.

Sin embargo, por nuestra parte no estamos de acuerdo en que se fundamente en una analogía de una causa de inimputabilidad, esto daría pie a que todo sujeto sea considerado un trastornado o enfermo momentáneo, cuando se concierta con otro para provocarse heridas o la muerte, o cuando se realiza una omisión del deber de socorro,

Otros autores, como GIMBERNAT ${ }^{831}$ entre otros, defienden en parte la posibilidad de apreciar en la eutanasia activa directa un estado de necesidad justificante incompleto, al dotar de mayor valor jurídico en el caso concreto (ponderación de intereses) a la disponibilidad de la vida y al libre desarrollo de la personalidad que al bien jurídico de la vida, es decir, consideran que el mal jurídico evitado es mayor que el que se causa.

Parte de la doctrina ${ }^{832}$ considera que esta circunstancia ya ha sido tenida en cuenta para la atenuante, por lo que no entendemos que abogue, aun así, por una atenuante fundamentada en una menor exigibilidad y menor necesidad de penar, incluso muy cualifica.

830 Romeo CASABOna, CMa ., El Derecho y la Bioética, op. cit., pp. 471 y ss.

831 GimbernAT, E., «Eutanasia y Derecho Penal», op. cit., pp. 52 y ss; también en sentido similar, MUÑOZ Conde, F., Derecho Penal, Parte Especial, $15^{\text {a }}$ ed., op. cit., p. 76; VAlle MuÑIZ, JM., «Relevancia jurídico-penal de la eutanasia», op. cit., p. 179.

832 TOMÁs-VAliente LANUZA, Carmen, La disponibilidad de la propia vida en el Derecho penal, Centro de Estudios Políticos y Constitucionales, Madrid, 1999, pp. 361 y ss; JERICÓ apela a la inexigibilidad subjetiva en casos de dificultad de prueba, y la concreta en el miedo insuperable como eximente tanto completa como incompleta, o en casos de motivación similar a la del miedo defiende la atenuante analógica, siempre que exista un deber moral inexcusable. Sin embargo, en los casos de aplicación analógica del miedo insuperable considera que no estaría presente ese deber moral inexcusable, sino el puro convencimiento, lo cual le lleva a defender en este caso la aplicación de las reglas del art. $66.1 .6^{\circ} \mathrm{CP}$ y la sustitución de la pena según los arts. 80 y ss. CP, JERICÓ OJER, L., El conflicto de conciencia, op. cit., p. 541 y 542. 
Más coherente nos parece al respecto la opinión de $\operatorname{RoXIN}^{833}$ al considerar impunes estas conductas atendiendo a la libertad de conciencia contenida en el art. 4 de la Ley Fundamental, al ayudarse a cumplir la voluntad del sujeto.

Amén de todo lo anterior, llama singularmente la atención, como ha puesto de manifiesto POLAINO-ORTS $^{834}$, que la mayoría de la doctrina defienda la criminalización de la eutanasia directa activa, pero a la vez defienda la impunidad de la eutanasia directa pasiva y la indirecta pasiva invocándose incluso un estado de necesidad o colisión de deberes justificante, por cuanto si la diferencia entre eutanasia directa, como causación inminente y directa de la muerte, y la eutanasia indirecta es, en esta última la aceptación probable del resultado, o sea, la aparición de un dolo eventual de causar la muerte, habría que sancionar también la eutanasia directa pasiva y la eutanasia indirecta. De aquí que el fundamento de impunidad no pueda ser la dignidad humana, el desarrollo de la personalidad, o el derecho a no soportar tratos inhumanos, tal y como hemos defendido supra.

Visto lo anterior, podemos concluir que existe normativamente, un derecho a morir ${ }^{835}$ derivado del at. $15 \mathrm{CE}$ en determinadas circunstancias, tales como una lesión que conduce a la muerte y el sujeto se niega a al tratamiento médico por los motivos que sean, salvo una relación especial de sujeción, según lo visto. En nuestra opinión, el fundamento de esta atenuante, desde una perspectiva estrictamente normativa de lege data, únicamente puede ser el acuerdo libre de voluntades (contingencia de expectativas), que casualmente se corresponden en valores morales de los sujetos, y que a su vez se corresponde con la libertad de conciencia de una minoría, en este caso concreto, de dos personas, como expresión del derecho a la libertad de conciencia.

El fundamento normativo está en el acuerdo de voluntades libres e ineludibles como contingencia de expectativas legítimas, que si bien pueden disminuir la gravedad del injusto, ampara, según nuestros postulados, una causa de exculpación de estado de necesidad por el

833 Roxin, C., PG, I, op. cit., pp. 948 y ss; fundamentándolo en el libre desarrollo de la personalidad CARbonell MATEU, JC., «Libre desarrollo de la personalidad y delitos contra la vida», op. cit., p. 664. Defiende la impunidad de lege ferenda, si bien de lege lata no cabe justificación alguna JERICó OJER, L., El conflicto de conciencia, op. cit., p. 541.

834 Polaino-OrTs, M., vv.aa., Lecciones de Derecho penal, Parte especial, T. I, op. cit., pp. 80 y 81.

835 Muy acertadamente, dando en el centro de la cuestión, FLORES MENDOZA afirma que no existe «un derecho absoluto e incondicionado a vivir contra la propia voluntad», FLORES MENDOZA, F., Objeción de conciencia, op. cit., p. 358; o «una libertad para morir garantizada frente a la intervención de terceros, que tendrán el deber de no interferir en aquellos actos de disposición realizados por su titular», ID., ibidem, op. cit., p. 362; sin que esto lleve a considerar que existe un derecho de interpelar al Estado o particulares para la ayuda a morir, ID., ibidem, op. cit., pp. 363 y 364; por eso concluye que podría admitirse la disponibilidad de la propia vida mediante el auxilio de terceros siempre y cuando no suponga la renuncia del derecho de la vida, o sea, en la pérdida de control en casos de incapacidad legal o facultades psíquicas para tomar tal decisión o con presiones externas, ID., ibidem, op. cit., p. 366; anteriormente y en el mismo sentido RoMEO CASABONA, CMa ., El Derecho y la Bioética, op. cit., pp. 101 a 109 y ss. 
renombrado déficit de comunicación/socialización normativo. La paradoja normativa es que en el tipo del art. 143 CP, la norma, sólo otorga una forma incompleta, pero no vemos impedimento para aplicar en la mayoría de casos su causa completa, sin embargo, la norma, por razones claramente contraorientativas o moralistas, no regula la causa completa.

\section{F. La eutanasia pasiva directa e indirecta}

1. La eutanasia pasiva directa como interrupción o no iniciación del tratamiento por el rechazo al tratamiento vital de forma consciente y con plenas facultades mentales de un mayor de edad

La eutanasia se diferencia entonces del suicidio en cuanto que en la eutanasia interviene un tercero, ya que el interesado no puede llevar por sí mismo a buen fin su suicidio. Es vital para la responsabilidad criminal la eficacia y validez del consentimiento o petición del sujeto pasivo. En primer lugar, el necesitado puede elegir o rechazar un tratamiento médico en el momento que lo desee, pues forma parte de su libertad como sujeto auto-responsable.

Como dijimos supra, la Ley 41/2002 de la autonomía del paciente, reguló más ampliamente el consentimiento informado en los arts. 8, 9 y 10. También comentamos que las previsiones de la LGS han sido sustituidas por la LAP en su art. 2, apartados 3 y 4 de donde se deriva el derecho del paciente a la elección del tratamiento. De tal suerte, se reconoce en nuestra legislación no sólo la autonomía del paciente mayor de edad, sino también la del menor de edad cuando sea capaz intelectual y emocionalmente de comprender el alcance de la intervención, o dicho de otro modo, el menor de edad, por motivos religiosos, o los que fueren, tiene derecho a negarse a determinada intervención siempre que sea capaz intelectualmente y emocionalmente comprender el alcance de dicha intervención ${ }^{836}$, de tal manera que con dicha fórmula se resolvieron los problemas que generaba la Ley General Sanitaria en su vigencia de 1986, que no otorgada dicha autonomía al menor de edad.

Sin embargo, la verdadera problemática surge cuando el menor de edad no tiene la suficiente capacidad de decisión, trasladándose el consentimiento a la representación paterna, que si fuere denegada puede hacer incurrir en un delito de omisión del deber de socorro. Pero en nuestra opinión, según lo expuesto supra se puede resolver por cuestiones de atipicidad cuando se realice una conducta alternativa que asegure la protección del menor, o en su caso, por la eximente

836 También en este sentido Gómez Rivero, Mª C., La responsabilidad penal del médico, op. cit., pp. 191 y ss; JERICÓ OJER, L., El conflicto de conciencia, op. cit., p. 205. 
completa de estado de necesidad exculpante cuando el sujeto obre por un déficit de comunicación/socialización normativo.

\section{La eutanasia pasiva indirecta}

La eutanasia pasiva indirecta abre un debate no solo jurídico, sino también ético. La problemática jurídico-penal sobre esta clase de eutanasia permitida, o más bien atípica, se resume en el efecto de las situaciones límite de la no iniciación del tratamiento o en la interrupción del mismo cuando el sujeto está inconsciente o no está capacitado para prestar el consentimiento.

Estos casos no son de tan difícil resolución jurídica, pues se resuelven a favor de una eutanasia pasiva no punible ${ }^{837}$. Los aparatos son una prolongación de la actividad, es decir, suponen una longa manus, una omisión de hacer con la interrupción de los aparatos que únicamente prolongan la situación de riesgo vital que existe antes de la conexión. El único problema de estas situaciones es estrictamente moral, por lo tanto no pueden incluirse este tipo de valoraciones en la solución normativa. Su problemática se centra en la posibilidad de incurrir en una omisión del deber de socorro de los arts. 195 o 196 del Código Penal, sobre todo por parte de los facultativos que ejecutan la desactivación. Evidentemente, este es un miedo personal, fundado en la respuesta jurídica que viene de la actividad esencial del profesional médico, pero también puede nacer de conflictos éticos que nadie discute que son lícitos ${ }^{838}$.

En nuestra opinión, al tratarse de una persona «muerta», sin expectativas, no podrá considerarse una omisión del deber de socorro de los familiares, el consentimiento para la interrupción del tratamiento, pues tal tratamiento únicamente evoca una situación insalvable anterior a la conexión de los aparatos. Con el mismo razonamiento la finalización del tratamiento realizada por el médico con el consentimiento de la familia, tampoco no podrá considerarse una omisión del deber de socorro.

Otro caso de eutanasia pasiva indirecta es el del sujeto en fase terminal o irreversible, sin que exista tratamiento curativo, por lo que se recomienda para no incurrir en un caso de distanasia, la suspensión también del tratamiento o la no iniciación. Por el mismo razonamiento, la finalización del tratamiento realizada por el médico con el consentimiento de la familia, tampoco no podrá considerarse una omisión del deber de socorro.

837 Ampliamente ALDONEY RAMÍREZ, R., «Tratamiento jurídico penal de la eutanasia», op. cit., p. 172.

838 Como apunta Souto PAZ es normal que el «profesional de la salud manifieste una resistencia decidida a mantener el tratamiento aun cuando sea previsible su ineficacia para remediar una situación irreversible», porque correría el peligro de incurrir en el tipo del 196 CP, Souto PAZ, JA., Comunidad política y libertad de creencias, op. cit., p. 367. 
En último lugar, la eutanasia pasiva indirecta también evoca casos en los que un sujeto permanece en estado vegetativo persistente, lo que significa, comúnmente, con inconsciencia permanente pero con los ojos abiertos, con fases de vigilia y sueño, pero sin conocimiento del entorno y/o sin conocimiento del estado de uno mismo, por lo que se suele recomendar la suspensión del tratamiento, incluso la suspensión del suministro de la nutrición para acabar con esta situación. Este caso plantea mayores problemas porque el estado vegetativo no es propiamente irreversible. Por los mismos razonamientos antes dados, la interrupción del tratamiento no constituirá una omisión del deber de socorro, pues falta la posibilidad de socorrer en beneficio del sujeto, falta su propia expectativa.

La doctrina mayoritaria alemana ${ }^{839}$ considera que las medidas paliativas del dolor que aceleran la muerte constituyen una conducta típica, pero se justifica en virtud de un estado de necesidad, siempre y cuando exista consentimiento del sujeto pasivo y la obligación de aliviar el dolor sea mayor que el deber de respetar la vida.

En conclusión, en los casos de eutanasia pasiva indirecta concurren conflictos de conciencia en los familiares, entre la esperanza de conseguir al paciente una vida normal o la convicción de mantenerle en vida en ese estado, o acabar con la vida de un ser que no siente ni la vida misma. Son casos de conflictos de conciencia en los que el derecho, paradójicamente, cuando el sujeto está consciente, no entra a valorar la conducta del sujeto que omite el deber de socorro, por eso son atípicos, por eso decimos que el conflicto de conciencia es ajeno al tratamiento penal, lo cual resulta contradictorio, por un lado, con los fundamentos de criminalización del auxilio activo al suicidio y por otro, con los de la omisión del deber de socorro por falta de consentimiento, o expreso rechazo del tratamiento, en menores incapaces, inmaduros y/o en estados de inconsciencia cuando en estos también hay un peligro objetivo de muerte.

Sobre estos últimos casos vamos a tratar centrar la cuestión a continuación mediante una detallada controversia entre el tipo de la omisión del deber de socorro propia o pura, la agravada, y la comisión por omisión o comisión impropia de homicidio, al objeto de comprobar si nuestros previos postulados de exención de la responsabilidad por atipicidad y por estado de necesidad exculpante se cumplen en los respectivos tipos y a su vez, si se confirma que el cambio de circunstancias no alteran la concepción del autor de conciencia que hemos defendido.

839 RoxIN, C., «Tratamiento jurídico-penal de la eutanasia», RECPC, 1-10, 1999. El Tribunal Federal alemán sostiene que «las medidas que alargan la vida no son imprescindibles por el hecho de ser tecnológicamente posibles», BGHSt 32, 379 y 380. 


\section{II.- Trasfusiones de sangre de terceros diferentes al titular del bien jurídico en manifiesto peligro de muerte: omisión del deber de socorro y homicidio en comisión por omisión}

\section{A. Introducción al conflicto de conciencia en las transfusiones de sangre}

Existe un caso típico de rechazo de tratamiento médico por motivos de conciencia, en concreto, el rechazo de transfusiones de sangre por miembros del grupo religioso Testigos de Jehová, aunque existen casos protagonizados por los seguidores del Cristo de Monfavet de la Iglesia Cristiana Universal.

Los Testigos de Jehová se niegan a la transfusión de sangre por motivos morales, que vienen de diversos textos religiosos como el Antiguo Testamento, que prohíbe alimentarse con sangre ${ }^{840}$. Además de estos argumentos tradicionales, los Testigos de Jehová y otros grupos religiosos encuentran otros argumentos para el rechazo, más allá de los puramente morales, como es el peligro que conlleva este tratamiento con la posible infección del SIDA y otras enfermedades susceptibles de transmitirse a través de transfusiones.

Desde 1927 la directiva de los Testigos de Jehová advirtió a sus miembros del pecado que se produce con la contaminación de la sangre. A partir de dicha fecha se comenzó a sancionar a todo aquel que permitiera una transfusión de sangre y manifestase una actitud impenitente con la expulsión de la congregación. Esto constata que antes de este año 1927 este grupo no se pronunciaba al respecto, es más, era alabada la donación de sangre. Fue a partir de este año cuando RUTHERFORD, presidente de la confesión, realizó cambios doctrinales de importancia en la objeción de conciencia. Además de la prohibición de trasfusiones de sangre, se incluyó la prohibición de las vacunas en 1928, y la prohibición del servicio militar más adelante cuando anteriormente, sus miembros colaboraron en guerras, por ejemplo durante la Primera Guerra Mundial, en la que si bien se auto-determinaban «neutrales», no excluían la cooperación ${ }^{841}$.

840 Concretamente se suelen citar los siguientes pasajes bíblicos: Hechos de los Apóstoles, capítulo 15, versículo 28 y 29, y capítulo 21, versículo 25; Levítico, capítulo 17, versículos 10 y 11; y Deuteronomio, capítulo 12 versículos 23 y siguientes. Destacamos el Levítico, XVII, 10: «Si un israelita o un extranjero residente entre vosotros come cualquier clase de sangre, yo me volveré contra él y los extirparé de su pueblo», vid., CERVELLÓ DONDERIS, V., El delito de coacciones, op. cit., p. 34.

841 Vidal Manzanares, C., Psicología de las sectas. Una aproximación al fenómeno sectario, $2^{\mathrm{a}} \mathrm{ed}$. , Ediciones Paulinas, 1990, pp. 31 y 32; GUERRA, Manuel, «Lo que es y lo que no es una secta», GUERRA M / AzCONA F / LoRdA JL., Sectas ¿De qué hablamos? Historia de las religiones, Sociología y Evangelización, Navarra gráfica Ediciones, Cuadernos del Instituto Martín de Azpilcueta, $1^{\text {a }}$ ed., 1999, p. 54, nota 37; ampliamente CARRERA, Antonio, 127 preguntas sobre la secta de Jehová, Chihuahua, 1994, pp. 169 y ss; GARCÍA GONZÁLEZ, Teodoro, Los testigos de Jehová. Una guía para católicos, $1^{\mathrm{a}}$ ed., Vita Brevis, Colección RIES núm. 1, Red Iberoamericana de Estudio de las Sectas, 2003. 


\section{B. Omisión del deber de socorro}

SCHOPENHAUER ya advirtió que la justicia es negativa (deber negativo) y que por el contrario la injusticia es positiva, por lo que el neminem laede supone un principio de justicia que se sustenta en el fundamento de la piedad como moral. Esto no excluye que haya deberes positivos como los estatales y familiares que exigen un mayor cuidado anticipadamente ${ }^{842}$. De esto resulta que el citado filosofo concluyera que el derecho no es otra cosa que la negación de la injusticia, negar hacer mal a otro, negar la voluntad legítima de otro, y de aquí que no puede existir injusticia alguna en «el negar ayuda en una necesidad apremiante o ver morir de inanición a un hombre» ${ }^{843}$, porque un comportamiento en este sentido no niega la voluntad del otro, es un deber positivo que emana «moralmente» del deber de no dañar, es una excitación a ayudar ${ }^{844}$, pero es una cuestión estrictamente moral, que como vamos a analizar se ha positivado en la mayoría de códigos penales, como clara influencia de un deber moral recogido en la ley, únicamente busca que los sujetos actúen moralmente (orientación normativa moral), no un verdadero resultado, a diferencia de los deberes positivos (contraídos, impuestos o como efecto de un determinado acto). Esta positivación de un deber de la moral (de la «virtud») supone, en definitiva, una clara operación de la moralidad del Derecho en sus operaciones, que como veremos, interfiere en el alcance de otras normas como la omisión de deber de socorro agravada y la comisión por omisión, pero fundamentalmente ocasiona la interferencia de la orientación comunicativa con otro deber moral reconocido como la libertad de conciencia.

El art. 195.1 CP castiga con la pena de multa de dos a doce meses, al «que no socorriere a una persona que se halle desamparada y en peligro manifiesto y grave de muerte, cuando pudiere hacerlo sin riesgo propio ni de terceras personas», también en su apartado 2, al «que impedido de prestar socorro, no demande con urgencia auxilio ajeno», y en el apartado 3 «si la víctima lo fuere por accidente ocasionado fortuitamente por el que omitió el auxilio, la pena será de prisión de seis meses a dos años y multa de seis a veinticuatro meses».

La doctrina mayoritaria ${ }^{845}$ estaba de acuerdo en considerar que el bien jurídico protegido en este delito es la solidaridad humana, pero más recientemente se ha precisado por parte de la

842 SCHOPENHAUER, A., El fundamento de la moral, op. cit., pp. 105 y ss.

843 SCHOPENHAUER, A., El mundo como voluntad y representación, T. I, op. cit., Libro IV, 62, p. 477.

844 SCHOPENHAUER, A., El fundamento de la moral, op. cit., pp. 117 y 118.

845 NAVARRETE URIETA, José María, «La omisión de socorro», Revista de la Facultad de Derecho de la Universidad Complutense de Madrid, RFDUCM, Vol. III, núm. 6, 1959, págs. 419 a 431; SAINZ CANTERO, A., «El delito de omisión del deber de socorro», RGLJ, 1960; TORío LÓPEZ, A., «Aspectos de la omisión especial de socorro», ADPCP, 1967. 
doctrina $^{846}$ que el bien jurídico es el valor de la solidaridad humana, que -como más acertadamente comenta POLAINO NAVARRETE ${ }^{847}$ - no supone un deber moral sino un «deber positivo» para el bienestar de la generalidad, a diferencia de los deberes negativos de «no dañar» cuando estén en peligro la vida y la salud. Sin embargo, otro sector ${ }^{848}$ considera que el bien jurídico protegido no es otro que la vida y la salud, por cuanto los ciudadanos en una sociedad, en determinados momentos, ahora sí, por solidaridad, deben ayudar a los demás cuando sea posible en determinados casos, cuando la solidaridad tenga conexión con la vida y la integridad $^{849}$.

Así las cosas, un sector doctrinal ${ }^{850}$ entiende que la obligación de actuar se refiere a existencia de un peligro manifiesto y grave contra la vida y/o la salud, sin embargo otro sector ${ }^{851}$ incluye también la libertad, la integridad moral, el honor y la libertad sexual ${ }^{852}$. Nos adherimos a esta segunda corriente por cuanto hace perfectamente comprensible el valor de solidaridad humana que justifica la tipificación penal, pero siempre y cuando el desamparo se refiera a un peligro manifiesto y grave contra bienes jurídicos que afecten a la vida y a la salud, y en este último sentido, la salud, comprendida en su más amplio termino, incluyendo la integridad moral, la libertad, cuando por su constreñimiento pueda resultar gravemente afectada la salud, y la libertad sexual, cuando su quebrantamiento también afecte de forma manifiesta y grave a la salud. Sólo así, con una comprensión amplia del concepto de salud puede tener efectividad el propósito de tipificar la omisión del deber de socorro, mientras que interpretarlo en sentido estricto, inclusive como si sólo se requiriera el peligro de la salud física, conllevaría situaciones absurdas, como

846 RodríGuez Mourullo, Gonzalo, La omisión de socorro en el Código penal, Madrid, 1966; PORTILlA Contreras, G., vv.aa., Curso de Derecho penal Español, Parte Especial, I, Marcial Pons, Madrid, 1996; POLAINO NAVArRete, M., Acción, omisión y sujetos en la Teoría del delito, op. cit., p. 71, porque «el titular del deber de solidaridad es cualquier persona, sin requerirse en el autor una cualificación o rol especial, sino únicamente e rol general o común de ciudadano».

847 Haciendo referencia a CARO JOHN, JA., La imputación objetiva en la participación delictiva, Grijley, Lima, 2003, reedición 2009, pp. 89 y ss; POLAINO NAVARreTe, M., Acción, omisión y sujetos en la Teoría del delito, op. cit., p. 73.

848 Carbonell Mateu Juan Carlos / GonzÁlez Cussac José Luis, Comentarios al Código penal de 1995, VIVES ANTÓN (coord.), Vol. I, Valencia, 1996; HuERTA TOCILDO, S., «Injerencia y artículo 489 bis, 3 CP», ADPCP, 1985.

849 Vid. Del Rosal Blasco, Bernardo, vv.aa., Derecho penal español, Parte especial, $2^{\mathrm{a}}$ ed., revisada, coord. Manuel Cobo del Rosal, Dykinson, 2005, p. 330.

850 Carbonell Mateu JC / GonzÁlez Cussac JL., en Vives Antón (coord.), Comentarios al Código penal de 1995, Vol. I, op. cit; MAQUEDA ABREU, Mª., Los delitos contra la libertad y seguridad de las personas, Granada, 1988; Muñoz CONDE, F., Derecho penal. Parte especial, 15 ${ }^{\mathrm{a}}$ ed., op. cit., pp. 309 y ss; PORTILLA CONTRERAs, G., vv.aa., Curso de Derecho penal español, Parte especial, I, op. cit; RodríGUEZ Mourullo, G., La omisión de socorro en el Código penal, op. cit.

851 RODRÍGUEZ DEVESA JM ${ }^{\mathrm{a}}$ / SERRANo Gómez A., Derecho penal español, Parte especial, $18^{\mathrm{a}}$ ed., revisada y puesta al día por Alfonso Serrano Gómez, Madrid, 1995, p. 121; Sola RECHE, Esteban, «Delitos de omisión pura y sistema de Derecho penal», vv.aa., La Ciencia del Derecho penal ante el nuevo siglo. Libro Homenaje al profesor Doctor Don José Cerezo Mir, Madrid, 2002.

852 Vid. Del Rosal Blasco, B., vv.aa., Derecho penal español, Parte especial, op. cit., p. 331. 
que un sujeto viera que la víctima se hallase inmersa en un estado de shock y nervios delirantes tras un accidente, que sin peligrar su vida directamente, permaneciera en el lugar sin avisar a las asistencias, y esto es, porque en tal estado, existe un peligro tanto para la salud psíquica, como eventualmente para la vida, al desconocerse las consecuencias a las que llevaría el deterioro grave de la salud psíquica, como las consecuencias delirantes en ese estado mental.

Por otra parte, el apartado segundo del art. $195 \mathrm{CP}$, criminaliza al que estando imposibilitado demorase el auxilio ajeno cuando pudiere pedirlo. Y de otra, el controvertido apartado tercero del art. $195 \mathrm{CP}$. La mayor parte de la doctrina ${ }^{853}$ considera que es posible aplicar la causación fortuita e imprudente respecto a la causa de la situación de desamparo. No obstante, esta última corriente se encuentra con dificultades de conciliar esta conclusión con el art. $11 \mathrm{CP}$ al menos en la actuación fortuita. La problemática se centra en si este apartado tercero puede considerarse un tipo autónomo e independiente, o agravado del tipo básico de apartado primero. En el primer sentido, no harían falta los requisitos del apartado primero, por lo que bastaría con que un sujeto causara un accidente, ya fuere fortuito o imprudente, sea la gravedad que sea, mientras que en un segundo sentido, si lo situamos como un tipo agravado, será necesario que la víctima quede en situación de peligro manifiesto y grave. En opinión de SILVA SÁNCHEZ ${ }^{854}$, este tipo penal esconde un delito de omisión pura agravada.

La misma problemática existe en relación al art. 195 y el art. 196 CP. Este último castiga «con las penas del artículo precedente en su mitad superior y con la de inhabilitación especial para empleo o cargo público, profesión u oficio, por tiempo de seis meses a tres años (...) al profesional que, estando obligado a ello, denegare asistencia sanitaria o abandonare los servicios sanitarios, cuando de la denegación o abandono de derive riesgo grave para la salud de las personas».

Los que defienden ${ }^{855}$ que es un tipo autónomo alegan que el riesgo en el art. 196 CP viene de la denegación o abandono del servicio profesional directamente, mientras que los que defienden que es un tipo agravado defienden que las figuras son básicamente las mismas por cuanto que también en el art. 196 CP se refiere a que la situación de riesgo viene generada antes de que el

853 Bustos Ramírez, J., Manuel de Derecho penal, Parte especial, $2^{\mathrm{a}}$ ed., aumentada, corregida y puesta al día, Ariel, Barcelona, 1991, pp. 86 y 87; Del Rosal Blasco, B., vv.aa., Derecho penal español, Parte especial, op. cit., pp. 334 y 335; GÓMEZ RivERO, $\mathrm{M}^{\mathrm{a}} \mathrm{C}$., «La producción del resultado muerte o lesiones en relación al supuesto agravatorio del art. 489 ter.», La Ley, 1995; MuÑoz Conde, F., Derecho Penal, Parte Especial, 15 ${ }^{\text {a }}$ ed., op. cit., p. 336; SiLVA SÁNCHEZ, J-Ma ., «Problemas del tipo de omisión del deber de socorro (comentario a la STS de 27 de abril de 1987, ponente Sr. Díaz Palos)», ADPCP, 1988.

854 SILVA SÁNCHEZ, J-Ma ., El nuevo Código penal: cinco cuestiones fundamentales, Bosch, Barcelona, 1997, pp. 51 a 78.

855 Huerta Tocildo, S., Principales novedades de los delitos de omisión en el Código penal de 1995, Valencia, 1997; RodríGuez Mourullo, G., vv.aa., Comentarios al Código penal, Madrid, 1997. 
sujeto activo abandone el servicio, es decir, si la víctima necesita asistencia es porque antes de la solicitud ya corre un riesgo, que en verdad, no ha sido generado por el sujeto activo, por lo que el abandono o la denegación constituirían un plus de reproche penal, por el especial deber normativo de este tipo de profesionales ${ }^{856}$. Precisamente la omisión pura por inactividad dada la inexigencia del resultado del apartado primero del art. $195 \mathrm{CP}$ ha llevado a parte de la doctrina a considerar al apartado 3 una omisión pura de garante, es decir, una agravación por la garantía exigida $^{857}$.

En este sentido, DEL RoSAL BLASCO considera que «(e)1 art. 196 no tipifica, como en el caso del art. 195, la infracción de un deber general de solidaridad, sino la de un deber jurídico (general) de actuar, que puede estar establecido legal o contractualmente, pero que no es, todavía, fuente de un deber de garante (v.gr., por asunción fáctica del compromiso de protección) para poder constituir un título de responsabilidad criminal sobre la base de la cláusula general de omisión del art. 11 y el correspondiente delito de resultado (homicidio o lesiones)» ${ }^{858}$. Esta es precisamente la principal problemática que abordaremos en el siguiente apartado.

En nuestra opinión, y siguiendo la doctrina mayoritaria, ha de interpretarse como un tipo simplemente agravado del tipo básico y autónomo del art. $11 \mathrm{CP}$. La problemática se centra en la fórmula «sin riesgo propio ni de tercero» del art. $195 \mathrm{CP}$ (similarmente el parágrafo 323c StGB), que ha sido entendida por parte de la doctrina como una representación del principio de inexigibilidad que tiene su transcendencia en la atipicidad de la conducta ${ }^{859}$. Sin embargo, otro sector - encabezado en la actualidad por JAKOBS ${ }^{860}$ - lo relacionada con una causa de justificación de la antijuricidad, y otro sector reclama su ubicación en la culpabilidad porque la fórmula habla de una acción esperada ${ }^{861}$.

Cada postura doctrinal tiene su trascendencia en materia de error, puesto que si se ubica la inexigibilidad en la tipicidad, el error invencible excluirá la responsabilidad, y la vencibilidad llevará a la imprudencia, mientras que si se ubica en la culpabilidad, se tratará como un error de prohibición con las repercusiones del art. $14 \mathrm{CP}$. Igualmente en la participación, convencer al obligado de que no actúe podría tratarse de inducción activa o de complicidad psicológica por

\footnotetext{
856 Portilla Contreras, G., vv.aa., Curso de Derecho penal español, Parte especial, I, op. cit; Del ROSAL Blasco, B., vv.aa., Derecho penal español, Parte especial, op. cit., pp. 337 y 338.

857 Silva SÁnCHEZ, J-Ma , El Nuevo Código penal: cinco cuestiones fundamentales, op. cit., pp. 70 y ss.

858 Vid. Del Rosal Blasco, B., vv.aa., Derecho penal español, Parte especial, op. cit., p. 338.

859 Silva SÁNCHEZ, J-M ${ }^{\text {. }}$, El delito de omisión. Concepto y sistemas, op. cit., p. 307 en relación al derogado art. 489 ter pero que mantiene la misma fórmula que el actual art. $195 \mathrm{CP}$.

860 JAKOBS, G., $P G$, op. cit., 29/98.

861 Carbonell Mateu Juan Carlos / González Cussac José Luis, Derecho penal, Parte especial, $2^{\mathrm{a}}$ ed., Valencia, 1996, pp. 245.
} 
quien no tiene capacidad de auxilio ${ }^{862}$, lo que adquiere igualmente trascendencia en la punibilidad del partícipe según si se ubica la inexigibilidad en la atipicidad, en cuyo caso, el partícipe de una conducta inexigible sería impune, pero más problemáticos son los casos si se ubica en la culpabilidad, por el principio de accesoriedad limitada de la participación aun eximiéndose al autor ${ }^{863}$. En nuestra opinión, en los delitos de omisión propia no será posible la participación ${ }^{864}$. Sin embargo, en la participación en los delitos de comisión por omisión es posible ya sea por inducción, ya participando con quien tiene la posición de garante ${ }^{865}$, mientras que otros admiten la participación y complicidad omisiva porque relegan la responsabilidad en estos casos a los delitos de omisión del deber de socorro ${ }^{866}$.

Parte de la doctrina considerada que la causación de un accidente propicia una ponderación de intereses entre el desamparo y el riesgo propio que fundamenta una mayor exigibilidad de actuar, sin embargo en algunas circunstancias, ese deber, considera parte de la doctrina, se neutraliza cuando existe la probabilidad de detención y enjuiciamiento ${ }^{867}$.

C. Comisión por omisión del art. 11 CP y los conflictos con los arts. 195 y 196 CP

1. Debate doctrinal sobre la delimitación objetiva de los preceptos

El Código penal preceptúa en el art. 11 que una omisión equivale a una acción: «a) Cuando exista una específica obligación legal o contractual de actuar. b) Cuando el omitente haya creado una ocasión de riesgo para el bien jurídicamente protegido mediante una acción u omisión precedente».

De aquí surge la problemática sobre cuándo estamos ante una conducta simplemente omisiva pura, agravada, o en comisión por omisión. Parte de la doctrina considera que el art. 11 b) se aplica exclusivamente en las conductas precedentes dolosas ${ }^{868}$, pues de lo contrario el art. 195.3

862 Admite la inducción aunque reconoce la dificultad de la complicidad AGUADO CORREA, T., Inexigibilidad, op. cit., pp. 178 y 179

${ }^{863}$ Aguado Correa, T., Inexigibilidad, op. cit., pp. 179 y 180.

864 JAKOBS, G., $P G$, op. cit., 30/3 y 30/4.

865 ID., ibidem, op. cit., 29/108.

866 Aguado CORREA, T., Inexigibilidad, op. cit., p. 198.

867 SILVA SÁNCHEZ, J-Mª, «Problemas del tipo de omisión del deber de socorro (comentario a la STS de 27 de abril de 1987, ponente Sr. Díaz Palos)», op. cit., pp. 562 y ss; MAQUEDA ABREU, MáL., «Exigibilidad y derecho a no declararse culpable», op. cit., p. 36 en cuanto al derecho constitucional de auto-encubrimiento como expresión del derecho a no confesarse culpable ni a declarar contra uno mismo, inherentes al art. 24.2 CE

868 CUADRADO RuIZ, María Ángeles, La responsabilidad por omisión de los deberes del empresario (análisis crítico del art. 363 del Código penal), Bosch, Barcelona, 1998, p. 177, ID., «La posición de garante», RDPC, 6, 2000, p. 35; GonZÁlez Rus, Juan José, vv.aa., Curso de Derecho penal español, Parte especial, I, Marcial Pons, Madrid, 1996, p. 30; SÁNCHEZ TOMÁs, José Miguel, Comisión por omisión y omisión de socorro agravada, Bosch, 2005, pp. 221 a 224; ID., vv.aa., Derecho penal. Parte especial, I, Ed. Facultad de Derecho, UCM, Madrid, 1996, p. 8; Silva SÁnchez, J-Mª, El Nuevo Código penal: cinco cuestiones fundamentales, op. cit., p. 67; ID., vv.aa., Comentarios al Código penal, T. I, (arts. 1 a 18), dir. Manuel Cobo del Rosal, Edersa, Madrid, 1999, p. 479; ID., 
CP no tendría aplicación alguna. Al respecto, comenta SILVA SÁNCHEZ ${ }^{869}$ que, no obstante, una conducta precedente imprudente se puede convertir en dolosa cuando alcanza la esfera de organización ajena, con lo que está afirmando que debe estudiarse un todo. Por eso algunos $\operatorname{otros}^{870}$ consideran que la conducta precedente imprudente sí puede entrar en el ámbito del 11 b). Una segunda línea entiende que hay otros elementos, los objetivos, más allá de los subjetivos, que resultan ser los criterios de distinción ${ }^{871}$.

Así pues, el art. 195.3 CP es un delito de simple inactividad según hemos visto, lo cual no genera responsabilidad por el resultado final producido, se consuma con esa simple inactividad. Sin embargo, esto no sucede con el art. $11 \mathrm{CP}$, que precisa una capacidad de la acción según refiere parte de la doctrina ${ }^{872} \mathrm{y}$, unánimemente, un resultado. Si falta el resultado, puede apreciarse la tentativa, tentativa que estaría más gravemente penada que la simple inactividad del art. 195.3 CP, y mucho menos en caso de que aceptemos la posibilidad de la tentativa en los delitos de simple actividad o inactividad.

El problema es que los términos «riesgo» y «peligro», de los arts. 195 y $196 \mathrm{CP}$, van referidos a la probabilidad del resultado, como así considera acertadamente parte de la doctrina ${ }^{873}$. Por eso, PolAino NAVARRETE argumenta que todos los delitos, incluso los de mera actividad exigen la producción de un resultado, al menos, jurídico (en los casos de delitos de mera actividad, por ejemplo, la omisión del deber de socorro el resultado se refiere al peligro o puesta en peligro), por lo que al no poder incluirse este tipo de delitos dentro la cláusula del art. $11 \mathrm{CP}$, es lógico pensar que el resultado que exige el art. 11CP, se refiere a delitos de resultado material. Este es el resultado que se imputa al garante que omite el deber.

«Entre la omisión de socorro y la comisión por omisión. Las estructuras de los arts. 195.3 y 196 del Código penal», vv.aa., Problemas específicos de la aplicación del Código penal, Manuales de formación continuada, núm. 4, Consejo General del Poder Judicial, Madrid, 1999, pp. 163 y ss., entiende que no está argumentada la comisión por omisión imprudente.

869 SILVA SÁnCHEZ, J-Mª, Comentarios al Código penal, T. I, op. cit., p. 479.

870 JAKOBS, G., PG, op. cit., $29 / 41$ a 29/43; HuERTA TOCILDO, S., Principales novedades, op. cit., pp. 37 y ss.

871 BacigaluPo, E., Principios de Derecho penal, Parte General, Akal, 4a ed., Madrid, 1997, pp. 392 y ss; GómEz RIVERO, MaC., «La regulación de los delitos de omisión del deber de socorro», La Ley, 1996, 3, p. 1386; Huerta Tocildo, S., Principales novedades, op. cit., pp. 37 y ss; JaKOBS, G., PG, op. cit., 29/41 a 29/43; MIR PUIG, S., PG, op. cit., pp. 315 y ss; Portilla Contreras, G., vv.aa., Curso de Derecho penal español, Parte especial, I, op. cit., p. 379.

872 Gracia Martín, L., vv.aa., Comentario al Código penal, Parte especial I (títulos I a VI y faltas correspondientes), coords. José Luis Díez Ripollés y Luis Gracia Martín, Tirant lo Blanch, Valencia, 1997, p. 76; MIR PUIG, $P G$, op. cit., p. 318.

873 Polaino Navarrete, M., Acción, omisión y sujetos en la Teoría del delito, op. cit., p. 88 ya sea por negligencia en el planteamiento o en la ejecución de la conducta evitadora del resultado, o por negligencia en el enjuiciamiento de la situación típica de riesgo; PORTILla CONTRERAS, G., vv.aa., Curso de Derecho penal español, Parte especial, I, op. cit., p. 371. 
Sin embargo, como en los delitos de mera actividad que se refieran a un resultado concreto, por ejemplo, el delito de falso testimonio, se pueden incluir en los delitos de resultado jurídico, en el art. 11 CP pueden incluirse toda clase de resultados ${ }^{874}$. Si bien, en nuestra opinión, habrá que hacer las salvedades propias de la Parte Especial que se refiera a delitos de peligro, y a aquellos de mera actividad que se refieran, también, a un deber positivo de evitar un peligro, como el de omisión del deber de socorro, para comprobar y excluir la norma más general del art. $11 \mathrm{CP}$.

Entonces, en principio, el art. $11 \mathrm{CP}$ se circunscribe en los delitos que consisten en la producción de un resultado, pero esto no debe ser entendido como una exigencia estricta de resultado material o de lesiones, sino que cabe aplicarse también en los de peligro ${ }^{875}$ y los de mera actividad que se refieran a un resultado concreto, p. ej., el delito de falso testimonio. Por ello, el mandato del art. 195 CP se refiere exclusivamente a un deber de simple actividad, que no niega tampoco la posibilidad de una tentativa ${ }^{876}$.

Un ejemplo nos puede dar la respuesta: Un sujeto causa un accidente a otro sujeto, y en la variante 1 muere el accidentado, y en la 2 no muere. Llevar la variante 2 al art. $195.3 \mathrm{CP}$ y la 1 a la solución del art. $11 \mathrm{CP}$, es cuando menos olvidar la tentativa de comisión por omisión, que como cabe recordar, es admitida por la mayoría de la doctrina ${ }^{877}$. De tal manera que si no se produce el resultado y la acción previa ha sido imprudente o fortuita, se debe aplicar el art. 195.3 CP para cubrir los casos en los que el art. 11 CP falta el título de imputación doloso, y esto porque no hay respaldo doctrinal ni legal aún para la punibilidad de la tentativa imprudente, por la que abogamos de lege ferenda por la punibilidad de la tentativa imprudente en los delitos muy graves $^{878}$.

El desamparo, por otro lado, se refiere a la falta de capacidad de la víctima para eliminar los focos de peligro para sus bienes jurídicos ${ }^{879}$. Como señala SÁNCHEZ TOMÁs, «(e)l concepto de desamparo está siendo interpretado de forma muy estricta por la jurisprudencia en los supuestos de omisión del deber de socorro agravada y de forma más laxa en la omisión del deber de

874 POLAino NAVARRETE, M., Acción, omisión y sujetos en la Teoría del delito, op. cit., pp. 84 y 85.

875 GonZÁlez Rus, JJ., Curso de Derecho penal Español, Parte Especial, I, op. cit., p. 25.

876 Jakobs, G., $P G$, op. cit., 30/5; Polaino NAVARRETE, M., «Injusto de la Tentativa y Vigencia de la Norma desde una Perspectiva Penal Funcionalista», op. cit., p. 739; PORTILla CONTRERAs, G., vv.aa., Curso de Derecho penal español, Parte especial, I, op. cit., pp. 363 y ss.

877 ALCÁCER GUIRAO, Rafael, «Comienzo de la tentativa en la comisión por omisión», $C P C, 2001,73$, pp. 7 a 33; ID., «Tentativa y desistimiento en la comisión por omisión», La Ley, 2002, 5, pp. 1453 a 1465.

${ }^{878}$ Esta es la tesis que defiende MOLINA FERNÁNDEZ, que considera que la relación de estos dos artículos es semejante a la de los delitos de peligro activo y delitos de lesión, Molina FernándEZ, F., vv.aa., Compendio de Derecho penal (Parte especial), Vol. II, Ceura, Madrid, 1998, pp. 172 y ss.

${ }^{879}$ Portilla Contreras, G., vv.aa., Curso de Derecho penal español, Parte especial, I, op. cit., p. 368. 
socorro básica, y ello por el especial carácter personalísimo de la obligación de auxilio que se deriva de la provocación previa de la situación de peligro» ${ }^{880}$.

La conclusión es que el elemento objetivo desamparo está inmerso en los tipos debatidos, tanto en los arts. 195 y 196 como en el 11 CP. Sin esta situación de desamparo, ninguna obligación nace ex tunc. Sin embargo, cabe exponer, en desacuerdo con parte de la doctrina, que la obligación, o al menos parte de ella, nace ex ante, tanto en los delitos de responsabilidad por organización, como en los delitos de infracción de deber del art. 11 CP. En un ejemplo expuesto por JAKOBS ${ }^{881}$ se puede ver esto: una madre no puede dejar de hacer sus deberes para con su hijo cuando dicha dejación crea focos de peligro, pues dicha omisión está ya produciendo el inicio de un desamparo que alargado en el tiempo es imputable en la producción del resultado prohibido.

En tal sentido, ha de matizarse que una conducta fortuita no cabe en el art. $11 \mathrm{CP}$ por la sencilla razón de que éste pena la infracción de un deber, no omisiones simples, de lo contrario se vulneraria el art. $6 \mathrm{CP}$; sin embargo, la acción precedente sí puede ser fortuita (o imprudente ${ }^{882}$ ) y a la postre igualmente entrar en el radio de acción del deber institucional, porque el fundamento de la injerencia reside en el hacer precedente. Del tal suerte, JAKOBS ${ }^{883}$ entiende que al estar la injerencia en los deberes de salvación, no se puede excluir a quien actúa en función de ese deber.

Así las cosas, existe una clara diferenciación entre los deberes de actuación y los deberes de evitación del resultado, que defiende la teoría de los delitos de infracción de deber, que magistralmente ha desarrollado SÁNCHEZ-VERA ${ }^{884}$, en continuación de los postulados de JAKOBS. El art. 195.3 CP no criminaliza el resultado, sino únicamente una omisión considerada socialmente insolidaria, si bien esto es incomprensible para algunos ${ }^{885}$. Si no se consigue la

880 SÁNCHEZ TOMÁs, JM., Comisión por omisión, p. 71, nota núm. 131, refiriéndose en concreto a la STS de 8 de noviembre de 1991, y en contra a la Sentencia de la AP de las Palmas (Sección 1ª), de 19 de noviembre de 1999.

881 JAKOBS, G., $P G$, op. cit., 15/15

882 SILVA SÁnCHEZ, J-Mª, Comentarios al Código penal, I, op. cit., p. 479.

883 JAKOBS, G., PG, op. cit., 29/39 y ss; MAURACH en el mismo sentido ya dijo en su tiempo que «es necesaria y suficiente una acción precedente de cualquier naturaleza, creadora o elevadora del peligro. Su calificación jurídica no interesa (...) También actos de cortesía, como el acompañar a un anciano al cruzar la calle, podrían producir efecto fundamentador de la garantía», MAURACH, R., Tratado, II, op. cit., p. 289.

884 SÁnCHEZ-VERA, J., Delito de infracción de deber y participación delictiva, op. cit., pp. 65 y ss. y pp. 181 y ss; Polaino Navarrete, M., Acción, omisión y sujetos en la Teoría del delito, op. cit., p. 96, si bien matiza que quizá por razones de política criminal se establece un tipo más atenuado como la del delito imprudente o la inferior en grado.

885 Silva SÁnCHEZ, J-Mª El delito de omisión. Concepto y sistema, op. cit., p. 291; en el mismo sentido, exigiendo que la acción se dirija a evitar el resultado BACIGALUPO, E., «Conducta precedente y posición de garantía en el Derecho penal», ADPCP, 1970, p. 41; GIMBERNAT, E., «La distinción entre delitos propios (puros) y delitos impropios de omisión (o de comisión por omisión)», vv.aa., La ciencia del Derecho Penal ante el nuevo siglo, Libro Homenaje al profesor Doctor Don José Cerezo Mir, Tecnos, Madrid, 2002, p. 694. 
evitación del resultado no existirá acción típica intentada, es decir, que el intento de socorrer pero con producción del resultado es atípico, no así en la comisión por omisión.

Parte de la doctrina se ha pronunciado también sobre la idea de la equivalencia de la omisión y la acción convirtiendo la posición de garante en un elemento razonador de dicha equivalencia, tanto en los delitos de infracción de deber como en los de dominio ${ }^{886}$. Por el contrario, otros como MIR PUIG ${ }^{887}$ - acuden a la relación de dependencia con el bien jurídico para establecer esa relación de identidad de la equivalencia estructural.

La doctrina del Tribunal Supremo ${ }^{888}$ en su día respaldó la interpretación doctrinal de que el art. $11 \mathrm{CP}$ criminalizaba las conductas de infracción de un especial deber jurídico, sin embargo, algunos -como SÁNCHEZ TOMÁs- exponen que «(i)gualmente quien causa un accidente provocando importantes lesiones en la víctima que amenaza su vida, produciéndose finalmente el fallecimiento ante la pasividad del sujeto, no sería responsable en comisión por omisión, ya que, aunque ha creado un riesgo, éste lo ha sido con una conducta previa y no con la omisión posterior» ${ }^{889}$. Entonces, se puede concluir que no se puede prescindir de la posición de garante de los deberes de control ${ }^{890}$, o de protección ${ }^{891}$, de modo que según el deber de protección se fundamenta una responsabilidad u otra, es decir, una comisión por omisión o la omisión de una simple actividad pura o agravada. Puede anticiparse que los delitos de comisión por omisión pueden cometerse tanto por infracción de un deber especial como por infracción de un deber que viene de la competencia de organización, y así, según el deber de cada cual y de cada situación, se pueda incurrir en un delito de comisión por omisión o en uno de omisión pura o agravada.

886 JAKOBS, G., PG, op. cit., 7/58; ID., «La competencia por organización en el delito omisivo», trad. Peñaranda Ramos, Estudios de Derecho penal, op. cit., pp. 347 y ss; ID., «La omisión, estado de la cuestión», trad. Javier Sánchez-Vera Gómez-Trelles, Roxin Claus / JAKOBS Günther / SchüNEMANN Bernd / FRISCH Wolfgand / KÖHLER Michael, Sobre el estado de la teoría del delito, (Seminario de la Universitat Pompeu Fabra), $1^{\text {a }}$ ed., Civitas, Madrid, 2000, pp. 131 y ss; SÁNCHEZ-VERA, J., Delito de infracción de deber y participación delictiva, op. cit., pp. 73 y ss; ID., «Intervención omisiva, posición de garante y prohibición de sobrevaloración del aporte», ADPCP, 1995, pp. 213 y ss; REQUENA JULIANI, Jaime, Intercambiabilidad de acción y omisión en los delitos de dominio: posición de garante e imputación objetiva, Dykinson, Cuadernos Luis Jiménez de Asúa, 2010, pp. 321 y ss; CUADRADO RUIZ, MªA., «La comisión por omisión como problema dogmático», ADPCP, 1997, pp. 395 y ss.

887 MIR PUIG, S., PG, op. cit., pp. 308 y ss. En otro sentido, SILVA SÁNCHEZ, J-M ${ }^{\text {a }}$, El delito de omisión. Concepto y sistema, op. cit., pp. 339 y ss; ID., El Nuevo Código penal: cinco cuestiones fundamentales, op. cit., pp. 68 y ss; GRACIA MARTíN, L., El actuar en lugar de otro en Derecho penal, Vol. I, Prensas universitarias de Zaragoza, Zaragoza, 1985, pp. 344 y ss; ID., «La comisión por omisión en el Derecho penal español», AP, 1995, 2, pp. 683 y ss.

${ }^{888}$ STS, de 9 de octubre de 2000 (RAJ 0058); STS, de 19 de octubre de 2002, en la que se reconoce la aplicación del art. 11 en delitos y faltas, y de peligro o de resultado.

889 SÁNCHEZ TOMÁs, JM., Comisión por omisión, op. cit., p. 110.

890 ID., ibidem, op. cit., pp. 123 y 124.

891 JAKOBS, G., PG, op. cit., 29/27. Similarmente POLAINO NAVARRETE, M., Acción, omisión y sujetos en la Teoría del delito, op. cit., pp. 69 y ss., concluye que las peculiaridades de la omisión pura están en torno a la noción de deber, y por tanto en su naturaleza, titularidad y alcance del deber. Por eso también la única diferencia entre acción y omisión, y así entre omisión pura y comisión por omisión reside en el deber; SÁNCHEZ TOMÁs, JM., Comisión por omisión, op. cit., pp. 123 y 124. 
De aquí que no podamos estar de acuerdo con la teoría de la creación del riesgo ${ }^{892}$, opuesta a la teoría de infracción de deber, porque consideramos que se contradice en varios puntos: no aprecia la necesidad de la injerencia y únicamente atiende a la creación de un riesgo material, p. ej., en el caso del sujeto que olvida un paquete que contiene una bomba, y al percatarse le es indiferente dónde explote, según la teoría del riesgo, el riesgo nace $-y$ por ende parece ser que también la tentativa- con la omisión de recoger el paquete, no se abandona el paquete, como resuelve la teoría de infracción de deber. En nuestra opinión, el deber se inicia con la obligación de no llevar consigo paquetes peligrosos que puedan atentar contra las personas. Del mismo modo, en el ejemplo del accidente que antes hemos expuesto, la responsabilidad dependerá de si la omisión ha provocado que un riesgo permitido pase a uno no permitido ${ }^{893}$. Por ende, parece ser, que la teoría de la creación de un riesgo pospone la punibilidad, sin un argumento jurídico de peso, y esto es porque tanto en el art. 11 CP como en el 195.3 CP, en ambos se crea un riesgo no permitido con la acción precedente, es decir, ambos poseen la misma estructura objetiva del tipo, por lo que será la relación especial jurídica de cada sujeto la que marque la responsabilidad ${ }^{894}$.

De lo anterior se puede deducir que la teoría del dominio del riesgo o asunción voluntaria de los controles sobre el riesgo ${ }^{895}$ como complemento de una específica posición de garante, se muestra igualmente escasa en sus razonamientos, pues la llamada asunción del riesgo se revela como la propia creación del riesgo.

Por otro lado, la tesis de SILVA SÁNCHEZ se apoya en que la posición de garante genérica no fundamenta por sí misma la equivalencia de la omisión a la acción, sino que falta la asunción voluntaria del garante de controlar los riesgos, y según el caso de omisión, se deducirá la negativa de la asunción del control del riesgo, y por tal motivo, la equivalencia ${ }^{896}$. En caso contrario una omisión agravada, por ejemplo, en los casos del médico rural que no asume el control, únicamente habrá omisión pura agravada por posición de garante genérica, no específica. En tal sentido, en los casos que no exista posición de garante genérica, únicamente se podrá imputar la simple omisión pura. Sin embargo dicho argumento ha de ponerse en reserva, ya que se vislumbra una contrariedad que estriba del propio ejemplo, pues alude a la condición

${ }^{892}$ LUZÓN PEÑA, D-M., «Injerencia, comisión por omisión y omisión de socorro (comentario a la Sentencia TS 24-3-1974)», Derecho penal de la circulación, Bosch, $1^{\text {a }}$ ed., Barcelona, 1985, pp. 126 y ss.

893 SÁNCHEZ TOMÁs, JM., Comisión por omisión, op. cit., p. 129.

894 ID., ibidem, op. cit., p. 133

895 GRACIA MARTín, L., «Los delitos de comisión por omisión (una exposición crítica de la doctrina dominante)», Modernas tendencias en la Ciencia del Derecho penal y en la Criminología, UNED, Madrid, 2001, pp. 413 y ss.

896 SILVA SÁNCHEZ, J-M ${ }^{a}$, El delito de omisión. Concepto y sistema, op. cit., pp. 370 y ss. 
de monopolio como elemento fáctico - no normativo- que tiene el médico rural, razón bastante para no hacer depender de su voluntad, y de la asunción, el control del riesgo.

En el mismo sentido, GRACIA MARTíN ${ }^{897}$ apela al concepto del «dominio social» como criterio para conocer la asunción sobre el riesgo. Exige que efectivamente se pueda conocer si la acción hubiera salvado con certeza el bien jurídico. La conclusión es igualmente a nuestro entender errónea, porque hace depender la punibilidad agravada del art. 195.3 CP de la asunción voluntaria del riesgo y del tipo de sujeto que omite la post-creación del mismo mediante una acción precedente ${ }^{898}$, pues no es lo mismo que omita el deber quien tiene posición de garante por sus conocimientos de medicina, que una madre que omite llamar a los servicios médicos cuando su hijo tiene una grave enfermedad.

La conclusión de SÁNCHEZ TOMÁs es que existe una identidad normativa entre los arts. 11. b y 195.3 CP sin que exista referencia al título de imputación subjetiva porque la conducta precedente se comparte en los dos injustos por igual. Para éste es exactamente lo mismo la ocasión de riesgo para un bien jurídico protegido y la situación de riesgo manifiesto y grave y el desamparo de la víctima del segundo precepto, pues dicha situación es una modalidad de riesgo y sobre unos bienes jurídicos personales como la vida y la integridad. Asimismo la referencia a la ausencia de peligro, para uno o terceros, también se entiende aplicable en el art. $11 \mathrm{CP}$ por las causas de justificación o de inexigibilidad, si bien en este caso no es un elemento accidental del tipo. Concluye también que la conducta de omisión es exacta a la del art. 11CP, puesto que la omisión del auxilio y la no evitación del resultado, hacen referencia a la finalidad de evitación de un «resultado lesivo» ${ }^{899}$. En este punto comete un error a resaltar, puesto que no cabe hablar de resultados en el art. 195.3 CP sino de omisión pura agravada, pero no se criminaliza por el resultado sino por la inactividad, cuestión que él mismo reconoce, sin embargo vuelve a afirmar que no existiría diferencia normativa en el resultado típico en la comisión por omisión intentada y la omisión de deber de socorro agravada del 195.3 CP, cuestión que lógicamente ponemos en reserva ya que la penalidad sería bien distinta, y ello fundamentado, precisamente, ya no por el título de imputación subjetiva como entiende este autor, sino por la mayor gravedad referida a la garantía institucional que no aparece tan nítida en el art. $195.3 \mathrm{CP}$ puesto que no se refiere al

\footnotetext{
897 GRACIA MARTín, L., «Los delitos de comisión por omisión», op. cit., pp. 412 y ss; ID., «La comisión por omisión en el Derecho penal español», op. cit., pp. 700 y ss.

898 También SÁNCHEZ-VeRA, J., Delito de infracción de deber y participación delictiva, op. cit., pp. 166 y ss; SÁNCHEZ TOMÁs, JM., Comisión por omisión, op. cit., pp. 143 y ss.

${ }^{899}$ SÁnCHEZ TOMÁs, JM., Comisión por omisión, op. cit., pp. 221 a 224. El entrecomillado pertenece a la p. 224.
} 
resultado, mientras que en el $11 \mathrm{CP}$ aun en tentativa, la gravedad sobrepasa el umbral porque el Estado reconoce que la garantía debe ser mayor al ser institucional.

La conclusión es que si se exige la peligrosidad ex ante, este criterio también aparecerá en los estadios previos, en la tentativa de la comisión por omisión, y en los delitos consumados de omisión pura (admitimos la tentativa en estos supuestos), sin embargo, si bien en éstos no se exige el control absoluto sobre el riesgo, ni que se evite el resultado, el actuar precedente en la omisión pura puede ser fortuita, pero también en la comisión por omisión también, de lo que se puede extraer que la imputación objetiva tampoco delimita los ámbitos de aplicación, sino los deberes institucionales en la formula expuesta por JAKOBS y que a continuación vamos a analizar.

\section{Solución funcionalista: intercambiabilidad de la acción y la omisión en los delitos de} dominio e infracción de deber

1) Imputación objetiva y funcionalismo normativo: La desobediencia a la norma como quebrantamiento de la vigencia normativa

La teoría funcionalista entiende el Derecho penal como acuerdo normativo ${ }^{900}$, o como subsistema normativo de otro mayor: el ordenamiento jurídico. Toda norma que estableciese deberes quedaría en saco roto si renunciase a evitar la consumación, por ello para estas teorías el fin del Derecho es orientar al ciudadano de tal forma que rechace iniciar lo injusto, que se adecúe a la norma, sin exigir el utópico moralismo -kantiano- de estar de acuerdo con la norma y sentirla como propia. En suma, podemos decir que el sentido comunicativo de la norma, va más allá de lo ontológico, pues su función preventivo-general-positiva adquiere especial relevancia en los estados previos a la «consumación» tradicionalmente entendida.

JAKOBS ha conseguido relegar a un plano secundario al paradigma de la protección de bienes jurídicos - pues este fundamento lleva a criminalizar tentativas de realizar un injusto- y a la teoría de la motivación de la norma ya considerada supra. Lo que trata de proteger el Derecho penal no es todo ataque al bien, sino su valor en sí mismo, su valor normativo, lo cognoscible sobre éste para orientar de forma general la conducta. Así la doctrina del funcionalismo normativo $^{901}$ se adelanta a la protección de bienes jurídicos pero sin llegar a negarlos.

900 Polaino-Orts, M., Derecho penal del enemigo. Fundamentos, op. cit., pp. 225 y ss.

901 JAKOBS, G., ¿Cómo protege el Derecho penal y qué es lo que protege? Contradicción y prevención; protección de bienes jurídicos y protección de la vigencia de la norma», op. cit., pp. 50 y 51; POLAINO-ORTS, M., Derecho penal del enemigo. Desmitificación del concepto, op. cit., pp. 27 y ss; ID., Derecho penal del enemigo. Fundamentos, op. cit., pp. 47 y ss., y 305 y ss., y pp. 319 y ss; ID., Lo verdadero y lo falso en el Derecho penal del enemigo, op. cit. 
Piénsese al respecto que los delitos de peligro concreto, diversas acciones típicas (promoción, facilitación, favorecimiento), los delitos de mera actividad, de omisión pura y de emprendimiento, son buenos ejemplos de esa función normativa y consecuentemente preventiva, pues debe entenderse que la tentativa es ya un quebrantamiento normativo, es ya una «consumación normativa», que no una «anticipación». Así, el fin de protección de bienes jurídicos es secundario pero también mediato ${ }^{902}$ a la función de la vigencia de la norma. A través de la comunicación de la vigencia de la norma se orienta y se ilustra sobre los deberes normativos y las expectativas sociales, para que las «personas»-en tanto sujetos a los que se les reconoce derechos y deberes, precisamente porque cuentan con un mínimo raciocinio exigido en cada sociedad y época- reconozcan la norma penal conformando su conducta al haz de luz del faro de guía o foco que representa simbólicamente la norma (algunos ${ }^{903}$ compatibilizan ambas tutelas).

El Derecho penal es incapaz por sí solo de proteger la vida, únicamente puede comunicar «racionalmente» que tal acto es comunicativamente negación de un deber normativo. De tal modo que el delito no siempre pone realmente en peligro al bien jurídico espiritualmente entendido, pero sí debilita siempre la idea de vigencia normativa ${ }^{904}$ o, como más acertadamente destaca POLAINO-ORTS, la tentativa en sí misma ataca «otro bien tan digno y merecedor de protección: la seguridad cognitiva de los ciudadanos en la vigencia de la norma» ${ }^{905}$.

No es de extrañar entonces que mientras que el finalismo configura al bien como un estado positivo y ético-socialmente valorado, el funcionalismo lo configure como valor social en sí mismo, normativamente valorado: «vigencia práctica de la norma». No es el acto negativamente valorado de matar lo que se prohíbe primordialmente, sino la comunicación del sentido injusto del acto y del motivo exteriorizado, que la norma no es válida para el autor ni para la sociedad.

902 SAX, W., «Tatbestand und Rechtsgutsverletzung», op. cit., p. 434; JAKOBS, G., ¿Cómo protege el Derecho penal y qué es lo que protege? Contradicción y prevención; protección de bienes jurídicos y protección de la vigencia de la norma», op. cit., pp. 59 y 60.

903 En España, AlCÁCER GUIRAO, R., La tentativa inidónea: fundamento de punición y configuración del injusto, Comares, Granada, 2000, p. 331; Polaino NaVArrete, M., Derecho penal, Parte general, T. II, Teoría jurídica del delito, Vol. I, op. cit., pp. 546 y ss., donde afirma que la tentativa es una «consumación anticipada» pero legítima; ID., Derecho penal, Parte general, I, $5^{\text {a }}$ ed., op. cit., pp. 151 y 152; ID., «El Injusto de la Tentativa en el Ejemplo de los Delitos de Mera Actividad y de Omisión Pura. Sobre el Concepto Jurídico-Penal de Resultado», op. cit., pp. 59 a 88; ID., «Injusto de la Tentativa y Vigencia de la Norma desde una Perspectiva Penal Funcionalista», op. cit., p. 711; SANTA RITA, G., El delito de organización terrorista, op. cit., p. 247 y pp. 285 y ss.

904 BERZ, U., Formelle Tatbestandsverwirklichung, op. cit; NIEPOTH, Der untaugliche Versuch beim unechten Unterlassungsdelikt, op. cit., p. 121.

905 Polaino-OrTs, M., Derecho penal del enemigo. Fundamentos, op. cit., pp. 353, fundamentación que procede del pensamiento de HEGEL, GWF., Fundamentos de la filosofía del Derecho, op. cit., p. 340 y ss. SANTA RITA, G., El delito de organización terrorista, op. cit., pp. 634 y ss. 
Por tanto, el fin del Derecho penal como fin ${ }^{906}$ en sí mismo es comunicar deberes al hombre autónomo, y por el contrario la pena es la comunicación del restablecimiento de la vigencia de la norma $^{907}$.

JAKOBS argumenta que el delito no es quebranto del bien jurídico sino defraudación de la expectativa normativa (Enttäuschung der normativen Erwartung), lesión de deber. No es el hecho material lo que comunica la negación de la norma, sino lo simbólico ${ }^{908}$ del acto, su expresión comunicante, lo que se toma por el raciocinio de los sujetos como social y comunicativamente relevante $^{909}$. Por eso, la teoría funcionalista entiende a la norma como subsistema funcional del ordenamiento, que asegura las expectativas normativas de los ciudadanos hasta el extremo de entender que la defraudación de la norma de flanqueo -aquella que es protectora de la principal- es ya un injusto, pues lógicamente ciertas conductas preparatorias y la tentativa en general son funcionales para el mantenimiento del sistema. Por ende, la tentativa es ya en sí un quebranto normativo o infracción de un riesgo permitido ${ }^{910}$ - un desvalor del resultado- causado por una expresión negativamente relevante -un desvalor de la acción-. El desvalor en la tentativa y en el delito consumado es el mismo, pues únicamente se añade en este último un plus cuantitativo $^{911}$, el resultado mayor de quebrantamiento normativo $^{912}$. En lógica, el desvalor del resultado en la inidónea es también el quebranto de la vigencia normativa $^{913}$. El resultado entendido como parte objetiva de la graduación ejecutiva del delito fundamenta la graduación de la pena, pero no la antijuricidad ${ }^{914}$, pues el resultado material -en sentido ontológico- sólo se aprecia en el injusto consumado ${ }^{915}$. La crítica ${ }^{916}$ al funcionalismo considera que el desvalor de la acción y del resultado se difuminan en el quebrantamiento de la vigencia de la norma.

906 JAKOBS, G., ¿Cómo protege el Derecho penal y qué es lo que protege? Contradicción y prevención; protección de bienes jurídicos y protección de la vigencia de la norma», op. cit., pp. 50 y 51. En concreto ZACZYK, R., Das Unrecht der Versuchten Tat, op. cit., pp. 119 y ss., sin negar la trascendencia del bien.

907 En sentido similar, BERZ, U., Formelle Tatbestandsverwirklichung, op. cit., p. 42.

908 Al respecto LESCH, HH., Das Problem der sukzessiven Beihilfe, op. cit., p. 256.

909 VEHLING, K-H., «Abgrenzung von Vorbereitung und Versuch», op. cit., p. 130.

910 Sobre ello, VeHLING, K-H., «Abgrenzung von Vorbereitung und Versuch», op. cit., p. 87; POLAINO-ORTS, M., «Imputación objetiva: esencia y significado», KINDHÄUSER Urs / POLAINO-ORTS Miguel / CORCINO BARRUETA Fernando, Imputación objetiva e imputación subjetiva en Derecho penal, pról. Miguel Polaino Navarrete, Grijley, Lima, 2009, pp. 43 a 50; SANTA RITA, G., El delito de organización terrorista, op. cit., p. 638.

911 LESCH, HH., Das Problem Der sukzessiven Beihilfe, op. cit., 257 y ss.

912 JAKOBS, G., $P G$, op. cit., 25/15, dice que «(e)1 fundamento de punición de la tentativa es exactamente el mismo de la consumación».

913 JAKOBS, G., «El concepto jurídico-penal de acción», trad. Manuel Cancio Meliá, JAKOBS, G., Estudios de Derecho Penal, op. cit., p. 120; en el mismo sentido, LESCH, HH., Das Problem der sukzessiven Beihilfe, op. cit., pp. 257 y 258.

914 LESCH, HH., Das Problem der sukzessiven Beihilfe, op. cit., p. 202.

915 ID., ibidem, op. cit., p. 204.

916 AlCÁCER GuIRAO, R., La tentativa inidónea, op. cit., p. 314 y ss. y pp. 324 y ss. 
Continuando con esto, cabe ahora plantearse precisamente una cuestión: ¿qué dota de sentido o relevancia penal objetivamente hablando de la imputación de la acción? Arguye JAKOBS al respecto - lo cual nos parece interesante- que «la libertad de organización interna que compete a cada persona responsable se sostiene sobre un sinalagma: la persona tiene que preocuparse de que su esfera de organización no salgan procesos causales dañosos (...) El abandono del dominio en perjuicio potencial de otro es, una tentativa en sentido material» ${ }^{917}$. Así, lo que configura el desvalor de la acción es la vulneración de un ámbito de organización asumido por los sujetos según su rol común o especial ${ }^{918}$, que establecen reglas y niveles de actuación u omisión en el riesgo permitido como veremos infra. Por ende, el quantum de defraudación del riesgo permitido (libertad) del que cuenta la esfera de competencia del rol, producirá el mayor o menor desvalor $^{919}$. No obstante, esto último (quebrantamiento del rol) no es suficiente para imputar la tentativa, sino que faltará conocer el título de imputación (dolo o imprudencia) para atribuir relevancia penal al sentido de la acción, lo cual va más allá de la mera casualidad o infortunio.

Ahora es entendible que en un sistema funcional basado en la teoría hegeliana ${ }^{920}$ la pena sea restitución proporcional del quebranto normativo ${ }^{921}$, sea simbólica y, comunicación dirigida tanto al autor como a la generalidad de una sociedad. Por ello, lo relevante es que en la representación

917 JAKOBS, G., $P G$, op. cit., 25/21.

918 JAKOBS, G., La imputación objetiva en Derecho penal, estudio preliminar Carlos J. Suárez González y Manuel Cancio Meliá, trad. Manuel Cancio Meliá, Civitas, 1996, pp. 145 y ss; ID., «La imputación objetiva, especialmente en el ámbito de las instituciones jurídico-penales "riesgo permitido", "prohibición de regreso" y "principio de confianza"», trad. Enrique Peñaranda Ramos, JAKOBS, G., Estudios de Derecho penal, op. cit., pp. 209 y ss.

919 En dicha línea VeHLING, K-H., «Abgrenzung von Vorbereitung und Versuch», op. cit., pp. 124 y ss. y pp. 147.

920 Hegel, GWF., Fundamentos de la Filosofía del Derecho, op. cit., p. 342: «La existencia positiva de la vulneración existe sólo como voluntad particular del delincuente. La Vulneración de esta voluntad en cuanto existente es por tanto la superación del delito, que de otro modo sería válido, y es el restablecimiento del derecho». Sobre la proporcionalidad de la pena en relación de igualdad al delito, ID., ibidem pp. 352 y 358; ID., Fenomenología del espíritu, trad. Wenceslao Roges, $20^{\mathrm{a}}$ reimpresión de la $1^{\mathrm{a}}$ ed. en español, Fondo de Cultura Económica, 2010, pp. 98 a 100: «si esta inversión que se representa en el castigo del delito se convierte en ley, tampoco ésta es sino la ley de un mundo que tiene que enfrentarse a un mundo suprasensible invertido, en el que se honra lo que en aquél se desprecia y se desprecia lo que en aquél se honra. La pena, que según la ley del primero infama y aniquila al hombre, se trueca en su mundo invertido en el perdón que mantiene a salvo su esencia y lo honra (...) Y el delito real tiene su inversión y su en sí, como posibilidad, en la intención como tal, pero no es una buena intención, pues la verdad de la intención es sólo el hecho mismo. Y, según su contenido, el delito tiene su reflexión en sí mismo o su inversión en la pena real; ésta es la reconciliación de la ley con la realidad que se opone con el delito».

921 También se dice que la pena es la reacción al quebrantamiento de una norma (Reaktion auf einen Normbuch), JAKOBS, G., «Sobre la teoría de la pena», op. cit., pp. 59 y ss., y en Cuadernos de conferencias y artículos, op. cit., p. 16. Críticamente FEIJOO SÁNCHEZ, BJ., «Prevención general positiva: estabilización normativa mediante imposición de males. Una réplica a la teoría de la pena de Günther Jakobs», en Teoría funcional de la pena y de la culpabilidad, Civitas, 2007, pp. 148 y 153 considera que «(e)l propio autor en sus últimos trabajos considera que la prevención general negativa se halla contenida en la positiva. Si esto es así, en sociedades donde la tendencia dominante sea la infidelidad parece que el recurso al dolor y al sufrimiento debe ser mayor». 
del autor exista una racional idoneidad ${ }^{922}$ del ámbito de organización objetivamente ${ }^{923}$ configurado, y subjetivamente intercomunicado (plan-representación), lo cual en nuestra opinión quiere decir que es bastante para la punibilidad que el plan ejecutado contenga un mínimo de racionalidad (idoneidad intercomunicativa), a pesar de su inidoneidad objetiva.

\section{2) El rol social}

La configuración sistémica de la sociedad puede representarse como un conjunto de sujetos libres que desempeñan funciones en cada aspecto de la vida. Estas funciones producen una comunicación, que es lo que causa que entre en un sistema determinado, y que cuenta con tres aspectos: información, notificación y acto de entender como fundamento para un comportamiento posterior (ulterior comunicación) ${ }^{924}$.

Indudablemente no todos los sujetos realizan las mismas funciones, y ese haz de diferencia establece la competencia y concepto que cada sujeto realiza cada día. Se pueden establecer distintas funciones como sujetos haya, y más funciones al sujeto como ámbitos de competencia controle. Es fácil imaginar que en la superestructura social contamos con diversos roles, y que cada sujeto puede asumir varios roles salvo excepciones normativas. Cuando la función de un rol contiene una comunicación determinada, en este caso, a través del código justo/injusto, puede afirmarse que la conducta se refiere al subsistema del Derecho penal, en otros casos, puede referirse esa diferencia al sistema Derecho (conforme a Derecho/disconforme con el Derecho), y otras a otros entornos, como la economía, la política, la moral, etc., si bien estos entornos en concreto ámbito de comunicación nutren de «energía» o «recursos» pero no comunicaciones jurídicas $^{925}$, o dicho de otro modo, el subsistema del Derecho penal no tendría sentido sin comprender el mundo social que le envuelve, o más bien trasforma (procesamiento) las comunicaciones existentes en el entorno, en concreto lo cognitivo (apertura cognitiva) ${ }^{926}$ a una función jurídica a través de código particular justo/injusto que tiene su virtualidad en su clausura operativa, el sistema o subsistema se cierra sobre sí mismo, ajeno al entorno pero nutriéndose de comunicaciones que trasforma funcionalmente para su propio código, si no puede transformarla

922 ZACZYK, R., Das Unrecht der versuchten Tat, op. cit., p. 252; JAKOBS, G., «La autoría mediata con instrumentos que actúan por error como problema de imputación objetiva», op. cit., p. 258; ID., PG, op. cit., 25/36; ID., «Representación del autor e imputación objetiva», trad. Carlos J. Suárez González, JAKOBS, G., Estudios de Derecho penal, op. cit., pp. 223 y ss; ID., «Criminalización en el estado previo a la lesión de un bien jurídico», trad. Enrique Peñaranda Ramos, JAKOBS, G., Estudios de Derecho penal, op. cit., pp. 293 y ss.

${ }_{923}$ JAKOBS, G., $P G$, op. cit., 25/1a.

924 PIÑA ROCHEFORT, JI., Rol social y sistema de imputación, op. cit., p. 202 y pp. 219 y ss. en referencia a LUHMANN, N., Sistemas sociales, op. cit; ID., «Acuerdo sobre riesgos y peligros», op. cit., pp. 321 y ss.

925 PIÑA ROCHEFORT, JI., Rol social y sistema de imputación, op. cit., pp. 205 y ss.

926 ID., ibidem, op. cit., p. 208. 
en su propio código/función no es porque dicha comunicación (conducta) no forma parte de la imputación en el Derecho penal. Por ejemplo, no es lo mismo el deudor en el Derecho tributario que en el Derecho penal ${ }^{927}$, la comunicación es completamente distinta en uno y en otro caso, sin embargo, en el Derecho penal se nutre cognitivamente de la comunicación producida en el Derecho tributario para procesarla en el código justo/injusto, de tal manera que si la pregunta se puede formular es porque dicha comunicación se ha podido procesar en el subsistema penal, al menos para procesar el sujeto.

Puede comprobarse que ya no estamos ante una simple causalidad natural/ontológica, como criterio de imputación penal, ni siquiera hipotética, sino normativa, propia del código justo/injusto del sistema del Derecho penal, incluso en la omisión no hay causalidad natural ni hipotética, sino que en ocasiones dicha omisión comunica la trasgresión normativa de las competencias del rol, que hace imputar normativamente el delito a pesar de esa falta de causalidad, si se quiere, ontológica. En todo suceso se puede defraudar una expectativa cognitiva (el anciano muere por indigestión) que comunica a los participantes de dicha comunicación qué se puede aprender ${ }^{928}$ de dicho suceso (a ciertas edades mejor no comer abusivamente), este hecho no puede cambiarse sino aprender de él porque responde a la libertad de las personas, sin embargo en el sistema del derecho, y más concretamente en el derecho penal sólo entran las comunicaciones procesadas como normativas (la hija ha sobrealimentado a la fuerza a su anciano padre), por lo que puede cambiarse dicha comunicación de manera contrafáctica reorientando al partícipe de dicha comunicación con las normas del Sistema ${ }^{929}$.

Así, el rol es el estatus social o jurídico que cada sujeto ocupa en cada momento de la vida social o la/s etiqueta/s que tiene colocada/s en la solapa (también la «máscara», en referencia al papel que tiene que desempeñar) lo que le hace reconocible ante los demás, auto-reconocerse, y por ende saber tanto el tercero como el rol, qué función cumple, en qué sistema está comunicando la información, y concretamente en el Derecho penal, la responsabilidad de su conducta en cada momento para de tal manera saber gestionarlo jurídica o socialmente, por lo que el rol supone el fundamento y el límite de la responsabilidad penal ${ }^{930}$, más allá de la

927 Expone este ejemplo PIÑA ROCHEFORT, JI., ID., ibidem, op. cit., pp. 230 y ss.

928 LUHMANN, N., «Las normas desde una perspectiva sociológica», op. cit., pp. 40 y ss.

929 PIÑA ROCHEFORT, JI., Rol social y sistema de imputación, op. cit., p. 258; LUHMANN, N., «Las normas desde una perspectiva sociológica», op. cit., pp. 42, comenta que «las normas son expectativas contrafácticamente estabilizadoras».

930 JAKOBS, G., La imputación objetiva en Derecho penal, op. cit., pp. 101 y ss; PIÑA ROCHEFORT, JI., Rol social y sistema de imputación, op. cit., pp., 268 y ss. y pp. 347 y ss. en especial pp. 268 y ss; POLAINO NAVARRETE, M., Lecciones de Derecho penal, Parte general, T. II, op. cit., pp. 85 y 86; POLAINO-ORTS, M., Funcionalismo normativo, op. cit., pp. 118 y ss; ID., «Imputación objetiva: esencia y significado», op. cit., p. pp. 33 y ss; REQUENA JULIANI, J., Intercambiabilidad de acción y omisión, op. cit., pp. 245 y ss. y p. 327; SANTA RITA, G., El delito de 
imputación del hecho, bien distinto que la imputación de responsabilidad por el hecho que supone el primer paso. Cada clase de rol al reconocerse y ser reconocido genera ya no sólo una responsabilidad, sino también el conocimiento por los demás de una expectativa. Así, cada rol espera que al enfrentarse a otro éste cumpla con la expectativa que el primero tiene de él (expectativa de una expectativa) para de tal modo poder cumplir con la suya. Por ende, los sujetos esperamos que el rol al que nos enfrentamos cumpla con la expectativa que anuncia su etiqueta, ya sea una expectativa social o jurídica, en definitiva, lo que se espera justamente de él.

Por lo dicho, no será difícil intuir que los roles generan un círculo de derechos y de deberes que interaccionan, se cortan y a menudo anulan los demás círculos de los demás roles que entran en concurso en una misma situación, en un día, o durante toda nuestra vida. Fíjense que el reconocimiento de un ámbito competencial de un rol sirve tanto para exigirle una acción o una omisión como para reconocer que el tercero no tiene acción o se le obliga a actuar. De lo anterior se deduce que el rol genera un reconocimiento (aspecto formal) que interacciona en los derechos y deberes limitándolos materialmente (aspecto material) ${ }^{931}$ que reproduce una comunicación social efectiva, relevante e imprescindible en la dialéctica social-normativa.

Visto lo anterior, el rol representa un estatus de responsabilidad concreto y limitado, precisamente porque gestiona ese ámbito competitivo de la persona que le demanda la sociedad por entero o una parte de ella. Vista una etiqueta y los derechos y deberes que contiene de forma inherente, que son de su competencia la gestión de cada esfera en la que interactúa. Por ello, los padres asumen un rol institucional puesto que su competencia viene trasferida del Estado en virtud de la imposibilidad material de gestionarlo él mismo, y dada la formulación normativa de derechos de una sociedad democrática, social y de Derecho. El incumplimiento de un rol institucional, como veremos, conlleva la responsabilidad aun en comisión por omisión por autoría, puesto que la demanda social ha confiado en la expectativa que normativamente se le ha trasferido a los padres.

El Estado no normativiza cómo cada padre debe educar a sus hijos, lo que supone una esfera de libertades en la administración del rol, pero el incumplimiento de las expectativas mínimas acarrea una funcional sanción fundamentada en que si bien ha podido adecuar su conducta a la norma en virtud del amplio abanico que despliega la esfera de libertad, su quebrantamiento de la

organización terrorista, op. cit., pp 118 y ss. pp. 152 y ss. y pp. 333 y ss. LUHMANN, N., La confianza, $1^{\text {a }}$ reimp. 2005, de la $1^{\text {a }}$ ed., 1996, Anthropos, México, p. 70, comenta que «los roles, no las leyes causales, son los que sirven en la vida social como base para juzgar cualquier conducta como intencional o involuntaria».

931 POLAINO-ORTS, M., «Imputación objetiva: esencia y significado», op. cit., p. 24; ID., Funcionalismo normativo, op. cit., p. 84; POLAINO NAVARRETE, M., Lecciones de Derecho penal, Parte general, T. II, op. cit., p. 84. 
norma mínima (jurídico-penal) equivale a la acción de defraudación de la expectativa «trasferida»o derecho «ajeno».

\section{3) Clases de roles: común, especial y concurrencia de roles}

Ya nos hemos referido sucintamente a dos clases de roles, el común y el especial ${ }^{932}$. La diferencia entre ambos es que el rol común cumple una expectativa ordinaria, de solidaridad mínima ${ }^{933}$ que afecta a todo ciudadano, atribuida o atribuible a todos los sujetos simplemente por ser sujetos de derecho, libres y por tanto responsables. Esta atribución común nace per se, por el simple hecho de habitar en un conjunto normativo.

Sin embargo, el rol especial nace de una atribución concreta en que se encuentra en una posición especial ${ }^{934}$, propiamente personal, por ejemplo el magistrado que así lo ha querido aprobando la oposición de judicaturas, o por una atribución ajena e institucional, por ejemplo las personas podemos ser padres, pero desde el nacimiento se atribuye un carácter especial de derechos y deberes sobre la persona menor de edad, y si bien es cierto que nadie está obligado a convivir, la institución de la patria potestad, conformada por este conjunto de derechos y deberes atribuidos al padre por la autoridad, es decir, institucionalmente, tiene un carácter irrenunciable, por ello la diferencia entre la atribución personal asumida por la voluntad del sujeto y esta otra ajena o institucional estriba en que aquél puede dejar su estatus jurídico especial por su voluntad, pues por esta misma voluntad es por la que fue asumido dicho estatus, mientras que en el caso del padre, al provenir su atribución de la autoridad, únicamente por un acto de ésta puede perderse (privación o suspensión de la patria potestad en casos graves). A diferencia del rol común, el rol especial no se fundamenta en un deber natural de solidaridad mínima (¡cuestionable!), sino en la garantía institucional o deberes de garantía precisamente por esa atribución ajena e institucional a la que nos referíamos. En tanto así, la comunidad del rol es social y por ello común a todos, mientras que la especial es imprescindiblemente taxativizada en lo normativo e individual, sin embargo, todos podemos tener varias clases de etiquetas, el

\footnotetext{
932 JAKOBS, G., La imputación objetiva en Derecho penal, op. cit., pp. 145 y ss; ID., «La imputación objetiva, especialmente en el ámbito de las instituciones jurídico-penales "riesgo permitido", "prohibición de regreso" y "principio de confianza"», Estudios de Derecho penal, op. cit., pp. 209 y ss; CARO JOHN, JA., La imputación objetiva en la participación delictiva, op. cit; PIÑA ROCHEFORT, JI., Rol Social y sistema de imputación, op. cit., pp. 292 y ss; Polaino Navarrete, M., Lecciones de Derecho penal, Parte General, T. II, op. cit., pp. 86 y 87; Polaino-OrTS, M., Derecho penal del enemigo. Fundamentos, op. cit; ID., Lo verdadero y lo falso en el Derecho penal del enemigo, op. cit; ID., «Imputación objetiva: esencia y significado», op. cit., pp. 27 y ss; ID., Funcionalismo normativo, op. cit., pp. 120 y 121; SANTA RITA, G., El delito de organización terrorista, op. cit., pp. 332 y ss.

933 Polaino Navarrete, M., Lecciones de Derecho penal, Parte general, T. II, op. cit., p. 86.

934 ID., ibidem, op. cit., p. 86.
} 
magistrado puede ser a su vez padre, y tener igualmente que pagar impuestos, a esto se le llama concurrencia de roles en un mismo sujeto.

La cuestión en cada caso será comprobar la intersección de esferas de competencia en cada sujeto y momento espacio-temporal concreto. Esta dicotomía representa que el rol especial supone mayor libertad y por tanto mayor responsabilidad, y que el rol común supone menor libertad y por tanto menor responsabilidad. Esto supone el fundamento de que al rol especial, tanto atribuido por el sujeto mismo como por ajenidad institucional, se le responsabilice en concepto de autor de un injusto realizado en comisión por omisión. De aquí viene la imputación del homicidio en comisión por omisión de un padre que por motivos de conciencia no avisa a las asistencias a pesar de que por un conocimiento especial conoce que se precisa para salvar la vida una transfusión de sangre, no se avisa a las asistencias médicas, sin que varíe su conceptualización como autor de conciencia, a pesar del mayor reproche penal.

Efectivamente, los padres que por motivo de conciencia omiten llamar a las asistencias, contribuyen siempre de forma relevante y grave por la esfera de libertad de la que se disfruta cuando administran las vivencias de las menores. Con otras palabras, en su caso, el Estado siempre hubiera actuado y en virtud de la trasferencia de responsabilidad y libertad que se les ha otorgado el quantum de la gravedad aumenta. Así es como los roles cumplen una función real y normativa. Por un lado, y de forma inherente, afianzan la norma y su vigencia, y por otro, comunican con su cumplimiento la vigencia de las normas. Generan capacidad de orientación en la adecuación normativa en los demás roles, supone un contagio de civismo normativo que impregna a la sociedad, es decir, supone la confirmación del horizonte de expectativas del Sistema Social. En concreto, que un rol cumpla con su función, sea un buen padre de familia, o ayude a quien está en peligro manifiesto de muerte, además de cumplir la norma, además de afirmar que esa norma está vigente, que es válida en la sociedad, comunica a los demás roles que cuando estén en la misma situación deben actuar de la misma manera, lo que trasfiere orientación a los demás para entender la norma y adecuar la conducta con ese haz que representa el horizonte de expectativas del Sistema. Así se cumple una doble garantía: comunica a los demás qué es ser persona en Derecho y que los demás saben que él es persona en el Sistema.

Esto representa la idea de fidelidad al Derecho, en esencia, la capacidad para orientar la conducta con lo normativo a pesar de una conciencia o convicción opuesta. Lo opuesto, como ya hemos reflejado en capítulos anteriores supone, salvo excepciones, una enemistad manifiesta y reprochable con la máxima sanción, excepciones que hemos analizado por ahora en el capítulo segundo. Y a mayor abundamiento, la esfera de libertad del rol corresponde a un campo de 
actuación que, si es incumplido, fundamenta funcionalmente el quebrantamiento de la norma, en definitiva la imputación penal por la defraudación de la expectativa, esto es, con palabras de POLAINO-ORTS, supone la «desviación de un rol».

De esta manera, la determinación competencial del tipo de rol delimita la responsabilidad por organización y la responsabilidad por competencia institucional ${ }^{935}$, el primero por la defraudación de un rol común y el segundo por la defraudación de un rol especial ${ }^{936}$. Mientras que en el primero es imputable su conducta por organizar el delito de tal modo que sobrepasa el riesgo permitido, por ende de forma negativa, se le prohíbe pero actúa u omite, en el segundo se quebranta una institución positiva, se le ordena pero quebranta la institución actuando u omitiendo el contenido de la orden.

Podemos observar que la distinción nace de la naturaleza de la vinculación que poseen los segundos delitos. En los de organización el autor no está relacionado directamente con el bien jurídico a proteger sino que de modo negativo se le compele a no quebrantarlo. En los segundos, existe previamente una relación positiva concreta que debe proteger, cooperar, y en definitiva respetar atentamente. En tanto que la organización jurídica establece deberes y derechos, los deberes pueden fragmentarse en positivos y negativos. Estos últimos son los que nos prohíben hacer $u$ omitir de una forma general porque incumben a todos. Los sujetos deben cuidar que de sus acciones u omisiones, su organización libre, produzcan sucesos causales que dañen la libertad de organización de otros. Esta concepción supone un sinalagma libertadresponsabilidad ${ }^{937}$.

La esfera de libertad de organización es amplia en la concepción de un rol común, pero más amplia en el especial. Los deberes positivos o institucionalizados son derechos y deberes especiales atribuidos a los sujetos, lo que puede comprenderse como un derecho ajeno, pero también un deber ajeno que el sujeto por diferentes causas (nacimiento de un hijo, toma de cargo

935 JAKOBS, G., PG, 21/16; ID., «La competencia por organización en el delito omisivo», op. cit., pp. 347 y ss; ID., «La omisión: estado de la cuestión», trad. Sánchez-Vera, vv.aa., Sobre el estado de la teoría del delito, op. cit., pp. 131 a 134; ID., La imputación objetiva en Derecho penal, op. cit., pp. 101 y ss; ID., «La relevancia del dominio del acto para la determinación de la participación», trad. Miguel Polaino Navarrete, RCP, núm. 6, Corrientes / Argentina, 2000, pp. 103 y ss; LESCH, HH., «Intervención delictiva e imputación objetiva», trad. Javier SánchezVera, ADPCP, 1995, pp. 911 a 972; POLAINO NAVARRETE, M., Lecciones de Derecho penal, Parte general, T. II, op. cit., pp. 232 y ss; REQUENA JULIANI, J., Intercambiabilidad de acción y omisión, op. cit., pp. 245 y ss. y pp. 327 y ss; SÁNCHEZ-VERA, J., Delito de infracción de deber y participación delictiva, op. cit., pp. 93 y ss.

936 JAKOBS, G., «La competencia por organización en el delito de omisión. Consideraciones sobre la superficialidad de la distinción entre comisión y omisión», op. cit., p. 347; ID., «Acción y omisión en Derecho penal», trad. Carlos Rey Sanfiz y Javier Sánchez-Vera Gómez-Trelles, JAKOBS, G., Dogmática de Derecho penal y la configuración normativa de la sociedad, op. cit., pp. 165 y ss., también con el mismo título en CPC, trad. Carlos Rey Sanfiz y Javier Sánchez-Vera Gómez-Trelles, 2001, p. 278; SÁNCHEZ-VERA, J., Delito de infracción de deber y participación delictiva, op. cit., pp. 183 y ss.

937 Así, tal y como afirma LESCH, la libertad sin responsabilidad es pura arbitrariedad, LESCH, HH., «Intervención delictiva e imputación objetiva», op. cit., p. 922. 
público, juramento o promesa de un ejercicio profesional como los médicos o abogados) adquiere y administra porque el Estado no puede asumirlo, o en otros casos porque la configuración normativa irradia dialécticamente estás competencias al sujeto, por ende, la defraudación por el sujeto especial de un deber ajeno o propio, pero en todo caso actualmente suyo, siempre es a título de autor, sólo él puede defraudar esa expectativa ${ }^{938}$, que a diferencia del quebrantamiento de los delitos de organización que impiden lesionar un bien (neminem laedere), los delitos de infracción de deber por responsabilidad de competencia institucional llaman a contribuir, ayudar y garantizar al bien jurídico en su propia existencia, consiste en realizar un bien común en la sociedad ${ }^{939}$.

\section{4) Solución doctrinal y toma de postura}

Como hemos visto, están quienes defienden una fundamentación de la garantía en las fuentes tradicionales (ley, contrato, e injerencia), mientras que otros se han preocupado en fundamentar y justificar materialmente éstas u otras fuentes ${ }^{940}$. Para mantener la equivalencia, no basta con la posición de garantía, sino que también será preciso la extensión de la imputación objetiva de los delitos comisivos a los de comisión por omisión, según refiere JAKOBS ${ }^{941}$, por lo que no puede ser confundida la competencia por organización, significativamente marcada por el dominio del hecho, y la competencia institucional, marcada por la posición de garante precisamente. A esta línea de pensamiento nos adherimos, y pasamos a desarrollar.

Venimos manteniendo por nuestra parte que en los delitos de infracción de deber, pero también en los de dominio o de responsabilidad por organización, la acción y la omisión es intercambiable, de tal modo que es una consecuencia natural de la configuración organizativa del delito. En cuanto a dicha intercambiabilidad, parece que existe un amplio consenso en aceptarla en los delitos de infracción de deber porque en estos el sujeto es autor responsable en virtud de una especial relación con una institución, sin embargo, la cuestión no es tan clara en los delitos de dominio o también denominados de responsabilidad por organización. En estos últimos,

\footnotetext{
938 JAKOBS, G., «La normativización del Derecho penal en el ejemplo de la participación», trad. Manuel Cancio Meliá, Modernas tendencias en la ciencia del Derecho penal y la Criminología, UNED, Madrid, 2001, p. 641; SÁNCHEZ-VERA, J., Delito de infracción de deber y participación delictiva, op. cit., pp. 183 y ss.

939 JAKOBS Günther / STRUENSEE Eberhard, «Problemas capitales del Derecho penal moderno», Libro Homenaje a Hans Welzel, trad. Marcelo A. SAncinetTi, Buenos Aires, 1998, p. 46; SÁnCHEZ-VerA, J., Delito de infracción de deber y participación delictiva, op. cit., p. 118; LESCH, HH., «Intervención delictiva e imputación objetiva», op. cit., pp. 957 y ss.

940 Más ampliamente GRACIA MARTín, L., «La comisión por omisión en el Derecho penal español», op. cit., p. 685 y pp. 695 y ss.

941 JAKOBS, G., PG, op. cit., 30/38 a 30/45; ID, «La competencia por organización en el delito de omisión. Consideraciones sobre la superficialidad de la distinción entre comisión y omisión», op. cit., pp. 347 a 363.
} 
REQUENA $^{942}$ ha expuesto convincentemente la intercambiabilidad de la acción y de la omisión, como superación del modelo de FEUERBACH que separaba acciones y omisiones como delimitación entre Derecho y moral. Esto es porque en la responsabilidad por organización se deriva una usurpación de la organización ajena de la que se fundamenta la posición de garante en deberes de aseguramiento y de salvamento. Esto se debe a que los criterios de imputación son los mismos tanto para la acción y para la omisión - como ya expuso en su día JAKOBS- según la configuración organizativa del delito, y de aquí que no exista una mayor restricción de la libertad en los deberes de mandato ${ }^{943}$. La fundamentación especial de la responsabilidad del autor en los delitos de infracción de deber, viene de su especial posición ante una institución.

La punibilidad del hecho viene causada de la defraudación por omisión de la expectativa negativa, que pende sobre toda persona -habitualmente denominados casos de injerencia o asunción- y que no precisa, naturalmente, de un fundamento jurídico especial, puesto que nace de la «obligación originaria», de la institución negativa de no dañar (neminem laedere) esferas jurídicas ajenas, lo mismo que la defraudación mediante una acción. como muy acertadamente señaló SÁNCHEZ-VERA ${ }^{944}$. Estos casos constituyen delitos de dominio del hecho y no de infracción de deber.

Sin embargo, hay quienes aducen que en la comisión por omisión además de la posición de garante hace falta requisitos adicionales ${ }^{945}$. Inclusive se ha llegado a decir ${ }^{946}$ que la injerencia es más grave que la por sí sola posición de garante (institucional). Quienes ${ }^{947}$ consideran que la comisión por omisión se fundamenta en una infracción de deber, y por tanto toda intervención es autoría, no aceptan la participación como sí lo hace otro sector ${ }^{948}$, bajo el argumento del dominio del hecho para el autor, y el potencial del partícipe. Un sector intermedio entre las dos anteriores

\footnotetext{
942 REQUENA JULIANI, J., Intercambiabilidad de acción y omisión, op. cit., p. 324; SÁNCHEZ-VERA, J., Delito de infracción de deber y participación delictiva, op. cit., pp. 65 y ss.

943 REQUENA JULIANI, J., Intercambiabilidad de acción y omisión, op. cit., p. 191 comenta al respecto que «la intensidad de la energía que pueda resultar necesaria para el cumplimiento del mandato no es relevante para la valoración de la gravedad del hecho: en unos casos la no realización de la llamada puede consistir en una omisión del deber de socorro castigada con una pena de multa; pero en el caso de la víctima de una actividad peligrosa previa del obligado (injerencia) la no realización de la llamada puede fundar una responsabilidad por homicidio»; antes KaUfmann, A., Dogmática de los delitos de omisión, op. cit., p. 97.

944 SÁnCHEZ-VERA, J., Delitos de infracción de deber, op. cit., pp. 83 y ss.

945 GIMBERnAT, E., «Recensión al libro de Bacigalupo "Delitos impropios de omisión”», ADPCP, 1970, p. 726; Gómez Rivero, Ma C., La inducción a cometer delito, Tirant lo Blanch, Valencia, 1995, p. 201; MUÑOZ CONDE F / GARCía ArÁn M., PG, op. cit., pp. 241 y ss; Silva SÁNCHEZ, J-Mª., El delito de omisión. Concepto y sistema, op. cit., p. 307 y ss; ID. «Aspectos de la comisión por omisión: Fundamento y formas de intervención. El ejemplo del funcionario penitenciario», $C P C$, núm. 38, 1989.

946 Vid. GÓMEZ RIVERO, MC., La inducción, op. cit., p. 202.

947 Kaufmann, A., Dogmática de los delitos de omisión, op. cit., p. 281 y ss; STRATEnwerth, G., PG, op. cit., pp. 309 y ss. En España BaCigalupo, E., Principios, op. cit., pp. 392 y ss; Bustos RAMíREZ J / HoRMAZÁBAL MALARÉE H., Lecciones de derecho penal, op. cit., p. 340.

948 En España GIMBERNAT, E., «Inducción y auxilio al suicidio», op. cit., pp. 281 y ss.
} 
corrientes lo representan quienes entienden que sólo será partícipe si no puede realizar el hecho por autoría. Otros apelan al criterio del ánimo de autoría o de participación y otros entienden que la diferencia estriba en si la acción ataca al bien jurídico (autoría) o únicamente supone un peligro (participación).

Resalta acertadamente SÁNCHEZ-VERA que ROXIN ha ubicado a «todos los delitos denominados de comisión por omisión como delitos de infracción de deber, si bien es cierto que dicha opinión, tras las aportaciones al respecto de JAKOBS y la aparición de la versión alemana de esta monografía, ha sido, al menos, puesta en duda por el propio Roxin» ${ }^{949}$. No todos los delitos de comisión por omisión son de infracción de deber, pues el código jurídico se basa en expectativas del determinado rol $^{950}$. Todo esto lo razona y lo fundamenta en la institución negativa neminem laedere, en la obligación originaria de no dañar, a partir de la revisión de filósofos ${ }^{951}$-como SCHOPENHAUER- que distinguió, además del deber general de no dañar como fuente negativa del Derecho, dos tipos de deberes positivos especiales, los familiares y los estatales $^{952}$.

En sentido similar, JAKOBS ${ }^{953}$ explica que en algunos delitos de omisión existe un deber especial equiparable a la comisión, en este sentido, la omisión pura agravada del art. 195.3 CP y su concordante parágrafo alemán, lo que fundamenta que no exista un deber mayor en los delitos de omisión que en los de comisión ,puesto que los mandatos de hacer o de prohibición de hacer dependen a menudo de la organización de un ámbito. De tal manera explica que los delitos de omisión no se fundamentan siempre en el incumplimiento de un deber de solidaridad sino en la competencia de organización (deberes de relación), cuyo fundamento es el mismo que la

949 SÁNCHEZ-VERA, J., Delito de infracción de deber y participación delictiva, op. cit., p. 275.

950 Señala que «(e)l sistema jurídico, pues, trabaja - en lo tocante a los delitos de dominio de hecho, en donde no hay roles especiales- con expectativas referidas a personas, y no con acciones u omisiones que, como tales per se en cuanto datos del mundo exterior que no han sido trasformados por el código jurídico, no son tenidos en cuenta (...) De esta forma, importa sólo si ha existido una defraudación de la expectativa, resultando intrascendente la forma externa de la misma -por acción u omisión»-, ID., ibidem, op. cit., p. 277.

951 ID., ibidem, op. cit., p. 278: «Merito de HEGEL es, sin duda, pues, haber incluido en la prohibición originaria neminem laede también deberes de actuar, esto es, para nuestra disciplina, mutatis mutandis, haber advertido que hay delitos de dominio del hecho u organización que, además de por acción, puede ser cometidos por omisión, sin que haya que hablar por ello de deber jurídico especial o de delitos de infracción de deber».

952 Vid. SÁNCHEZ-VERA, J., Delito de infracción de deber y participación delictiva, op. cit., pp. 99 y ss., refiriéndose a SCHOPENHAUER, A., El mundo como voluntad y representación, T. I, op. cit., Libro IV, 62 y ss; ID., El fundamento de la moral, op. cit., 17, pp. 103 y ss.

953 JAKOBS, G., $P G$, op. cit., 28/13 a 28/16, y concreta que «como hay mandatos que no presuponen solidaridad, y prohibiciones que sólo existen en caso de solidaridad, el cambio de fundamentación de la responsabilidad no puede ser entre todas las omisiones, por una parte, y todas las comisiones, por otra parte, sino dentro de las comisiones, así como dentro de las omisiones», ID., ibidem 28/14; similarmente POLAINO NAVARRETE, M., Acción, omisión y sujetos en la Teoría del delito, op. cit., p. 50 comenta que «(1)a noción de deber ha de quedar, pues, incluida en el supraconcepto de acción y omisión». SÁNCHEZ-VERA, J., Delito de infracción de deber y participación delictiva, op. cit., pp. 148 y ss. y pp. 173 y ss; REQUENA JULIANI, J., Intercambiabilidad de acción y omisión, op. cit., pp. 324 y ss. 
responsabilidad por los delitos de dominio de comisión: «tener consideración por los otros al configurar el propio ámbito de organización».

Junto a estos deberes, existen otros relacionados con la responsabilidad de deberes de sacrificarse como garantía de solidaridad en las relaciones matrimoniales, paterno-filiales de confianza especial, en los que la garantía no proviene de la organización, sino de una «institución».

A este respecto, en la imputación objetiva de la omisión impropia (así denominada en Alemania), o comisión por omisión, afirma JAKOBS ${ }^{954}$ que el autor tiene que haber sido capaz «en abstracto» de evitar el resultado mediante una acción, refiriéndose a que dicha capacidad abstracta es la voluntariedad, lo realizable voluntariamente. En este sentido, expone que quien no sabe nadar, no tiene capacidad física, pero sí en abstracto de proferir gritos de socorro y avisar a terceros, ejemplo que podemos equiparar al de los padres, Testigos de Jehová, que si bien no pueden ayudar en el traslado al hospital, porque por ejemplo no supieran conducir, sí están obligados a avisar a los servicios médicos.

Asimismo, en la organización arriesgada, pero permitida, no se fundamenta una posición de garantía precisamente porque nace de un riesgo permitido, salvo que se irrogue un riesgo especial $^{955}$, sin que pueda exigirse que la acción evitadora del resultado hubiera sido posible con una probabilidad rayana a la seguridad. Por eso, JAKOBS rechaza la teoría de la salvación hipotética, o la imputación en virtud de incremento del riesgo y el principio de disminución del riesgo, a las que antes nos hemos referido, salvo en los casos en que «se omite reducir un alto riesgo hasta convertirlo en un resto de riesgo insignificante» ${ }^{956}$, lo cual también se cumple en los delitos de omisión. Entonces, la clave para diferenciar la imputación de un delito de comisión por omisión, y otro de omisión pura o agravada, es que hay que atender a la evitación de un riesgo al que se está obligado $^{957}$.

En este sentido, el autor de un delito de omisión sólo puede ser quien tiene el deber de evitar el resultado. Esto es el deber de garante, sin embargo, para fundamentar esta posición de garante se ha utilizado diversos criterios como la ley, el contrato, la acción precedente (injerencia) y las comunidades vitales. A este respecto $\mathrm{JAKOBS}^{958}$ niega que el fundamento sea el deber de

954 JAKOBS, G., $P G$, op. cit., 29/10.

955 ID., ibidem, op. cit., 29/19.

956 ID., ibidem, op. cit., 29/20.

957 ID., ibidem, op. cit., 29/22.

958 ID., ibidem, op. cit., 29/27. Similarmente POLAINO NAVARRETE, M., Acción, omisión y sujetos en la Teoría del delito, op. cit., pp. 69 y ss., concluye que las peculiaridades de la omisión pura están en torno a la noción de deber, y por tanto en su naturaleza, titularidad y alcance del deber. Por eso también la única diferencia entre acción y omisión, y así entre omisión pura y comisión por omisión reside en el deber. 
protección y en otros casos el deber de vigilancia, sino que todos los deberes son de protección según el concreto ámbito de organización, de tal manera que el fundamento se divide en dos grupos. Uno se refiere a los delitos de dominio por comisión, cuyo fundamento es la responsabilidad por la configuración de un ámbito de organización, y otro se refiere a la infracción de deber de comisión. En el primero el deber de garante se fundamenta en la responsabilidad por organización, y en los segundos por infracción de deberes por responsabilidad institucional ${ }^{959}$.

Los deberes por organización surgen de deberes de aseguramiento por deberes de relación o por injerencia. Los deberes de relación - explica JAKOBS- aseguran peligros derivados de objetos y actividades empresariales, y más generalmente, de fuentes de peligros externos y dañosos a terceros, del que es competente por la organización interna el sujeto, o cuando se elimina el poder asegurador propio del tercero. El límite lo constituye lo socialmente adecuado o neutro ${ }^{960}$. Los deberes por organización emanan del rol más básico como persona. De tal manera, la injerencia está absorbida en este macro-deber de aseguramiento fundamentado en la relación, puesto que «el comportamiento precedente es un acto de organización que da lugar a un peligro que obliga al aseguramiento al titular del ámbito de organización que se ha convertido en peligroso», ya sea con una acción o una omisión, hasta el punto que sólo en caso de delegación del deber aceptado por un tercero que emprenda a satisfacer la eliminación del riesgo, podrá eliminar esa posición de garantía ${ }^{961}$.

También existen deberes de aseguramiento en la relación de un comportamiento peligroso de otras personas que han activado un hecho criminal (inducción, complicidad, coautoría); en la

959 JAKOBS, G., PG, op. cit., 29/28; SÁNCHEZ-VERA, J., Delito de infracción de deber y participación delictiva, op. cit., pp. 173 y ss. y pp. 275 y ss; MARAVER GÓMEZ, M., El principio de confianza en Derecho penal. Un estudio sobre la aplicación del principio de autorresponsabilidad en la teoría de la imputación objetiva, pról. Jorge Barreiro, Civitas, $1^{a}$ ed. 2009, pp. 254 y ss; REQUENA JULIANI, J., Intercambiabilidad de acción y omisión, op. cit., pp. 147 y ss. pp. 233 y ss. y pp. 325.

960 JAKOBS, G., PG, op. cit., 29/30; ID., Injerencia y dominio del hecho. Dos estudios sobre la parte general del Derecho penal, trad. Manuel Cancio Meliá, Bogotá, 2001, pp. 14 y ss; ID., «La competencia por organización en el delito de omisión. Consideraciones sobre la superficialidad de la distinción entre comisión y omisión», op. cit., p. 347; ID., «La imputación penal de la acción y de la omisión», trad. Javier Sánchez-Vera Gómez-Trelles, JAKOBS, G., Dogmática de Derecho penal y la configuración normativa de la sociedad, op. cit., pp. 116 y ss., con el mismo título en Cuadernos de Conferencias y artículos, trad. Javier Sánchez-Vera, núm. 12, Universidad Externado de Colombia, Centro de Investigaciones de Derecho Penal y Filosofía del Derecho, 1996; PIÑA RochEFORT, JI., Rol social y sistema de imputación, op. cit., p. 290 y ss; POLAINO-ORTS, M., Funcionalismo normativo, op. cit., pp. 118 y ss; ID., «Imputación objetiva: esencia y significado», op. cit., pp. 35 y ss; SÁNCHEZ-VERA, J., «Intervención omisiva, posición de garante y prohibición de sobrevaloración del aporte», op. cit., p. 195; ID., Delito de infracción de deber y participación delictiva, op. cit., pp. 65 y ss.

961 JAKOBS, G., $P G$, op. cit., 29/31, si bien en caso de que el primer obligado advierta un riesgo que frustrara la garantía del tercero, ha de intervenir, no puede fundar la falta de responsabilidad en relación al principio de confianza; también MARAVER GÓMEZ, M., El principio de confianza en Derecho penal, op. cit., p. 302; REQUENA JULIANI, J., Intercambiabilidad de acción y omisión, op. cit., pp. 251 y ss. y pp. 327 y ss. 
utilización de cosas peligrosas por parte de terceros cuando dichas cosas son de dominio del sujeto (dominio sobre cosas); por el poder sobre otras personas, por ejemplo, los padres sobre las acciones punibles de los hijos o acciones peligrosas (dominio sobre personas) ${ }^{962}$. Estos deberes de aseguramiento se fundamentan entonces en el deber que surge de la relación con el propio ámbito de organización, o ajeno en otras ocasiones, pero del que se es también competente, por ejemplo, en los deberes de salvación que parten del ámbito de organización ajeno ${ }^{963}$, en la injerencia por una acción precedente antijurídica de un tercero, aunque no necesariamente culpable, puesto que «se trata de que el peligro no da lugar a ningún deber de salvación equivalente a la comisión si es consecuencia del riesgo existencial general y no cabe dirigirlo conforme al plan mediante la evitación de la acción previa» ${ }^{964}$.

Existe deber de salvación cuando la acción previa es antijurídica, o cuando aun a pesar de un riesgo permitido, se irroga un riesgo mayor que el existente en el comportamiento cotidiano ineludible ${ }^{965}$, o cuando ante acciones justificadas se deriva un deber de salvación (estado de necesidad agresivo) pero no una comisión por omisión ${ }^{966}$. De tal manera, la comisión por omisión del art. 11 CP también puede venir de una acción previa fortuita, imprudente o incluso justificada, cuyo resultado provoque un deber de actuación.

De otra parte, también la asunción de un deber supone el inicio de una competencia del rol denominada responsabilidad por asunción, que además puede liberar a quien previamente ha tenido dicha competencia al tratarse de una confianza «cualificada» o especial que crea una incumbencia institucional con el mismo fundamento que en la injerencia ${ }^{967}$, pero por una expectativa cognitiva, no normativa, pues esta última se garantizaría jurídicamente. En la cognitiva existe una conexión fáctica, un promesa de una prestación expresa o concluyente, y el tercero deja de asumir la protección, aun cuando se conozca después de la asunción que dicha protección no habría sido eficaz, aun cuando no se conozca dicha protección por el tercero, también en casos de asunción de un riesgo aun permitido, y en casos de asunción que no

2 JAKOBS, G., $P G$, op. cit., 29/32 a 29/36.

963 ID., ibidem, op. cit., 29/38; PIÑA ROCHEFORT, JI., Rol social y sistema de imputación, op. cit., pp. 416 a 418; REQUENA JULIANI, J., Intercambiabilidad de acción y omisión, op. cit., pp. 265 y ss. y 327 y ss

964 JAKOBS, G., $P G$, op. cit., 29/39.

965 ID., ibidem, op. cit., 29/41 y 29/42, pone el ejemplo: «El conductor, hacia cuyo coche se acerca tambaleándose una persona embriagada, tiene deber de aseguramiento, pero si ocurre un accidente no es garante de la salvación de ésta si resulta accidentada», ID., ibidem, op. cit., 29/42.

966 ID., ibidem, op. cit., 29/43.

967 ID., ibidem, op. cit., 29/46 a 29/52; REQUENA JULIANI, J., Intercambiabilidad de acción y omisión, op. cit., pp. 327 y ss; similarmente POLAINO NAVARRETE, M., Acción, omisión y sujetos en la Teoría del delito, op. cit., p. 91. 
eliminan la calificación del rol por completo, todo ello salvo que esté viciada dicha asunción ${ }^{968}$. Así, se puede concluir que los deberes en virtud de responsabilidad por organización, protegen expectativas de aseguramiento y salvación que -como bien recuerda JAKOBS- también protegen relaciones institucionales pero en sentido «inespecífico».

Sin embargo, los deberes por responsabilidad institucional en sentido estricto se equiparan a deberes de comisión por la importancia básica de la existencia de la sociedad, como las relaciones paterno-filiales, la confianza especial y los deberes estatales ${ }^{969}$. En este sentido, parte de la doctrina ${ }^{970}$-en contra de la opinión mayoritaria ${ }^{971}$ - niega en los delitos de comisión por omisión trascendencia al principio de inexigibilidad en relación a una mayor intensidad de la exigencia en los delitos de comisión, precisamente por la cláusula de correspondencia entre omisión y acción, y por la posición de garante, es decir, el deber de protección de la institución. No se exige un mayor deber, sino que la protección se refiere exclusivamente, en la comisión por omisión, a una institución mayor. Exclusivamente se afirma que podrá haber alguna graduación de la exigibilidad en el estado de necesidad exculpante ${ }^{972}$.

Por otro lado, es menester aclarar la diferencia de la confianza especial que se deriva del deber en la asunción de la responsabilidad por organización, de la confianza especial en la responsabilidad institucional. En la institucional -según JAKOBS- se crea una confianza con «intensidad equivalente a la comisión», que posibilita determinados «contactos sociales» que fundamentan la garantía, y que puede venir de una «confianza que genera garantía» o de una «confianza que proporciona garantía».

En la primera se crea una confianza ex novo, que garantiza por el receptor de ésta asegurar un bien o el combate de un peligro ${ }^{973}$. En la segunda, en la confianza que proporciona garantía, ya

968 JAKOBS, G., PG, op. cit., 29/47; PIÑA ROCHEFORT, JI., Rol social y sistema de imputación, op. cit., pp. 418 y 419, explica que «el que asume de forma eficaz el auxilio de una persona respecto de la que no estaría obligada más allá de la omisión de socorro (o sin obligación alguna), no genera por dicha conducta una posición de garante. Es preciso que con su conducta se produzca un desplazamiento de otras medidas de salvamento (quedando a salvo la omisión de socorro cuando corresponda)»; MARAVER GÓMEZ, M., El principio de confianza en Derecho penal, op. cit., pp. 126 y ss., en relación a niños, ancianos y discapacitados, cuya condición han de tener en cuenta los terceros a la hora de organizar su conducta; REQUENA JULIANI, J., Intercambiabilidad de acción y omisión, op. cit., pp. 276 y ss. y pp. 327 y ss.

969 JAKOBS, G., PG, op. cit., 29/58; PIÑA ROCHEFORT, JI., Rol social y sistema de imputación, op. cit., pp. 296 y ss. y pp. 419 a 421; REQUENA JULIANI, J., Intercambiabilidad de acción y omisión, op. cit., pp. 147 y ss. y p. 325.

${ }_{970}$ JAKOBS, G., $P G$, op. cit., 29/96 y ss.

971 Vid. y de la misma opinión AgUADO CORREA, T., Inexigibilidad, op. cit., pp. 183 y ss. y p. 191.

972 JaKOBS, G., PG, op. cit., 29/98. Críticamente AGUADO CORREA, T., Inexigibilidad, op. cit., p. 182; SILVA SÁNCHEZ admite cierta relevancia del principio de inexigibilidad en la delimitación de las clases de posición de garante y su alcance, SILVA SÁNCHEZ, J-Mª., El delito de omisión. Concepto y sistema, op. cit., p. 307 y ss.

973 JAKOBS, G., PG, op. cit., 29/67 y ss. y 29/73; PIÑA ROCHEFORT, JI., Rol social y sistema de imputación, op. cit., p. 421, comenta que «la diferencia entre ellos radica en la participación de un determinado rol (y por ende todas sus implicaciones prescriptivas), mientras que en la asunción se trata precisamente de que no participe rol alguno más allá del rol general de "persona"». En contra de JAKOBS, entiende que en la «comunidad de peligro», así 
existe un deber de garante en el que se concreta tan sólo el sujeto competente según el ámbito de organización, no por su comportamiento, sino cuando entra en un determinado ámbito de organización, por ejemplo -dice JAKOBS- según el plan servicio médico. Al igual que sucede en la confianza que genera garantía, y a diferencia de la asunción, no resulta relevante si se anula otra posición de garante, siempre existe el deber ${ }^{974}$. Mientras que en la confianza que se deriva en la asunción del deber de garante que genera responsabilidad por organización, simplemente existe la injerencia por la asunción de un deber, o dicho de otro modo, el sujeto acepta ese deber, nace y se puede anular por la concurrencia del deber de otro sujeto ${ }^{975}$. Así, en los deberes de impedir autolesiones dolosas de personas responsables -conforme a la tesis de JAKOBS- no surgen de una especial confianza, no al menos para los médicos ${ }^{976}$.

Otras veces, la convivencia puede obligar a diversos deberes por asunción, pero sólo surgiría la confianza especial cuando se promete el auxilio y se llevan a cabo actos claros de preparación para su caso, o en la unión de ámbitos de organización como en la «comunidad del riesgo», en la que se acuerda el auxilio mutuo, también la «comunidad de vida» para la evitación de riegos vitales, en la que existen riegos mayores a los normales, y cuya obligación surge de la superación común, y también en casos sustitución de la confianza especial de la protección estatal como en el caso de bomberos voluntarios ${ }^{977}$.

Al respecto PIÑA ROCHEFORT acierta a concluir que la responsabilidad institucional se fundamenta como defraudación de un rol especial ${ }^{978}$, por eso en la omisión del deber de socorro no se detenta una posición de garante, sino exclusivamente está el «apercibimiento» del art. 195 $\mathrm{CP}$, si bien reconoce que en estos casos sí se imputan los conocimientos especiales porque este delito es un cuerpo extraño del ordenamiento jurídico al colocar a un rol común como garante,

también en los casos de convivencia, no existe posición de garante por una confianza especial, se trata de casos de responsabilidad por asunción, ID., ibidem, op. cit., p. 422.

974 JAKOBS, G., PG, op. cit., 29/73.

975 Ampliamente sobre la confianza que no genera deber institucional REQUENA JULIANI, J., Intercambiabilidad de acción y omisión, op. cit., pp. 255 y ss.

976 Comenta que el «(f)undamento del deber de evitar el resultado sería, en el médico, «la relación médicopaciente que surge por la asunción del tratamiento médico», a la cual «antes de la cesión del dominio del hecho» se ha superpuesto la decisión del legislador de dejar impune el auxilio a un suicida que actúa libremente y responsablemente (se quiere decir: la participación en un suicidio)», pero esto no puede ser el fundamento puesto que «i(c)ómo va a poder surgir deberes del médico, contra la voluntad del paciente, a partir de una relación de tratamiento que el paciente puede rescindir sin alegación de causa alguna en cualquier momento, y limita en su contenido (no se confió la vigilancia de decisiones suicidas? (...) es inadmisible presumir como algo cierto en la víctima el carácter pasajero de la voluntad de quitarse la vida tan sólo porque podría ser así. Siempre que la víctima manifieste de modo responsable que quiere morir, el riesgo de error va en perjuicio suyo», JAKOBS, G., $P G$, op. cit., 29/70, nota 141 .

977 ID., ibidem, op. cit., 29/70. La fuente del deber que emana de la «estrecha comunidad de vida», procede de la construcción de la jurisprudencia alemana, véase al respecto, Sentencia de la sala $1^{\text {a }}$ RGSt, de 10 de octubre de 1935 , vid., PIÑA ROCHEFORT, JI., Rol social y sistema de imputación, op. cit., p. 405.

978 PIÑA ROCHEFORT, JI., Rol social y sistema de imputación, op. cit., pp. 295 y ss. 
siempre que no le concurra riesgo, por lo que de tal manera se difumina la figura del garante ${ }^{979}$. Aquí afirma, muy acertadamente, que el art. 195 CP constituye un elemento extraño al rol básico de persona, al exigir un deber positivo fundado en la solidaridad general, y de tal manera, la posición de garante puede venir tanto de las funciones de un rol general como de uno especial, y en tal medida, así, la comisión por omisión no es una institución exclusiva de los deberes especiales, ni se exige ser solidario siempre ${ }^{980}$.

No obstante, la omisión en la comisión por omisión ha de corresponder (cláusula de correspondencia) con el resultado mediante comisión, pero para esta correspondencia se precisa acudir a los casos de la Parte Especial ${ }^{981}$.

De tal manera, no parece problemático mantener -con JAKOBS- que entre dos deberes del mismo rango no existen «máximas jurídicamente vinculantes», de manera que se trata de un ámbito «exento de derecho» ${ }^{982}$. Si los deberes son del mismo género pero no del mismo rango prevalece el de mayor rango, esto parece claro, pero si concurren deberes distintos de género, prevalece la posición de garante, por cuanto en el ejemplo que expone, en un accidente el padre debe salvar antes a su hijo que a terceros para cumplir con el mandato de los parágrafos 13 y 212 StGB en detrimento del deber de socorro ante terceros del 323c StGB. Esto se ve más claramente en el hecho de que en caso de no cumplir ninguno de los deberes, responderá por el que pudo cumplir, y si pudo elegir, por el injusto menor, pero en el caso de concurrir un deber de actuar (mandato) y un deber de omitir (prohibición), prevalece el deber de omitir puesto que en el ejemplo que expone «(u)n garante que, en una situación de peligro, sólo puede salvaguardar la vida de una persona a la que debe proteger mediante la muerte de un tercero no partícipe, si lo omite, se comporta simplemente de modo conforme a Derecho», por lo que en caso de proteger la propia conservación o el deber de omitir, se corresponden con el estado de necesidad ${ }^{983}$.

Aquí llama la atención -como refiere JAKOBS- que parece existir un derecho a ser egoísta, tan poderoso como el deber/derecho de ser altruista, por eso en la posición de garante en virtud de responsabilidad por organización el obligado responde, salvo casos de legítima defensa, hasta el límite de la solidaridad mínima, en el estado de necesidad defensivo hasta el interés desproporcionado, y en los deberes en virtud de responsabilidad institucional, no se exige un sacrificio ni el empleo de capacidades especiales, salvo que se hayan empleado en situaciones análogas, modificándose por ejemplo la lex artis, o en casos de relaciones paterno-filiales, en los

979 ID., ibidem, op. cit., pp. 371 a 373.

980 ID., ibidem, op. cit., pp. 414 a 416, y critica que se aperciba penalmente; JAKOBS, G., PG, op. cit., 29/29.

981 JAKOBS, G., $P G$, op. cit., 29/81.

982 ID., ibidem, op. cit., 15/7 y nota 11.

983 ID., ibidem, op. cit., 15/7 y ss. 
que se deben activar las capacidades personales. En este último sentido expone el ejemplo de la madre que con formación médica debe auxiliar a su hijo en calidad de experta aun cuando antes no haya asumido ese papel. No obstante, no se le exige llegar a donar un órgano ${ }^{984}$.

En este sentido, JAKOBS acierta al entender que sólo en los delitos de resultado, tanto en los comisivos como en los omisivos, puede plantearse la posición de garante ${ }^{985}$. Según lo visto, estamos de acuerdo con sus consideraciones, por cuanto la injerencia sólo es una forma de asunción del deber, y por lo tanto se aprecia tanto en el delito agravado de omisión del deber de socorro como en la comisión por omisión.

Todo esto se comprende mejor en los delitos de omisión propia o pura, en los que la posición de garante no viene determinada por la ley, ni se equipara dicha posición a la comisión ${ }^{986}$. Esto se debe a que en los delitos de omisión propia la posición de garante se define por la situación del autor en un determinado contexto como poseedor de un determinado conocimiento (p. ej. el desamparo) y entonces una responsabilidad por organización, ya sea por injerencia o asunción. Sin embargo, la ley, en ocasiones, configura dicha posición específicamente en los delitos especiales, en donde tanto la omisión propia como la comisión por omisión responden a un deber institucional (p. ej. confianza especial a diferencia de la asunción), y por eso hay tipos especiales que responde a la estructura del art. $11 \mathrm{CP}$. En este sentido JAKOBS comenta que «(e)l parágrafo 13.2 StGB ha de aplicarse a los delitos de omisión propia en caso de deberes en virtud de responsabilidad institucional». De tal modo que cuando los padres de un menor no consienten un tratamiento médico y se impide de alguna forma actuar a los servicios médicos, la responsabilidad de los padres será institucional de un delito de homicidio en comisión por omisión.

Un ejemplo sería aquel en que los padres no avisan a las asistencias médicas (no hay ni posibilidad de pedir el consentimiento), o rechazan su traslado, mientras que la orden judicial llega tan tarde que fallece el menor. Si bien en estos dos casos existe una falta de consentimiento, en ambos la responsabilidad pasa a un deber institucional por las circunstancias de lugar y tiempo, de tal modo que la exigencia normativa, primero, obliga a avisar a las asistencias, como deber institucional, que si fuera cumplida, a la postre se requeriría una exigencia de organización mediante el consentimiento del tratamiento si el menor es incapaz, inmaduro, y/o está inconsciente. Por eso se incurre ya en la responsabilidad institucional del art. $11 \mathrm{CP}$ y no en la

984 ID., ibidem, op. cit., 15/12 y ss.

985 JAKOBS, G., La imputación objetiva, op. cit., pp. 103; MARAVER GÓMEZ, M., El principio de confianza en Derecho penal, op. cit., pp. 254 y ss.

986 JAKOBS, G., $P G$, op. cit., 30/1. 
omisión pura, porque dadas las circunstancias del caso (están en el domicilio), se activa antes el deber institucional que el organizativo.

La consecuencia jurídico-penal en el modo de concebir estos delitos es que en los delitos de omisión propia no cabrá la participación puesto que «el no auxiliar abarca como autoría a toda forma de intervención, y además se puede cometer mediante acción» ${ }^{987}$. Sin embargo, en la participación en los delitos de comisión por omisión es posible ya sea por inducción, o participando con quien tiene la posición de garante ${ }^{988}$, mientras que otros admiten la participación y complicidad omisiva porque relegan la responsabilidad en estos casos a los delitos de omisión del deber de socorro ${ }^{989}$.

Acertadamente también REQUENA ha aportado a la resolución de la problemática de estos delitos que el contexto en que se desarrolla procura la intercambiabilidad de la acción y la omisión en ambas tipologías delictivas, tanto en la delimitación del riesgo permitido como en los conocimientos especiales ${ }^{990}$.

\section{Solución jurisprudencial y doctrinal a la casuística: toma de postura}

Ahora vamos a profundizar en la casuística acontecida en las últimas décadas, y en el debate doctrinal y soluciones planteadas.

En primer lugar, vamos a analizar la jurisprudencia más destacada y el debate doctrinal sobre la negativa a intervenciones médicas vitales por el propio titular, y después los casos de omisión del deber de socorro limítrofes con el delito de homicidio en comisión por omisión.

Los autos del TS de 14 de marzo de 1979 y de 22 de diciembre de 1983, y el Auto del Tribunal Constitucional 396/1984 de 20 de junio se pronunciaron sobre la negativa a las trasfusiones de sangre.

El Auto del TS de 14 de marzo de 1979 apreció la concurrencia de un estado de necesidad justificante en la conducta de un médico que practicó una trasfusión de sangre contra la voluntad de una Testigo de Jehová. Fue el primer caso en España sobre esta problemática. El Auto de un Juez de instrucción ordenó a un facultativo a realizar una transfusión de sangre a un Testigo de Jehová que se negaba a ello, cuando existía peligro de muerte para su vida. Una vez salvada la vida, el sujeto denunció al Juez por delitos de coacción y delito contra la libertad de conciencia.

987 ID., ibidem, op. cit., 30/3 y 30/4.

988 ID., ibidem, op. cit., 30/1 y ss.

989 AGUADO CORREA, T., Inexigibilidad, op. cit., p. 198.

990 REQUENA JULIANI, J., Intercambiabilidad de acción y omisión, op. cit., p. 241. Expone que «(e)l profesor de natación que no ayuda al alumno que se ahoga comete un delito de homicidio; el usuario de piscina que es gran nadador y que puede salvar a la víctima fácilmente, comete únicamente un delito de omisión del deber de socorro del art. 195 CP», ID., ibidem, op. cit., p. 247. 
El TS confirmó la orden del juez con el argumento siguiente: existe obligación y también derecho para intervenir y evitar incurrir en el tipo de cooperación pasiva al suicidio (art. 409 del anterior CP), o incurrir en una omisión de socorro del art. 489 bis del anterior CP, máxime cuando la actuación estaba justificada por un estado de necesidad del número 7 del art. 8 del anterior CP. Afirma el Auto que la autorización «lesionó un bien jurídico de dicha persona (...) pero con ello causó un mal menor que el que se trataba de evitar como era la más que posible muerte», a lo que añade y niega que «pueda hablarse de un derecho a morir basado en la impunidad del suicidio, pues éste sigue siendo un acto de antijuricidad normativa aunque impune por razones de política criminal, como prueba que sean castigados tanto el auxilio e inducción al suicidio como el homicidio consentido (...), hasta el punto de que esta Sala consideró el no impedir el suicidio como acto de auxilio moral y material pasivo» ${ }^{991}$.

Otro caso similar fue resuelto por el Auto del TS de 22 de diciembre de 1983, que esgrime los mismos argumentos que en el caso anterior, pero añade a los ya citados la eximente de ejercicio legítimo de oficio o cargo, o cumplimiento de deber del médico. Posteriormente el Auto del Tribunal Constitucional 396/1984 de 20 de junio que resolvía el recurso de amparo presentado por el miembro de la confesión religiosa, razonaba que «(a) la esposa del actor se le sugirió por parte del médico que la atendía la conveniencia de una transfusión de sangre para resolver los diversos problemas hemorrágicos derivados de un parto previo, y ante la negativa y reiterada oposición de su esposo, en razón de sus creencias religiosas, al ser Testigo de Jehová, se recabó del Juzgado de Guardia núm. 4 de Santa Cruz de Tenerife la autorización para practicarla, que fue otorgada primeramente por Auto y luego por Providencia de 20 de enero de 1983. Practicadas las transfusiones sanguíneas, la paciente murió cuatro días después, el 24 de enero». El viudo recurrió en amparo, acusando al Juez de un delito de coacciones, y el TC declaró al respecto que «se excluye el delito de coacciones, con independencia de la concurrencia de cualquiera de las circunstancias exigidas señaladas en el art. 8 del Código Penal, por entender que existía una autorización legítima derivada de los arts. 3 y 5 de la LOLR 7/1980 de 5 de julio, para la actuación judicial, ya que el derecho garantizado a la libertad religiosa por el art. 16.1 de la Constitución tiene como límite la salud de las personas, según dicho art. 3, y en pro de ella actuó el magistrado-juez, otorgando autorización para las transfusiones sanguíneas».

A nuestro modo de ver, el Auto del TC, y los demás mencionados del TS, incurren en un grave error interpretativo, cuando fundamentan y legitiman la autorización para la transfusión,

\footnotetext{
991 Vid. Romeo Casabona, CMa ${ }^{\mathrm{a}}$, El médico ante el Derecho, $1^{\mathrm{a}}$ ed., Servicio de Publicaciones Ministerio de Sanidad y Consumo, 1985, pp. 48 y 49.
} 
con base al límite que constituye la salud de las personas del art. 3 de la LOLR 7/80 para la libertad religiosa del art. 16.1 CE. Lo cierto es que el art. 3 de dicha Ley no se refiere a la salud individual, como es el caso que nos ocupa, sino a la salud pública, por tal motivo para que quede limitada la libertad religiosa debe ponerse en peligro al menos a una pluralidad de personas, lo suficientemente amplia para que afecte a la salud pública, y claro está, en el caso en cuestión, la no realización de la transfusión de sangre no afectaba a nadie más que al propio sujeto.

En otro orden, el TC incurre en otra deficiencia. Como señala SoUTO PAZ, «(a)unque por la fecha en que se pronunció todavía no estaba vigente la Ley General de Sanidad, el Tribunal podría haber hecho referencia a las tendencias patentes ya en el Derecho comparado sobre la necesidad del consentimiento informado para la aplicación de cualquier tratamiento» ${ }^{992}$. El TC debería haber respetado los deseos de la mujer en caso de «consciencia» de ésta, o del marido, pues ya en aquel tiempo se regulaba la autonomía del paciente, según lo visto supra.

El giro jurisprudencial del TC se produjo, mucho después, con la Sentencia núm. 154/2002 de 18 de julio, a la par de LAP del 2002, cuando ratificó que uno de los límites de la libertad religiosa es «la salud pública, entendida con referencia a los riesgos de la salud en general» ${ }^{993}$.

La mayor parte de la doctrina - como hemos visto- se ha pronunciado en contra de estas resoluciones o conclusiones ${ }^{994}$, siendo sin embargo de destacar la opinión de BAJO FERNÁNDEZ que, si bien no posee el mismo razonamiento que las sentencias anteriores, concluía que existiría un estado de necesidad en la actuación del juez y del médico. Su razonamiento se centra en que el paciente no puede rechazar un tratamiento médico más que solicitando el alta médica, por lo que si no la hay, el médico actuaría en estado de necesidad ${ }^{995}$. De tal manera rechaza la posibilidad del auxilio omisivo al suicidio, porque dentro de los deberes de los facultativos no

992 SoUto PAZ, JA., Comunidad política y libertad de creencias, op. cit., p. 305.

993 FJ $13^{\circ}$ STC 154/2002, de 18 de julio.

994 CARBONEll MATEU, JC., «Libre desarrollo de la personalidad y delitos contra la vida», op. cit., p. 667; Flores MendoZA, F., Objeción de conciencia, op. cit., pp. 468 y ss; GARCÍA ÁlVAREZ, La puesta en peligro, op. cit., p. 497; JERICÓ OJER, L., El conflicto de conciencia, op. cit., pp. 487 a 492, lo fundamenta en el respeto a la dignidad y libre desarrollo de la personalidad del art. 10 CE; POLAINO-ORTS, M., vv.aa., Lecciones de Derecho Penal, Parte Especial, T. I, op. cit., pp. 66, 68, 74 y 75. En relación a un derecho a la autopuesta en peligro, GóMEZ RIVERO, MåC., La responsabilidad penal del médico, op. cit., pp. 202 y ss; JERICÓ OJER, L., El conflicto de conciencia, op. cit., pp. 490 y 491; FLORES MENDOZA, F., Objeción de conciencia, op. cit., p. 380; TAMARIT SuMALlA, JMa ${ }^{\text {. }}$ «Responsabilidad penal de terceros ante la negativa a la trasfusión de sangre de Testigo de Jehová menor de edad con resultado de muerte», op. cit., p. 2; JAKOBS, G., «La organización de autolesión y heterolesión, especialmente en caso de muerte», op. cit., pp. 404 y ss; ID., $P G, 29 / 70$, nota 141.

995 BAJO FERNÁNDEZ, Miguel, «Agresión médica y consentimiento del paciente», CPC, núm. 25, 1985, pp. 130 y ss. También NAVAS RENEDO consideraba que en estos casos no cabe «la alegación del estado de necesidad» por parte del Testigo de Jehová, pues el Juez entiende que con la orden que autoriza la transfusión sanguínea se produce un mal jurídico en la libertad ideológica, pero este mal jurídico es menor que el mal jurídico que produce el peligro de muerte del sujeto, NAVAS RENEDO, Begoña, Tratamiento jurídico de las sectas. Análisis comparativo de la situación en España y Francia, Comares, 2002, pp. 346 y 347. 
está poner en peligro la salud sin consentimiento ${ }^{996}$. Pero si consideramos que realmente el Testigo de Jehová no quiere encaminarse hacia su propia muerte, sino asumir un peligro inminente de muerte (autopuesta en peligro), cuando no rechaza otro tratamiento médico ${ }^{997}$ que pueda salvar la vida, y máxime, cuando lo que no quiere es vivir a cualquier precio, no puede fundamentarse un estado de necesidad del médico, ni un cumplimiento de deber por parte del Juez.

En este sentido, se ha sostenido mayoritariamente ${ }^{998}$ que no puede apreciarse el estado de necesidad en la intervención del médico, ni ninguna causa de justificación ${ }^{999}$. Así, DíEZ RIPOLLÉS ${ }^{1000}$ consideraba que no existe un deber de alta forzosa, sino que es una mera facultad, y aunque fuera así, no se reputaría mayor valor al deber de salvar la vida que a la libre voluntad del paciente.

En este sentido -según lo expuesto por JAKOBS ${ }^{1001}$ - resulta importante tener en cuenta si el sujeto quiere realmente suicidarse o simplemente realiza una conducta de autopuesta en peligro.

996 BAJO FERNÁNDEZ, M., «Agresión médica y consentimiento del paciente», op., cit., pp. 133 a 135. Sin embargo, años antes, el mismo antor en todo caso mantenía que «(d)e ahí que el mal causado contra la voluntad de quien lo sufre, producido por quien no se encuentra en una situación de necesidad, haya de considerarse superior al evitado, aunque se tratara de la muerte, si falta la necesaria adecuación a los valores fundamentales de la comunidad jurídica», BAJO FERNÁNDEZ, M., «La intervención médica contra la voluntad del paciente», ADPCP, 1979, pp. 494 y 495 y p. 496.

997 JORGE BARREIRO, Agustín, «La relevancia jurídico-penal del consentimiento del paciente en tratamientos médico-quirúrgicos», $C P C, 1982$, p. 20.

998 DíEZ RIPOLlÉs JL / GRACIA MARTín L., Delitos contra bienes jurídicos fundamentales. Vida humana independiente y libertad, op. cit., p. 253; BUENO ARÚS, F., «El rechazo del tratamiento en el ámbito hospitalario», op. cit., p., 405; GARCÍA ÁlvAREZ, P., La puesta en peligro, op. cit., p. 556; JAKOBS, G., «La interrupción del tratamiento», op. cit., pp. 419 y ss; considera que no puede acudirse al estado de necesidad porque no constituye un mal jurídico LUZÓN PEÑA, D-M., «Estado de necesidad e intervención médica (o funcionarial, o de terceros) en casos de huelga de hambre, intentos de suicidio y de autolesiones: algunas tesis», La Ley, T. I, 1988, pp. 996 a 998 ; SILVA SÁNCHEZ, J-Mª , «La responsabilidad penal del médico por omisión», op. cit., pp. 955 y ss.

999 CEREZO MIR, J., «La eximente de obrar en cumplimiento de un deber», op. cit., pp. 277 y ss; CASTRO JOVER, A., «La libertad de conciencia y la objeción de conciencia individual», op. cit., pp. 181 y ss; EsCOBAR ROCA, G., La objeción de conciencia, op. cit., p. 359; GÓMEZ RIVERO, $\mathrm{M}^{\mathrm{a}} \mathrm{C}$., La responsabilidad penal del médico, op. cit., pp. 206 y ss; JERICÓ OJER, L., El conflicto de conciencia, op. cit., p. 531; ROMEO CASABONA, CMa ., El médico y el Derecho penal, op. cit., p. 382; TAMARIT SUMALLA, JMa., La libertad ideológica, op. cit., pp. 437 y ss.

${ }^{1000}$ DíEZ RIPOLlÉS JL / GRACIA MARTín L., Delitos contra bienes jurídicos fundamentales. Vida humana independiente y libertad, op. cit., p. 253; Por su parte BUENO ARÚs considera que al paciente le asiste un derecho a recibir asistencia, aunque rechace las medidas extraordinarias que pudieran ser precisas, ya que en caso contrario, la falta de esta asistencia ordinaria, o la imposición del alta médica, podría constituir un delito de omisión del deber de socorro, BUENO ARÚS, F., «El rechazo del tratamiento en el ámbito hospitalario», op. cit., p. 405, si bien acepta el estado de necesidad en caso de riesgo para la salud pública, ID., ibidem, op. cit., p. 401. Por eso BuENO ARÚs también rechaza la imposición de un tratamiento vital como causa de justificación de estado de necesidad del médico, pues acertadamente considera que los bienes en conflicto son del paciente, lo contrario significaría negar la disponibilidad del propio cuerpo y la libertad, ID., ibidem, op. cit., pp. 402 y ss; GARCía ÁlVAREZ, P., La puesta en peligro, op. cit., pp. 551 y 552; ZUGALDÍA ESPINAR, JM., «Eutanasia y homicidio a petición: situación legislativa y perspectivas político-criminales», RFDUG, núm. 13, 1987, p. 284; GARCÍA ÁlVAREZ, P., La puesta en peligro, op. cit., pp. 554 y 555 .

1001 JAKOBS, G., «La organización de autolesión y heterolesión, especialmente en caso de muerte», op. cit., pp. 395 a 412. 
Así, parte de la doctrina ${ }^{1002}$ considera que se precisa dolo directo para poder hablar de acción suicida, porque se requiere una verdadera intención de morir, querer este resultado, mientras que otro sector ${ }^{1003}$ considera que bastaría con el dolo eventual, lo cual, en nuestra opinión, dificulta la distinción con la culpa consciente. A nuestro modo de ver, el suicidio sólo se puede caracterizar por una clara voluntad de que concurra el resultado de muerte, nada más que eso, por lo que el querer otros resultados por encima de la muerte aunque aceptada como probable (dolo eventual), llevará a considerar la acción como una autopuesta en peligro o autolesión, y en tal sentido también sería aplicable este criterio en los casos de «culpa consciente» si bien cabe entenderlo en verdad como «riesgo permitido».

En estos casos debemos concluir que no se produce un problema entre conciencia y norma, sino que realmente asiste al Testigo de Jehová, en este caso, y a los pacientes en general, el derecho al consentimiento informado, y en definitiva a decidir sobre el tratamiento ${ }^{1004}$. No estamos ante casos de suicidio, sino de autopuestas en peligro. No obstante, según lo resuelto supra, los casos de participación en el suicidio, lege lata, son insostenibles normativamente.

De otra parte, en la actuación del médico que no practica la intervención, cuando no se consiente por el paciente, se elimina claramente la posición de garante ${ }^{1005}$ (hay peligro objetivo pero no auxilio), tanto en el médico como en cualquier otro familiar al que se le tratase de recabar el consentimiento, es más, si el médico actuase por voluntad propia evitando la muerte mediante un tratamiento no consentido, sería constitutivo de un delito de coacciones ${ }^{1006}$, aunque

1002 BAJO FernándeZ, M., Manual de Derecho penal, Parte Especial, I, delitos contra las personas, $2^{\mathrm{a}}$ ed., CEURA, Madrid, 1987, p. 90; GARCÍA ÁlvareZ, P., La puesta en peligro, op. cit., p. 101 y 104; LUZÓN PEÑA, DM., «Problemas de las trasmisión y prevención del SIDA en el Derecho penal español», en Santiago Mir (ed.), Problemas jurídico penales del SIDA, Bosch, Barcelona, 1993, p. 15; SILVA SÁNCHEZ, J-Ma ., «Causación de la propia muerte y responsabilidad penal de terceros (A propósito de la STS 8 de julio de 1985), ADPCP, 1987, p. 457.

${ }^{1003}$ DíAZ Y García CONLlEDo, Miguel, «Homicidio consentido y participación en el suicidio», Enciclopedia Jurídica Básica, Vol. II, Civitas, Madrid, 1995, p. 3332; DíEZ RIPOLlÉS JL / GRACIA MARTín L., Delitos contra bienes jurídicos fundamentales. Vida humana independiente y libertad, op. cit., p. 215.

1004 También Flores MendozA, F., Objeción de conciencia, op. cit., p. 374; RomeO CASABONA, CM ${ }^{\mathrm{a}}, E l$ Derecho y la Bioética, op. cit., pp. 132 y 134.

1005 También Flores MendOZA, F., Objeción de conciencia, op. cit., pp. 379 y 380; PÉREZ DEL VALLE, C., Conciencia, op. cit., p. 130 y ss; Romeo CASABOna, CM ${ }^{\mathrm{a}}$, El Derecho y la Bioética, op. cit., pp. 113, y 439 y ss; TAMARIT SUMALLA, JMa ., La libertad ideológica, op. cit., 403

1006 BAUCELls I LLADÓs, J., La delincuencia por convicción, op. cit., p. 231; CASTRO JOVER, A., «La libertad de conciencia y la objeción de conciencia individual», op. cit., p. 175; DíEZ RIPOLLÉS considera que la intervención médica coactiva en las intervenciones médicas a Testigos de Jehová es constitutiva de coacciones, si la intervención tiene éxito, rechaza el tipo de lesiones, y si no lo tiene, no se forma el tipo subjetivo, DíEz RIPOLLÉS JL / GRACIA MARTÍN L., Delitos contra bienes jurídicos fundamentales. Vida humana independiente y libertad, op. cit., p. 243 y 250; también LUZÓN PEÑA, D-M., «Estado de necesidad e intervención médica (o funcionarial, o de terceros) en caso de huelga de hambre intentos de suicidio y de autolesiones: algunas tesis», op. cit., pp. 992 y 993; FLORES MENDOZA, F., Objeción de conciencia, op. cit., pp. 431 y ss; GÓMEZ RIVERO, M ${ }^{\mathrm{a} C}$., La responsabilidad penal del médico, op. cit., p. 206; HIGUERA GUIMERÁ, JF., El delito de coacciones, op. cit., p. 219; con matices y sin descartar el delito de lesiones JERICÓ OJER, L., El conflicto de conciencia, op. cit., p. 530; ROMEO CASABONA, CMa ., El 
en nuestra opinión y de un sector de la doctrina, como ya explicamos, se incurriría en un delito de lesiones, aunque según los casos, podría aplicarse el concurso con el delito contra el sentimiento religioso del art. $522 \mathrm{CP}$ si la negativa fuera motivada por motivos de conciencia, amén de ello, la actuación del médico que deja de aplicar el tratamiento (omisión por prolongación de la mano) o del familiar, que no consiente la trasfusión, es conforme a Derecho cuando el propio titular del derecho se niega.

Así, en nuestra opinión, en estos casos, no sería apreciable, de ningún modo, una causa de justificación del tipo que sea, si bien, como dijimos, se plantean problemas de error de prohibición, o incluso de miedo insuperable, debido a la angustia de ver morir, aunque estos supuestos serían casos excepcionales, que no serían supuestos de conflicto de conciencia.

Por otro lado, existen varias sentencias de notoria importancia en la problemática de la delimitación jurídico-penal entre el delito de omisión del deber de socorro y delito de homicidio en comisión por omisión.

La Audiencia Provincial de Málaga, en Sentencia de 25 de febrero de 1987, condenó a un miembro de los Testigo de Jehová por un delito de homicidio en imprudencia temeraria (homicidio por imprudencia grave), con la concurrencia de una atenuante de arrebato $u$ obcecación del art. 9.8 $\mathrm{CPd}\left(21.3^{\mathrm{a}} \mathrm{CPv}\right)$, por impedir una transfusión de sangre al quitar, en un descuido de las enfermeras, el catéter que tenía colocado la víctima, pero procurando, a la vez, controlar la hemorragia que se había producido al retirarlo. A consecuencia de esto, la mujer falleció. En el caso se desconoce la voluntad de la víctima, a pesar de su membrecía a los Testigos de Jehová. La trasfusión se realizó porque la paciente estaba inconsciente. La sentencia absuelve del delito de asesinato por el que venía siendo acusado, reconduciéndolo al de imprudencia temeraria.

El TS, en Sentencia de 27 marzo de 1990, resolvió el recurso de casación interpuesto por el Ministerio Fiscal contra la meritada anterior Sentencia. El TS utilizó, para determinar la imputación objetiva, la teoría la «equivalencia de las condiciones». Entendió que la conducta del imputado era adecuada para provocar la muerte ${ }^{1007}$. La Sentencia fundamentó la conducta doloso eventual del sujeto, porque se representó el resultado de la muerte en el momento del hecho, conocía que la retirada del catéter produciría una hemorragia que podría causar la muerte. A lo que no alude la Sentencia es al concepto de probabilidad o posibilidad que diferencian, en buena medida, las doctrinas sobre el dolo eventual y la culpa consciente, si bien, parece decantarse por

médico y el Derecho penal, op. cit., p. 357; TAMARIT SUMALlA, JMa ., La libertad ideológica, op. cit., p. 427; STC 120/1990.

${ }^{1007}$ FJ $1^{\circ}$ STS, de 27 marzo de 1990. 
la «teoría de la probabilidad». Como ya concluimos, en nuestra opinión, para apreciar el dolo eventual no basta con la representación de la posibilidad del resultado representado y su aceptación por el sujeto activo, sino que se haya representado la alta probabilidad del resultado material y además acepte el resultado (teoría del consentimiento).

Sin embargo, argumenta la Sentencia que «si a esto se añade la profesión de unas creencias religiosas, compartidas al parecer por la víctima, que proscriben toda transfusión sanguínea aun con riesgo de muerte, no es difícil deducir que la retirada de la cánula o catéter (...), que el acusado se representó y aceptó, o, al menos, contó o se conformó con él» ${ }^{1008}$. De tal manera, al final de su consideración, admite la posibilidad de que el sujeto no aceptara el resultado, por lo que en nuestra opinión debió rebajar el título de imputación al de culpa consciente en virtud del principio de presunción de inocencia e in dubio pro reo, derechos que también se trasladan a la valoración del título de imputación.

Pero es que además, el anterior razonamiento utiliza el conocimiento por parte del sujeto activo de que la víctima era testigo de Jehová, y que ésta congregación prohíbe tales prácticas bajo sanción de expulsión de la misma y la condena del alma, como dato añadido para apreciar la conducta dolosa. De tal manera que concluye que el sujeto tenía conocimiento y voluntad de realizar la conducta típica, como acepta en este caso parte de la doctrina ${ }^{1009}$, lo que constata la imposibilidad de apreciar el error de prohibición vencible, pero según las conclusiones a las que hemos llegado en el anterior capítulo, si se valora el motivo de conciencia de forma normativa, nada impide apreciar en este caso, el estado de necesidad exculpante aun cuando el título de imputación era el delito doloso.

Sin embargo, la Sentencia aprecia una atenuante muy cualificada de arrebato por ofuscación y pérdida del dominio de la voluntad del art. 9.8 CPd (arrebato u obcecación del art. 21.3 ${ }^{\mathrm{a}} \mathrm{CPv}$ ). Llega a esta conclusión por apreciar una esquizofrenia paranoide con delirios de celos y persecución. La Sentencia fundamenta la atenuante en un conflicto de conciencia directo, es decir, se trata al conflicto de conciencia como una cuestión patológica ${ }^{1010}$.

\footnotetext{
1008 Ibidem

1009 BAUCELls I LLADÓs, J., La delincuencia por convicción, op. cit., pp. 270 y ss; TAMARIT SUMALLA, JMa ., «La objeción de conciencia», op. cit., pp. 40 y ss.

1010 TAMARIT SuMALla, JM ${ }^{\mathrm{a}}$., «La objeción de conciencia», op. cit., pp. 40 y ss. En concreto la Sentencia argumenta sobre la atenuante que «el dogmatismo y la rigidez de los esquemas morales que dan, en la indicada opción religiosa, un valor absoluto al consentimiento, con preeminencia de la libertad de conciencia sobre el derecho a la vida, y un ferviente y radical altruismo, conformado por dichas creencias, que autoriza a poner en riesgo o a sacrificar la vida de los fieles por razones trascendentes que surgen de una particular exégesis de los Textos Sagrados, pueden conducir, y de hecho conducen, a una ofuscación del raciocinio y la pérdida del pleno dominio de la voluntad, a un estado pasional caracterizado por el disturbio psicológico derivado del aludido orden de valores que merman o recortan la capacidad de culpabilidad del sujeto; y como en el momento de los hechos se
} 
En opinión de JERICÓ ${ }^{1011}$, este caso habrá de reconducirse al ámbito de la culpabilidad, con la aplicación de la eximente de miedo insuperable, o la atenuación simple o muy cualificada, cuando provenga de un conflicto de conciencia inexcusable, no así en caso de mero convencimiento o conducta no inexcusable.

En el caso en cuestión, el título de imputación es ajeno al tratamiento jurídico-penal del conflicto de conciencia, puesto que ya explicamos que tanto la autoría de conciencia como la autoría por convicción y el enemigo se pueden realizar en delitos imprudentes y de peligro. La cuestión es que en este caso se reproduce de forma ejemplar nuestros postulados previos. Nadie de la doctrina, ni la jurisprudencia, niegan que éste sea un caso de conflicto de conciencia, es más, la Sentencia vincula dicho conflicto a la causa de atenuación. Sin embargo, en este caso se reproduce una conducta de la autoría de conciencia de forma activa y dolosa, sin que haya un cambio del paradigma a la autoría por convicción o del enemigo, sino que constata que en la autoría de conciencia no sólo se comenten delitos por omisión, u omisión pura, sino que cabe la posibilidad de conductas activas que además de dolosas incurran en delitos altamente penados. Esto se debe a que, en este caso en concreto, en la conducta del autor, por la especialidad de las circunstancias (estaba presente y tenía acceso al catéter), actuó en ese momento la conexión inevitable entre conciencia y voluntad, por un previo déficit de comunicación/socialización atribuido a la norma, según hemos explicado, que fundamenta el estado de necesidad exculpante, si bien en este caso, se podría apreciar la causa incompleta si el sujeto, después de unos días, accedió al lugar donde se encontraba la víctima para quitar el catéter, pues en tal caso, si bien las circunstancias del conflicto de conciencia se le presentaron igualmente de forma sorpresiva, el trascurso del tiempo refuerza la socialización de la segunda norma, la que ordena en este caso no matar.

Un caso similar, en el que también se imputó el dolo eventual, se resolvió finalmente por la STS de 27 de junio de 1997 (rec. 3248/1996). Se condenó por homicidio doloso, bajo la concurrencia de la atenuante de arrebato u obcecación del $21.3^{\mathrm{a}} \mathrm{CP}$, a los padres de un menor de edad de 13 años que necesitaba de una transfusión de sangre, al negarse éstos a prestar el

exteriorizó en el acusado el estado emocional descrito, procede aplicar a su acción homicida la atenuante prevista», FJ $3^{\circ}$ STS, de 27 marzo de 1990.

1011 JeRICÓ OJER, L., El conflicto de conciencia, op. cit., pp. 549 y 550. Ya expusimos que no estamos de acuerdo con esta conclusión, porque el criterio de la insuperabilidad psicológica no se presenta en la autoría de conciencia. La conexión de la conciencia y la voluntad, de forma tan ineludible, no está en un miedo, algo que inevitablemente es psicológico, sino al hecho cierto de que la conciencia y la voluntad, máxime en la configuración moral/religiosa o ideológica, fundamentan al ser humano en cuanto persona libre. Lo ineludible no se refiere al miedo, sino al obrar que necesariamente se dirige a quebrantar la norma, y de aquí que se haya elevado a norma fundamental el derecho a la libertad de conciencia. 
consentimiento. Los dos acusados no consintieron la transfusión de sangre de su hijo menor de edad, pero sí aceptaban otro tratamiento médico. El centro hospitalario denegó el alta médica solicitada por los padres, bajo el argumento de que se pondría en grave peligro al menor. El centro solicitó autorización judicial para realizar una trasfusión de sangre vital en el caso de que existiera grave peligro de muerte, y sólo en el caso de que fuere la única medida posible para su salvación.

Se declaró probado que una vez se dictó la autorización judicial los dos acusados acataron la decisión. En el momento de realizar la transfusión, el menor, de trece años de edad, «sin intervención alguna de sus padres, la rechazó con auténtico terror, reaccionando agitada y violentamente en un estado de gran excitación que los médicos estimaron muy contraproducente, pues podía precipitar una hemorragia cerebral». Los médicos intentaron convencer al menor, e incluso pidieron a los padres que le convencieran, lo cual fue también rechazado por los repetidos motivos de conciencia, a pesar de desear su salvación. Tras consultar el centro médico el hecho acaecido al Juzgado de Guardia, y al no existir ningún otro tratamiento alternativo, el centro decidió ejecutar el alta médica voluntaria para que el menor pudiera ir a otro centro como solicitaban los padres. Los padres solicitaron que el menor permaneciera hospitalizado hasta localizar un nuevo especialista médico. El hospital no accedió entendiendo que al no haber ya tratamiento por negativa ya no existía obligación del centro de auspiciarlo. En este caso, estamos de acuerdo con DíEZ RIPOLLÉs ${ }^{1012}$ en que no existe un deber de alta forzosa, y con BUENO ARÚS $^{1013}$ en que al paciente le asiste un derecho a que se le ayude aunque rechace medidas extraordinarias, en cuyo caso contrario, la falta de asistencia ordinaria, o la imposición del alta médica podría constituir un delito de omisión del deber de socorro. Los facultativos debieron seguir asistiendo al menor con medidas ordinarias tendentes a controlar y paliar la situación, de tal manera que también estamos de acuerdo en que hasta que no fuera dado de alta por voluntad paterna, pudo incurrirse en un delito de omisión del deber de socorro. Tras llevarlo a su domicilio le trasladaron nuevamente a un hospital de Barcelona, en el que se le diagnosticó un síndrome de pancetopenia grave debido a una aplaxia medular, o una infiltración leucémica, por lo que se consideró urgente la práctica de una transfusión para neutralizar el riesgo hemorragia y de anemia. Los acusados y el mismo menor, nuevamente, expresaron por escrito su negativa a aceptar la transfusión. El centro decidió no recabar auxilio judicial, ni intentar una transfusión.

\footnotetext{
1012 DíEZ RIPOLlÉs JL / GRACIA MARTín L., Delitos contra bienes jurídicos fundamentales. Vida humana independiente y libertad, op. cit., p. 253.

${ }^{1013}$ BUENO ARÚS, F., «El rechazo del tratamiento en el ámbito hospitalario», op. cit., p. 405, si bien acepta el estado de necesidad en caso de riesgo para la salud pública, ID., ibidem, op. cit., p. 401.
} 
Tras el nuevo alta, los padres llevaron al menor a otro hospital, esta vez privado, en el que nuevamente, se estimó la necesidad vital de la transfusión, y se descartó también la posibilidad de otro tratamiento alternativo, por lo que los padres llevaron al menor al domicilio familiar.

El Juzgado de Instrucción de Fraga (Huesca), teniendo conocimiento de la situación del menor a través del Ayuntamiento de la ciudad, ordenó mediante Auto la entrada en el domicilio del menor para que se le practicase todas las oportunas y necesarias medidas para salvarle la vida. Los padres, nuevamente declararon sus convicciones y su negativa a la trasfusión, pero no a que el menor fuera trasladado al hospital, inclusive uno de ellos ayudó a las asistencias a trasladarlo hasta la ambulancia, en ningún momento impidieron el traslado a un nuevo Hospital, donde llegó en coma profundo, totalmente inconsciente, y en donde a pesar de practicarle una transfusión sanguínea, el menor finalmente falleció. Al respecto comenta la Sentencia, en el último párrafo del punto primero de los Hechos Probados, que «(s)i el menor hubiera recibido a tiempo las transfusiones que precisaba habría tenido a corto plazo y a medio plazo una alta posibilidad de supervivencia y, a largo plazo, tal cosa dependía ya de la concreta enfermedad que el mismo padecía, que no pudo ser diagnosticada, pudiendo llegar a tener, con el pertinente tratamiento apoyado por varias transfusiones sucesivas, una esperanza de curación definitiva de entre el sesenta al ochenta por ciento, si la enfermedad sufrida era una leucemia aguda linfoblástica, que es la enfermedad que, con más probabilidad, padecía el hijo de los acusados, pero sólo a título de probabilidad pues, al no hacerse en su momento las transfusiones, ni siquiera hubo ocasión para acometer las pruebas pertinentes para diagnosticar la concreta enfermedad padecida que por poder, aunque con menor probabilidad, también podía tratarse de una leucemia aguada en la que, a largo plazo, el pronóstico ya sería más sombrío».

La Sentencia de instancia absolvió a los padres del delito de homicidio en comisión por omisión del 138 y 11 del CP. Sin embargo, el TS apreció la imputación objetiva del resultado en cuanto equivalencia de la posición de garante con la comisión por omisión, es decir, por injerencia del actuar precedente como fundamento de la responsabilidad a título de comisión por omisión del delito de homicidio. La Sentencia entendió que los padres no evitaron un resultado que hubiesen podido evitar, y que les era exigible evitar a través del consentimiento, por lo que incrementaron con el rechazo el peligro de muerte.

No podemos estar de acuerdo con esta conclusión. Entendemos que a pesar de la posición de garante que los padres ostentaron en todo momento, no surgió competencia sobre el resultado de muerte desde el momento en que se avisan a las asistencias o trasladaban al menor a los centros médicos. La muerte se debió al propio rechazo del menor motivado por la convicción moral, que 
se vio materializada con la fuerte repulsa al tratamiento hasta llegar a unas cotas de imposibilidad de ejecución. Así pues, la Sentencia comete un grave error en la imputación objetiva, ya desde la teoría del delito, error por el que se llegó a condenar por homicidio doloso de comisión por omisión. Sin embargo, los padres no fueron garantes del resultado sino exclusivamente de la conducta de auxilio, de tal modo que en todo caso, el debate se debió centrar en si existió o se transfirió este deber a los facultativos.

El Tribunal de primera instancia consideró que la posición de garante de los padres se transfirió una vez reclamaron la asistencia médica, momento en el que opera la posición de garante del centro hospitalario ${ }^{1014}$; sin embargo, la Sentencia del TS no lo entendió así y aplicó la obligación legal conferida por el apartado primero del art. 39 CE y el art. 110 CC que preceptúan que los padres están obligados a velar por los hijos menores, incluso aunque no ostenten la patria potestad. La Sentencia apoya su decisión en su propia línea jurisprudencial, para fundamentar el dolo de la conducta de los padres, en concreto en la Sentencia de 19 de enero de 1994, que hacía referencia a la Sentencia de 30 de junio de 1988, en la que se destaca que en los delitos de omisión el dolo «se debe apreciar cuando el omitente, a pesar de tener conocimiento de la situación de hecho que genera el deber de actuar y de su capacidad de realizar la acción no actúa. Y en su caso de los delitos de comisión por omisión o delitos impropios de omisión, el conocimiento del omitente se debe referir también a las circunstancias que fundamentan su obligación de impedir la producción del resultado». El TS apreció el dolo eventual, porque éste no se excluye por «el deseo vehemente de que no hubiese producido el resultado de muerte».

Sin embargo, posteriormente la STC núm. 154/2002, de 18 de julio, anuló la STS en el sentido de amparar a los padres en su derecho a la libertad de conciencia, pero más claramente al reconocer la libertad de conciencia/religiosa del menor, porque además de ser también titular del derecho a la integridad física, al no poderse comprobar la capacidad y madurez del menor, no había posición de garante al aceptarse la decisión judicial que acordaba la trasfusión. En nuestra opinión, la posición de garante, o la salvaguarda de los hijos por parte de los padres es un deber, por tanto, que no se pierde, ni se sustituye, nace o no nace, se cumple o no se cumple. La cuestión a debatir es cuándo se actúa conforme al deber y cuándo no. La libertad de conciencia no elimina la posición de garante, sino una conducta alternativa que tiene el mismo sentido permitido por la norma, que hace cumplir el deber, y entrar consecuentemente el deber de los

\footnotetext{
${ }^{1014}$ FJ Único STS, de 27 de junio de 1997, rec. 3248-1996, en la que se recuerda el argumento del Tribunal de instancia para entender sustituida la posición de garante: «los padres habían perdido su condición de garantes una vez que habían reclamado la asistencia médica por los cauces convencionales, dando a la sociedad la oportunidad efectiva de sustituirles y dando entrada a los mecanismos de sustitución que nuestra sociedad tiene previstos para actuar al amparo de los menores».
} 
facultativos, en este caso. De tal manera, entendemos que el TC erró al considerar cumplido el deber de socorro por razones de libertad de conciencia, porque de tal forma parece que la norma tiene excepciones normativas. En nuestra opinión, el motivo de conciencia es ajeno a este caso, o dicho de otro modo, otros cualesquiera padres, hubieran cumplido con el deber por el mero hecho de avisar y en su caso, trasladar al menor al hospital. Si bien consideramos acertada la conclusión del TC al declarar que no existía un deber de convencer por los padres a que su hijo aceptara la trasfusión.

Pero estas no son las cuestiones relevantes para solucionar el caso. Por nuestra parte consideramos que el menor tenía derecho a negarse a la intervención médica porque contaba con la suficiente madurez, de aquí que en ningún momento se activó el deber de socorro. Por ello estamos parcialmente de acuerdo con ROMEO CASABONA ${ }^{1015}$ cuando considera que no se elimina la posición de garante aunque intervenga el Juez, sólo sería en el caso de que se dotara de relevancia a la opinión del menor. Acepta la exclusión de la culpabilidad por inexigibilidad de la conducta de las medidas adoptadas por el Juez, es decir, no les es exigible convencer al menor, si bien, según nuestros postulados, dicha inexigibilidad pertenecería al propio deber de socorro, al tipo, por lo que no estaríamos ante una casa de exclusión de la culpabilidad, sino de atipicidad.

En la doctrina española, TAMARIT SUMALla y MAQUEDA ABREU, entre otros ${ }^{1016}$, defienden la comisión de homicidio doloso cuando la víctima sea menor de edad o «incapaz de decidir por sí mismo», aunque esta última penalista, llega a afirmar, erróneamente, que nadie hoy lo discute $^{1017}$, sin embargo lo discute parte de la doctrina entre la que nos encontramos ${ }^{1018}$.

1015 Romeo CASABONA, CM ., «¿Límites de la posición de garante de los padres respecto al hijo menor? (La negativa de los padres, por motivos religiosos, a una transfusión de sangre vital para el hijo menor)», $R D P C, 2$, 1998, pp. 331 y ss; también JAKOBS, G., $P G$, op. cit., pp. 20/24 y ss., en relación a un deber institucional cuando no existe alternativa de organización institucional pero dicha organización no depende del deber cuando los padres rechazan la asistencia médica.

1016 TAMARIT SUMALLA, JMª ., «Responsabilidad penal de terceros ante la negativa a transfusión de sangre de Testigo de Jehová menor de edad con resultado de muerte», op. cit., pp. 1 y ss; también en cuanto que prima la vida del menor ante la libertad de conciencia de los padres y porque la patria potestad implica el deber de los padres en no afectar en el proceso de formación de la libertad de conciencia del menor, ID., La libertad ideológica, op. cit., p. 427; Maqueda Abreu, Mál., «Las sectas destructivas ante el derecho», Eguzkilore, San Sebastián, diciembre, 2004, p. 236; También CEREzO MIR, además de negar cualquier tipo de exención o disminución de la responsabilidad, considera que «no hay culpabilidad moral, pero sí culpabilidad jurídica», de manera que por aplicación del principio de alternatividad, se aplicará el delito de homicidio en comisión por omisión, en detrimento de la omisión del deber de socorro, CEREZo MIR, J., Curso de Derecho penal español. Parte general, III/2, op. cit., p. 35 y nota núm. 91; ID., Derecho penal, Parte general, Lecciones, op. cit., p. 31, nota núm. 84; FLORES MENDOZA, F., Objeción de conciencia, op. cit., p. 403; Romeo CASABOnA, CMª., El Derecho y la Bioética, op. cit., p. 454.

${ }^{1017}$ MAQUEDA ABREU, Má,., «Las sectas destructivas ante el derecho», op. cit., p. 236.

1018 PÉREZ DEL VAlle, C., Conciencia, op. cit., p. 226; BAJO FERnÁNDEZ, M., «La nueva Ley de Autonomía del paciente», Dogmática y Ley Penal, Libro Homenaje a Enrique Bacigalupo, T. II, 2004, pp. 933 y ss. 
Contrariamente BAJO FERNÁNDEZ ${ }^{1019}$ esgrime que la posición de garante se sustituye cuando entra la autoridad pública, lo que hace que se elimine la posibilidad de imputar una comisión por omisión. Su criterio concuerda con el anterior razonamiento del TC, en Sentencia de 18 de julio de 2002, aunque le otorga mayor valor al derecho de la libertad religiosa de los padres que al deber de convencer al menor.

En cambio, LUZÓN PEÑA admite la justificación en delitos de omisión propia por razón del art. $16 \mathrm{CE}$, siempre que no afecte a bienes jurídicos como la vida y la integridad (aunque admite en esto cierta atenuación) ${ }^{1020}$, porque en la ponderación de intereses resultan superiores éstos a los de la libertad de conciencia, ni cuando pese más la actuación exigida que la salvaguarda de la libertad de conciencia ${ }^{1021}$; sin embargo en los casos en los que se pretenda impedir la trasfusión de sangre considera que han de ser reconducidos a una comisión por omisión en tentativa de lesiones u homicidio ${ }^{1022}$.

En nuestra opinión, si bien el caso queda resuelto por la libre voluntad legítima del menor de rechazar el tratamiento médico vital, en el caso de que fuera incapaz, o claramente inmaduro, o estuviera inconsciente, no existió impedimento material de los padres a la transfusión, máxime cuando ayudaron al traslado hasta la ambulancia, lo que constata que los padres realizaron una conducta alternativa de cumplimiento del deber de socorro, de lo que deviene que la falta de consentimiento, como deber de socorro, se sustituyó por otra conducta que tiene la misma capacidad de cumplir con el deber. Si bien, debemos admitir, que esta conclusión en polémica porque la LAP exige el consentimiento de los padres en estos supuestos, lo que redunda en la idea de que taxativamente se exige el consentimiento como cumplimiento del deber de socorro. La conducta alternativa en este caso, debemos concluir, se refiere al tipo del resultado de homicidio, o dicho de otro modo, en este caso hipotético, el aviso a las asistencias y/o traslado del menor con esas circunstancias cumplió el deber de garante institucional, pero la falta de consentimiento incumple un deber que genera responsabilidad por organización.

La clave también es no confundir la negativa de los padres con la repulsa airada del menor a la transfusión, que fue la única causa de la imposibilidad de realizar la trasfusión, si bien, según nuestras conclusiones, si se hubiera realizado podría haberse incurrido en un delito de lesiones en concurso con uno del art. 522 CP. Por tanto, el Tribunal partió de un erróneo planteamiento de la

${ }^{1019}$ BAJO FERNÁNDEZ, M., «La nueva Ley de Autonomía del paciente», op. cit., pp. 933 y ss; JERICÓ OJER, L., El conflicto de conciencia, op. cit., pp. 566 y 567.

${ }^{1020}$ LUZÓN PEÑA, D-M., «Actuación en conciencia», op. cit., pp. 8 y 13.

${ }^{1021}$ ID., ibidem, op. cit., p. 11.

${ }^{1022}$ Comenta que «no sólo porque tienen posición de garante respecto del mismo, sino por querer impedir un curso causal salvador del personal médico con el cual la vida e integridad del menor está garantizada o en mucho menor peligro», ID., ibidem, op. cit., pp. 8 y 12 . 
imputación objetiva, asimiló la falta de consentimiento con la agravación del peligro y la muerte del menor.

Como ya comentamos, nos mostramos partidarios de la doctrina del Tribunal Federal Alemán de 19 de octubre de 1971, por la que los familiares no tienen obligación de convencer en aceptar la transfusión a los mayores de edad en estado consciente, y en nuestra opinión a menores de edad con suficiente madurez, porque ello vulneraría el derecho a la libertad de conciencia. Comenta PÉREZ DEL VALLE sobre el caso alemán que «el recurrente no puede ser reprochado por lo que ha omitido: persuadir a su mujer para que abandonase su convicción coincidente con la propia ${ }^{1023}$, es decir, «(e)l recurrente tampoco tenía el deber de colocar su decisión en el lugar de la de su mujer. Ello entraría en cuestión, si ella no pudiese decidir en absoluto por sí misma» ${ }^{1024}$. En armonía a lo dicho por el Tribunal Federal estima que «la aplicación de este principio en el caso llevaría a que el Tribunal Superior y la Audiencia han negado la eficacia irradiante del 4.1 de la Ley Fundamental en la interpretación y aplicación del 330c StGB » ${ }^{1025}$. Y añade finalmente que «(e)l recurrente tampoco tenía el deber de colocar su decisión en el lugar de la de su mujer. Ello entraría en cuestión, si ella no pudiese decidir en absoluto por sí misma» ${ }^{1026}$. Si bien estamos de acuerdo con la conclusión absolutoria de PÉREZ DEL VALLE, no compartimos la argumentación aducida, porque el motivo de conciencia es ajeno cuando existe suficiente capacidad del mayor de edad o en su caso, madurez del menor de edad. No es una cuestión del efecto normativo de la libertad de conciencia, estrictamente hablando, sino del derecho a la autopuesta en peligro por el motivo que sea.

El Tribunal Federal alemán ${ }^{1027}$ consideró que la conducta del marido es típica, por lo que reconocía que existió al menos la necesidad de auxiliar desde una posición de garante ex ante. En

1023 PÉREZ DEL VAlle, C., Conciencia, op. cit., p. 225.

1024 ID., ibidem, op. cit., p. 226.

1025 ID., ibidem, op. cit., p. 226. Ampliamente JERICÓ OJER, L., El conflicto de conciencia, op. cit., pp. 542 y ss.

1026 PÉREZ DEL VAlle, C., Conciencia, op. cit., p. 226.

1027 Sentencia del Tribunal Federal alemán de 19 de octubre de 1971. El caso en cuestión versa sobre los siguientes extremos: Una mujer miembro de la Hermandad Evangélica muere por no practicarse una transfusión de sangre tras un parto en casa, transfusión y traslado al hospital que el médico recomendó, pero el marido, de la misma Hermandad ni influyó en la decisión de la mujer ni accedió a trasladarla. El Tribunal de Instancia condenó al marido por homicidio imprudente, pero más tarde y en apelación, la Audiencia le absolvió por entender que no se demostraba que la muerte fuera a consecuencia de no haberse ingresado a la mujer, y porque entendió que no se podía demostrar que el marido había omitido el deber de socorro que exige el art. 330 del StGB (hoy 323c). En el recurso de revisión el Tribunal Superior entendió que este artículo era aplicable pues parece que el marido estaría obligado a convencer a la mujer para que consintiera su ingreso, sin que se oponga ello al 2.2 y 4.2 de la Ley Fundamental. Y así nuevamente la Audiencia volvió a sentenciar, condenando al marido finalmente por omisión del deber de socorro del art. 330 del StGB y no como se sentenció en un principio, por homicidio imprudente.

Finalmente el Tribunal Federal alemán entendió que la libertad religiosa no sólo se garantiza y se protege para las confesiones reconocidas sino también para la suya (Hermandad Evangélica) y que la libertad de creencias no es sólo la tolerancia religiosa o de convicciones no religiosas, pues ella también abarca la libertad interna moral y actuar conforme a ella, como se concreta en la manifestación de las creencias y en lo que significa profesarlas. 
nuestra opinión, al no existir peligro de muerte, o por lo menos no era predecible desde una posición ex ante, la libertad de conciencia, o el motivo que fuere, no se encuentra con ningún límite, como ya hemos apuntado con el comentario del Auto del TC núm. 396/1984, de 20 de junio, pues ni el orden público, la moral pública, ni la salud pública se ponen en juego, ni se contradice el mandato jurídico que preceptúa intervenir en caso de peligro inminente de muerte de un tercero. El marido no tenía obligación de persuadir a su mujer para que consienta, ni tenía obligación de consentir por ella. Sólo existirá obligación del marido de consentir el tratamiento médico en el caso de que su mujer, estando en tal peligro manifiesto y grave de muerte, tuviera mermada la capacidad de decisión o fuere incapaz, o estuviere inconsciente, porque en tales casos la falta de consentimiento, sin concurrir una competencia sobre el resultado de muerte de la mujer, acarrearía la omisión del deber de socorro, y esto es porque la competencia de los servicios sanitarios se refiere al resultado unas veces, y otras como injerencia al tipo de omisión agravada.

En el caso que un marido que no llamase a las asistencias ni trasladase a su mujer, porque ésta rechaza el tratamiento médico vital, opino -al igual que PÉREZ DEL VALLE- que «tampoco existe posición de garante, aunque subsista un deber de socorrer en función de las posibilidades concretas. En general, se debe reducir al intento de conseguir, por una vía adecuada a la dignidad de la persona, el consentimiento para el tratamiento. Pero la omisión de este deber está justificada porque prevalece el deber de omitir toda intervención en las convicciones de la mujer» $^{1028}$.

Un caso parecido se debatió en la Sentencia del Tribunal Superior de Stuttgart, de 6 de junio de 1964, en el caso de un matrimonio en el que ambos miembros pertenecían a la Hermandad Evangélica, desaconsejando el marido someterse a una trasfusión de sangre a la mujer, que tras el rechazo murió. La Sentencia argumentó que el marido estaba obligado a convencer a su mujer y por lo tanto su omisión constituía un delito de omisión del deber de socorro. La Sentencia del Tribunal Constitucional Federal 32, 98, admitió el efecto irradiante del art. 4.1 de la Ley Fundamental puesto que no se podía reprochar omitir una acción de convencer contrario a sus

\footnotetext{
Aunque bien es cierto que la libertad de creencia no se garantiza ilimitadamente. Según el Tribunal Federal, el marido se ve en una situación imperiosa en la que el ordenamiento jurídico contradice un mandato de fe, al que el sujeto atribuye una mayor valoración, y es por ello que su conducta es típica, pero si fuere impuesta la pena, no cumpliría la proporción legal, es decir, la resocialización, la retribución o la prevención. El Tribunal Federal entendió que el marido no tenía obligación de convencer a su mujer, pues ese acto vulnera íntegramente la libertad de conciencia. La problemática, como ya veremos, será determinar si existe obligación de convencer a un menor de edad.

${ }^{1028}$ PÉReZ Del VAlle, C., Conciencia, op. cit., p. 315.
} 
creencias $^{1029}$. Según nuestra opinión, el argumento es claramente erróneo, no existe ni el deber de convencer ante un tercero que libremente rechaza el tratamiento ${ }^{1030}$ ni puede equipararse el consejo a su mujer como acción de inducción porque el consejo no fue relevante en la formación de la decisión de la mujer, es más, no es punible la inducción a una autopuesta en peligro si no existe posición de garante, por lo que no hay desamparo alguno ${ }^{1031}$. Así, estamos de acuerdo con los autores que defienden que este tipo de casos es una evidente desgracia o infortunio de una autopuesta en peligro.

La solución práctica que se ha esgrimido para solventar estos casos de antemano es que los miembros de estas doctrinas religiosas realicen voluntariamente extracciones de sangre como reserva antes de que surja el problema, para llegado el momento su propia sangre sea la utilizada en la transfusión. Así se evitaría que estos sujetos se «alimenten» con sangre distinta a la suya, que es la cuestión por la que la rechazan, de tal modo que el conflicto de conciencia no llegue a nacer ${ }^{1032}$. Esta solución, evidentemente, hay que ponerla en reserva según lo referido supra.

\section{III.- Conflicto de conciencia y delito electoral}

\section{A. Introducción}

El conflicto de conciencia también se ha esgrimido en el ámbito de la participación en las mesas electorales y concretamente en el delito electoral realizado en muchas ocasiones por miembros pertenecientes al grupo religioso Testigos de Jehová. Precisamente por ser uno de los delitos en los que más se ha incurrido en los últimos años por miembros de sectas, y precisamente por la abundante jurisprudencia que ha podido pronunciarse, hace de éste ilícito y de éste grupo religioso digno de estudio por las controversias que se han generado en las últimas décadas.

\section{B. Bien jurídico protegido y elementos del tipo}

El art. 143 de la Ley Orgánica 5/1985, de 19 de junio, del Régimen Electoral General incrimina a «los que dejen de concurrir o desempeñar sus funciones, las abandonen sin causa

\footnotetext{
1029 TOMÁs-VAliEnTE LANUZA, C., La disponibilidad de la propia vida en el Derecho penal, op. cit., pp. 361 y Ss.

${ }^{1030}$ BURSKI, U. von, Die Zeugen Jehovas, op. cit., p. 141; el reconocimiento del derecho de libertad de conciencia en este caso supondría un derecho para decidir sobre la vida de un tercero, cuestión que niega PETERS, K., «Anmerkung zum BverfG, Beschluss v. 11.4.1972», JZ, 1972, pp. 515 y ss. (vid. JERICÓ OJER, L., El conflicto de conciencia, op. cit., pp. 544 y 545). También a favor de la justificación Roxin, C., PG, I, op. cit., pp. 948 y ss; a favor de una causa de exclusión de la culpabilidad si bien la conducta es antijurídica por el deber de velar por los hijos JAKOBS, G., PG, op. cit., 20/25, nota 41.

1031 JERICÓ OJER, L., El conflicto de conciencia, op. cit., p. 547.

1032 Romeo Casabona, C.Mª., El Derecho y la Bioética, op. cit., p. 448.
} 
legítima o incumplan sin causa justificada las obligaciones de excusa o aviso previo que les impone esta Ley, incurrirán en la pena de arresto mayor y multa de 30.000 a 300.000 pesetas». La conducta que se sanciona es la omisión de la acción de concurrir o desempeñar las funciones propias del cargo. Tanto así, el tipo de configura como un tipo omisivo especial propio sobre dos conductas alternativas que se establece por la disyunción «0». Entonces, la omisión incurrirá en el tipo cuando no se concurra a la Mesa Electoral, o acudiéndose a ésta, no se desempeñe la función propia del cargo designado. El tipo también establece, o recuerda, la posibilidad de justificar la tipicidad, pero también restringe las mismas causas de justificación a una condición previa: a la efectiva comunicación del aviso previo o excusa. Esto en nuestra opinión, plantea problemas generales y graves con las causas de justificación del art. 20 del CP.

En primer lugar, el art. 143 se configura también en un tipo de peligro concreto, pues penaliza una conducta sin la necesidad de que efectivamente se vulnere el bien jurídico protegido. En virtud de esto, es de especial importancia concretar el bien jurídico protegido, para ya no sólo determinar la naturaleza del tipo, sino también para resolver los posibles problemas consumativos y de iter criminis que se puedan plantear. La problemática en este ilícito se plantea en torno a la aplicación de algún tipo de atenuante, o inclusive el mismo error de prohibición vencible o invencible del art. 14 del CP, en virtud de la imposibilidad de conocer en mayor o menor medida la norma a la que se estaba obligado, o aun conociéndola, si existe la posibilidad de atenuar su pena por imposibilidad de obrar de otra manera. La jurisprudencia española ha sido tajante al respecto y no ha dejado la más mínima oportunidad de apreciar tales instituciones penales en conductas penales nacidas de la convicción o en la conciencia.

Estos casos se inician con la comunicación al sujeto de la obligación de asistir como Presidente, miembro o suplente de una mesa electoral. En la mayoría de casos vistos, el obligado comunica a la Junta Electoral, mediante escrito, su decisión de no comparecer por tratarse de una actividad que entra en conflicto con sus convicciones morales, que es denegada por la Junta al tratarse de una razón injustificada. En tal medida confluyen en estos casos dos aspectos a proteger, a saber: la libertad de conciencia o libertad de creencias y su efectiva materialización en la vida social, y la salvaguarda de la «neutralidad política en los procesos de formación democráticos». Veamos a continuación las diversas sentencias que versan sobre esta problemática.

La Sentencia del Tribunal Supremo, Sala Segunda de lo Penal, de 14 diciembre de 1994, confirmó la Sentencia condenatoria de la Audiencia Provincial de Barcelona, Sección 6a , de 27 enero de 1994. El caso versa sobre la negativa de un Testigo de Jehová a formar parte de una 
mesa electoral como suplente, y a quien se le deniega por la Junta la justificación de incomparecencia por el conflicto moral al pertenecer a tal grupo religioso. El motivo segundo del recurso, de preferente atención conforme al art. 901 bis a) LECrim., se formula con invocación del art. 851.1.1 LECrim. por decir que la sentencia no expresa clara y terminantemente cuáles son los hechos que se consideran probados.

El primer motivo señalaba que se vulneraban los preceptos penales de carácter sustantivo, y con cita del art. 5.4 LOPJ se consideraba infringido el principio constitucional de presunción de inocencia del art. 24. Afirma el TS que «(c)arece de sentido esta última invocación ante la prueba documental y de otra índole acumulada en la causa acerca de la realidad de cuanto se recoge en el presupuesto fáctico de la sentencia, hecho por demás reconocido por el inculpado» ${ }^{1033}$. Entonces, más allá de los problemas probatorios, que en este caso no aparecen, la denegación escrita por la Junta Electoral y el conocimiento y voluntad del sujeto activo de realizar los elementos objetivos del tipo del art. 143 de la LORGE, al haberse pedido la dispensa, hacen imposible apreciar un error de prohibición con base a un estado de necesidad. Bien es cierto que en la quastio facti no se desprende la más mínima necesidad imperiosa del sujeto activo, sino que la quaestio iuris únicamente versa sobre cuestión probatoria, que suficientemente queda acreditada.

El bien jurídico protegido -según la STS, de 14 diciembre de $1994^{1034}$ - es constituido por la «pureza del sistema democrático en formación» o la propia «neutralidad política en la formación democrática». La pertenencia a una mesa electoral no supone en sí misma una posición política, que es precisamente lo que rechazan los Testigos de Jehová, esto bien se protege con el propio Derecho al voto en su vertiente negativa, no existe obligación al voto. Las exigencias morales impuestas por los dirigentes de los Testigos de Jehová, y por la propia palabra de Yahvé, no se contradice con la participación neutral de control de unas elecciones políticas, en las que únicamente se supervisa el buen funcionamiento de la formación

${ }^{1033}$ FJ $^{\circ}{ }^{\circ}$ STS, de 14 diciembre de 1994.

${ }^{1034}$ El FJ $3^{\circ}$ STS, de 14 diciembre de 1994, muestra no sólo la justificación y necesidad de proteger al bien jurídico protegido, sino que también justifica la necesidad punitiva. De su razonamiento se vislumbra también cuál es el bien jurídico protegido: «Para la adecuada vigilancia del proceso electoral la Ley ha construido un sistema (...) se configuran Mesas Electorales con un Presidente y 2 Vocales (y sus respectivos suplentes), en quienes recae la muy importante función de velar por la pureza del sistema mismo. Como dice la Sentencia de 18 de octubre de 1994, para que una sociedad democrática funcione es absolutamente imprescindible que las personas que la formen coadyuven a su propio desenvolvimiento y desarrollo y, para evitar su parálisis, es la propia sociedad la que, con toda legitimidad, establece un sistema de sanciones para los incumplidores». Sigue diciendo el TS en el FJ $4^{\circ}$ que «(l)a incorporación a una Mesa Electoral no solamente no atenta contra la neutralidad política que se invoca sino que, en cierto modo, coadyuva a la evitación de interferencias partidistas en el desarrollo de los comicios». 
democrática $^{1035}$. Precisamente la pertenencia de los sujetos a las normas de un país hace comulgar con el ordenamiento jurídico de éste pero no con los principios básicos, pues el bien jurídico protegido no es sí la misma democracia sino la neutralidad política. Bien es cierto que la neutralidad política sirve de base a la formación de la democracia a través del proceso electoral, pero la razón sancionadora no parte de negativa política, sino de la negativa de neutralidad política. Si la conciencia de los Testigos de Jehová impide participar en procesos políticos precisamente por su neutralidad política, es ilógica una negativa a esa participación cuando lo que se trata de proteger es esa misma neutralidad política.

El artículo 8.1 de la LOREG preceptúa claramente cuál es el fin de protección de ésta Ley ${ }^{1036}$. La participación en una mesa electoral es un «deber cívico, de carácter general y exigible», que nace de la propia configuración de nuestra Nación, es decir, como «Estado social y democrático de Derecho» (art. 1.1 CE), y esto porque «la soberanía reside en el pueblo español, del que emanan los poderes del Estado» (art. 1.2 CE). Y en esa justificación constitucional versan también los artículos 1.2, 6, 23.1 y 66.1 de nuestra Constitución.

Esas condiciones constitucionales, como afirma la STS de 23 diciembre de 1992, justifican el afán del legislador de convertir en delictivo «el injustificado incumplimiento de tal obligación, por lo que no puede ser suficiente la mera excusa de pertenencia a un credo religioso determinado y a la personal decisión de objeción de conciencia a la actividad electoral». No existe conflicto de bienes jurídicos, ni posibilidad de que la declaración de objeción de conciencia al servicio militar preceptuado en el art. 30.2 CE, pueda servir como base general de excepción a todas las actuaciones basadas en conciencia. En realidad, nos encontramos ante casos típicos de autoría por convicción o de conciencia, que en nuestra opinión plantean más dudas sobre la punibilidad, o necesidad de la pena, que en cuanto a la teoría del delito.

${ }^{1035}$ En tal sentido, el TS en la misma Sentencia dice que «(l)a intervención de los integrantes de una Mesa Electoral es de una absoluta imparcialidad, sin implicación alguna de deber de voto, encaminada al control y debida vigilancia y comprobación de que la votación discurre conforme a la ley, libre de fraudes e incorrecciones. Difícilmente puede llevarse la actuación de un miembro de ella al terreno de la coacción o imposición interferente o atentatoria a la libertad religiosa», FJ 5 STS, de 14 diciembre de 1994.

${ }^{1036}$ Art. 8.1 de la LOREG: «La Administración Electoral tiene por finalidad garantizar en los términos de la presente Ley la transparencia y objetividad del proceso electoral y del principio de igualdad». Y su artículo 9.5 establece el periodo de la obligación: «El Presidente de la Junta Electoral Central estará exclusivamente dedicado a las funciones propias de la Junta Electoral desde la convocatoria de un proceso electoral hasta la proclamación de electos y, en su caso, hasta la ejecución de las sentencias de los procedimientos contenciosos, incluido el recurso de amparo previsto en el artículo 114.2 de la presente Ley, a los que haya dado lugar el proceso electoral. A estos efectos, el Consejo General del Poder Judicial proveerá las medidas oportunas». 


\section{Jurisprudencia y soluciones doctrinales}

En atención a la posible concurrencia de una causa de justificación por motivos de conciencia, que pueda eximir por la concurrencia de todos los elementos esenciales y no esenciales, o atenuar la pena por la falta de uno de los requisitos no esenciales de ésta, puede anticiparse que no aparecen sentencias en la jurisdicción española al respecto.

En algún procedimiento, sin éxito ${ }^{1037}$, se ha alegado el ejercicio legítimo de un derecho amparado por el art. 9 CEDH y el art. 18.2 del PIDCP. También se ha alegado el estado de necesidad en estos casos, sin embargo la jurisprudencia la ha rechazado porque haría ineficaz el proceso electoral y no afecta a la neutralidad política del sujeto ${ }^{1038}$.

Sin embargo, para RuIz Miguel ${ }^{1039}$ bastaría la simple acreditación de la pertenencia a la determinada confesión religiosa para aplicar el art. 27.2 LOREG $^{1040}$ (ahora en el art. 27.3) como «causa justificada y documentada» y amparada por el art. $16 \mathrm{CE}$.

La Audiencia Provincial de Barcelona, Sección 9a, en Sentencia de 19 de abril de 1993, apreció la concurrencia de un error de prohibición invencible sobre una causa de justificación de estado de necesidad putativo. Aunque la Audiencia Provincial consideró que no era posible un conflicto entre los bienes jurídicos en controversia, a saber, neutralidad política en la formación democrática y la libertad de conciencia, considera -erróneamente- la ausencia de dolo por la imposibilidad por parte del sujeto activo de conocer la fuerza de la obligación normativa, es decir, creyendo actuar bajo un estado de necesidad que no reúne los elementos objetivos por tratarse una causa de justificación inexistente en nuestro ordenamiento jurídico (en concreto, el llamado estado de necesidad putativo). De sus palabras se extrae que esta imposibilidad o apreciación iuris errónea nace del propio conflicto moral del sujeto activo del delito ${ }^{1041}$. En

${ }^{1037}$ STS, de 23 de diciembre de 1992, y SAP de Barcelona, de 19 de enero de 1994.

1038 STS, de 6 de diciembre de 1997.

1039 RUIZ MiguEL, A, «La objeción de conciencia», op. cit., p. 114.

1040 Art. 27.2 derogado LOREG: «En los tres días posteriores a la designación, ésta debe ser notificada a los interesados, que disponen de un plazo de siete días para alegar ante la Junta Electoral de Zona causa justificada y documentada que les impida la aceptación del cargo. La Junta resuelve sin ulterior recurso en el plazo de cinco días y comunica, en su caso, la sustitución producida al primer suplente. En todo caso, se considera causa justificada el concurrir la condición de inelegible de acuerdo con lo dispuesto en esta Ley». Derogado por la Ley Orgánica 8/1991, de 13 de marzo e introducido en el art. 27.3 LOREG: «Los designados Presidente y Vocal de las Mesas electorales disponen de un plazo de siete días para alegar ante la Junta Electoral de Zona causa justificada y documentada que les impida la aceptación del cargo. La Junta resuelve sin ulterior recurso en el plazo de cinco días y comunica, en su caso, la sustitución producida al primer suplente. La Junta deberá motivar sucintamente las causas de denegación de las excusas alegadas por los electores para no formar parte de las Mesas. En todo caso, se considera causa justificada el concurrir la condición de inelegible de acuerdo con lo dispuesto en esta Ley. Las competencias de las Juntas Electorales de Zona se entenderán sin perjuicio de la potestad de unificación de criterios de la Junta Electoral Central».

${ }^{1041}$ La referida sentencia fundamenta su decisión en que aunque «los móviles religiosos no son por sí solos suficientes para eliminar el dolo, es de observar que la acusada no tuvo pleno conocimiento de su significación antijurídica, por creer erróneamente que concurrían en su acción los presupuestos de una causa de justificación, no 
nuestra opinión, la Sentencia comete un error fundamental, que es subjetivar excesivamente al llamado error de prohibición. Téngase en cuenta que la institución penal del ahora art. 14.3 CP exonera totalmente en caso de error invencible, o atenúa en caso de error vencible. La vencibilidad e invencibilidad son categorías normativas que se sustentan en una mínima objetividad. En este caso y como bien resolverá el TS en casación, lo relevante es el conocimiento que tiene el sujeto activo como ente responsable, tiene o tuvo oportunidad de acceso al conocimiento de la norma, y como se relata en la quaestio facti, se le desestimó la justificación de incomparecencia a la Mesa mediante escrito por la Junta Electoral, por lo que conocía la obligación comparecencia, y conocía que su pretensión moral no era justificación para tal conducta. No obstante, el sujeto activo prefirió desatender la norma, alegando un estado de necesidad inexistente en nuestro Derecho, precisamente por la falta de conflicto entre bienes jurídicos.

La moral o convicciones morales no afectan en sí mismas al intelecto, ni mucho menos al acceso u oportunidad de conocimiento de la obligación normativa. Toda condición social pueden ayudar en mayor o menor medida a la formación intelectual, social y cultural de sujeto, pero no cabe por ello determinar que la libre decisión moral afecte por sí al intelecto, pues si fuere así se debería reconducir la problemática a la categoría penal de la inimputabilidad, y sólo como caso aislado, mientras que apreciar una imposibilidad de acceso al conocimiento de la norma por la presencia de una motivación moral, sería caer en un absurdo que iría en contra de la propia naturaleza de las leyes. El sujeto en este caso evidencia una normalidad cognitiva y volitiva, que no es mermada por su libre motivación moral. Por lo que en tanto no es afectada, ni aun siquiera probada, no cabe apreciar el referente error de prohibición invencible, ya que esta institución jurídica parte y debe partir de una mínima objetividad en los seres humanos y de las cualidades que permiten a éste desenvolverse en un ordenamiento jurídico. Todo lo demás debe apreciarse como culpabilidad, o por otras razones semi-imputabilidad o inimputabilidad, dejando el error de prohibición vencible o invencible para los casos en los que el sujeto activo con capacidad natural yerre por acción de las leyes naturales y humanas. En tanto que no se puede vivir o actuar en contra de la naturaleza, la lógica, las matemáticas y otras leyes, la concurrencia de ellas en la conducta del sujeto pueden ser causa de una imposibilidad de acceso al conocimiento de la obligación normativa, que, ahora sí, haría apreciar un error de prohibición.

prevista realmente en el ordenamiento jurídico; se da, pues, un error de prohibición, de carácter invencible, pues el sujeto activo se creía amparado por un estado de necesidad putativo, al ser el conflicto de bienes sólo aparente». 
En otras ocasiones se ha alegado la exclusión de la culpabilidad por falta de dolo o de la conciencia de la antijuricidad siguiendo así la vieja doctrina causalísta que ubicaba el dolo en la culpabilidad, que respaldó en su día la STS de 30 de enero de 1979. Esta sentencia fue seriamente criticada por TAMARIT SUMALLA ${ }^{1042}$, porque el autor conoce no sólo la antijuricidad formal en relación a que el abandono está prohibido, sino que también causa un anómalo funcionamiento del proceso electoral, si bien de lege ferenda propone introducir en el tipo que se afecte gravemente o peligre el proceso y la sustitución de las penas por privativas de derechos ${ }^{1043}$. Sin embargo, años después la STS de 15 octubre 1993 declara haber lugar al recurso de casación interpuesto por el Ministerio Fiscal contra la sentencia absolutoria de instancia que apreció el error de prohibición ${ }^{1044}$. Los hechos que acaecieron el día de autos son semejantes a los casos ya citados, es decir, desestimación por la Junta Electora del motivo de conciencia alegado por pertenencia al citado grupo religioso, e incomparecencia a la constitución de la Mesa Electoral. El TS, en armonía a su línea jurisprudencial seguida en estos casos, argumenta la estimación del recurso, y por tanto la culpabilidad del sujeto activo con base al previo conocimiento de éste de la obligación normativa, y en la falta de conflicto jurídico entre el bien jurídico protegido que protege el art. 143 de la LOREG, la neutralidad política, y el de libertad de conciencia del art. $16 \mathrm{CE}$, pues el último no se ve afectado precisamente por la naturaleza del primero ${ }^{1045}$.

Al respecto, el TS explica suficientemente que el sujeto activo no sólo tiene conocimiento o conciencia de los elementos objetivos del tipo, sino que tiene además conocimiento de que su obrar es antijurídico, y tiene voluntad de materializar el tipo, es decir, existe no sólo un dolo natural que se integra en la categoría del delito de la tipicidad, sino que existe también dolus malus. En tanto así, cabe precisar que el dolus malus no pertenece a la tipicidad, sino a la culpabilidad, pues de lo contrario, el desconocimiento de la antijuricidad y la falta de voluntad de materializar tal conocimiento, harían atípica su conducta, cuando en realidad se denotaría una falta de culpabilidad por la falta de imputación subjetiva.

Las referidas son constantes que se van a repetir a lo largo de las sentencias que se han pronunciado sobre este ilícito. La problemática versará en nuestra opinión, y como

1042 TAMARIT SUMALLA, JMa., La libertad ideológica, op. cit., pp. 382 y ss. y p. 416.

${ }^{1043}$ ID., ibidem, op. cit., pp. 382 y ss.; ID., «Libertad de conciencia y responsabilidad penal», op. cit., pp. 399.

${ }^{1044}$ La STS, de 15 de octubre de 1993, señala que «la presentación de la excusa ante la Junta Electoral de Zona haciendo constar su voluntad de no intervenir, al tiempo de que explicaba sus razones o motivaciones, permiten apreciar la ausencia de dolo, en cuanto que la omisión del acusado no pone de relieve, de forma clara y terminante, la antijuridicidad material que daría lugar a la reprochabilidad penal (...) La falta de intencionalidad del acusado excluye el dolo genérico preciso para la existencia de cualquier forma delictiva».

${ }^{1045}$ Las ya señaladas SSTS, de 15 de octubre de $1993 \mathrm{FJ} 2^{\circ}$, y de 14 diciembre de 1994, FJ $7^{\circ}$. 
posteriormente plantearemos, sobre la necesidad punitiva de estas conductas en referencia al bien jurídico que se trata de proteger.

Dentro de las sentencias condenatorias merecen especial atención aquellas en las que la conducta típica plantea problemas de culpabilidad por la especial problemática sobre la conciencia o potencial conciencia de la antijuricidad penal, es decir, el desconocimiento por parte del sujeto activo de que su incumplimiento acarrea una sanción, o conociendo que existe sanción, se desconoce que ésta es una sanción penal.

En primer lugar, la STS de 17 abril de 1995, rec. 2696-1994, confirma la Sentencia de la Audiencia Provincial de Barcelona de 8 de marzo de 1994. La diferencia con la precedente sentencia estriba en la aplicación indebida del art. 143 de la citada Ley, por la concurrencia de un error de prohibición que según el recurso de casación planteado eliminaría el dolo. Como en el anterior caso, el Testigo de Jehová comunicó su negativa a personarse en la Mesa Electoral como así se le designó y como así fue obligado en virtud del sorteo efectuado, excusándose bajo un imperativo de conciencia por la pertenencia al grupo religioso, cuestión que fue rechazada por injustificada, y advirtiéndosele que su incomparecencia podría constituir la perpetración de un ilícito penal. Como lógicamente resuelve el TS, esa misma comunicación rechazando el motivo de su incomparecencia, hace imposible la apreciación de un error de prohibición basado en el desconocimiento de una norma imperativa y de que su quebrantamiento acarrea sanción penal $^{1046}$.

En armonía a lo afirmado por la anterior Sentencia, se concluye que no existe en estos casos un verdadero caso de conflicto entre dos bienes jurídicos a proteger. La libertad de conciencia o de creencias no están en controversia con el neutralidad política que se protege con la norma del $143^{1047}$.

En otras ocasiones, el motivo alegado del error de prohibición se intenta sustentar por el desconocimiento del sujeto activo de que el incumplimiento normativo lleva aparejada una sanción penal. Sobre este aspecto nos interesa si el desconocimiento de la antijuricidad penal es causa suficiente para la aplicación de un error de prohibición. La doctrina mayoritaria y la

${ }^{1046}$ Señala el TS que «(s)i existía algún error de valoración sobre la antijuridicidad de su conducta, la contestación recibida de la Junta Electoral de Zona despejaba sus dudas y la expresaba con claridad, fácilmente comprensible, que la inasistencia constituía un delito», FJ Único, punto segundo, de la STS, de 17 abril de 1995, rec. 2696-1994.

${ }^{1047}$ FJ Único, punto segundo, de la STS, de 17 abril de 1995, rec. 2696-1994: «la participación en una mesa electoral no constituye en sí misma una actividad política que puede entrar en colisión con dichas creencias ya que es sabido que los miembros que la componen, no sólo por conciencia sino por imperativo legal, como ya se ha dicho, deben actuar con total imparcialidad y neutralidad sin implicarse ni directa ni indirectamente en la contienda política». 
jurisprudencia de nuestro país no admite tal razonamiento jurídico, aunque algunos -como PLANCHAT TERUEL ${ }^{1048}$ - apelan a un error de prohibición sobre la existencia misma de una causa de justificación pero de forma vencible. La culpabilidad o imputación subjetiva se basa en el conocimiento (o potencial conocimiento) y voluntad del sujeto activo de la conducta típica y antijurídica. Es decir, la culpabilidad no va aparejada al concreto conocimiento del tipo de sanción normativa ${ }^{1049}$ ante un incumplimiento, pues es suficiente que el sujeto conozca y actúe en armonía a tal conocimiento de que su conducta es contraria al ordenamiento jurídico, o que no existe causa de justificación.

Debemos destacar que el TS utiliza además de otros criterios que mencionaremos, el elemento del conocimiento profano para imputar ya un conocimiento al menos potencial de la obligación normativa, inexcusable en nuestra opinión, cuando el error cognitivo se produce por un previo error volitivo o por desinterés en el conocimiento de la norma ${ }^{1050}$. En otros casos, el recurso se sostiene no sólo por la vulneración del art. 16 de la CE, sino amparándose también en normas comunitarias como el CEDH, que en su art. 9 protege la libertad de conciencia, o su homólogo en el PIDCP en su art. 18. La pretensión del recurso se amparó en un error iuris por haber sido declarado el sujeto exento al servicio militar por objeción de conciencia en virtud del art. 30.2 de la $\mathrm{CE}^{1051}$.

Otra Sentencia de digna alusión es la STS de 8 junio de 1994, en la que al igual que las anteriores se alega un error de prohibición, con base al desconocimiento del carácter obligatorio de permanencia en la Mesa Electoral. La acusada se ausentó de la Mesa Electoral una vez que ya había sido constituida con ella presente, pero a sabiendas de que el motivo alegado, el motivo de

\footnotetext{
1048 PlANChAT TERUEL, José María, «Un conflicto entre conciencia y ley: a propósito de la incomparecencia a mesa electoral por motivos religiosos», CDJ, 1995, XVII, Vinculación del Juez a la ley, 1995, pp. 270 y ss.

${ }^{1049}$ En concreto la STS, de 27 diciembre de 1994 dice al respecto que «el alcance de tal conciencia o conocimiento de estar obrando ilícitamente no exige el exacto saber del contenido concreto del tipo infringido». Dice acertadamente el TS que « $(l)$ a conciencia de antijuridicidad como elemento del delito no requiere el conocimiento concreto de la norma penal que castiga el comportamiento de que se trate, ni tampoco el conocimiento de que genéricamente el hecho está castigado como delito. Para incurrir en responsabilidad penal no hace falta conocer ni siquiera que hay un CP que castiga determinadas conductas. Basta con saber, a nivel profano, que las normas que regulan la convivencia social (el Derecho) prohíben ese comportamiento que él realiza», FJ $3^{\circ}$ STS, de 28 de octubre de 1998 rec. 966-1998.

${ }^{1050}$ FJ $6^{\circ}$ STS, de 30 de marzo de 1993, al respecto los requisitos del dolus malus como elemento de la culpabilidad.

${ }^{1051}$ En concreto la STS, de 23 diciembre de 1992, comenta resumidamente a la par de otros pronunciamientos relativos a los límites de la objeción de conciencia que «está limitada en nuestro Derecho al no cumplimiento del servicio militar y no puede equipararse nunca a ella la pretendida de formar parte de una Mesa electoral que permite, por otra parte, la más completa neutralidad política, ya que el voto no es obligatorio y circunscrito a una actividad de mero control de la ajena votación». En este sentido se pronuncia la STS, de 27 de diciembre de 1994 cuando señala que «no reconociéndose en nuestro Texto Fundamental una expresa objeción de conciencia electoral, no puede admitirse que la mera excusa del obligado le legitime para dejar de cumplir el deber impuesto en el art. 27 de la LO 5/85 citado, pues con ello se vaciaría de contenido tal deber y se dejaría al libre arbitrio del ciudadano a quien tal deber incumbe el funcionamiento del sistema».
} 
conciencia por pertenencia al grupo religioso Testigos de Jehová, le fue rechazado por la Junta electoral. En éste caso se aplica la segunda de las conductas típicas alternativas sancionadas, en concreto el abandono de las funciones propias en la Mesa. Bien es cierto que el sujeto activo conocía su obligación de asistir a las mismas, y así lo cumplió, pero es posible que desconociera la obligación de permanecer realizando esas funciones. No obstante, no parece que tal desconocimiento pueda imputarse a un conflicto de conciencia como estado de necesidad. El motivo de conciencia por el que se incurre en un tipo penal parte del propio conocimiento o al menos potencialidad de conocimiento de la obligación, y de su antijuricidad en caso de incumplimiento, es decir, al menos existe un error por indiferencia al Derecho.

De tal suerte, bien distinto es el error de prohibición por desconocimiento imputable al sujeto, es decir, lo que denominamos «creencia discrepante» o «o creencia de enemistad al derecho», que producen en el sujeto un error en la voluntad para conocer la norma, y otra cosa es el error de prohibición por creencia de una norma de mayor fuerza de aplicación. En nuestra opinión, es precisamente el motivo moral, el causante de la despreocupación por conocer la norma. Existe entonces, una diferencia fundamental entre esa despreocupación, y el error de prohibición vencible.

Un caso de especial interés es aquel en el que se alega la imposibilidad física de permanecer en la Mesa Electoral por causa de conciencia. La Sentencia del TS desestima el recurso de casación por falta de prueba, «pues no se ha acreditado ni siquiera intentar demostrar que la permanencia podría producirle unas desfavorables consecuencias físicas o psíquicas, pero además tampoco es válida como excusa con virtualidad suficiente para excluir la punibilidad el alegar motivos de conciencia» ${ }^{1052}$, respecto de lo que -en opinión de CASTRO JOVER ${ }^{1053}$ - llama la atención el hecho de que se pida una prueba de dicha afección, y otras de la pertenencia a una confesión cuando en la objeción de conciencia al servicio militar bastaba con la simple alegación, si bien -en nuestra opinión- en el delito electoral no existe alternativa alguna, lo que implica que se deba cumplir la norma sin importar el conflicto por cuanto la obligatoriedad de la norma no afecta a ninguna postura política sino a los propios valores democráticos y de libertad que con toda seguridad respaldaba el objetor.

Por lo expuesto en el recurso de casación, parece que la lesión que se produciría sería una «incomodidad» por la presencia del sujeto durante tales actos. En nuestra opinión, este mal no constituye un mal jurídico digno de protección en nuestro ordenamiento jurídico suficiente para

\footnotetext{
1052 FJ Único de la STS, de 30 de septiembre de 1994.

1053 CASTRO Jover, A., «La libertad de conciencia y la objeción de conciencia individual», op. cit, pp. 165 y ss.
} 
desvirtuar la protección de otro bien jurídico. Pudiera pensarse que la eventual lesión psíquica insuperable, o al menos transitoria en el tiempo, como las enfermedades reconocidas por la ciencia médica (trastorno por estrés post-traumático) podría acreditar no ya un caso de error de prohibición invencible, sino una causa de justificación de estado de necesidad del $20.5^{\circ} \mathrm{CP}$.

La única resolución del TS que absolvió a los imputados por apreciación de un error de prohibición es la Sentencia de 29 de septiembre de 1993, rec. 759-1993. El Tribunal de instancia absolvió a los acusados por un delito electoral por incomparecencia en la Mesa Electoral durante la vigencia de la vigente LORGE de 1985, por la concurrencia de un error de prohibición del art. 6 bis a) del CP de 1973. Apela a la simple creencia firme de los imputados como criterio suficiente para desvirtuar el bien jurídico de «neutralidad política en la formación democrática», en pro del de libertad de conciencia o de creencias ${ }^{1054}$.

Es evidente la errónea técnica jurídica utilizada por el TS en la resolución del recurso. Al parecer la Sala del TS únicamente apreció y valoró los bienes jurídicos en juego en el caso para aceptar la posibilidad de un error. El TS parte de una premisa errónea desde el principio, a saber, que la conciencia puede ser causa del desconocimiento de las leyes pero no aclara precisamente esto. No obstante y como hemos mencionado en estos casos no existe realmente un conflicto entre bienes jurídicos a proteger, pues es evidente que la neutralidad política que se exige por la norma no desvirtúa o lesiona la libertad de conciencia de no participación en asuntos políticos, que ya se protege con la vertiente negativa del derecho al voto, esto es: una conducta alternativa.

Por otro lado, es interesante también apreciar como el TS en innumerables sentencias al respecto resalta ya no sólo la falta de conflicto jurídico entre los bienes dignos de protección, sino la falta de prueba de pertenencia al grupo religioso, y que por tal, se les impida la concurrencia a las Mesas Electorales ${ }^{1055}$. La falta de prueba de pertenencia a un grupo religioso, y la propia prohibición moral que ordena ésta en determinadas conductas se suele repetir a lo largo de una gran mayoría de casos de autoría por convicción o de conciencia. Al menos, la jurisprudencia sobre delitos electorales aprecia esta falta de prueba como criterio previo para desentrañar el thema decidendi, concluyendo finalmente que aun con prueba ello no vulnera ni afecta al bien jurídico de la libertad de conciencia pues ésta no es derecho absoluto.

\footnotetext{
${ }^{1054} \mathrm{Al}$ respecto dice el TS que «bajo esta firme creencia, este derecho fundamental no debía verse desnaturalizado por las normas de legalidad ordinaria ya citadas- (Cfr. sentencias del Tribunal Constitucional de 22 de enero de 1989 y 15 de febrero de 1990, entre otras)», FJ 6º STS, de 29 de septiembre de 1993, rec. 759-1993.

${ }^{1055}$ FJ $2^{\circ}$ STS, de 23 diciembre de 1992, en la que se recuerda al recurrente la exigencia de base probatoria de los siguientes: «1) Que el recurrente sea miembro del grupo religioso denominado Testigos de Jehová. 2) Que los miembros de tal creencia tengan prohibido el participar en los procesos electorales y, en el caso de que así ocurriera, que sus creencias y doctrina las prohíben e impiden la participación como Presidente o Vocal de Mesa, habida cuenta que en nuestra normativa vigente no es preceptivo el voto».
} 
A pesar de la reiterada jurisprudencia en este ámbito penal de los motivos de conciencia, algunos autores -como RUIZ Miguel, BAUCELls i LlAdós, y JERICó ${ }^{1056}$ - defienden que en algunos casos primará la libertad religiosa frente al deber de participar en los procesos electorales por la escasa afección al bien jurídico, mientras que LUZÓN PEÑA lo fundamenta en una ponderación de intereses ${ }^{1057}$.

En nuestra opinión, y a modo de conclusión, las conductas claramente impeditivas del buen funcionamiento del sistema electoral, como la incomparecencia, suponen conductas propias del autor por convicción, porque demuestran una clara manifestación de combate a la vigencia material de la norma y al sistema democrático, merecedoras de la máxima pena, salvo que exista un déficit de socialización atribuido a tercero. De tal manera, que la simple negativa, cuando se permita una conducta alternativa y/o la suplencia por un tercero, en el peor de los casos, correspondería a una conducta del autor de conciencia que podría eximirse, según las circunstancias y a la conexión ineludible entre conciencia y voluntad, a un estado de necesidad exculpante por déficit de comunicación/socialización de la norma. Si bien, según lo visto, al no activarse la norma de deber sorpresivamente puesto que al sujeto le da tiempo a amoldar su comportamiento al deber (alternativa), y al no suponer dicho deber una clara confrontación a la conciencia, difícilmente podrá aplicarse la eximente completa.

\section{IV.- Conflicto de conciencia y participación en el Tribunal del Jurado}

La Ley Orgánica 5/1995, de 22 de mayo, del Tribunal del Jurado regula el ejercicio del derecho del ciudadano a formar parte de un tribunal de justicia como derecho inspirado en la democracia pero, a la vez, como un deber del ciudadano de formar parte de él. En este sentido no son pocos los casos, sino que es muy habitual, que los ciudadanos repelan ser parte del Tribunal por motivos ideológicos o religiosos, si bien no está contemplada en el art. 12 como causa de objeción de conciencia, salvo el apartado 7 que se refiere a «(l)os que aleguen y acrediten suficientemente cualquier otra causa que les dificulte de forma grave el desempeño de la función de jurado». Es por ello que la doctrina se muestra dividida a la hora de concebir que esta causa u otra legitime la exención del deber de participar del Tribunal de Jurado. La doctrina contraria a excusar dicho deber suele referirse a los casos análogos al de la formación de mesas electorales,

\footnotetext{
${ }^{1056}$ RuIZ Miguel, A., «La objeción de conciencia», op. cit., pp. 117; y ss; BAUCELls I LLADÓs, J., La delincuencia por convicción, op. cit., p. 244 y ss; JERICÓ OJER, L., El conflicto de conciencia, op. cit., pp. 593 y ss., en virtud del principio de tolerancia o insignificancia social (menor desvalor) y fungibilidad del bien jurídico, aunque de forma excepcional y en principio para los casos de conflictos de conciencia inexcusable, llevaría el asunto a la sanción administrativa, por lo que de lege ferenda propone la destipificación de estos delitos.

1057 LUZÓN PEÑA, D-M., «Actuación en conciencia», op. cit., p. 10.
} 
y la doctrina a favor de algún tipo de exención de la obligación apela a la meritada causa del art. 12.7 LOTJ $^{1058}$ o al art. $16 \mathrm{CE}^{1059}$. Sin embargo, volvemos al problema de siempre, la necesidad de acreditar que existe dicho conflicto, cuestión que en verdad es ajena a nuestro estudio.

BAUCELLS ${ }^{1060}$ considera que, al igual que los casos de mesas electorales, el incumplimiento se refiere a intereses colectivos pero justificados en relación a las causas tasadas en virtud del principio de ponderación, respeto de la libertad de conciencia y la dignidad, pero previa notificación de la causa. En sentido similar se muestran FLORES MENDOZA y JERICó ${ }^{1061}$, pero discrepan en que estemos ante una verdadera objeción de conciencia porque el incumplimiento no supone una sanción penal sino administrativa de multa que recoge el art. 39.2 LOTJ, si bien la Disposición Adicional 2a LOTJ en relación al art. 41 LOTJ recoge sanciones penales en relación al abandono de funciones, incumplimientos reiterados de deber de juramento o promesa (similarmente a la objeción de conciencia al juramento de cargos políticos) ${ }^{1062}$, y votación en la emisión del veredicto.

En opinión de JERICó, la mayoría de incumplimientos tendrán una sanción administrativa en relación al art. 39.2 LOTJ por cuanto el art. 41.1 LOTJ se refiere sólo a los casos en los que el sujeto se niega a la comparecencia, mientras que el art. 39.2 LOTJ se refiere a la incomparecencia injustificada «de ahí que los supuestos comunes de objeción de conciencia al jurado, que se manifestarán generalmente mediante la incomparecencia, no sean castigados con una sanción de carácter penal, sino administrativo (...) Porque una cosa es que el incumplimiento del deber de formar parte en el jurado por motivos de conciencia se castigue con una sanción administrativa (...) y otra muy diferente que la LOTJ, una vez que el sujeto ha

1058 GONZÁLEZ CuSSAC, José Luis, «Los nuevos delitos contenidos en la Ley Orgánica del Tribunal del Jurado», El nuevo Código penal: presupuestos y fundamentos, Libro Homenaje a Ángel Torío, Estudios de Derecho penal, 1999, p. 751.

${ }^{1059}$ FlORES MENDOZA, F., Objeción de conciencia, op. cit., pp. 473 y ss; MARTÍNEZ-TORRÓN, J., «Ley del jurado y objeción de conciencia», op. cit., pp. 124 y ss. y 137 y ss; NAVARRO VALlS R / MARTínEZ-TORRÓN J., Las objeciones de conciencia en el derecho español y comparado, op. cit., p. 1989; RUIZ MiGUEL, A., «La objeción de conciencia», op. cit., p. 120.

${ }^{1060}$ BAUCELLS I LLADÓS, J., La delincuencia por convicción, op. cit., pp. 240 y ss.

${ }^{1061}$ Flores MendOZA, F., Objeción de conciencia, op. cit., p. 475; JeRICÓ OJER, L., El conflicto de conciencia, op. cit., pp. 604 y 605.

${ }^{1062}$ La STC 101/1983, de 18 de noviembre declaró que «(e)n un Estado democrático que relativiza las creencias y protege la libertad ideológica; que entroniza como uno de sus valores superiores el pluralismo político; que impone el respeto a los representantes elegidos por sufragio universal en cuanto poderes emanados de la voluntad popular, no resulta congruente una interpretación de la obligación de prestar acatamiento a la Constitución que antepone un formalismo rígido a toda otra consideración, porque de ese modo se violenta la propia Constitución de cuyo acatamiento se trata, se olvida el mayor valor de los derechos fundamentales (en concreto los del art. 23) y se hace prevalecer una interpretación de la Constitución excluyente frente a otra integradora». La obligación de juramento como dice SOUTO PAZ «es discutible, por cuanto carece de eficacia jurídica alguna», SOUTO PAZ, JA., Comunidad política y libertad de creencias, op. cit., p. 308. En nuestra opinión, al sujeto en cuestión le basta con someterse a su ejercicio representativo conforme a lo ordenado por la CE y el ordenamiento jurídico, que en el caso contrario sí que vulneraría su deber y demostraría una conducta propia de la autoría por convicción. 
aceptado formar parte del mismo, sancione penalmente otros incumplimientos de deberes propios del cargo» ${ }^{1063}$, por eso rechaza la equiparación que hace BAUCELLS del deber de formar parte del Jurado con el deber a formar parte de la mesa electoral en relación a la dispensa de la objeción de conciencia, si bien no niega que la objeción de conciencia se pueda apelar en incumplimientos que acarreen sanción penal según la Disposición Adicional $2^{\mathrm{a}}$ en relación al art. 41 LOTJ; y además relega la causa de exención del art. 12.7 LOTJ para aquellos casos de meros incumplimientos administrativos derivados de la objeción de conciencia, o por la aplicación del art. $16 \mathrm{CE}$ para casos menos claros en los que haya que realizar una ponderación de intereses, que podría ser también «el carácter fungible del deber de formar parte de un jurado (...) puesto que dicha función también puede ser realizada mediante la concurrencia de cualquier sujeto» ${ }^{1064}$. Con lo que concluye que la diferencia estriba en que LOTJ sí regula unas dispensas que consolidan la objeción de conciencia, no así la Ley Electoral ${ }^{1065}$. En relación al incumplimiento de deberes del art. 41 LOTJ (abandono de funciones, negativa a emitir el voto del veredicto, negativa a prestar juramento o promesa), se decanta por la justificación a través del principio de insignificancia cuando no se afecte al bien jurídico, por ejemplo, en la negativa al juramento o promesa, al no iniciarse el juicio o existir una alternativa como la de llamarse al suplente, con lo que concluye proponiendo de lege ferenda la destipificación penal para dar realidad al principio de intervención mínima, o en su caso, la previsión de una Ley ${ }^{1066}$. De tal manera, lo reconoce que en casos tales como el abandono de funciones, negativa a emitir veredicto y en casos de incumpliendo del deber de secreto, la respuesta penal estaría justificada por la mayor lesividad de la conducta, puesto que una vez que el sujeto ha aceptado a participar «es consciente de que tiene que realizar una serie de conductas que pueden ser cuestionadas por el juicio de conciencia». Así, rechaza cualquier tipo de privilegio de tratamiento penal, si bien acepta la aplicación de un error de prohibición sobre la existencia de la norma penal, y la atenuante analógica con base a ese desconocimiento, o una causa de inexigibilidad de miedo insuperable, aunque cree que sólo sería posible la aplicación de la eximente incompleta, si se incumpliese la aplicación de la atenuación por mero convencimiento en virtud del art. 66.6.1 ${ }^{\circ} \mathrm{CP}$, la pena en su mitad inferior.

\footnotetext{
1063 JERICÓ OJER, L., El conflicto de conciencia, op. cit., p. 606.

1064 ID., ibidem, op. cit., p. 607.

1065 ID., ibidem, op. cit., p. 608.

1066 ID., ibidem, op. cit., pp. 609 y 610.
} 
TAMARIT SUMALLA ${ }^{1067}$ propone la justificación porque no se pone en peligro el bien jurídico como en el abandono de la mesa electoral. Otros autores -como RUIZ MIGUEL ${ }^{1068}$ - siguen este criterio, si bien como decíamos supra, para este penalista bastaría la simple acreditación de la pertenencia a la determinada confesión religiosa ${ }^{1069}$, refiriéndose a supuestos de incumplimiento del deber de participar en mesa electoral, argumento que también ha sido utilizado por MARTÍNEZ-TORRÓN ${ }^{1070}$ en los supuestos del jurado. En cambio, LuZÓN PEÑA lo fundamenta en una ponderación de intereses ${ }^{1071}$. En nuestra opinión, la negativa a formar parte del jurado puede ser atípica en supuestos reglados normativamente, pero en otros casos y según las circunstancias, eximirse cuando la conducta no haya mostrado un perjuicio al funcionamiento del proceso, lo que constata la idea de que la negativa no vulnera la vigencia material de la norma, ni el Sistema, y fundamenta la aplicación del estado de necesidad exculpante por déficit de comunicación/socialización atribuido a la norma.

Estimamos las anteriores consideraciones avalan precisamente que pueda aplicarse la objeción de conciencia más si cabe ante deberes cuyo incumpliendo acarrean una sanción penal, aunque fuere de multa como son los casos. Sin embargo, cabe críticamente concluir entonces que si bien no existe una tipificación penal que sancione gravemente los incumpliendo del deber, no habrá duda que la incomparecencia, el abandono, la negativa a votar, o la vulneración del secreto según las circunstancias en que se incumpla cuando afecte gravemente al desarrollo del proceso y/o se cause un perjuicio en el derecho de las partes, y exista un ánimo de perjudicar, que por aplicación de las reglas del art. $8 \mathrm{CP}$, la mayor gravedad de este último delito, opere en caso de concurso de leyes.

Por otro lado, no estamos de acuerdo en aquellas propuestas que otorgan algún valor al error de prohibición en los incumplimientos sancionados penalmente, y esto es porque el sujeto está perfectamente informado de las obligaciones, lo que hace inoperante el error sobre el conocimiento de la sanción penal, por cuanto al conocer la antijuricidad, el error sobre la sanción no desvirtúa dicho conocimiento, es más, supone o comunica una postura de enfrentamiento claro al ordenamiento jurídico, que bien pudo expresarse con la negativa a ser parte del Jurado o al deber de jurar o prometer, por lo que el incumplimiento posterior cuando ya no existe alternativa sin perjuicio del procedimiento, supone, en contra de las posturas que otorgan algún

\footnotetext{
1067 TAMARIT SUMALlA, JMª, La libertad ideológica, op. cit., pp. 416 y 438 ss; ID., «La objeción de conciencia», op. cit., p. 4 y 40.

1068 RUIZ Miguel, A., «La objeción de conciencia, op. cit., p. 117.

1069 ID., ibidem, op. cit., p. 114.

1070 MARTínEZ-TORRÓN, J., «Ley del jurado y objeción de conciencia», op. cit., p. 133.

1071 LUZÓN PEÑA, D-M., «Actuación en conciencia», op. cit., p. 10.
} 
privilegio a supuestos conflictos de conciencia en conductas graves, una conducta paradigmática del autor por convicción, merecedora de la máxima respuesta penal. No puede haber conflicto de conciencia sino autoría por convicción en quien, teniendo oportunidad de manifestar su conflicto, prefiere causar un perjuicio, de por sí ya grave, al procedimiento, por ejemplo la suspensión de las sesiones hasta la incorporación del suplente con la repetición de las sesiones.

El error de parte de la doctrina al parecer privilegiar toda conducta movida por conciencia religiosa/moral/ideológica es no haber delimitado los casos de autoría de conciencia y por convicción, lo que en algunos penalistas ha desembocado en un tratamiento privilegiado en autores por mero convencimiento, en los que no es comprensible por qué han de tener algún privilegio y no la máxima pena atendiendo a la clara voluntad de desatender la norma de forma combativa. Dichas conductas, también las realizadas por mero convencimiento, o sea, por convicción, suponen una claro desprecio y combate al ordenamiento que merecen la máxima culpa y penalidad, porque demuestran una convicción de lucha y el elemento subjetivo de perjudicar al procedimiento, por eso nos llama la atención que existan posturas que encuentren algún privilegio en conductas que, interesadamente, denuncian un conflicto de conciencia. Lo que sucede es que en el mejor de los casos hay un error volitivo, el sujeto no expone su conflicto de conciencia, lo que demuestra la escasa intensidad del mismo, para a la postre intentar escudarse en un error sobre la sanción o sobre la validez o existencia misma de la norma, lo que acredita que su error volitivo aunque pudiera causar su posterior error cognitivo, es imperdonable por la falta de diligencia y respeto a la norma, máxime cuando en el juramento o promesa se informa de derechos y obligaciones, por lo que su negativa durante el procedimiento contiene el especial elemento subjetivo de tratar de perjudicar al procedimiento, lo que nos lleva a concluir que su conducta es especialmente combativa de la norma y olvida cualquier conflicto de conciencia, pasa a ser un autor por convicción que lucha contra la norma, si bien, en casos límite, como aquellos referidos de déficit de socialización atribuido a un tercero, se le podría aplicar un eximente de estado de necesidad exculpante, pero serían raros los casos, por ejemplo cuando existe aislamiento cultural desde la niñez.

\section{V.- Conclusiones}

En el presente capítulo hemos entendido que con el reconocimiento de la autonomía de la voluntad, como expresión de la libertad del ser humano, se fundamenta la legalidad del rechazo de tratamientos médicos vitales, el derecho a la autopuesta en peligro e incluso mantener el derecho al suicidio, en todos aquellos sujetos con suficiente madurez que de forma expresa y 
clara manifiesten su voluntad. También hemos concluido que nuestro ordenamiento jurídico incurre en varias paradojas, como criminalizar el «auxilio al suicidio» y atenuar la pena por motivos humanitarios y morales, cuando en otros casos, la descriminalización o atipicidad de otras conductas, se fundamentan paradójicamente en las mismas razones (el aborto). Dicho esto, el único fundamento que encontramos, común en todos, es la libertad del ser humano a comportarse conforme a su voluntad, cuyo motivo, sea de conciencia o no, es ajeno a esta problemática.

De otra parte, las cuestiones problemáticas se centran en el deber de protección en virtud de la organización (aseguramiento/salvamento), o por deberes institucionales.

Concluimos en el capítulo anterior, y hemos desarrollado en el presente, que cuando existe una conducta alternativa para cumplir el deber, ya sea porque la norma la recoge, o porque sustancialmente equivale al cumplimiento, el motivo de conciencia es ajeno a la atipicidad de la conducta. La alternatividad de la conducta, puede realizarse tanto en los deberes que generan la responsabilidad por organización como en la institucional, si bien cuando la norma no informa sobre cómo realizar una conducta alternativa y existen motivos de conciencia ineludibles, subyace el déficit de comunicación/socialización atribuido a la norma que fundamenta el estado de necesidad exculpante completa o incompletamente, según los casos.

La otra gran problemática que hemos tratado de solucionar en este capítulo son los deberes que generan responsabilidad por organización, los cuales se fundamentan en el dominio, y los de infracción de deber institucional que vienen precisamente fundamentados en la garantía. Hemos concluido que se puede intercambiar la acción y la omisión en ambas tipologías, o concurrir a la vez, según las circunstancias del caso, el contexto y la competencia del rol, hasta el punto que no existe mayor energía en las acciones $u$ omisiones precisamente por dicha intercambiabilidad y dependencia del contexto organizativo y competencial, sin que la categoría conceptual del autor de conciencia sufra, según lo visto, ninguna repercusión jurídica y, por lo tanto, se pueda aplicar el estado de necesidad exculpante en ambas infracciones, ya sea en la omisión del deber de socorro del tipo básico, agravado, y en la comisión por omisión del art. 11 CP por infracción del deber que se genera por organización o por infracción de un deber institucional. Tanto es así que, en algunos delitos de omisión existe un deber especial equiparable a la comisión, en este sentido, la omisión pura agravada del art. 195.3 CP, lo que fundamenta que no existe un deber mayor en los delitos de omisión que en los de comisión puesto que los mandatos de hacer o de prohibición de hacer dependen de la organización de un ámbito. 
En virtud de ello, hemos podido llegar a la conclusión de que no son correctas aquellas opiniones que fundamentan el trato privilegiante de la autoría de conciencia en la mayor exigencia de los delitos de omisión propia. Estos delitos también se pueden realizar con una acción, o con otras palabras, no existe diferencia en cuanto al deber en los mandatos de hacer y omitir, sino únicamente diferencia en cuanto al deber, pudiendo concurrir tanto el de organización como el institucional en una misma situación, aparecer uno después de otro cronológicamente o intercambiarse, es decir, excluirse uno del otro según las circunstancias. Un ejemplo es el tratado supra, el padre que por sus conocimientos especiales en medicina ${ }^{1072}$ no avisa a las asistencias, conociendo que su hijo en estado inconsciente precisa de una transfusión. En el mismo ejemplo, si el conocimiento del desamparo nace con la presencia de las asistencias, la imputación cambia a la de omisión del deber de socorro si no se consiente el tratamiento vital. Y ambas situaciones se pueden dar una después de otra y viceversa, o incurrir en los dos tipos, el primero en tentativa y el segundo consumadamente y aplicar un concurso.

Los delitos de omisión propia se configuran como delitos de responsabilidad por organización, ya sea por injerencia, asunción o confianza, cuyo fundamento es el mismo que la responsabilidad por los delitos de dominio de comisión, mientras que en los delitos de comisión por omisión el deber nace de una garantía institucional, o también de organización (dominio), sin embargo en ambos existe un mismo fundamento: el deber configurado por unas expectativas.

Es por ello que estimamos que no puedan establecerse diferencias normativas en el tratamiento del autor de conciencia por el simple hecho de haber omitido ejecutar un deber, sino en cuanto que existen deberes más altamente protegidos o institucionalizados como, por ejemplo, en las relaciones paterno-filiales, o a diferencia de la asunción que responde a una confianza entre obligado y depositante de la confianza, en la confianza especial institucional, la mayor exigibilidad se representa en dicha especialidad de la confianza, pero ocasiona el mismo quebranto normativo. En ambos casos, la comisión por omisión genera más responsabilidad (ya sea por organización o institucional) que la omisión pura o agravada.

Esto se debe -como apuntábamos supra- a que los deberes por responsabilidad institucional, en sentido estricto, se equiparan a deberes de comisión por la importancia básica de la existencia de la sociedad, como así representan las relaciones paterno-filiales, la confianza especial y los deberes estatales. En este sentido, parte de la doctrina, en contra de la opinión mayoritaria, niega en los delitos de comisión por omisión trascendencia al principio de inexigibilidad en relación a una mayor intensidad de la exigencia en los delitos de comisión, precisamente por la cláusula de

${ }^{1072}$ Similarmente JAKOBS, G., $P G$, op. cit., 15/12 y ss. 
correspondencia entre omisión y acción y por la posición de garante, es decir, el deber de protección de la institución. Así, no se exige un mayor deber, sino que la protección se refiere exclusivamente, en la comisión por omisión, a una institución mayor. De tal modo, y en concordancia con estos postulados, sólo podrá haber alguna graduación de la exigibilidad en el estado de necesidad exculpante.

Por ejemplo, en la comisión por omisión, el reproche más altamente penado se suscita por el deber de proteger una institución más altamente considerada, como sería la vida del menor (incumplimiento de un deber que genera responsabilidad por organización), en la que el padre ha de actuar en su protección omitiendo en su esfera de organización conductas que irroguen peligros, a pesar de que concurra un deber institucional. Lo que sucede es que el deber institucional se posterga o no se activa materialmente, según el caso, puesto que el resultado llega por el incumplimiento del deber de organización, o sea, por dominio de comisión, pero en otras ocasiones, el deber institucional se activa. Un ejemplo sería el de un padre que conoce que su hijo va a morir de leucemia, pero no sabe cuándo, y no se preocupa, por motivos de conciencia (no desea que se le practique una transfusión), en cerrar la ventana en invierno, con lo cual se agrava la situación del menor, adelantándose la necesidad de una trasfusión de sangre, que el padre omite mediante la falta de aviso de las asistencias. A la misma conclusión llegaríamos en caso de cambiar la víctima menor por la mujer del obligado (responsabilidad por asunción basada en la «convivencia»). En ambos supuestos, la responsabilidad deviene de la organización, y no estrictamente de un deber institucional, al concurrir la activación del deber de la organización antes que el deber institucional ${ }^{1073}$.

Pero en todo caso es de advertir -como recuerda JAKOBS- que «tanto si se trata del status general como del status especial, el fundamento de la responsabilidad es siempre la lesión de las reglas de status (...) se trata de una sola sociedad, sólo que en ella se distingue el status general, sin más, del status especial que en cada caso corresponda» ${ }^{1074}$. Por eso, a colación, PIÑA ROCHEFORT añade que «puede tratarse de un modo diverso el padre sectario que luego de que un rayo ha caído sobre su hijo no lo lleva al hospital (produciéndose la muerte) para aceptar la

\footnotetext{
1073 Acertadamente comenta PIÑA ROCHEFORT conclusión ya alcanzada en la doctrina funcionalista, pero que reproducimos por la elegancia de sus palabras: «tanto acciones como omisiones, en cuanto sucesos que tienen lugar en el mundo físico (movimiento o ausencia de movimiento), no forman parte del sistema jurídico. El sistema del Derecho sólo opera con comunicaciones a las que pueda asignar uno de los dos valores del código (jurídico/antijurídico), de modo que eso es lo único que le interesa (...) Si esa comunicación (en cuanto hecho institucional) tiene como base una acción u omisión (en cuanto hecho bruto), resulta totalmente irrelevante», PIÑA RochefORT, JI., Rol social y sistema de imputación, op. cit., p. 288; JAKOBS, G., PG, op. cit., 28/2; ID., «La imputación penal de la acción y de la omisión», op. cit., pp. 129 y 130; SÁNCHEZ-VERA, J., Delito de infracción de deber y participación delictiva, op. cit., pp. 61 y ss.

1074 JAKOBS, G., «La competencia por organización en el delito omisivo», op. cit., p. 348.
} 
«voluntad de Dios», que el padre que en idéntico caso lo mata a golpes, no se deduce de que la conducta se lleve a cabo activa u omisivamente. La diferencia radica en que en el primer caso el padre quebranta los deberes de la relación paterno-filial, mientras que en el segundo, además, quebranta el deber común del neminem laede» ${ }^{1075}$. Sin embargo, es de tener presente que JAKOBS ${ }^{1076}$ reconoce -y así lo admite PIÑA ROCHEFORT- que «la sociedad se las arregla mejor» con el padre que deja morir alcanzado por un rayo por creer que se trata de una decisión divina, que con el que mata a su hijo estigmatizado, pero por razones subjetivas. La comparación no prueba nada más que en el segundo caso se quebranta también la responsabilidad por organización además de la institucional como en el primer caso.

A juicio propio, esta forma de «arreglárselas mejor» la sociedad procede de que las razones subjetivas, es decir, los motivos de conciencia o por convicción o las del enemigo, en ocasiones nuestro ordenamiento las valora moralmente pero no normativamente, por eso tradicionalmente se ha asociado la conducta activa al autor por convicción, y la omisiva al de conciencia, sin embargo, normativamente la conducta es la misma o intercambiable. La diferencia en ambos supuestos es estrictamente normativa, pero se concreta en el motivo o móvil desde una valoración funcional sistémica. En el primero una actitud de conciencia ineludible atribuible a la norma, o en otros casos, a un tercero, en el segundo, una actitud de lucha contra la vigencia de la norma, y en ocasiones contra la configuración normativa de la sociedad. Esta aptitud y su causa es la que valora el Sistema de forma objetiva al tratarse de influjos de la propia operatividad del Sistema en la autoría de conciencia, o lo valora, también de forma objetiva, opuesta al Sistema en el caso de la autoría por convicción sin causa atribuible a tercero, sino a la libertad, por eso el Sistema, en ocasiones, aquellas en las que la conducta directamente se enfrenta a todo el Sistema, lo excluye de su propia operatividad y lo valora en otro subsistema denominado Derecho penal del enemigo.

De otra parte, en el tipo básico de omisión del deber de socorro se reprocha una omisión (también podría reprocharse por una acción) de creación o descontrol de un riesgo en la organización propia o ajena (injerencia), o por asunción o confianza, sin embargo no se responsabiliza de la consecuencia final del resultado, porque el deber de evitación no entraña guardar precauciones sobre el resultado, a diferencia de la comisión por omisión en donde la institucionalización del deber se corresponde con la máxima protección de bien jurídico o de la vigencia normativa material, en donde tanto la injerencia (la organización) como la especial

1075 PIÑA ROCHEFORT, JI., Rol social y sistema de imputación, op. cit., p. 297.

1076 JAKOBS, G., «La imputación penal de la acción y de la omisión», op. cit., p. 143; PIÑA ROCHEFORT, JI., Rol social y sistema de imputación, op. cit., p. 297, nota 927. 
confianza son formas de la protección. En sentido similar, en la omisión del deber de socorro agravada se institucionaliza un especial deber de salvamento o protección, sin atender a una correspondencia con la comisión, pero de la que se deriva igual exigencia de la actuación evitadora que en la comisión.

En suma, no puede ser fundamento de la autoría de conciencia la mayor exigibilidad del mandato de hacer, ni por ende, puede fundamentarse la autoría por convicción en los mandatos de omitir, sino que existe, según las circunstancias, un deber de protección derivado de la organización propia, o un deber institucionalizado en otras ocasiones ${ }^{1077}$. Dicho de otro modo, y respecto a nuestra investigación, un autor de conciencia seguirá siéndolo a pesar de matar en comisión por omisión, inclusive si obra activamente, por ejemplo en el supuesto del «auxilio al suicidio», o en algún caso aislado, como veremos en el capítulo sexto, cuando obra por déficit de socialización atribuido a un tercero (aislamiento cultural, persuasión coercitiva, y obediencia a la autoridad). Sin embargo, puesto que su actitud no está en contra de la vigencia material de la norma, normalmente incurrirá en la omisión el deber de socorro. La diferencia entonces no es la acción ni la omisión, ni el mayor deber cualitativo de los deberes institucionalizados, sino las circunstancias que hacen que se active uno u otro tipo de deber.

En este sentido, JAKOBS expone que en los delitos de comisión por omisión el dolo de omitir se refiere a la cognoscibilidad, pero también en los delitos de omisión propia, puesto que quien no avisa a la policía conociendo un complot «no merece un juicio de valor menos grave que aquel que no utiliza una posibilidad de evitación que ha advertido» ${ }^{1078}$. Con palabras simples: el dolo típico tampoco diferencia al autor de conciencia y al autor por convicción. Repárese que este último también puede cometer el injusto en comisión por omisión, cuando se aprovecha o concurre un deber institucionalizado. Basta ver el supuesto de un médico abortista que fuera de los periodos de descriminalización, masivamente realiza abortos sin conocimiento de las madres.

Así, se requiere la consciencia típica para configurar el dolo, pero también la consciencia de la necesidad de un comportamiento complejo (formas y medidas) para evitar el resultado, por eso sólo importa que se conozcan las medidas de auxilio, o sea, el nexo causal entre la acción de salvamento y un resultado no improbable. Si no se conoce dicho nexo causal salvador, la omisión

\footnotetext{
1077 Como dice JAKOBS «(1)a diferencia entre acción y omisión depende, en el ámbito de la responsabilidad organizativa, de datos contingentes de la organización, y el Derecho prevé a menudo prohibiciones a pesar de riesgos existenciales, o sea, deberes de soportar la aniquilación de bienes existenciales, siempre que falte una causa de justificación para rechazar un conflicto existencial», mientras que igualmente en los deberes por responsabilidad institucional, no se exige activar capacidades o conocimientos especiales, salvo en las estrechas relaciones paternofiliales, o en casos de activación de éstas en casos análogos previos, o modificación de la lex artis, JAKOBS, G., PG, op. cit., 15/13 b') y 15/15.

${ }^{1078}$ JAKOBS, G., $P G$, op. cit., 29/83.
} 
será imprudente ${ }^{1079}$, porque aunque se conoce la posibilidad del resultado, y se conoce el deber de actuar, se desconoce cómo salvarlo, sin embargo se debió conocer ese cómo. En el mismo sentido, y respecto a la omisión imprudente, la cognoscibilidad se refiere a que el autor debió conocer la no improbabilidad del resultado; sin embargo -como dice JAKOBS- «que el autor tenga una ocasión, entendida de modo psicologizante, para juzgar es tan indiferente como la situación correspondiente del delito de comisión» ${ }^{1080}$. Así, la omisión imprudente también puede concurrir en la autoría de conciencia y por convicción, si partimos de los postulados de que el motivo de conciencia o la convicción pueden hacer desatender cómo salvar la situación y exponer a alguien a un riesgo.

De esta manera, el conocimiento de los elementos que constituyen la posición de garante pertenecen al dolo, en este sentido, los deberes de aseguramiento en las fuentes de peligro o los deberes de salvación sobre el conocimiento de riesgos no cotidianos en los deberes de organización, o el alcance del deber en la responsabilidad institucional, pero no la consciencia del mandato que es una cuestión de la culpabilidad ${ }^{1081}$, y por ende, según los casos, apreciar un déficit de socialización atribuido a un tercer, tanto en el autor de conciencia, como en el autor por convicción, o en el enemigo. Es más, como bien acierta a expresar JAKOBS, «(t)odo autor de omisión prefiere la situación sin acción aseguradora o salvadora a la situación con tales acciones (...) siempre es intencional, así también la omisión dolosa (...) el autor de comisión que obra intencionalmente para producir las consecuencias, debido a la producción de tales consecuencias prefiere la situación producida por la acción con consecuencias a la situación sin esta acción (...) la disposición psíquica $(. .$.$) es irrelevante» { }^{1082}$. Esto mismo puede trasladarse al autor de conciencia y por convicción: Que el hecho se haya realizado por omisión o comisión, o que el delito en que se incurra sea una omisión propia o pura, o una comisión por omisión, nada aporta al debate, es ajeno o simplemente circunstancial al conflicto del autor de conciencia, o a la lucha del autor por convicción y del enemigo.

Si el padre testigo de Jehová no avisa a las asistencias porque conoce, gracias a sus altos conocimientos médicos, que su hijo menor de edad, necesitará una transfusión de sangre, la falta de salvamento puede equipararse a la acción de matar, en tanto el padre conoce el alcance de su deber, si bien nadie negará que el conflicto de conciencia sigue presente. En este ejemplo no puede afirmarse que el padre sea un autor por convicción equiparable en alguna medida a los

\footnotetext{
${ }^{1079}$ ID., ibidem, op. cit., 29/86.

1080 ID., ibidem, op. cit., 29/87.

1081 ID., ibidem, op. cit., 29/89 y ss.

1082 ID., ibidem, op. cit., 29/91.
} 
terroristas, a un enemigo, o al furtivo que caza fuera de los periodos de veda, sino un autor que por las circunstancias, en este caso, por sus conocimientos especiales, unido a los deberes institucionales, han propiciado el cambio de imputación objetiva, del delito normalmente cometido en estos casos de omisión del deber de socorro, al de homicidio en comisión por omisión. De aquí que a la misma conclusión podemos llegar en la autoría por convicción y en el enemigo: que la conducta sea omisiva o activa no cambia la conceptualización, ni que se incurra en una responsabilidad institucional, o por organización, ni dolosa ni imprudentemente, la cuestión que transciende es qué comunica la conducta a la operatividad del Sistema social, si es una conducta que puede operar en el Sistema y si es en cierto sentido acorde a la propia operatividad del Sistema (autoría de conciencia), o simplemente puede operar en el Sistema como cualquier otro delito (autoría por convicción «blanda» y casos normales de autor de conciencia), o en casos extremos, si debe apartarse cuando se enfrenta al Sistema (autor por convicción-enemigo), sin perjuicio de los déficits referidos. 


\section{Capítulo IV}

\section{ESTRUCTURA CRIMINOLÓGICA Y JURÍDICO-PENAL DE LAS SECTAS CRIMINALES}

\section{I.- Aproximación al peligro}

En los tres primeros capítulos de la presente investigación hemos tratado la conducta de los autores de conciencia, por convicción y del enemigo desde el presupuesto de que la conducta es libre o, dicho de otro modo, sin que exista interferencia imputable a un tercero. En los próximos capítulos vamos a realizar el análisis contrario: las mismas tipologías criminales desde el presupuesto de la interferencia imputable a un tercero en la conducta del autor. Para esto nos hemos servido del caso paradigmático de las sectas criminales, en éstas, como veremos, además de confluir las tres tipologías citadas, éstas se ven condicionadas por la interferencia imputable de un tercero (líder) y/o por la dinámica comportamental del grupo de modo que afecta a la responsabilidad.

Los asesinatos o suicidios masivos de Jonestown (EEUU) en 1978, los homicidios cometidos por miembros de la secta satánica Mason y los suicidios colectivos de Guyana en 1978 conmovieron al mundo y lo pusieron en alerta ante la expansión del fenómeno criminal de las sectas. El mundo occidental, y especialmente el Derecho penal del ciudadano, ha dejado una puerta, quizá demasiado grande para que los enemigos de la sociedad, gracias a la globalización del mercado y de las culturas, se aprovechen criminalmente de las pocas medidas o herramientas de las que dispone el Estado ante ataques criminales organizados. Evidentemente no nos referimos a las sectas en general, tan legítimas como sanas para una sociedad moderna que se caracteriza por el reconocimiento de las libertades, sino a las que sectas criminales, que comparten junto a cualquier otra organización criminal la peligrosidad objetiva de desestabilizar el sistema normativo.

En este capítulo estudiaremos la fenomenología de las sectas criminales y el peligro que representan para el ciudadano y para la configuración normativa de la sociedad. Analizaremos las perspectivas sobre las que se ha estudiado las sectas, la confusa terminología, a sus líderes y miembros activos, a los adeptos y el rol que ocupa cada uno en una estructura criminal, las 
tipologías sectarias y, finalmente el mito o realidad del denominado «lavado de cerebro» y las posibles consecuencias.

Sobre los años sesenta del pasado siglo proliferaron en Estados Unidos con mayor fuerza grupos calificados tradicionalmente de sectas. Los movimientos juveniles de mayo del 68, arraigados en el inconformismo, la utopía, la música, las drogas, el sexo y la efervescencia de los seductores reclamos hinduistas, budistas y esotérico representaron como antes no había sucedido una época de consumismo espiritual bajo la Ley de la oferta y la demanda ${ }^{1083}$. Precisamente esta gran gama de productos y ofertas religiosas, sumada a la necesidad de los ciudadanos de escapar, quizá por hastío, de los tradicionales credos religiosos produjo la alarma de la sociedad tradicionalista que denunciaba algunas prácticas religiosas y métodos proselitistas. De este modo, a partir de los años ochenta se comenzó a asociar a cualquier grupo religioso discrepante u opuesto a la religiosidad tradicional con la sospecha de ser organizaciones criminales secretas y destructivas de la sociedad.

En España apenas hay jurisprudencia en el ámbito de las asociaciones ilícitas asociadas a las sectas, o en su caso, escasísimas referencias a la criminalidad de grupos religiosos, a la vez que la doctrina penal tampoco se ha pronunciado expresamente sobre la posible criminalidad de estos grupos, lo que ha dificultado sobremanera la investigación de la problemática. Por el contrario, en los Estados Unidos se encuentran diversas condenas a grupos religiosos sobre defraudaciones fiscales y sobre delitos realizados por adeptos pero sin vinculación probada con dinámicas de organización criminal. Además, no existe apenas bibliografía en lengua castellana sobre sectas y sectarismo, y la que hay en mayoría se dedica a estudios sensacionalistas. La bibliografía de cierta seriedad procede del mundo anglosajón, y principalmente del Center for Studies on New Religions y de revistas especializadas como Internet Journal of Religion.

La problemática asociada a las sectas, y especialmente a las criminales, se trasladó a nuestro país tras la Comisión de investigación de la Unión Europea por el Parlamento Europeo y el Consejo de Europa, que tras la Resoluciones de 1984 y $1987^{1084}$ denunciaron la intromisión de ciertos grupos religiosos en la capacidad de la libertad de la voluntad en cierto sector vulnerable como los jóvenes y ancianos. Gracias también a la alerta de una de las Diputadas del Congreso, Pilar Salarrullana, y a las múltiples denuncias de afectados en nuestro país, se propició que se constituyera en el Congreso de los Diputados una Comisión de estudio y repercusiones de las sectas en España, cuyo dictamen, conclusiones y propuestas de resolución fueron elevadas al

\footnotetext{
1083 GREENFIELD, Robert, El supermercado espiritual, Anagrama, Barcelona, 1979.

1084 Véase más ampliamente en MARTínez MuÑoz D / CARretero SÁEZ P / Alonso RAmos LM / PERALES PIZARRO A / RODRÍGUEZ RUIZ O., «Sectas y Derecho Internacional», op. cit., pp. 23 y ss.
} 
Pleno del Parlamento. El 2 de marzo de 1989 fue aprobada la Resolución instando al Gobierno a que adoptase medidas administrativas y civiles para dar solución a las denuncias de gran parte de la población. Lo paradójico fue que a pesar de que la mayoría de las denuncias presentadas por afectados se relacionaban con conductas que restringían la libertad de voluntad, no se instaron medidas penales, lo cual puede resultar hasta lógico teniendo en cuenta que nuestro Código penal ya regulaba los delitos de coacciones asociados a la restricción de derechos fundamentales, y el delito de proselitismo ilícito, máxime cuando en aquel momento no se conocía detalladamente cuál era la peligrosidad delictiva estricto sensu, pero tampoco mediadas preventivo-penales, tales como la formación de grupos policiales especializados en organizaciones sectarias criminales, o por lo menos, los grupos policiales dedicados a la lucha contra la criminalidad organizada, no se interesó, ni fue instada a investigar ciertas dinámicas criminales asociadas a las sectas.

Las dos Resoluciones del Parlamento Europeo y del Consejo de Europa de 1984 y 1987 no prejuzgaron a los grupos sectarios por la doctrina moral, religiosa o cosmológica, ni por el arraigo social que tenían en el país de permanencia, ni siquiera por la estructura, ámbito o círculo de personas que captan, como en algunos casos son los jóvenes o ancianos, pues en definitiva esos aspectos son lícitos dentro de la libertad de conciencia. El interés surgió de algunas conductas asociadas a la «reforma del pensamiento»o «lavado de cerebro», si bien, como decimos, a pesar de estudiarse las técnicas psicológicas y fisiológicas de persuasión que pueden suponer un peligro para la capacidad de la libertad de voluntad, y los sectores de población vulnerables, salvo la simple advertencia de que algunas conductas podrían constituir injustos contra la libertad, no se instó medida penal o preventiva alguna.

Pues bien, toda investigación debe partir de un interés, y desde luego la libertad de conciencia, de creencias, y en definitiva de pensamiento, como también el interés que en general suscitan las sectas en todos los ámbitos, desde el criminológico, sociológico, pasando por el psicológico y psiquiátrico, fundamentan el presente estudio, pero más si cabe un estudio en el orden penal que brilla por su ausencia ${ }^{1085}$

No obstante, como dijimos, la mayoría de la doctrina que se ha ocupado de las sectas, lo ha

1085 En ese sentido, como bien apunta MAQUEDA ABREU «(h)ay que contar, asimismo, con que los instrumentos legales existentes para asegurar la defensa de la libertad de voluntad de los individuos no son los más adecuados. En particular, los punitivos, que se muestran inidóneos tanto cuando se trata de preservar la libertad de conciencia frente a los actos de proselitismo ilegal como cuando se pretende garantizar su libre ejercicio frente a un comportamiento sectario violento o intimidatorio. Y básicamente porque las maniobras de persuasión coercitiva y de control psicológico que merma la capacidad de percepción de quien se ve sometido a ellas son cada vez más sofisticadas. Se ha llegado incluso de hablar de una "segunda generación" en el empleo de esas técnicas de influencia que vienen a incidir en los aspectos más centrales de la personalidad del sujeto», MAQUEDA ABREU, ML., «Las sectas destructivas ante el derecho», op. cit., p. 236. 
hecho desde la única perspectiva de la autoría de conciencia pero con la constante referencia a los delitos de omisión del deber de socorro de los Testigos de Jehová. En este sentido parece que estaba predispuesta a encontrar algún tipo de exoneración o disminución de la responsabilidad. Este ha podido ser el problema. El escaso estudio penal de las sectas desde todas las perspectivas ha resultado claramente inexistente, al igual que la falta de confrontación de la autoría de conciencia con la autoría por convicción y con el enemigo. Así las cosas, nuestro análisis, como ya ha sido dicho tantas veces, pasa por confrontar todas las tipologías de autoría asociada a la moral, resultando que en las sectas criminales redundan todas ellas de manera especialmente acusada, por lo que se justifica un análisis detallado de este estricto ámbito fenomenológico desde la perspectiva penal, porque a diferencia del tratamiento que hemos realizado en los tres primeros capítulos dedicados a las tipologías del autor de conciencia, por convicción y enemigo, desde el presupuesto de la conducta libre, en las sectas criminales suele aparecer la interferencia imputable a un tercero en la conducta de éstos, lo que plantea problemas de responsabilidad.

\section{II.- Terminología vacilante}

\section{A. Perspectiva histórica}

La palabra «secta» ha sido y será en la historia un vocablo maldito que nadie quiere abanderar, ni grupo, ni nación, ni religión. Algunos ${ }^{1086}$ consideran que realmente lo peyorativo del fenómeno sectario no es la palabra secta, sino el adjetivo «sectario», pues no todos los integrantes de una secta se comportan como sectarios, sino sólo algunos. La «maldición»o «posesión demoníaca» que pesa sobre este fenómeno motiva, no sólo un estudio introductorio sobre la problemática, sino también sobre la propia realidad de éstas disociadas de las grandes y tradicionales religiones.

El vocablo «secta» procede de sectus, que derivada del verbo latino secare que significa «cortar»o «separar» ${ }^{1087}$, aunque parte de la literatura que se ha ocupado sobre el tema considera que proviene del verbo sequi, seguir. En nuestra opinión ambas consideraciones son correctas pues postulan modelos de pensamiento que efectivamente se han asentado en el acervo social.

El diccionario de la RAE dice que una secta es la «(d)octrina religiosa o ideológica que se aparta de lo que se considera ortodoxo; conjunto de seguidores de una secta; comunidad cerrada, que promueve o aparenta promover fines de carácter espiritual, en la que los maestros ejercen un poder absoluto sobre los adeptos». De tales acepciones se puede vislumbrar tres

\footnotetext{
1086 CHERY, Henri Charles, ¿Qué es una secta? en 2000 años de Cristianismo, T.V, Madrid, 1979, p. 166.

1087 GuerRA, M., «Lo que es y lo que no es una secta», op. cit., p. 40.
} 
elementos importantes: la identificación social, la identificación religiosa o ideológica, y la identificación falsaria de los no pertenecientes a estos grupos de lo que se evidencia la peyoratividad del término en la lengua española, al menos en su última acepción.

Sin embargo, una secta se define normalmente en el acervo social como «conjunto de seguidores de una doctrina, utilizándose el término con frecuencia en sentido peyorativo y despectivo» o también «comunidad religiosa de carácter minoritario, separada de una religión o confesión», cuyos ejemplos históricos podrían ser, entre otros, los cuáqueros, los baptistas y los anabaptistas. En el campo de los sinónimos se relaciona el término secta popularmente con «herejía», «heterodoxia», «cisma», «apostasía».

El sociológico Max WEBER ${ }^{1088}$ concluyó que el nacimiento de las sectas se debe a la lucha fanática contra la progresividad creciente de la secularización racionalista (o racionalismo éticometafísico) que provenía de la evolución dialéctica de la cultura occidental. El renacimiento del término se debe probablemente al conflicto surgido con la reforma protestante, época de mayor auge de éstas y que se mantiene hasta nuestros días, aunque es bien cierto que ya existían sectas o grupos religiosos discrepantes de la religión dominante en la antigüedad y proliferaron en mayor medida con la caída del Imperio Romano. De hecho, el término secta ya se utiliza en los Hechos de los Apóstoles ${ }^{1089}$.

Aunque sectas han habido en todos los lugares y tiempos, éstas prosperaron primeramente tras la caída de Roma, posteriormente hacia el año 1530, una década después de las primeras iniciativas de la Reforma de Lutero ${ }^{1090}$. Tras la revolución francesa se extendieron por todo el continente europeo, y más aun con la revolución industrial, momento de grandes migraciones. Con la colonización el auge y la expansión fueron mayores, hasta la época del protestantismo, como hemos anticipado antes, la preocupación y el estudio crecieron ${ }^{1091}$.

El término sectas sufrió una radical evolución sociológica a partir de los años sesenta del siglo $\mathrm{XX}$, cuando aparecieron los grupos religiosos ligados a tradiciones esotéricas o a movimientos mesiánicos y milenaristas ${ }^{1092}$. Algunos han llegado a afirmar que estos cultos no son estrictamente religiosos desde el punto de vista sociológico que se aplica a las religiones tradicionales, porque les falta el requisito profético, la utopía, lo innovador.

\footnotetext{
${ }^{1088}$ WeBer, M., La ética protestante y el espíritu del capitalismo, op. cit., pp. 153 y ss. y pp. 265 y ss.

${ }^{1089}$ En concreto se dice en los Hechos de los Apóstoles (Act. 14.14): «sirvo al Dios de mis padres con plena fe en todas las cosas escritas en la ley y en los Profetas, según el camino que ellos llaman secta». Inclusive en el Corán se menciona la escisión del Islam en diversas sectas (v. 43.65).

${ }^{1090}$ WILSON, B., Sociología de las sectas religiosas, Guadarrama, 1970, p. 7.

1091 SINGER Margaret Thaler / LALICH Janja, Las sectas entre nosotros, Gedisa, Barcelona, 1997, p. 58.

1092 Vid. TeDESCHI, M., «Nuove religioni e confesión religiose», Studi in Memoria de Mario Condorelli, Vol. I, T.2, Milano, 1988, p. 1215.
} 
Es evidente que la palabra «secta» durante la historia no ha sido ni es neutral, sin embargo en el ámbito anglosajón se prefiere utilizar el término cults, cultos o ritos ${ }^{1093}$, para neutralizar el significado peyorativo del término «secta» que se utiliza en la cultura latino-germánica, y en concreto en España, con el objeto de designar grupos religiosos extranjeros y no cristianos.

En EEUU, el gran apogeo de los grupos religiosos, además de las causas citadas, se debe al extraordinario amparo de la libertad religiosa en su Constitución ${ }^{1094}$. No resultará extraño concluir que la diferencia con España es clamorosa, cuando según vimos en el capítulo primero, la doctrina constitucional de la libertad de conciencia se interpreta conforme a la moral pública, y en otras conforme al orden público, y de aquí que también en la doctrina penal tradicionalmente las propuestas en torno a la autoría de conciencia en general, y especialmente en el seno de grupos religiosos, haya sido combatida con la máxima responsabilidad asociada y confundida con la autoría por convicción, de modo que sólo los estudios pormenorizados sobre la problemática encuentran algún tipo de exoneración de la responsabilidad, si bien, como ya concluimos, también en torno a una interpretación, si bien distinta, vinculada a los valores y principios interpretados desde particulares concepciones, o modificando la moral pública dominante. Sin embargo, en EEUU la separación del sentimiento religioso y el Estado es tan marcada que evidencia la funcionalidad normativizada del Sistema, lo que ha propiciado que difícilmente se encuentren condenas a conductas asociadas a motivos morales o religiosos. La separación de la norma y la moral es tan tajante que apenas la norma tiene influencias morales salvo los llamativos casos de aborto y matrimonio del mismo género. Un ejemplo resulta de la imposibilidad de condenar o ilegalizar al $K K K$ porque se considera que la manifestación racista supone el libre ejercicio de la libertad de expresión.

El Informe del Parlamento Francés del año 1995 Les sectes en France, a diferencia del informe de la Comisión del Parlamento español, se basó en los servicios de investigación de la Policía francesa que investigaron la dinámica de las sectas, sin embargo, finalmente el informe se limitó a señalar alguno de los problemas asociados a las sectas. Por ejemplo, señaló la desestabilización mental de algunos adeptos, lesiones físicas, reclutamiento de menores, la

1093 WILSON, B., Sociología de las sectas religiosas, op. cit., p. 16.

1094 En concreto, la 1. ${ }^{\mathrm{a}}$ y 14. ${ }^{\mathrm{a}}$ Enmienda de la Constitución Americana garantizan la igualdad de todos los ciudadanos en materia religiosa, que unido la separación rotunda y firme entre las iglesias y el Estado, es decir, a su aconfesionalidad, a diferencia de España, prohíbe juzgar las creencias de los grupos o de una persona en concreto. En este sentido es llamativa la Sentencia de la Corte Suprema del estado de Nueva York, que en palabras del Juez Leahy declara que «(l)a libertad de una religión no debe ser reducida porque sea poco convencional en sus creencias y prácticas, o porque sea aprobada o desaprobada por la mayor parte de la sociedad o de las religiones más convencionales», vid. MotiLlA, A., Sectas y derecho en España, op. cit., p. 38; más ampliamente WoOD, James E., «New religions and the first Amendmen», Journal Church and State, 24, 1982, p. 459. 
existencia de querellas y fraudes fiscales. En este país, la Asociación Holosófica fue calificada de secta «peligrosa» por la Asamblea Nacional, sin embargo en España se instalaron en Ibiza ${ }^{1095}$. Esto demuestra, al menos, la falta de coordinación y regulación del derecho a la libertad religiosa, o en su caso, de normativa penal armonizada en Europa, de manera que la peligrosidad criminal de una organización se combate en un país y en su vecino ni lo tenga en cuenta.

Así las cosas, desde una perspectiva histórica, el término secta o culto tiene claras reminiscencias religiosas, excepto en los casos en los que se relaciona el sectarismo con la política. En ambos casos, lo cierto es que existe una clara tendencia a combatir los grupos religiosos de nueva creación, o discrepantes u opuestos al sentimiento de las grandes y tradicionales religiones como el cristianismo, pero sin un claro motivo, o sin la constatación de un peligro objetivo. Vimos que históricamente las sectas fueron combatidas como herejías y enemigos del Imperio y de los Estados, lo que demuestra la clara tendencia histórica a interpretar la libertad de conciencia y religiosa desde el Poder, defenestrando los sentimientos religiosos minoritarios u discrepantes.

Esta tendencia debería haber terminado con la Declaración Universal de los Derechos del Hombre y su incorporación en el ordenamiento interno de los países modernizados, sin embargo, podemos anticipar que esto no ha sido así, sino todo lo contrario. Existe la misma tendencia -tal y como constatamos en el capítulo primero- a interpretar la libertad de conciencia conforme al sentimiento o moral dominante, lo cual ya no sólo impide una valoración puramente normativa de las conductas criminales asociadas a los motivos morales, sino más acusadamente la constatación clara de que la libertad de conciencia no está claramente regulada en los países normativizados, lo cual llama la atención por cuanto en éstos se regula sobre todo, y a veces sobre nada, y los estudios que se han dedicado a la problemática normalmente lo hacen desde una clara tendencia combativa e irrespetuosa de los grupos religiosos minoritarios. Ello se debe en nuestra opinión- al escaso estudio de esta fenomenología social desde la perspectiva penal, si bien se dice amparar la libertad de conciencia de los ciudadanos cuando surgen conflictos, o bien se tiende a atenuar o justificar la conducta como autoría de conciencia, o se asocia a conductas peligrosas, enemigas, sin más.

En la actualidad se está produciendo un cambio de tendencia en la denominación de estos grupos y en la metodología científica. Se ha comenzado a abandonar el término secta o en otros ámbitos denominado «nuevos movimientos religiosos»o «pseudorreligiosos» para poner el acento en la dinámica grupal con terminologías como «grupo de manipulación psicológica»

1095 Periódico digital El Mundo.es, domingo 29/11/2009. 
(GMP) o de «abuso psicológico».

\section{B. Perspectiva combativa: «nuevos movimientos religiosos»o «pseudorreligiosos»}

Un ejemplo claro de la interpretación de la libertad de conciencia desde la perspectiva de la moral dominante son algunas de las consideraciones sobre las sectas desde sectores de la Iglesia Católica.

Gran parte de la doctrina eclesiástica católica, en este sentido, ha preferido denominar al fenómeno sectario como «Nuevos Movimientos Religiosos» $(N M R)^{1096}$, en un intento de abstraer la peyoratividad del término secta a otro más neutral, y aunque también se propuso por teólogos y sociólogos influidos por el cristianismo el término «culto» que hoy en día ha triunfado en los países anglosajones (cults), pero en nuestra opinión más que ayudar a resolver la problemática del término, la agrava, porque los grupos a los que nos referimos ni tienen por qué ser ni nuevos ni religiosos estrictamente hablando ${ }^{1097}$.

En esta aproximación terminológica, en el debate actual, un sector doctrinal denomina sectas como grupos «pseudorreligiosos». En concreto, JORDÁN VILLACAMPA define y conceptualiza el término «secta» como aquellas «pseudorreligiones» que son objeto de controversia por considerarse dañosas para el individuo y la sociedad» ${ }^{1098}$, intentando con tal definición restringir mediante el vocablo «pseudorreligiosas» la naturaleza de las sectas, neutralizando el término sectas, y restringiendo el campo de las sectas perjudiciales a un ámbito casi ajeno a lo religioso

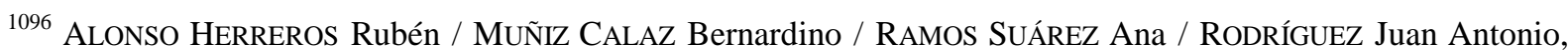
«Actitud del ordenamiento español ante las sectas», Sectas y Derechos Humanos, op. cit., p. 43, y en concreto nota núm. 1, en donde se menciona que esta terminología se impone en el ámbito de la sociología de las religiones dada su neutralidad; BosCH, Juan, «Un capítulo especial del "revival religioso". Los "Nuevos Movimientos Religiosos" en España», Razón y Fe, 1.110, 1991, p. 391; ID., «Bibliografía española sobre sectas y nuevos movimientos religiosos», Cuadernos de Realidades Sociales, núm. 35-36, ejemplar dedicado a Las Sectas en España, 1990; ID., Para conocer las sectas, Estella, 1993; MORALEDA, José, Las sectas hoy. Nuevos movimientos religiosos, Ed. Sal Terrae, Cuadernos Fe y Securalidad, 20, 2a ed., Bilbao, 1992, pp. 7 y ss; MotiLla, A., Sectas y Derecho en España, op. cit., pp 40 y 41; aunque sólo para las de nueva creación, VÁZQUEZ, Jesús María, Familia y sectas, Instituto de Sociología Aplicada de Madrid, Madrid, 1994, p. 16; por representar las sectas un carácter novedoso, ENROTH, Ronald S., The Lure of the Cults and new Religions. Why They Attract and What We Can Do, Downers Grove, Illinois, Intervarsity Press., 1977; ID., Las sectas y la Juventud, Crie, Tarrasa, 1980; BECK, Huber F., How to respond to the Cults. A Sociological Study of Jehova's Witnesses, Oxford, Basil Blackwell, 1979. La doctrina italiana mayoritaria está de acuerdo también en la utilización de «nuevos movimientos religiosos» por su valor neutro. El término «cultos» es desechado por la doctrina italiana por apreciar un carácter peyorativo similar al de sectas, y lo mismo ocurre con la expresión «religiones alternativas», FERRARI, Silvio, Diritto dell' uomo e libertà dei gruppi religiosi. Problemi giuridici dei nuovi movimenti religiosi, Editado por Silvio Ferrari, Università degli Studi di Parma, Publicazioni della Facoltà di Giurisprudenza, nuova serie, 7, Padova (Cedam) 1989, pp. 3 y ss.

${ }^{1097}$ En el mismo sentido RodríGuEZ, Pepe, Adicción a sectas, Ed. B, Barcelona, 2000, p. 22 a 24; CUEVAS BARRANQUERO, José Miguel, Evaluación de persuasión coercitiva en contextos grupales, Publicaciones y Divulgaciones, Facultad de Psicología, Universidad de Málaga, 2016, p. 54.

1098 JordÁn VillacAmPA, Má,. Las sectas pseudorreligiosas, Ministerio de Justicia, Centro de publicaciones, Madrid, 1991, p. 9; también BENTERRAK AYENSA Miriam / COLLADO MÁrQUEZ Ana Isabel / FuENTES CASTILLEJOS Miguel / MARTínEZ RuBio Agustina / REDONDO GARCÍA Manuela, «Aspectos históricos y sociológicos de las sectas en España», Sectas y Derechos Humanos, op. cit., p. 155.
} 
cuando se refiere a la pseudorreligión. Consideramos que no es acertada tal postura pues acota la peligrosidad al campo religioso, o circunscrito a una religión, lo que excluye un concepto de secta más amplio vinculado a la moral, la ideología o la filosofía. Además parece poner en duda la fe, credo, o religión de los miembros.

Dicho esto, la autora nos aclara su terminología: «La denominación que demos a estos grupos carece, a mi modesto entender, de especial significación. Es irrelevante llamarlos sectas "pseudorreligiosas", "cultos", "nuevas religiones", "movimientos totalitarios pseudorreligiosos", etc., pues la denominación no variará su naturaleza: pero al ser necesaria para su identificación nos referiremos a los mismos como «sectas pseudorreligiosas» por ser la terminología más común en nuestro país. No obstante, entiendo que añadirles el término religión puede suponer dotarlas de una responsabilidad inmerecida en relación a sus actuaciones» ${ }^{1099}$.

Este tipo de definición ha sido ampliamente seguida por diversos sectores doctrinales, llegándose a definir en armonía como «grupos religiosos de nuevo cuño, ya sea por separación de otro grupo más numeroso o por simple creación, consecuentemente minoritario, cuya implantación en los distintos países es bastante reciente» ${ }^{1100}$.

En contraposición a la última afirmación de JORDÁN VILLACAMPA, Agustín Motilla considera que a este fenómeno se le debe denominar «nuevos movimientos religiosos», pues son los términos que hasta la fecha se utilizaban comúnmente en la tradición hebraico-cristina, y relega el término «sectas» cuando incurran en delitos tipificados o en sanciones $\operatorname{administrativas~}^{1101}$.

Así pues, en nuestra opinión, parece ser que esta terminología es más neutral y pacífica que la de sectas u otras denominaciones, aunque desvirtúa o puede dar lugar a equivocaciones de comprensión precisamente por la neutralidad que supone, dejando fuera aquéllas que representan peligros objetivos graves para la sociedad, de manera que desde una perspectiva penal estaríamos obligados a calificar a estos grupos como «nuevos movimientos religiosos y criminales». Pero también el término «movimientos» no refleja su realidad en la acepción de la Lengua española, parece inútil este vocablo, pues se define «movimientos» en el Diccionario de la Real Academia de la Lengua española como «(d)esarrollo y propagación de una tendencia religiosa, política, social, estética (...) de carácter innovador», por lo que sólo es aplicable a los

\footnotetext{
1099 JORDÁN VILLACAMPA, Mª., Las sectas pseudorreligiosas, op. cit., pp. 11 y 12; ID., «Aproximación al tema de las sectas pseudorreligiosas», Dimensiones jurídicas del factor religioso. Estudio al profesor López Alarcón, Murcia, 1987, p. 258.

${ }^{1100}$ Vid. MArtínez Muñoz D / CARretero SÁez P / Alonso Ramos LMa / Perales Pizarro A / RodríGueZ RuIZ O., «Sectas y Derecho Internacional», op. cit., p. 17.

${ }^{1101}$ Motilla, A., Sectas y Derecho en España, op. cit., pp 40 y 41.
} 
grupos innovadores. Por otro lado, el vocablo «nиеvos» presupone una novedad que no aparece en algunas de las sectas consideradas con mayor número de adeptos, como los Testigos de Jehová, Rajnesh en la India o Hare Krishna. Quizás lo nuevo sea -como dice LLAMAZARES FERNÁNDEZ ${ }^{1102}$ - la reacción actual contra estos grupos, problemática que antes no sucedía, por lo que prefiere utilizar el término tradicional «sectas». Por último, el término «religiosos» tampoco describe en su totalidad el fenómeno sectario, pues algunos grupos como la Cienciología parecen adolecer de una falta de doctrina de fe estrictamente religiosa. En este sentido, no son pocos los grupos que -como expuso WILSON ${ }^{1103}$ - contienen una ideología entre lo religioso, la tecnología, la medicina, incluso el ocultismo, etc.

Similarmente algunos autores entienden que la crítica al vocablo «sectas» es de poco peso, es esta misma doctrina «la que achaca a la sociedad y a su lenguaje, la circunstancia de que la palabra secta haya dejado de ser adecuada para designar la realidad a la que nos referimos» ${ }^{104}$.

En opinión de Singer y LALich, más que hablar de sectas, deberíamos hablar de las «relaciones sectarias» y en su caso de «persuasión organizada» refiriéndose a la denominación propuesta por SINGER años antes ${ }^{1105}$, y criticando a la vez el término «lavado de cerebro». Opinan que las relaciones sectarias son «aquellas en la que una persona induce intencionalmente a otras a volverse total o casi totalmente dependientes de ella respecto de casi todas las decisiones importantes de la vida, e inculca en esos seguidores la creencia de que ella posee algún talento, don o conocimiento especial» ${ }^{1106}$.

Desde una perspectiva no tan combativa, denominada «misional» ${ }^{1107}$, se considera a las sectas como grupos proselitistas que con fanatismo realizan la captación de creyentes, y se reducen a grupos no cristianos o de ruptura con el cristianismo ${ }^{1108}$.

${ }^{1102}$ LlAMAZARES FERNÁNDEZ, D., «Sectas y Derecho fundamental de Libertad de conciencia», op. cit., p. 131; MEYER, TF., «Nouveaux mouvements religieux: une perspectiva historique et culturelle», Diritto dell "uomo e libertà dei gruppi religiosi, op. cit., pp. 39 y 40.

${ }_{1103}$ WILSON, B., Sociología de las sectas religiosas, op. cit., p. 141 y ss.

${ }^{1104}$ BARBA LÓPEZ Daniel / GARCÍA Oliva Francisco Javier / GARCÍA-PARDo GÓMEZ David / Morales MonTeOliva Yolanda / VAlencia Benítez Fernando, «La protección jurídica del individuo ante las sectas destructivas», Sectas y Derechos Humanos, op. cit., p. 76.

${ }^{1105}$ SINGER Margaret Thaler, «The Systematic Manipulation of Psychological and Social Influence», Ponencia en el encuentro anual de la Cult Awareness Network / Citizens Freedom Foundation, Washington D.C, 1982.

${ }^{1106}$ Singer MT / LALICH J., Las sectas entre nosotros, op. cit., p. 36. Para estas especialistas tal denominación se circunscribe en tres factores: «El origen del grupo y el rol del líder; la estructura de poder o relación entre el líder (o líderes) y los seguidores; y el uso de un programa coordinado de persuasión (que se denomina reforma del pensamiento o, más comúnmente, lavado de cerebro)», ID., ibidem, op. cit., pp. 36 y 37; aunque finalmente aceptan que «el término sectas es sólo descriptivo, no peyorativo. Se refiere a los orígenes, la estructura social y la estructura de poder de un grupo. Pero el manejo de ciertas sectas, en especial los grupos que tienden a explotar a la gente y abusar abiertamente de ella y que tienen un comportamiento engañoso, falto de ética e ilegal, provoca, una actitud crítica en la sociedad que los rodea», ID., ibidem, op. cit., pp. 40.

${ }_{1107}$ GUERRA, M., «Lo que es y lo que no es una secta», op. cit., p. 37; BosCH, Juan, Para conocer las sectas, Estella, 1993, p. 63; GARCíA HERNANDO, Julián, «La tipología como problema al estudio de las sectas», vv.aa., Las 


\section{Criterio psicológico}

Se ha considerado por RODRÍGUEZ-CARBALLEIRA ${ }^{1109}$ más neutral y preciso calificarlas de sectas «coercitivas», en función del objetivo ilícito que persiguen algunos grupos a través de las técnicas de persuasión coactivas. De este modo, el referido autor lleva al ámbito penal la constatación de la peligrosidad social de algunos grupos cuando utilizan técnicas que modifican o disminuyen la voluntad. Me parece acertada tal terminología porque, además de determinar la naturaleza de la activicidad, se refiere a un peligro jurídicamente desaprobado, o riesgo no permitido, como es la coerción de la voluntad, de tal manera que ayuda a comprender su ubicación sistemática en el delito de coacciones.

De otra parte, se han denominan con el adjetivo de sectas «destructivas» ${ }^{1110}$ aquellas que crean un vínculo afectivo subjetivo y objetivo, primero con el proceso de captación y adoctrinamiento, y más severamente con las técnicas de persuasión coercitiva que generan una destrucción tanto individual como social del adepto, que evoca signos afectivos de dependencia,

sectas en una sociedad en trasformación, dir. Oleza Le-Senne, Fundación para el Análisis y los Estudios Sociales, Madrid, 1997, pp. 78 a 125.

${ }^{1108}$ DE GoITA, Javier, El sectarismo roto. Entre la libertad y el sectarismo II, Cuadernos de Teología Deusto, núm. 13, Universidad de Deusto, Bilbao, 1997, pp. 20 y 48, en esta obra el autor distingue entre Iglesias del Pueblo como el Luteranismo y el Calvinismo o la Iglesia de Inglaterra, las Iglesias libres, aquellas que nacieron en la Iglesia Romana y las sectas que nacen en todo tiempo.

1109 RoDRíGUEZ-CARBALLEIRA, Álvaro, «La persuasión coercitiva en sectas: ¿Una nueva teología?», Papers d’Estudis y Formació, núm. 9, junio de 1992, p. 61; ID., Psicología de la persuasión coercitiva, Universitat de Barcelona, 1992; ID., El lavado de cerebro, Boixareu Editores, Barcelona, 1992; ID., «Sectas coercitivas y juventud», Revista de Estudios de Juventud, ejemplar dedicado a Juventud, Creencias y Sectas, núm. 53, 2001, pp. 117 a 129; ID., «El fenómeno de las sectas coercitivas», CDJ, ejemplar dedicado a Sociología de Grupos pequeños: sectas y tribus urbanas, dir. Andrés Canteras Murillo, núm. 11, 2000, pp. 225 a 266; ID., «La actuación de las sectas coercitivas», Eguzkilore, 18, San Sebastián, Diciembre 2004, pp. 247 a 268; RoDRíGUEZ-CARBALLEIRA Álvaro / ALMENDROS Carmen «Análisis de las sectas coercitivas y de su principal problemática jurídica», Psicología Jurídica, 2006, pp. 335 a 362.

${ }^{1110} \mathrm{Ha}$ de advertirse que la denominación de «sectas destructivas» procede del Congreso de Wisconsin sobre sectas en 1986, como movimiento totalitario con personas dependientes de las ideas del líder y de sus doctrinas bajo la forma de identidad religiosa, asociación cultural, científica o terapéutica y que utilizan técnicas de control mental y de persuasión coercitiva para que los miembros dependan de la dinámica del grupo, de manera que se crea una «epidémica psíquica»y «fenómeno de pensamiento colectivo». Se muestran favorables del uso de este adjetivo gran parte de los estudios, FrIAS LINARES, Mercedes, «El fenómeno del sectarismo en occidente: condicionantes históricos, sociológicos y jurídicos», vv.aa., Aspectos socio-jurídicos de las sectas desde una perspectiva comparada, op. cit., p. 104; Goti ORDEÑANA, J., «Concepto histórico y concepto actual de secta », vv.aa., Aspectos socio-jurídicos de las sectas desde una perspectiva comparada, op cit., p. 101; MoRALEDA, José, Las sectas hoy. Nuevos movimientos religiosos, op. cit., p. 8; RoDRíGUEZ, P., Adicción a sectas, op. cit., pp. 63 y ss; ID., «La Justicia ante el fenómeno de las sectas», Sociología de grupos pequeños: sectas y tribus urbanas, Consejo General del Poder Judicial, Madrid, 2001, pp. 325 a 383; ID., «La sectadependencia, otra forma de adicción», Estudios de Juventud, núm. 53/2001, pp. 154 y ss; VÁZQUEZ, JMa ., Familia y sectas, op. cit., pp. 26 y 27. En el mismo sentido, André DENAUX configura como «destructivas» a aquellas «organizaciones pseudorreligiosas, pseudofilosóficas o pseudoculturales que se dedican a la captación de adeptos para explotarlos mediante falsas promesas y técnicas de coerción psicológicas, siempre en provecho del afán de poder y de lucro de sus líderes», vid. SALARRULLANA, P., Las sectas, op. cit., p. 53 
quasi-adicción o propiamente una adicción ${ }^{1111}$. En contra, se entiende que tal terminología debe ser desechada a priori porque induce a una previa ilegalidad de la secta, y por tanto no representa la realidad ni respeta la libertad religiosa ${ }^{112}$. Sin embargo, este calificativo no es menos peyorativo que el sustantivo. Si bien este término parece haberse acomodado en la terminología cotidiana de la doctrina y en las disposiciones parlamentarias, no puede esperarse de él más que un acotamiento sociológico y psicológico. No obstante, nos parece más acertada una clasificación de los puntos esenciales que concurren en el fenómeno sectario de entidad, al menos peligrosa, o como baremo de riesgo ${ }^{1113}$.

También se las ha denominado «psicogrupos» en relación al intrusismo profesional descubierto a raíz del informe elaborado para el Bundestag en 1998 referente al uso de técnicas pseudo-terapéuticas $^{1114}$.

Finalmente, la terminología que parece se está imponiendo en el ámbito de estudio psicológico hace referencia a la dinámica grupal y su relación con ciertos abusos. En este caso se ha denominado «grupo de abuso psicológico»o «grupo de manipulación psicológica» (GMP) ${ }^{1115}$ con el fin de poner el acento de estudio además de la dinámica grupal en el factor abusivo de la misma de forma intencionalidad y que parece se ha impuesto especialmente en la legislación penal francesa.

\footnotetext{
${ }^{1111}$ RODRÍGUEZ, P., Adicción a sectas, op. cit., p. 29, y pp. 63 y ss; ID., «Sectadependencia», op. cit., pp. 154 y ss; se muestran partidarios también de la analogía con la adicción, ECHEBARRía ECHABE, Agustín, «Procesos grupales y construcción de la identidad: el caso de las sectas», vv.aa., Aspectos socio-jurídicos de las sectas desde una perspectiva comparada, op. cit., p. 49; Cuevas BARRANQUERo José Miguel / CANTO ORTIZ Jesús M., Sectas, Cómo funcionan, cómo son sus líderes, efectos destructivos y cómo combatirlas, Ediciones Aljibe, 2006 pp. 61 a 63.

1112 Alonso Herreros R / MuÑIz Calaz B / Ramos SuÁrez A / RodríGueZ JA., «Actitud del ordenamiento español ante las sectas», op. cit., p. 43.

${ }^{1113}$ Se pueden resumir en las siguientes características descritas por Pepe RODRÍGUEZ: cohesión del grupo en la doctrina; estructura teocrática, vertical y totalitaria; exigencia de adhesión incondicional al grupo y al líder; grupo cerrado y dependencia al grupo; debilitamiento de los derechos individuales por la misma normativa doctrinal; control de la información como técnica de aislamiento, aglutinante de la identidad y control de la pervivencia del grupo ante ataques de foráneos al grupo; empleo de técnicas de manipulación, coerción persuasiva que se ocultan en actividades terapéuticas, espirituales; y rechazo total de la sociedad y de las instituciones, puesto que fuera del grupo - comenta el citado autor- todos son enemigos; actividad prosélica, recaudación de dinero; obtención por medio de la coacción psicológica del patrimonio de los miembros, y obtención de dinero a través de la venta de cursos, explotación laboral», RODRÍGUEZ, P., Adicción a sectas, op. cit., pp. 30 a 33.

${ }_{1115} \mathrm{Vid}$. CUEVAS BARRANQUERO, JM, Evaluación de persuasión coercitiva en contextos grupales, op. cit., p. 55.

1115 Langone Michael D., «Psychological abuse», Cultic Studies Journal, 9, 1992, pp. 206 a 218; conforme también CUEVAS BARRANQUERO, JM, Evaluación de persuasión coercitiva en contextos grupales, op. cit., p. 57 y pp. 261 y ss; Almendros Carmen / GámeZ-GuadiX Manuel / CARrobles José Antonio / RodríGueZCARBAlleira Álvaro, «Abuso psicológico en grupos manipuladores», Behavioral Psychology/Psicología Conductal, 19, pp. 157 a 182; PASCUAL Jordi / VIDAURRÁZAGA MEZA Enrique, Grupos de manipulación psicológica en Cataluña, situación y conceptos, Carles Riera i Albert y Jordi Pascual i Saüc (dir.), AIS, Servicio de Estudios, 2005, pp. 23 y ss., en concreto «entendemos por grupo de manipulación psicológica el resultado de la utilización, por parte de los miembros de una organización social, de prácticas de sujeción basadas, sobre todo, en la satisfacción no consciente de necesidades afectivas -tanto de los seguidores, como de los líderes-, que producen vínculos múltiples de dependencia recíproca entre los miembros y una adhesión exclusiva o preeminente de éstos en relación al grupo», ID., ibidem, op. cit., pp. 85 y 86.
} 


\section{Criterio sociológico}

El término «sectas», fue re-introducido por Max WEBER y Ernst TROELTCH ${ }^{116}$, como término contrapuesto al de «iglesias» conocidas, tradicionales, como institución obligatoria que administraba la gracia divina, cuya adscripción personal es desde el nacimiento ${ }^{1117}$, mientras que en las sectas la adscripción es voluntaria pero bajo la exclusividad, meritocracia y deber social que delimita cada grupo.

En los años setenta ya se concluyó que el problema de las sectas, desde una perspectiva sociológica, era uno de los más importantes. La problemática efectivamente también es sociológica si atendemos a la estructuración y a la organización, y especialmente a la separación y creencias diferentes de las tradicionales, de manera que para el sistema social y normativo, supone cierto riesgo la aparición de grupos de esta índole.

WILSON $^{1118}$ expone que las sectas son agrupaciones de carácter voluntario en una diversidad de creencias religiosas, la secta admite o rechaza a la persona por medio de cierta prueba de méritos, lo que constituye un acceso especial para que la secta pueda comprobar si existe un fuerte sentido de identidad, y de tal forma un sometimiento pleno y consciente en el grupo, cuya formación y reclutamiento son conscientes y deliberados. Todo ello bajo la dirección de la autoridad, que puede ser la suprema revelación de un líder carismático, o la reinterpretación de escritos sagrados, pero siempre como forma de rechazo de las autoridades oficiales de la fe ortodoxa.

Propone una definición de secta sustanciada en ocho aspectos de la dinámica grupal ${ }^{1119}$. WILSON acierta al advertir que existe un error ordinario en la tradición del estudio de las sectas,

${ }^{1116}$ Véase sobre la problemática del término y la trascendencia de las sectas en el mundo de la ética protestante, WEBER, M., La ética protestante y el espíritu del capitalismo, op. cit., pp. 153 y ss., y 265 y ss; ID., «Kirchen» und «Sekten» in Nordamerika. Eine Kirchen und sozialpolitische Skizze - Soziologie, Weltgeschichtliche Analyse, Stuttgard, 1956, pp. 382 y ss; TROELTCH se contrapone a WEBER en lo referente a la tipología de los sujetos adeptos a sectas. Considera que estos sujetos pertenecen a clases bajas y marginales, que se vinculan por lazos de afinidad. A diferencia de WEBER entiende que la iglesia es conservadora y universalista mientras que las sectas buscan la diferencia y la innovación en grupos reducidos, TROELTCH, Ernst, The social teaching of the Christian churches, McMillam, New York, 1931.

${ }^{1117}$ WeBER, M., Ensayos sobre sociología de la religión, Vol. I, op. cit., pp. 207 a 231, Vol. II, op. cit., pp. 15 y 16; ID., Sociología de la religion, op. cit., p. 114 y ss.

${ }_{1118}$ WiLSON, B., Sociología de las sectas religiosas, op. cit., pp. 26 a 28.

${ }^{1119}$ Concretamente: a) la voluntariedad en la adscripción como exigencia adictiva; b) exclusivismo o sometimiento absoluto al grupo en la vida diaria, de manera que la secta se convierte en el punto más importante de la persona; $c$ ) méritos o acto de aceptación para el acceso y ascenso en la secta como reforzamiento de la identidad grupal, si bien conforme la secta va teniendo mayor aceptación en el mundo va restando importancia a la prueba de méritos; $d$ ) autoidentificación del sujeto con el grupo mediante una fuerte concepción del «nosotros»; $e$ ) estatus de élite a semejanza de pueblo elegido en clara distinción con los demás; $f$ ) expulsión en caso de contradecir las normas del grupo, sin embargo dicha característica se relaja conforme el grupo tiene miembros desde el nacimiento; $g$ ) conciencia de la entidad grupal, aunque igualmente se puede relajar dicha característica, depende del principio de 
que se refiere a que siempre se señala que el grupo gira alrededor de un líder carismático, profético o mesiánico; sin embargo, este dato parece sólo cumplirse antes del siglo XIX, sobre todo en aquellos movimientos aun hoy existentes que apelan a la fe mesiánica o la creencia en la segunda venida, o instauración de un nuevo orden social, sin embargo con la llegada de las sociedades industrializadas (podríamos decir en verdad con la llegada de sociedades funcionalmente diferenciadas o institucionalizadas), las sectas no se erigen tanto en el eje central de líderes carismáticos, sino en las «expectativas» de un rol en otro rol y en la organización. No se trata tanto de una confianza personal por cuanto «(l)as pretensiones carismáticas sólo se encuentran en sectores marginales del sistema social, en las actividades de la sociedad menos institucionalizada» ${ }^{120}$, lo que coincide, como veremos más abajo, con las aportaciones de LUHMANN a la sociología de las religiones.

De este modo, WILSON concluye que aunque la mayoría de las sectas están integradas por «grupos primaros compactos y de carácter local, esto no ocurre ya tanto cuando se trata de grandes organizaciones internacionales (...) ya que todos estos grupos no consideran a la comunidad como un elemento vital de por sí para la religión» ${ }^{1121}$, por eso afirma que «(l)as nuevas sectas nacen como respuesta no tanto a una coyuntura económica determinada cuanto a una situación de inseguridad social y cultural en las sociedades avanzadas opulentas y pluralistas (...) La salvación que ofrecen no consiste en la nueva formación de una Gemeinschaft, ya que es frecuente que no hayan experimentado nunca una vida comunitaria estable, sino más bien en la legitimación y consagración del anonimato y del impersonalismo» ${ }^{1122}$.

Por otro lado, el Instituto de Ateísmo Científico de la Academia de las Ciencias Sociales, instituto adjunto al Comité Central del Partido Comunista, como ente del ateísmo llamado científico calificó a las sectas como grupos opositores de las Iglesias dominantes caracterizadas por una religiosidad intensificada, hasta el extremo del fanatismo, con conductas de exclusividad y tendencia al aislamiento ${ }^{1123}$. Estas características no difieren mucho de las señaladas por WEBER, según hemos visto.

voluntariedad cuando los seguidores no han sido aun «socializados»; $h$ ) legitimación alrededor de un líder carismático, y en otras ocasiones una legitimación ideológica/religiosa en relación al grupo del que se escinden o de otros, pero en ambos casos se afirma la legitimidad propia de su normativa moral sobre la medida de su propia autoridad, ID., ibidem, op. cit., pp. 29 a 35.

${ }^{1120}$ ID., ibidem, op. cit., p. 20 . Amplio estudio sobre sectas de aparición en el siglo XIX, VIDAL MANZANARES, C., Psicología de las sectas, op. cit., pp. 23 a 94.

${ }^{1121}$ WILSON, B., Sociología de las sectas religiosas, op. cit., p. 226.

1122 WiLsON, B., Sociología de las sectas religiosas, op. cit., pp. 228 y 229.

1123 Instituto de Ateísmo Científico de la Academia de las Ciencias Sociales de la URSS, El Ateísmo científico, Madrid, 1983, pp. 76 a 79. 
La tesis funcionalista considera que el auge de las sectas se debe a una lucha o conflicto propio de las sociedades avanzadas, industrializadas. La sociología alemana funcionalista ${ }^{1124}$ se decanta por la utilización de la expresión religiones de la juventud (Jugendreligionen), sin embargo el paso del tiempo ha demostrado que estos «nuevos» grupos se han consolidado, nada de jóvenes o de juventud tienen más que los hijos nacidos en el seno del grupo. La doctrina alemana socio-funcionalista centra las causas en la satisfacción de necesidades, válvulas de seguridad de las tensiones entre grupos ${ }^{1125}$.

Otro sector doctrinal circunscribe el fenómeno sectario en unos parámetros más neutrales, pero excesivamente amplios para su compresión. En concreto, CANTERAS MURILLO define secta religiosa «como un producto genuinamente antropológico asociativo dotado de un simbolismo propio de carácter transcendente, que espera con ánimo de exclusividad, a diferenciarse objetiva y/o subjetivamente de un cuerpo social y/o doctrinal más amplio» ${ }^{1126}$.

Otra opinión sobre la diferenciación entre religión y secta es sustentada por LLAMAZARES FERNÁNDEZ ${ }^{1127}$, quien afirma que en los grupos denominados sectas existe un poder de liderazgo del líder, «personal», en relación a que «es receptor permanente de comunicaciones divinas», como «dictador de la conciencia»y portador del «germen de la división», mientras que en las religiones tradicionales y en aquellos grupos no sectarios, el liderazgo es «institucional». De ahí que en las sectas exista una organización cerrada, fuerte y jerárquicamente estructurada por un líder que utiliza el oscurantismo como principio de la sumisión de los adeptos. En lo que estamos especialmente de acuerdo con este autor es en que no podemos denominar secta a aquellos grupos que lícita y legítimamente ejercitan el derecho de la libertad de conciencia ${ }^{128}$. En tal medida, nosotros proponemos que el término secta sea complementado con un adjetivo, lo cual ayudará a distinguir a los grupos religiosos de los criminales.

AMORÓS BUQUERAS realiza un loable intento por definir jurídicamente a estos grupos como «(a)quellas agrupaciones con finalidad pretendidamente religiosa, sin raigambre histórica en Occidente y nivel de afiliación bajo, carentes de un cuerpo de doctrina religiosa propia y de una liturgia que se propone a la sociedad como alternativa a las grandes religiones tradicionales.

\footnotetext{
1124 Vid., MAYER, Jean Francois, «El mundo de los nuevos movimientos religiosos», Cristianismo y sociedad, XXV/3 núm. 93, Tierra Nueva, México, D.F., 1987, p. 21: «En Alemania han sido designados como Jugendreligionen (religiones de la juventud), término muy poco satisfactorio científicamente pues los adherentes envejecen y no necesariamente defeccionan, en los países de habla inglesa se emplea cults para referirse a «una nueva religión en sus inicios, un grupo poco estructurado reagrupado alrededor de un líder carismático».

1125 Vid. VÁZQUEZ, JMa ., Familia y sectas, op. cit., p. 45.

1126 CANTERAS Murillo, A., «Asociacionismo y libertad individual: Los movimientos religiosos-sectarios», vv.aa., Aspectos socio-jurídicos de las sectas desde una perspectiva comparada, op. cit., pp. 55 y 56.

1127 LLAMAZARES FERNÁNDEZ, D., «Sectas y Derecho fundamental de Libertad de conciencia», op. cit., p. 139.

1128 LlamaZARES FernÁNDEZ, D., Derecho de la libertad de conciencia, I, op. cit., p. 242.
} 
También se llama así a los grupos similares a la religión» ${ }^{1129}$. Sin embargo, define -junto a otros autores, como COLLADO CAÑo y MARTínEZ VILLASEÑOR- el fenómeno como «agrupación de personas en la que la sociedad percibe un vínculo con lo religioso y que desarrolla de modo habitual un comportamiento lesivo de la libertad individual y perturba la estabilidad social» ${ }^{1130}$, aceptando por tanto que toda secta es per se destructiva, incurriendo en el mismo error que algunos de los otros autores estudiados.

En conclusión, desde la sociología se impone un modelo de estudio de las sectas basado en la estructuración social del grupo y su diferenciación en el factor de lo transcendental.

\section{E. Punto de vista penal}

Acertadamente BONET ESTEVA entre otros según lo visto, aboga por un cambio de concepto, introduciendo elementos normativos de diferenciación, de «sectas» a «grupos de manipulación mental». Con dicho cambio se pretexta un cambio de paradigma en el tratamiento jurídico penal de las sectas, por cuanto no todas las sectas utilizan técnicas de manipulación mental, ni todos los que utilizan estas técnicas tienen el carácter de sectas ${ }^{1131}$.

La denominación que propone la citada autora la consideramos muy acertada también, por cuanto desmitifica el reducido y concreto ámbito de criminalidad de la manipulación mental o persuasión coercitiva que tradicionalmente había sido asociado a las sectas y pone el acento en la habitualidad de que sean los grupos del género social que fueren, los que aplican estas técnicas ilegítimas. De este modo, consideramos acertado el cambio de paradigma porque centra y amplia el debate y la problemática a todo grupo criminal con fines lícitos o ilícitos, de manera que, en

${ }^{1129}$ Vid. BuQUERAS, María Elena, «Las religiones alternativas y el derecho a la libertad religiosa», vv.aa., Derecho y Opinión, núm. 0, 1992, p. 93.

${ }^{1130}$ Vid. AmORÓS BuQueras A / COllado CAÑo ML / MARTíneZ Villaseñor L., «Concepto jurídico de sectas», Sectas y Derechos Humanos, op. cit., p. 150 y 140. También utilizan el adjetivo «destructivas» otros autores, quienes señalan diversas características básicas, que al menos varias de ellas coinciden en estos grupos: Grupo absoluto; organización estructurada en dos niveles, grupo teocrático, vertical y totalitario, y por otro lado el carácter igualitario; una doble personalidad social, caracterizada por el secretismo interno, y la proyección hacia el exterior de una imagen sana beneficiosa; el trabajo a favor de la secta como medio de salvación; fanatismo; y el afán de lucro, Benterrak Ayensa M / Collado Márquez Ai / Fuentes Castillejos M / Martínez Rubio A / REDONDO GARCÍA M., «Aspectos históricos y sociológicos de las sectas en España», op. cit., p. 113.

${ }^{1131}$ BONET ESTEVA, Margarita, «Grupos de manipulación mental ¿Un cambio de paradigma en el tratamiento jurídico penal?», Estudios penales en homenaje al profesor Manuel Cobo del Rosal, enero 2005, p. 148. Hace décadas GÖPPINGER aludía, en su manual Criminología, a la fenomenología criminal de las sectas de la siguiente manera: «Las sectas constituyen asociaciones religiosas de volumen variable y de formas de conducta y objetivos diversos. Casi siempre ofrecen la imagen de un aislamiento de diferente intensidad que les hace vivir más o menos al lado de la sociedad. Dado que la moral del grupo suele ser muy alta, precisamente en las sectas de mayor volumen apenas se encuentra criminalidad. En este aspecto, sin embargo, están expuestas al peligro las comunidades pequeñas, en las que en ocasiones se produce una violación de las normas del Derecho penal en el curso de la persecución de misiones con motivación religiosa, fanáticamente mantenidas», si bien reconoce que sólo existen «algunas descripciones de casos penales notables», asociados al fanatismo, GöPPINGER, Hans, Criminología, trad. MaL Schwarck e Ignacio Luzarraga Castro, 2a ed., Reus, 1973, pp. 176 y 453. 
nuestra opinión, adquiere más sentido y coherencia nuestra propuesta de analizar la autoría de conciencia, por convicción y al enemigo, desde el punto de las organizaciones criminales, especialmente en las sectas criminales.

Como ya expusimos en el capítulo segundo, parte de la doctrina penalista ${ }^{1132}$ cuando se ha referido a ciertos fanáticos y líderes o miembros de sectas, admite la posibilidad de un trastorno mental transitorio o causas de inimputabilidad producidas fundamentalmente por causas de «aislamiento cultural». En nuestra opinión, el aislamiento cultural no sería una causa de exención o disminución de la inimputabilidad, sino de inexigibilidad subjetiva que fundamenta la aplicación de un estado de necesidad exculpante en aquellos supuestos que sin llegar a suponer una alteración de la percepción o anomalía de la realidad (esto sería una consecuencia, otro injusto, o causa) propician en el sujeto un déficit de socialización atribuido al contexto cultural, a la autoridad, o a la norma totalitaria y autoritaria, pero también en supuesto concurrentes de «adicción comportamental», «manipulación mental» o «persuasión coercitiva». Ejemplo paradigmático de estos casos serían el de algunos jóvenes nazis y miembros de sectas criminales totalitarias y autoritarias, o que por dinámicas comportamentales hayan nacido en el seno de la organización o lleven muchos años aislados de un contexto de libertades y democrático.

Desde este cambio de perspectiva, consideramos que adquieren relevancia jurídico-penal diversos supuestos especiales del déficit de socialización en el estado de necesidad exculpante, de modo que en determinadas organizaciones criminales -y especialmente como fenomenología paradigmática- en las sectas criminales coexisten las tres tipologías de autores morales: el autor de conciencia, el autor por convicción y el enemigo. Mediante el modelo que estamos desarrollando se pueden explicar posteriormente no sólo la coexistencia de estas tres tipologías que habitualmente se habían tratado separadamente en la doctrina, sino su especial transcendencia en el delito de organización o delito sistémico, en la coautoría y en la autoría mediata de aparatos de poder organizados, con la especial consecuencia de que el tratamiento penal en estos grupos puede ser particularizado e individualizado a cada sujeto, dejando de esta manera atrás la vieja doctrina roxiniana de los aparatos de poder, para concluir que en cualquier tipo de organización delictiva, también en la coautoría, subyace el modelo sistémico de explicación de la dinámica grupal, hasta el punto que la anulación de la voluntad de un sujeto o

\footnotetext{
1132 BAUCElls I Lladós, J., La delincuencia por convicción, op. cit., pp. 335 y ss; JeRICó OJER, L., El conflicto de conciencia, op. cit., p. 371; LUZÓN PEÑA, D-M., «Actuación en conciencia», op. cit., p. 15; FLORES MENDOZA, F., Objeción de conciencia, op. cit., pp. 203 y 204. En la doctrina española únicamente TAMARIT SUMALLA acepta expresamente la posibilidad de una atenuante de alteración de la percepción del art. $20.3^{\circ} \mathrm{CP}$ en «supuestos de aislamiento cultural» que impida valorar al sujeto las circunstancias por el lejano conocimiento de los valores de una sociedad, TAMARIT SUMALlA, JMa ., «Libertad de conciencia y responsabilidad penal», op. cit., pp. 397 y ss.
} 
la disminución de la voluntad o la máxima responsabilidad de otros no perjudica la imputación objetiva del delito sistémico o de organización, si bien se individualiza la responsabilidad de cada sujeto mediante un modelo de imputación basado en el injusto propio.

\section{F. Propuesta de terminología jurídica: sectas «criminales» y especialmente «coercitivas»}

Visto todo lo anterior, puede ya concluirse que la denominación de estos grupos religiosos por parte de la doctrina lleva inherentemente una concepción negativa de este fenómeno social.

En nuestra opinión, consecuentemente, el término secta y su definición siguen siendo peyorativos, pero en puridad científica este término es neutro ${ }^{1133}$ o estrictamente sociológico. Además este término no resalta la fenomenología criminal que es precisamente la que se alude con la concepción peyorativa del término. Sin embargo, no parece justo denominar a un grupo socialmente considerado secta, como un grupo criminal o cuyos miembros tengan fines delictivos particulares pero enraizados en la secta.

Consideramos «secta» a aquellas agrupaciones de personas que la sociedad percibe como religiosas, o más ampliamente como grupos unidos por el vínculo de una creencia o ideología común con independencia de la naturaleza de ésta, y que en el acervo social se considera su estructura, conductas, credos o ideales, un perjuicio para el modelo tradicional de convivencia.

Por esta razón hemos tratado de evitar la palabra secta siempre que hemos podido, sustituyéndola por grupo. Sin embargo, una secta (grupo) como organización criminal posee una delimitación conceptual mayor, precisamente por el calificativo que se le acompaña. Lo relevante para diferenciar la realidad de un concepto es que el término que se le asigne sea capaz de distinguir jurídicamente las sectas peyorativamente consideradas por el acervo social, de aquellas que tienen fines delictivos y/o utilizan técnicas de control mental. Podríamos denominarlas sectas «delictivas» o «criminales» sin más, con esto se pone el acento en su verdadera dimensión científica, en este caso, aquella que reclama o se aprecia por los demás como peligrosa o quebrantadora de derechos fundamentales, y en definitiva, aquellas que cometen algún delito mediante su ser organizativo.

Sin embargo, se podría hilar más fino y sumar una subcategoría penal más. Consideramos que con el adjetivo «coercitivas», que hace años ya tuvo cierto respaldo ${ }^{1134}$, se expresa con mayor

\footnotetext{
1133 Guerra, M., «Lo que es y lo que no es una secta», op. cit., p. 17.

1134 RoDRÍGUEZ-CARBALlEIRA, A., «El fenómeno de las sectas coercitivas», op. cit., pp. 229; ID., «La actuación de las sectas coercitivas», op. cit., pp. 248 y ss., y en coherencia denomina a dichas técnicas «persuasión coercitiva»; VV.AA., «Totalisme i voracitar. Una aproximació interdisciplinária al «fenomen sectari» a Catalunya», AIS/CROAS, Barcelona, 1994; PASCUAL J / VIDAURRÁZAGA MEZA E., Grupos de manipulación psicológica en Cataluña, situación y conceptos, op. cit., pp. 23 y ss.
} 
claridad la naturaleza criminal y normativa de los delitos contra la libertad de obrar en general que perpetran algunos grupos, concretamente con la comisión de un delito de coacciones agravado, y esto a diferencia de la denominación «grupos de manipulación psicológica» con la que se señala generalmente cualquier otro ámbito. En esencia, los métodos, fines y delitos que persiguen y la convicción con la que se actúa suponen un grave atentado contra la configuración normativa de la sociedad, y especialmente contra uno de los derechos básicos de la persona y su dignidad, el ataque sin escrúpulos a la libertad de pensar y actuar en general.

Así, el término «coercitivas» constata la relevancia jurídica y criminal del grupo que utiliza la persuasión coercitiva. Esta peligrosidad inherente se puede concretar en el siguiente concepto normativo: el consentimiento desinformado. El adepto no sabe en qué grupo se está integrando, ni su verdadero nombre muchas veces, ni su doctrina religiosa o ideológica, ni las conductas y procedimientos que tendrá que realizar para pertenecer a al grupo de forma plena y estable. El adepto está desinformado de los tratamientos a los que se somete, que muchas veces son realizados por personas sin título o habilitación, o sin que se hayan incorporado a los colegios administrativamente autorizados. El adepto desconoce la utilización de técnicas de persuasión que se utilizan sobre él, ni el constreñimiento físico y psicológico que suponen muchas de las técnicas que se utilizan contra él, ni la obligatoriedad muchas veces de separarse de la familia, de sus hijos, del trabajo como contraprestación al servicio que ofrece el grupo, o la obligatoriedad de pagar grandes sumas de dinero para conseguir la «salvación» o mayor formación. El adepto desconoce que convivirá con la censura del exterior.

En definitiva, una secta «coercitiva» es aquella que, aun no habiendo ejecutado un delito (delito-fin), por su doctrina, estructura, y captación prosélica o medios de adoctrinamiento, constituye una organización criminal en sí misma. La secta criminal responde a todos y cada uno de los presupuestos del enemigo, pero de igual manera la dinámica criminal puede trasladarse a cualquier otra clase de organización criminal, si bien, las técnicas de persuasión coercitivas suelen aflorar en organizaciones terroristas y bandas de índole religioso y/o político.

Lo que no se puede pretender es relacionar el término secta, o el fenómeno sectario, con una decadencia de valores ${ }^{1135}$. Es evidente que quien pertenece a un credo considerara falsas todas las demás creencias, pero el término secta es peyorativo en tanto que la condición de falsedad es vista por el hablante como un peligro criminal. Esto es que principalmente el fenómeno sectario es un síntoma de democracia, Derecho, libertad, y ante todo de libertad de conciencia, y no como

1135 También Cuevas Barranquero JM / Canto Ortiz JM., Sectas, Cómo funcionan, op. cit., p. 17. 
consideran algunos «manifestaciones de una crisis de civilización, de un cambio cultural del hombre occidental» ${ }^{136}$.

Así las cosas, podemos tomar como hipótesis de trabajo las sectas como sistemas sociales que fomentan precisamente la libertad de conciencia y religiosa y que ante la perpetración de injustos merecen, según a la conclusión a la que hemos llegado en los capítulos precedentes, la atenuación o exoneración de la responsabilidad por déficit de comunicación/socialización atribuido a la norma, sin embargo, y por otro lado, no se ha analizado en la doctrina penal el peligro que suponen las sectas con estructuras y dogmas totalitarios que utilicen medios que ponen en peligro la libertad de obrar en general. Sobre esta otra cara de la moneda, convergen grupos o sujetos que representan casos paradigmáticos de la autoría por convicción y del enemigo, asociados a fanáticos extremistas, si bien, según nuestras conclusiones del capítulo segundo, también especialmente coexisten motivos de atenuación y de exoneración de la responsabilidad criminal, en casos muy particulares asociados al déficit de socialización atribuido a un tercero, y que pueden llevar a la concurrencia del estado de necesidad exculpante, sin que suponga ninguna contradicción, sino que por el contrario: la confirmación de un análisis estrictamente normativo y funcional.

En conclusión, y en cuanto a lo que interesa a la ciencia penal y criminológica, las sectas pueden ser «criminales», aquellas que cometan cualquier delito-fin en el seno de la organización, y especialmente «coercitivas», aquellas que utilizan particularmente la manipulación mental o persuasión coercitiva para configurar la organización criminal y sirve a la postre para perpetrar los delitos-fin.

\section{III.- Naturaleza de la activicidad}

\section{A. Introducción}

Es notorio que gran parte de la sociedad tiene miedo a ciertos grupos religiosos porque, entre otras razones, se aíslan o tratan de evangelizar, conviven con sus propios dogmas y costumbres, sin embargo, muy acertadamente el antropólogo PRAT ha puesto de manifiesto que «lo más parecido a los sectarios actuales han sido los sectarios del pasado, esto es los herejes, los cristianos, los grupos milenarios y mesiánicos, etc., que han proliferado a lo largo de los siglos y

\footnotetext{
${ }^{1136}$ FRIAS LINARES, Mercedes, «El fenómeno del sectarismo en occidente: condicionantes históricos, sociológicos y jurídicos», vv.aa., Aspectos socio-jurídicos de las sectas desde una perspectiva comparada, op. cit., p. 108 .
} 
sobre los que existe una buena acreditación histórica» ${ }^{1137}$. Los inicios de una secta, los inicios de un miembro en la secta, y la pautas de conducta en éstas no se diferencian mucho de otros estamentos sociales como en las órdenes religiosas cristianas de los conventos, o el servicio militar y el ejército, sin embargo, este antropólogo, centra la problemática en el conflicto de intereses entre grupos hegemónicos que controlan a los demás grupos minoritarios que suponen una alternativa y por lo tanto un peligro para poder de los grupos hegemónicos ${ }^{1138}$.

Podemos dividir en tres tipos la investigación de la problemática sectaria. Por un lado, existen investigaciones, minoritarias ha de aclararse, que se centran en un modelo de análisis denominado social drift model, un modelo más bien causal que estudia la fenomenología de las sectas como sistemas sociales. Por otra, existen posiciones que defienden que el proceso de conversión que sufre la persona viene a causa directa de un procedimiento de «lavado de cerebro», «manipulación mental» o «persuasión coercitiva» como técnicas que constriñen la voluntad y el pensamiento. $\mathrm{Y}$ finalmente otra a la que podemos denominar sistémica al diferenciar su funcionalidad operativa.

Una secta como agrupación de personas está integrada por diversas formas y circunstancias que la hacen especialmente atípica respecto a las «iglesias»o religiones mayoritarias. Su organigrama, estructura, miembros, roles, líder o líderes, en determinadas circunstancias puede representar, por un lado la creación de un riesgo no permitido, cuando los miembros desconocen la doctrina moral ética y la trascendencia de su ejercicio, o de otra, una «comunidad riesgosa» cuando todos sus miembros son conocedores de los medios peligrosos que se utilizan para captar a futuros miembros.

La identidad en el ámbito sectario, o la personalidad, quizás sea la clave para articular una configuración básica del fundamento estructural, organizativo y conductual de los sujetos perteneciente a estos grupos, si bien difiere en todo grupo de personas, la identidad social como categorización social y proceso de comparación social y personal, es decir, la identidad que se adquiere dentro de un grupo, y la identidad que nos diferencia dentro del mismo, respectivamente. La identidad social ${ }^{1139}$ es la base para diferenciar un tipo de grupo de otro 10.
1138 ID., ibidem, op. cit., p. 13 .
1139 TAJFEL, Henri, Grupos humanos y categorías sociales, Herder, Biblioteca de Psicología 15, Barcelona, 1984,
pp. 292 y 293 comentaba «por identidad social aquella parte del autoconcepto de un individuo que deriva del
conocimiento de su pertenencia a un grupo (o grupos) social junto con el significado valorativo y emocional
asociado a dicha pertenencia (...) Vista desde esta perspectiva intergrupal de la identidad social, la categorización
social puede, por tanto, considerarse como un sistema de orientación que ayuda a crear y definir el puesto del
individuo en la sociedad» y remata que «(l)a supuesta necesidad de diferenciación (...) es lo que parece determinar,
en ciertas condiciones, la mayor eficacia de la secuencia categorización social-identidad social-comparación social»,

${ }^{1137}$ PRAT, Joan, El estigma del extraño. Un ensayo antropológico sobre sectas religiosas, $3^{\mathrm{a}}$ ed. Ariel, 2007, p. 
(endogrupolexogrupo), pero también de uno legal a otro criminal. En determinadas organizaciones criminales especialmente en las sectas se categoriza de una forma fanática la identidad social, lo que produce una progresiva categorización social de la identidad personal e individual que va perdiendo su autonomía a favor de la identidad social del endogrupo (conformidad, obediencia, influencia, sugestión, persuasión) y en contra del exogrupo. Este fenómeno se asemeja a la adicción ${ }^{1140}$ a una conducta, y así convincentemente se ha expresado, caracterizándolo como «adormilamiento de la identidad personal», o «activación crónica de su identidad social de "sectario"»"

\section{B. Tratamiento del sectarismo: modelo del «lavado de cerebro», modelo causal y sistémico \\ 1. Introducción}

La Sociología y anteriormente la psicología han dado buenas muestras de la capacidad del ser humano para persuadir. Prueba de ello es, aunque más levemente, la inducción como forma de participación criminal. Pero la influencia social es un factor que en muchas ocasiones consigue determinar la voluntad de los sujetos sin percatarse de ello. En su virtud, VIDAL MANZANARES expone que en las sectas confluyen necesidades legítimas como la necesidad de amor, de identidad, de ser útil, amistad y consuelo, de respuestas trascendentales ${ }^{1142}$; sin embargo, en otras ocasiones, aparecen otras necesidades que entran en conflicto con la sociedad y que son o rayan lo ilegítimo, como la rebeldía contra el entorno, de manera que no puede concluirse que todos los adeptos a sectas estén manipulados, sino que el adepto es un a veces un «rebelde con retraso» ${ }^{1143}$, o actúa como venganza contra el entorno, de modo que su membrecía en la secta es la «firme garantía de que el adepto podrá obtener la venganza a la que cree tener derecho», por eso, el adepto trata a los sujetos externos al grupo como enemigos ${ }^{1144}$. En este sentido el adepto supera sus frustraciones mediante el combate del entorno.

ID, ibidem, op. cit., p. 311; TAJFEL Henri / TURNER JC., «The social identity theory of intergroup behavior», S. Worchel / W Austin (Edit.) Psychology of Intergroup Relations, IL Nelson Hall, Chigago, 1986, pp. 7 a 24; AllPORT, Gordon W., La naturaleza del perjuicio, $4^{\mathrm{a}}$ ed., Ed. Universitaria de Buenos Aires, 1971; DoISE, W., «Las relaciones entre grupos», en MoscovicI, S., (ed.), Psicología Social (I), Paidós, Barcelona, 1985; MosCOVICI S / FAUCHEUX C., «Social influence, conformity bias, and the study of active minorities», Advances in Experimental Social Psychology, 6, 1972, pp. 149 a 202; ID., (ed.), Psicología Social (I), Paidós, Barcelona, 1985; TURNER, JC., Social influence, Buckingham, Open University Press., 1991.

${ }_{1140}$ RodríGUEZ, P., Adicción a sectas, op. cit; ID., El poder de las sectas, Ed. B, Barcelona, 1989.

1141 ECHEBARRÍA dice que «en un contexto en el que la identidad social determinada es activada por factores contextuales, el resto de las identidades se mantienen adormecidas», ECHEBARRÍA ECHABE, Agustín, «Procesos grupales y construcción de la identidad: el caso de las sectas», vv.aa., Aspectos socio-jurídicos de las sectas desde una perspectiva comparada, op. cit., p. 41, y 42.

1142 Vidal ManZanares, C., Psicología de las sectas, op. cit., pp. 41 a 80.

1143 ID., ibidem, op. cit., pp. 82 y ss.

1144 ID., ibidem, op. cit., p. 94. 
PÉREZ / MugnY ${ }^{1145}$ establecieron que la influencia social era capaz de modificar las percepciones, los juicios y el comportamiento, en definitiva, la voluntad. Antes AscH habló de la conformidad ciega y MILGRAM de la obediencia a la autoridad ${ }^{1146}$. Es evidente en este respecto el gran paralelismo entre algunas formas de captación terroristas, en concreto del terrorismo yihadista y las técnicas de persuasión de las sectas coercitivas, lo que hace que se confundan o más bien se complementen y asocien los conceptos de autor de conciencia, autor por convicción, enemigo, y persuasión coercitiva o manipulación mental en las sectas, al trascender la fenomenología criminal a todos los ámbitos sociales, especialmente en las organizaciones criminales.

Por ello, en los casos en los que se pruebe que han utilizado técnicas de persuasión, unidas al aislamiento cultural muchas veces, podemos concluir, al igual que lo hicimos en el capítulo dedicado a la autoría de conciencia, por convicción y al enemigo, que en algunos terroristas, al igual que en adeptos concurra una causa de exculpación para el Derecho penal sin tener que recurrir a las causas de inimputabilidad.

\section{Modelo del «lavado de cerebro»}

No todos los especialistas se ponen de acuerdo sobre la realidad del «lavado de cerebro». En Estados Unidos la libertad de conciencia se halla amparada por la $4^{\text {a }}$ Enmienda de la Constitución, como ya explicamos supra, sin embargo esta libertad se limita por los medios o actos que atenten lógicamente contra los derechos de los ciudadanos y contra el orden público, inclusive cuando se usen medios como las drogas, la manipulación ritual de serpientes venenosas o la poligamia ${ }^{1147}$.

La persuasión no es jurídicamente reprochable, ni está prohibida. Tanto es así, que es un mecanismo de defensa en muchos ámbitos, o de control jurídicamente regulado. Piénsese en el padre que persuade a su hijo de no comprarse una moto, o para que llegue habitualmente pronto a casa, o más concretamente, para que profese su misma religión. Sin embargo si la persuasión es coercitiva, es decir, no jurídicamente permitida, se quebranta la libertad de la persona por entero y de forma general su libertad de actuar. Ejemplos de la persuasión coercitiva se dan en los

\footnotetext{
${ }^{1145}$ PÉREZ JA / MugnY G., «Categorización e influencia minoritaria», Anuario de Psicología, 32, 1985, pp. 99 a 116.

${ }^{i 146}$ MILGRAm, Stanley, Obediencia a la autoridad. Un punto de vista experimental, $4^{\text {a }}$ ed., Editorial Declee de Brouwer, Bilbao, 1980; véase al respecto también Cuevas BarRanquero JM / CANTO OrTiz JM., Sectas, Cómo funcionan, op. cit., pp. 36 y 37.

1147 Vid. TAMARIT SumAlla, JMª, «Las sectas y el Derecho penal», vv.aa., Aspectos socio-jurídicos de las sectas desde una perspectiva comparada, op. cit., p. 279, hace referencia al estudio de WOOD, JE., «New religions and the first Amendment», op. cit., p. 458 y ss.
} 
estafadores, en los terroristas para captar sus miembros, en algunas formas de inducción y, especialmente, en las coacciones psicológicas.

Como decíamos, el modelo del lavado de cerebro se basa en que es posible controlar la voluntad de las personas. Esta corriente de opinión se denominó primero «lucha del pensamiento» por Mao TSE-TUNG. Posteriormente se acuñó por Edward HUNTER ${ }^{1148}$ la expresión de «lavado de cerebro» (hse nao). Esta denominación nació del libro «Brainwashing in Red China» del citado HUNTER publicado en 1951, a raíz de varias entrevistas, en las cuales su intérprete le manifestó que la China comunista y Corea del Norte usaban para implantar tal régimen un proceso llamado hse nao, que significa «lavado de cerebro». También se ha denominado «reforma del pensamiento», «persuasión coactiva», «control mental», «programas coordinados de influencia coercitiva», «control de la conducta»y «persuasión aprovechada». Ejemplos históricos de estas reformas del pensamiento los encontramos en China, con el comunismo de Mao TSE-TUNG, que ideó una «remodelación ideológica (...) mediante el empleo de un programa coordinado de coerción psicológica, social y política» ${ }^{1149}$.

Edward HUNTER se basó en las investigaciones de PAULOV sobre la reforma conductista para asociar sus conclusiones a los procedimientos usados en los regímenes comunistas. Poco después de la publicación del libro comenzaron a salir una marabunta de libros relacionados con el tema, si bien podemos reseñar -entre los de mayor prestigio- el de Robert LIFTON, titulado Thought Reform and the Psichology os Totalism ${ }^{1150}$, y el de Edgar SCHEIN, con el título Coercitive Persuasion ${ }^{1151}$.

LIFTON $^{1152}$ denominó a este proceso de cambio «reforma del pensamiento». Realizó varios estudios en la materia mediante entrevistas a prisioneros de Corea del Norte y concluyó que no era necesaria la tortura como tradicionalmente se entendía (tormento) para obtener información, sino que podía cambiarse la personalidad mediante técnicas de control en un contexto de «totalitarismo ideológico». Dividió la reforma del pensamiento en ocho condicionantes: Control del ambiente, Carga del lenguaje, Demanda de pureza, Confesión, Manipulación mística, Doctrina sobre la persona, Ciencia sagrada, y Otorgamiento de existencia.

\footnotetext{
1148 Posteriormente publicó otro libro sobre el mismo tema, HunTER, Edward, Brainwashing. The Story of Men Who Defied It, Forgotter Books, 1956.

1149 SINGER MT / LALICH J., Las sectas entre nosotros, op. cit., p. 79.

${ }^{1150}$ LIFTON, Robert, Thought Reform and Psychology of Totalism: A Study of Brainwashing in Red China, Nueva York, Norton, 1961.

${ }^{1151}$ SCHEIN Edgar H / SCHNEIER Inge / BARKER Curtis H., Coercitive Persuasion: A socio-psychological Analusis of the Brainwashing of American Civilian Prisoners by the Chinese Communists, Nueva York, W. W. Norton, 1961.

${ }^{1152}$ LIFTON, R., Thought Reform and Psychology of Totalism, op. cit., pp. 419 a 425; le sigue HASSAN, Steven, Cómo combatir las técnicas de control mental de las sectas, pról. Margaret Thaler Singer, Urano, 1995.
} 
En nuestra opinión, SCHEIN ${ }^{1153}$ da un paso más preciso, denominando la reforma del pensamiento con la expresión de «persuasión coactiva». Clasificó este fenómeno psicológico en tres etapas de la conciencia del sujeto: el Descongelamiento cuyo resultado es la crisis de identidad; el Cambio, el sujeto empieza a creer que sus problemas y la ansiedad desaparecerán $y$ sigue las directrices del líder; y Recongelamiento, en este momento se implanta definitivamente los nuevos valores y la fidelidad al líder.

Por su parte, FARBER, HARLOW y WEST ${ }^{1154}$ lo denominaron «debilidad, dependencia y temor» (Síndrome $D D D$, sus siglas en inglés), refiriéndose a las consecuencias que observaron en los prisioneros de guerra en Corea del Norte.

Y otro de los estudios realizados en este campo de significativa trascendencia fue el programa secreto de los Estados Unidos (CIA) bajo el nombre de $M K$-Ultra ${ }^{1155}$ cuyo fin era el «control mental» mediante drogas como el LSD.

La persuasión coercitiva -en palabras de SINGER y LALICH- consiste en «mantener a los sujetos inconscientes de que se los manipula y controla, en especial no permitirles percatarse de que se los hace avanzar por un sendero de cambio que los lleva a servir intereses que los perjudican» ${ }^{1156}$. Así, las clasifican ${ }^{1157}$ de la siguiente manera: primera, mantener a la persona inconsciente de lo que sucede y de los cambios que tienen lugar; segunda, control del tiempo; tercera: crear una sensación de impotencia, temor encubierto y dependencia; cuarta: suprimir parte de la conducta y las actitudes antiguas de la persona; quinta, inculcar conducta y actitudes nuevas; y sexta, presentar un sistema cerrado de lógica, no permitir ninguna crítica».

Los casos de persuasión coercitiva más intensos pueden llegar a tener un éxito tal que según este modelo de pensamiento se puede conseguir ordenar la ejecución de personas o el suicidio $^{1158}$. Sin embargo, este modelo de pensamiento, con toda la razón, ha sido denunciado

\footnotetext{
1153 SCHEIN EH / SCHNEIER I / BARKER CH., Coercitive Persuasion, op. cit.

1154 FARBER IE / HARLOW Harry F / WEST Louis Jolyon, «Brainwashing. Conditioning and D.D.D.», Sociometry, 20 , pp. 271 a 285.

${ }_{1155}$ Más ampliamente CUEvas BARRANQUERo JM / CANTO OrTIZ JM., Sectas, Cómo funcionan, op. cit., pp. 54 a 56; CUEVAS BARRANQUERO, JM, Evaluación de persuasión coercitiva en contextos grupales, op. cit., p. 235 y ss.

1156 SINGER MT / LALICH J., Las sectas entre nosotros, op. cit., p. 77; en el mismo sentido también MotILLA, A., Sectas y Derecho en España, op. cit., p. 179; JORDÁN VILlACAMPA, ML., «Aproximación al tema de las sectas pseudorreligiosas», op. cit., p. 258.

1157 SinGER MT / LALICH J., Las sectas entre nosotros, op. cit., pp. 87 a 92.

${ }^{1158}$ Uno de los casos más famosos fue el de un marine norteamericano, con felicitaciones por su labor, que fue convencido por un líder de una secta para ayudarle a matar a una familia entera; SINGER MT / LALICH J., Las sectas entre nosotros, op. cit., p. 81 
por gran parte de científicos porque en definitiva respalda la hipótesis de la programación y desprogramación mental como si el ser humano se tratara de un robot ${ }^{1159}$.

Es necesario advertir que no existen muchos estudios sobre la reforma del pensamiento, debido a que estos mismos se consideran experimentos no permisibles, es decir, ilícitos, pero existe un presupuesto previo en el que suele concordar la mayoría de estudios: que el sujeto esté en el lugar y momento oportuno. Estos dos factores, tiempo y lugar, unidos al caso concreto de la persona, el grado de consciencia de la situación y la capacidad de voluntad personal, pueden ayudar a comprender ciertos comportamientos en principio inexplicables. En este sentido existe cierta relación entre el grado de utilización de las técnicas de persuasión coercitiva y el grado de control, y a su vez con el grado de peligrosidad o consumación de injustos típicos como el daño físico, psicológico y moral, que podrán variar según el grado de prolongación a la exposición de la persuasión, la fuerza o debilidad de la víctima como la baja autoestima, la inseguridad personal, trastornos mentales y problemas sociales, laborales y familiares; el apoyo familiar y el tratamiento post-secta, que han de ser tenidos en cuenta, si bien no para resolver la problemática como si de robots se tratara, sí para hallar un marco común de estudio.

\section{Modelo causal}

El modelo causal sociológico y antropológico de LOFLAND y STARK ${ }^{1160}$-para su examen seguiremos el análisis de PRAT ${ }^{1161}$ - se basa en las relaciones que se producen en el sistema sectario desde la perspectiva del converso/adepto. En concreto, LOFLAND ${ }^{1162}$ señala siete etapas por las que pasa el sujeto hasta su conversión total: tensión con las experiencias vitales pasadas; acercamiento a una respuesta religiosa novedosa que puede solucionar los problemas; camino a una exploración de nuevo mundo religioso; llegada a un punto de inflexión en el que las nuevas soluciones satisfacen; el sujeto incrementa y positiva las relaciones afectivas con los miembros; neutralización otros posibles problemas anteriores y exteriores a su nuevo ambiente vivencial; y

\footnotetext{
${ }^{1159}$ En este sentido POLAINO-LORENTE comenta que «(1)o que algunos califican como "programación”, no es nada más que la aparición de un cuadro delirante trastorno psicótico ampliado y compartido padecido simultáneamente por diversas personas», POLAINO-LORENTE A., «Las sectas y los problemas personales», AltAREJos Francisco / POLAINO-LORENTE Aquilino / LÓPEZ-EsCOBAR Esteban, Tres reflexiones sobre sectas: (educación, psiquiatría, opinión pública), Cuadernos del Instituto Martín de Azpilcueta, Influencia sectaria e información personal, Pamplona, 1999, pp. 87 y 88; le sigue FONT BOIX, Ignacio, «El concepto de manipulación mental en las llamadas sectas», Ius Canonicum, XLII, 83, 2002, pp. 331 y ss.

${ }^{1160}$ LOFLAND John / STARK Rodney, «Become a World-Saber: a theory of conversion to a deviant perspective», American Sociological Review, 30, 1965, pp. 862 a 875.

${ }^{1161}$ PRAT, J., El estigma del engaño, op. cit., p. 123 y ss.

1162 Vid. y más ampliamente ID., ibidem, op. cit., p. 127; Lofland, John, Doomsday Cult: A Study of Conversion, Proselytization, and Maintenance of Faith, Nueva York, Irving.
} 
finalmente la disponibilidad e interacción con el grupo se intensifica. En este momento se finaliza la conversión ${ }^{1163}$.

También son interesantes al respecto las aportaciones de BROMLEY y SHUPE ${ }^{1164}$. Analizan la problemática desde una perspectiva motivacional y otra más sistémica, desde la perspectiva grupal y el modelo social del rol del adepto dentro del grupo.

BARKER «se pregunta qué versión es la buena: ¿la que acepta que el proceso de conversión ha sido asumido plenamente por el converso o la que afirma que aquel ha sido la víctima (involuntaria si se quiere, pero víctima) de un severo control mental». La respuesta del citado autor -en opinión de PRAT- es que la posibilidad de elegir «es una capacidad típicamente humana que incluye tanto la posibilidad de imaginar alternativas futuras como la de recordar el pasado. De este modo, toda elección supone una reflexión (en el presente) que activa la memoria para imaginar un futuro posible. Decidir entre dos o más opciones significa activar toda una serie de posibilidades. Éstas se organizan en torno variables: la variable individual, es decir, las predisposiciones, intereses, valores, deseos y miedos que caracterizan a un individuo cualquiera; en segundo lugar, las alternativas que se presentan al mismo sujeto -BARKER distingue entre las alternativas convencionales como la búsqueda de respuestas previstas en el propio contexto, y las no convencionales, que suponen un cambio radical en la vida-; y por último, la variable del contexto, donde la solución debe ser negociada» ${ }^{1165}$.

En nuestra opinión, tanto la postura de BARKER como las de BROMLEY y SHUPE guardan mayor distancia en el análisis del sectarismo, lo analizan como sociedad/individuo/rol, pero como si fuera una única perspectiva. En este sentido, ambas posturas parecen analizar el fenómeno desde una teoría sistémica del sectarismo, despojando a la problemática de condicionamientos psicológicos, morales y éticos, por lo que nos parece un estudio más neutro por cuanto se analiza las sectas como sistema social semejante al de las religiones tradicionales, lo cual desoja todo lo peyorativo subyacente del término secta. BROMLEY y SHUPE ponen el acento de la problemática en la relación de los sistemas sociales y sus subsistemas, en el sentido que las nuevas religiones cuestionan los símbolos imperantes de las religiones tradicionales, lo que genera hostilidades, conflictos sociales y de competencia entre las diversas organizaciones,

\footnotetext{
1163 Más ampliamente, PRAT, J., El estigma del engaño, op. cit., p. 123 y ss.

1164 Vid. y más ampliamente, PRAT, J., El estigma del engaño, op. cit., p. 123 y ss. (BROMLEY David G / SHUPE Anson D., «Just a few years seem like a lifetime: a role theory approach to participation in religious movements», Kriesberg, L. (ed.), Research in Social Movements, Conflicts and Chance, 2, Greenwich, Connecticut, JAI Press., pp. 149 a 185).

${ }_{1165}$ Vid. PRAT, J., El estigma del engaño, op. cit., p. 129 (BARKER, Eileen, The Making of Mooni: Choice or Brainwashing, Oxford, Black-well, 1984).
} 
lo que en nuestra opinión lleva a la sinalgia del código legitimación/no legitimación social de las nuevas formas organizativas de creencias.

Por otro lado, según hemos dicho, se ha denominado con el adjetivo de sectas «destructivas» a aquellas que crean un vínculo afectivo subjetivo y objetivo primero con el proceso de captación y adoctrinamiento, y más severamente con las técnicas de persuasión coercitiva que generan una destrucción tanto individual como social del adepto, que avoca precisamente una «sectadependencia» de la que, aun saliendo el adepto del grupo, se vislumbran signos afectivos de dependencia, quasi-adicción o propiamente una adicción ${ }^{1166}$, que normalmente propician trastornos de la personalidad, y que acaban destruyendo el ámbito personal, familiar y social del adepto. Para este autor existe una relación directa y semejante entre la adicción que provocan las drogas y la dependencia al grupo sectario como una adicción comportamental como lo son la adicción al juego o ludopatía. Esta asimilación se acredita por diversos estudios y organismos públicos. En concreto, el Plan Nacional de Drogas, el Máster de Drogodependencia de la Facultad de Medicina de la Universidad Complutense de Madrid impartió una asignatura sobre sectadependencia ${ }^{1167}$. En sentido similar se ha denominado también «síndrome de dependencia grupal» $^{1168}$

Algunos autores ${ }^{1169}$ han concluido que existe un «elevado paralelismo (...) entre las estrategias de abuso utilizadas en el seno de grupos manipulativos del estilo de las sectas coercitivas y las utilizadas en la relación violenta de pareja, como en parte se había adelantado en otros estudios (BouletTe, 1980; BouletTe y ANDERSEN, 1985; WARD, 2000; WolfSON, 2002)», y su estrecha relación con el mobbing, por cuanto en las tres situaciones, el denominador común es «la búsqueda del aislamiento de la persona, la intervención sobre las posibles variables de su entorno inmediato y el abuso emocional hacia ella». Pero también en adoctrinamientos

1166 RoDRíGUEZ, P., Adicción a sectas, op. cit., p. 29, y pp. 63 y ss; ID., «Sectadependencia», op. cit.; se muestran partidarios también de la analogía con la adicción, ECHEBARRÍA ECHABE, Agustín, «Procesos grupales y construcción de la identidad: el caso de las sectas», vv.aa., Aspectos socio-jurídicos de las sectas desde una perspectiva comparada, op. cit., p. 49; CUEVAS BARRANQUERO JM / CANTO ORTIZ JM., Sectas, Cómo funcionan, op. cit., p. 61 a 63.

${ }^{1167}$ Vid. Cuevas BarranQuero JM / CANTO OrTiz JM., Sectas, Cómo funcionan, op. cit., p. 62.

1168 VV.AA., «Totalisme i voracitar. Una aproximació interdisciplinária al «fenomen sectari» a Catalunya», op. cit., pp. 64 y 65.

1169 RoDríGUEZ-CARBALleira Álvaro / ALMENDros Carmen / ESCARTÍN Jordi / PORRÚA Clara / MARTÍNPEÑA Javier / JAVALOY Federico / CARROBLES José Antonio, «Un estudio comparativo de las estrategias de abuso psicológico: en pareja, en el lugar de trabajo y en grupos manipulativos», Anuario de Psicología, Vol. 36, núm. 3, 2005, pp. 311; CUEVAS BARRANQUERO, JM, Evaluación de persuasión coercitiva en contextos grupales, op. cit., p. 218 y pp. 283 y ss. en donde asimila la persuasión coercitiva a las dinámicas de regímenes totalitarios, al adoctrinamiento terrorista, al terrorismo de Estado y contextos bélicos, a regímenes convencionales, contextos pseudoterapéuticos, escolares, acoso sexual, mobbing y a las relaciones duales de intensidad. 
terroristas se pueden percibir dinámicas de persuasión coercitiva que vincula a los grupos terroristas y las sectas coercitivas ${ }^{1170}$.

En concreto, subrayan ZIMBARDO ${ }^{1171}$ y otros que la gravedad y la fuerza de la persuasión se debe a factores intrínsecos de la misma y que se deben al «control social». Esos factores resumidamente son: el consentimiento sin información; confinamiento físico o constricción psicológica; inaccesibilidad a las fuentes de información usuales y al soporte social; contacto directo e intensivo con los agentes sociales; amenaza de terribles consecuencias si no se cumple el cambio; uso de técnicas que confunden la razón; vulnerabilidad de la víctima; cohesión del grupo en una doctrina demagógica liderada por un jefe carismático; organización vertical y totalitaria; convivencia en una comunidad cerrada y de dependencia; falta de libertad personal y de la intimidad; rechazo de la sociedad externa y sus instituciones; actividades prosélicas y recaudatorias.

Los elementos necesarios pero no excluyentes que se han establecido para darse las notas propicias para la influencia social persuasiva son: la credibilidad de la fuente y su poder; el atractivo de la fuente; la semejanza; la reciprocidad; la coherencia; la validación social y la simpatía entre otras ${ }^{1172}$.

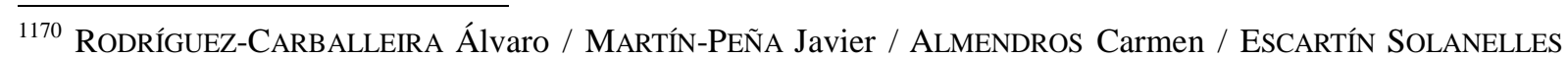
Jordi / PORRÚA GARCíA Clara, «Un análisis psicosocial del grupo terrorista como secta», Revista de Psicología Social, ejemplar dedicado a Explicaciones y análisis sobre la violencia terrorista, Vol. 24, núm. 2, 2009, pp. 183 a 195. Esta peculiaridad, la muerte suicida-terrorista, es la que hace comparar al terrorismo islámico con una secta o grupo que utiliza la «adicción comportamental», la «manipulación mental» o «persuasión coercitiva», o la «obediencia ciega a la autoridad o norma», o el «aislamiento cultura» para cometer delitos. En este sentido, no podemos olvidar que en todo grupo que se mueve por creencias, puede haber sujetos sometidos o adoctrinados por técnicas estas circunstancias. Este paralelismo con las sectas criminales fundamenta la conexión del autor por convicción, el enemigo, pero a la vez la problemática del autor de conciencia.

${ }^{1171}$ Vid. CUEVAS BARRANQUERO JM / CANTO ORTIZ JM., Sectas, Cómo funcionan, op. cit., op. cit., pp. 48 y 49; vid. CueVas BARRANQUero, JM, Evaluación de persuasión coercitiva en contextos grupales, op. cit., p. 243 y ss.

${ }_{1172}$ Más ampliamente a) La credibilidad de la fuente y su poder: hay roles que ejercen mayor credibilidad en las personas por su competencia social, familiar, profesional (policías, jueces, médicos, psicólogos y psiquiatras, y también los padres), ejercen una credibilidad en el tercero, y por ello mismo, es más fácil someterse a la regulación de la relación jurídica cuando el sujeto entra en la esfera de acción de la fuente. A pesar del error de la fuente, el receptor o víctima puede perdonar y volver a confiar, o en su caso, no otorgar validez a la fuente que afirma el quebrantamiento de la credibilidad jurídica. Es normal ver en los grupos sectarios que sus líderes y miembros activos se disfracen del rol de psicólogo, psiquiatra, médicos, denominando a sus grupos como entidades terapéuticas. El poder de la fuente prosigue vigente cuanto mayor sea el aluvión de información sobre la fuente. En este caso, no es lo mismo un simple psiquiatra que un psiquiatra que dice haber publicado estudios o que ganado premios científicos.

b) El atractivo de la fuente: el atractivo de un sujeto, su apariencia, vestimenta, vocabulario culto genera en diversas personas una mayor influencia y credibilidad, que suele ser nota característica de algunos líderes.

c) La semejanza: hemos hablado de la identidad, la asimilación y enamoramiento libidinoso. Amén de ello, la semejanza entre padres e hijos es clara, pero también en sujetos extraños puede suceder. La utilización de elementos que se asemejen al del receptor promueve y facilita la influencia. Es habitual que en las sectas se utilice la técnica de exposición de relatos de los miembros, de sus dramas, como semejanza entre los individuos.

d) La reciprocidad: se genera reciprocidad entre los miembros y enlace entre el objeto ideal y el yo personal. El ser humano habitualmente realiza una contraprestación cuando es ayudado. Es habitual en las sectas que el grupo 
Con estos modelos explicativos de la fenomenología de las sectas se consigue comprender adecuadamente la dinámica comportamental del adepto, pero a la vez, la dinámica del todo el grupo en tanto comportamiento grupal, y trasladarse la problemática no sólo a este tipo de grupos religiosos, sino a cualquier agrupación, máxime a las organizaciones criminales que tienen fuertes lazos de comportamiento y dinámica grupal. Como advierte CuEvas BARRANQUERO «(e)1 proceso de obediencia, como la captación, será un proceso sumamente gradual (...) no suele darse en las primeras fases de acercamiento al grupo, sino que será fruto del compromiso adquirido con éste, tras un sutil e intenso procedimiento de captación y adoctrinamiento» $^{1173}$.

\section{Técnicas de persuasión coercitiva}

La dinámica criminal de las sectas comienza con la captación o reclutamiento de personas susceptibles de amoldarse a la propia tipología sectaria. Posteriormente se somete al adepto a técnicas fisiológicas y psicológicas de persuasión extremas, y finalmente se le intimida si no funcionan las anteriores. La forma de captación comienza con el ofrecimiento de algo como consuelo, ayuda, salvación ${ }^{1174}$, ya sea en lugares públicos (centros comerciales), o mediante cursos de meditación. Tras el primer contacto con el sujeto, atacan críticamente a la sociedad, a su organización, y finalmente a las creencias de los demás, para evidenciar ante el sujeto que ellos pueden ser una respuesta alentadora. Posteriormente, una vez conseguido que asista el posible adepto a una sesión o reunión, se le colma de atenciones, halagos, promesas de amor y

haga regalos, ayuden en la desintoxicación en la rehabilitación médica de forma gratuita. A esta prestación el ser humano suele contestar con una contraprestación que aumenta los lazos.

e) La coherencia: si las contraprestaciones que otorga el receptor son validadas y ratificadas, agradecidas e incluso compensadas por la fuente de la influencia, esto crea un sentimiento de coherencia entre el acto de contraprestación y la conciencia interna sobre el acto. Por ejemplo, el padre adepto de una secta que deja su trabajo para contraprestar la ayuda religiosa que le asiste el grupo, suele causar el incumplimiento de las obligaciones jurídicas de padre ante sus hijos.

f) La validación social: cuanto mayor es el grupo o mayor es la ratificación de la conducta por terceros, mayor validación social respaldará la conducta individual del sujeto. Es más fácil aceptar una conducta en la medida de que un grupo de personas la validen. Si este grupo es toda una entidad supranacional, más reconfortado estará el sujeto, por eso no es extraño que determinados grupos -también sectarios- inflen el número de miembros para conseguir una apariencia de validez social y por ende, mayor credibilidad.

g) Y la simpatía: supone la correspondencia de la personalidad, se comunica confiabilidad. En este caso, es evidente que la simpatía une y entrelaza conductas, comunica la confianza de manera que se modifican expectativas.

Más ampliamente sobre la influencia social y persuasión CUEVAS BARRANQUERO JM / CANTO ORTIZ JM., Sectas, Cómo funcionan, op. cit., pp. 39 y ss; CUEVAS BARRANQUERO, JM., Evaluación de persuasión coercitiva en contextos grupales, op. cit., pp. 165 y ss; CANTO ORTIZ, Jesús M., Psicología social e influencia. Estrategias del poder y procedimientos de cambio, Ed. Aljibe, Málaga, 1994; ID., Psicología de los grupos: estructura y procesos, Ed. Aljibe, Málaga, 1998.

${ }_{1173}$ CUEVAS BARRANQUERO, JM, Evaluación de persuasión coercitiva en contextos grupales, op. cit., p. 98.

1174 JORDÁN VILLACAMPA, Mª., Las sectas pseudorreligiosas, op. cit., pp. 14 y 15. 
afecto. Esta fase dura el tiempo que resista la vulnerabilidad de la persona ${ }^{1175}$. Después se abre un bombardeo «sistemático a la validez de las fuentes tradicionales de cultura» ${ }^{1176}$. Y finalmente «se tiende a producir un progresivo debilitamiento del adepto mediante largas jornadas laborales, escaso tiempo de reposo y alimentación desequilibrada» ${ }^{1177}$. Estas últimas fases son las que se denominan tradicionalmente como «lavado de cerebro», si bien no puede olvidarse que los medios de comunicación social son factor importante para la captación y forma propaganda ${ }^{1178}$.

Hemos visto los pasos por los que pasa la reforma del pensamiento y los modelos de comprensión del fenómeno. Estas etapas se producen y se dividen en dos técnicas principalmente: la persuasión «fisiológica», y la «psicológica» ${ }^{1179}$ :

a) La primera consiste en unas técnicas que producen respuestas fisiológicas ${ }^{1180}$ predecibles, que causan en el sujeto unas sensaciones extrañas, como por ejemplo la utilización de frases tales como «que salga el demonio de ti». De tal modo se produce en el sujeto la veracidad de la información. El líder intenta con estas técnicas demostrar al sujeto que tiene serios problemas o que gracias a sus directrices puede mejorar su estado de ansiedad, depresión, etc.

Estas técnicas fisiológicas se pueden concretar en la hiperventilación, el movimiento repetitivo, el cambio de dieta, y del sueño (produce cambios hormonales), las manipulaciones corporales como la presión en el ojo (produce luces extrañas que se asocian a la luz divina), la presión sobre los oídos (produce zumbido que se asocia a música divina), los ejercicios dolorosos y la relajación, cuyo efecto contrario es la ansiedad intencionada ${ }^{1181}$.

b) Por otro lado, la segunda posible técnica de persuasión es la psicológica ${ }^{1182}$.

En ella se realiza un control ambiental que fructifica con el aislamiento social, el control de la información, estados de dependencia existencial, debilidad psíquica y física. También el control emocional, mediante la creación de estados falsos de satisfacción, inducción al sentimiento de

1175 ID., ibidem, op. cit., p. 16.

1176 ID., ibidem, op. cit., p. 16.

1177 ID., ibidem, op. cit., p. 16.

1178 VÁZQUEZ, JMa ., Familia y sectas, op. cit., pp. 36 y ss; ID., «Sectas y Medios de Comunicación Social», vv.aa., Pluralismo religioso II, Sectas y nuevos movimientos religiosos, Atenas, Madrid, 1993.

${ }^{1179}$ Para un estudio conjunto y comparado CUEVAS BARRANQUERO, JM, Evaluación de persuasión coercitiva en contextos grupales, op. cit., pp. 289 y ss.

${ }^{1180}$ Más ampliamente CUEvas BARRANQUERo JM / CANTO ORTIZ JM., Sectas, Cómo funcionan, op. cit., pp. 134 a 154.

${ }^{1181}$ Véase sobre estas técnicas más concretamente y casos reales, SINGER MT / LALICH J., Las sectas entre nosotros, op. cit., pp. 145 a 164; CUEVAS BARRANQUERo JM / CANTO ORTIZ JM., Sectas, Cómo funcionan, op. cit., pp. 36 y ss; RodríGueZ, P., Adicción a sectas, op. cit., pp. 47 y ss; ID., Las sectas hoy y aquí, $3^{\mathrm{a}}$ ed., Ed. Tibidabo, 1991, pp. 26 y ss; ID., El poder de las sectas, op. cit., pp. 51 y ss.

1182 Ampliamente ENROTH, RS., Las sectas y la Juventud, op. cit; SINGER MT / LALICH J., Las sectas entre nosotros, op. cit., pp. 166 y ss; CUEVAS BARRANQUERO JM / CANTO ORTIZ JM., Sectas, Cómo funcionan, op. cit., pp. 36 y ss; RoDRíGUEZ, P., Adicción a sectas, op. cit., pp. 47 y ss; ID., Las sectas hoy y aquí, op. cit., pp. 26 y ss; ID., El poder de las sectas, op. cit., pp. 51 y ss. 
miedo, culpa y la realización de castigos y premios selectivos. Se utiliza el control cognitivo, como por ejemplo la denigración del pensamiento crítico, la mentira y el engaño, la condescendencia e identificación al grupo, el control de la atención y del lenguaje, la alteración de las fuentes de autoridad. También son propiamente técnicas de persuasión psicológicas las técnicas de inducción de estados disociativos mediante el uso de drogas, síndromes de abstinencia sin tratamiento facultativo especializado y autorizado legalmente, los cánticos, las oraciones y la meditación excesiva, la hipnosis y los trances. Esta técnica se divide en varias: los trances ${ }^{1183}$ mediante el cual se puede conseguir el debilitamiento del pensamiento; la hipnosis ${ }^{1184}$ por la que se puede manipular la conciencia, el querer y la voluntad; los trances naturalistas ${ }^{1185}$, mediante la hipnotización con previo aviso (similar a la sofrología); y la imaginería guiada ${ }^{1186}$ que produce la evocación de situaciones del pasado, por ejemplo, dirigidas a recordar acontecimientos dolorosos en la familia, con la intención de desvincular al sujeto de esta.

Otras técnicas de esta índole son las denominadas técnicas indirectas, como la revisión de la historia personal. Consiste en recordar y narrar la propia historia del sujeto, y de esta manera se consigue que recuerde los peores momentos, los más dolorosos e injustos, para con ello después utilizar la información para guiar, adelantar y finalmente para poder ordenar conductas criminales.

La presión de los pares y el modelado ${ }^{1187}$ consisten en la presión a los potenciales miembros para que imiten conductas. Esta manera se refuerza la dinámica comportamental del grupo, la identidad social, y con esto la conducta individual del sujeto asociada a la grupal.

Por otro lado, con la manipulación personal se pretende que el sujeto actúe conforme a los beneficios que da la secta: «pagar con la misma moneda sin pensarlo». CIALDINI ${ }^{1188}$ define la

${ }^{1183}$ Mediante el trance se modifica y divide la conciencia, debilitando el pensamiento activo crítico, hasta un punto pasivo-receptivo. Esto propicia la debilitación de la voluntad y fácil penetración de nuevas directrices.

${ }^{1184} \mathrm{La}$ hipnosis es «en esencia una forma de concentración mental, altamente centrada, en que una persona permite a otra que estructure el objeto de la concentración y al mismo tiempo suspenda el juicio crítico y la conciencia periférica», por lo que la utilización de tal técnica, con fines ilícitos, conlleva la «manipulación» del sujeto sometido, hasta posibles consecuencias delictivas, SINGER MT / LALICH J., Las sectas entre nosotros, op. cit., pp. 166 y 167.

1185 Milton ERICKSON propuso y demostró científicamente una nueva técnica de hipnotización que negaba la formula «va a ser usted hipnotizado», por la fórmula de inducción naturalista sin tan ni siquiera avisar al sujeto, ERICKSON, Milton H., The Nature of Hypnosis and Suggestion, Vol. 1, Irvington Publishers, 1980; MILLER J., «The Utilization of Hypnotic techniques in Religious Conversion», Cultics Studies Journal, 1986, Vol. 3, núm. 2, pp. 243 a 250.

${ }^{1186}$ La imaginería guiada consiste en la repetición verbal y compleja de la narración de situaciones, parábolas, que encaminan al sujeto receptor a un mundo inusual, e imaginario, SINGER MT / LALICH J., Las sectas entre nosotros, op. cit., pp. 172 y 173.

${ }^{1187}$ En palabras de SINGER y LALICH, esta técnica consiste en «aumentar el potencial reclutador de los miembros, los grupos enseñan a los miembros a sonreír, parecer felices, ser amistosos y prestar atención a los recién llegados», con lo que se consigue que los nuevos miembros se comporten como ellos. Es una técnica de modelo, que se reduce a la imitación, ID., ibidem, op. cit., pp. 180 y 181. 
manipulación emocional como una influencia automática en actos del sujeto sin ser pensados previamente. Un ejemplo de ello es la obediencia en aquellos que nos ayudan, o nos gustan, es decir, se obedece sin pensar, de forma inconscientemente, desde a comerciales pasando por la familia y en casos extremos obedeciendo a dictadores de toda clase. En palabras de CUEVAS BARRANQUERO «(l)a persuasión implicaría dirigir un mensaje a una audiencia con la intencionalidad de formar, reforzar o cambiar sus actitudes (...) la influencia abarcaría cualquier forma de cambio, intencionalidad o no, e incluiría la persuasión; mientras que esta última requeriría intencionalidad de cambio por parte de la fuente de influencia, tratando de modificar o generar nuevas actitudes o comportamientos. Los procesos persuasivos pertenecen al universo más amplio de la influencia social» ${ }^{1189}$. Hace hincapié en el uso deliberado de la persuasión coercitiva, análogo a la coacción, a diferencia de la influencia u otras técnicas en principio lícitas, si bien reconoce que no es del todo necesaria la intencionalidad ${ }^{1190}$, y es que no se nos escapará el hecho de que ciertas dinámicas grupales son susceptibles de generar el mismo resultado sin la necesidad de que exista clara intencionalidad o dolo en el autor, apreciándose por otros, como PERLADO, una función de «retroalimentación» entre los miembros del grupo, si bien referida a delirios compartidos ${ }^{1191}$, lo que en ambos casos pone de manifiesto la necesidad de prevención ante graves resultados masivos y/o individuales.

Mientras que la manipulación psicoterapéutica ${ }^{192}$ se realiza por sectas de psicoterapia, aquellas que se publicitan muchas veces que están dirigidas a curar. En realidad hacen creer al sujeto que la única forma de recuperar su salud física o mental será a través de las directrices del líder, por ejemplo, el abandono de la familia, el pago de altas cantidades de dinero para sufragar el «buen fin» y el trabajo total o casi total en el grupo.

\footnotetext{
1188 CIALdini Robert B., Influence: The New Psychology of Modern Persuasión, New York, Quill, 1984; ID., Influencia. Ciencia y práctica. Cuáles son los factores determinantes para que una persona diga sí a otra persona, Prodilu, Barcelona, 1990.

1189 Cuevas BARRANQUero, JM., Evaluación de persuasión coercitiva en contextos grupales, op. cit., p. 86 y pp. 220 y ss. y ampliamente pp. 148 y ss. con referencias a HovLAND y seguidores, HovLAND Carl I / JANIS IL / KELly HH., «Comunication and persuasion», Psychological studies of opinión change, Yale University Press, New Haven, 1953.

${ }^{1190}$ CUEVAs BARRANQUERO, JM., Evaluación de persuasión coercitiva en contextos grupales, op. cit., p. 262; FARÍAS DÍAZ, Álvaro, Sectas y manipulación mental. Un enfoque desde la psicología, $1^{\mathrm{a}}$ ed., Vita Brevis, Colección RIES núm. 3, Red Iberoamericana de Estudios de las Sectas, 2015, p. 62; PASCUAL J / VidAurRÁZAGA MEZA E., Grupos de manipulación psicológica en Cataluña, situación y conceptos, op. cit., pp. 31 y 32.

${ }_{1191}$ PERLADO, Miguel, «La atadura sectaria», Intercambios, Papeles de Psicoanálisis, 15, 2005, pp. 27 a 35.

1192 Algunos ejemplos de esta manipulación son los siguientes: En la secta de Los Sullivanianos, uno de los «dogmas» más importantes era cortar el contacto con la familia, debido a que el líder (Stack Sullivan, psiquiatra) cuestionaba el fin terapéutico si la fa familia se entrometía, y por ende, fuera más fácil la reforma del pensamiento, vid., Singer MT / LALICH J., Las sectas entre nosotros, op. cit., pp. 186 a 188. Otro ejemplo lo encontramos en la secta del doctor Tim, que diagnosticaba a cada miembro una enfermedad, se le decía al sujeto que si no era tratada según sus directrices no sería posible la curación, vid. ID., ibídem, op. cit., pp. 188 y 189.
} 
Por último, la amenaza y la intimidación también son recursos que las sectas criminales utilizan para impedir la salida de miembros de la secta, pero también son un recurso suficiente para ir debilitando la capacidad de la voluntad del sujeto. Otras veces sirven para atemorizar e impedir el libre ejercicio de escritores e investigadores sobre esta fenomenología criminal, al cuestionar el proceder de las sectas, y desenmascarar el «verdadero» fin de estos grupos. Desde periodistas, escritores e investigadores, todos estos y cualquier otros, como los propios familiares de las sectas, se ven sometidos a estas coacciones, que a menudo se basan en acciones legales de los propios grupos criminales para eliminar «legalmente» a adversarios o familiares ${ }^{1193}$.

Podemos concluir anticipadamente que las técnicas o estrategias de persuasión o de influencia no son estrictamente injustas o delictivas, basta ver las técnicas de vendedores y comerciales para concluir que no constituyen injusto alguno ${ }^{1194}$, salvo que la unión de varias o la frecuencia e intensidad y la finalidad y su contexto se constituyan en una clara limitación de la capacidad de obrar en general y/o como forma de «proselitismo engañoso» mediante diferentes niveles de verdad $^{1195}$. En tales casos surge la persuasión coercitiva, un injusto propio y autónomo que no se asemeja a otros recogidos en el Código penal y hemos elegido la terminología persuasión coercitiva porque con el término de persuasión se asocia a la dinámica de captación y técnicas concretas de persuasión ya comentadas, y con el adjetivo coercitivas se consigue asociarlo al concepto de coacción sin romper con el delito sectario estricto sensu, es decir, el de las sectas a las que hemos denominado coercitivas. Así, la persuasión que causa coerción es la clave de la comisión de otros delitos (delitos-fin), como el fraude con la petición de altas cantidades de dinero, o de delitos como la inducción al suicidio o asesinatos masivos, agresiones sexuales, etc.

\section{Extrapolación desde la teoría de sistemas y sociología de la religión de Luhmann}

Para LUHMANN, la religión es un sistema que se fundamenta en las comunicaciones religiosas. Éstas cumplen una función social que consiste en el aseguramiento de la civilización ${ }^{1196}$ que proviene de la creación de expectativas sociales que se han ido desarrollando en un proceso de generalización religiosa con su propia estructura sistémica, de modo que la religión trasforma la complejidad indeterminada en determinada o determinable ${ }^{1197}$.

\footnotetext{
1193 ID., ibidem, op. cit., pp. 229 y ss.

1194 Recalca esta conclusión CUEVAS BARRANQUERO, JM, Evaluación de persuasión coercitiva en contextos grupales, op. cit., p. 215.

1195 BAAMONDE, José María, La Manipulación Psicológica de las Sectas, Ediciones San Pablo, Madrid, 2003.

1196 LUHMANN, N., «La dogmática religiosa y la evolución de las sociedades», op. cit, p. 89.

1197 ID., ibidem, op. cit., pp. 83, 91.
} 
Por eso la comunicación religiosa ha supuesto la primera construcción social con sentido (horizonte de posibilidades) que ha ido evolucionando desde: primero el mecanismo original del ritual $^{1198}$ propio de la sociedades segmentarias basadas en la interpretación por los sujetos del código familiar/no familiar, lo conocido/no conocido; segundo a la estratificada o jerarquizada que propició la creación de dogmas desritualizadores en término de revelación; posibilitó el reclutamiento y la aceptación del código Dios/no Dios, la tradición y una moral basada en el pecado original, el autocontrol, la confesión; operaciones que fructificaban el intercambio social específicamente cristiano bajo códigos bueno/malo, transcendente/inmanente cuya significado era que lo trascendente conduce a lo inmanente, que se generen expectativas como por ejemplo que el creyente luche por ganarse el amor o trate de dominar la expectativa salvación (meritogracia/condena eterna), todo ello con un supremo punto de contingencia: Dios. De tal forma se posibilitaban las comunicaciones en mayor medida que en las sociedades segmentarias o ritualizadas; y tercero, hasta la actual sociedad, dividida y diferenciada funcional y comunicativamente mediante el símbolo fe que dota de sentido a las comunicaciones entre creyentes o en la acción prosélica que otorga seguridad, pero que en la actualidad ha dejado de ser un medio de comunicación religiosa.

LUHMANN parece concluir que en todas las épocas se aprecia un proceso de generalización de la religión en el que se produce la comunicación del sentido. Sin embargo, en la actual sociedad, la religión ha sido sustituida por medios de comunicación simbólicamente generalizados como la Verdad, Poder político, el Dinero, la Confianza, el Amor ${ }^{1199}$. En este sentido, podemos concluir que las religiones tradicionales ya no cumplen para la sociedad un medio de comunicación simbólicamente generalizado, sólo en determinados grupos religiosos o sectas apuestan por cerrar su propio sistema, elevar sus códigos a los únicos existentes. En las sociedades primitivas la diferenciación de roles se basaba en el sexo, edad, relación, logros, esto es, con base a criterios poco complejos, aunque poco después la diferenciación se basó en las regiones y países; en la sociedad estratificada predomina la estructura jerárquica en la que religión andaba a la par del poder, mientras que en la sociedad moderna se combinan todos los subsistemas (poder, política, economía, religión), sin embargo, la función de la religión es comprender lo contingente, lo problemático, como si no fuera un problema, nada contingente, sin embargo esto es precisamente

\footnotetext{
1198 ID., ibidem, op. cit., p. 83.

1199 Su toma de posición se puede resumir con sus propias palabras: «En el dominio del poder, la referencia a la fuerza física parece ser indispensable. Lo mismo vale para la precepción en el dominio de la verdad, y para la sexualidad en el dominio del amor, sin importar qué tanto esta referencia es dejada atrás y minimizada», vid. ORNELAS, Marco, «La sociología de la religión de Niklas Luhmann», LUHMANN, N., Sociología de la religión, op. cit., p. 24.
} 
la problemático. La fe ya no es un medio de comunicación simbólicamente generalizado, por eso las sectas y las grandes religiones tratan de utilizar la fe de este modo primitivo.

Es de interés analizar las dinámicas grupales, estructura, jerarquía y lo roles en el sectarismo religioso y especialmente en el criminal. En éstas últimas se alcanza el paradigma de que cada acción, fuera o dentro del sistema, tiene su correspondencia fuera y dentro del sistema y produce en el sistema su propia identidad, su diferencia interna y externa. En las sectas coercitivas, pero también en las organizaciones criminales en general, el Sistema reduce la complejidad, pero también un riesgo al eliminar posibilidades mediante la selección. Esto se puede apreciar en dinámicas sectarias con el ocultamiento del totalitarismo o autoritarismo o su ejercicio progresivo sutil asociado al «aislamiento cultural», la «obediencia a la autoridad», y al uso de «técnicas de persuasión». Por eso estamos de acuerdo -como proponía BONET ESTEVA entre otros- en analizar más que la manipulación mental la dinámica grupal o al «grupo de manipulación mental» ${ }^{1200}$.

\section{El líder, jefe, co-líderes, miembros activos y simples adeptos: roles sectarios}

La naturaleza de una secta criminal parte de un líder o fundador, quien es el que toma las decisiones directivas de la secta, además de crear la línea doctrinal, sólo o junto a otros colideres o miembros. Las características de estos sujetos se pueden resumir en las siguientes palabras de SINGER y LALICH: «Los líderes de sectas son personas auto-designadas y persuasivas que afirman tener una misión especial en la vida o poseer un conocimiento especial (...) suelen ser decididos y dominantes y a menudo son descritos como carismáticos (...) centran la veneración en sí mismos» ${ }^{1201}$. Desde este punto, el líder o los líderes, están dentro de los límites del libre ejercicio de la libertad de conciencia, es más, poseen las mismas características que cualquier fundador de una gran religión. Lo habitual de estos líderes y miembros activos es que sean totalitarios, dominantes, persuasivos, sugestivos, carismáticos, con capacidades oratorias pero a su vez con trastornos como los delirios de grandeza (trastorno delirante incluido en el DSM-V), con una personalidad trastornada neurótica, psicótica, paranoide y narcisista ${ }^{1202}$ que recuerda al pater. Por ello, para conocer la verdadera personalidad del líder es necesario ver la

${ }^{1200}$ Bonet Esteva, M., «Grupos de manipulación mental», op. cit., p. 148.

${ }^{1201}$ ID., ibidem, op. cit., pp. 37 y 38; en el mismo sentido ECHEBARRÍA ECHABE, A., «Procesos grupales y construcción de la identidad: el caso de las sectas», vv.aa., Aspectos socio-jurídicos de las sectas desde una perspectiva comparada, op. cit., p. 45.

${ }^{1202}$ Más ampliamente sobre la personalidad de algunos líderes CUEVAS BARRANQUERO JM / CANTO ORTIZ JM., Sectas, cómo funcionan, op. cit., pp. 72 a 130; CUEVAS BARRANQUERO, JM, Evaluación de persuasión coercitiva en contextos grupales, op. cit., p. 42 y pp. 67 y ss; RODRÍGUEZ, P., Las sectas hoy y aquí, op. cit., pp. 19 y 20. 
personalidad del grupo, su ideología, sus comportamientos y estructura, con otras palabras, el líder se refleja en el grupo y viceversa.

Estás patologías provocan características propias de los líderes y miembros activos de la secta. Los estudios que se han ocupado sobre el tema suelen señalar que con frecuencia se repiten varias: la creación falsas biografías otorgándose heroísmos o estudios especializados; la atribución de sabiduría en ámbitos del conocimiento; una falsa generosidad; culpabilizan a los demás de sus fracasos; no admiten la crítica; son vengativos, fríos, hostiles y antisociales. Estas características de la personalidad les hace ver a los demás como enemigos, y a la postre actuar como enemigos de la Sociedad cuando realizan actividades delictivas que se trasladan al grupo y a sus miembros a modo de ejecutores/víctimas ${ }^{1203}$.

Motilla sobre las características de los miembros señala que los mismos suelen ser «laicos» ${ }^{1204}$. En nuestra opinión, ello no es del todo cierto, pues esta característica se evidencia más claramente en sectas filosóficas o místicas, pero no en todas, ni generalmente.

En cuanto a la estructura de las sectas criminales o coercitivas -como podemos suponer-, la misma es estrictamente totalitaria, aparentemente innovadora o seductora en sus cánones y exclusiva $^{1205}$. Estas características las hacen ser únicas y apetecibles para aquellas personas que no han encontrado un consuelo en otros grupos, y -como dice MotiLlA- «sin que existan- por lo menos estatutariamente y salvo excepciones- jerarquía de especialistas de lo sagrado» ${ }^{1206}$. Como aseguran SINGER y LALICH, poseen «un sistema ético doble (...) Se insta a los miembros a ser abiertos y honestos dentro del grupo y a confesar todo al líder. Al mismo tiempo, se los alimenta a engañar y manipular a los que no son miembros» 1207.

${ }^{1203}$ En concreto señala CUEVAS BARRANQUERO acertadamente que «en algunos grupos se puede pasar de un papel de víctima a victimario: de recibir los castigos a pasar a ejercitarlos directamente, de cumplir fielmente las instrucciones de superiores a imponerlas a subalternos», CUEVAS BARRANQUERO, JM, Evaluación de persuasión coercitiva en contextos grupales, op. cit., p. 140.

${ }^{1204}$ Motilla, A., Sectas y Derecho en España, op. cit., p 31, en donde dice concretamente, que los rasgos comunes de las sectas, o también llamadas, en su terminología, «nuevos movimientos religiosos» (NMR) es «el de ser sus miembros laicos»; también RODRÍGUEZ, P., Las sectas hoy y aquí, op. cit., p. 20.

1205 Según SINGER y LALICH, las sectas «suelen ser totalitarias, u omnicomprensivas, en el control de la conducta de sus miembros y también ideológicamente totalitarias, y exhiben fanatismo y extremismo en su cosmovisión», además de «exigir a sus miembros que se sometan a una importante ruptura o cambio en el estilo de vida», SINGER MT / LALICH J., Las sectas entre nosotros, op. cit., p. 39. En concreto comenta SINGER que los programas coordinados de influencia coercitiva y de control de comportamiento, tienen el propósito de desestabilizar «el sentido de ser de la persona en sí y su concepto de realidad (...) los aspectos más centrales de la persona, minar la conciencia básica, su percepción de la realidad, el control de la emoción y los mecanismos de defensa», SINGER, MT., «Los programas de modificación del pensamiento y la producción de casos psiquiátricos», ponencia presentada en el I Congreso Internacional, Sectas y Sociedad, Las sectas como problema social, San Cugat del Vallés, Barcelona, noviembre de 1987, p. 54.

1206 Motilla, A., Sectas y Derecho en España, op. cit., p. 31.

1207 Singer MT / LALICH J., Las sectas entre nosotros, op. cit., p. 38. 
La autoridad del líder, como ente iluminado o supremo, otras veces como foco de guía, junto a una doctrina nueva, exclusiva, e innovadora, atrae a multitud de gente diversa, de todos las clases, es decir, el líder y la posterior dinámica grupal condiciona una «moral» persuasiva, se propone una salvación más directa, más «explicita e inmediata» ${ }^{1208}$.

Un ejemplo característico son los denominados programas de entrenamiento para la concientización de grupos grandes, los denominados $\mathrm{PECGG}^{1209}$. El fin de estos programas es la venta de productos místicos o de miscelánea. No se busca por parte de la secta el adoctrinamiento total del sujeto más que en lo estrictamente necesario hasta la culminación de la venta, o -como dice MotiLlA- se pretende «la utilización de medios de proselitismo agresivos con técnicas propias de la sociedad de consumo actual» ${ }^{1210}$, tanto en el adoctrinamiento, como en la venta de productos para sufragar los gastos de la secta y materializar así el fin lucrativo. Esta técnica de reclutamiento impropia es en otras ocasiones una forma de adoctrinamiento y captación propia. Muchos de los miembros de las sectas son captados en los grupos de venta y sirve de iniciación a la doctrina de la secta. Por otro lado esta conducta supone también una clara intromisión en el ámbito del trabajo, pues se ofertan en muchas ocasiones por la misma empresa $^{1211}$.

Parece ser que los jóvenes por necesidad de autonomía y libertad individual, la falta de identidad social, y por el atractivo de la oferta religiosa y la curiosidad ${ }^{1212}$, son el sector social más vulnerable para entrar en sectas, si bien el perfil del adepto cambia sustancialmente según el autor o informe que analicemos. Sin embargo, se ha expresado ${ }^{1213}$ que todos somos potenciales adeptos, aunque existen grupos potencialmente más susceptibles de ser captados como los jóvenes. Esto difiere del informe de la Comisión del Parlamento español de 1988, en el cual se concluía que el perfil del adepto es el de un mayor de 18 años, cuya familia posee una renta baja,

${ }^{1208}$ En terminología de Motilla, A., Sectas y Derecho en España, op. cit., p. 31

${ }^{1209}$ En inglés «Large Group Awareness Training Programs» (LGATP). La doctrina se basa en «que cada persona puede crear su propia realidad. Empleaban grupos de encuentro y técnicas hipnóticas para desestabilizar la visión del mundo de los participantes. Se usaba la presión fuerte de los pares para terminar la tarea y producir conformidad», SINGER MT / LALICH J., Las sectas entre nosotros, op. cit., p. 68.

${ }^{1210}$ Motilla, A., Sectas y Derecho en España, op. cit., p. 31.

${ }^{1211}$ SINGER MT / LALICH J., Las sectas entre nosotros, op. cit., pp. 196 a 199.

${ }^{1212}$ CANTERAS MURILlo, A., «Asociacionismo y libertad individual: Los movimientos religiosos-sectarios», op. cit., 66 y ss. Este autor y sus colaboradores en este informe-artículo consideran que no está en crisis el sentimiento religioso de los jóvenes «sino su aceptación del modelo eclesiástico-institucional al que es aplicable dicho rechazo asociativo formal», ID., ibidem, op. cit., p. 68.

${ }^{1213}$ RodríGUEZ, P., Esclavos de un Mesías. Sectas y lavado de cerebro, Ed. Elfos, Barcelona, 1984, p. 39. En opinión de SINGER y LALICH, de las personas que han ingresado en sectas, dos tercios «provenían de familias normales de buenas relaciones y demostraban una conducta apropiada a su edad (...) Del tercio restante, sólo alrededor del $5 \%$ al $6 \%$ tenían dificultades psicológicas serias antes de ingresar. La restante porción del tercio tenía depresiones diagnosticables relacionadas con pérdidas personales (...) o luchaba con dilemas sexuales o profesionales», SINGER MT / LALICH J., Las sectas entre nosotros, op. cit., p. 49. 
un trabajo con baja cualificación, inadaptación, baja autoestima, y un sentimiento religioso desmesurado. Esto evidencia que los miembros de las sectas, en contra del mito, no son, en principio, personas con dificultades mayores que la de los demás. La característica del perfil de un sujeto susceptible de entrar en sectas es una previa disposición a someterse a dinámicas grupales, ya sea por carencias afectivas o rebeldía, si bien consideramos que en ambos casos proviene de un sentimiento de someterse a la autoridad y a la confianza de otro para que éste sirva de foco o faro de guía, del mismo modo que la norma jurídica sirve, funcionalmente hablando, de guía de orientación en el comportamiento permitido.

El gran peligro de las sectas criminales es el uso de técnicas del lavado de cerebro o persuasión coercitiva, problemática que tiene su especial trascendencia en la capacidad de libertad de la voluntad o de obrar en general, como «nuevo mal» de nuestro siglo. Sin embargo, lo llamativo y especialmente característico de la dinámica persuasiva de las sectas coercitivas es que sólo cuando el adepto abandona al grupo criminal afloran los males vividos en ella. En ese momento es cuando se produce una desestructuración de la identidad y su vaciamiento, lo que produce una progresiva invalidación de la identidad social, que causa una confusión y disociación de la realidad, a lo que se le denomina médicamente «síndrome disociativo atípico». El ex-adepto sufre una desorientación sobre su propia imagen, sobre su identidad no sólo social sino también personal, una desorientación de los marcos actitudinales, valorativos e ideológicos; sensaciones de amenaza, agresividad hacia la nueva realidad social y personal, culpabilidad, abandono, y rechazo social del anterior grupo

En este momento aflora la idea de que el sujeto tiene una «adicción» a la secta, al grupo, a la conducta social, al líder, y a la necesidad de falta de decidir ${ }^{1214}$, en analogía a los drogodependientes que precisamente tienen una dependencia a sustancias, o a la dependencia a conductas de los ludópatas. De esta manera, la persuasión coercitiva fundamenta y procura una adicción comportamental y/o trastorno mental que unida al aislamiento cultural que se realiza muchas de las veces, consigue una obediencia a la autoridad que se representa en el líder o en la dinámica comportamental del sujeto.

\footnotetext{
1214 ECHEBARRÍA ECHABE, A., «Procesos grupales y construcción de la identidad: el caso de las sectas», vv.aa., Aspectos socio-jurídicos de las sectas desde una perspectiva comparada, op. cit., p. 49.
} 


\section{Estructura criminal sectaria: totalitarismo sistémico y comportamental}

Una organización es siempre una institución ${ }^{1215}$ que converge, funciona o es posible su funcionalidad en el Sistema, o en ocasiones lo pone en peligro. La aportación de LuHMANN al concepto de organización estriba en la consideración de las organizaciones como sistemas autopoiéticos que se producen y se reproducen por operaciones propias, de modo que son sistemas históricos no calculables pero a la vez reductores de la complejidad. Estas operaciones están formadas principalmente por decisiones, que ofrecen la peculiaridad de autodiferenciarse de otros sistemas autopoiéticos, de modo que cada decisión produce una operación en la organización que trata de «absorber incertidumbre» que viene del «entorno»(otros sistemas) para transformarla en certidumbre, de aquí que antes de cada decisión existan premisas de decisión ${ }^{1216}$.

En las sectas coercitivas, los dogmas por ejemplo, son premisas de decisión, y pueden generar cierto riesgo cuando se relacionan con un inminente apocalipsis o Armagedón ${ }^{1217}$, que según las circunstancias sociales del grupo constituyen a la vez una premisa de decisión sobre la decisión de «suicidios» colectivos. En opinión de VIDAL MANZANARES ${ }^{1218}$, las sectas se definen en su propia estructura. Tienen una estructura piramidal estratificada, donde la sumisión es incondicional al dirigente sin que exista una autoridad superior, se anula la crítica interna mediante la limitación o el impedimento total de acceso a las fuentes de información, la secta persigue objetivos generalmente económicos y/o políticos bajo la apariencia de una ideología de tipo filosófico o religioso, instrumentalizando a los adeptos para conseguir dichos fines. Unánimemente la literatura que se ha ocupado del tema ${ }^{1219}$ coinciden, grosso modo, en estructurar las sectas según un sistema de organización piramidal, jerárquico y cerrado, bajo una estructura familiar sectaria entorno al líder y al grupo, como institución global o totalitaria que propicia el aislamiento social en pro de la liberación. No parece necesario una comunicación presencial entre los miembros del grupo, basta con cualquier tipo de comunicación, en la lejanía

${ }^{1215}$ LuHMANN, N., Organización y decisión, Herder, 2010, p. 255

${ }^{1216}$ ID., ibidem, op. cit., pp. 25 y 26; ID., Organización y decisión. Autopoiesis, acción y entendimiento comunicativo, intr. Darío Rodríguez Mansilla, Anthropos, $1^{\text {a }}$ reimp. 2005, de la $1^{\text {a }}$ ed. 1997, pp. 14 y ss., del original «Organisation und Entscheidung. Autopoiesis, Handlung und kommunikative Vertändigung», Zeitschrift für Soziologie, 11, núm. 4, octubre de 1982, pp. 366 a 379.

${ }^{1217}$ Sobre grupos que anuncian el fin del mundo y las bases de pensamiento SANTAMARÍA DEL Río, Luís, Entre las sectas y el fin del mundo. Una noche que murmura esperanza, $1^{\mathrm{a}}$ ed., Vita Brevis, colección RIES núm. 2, Red Iberoamericana de estudios de las sectas, 2013, pp. 145 y ss; RODRíGUEZ P., El poder de las sectas, op. cit., pp. 91 y ss.

${ }^{1218}$ Vidal ManZanares, C., Psicología de las sectas, op. cit., pp. 11 a 13; ID., El infierno de las sectas, op. cit., pp. 11 y 12.

${ }^{1219}$ AZCONA, Francisco, «Las Sectas en España», Cuadernos de realidad social, núm. 35-36, 1990, pp. 176 y ss; CUEVAS BARRANQUERO, JM, Evaluación de persuasión coercitiva en contextos grupales, op. cit., p. 101; GUERRA, M., «Lo que es y lo que no es una secta», op. cit., pp. 28 y ss; VÁZQUEZ, JMª., Familia y sectas, op. cit., p. 56. 
de la cúpula ${ }^{1220}$ o la aceptación de los fundamentos que presuponen la criminalidad. A pesar de que la apariencia de las sectas criminales tiene una distribución horizontal y democrática de funcionamiento, lo cierto es que la mayoría de los estudios consideran que es una imagen que pretenden dar al objeto de facilitar la captación. Sin embargo, en nuestra opinión, a pesar de existir una jerarquía, la dinámica grupal y la inercia comportamental se asemejan a una estructura sistémica que se desvincula de la realidad jerárquica tomando más peso la primera, y cuyo resultado trae como consecuencia habitual la responsabilidad de todos: cada de los miembros es en sí mismo la organización.

Todas las opiniones consideran que las sectas se estructuran bajo el totalitarismo de la autoridad, si bien éste es sólo el caldo de cultivo para que nazca un grupo u organización criminal, dinámicas de sometimiento ciego y de persuasión coercitiva. Sin embargo, no podemos estar de acuerdo con los autores que mayoritariamente asocian la estructura totalitaria con la estratificada o jerarquizada, en nuestra opinión, estas formas sólo procuran una dinámica comportamental, si bien -como ya definió LUHMANN- la sociedad actual se caracteriza por sociedades funcionalmente diferenciadas, lo que significa que es sistémica. De esta manera, también podremos encontrar organizaciones o grupos sociales, y especialmente organizaciones criminales como algunas sectas, que no se caracterizan por tener una organización escalonada, jerarquizada o por estratos sociales, sino que en algunas, la modernidad y la gran cantidad de adeptos las llevan a organizarse sistémicamente, sin que exista una clara jerarquía de sujetos ${ }^{1221}$, sino una forma institucional de funcionar, y por lo tanto, una dinámica grupal que de manera más eficiente puede procurar el mismo fin sin necesidad de órdenes y mandatos expresos y continuados. De tal manera, la estructura sistémica criminal sectaria también dota de sentido al poder, más si cabe que el poder individualizado o jerarquizado ${ }^{1222}$. Esto se debe fundamentalmente a que el comportamiento grupal unísono se basa en principios ampliamente estudiados como el de complacencia, reciprocidad, compromiso y coherencia (comparación y «disonancia cognitiva», validación/sanción social, simpatía, cambio de la fuente de autoridad, escasez $^{1223}$. No obstante, sea jerarquizada o sistémica la organización criminal sectaria, en ambos

${ }^{1220}$ Cuevas Barranquero, JM., Evaluación de persuasión coercitiva en contextos grupales, op. cit., pp. 30 y 31; ID., «Aspectos psicológicos de las sectas destructivas. Situación de las sectas en España y formas de combatirlas. Características de los líderes y los miembros del grupo», Tratado de Medicina Legal y Ciencias Forenses, S. Salgado (dir.), Vol. IV, Barcelona, 2012, pp. 1471 a 1501.

${ }_{1221}$ WILSON, B., Sociología de las sectas religiosas, op. cit., p. 20.

1222 LUHMANN decía que «el perfil de poder de una organización no coincide con la súper- y subordinación formal de los puestos», LUHMANN, N., Organización y decisión, op. cit., p. 239.

${ }^{1223}$ Ampliamente con referencias bibliográficas sobre estos principios comportamentales y de influencia social, CUEVAS BARRANQUERO, JM, Evaluación de persuasión coercitiva en contextos grupales, op. cit., p. 103 a 144. Sobre la «comparación social» como forma de evaluar las propias opiniones FESTINGER, Leon, «A theory of 
supuestos pueden alimentarse déficits de socialización por el aislamiento u otro de los factores señalados del sujeto a la configuración normativa exterior: restricción o eliminación de expectativas normativas y del Sistema social.

Existen tantos tipos de sectas como sectas hay. Cada una posee unas características que la hace única. La oferta es tal que se dice que existe una secta adecuada a cada una de las personas. La doctrina que las inspira es diferente en unas y en otras. Mientras unas sectas tienen inspiración hebraico-cristina, otras son laicas, o filosófico-budistas o místicas. Desde una perspectiva sociológica, WILSON ${ }^{1224}$ las dividió en grupos conversionistas, revolucionarias, introversionistas, manipulacionistas, taumatúrgicas o reformistas y utópicas. Si bien no es este el lugar para estudiar todas y cada una de las clasificaciones de tipos de sectas o grupos religiosos, puede concluirse que éstas son tan variadas como formas de entender el mundo y de organización que se puedan concebir, lo que dificulta una clara clasificación de grupos religiosos, y menos aún criminales.

No obstante, las sectas coercitivas se diferencian de cualesquiera otros grupos religiosos en la estructura sistémica, institucional, totalitaria y autoritaria, en la dinámica comportamental grupal, la forma de captación y adoctrinamiento, en definitiva en la restricción o eliminación del horizonte de expectativas con las que opera el Sistema social. De aquí que las consecuencias de dicha restricción o eliminación de expectativas sea la distorsión de las operaciones que se realizan en el marco exclusivamente señalado por la dinámica comportamental del grupo. En este sentido, el sentimiento de libertad se ve modificado, y consecuentemente aquellas operaciones que se realizan bajo dicho sentimiento.

En las sectas coercitivas los delitos más habituales suelen ser la estafa por su conexión con el ánimo de lucro perseguido por la organización, por eso es que conceptos como el de compraventa se ven restringidos o eliminados y causan una obligación ineludible para alcanzar la «salvación», de tal forma que el precio nunca se constituye como un motivo de aceptación o rechazo del producto: está eliminado o restringido el horizonte de expectativas de elección. También se cometen delitos contra la salud y la vida, se relaja la autoconciencia de los sujetos sobre dichos bienes y los conceptos que los sustentan, de modo que se restringe o elimina la realidad de estos, es irresistible la aceptación de programas terapéuticos o en las formas más

comparison processes», Human Relations, 7, 1954, pp. 117 a 140; sobre la «disonancia cognoscitiva» como discrepancia habitual entre el pensar (también convicciones morales) y el hacer ID., Teoría de la disonancia cognoscitiva, CEC, Madrid, 1975. TAJFEL al respecto señaló que «la eficaz difusión de la idea de que «pasar» individualmente del grupo propio a otro es imposible o extremadamente difícil hace que cada vez más gente de ese grupo sienta y actúe al unísono», TAJFEL, H., Grupos humanos y categorías sociales, op. cit., p. 329.

${ }^{1224}$ WILSON, B., Sociología de las sectas religiosas, op. cit., pp. 37 a 41. 
graves son inevitables los «suicidios colectivos»: se difuminan los conceptos de salud, vida y muerte de tal forma que no son específicamente considerados.

La organización totalitaria sectaria que opera bajo tales dogmas, dinámicas y, en definitiva, con la restricción o eliminación de expectativas normativas, produce operaciones contra el Sistema social. Se conectan premisas de decisión con decisiones de aniquilación y/o dinámicas de comportamentales que restringen o eliminan el horizonte de expectativas, por ejemplo, cuando se disocia la muerte con una vida en el más allá, en otro planeta u otra dimensión, bajo dinámicas comportamentales grupales, que producen una consecuencia indeseada para el Sistema: la desocialización de los sujetos. Es una forma de facilitación de injustos, o en sí mismo un peligro autónomo. Entonces, se determina un fundamento de ilegalización de la organización, y de otra, la competencia por una «comunidad riesgosa» para el Sistema Social.

De aquí que para el subsistema del Derecho penal es indiferente si dichas decisiones son tomadas con toda conciencia y voluntad (dolo), se toman como un riesgo (dolo eventual e imprudencia consciente, autopuesta en peligro) o como creación de un riesgo (peligro). Para el Derecho penal interesa si una operación (comportamiento) puede valorarse e incluirse en el Sistema social, o debe descartarse reparándose el daño producido, o directamente no tenerla en cuenta: esto significa que se valora el hecho de si la operación ha producido comunicación en la Sociedad. De este modo, cualquier operación realizada por una organización que pone en peligro la operatividad del Sistema Social se combate de tal modo que se expulsa del mismo, siendo de este modo ajeno el dolo, la imprudencia, o la auto-puesta en peligro. El Sistema trata estas operaciones como peligro para su propia operatividad.

Aquí pueden tratarse los casos de suicidios colectivos bajo la creencia de un más allá, traslado a otro planeta o dimensión. Si bien es lícito creer tanto en una vida después de la muerte o que con la muerte existe un traslado a otro planeta o dimensión, lo que no es lícito es difuminar/restringir o eliminar el concepto básico de la muerte de tal modo que surja la necesidad de vivir en el más allá, en otro planeta o dimensión, porque de tal modo, el concepto de muerte se esfuma, se genera una expectativa que cuando se forma de manera ineludible deja de tener sentido la muerte, máxime cuando la fuerza que genera la decisión de suicidio viene de la garantía de que efectivamente existe ese más allá, tal traslado a un planeta, o tal vida en dicha dimensión, lo que lleva al sujeto a desterrar la posibilidad real de la muerte, pues se comunica una «confianza que genera garantía» (en el sentido expuesto por JAKOBS sobre la confianza especial que genera responsabilidad institucional y a diferencia de la confianza que proporciona garantía) de que tal muerte, no se produce realmente. Se produce una «absorción de 
incertidumbre» para transformarla en certidumbre: no se muere. Lo que el Sistema valora como un peligro para sus propias operaciones es la constitución de una «confianza que genera confianza», una garantía de una expectativa que unida al modo en que se restringen o eliminan las expectativas normativas y del Sistema social, facilita la exclusividad de dicha nueva expectativa, que al no existir otras, propicia que se conecta forzosamente la voluntad con esa expectativa, difuminando los conceptos de dinero, salud, vida, muerte, etc. Esto significa que la garantía y su conexión ineludible de voluntad con esa nueva expectativa constituya una expectativa anti-normativa y anti-sistémica-social cuando se produce una «absorción de incertidumbre» del «entorno» (otros sistemas) para transformarla en certidumbre.

Sobre esto volveremos al tratar los delitos-fin en particular, si bien de lo dicho se puede concluir anticipadamente que en las sectas coercitivas que operan bajo una dinámica comportamental contra el Sistema Social se restringe o elimina el sentido de la acción de compraventa, auto-puesta en peligro y la realidad de la vida y la muerte. Entonces, y en definitiva, aquí se produce un «déficit de garantía cognitiva» imputable al comunicador, que precisa de «aseguramiento no sólo contrafáctico sino también cognitivo».

\section{IV.- Los trastornos típicos de los sectarios y ex-sectarios}

Los trastornos ligados a las sectas son consecuencias derivadas de la misma pertenencia a ellas, resultantes no sólo de la intensidad y gravedad de la propia situación coercitiva, sino también de los renombrados aislamiento cultural, adicción comportamental y obediencia ciega a la autoridad, sin embargo no siempre afloran.

La Asociación Americana de Psiquiatría reconoce varios trastornos de personalidad que suelen desarrollar los miembros sectarios expuestos a la coerción ${ }^{1225}$. Entre los trastornos que la psiquiatría y la psicología aprecian se encuentran el Síndrome de Estocolmo, Síndrome de Adoctrinamiento Sectario y el Síndrome Post-Sectario ${ }^{1226}$. Estos síndromes incluyen una serie de

${ }^{1225}$ El neuropsiquiatra Jolyon WEST expuso el carácter del problema de salud y enfermedad de la mente que tiene el sectario que requiere un tratamiento médico y de sanidad pública, WEST, Jolyon Louis, «Propuestas de Salud Pública sobre las sectas», Ponencia en el I Congreso Internacional, Sectas y Sociedad, pp. 29 a 40.

${ }^{1226}$ DSM-V. Diagnostic and Statistical Manual of Mental Disorders. Ed. American Psychiatric Association; JANSÁ, Josep Ma., La coartación de la libertad a través de las sectas destructivas, una sutil forma de violencia, Barcelona, 2003; MARTíneZ BernAL, Juan Carlos, Lavado de Cerebro y su Desprogramación Psicológica, Universidad Gestalt de América, recuperado el 31 de Julio de 2007 de http://www.mundogestalt.com; PERLADO, M., «La violencia del sectarismo», Ponencia presentada en el XVII Congreso Internacional de la Asociación de Estudios Médico Psicológicos y Religiosos (AIEMPR), Estrasburgo, del 10 al 14 de julio de 2006; VV.AA., «Sectas y grupos destructores de la personalidad, Cuidado: respuestas definitivas a las dudas existenciales», Revista Consumer Eroski, Sección de Psicología, núm. 33, Fundación Eroski, B º San Agustín s/n. 48230 Elorrio, Vizcaya, España. Recuperado el 31 de Julio de 2007, de http://revista.consumer.es. 
trastornos de personalidad, los cuales están incluidos en el Manual Diagnóstico y Estadístico de Trastornos Mentales de la Asociación Americana de Psiquiatría. En concreto, los siguientes.

La Psicosis Reactiva Esquizoafectiva se caracteriza por la esquizofrenia, contiene características maniaco-depresivas y esquizoafectivas, y episodios psicóticos. El Trastorno Disociativo Atípico se caracteriza por alteración de la memoria y de la conciencia, de la identidad, con conflictos con la personalidad previa o con el yo, con regresiones psicológicas. Es el síndrome más diagnosticado en ex adeptos a sectas que han utilizado la persuasión coercitiva durante periodos largos que crea una dependencia denominada «sectadependencia», consiguiéndose de tal forma que el adepto no piense por sí mismo, adopte una postura infantil e irresponsable. El Trastorno Psicótico Compartido, o también denominado Trastorno Delirante Inducido, se caracteriza por un trastorno psicótico en una idea delirante que se comparte con una o varias personas que finalmente se contagian de la idea delirante total o parcialmente y por ende también el trastorno. La Ansiedad inducida por la relajación o ansiedad generalizada se forma por estados de relajación y meditación excesivos provocando ansiedad, preocupación, incontrolabilidad de la ansiedad, fatiga, susceptibilidad y alteración del sueño, lo que lleva al sujeto a alejarse de su vida social, familiar y laboral. El Trastorno por Estrés Postraumático es un trastorno que nace de un suceso peligroso, amenazante y estresante para su vida o integridad física, que conlleva un eterno retorno de la vivencia en el sujeto afectado. Los Trastornos del Estado de Ánimo (Depresivo Mayor Único y Depresivo Mayor Recidivante), están dentro del DSM bajo la categoría de Trastornos del Estado de Ánimo. La única diferencia entre ambos trastornos es cuestión de incidencia. El Trastorno Depresivo Mayor Único se caracteriza por un episodio único depresivo mayor, mientras que el Trastorno Depresivo Mayor Recidivante se caracteriza por contener dos o más episodios depresivos mayores. Su sintomatología presenta cambio de peso y apetito, irritabilidad, falta de sueño y energía e ideas de suicidio. Los miembros sectarios suelen experimentar este trastorno al abandonarla, se deprimen, se aíslan y/o sienten miedo. Las Reacciones Varias o Misceláneas incluyen déficits cognoscitivos como dificultades de concentración, incapacidad para mantener la atención, déficits de memoria (sobre todo la memoria a corto plazo), automutilaciones, fobias, suicidio y homicidio, y factores psicológicos con consecuencias orgánicas, como infartos de miocardio, muertes súbitas, úlceras pépticas recurrentes o asma.

Hemos hablado de los trastornos típicos de los miembros sectarios que surgen durante la pertenencia al grupo, sin embargo una de las más graves consecuencias del influjo de las sectas coercitivas es el Síndrome Post-sectario. Es el que se reproduce en el sectario una vez 
abandonada la misma, cuando vuelve a la realidad familiar, social y laboral. Éste suele experimentar ansiedad al percatarse del cambio sufrido, con otras palabras, por el cambio de su yo al objeto ideal o yo del líder y nuevamente al yo personal. Se enfrenta el sujeto al conflicto de yos, de personalidades, que le hace sentir miedo y dolor por el abandono del grupo, insatisfacción o frustración. En los peores casos, esa «adicción» o dependencia al grupo puede ya no sólo durar de por vida, sino que también afecta en la voluntad y en su capacidad de decisión, o cambio en las metas vitales que dependerá de qué forma se haya conseguido salir del sectarismo (abandono, desinterés del grupo o expulsión).

A consecuencia de todo lo explicado, es fácil prever que los miembros de las sectas que utilizan diversas técnicas de persuasión coercitiva y que finalmente escapan sufren en la mayoría de casos diversos daños de distinta índole, desde enfermedades mentales o emocionales y físicas, o un desarrollo psicológico repercutido, estrés, hasta lesiones, explotación económica y laboral, y la propia muerte.

Sobre las enfermedades mentales ${ }^{1227}$, los estudios dedicados al tema resaltan hasta cinco grupos de psicopatía inducida ${ }^{1228}$ : la reacción esquizo-afectiva-reactiva del tipo de psicosis, desórdenes de estrés postraumático, desórdenes de disociación atípica, ansiedad inducida por la relajación y otras reacciones como ansiedad aparejada a deficiencias cognitivas (problemas de concentración, por ejemplo), reacciones por estrés que pueden producir ataques al corazón y derrames cerebrales, automutilación, fobias y suicidio. Inclusive los niños que han pertenecido a sectas presentan cuadros similares a los niños que estuvieron en campos de concentración, como el «síndrome de supervivencia de campo» ${ }^{1229}$, aunque también puede aparecer una enfermedad que suele apreciarse en ex-miembros, como es la psicosis postsecta, que consiste en paranoias y complejos de culpabilidad $^{1230}$.

En concreto el trastorno típico de los ex-adeptos a sectas es el Síndrome Disociativo Atípico, cuyos rasgos principales los podemos resumir conforme a la clasificación de LANGONE ${ }^{1231}$ en las siguientes características: un cambio repentino y drástico, súbito y catastrófico en la jerarquía

\footnotetext{
1227 Sobre las enfermedades mentales o trastornos psíquicos y terminología que tiene en cuenta la psiquiatría, véase el Manual Diagnóstico y Estadístico de la Sociedad Americana de Psiquiatría, llamado «DSM-V»; JORDÁN VillaCAMPA, Mª., Las sectas pseudorreligiosas, op. cit., pp. 19 y 20; SINGER, MT., «Los programas de modificación del pensamiento y la producción de casos psiquiátricos», op. cit., pp. 53 a 58.

${ }^{1228}$ Véanse sobre estos cinco grupos calificados por SINGER, MT., «Los programas de modificación del pensamiento y la producción de casos psiquiátricos», op. cit., p. 53 a 58; JORDÁN VILLACAMPA, Mál., «Las sectas pseudorreligiosas», op. cit., pp. 21 y 22.

${ }^{1229}$ LANDA, Shirley, «Niños en sectas. Sus relaciones familiares y su educación», ponencia del I Congreso Internacional Sectas y Sociedad, celebrado en San Cugat del Vallés, Barcelona, 1987, pp. 77 y ss.

${ }^{1230}$ Más ampliamente SINGER, MT., «Repercusión en el núcleo familiar», Sectas y Sociedad, op. cit., p. 63; JORDÁN VILLACAMPA, Mª., «Las sectas pseudorreligiosas», op. cit., p. 23.

${ }^{1231}$ LANGONE, MD., La conversión a las sectas peligrosas: teoría, investigación y tratamiento, Boston, 1981.
} 
de valores del sujeto pasivo, influyendo normalmente el abandono de las metas académicas anteriores; reducción de la flexividad y adaptabilidad cognitiva, la víctima contesta a las preguntas de forma mecánica sustituyendo lo que podían haber sido sus respuestas por las de la secta; un afecto cerrado y estrecho, se eliminan los sentimientos espontáneos afectivos; una regresión que recuerda a un volver a empezar la infancia; los cambios físicos como la pérdida de peso, la palidez, el agotamiento que se materializan en una mirada en blanco y perdida; y en los casos más excepcionales pueden aparecer trastornos psicopatológicos como la disociación, la obsesión y alucinaciones que pueden llegar a cuadros psiquiátricos graves.

Recientemente CUEVAS BARRANQUERO ${ }^{1232}$ ha propuesto un método de detección de las técnicas coercitivas mediante la Entrevista de Evaluación de Persuasión (EPC) y la Detección de Dinámica Sectaria Destructiva (EDPC), que las ha aplicado como perito a diversos procedimientos judiciales.

\section{V.- Adicción comportamental}

\section{A. Concepto de adicción sectaria}

Al hilo de las consideraciones expuestas en el capítulo primero sobre la psicología de las masas de los grupos sociales (FrEUD), Pepe RoDRíGUEZ ${ }^{1233}$ señala que si analizamos aquel sectarismo que emplea técnicas de persuasión coercitivas y realizamos un estudio pormenorizado de las vivencias completas de los afectados, desde ya antes de la entrada a la secta hasta su situación post-secta, la inmensa mayoría de sujetos presentan un perfil psicosocial con muchísimas coincidencias al de un adicto a sustancias estupefacientes, o adictos a comportamientos como el juego, internet, etc. ${ }^{1234}$. Los problemas previos de un «sectariodependiente» - en la terminología de RODRÍGUEZ ${ }^{1235}$ - nacen de factores de determinación que ha expuesto la Teoría de Desarrollo Social, la familia como principal factor, la escuela y la adhesión de los sujetos en grupos de iguales (amistades, grupos profesionales, asociaciones deportivas etc.). Estos tres factores marcan en gran medida el desarrollo de la personalidad de los sujetos, su identidad y, por ende son causantes de estímulos de satisfacción y de dolor.

\footnotetext{
1232 CUEVAS BARRANQUERO, JM, Evaluación de persuasión coercitiva en contextos grupales, op. cit., pp. 278 y ss. y pp. 407 y ss.

${ }_{1233}$ RODRÍGUEZ, P., «La sectadependencia», op. cit; ID., Adicción a sectas, op. cit., pp. 63 y ss.

1234 En este sentido, GARCÍA-PABLOS ha denominado a este tipo de conductas adictivas (ludopatía, cleptomanía, piromanía) de «trastorno en el control de impulsos», GARCÍA-PABLOS DE MOLINA, Antonio, Tratado de Criminología, $4^{\mathrm{a}}$ ed., Tirant lo Blanch, Valencia, 2009, pp. 575 a 580.

${ }^{1235}$ RODRÍGUEZ, P., «La sectadependencia», op. cit; ID., Adicción a sectas, op. cit., pp. 63 y ss.
} 
Cuando alguno de estos factores crea ambientes de frustración, carencia afectiva, el sujeto tiende a la soledad y a que sus niveles bioquímicos de neurotransmisores aminoren a niveles más bajos de los normales. Amén de ello, una sustancia o conducta que los incremente genera un gran bienestar que tiende a ser repetida por el sujeto. Estas sustancias o conductas son perjudiciales para el sujeto, ya sea por administración directa (drogas) o porque quien se las facilita las utiliza para conseguir la anuencia del administrado, que repetida en el tiempo, puede conseguir la influencia necesaria para que cometa delitos ordenados o acciones en beneficio del administrador.

Según lo expuesto, el «lavado de cerebro» adolece de realidad psicosocial. No podemos hablar de marionetas que en todo momento y espacio adecúen su conducta al libre designio de otro. Los sujetos «sectariodependientes» tienen conciencia de su conducta, de la antijuricidad de sus actos cuando perpetran un delito. Al igual que el drogodependiente conoce que la droga le satisface para evadirse de los problemas, el «sectariodependiente» utiliza ese rol para reducir su ansiedad, sin embargo como en toda dinámica adictiva, la sustancia o lo comportamental acaba por dominar gran parte de los quehaceres del sujeto, necesitando el afecto del grupo, su amor, el afán de divinidad, por ello realiza todo lo necesario para cumplir con la meta que se le ha marcado. Sin embargo, las metas sectarias son difusas, ambiguas e inalcanzables a pesar de que los sujetos hagan todo lo necesario para alcanzarlas y adecúen su conducta a la del rol sectario, lo que genera un círculo infinito de frustración-felicidad-frustración, similar al que representa el consumo de drogas.

Las drogas y diversos comportamientos son reductores de ansiedad. Piénsese en quien fuma un cigarrillo o juega a las tragaperras. Normalmente, la solución rápida y eficaz para eliminar frustraciones, o la ansiedad, es la menos aconsejable por las repercusiones que tiene. Sin embargo el consumo habitual de las drogas y el juego, acaban por someter al sujeto a un rol adictivo, que genera conductas tendentes a aliviar la ansiedad de forma constante.

Con el mismo significado de analogía, se considera que las sectas actúan como traficantes de drogas, suministrando el material necesario para lucrarse mediante sujetos que acceden al producto por la fragilidad del momento que presentan desesperación, fragilidad y carencias psicosociales. Por eso, la problemática no puede centrarse únicamente en la conducta del grupo sectario-enemigo, sino en ciertas ocasiones también en el sujeto «presectario», que sumando la utilización de técnicas de control de forma dolosa provocarán una dependencia similar a la de un adicto. Podemos adelantar que en esta dinámica el grupo se aprovecha de la especial vulnerabilidad que presenta en ocasiones la víctima para crear un estado de dominación y 
conseguir determinados fines, entre ellos que el sujeto finalmente dependiente cometa delitos para procurar la impunidad del grupo, de su líder y miembros. Por eso, la forma, la intensidad de aplicación de una técnica manipuladora únicamente nos aportará el dato del grado de control teórico, el grado de ejecución del delito de lesiones en la psique de la víctima, pero no si en efecto el sujeto está dominado, es dependiente. Por el contrario, la situación anterior a la inserción del sujeto en la secta nos mostrará el grado de dependencia alcanzado en el momento del análisis.

Pero debe quedar claro que no todos los miembros de sectas son sectadependientes, ni son sujetos expuestos a técnicas de persuasión, igual que no todos los miembros de una organización criminal dedicada al tráfico de drogas son adictos o consumidores, sino que la captación e inserción en grupos que utilizan dichas técnicas son factores que aumentan la probabilidad de éxito de la dependencia. Supone un principio de peligrosidad objetiva cuando estas técnicas son idóneas para crear la dependencia (acto preparatorio), o una tentativa cuando se comience a ejercer sobre el sujeto.

Cuando se dice que todos podemos ser víctimas de una secta no es del todo exacto -según lo expuesto por RODRÍGUEZ-, pues falta que el sujeto tenga un perfil presectario idóneo para consumir la identidad sectaria, o si se prefiere, el sujeto debe estar frágil psicosocialmente hablando, pero esto no supone una asunción de autopuesta en peligro de la víctima, puesto que la libertad de conciencia es un bien irrenunciable, que no indisponible, al menos no de un modo absoluto. Un factor es la vulnerabilidad previa del sujeto, pero ha de quedar claro que no existen estudios que avalen una personalidad presectaria ${ }^{1236}$. Supone un factor, en nuestra opinión, tanto para la aplicación de cierta agravante por el aprovechamiento de la especial vulnerabilidad de la víctima $\mathrm{o}$, en otros casos, $\mathrm{y}$ esta es la problemática, también para deducir su propia responsabilidad.

Este proceso de adicción, a nuestro juicio, viene de la prolongación de la restricción del horizonte de expectativas sociales, imponiéndose con sutileza exclusivamente las sectarias, de tal modo que con el paso del tiempo el sujeto se desocializa (déficit de socialización), y llega un momento que sólo puede elegir las expectativas sectarias aunque se le presenten otras, lo que supondrá ya la consumación de otro injusto, la adicción como lesión psíquica.

\footnotetext{
${ }^{1236}$ Entre otros CUEVAS BARRANQUERO, JM., Evaluación de persuasión coercitiva en contextos grupales, op. cit., pp. 37, 58 y 59 y pp. 409 y ss; PERLADO, M., «La intervención clínica con pacientes vinculados a sectas», Cuevas BARRANQUero JM / PeRlado M., Abuso psicológico grupal y sectas destructivas, AIIAP, Barcelona, 2011, pp. 43 a 70.
} 
El proceso bioquímico que sufre el cuerpo del adepto es semejante al de cualquier otra adicción a sustancias. La razón de que una sustancia o una conducta repetida pueda llegar a ser adictiva para un sujeto en concreto es, precisamente su personalidad previa, sus condicionantes sociales, familiares y profesionales. Dicho de otra manera, la condición de que un sujeto acabe sometiéndose a la adicción comportamental es que el sujeto acepta que la forma de mermar sus carencias y vivencias traumáticas es la realización de la conducta grupal. El sujeto cree no poder asumir por sí solo su estado emocional, y se lanza a confiar en un grupo e identidad grupal que con el tiempo sustituye la suya propia, con lo que consigue una sensación de satisfacción emocional y de estabilidad que antes no tenía, por ejemplo con su familia y/o con su grupo de amigos o trabajo. Como decimos, la doctrina sectaria-criminal es difusa, ambigua, con unas metas que sólo se pueden conseguir normalmente tras la muerte (la salvación eterna), por eso el sujeto vuelve a un estado de frustración y ansiedad, que se palia por el adicto aceptando conductas ordenadas por el grupo y su líder.

El sujeto siente que no puede alcanzar la salvación, la iluminación, por eso luego acepta volver a adecuar su comportamiento conforme a los inspirados en los ritos, los tantras, las jornadas de trabajo abusivas, la dieta escasa, la meditación, las donaciones, etc... Sin embargo, mientras se realizan estas conductas -y parafraseando a NIETZSCHE-, el sujeto tiene Voluntad de Poder, pero conforme trascurre el tiempo y ve que esas metas no se consiguen, siente ansiedad y este estado emocional sólo puede aliviarse con otra dosis comportamental, la ejecución de una orden de la secta, que el grupo le agradece con amor, afecto y alabando la rectitud de su conducta a la norma sectaria. En definitiva, esa Voluntad de Poder a la que nos referimos es cíclica, espuria y eterna en lo idéntico. La conducta adecuada a la norma sectaria crea satisfacción pero a su vez ansiedad, por lo que al igual que sucede en un drogodependiente, cuanto más se repite este ciclo más inmerso y sectadependiente se es.

Ahora es más entendible que las terapias consistentes en el choque de la realidad, como la desprogramación, resulten inidóneas para la sanidad del sujeto, puesto que mediante éstas el sujeto se encierra más en sí mismo y en el grupo. Una terapia brusca e intensa se percibe por el sujeto como un atentado contra la única cosa que le procura placer, la conducta adecuada a la norma sectaria. Se produce una adicción a la norma que en algunos casos supone una adicción a normas contrarias a la Ley penal, una adicción a cometer delitos que se inició con el proceso de desocialización, que culmina con el déficit de socialización, cuando no en una verdadera adicción comportamental. De este modo, es comprensible que la restricción de las posibilidades 
y expectativas de elección a la larga causan un déficit de socialización y en su máxima gravedad una adicción comportamental.

En tal sentido, se comenta ${ }^{1237}$ que las sustancias endógenas como la serotonina, la dopamina y la noradrenalina funcionan como trasmisores bioquímicos de satisfacción. Si estos neurotransmisores tienen niveles normales en el cuerpo, cuando se incrementan la sensación de bienestar será leve, y al contrario, en un sujeto con niveles bajos su incremento dará una satisfacción inmensa, lo que hará que el sujeto recurra nuevamente a la sustancia o conducta que le haya reportado ese bienestar rápido y eficaz.

En nuestro caso, la administración de normas sectarias, la ritualización de la conducta y la adecuación de la conducta a los dogmas y normativas sectarias que esencialmente son totalitarias y autoritarias, según lo visto, incrementa la satisfacción del sujeto, pero a su vez le mantiene en la dinámica sectaria. Si comparamos estos comportamientos con los realizados por adictos a sustancias, vemos que existe cierta similitud ${ }^{1238}$. Así, podemos concluir que la adicción supone un delito contra la integridad y la salud de la persona, pero que se inicia por un proceso de persuasión coercitiva, análogo a la coacción, que produce un déficit de socialización, que con el tiempo, se representa como una adicción comportamental, cuya relevancia es una lesión psíquica.

Como afirma FAULKNER ${ }^{1239}$, la adicción es un trastorno que supone un daño en el equilibrio bioquímico del organismo que lleva a la pérdida de habilidad para relacionarse con el mundo exterior. Repárese que la ludopatía como adicción comportamental está reconocida como un trastorno. Se señala ${ }^{1240}$ que la conducta adictiva más que favorecer el comportamiento lo reduce, puesto que no busca tanto el placer, sino la reducción del dolor, por ello, que de tal manera sea más habitual incurrir en delitos omisivos que en delitos activos, salvo en los casos más graves de la autoría de conciencia en comisión por omisión, o los de la autoría por convicción y del enemigo.

\footnotetext{
${ }^{1237}$ En concreto Pepe RODRÍGUEZ se refiere a esta dinámica de la adicción comportamental en el siguiente sentido: «(a)l analizar el entorno psicosocial previo de los sectarios encontramos siempre una constante de «dolor emocional» como sentimiento derivado de rutinas cotidianas escasamente satisfactorias, por eso será oportuno recordar que la percepción del dolor a extinguirse a partir de la activación de los opiáceos endógenos -como las endorfinas, que bloquean o reducen la acción de la «sustancia P», responsable de la trasmisión de la información del dolor $-\mathrm{y}$ que, dado que el pensamiento y las emociones pueden activar la producción de endorfinas, aspecto documentado en los estudios de Orsntein y Sobel sobre el efecto placebo, resulta evidente que ambos procesos -base del consumo de «secta»-, al ser capaces de evocar la producción de betaendorfinas, pueden sostener dinámicas adictivas (...) es muy significativo que el aislamiento social reduzca precisamente la liberación de dopamina y, entre otras, disminuya la presencia de endorfinas que llevan a incrementar la percepción dolorosa», RODRÍGUEZ, P., «La sectadependencia», op. cit., pp. 159 y 160.

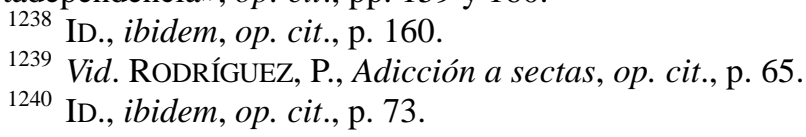


Por otro lado, no podemos estar de acuerdo con RODRÍGUEZ-CARBALLEIRA ${ }^{1241}$ cuando explica que la clave para el entendimiento de la dinámica sectaria y su peligrosidad nace de la forma en la que se adentra el sujeto en la secta, por afiliación voluntaria o captación mediante técnicas de manipulación coercitiva y por tanto sin libertad. Claro está que ex initio el uso de estas técnicas hacen más peligrosa la dinámica posterior, la gravedad y en definitiva el delito, pero -como ha explicado RODRÍGUEZ, entre otros- es posible que un sujeto entre voluntariamente gracias a ese perfil presectario, o con otras palabras, porque demanda sectarismo, afecto obsesivo, y finalmente se someta a la voluntad del grupo, sin embargo de esto tampoco se puede concluir que exista una condición previa de debilidad o de psicopatías previas ${ }^{1242}$. Claro está que si se reúnen tres requisitos fundamentales a saber, perfil presectario, técnicas de persuasión coercitiva y la prolongación larga en la dinámica sectaria, la probabilidad de que el adepto llegue a ser un sectadependiente o que su capacidad de libertad de voluntad se anule como adicción comportamental, o sea, como trastorno que ampare una causa de inimputabilidad a la que se refería parte de la doctrina, es elevadísima.

Se puede ya concluir que la dinámica sectaria supone la restricción del horizonte de expectativas, y a la vez la administración progresiva de conductas adictivas. En primer lugar, la administración de técnicas de persuasión coercitiva pretende, exclusivamente, y por tanto pertenece al delito-fin de una secta-criminal, la nublazón de la formación de la decisión y en su consecuencia de la capacidad y ejercicio de la voluntad, que si es perdurable en el tiempo, intenso en su administración y con predisposición por el sujeto, producen una lesión psicológica de relevancia jurídico-penal como adicción comportamental, de lo que deviene que hasta que se alcanza ese estado de sumisión adictiva completa el sujeto tiene un déficit de socialización por la habitualidad de la restricción de las posibilidades de elección, en este caso, atribuido a un tercero, y no a la norma jurídica como expusimos en el capítulo segundo. El segundo fin, no necesario y por tanto impropio, la utilización de ese estado por quien lo administra u otro sectariodependiente, como medio de un delito sobre otros o sobre él mismo.

Las personas que se adentran inicialmente en una secta estrictamente criminal cambian en pocos días su estado de ánimo, de sentirse habitualmente temerosos, aislados y depresivos a actitudes positivas, eufóricas y alegres. Modifican de forma repentina y esencial la vestimenta, la dieta, la lectura y la música, las aficiones, los hobbies, las expresiones y discursos dialecticos, el

\footnotetext{
1241 RoDRÍGUEZ-CARBALlEIRA, A., «Sectas coercitivas y juventud», op. cit., pp. 119 y 120.

1242 CUevas BARRANQUero, JM, Evaluación de persuasión coercitiva en contextos grupales, op. cit., p. 37.
} 
carácter y metas en la vida ${ }^{1243}$. Esto se debe precisamente a que desde el primer minuto la secta aborda al sujeto con mensajes personales de amor, cariño y respeto, que hace aumentar en el sujeto de forma rápida y eficaz sus niveles de neurotransmisores del bienestar, lo que en definitiva se trata también de un problema neurobiológico como vamos a ver a continuación, y de aquí la lesión psicológica.

\section{B. Teorías sobre la adicción: la adicción comportamental y sus consecuencias penales}

OLD y MILNER ${ }^{1244}$ descubrieron los mecanismos cerebrales de refuerzo. Comprobaron que la recompensa aumentaba los neurotransmisores dopaminérgicos que regulan el control motriz y cognitivo, y que la endorfina regula los niveles de dolor y placer, de tal manera que las conductas en sí mismas constituyen reforzadores positivos o negativos naturales o endógenos.

La dopamina, más que generar placer o dolor, refuerza los estímulos recibidos en el momento de la administración de una sustancia o al realizar determinada conducta. Las drogas, pero también los comportamientos, aumentan los niveles de dopamina, y en tanto se repita el consumo genera en el cerebro un reforzamiento negativo que sólo desaparecerá con otra dosis de sustancia o de comportamiento, puesto que la repetición hace que el cerebro precise de mayor cantidad para lograr el mismo efecto, hasta el punto que los sujetos adictos asocian el momento previo al consumo como un estado ya de eliminación del dolor ${ }^{1245}$.

1243 Más ampliamente RoDRíGUEZ, P., Adicción a sectas, op. cit., pp. 262 a 268.

1244 Con amplias referencias y explicaciones ID., ibidem, op. cit., pp. 74 a 91.

1245 Señala Pepe RodRíGUEZ que «cuando los niveles de estrés superan los que una determinada persona puede manejar, comienza a alterarse seriamente el funcionamiento de tres hormonas y neurotransmisores básicos serotonina, noradrenalina y dopamina- que actúan a modo de «mensajeros del bienestar». El nivel de serotonina es una causa para sentirse bien ya que interviene en la fisiología del sueño, apetito, digestión, vasoconstricción, depresión y trastornos de ansiedad y pánico. La noradrenalina -o norepinefrina-, pariente de la adrenalina, tienen muchas funciones básicas... el establecimiento de los niveles de energía... cuando baja el nivel de endorfinas en el cerebro, las glándulas adrenales, estimuladas por la hormona adrenocorticotropa, pueden producir dopamina y usarla como un precursor de la noradrenalina; un mecanismo que explica la razón por la cual muchas personas buscan provocarse un subidón de adrenalina para levantarse el ánimo (en el extremo de este comportamiento encontramos a los adictos al juego, al trabajo, al riesgo y muchas otras conductas, entre las que están algunas pautas básicas del sectarismo)... cuando se reduce la acción de la dopamina también lo hacen las endorfinas, por eso, cuando el sujeto de estrés ocasiona una disminución de dopamina, el sujeto pierde su anestésico natural. Dado que la dopamina dirige el sistema de recompensas cerebrales o «centro del placer», cuando el estrés interfiere con la función dopaminérgica este sistema de recompensa se vuelve inoperante $\mathrm{y}$, en consecuencia, las actividades cotidianas capaces de despertar sensaciones placenteras ya $\mathrm{n}$ producen bienestar (...) Cuando se tiene niveles normales de «mensajeros del bienestar», cualquier estimulación adicional -que afecte a cualquier sentido de forma placentera- no pasará de ser una experiencia agradable que se mezclará con el resto de vivencias cotidianas sin más; pero cuando un sujeto presenta niveles bajos de esos mensajeros -ya sea por estrés excesivo o debido a causas genéticas-, su sistema de recompensa cerebral se encuentra en un estado muy debilitado y, por ello, cualquier estimulación que reciba - vía administración de sustancias y/o conductas- tendrá un efecto extraordinariamente impactante». Así, de esta forma, añade este autor que «( e)l sectadependiente pasó a depender de su secta para reducir su angustia vital y aprendió a servirse de los usos sectarios -dogmas y prácticas ritualizadas, que le incrementan los niveles de «mensajeros del bienestar»- para mejorar su estado anímico; pero se angustia de nuevo si no practica esos usos -ya que decrece su nivel de neurotransmisores del bienestar (...) Además, dado que toda dinámica sectaria establece una 
La bioquímica del cerebro y los niveles de las neuronas dopiminérgicas pueden generar procesos adictivos cuando el sistema de refuerzo de la conducta emocional es intenso, sin que el raciocinio tenga un papel importante porque se ve sometido a una necesidad imperiosa de saciar la carencia de valores inherentes al ser humano como el afecto, el amor y, en definitiva, el crecimiento personal, o esa la Voluntad de Poder del ser humano.

$\mathrm{Si}$ un sujeto no adquiere los elementos necesarios para colmar esas necesidades, su debilitamiento le hace más vulnerable, pero a su vez, más manejable, si un tercero se lo administra, o utiliza ese estado para fines delictivos contra terceros o contra el mismo sujeto de la adicción. De tal manera se pasa de una restricción del horizonte de expectativas, o de las escasas posibilidades de elección que ofrece la secta (déficit de socialización), a la necesidad de escoger esas expectativas, como adicción cuando es abusiva. Por eso, en nuestra opinión, entre el déficit de socialización y la adicción como anulación o relevante disminución de la capacidad neuronal, existe una fase intermedia, similar al del consumidor de algún tipo de sustancia adictiva, que aún puede controlar los impulsos, si bien está habituado, o sea, socializado en una determinada conducta.

MASLOW en su escala de necesidades explicó convincentemente que las necesidades se superponen, se priorizan, de las que se encaminan a la supervivencia existencial (fisiológicas, protección y seguridad), a las que se refieren al crecimiento personal como individuo (amor y pertenencia, de valoración, y de autorrealización). Más allá de las puramente fisiológicas, las sectas coercitivas aprovechan que el presectario no puede colmar estas necesidades. Se nutren de que el sujeto se siente desprotegido, inseguro, falto de amor, que se desvalora y no puede conseguir su autorrealización. Si la secta consigue colmar esas necesidades y el fin o dinámica lleva a la perpetración de delitos se rebasa el riesgo permitido.

En suma, se puede estimar que el adicto tiene mermada o anulada, según los casos, su capacidad de decisión en el comportamiento general de su comportamiento en general.

\section{Presectarismo, sectarios y «sectadependencia»}

Por lo expuesto anteriormente es fácilmente comprensible que cualquier persona pueda caer en las redes de una secta criminal si se dan cuantos más factores haya y la intensidad y frecuencia de su aplicación.

gradiente de estados superiores -más «perfección», «pureza», «santidad», etc.-, el hecho de no lograrlos -es imposible alcanzar metas tan relativas, ambiguas y nebulosas- es generador de ansiedad que... potencia el uso de dinámicas adictivas sectarias, y así ad infinitum», ID., ibidem, op. cit., pp. 82 a 84. 
A este respecto, Pepe RoDRÍGUEZ ${ }^{1246}$ señala varios factores a tener en cuenta, de forma que cuanto más factores aparezcan, y con mayor intensidad se presenten, mayor será la probabilidad de adicción sectaria: a) personalidad presectaria; b) crisis personal; c) contacto con secta destructiva; d) que la oferta sectaria se adecúe a la demanda del presectario ${ }^{1247}$. Como asimismo resalta $^{1248}$, el modelo explicativo de las sectas basado exclusivamente en la incidencia de las técnicas y estrategias de persuasión (modelo del lavado de cerebro) es insuficiente, puesto que la problemática central se halla en los estados emocionales previos del sujeto presectario (inmadurez, inseguridad, culpabilidad, carencias afectivas, ansiedad, etc...), y a su vez en el aprovechamiento por parte de estos grupos de los estados de necesidad emocional de los sujetos que acuden a su ayuda, que prolongado en el tiempo causa estados adictivos de dependencia por la aplicación de los procesos de técnicas coercitivas. Si bien, y en nuestra opinión, según lo expuesto, entre un estado previo de carencias del sujeto y la adicción media el proceso de desocialización (o socialización conforme a la secta), que produce el déficit de socialización estudiado, pero esta vez, atribuido a un tercero. Explica acertadamente que se puede ser sectario sin pertenecer o ser adepto a una secta. Esto puede comprenderse si se analizamos otros ámbitos que no tengan relación con las sectas. Un sujeto puede ser sectario si vuelca toda su actividad a una determinada conducta, desechando sus deberes, despreciando el mundo que lo envuelve con «indiferencia al Derecho». Debe aclararse sobre esto último que el sectarismo, como tal, no supone más que la adopción personal de unos valores excluyentes, sin embargo el sectarismo criminal y sus miembros sectarios se aúnan para un fin consecuentemente delictivo (delito-fin). Esta delgada línea es confundida por familiares y amigos del sectario, suelen responsabilizar al grupo al que se ha adherido, sin advertir que en la mayoría de ocasiones, se debe a una adhesión en sí misma generalmente libre a un grupo neutral o simplemente religioso.

No obstante, a nuestro parecer, el concepto de sectario también se puede aplicar a otros sujetos que pertenecen a otro tipo de organizaciones criminales en las que también se puede presentar el fanatismo, el totalitarismo, el autoritarismo y en definitiva, la criminalidad con sujetos que presentan déficit de socialización, y en su consecuencia más grave, la adicción

${ }^{1246}$ ID., ibidem, op. cit., pp. 48 y 49.

1247 En concreto señala Pepe RODRÍGUEZ que la personalidad presectaria diverge en varios factores de diversa índole y naturaleza, pero todos pueden enclavarse en factores que afecta a la dignidad, a lo emocional y a lo psicosocial: a) problemas de la adolescencia y en la formación de la identidad que afectan al desarrollo de yo; b) problemas derivados de una familia desestructurada; c) problemas de trastorno de personalidad; d) falta de adaptación social e insatisfacción de la oferta espiritual tradicional; e) y problema derivados de un desconocimiento por parte el sujeto de la peligrosidad de su vulnerabilidad y de los procesos de persuasión, ID., ibidem, op. cit., p. 55; similarmente POLAINO-LORENTE A., «Las sectas y los problemas personales», op. cit.

${ }^{1248}$ RODRÍGUEZ, P., Adicción a sectas, op. cit., pp. 183 y 188. 
comportamental y/o trastornos postraumáticos. Un ejemplo podría ser algunas formas del terrorismo religioso.

Lo adictivo de una secta no es tanto el dogma de fe o doctrina sagrada, sino cómo se viven las instrucciones comportamentales de las que se nutre al adepto; no es tanto la oferta, sino cómo se hace consumir al adepto esa oferta ${ }^{1249}$. En nuestra opinión, cabe concluir que eso a lo que se llama oferta, o de lo que se nutre el sujeto, es un horizonte de posibilidades y expectativas de elección, escasas y/o estrictamente sectarias que vulneran la libertad y dignidad del sujeto, y otras veces fundamentan la adecuación del comportamiento a un horizonte de expectativas estrictamente criminales. En suma, la atracción de las sectas, su oferta, se circunscribe o dirige, a lo emocional, es decir, al sistema psíquico-cognitivo del sujeto, se le aparta del sistema normativo social, más que en lo puramente religioso, ideológico o cosmológico, esto sólo es la excusa o la forma de captación, de manera que su sistema cognitivo se reduce en comparación al sistema de libertades que ofrece la sociedad normativizada, todo ello con el objetivo medial, de aliviar la ansiedad, y ser esto pretexto para disminuir o anular la identidad y en su consecuencia la capacidad de libertad de la voluntad.

\section{VI.- Conclusiones}

Tradicionalmente existen problemas para designar y delimitar aquellos grupos religiosos discrepantes y/o diferentes a las religiones tradicionales de los grupos criminales que utilizan o aprovechan el sentimiento religioso para cometer delitos y/o de los que se utilizan técnicas de persuasión. Las primeras son simples organizaciones religiosas, ideológicas, filosóficas o, en definitiva, agrupaciones con sentimientos de conciencia comunes, mientras que las segundas utilizan la persuasión de manera coercitiva para doblegar la voluntad, y en su caso utilizar al sujeto como instrumento de un delito, y en ambos casos comprendiéndose en éstas las tres tipologías criminales (autor de conciencia, por convicción y enemigo).

Existen fundamentalmente dos modelos de comprender la naturaleza propiamente delictiva de las sectas. Uno es entender que las sectas coercitivas utilizan técnicas de lavado de cerebro que anulan o disminuyen significativamente la capacidad de voluntad inherente del sujeto. Sin embargo, en nuestra opinión, este modelo de pensamiento lleva a la conclusión de que los sujetos a los que se les ha sometido a estas técnicas pierden su total capacidad de voluntad y/o conciencia (robots), lo que conduciría a que se trataría exclusivamente de delitos contra la integridad psíquica que causaría la inimputabilidad del sujeto. Después de analizar las técnicas

${ }^{1249}$ ID., ibidem, op. cit., p. 101. 
habitualmente utilizadas y los tipos de trastornos que se producen en el sujeto, no cabe entender que tales trastornos se exterioricen durante la permanencia del sujeto en el grupo, sino que por regla general afloran a la salida, lo cual nos lleva a considerar que estos trastornos serían un resultado tardío.

Otro modelo estima que se puede influir de tal manera que el sujeto acepte las directrices del líder y/o adecúe su comportamiento a la dinámica comportamental del grupo. Esta influencia va más allá de la inducción al delito, o de la inducción a cualquier otro comportamiento como sería una persuasión legítima (la persuasión del padre a su hijo para que vuelva los fines de semana más pronto a casa). En la inducción como participación criminal no existe una merma de la capacidad del sujeto, sino la intervención del inductor aportando un dato relevante que anima o ayuda significativamente al autor a actuar, sin embargo, en la persuasión coercitiva, se restringe o se elimina el horizonte de expectativas del sujeto, lo que hace que se restrinja la capacidad de la voluntad en la formación de expectativas normativas y las que el Sistema social provee, pero sin que suponga la anulación o disminución endógena de la capacidad natural inherente del sujeto. Si bien, en las formas más graves, la continuidad e intensidad de la restricción o eliminación de expectativas, lleva a la exclusividad de una expectativa comportamental grupal, lo que suele generar una «adicción comportamental» o trastorno mental que pueden constituir un delito de lesiones psicológicas.

En suma, consideramos que el modelo sistémico explica mejor la naturaleza de la persuasión. El sujeto obra aceptando libremente las decisiones, pero a causa de una restricción de las posibilidades de elección o de las expectativas, cuando a dicha restricción se unen factores como el aislamiento social y cultural y la dinámica comportamental del grupo. De esta forma se puede explicar que el sujeto sigue teniendo capacidad de voluntad pero queda necesariamente limitada a unas pocas expectativas, que son las que el líder y la dinámica del grupo le ofrecen. El choque social y cultural que sufre el sujeto cuando abandona, por diversas causas, al grupo, produce tal confrontación con la realidad en cuanto a la infinitud de posibilidades de elección y de expectativas, que el sujeto siente una inseguridad cognitiva que causa en su caso después los trastornos referidos. Si bien, excepcionalmente, la continuidad e intensidad de la restricción o eliminación de expectativas puede llevar al sujeto a la exclusividad de una expectativa, generalmente del comportamiento grupal, que le lleve en esa única dirección, mermando en casos graves su capacidad de voluntad: adicción comportamental o trastorno mental.

Desde este planteamiento se puede explicar más convenientemente tanto la fenomenología criminal de las sectas como su traslación a cualquier otra dinámica grupal más allá de lo 
religioso. Este modelo lo tomamos en parte de la teoría sistémica de la sociedad de LUHMANN. Mediante este modelo podemos explicar también algunos supuestos que concurren en organizaciones criminales que utilizan la persuasión coercitiva para que algunos miembros comentan acciones delictivas en determinados supuestos de aislamiento social y cultural (terrorismo yihadista y determinados crímenes durante el Tercer Reich). Mediante este modelo de explicación, la persuasión coercitiva consistiría en aquella conducta criminal por la que se restringen las expectativas a las que tiene acceso un sujeto y consecuentemente las posibilidades de elección de expectativas. La capacidad de voluntad está restringida si entendemos que esta capacidad es el producto de la libertad: la capacidad de confrontar todas las expectativas que están presentes en un momento dado. Entonces no podemos concluir que el sujeto sufra ninguna causa de inimputabilidad al modo de enfermedad mental, salvo las excepciones de tal intensidad que representa la adicción comportamental o trastorno, sino un mundo social restringido que causa un déficit de socialización que impide orientarse conforme a la norma jurídica, y que sólo posibilita adecuarse a la orden, mandamiento, doctrina, y a la dinámica grupal: un determinado mundo.

Por regla general, los trastornos serán la consecuencia de un déficit de socialización que se confronta con un mundo socializado y lleno de expectativas sociales, por lo que tan sólo podremos tratarlos como una consecuencia no siempre resultante de la creación de un déficit de socialización atribuido a un tercero o a su agravación (también al propio sujeto), que posibilita que concurran una causa de exculpación como el estado de necesidad exculpante, y en los casos más intensos una «adicción comportamental» o trastorno como supuestos de inimputabilidad en su caso.

Y en definitiva, estas conclusiones sirven tanto para la tipología del autor de conciencia, por convicción y el enemigo. En cualquiera de ellos, máxime en la dinámica criminal de una secta criminal y especialmente coercitiva, aparecen presupuestos de interferencia imputable a terceros que condicionan o afectan a la libertad de la conducta por mediación de la persuasión coercitiva sin que cambie su conceptualización, y esto en el mismo sentido que en aquellos supuestos en los que el sujeto nace en el seno de una organización con estos condicionantes creados intencionalmente o no. 


\section{CAPítulo V}

\section{DELIMITACIÓN DEL «DELITO SECTARIO»: LA RELEVANCIA TÍPICA DE LA «PERSUASIÓN COERCITIVA»}

\section{I.- Introducción histórica al acto delictivo de la «persuasión coercitiva» y Derecho comparado}

La moral parece en innumerables ocasiones un reducto infranqueable, pero se estará de acuerdo en que no toda facultad se puede ejercitar contra todo y contra todos, sino que tiene límites. Se suele apelar a la moral y el derecho a la libertad de conciencia, creencia, ideología, y de religión para salvar los escollos de las legislaciones restrictivas a cerca del aborto, la eutanasia, la objeción de conciencia y tantos otros casos no típicos. La libertad de conciencia, al menos en su vertiente interna, puede ser el único derecho absoluto.

Las problemáticas se centran en la manifestación o vertiente externa de la libertad de conciencia, si bien históricamente también el simple pensamiento interno ha sido castigado y perseguido hasta hace bien poco. Por ejemplo, la herejía supuso la más especial forma de castigar y combatir el pensamiento de conciencia y/o religioso. En las sociedades segmentarias, estratificadas y jerarquizadas ha existido la analogía entre el poder político y divino de forma que cualquier pensamiento o conducta en contra del poder era visto como un atentado al Estado y a la ley divina. En la herejía se refunde el histórico combate contra la libertad individual y/o colectiva en la conciencia y sentimiento religioso discrepante. Las sectas, o dicho de otro modo, las prácticas religiosas diferentes y opuestas al poder político y religioso, en definitiva, la herejía, tradicionalmente siempre ha sido considerada enemiga ${ }^{1250}$ de dicho poder dominante, también el

\footnotetext{
${ }^{1250}$ La palabra herejía viene del griego hairein, cuyo significado entre otros es escoger. El hereje es el que escoge, el que opina. En este sentido, tradicionalmente la herejía ha sido combatida por el sistema de poder político y religioso. Las sectas desde el inicio de la historia antigua han sido denunciadas como herejías contra el sistema de poder imperante al poner en duda o divergir de la ley divina, se combatía a las minorías que ponían en conflicto los valores y el orden establecido.

En el Imperio Romano a pesar de tolerarse en buena medida los demás cultos que coexistían en el Imperio, se consideró una herejía ser seguidor de Cristo, cuya consecuencia era la pena capital. Se consideraba la herejía un crimen de lesa majestad, PRAT, J., El estigma del extraño, op. cit., pp. 42 a 45. Esto se debe fundamentalmente a la unión de poder político y religioso. A pesar de permitirse en el Imperio Romano la coexistencia de otros cultos, aquellos que declaraban expresamente la enemistad con el poder religioso se combatían como enemigos del Imperio, como cualquier otro Estado enemigo. Los cristianos eran vistos como una clase social baja pero a la vez peligrosa para el Imperio.
} 
cristianismo en sus inicios, que paradójicamente después luchó contra los demás grupos y creencias en cuanto adquirió poder.

España es un país que además de ser tradicionalmente religioso cuenta con una tradición en la superstición pararreligiosa y pseudocientífica. Históricamente ha existido la constante y

El primer cristianismo era una sociedad secreta. Se consideraba por el Imperio una sociedad subversiva por tener códigos propios, por despreciar los ritos, los templos y los sacerdotes del Imperio. No es de extrañar que por muchos -como el filósofo CELSO- se considerase a los cristianos como enemigos globales del Imperio. Por su novedad, el cristianismo puso en cuestión ese «poner como verdadero» que representaba la religión del Imperio, se consideraba potencialmente peligrosa, sediciosa, y si bien también pacifista, se veía este pacifismo como una conducta insolidaria de los cristianos con la sociedad. También era visto como un peligro para el Imperio que los cristianos practicasen muy activamente el proselitismo. Esto generó odium humani gener, hasta que en el año 313 Constantino declaró el cristianismo la religión oficial y única del Imperio, lo que representó la alianza estrecha entre el poder político y el religioso, ID., ibidem, op. cit., p. 43.

A partir de ese momento en el Bajo Imperio, en el Derecho Postclásico y en la legislación visigoda se luchó contra los herejes y los sectarios aún con más fervor. La pertenencia a un grupo religioso diferente o secta se consideraba una forma de practicar la modificación de la capacidad de obrar, AGUILAR Ros, Paloma, «Religión y capacidad de obrar (los no católicos en el derecho romano-visigodo)», vv.aa., Aspectos socio-jurídicos de las sectas desde una perspectiva comparada, op. cit., p. 215. Con el término «no católicos» la autora hace referencia a los «herejes». Pero a la vez era la mayor traición, la peor ofensa a la sociedad y al orden político y religioso del Imperio, PRAT, J., El estigma del extraño, op. cit., p. 47.

Con el cristianismo de Constantino se excluyó a los herejes y a los maniqueos de cualquier liberalidad jurídica, desde realizar contratos de compra-venta hasta la sucesión. Los emperadores Teodosio y Valentiniano prohibieron el derecho de reunión y el culto de las sectas del Imperio (p. ej. arrianos, pelagianos, donatistas, macedonios, nestorianos, eutiquianos, apolinaristas, sabelianos y priscilianos), que tuvo como mayor consecuencia la expulsión de los maniqueos de las ciudades y la pena capital de todos ellos.

En el Derecho Romano cristiano y en la legislación visigoda, tanto el Código teodosiano como en el Código Justiniano y otras normas, aplicaron altas penas para los herejes. En concreto en el siglo IV se prohibieron determinadas sectas y movimientos heréticos no católicos (cátaros serdonianos, montanistas, sabelianos, patripasianos, los eunucos, catafrigas, maniqueos y melecianos). Ya en el Derecho Romano Post-clásico y Justiniáneo se restringió la capacidad de obrar y jurídica de los herejes, paganos, apóstatas y judíos, se les prohibió realizar testamentos, la recepción de herencias y legados y hacer donaciones y contratos.

El Concilio de Ilíberis celebrado en España condenó diversas prácticas religiosas heréticas y pagánicas. Se prohibieron los matrimonios entre cristianos y gentiles, herejes y judíos, para evitar de esta forma la apostasía. Ya en el Derecho Visigodo se atenúa considerablemente la represión cristiana contra el infiel, con la modificación de la capacidad de obrar jurídica, abriéndose un periodo de mayor tolerancia religiosa, sin embargo se siguieron prohibiendo las prácticas de la adivinación y de la hechicería. El Breviario de Alarico continuó con la incapacidad de obrar pero cierta con tolerancia, sobre todo para los arrianos. Con la conversión de los visigodos al cristianismo se abrió una época de mayor tolerancia del ejercicio religioso y de la capacidad de obrar pero bajo la «condición de ser bautizado», excepto para los herejes. Recesvinto incapacitó a los no católicos, pero otorgaba la capacidad si se convertían al catolicismo. Con el Concilio IV se privó de la patria potestad a los no católicos, separándose de tal manera a los hijos bautizados de los padres no católicos. Además se prohibió residir en el Reino a los no católicos.

Ya en la Edad Media, la herejía fue más escasa y excepcional, pero no motivó la modificación de las legislaciones punitivas contra los herejes. A finales del siglo XII, las nuevas corrientes heréticas propiciaron la incapacidad de obrar de los herejes y la expulsión de los territorios de los reinos cristianos en virtud del acuerdo adoptado en el Concilio de Letrán. En España concretamente, las Partidas (I, 9; 32; VII, 26) regularon la plena incapacidad de los herejes. Más ampliamente sobre la historia jurídica de los no católicos AgUILAR ROS, P., «Religión y capacidad de obrar (los no católicos en el derecho romano-visigodo)», op. cit., pp. 225 y ss.

De otra parte, en Estados Unidos renace un despertar de corrientes religiosas -tratadas tradicionalmente como sectas- durante el siglo XVIII hasta el siglo XIX gracias a que el nuevo continente no tenía una religión hegemónica sino una pluralidad de confesiones debido a la gran cantidad de inmigrantes venidos de todas partes, lo que generó la lucha entre cada opción religiosa por el poder político, especialmente la lucha entre el protestantismo y el cristianismo irlandés asentado en el norte del país. Esta pugna por el poder político generó críticas contra el cristianismo sobre la ilegitimidad de sus creencias, se les criticaba que utilizaban la coerción y el engaño a través de la confesión para someter a sus adeptos, y se acusó a los sacerdotes cristianos de prácticas sexuales y explotación económica a sus fieles, PRAT, J., El estigma del extraño, op. cit., pp. 54 a 58. 
sistemática persecución estatal y clerical de la libertad de conciencia o religiosa. Tradicionalmente además de la lucha del poder político y religioso contra las creencias diferentes y discrepantes (herejías) se neutralizaban opciones o sentimientos en particulares como la magia y la superstición ${ }^{1251}$. Esto puede llevarnos a pensar que la magia y la superstición son propias de períodos previos a la religión, sin embargo es notorio que durante toda la historia han proliferado tanto el ocultismo como la práctica de la brujería hasta nuestros días y su combate continuado por el poder político y religioso ${ }^{1252}$.

Llama la atención que se haya pasado de criminalizar durante siglos la tentativa supersticiosa, a no criminalizar las estafas en las que la víctima incurre en un error burdo ${ }^{1253}$. Ha supuesto un

${ }^{1251}$ La magia, según refiere LEHMANN es «la puesta en práctica de las supersticiones», se diferencia de lo estrictamente religioso y científico, vid. MARTíneZ-PEREDA, José Manuel, Magia y delito en España, pról. Julio Caro Baroja, Editorial Laida, 1991, p. 15.

${ }^{1252}$ En la prehistoria, la magia y la superstición precedieron pero a su vez coexistieron con lo religioso. La magia era en realidad un delito privado cuya pena se dejaba en manos de la víctima. Ya con el Derecho Romano primario se comenzó a criminalizar los malos encantamientos en la Ley de las XII Tablas, sólo si el fin perseguido era «malo», por ejemplo con el fin de que alguien sufriera algún tipo de perjuicio. Este criterio perduró durante el Imperio y continuó en Castilla con las Siete partidas y en el Imperio alemán con la Constitutio Criminalis Carolina.

El Derecho Romano criminalizaba también la necromancia (magia con cadáveres) y los actos mágicos para hacer daño o hacer desaparecer a personas. A estas conductas se las castigaba con la pena más grave, la muerte por el fuero. También se penalizaban las conductas a las que ahora se denomina delitos de organización, como la enseñanza de los actos mágicos o simples actos preparatorios como la iniciación en la magia o la magia practicada por la noche. Con la llegada del Cristianismo se criminalizaron los delitos religiosos como la blasfemia, la herejía y la apostasía, pero también la magia y la brujería, conceptualmente distintos de los primeros.

Durante la Edad Media, y concretamente en la época visigoda, se continuó con la vigencia de las sanciones del desaparecido Imperio Romano de Occidente. Por ejemplo, el IV Concilio de Toledo del año 633 sancionaba en su canon XXIX «si algún obispo (...) consulta magos, arúspices, ariolos, sortilegio (...) sea depuesto de su dignidad y condenado a perpetua penitencia en un monasterio».

Durante la Reconquista, Ramiro I castigaba a los adivinos y hechiceros con la muerte en el fuego. Los Fueros Municipales de Alcaraz, Cuenca y Teruel, regularon sanciones penales con el propósito de combatir la magia y la brujería como conductas de estafa, y la alcahuetería únicamente en las mujeres. El Fuero Juzgo también recogió el delito de magia con yerbas y la adivinación de la muerte.

Con la Inquisición la responsabilidad penal de la magia exigía que su práctica consiguiera algún resultado, y si bien se redujeron las penas de tortura e inclusive podemos decir que se abolió el tormento sobre todo por desuso, también introdujo nuevas penas como el crimen lesae maiestatis contra lo divino, vid. MARTínEZ-PEREDA, JM., Magia y delito en España, op. cit., 106. En este periodo la herejía fue la conducta más altamente penada con la muerte en el fuego. La Novísima Recopilación también sancionó con la pena de muerte la simple superstición, y se incrementó la investigación y persecución de adivinos y hechiceros.

En la Edad Moderna abundaron los juicios de brujería. Por ejemplo, el Papa Inocencio VIII, con su Summis desiderantes afectibus de 1494, ha pasado a la historia como el Papa de la bula contra las brujas.

Fue en el siglo XVIII cuando los códigos penales europeos despenalizaron las conductas de magia y brujería. Pero no es menos cierto que hasta recientes fechas aun se incluían en los códigos penales fórmulas que criminalizaban la estafa relacionadas con la magia y la superstición. Se consideraba que tales prácticas atentaban contra el patrimonio o el orden público, vid., ID., ibidem, op. cit., p. 28.

${ }^{1253}$ El primer Código penal español de 1822 contenía un capítulo que rezaba sobre «los delitos contra la Religión del Estado». Dentro de ese capítulo, el art. 241 criminalizaba «(e)l eclesiástico que enseñare o predicare doctrinas repugnantes a las máximas evangélicas, prácticas supersticiosas, supuestos milagros o profecías y otras cosas semejantes en perjuicio de la religión y del pueblo». Dicho artículo penaba las actividades supersticiosas y heréticas de los propios clérigos, y otros artículos a lo largo de la Parte Especial penaban las lesiones y las estafas. En concreto el art. 637 criminalizaba al que «sin intención de matar ni hacer daño a una persona y sólo para inspirarle alguna aflicción o desafecto, le aplique o haga tomar droga o confección que pueda ser nociva a la salud, será castigado según el daño que resulte, como si causare heridas o golpes». Mientras que el art. 766 castigaba a 
logro del pensamiento democrático que las constituciones y códigos penales modernos eliminen cualquier tipo de sanción por ejercer la libertad de conciencia o religiosa, sin embargo, la consecuencia de esto es la impunidad de la manipulación o persuasión cuando produce algún tipo de daño en las personas o se utilizan como instrumento de otro delito. En estos casos ya no estaríamos ante el libre ejercicio de la libertad religiosa, sino ante una intromisión de la libertad de conciencia, ante un ataque a la libertad de actuar en general.

Históricamente el poder político y divino han combatido las creencias discrepantes y opuestas. Ejemplo de esto es la criminalización de la herejía, brujería, la magia y la superstición. En épocas y sociedades estratificadas, segmentarias y jerarquizadas, el poder reprimió constantemente, con más sombras que luces, la libertad de creencias. Aquellos que eran perseguidos, cuando tomaban el poder político, asemejaban el poder divino y se convertían en perseguidores de las demás creencias. La razón estriba en la Voluntad de Poder, en otros casos la Voluntad de ser sometido y obedecer.

Lo paradójico es que en épocas de mayor libertad, en momentos históricos donde se comienza y se asienta el reconocimiento expreso de la libertad de conciencia, ese miedo, ese temor, sigue impregnando la forma de valorar y juzgar la conducta de conciencia y religiosa de las minorías. En las sociedades modernas y funcionalmente diferenciadas, aún se intenta relegar la religión y la moral al ámbito propio del psiquismo del sujeto. La moral dominante impregna a la norma de formulismos que paradójicamente destierran la conciencia moral minoritaria de su representación en la norma, por lo que sucede que la norma, sobre todo aquella que pretende ser un derecho a la libertad de conciencia, no se identifica con toda la Sociedad, dejando de este modo sin sentido social y totalizador a la norma.

Después de esta breve introducción histórica, se afronta la difícil tarea de aclarar en qué figura delictiva encaja normativamente la conducta consistente en el control de la personalidad o persuasión coercitiva, y si en su caso se precisa crear un tipo concreto de protección contra la

«cualquiera que con algún artificio o engaño, práctica supersticiosa u otro embuste semejante hubiese sonsacado a otro dinero, efectos o escrituras o le hubiese perjudicado de otra manera en sus bienes...».

Posteriormente el Reglamento de la Ley de Vagos y Maleantes de 4 de agosto de 1933 criminalizaba a los llamados «explotadores de la credulidad pública». Y más recientemente y antes de la Reforma del Código penal de 1989 se castigaba en el art. 587.4 ${ }^{\circ}$, dentro de las faltas contra la propiedad a «los que por interés o lucro interpretaren sueños, hicieren pronóstico o adivinaciones o abusaren de la credulidad pública de una manera semejante». Esta línea punitiva continúo por los diferentes códigos penales españoles hasta el código penal de 1996. Se puede concluir que si bien antes de nuestro actual Código penal no se criminalizaba la práctica de la magia en sí misma, pero sí la hechicería y la práctica de la superstición pero sólo en aquellos casos en los que el fin perseguido fuere el ánimo de lucro. 
especial peculiaridad de las técnicas de persuasión y sus consecuencias, que afectan tanto a la responsabilidad del autor de conciencia como a la del autor por convicción y enemigo.

El Derecho penal tradicionalmente protege, más allá de bienes jurídicos concretos, la libertad de los ciudadanos de organizar sus quehaceres. Por eso, los Códigos penales, desde siempre, han hecho expresa mención a los delitos contra la libertad y seguridad, si bien algunos autores ${ }^{1254}$ cuestionan que dicha protección tenga que ver con la metafísica de la libertad de la voluntad. En nuestra opinión, el planteamiento metafísico estudiado en el primer capítulo, esto es la consideración del ser en cuanto conciencia y voluntad, es clave para comprender la gravedad de estos ataques y la forma de comisión tan sutil con la que se realizan.

El control de la personalidad o persuasión coercitiva ataca el propio yo de la personalidad, la configuración de las ideas más íntimas, la libertad de conformar un mundo lleno de expectativas y sus posibilidades y restringe la capacidad de elección al eliminarse una amplia gama de expectativas, en definitiva, la capacidad de voluntad en general y consecuentemente la capacidad o libertad de formación de la decisión. Al mermarse la configuración interna del sujeto, su dignidad como ser humano también se quebranta en las situaciones más graves, o al menos se comienza a atacar la integridad psíquica del sujeto, por lo que nos encontramos ante una conducta claramente pluriofensiva, que difícilmente tiene encaje en un solo delito después de establecer estos presupuestos.

Puesto que dentro del ámbito de la libertad y la integridad existen varios tipos que podrían criminalizar el ataque a las mismas (coacciones, detención ilegal, proselitismo ilícito, esclavitud, delitos contra la integridad psíquica en sus diversas gravedades según el resultado, y contra la integridad moral), es menester aclarar esta cuestión para comprender con precisión qué respuesta ha de dar el Código penal a la fenomenología criminal de las sectas en su delito-fin estricto sensu, en las que parece acusarse con mayor intensidad este tipo de conductas, si bien, según nuestros postulados previos, también aparecen en otras organizaciones criminales y en grupos de toda clase.

La pregunta que es lícita hacer es si las sectas coercitivas y la denominada manipulación mental o control de la personalidad, o en la terminología aceptada por nosotros la persuasión coercitiva, precisan de una nueva legislación penal o, por el contrario bastan los actuales tipos del Código, y en su caso, cuál sería el que recogería las diversas conductas examinadas en el

1254 Bajo Fernández Miguel / Díaz-Maroto Y Villarejo Julio, Manual de Derecho Penal, Parte especial, Delito contra la libertad y seguridad, libertad sexual, honor y estado civil, $3^{\mathrm{a}}$ ed., Editorial Centro de Estudios Ramón Areces, 1995, p. 5. 
capítulo anterior, y si los tipos de concurso resuelven la problemática. En este caso, la mayoría de la doctrina defiende la suficiencia de la regulación penal para combatir las sectas criminales.

Es evidente que la problemática de las sectas, tanto en la institución familiar como en aquellas fenomenologías peligrosas o criminales, ha sido objeto de especial estudio y preocupación en los ordenamientos jurídicos de todas las naciones pluralistas (dejamos de lado los controles en Estados dictatoriales o sin libertad religiosa), si bien prácticamente ningún país de nuestro sistema tiene regulaciones específicamente combativas, a excepción de algunos países que analizaremos y algunos intentos en Argentina ${ }^{1255}$ y Colombia ${ }^{1256}$.

${ }^{1255}$ En Argentina en 1993 se presentó en Cámara de Diputados de la Provincia de Buenos Aires un proyecto para crear una Comisión Especial para el Estudio de los Movimientos Religiosos o Seudorreligiosos libres. Tras una investigación profunda sobre el tema, la comisión lo aprobó por unanimidad en diciembre de 1995, sin embargo, el Ejecutivo provincial no lo elevó a reglamento. En 2009, en la Provincia de Córdoba se planteó otro proyecto de ley en relación a los grupos que usan técnicas de manipulación psicológica que finalmente fue aprobado por la Ley 9891 de Prevención y Asistencia a las Víctimas de Grupos que usan Técnicas de Manipulación Psicológica, sancionada el 9 de noviembre de 2011 y reglamentada por Decreto 564 del 3 de junio de 2013, y que pone de relieve aquellas organizaciones que propician la destrucción de la personalidad y los lazos de comunicación cuando se emplean «en su dinámica de captación o adoctrinamiento técnicas de persuasión coercitivas». Concretamente en su art. 3 se refiere a dichos grupos de manipulación de la siguiente forma:

«todas aquellas organizaciones, asociaciones o movimientos que exhiben una gran devoción o dedicación a una persona, idea o cosa y que emplean en su dinámica de captación o adoctrinamiento técnicas de persuasión coercitivas que propicien:

a) La destrucción de la personalidad previa del adepto o la dañen severamente, y

b) La destrucción total o severa de los lazos afectivos y de comunicación afectiva del adepto con su entorno social habitual y consigo mismo, y el que por su dinámica de funcionamiento le lleve a destruir o conculcar derechos jurídicos inalienables en un estado de derecho».

En los Fundamentos de la ley se expone la casuística de las dinámicas de persuasión y su gravedad:

«El problema no surge por sus doctrinas y dogmas, por más extrañas que sean. No se cuestionan las ideas en los cuales se fundan los grupos analizados, sino su conflictividad con la sociedad, ya que algunos de estos grupos no respetan y violan sistemáticamente los derechos humanos de los individuos, utilizando para ello técnicas manipulativas y no éticas en sus adeptos, provocando en el individuo la pérdida de la noción de ciudadanía mediante la adhesión a un grupo que desarrolla una identidad de clan opuesta al ciudadano individual que constituye parte de la sociedad y; en la sociedad crea zonas que escapan al derecho. Las leyes del "gurú» o las del grupo son declaradas superiores a la ley del Estado. Se rechazan tanto la ciencia, como los adelantos científicos. Se trata, en definitiva, de un retorno al mundo paralelo (medicina paralela, educación y pedagogía alternativas, nueva economía, nuevo urbanismo, etc.) y de un retorno a una tradición sesgada (...) Por eso entendemos que la intervención estatal se justifica y es necesaria en los casos en los que estos grupos usen técnicas de persuasión coercitiva y control mental, algo que por supuesto debe dilucidarse fácticamente, tornándose en técnicas delictivas, ya sea porque causan algún tipo de lesión a algún bien jurídico protegido o porque su utilización incluye que las finalidades del grupo sean delictivas o si mediante estas técnicas se induce a cometer delitos. El empleo de los tres factores que son: líder, estructura de poder o relación entre el líder (o líderes) y los seguidores, y reforma del pensamiento, nos permiten evaluar la naturaleza sectaria de un grupo o situación específicos con independencia de su sistema de creencias».

Esta ley ha sido denunciada por diversos sectores por la inconstitucionalidad que plantea contra el art. 14 de la Constitución de la Nación que ampara «profesar libremente su culto, de enseñar y aprender», en relación al art. 19 que impide la interferencia estatal en la zona de reserva de la libertad personal.

${ }^{1256}$ El Proyecto de Ley 055 de 2010 de Colombia dentro del capítulo dedicado a los delitos contra el sentimiento religioso y el respeto a los difuntos, iba a incluir un tipo específico de Constreñimiento religioso con la siguiente redacción: «Artículo $1^{\circ}$. Adiciónense dos artículos al Libro Segundo Título III Capítulo Noveno del Código Penal Colombiano, los cuales quedarán así: Artículo 202 A. El que utilizando una secta, culto o doctrina religiosa perturbe, afecte o deteriore la conducta de sus seguidores sustrayéndolos parcial o definitivamente de su entorno social, cultural, económico o familiar y les genere adicción o servidumbre respecto del predicador o de la misma secta, culto o iglesia incurrirá en prisión de cuatro (4) a ocho (8) años. 
Llama la atención que en los sistemas jurídicos estatales brille la libertad de conciencia pero se criminalicen por regla general conductas de omisión del deber de socorro. Si bien ningún país deniega la inscripción de los grupos o sectas religiosas en el registro de entidades religiosas, salvo los casos polémicos mencionados, no existe un control sobre la estructura y modelo de dinámica comportamental, más allá del análisis de los fines religiosos y la fiscalización de impuestos, salvo en este último caso en el sistema de países de la Common Law, donde por regla general existe la exención fiscal de todas las entidades religiosas ${ }^{1257}$, si bien también en España con algunas excepciones en actividades no estrictamente religiosas.

La elección de expectativas morales o de conciencia religiosa supone una cuestión riesgosa, tanto a nivel personal o privado, como en los casos de agrupación de sujetos en torno a ideales o sentimientos religiosos al trascender a la sociedad, en definitiva por formar parte de la sociedad. El exclusivo control fiscal y de la finalidad religiosa es insuficiente en un mundo que pretende ser normativo. Este vacío no puede ser reprochado sino como síntoma o identidad de la ausencia normativa o contraorientación de la norma con parte de la Sociedad. El control debe ponerse en las dinámicas de comportamiento estructural y sistémico de los grupos, como en toda otra forma de organización: véase la Ley de propiedad horizontal en lo que respecta a las normas de funcionamiento vecinal. Esta forma de control no sería nada nuevo en un mundo, como decimos, normativizado y característico de sociedades funcionalmente diferenciadas, por eso llama la atención que la falta de regulación de las estructuras y dinámicas religiosas o de conciencia se utilice posteriormente como reproche del exceso de manifestación de la libertad de conciencia $^{1258}$.

No existe regulación alguna del delito de «manipulación mental» o «persuasión coercitiva» como tal. Ha desaparecido en la mayoría de los códigos occidentales, si bien han habido esfuerzos por parte de la doctrina para restaurarlo, sobre todo en Italia con el llamado delitto di

Circunstancias de agravación punitiva

Artículo 202 B. El que además de la conducta anterior persuada, engañe o constriña a otro a entregar para la misma secta, iglesia o culto dinero, bienes muebles e inmuebles incurrirá en prisión de seis (6) a doce (12) años.

La secta o congregación religiosa que incurra en las causales previstas en los dos anteriores artículos será objeto de extinción de dominio en favor de las personas que resultaren afectadas».

1257 Vidal ManZanares, C., Psicología de las sectas, op. cit., p. 130.

1258 En sentido muy similar el experto en sectas VIDAL MANZANARES se pronunció hace años con el siguiente razonamiento: «Cuando cualquier ciudadano fabrica algo se le exige unos mínimos controles de calidad. El Estado no entra en si debe fabricar bicicletas o caramelos, pero sí en que estos no sean nocivos para la sociedad. El tema de las sectas exige un planteamiento similar. Al Estado le es indiferente si la gente cree que Moon es el Mesías (...) Cada uno es libre de creer lo que desee o de no creer nada en absoluto pero, en cualquiera de los casos, no tiene derecho a producir daños morales, psíquicos, físicos o económicos a nadie», VIDAL MANZANARES, C., El infierno de las sectas, op. cit., 171. 
plagio $^{1259}$. El plagium es un término latino procedente del griego y que se refería «a la acción de tomar posesión, retener o vender un hombre libre o el esclavo de otra persona». Durante la Edad Media -comenta NAVAS RENEDO- «las leyes góticas conservaban el plagium referido al acto de alguien que ilegalmente sujeta a otro ser humano a la esclavitud» ${ }^{1260}$. También HEGEL ${ }^{1261}$ explicó que si se pierde la autoconciencia de sí, ello puede deberse a que el sujeto voluntariamente se ha apartado de sí mismo y por ende de las cosas, del mundo, del Derecho, o por enajenación de la personalidad, o sea, por esclavitud, servidumbre, o incapacidad para poseer. De tal manera, la pérdida de la personalidad se asocia tradicionalmente como esclavitud, por eso podemos asociar la persuasión coercitiva como una forma de esclavitud y así excluir anticipadamente este tipo de conductas del art. $522 \mathrm{CP}$, si bien volveremos sobre este análisis.

$\mathrm{El}$ art. 607 bis. $2.10^{\mathrm{a}}$ de nuestro CP criminaliza la esclavitud pero con la particularidad de que se ejerza sobre todos o algunos de los atributos del derecho de propiedad, como comprarla, venderla, prestarla o darla en trueque, de lo que viene que el precepto no recoge expresamente las conductas de persuasión coercitiva a las que nos hemos referido en el anterior capítulo. De este modo, si bien la esclavitud tiene similitudes con el injusto de la manipulación mental o persuasión coercitiva, no se asocia en cuanto a la realidad de las técnicas que se utilizan y las consecuencias materiales, sino que su reminiscencia se debe a la analogía con la coerción de la libertad de actuar en general que rebaja la dignidad del ser humano a simple res.

A este respecto, el Grupo Popular presentó en 1995 unas enmiendas ${ }^{1262}$ que planteaban la protección penal del Derecho a la formación de la conciencia a través de un tipo ${ }^{1263}$, que fue rechazado por la indeterminación normativa y probatoria que recogía la formulación «medio ilegítimo de persuasión». En la doctrina española, TAMARIT SUMALLA y MARTín SÁNCHEZ se mostraron contrarios a la expresión «medio ilegítimo de persuasión» que proponía la enmienda por la aparente falta de concreción ${ }^{1264}$, si bien el segundo explica y critica al primero al señalar que la expresión «medio ilegítimo de persuasión» no sólo incluye los medios psicológicos, sino también los violentos e intimidatorios, del tal modo que se acredita la necesidad en este cauce, y

1259 COPPI, F., «Plagio», Enciclopedia del Diritto, Vol. XXXIII, Giuffré Editore, 1983, pp. 932 y ss; MARVELLI Elga / SCIARRINO Maria, L'evuluzione giuridica del plagio nella normativa italiana e sammarinese, Giornale scientifico a cura dell'osservatorio Nazionale Abusi Psicologici, anno 4, N. 4, dicembre 2013, Sul filo del diritto.

${ }_{1260}$ NAVAS Renedo, B., Tratamiento jurídico de las sectas, op. cit., p. 277.

1261 HeGEL, GWF., Fundamentos de la filosofía del Derecho, op. cit., p. 262.

1262 Enmienda núm. 499, Boletín Oficial de las Cortes Generales de 6 de marzo de 1995, (Serie A, núm. 77-6, p. 232), y Enmienda núm. 706 de 21 de septiembre de 1995, (num. 87, p. 297).

${ }_{1263}$ El tipo rezaba así: «El que, mediante cualquier medio ilegítimo de persuasión, violare el derecho de otro a la libre formación de su conciencia, impidiéndole así la elección de una ideología, religión o creencia, será castigado con la pena de prisión de dos a cuatro años».

${ }^{1264}$ TAMARIT Sumalla, JMª., La libertad ideológica, op. cit., p. 243; MARTín SÁNCHEZ, I., El Derecho a la formación de la conciencia, op. cit., p. 321. 
también considera que no se requeriría la «sustitución absoluta de la voluntad del sujeto pasivo por la del activo», sino que bastaría con que el persuadido formara una nueva conciencia que se adecuara a la voluntad final del persuasor, de modo que bastaría con que el sujeto pasivo «debido a su incapacidad para entender y querer, lleve a cabo una acción que, de no ser por el empleo de dichos medios, no habría realizado». De esta forma de resolver la problemática se podría complementar el mandato del derecho a la libertad de conciencia del art. $16 \mathrm{CE}^{1265}$.

La propuesta de enmienda del Grupo Popular en 1995 viene a colación de la declaración de inconstitucionalidad por la Sentencia núm. 96, de 8 de junio de 1981, del Tribunal Constitucional italiano, sobre el art. 603 del Código penal que tipifica el denominado delito de plagio, respecto del que -como con precisión indica MAQUEDA ABREU- «seguramente la más antigua en el tiempo fue la incriminación del plagio bajo el Código Zanardelli de 1889 referido a los casos en que se «reduce a una persona a esclavitud o a otra condición análoga» ${ }^{1266}:$ «Quien somete a una persona al propio poder, reduciéndola a un estado de total sujeción, será castigado con la reclusión de cinco a quince años».

El Tribunal constitucional italiano razonaba la inconstitucionalidad por la falta de concreción del tipo penal que se exige en el art. 25 de su Constitución, y esto porque según refiere la Sentencia, se debe a «la imposibilidad de encontrar en la realidad un estado total de sujeción, idóneo para suprimir íntegramente (y no «cuasi integralmente) toda la libertad y autonomía de determinación del sujeto que se considera plagiado», y de tal modo, en la imposibilidad de demostrar «según los conocimientos y experiencias actuales, de que puedan existir seres capaces de obtener con sólo medios psíquicos la total sujeción de una persona» ${ }^{1267}$.

A este respecto, si bien TAMARIT SUMALLA rechaza la fórmula del «medio ilegítimo de persuasión», acepta que es necesario proteger las agresiones a la capacidad de la voluntad ${ }^{1268}$, sin embargo, el delito de proselitismo ilícito es insuficiente para tal cometido, de manera que para protegerla de los ataques de medios de manipulación psicológica haría falta un tipo similar al actual art. 613 CP italiano que dentro de capítulo tercero, dedicado a los delitos contra la libertad individual, y dentro de la sección tercera de los delitos contra la libertad moral, establece el delito sobre el «estado de incapacidad adquirida mediante violencia» ${ }^{1269}$. De este modo,

1265 MARTín SÁNCHEZ, I., El Derecho a la formación de la conciencia, op. cit., pp. 322 y 323.

1266 MAQUeda ABReU, Mª., Las sectas destructivas ante el derecho, op. cit., p. 241.

1267 Vid. Giustizia Penale, pp. 226 y ss.

1268 TAMARIT SUMALLA, JM ${ }^{\mathrm{a}}$, La libertad ideológica, op. cit., pp. 243 a 245 y 286 a 288.

1269 Preceptúa el art. 613 CP italiano: «El que, mediante sugestión hipnótica o en vigilia, o mediante el suministro de sustancias alcohólicas o estupefacientes, o con cualquier otro medio, pone a una persona, sin su consentimiento, en estado de incapacidad de entender o querer, será sancionado con reclusión hasta un año. El consentimiento prestado por las personas mencionadas en el último parágrafo del art. 579 no excluye la 
proponía que esta formulación se debería complementar con el parágrafo 11-II del Proyecto de CP italiano de 1960 que establecía: «Equivale a la violencia en el sentido de esta Ley (...) cuando el delincuente emplea sobre otra persona sin el consentimiento de ésta la hipnosis u otro medio para dejarla sin conocimiento o incapacitada corporalmente para la resistencia». Sin embargo, considera inadecuada la protección sobre el proceso de decisión y ejecución de la voluntad, porque estas manifestaciones ya estarían protegidas por el tipo de proselitismo ilícito del Código penal español.

Por lo demás, tanto TAMARIT SUMALla como MARTín SÁNCHEZ están de acuerdo en proteger, además de la capacidad de voluntad, la inviolabilidad psíquica de la persona cuando mediante modernas tecnologías se repercuta en el ámbito personal ${ }^{1270}$.

En los últimos años parte de la doctrina ${ }^{1271}$ ha reclamado la regulación de un delito de «manipulación mental» en nuestro ordenamiento jurídico, al igual que sectores de perjudicados y grupos anti-secta como AIS ${ }^{1272}$. En concreto, MARTín SÁNCHEZ propone la inclusión en el CP de un tipo dentro del mismo capítulo del delito referido:

«Incurrirán en la pena de dieciocho meses y un día a tres años: $1^{\circ}$ Los que mediante el empleo de la violencia, intimidación, fuerza, engaño o de medios de alteración o control de la personalidad violaren el derecho de una persona a la libre formación de su conciencia, impidiéndola la elección, el cambio o el abandono de una ideología, religión o creencias, o forzándola a ella. $2^{\circ}$ Los que mediante el empleo de idénticos medios violaren el derecho de una persona a la libre formación de su conciencia, impidiéndola no tener ninguna ideología, religión o creencias».

punibilidad. La pena será de prisión hasta cinco años: $1^{o}$ si el culpable ha actuado con el fin de hacer que se cometa un delito; $2^{\circ}$ si la persona incapaz comete, en tal estado, un hecho previsto en la ley como delito».

${ }^{1270}$ TAMARIT Sumalla, JMa., La libertad ideológica, op. cit., p. 289; MARTín SÁNCHEZ, I., El Derecho a la formación de la conciencia, op. cit., pp. 140 y 141, y pp. 324 y 325; DEL RE, MC., «Modellamiento psichico e diritto penale: la tutela penale dell'integrità psichica», Guistizia Penale, 11, 1983, pp. 187 a 190, propone la protección de la protección de la integridad psíquica en del delito de lesiones cuando también con dolo se modele o se modifique la mente de una persona. Sobre las técnicas y métodos, ID., ibidem, op. cit., pp. 173 y ss.

${ }^{1271}$ Doctrina a favor de la creación de un nuevo delito o reforma del 522 CP, BALLESTA, Félix, «Mecanismos psicológicos de vinculación a las sectas», vv.aa., Aspectos socio-jurídicos de las sectas desde una perspectiva comparada, op. cit., p. 130; BUENO SALINAS, Santiago, «El ámbito de amparo del derecho de libertad religiosa y las asociaciones», ADEE, 1985, p. 199; FERNÁNDEZ-CORONADO, A., «La tutela penal de la libertad de conciencia», ADEE, 1986, p. 46; FRIAS LINARES, M., «El fenómeno del sectarismo en occidente: condicionantes históricos, sociológicos y jurídicos», vv.aa., Aspectos socio-jurídicos de las sectas desde una perspectiva comparada, op. cit., p. 116; JORDÁN VILLACAMPA, MaL., «Las sectas pseudorreligiosas», op. cit., pp. 42 y de 94 a 103, especialmente p. 97; MARTín SÁNCHEZ, I., El Derecho a la formación de la conciencia, op. cit., pp. 320 y ss. y p. 326; si bien años antes defendió la suficiencia de la legislación Motilla, A., Sectas y Derecho en España, op. cit., pp. 181 y 182, y se muestra a favor de la vía penal como solución de la problemática de las sectas: «de conseguir la extinción de las sectas y acabar con sus acciones delictivas, sin que ello suponga merma o quebranto ilegítimo de la libertad religiosa de los creyentes», ID., ibidem, op. cit., 186; «Reflexiones sobre el tratamiento jurídico-penal de las sectas religiosas en España», Aspectos Socio-Jurídicos de las sectas, op. cit., pp. 316 y 317; con ciertas reservas TAMARIT SUMALLA, $\mathrm{JM}^{\mathrm{a}}$., La libertad ideológica, op. cit., p. 289.

${ }^{1272}$ Vid. NAVAS RENEDO, B., Tratamiento jurídico de las sectas, op. cit., p. 278. 
Para MARTín SÁNCHEZ ${ }^{1273}$, el sujeto pasivo de estos ataques puede ser cualquier persona, sin embargo, según el tipo propuesto, para el caso de las acciones de impedir o formar, el sujeto pasivo no deberá profesar ideología o religión alguna, y en el caso de impedir o formar el cambio o el abandono de una ideología, religión o creencias, el sujeto pasivo deberá tener unas concretas creencias o convicciones ideológicas. Por último, en el caso del núm. $2^{\circ}$ propuesto (impedir que una persona no tenga ninguna ideología, religión o creencia), considera el citado que habrá que requerir que el sujeto pasivo carezca de convicciones, de lo contrario, se estaría en el supuesto de forzar a abandonarla del núm. $1^{\circ}$.

JORDÁN VILLACAMPA propone criminalizar la «manipulación mental ilícita originadora de dependencia psicológica» ${ }^{1274}$.

Cabe citar la STEDH de 25 de mayo de 1993 (caso Kokkinakis). El TEDH aplicó por primera vez el art. $9 \mathrm{CEDH}$, al aceptar también como técnica de proselitismo ilícito la técnica del «lavado de cerebro» ${ }^{1275}$.

En nuestra jurisprudencia no hay condenas por un delito de atentado contra la libertad de conciencia por persuasión coercitiva o lavado de cerebro. Sin embargo, puede destacarse la Sentencia de la Audiencia Provincial de Barcelona, de 16 de julio de 1990, respecto del grupo CEIS, y que ratificó finalmente el Tribunal Supremo en Sentencia de 14 de abril de 1993, reconocía: «la pertenencia a una secta que (...) amén de tener un carácter falsamente religioso, tenía como finalidad llevar a cabo unas actividades clandestinas consistentes, entre otras, en influir mediante coacciones en los individuos que captan «el cambio de su personalidad (...) haciéndoles perder todo lazo afectivo con sus familiares y amigos, incitándoles a la prostitución y a otras actividades encaminadas a obtener dinero para lucro de sus dirigentes», concluyendo que «una cosa es pensar o creer en unos dogmas o enseñanzas y otra muy distinta es actuar o trasladar extramuros de la conciencia individual unas ideas concretas, empleando para ello medios coactivos».

1273 MARTín SÁNCHEZ, I., El Derecho a la formación de la conciencia, op. cit., p. 327.

1274 JORDÁN VILLACAMPA, ML., «Las sectas pseudorreligiosas», op. cit., p. 99. Similarmente BARBA LÓPEZ D / García Oliva FJ / García-PARdo D / Morales Monteoliva Y / VAlEncia F., «La protección jurídica del individuo ante las sectas destructivas», op. cit., p. 83 .

${ }^{1275} \mathrm{La}$ Sentencia argumentó que «(p)rocede ante todo distinguir el testimonio cristiano del proselitismo abusivo: el primero corresponde a la verdadera evangelización que un Informe elaborado en 1956, en el marco del Consejo Ecuménico de las Iglesias, califica de misión esencial y de responsabilidad de cada cristiano y de cada iglesia. El segundo representa la corrupción o la deformación. Puede revestir la forma de actividades que ofrecen ventajas materiales o sociales para obtener la aproximación a una iglesia o que ejercen una previsión abusiva sobre las personas en situación de debilidad o de necesidad, según el mismo Informe, e incluso pueden implicar el recurso a la violencia o lavado de cerebro; más genéricamente, el concepto de proselitismo abusivo no se ajusta al respeto debido a la libertad de pensamiento, de conciencia y de religión de los demás», STEDH de 25 de mayo de 1993. 
Más allá de esta Sentencia, únicamente existen referencias jurisprudenciales a las técnicas de persuasión que trascienden en reformas del pensamiento, pero sin juzgar su ilegalidad por no presentarse querella al respecto. Por ejemplo, en la Sentencia del Juzgado de Primera Instancia de Guadalajara de 13 de octubre de 1982 se declaró la nulidad matrimonial de dos miembros del grupo religioso Hare Krishna por considerar que uno de los contrayentes, en el momento de manifestar el consentimiento «era incapaz de entender y querer dada su despersonalización». El sujeto poseía «un estado sofrónico que inhibe su capacidad de análisis y censura intelectual, anulación de su voluntad, sugestionabilidad externa y robotización mental» ${ }^{1276}$.

La jurisprudencia penal en otras ocasiones se ha referido al «secuestro de la voluntad»o «indefensión intelectual». En concreto, la Sentencia de la Audiencia Provincial de Madrid de 22 de octubre de 1991, sobre el caso del grupo Edelweiss, condenó a su líder y a sus miembros activos, pero con atenuación de la pena por la concurrencia de una eximente incompleta de enajenación mental. Y en otro caso, la Sentencia de la Audiencia Provincial de Huelva de 21 de noviembre de 1991 apreció la atenuante muy cualificada de obediencia debida al líder espiritual de una secta ${ }^{1277}$.

Dicho todo lo cual, es evidente que ni la jurisprudencia ni la doctrina se ponen de acuerdo en catalogar las técnicas de persuasión, su trascendencia jurídico-penal y ubicación criminológica. La problemática viene, como decíamos supra, de la heterogeneidad pluriofensiva de este ataque, es decir, ¿supone un atentado exclusivamente contra la libertad de conciencia, contra la libertad de actuar en general (delito de coacciones), una detención ilegal, un delito de lesiones, contra la moral o un ataque contra todos ellos?

Concretamente y entre otros países (Bélgica, Austria, Gran Bretaña) en Alemania se creó un organismo de vigilancia de las sectas (Bundestelle für Sektenfragen), y en Francia se creó la Misión Interministerial de Vigilancia y Lucha contra las Derivas Sectas (MILVILUDES). También en Bélgica se elaboró un informe de las mismas características en el Parlamento, del que únicamente se puede reseñar que definió las sectas como grupos peligrosos por sus labores delictivas, si bien aprobó la Ley Orgánica de Información sobre la Seguridad del Reino de Bélgica, de 30 de noviembre de 1998, Monitor Belga (BOE) del 18 de diciembre de $1998^{1278}$.

\footnotetext{
${ }^{1276}$ En el mismo sentido también se pronunció la Sentencia del Juzgado de Primera Instancia e Instrucción núm. 1 de Zaragoza de fecha de 12 de septiembre de 1995. Este reconocimiento pone de relieve el Informe realizado por la Sociedad de psiquiatría de Madrid para el Ministerio de Sanidad y Consumo de fecha 20 de julio de 1989, que se aportó al proceso penal de la Cienciología, y que alertó sobre las consecuencias de la utilización de algunas técnicas terapéuticas encaminadas a la sanidad de la moral de las personas.

1277 SERRANO MAÍlLL, Alfonso, «Exorcismo. Crimen ritual», RDPC núm. 3, UNED, 1993, pp. 997 a 1007.

1278 REDONDO HeRmidA, Álvaro, «Las sectas dañosas ante el Derecho Penal», Diario La Ley, núm. 6463, XXVII, 2006, XVII: «La Ley se fundamenta en el peligro que dichas agrupaciones pueden representar para el
} 
Posteriormente se creó un organismo especializado (CIAOSN) con la Ley de 2 de junio de 1998, y finalmente se aprobó la Ley de 26 de noviembre de 2011 que modifica y completa el Código Penal para tipificar como delito el abuso de una posición de debilidad de las personas y para extender la protección penal de los individuos vulnerables contra el abuso.

En Israel se criminaliza el proselitismo contra personas vulnerables y cuando se utilicen medios engañosos o la promesa de ventajas materiales ${ }^{1279}$.

En Francia se intentó ya en el año 2000 por medio de un proyecto de ley instaurar el delito de viol psychique o manipulation mentale ${ }^{1280}$, y finalmente el año 2001, el Parlamento francés aprobó la ley denominada «About-Picard», núm. 2001/504 de 12 de junio de 2001 (art. 20 del Diario Oficial de 13 de junio de 2001), que creó el «delito de manipulación mental» el cual quedo redactado en su art. 223-15-2 $2^{1281}$ de la siguiente forma: el «abuso fraudulento del estado de ignorancia o de la situación de debilidad de un menor, o de una persona cuya especial vulnerabilidad (...) o de una persona en estado de sometimiento psicológico o físico resultante del ejercicio de presiones graves o reiteradas o de la aplicación de técnicas propias para alterar su juicio». En los arts. 223-15-3 y 223-15-4 se establecen penas accesorias para las personas físicas (prohibiciones) y jurídicas (disolución), respectivamente ${ }^{1282}$. El art. 19 de la citada ley se centra

equilibrio psicológico de las personas, las rupturas familiares los fenómenos de aislamiento personal que pueden provocar. Incluso la Ley afirma en su Exposición de Motivos que se ve amenazada por la actividad de las sectas la propia seguridad del Estado, dado el potencial político y económico de las mismas».

${ }^{1279}$ FERRARI, S., «Il proselitismo tra diritti delle religioni e diritti degli Stati», Religión, matrimonio y Derecho ante el siglo XXI. Estudios en homenaje al Profesor Rafael Navarro-Valls, J. Martínez-Torrón / S. Meseguer Velasco / R. Palomino Lozano, (Coords.), Vol. I, Iustel, Madrid, 2013, p. 530.

${ }^{1280}$ NAVAS RENEDO, B., Tratamiento jurídico de las sectas, op. cit., pp. 277 a 279.

1281 Art. 223-15-2: "Será castigado con tres años de prisión y multa de 375.000 euros el abuso fraudulento del estado de ignorancia o de la situación de debilidad de un menor, o de una persona cuya especial vulnerabilidad, debida a su edad, enfermedad, invalidez, deficiencia física o psíquica o a su estado de embarazo, sea aparente y conocida por el autor, o de una persona en estado de sometimiento psicológico o físico resultante del ejercicio de presiones graves o reiteradas o de la aplicación de técnicas propias para alterar su juicio, para llevar a este menor o a esta persona a realizar un acto o una abstención que le sean gravemente perjudiciales.

Cuando la infracción haya sido cometida por el dirigente de hecho o de derecho de un grupo que desarrolle actividades que tengan por objeto o por efecto crear, mantener o explotar el sometimiento psicológico o físico de las personas que participen en estas actividades, las penas se elevarán a cinco años de prisión y a 750.000 euros de multa».

1282 Art. 223-15-3: «Las personas físicas culpables del delito previsto en la presente sección incurrirán igualmente en las penas accesorias siguientes: $131-26$.

$1^{\circ}$ La prohibición del ejercicio de derechos cívicos, civiles y de familia, conforme a los previsto en el art.

$2^{\circ}$ La prohibición, conforme a lo previsto en el art. 131-27, de ejercer una función pública o de la actividad profesional o social en cuyo ejercicio o con ocasión de la cual se haya cometido la infracción.

$3^{\circ}$ La clausura, por periodo de hasta cinco años, de los establecimientos o de uno o varios de los establecimientos de la empresa que hayan servido para cometer los hechos incriminados.

$4^{\circ}$ El comiso de la cosa que haya servido o estaba destinada a cometer la infracción o de la cosa producto de la misma, con excepción de los objetos susceptibles de restitución.

$5^{\circ}$ La prohibición de acudir a determinados lugares, conforme a lo previsto en el art. 131-31. 
en la difusión de mensajes dirigidos a jóvenes con el fin de crear, mantener o aprovechar la sujeción psicológica o física de los concurrentes a sus actividades, pero exige que la entidad o sus dirigentes hayan sido condenados por atentados contra la integridad psíquica o física, contra su seguridad, la dignidad, las libertades, o la personalidad o cuando se ponga en peligro a menores.

El Código penal francés permite perseguir dinámicas comportamentales de este tipo, también en relación a la estafa, a la extorsión de fondos, abuso de confianza, al atentado sexual, a la corrupción de menores, en materia de derecho laboral y cuando exista abuso de debilidad como circunstancia agravante de otra infracción. Permite a las autoridades judiciales intervenir antes de la ejecución de los delitos concretos que se persigan con tal coerción, por lo que puede concluirse que se trata de una norma penal específica contra los comportamientos que al menos produzcan un grave riesgo para los bienes personales y en aquellos casos que trascienda en un peligro para la Sociedad.

La dificultad estriba en dicho caso en la acreditación del abuso fraudulento, el estado de ignorancia o de sujeción, las presiones graves o reiteradas, la alteración del juicio, el acto o abstención y el perjuicio. En nuestra opinión, con estos requisitos objetivos y subjetivos ubicados en el tipo básico se desnaturaliza y se dificulta precisamente la persecución y demostrabilidad probatoria del delito, y menos aún es entendible que se exija un perjuicio en la víctima, más allá de la pérdida de la capacidad de libertad de voluntad, una manifestación concreta y material de la voluntad como acto o abstención, por cuanto el resultado claramente injusto para la persona puede producirse de forma interna, sin que tenga que esperarse a una dirección distinta de la ejecución de la voluntad.

Dicho esto vamos a analizar qué figura delictiva recoge en mejor medida los presupuestos de la persuasión coercitiva desde el ámbito de las sectas y si, en su caso, precisa de una nueva tipificación concreta o basta con los recursos que ofrece la normativa penal tradicional, todo ello aplicable a los supuestos de la autoría de conciencia, por convicción y al enemigo.

$6^{\circ}$ La prohibición, por periodo de hasta cinco años, de emitir cheques, salvo los que permitan la retirada de fondos por el librador contra el librado o los que estén conformados.

$7^{\circ}$. La publicación o difusión de la resolución adoptada, en las condiciones previstas por el artículo 131-35». Y el art. 223-15-4 establece:

«Las personas jurídicas podrán ser declaradas penalmente responsables de la infracción definida en la presente sección en las condiciones previstas en el art. 121-2.

Las penas aplicables a las personas jurídicas serán:

$1^{\circ}$ la multa, conforme a lo previsto en el art. 131-38.

$2^{\circ}$ Las penas mencionadas en el artículo 131-39.

La prohibición mencionada en el apartado $2^{\circ}$ del art. 131-39 se aplicará a la actividad en cuyo ejercicio o con ocasión de la cual se haya cometido la infracción» 


\section{II.- Persuasión coercitiva como «proselitismo ilícito»}

Se dice que la deificación es el más alto grado de realización personal del hombre, la renuncia al propio yo, la despersonalización, el «vaciamiento de sí mismo» ${ }^{1283}$. La libertad de conciencia es entendida, ya no tradicionalmente como libertad a la concepción divina, sino como libertad de toda concepción que domine la voluntad y el raciocinio básico moral como manifestación externa de lo más interno de la persona.

La libertad de conciencia tiene inherentemente unida la libertad de convencer a los demás, al menos como libertad de expresión, de la positividad de una ideología, moral o religión. A este acto se le denomina proselitismo o evangelización. Es la libertad de captar, reclutar, enseñar y convencer a los demás de las ideas religiosas o morales que un sujeto o un grupo tienen, con el objetivo, normalmente, de universalizar el sentimiento moral.

El ejercicio de esta libertad termina en donde comienza la libertad de los demás de no escuchar, aceptar, creer ni obrar conforme un sentimiento religioso. Por eso, el Derecho penal criminaliza el impedimento a practicar o asistir a los actos propios de las creencias, o forzar a practicar, concurrir, realizar actos relevadores, no profesar o mudar de creencia, bajo violencia, intimidación, fuerza $\mathrm{u}$ otro apremio ilegítimo. Los antecedentes punitivos del delito de proselitismo ilícito, demuestran el mayor interés por proteger la libertad de conciencia y religiosa, si bien la evolución de estos delitos es tan amplia y divergente que precisa de examinar, aun brevemente, sus antecedentes.

Morillas CuEva, al estudiar los antecedentes históricos del art. 205 CPd, acierta en diferenciar diversas concepciones del «delito religioso», desde una interpretación como atentado a la vida cotidiana o a la libertad de creencias individual ${ }^{1284}$, y cuyo hito histórico se debe a la declaración Dignitatis humanae en el Concilio Vaticano II. Este hito aun tuvo más repercusión en aquellos países que, como España, tenían una legislación basada en la protección de la confesionalidad y la religión católica del Estado ${ }^{1285}$.

Antes de llegar a este punto, fue evidente la tendencia de cada Estado, asociada a su política interna y configuración religiosa de la sociedad, a defender o criticar una tutela penal de lo

\footnotetext{
1283 Vid. LlamaZARES FernánDeZ, D., Derecho de la libertad de conciencia, I, op. cit., p. 244.

1284 Vid. MORILLAS CUEVA, Lorenzo, Los delitos contra la libertad religiosa (Especial consideración del artículo 205 del Código penal español), pról. José Antonio Sainz Cantero, Universidad de Granada, 1977, pp. 101 y 102.

${ }^{1285}$ Vid. ID., ibidem, op. cit., pp. 155 a 167. Concretamente la declaración Dignitatis humanae en cuyo número 2 establecía que la libertad religiosa se refiere a «que todos los hombres deben de estar inmunes de coacción, tanto por arte de personas particulares como de grupos sociales y de cualquier potestad humana, y ello de tal manera que en materia religiosa ni se obligue a nadie a obrar contra su conciencia ni se le impida que actúe conforme a ella en privado o en público, solo o asociado con otros, dentro de los límites debidos», vid. ID., ibidem, op. cit., p. 190.
} 
religioso. Basta ver las consideraciones de tutelar el sentimiento religioso colectivo o del pueblo que en Alemania se materializó en el Proyecto Oficial de Código penal de 1962 y en Austria en el Código penal de 1974. De otra parte, como sentimiento religioso individual, o como valor social relevante, se veía en el Proyecto de Código penal alemán de 1922, redactado por RADBRUCH, y que tuvo influencia en el Código penal italiano de $1930^{1286}$, pero por el contrario, la doctrina italiana se decantó por una mínima tutela penal ${ }^{1287}$, y algún sector doctrinal muy determinado -encabezado por HASSEMER- se decantó por la despenalización de las conductas atentatorias de lo religioso, esto motivado por la suficiencia de las normas penales tradicionales como el honor, la libertad de reunión y la paz pública ${ }^{1288}$.

Las confesiones religiosas inscritas en el Registro de Entidades Religiosas son consideradas normativamente como instituciones. Basta ver el art. 16.1 CE en relación con el art. 2.2 de la Ley Orgánica 7/1980, de 5 de julio, de Libertad Religiosa, y la Sentencia del Tribunal Constitucional 1/1981, de 26 de enero, en su Fundamento Jurídico $10^{\circ}$.

La principal conclusión a la que llega MORILLAS CUEVA ${ }^{1289}$ tras examinar los antecedentes históricos comparados es que el derogado art. 205 CP protegía la libertad religiosa como derecho individual de la persona en dos vertientes. Por un lado, la libertad de culto a la que se refería el núm. $1^{\circ}$ y $2^{\circ}$ y la libertad de creencia, de aquí que también el ateo pueda ser sujeto pasivo del delito en relación a la libertad de culto ${ }^{1290}$.

Respecto a la libertad de culto, el verbo constreñir equivalía -según el referido penalista- a obligar, ya fuere con violencia o amenaza ${ }^{1291}$, o mediante una fórmula abierta e integrado de otras formas en relación a los «apremios ilegítimos» que fueren idóneos para doblegar la voluntad de la persona ${ }^{1292}$. La trascendencia de esta conclusión es que el tipo, en su modalidad de protección de la libertad de culto, sólo se podía realizar con dolo directo, pero dicho penalista

\footnotetext{
${ }^{1286}$ Ampliamente ID., ibidem, op. cit., pp. 25 a 102; MARTín SÁNCHEZ, I., El Derecho a la formación de la conciencia, op. cit., pp. 165 a 203.

1287 MARTín SÁNCHEZ, I., El Derecho a la formación de la conciencia, op. cit., pp. 209 y ss.

1288 Vid. ID., ibidem, op. cit., pp. 219 y ss. (HASSEMER, W., «Religionsdelikte in der säkularisierten Rechtsordung», LOMBARDIVALlaURI / DILCHER, Cristianesimo, Secolarizzazine, diritto moderno, II, Milano, 1981, pp. 1320 a 1330).

1289 Morillas CUEVA, L., Los delitos contra la libertad religiosa, op. cit., p. 206.

${ }^{1290}$ ID., ibidem, op. cit., pp. 217 a 220; ID., «Los delitos contra la libertad de conciencia y de culto», Documentación Jurídica, Monográfico dedicado a la Propuesta de Anteproyecto del nuevo Código penal, Vol. 2, diciembre/enero, 1983, Madrid, p. 1358, se refiere a la que la libertad de culto sería el núcleo de la tutela penal.

${ }^{1291}$ MORILlas CUEVA, L., Los delitos contra la libertad religiosa, op. cit., pp. 230 y 231.

1292 ID., ibidem, op. cit., pp. 238 y 239.
} 
no excluía la comisión culposa en relación a su inclusión en otros delitos más genéricos, pero sin especificar cuáles $^{1293}$.

Sin embargo, en relación a la libertad de creencias que se contenía en el núm. $2^{\circ}$, además de la violencia o amenaza, se contemplaba la dádiva o engaño con el fin de ganar adeptos para determinada creencia o confesión, o desviarlos de la que tuvieren. De esta manera, mediante el término engaño se podrían apreciar conductas persuasivas «cuando se hace creer a otro lo que no es cierto» ${ }^{1294}$, en el sentido expuesto por MoRILlAs CUEVA, para quien las conductas que transgreden la libertad religiosa se constituyan como delitos de simple actividad, a diferencia de la comisión contra la libertad de culto que podía secuencializarse ${ }^{1295}$; asimismo, tampoco podría contemplarse ni el dolo eventual en esta modalidad ${ }^{1296}$, lo que le lleva a concluir que el tipo subjetivo doloso determinaba la autoría ${ }^{1297}$.

En la actualidad, este derecho se protege especialmente en el art. $522 \mathrm{CP}$, dentro de los Delitos contra la constitución del Título XXI, bajo la sección $2^{\mathrm{a}}$ sobre Delitos contra la libertad de conciencia, los sentimientos religiosos y el respeto a los difuntos. De tal manera se criminaliza de forma clara el segundo párrafo del art. $16 \mathrm{CE}$ que preceptúa que «(n)adie podrá ser obligado a declarar sobre su ideología, religión o creencia».

En concreto, la derogación del art. 205 CP y su modificación en el art. 522 CP, puede decirse que no fue del todo afortunada, puesto que ni resuelve las problemáticas de aparente falta de protección de los sentimientos religiosos o de otro tipo que no están enmarcados en una confesión registrada legalmente, ni aclara la fórmula «medios»o «apremios ilegítimos» como cláusula residual a las conductas violentas, intimidatorias y mediante fuerza, elimina el engaño como elemento del tipo, y además, para sorpresa de gran parte de la doctrina, se suaviza significativamente la penalidad.

Dicho esto, el apartado primero del art. 522 CP criminaliza la conducta de proselitismo ilícito $^{1298}$, que mediante violencia, intimidación, fuerza o cualquier medio ilegítimo «impida»a

${ }^{1293}$ ID., ibidem, op. cit., pp. 253 y 254; también MARTín SÁNCHEZ, I., El Derecho a la formación de la conciencia, op. cit., p. 330.

${ }^{1294}$ Morillas CUEVA, L., Los delitos contra la libertad religiosa, op. cit., p. 290.

1295 ID., ibidem, op. cit., pp. 296 y 297.

1296 ID., ibidem, op. cit., p. 294; MARTín SÁNCHEZ, I., El Derecho a la formación de la conciencia, op. cit., p. 330.

${ }^{1297}$ MORILlas CUEVA, L., Los delitos contra la libertad religiosa, op. cit., pp. 297 y 298.

1298 López Alarcón, M., «Tutela de la libertad religiosa», Derecho eclesiástico del Estado Español, coord. Javier Ferrer Ortiz, Ediciones Universidad de Navarra, 1996, p. 162; MARTín SÁNCHEZ, I., El Derecho a la formación de la conciencia, op. cit., p. 369; PRIETO SANCHÍs, L., «El derecho fundamental de libertad religiosa», en IBÁN / PRIETO SANCHís / Motilla, Curso de Derecho Eclesiástico, Madrid, 1991, p. 338; TAMARIT SuMALla, JMa ., «De los delitos contra la libertad de conciencia», QuiNTERo Olivares Gonzalo (dir.) / VAlLE MuÑIZ José Manuel (coord.), Comentarios al Nuevo Código penal, Aranzadi, Pamplona, 1996, p. 2103. 
«un miembro o miembros de una confesión religiosa» realizar sus prácticas propias o asistir a ellas. Impedir en el sentido de no dejar hacer lo que el sujeto pasivo desea hacer, e imposibilitar, en relación a otro verbo del tipo, «asistir» (ir, estar, estar presente), y «practicar» en relación a ejercitar «actos propios de las creencias que profesen». Es decir, se protege la vertiente externa $^{1299}$ de la práctica de una religión.

El verbo «forzar», recogido en el número $2^{\circ}$ del art. $522 \mathrm{CP}$, se refiere a obligar a hacer lo que no se desea hacer, o sea, practicar o concurrir a actos de culto o ritos, o no profesar, o mudar de creencia. La referencia «o a mudar la que profese» parece incluir también el sentimiento como acto interno, si bien no queda claro en todo el articulado. De aquí que algún autor ${ }^{1300}$-como MARTÍN SÁNCHEZ- haya denunciado, con razón, que dicho artículo resulta incompleto y técnicamente defectuoso, al no proteger en sí mismo el derecho a la formación de conciencia. Esto se debe, según el meritado penalista, a que el apartado $1^{\circ}$ protege exclusivamente la libertad religiosa y no la ideológica, por lo cual únicamente se tutela una de las vertientes de la libre formación de conciencia.

La primera conducta criminaliza, entonces, impedir, practicar, concurrir o asistir a los actos propios de las creencias en relación «a un miembro o miembros de una confesión religiosa», hace pensar que se incluyen los ritos a los que alude el número $2^{\circ}$ del art. $522 \mathrm{CP}$; sin embargo, esta es una interpretación evidentemente extensiva, si bien necesaria para adecuar el artículo a la protección constitucional de todo sentimiento o convicción y a la forma de practicarlos.

En cuanto al término ritos del derogado art. $205 \mathrm{CP}$, comentaba MoRILlas CuEva que «(s)u inclusión en el Código vigente no puede pasar desapercibida. Dos significados pueden marcarse: uno, como costumbre o ceremonia; otro, como conjunto de reglas establecidas para el culto y ceremonias religiosas. El primero es excesivamente amplio, el segundo restrictivo» ${ }^{1301}$.

En nuestra opinión, ha de hacerse una interpretación amplia al objeto de adecuar el tipo a todos los ritos posibles, tanto desde una perspectiva individual, como desde una perspectiva general relacionada con el rito conformado en una confesión, al objeto de no incurrir en desigualdades constitucionales en la protección del ejercicio de tales derechos.

\footnotetext{
${ }^{1299}$ Corcoy Bidasolo Mirentxu / Cardenal Montraveta Sergi / Fernández Bautista Silvia / Gallego Soler José Ignacio / Gómez MARTín Víctor / Hortal IBARRA Juan Carlos, Manual práctico de Derecho penal, Parte Especial. Doctrina y jurisprudencia, con casos solucionados, coord. Mirentxu Corcoy Bidasolo, $2^{\mathrm{a}}$ ed., ampliada y puesta al día, Tirant lo Blanch, Valencia, 2004, p. 184

${ }^{1300}$ MARTín SÁNCHEZ, I., El Derecho a la formación de la conciencia, op. cit., pp. 270 y 271; le sigue GOTI ORdEÑANA, Juan, «Tratamiento jurídico de las sectas en España», Estudios de Juventud, 53/01, pp. 149 y 50.

${ }^{1301}$ Morillas Cueva, L., vv.aa., Derecho penal español, Parte especial, $2^{\mathrm{a}}$ ed., revisada, coord. Manuel Cobo del Rosal, Dykinson, 2005, p. 1072.
} 
Estamos más de acuerdo con MoRILlas CuEva en que ambos apartados también protegen a los ateos. La diferencia entre el apartado $1^{\circ}$ y $2^{\circ}$, es que en el $2^{\circ}$ no se hace expresa mención al ataque a un miembro perteneciente a una confesión religiosa como sí lo hace el apartado $1^{\circ}$, por lo que parece que el verbo «impedir» del apartado $1^{\circ}$ se refiere sólo a los miembros de una confesión, excluyendo a los que no lo fueren, por lo que la protección de sujetos que no ostentasen tal cualidad vendría sólo referida en el $2^{\circ}$ apartado en el sentido de forzarles a practicar o concurrir a actos de culto o ritos, pero no cuando se les impidiese realizarlos, lo cual es llamativamente incoherente, lo que obliga a reparar tal incoherencia ${ }^{1302}$-en relación a la finalidad del art. $16 \mathrm{CE}$ y su amplia protección las creencias religiosas y a la conciencia- con la inclusión de la protección referida en el apartado $1^{\circ}$, de sujetos que profesen su propia creencia o la de un grupo no inscrito en el Registro de Entidades Religiosas. Excluir una interpretación extensiva llevaría a la atipicidad de la conducta de impedir actos «religiosos» cuando estos actos se lleven a cabo por una secta, como acertadamente resalta un sector de la doctrina ${ }^{1303}$. Por eso, estamos de acertado con el sector doctrinal ${ }^{1304}$ que interpreta el ejercicio de las creencias sin exigir vinculación a una confesión religiosa determinada, que en caso contrario, parecería vulnerar el principio de igualdad como ha puesto de manifiesto algún autor ${ }^{1305}$.

Así, la redacción del artículo resulta ya problemática en la determinación del bien jurídico. Se han barajado varias alternativas ${ }^{1306}$ : el atentado a la religión como valor fundamental de la sociedad, el quebrantamiento del orden público, del sentimiento religioso, o del derecho individual de la persona.

La doctrina, casi unánimemente, se decanta por el sentimiento religioso, aunque alguno se desmarque y pretenda ver afectado algún otro bien jurídico ${ }^{1307}$. MORILLAS CUEVA va más allá y entiende que el bien jurídico es la misma sociedad, puesto que no se precisa la afección real al sentimiento religioso ${ }^{1308}$. LÓPEZ ALARCÓN ${ }^{1309}$ ubica estos tipos como atentado contra la libertad

\footnotetext{
${ }^{1302}$ En el mismo sentido, Morillas Cueva, L, vv.aa., Derecho penal español, Parte especial, op. cit., p. 1072.

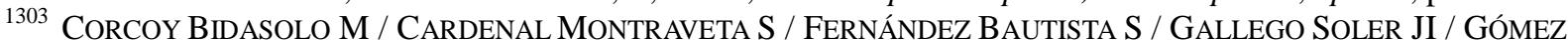
Martín V / Hortal IBARRA JC., Manual práctico de Derecho penal, Parte Especial, op. cit., p. 184.

1304 ID., ibidem, op. cit., p. 184; NAVAS RENEDO, B., Tratamiento jurídico de las sectas, op. cit., p. 293; Motilla, A., Sectas y Derecho en España, op. cit., p. 181; SouTo PAZ, JA, Comunidad política y libertad de creencias, op. cit., p. 279.

${ }^{1305}$ MARTÍN SÁNCHEZ, I., El Derecho a la formación de la conciencia, op. cit., p. 252; TAMARIT SUMALLA, JM ${ }^{\text {. }}$, La libertad ideológica, op. cit., pp.

1306 Morillas Cueva, L., vv.aa., Derecho penal español, Parte especial, op. cit., pp. 1070 y 1071.

1307 Muñoz Conde, F., Derecho Penal, Parte Especial, 15ª ed., op. cit., pp. 838 y ss.

1308 Morillas Cueva, L., vv.aa., Derecho penal español, Parte especial, op. cit., 1070.

1309 LÓPEZ ALARCÓN, M., «Tutela de la libertad religiosa», op. cit., pp. 160 y ss.
} 
religiosa colectiva e individual. De manera similar, PÉREZ-MADRID defiende la libertad religiosa en toda su amplitud como derecho individual y a la vez colectivo ${ }^{1310}$.

Es de otra opinión MARTín SÁNCHEZ ${ }^{1311}$, quien se refiere a una protección religiosa e ideológica, pero ésta última de forma incompleta al no contemplar expresamente, ni en ambos casos el derecho a la formación de conciencia, del punto que existe una «reducción» de los tipos penales actuales respecto al $\mathrm{CPd}$, criticable por cuanto la referencia al sentimiento individual no contempla el sentimiento colectivo, ni a los grupos ideológicos ni de convicciones ${ }^{1312}$, de manera que no se protege la libertad de conciencia en su vertiente a la formación de la conciencia ${ }^{1313}$. Para él, el bien jurídico protegido no sería ni la integridad psíquica, ni las libertades ideológica y religiosa, sino el Derecho a la formación de la conciencia «contra el empleo de diversos medios ilegítimos que impiden su ejercicio» ${ }^{1314}$.

Si aceptamos que el bien jurídico es el sentimiento religioso, habrá que admitir también que supone un delito contra la libertad religiosa, al menos de especial protección respecto a las coacciones o amenazas, por cuanto que el tipo versa sobre impedir realizar actos propios de una determinada creencia o, a asistir a ellos, forzar, lo que llama poderosamente la atención ya que el delito de coacciones, en su modalidad agravada, sanciona la coacción que afecte al ejercicio de derechos fundamentales, de lo que deviene una problemática de concurso de leyes cuando se impida de alguna manera profesar una religión.

La confusión es absoluta. El tipo del art. 522 CP parece referirse más a actos concretos de profesar o no una religión, sin embargo en su segundo párrafo incluye la formula «o a mudar la que profesen», lo que agudiza el problema concursal. Al ser el $522 \mathrm{CP}$ el tipo especial respecto al de coacciones, podría reconducirse a éste primero, pero la consecuencia es grave: renunciar a una penalidad quizá más proporcionada respecto a determinados ataques que suponen doblegar la voluntad de algo tan cercano a la identidad propia como es la libertad de conciencia y los sentimientos religiosos que reclama el título de la sección $2^{\mathrm{a}}$.

La pena del art. 522 CP de multa de cuatro a diez meses es irrisoria en relación al desvalor de la acción y del resultado que se pueden dar, máxime en comparación al derogado art. 205 CP que penaba con prisión de seis meses a seis años y multa, lo que en nuestra opinión obligaría a aplicar el delito de coacciones, en virtud del art. 8.4 CP, cuando dicho desvalor se represente

\footnotetext{
${ }^{1310}$ PÉREZ-MADRID, Francisca, La tutela penal del factor religioso en el Derecho español, EUNSA, Ediciones Universidad de Navarra, 1995, p. 153.

1311 MARTín SÁNCHEZ, I., El Derecho a la formación de la conciencia, op. cit., p. 250.

1312 ID., ibidem, op. cit., pp. 251 y 252.

1313 ID., ibidem, op. cit., pp. 252 y 253.

${ }^{1314}$ ID., ibidem, op. cit., p. 326.
} 
especialmente grave como en los casos de persuasión coercitiva que causan un aislamiento social y cultural.

En relación al derogado $205 \mathrm{CP}$, Morilla Cueva concluía que existía una relación de especialidad entre este delito y el de coacciones y amenazas a favor del primero, y esto porque los tipos de amenazas y coacciones están contenidos en el núm. $1^{\circ}$ del art. $205 \mathrm{CPd}$ y entre ambos se protege el mismo bien jurídico, sin embargo en este último se especifica el carácter religioso, por lo que rechaza de plano el concurso ideal entre estas figuras, sin perjuicio de un concurso ideal de este delito con otro lesiones o contra la vida ${ }^{1315}$.

Por nuestra parte, no vemos impedimento en que la imposición de un tratamiento médico sin el consentimiento del paciente no constituya un delito de coacciones ${ }^{1316}$, sino un delito de lesiones $^{1317}$, por la especialidad de bien jurídico afectado, aunque según los casos podría aplicarse, como dijimos en el capítulo tercero, en concurso con el delito contra el sentimiento religioso del art. $522 \mathrm{CP}^{1318}$ si la negativa fuera motivada por motivos de conciencia, si bien críticamente se ha sostenido - por ROMEO CASABONA y otros ${ }^{1319}$ - que la intervención no impide al paciente practicar actos propios de creencias o profesar. En nuestra opinión, esta conclusión hace una interpretación demasiado estricta de las creencias. No toma en consideración aquellas situaciones que sin ser estrictamente actos propios de profesar una religión o sentimiento, así en el caso de los Testigos de Jehová la trasfusión de sangre, son parte de las costumbres y credos de la confesión y su contravención supone una clara vulneración de los dogmas. Tanto es así que hemos visto que uno de los casos paradigmáticos de la autoría de conciencia es la negativa a tratamientos médicos vitales, es decir, la aceptación de la muerte, lo que constituye un claro ejemplo de que tales motivos pertenecen a parte del credo y de la práctica de una religión negativamente: no aceptar la sangre de otros porque contamina el alma.

La problemática sobre la ubicación típica de fórmulas amplias, tales como «medios ilegítimos» o expresiones como «control mental», «manipulación mental» o la -que por nuestra parte proponemos- de «persuasión coercitiva» reside en si cabe asimilar estas dinámicas a la

${ }^{1315}$ MORILlas CUeVA, L., Los delitos contra la libertad religiosa, op. cit., pp. 269 a 274 y p. 298.

1316 BAUCELls I LLADÓs, J., La delincuencia por convicción, op. cit., p. 231; CASTRO Jover, Adoración, «La libertad de conciencia y la objeción de conciencia individual», op. cit., p. 175; FLORES MENDOZA, F., Objeción de conciencia, op. cit., pp. 431 y ss; GÓMEZ RIVERO, $\mathrm{M}^{\mathrm{a}} \mathrm{C}$., La responsabilidad penal del médico, op. cit., p. 206; Higuera GUIMERÁ, JF., El delito de coacciones, op. cit., p. 219; con matices y sin descartar el delito de lesiones JERICÓ OJER, L., El conflicto de conciencia, op. cit., p. 530; ROMEO CASABONA, CMa ., El médico y el Derecho

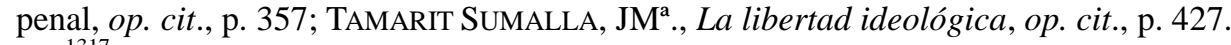

1317 Gómez Benítez, JM., Teoría jurídica del delito, op. cit., p. 395.

1318 CEREZO MIR, J., «La eximente de obrar en cumplimiento de un deber», op. cit., p. 277.

1319 ROMEO CASABONA CMa ., El médico y el derecho penal, op. cit., p. 382; JERICÓ OJER, L., El conflicto de conciencia, op. cit., p. 530. 
violencia, intimidación o fuerza. Parte de la doctrina asemeja la violencia, la intimidación o fuerza a la configuración de art. $522 \mathrm{CP}^{1320}$, las dos primeras como fuerza física o coacción moral, mientras que la fuerza como capacidad de limitar la libertad de las personas. Sin embargo, dicha fórmula no puede entenderse estricta ni tradicionalmente, sino en relación a la subordinación ${ }^{1321}$ relevante del sujeto en su capacidad de obrar y de tomar decisiones.

De tal forma, la mayor parte de la doctrina no considera que el engaño, la hipnosis y determinadas drogas puedan incluirse en la expresión de procedimientos ilegítimos del art. 205 CPd o $522 \mathrm{CPv}^{1322}$. Esto es porque la doctrina mayoritaria ubica el uso de drogas, narcóticos, y la hipnosis en el concepto normativo de «violencia» ${ }^{1323}$, lo que llevaría a integrar la persuasión coercitiva en el delito de coacciones, como veremos infra.

Sin embargo, TAMARit Sumalla e Higuera Guimerá ${ }^{1324}$ incluyen en dicha expresión la hipnosis, el suministro de drogas y otros procedimiento novedosos y más complejos como el tratamiento quirúrgico, la psicocirugía (similar a la lobotomía) o las llamadas terapia del dolor a base de impulsos eléctricos en el cerebro. Estos procedimientos tienen una gran semejanza con la persuasión coercitiva ${ }^{1325}$, por lo que con la inclusión de éstas en la expresión «apremio ilegítimo» se podría integrar las técnicas de manipulación o persuasión coercitiva en este tipo. Por eso, algún sector que ha estudiado con detalle la problemática -como JORDÁN VILLACAMPA y NAVAS RENEDO- considera que en la controvertida expresión entraría toda «utilización de técnica de modificación del pensamiento que produzcan dependencia psíquica o control mental» ${ }^{1326}$.

Mientras que en relación al engaño, su presencia típica se reclama por parte de la doctrina en la actual regulación. Ya el art. 205 CPd en su núm. 2 lo contendía en el sentido expuesto por MORILlas CUEVA: «una perturbación de la voluntad del individuo con el fin de conseguir los

\footnotetext{
${ }^{1320}$ CANCIO Meliá, M., «De los delitos contra la libertad de conciencia, los sentimientos religiosos y el respeto a los difuntos», Comentarios al Código penal, Gonzalo Rodríguez Mourullo (dir.), op. cit., p. 1297; LóPEZ ALARCÓN, M., «Tutela de la libertad religiosa», vvaa, Derecho eclesiástico del Estado español, pp. 160 y ss; PÉREZ-MADRID, F., La tutela penal del factor religioso en el Derecho penal, op. cit., 193.

${ }^{1321}$ Habla de jerarquía también MARTín SÁnchEZ, I., El Derecho a la formación de la conciencia, op. cit., p. 272.

1322 BUENO SALINAS, S., «El ámbito de amparo del derecho de libertad religiosa y las asociaciones», op. cit., p. 119; FERNÁNDEZ-CORONADO, A., «La tutela penal de la libertad religiosa», op. cit., p. 46; MARTín SÁNCHEZ, I., El derecho a la formación de conciencia, op. cit., p. 275; Motilla, A., «La protección de la religión en el Código Penal español de 1995», Quaderni di Diritto e Politica Ecclesiastica, Vol. II, Milán, 1996, p. 460.

${ }^{1323}$ Vid. Alonso Herreros R / MuÑiz CAlaz B / RAmos SuÁrez A / RodríGuez JA., «Actitud del ordenamiento español ante las sectas», op. cit., p. 52.

${ }^{1324}$ TAMARIT SUMALLA, JM"a., «Las sectas y el Derecho penal», op. cit., pp. 283 y 285; acepta algunos de estos supuestos HigUERA GUIMERÁ, JF., El delito de coacciones, op. cit., pp. 123 a 129.

${ }^{1325}$ Según DEL RE son métodos probados de manipulación, DEL RE, MC., «Modellamento psichico e diritto penale: tutela penale dell'integrità psichica», op. cit., pp. 174 a 180.

${ }^{1326}$ Vid. JORDÁN VILlACAMPA, ML. «Las sectas pseudorreligiosas», op. cit., p. 103; NAVAS RENEDO, B., Tratamiento jurídico de las sectas, op. cit., p. 293.
} 
objetivos previstos» ${ }^{1327}$. De esta manera, mediante el término engaño se podrían apreciar conductas persuasivas «cuando se hace creer a otro lo que no es cierto» ${ }^{1328}$, un medio que no sería estrictamente violento pero sí injusto, al igual que el engaño como medio para la detención ilegal $^{1329}$. Además, se denuncia que la experiencia demuestra que el engaño es el medio más utilizado para captar adeptos por las «sectas destructivas» ${ }^{1330}$. Sin embargo, TAMARIT SUMALLA ${ }^{1331}$ considera que el engaño se puede incluir en la formulación «otro apremio ilegítimo» del art. $205 \mathrm{CPd}$, (ahora $522 \mathrm{CPv}$ ), al tratarse el engaño del elemento central del injusto como en otros tipos penales (delitos contra los derechos de los trabajadores, delios de abusos sexuales, de prostitución, estafa, detención ilegal, etc.).

Así las cosas, puede concluirse que la formula residual del delito de proselitismo ilícito «cualquier apremio ilegítimo» del art. $522 \mathrm{CP}$ ha sido justamente criticada por la doctrina por su falta de claridad. Parece una fórmula de carácter abierto e integrador, pero en todo caso, puesto que al exigirse que sea ilegítimo, al igual que sucede con los conceptos de violencia, intimidación y fuerza, ya de por sí redundantes en el tipo, ha de ser contrario a derecho ${ }^{1332}$, antijurídico. Por eso algunos autores consideran que no cabe en tal expresión el engaño o la promesa para conseguir que la víctima profese o practique un determinado sentimiento moral cuando no intervenga la violencia, la fuerza o la intimidación. A este respecto, LóPEZ ALARCóN considera que «el apremio ilegítimo es un instrumento diferente de los demás para la comisión del delito que, por consiguiente, opera como elemento autónomo de la figura delictiva y no han de concurrir los demás que enumera el texto primitivo» ${ }^{1333}$. Este último autor, por tanto, considera que la persuasión coercitiva tiene cabida en ésta expresión del art. 522 CP.

Si bien no existe en nuestro Código penal un delito autónomo de «lavado de cerebro»o «manipulación mental», lo paradójico es que en el delito dedicado al asociacionismo ilícito $\left(515.2^{\circ} \mathrm{CP}\right)$ se criminalicen las asociaciones «que, aun teniendo por objeto un fin lícito, empleen medios violentos o de alteración o control de la personalidad para su consecución», lo cual no deja de ser un reconocimiento de la realidad de las técnicas de persuasión, sin embargo, no existe regulación específica alguna que sancione el «control de la personalidad». Ahora bien, no

\footnotetext{
${ }^{1327}$ Morillas CUEVA, L., Los delitos contra la libertad religiosa, op. cit., p. 290; también MARTín SÁNCHEZ, I., El Derecho a la formación de la conciencia, op. cit., p. 328.

${ }^{1328}$ Morillas Cueva, L., Los delitos contra la libertad religiosa, op. cit., p. 290.

${ }^{1329}$ Polaino NAVARRETe, M., El delito de detención ilegal, op. cit., p. 106.

1330 MARTín SÁnCHEZ, I., El Derecho a la formación de la conciencia, op. cit., p. 329.

${ }^{1331}$ ID., ibidem, op. cit., p. 246.

1332 Morillas Cueva, L., vva.aa., Derecho penal español, Parte especial, op. cit., p. 1072.

1333 LÓPEZ Alarcón, M., «Las Sectas y los NMR's. Problemas de su tratamiento jurídico. ¿Reconocimiento o prohibición?», Ius Canonicum, Vol. 37, núm. 74, julio-diciembre, 1997, pp. 451 y ss.
} 
resultará ilógico considerar que en algún recodo del Código penal puede extraerse la criminalidad de la conducta de manipulación o control de la personalidad.

Parte de la doctrina ${ }^{1334}$ considera que el fundamento del art. $515.2^{\circ} \mathrm{CP}$ tiene como finalidad la persecución del proselitismo ilícito de las sectas, tal y como se expresaba la Exposición de Motivos del Proyecto de Ley Orgánica del Código penal de $1992^{1335}$.

Hemos visto que existen propuestas - como la de TAMARIT SUMALLA- que consideran que la protección de la capacidad de decidir y su ejecución ya viene recogida en el delito de proselitismo ilícito de actual art. $522 \mathrm{CP}$, y por tal motivo la capacidad de voluntad y la inviolabilidad psíquica precisan de una protección similar a la italiana. Por nuestra parte, como puede apreciarse, la protección penal abarca la criminalización de conductas que fuercen de alguna manera a un sujeto a dirigir su voluntad a realizar actos discrepantes con su conciencia interna, sin embargo no se protege explícitamente la formación o conciencia interna, sino exclusivamente su ejercicio en la modalidad religiosa colectiva o individual.

En opinión de MARTín SÁNCHEZ, no resulta suficiente la tipificación del ahora art. 513.2 CP en relación a los ataques realizados por asociaciones ideológicas o religiosas ${ }^{1336}$. De aquí que en relación a los medios de alteración o control de la personalidad sea necesaria para una eficaz protección del derecho a la formación de la conciencia, incluyendo en una fórmula todas las técnicas y medios de control psicológicos que no se puedan subsumir en los restantes medios ${ }^{1337}$, tales como la «alteración o control de la personalidad», que al no estar tipificados como delito autónomo, precisan complementarse con otros tipos penales -bajo pena de inconstitucionalidad $^{1338}$ - en relación con el art. $22 \mathrm{CE}$, de modo que se debería incluir «a la hipnosis, al uso de narcóticos, drogas, sustancias psicotrópicas y diversas técnicas de control

${ }^{1334}$ CANCIO Meliá, M., «De los delitos cometidos con ocasión del ejercicio de los derechos fundamentales y de las libertades públicas garantizadas en la Constitución», Comentarios al Código penal de 1995, Gonzalo Rodríguez Mourullo (dir.), op. cit., pp. 1288 y 1289; MARTíN SÁNCHEZ, I., El derecho a la formación de la conciencia, op. cit., p. 276; Motilla, A., «La protección de la religión en el Código Penal español de 1995», op. cit., p. 460; ID., Sectas y Derecho en España, op. cit., p. 40; TAMARIT SUMALLA, JM ${ }^{\mathrm{a}}$., «De los delitos contra la libertad de conciencia», op. cit., p. 2013; VÁzQUEZ HonRUBIA, José María, «El Código Penal de 1995 y las organizaciones sectarias», Infosect, Boletín de la Asociación A.I.S.

${ }^{1335}$ En concreto decía que «por primera vez, y a fin de ofrecer un instrumento eficaz en la lucha contra las sectas, las que, aún teniendo por objeto un fin lícito (...) emplearen medios violentos o de alteración o control de la personalidad para su consecución», Boletín Oficial de las Cortes Generales, Congreso de los Diputados, serie A, de 23 de septiembre de 1992, p. 26.

${ }^{1336}$ Se debería incluir la intimidación y el engaño MARTín SÁNCHEZ, I., El Derecho a la formación de la conciencia, op. cit., pp. 284 y ss y p. 327; le sigue GOTI ORDEÑANA, J., «Tratamiento jurídico de las sectas en España», op. cit., p. 152.

${ }^{1337}$ MARTín SÁNCHEZ, I., El Derecho a la formación de la conciencia, op. cit., p. 329.

${ }^{1338}$ Lo considera inconstitucional y en todo caso aboga por la derogación FONT BOIX, I., «Propuesta de despenalización radical en la legislación española de los medios de control o de alteración de la personalidad en relación con las llamadas sectas», Cuadernos doctorales: derecho canónico, derecho eclesiástico del Estado, 20, 2003-2004, pp. 111 y 112. 
psicológico, tales como el lavado de cerebro y la desprogramación (...) a todos aquellos medios susceptibles de impedir a una persona actuar de un modo consciente y libre» ${ }^{1339}$. Por eso, parte de la doctrina no considera acertado que los medios de «alteración o control de la personalidad» diesen lugar a la comisión de delitos autónomos ${ }^{1340}$, salvo -dice MARTín SÁNCHEZ ${ }^{1341}$ - en casos de menores de edad o cuando se cause un resultado de lesiones o grave atentado a la dignidad (arts. 155 y $173 \mathrm{CP}$ ).

En nuestra opinión, la protección penal abarca la criminalización de conductas que fuercen de alguna manera a un sujeto a dirigir su voluntad a realizar actos discrepantes con su conciencia interna, sin embargo no se protege explícitamente la formación o conciencia interna, sino exclusivamente su ejercicio estrictamente externo y material en la modalidad religiosa colectiva o individual. Por eso, el delito del art. 522 CP no criminaliza técnicas de persuasión coercitiva, que son, precisamente, junto a la hipnosis y los narcóticos, medios capaces de modificar la vertiente interna de la conciencia, la capacidad de la formación y de decisión. De aquí que el art. 522 CP sea insuficiente para proteger estas dinámicas criminales, máxime cuando su penalidad no abarca ni el desvalor de la acción ni del resultado, lo que lleva a que en caso de concurso se decante a favor del delito de coacciones.

Lo cierto es que la gravedad que supone atentar con la libertad de actuar en general, que en ocasiones dura años, sumados el ataque contra la dignidad y la integridad psíquica de las personas, no puede abarcarse por el delito de proselitismo ilícito del art. $522 \mathrm{CP}$, aun a pesar de la fórmula «cualquier apremio ilegítimo», puesto que esta fórmula se refiere, al igual que la violencia, la intimidación o fuerza, a medios comisivos sobre el ejercicio material de la voluntad y en relación al ejercicio religioso colectivo o individual, si se quiere también extensivamente a la ideología o a las convicciones (ateísmo). Además su penalidad máxima no supera los diez meses de pena de multa, no tiene ni tan siquiera una pena de prisión.

MORILlas CUEVA ${ }^{1342}$ llama igualmente la atención en la penalidad del art. $522 \mathrm{CP}$, puesto que la pena de multa rompe con la penalidad del delito de coacciones, amenazas y la protección de otros derechos fundamentales. En su opinión, acorde a la nuestra, se debería aumentar la pena mediante una protección más cualificada como lo hacía el Código penal anterior, que penaba con prisión menor de seis meses a seis años de privación de libertad, lo que en palabras del autor, y

${ }^{1339}$ MARTÍN SÁNCHEZ, I., El Derecho a la formación de la conciencia, op. cit., p. 281.

${ }^{1340}$ ID., ibidem, op. cit., p. 282; MotILLA, «Reflexiones sobre el tratamiento jurídico-penal de las sectas religiosas en España», Aspectos Socio-Jurídicos de las sectas, op. cit., p. 317; PÉREZ-MADRID, F., La tutela penal del factor religioso en el Derecho español, op. cit., p. 203; TAMARIT SUMALLA, JMa ., La libertad ideológica, op. cit., pp. 247 y ss.

${ }^{1341}$ SÁNCHEZ, I., El Derecho a la formación de la conciencia, op. cit., pp. 282 y ss.

${ }^{1342}$ Morillas Cueva, L., vv.aa., Derecho penal español, Parte especial, op. cit., p. 1073. 
que ratificamos, parece deberse a un error, o a una falta de coordinación del $\mathrm{CP}$, que precisa de una urgente revisión.

En el mismo sentido, POLAINO-ORTS, con el que aun estamos más de acuerdo, si bien explica que la benignidad del tipo se debe a que el legislador concede «una menor relevancia normativa a determinados derechos fundamentales, como el presente. Con ello, el legislador configura un censurable sistema de derechos fundamentales escalonados (de primer, de segundo, de tercer rango) que, en todo caso, no se corresponde con el reconocimiento concedido en la Constitución a estos derechos fundamentales» 1343 .

En conclusión, el art. $522 \mathrm{CP}$ es insuficiente para criminalizar aquellas conductas que sutilmente utilizan técnicas de persuasión coercitiva, lo que requiere el análisis de otros tipos.

\section{III.- La persuasión coercitiva como «delito contra la integridad moral»}

La referencia a la seguridad que hace el Código penal en los delitos contra la libertad viene en relación a la protección a los derechos de la personalidad y la dignidad humana. En este caso, son representativos los arts. 173 y $174 \mathrm{CP}$ porque tienen una clara reminiscencia con la persuasión coercitiva. El delito contra la integridad moral protege la inviolabilidad de la persona y su dignidad, es decir, que no pueda ser tratada como una cosa, a lo que alude el art. 15 de la CE. De tal suerte, parte de la doctrina delimita el concepto normativo de «trato degradante» del tipo de torturas a los sufrimientos físicos o psíquicos que tengan el fin de afectar a la capacidad de conocimiento, discernimiento y decisión. De aquí que exista una clara relación entre este delito y las dinámicas coercitivas descritas.

La STEDH de 25 de abril de 1979 recoge la diferencia entre la tortura o trato inhumano y el trato degradante. En esta Sentencia se confiere un plus a la tortura o trato inhumano, mientras que en el trato degradante se requiere la habitualidad y una menor entidad. De tal manera, la tortura requiere una conducta más intensa, que en nuestro $\mathrm{CP}$ se sanciona con un tipo cualificado y agravado por el sujeto activo, autoridad o funcionario público cuando en su actividad específica pretende conseguir del sujeto pasivo una confesión o, simplemente, hacer que padezca, rebajándolo al concepto de cosa o castigo como refiere el art. 1.1 de la Convención de Nueva York de 10 de diciembre de 1984 contra la Tortura y otros Tratos o Penas Crueles, Inhumanas o Degradantes. La STC 120/1990 declaró que el trato degradante significa causar

\footnotetext{
${ }^{1343}$ Polaino-OrTs, M., vv.aa., Lecciones de Derecho penal, Parte Especial, T. II, Dir. Miguel Polaino Navarrete, Tecnos, Madrid, 2011, p. 508.
} 
padecimientos físicos o psíquicos de modo vejatorio con la misma intención de degradar o doblegar la voluntad.

Llama la atención en relación a nuestra investigación la STEDH de 18 de enero de 1978, que reprochó cinco técnicas utilizadas por la fuerzas de seguridad -tales como someter a ruidos monótonos y continuos, limitar la dieta y el agua o privar de sueño-, lo que precisamente recuerda a las técnicas de persuasión coercitiva fisiológicas estudiadas. En principio, parece aplicable este tipo a las conducta de persuasión coercitiva en relación al concepto de trato degradante, y en algunos casos como tortura, puesto que como recuerda la STS de 29 de septiembre de 1998, por trato degradante ha de entenderse «aquel que pueda crear en las víctimas sentimientos de terror, de angustia y de inferioridad susceptible de humillarles, de envilecerles y de quebrantar, en su caso, su resistencia física o moral», lo que parece demandar una cierta perdurabilidad repetición, sin perjuicio de que un solo acto, por su intensidad, pueda constituir este delito, lo que en definitiva recuerda las consecuencias de las técnicas de persuasión estudiadas.

Sin embargo, la amplitud del término «trato degradante» es de tal índole que puede decirse que choca con el planteamiento con el que el Código penal, en su totalidad, protege la integridad moral. Precisamente esto crea en muchas ocasiones problemas de concursos. No queda muy claro qué se pretende proteger con este delito, pues si se pretende criminalizar el ataque a la dignidad hubiera bastado con la agravación, pero si lo que se pretendía era sancionar ciertas formas de torturas por su particularidad, quizá era mejor forma la de la regulación anterior ${ }^{1344}$.

A este respecto, en el delito de tortura del art. $174 \mathrm{CP}$ se suprimió el requisito de estar en curso de una investigación policial o judicial con el fin de que una persona confesara, obtener información de ella o castigarla. De esta manera, el delito en cuestión se ocupa del quebrantamiento de un bien jurídico supraindividual, más allá de la integridad moral y la dignidad: la confianza del ciudadano en la administración de justicia. Esto fundamenta que se trate de un delito especial por la comisión realizada por una autoridad o funcionario, pero a la vez su mayor gravedad y penalidad por la especial defraudación.

MAQUEDA ABREU considera que «(e)l concepto aproximativo que el art. $174 \mathrm{CP}$ ofrece de esos atentados, en tanto que causantes de «la supresión o disminución de (las) facultades de conocimiento, discernimiento o decisión», es suficientemente ilustrativo en orden a evidenciar el

\footnotetext{
${ }^{1344}$ Lascuraín SÁnChez, Juan Antonio, vv.aa., Compendio de Derecho Penal, Parte especial, Vol. II, Dir. Miguel BAJO FERNÁNDEZ, Centro de Estudios Ramón Areces, 1998, p. 90.
} 
grave ataque a la inviolabilidad de la personalidad humana que representan», concluyendo que la legislación penal es suficiente, si bien otra cosa es saber aplicarla ${ }^{1345}$.

Al respecto, ha recordado MAQUEDA ABREU las palabras de COPPI sobre la gravedad y trascendencia del delito de plagio en el CP italiano como delito de tortura y esclavitud: «Sin perspectiva alguna de recuperar la libertad propia». De ahí la analogía con la esclavitud, con la idea de instrumento de la voluntad de otros. Son, las del texto, palabras del Tribunal de Casación italiano en la sentencia de 3 de noviembre de 1949 referidas al plagio: es «suficiente para la consumación del delito que la voluntad y la personalidad de la víctima sean 'casi completamente anuladas' y que la misma 'pueda considerarse casi una cosa' en poder del plagiante» ${ }^{1346}$.

$\mathrm{El}$ art. $177 \mathrm{CP}$ contiene una cláusula residual que permite el concurso real de este delito con el delito de lesiones y coacciones (SST de 2 de abril de $2003^{1347}$ ), para otros un concurso ideal o medial $^{1348}$. Esta cláusula, entonces, lleva a la posibilidad de compatibilizar sanciones por tratos degradantes, coacciones y lesiones, todas ellas concurrentes en las dinámicas propias de la persuasión coercitiva, sin embargo, de tal manera se crearía una confusión tal que difuminaría el contenido material propio de un injusto de persuasión coercitiva. Dicho de otro modo, si aceptamos la pluriofensividad de la persuasión coercitiva, habrá que concluir también que existe una necesidad real de tipificar de lege ferenda dicha fenomenología criminal pero a la vez restringir su injusto, puesto que de lo contrario se caería en la tendencia de sumar tantos injustos que haría de la persuasión coercitiva un injusto total del Código penal.

Por tal motivo, MARTín SÁNCHEZ se ha mostrado expresamente disconforme en aceptar que los delitos contra la integridad moral recojan los atentados contra la libre formación de la conciencia, aunque sea a través de técnicas de manipulación. En concreto explica que al requerir una especial humillación, envilecimiento o trato degradante, «resulta evidente la posibilidad de atentar contra esa libertad mediante medios que, al no conllevar el requisito de humillación o el envilecimiento del sujeto pasivo, no resultan subsumibles» ${ }^{1349}$.

\footnotetext{
1345 Maqueda Abreu, Mál, Las sectas destructivas ante el derecho, op. cit., pp. 245 y 246.

1346 Vid. MAQUEDA ABREU, ML., Las sectas destructivas ante el derecho, op. cit., p. 246, nota 76 (COPPI, F. «Plagio», Enciclopedia del Diritto, Vol. XXXIII, Giuffré Editore, pp. 940, 944 y 945).

1347 Vid. CORCOY Bidasolo M / CARDEnal MontraVeta S / FERnÁndEZ BAUTiSTa S / Gallego SOLER JI / Gómez Martín V / Hortal Ibarra JC., Manual práctico de Derecho penal, Parte Especial, op. cit., p. 174. Si bien la STS de 29 de septiembre de 1998 declaró que debe primar el delito de torturas sobre el de lesiones cuando los actos de violencia excedan de los propios del delito de coacciones.

1348 Vid. ID., ibidem, op. cit., p. 174.

1349 MARTÍN SÁNCHEZ, I., El Derecho a la formación de la conciencia, op. cit., p. 152.
} 
Estamos de acuerdo en esta conclusión. Es evidente que este tipo no pertenece a la delincuencia estricto sensu de las sectas coercitivas, salvo que entendiéramos, en primer lugar, que el líder de un grupo religioso puede tratarse dentro del concepto normativo de autoridad, puesto que el delito de tortura implica un abuso de poder, la superioridad del autor sobre la víctima y la inherente concurrencia de su actuar alevoso o superioridad ${ }^{1350}$, sin embargo, inclusive si realizáramos una interpretación extensiva del sujeto activo, en segundo lugar, es cierto que en la dinámica persuasiva la víctima no siente trato humillante o degradante alguno, salvo cuando afloran los trastornos post-secta, sino que inclusive participa en la coerción, de manera que se asimila a otros medios coercitivos, tales como la hipnosis y el uso de narcóticos que no se incluyen en los delitos contra la integridad moral. De otra parte, tampoco estos delitos protegen la formación o capacidad de decisión del sujeto, sino estrictamente, la ejecución de la decisión, en su caso a modo de confesión, o la dirección material de la voluntad, pero no se protege especialmente la capacidad de formar la conciencia interna del sujeto, ni la capacidad de decisión, modalidades que están inherentemente más ligadas a la libertad de actuar en general.

De aquí que la inclusión de la persuasión coercitiva en los delitos contra la integridad moral sea muy forzada y, en su caso, muy excepcional, si bien su penalidad se ajusta en mejor medida al desvalor de la acción y del resultado que se aprecia en las dinámicas de la persuasión coercitiva, lo que nos lleva a analizar otro tipo penal.

\section{IV.- La persuasión coercitiva como «delito de coacciones»}

\section{A. Introducción}

Se dice que el delito de coacciones proviene de la ilustración penal alemana, y esto porque los Códigos de inspiración napoleónica no castigaban la coacción para evitar así restringir la libertad, sin embargo ya nuestro Código penal de 1822 recogía una figura delictiva al respecto, por lo que puede concluirse que nuestra tipificación, al igual que la de nuestro entorno, se inspira en la regulación penal alemana ${ }^{1351}$, si bien hay que convenir que genuinamente proviene del Derecho romano con el crimen de violencia (crimen vis) como violencia física o psicológica antijurídica que no esté penado por un delito especial ${ }^{1352}$.

\footnotetext{
1350 LaSCuraín SÁnChEZ, JA., vv.aa., Compendio de Derecho Penal, Parte especial, Vol. II, op. cit., p. 93.

1351 Mezger, E., Derecho Penal, Parte Especial. Libro de estudio, trad. de la $4^{\text {a }}$ ed. alemana de 1954 por Conrado A. Finzi, Editorial Bibliográfica Argentina, Buenos Aires, 1959, pp. 89 y ss.

${ }^{1352}$ ID., ibidem, pp. 89 y ss.
} 
El actual delito de coacciones constituye un tipo penal abierto que depende de las múltiples circunstancias concomitantes en el hecho para interpretar si, efectivamente, existe tal comisión o su degradación a falta.

El bien jurídico que se protege en el tipo de coacciones es, quizá, la piedra angular de toda la problemática sectaria criminal por la conexión con el delito de proselitismo ilícito del actual art. 522 CP. La confrontación de la libertad y la seguridad básica del ser humano con el sujeto dominador, y más concretamente en el ámbito sectario, hace del delito de coacciones y del proselitismo ilícito dos caras de una misma moneda, si bien, tras el análisis efectuado, el segundo se dirige a proteger manifestaciones concretas de la ejecución de la libertad religiosa o de convicciones colectiva o individual, pero no a la configuración inherente del ser humano en su libertad de actuar en general basaba en la libertad de formación de la conciencia y la decisión.

\section{B. El bien jurídico protegido}

No podemos pretender la libertad absoluta del ser humano, pero sí crear un sistema que auspicie la libertad en términos jurídicos para el ser humano. Por tanto, no podemos hablar de libertad en sentido absoluto, pero sí en sentido relativo «frente a determinadas formas de ataque que hacen insoportable la vida de relación, desde el punto de vista ético-social», como señala HigUERA GUIMERÁ ${ }^{1353}$.

La jurisprudencia alemana ya definió hace tiempo el concepto jurídico de libertad: «aquel estado de la persona en el que hace valer sin obstáculos la capacidad natural de autodeterminación y control propios del ser humano y determinante del carácter de la persona sin sufrir ninguna obstaculización exterior en su actividad, de forma que su círculo de actuación no tiene otras barreras que las que pone la naturaleza exterior, la misma capacidad de actuación y el orden jurídico de la sociedad» ${ }^{1354}$. Esta definición es lo suficientemente amplia para acordar que la libertad que se protege en el delito de coacciones, deja paso a otros tipos de libertades más específicas, por eso el delito de coacciones es un tipo de recogida ${ }^{1355}$.

La problemática estriba en que tanto el delito de coacciones, el de amenazas y también el de detención ilegal protegen el mismo bien jurídico, entendido genéricamente como la libertad

\footnotetext{
1353 Higuera GUIMERÁ, JF., El delito de coacciones, op. cit., p. 304.

1354 Entscheidungen des reichsgerichts in Strafsachen, Vol. 48, p. 348, vid. HIGUERA GUIMERÁ, JF., El delito de coacciones, op. cit., p. 38.

1355 Del Rosal Blasco, B., vv.aa., Derecho penal español, Parte especial, op. cit., p. 209; CERVELló DONDERIS, V., El delito de coacciones, op. cit., p. 17.
} 
personal $^{1356}$, aunque -como bien apunta POLAINO NAVARRETE ${ }^{1357}$ - también pueden incluirse la «libertad de ubicación espacial (privacidad del lugar de domicilio o trabajo), la libertad sexual (criterio básico de determinación de la sexualidad), la libertad de comunicación (reserva de la intercomunicación personal) o la libertad de privación personal (reserva de datos no destinados al conocimiento ajeno).

La libertad jurídica y fáctica es el paradigma del Derecho y del ser humano como fin en sí mismo. Lógicamente, una libertad de actuar per se merece la protección penal para que los ciudadanos puedan ejercitar los pensamientos y, a la postre, la voluntad. De tal modo, la libertad de actuar en general se protege con el delito de coacciones -como bien aprecia POLAINO NAVARRETE ${ }^{1358}$-, mientras que la libertad de creencias y su ejercicio se protegen especialmente en el delito de proselitismo ilícito. Sin embargo, y en lo que nos interesa, la libertad de pensamiento, en tanto libertad de conciencia, tampoco parece protegerse en sí misma en el delito de coacciones, al menos, no parece dedicado especialmente a esta vertiente del ejercicio de la libertad.

HIGUERA GUIMERÁ ${ }^{1359}$ considera que el tipo de coacción unifica e interrelaciona dos aspectos fundamentales para determinar el bien jurídico protegido, por un lado la libertad y por otro la seguridad en su sentido subjetivo, como «persuasión de que nadie perturbará nuestra existencia mientras no traspasemos el límite de nuestro derecho, persuasión que lleva a la tranquilidad del ánimo», y en su sentido objetivo, como seguridad jurídica, sin peligro para el bien. En tanto en cuanto que para apreciar libertad debe existir, entonces, seguridad, y en tanto se ataque la seguridad se ataca la libertad. Así, el ataque a la libertad, y consecuentemente a la seguridad, produce un ataque en diverso grado a la voluntad personal del ser humano. En palabras de HigUERA GUIMERÁ: «en el delito de coacciones se protege la libertad, pero como manifestación de la voluntad, quedando interrelacionada con la seguridad. Sin embargo, cuando el objeto de ataque es la libertad de decisión», es decir, únicamente el ataque a la libre decisión «en la que ésta queda motivada, nos estamos moviendo en el campo de las amenazas condicionales, y por consiguiente es la seguridad la que se pone de relieve en primer término, es entonces el bien jurídico, prevalente, fundamental o primario» ${ }^{1360}$.

\footnotetext{
${ }^{1356}$ Blanco Lozano, C., vvaa., Lecciones de Derecho Penal, Parte Especial, T. I, Dir. Miguel Polaino Navarrete, Tecnos, 2010, p. 166.

${ }^{1357}$ Polaino Navarrete, M., vv.aa., Lecciones de Derecho Penal, Parte Especial, T. I, Dir. Miguel Polaino Navarrete, Tecnos, 2010, p. 143.

${ }^{1358}$ ID., ibidem, op. cit., p. 143; también BlanCO LOZANO, C., vv.aa., Lecciones de Derecho Penal, Parte Especial, T. I, op. cit., p. 166.

1359 HiguERA GUIMERÁ, JF., El delito de coacciones, op. cit., pp. 59 y 60.

${ }^{1360}$ ID., ibidem, op. cit., pp. 60 y 61.
} 
No podemos empero estar de acuerdo con esta conclusión, pues la libertad de configurar el pensamiento (sistema psíquico), que a su vez determina la conciencia en tanto puente con la libertad de decisión, puede constreñirse sin conductas directamente sentidas o amenazantes, a través de las técnicas de persuasión, si bien hay que determinar si éstas se pueden ubicar en el delito de coacciones.

El término persuasión coercitiva es adecuado para centrar la problemática penal de las técnicas que modifican la voluntad pero no en un sentido general, puesto que cualquier comportamiento de tercero puede modificar la voluntad de otro (neutral y cotidiano), sino de forma antijurídica o antinormativa. Esto significa que el bien jurídico del delito de coacciones no es la libertad de obrar en general en sentido amplio, sino en sentido normativo, pues -como afirma JAKOBS- «(1)a libertad de obrar no es un bien jurídico autónomo, sino derivado (...) en derechos garantizados» ${ }^{1361}$. De esto extrae que el objeto de protección del delito de coacciones es una libertad garantizada pero a la vez limitada en la prohibición de coaccionar, lo que lleva a que el comportamiento coaccionador no pueda determinarse antes de la norma, sino que se codetermina por medio de esta ${ }^{1362}$. De modo que la clave para saber si se está ante un delito de coacciones es si «el comportamiento no libre de la víctima aporta un plus de libertad al autor» ${ }^{1363}$

No obstante, resulta de especial interés delimitar el objeto del ataque en el delito de coacciones y su delimitación con el tipo de amenazas porque en éste también se vulneran mediante la amenaza de un mal relevante, derechos garantizados. Esto se precisa porque la doctrina penal no es unánime en la distinción del ataque que se produce entre el delito de coacciones y en el delito de amenazas, lo que confunde su delimitación normativa. Dicho de otro modo, a pesar del impedimento normativo que produce que la persuasión coercitiva no pueda incluirse en el delito de amenazas por la faltar la comunicación amenazante, sentida como tal por el sujeto, la singular determinación doctrinal de que el delito de amenazas se constituye como un tipo sobre ataques contra la capacidad de decisión y su ejecución, llevaría a considerar que la persuasión coercitiva, supone un delito de estas características. De esto resulta la cuestión de determinar cuál es el objeto del ataque del delito de coacciones, y si las dinámicas persuasivas y coercitivas entran en este tipo de ataque, o si por el contrario, representan una dinámica criminal

\footnotetext{
1361 JaKoBS, G., «Coacciones por medio de violencia», trad. Carlos J. Suárez González, JAKOBS, G., Estudios de Derecho penal, op. cit., p. 455.

1362 JAKOBS, G., «Las coacciones por medio de amenazas como delito contra la libertad», trad. Carlos J. Suárez González, JAKOBS, G., Estudios de Derecho penal, op. cit., p. 462. Gráficamente señala que el delito de coacciones supone «una ampliación del poder del autor a costa del comportamiento de la víctima», ID., ibidem, op. cit., p. 470.

1363 ID., ibidem, op. cit., p. 470.
} 
tan particular que sin entrar en el delito de amenazas, la hacen merecedora de ser el tipo más básico contra la libertad y la seguridad.

\section{Objeto del ataque y distinción con el delito de amenazas}

La mayor parte de la doctrina ${ }^{1364}$ considera que la libertad a la que se refiere el delito de coacciones es la libertad de voluntad, sin embargo la doctrina no se pone de acuerdo a la hora de concretar cuál es el objeto del ataque, lo que lleva a confusiones normativas con el delito de amenazas.

\section{La libertad de capacidad/formación de la voluntad: la capacidad de la libertad}

En un principio se consideró que sólo podría incluirse en la violencia denominada vis corpore corpori afflicta el vencimiento mecánico de la fuerza corporal de quien se resiste, como ataque específico a la libertad de capacidad o formación de la voluntad.

Sin embargo, pronto se empezó a incluir otros medios como ataque a la capacidad o formación de la voluntad, tales como la hipnosis o la suministración de narcóticos. Esto se debió a que se comenzó a considerar que la hipnosis y los narcóticos eran medios idóneos para doblegar la capacidad de voluntad, por la producción de la inconsciencia, o por la imposibilidad de actuación cuando se suministra el narcótico directamente al sujeto respectivamente, al producirse un «impedimento mecánico» similar a la violencia tradicionalmente entendida como vis corpore corpori afflicta.

En este sentido, Higuera GUIMERÁ considera que «(e)n el delito de coacciones el ataque va dirigido, o contra la libre formación de la voluntad o capacidad misma de la voluntad, quedando por tanto afectadas, y vulneradas, la libre decisión de la voluntad, y la libre ejecución de la misma; o contra la libre ejecución en concreto de la voluntad» ${ }^{1365}$. Otros autores -como MIR PUIG ${ }^{1366}$ - se refieren a que el tipo de coacciones versa sobre la restricción de la ejecución de la voluntad o voluntad de obrar. De tal modo se eliminan interferencias con el concepto de intimidación que normalmente se excluye del elemento normativo de violencia.

${ }^{1364}$ Higuera GuIMERÁ, JF., El delito de coacciones, op. cit., p. 60, concluye que «(e)1 sentimiento de descontento, o, de «desilusión no esperada», provoca en las personas una «frustración» que es el origen de las conductas coactivas punibles», ID., ibidem, op. cit., pp. 304; RoDRÍGUEZ DEVESA José María / JASO ROLDÁN Tomás / RodríGueZ MuÑoz José Arturo, Derecho penal, Parte especial, T. II, Madrid, 1949, pp. 298 y 299; RODRÍGUEZ DEVESA JM ${ }^{\text {a }}$ SERRANO GÓMEZ A., PE, op. cit., pp. 281 y ss.

1365 Higuera GUIMERÁ, JF., El delito de coacciones, op. cit., p. 304; JAKOBS, G., «Consumación material en los delitos contra la persona. Al mismo tiempo, una contribución a la generalización de la parte especial», op. cit., p. 13; MEZger, E., Derecho Penal, Parte Especial, op. cit., pp. 85 y ss.

${ }^{1366}$ MIR PUIG, S., «El delito de coacciones en el Código penal», op. cit., p. 270. 
En lo que a nuestra investigación respecta, según las conclusiones a las que hemos llegado supra, no resultará ilógico equiparar la eliminación de alternativas, que en algunos casos sufre el adepto a una secta, como una forma de impedimento a la capacidad o la formación la libertad de la voluntad. Estos casos se asimilan a los de adicción comportamental especialmente graves, en los que el sujeto tiene restringido el horizonte de alternativas de tal modo que la única alternativa posible es la ofrecida por el líder y/o la dinámica grupal. De aquí la eliminación de alternativas en relación a las ofrecidas por el sistema normativo y social.

La problemática que existe sobre este tipo de ataque es la consecuencia en las formas de autoría y participación. Si comprendemos que el ataque se refiere a la capacidad o a la formación de la voluntad, parece adecuado concluir que la intensidad es tal (vis absoluta) que la instrumentalización del sujeto con fines criminales puede considerarse casos de autoría mediata. Sin embargo, estos casos son los más excepcionales, porque la adicción comportamental se presenta tras un largo periodo de desocialización que parece afectar al sujeto en su salud psíquica a modo de adicción similar a la de suministro de sustancias estupefacientes o narcóticas, lo que se confunde también con el delito de lesiones psíquicas. Amén de ello, la problemática general entre el delito de coacciones y el de amenazas se centra en casos en los que el sujeto, sin perder su propia capacidad inherente de formar la voluntad, en un estado posterior referido a la dirección de las decisiones, está condicionado de forma relevante.

Como decíamos, la doctrina penal ha discutido desde siempre si el ataque a la capacidad de decisión se trata de un delito de coacciones o de amenazas. Aquí es donde se ubica la problemática más agudizada, puesto que según la distinción normativa que se haga de la incapacidad de decisión, se determinará su ubicación el delito de coacciones o en el de amenazas de forma que sería preciso su reformulación o de lege ferenda un nuevo de injusto.

\section{La libertad de decisión de la voluntad o capacidad de actuación de la propia voluntad}

Algunos penalistas ${ }^{1367}$ entienden que el ataque del delito de coacciones se dirige, ya no a la misma formación o capacidad de la voluntad, sino a la formación de una decisión. Este

\footnotetext{
${ }^{1367}$ Vid. Del Rosal Blasco, B., vv.aa., Derecho penal español, Parte especial, op. cit., p. 209.
} 
planteamiento parte de otorgar mayor relevancia a la decisión como bien digno de protección ${ }^{1368}$, por eso consideran que el delito de amenazas es un delito de mera $\operatorname{actividad}^{1369}$.

Otros consideran que el delito de amenazas se refiere al impedimento de ejecutar una decisión, lo que les hace tratarlo como un delito de resultado. Aunque muy acertadamente, y con toda coherencia, TORÍO LÓPEZ y PRATS CANUT ${ }^{1370}$ consideran que la acción de impedir ejecutar la decisión de comenzar un proceso de deliberación es una tentativa de coacciones, pero $\operatorname{otros}^{1371}$, reconducen la tentativa al delito de amenazas condicionales.

Así las cosas, la discrepancias se refieren a que parte de la doctrina ${ }^{1372}$ ubica en el proceso de formación de la voluntad el bien jurídico del delito de amenazas, mientras que otros -como POLAINO NAVARRETE ${ }^{1373}$ - ubican el ataque a la «libertad de decisión de conducta y la seguridad personales» en el delito de amenazas.

Estas discrepancias se deben a la tipificación separada y autónoma del delito de coacciones respecto a las amenazas condicionales en nuestro Código penal a diferencia de otros códigos de nuestro entorno. En tal medida, RoDRíGUEZ DEVESA ${ }^{1374}$ consideraba que no es el delito de coacciones el tipo básico de protección de la libertad, sino el de amenazas por cuanto afecta al proceso de formación de la voluntad, en contra de las apreciaciones de la doctrina alemana más autorizada, que colocaba el tipo básico de la libertad en el de coacciones (TITTMANN, BINDING, MEZGER, WELzEL). La opinión generalizada de la doctrina alemana se debe a que las amenazas condicionales se hallan ubicadas en el tipo de coacciones, mientras que en nuestro Derecho penal, desde antaño, la ubicación sistemática se halla diferenciada entre delito de coacciones y delito de amenazas condicionales e incondicionales, lo que ha producido en la doctrina la habitual confusión del tipo de ataque sobre las formas de manifestación de la voluntad y en la determinación del bien jurídico protegido.

\footnotetext{
1368 BAJO FERnÁnDEZ, M., «El delito de coacciones», Estudios penales. Libro homenaje al Prof. Agustín Fernández Albor, Santiago de Compostela, 1989, pp. 57 y ss; DíaZ-MARoto Y Villarejo, J., vv.aa., Compendio de Derecho Penal, Parte especial, Vol. II, op. cit., p. 60; Higuera GuIMERÁ, JF., El delito de coacciones, op. cit., pp. 60 y 61; MIR PUIG, S., «El delito de coacciones en el Código penal», op. cit., pp. 270 y 284; MUÑOZ CONDE, F., Derecho Penal, Parte Especial, 15 a ed., pp. 154 y ss. y pp. 162 y 163.

1369 Vid. Del Rosal Blasco, B., vv.aa., Derecho penal español, Parte especial, op. cit., p. 201. En este sentido STS de 5 de mayo de 2003.

${ }^{1370}$ Vid. ID., ibidem, op. cit., p. 209.

1371 Vid. ID., ibidem, op. cit., p. 209.

1372 Vid. ID., ibidem, op. cit., p. 200.

1373 Polaino Navarrete, M., vv.aa., Lecciones de Derecho Penal, Parte Especial, T. I, op. cit., p. 143, en negrita en el original; también Blanco LozAno, C., vv.aa., Lecciones de Derecho Penal, Parte Especial, T. I, op. cit., p. 166.

${ }_{1374}$ RODRÍGUEZ DEVESA JMa / JASO ROLDÁN T / RODRÍGUEZ MUÑOZ JA., PE, op. cit., p. 301. RODRÍGUEZ DEVESA JMa / SERRANO GÓMEZ A., PE, op. cit., pp. 300 a 302.
} 
Por eso parte de la doctrina ${ }^{1375}$ entiende que el bien jurídico de las amenazas condicionales no es el mismo que el de las incondicionales, en las que el bien jurídico sería el «sentimiento de seguridad»o la «tranquilidad del ánimo», mientras que en las condicionales el bien jurídico sería la misma libertad de decisión, libertad que se confunde con la libertad de decisión en el delito de coacciones. En este sentido es destacable, por ejemplo, que DEL ROSAL BLASCO ${ }^{1376}$ considere que tanto en las amenazas condicionales como en las incondicionales el bien jurídico es la libertad de decisión, o la libertad en el proceso de formación de la voluntad. Y tampoco han faltado quienes de forma más general entienden que el delito de amenazas protege la seguridad cuando afecta a la libertad (STS de 5 de mayo de 2003).

Es evidente que la discrepancia doctrinal es tal que impide observar una postura clara en la distinción normativa entre delito de coacciones y el de amenazas. A este respecto, por nuestra parte, es de recordar que gráficamente JАKOBS concluía que la clave para saber si se está ante un delito de coacciones es si «el comportamiento no libre de la víctima aporta un plus de libertad al autor ${ }^{1377}$, pero esto ha de entenderse también en relación a la coacción por medio de amenaza en detrimento de un derecho garantizado de la víctima, en cuyo caso contrario, no habrá coacción alguna: «a quien sufre la amenaza no se le priva de libertad alguna cuando sólo se le formulan exigencias que están dentro del marco de aquello a lo que jurídicamente se halla vinculado» ${ }^{1378}$.

La confusión habitual en la doctrina se puede resumir en que tradicionalmente se ha incluido una valoración ontológica que ha impedido discernir entre capacidad y libertad normativamente hablando. De una parte, las capacidades inherentes del ser humano en el más puro sentido ontológico, cuya falta fundamenta las causas de falta de acción humana y de la inimputabilidad (ausencia de capacidad volitiva y/o cognitiva), de otra, la capacidad de representación de expectativas que consiste en la auto-representación de un horizonte de expectativas adecuadas al sistema normativo y social. De este modo, se pueden encontrar causas de incapacidad asociadas a causas sociales, sin que se haya visto afectada la capacidad natural, tradicionalmente entendida como acción, volición y cognición.

En este sentido, JAKOBS ${ }^{1379}$ acierta en que el efecto coaccionardor se relaciona con las menos alternativas de comportamiento de las que se deberían dejar jurídicamente garantizadas, salvo que el «autor»se comporte en los límites del derecho, aun cuando amenace con ejercitar algo

\footnotetext{
${ }^{1375}$ Vid. Del Rosal Blasco, B., vv.aa., Derecho penal español, Parte especial, op. cit., p. 200.

${ }^{1376}$ ID., ibidem, op. cit., p. 200.

1377 JAKOBS, G., «Las coacciones por medio de amenazas como delito contra la libertad», op. cit., p. 470.

${ }^{1378}$ ID., ibidem, op. cit., p. 471

${ }^{1379}$ ID., ibidem, op. cit., p. 468.
} 
que moralmente es repudiable, como aquel comerciante que pretende sacar a la luz la deuda tributaria de un competidor si no acepta vender el endeudado negocio, pues si bien se limita el comportamiento de la víctima, y ese «autor» amplia el suyo, también se amplía -existe conexidad- el de la víctima con la posibilidad de ulterior alternativa, de lo que deviene que no hay una libertad jurídicamente reconocida a la víctima en todos los casos de coacciones por amenazas ${ }^{1380}$. JAKOBS cierra la problemática con esta máxima: «si el mal con el que se ha conminado no restringe la libertad jurídicamente garantizada, el comportamiento obtenido por medio de coacción ha sido realizado de modo libre porque se ha creado una ulterior alternativa de libertad en el ámbito del espacio de libertad jurídica que le queda remanente a la víctima (...) Expresado por medio de los elementos de la estafa: se engaña sobre la posibilidad de obtener una contraprestación. Expresado ahora en las categorías de las coacciones: la libertad pretendidamente detraída, pero en realidad perdida, se convierte en una falta de libertad real del comportamiento de la víctima» ${ }^{1381}$, sin perjuicio, claro está, de los supuestos en los que se restringe la libertad, pero que habitualmente se pueden incluir en el tipo de coacciones, como el aprovechamiento de la debilidad de la víctima o los conocimientos sobre el comportamiento de la víctima.

Aquí podemos ya diferenciar entre libertad y capacidad, tanto en sentido ontológico como normativo. La libertad es el producto de la elección, mientras que la capacidad referida a causas sociales se refiere al horizonte de expectativas y a la auto-representación de éstas. De este modo, la afección a la libertad es sentida por el sujeto como condicionante del producto de la elección, o dicho de otra manera, la libertad se ve condicionada pero el horizonte de expectativas no.

Tras esta delimitación podemos diferenciar más claramente el tipo de ataque que se produce en el delito de amenazas y en el delito de coacciones. En las amenazas se incluye otra expectativa en el horizonte de expectativas, en este caso indeseada, que es la finalmente elegida, de manera que su producto es la falta de libertad. Sin embargo, en la capacidad de libertad de voluntad se restringe o se elimina el horizonte de expectativas:

i) En cuanto a la eliminación del horizonte de expectativas, el sujeto ve anuladas las expectativas normativas y sociales que le ofrece el Sistema, y se sustituyen por completo por las expectativas del grupo, de modo que la capacidad de decidir y la capacidad de ejecutar la voluntad están totalmente condicionadas en una dirección, y secundariamente la libertad.

\footnotetext{
${ }^{1380}$ ID., ibidem, op. cit., p. 473.

1381 ID., ibidem, op. cit., p. 475.
} 
ii) En la restricción del horizonte de expectativas la capacidad de elección está limitada en relación a las alternativas ofrecidas por el sistema normativo y social, de modo que la ofrecida por el tercero (autor) es la única viable. Aquí la libertad está restringida en un horizonte de expectativas claramente marcado por la descompensación entre expectativas normativas y sociales que le llegan al sujeto, y la gran cantidad de expectativas que comunica el grupo, así que la ejecución de la voluntad queda restringida en la dirección conforme a las expectativas del grupo, y secundariamente la libertad.

En nuestra opinión, si sólo se ataca la libertad de la decisión, sin afectar a la capacidad o formación de la voluntad, a la capacidad de inherente de decidir, y a la capacidad de ejecución de la voluntad, estaremos vulnerando únicamente, si bien directamente, la libertad psíquica personal «consciente», unas veces como atentado contra la seguridad (amenazas no condicionales), otras como atentado, no contra la capacidad de decisión, sino contra la libertad de decisión y posterior ejecución en su caso (amenazas condicionales), pero no en sí misma la capacidad cognitiva de constituir un horizonte de expectativas (capacidad o formación de voluntad), y la capacidad volitiva de decidir conforme a un horizonte de expectativas y amoldar la voluntad a tal decisión (capacidad de decisión).

Ahora bien, la premisa básica del delito de amenazas es que el sujeto pasivo sienta, en mayor o menor medida, una amenaza sobre alguno de sus derechos, de forma que sienta la inseguridad cognitiva sobre la posesión y disfrute de estos, o dicho de otro modo, el delito de amenazas precisa que el contenido material además de comunicarse al sujeto haya sido comprendido como tal. En su virtud la dinámica persuasiva no puede comportar un delito de amenazas, por cuanto aquella impide al sujeto su conocimiento. La información y la relevancia en el sistema psíquico llegan de tal manera que el sujeto es incapaz de procesarla conscientemente, por eso el término persuasión es adecuado para centrar la problemática penal de las técnicas que modifican la voluntad.

De aquí resulta que -en nuestra opinión- el delito de coacciones se refiere siempre a la violencia o medio funcionalmente similar en el contexto, ejercida sobre la capacidad de libertad de voluntad en cualquiera de sus tres manifestaciones (formación, decisión y ejecución), lo que propicia que también pueda constreñirse la capacidad de forma inconsciente. Sin embargo, las amenazas exclusivamente se refieren a la libertad de decisión de forma consciente, no a la propia capacidad. De esta manera, aquellos ataques que se dirijan a la elección de la decisión de forma inconsciente pueden tratarse como delitos de coacciones e incluir formas sutiles de persuasión coercitiva que antes, sin esta formulación, se veían abocados al delito de amenazas, según la 
interpretación que hace parte de la doctrina de este delito, lo que llevaba a la atipicidad porque el sujeto pasivo no la sentiría como tal.

\section{La libertad de ejecución de la voluntad o libertad de voluntad conforme a motivos propios}

La doctrina y jurisprudencia unánimemente consideran que el impedimento del ejercicio de la voluntad constituye una forma de violencia y, por ende, un delito de coacciones cuando por el contexto y la organización del delito existe una intensa gravedad contra la libertad de obrar del sujeto. Sin embargo, también una amenaza puede ya no sólo determinar la decisión, sino producir tal intranquilidad en el sujeto de forma tal que se vea abocado a no tomar decisiones. Aquí la imposibilidad de tomar decisiones se constituiría en tal intensidad que afectaría ya no a la libertad del sujeto, sino a la capacidad de tomar decisiones, o a tomarlas en el sentido amenazante, de manera que cuando se produzca tal intensidad, estaremos en el campo de las coacciones.

En este punto, puede destacarse la postura de HRUSCHKA que defiende que el bien jurídico protegido en el delito de coacciones es la libertad de acción, no específicamente «la libertad de decisión de la voluntad y la libertad de realización de la voluntad». Razona su conclusión con base al parágrafo $240 \mathrm{StGB}^{1382}$. Este razonamiento hace comprensible que fueran criminalizadas originariamente las formas de violencia como el homicidio y las lesiones, y muy posteriormente, la libertad de acción individual. Por eso el delito de coacciones -para HRUSCHKA- precisa aún de mayor depuración ${ }^{1383}$ para contemplar en su tipo las otras diversas formas de ataque.

Con esta explicación estamos de acuerdo. Efectivamente el delito de coacciones precisa de mayor depuración para incluir todas las posibles formas de ataque a la libertad, salvo si formulamos la delimitación entre ambos tipos (coacciones y amenazas) desde una observación puramente funcional y mediante la distinción entre capacidad (horizonte de expectativas) y libertad (producto del horizonte). Con esta distinción podemos ubicar los ataques a la capacidad y formación de la voluntad y a la capacidad de decidir en el delito de coacciones y los ataques a la libertad de decidir consciente en el delito de amenazas.

\footnotetext{
1382 Señala que «(s)i fuera atacada la libertad de formación de la voluntad, entonces no sería coaccionado el afectado a realizar, permitir u omitir, más bien se aplicaría contra él lisa y llanamente violencia, lo que por sí solo es punible de conformidad con los tipos penales respectivamente competentes en particular», HRUSCHKA, J., «La coacción en el sistema del Derecho penal», HRUSCHKA, J., Imputación objetiva en Derecho penal, op. cit., p. 212. También a favor de ubicar el delito de coacciones como ataque a la libertad de obrar, CERVELLÓ DonDERIS, V., El delito de coacciones, op. cit., p. 21; MIRA BENAVENT, Javier, «El concepto de violencia en el delito de coacciones», CPC, 22, 1984, pp. 123 y ss.

${ }^{1383}$ HrusCHKA, J., «La coacción en el sistema del Derecho penal», op. cit., p. 213.
} 


\section{Menosprecio a la voluntad}

Con el «menosprecio a la voluntad» la doctrina se ha referido a aquellas situaciones en las que el sujeto activo ignora la voluntad del sujeto pasivo, haciéndole permanecer, por ejemplo, en el domicilio, o en casos en los que se revelan secretos ${ }^{1384}$

Algunos tratadistas - como VIADA ${ }^{1385}$ - consideraron que el concepto de violencia, propio del delito de coacciones puede también dirigirse contra la moral, o sea, como violencia moral. En este sentido, RODRÍGUEZ DEVESA ${ }^{1386}$ aclaró que el concepto de violencia, que proviene del CP de 1848 en su art. 410, era una referencia a los medios de comisión que ya designó el art. 664 del $\mathrm{CP}$ de 1822. De aquí que la violencia moral resulta también de los ataques a los sentimientos asociados a postulados morales, que también pueden ser condicionados gravemente de manera que el sujeto sufra tal presión que le incapacite en la formación de la voluntad, en la capacidad de elección, y en la dirección de la voluntad, pero en otras ocasiones también a la libertad de decisión cuando el sujeto sigue contando con el mismo horizonte de alternativas antes de la amenaza, si bien se añade ésta de forma que condicionante. De modo que la violencia moral se refiere a otra de las muchas formas de realizar la coacción o la amenaza, pero no determina en qué delito se ubica.

De aquí que podamos concluir también que los medios de la comisión no fundamenten enteramente la distinción entre coacciones y amenazas, sino el efecto en el sujeto: en su capacidad natural, capacidad de formación, decisión y ejecución de expectativas, y la libertad de decisión, por eso ha de analizarse la intensidad y el efecto del ataque para distinguir entre las consecuencias jurídico-penales.

D. Los elementos objetivos del tipo: la violencia/vis absoluta, la intimidación/vis compulsiva

En la concepción clásica, decimos supra, que el concepto normativo «violencia» se concebía como «fuerza físico-mecánica» (vis corporis corpori afflicta), sin embargo, la evolución

\footnotetext{
${ }^{1384}$ RODRÍGUEZ DEVESA JMa / JASO ROLdÁn T / RODRÍGUEZ MUÑOZ JA., PE, op. cit., p. 299; RODRÍGUEZ DEVESA JM ${ }^{\mathrm{a}}$ / SERRANo GómEZ A., PE, op. cit., pp. 321 y ss; BAJo FERnÁndeZ M / DíAZ-MAROTO Y VILLAREJO J., Manual de Derecho Penal, Parte especial, Delito contra la libertad y seguridad, libertad sexual, honor y estado civil, op. cit., p. 6.

${ }^{1385}$ Vid. RODRÍGUEZ DEVESA JMa / JASO ROLDÁN T / RODRÍGUEZ MUÑOZ JA., PE, op. cit., p. 302 (VIADA Y VILASECA, Salvador, Código penal reformado de 1870, concordado y comentado, $4^{\mathrm{a}}$ ed., Madrid, 1890, pp. 424 y Ss.).

${ }^{1386}$ ID., ibidem, op. cit., p. 302; RODRÍGUEZ DEVESA JMa / SERRANO GÓMEZ A., PE, op. cit., pp. 322 y ss.
} 
doctrinal ${ }^{1387}$ ha girado en cuanto a ampliar el concepto de violencia más allá de lo estrictamente físico o material.

Fue en primer lugar BINDING ${ }^{1388}$ quien con mayor fervor mantuvo que la violencia sólo podía ser entendida como vis absoluta, contra la capacidad de formación de la voluntad, y únicamente ésta aparece en el delito de coacciones, por lo que renegó de la idea de la que vis compulsiva (intimidación) se incluyera en el delito de coacciones, sino en el delito de amenazas. También WELzEL, entre otros, consideró que basta que el sujeto sienta la coacción indirectamente. La doctrina española ${ }^{1389}$ también refrendó esta teoría iniciada por la formulación de BINDING. Otros, en cambio, se desvincularon de esta conclusión y opinaban que el concepto normativo de fuerza debía entenderse como efecto de la coacción ${ }^{1390}$.

El criterio de la violencia como desarrollo de la fuerza ya ha sido superado gracias, en gran parte, a que se comenzó a concebir la vis compulsiva o intimidación y la fuerza en las cosas o vis in rebus, dentro del concepto de violencia, pero también por mor de la aparición de nuevas formas de violencia, que puede ser introducidas en tal concepto normativo, y que no son en nada formas de fuerza física, tales como la hipnosis, el suministro de narcóticos y otras sustancias o la violencia por omisión.

La doctrina dominante en Alemania consideraba que la producción de miedo, o sea, vis compulsiva, en el sujeto pasivo, podía ser entendida como violencia para el tipo de coacciones, a diferencia de parte de la doctrina española ${ }^{1391}$. Así, parte de la doctrina considera que el elemento

\footnotetext{
1387 Ampliamente HigUERA GUIMERÁ, JF., El delito de coacciones, op. cit., p. 90 y 91.

1388 BINDING, K., Lehrbuch des gemeinen deutschen Strafrechts, Besonderer Teil, I, reimp. $2^{\text {a }}$ ed. Leipzig, 1902, 1969 , pp. 83 y ss.

${ }^{1389}$ RODRÍGUEZ DEVESA JMa / JASO ROLdÁN T / RODRÍGUEZ MuÑOZ JA., PE, op. cit., p. 298; RoDRÍGUEZ
} Devesa JM / SERrano GómeZ A., PE, op. cit., pp. 286 y ss; MIR PUIG, S., «El delito de coacciones en el Código penal», op. cit., pp. 280 a 284; HIGUERA GUIMERÁ, JF., El delito de coacciones, op. cit., p. 90, diferencia la violencia en el tipo de coacciones y en el de amenazas, concluyendo que la violencia en la libertad de decisión de la voluntad, o en los motivos, debe introducirse en el campo de las amenazas, mientras que la violencia en la capacidad de la voluntad (vis absoluta), o en la ejecución de la voluntad, es una violencia coactiva, y por tanto integrada en el tipo de coacciones.

${ }^{1390}$ KNODEL afirmaba que violencia es «todo proceder destinado y adecuado a superar la resistencia efectiva o esperada del coaccionado, que le imposibilite sin su consentimiento la formación o actuación de su voluntad o le arrebate su libertad de decisión infligiéndole un mal de cierta gravedad», KNODEL, Klaus Dieter, Der Begriff der Gewalt im Strafrecht, München, Berlin, 1962, p. 59 (vid. HigUERA GuIMERÁ, JF., El delito de coacciones, op. cit., p. 102, vid. también MIR PUIG, S., «El delito de coacciones en el Código penal», op. cit., p. 276, nota 26).

${ }^{1391}$ Por ejemplo HIGUERA GUIMERÁ considera en armonía a su postura sobre el concepto de violencia, que al no sentir el sujeto pasivo un miedo físico, no existe repercusión en el cuerpo. Por ello afirma que «(l)a amenaza se distingue de la violencia porque en la primera se actúa a través de la mente - del psiquismo-, y la violencia actúa sobre el cuerpo, que en el caso de la «vis compulsiva» puede llevar a una situación psíquica de coacción. En la amenaza esta situación psíquica de coacción se produce directamente sin intervención del cuerpo, por lo tanto siempre que se actúe directamente sobre la mente (psiquismo), existe amenaza y no violenta», HIGUERA GUIMERÁ, JF., El delito de coacciones, op. cit., p. 118 y 119; similarmente BAJO FERNÁNDEZ M / DÍAZ-MAROTO Y VILLAREJO J., Manual de Derecho Penal, Parte especial, Delito contra la libertad y seguridad, libertad sexual, honor y estado civil, op. cit., p. 122; MIR PUIG, S. «El delito de coacciones en el Código penal», op. cit., p. 284; TORÍO LÓPEZ, A., 
diferenciador de la violencia o intimidación coactiva y el tipo de amenazas es la temporalidad del mal, más lejano en relación al bien jurídico que se protege en el delito de amenazas: la libertad de elegir los motivos y estímulos de una decisión ${ }^{1392}$. El eje central del tipo de coacciones gira, entonces, en torno al efecto de la coacción, y no en cuanto al medio empleado para la coacción, por tanto habrá que determinar si el resultado material posee una entidad suficiente en la capacidad de libertad de la voluntad.

En tal sentido, la violencia tiene dos alternativas o efectos en la libertad de voluntad. En primer lugar la violencia puede ser vis absoluta en el sentido de dominación del sujeto activo en un abanico de posibilidades (Gewalt als Zwangslage ${ }^{1393}$, como impedimento en la capacidad o formación de la voluntad, en la capacidad de decisión, o también en su último estadio, como impedimento en la ejecución de la capacidad, mientras que si la violencia se ejerce sobre el intelecto del sujeto pasivo, afectando a la voluntad, estamos ante un impedimento ejercido sobre los motivos de la voluntad, lo que se denomina vis compulsiva, no queda impedida la capacidad de voluntad, ni la ejecución de ésta, sino que la voluntad se ve afectada en su dirección por lo motivos previamente afectados, lo que produce una dirección de la voluntad ajena a la dirección sin afección a los motivos. A esto nos hemos referido con la afección a la libertad de decisión, propiamente de las amenazas, por lo que cuando se restringe la capacidad de decisión en cuanto restricción del horizonte de expectativas estaremos en el campo de las coacciones.

Al respecto, HRUSCHKA explica que la vis absoluta referida a la necessitudo simplex seu absoluta, como fuerza física que repercute en el sujeto para que actúe u omita sin «volición», excluye la imputación ordinaria de primer nivel, aquella referida a la imputación del hecho ${ }^{1394}$, mientras que la necessitudo cum adjunctione se refiere a los casos de necesidad justificante y exculpante, en las que el sujeto tiene una «elección», tiene voluntad pero no obra «voluntariamente» ${ }^{1395}$, de aquí que la vis compulsiva se refiera a ésta última ${ }^{1396}$. De esta manera

«La estructura típica del delito de coacción», Homenaje al profesor Emilio Gómez Orbaneja, Ed. Moneda y Crédito, Madrid, 1977, p. 403.

${ }^{1392}$ Así Bajo Fernández M / DíAZ-Maroto Y Villarejo J., Manual de Derecho Penal, Parte especial, Delito contra la libertad y seguridad, libertad sexual, honor y estado civil, op. cit., p. 135.

${ }^{1393}$ En tal sentido es interesante la apreciación de KNODEL, que entendía que la fuerza o violencia se refiere al poder de dominación del sujeto activo, es decir, posesión de poder (statischen Sinn) la fuerza o violencia como situación o estaticidad o estado, para explicar la violencia y su efecto en el propio empleo, vid. HIGUERA GUIMERÁ, JF., El delito de coacciones, op. cit., pp. 95 y 102. Explica KNODEL que también se puede entender la violencia como fuerza dinámica, o ejecución de un poder, es decir, el poder de dirigir la voluntad ajena en uno u otro sentido, o como situación forzosa (Gewalt als Zwangslage), como sumisión de la voluntad por el poder de tercero, y abanico de posibilidades que se puede ejercer sobre la voluntad de tercero, vid. HIGUERA GUIMERÁ, JF., El delito de coacciones, op. cit., p. 95.

${ }^{1394}$ HrusChKA, J., «La coacción en el sistema de Derecho penal», op. cit., p. 200.

1395 ID., ibidem, op. cit., p. 201. Sobre la distinción y relevancia jurídica de los conceptos de «volición» y «voluntariamente», SÁNCHEZ-OSTIZ explica que la «volición» designa el acto de la voluntad por un objeto sin 
la vis absoluta encuentra acomodo en los casos de autoría directa, mientras que la vis compulsiva encuentra su inclusión estructural en la autoría mediata, por eso concluye que «(l)os conceptos de «coacción», «estado de necesidad exculpante» y «autoría mediata» pertenecen a un mismo nivel» 1397 .

En este sentido, cabe concordar con HRUSCHKA, porque efectivamente entre vis absoluta y vis compulsiva media tal grado de libertad que afecta a la estructura de la imputación. En este sentido, la incapacidad natural de obrar u omitir, pero también la incapacidad de formar un horizonte de expectativas se comprende como vis absoluta, de modo que la imputación del causante se configura como autoría directa. Mientras que la restricción del horizonte de expectativa, al caracterizarse por un margen mínimo de expectativas normativas y sociales, se adecúe mejor como vis compulsiva coactiva, cuyo efecto será la autoría del sujeto, si bien dicha restricción puede fundamentar el estado de necesidad exculpante.

Así también -en nuestra opinión- nada impide que una vis absoluta pueda ser tratada también como delito autónomo de coacciones cuando se crea una adicción comportamental que como segundo resultado de una persuasión coercitiva (restricción del horizonte de alternativas) produce una lesión psíquica (eliminación del horizonte de alternativas), y después, se aprovecha dicha situación para cometer otro delito contra el mismo sujeto o contra otro (autoría directa o mediata). Sin embargo, en la causación de una persuasión coercitiva la intensidad de la coacción se refiere a la restricción del horizonte de alternativas, de aquí que exista capacidad de elección, si bien limitada, de tal punto que el sujeto, según los casos, sufre un déficit de socialización que constituye un delito de coacciones sin el extremo de la lesión psicológica, y cuya participación posterior en un delito a causa de dicha restricción de alternativas, pueda tratarse como una autoría.

Las anteriores conclusiones han de ponerse en relación con las alcanzadas previamente por JAKOBS. Ya comentamos supra que la consumación de los tipos especiales ha de comprenderse en relación con la parte general pero también en cuanto a su afección. Esto es porque el derecho de la persona a no ser desorientado de su libre organización se lesiona por completo cuando se le desorienta. Esta desorientación ya es una vis absoluta y, ocasionalmente, vis compulsiva ${ }^{1398}$. Esto significa que todo ataque a la libertad de organización supone el quebrantamiento de la vigencia

\footnotetext{
incluirse en dicha valoración el motivo, mientras que por en «voluntariedad» se incluye el sentido moral del hecho (bueno/malo, justo/injusto), SÁNCHEZ-Ostiz, Pablo, La libertad del Derecho penal. Estudios sobre la doctrina de la imputación, Atelier, 2014, p. 37, y pp. 192 y ss.

1396 HRUSCHKA, J., «La coacción en el sistema de Derecho penal», op. cit., p. 203.

1397 ID., ibidem, op. cit., pp. 205 y 206.

1398 JAKOBS, G., «Consumación material en los delitos contra la persona. Al mismo tiempo, una contribución a la generalización de la parte especial», op. cit., p. 11 y nota 37.
} 
de la norma, que generalmente se imputa como delito de coacciones o amenazas, y tras el efecto producido, se consuma otro delito por la pérdida de un derecho «ulterior», salvo reacciones arbitrarias de la víctima ${ }^{1399}$. Esto se ve claramente en la relación de los delitos de posesión, coacciones y delitos contra las personas generalmente con otro tipo de delitos, o dicho con otras palabras, de la trascendencia de la desorientación. De aquí se deduce que -como recuerda JAKOBS- el delito de coacciones «es el delito general de todos los delitos contra la persona», y habrá que convenir que «un delito contra la persona está consumado tan pronto como otro organiza aquello que se ha asignado al propietario -entendido en sentido amplio- para ser organizado. Las consecuencias de cómo se ajusta la organización, o sea, la pérdida de oportunidades que podían utilizarse y, mucho menos, la pérdida de oportunidades que de otro modo podían utilizarse racionalmente, no importan» ${ }^{1400}$. De este modo concluye que «(l)a solución de la ley de exigir más que la desorientación y la pérdida de libertad para la consumación, y exigir para la estafa una disposición perjudicial y respecto de las coacciones una conducta coaccionada, se ajusta a este diagnóstico: en la conducta de la víctima se pone de manifiesto la importancia del ataque a la orientación y la libertad, formulado de otro modo: se pone de manifiesto si se producen consecuencias desagradables y respecto de quién se producen (y, a diferencia de lo que ocurre con los «delitos de posesión», esto supone que no son prácticamente todos los que resultan lesionados en su derecho)» ${ }^{1401}$. Esto no ha de entenderse en relación al ámbito interno sino que la coacción ha de determinarse normativamente ${ }^{1402}$. En muchos casos, independientemente de que el efecto coactivo pueda definirse como violencia, falta un comportamiento obtenido por coacción, basta ver el ejemplo que expone JAKOBS ${ }^{1403}$ sobre que alguien ocupa una plaza de aparcamiento para llegar a esta conclusión (coerciones cotidianas: deber de soportar) ${ }^{1404}$, por eso la diferencia entre vis absoluta y vis compulsiva es poco productiva en la cuestión de la determinación del delito de coacciones, esto es porque también el sujeto que sufre un incendio tiene que pagar la deuda se ve imposibilitado para seguir yendo al teatro ${ }^{1405}$, sino que hay que atender a la «dimensión jurídica» ${ }^{1406}$ de la persona en su

1399 ID., ibidem, op. cit., pp. 17 y 18.

1400 ID., ibidem, op. cit., p. 7.

1401 ID., ibidem, op. cit., p. 12.

1402 JAKOBS, G., «Coacciones por medio de violencia», op. cit., p. 448, nota 31.

1403 ID., ibidem, op. cit., p. 446.

${ }^{1404}$ Así «(1)a intensidad del efecto coactivo es —al menos de acuerdo con esta formulación- un criterio demasiado naturalista (...) sensoriales tales como lucha, fuerza, cuerpo, significando la expresión cuerpo: vida, integridad física, libertad», ID., ibidem, op. cit., pp. 447 y 448.

${ }^{1405}$ ID., ibidem, op. cit., p. 449, nota 33.

1406 ID., ibidem, op. cit., p. 450. 
libertad de organización en el contexto concreto del derecho perjudicado, es decir, si existe garantía de esa vertiente del derecho a no ser lesionado con violencia.

De estas conclusiones podemos completar la aquí mantenida. Si el tipo especial de las coacciones exige una afección puesta en relación con la garantía de un derecho de la víctima, se excluye la elección de la alternativa ${ }^{1407}$, el delito se consuma. Entonces, tanto la vis absoluta que ejerce la adicción comportamental como el déficit de socialización en tanto vis compulsiva, defrauda esa libertad de orientación del sujeto, si bien la trascendencia, su instrumentalización o delito-fin perseguido por el autor puede absorber la coacción en otro injusto o forma de participación, o quedarse en este quebrantamiento, pero esta es otra cuestión que atiende a la parte subjetiva del hecho, pero ha de adelantarse que no es entendible que se exija habitualmente un dolo específico, como sin que éste no existiera la posibilidad de coaccionar.

\section{E. Otras formas de violencia: violencia sobre terceros, por omisión y mediante medios}

indirectos o engaños

Respeto a la violencia sobre terceros, en el ámbito sectario criminal no es difícil imaginar coacciones a familiares de adeptos para que dejen de hacer, o actúen en otro u otro sentido, en beneficio del grupo. La violencia sobre terceros se ejercita en un agente denominado trasmisor. Es el medio coactivo para doblegar la voluntad del sujeto al que se dirige. Este último debe tener una relación humana de cierta entidad con el sujeto o agente trasmisor, o -como parte de doctrina alemana consideraba (SCHWARZ / DREHER, FRANK ${ }^{1408}$ )- que exista entre ambos además de una estrecha relación, una capacidad de influir del tercero sobre el sujeto al que dirige la coacción. Esta consideración nos parece la más adecuada desde un plano abstracto de la violencia, pues a pesar de existir una relación de confianza o estrecha relación, debe existir, al menos, susceptibilidad de influir en la voluntad.

Por eso, no será tampoco difícil imaginar que se puede tratar como una coacción las técnicas de persuasión coercitiva como violencia sobre tercero, referida a una relación de confianza o estrecha relación con otro. Sirva de ejemplo la dinámica grupal de sujetos persuadidos, quienes a su vez, por dicho comportamiento grupal, aportan un elemento relevante en la persuasión de un nuevo adepto, ya sea a modo de orden implícita, obediencia a la autoridad o reafirmación del aislamiento socio-cultural, del tal modo que propicia el déficit de socialización de sujeto.

\footnotetext{
1407 JAKOBS, G., «Consumación material en los delitos contra la persona. Al mismo tiempo, una contribución a la generalización de la parte especial», op. cit., p. 13.

${ }^{1408}$ Vid. Higuera GUIMERÁ, JF., El delito de coacciones, op. cit., p. 122.
} 
De otra parte, la doctrina alemana mayoritaria ${ }^{1409}$, desde hace décadas mantiene la posibilidad de coaccionar mediante omisión. BLEI pone el siguiente ejemplo que parece probar la posibilidad de una comisión omisiva: «A, no abre la puerta del piso a su mujer B, y la obliga de esta forma a pernoctar fuera en un almacén frío; con ello espera conseguir su consentimiento para el divorcio» ${ }^{1410}$. SCHÄFER acepta también esta posibilidad, pero va más allá aceptando la coacción por omisión mediante la utilización de una coacción de tipo psicológico, como el hambre o la sed. Y en la doctrina española, HigUERA GUIMERÁ ${ }^{1411}$ se pronunció en el sentido de que «la omisión sólo puede considerarse como violencia cuando es sentida por el sujeto pasivo y además hace imposible socialmente que realice su voluntad».

Fundamentalmente para apreciar una coacción por omisión, además de darse los elementos comunes de la omisión típica (producción de una lesión o riesgo inminente para el bien jurídico de la libertad de la voluntad, la no realización de una acción que hubiera evitado el resultado, es decir, equiparación de la omisión con la acción, con conocimiento de la situación de peligro, o posibilidad de conocimiento y poder de evitación) ha de existir un deber de protección o salvamento, esto es, «deberes de garantía» ${ }^{1412}$ por el sujeto activo, en el modo descrito en el capítulo tercero, lo que nos lleva a concluir que es posible la coacción por omisión, sobre todo, y en nuestro caso, en aquellas situaciones en las que exista una relación de especial confianza, o comunidad de vida, especial relación de lealtad que afecte a la capacidad y libertad de voluntad.

Por último, es opinión dominante excluir del delito de coacciones los medios indirectos y los engaños porque no representan violencia alguna ${ }^{1413}$, si bien contienen suficiente gravedad, o porque entraría en los supuestos de dominio del hecho en la autoría mediata bajo engaños, que fundamentó RoxIN ${ }^{1414}$. Sin embargo, con los postulados a los que hemos llegado previamente, no resultara ilógico concluir que los medios indirectos, los engaños o el ardid puedan ser -como refiere JAKOBS- una forma de violencia («pseudo-fuerza», cuando se hace creer que cualquier resistencia no tiene sentido) o al menos semejante a la violencia en función del contexto y del deber de veracidad, cuando «el sentido objetivo de una información sólo puede tener como base

1409 Vid. ID., ibidem, op. cit., p. 159.

${ }^{1410}$ Vid. ID., ibidem, op. cit., p. 160.

1411 ID., ibidem, op. cit., p. 161. También admiten la coacción por omisión, CuELlo Calón, E., Derecho penal, Parte Especial, T. II, op. cit., p. 809; DíAZ PALOS, F., «Coacción», Nueva Enciclopedia Jurídica Seix, T. VI, 1954, p. 215; Bajo Fernández M / DíAZ-Maroto Y Villarejo J., Manual de Derecho Penal, Parte especial, Delito contra la libertad y seguridad, libertad sexual, honor y estado civil, op. cit., p. 120, por ejemplo, no abrir la puerta de la vivienda, no suministrar alimentos hasta que el enfermo nombre heredero.

1412 JAKOBS, G., «Coacciones por medio de violencia», op. cit., p. 453.

1413 MIR PUIG, S., «El delito de coacciones en el Código penal», op. cit., p. 279.

1414 RoXIN, C., Autoría y dominio del hecho, op. cit., pp. 194 y ss. 
su veracidad», lo que genera en ocasiones un «derecho a la verdad» ${ }^{1415}$. Volveremos sobre esto, en el capítulo séptimo, al objeto de distinguir entre engaños como dominio de la voluntad en la autoría mediata o como delito autónomo.

En conclusión, no pueden establecerse un numerus clausus de los supuestos o medios violentos. La violencia (vis absoluta y vis compulsiva coactiva) depende exclusivamente del efecto en la capacidad de libertad de voluntad. Por lo tanto, no depende del medio en sí mismo considerado, ni del tipo de objeto de ataque sobre el que se realice, lo que fundamenta la inclusión del engaño como medio coactivo, si bien no violento, pero con semejante gravedad de lo injusto, al igual que sucede en una posible modalidad de detención ilegal mediante engaños $^{1416}$.

\section{F. Conclusiones parciales: eliminación de alternativas como incapacidad de formación de}

la voluntad, y restricción de alternativas como incapacidad de formación de horizontes de expectativas y como incapacidad de decisión propia

La principal conclusión a la que podemos llegar es que el delito de coacciones criminaliza el ataque a la capacidad de libertad de voluntad en sus tres manifestaciones (formación, decisión, y ejecución). Puesto que se refiere a la capacidad, ésta puede constreñirse de forma consciente o inconsciente en el sujeto pasivo. Como indicábamos supra, la confusión entre las coacciones y las amenazas viene de que tradicionalmente se ha utilizado un criterio ontológico para describir toda restricción de la voluntad. Sin embargo, esta forma de explicación en la doctrina española se encuentra con el escollo de explicar cómo la afección a la decisión puede considerarse un delito de coacciones sin entrar en contradicción con la configuración de injusto de amenazas.

Nuestro planteamiento es puramente funcional. Se ha de distinguir entre la capacidad cognitiva y volitiva del sujeto pasivo, aquella que posee naturalmente, y entre capacidad de formación de un horizonte de expectativas y de elección con la posterior libertad de elección. Para tener capacidad, además de la puramente natural, cuestión que afecta del todo a la integridad psíquica, hay que observar qué alternativas/expectativas tiene el sujeto. Si el sujeto no tiene alternativas socialmente adecuadas al Sistema Social, esto puede ser por obra de un tercero que las ha eliminado. Aquí surge una incapacidad de formación de expectativas que a la postre causa la incapacidad de elección, y a lo que hemos denominado adicción comportamental, mientras que si se restringen las alternativas de modo que apenas existen expectativas conforme

\footnotetext{
1415 JAKOBS, G., «Coacciones por medio de violencia», op. cit., pp. 456 y 457; MEZGER también aludía a la «cualquier forma de violencia», MEZGER, E., Derecho Penal, Parte Especial, op. cit., p. 93.

${ }^{1416}$ Polaino Navarrete, M., El delito de detención ilegal, op. cit., p. 106.
} 
al Sistema, se produce una incapacidad de elección en tanto que al sujeto se le presentan tantas otras discordantes que difícilmente puede elegir la acorde al Sistema.

La libertad de decisión y su afección se refieren a la introducción en el horizonte de expectativas sociales de una disconforme y atentatoria contra los bienes del propio sujeto, de manera tan intensa que condiciona la elección. Por eso decíamos que si la intensidad era de tal magnitud que de forma directa condiciona en la elección no deseada, surgía también el delito de coacciones como vis compulsiva coactiva, en detrimento del delito de amenazas. En concreto, el adepto a una secta criminal al que se le ha sometido a procesos de persuasión coercitiva, tiene su capacidad de formar la voluntad de decisiones significativamente mermada por acción de las técnicas de persuasión, al restringirse el horizonte de expectativas ofrecidas por el Sistema normativo y social y al plantearse más alternativas adecuadas a la dinámica grupal: así las decisiones se adecúan a las del grupo. Esto es a lo que hemos denominado restricción de alternativas o restricción del horizonte de posibilidades que afecta a la capacidad de decidir conforme a la voluntad propia.

Sin embargo, la persuasión coercitiva no sólo ataca la formación de la decisión, sino de forma más íntima, a la capacidad misma de la formación de la voluntad en aquellos casos que especialmente se somete al sujeto a factores temporales de continuidad de los procesos restrictivos del horizonte de alternativas. Las técnicas de persuasión crean en su máxima gravedad un estado de dependencia, de adicción comportamental, que merman no sólo la libertad de la decisión, sino la misma capacidad de la voluntad, referida ésta a la eliminación de un mundo lleno de posibilidades y de expectativas sociales, de modo que únicamente se le presentan expectativas del grupo, con lo que el campo de elección se reduce de tal manera que el sujeto está orientado «ineludiblemente» a la elección de las expectativas del grupo. Este proceso es al que hemos denominado adicción comportamental que se crea tras una intensidad significativa del proceso de restricción de alternativas. No existen expectativas del Sistema normativo y social en tal intensidad del horizonte de expectativas que el grupo ha configurado.

Esto hace que la discrepancia conceptual entre violencia e intimidación (vis absoluta/vis compulsiva $)^{1417}$, como ataque a la libertad de actuar en general, desde nuestra formulación, sea del todo inoperante. La verdadera problemática del delito de coacciones es la concurrencia de un elemento propiamente perteneciente, por su naturaleza, al delito de amenazas, la «intimidación», entendida como ataque a la formación de la libre voluntad. En este sentido, la doctrina suele

\footnotetext{
${ }^{1417}$ Denuncia la falta de inclusión en el tipo del término «intimidación», de cuya falta procede las confusiones entre el delito de coacciones y el de amenazas, Blanco LozAno, C., vv.aa., Lecciones de Derecho Penal, Parte Especial, T. I, op. cit., p. 174.
} 
diferenciar atendiendo a si la intimidación al sujeto es lejana temporalmente, en cuyo caso pertenece al delito de amenazas, o si la intimidación ejerce un constreñimiento de libertad de la voluntad temporalmente cercano desde su manifestación, siendo entonces constitutiva de un delito de coacciones. De tal manera se evita la impunidad del constreñimiento mediante la amenaza de un mal inmediato («constreñimiento por intimidación»), de lo que resulta que el concepto de violencia debe incluir también el de intimidación ${ }^{1418}$. En definitiva no se trata de una cuestión delimitante entre violencia e intimidación, sino sobre el efecto que se produce en la capacidad de formar, decidir y ejecutar la voluntad, o en la libertad de decisión. El delito de coacciones gira en torno al efecto de la coacción relacionado con la garantía de un derecho, y no en cuanto al medio empleado para restringir la libertad de obrar. De tal modo habrá que determinar si la acción de persuasión coercitiva posee entidad suficiente para afectar a la libertad de la voluntad para ubicarlo como delito de coacciones.

Con lo anterior se puede concluir que tanto la afección a la capacidad de formar la voluntad como la afección al intelecto, y por ende a los motivos que hacen formarse el ejercicio de voluntad, son coacciones delictivas cuando el medio empleado es idóneo para tal resultado, no así cuando se condiciona el producto de la libertad (amenaza), o simplemente se aconseja, se asesora o se induce. De tal manera, puede aceptarse que las técnicas de persuasión coercitiva entran en el concepto de violencia del tipo de coacciones de mejor forma que en los arts. 522, 169 y ss., y arts. 173 y 174 del CP, sin embargo desde nuestra formulación, la persuasión coercitiva oscilará entre la vis absoluta y la vis compulsiva coactiva, así que el efecto que se produzca delimitará a la vez la consecuencia jurídico-penal en la autoría y participación en los delitos-fin.

Hemos visto que la vis absoluta incapacita al sujeto en su propia capacidad de voluntad, de este modo la vis absoluta tiene que referirse a la adicción comportamental, con los mismos efectos que la suministración de drogas o hipnosis o como lesión psíquica, cuya trascendencia es la autoría directa o la autoría mediata. Mientras que la persuasión coercitiva con efecto de vis compulsiva en la restricción del horizonte de expectativas, tiene la trascendencia de tratarse de autoría cuando el sujeto pasivo realiza un delito. Y estas conclusiones anticipadas tienen que compararse con otros medios violentos, como la hipnosis y los narcóticos, al objeto de comprobar si existen semejanzas tales que efectivamente nos permitan incluir la persuasión coercitiva en del delito de coacciones.

\footnotetext{
1418 RODRÍGUEZ DEVESA JM ${ }^{\mathrm{a}}$ / JASO ROLdÁN T / RODRÍGUEZ MUÑOZ JA., PE, op. cit., pp. 303 y 304 ; RodríGUEZ DEVESA JM / SERRANO GÓMEZ A., PE, op. cit., p. 287.
} 


\section{G. La violencia mediante anestesia, narcóticos, suero de la verdad o hipnosis \\ 1. Debate doctrinal}

La doctrina mayoritariamente ${ }^{1419}$ incluye el suministro de narcóticos y la hipnosis en el delito de coacciones como ataque a la capacidad de la voluntad, sin embargo si el ataque a dicha formación de la voluntad produce una incapacidad permanente se suele castigar como delito de lesiones ${ }^{1420}$. La administración de narcóticos como el «Evitan», «Eunarcon», «Éter» y la «Morfina», al alterar el organismo, ejercen una violencia que altera la libertad de la voluntad, inclusive hasta eliminar la capacidad de voluntad. El llamado «suero de la verdad», o drogas de la verdad, o de la confesión, también entrarían en el concepto de medio violento. De otra parte, la llamada violencia por hipnosis, considerada como «un estado mental de carácter anormal provocado por medio de la sugestión ${ }^{1421}$ o influencia psíquica, se admite generalmente por la doctrina como delito de coacciones. Sin embargo, algunos penalistas ${ }^{1422}$ se pronunciaron en contra, por la falta de incidencia en el cuerpo del sujeto pasivo.

La violencia por anestesia mediante un golpe, la llamada vis corporiaflicta, ha sido admitida ampliamente por la doctrina en el delito de coacciones, no así cuando la administración de narcóticos se realiza con violencia corporal. Algunos penalistas ${ }^{1423}$ opinan al respecto que la suministración de narcóticos sólo entraría en el tipo de coacciones cuando fueran suministrados con violencia, de aquí que descarten que se pueda -con violencia- realizar la hipnosis al ser un

1419 Vid. Alonso Herreros R / Muñiz CAlaz B / RAmos SuÁrez A / Rodríguez JA., «Actitud del ordenamiento español ante las sectas», op. cit., p. 52; vid. y de la misma opinión, BAJO FERNÁNDEZ M / DíAZMaroto Y Villarejo J., Manual de Derecho Penal, Parte especial, Delito contra la libertad y seguridad, libertad sexual, honor y estado civil, op. cit., pp. 119 y 120; BuSTOS RAMÍREZ, J., Manual de Derecho penal, Parte especial, op. cit., p. 101; DíAZ-Maroto Y Villarejo, J., vv.aa., Compendio de Derecho Penal, Parte especial, Vol. II, op. cit., p. 74; MIR PUIG, S., «El delito de coacciones en el Código penal», op. cit., pp. 277 y 278; MoRILLAS CUEVA, L., Los delitos contra la libertad religiosa, op. cit., p. 238; MuÑOZ Conde, F., Derecho Penal, Parte Especial, 15ª ed., op. cit., p. 157; RODRÍGUEZ DEVESA JMa / SERRANO GÓMEZ A., PE, op. cit., p. 286 ubicaban la hipnosis en el delito de coacciones porque ataca la capacidad de formación de la voluntad; en Alemania MEzGER, E., Derecho Penal, Parte Especial, op. cit., pp. 88; KNODEL afirmaba, con base a su concepción de violencia como efecto o resultado, que sólo puede considerarse a la hipnosis como violencia en el tipo de coacciones, cuando tenga la suficiente entidad, profundidad en la conciencia, y que por tanto anule por completo la formación de la voluntad, vid. HIGUERA GUIMERÁ, JF., El delito de coacciones, op. cit., p. 126.

${ }^{1420}$ RODRÍGUEZ DEVESA JMa / JASO ROLdÁN T / RodRíGUEZ MuÑoz JA., PE, op. cit., p. 298; RodríGUEZ DEVESA JM / SERRANO GÓMEZ A., PE, op. cit., p. 291.

${ }^{1421}$ Higuera GuIMERÁ, JF., El delito de coacciones, op. cit., p. 122, en referencia a FOREL, Auguste, «Der Hipnotismus und seine Strafrechliche Bedeutung», Zeitschrift für die gesamte Strafrechtswissenschaft, 9, p. 149.

${ }^{1422}$ HIGUERA GUIMERÁ afirma que «(n)o se da el concepto de violencia cuando se emplea la hipnosis, pues en este caso existe solamente sugestión», HIGUERA GUIMERÁ, JF., El delito de coacciones, op. cit., pp. 306; TORÍO consideraba que la consumación del delito de coacciones mediante el suministro de narcóticos o hipnosis no se produce aunque se ataque a la capacidad de la voluntad o a la formación de la decisión de voluntad, sino cuando se ataca la ejecución de la voluntad, TORÍO LóPEZ, A., «La estructura típica del delito de coacción», op. cit., p. 407.

${ }^{1423}$ CerVelló DONDERIS, V., El delito de coacciones, op. cit., p. 19; MIRA BenAVENT, J., «El concepto de violencia en el delito de coacciones», op. cit., pp. 127 y ss. 
mecanismo de sugestión, y al tratarse de un mecanismo anterior a la ejecución de las decisiones. No obstante, este planteamiento se ha ido abandonado poco a poco, al entenderse que al ser posible la coacción por medios técnicos también lo es mediante químicos ${ }^{1424}$.

Tal y como exponíamos supra, la problemática que nos interesa es si la persuasión coercitiva tiene semejanzas con la suministración de narcóticos o con la hipnosis, pues de tal modo, aceptada generalmente por la doctrina que ambas pertenecen a medios violentos del delito de coacciones, podremos aceptar que también la persuasión coercitiva se trataría de un medio violento. Sin embargo, como también decíamos, parte de la doctrina ${ }^{1425}$ incluye la hipnosis, suministro de drogas y otros procedimiento novedosos y más complejos como el tratamiento quirúrgico, la psicocirugía o la llamada terapia del dolor a base de impulsos eléctricos en el cerebro, dentro de la expresión «apremio ilegítimo» del art. 522 CP. Por eso, algún sector que ha estudiado con detalle la problemática de la especialidad de la dinámica criminal de las sectas considera que en la controvertida expresión «apremio ilegítimo» entraría toda «utilización de técnica de modificación del pensamiento que produzcan dependencia psíquica o control mental» $^{1426}$.

La jurisprudencia española delimitó, en su tiempo, un concepto demasiado estricto del concepto de violencia. No admitía como violencia el suministro de narcóticos o la hipnosis, sin embargo, contradictoriamente concebía en la violencia toda fuerza material. Asimismo también la jurisprudencia alemana del Reichsgericht ${ }^{1427}$ y del Tercer Reich ${ }^{1428}$ sostuvo que el suministro de narcóticos sólo podía entrar en el delito de coacciones si se suministraban con violencia, no así por ejemplo con la administración de la disolución del narcótico en un vaso. Sin embargo, desde hace algunos años, el Tribunal Supremo afirma que la hipnosis y uso de drogas susceptibles de producir sueño para la práctica hipnótica, sin el debido conocimiento del sujeto pasivo, acarrea un atentado contra la libertad tipificado en el delito de coacciones. En concreto,

${ }^{1424}$ Vid. HigUERA GUIMERÁ, JF., El delito de coacciones, op. cit., p. 124.

${ }^{1425}$ TAMARIT Sumalla, JM ${ }^{\mathrm{a}}$., «Las sectas y el Derecho penal», op. cit., pp. 283 y 285; acepta algunos de estos supuestos HigUERA GUIMERÁ, JF., El delito de coacciones, op. cit., pp. 123 a 129. Sin embargo, HigUERA GUIMERÁ reconoce que los casos de suministros de narcóticos o sugestiones hipnóticas, plantea problemas especiales «en que la víctima no se va dando cuenta de la presión que se ejerce sobre la misma, pues el proceso narcótico y las sugestiones hipnóticas tienen una duración indefinida. Así cuando se suministra algún narcótico a una persona, pero persiguiendo con ello en realidad que acuda a una importante cita de negocios, en estos casos, existe coacción porque el comportamiento del coaccionador no se mantiene dentro de la esfera del consentimiento del coaccionado», ID., ibidem, op. cit., p. 230.

${ }^{1426}$ JORDÁN VILLACAMPA, MáL., «Las sectas pseudorreligiosas», op. cit., p. 103; NAVAS RENEDO, B., Tratamiento jurídico de las sectas, op. cit., p. 293; según DEL RE, estos medios son métodos probados de manipulación, DEL RE, MC., «Modellamento psichico e diritto penale: tutela penale dell'integrità psichica», op. cit., pp. 174 a 180.

${ }_{1427}$ RG 56, pp. 87 y ss. vid. JAKOBS, G., «Coacciones por medio de violencia», op. cit., p. 442.

${ }^{1428}$ Vid. HigUERA GUIMERÁ, JF., El delito de coacciones, op. cit., pp. 123 y 124. 
la STS de 10 de octubre de $2005^{1429}$ afirma que la acreditación de una vis no sólo como la violencia física, sino también como coactiva o compulsiva, sobre la víctima mediante hipnosis o narcóticos (p. ej., neurolépticos y benzodiazepinas) supone un ataque a la voluntad del sujeto pasivo, pues los acusados, en éste caso, suministraban a la víctima medicamentos que la mantenían en estado de somnolencia y debilidad. En el mismo sentido se decanta lógicamente la jurisprudencia del TS en relación al «suero de la verdad» o el «narcoanálisis» aun a pesar de la voluntariedad del imputado como medio probatorio ${ }^{1430}$.

A nuestro entender, es perfectamente admisible la inclusión de la hipnosis, los narcóticos y otras sustancias en el concepto de violencia, pues el medio utilizado tiene incidencia ya en el primer estadio de la coacción, en la capacidad de la formación de la voluntad, por cuanto se restringe o elimina la capacidad cognitiva y volitiva natural, siendo irrelevante el modo con el que se consigue. Tal conclusión debe entenderse por una concepción amplia del término normativo de los medios que pueden causar violencia. Así las cosas, en coherencia con nuestros postulados explicados supra, la eliminación o restricción del horizonte de expectativas, de forma inconsciente por el sujeto pasivo, suponen otras formas de violencia, si bien graduada en vis absoluta y vis compulsiva. Esto se debe a la vulneración de las posibilidades de actuación conforme a las expectativas normativas y sociales sobre las que orienta el Sistema, de modo que tiene el mismo efecto que la anulación o disminución de la capacidad cognitiva y/o volitiva natural de las personas. Sin embargo, para un mejor análisis, se precisa comparar la hipnosis con la persuasión coercitiva, puesto que aquélla representa una sutil forma de modificación de la voluntad en la que el sujeto, en ocasiones, no es consciente de su aplicación, y de tal modo podremos concluir si la persuasión coercitiva, efectivamente, pertenece al concepto de violencia del delito de coacciones, al asemejarse normativamente con la hipnosis.

\section{2. ¿Los medios sofrológicos y la hipnosis como medios violentos?: la sugestión como} persuasión coercitiva violenta

En un brillante artículo, POLAINO-LORENTE y POLAINO NAVARRETE diferenciaron la hipnosis, los medios sofrológicos y la sugestión. Plantearon que existía una confusión conceptual pero a la vez científica entre los citados conceptos, que tenían diferentes tratamientos en el Derecho penal,

\footnotetext{
${ }^{1429}$ FJ $3^{\circ}$, de STS de 10 octubre de 2005, rec. 1252-2004, en donde se dice que «(d)e no ser así se crearían espacios de impunidad inasumibles, de forma que tan relevante para doblegar la voluntad es el empleo de la violencia física como de otros medios que producen el mismo efecto».

${ }^{1430}$ FJ $1^{\circ}$ STS, de 26 de noviembre de 1991.
} 
y que en nuestro estudio tiene especial trascendencia para el tratamiento jurídico de la persuasión coercitiva.

Polaino-Lorente y Polaino NAVARRete ${ }^{1431}$ consideran que en la hipnosis el sujeto sometido no tiene capacidad para la libertad de la voluntad. Esta conclusión se debe a que la hipnosis es «aquel estado medial de la conciencia que, provocado artificialmente, sitúa al sujeto entre la vigilia y el sueño, como un modo supuesto de estar-en-el-mundo de tal índole que la mayor parte de las sugerencias del hipnotizador son secundadas por la conducta del sujeto que a ellas se somete» ${ }^{1432}$.

Sin embargo, por medios sofrológicos se entiende la dominación de la voluntad ajena mediante ayuda del sometido, por lo que algunos consideran que no es más que un entrenamiento para la desconexión de la propia conciencia, ni existe voluntad ajena impuesta ni sometida como ocurre con la hipnosis. Con los medios sofrológicos se tienen grados de participación de la voluntad durante el desarrollo de la sesión, por cuanto la Sofrología -según RAGER- «se ocupa de las modificaciones y fenómenos de la conciencia humana obtenido por procedimientos psicológico, físicos y químicos» ${ }^{1433}$, mientras que la sugestión -según WEINTZENHOFFER- es el «proceso psicológico por el cual aceptamos una idea sin que haya ninguna razón lógica para hacerlo así. Es, pues, un proceso que permite aceptar sin crítica ideas. Se llama igualmente sugestión a la idea que se ofrece al sujeto para que la acepte de manera no crítica» $^{1434}$.

POLAINO-LORENTE y POLAINO NAVARRETE ${ }^{1435}$ delimitaron con gran precisión la hipnosis y los métodos sofrológicos en los siguientes criterios: la hipnosis supone la dependencia del sujeto en mayor medida que en la sofrología por cuanto, en esta última, el sujeto tiene una explicación sobre el método que se le va a aplicar, mientras que en la hipnosis, el sujeto desconoce el sometimiento y el grado; en la hipnosis el sujeto tiene sometida su propia voluntad, desconectada de la conciencia, mientras que con la sofrología la conciencia del sujeto se «espiritualiza» con el cuerpo; la conciencia sofrónica supone su autocontrol cuando aprende la propia técnica, mientras

\footnotetext{
1431 Polaino-Lorente A / Polaino NAVARRETE M., «Dimensiones Psicológico-Psiquiátrica y Jurídico-Penal en el ejercicio de la sofrología», op. cit., pp. 11 y ss.

${ }^{1432}$ ID., ibidem, op. cit., p. 7.

1433 Vid. ID., ibidem, op. cit., p. 9 (RAGER, GR., Hipnosis, Sofrología y Medicina, Ed. Scientia, Barcelona, 1973, p. 141).

${ }^{1434}$ Vid. ID., ibidem, op. cit., p. 8 (WEINTZENHOFFER, A., Hynose et suggestion, Payot, 1905).

1435 ID., ibidem, op. cit., pp. 11 a 21. En el mismo sentido HIGUERA GUIMERÁ opina que «la sofrología no necesita del presupuesto de la voluntad libre del sujeto desde el principio hasta el fin», por lo que «el empleo de los medios sofrológicos no está comprendido en el concepto de violencia, pues en la sofrología es preciso contar con la voluntad ajena; sin ella prácticamente se hace imposible el éxito del plan sofrológico», HiGUERA GUIMERÁ, JF., El delito de coacciones, op. cit., p. 126.
} 
que en la hipnosis la conciencia es reactiva y referencial por la mediatización del hipnotizador; la hipnosis causa la pasividad del sujeto pero en la sofrología precisa de la voluntad libre del sujeto en el inicio y final del proceso y con una clara finalidad; en la hipnosis la conciencia se disocia provocando resultados en algunas ocasiones «inconscientes, histéricos o mágicos-primitivos» que estaban ocultos o formaban parte del pasado, mientras que en la sofrología el sujeto no pierde la conciencia totalmente, sino que se centraliza en el objeto al que se le guía con la aceptación voluntaria y consciente, pudiendo abandonar la terapia en cualquier momento a diferencia de la hipnosis.

No obstante, los métodos sofrológicos también entrañan el peligro de ser usados de manera tal que ocasionen daños al sujeto, o que empleados desorbitadamente, anulen o disminuyan la voluntad, pero a diferencia de los resultados de la hipnosis, no parece posible la instrucción en fines delictivos. En la hipnosis es posible teóricamente una orden delictiva pero sólo en los casos en los que no se contradice la voluntad propia, es decir, el sujeto hipnotizado no perpetrará un delito en contra de su ser moral ${ }^{1436}$. Sin embargo, esta coincidencia en la tendencia tiene que ser aclarada para determinar la responsabilidad penal.

Ambas técnicas, hipnosis y sofrología, sólo coinciden en la exigencia de titulación profesional. Se requiere una titulación médica ${ }^{1437}$ por cuanto que en ambas existen riesgos de lesiones psicológicas, o de que afloren o se agraven. Con dicha titulación su práctica es atípica $^{1438}$, pero la experiencia demuestra que suelen practicarse sin titulación, por lo que pueden considerarse delitos de intrusismo profesional cuando no ya delitos contra la integridad psíquica.

La relevancia penal de la aplicación de tales técnicas tiene repercusiones en el concepto normativo de voluntariedad de la acción como casos de falta de acción humana (sonambulismo, estados de sueño por embriaguez y estados crepusculares hipnóticos), o en aquellos en los que puede existe cierta acción humana, aunque sea primitiva, que lleve más bien a casos de inimputabilidad por trastorno mental ${ }^{1439}$.

Dicho esto, parece claro que la hipnosis y la sugestión hipnóticas, también los simples casos de sugestión prolongada según las circunstancias, son reconducibles a los casos de persuasión coercitiva, inclusive en aquellos adeptos que consciente y voluntariamente se someten a técnicas

\footnotetext{
1436 POLAINO-LORENTE y POLAINO NAVARRETE comentan que «esto no se efectuará, al ser más fuerte estos efectos que las ideas sugeridas. Únicamente podemos admitir el delito si las tendencias del sujeto coinciden con la idea criminal sugerida, o cuando el individuo se vale o quiere la sugestión hipnótica para ejecutar el acto delictivo», Polaino-Lorente A / Polaino NAVARRete M., «Dimensiones Psicológico-Psiquiátrica y Jurídico-Penal en el ejercicio de la sofrología», op. cit., p. 24.

${ }^{1437}$ En el mismo sentido ID., ibidem, op. cit., p. 26.

1438 ID., ibidem, op. cit., p. 39.

1439 En este sentido ID., ibidem, op. cit., p. 33.
} 
psicológicas y fisiológicas de meditación, pero sin embargo no conocen el fin perseguido: ¿quién se somete voluntaria y conscientemente a que otros le dominen? Las técnicas psicológicas y fisiológicas de persuasión constituyen una intromisión ilegítima en la capacidad de libre voluntad y en la dignidad, aun a pesar de un hipotético consentimiento del sujeto, porque, en definitiva, la capacidad y la libertad de voluntad son bienes irrenunciables de la persona cuando afecta de manera esencial a su contenido.

3. Relevancia jurídico-penal de la voluntariedad de la acción e injusto de la hipnosis, sofrología y de la persuasión coercitiva en la autoría y participación

Ya desde hace décadas se ha convenido en afirmar que la acción humana en el Derecho penal no es simplemente naturalística o finalística, sino normativa, o sea, atribuible a la responsabilidad/libertad del «querer humano», de la «voluntad subjetiva» manifestada externamente $^{1440}$. En el caso de la hipnosis, sofrología, sugestiones - tal y como exponen POLAINO-LORENTE y POLAINO NAVARRETE ${ }^{1441}$ - y por ende incluyo por mi parte también en la persuasión coercitiva, la problemática estriba, no tanto en la presencia de la voluntad del sujeto pasivo, sino en el grado en que se manifiesta/representa dicha voluntad.

En concreto, POLAINO NAVARRETE ${ }^{1442}$ aclara la noción de voluntariedad en la acción penal. Partiendo de las consideraciones de GROIZARD sobre la voluntariedad y abundando en el alcance dogmático de la misma, afirma que la voluntariedad de la acción, como momento del querer, comprende el dolo y la culpa por medio del carácter psicológico de ambos. Entiende que voluntariedad es, entonces, la capacidad de conducta personal, puesto que «la acción en sentido penal puede entenderse como una singular forma de comportamiento humano que se caracteriza por la capacidad de voluntad de actuación consustancial al ser racional, referida a un concreto acaecimiento que refleja externamente la personalidad del hombre, con independencia de la concurrencia o no de la libertad de voluntad personal, integrante de una problemática trascendente fuera del ámbito de la conducta», de tal forma que «(l)a acción no constituye en Derecho penal manifestación de la voluntad libre del sujeto humano, sino sólo una realización exterior por un ser humano en cuanto tal dotado de capacidad de voluntad reveladora de su personalidad» ${ }^{1443}$.

${ }^{1440}$ ID., ibidem, op. cit., pp. 42 y 43 .

${ }^{1441}$ ID., ibidem, op. cit., p. 43.

${ }^{1442}$ Polaino NaVArRete, M., La voluntariedad de las acciones punibles, Sevilla, 1979, pp. 50 a 58.

${ }^{1443}$ Polaino-Lorente A / Polaino NAVARRete M., «Dimensiones Psicológico-Psiquiátrica y Jurídico-Penal en el ejercicio de la sofrología», op. cit., p. 43. 
No ha de sorprender entonces que POLAINO-LORENTE y POLAINO NAVARRETE ${ }^{1444}$ concluyan que en la hipnosis, en la falta la voluntad libre manifestada externamente, falta también la acción humana por lo que ya no cabe plantearse la inimputabilidad/culpabilidad del sujeto al no poder atribuirse la acción al sujeto, cuya trascendencia será la autoría directa del hipnotizador por falta de acción humana, y en casos excepcionales, la autoría mediata, cuando medie la voluntad del hipnotizado como instrumento no doloso de comisión («irrelevante»), y cuando actúe como instrumento doloso: «aun no suponiendo la consciencia y la voluntad humana del hipnotizado, determina una no exigibilidad en la conducta del sujeto cuya voluntad -dominada por el impulso psicológico del hipnotizador- carece de la eficacia humana suficiente para poder resistir (...) deber ser equiparado (...) la intervención del instrumento no doloso de comisión que proclama la responsabilidad del hipnotizador bajo el concepto de autor mediato» ${ }^{1445}$. No así en la práctica sofrónica, donde existe la participación bilateral de ambos, y por ende, se podría apreciar la culpabilidad y el sofronizado podrá ser responsable penalmente por las reglas generales, si bien el sofrólogo podrá asumir la modalidad del inductor. En la culpabilidad del hipnotizador y sofrólogo pueden concurrir circunstancias agravantes relacionadas con el abuso de la confianza cuando se exceda de los límites propios de tratamiento médico. No obstante, ambos autores resaltan la especialidad de la autoría principal del sujeto que luego resulta hipnotizado a fin de cometer el delito propuesto por un hipnotizador, a la vez inducido por el primero a la dinámica del episodio hipnótico con fines delictivos, que se podrá reconducir a las actiones liberae in causa.

En conclusión, si trasladamos estas argumentaciones a la persuasión coercitiva, donde el sujeto interviene con conciencia y voluntad pero no sobre sus efectos desocializantes, se produce una restricción del horizonte de expectativas (vis compulsiva coactiva) que hace que la problemática igualmente se pueda trasladar a la culpabilidad, y así a casos de autoría mediata en cadena o simultánea o a la coautoría en el delito-fin, que análogamente al caso expuesto supra se podrán reconducir a problemáticas de actio libera in causa. Por el contrario, en aquellos casos en los que el sujeto interviene pero cuyo efecto es la eliminación del horizonte de expectativas (vis absoluta), se pueden reconducir a casos de autoría directa, al faltar la acción humana propiamente dicha.

\footnotetext{
${ }^{1444}$ ID., ibidem, op. cit., pp. 43 a 52.

1445 ID., ibidem, op. cit., p. 51.
} 


\section{Conclusiones: la persuasión coercitiva como violencia en el delito de coacciones}

Hemos visto que mayoritariamente se considera por la doctrina y la jurisprudencia penal que la aparición de nuevas formas de violencia como la hipnosis, los narcóticos y otras sustancias, e inclusive la violencia por omisión, pueden ser introducidas en el delito de coacciones como formas de violencia. Cabe preguntarse si las técnicas de persuasión psicológica y fisiológica pertenecen a estas formas de violencia, y por ende, al delito de coacciones.

TAMARIT SUMALla entre otros ${ }^{1446}$ considera que estas técnicas no entrarían en el tipo de coacciones porque este delito no protege la capacidad de la voluntad. La violencia del tipo no se refiere a estas técnicas, ni a la hipnosis, ni a los narcóticos y a otras sustancias. Opinamos que la persuasión coercitiva es una forma de violencia del tipo de las coacciones, por cuanto se elimina o se restringe el horizonte de posibilidades y expectativas, siendo irrelevante el modo con el que se consigue, por la amplísima gama de técnicas existentes para eliminar o reducir el abanico de posibilidades de elección. La analogía con la hipnosis y narcóticos es clara, en cuanto que producen la ausencia de acción humana ${ }^{1447}$, o cuando existe cierto margen de capacidad de libertad, producen la inimputabilidad o semi-imputabilidad del sujeto, consecuencias jurídicopenales que también se aprecian en la persuasión coercitiva. En la persuasión coercitiva la capacidad cognitiva y volitiva natural, si bien queda intacta, se presenta inoperativa por el escaso horizonte de posibilidades de elección, o dicho de otro modo, las posibilidades y expectativas que se le presentan al sujeto en un momento determinado son exclusivamente las del grupo, secta u organización, cuando no una gama de expectativas enteramente criminales. De aquí que la adicción comportamental se refiera a la incapacidad volitiva en relación a la eliminación del horizonte de expectativas adecuadas a las del Sistema, contando sólo con las ofrecidas por el grupo, de modo que pueda asociarse a una lesión psíquica.

1446 TAMARIT SumAlla, JMa ., La libertad de ideológica, op. cit., pp. 242 y 243; en el mismo sentido FONT BOIX, I., «Propuesta de despenalización radical en la legislación española de los medios de control o de alteración de la personalidad en relación con las llamadas sectas», op. cit., p. 105; también similarmente MARTíN SÁNCHEZ considera que estas técnicas no pueden englobarse en el delito de coacciones, porque el bien jurídico que se tutela no es la libertad en general, sino exclusivamente la de obrar o ejecutar lo decidido, ni cubre todas las posibilidades delictivas que atentan contra la formación de la conciencia más allá de los ataques violentos o intimidatorios. Su negativa, como puede verse, parte de concebir el delito de coacciones como un delito contra la ejecución externa y final de la voluntad, y por conceptos demasiados restrictivos de violencia, lo cual, según lo dicho, es impreciso porque utiliza concepciones anquilosadas en la dogmática tradicional. Si bien estamos de acuerdo en que las técnicas -como indica el referido autor-vulneran la capacidad de decidir (en nuestra opinión por restricción de las expectativas), ello no es ápice para desterrar de este tipo las conductas y técnicas descritas, MARTíN SÁNCHEZ, I., El Derecho a la formación de la conciencia, op. cit., pp. 146 a 148; y también CERVELLó DONDERIS, V., El delito de coacciones, op. cit., p. 34.

1447 Polaino-LORENTE A / Polaino NAVARRETE M., «Dimensiones Psicológico-Psiquiátrica y Jurídico-Penal en el ejercicio de la sofrología», op. cit., pp. 43 y 44. 
Por ende, como decíamos, lo que realmente tiene relevancia penal en el delito de coacciones, no es tanto el medio que se emplea para restringirla libertad, sino el efecto de la violencia en la libertad, aunque lógicamente hay medios más idóneos y potencialmente más peligrosos para restringir la libertad, pero esto sólo supone un mayor o menor desvalor de la acción dentro de la gravedad del resultado que supone la restricción de la libertad. Sin embargo, en relación a las técnicas de persuasión coercitiva, la irrenunciabilidad de la dignidad/voluntad impide su aplicación aun cuando el sujeto se someta voluntariamente. A este respecto, puede concluirse que los sujetos que entran a formar parte de una secta criminal que utiliza este tipo de técnicas desconocen del fin y el trasfondo de su aplicación, aun cuando, a grosso modo, conozcan y quieran vivir conforme a otros sentimientos religiosos o de conciencia que oferta el grupo.

Dicho esto, la problemática que surge es si deben incluirse estás técnicas, ya sea la hipnosis, la suministración de drogas y las técnicas de persuasión en el delito de proselitismo ilícito dentro de la expresión «cualquier apremio ilegítimo». Precisamente la especialidad del delito de proselitismo ilícito, en cuanto que el autor persigue que un sujeto profese o actúe conforme a los principios de una confesión, o abandone la suya propia, hace finalmente que concluyamos que cuando sea ese el fin perseguido se impute al autor el delito de proselitismo ilícito, mientras que cuando el fin sea otro, o el fin sea restringir la libertad de actuar en general, no hay impedimento alguno para apreciar el delito de coacciones.

Las sectas coercitivas no pretenden únicamente que sus adeptos profesen un credo o visión cosmológica, sino también que actúen generalmente conforme a la voluntad grupal, a la voluntad del páter, del líder, precisamente como medio para perpetrar otros delitos, lo que hace que el ataque a la libertad de conciencia que protege el delito de proselitismo ilícito sea, más que un medio (delito medial), una consecuencia del quebrantamiento de la libre voluntad de actuar en general, que haga que las técnicas de persuasión se amolden mejor al delito de coacciones,y esto porque el sujeto ya no sólo ve modificada su libertad de conciencia, sino más especialmente, más ampliamente, su libertad de obrar en general. Puede parecer que esto vulnera la regla genérica del concurso de leyes, pero lo que podríamos llamar concurso de elementos objetivos en el delito hace que para evitar problemáticas y discusiones sea más adecuado incluir las técnicas de persuasión en los conceptos (elementos objetivos del delito) más amplios, es decir, en el concepto de violencia que ataca la libertad de actuar en general. 


\section{H. El tipo subjetivo en el delito de coacciones y en la persuasión coercitiva}

Ya hace tiempo BINDING ${ }^{1448}$ reparó en la necesidad de establecer un elemento finalista en el tipo de acción del tipo de coacciones. Posteriormente parte de la doctrina alemana requirió en el elemento subjetivo del injusto la concurrencia de un deseo manifiesto de violar la libertad ajena, lo que parece producir que el delito de coacciones es exclusivamente doloso. En la doctrina española hasta los años setenta no se reconoció mayoritariamente que existía un elemento subjetivo del injusto en el aludido tipo legal. POLAINO NAVARRETE ${ }^{1449}$ se refirió a este delito como aquel que precisa de «determinados medios de manifestación», concretamente, medios de violencia bajo una específica finalidad del sujeto activo. Sin embargo, HigUERA GUIMERÁ ${ }^{1450}$, entre otros, sostiene que «al no requerirse otra finalidad que el constreñimiento mismo, no cabe hablar en rigor de que en el tipo se contenga expresamente un especial elemento subjetivo de lo injusto», y que «el concepto de violencia, y los verbos que se emplean en el tipo del artículo 496 del CP -impedir o compeler- están «coloreados»o presentan un matiz anímico-subjetivista (...) El concepto de violencia encierra una necesaria dimensión finalista», que al menos justifica la exigencia de un elemento subjetivo del injusto ${ }^{1451}$.

La jurisprudencia española reconoce que el delito de coacciones exige el denominado «dolo específico». En la STS de 6 de noviembre de 1967, se requiere el «elemento intencional que caracteriza a este delito». Ya la STS de 15 de octubre de 1970 comienza a hablar de un «proceder malicioso» ${ }^{1452}$. Más recientemente, la STS $1019 / 04^{1453}$ requiere un elemento subjetivo del injusto en el delito de coacciones, determinado por la finalidad de atentar contra la libertad como ánimo tendencial de restringir la libertad ajena. Si bien la mayoría de la doctrina considera que no se exige un singular elemento subjetivo del injusto, así MIR PUIG ${ }^{1454}$, quien afirma que únicamente se exige el dolo directo, pero no el dolo directo de segundo grado o eventual, y esto es porque la violencia ya recoge ese ánimo («dimensión finalística») de completar el tipo, y dicho

1448 BINDING, K., Lehrbuch, I, op. cit., pp. 82 y ss;

1449 Polaino Navarrete, M., Los elementos subjetivos del injusto en el Código penal español, Anales de la Universidad hispalense, Publicaciones de la Universidad de Sevilla, Serie Derecho, núm. 13, Sevilla, 1972, pp. 166 a 172; CUEllo CALÓN consideraba que al tener el delito de coacciones un elemento subjetivo de lo injusto se consumará cuando, además de doblegarse la voluntad ajena, se materialicen los fines perseguidos, CuELLO CALón, E., Derecho penal, Parte Especial, T. II, op. cit., p. 813.

${ }^{1450}$ HigUera GuIMERÁ, JF., El delito de coacciones, op. cit., p. 169.

${ }^{1451}$ ID., ibidem, op. cit., p. 173. No admite DEL RoSAL BLASCO ningún elemento subjetivo del injusto distinto al dolo, Del Rosal Blasco, B., vv.aa., Derecho penal español, Parte especial, op. cit., p. 211.

${ }_{1452} \mathrm{Vid}$. Higuera GuIMERÁ, JF., El delito de coacciones, op. cit., pp. 171 y 172.

1453 También al respecto la STS, de 10 octubre de 2005, rec. 1252-2004.

${ }^{1454}$ MIR PUIG, S., «El delito de coacciones en el Código penal», op. cit., pp. 290 a 294; BAJO FERNÁNDEZ M / Díaz-Maroto Y Villarejo J., Manual de Derecho Penal, Parte especial, Delito contra la libertad y seguridad, libertad sexual, honor y estado civil, op. cit., p, 125; DíAZ-MAROTO Y VILlareJO, J., vv.aa., Compendio de Derecho Penal, Parte especial, Vol. II, op. cit., p. 81. 
razonamiento le lleva a admitir que es posible la imprudencia punible ${ }^{1455}$ respecto del tipo negativo (causa de justificación) y en el error de prohibición (teoría de los elementos negativos del tipo), si en ambos casos es vencible.

En nuestra opinión, al tratarse de un delito de resultado, si bien no descarta la especialidad de la consumación permanente, que en ambos casos faculta la posibilidad de la tentativa, se precisa la exigencia de un elemento subjetivo en el sentido expuesto por POLAINO NAVARRETE: la finalidad de restringir la voluntad, un plus que va más allá del dolo, indicando que, de lo contrario, la diferenciación con conductas limítrofes a la imprudencia se haría prácticamente imposible, cuestión que también recuerda de manera similar JAKOBS ${ }^{1456}$. Este planteamiento no impide la tipificación de lege ferenda de las coacciones imprudentes graves, como la persuasión coercitiva realizada imprudentemente en culpa consciente, según los postulados que hemos venido manteniendo, de lo que deviene que en la persuasión coercitiva se requiera ese plus de coaccionar, mientras que en los casos que falte, reconducirlo de lege ferenda a la culpa consciente punible. Sin embargo, como expondremos infra, existen convincentes argumentos a favor de la modalidad imprudente del delito de coacciones, que haría innecesaria su tipificación de lege ferenda, salvo por cuestiones de graduación de la penalidad enmarcadas también en las necesidades normativas en el ámbito de la especialidad de la persuasión coercitiva.

\section{I. ¿Concurrencia de agravantes en las coacciones por persuasión coercitiva?}

No es difícil imaginar que puedan concurrir agravantes genéricas y específicas o accidentales en las conductas de aquellos sujetos que ejercitan una persuasión coercitiva. Sin embargo, si fuere así el caso, se nos plantea la duda de si estas circunstancias agravantes ya están contenidas en el concepto de violencia y en la dinámica criminal de la persuasión coercitiva, y en su caso, si convergen o se excluyen entre sí. Esta consideración tiene especial importancia a la hora de tratar posteriormente los posibles concursos con otras figuras como en los delitos contra la vida, las estafas, contra la salud y contra la libertad e indemnidad sexual y las agravantes específicas que en éstos se refieren.

1455 MIR PUIG, S., «El delito de coacciones en el Código penal», op. cit., p. 294.

1456 JAKOBS comenta que «en una sociedad anónima de personas libres, en el caso básico debería tipificarse el hecho sin referencia a los planes del autor. Si se hace tal cosa, al concepto de coacción no pertenece ningún ánimo de coaccionar, sino que basta toda ausencia de consideración frente a la libertad ajena. Por ejemplo, cuando un autor deposita sin autorización materiales en la entrada de una estación y algunos pasajeros no pueden salir del edificio, se les está privando típicamente de su libertad, - y cuando otros no pueden entrar, ¿acaso no están coaccionados si falta una referencia a la intención? Considerado al revés resulta lo siguiente: ¿Por qué deben añadirse siempre unas coacciones a otro delito contra la persona cuando el autor perseguía una determinada conducta de la víctima?», JAKOBS, G., «Consumación material en los delitos contra la persona. Al mismo tiempo, una contribución a la generalización de la parte especial», op. cit., p. 16. 
Por otro lado, surge la problemática de la naturaleza de las agravantes. No existe un consenso unánime sobre la naturaleza jurídica de las agravantes genéricas, pues para sectores doctrinales la naturaleza dogmática de las agravantes sólo puede ser el aumento del injusto penal del hecho, y no el aumento de la culpabilidad como consideran algunos otros, o por un criterio mixto que defiende POLAINO NAVARRETE ${ }^{1457}$ y que nosotros también seguimos, por cuanto el mayor desvalor de la acción y/o del resultado conlleva siempre una mayor quebrantamiento normativo por razón de la culpabilidad del autor. Todo ello no excluye que las circunstancias puedan ser objetivas y/o subjetivas ${ }^{1458}$.

Por la peligrosidad del hecho, en cuanto a la facilidad de comisión por los medios y procedimientos utilizados, encontramos la alevosía en el art. 22.1. ${ }^{\circ} \mathrm{CP}$. La alevosía es un procedimiento que desvalora los medios, los modos o formas en la comisión delictiva. La aplicación de esta agravante no debe sólo ser entendida en relación a delitos contra personas estrictamente, sino que, como bien apunta POLAINO NAVARRETE, comprende «todos los delitos que atenten contra bienes jurídicos personales, con independencia de la ubicación sistemática de los mismos en el cuerpo punitivo» ${ }^{1459}$, lo que permite su apreciación en del delito de coacciones cometido por medio de persuasión coercitiva, en delitos de agresiones a adeptos, abusos sexuales a niños, e incluso podríamos aplicar la agravante en situaciones de inferioridad psicológica del sujeto que pone menor resistencia en la aplicación de técnicas de manipulación o persuasión coercitiva, o cuando el consentimiento está viciado por dicha alevosía, o cuando al sujeto se le «ordena», sugiere o induce a suicidarse (asesinato).

Otras de las circunstancias agravantes que denotan mayor peligrosidad por la facilitación en la comisión, pero no tanto por los medios utilizados como por la posición del sujeto activo respecto del sujeto pasivo, es el abuso de superioridad del art. $22.2^{\mathrm{a}} \mathrm{CP}$, el abuso de confianza del art. 22.6 y el abuso del carácter público que tiene el sujeto activo del art. $22.7^{\mathrm{a}}$ del CP.

El abuso de superioridad se basa en la desigualdad de fuerzas entre los sujetos, buscada especialmente por edad, ascendencia moral, superioridad jerárquica o el rol social que se represente. Se podría decir que la alevosía es el género y el abuso de superioridad la especie. En este abuso concurre un especial conocimiento del sujeto activo en la comisión del delito, pero que más allá de la forma en la que se comete, radica en su conocimiento especial y en la

\footnotetext{
1457 Polaino Navarrete, M., Lecciones de Derecho penal, Parte General, T. II, op. cit., p. 202.

1458 ID., ibidem, op. cit., p. 203

1459 ID., ibidem, op. cit., p. 203.
} 
utilización de aquellas circunstancias que le benefician ${ }^{1460}$. No resultará ilógico concluir que la superioridad moral o jerárquica del rol de un líder, miembros activos o conjuntos de miembros de una secta criminal concurra en la dinámica de la persuasión coercitiva.

La circunstancia de abuso de confianza precisa de un vínculo de confianza especial o «interpersonal», ya sea expreso o tácito, con intención de aprovecharse de ese vínculo, y siendo indiferente el origen de esta relación de confiabilidad ${ }^{1461}$. El abuso de la confianza también puede apreciarse en diversas conductas perjudiciales realizadas por miembros de sectas coercitivas contra sus propios y lógicos intereses.

La última de las circunstancias agravantes por la especial peligrosidad basada en la posición del sujeto activo del respecto del pasivo es la de «prevalerse del carácter público que tenga el culpable». Esta circunstancia tiene tres requisitos de vital importancia: la cualidad de funcionario público o la de tener encargo público el culpable, el abuso de las facultades que le proporciona tal estatus, y la finalidad de utilizar estas facultades para ejecutar el delito con mayor probabilidad de éxito y con menos riesgo en ser apresado. Esta circunstancia agravante podría aplicarse en líderes religiosos si efectuamos una interpretación extensiva del concepto de autoridad, pero en verdad ya la recoge la agravante de abuso de superioridad, porque la superioridad jerárquica inherente al carácter en algún sentido público del autor que fundamenta la agravante se reproduce, acaso con mayor intensidad, en el funcionamiento sistémico del grupo sectario.

Por último, en cuanto a las circunstancias objetivas que aumentan la gravedad de lo injusto del hecho, otra de las circunstancias que pueden concurrir es el ensañamiento, pero no porque suponga una mayor peligrosidad, sino un ataque más intenso. El ensañamiento es entonces una circunstancia que aumenta la gravedad de lo injusto del hecho realizado porque supone una mayor materialización de la lesión, que se considera como innecesaria para la realización material del delito, además de expresar un auténtico desprecio a la condición humana y a su naturaleza. No es humano aumentar el dolor de la víctima. Esta circunstancia parece difícil apreciarla en la dinámica persuasiva salvo casos aislados (torturas).

Por otro lado, entre las circunstancias agravantes estrictamente subjetivas, de una parte el fundamento de la agravante de precio, recompensa y promesa es la especial perversión moral del sujeto que agrava el reproche de culpabilidad normativa por el desvalor que suponen «móviles

\footnotetext{
${ }^{1460}$ MIR PUIG, S., PG, op. cit., p. 648 en el caso de un forzudo que no puede evitar su fuerza, no se aprecia esta agravante porque el abuso no se buscó ex profeso.

${ }^{1461}$ Polaino Navarrete, M., Lecciones de Derecho penal, Parte General, T. II, op. cit., p. 207.
} 
abyectos» y deja inalterado el injusto típico ${ }^{1462}$. Esta agravante quedaría consumida en el tipo de estafa en su caso, salvo que se realice la persuasión con exclusivos fines lucrativos cuando el autor fuera retribuido en el simple ejercicio. De otra, la circunstancia de obrar impulsado por motivos discriminatorios subyace de «móviles abyectos» de la ejecución del delito lo que incrementa el reproche de culpabilidad ${ }^{1463}$, si bien esta agravante establece supuestos genéricos o hipotéticos que dejan abierta la puerta a otras modalidades discriminatorias, denota un deseo de crear y establecer, aunque sea temporalmente, una desigualdad indigna en las personas. La discriminación puede ser de cualquier clase, diversos motivos que establecen una especie de numerus apertus. La discriminación puede venir de menospreciar a un ciudadano en particular, simplemente por ser tal, o puede partir de un simple odio hacia una clase, raza o ideología distinta, pero también puede nacer de discriminaciones menos conocidas pero con igual fundamento: el odio. Entonces, tampoco parece concurrir esta agravante salvo raros casos en los que un grupo religioso ataque precisamente a otro por motivos religiosos o similares, y amén de que hemos concluido que la persuasión coercitiva entraría en el tipo agravado de coacciones al atacarse un derecho fundamental.

Visto lo anterior y en relación a las conclusiones alcanzadas en el capítulo cuarto, la dinámica criminal habitual de las sectas coercitivas recoge varias figuras agravantes. Por un lado, es la persuasión coercitiva como dijimos un ataque más grave y peligroso para la libertad de la voluntad y la integridad psíquica, de modo que aumenta significativamente la probabilidad del resultado coactivo y lesivo a la vez que disminuye las posibilidades de defensa de la víctima, lo que en definitiva encaja en los presupuestos de la alevosía. Por otro lado, la condición de autoridad (religiosa) del líder y la superioridad numérica del grupo de adeptos que sigue y condiciona la dinámica comportamental grupal crea una superioridad ante la nueva víctima que encaja en la agravante de abuso de superioridad que facilita específicamente el resultado de la persuasión coercitiva como la disminución de defensa de la víctima. Y por último, diferentes modalidades de persuasión, como el bombardeo de amor, la apariencia de cualidades especiales del líder y del grupo y su dinámica excluyente del entorno social, propician una garantía que genera confianza que encaja en la agravante de abuso de confianza.

Las restantes agravantes son meramente casuales en la fenomenología criminal. Por ejemplo, en nuestra opinión, no vemos posibilidad de aplicar la agravante de especial vulnerabilidad de la víctima porque precisamente ésta pertenece al resultado de la persuasión y/o de la lesión

1462 ID., ibidem, op. cit., p. 206.

1463 ID., ibidem, op. cit., p. 206. 
psicológica, y esto porque como se dijo, apenas existen casos en que se aproveche una previa enfermedad o vulnerabilidad especial, sino factores como las carencias sociales de la víctima, traumas, que no pueden comprenderse como especiales sino como circunstancias que facilitan la persuasión, pero no pueden en principio calificarse de especiales. La pérdida de familiares, amigos, del trabajo, etc... si bien condiciona nuestro ánimo no pueden catalogarse de especiales sino como factores que facilitan la persuasión.

Como decíamos, de aquí parte otro problema. Puesto que hemos concluido que pueden apreciarse persuasiones coercitivas imprudentes y que con una interpretación más allá de lege ferenda, sino estrictamente normativa, se pueden criminalizar coacciones imprudentes, la pregunta que deviene es si pueden aplicarse las agravantes concurrentes en la modalidad imprudente. La naturaleza mixta (objetiva y subjetiva) de la alevosía, abuso de superioridad y de abuso de confianza parece impedir en una solución de lege data de su aplicación, sin embargo si partimos de la base expuesta de que la modalidad imprudente se fundamenta en la desatención de un deber de no dañar y en su caso de no crear situaciones que dañen cuando previamente existe competencia de salvamento o de aseguramiento (comisión por omisión), se puede concluir que dicho deber o competencia también existe en la creación de situaciones alevosas, de superioridad y de especial confianza.

Así las cosas, la concurrencia general de estas circunstancias en la fenomenología criminal consolidan la necesidad de un nuevo tipo específico de persuasión coercitiva al objeto de evitar impunidades y reflejar en su justa medida en la penalidad la gravedad del hecho y la culpabilidad.

\section{J. Delimitación y similitudes del delito de coacciones como persuasión coercitiva con el delito de detención ilegal}

\section{Delimitación doctrinal}

El delito de detención ilegal es una forma específica contra la libertad, en este caso contra el bien jurídico de la libertad personal de movimiento pero entendida en sentido pluridimensional (ambulatoria, traslaticia y locomotriz o cibernética) ${ }^{1464}$, y en sí mismo un delito de coacciones por cuanto ataca inherentemente la libertad de voluntad ${ }^{1465}$ que, sin embargo, está tipificado

\footnotetext{
${ }^{1464}$ Polaino Navarrete, M., vv.aa., Lecciones de Derecho Penal, Parte Especial, T. I, op. cit., p. 147; ID., El delito de detención ilegal, op. cit., pp. 73 y ss. y pp. 99 y ss.

1465 Polaino NaVARrete, M., El delito de detención ilegal, op. cit., p. 76.
} 
separadamente al protegerse especialmente la libertad de movimientos o ambulatoria ${ }^{1466}$, o la libertad para abandonar un determinado lugar, como ya mantuvo BINDING ${ }^{1467}$ en contra de otros que consideraban que la detención ilegal era el impedimento de moverse o determinarse libremente en un lugar, incurriéndose, a nuestro modo de ver, en una confusión con el delito de coacciones (sin perjuicio de que el art. 163.1 CP también criminaliza la acción del que «encerrare», pero en nuestra opinión la diferencia estriba en que con esta acción se limita el sentido de la clausura espacial) ${ }^{1468}$.

POLAINO NAVARRETE analizó el elemento típico normativo «acto de detener» ${ }^{1469}$ desde las teorías que lo han interpretado (teoría de la privación del movimiento actual; de la privación del movimiento futuro; de la escasez de bienes; de la adecuación social; y de la privación del movimiento humano») y ninguna de ellas, en nuestra opinión, a pesar de poder ejecutarse mediante medios psíquicos ${ }^{1470}$, responden a la acción de manipular, persuadir o sugestionar coercitivamente, por cuanto dicho «acto de detener», como bien apunta el penalista en referencia, tiene la relación típica ocasional de la vinculación con la privación de libertad de «movimiento» o «locomotriz», que exige la concurrencia incidental de ambos momentos de acción «convergentes en una momentánea coincidencia» ${ }^{1471}$, lo que apoya la idea de que el delito de coacciones es el tipo básico y el delito de detención la especie, como afirma parte de la doctrina y la jurisprudencia ${ }^{1472}$, y que a diferencia del delito de coacciones puede perpetrarse instantáneamente pero también puede ser susceptible de permanencia (mantenimiento

\footnotetext{
1466 Bajo Fernández M / Díaz-Maroto Y Villarejo J., Manual de Derecho Penal, Parte especial, Delito contra la libertad y seguridad, libertad sexual, honor y estado civil, op. cit., p. 10; CÓRDOBA RODA, «El delito de detenciones ilegales en el Código penal español», ADPCP, 1964, p. 390 y ss.

1467 BINDING, K., Lehrbuch, I, p. 99.

1468 Como bien apunta POLAINO NAVARRETE en este caso, «(l)o determinante es introducir a alguien en un espacio en el que el mismo no se ha insertado de propio grado y del que normalmente no puede salir por sus propios medios», Polaino Navarrete, M., vv.aa., Lecciones de Derecho Penal, Parte Especial, T. I, op. cit., p. 144; ID., El delito de detención ilegal, op. cit., pp. 120 y ss.

1469 Polaino Navarrete, M., vv.aa., Lecciones de Derecho Penal, Parte Especial, T. I, op. cit., pp. 144 y 145 ; ID., El delito de detención ilegal, op. cit., p. 77 y pp. 123 y ss.

${ }^{1470}$ Polaino NaVArRete, M., El delito de detención ilegal, op. cit., pp. 124 y 125.

1471 Polaino Navarrete, M., vv.aa., Lecciones de Derecho Penal, Parte Especial, T. I, op. cit., p. 145; POLAINO NAVARrete, M., El delito de detención ilegal, op. cit., pp. 99 y ss. y pp. 128 y ss.

1472 Polaino Navarrete, M., vv.aa., Lecciones de Derecho Penal, Parte Especial, T. I, op. cit., p. 145; ID., El delito de detención ilegal, op. cit., p. 76; para RODRíGUEZ DEVESA, el delito de detención ilegal es la especie del de coacciones, en tanto en cuanto es un ataque a la libertad de la voluntad en el sentido de libertad de movimientos, o ambulatorio, RodríGUEZ DEVESA JM / JASO ROLDÁN T / RODRÍGUEZ MUÑOZ JA., PE, op. cit., pp. 306 y 307 ; Rodríguez DEVESA JM / SERrANo Gómez A., PE, op. cit., pp. 306 a 309. La jurisprudencia española antes del Código penal de 1995 era vacilante en cuanto a la diferenciación de los dos tipos, precisamente porque el bien jurídico protegido es similar, la libertad. Más recientemente, la jurisprudencia del Tribunal Supremo se ha decantado por considerar que el delito de detención es la especie y el de coacciones el tipo básico: Sentencia del Tribunal Supremo núm. 823/04, que se ampara en la Sentencia del mismo Tribunal núm. 2/03.
} 
cronológico: «está siendo consumado» ${ }^{1473}$, o delito instantáneo de «eventual»o «relativa» permanencia ${ }^{1474}$ ), lo cual nuevamente diverge del delito de coacciones que se consuma por «regla general» con un resultado, si bien, hay que anticipar que también puede consumarse permanentemente en casos especiales como los de persuasión coercitiva, al no exigirse un resultado ciertamente material, y que fundamenta una mayor penalidad de lege ferenda en estos casos, cuestión que abordaremos infra.

No obstante, la jurisprudencia exige para la apreciación del delito de detenciones un lapso de tiempo que acredite ese ánimo de constreñir la libertad de movimientos (SSTS 12 y 4 de octubre de 1986 y 25 de enero de 1997) ${ }^{1475}$, lo cual diverge de otras SSTS, como por ejemplo la núm. 1511/2003, de 17 de noviembre ${ }^{1476}$, que declara la consumación desde el momento del encierro o la detención, lo que en verdad no es incompatible con otros métodos comisivos o circunstancias del caso, que precisen una mayor perduración para entender agotada la ejecución. Existe una línea jurisprudencial que aplica normalmente el tipo de coacciones porque su penalidad es menor que la del tipo de detenciones ilegales, por ello podríamos decir que tal línea jurisprudencial se basa en el principio in dubio pro reo ${ }^{1477}$.

Parte de la doctrina española ${ }^{1478}$ y parte de la jurisprudencia entienden que la privación de la capacidad ambulatoria de personas inconscientes, paralíticos, narcotizados puede incluirse en el delito de detención ilegal, no en el de coacciones, con lo que no podemos estar de acuerdo por los motivos expuestos, salvo que el fin sea exclusivamente la restricción de la libertad de abandonar un lugar o con el objetivo de facilitar el encierro.

En nuestra opinión el delito de detención ilegal se puede cometer por medio de dichas sustancias, con la aplicación de métodos hipnóticos, y en su caso, con la persuasión coercitiva, si bien se requerirá el fin de anular libertad de movimientos en la «perspectiva de acto como la de mera capacidad de decisión de ejercicio de esta facultad inherente a la racionalidad del ser

\footnotetext{
1473 Polaino NaVArRete, M., vv.aa., Lecciones de Derecho Penal, Parte Especial, T. I, op. cit., p. 146; ID., El delito de detención ilegal, op. cit., pp. 145 y ss.

1474 Polaino Navarrete, M., El delito de detención ilegal, op. cit., p. 148 y p. 199.

1475 Díaz-Maroto Y Villarejo, J., vv.aa., Compendio de Derecho Penal, Parte especial, Vol. II, op. cit., p. 41.

1476 Vid. Polaino Navarrete, M., vv.aa., Lecciones de Derecho Penal, Parte Especial, T. I, op. cit., p. 145.

1477 De otra opinión Higuera GuIMERÁ aprecia las siguientes diferencias entre el de detención y el de coacciones: «(m)ientras que las detenciones ilegales equivalen al atentado contra la libertad ambulatoria, las coacciones estriban en el ataque a la libertad considerada abstractamente (...) en tanto que las detenciones ilegales pueden ser efectuadas en virtud de la interposición de toda clase de medios, directos o indirectos, las coacciones requieren de la aplicación de violencia, ya sea material o psíquica». Y añade que «(e)sa mayor amplitud de los medios comisivos de las detenciones ilegales, impide considerar a las mismas como una simple especie de las coacciones, y a éstas como un tipo residual de aquéllas», HiGUERA GUIMERÁ, JF., El delito de coacciones, op. cit., p. 133. Similarmente MuÑoz CONDE, F., Derecho Penal, Parte Especial, $15^{\mathrm{a}}$ ed., op. cit., pp. 156 y ss.

1478 Muñoz Conde, F., Derecho Penal, Parte Especial, 15ª ed., p. 157; BAJO FERNÁndez M / DíAz-MAROTO Y Villarejo J., Manual de Derecho Penal, Parte especial, Delito contra la libertad y seguridad, libertad sexual, honor y estado civil, op. cit., p. 11.
} 
humano» ${ }^{1479}$, sin perjuicio, claro está, de otros fines concurrentes, condicionales o no, de modo que si falta ese elemento intencional de anular la libertad de movimientos, se reconduzca al delito de coacciones, aunque el empleo de la coacción o el engaño pueden servir, en ocasiones, para perpetrar la detención ilegal ${ }^{1480}$.

De otra parte, llama la atención que se criminalicen los actos preparatorios (provocación, conspiración y la proposición) para cometer el delito de detención ilegal en el art. 168 CP, y no en el tipo general de protección de la libertad como es el de coacciones.

Todo ello aplicado al ámbito de las sectas coercitivas nos lleva a concluir que si el suministro no consentido de drogas, la hipnosis o la persuasión coercitiva anulan de forma plena o parcialmente la libertad de voluntad, sin más motivo que restringir la libertad de actuar en general, se aplicaría el delito de coacciones. Rara vez las sectas coercitivas tendrán el propósito de realizar una detención ilegal, ésta es una consecuencia inherente a la dinámica de la coerción de la libertad de actuar en general. De aquí que pueda criticarse que en casos de persuasión coercitiva la pena del delito de coacciones sea claramente insuficiente en relación al desvalor de la acción y del resultado, lo que fundamenta de lege ferenda la creación de un tipo penal altamente penado, que englobe el grave desvalor similar a las detenciones ilegales o secuestro, agravados por la temporalidad y/o por las especiales circunstancias de la víctima, con una pena abstracta lo suficientemente amplia al objeto de modular todas las posibilidades del desvalor del hecho, con la inclusión del engaño que si bien no puede referirse al concepto de violencia, contiene semejante desvalor de injusto.

Téngase en cuenta que en el delito de coacciones y en el de detención ilegal se protege la libertad, por lo que en caso de atacarse además otro bien jurídico no perteneciente estrictamente a la libertad, podrá plantearse el concurso de delitos ${ }^{1481}$, por ejemplo, el delito de lesiones.

\section{Casuística}

La Sentencia de la Audiencia Provincial de Barcelona, de 16 de julio de 1990, condenó a los dirigentes de la secta CEIS, Centro esotérico de investigaciones, por el delito de intrusismo profesional por utilizar la apariencia de psicólogos y por la promoción y explotación de la prostitución. La Sentencia se refiere a las técnicas de captación y de control psicológico para integrar a las personas en la secta e inducirles a la prostitución.

\footnotetext{
1479 Polaino Navarrete, M., vv.aa., Lecciones de Derecho Penal, Parte Especial, T. I, op. cit., p. 144.

1480 Polaino NaVArRete, M., El delito de detención ilegal, op. cit., p. 106; DíAZ-MAROTO Y Villarejo, J., vv.aa., Compendio de Derecho Penal, Parte especial, Vol. II, op. cit., p. 44.

${ }^{1411}$ Higuera GUIMERÁ, JF., El delito de coacciones, op. cit., pp. 304 y 305.
} 
Varias de las personas que en la Sentencia condenatoria aparecían como «captadas» demandaron a España ante el TEDH por la privación de libertad que realizaron funcionarios policiales durante casi diez días cuando se estaba investigando este proceso. El Juez de instrucción autorizó a los funcionarios policiales a entregar a las víctimas de los delitos relativos de prostitución a los familiares respectivos, advirtiendo que los mayores de edad tenían plena libertad de decidir si continuar con ellos o no, advirtiendo nuevamente a las víctimas que sería recomendable que iniciaran un tratamiento médico psiquiátrico en virtud de los sucesos acaecidos y por el riesgo de suicidio que apreció el Juez, lo cual también motivó la orden de acompañamiento de las víctimas hasta sus familiares. Los funcionarios policiales ayudaron a miembros de los familiares y de un grupo anti-secta a custodiar las puertas de las habitaciones de un hotel, en donde se realizaron sesiones de desprogramación por miembros del grupo anti-secta en contra de la voluntad de las víctimas durante un periodo de aproximadamente diez días.

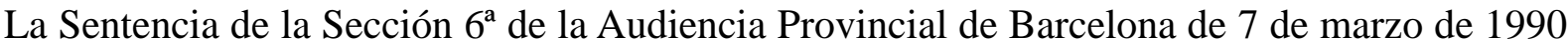
absolvió a los funcionarios policiales por apreciar que el móvil por el que actuaron fue «filantrópico, legítimo y bien intencionado, y no el de privar de su libertad a los querellantes» ${ }^{1482}$. Se presentó recurso de casación, que en Sentencia del TS de 23 de marzo de 1993, fue desestimado por entender que no existió voluntad de privar de libertad, ni existió el requisito de la «ilegalidad» ${ }^{1483}$. El TS reconoció la desprogramación llevada a cabo por funcionarios públicos, pero a pesar de este reconocimiento lo entendió justificado, en virtud de la previa despersonalización que habían sufrido ${ }^{1484}$. Este razonamiento, en nuestra opinión, carece de todo respeto a la libertad de conciencia, ideológica y religiosa, pues sin prueba de ello, y de la debida declaración de incapacitación cuando el sujeto no lo consiente, no se puede realizar una desprogramación calificándola de justificada.

Los querellantes, excepto uno de ellos, desistido por falta de representación procesal, plantearon recurso de amparo ante el TC con la intención de anular la sentencia absolutoria de

\footnotetext{
${ }^{1482}$ La Sentencia concluye que la SAP de Barcelona no hizo caso omiso del «derecho a la libertad personal, ideológica, religiosa y de conciencia, puesto que sus diversas apreciaciones fácticas y jurídicas —acertadas o erróneas - se limitaron a declarar que el presupuesto para la imposición del castigo —el delito - no existía, sin que tal declaración, basada en una resultancia fáctica que este Tribunal no puede revisar [art. 44.1 b) LOTC], excluya que haya podido, efectivamente, haber vulneración de los derechos fundamentales aludidos ni que ésta pueda repararse en la vía procedente», FJ $8^{\circ}$ de la STC 41/1997, de 10 de marzo.

${ }^{1483}$ Concretamente dice la Sentencia que «no se puede considerar cometido el delito de detención ilegal porque: en primer lugar, no existió voluntad en los querellados de privar de libertad a ninguna persona, sino, por el contrario, su intención, plenamente demostrada, fue la de evitarles unos males inminentes y muy graves, con lo que falta el elemento subjetivo o dolo concreto de tipo delictivo; en segundo término, no existe el requisito de la 'ilegalidad', ya que, por lo antes expuesto, la actuación de los querellados fue acorde y ceñida al marco de lo que la sociedad y el Ordenamiento Jurídico, apreciado en su conjunto, exigen en situaciones y momentos como los enjuiciados», FJ $10^{\circ}$ de la Sentencia del TS, de 23 de marzo de 1993.

${ }^{1484}$ FJ $^{\circ}$ y $6^{\circ}$ de la STS, de 23 de marzo de 1993.
} 
los funcionarios policiales. La STC 41/1997, de 10 de marzo, señala que al tratarse de una sentencia penal «firme, de fondo y absolutoria», no viene el thema decidendi en causa amparo constitucional, pues «no forma parte del contenido de los derechos fundamentales el de la obtención de la condena penal de quien los vulnere» ${ }^{1485}$.

La STEDH de 14 de octubre de 1999 (asunto Riera Blume y otros contra España ${ }^{1486}$ ) declaró que se había producido una vulneración del art. 5.1 CEDH, por lo que España tendrá que abonar una cantidad, a mi juicio irrisoria, 250.000 ptas., a cada afectado de la detención ilegal. La desprogramación fue reconocida por la condena del TEDH a España, la conducta de los funcionarios públicos no estaba justificada, no existió consentimiento de los sectarios y, por ende, la Sentencia del Tribunal español fue totalmente errónea. Sin prueba, toda actuación al respecto carece de fundamento y vulnera todas las garantías constitucionales y procesales. Al realizarse la detención con el fin de cambiar/modificar la voluntad de obrar, consideramos más acertado aplicar igualmente el delito de coacciones por las razones explicadas.

Una vez publicada la Sentencia del Tribunal Europeo de Derechos Humanos, que apreció la vulneración del art. 5.1 del CEDH, los demandantes promovieron un recurso de revisión ante la Sala Segunda del TS, por considerar que dicha Sentencia constituía un hecho nиеvo, que evidenciaba la inocencia de los condenados de los delitos de intrusismo profesional y relativos a la prostitución. Recurrieron en concreto que el razonamiento jurídico de la sentencia se había basado en las declaraciones de las personas que habían participado en la detención ilegal, o por el contrario, en las propias declaraciones de las personas detenidas si bien estaban a favor de la absolución de sus guías esotéricos. El Auto de la Sala de lo Penal del Tribunal Supremo, de 27 de

${ }^{1485} \mathrm{FJ} 4^{\circ}$ de la STC 41/1997, de 10 de marzo.

${ }^{1486}$ El apartado 33 de la STEDH de 14 de octubre de 1999, relata las conductas de detención ilegal que sirvieron para declarar la vulneración del 5.1 del CEDH: «fueron los funcionarios de la Policía Autónoma catalana quienes, siguiendo las instrucciones de sus superiores y, concretamente, las del Juez de Instrucción, trasladaron a los demandantes de los locales de la Policía catalana al hotel, utilizando para ello vehículos oficiales. De las declaraciones de los demandantes resulta que su traslado al hotel por la Policía se realizó sin su consentimiento, les fue impuesto. El hecho de que no fueran maniatados durante el trayecto no podría disminuir el carácter violento y forzado del traslado. Una vez entregados a sus familias, los demandantes fueron sometidos a una detención que se asemeja a un secuestro y que no finalizó hasta el 30 de junio de 1984, cuando fueron autorizados a abandonar el hotel. A este respecto, el Tribunal considera que los días 29 y 30 de junio de 1984, en el momento en el que los demandantes se encontraban todavía retenidos en el hotel, funcionarios de la Policía interrogaron a los demandantes tras haberles informado de sus derechos en presencia de un abogado. Esto demuestra que las autoridades catalanas supieron en todo momento que los demandantes se encontraban retenidos en el hotel y que no hicieron nada para poner fin a la situación». Y sigue diciendo que los policías «no respetaron plenamente la orden del Juez, según la cual la asistencia psiquiátrica que les permitía encontrar de nuevo su estabilidad psíquica debía ser dispensada de forma voluntaria en el caso de las personas mayores, siéndolo todos los demandantes. En cualquier caso, suponiendo incluso que existiera riesgo de suicidio, tal riesgo no justificaría una privación de libertad tan importante. El hecho de que, una vez en libertad, los demandantes presentaran una querella criminal contra los funcionarios del Gobierno catalán y contra cualquier otra persona responsable por la detención ilegal y otros delitos, demuestra que estuvieron encerrados en el hotel en contra de su voluntad» (apartado 34). 
julio de 2000, denegó el trámite de interposición del recurso de revisión por razones meramente formales. No concurrían «nuevos hechos» según el art. 954.4 LECrim. La STEDH no constituyó un «hecho nuevo» que revelara la inocencia de los condenados, no había conexión entre el contenido de dicha Sentencia y la revisión ${ }^{1487}$. Posteriormente el TC criticó en amparo el Auto del TS por considerar que no se puede denegar la revisión por un argumento formal, cuando el fin del recurso de revisión es «remediar errores sobre los presupuestos fácticos de la infracción», y por no considerar un hecho nuevo la Sentencia del TEDH ${ }^{1488}$. Sin embargo, el TC desestima el recurso de amparo porque el TS, a pesar de desestimar la admisión del recurso, sí entró en el fondo del asunto realizando la debida revisión de las pruebas ${ }^{1489}$.

Por último, un caso de detención ilegal, aunque de menor entidad, se produjo por miembros del grupo religioso Hare Krishna, que con relación a un miembro de la misma que padecía de esquizofrenia «le condujeron a un sótano, donde le despojaron de los hábitos (...) tras lo que (le obligaron) a subir a una furgoneta (...) ataron fuertemente a aquél con la finalidad de inmovilizarle (...) hasta llegar a un pinar (...) donde le dejaron fuertemente maniatado, amordazado y con las piernas atadas». En este caso es evidente que la finalidad era simplemente la detención por cuanto no medió una intención específica de modificar o disminuir la voluntad, sino de alargar en el tiempo la restricción de movimientos.

\section{K. Conclusiones sobre el delito-fin sectario estricto sensu: la persuasión coercitiva como}

delito de coacciones doloso o imprudente

Parece lógico entender que la persuasión coercitiva, al atacar la libertad de la voluntad en sí misma, ataca a la vez la libertad de conciencia especialmente, pero de forma secundaria o consecuentemente al tratarse de un grupo criminal de corte religioso, ideológico o moral. En este

${ }^{1487}$ El TS señalaba que «ninguna conexión existe entre la sentencia del TEDH que estimó que los recurrentes, adeptos del Grupo CEIS hubieran sido privados de su libertad ilegítimamente, con que los dirigentes de dicho Grupo hubiesen sido condenados por delito de intrusismo, al atribuirse la condición de psicólogos sin serlo y el haber inducido o determinado a adeptos del Grupo a la prostitución», FJ $2^{\circ}$ de la STC 41/1997, de 10 de marzo.

${ }^{1488}$ Declaró que «ni cabe negar que respecto al proceso que finalizó con su condena la Sentencia invocada del Tribunal Europeo de Derechos Humanos constituya un dato nuevo, consistente en la imposibilidad de valorar dicha prueba». Añade que «con la incorporación a nuestro ordenamiento de la jurisdicción del Tribunal Europeo de Derechos Humanos, la expresión "hechos nuevos (...) que evidencien la inocencia del condenado" del art. 954.4 LECrim, debe interpretarse de modo que en él se incluyan las declaraciones de dicho Tribunal que puedan afectar a procedimientos distintos a aquellos en los tiene origen dicha declaración», FJ $6^{\circ}$ de la STC 240-2005, de 10 de octubre de 2005 (recurso de amparo núm. 5430-2000).

${ }^{1489}$ Vid. FJ $6^{\circ}$ de la STC 240-2005, de 10 de octubre de 2005 (recurso de amparo núm. 5430-2000), en donde dice que «(e)n el presente caso hemos de señalar que el Auto recurrido, siquiera sea en fase de admisión, procedió a la revisión instada». 
sentido, las técnicas de persuasión coercitiva constituyen una forma de violencia o engaño coercitivo semejante al concepto del delito de coacciones ${ }^{1490}$.

El delito de coacciones castiga de forma agravada cuando el ataque produzca el impedimento de un derecho fundamental, en este caso también la libertad de conciencia, de lo que deviene que sea este delito el que mejor se adecúe a la dinámica criminal de la persuasión coercitiva. Sin embargo, la pena por coacciones graves que impiden el ejercicio de un derecho fundamental, es la mitad superior de una pena de prisión de seis meses a tres años, o de doce a veinticuatro meses de multa, es decir, su mitad superior sería una pena entre un año y nueve meses y un día a tres años, o entre dieciocho y veinticuatro meses de multa. Pero también preceptúa el delito de coacciones que estas penas actuarán «salvo que el hecho tuviera señalado mayor pena en otro precepto de este código», lo cual constituye una cláusula residual que impide la aplicación del delito de proselitismo ilícito, al contemplar una pena de cuatro a diez meses de multa, menor que la pena del delito de coacciones.

Así las cosas, la persuasión coercitiva encaja mejor en los elementos objetivos del delito de coacciones, y éste absorbe (art. 8 CP) al delito de proselitismo ilícito y al de detención ilegal.

La problemática que habrá que resolver posteriormente es que si la gravedad de la persuasión coercitiva, que supone un ataque a la libertad de actuar en general, también afecta a la integridad psíquica, es decir, dado que la misma acción que restringe la libertad de la voluntad suele conllevar un ataque a la integridad psíquica, qué debemos aplicar, si los dos delitos (concurso ideal o medial de delitos), en el que por las reglas del art. 77 CP se aplicaría la pena del delito más grave, por lo general, el de lesiones agravadas en su mitad superior, o el denominado concurso de leyes o normas del art. 8 del CP, por el que sólo se aplica un delito.

Para hallar una solución al respecto, debemos analizar primero el delito de lesiones, para después compararlo con los supuestos de la persuasión coercitiva para establecer si puede tratarse también como un delito de lesiones, y después determinar qué tipo de solución ha de aplicarse en relación a posibles concursos.

\footnotetext{
${ }^{1490}$ Similarmente JANSÁ, JMa ${ }^{\mathrm{a}}$, La coartación de la libertad a través de las sectas destructivas, una sutil forma de violencia, op. cit; PASCUAL / VIDAURRÁZAGA MEZA aciertan en que «lo que caracteriza a lo que hemos llamado grupos de manipulación psicológica es el engaño basado en el autoengaño -y de aquí la gran fuerza reproductiva, porque cada nuevo seguidor se convierte en un captador potencial de más seguidores-, más que la manipulación consciente, más difícil de mantener y propagar en una sociedad que se presenta como pluralista y abierta como la catalana», PASCUAL J / VIDAURRÁZAGA MEZA E., Grupos de manipulación psicológica en Cataluña, situación y conceptos, op. cit., pp. 37 y 38, y «(c)uando hablamos de autoengaño nos referimos a un fenómeno que tiene una parte de interiorización y, por lo tanto, de carácter subjetivo, pero que a su vez viene reforzado por la dimensión intersubjetiva, a dos niveles: por la relación que mantienen líder y seguidor, y por el refuerzo que se da entre entidades afines y que constituyen redes de apoyo y reconocimiento mutuo», ID., ibidem, op. cit., nota 35.
} 
La similitud del delito de coacciones con el delito de detención ilegal, tanto en su estructura típica como por las modalidades del ataque, permite asociar la comisión imprudente en el primero. Ya en su día PolAino NAVARRETE reseñaba la falta de dificultad de la comisión imprudente en el delito de detención ilegal del art. 480.1 CPd por «la defectuosa apreciación de los elementos del acto típico o de la significación de los mismos» ${ }^{1491}$. Esta conclusión es hoy en día igualmente trasladable a este delito pero también al delito de coacciones en su redacción actual, como ya mantuvo en su día parte de la doctrina ${ }^{1492}$, sobre todo en cuanto a la acción de impedir, y más dudosa en la acción de compeler, si bien, la intercambiabilidad de la acción y omisión desarrollada hace superflua esta distinción. Sólo el segundo párrafo del art. 172 CP referido a la coacción con objeto de impedir el ejercicio de un derecho fundamental, parece contemplar la modalidad exclusivamente dolosa.

Evidentemente, la doctrina y jurisprudencia de forma casi unánime han negado la modalidad imprudente en el delito de coacciones, sin embargo, de los fundamentos que hemos esgrimido con base a la naturaleza constitutiva de la libertad de actuar en general que protege este delito, debemos reconocer al menos las comisiones graves, que al igual que por otra parte se exige en la comisión dolosa para diferenciar el delito de la falta, llevan a concluir dicha posibilidad teórica y práctica en la comisión imprudente grave, tanto en la acción como en su resultado pero también en el tipo subjetivo, esto es: la culpa consciente. Esto se debe a que la imprudencia inconsciente y la acción y resultado leve se asemejaría en mucho a casos fortuitos, o sin necesidad de prevención criminal, salvo deber de aseguramiento, salvación, o ilicitud previa ${ }^{1493}$, según lo expuesto supra.

En este sentido -y extrapolando las conclusiones de POLAINO NAVARRETE sobre el delito de detención ilegal imprudente-, sería necesaria «la constatación de realización culposa del primer momento típico de la acción y asimismo de realización culposa del segundo momento de la conducta típica (...), por idénticas exigencias, la necesidad de formulación del juicio de reproche de culpabilidad correspondiente a la realización culposa global del tipo de injusto», y lo mismo

\footnotetext{
${ }^{1491}$ Polaino NaVArRete, M., El delito de detención ilegal, op. cit., pp. 179 y ss.

1492 Admiten la posibilidad de las coacciones imprudentes MIR PUIG, S., «El delito de coacciones en el Código penal», op. cit., p. 294 pero bajo la teoría de los elementos negativos del tipo y cuando sea vencible el error; JASO RoldÁn, T., en RodríGuez Devesa JMa / JASO ROLdÁN T / RODRÍGUEZ MuÑOZ JA., PE, op. cit., p. 305; Quintano RIPOllÉS, A., Tratado de la Parte especial del Derecho penal, T. I, II, Infracciones contra la personalidad, $2^{a}$ ed., puesta al día por Enrique Gimbernat Ordeig, Ed. Revista de Derecho Privado, Madrid, 1972, p. 1139.

${ }^{1493}$ Parece sostener lo contrario en relación a la intrascendencia de la conducta ilícita previa, por mor de que la falta de dolo o culpa llevan a la «irrelevancia típica de tal supuesto de caso fortuito» POLAINO NAVARRETE, M., El delito de detención ilegal, op. cit., pp. 189 y 190.
} 
para conductas de realización dolosa o imprudente en la acción e imprudente o dolosa posteriormente en el segundo momento referido al resultado de la privación de libertad ${ }^{1494}$.

En la dinámica criminal y en unidad de acción confluyen las agravantes generales del art. 22 $\mathrm{CP}$ en el delito de coacciones por persuasión coercitiva, al menos en el tipo doloso (alevosía, abuso de superioridad, abuso de confianza). Esto fundamenta también la necesidad de un tipo específico.

\section{V.- Delitos contra la libertad sexual con reclamo sexual flirty fishing}

Son pocos los casos acreditados en España en sentencias firmes sobre procesos a sectas o miembros por delitos de abusos sexuales. En estos casos se suele utilizar el reclamo sexual (flirty fishing ${ }^{1495}$. NAVAS RENEDO nos comenta que en la secta Waco Texas, su fundador tenía derecho a mantener relaciones sexuales con los miembros y era obligación de estos mantenerlas ${ }^{1496}$.

Hemos comentado que tanto en los delitos contra la vida como en la estafa puede mediar modalidades de persuasión coercitiva que rivalizan con los elementos centrales de los tipos. Esto sucede también en los delitos de agresión, violación y abusos sexuales.

En el delito de agresión sexual y violación, el concepto de violencia se asimila al de violencia del delito de coacciones por persuasión coercitiva, inclusive la agravante del art. 180.1.3 ${ }^{\mathrm{a}} \mathrm{CP}$ cuando la víctima sea especialmente vulnerable, en nuestro caso por enfermedad, discapacidad o situación, o la 4. a del mismo precepto cuando, para la ejecución del delito, el responsable se haya prevalido de una relación de superioridad, o la $5^{\text {a }}$ cuando el autor haga uso de armas u otros medios igualmente peligrosos, susceptibles de producir la muerte o alguna de las lesiones previstas en los artículos 149 y 150. Tanto es así que pueden confluir las anteriores con la agravación de la pena en su mitad superior (180.2 CP). La cuestión es si la violencia de la persuasión coercitiva integraría ya la violencia de tipo básico de agresión sexual del art. 178, o en su caso la del 179 CP cuando consistiere en acceso carnal. En nuestra opinión, se reconduciría directamente a las formas agravadas, similarmente a la agravación o autonomía del asesinato, y esto porque se concluyó que en las modalidades de la persuasión coercitiva median la alevosía, una relación de superioridad o de confianza especial, y el aumento del riesgo similar al uso de

${ }^{1494}$ ID., ibidem, op. cit., pp. 181 y 182.

1495 Flirty fishing en palabras de NAVAS RENEDO es «la atracción de adeptos mediante el reclamo sexual e incluso la promoción de la prostitución de los menores que se someten a ellas», NAVAS RENEDO, B., Tratamiento jurídico de las sectas, op. cit., p. 302.

${ }^{1496}$ ID., ibidem, op. cit., p. 299. Este mismo comportamiento fue objeto de denuncia por miembros en la secta fundada por Raël (Los Raelianos), en la secta Niños de Dios, en Familias del Amor, en Edelweiss, en CEIS, en El Ave Fénix, e incluso en El Partido Humanista como apunta SAlarrullana, vid. Salarrullana, P., Las sectas, op. cit., pp. 88 a 92 y 138. 
armas o medios peligrosos (similar al art. $148 \mathrm{CP}$ ), sin embargo no podemos incluir la vulnerabilidad de la víctima (no per se su inimputabilidad) porque supone un resultado de la persuasión coercitiva o de la lesión psíquica, lo que lleva a que su aplicación se limite a los casos en que se aproveche de dicha situación cuando venga previamente de la víctima. Así, concluimos que en la persuasión coercitiva confluyen las agravantes (alevosía, abuso de superioridad y de confianza) en la misma unidad de acción, lo que posibilita la aplicación de las agravantes específicas del delito de violación en el concurso de leyes con el de persuasión coercitiva a favor aquél. De aquí recuérdese también que denunciáramos la escasa penalidad que tiene el tipo agravado de coacciones, y la necesidad de un tipo específico.

En cuanto al delito de abusos sexuales también sucede una similar equiparación estructural del tipo de engaño y violencia de la persuasión coercitiva en la falta o vicio de consentimiento del art. 181.2 CP «sobre personas que se hallen privadas de sentido o de cuyo trastorno mental se abusare, así como los que se cometan anulando la voluntad de la víctima mediante el uso de fármacos, drogas o cualquier otra sustancia natural o química idónea a tal efecto», o la del apartado 3 «cuando el consentimiento se obtenga prevaliéndose el responsable de una situación de superioridad manifiesta que coarte la libertad de la víctima». La cuestión es si puede aplicarse la agravante del apartado 5 «si concurriere la circunstancia $3 .^{a}$ o la $4 .^{a}$, de las previstas en el apartado 1 del artículo 180 de este Código», puesto que de aquí resultan discusiones de vulneración del principio ne bis in idem en relación a la obtención del consentimiento o su falta, cuestión que nos posicionamos en la prohibición por dicha asimilación estructural de los conceptos de engaño y violencia que se consumen ya en el tipo básico del art. $181 \mathrm{CP}$.

También habrá que convenir que la modalidad de engaño de la coacción por persuasión coercitiva puede consumirse en el concepto de engaño o abuso «de posición de reconocida confianza, autoridad sobre la víctima (...) con persona mayor de dieciséis años y menor de dieciocho» del art. 182.1 CP, y la misma problemática del ne bis in idem puede resolverse con la prohibición en la relación a la agravante de acceso carnal si concurriera la circunstancia $3^{\mathrm{a}}$, o la $4^{\mathrm{a}}$, de las previstas en el artículo 180.1 de este Código.

Así las cosas, los abusos sexuales, distintos a las agresiones sexuales por no mediar violencia ni intimidación, pueden realizarse con consentimiento de la víctima. El líder o sujeto con similares poderes puede realizar el abuso con prevalecimiento de superioridad y/o sobre personas a las que se ha mermado su capacidad volitiva o se aprovecha de tal ocasión. El consentimiento, en todo caso, estaría viciado cuando la víctima tiene disminuida la conciencia y/o voluntad, en 
los casos de víctimas menores de dieciséis años (art. $183 \mathrm{CP}$ ), o en sujetos que padezcan un trastorno mental del que conozca el autor y se aproveche de tal circunstancia.

El caso más importante en España fue la condena a los dirigentes de Edelweiss por 28 delitos de corrupción de menores. La Sentencia de la Audiencia provincial de Madrid, sección 26, de fecha 22 de octubre de 1991, señaló que «el efecto producido en los miembros era el propósito de una secta». En la Sentencia del Tribunal Supremo de 22 de octubre de 1991 que resuelve el recurso de casación del caso «Edelweiss», se describe que las actividades de esta secta se encaminaban a «captar a los menores para su ingreso en el grupo, y tras fomentar su imaginación y crearles un atractivo (...) a través de conversaciones individuales y en grupo y luego en las acampadas (...) acababan manteniendo relaciones sexuales con todos los que asumían estas ideas (...) al hacerles creer que podían, a través de su unión y lealtad a los componentes de «Edelweis» y asunción de las ideas del grupo, acceder a Delhais», un planeta imaginario ${ }^{1497}$. El Tribunal Supremo reconoció en esta sentencia el injusto autónomo del delito de persuasión coercitiva, al menos y en principio, en aquellos sujetos que por su grado de inmadurez, son más fáciles de seducir, de manipular.

También la Sentencia de la Audiencia provincial de Barcelona de 16 de Julio de 1990 sobre el caso el famoso caso CEIS describió la intencionalidad lucrativa, sexual, coercitiva y mental de esta secta: «una estructura organizativa (que se caracteriza por) la utilización de terapias con pretensiones (...) de la explotación del trato sexual de miembros de la misma».

Otra de las sentencias dignas de mención sobre esta temática delictiva, es la Sentencia del Tribunal Supremo de 28 Junio de $2006^{1498}$, que resuelve el recurso de casación contra la Sentencia de la Audiencia Provincial de Pontevedra ${ }^{1499}$. El caso versó sobre una agresión sexual de un miembro y monitor juvenil de la secta Adventista del Séptimo día a uno de sus miembros. Fue condenado por un delito continuado de agresión sexual, cometido durante las diversas ocasiones entre las que se encontraban monitor y joven aprendiz y durante los años de infancia

${ }^{1497}$ FJ $3^{\circ}$, de la SAP de Madrid, sección 16a , de 22 de octubre de 1991. En la misma se describe la doctrina moral-imaginaria que impartía discriminatoriamente el líder de esta secta: "enviado a la Tierra desde el planeta Delhais -que era el de la libertad, amor y justicia-donde el amor tenía una expresión libre y homosexual». El líder y miembros activos «acababan manteniendo relaciones sexuales con todos los que asumían esas ideas, sodomizando a los menores, todo ello precedido de abrazos y caricias lascivas, introduciéndose en la cama de los niños por la noche que en todos los casos eran menores de dieciocho años... (haciéndoles) creer que podian a través de su unión y lealtad a los componentes de «Edelweis»... acceder a «Delhais», si eran escogidos por Eddie... al haber alcanzado la perfección, acceso que se produciría en 1992, después de la destrucción de la tierra por un cataclismo termonuclear que se anunciaba para dicha fecha». Este mismo sujeto fue condenado por corrupción de menores y escándalo público en la SAP de Madrid, de 25 de septiembre de 1982, en la SAP de Alicante, de 5 de abril de 1979, y también por otras causas como estafa y apropiación indebida.

1498 STS, de 28 Junio de 2006, rec. 2451-2005.

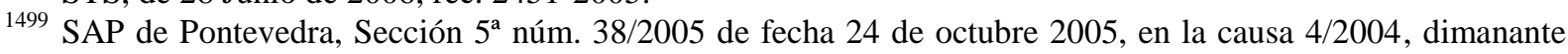
del Sumario núm. 2/2004 del Juzgado de Instrucción núm. 7 de Vigo. 
de la joven. El monitor se ganó la confianza de la víctima de 12 años de edad, aprovechándose además del carácter tímido de ésta, con lo que consiguió en innumerables ocasiones materializar su ánimo lubrico a través de las referidas agresiones sexuales prolongadas en el tiempo. Estos hechos produjeron en la joven un trastorno por estrés postraumático crónico.

Huelga decir únicamente que respecto a las denominadas sectas satánicas, parte de la doctrina considera que son en éstas en las que con mayor frecuencia se perpetran delitos contra la libertad sexual y en las que se lleva al extremismo el reclamo sexual o flirty fishing para la captación y reclutamientos de miembros. Algunas de éstas cuentan entre sus ritos y dogmas la violación y el asesinato que se conciben como contra-ritos cristianos ${ }^{1500}$.

\section{VI.- La persuasión coercitiva como «delito contra la salud psíquica»}

\section{A. El delito de lesiones: el bien jurídico}

Ya hace dos siglos FICHTE comentaba que «(a)tentar contra el cuerpo es violar de un golpe todos los derechos del ciudadano; es por tanto ciertamente un crimen en el Estado, porque el uso de todos sus derechos está condicionado por la libertad del cuerpo» ${ }^{1501}$, ahora bien, más si cabe puede decirse de la libertad de actuar en general, tal y como lo hemos expuesto supra. De esta vinculación entre la salud y la libertad con el ejercicio de los demás derechos nace la ultraprotección penal que tradicionalmente se recoge en los códigos, de manera que existe una garantía de funcionalidad de la operatividad del Sistema Social a través de esta relación. Por eso tradicionalmente el delito de lesiones se ha comprendido como delito de resultado, cuya diferencia punitiva se determina en virtud de la gravedad de las consecuencias que se produzcan.

Concretamente, nuestro Código penal de 1973, en los arts. 420 y 421, contemplaba como medios de comisión del delito de lesiones los contagios de enfermedad sexuales, además de medios materiales externos como el herir, el golpear y el maltratar, o internos, como la administración de sustancias o bebidas nocivas. En cuanto a nuestro estudio, resulta interesante que ya nuestro derogado Código penal recogiera medios de comisión tan detallados, que si bien se refería a los contagios, podía aplicarse extensivamente a otros resultados. Los preceptos

\footnotetext{
1500 Señala MUSTI que para «lograr la relación con Satanás, es necesario realizar actos sexuales, con la consiguiente eyaculación. Las víctimas de tales acciones son, por lo general, mujeres, frecuentemente en estado de incapacidad para entender y querer, porque se les ha suministrado bebidas adulteradas o sustancias estupefacientes; o bien son menores», sin embargo, también es cierto que estas sectas y las conductas descritas no proliferan muy a menudo, Musti, Lucia, «Aspectos legales y jurídicos del satanismo», vv.aa., Sectas satánicas y fe cristina, pról. Julián García Hernando, Editorial Palabra, 1998, p. 52.

${ }^{1501}$ FiCHTE, JG., Fundamentos del Derecho natural según los principios de la doctrina de la ciencia, trad. José Luis Villacañas Berlanga, Manuel Ramos Valera y Faustino Oncina Coves, Centro de Estudios Constitucionales, Madrid, 1994, p. 304.
} 
también contemplaban el medio de comisión moral (vis moralis), cuando se abusase de la credulidad o de flaqueza de espíritu ${ }^{1502}$. De aquí que la comisión moral se suele asociar a la persuasión coercitiva, sin embargo el CPd lo reservaba a la criminalización del contagio de enfermedades sexuales, pero como decimos, su aplicación resultaba extensiva a otros delitos de resultado de lesión.

Dicho lo cual, parece cuando menos contradictorio que se derogara el delito de comisión moral, cuando se criminalizan en nuestro actual Código las asociaciones que utilizan la manipulación mental, aun con fines lícitos. Esta laguna nos lleva a considerar que la derogación del delito de comisión moral cuando el autor se aprovechase de la credulidad o flaqueza de espíritu de una persona fue un desacierto, porque se trata de un delito de lesiones o de un delito autónomo de persuasión coercitiva, lo cierto es que se despojó al Código penal de la posibilidad de criminalizar, sin problemáticas, aquellas situaciones que entre la inducción y el delito de lesiones producen un déficit de socialización en el sujeto que merma su capacidad de voluntad, aprovechándose o no de su flaqueza de espíritu, pero en cualquier caso restringiendo el horizonte de expectativas. De aquí surge una evidente similitud entre la persuasión coercitiva y el delito de lesiones.

Por otro lado, no existe acuerdo por parte de la doctrina sobre cuál es el bien jurídico del delito de lesiones. BERISTAIN IPIÑA, y en parte TAMARIT SumALlA, sostienen que es la incolumidad corporal o el bienestar corporal (tesis monista), incluyendo en éste la salud física y mental. De manera más concreta, se pronunciaron RoDRÍGUEZ DEVESA / SERRANO GóMEZ, BAJO FERNÁNDEZ, DÍEZ RIPOLLÉS y otros, aludiendo a la integridad corporal y la salud física o mental (tesis dualista), en tanto que otros hablan de salud (física o mental) ${ }^{1503}$ y CORCOY BIDASOLO de bienestar físico y psíquico en un sentido subjetivo como se refiere la OMS ${ }^{1504}$. En verdad todos los penalistas aluden al mismo concepto: la salud personal general.

El actual art. 147 CP habla del menoscabo de la integridad corporal o la salud física o mental, derivándose en los demás artículos la gravedad por el resultado, excepto en el art. 148 que lo

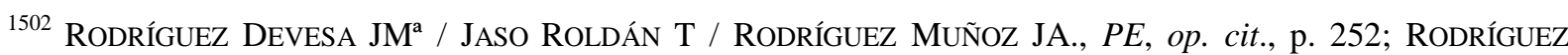
DEVESA JM / SERRANO GÓMEZ A., PE, op. cit., p. 287.

1503 GonzÁlez Rus, Juan José, vv.aa., Derecho penal español, Parte especial, $2^{\mathrm{a}}$ ed., revisada, coord. Manuel Cobo del Rosal, Dykinson, 2005, p. 143, comenta que «(1)a integridad en sí misma, desconectada del concepto más general de salud, no puede ser el bien jurídico protegido, en la medida en que puede haber pérdidas provocadas de sustancia corporal que persiguen precisamente mejorar la salud del sujeto...». En sentido similar Myriam HERRERA concibe el bien jurídico en la «integridad y salubridad física o psíquica de las personas», HERRERA MORENO, M., vva.aa., Lecciones de Derecho penal, Parte Especial, T. I, op. cit., p. 99; MARTínez RuIZ, Jesús, Los delitos de lesiones, Bosch, 2002, p. 15.

${ }^{1504}$ CORCOY Bidasolo M / CARdenal Montraveta S / FernÁndez Bautista S / Gallego Soler JI / GómeZ Martín V / Hortal IBARra JC., Manual práctico de Derecho penal, Parte Especial, op. cit., p. 123.
} 
señala como un delito de peligro. De este modo, es patente la evolución del delito lesiones en nuestro ordenamiento penal, de la protección de la integridad física en sentido naturalista al concepto de salud, lo que plantea problemas de constatación entre el daño moral y la perturbación mental o menoscabo psíquico. En este sentido, merece destacar la Sentencia del TS de 20 de octubre de 1994 que delimita la lesión en casos de formación de la personalidad por métodos educativos en un grupo religioso.

La doctrina mayoritaria requiere que el dolo contemple la realización del resultado, cuando menos eventualmente (así, BAJO FERNÁNDEZ, DíEZ RIPOLLÉS, HERRERA MORENO), mientras que otro sector exige un «dolo genérico de lesionar», esto es, la simple intención de lesionar sin contemplar específicamente un resultado, porque en muchas ocasiones resultaría difícil exigir al sujeto activo el conocimiento sobre la necesidad de un tratamiento, sin perjuicio de que pueda ser evidente en determinadas acciones de agresión, incluyendo las psíquicas, la necesidad de una respuesta médica ${ }^{1505}$.

Por nuestra parte, nos adherimos a esta segunda postura, que exige únicamente un «dolo genérico de lesionar» en relación a la aplicación de técnicas de persuasión coercitiva porque al tratarse de un delito contra la libertad, y concretamente sobre la capacidad de libertad de voluntad, parece lógico pensar que se puedan producir lesiones psíquicas, lo que nos lleva a concluir que el especial elemento subjetivo de coaccionar violentamente incluye el dolo genérico de lesión, lo que nos remite nuevamente a problemáticas de concurso.

\section{B. La persuasión coercitiva como alteración o anomalía psíquica}

Ya hemos examinado la posibilidad de apreciar una causa de inimputabilidad por alteración o anomalía psíquica en casos de conflicto de conciencia. Cabe ahora plantearse si la persuasión puede dar motivos bastantes para apreciar una disminución o anulación de la culpabilidad en relación a una lesión psíquica.

La mayoría de la doctrina ${ }^{1506}$ ha rechazado la aplicación de una causa de inimputabilidad en el conflicto de conciencia, si bien BAUCELLS ${ }^{1507}$ admite la posibilidad de ciertas neurosis obsesivas, el fanatismo y la esquizofrenia como posible causa de trastorno mental en determinados casos.

\footnotetext{
1505 Vid. CAncio Meliá, M., vv.aa., Compendio de Derecho penal, Parte especial, Vol. I, op. cit., p. 404; Herrera Moreno, M., vv.aa., Lecciones de Derecho penal, Parte Especial, T. I, op. cit., p. 102.

${ }^{1506}$ BAUCELls I Lladós, J., La delincuencia por convicción, op. cit., pp. 335 y ss; FlORES MENDOZA, F., Objeción de conciencia, op. cit., pp. 202 a 204; JERICÓ OJER, L., El conflicto de conciencia, op. cit., pp. 370 a 374, y pp. 463 y 464; TAMARIT SUMALLA, JM ${ }^{\mathrm{a}}$., «La objeción de conciencia», op. cit., p. 41.

1507 BAUCELls I LLADÓs, J., La delincuencia por convicción, op. cit., pp. 335 y ss.
} 
Considera $^{1508}$ posible la eximente de alteración psíquica en casos de sujetos que desde su infancia están sometidos a un determinado contexto cultural y de valores que impide acceder a las normas culturales de la sociedad. Por el contrario, JERICó le critica por estimar que estos casos se reconducirían a los de error de prohibición «ya que el hecho de que el sujeto se encuentre aislado de lo considerado socialmente normal no afecta a su capacidad biológica para conocer la norma, sino al hecho de que desconozca la norma jurídica imperante en dicha sociedad ${ }^{1509}$, pero admitiendo que en casos de sectas fanáticas el adepto pueda tener afectada su capacidad de culpabilidad, «su comprensión acerca de lo ilícito de su hecho y la actuación conforme a dicha comprensión» ${ }^{1510}$, si bien no lo atribuye a un conflicto de conciencia sino de la misma alteración psíquica aunque existen casos que podrían venir de dicho conflicto.

TAMARIT SUMALLA ${ }^{1511}$ critica la aplicación del arrebato y obcecación en determinadas circunstancias como en el caso recogido por la STS de 27 de marzo de 1990, que ya fue comentado anteriormente, en el que se condena por homicidio doloso a un Testigo de Jehová por desconectar el catéter durante la trasfusión de sangre, puesto que no es admisible en un Estado de Derecho tratar a los sujetos creyentes como obcecados. JERICó ${ }^{1512}$ comenta al respecto que, si se ampara la libertad de conciencia, a la postre no puede ser tratada como una anomalía psíquica lo que sería una especie de superioridad moral del Estado ante determinadas conductas realizadas por conciencia.

LUZÓN PEÑA, si bien considera que el autor por convicción merece el máximo reproche penal por su peligrosidad y por su enfrentamiento «total» con el ordenamiento jurídico, admite que en casos «muy excepcionales» la situación psicológica de fanatismo del autor por convicción puede ser «anormal», y expone el caso de los lavados de cerebro en los que existe una anomalía psíquica o de trastorno mental transitorio que excluya la culpabilidad por inimputabilidad que fundamenta la aplicación de medidas de seguridad por la peligrosidad que demuestra ${ }^{1513}$.

De manera similar, FloREs MENDOZA ${ }^{1514}$ considera aplicable la eximente de alteración o anomalía psíquica en un sujeto obligado a los dictados de una conciencia cuando llega al fanatismo, o neurosis o la patología, con lo que estamos de acuerdo, lo cual tampoco lleva a negar -como bien ha apuntado JERICó- que dicha alteración llegue a fijar siempre una conciencia y valores considerados supremos que originen a la postre un conflicto de conciencia de obligado

\footnotetext{
1508 ID., ibidem, op. cit., p. 336.

1509 JERICÓ OJER, L., El conflicto de conciencia, op. cit., pp. 371 y 463.

1510 ID., ibidem, op. cit., p. 371.

1511 TAMARIT SUMALLA, JM ${ }^{\text {. }}$, «La objeción de conciencia», op. cit., p. 41.

1512 JERICÓ OJER, L., El conflicto de conciencia, op. cit., pp. 370 a 374.

1513 LUZÓN PEÑA, D-M., «Actuación en conciencia», op. cit., p. 15.

1514 Flores MenDOZA, F., Objeción de conciencia, op. cit., pp. 203 y 204.
} 
cumplimiento. Así niega que en estos casos se pueda hablar de verdadero conflicto de conciencia porque se aplicaría la inimputabilidad.

Con este último argumento no podemos estar de acuerdo según lo visto. Quien llega con una previa dolencia o alteración a una secta, y su dolencia se incrementa, inclusive por causa ajena o de tercero, puede igualmente desarrollar una prelación de valores que a la postre le hagan actuar contra la norma sin tener ya anomalía psíquica alguna, o dicho de otro modo, si bien la doctrina mayoritaria niega la aplicación de la eximente o la atenuación por causas de alteración mental o anomalía psíquica o enfermedad mental, parte de la doctrina que se ha interesado especialmente sobre el tema de la autoría de conciencia y por convicción (BAUCELLS, JERICó, FLORES Mendoza, Luzón PeÑa y TAmarit Sumalla) acepta la posibilidad de que, en ciertos circunstancias de fanatismo y/o de contexto cultural desde la infancia, se reproduzca una alteración psíquica tan relevante que produzca el conflicto de conciencia o la actuación por convicción.

La cuestión central es que de este modo la producción de una lesión psíquica, a través de la persuasión coercitiva intensa y/o prolongada en el tiempo, puede acarrear aquellas situaciones a las que la doctrina ha asimilado a la alteración o anomalía psíquica como causas de inimputabilidad, pero sin apreciar la causa precedente: la persuasión coercitiva como lesión psíquica. De tal manera, la exención o atenuación de la responsabilidad criminal, en ambos casos, puede también fundamentarse, sin irrogar el alcance normativo de las causas de inimputabilidad, más bien, y especialmente, en la inexigibilidad. Esto es porque antes de la causación de un trastorno o anomalía psíquica que se desarrolla por el fanatismo y/o el contexto cultural del sujeto desde la infancia (eliminación del horizonte de expectativas) existe un estado previo en el que el sujeto ve significativamente restringido el horizonte de expectativas, de modo que dicho horizonte le socializa en una dirección disconforme con el horizonte de expectativas normativas y sociales que le ofrece el Sistema: esto es la desocialización o déficit de socialización a tribuido a tercero o al propio sujeto que, sin constituir una lesión psíquica, incapacita la decisión de la voluntad con un contenido de inexigibilidad normativa.

\section{La persuasión coercitiva como adicción comportamental que causa un delito de lesión} psíquica por eliminación de expectativas normativas y sociales

Los medios de coerción psicológicos, también llamados «lavado de cerebro», «despersonalización», «persuasión», «persuasión coercitiva», inclusive manipulación «por medios químicos», «quirúrgicos»o «behaviorísticos», según lo visto, constituyen una laguna en 
la normativa penal, que por ahora nos ha llevado a concluir que pertenecerían al tipo de coacciones al tratarse de medios violentos. Sin embargo, existe semejanzas con el delito de lesiones, o al menos, la casuística nos muestra que mucha de las veces se produce una lesión psíquica. Basta ver uno de los casos más espeluznantes sobre lesiones causadas en el ámbito sectario en España en la Sentencia de la Audiencia Provincial de Huelva de 21 de noviembre de 1992, en la que se narra que la acusada y líder de la secta, «Ana» o «Gran Águila», obligó a la víctima, con cierta aceptación por ésta, «a ingerir el pelo tras los tirones, clavándole cuchillos y cortándole la lengua por fumar».

Como bien afirma Bonet EstevA, «las dificultades se centran en dos grandes cuestiones; en primer lugar, la gran distancia que existe entre el ámbito terapéutico de las alteraciones mentales o psicológicas y los razonamientos jurídicos de culpabilidad; y en segundo término, que los mismos expertos en psiquiatría forense mantienen posturas divergentes sobre los conceptos de enfermedad mental (...) desde la aplicación de la psiquiatría forense tradicional, la sintomatología que los adeptos manipulados presentan raramente coincide con un diagnóstico concreto y que, en pocas ocasiones, produce trastornos concretos que lleven a la conclusión de que existe una afección mental de las preestablecidas por los productos de dicha práctica forense» ${ }^{1515}$. Y concluye que no hay «acuerdo en la medicina psiquiátrica sobre los efectos de las manipulaciones sobre los individuos y si éstas pueden ser consideradas enfermedades mentales» ${ }^{1516}$.

Por esta razón, parte de la doctrina se ha mostrado disconforme en ubicar normativamente la manipulación o control mental en el delito de lesiones. En concreto, MARTín SÁNCHEZ explica que el delito de lesiones no puede cubrir las posibilidades en relación a la protección de la formación de la conciencia «porque las agresiones contra la salud física y psíquica no siempre cumplirán los requisitos establecidos por el art. $147 \mathrm{CP}$ » ni del $153 \mathrm{CP}^{1517}$. Sin embargo, con un depurado análisis del tipo de lesiones, tanto en lesiones físicas como psíquicas, se aprecia que se protege un bien jurídico de estricta necesidad en la convivencia social, la salud. La Organización Mundial de la Salud recuerda que las lesiones o padecimientos que constituyen una enfermedad no sólo son las que se derivan de una agresión material con trascendencia de lesiones físicas, sino también cualquier delito de agresión que produzca padecimientos o secuelas psíquicas (o

\footnotetext{
1515 Bonet Esteva, M., «Grupos de manipulación mental», op. cit., p. 159.

1516 ID., ibidem, op. cit., p. 160.

1517 MARTín SÁNCHEZ, I., El Derecho a la formación de la conciencia, op. cit., p. 144.
} 
físicas). Dicha afección a la salud psíquica constituye, sin duda, un elemento normativo ${ }^{1518}$ que se debe valorarse mediante los manuales diagnósticos.

Por ello se exige en el delito de lesiones un resultado lesivo físico o psíquico, o la ejecución idónea de producir la lesión, pero también un animus laedendi (ánimo de lesionar, al menos en dolo eventual ${ }^{1519}$ ), en definitiva, una cierta entidad en la lesión que precise de un tratamiento médico o quirúrgico para su sanidad física, o la intervención de psiquiatra, neurólogo o neurocirujano para la sanidad psíquica, pero asimismo un nexo causal que conecte la conducta del autor y la lesión física o psíquica. De tal modo, debemos preguntarnos si la aplicación de técnicas de persuasión coercitiva conlleva en el sujeto un resultado lesivo que precise para su sanidad de un tratamiento médico, como acción tendente a la sanidad más allá de la primer acto médico y de la reiteración de cuidados, cautelas, medidas de prevención (STS 9 de marzo de 1999, entre otras muchas), tratamiento que debe ser necesario objetivamente para la sanidad de la lesión, lo que depende de la lex artis y del criterio médico.

Hemos concluido que las técnicas de persuasión suponen medios violentos de coacción. Así las cosas, las técnicas de persuasión pueden encontrar acomodo en el art. 148 CP (tipo cualificado de estructura mixta alternativa), en la modalidad del apartado $1^{\circ}$ «medios, métodos o formas concretamente peligrosas para la vida o salud, física o psíquica» por aumentar el resultado o riesgo. Sin embargo, parte de la doctrina entiende que el precepto se limita a las conductas del art. $147 \mathrm{CP}$, no a las lesiones agravadas en su resultado de los arts. 149 y 150 $\mathrm{CP}^{1520}$, lo que genera en nuestra opinión una confusión, por cuanto como decimos es posible que no se genere una grave enfermedad psicológica cuando se utilizan técnicas de persuasión coercitiva pero merezca, por los medios utilizados, la agravación del art. $148 \mathrm{CP}$, al generarse un riesgo grave para la salud psíquica. De esta manera, el art. $148 \mathrm{CP}$ no se reconduce exclusivamente al resultado de lesiones del art. $147 \mathrm{CP}$, sino que también agrava la pena cuando a pesar de generarse dicho resultado, exista un riesgo mayor, lo que reconduce dicho riesgo al contenido normativo de los arts. 149 y $150 \mathrm{CP}$.

En este sentido, GONZÁLEZ Rus ${ }^{1521}$ y CORCOY BIDASOLO ${ }^{1522}$ consideran que el art. $148 \mathrm{CP}$ constituye un delito de peligro concreto (resultado de peligro) referido a una grave enfermedad psíquica mayor que la que se hubiera producido sin la aplicación de tales medios peligrosos. Sin

${ }^{1518}$ Herrera Moreno, M., vv.aa., Lecciones de Derecho penal, Parte Especial, T. I, op. cit., p. 101.

1519 ID., ibidem, op. cit., p. 102.

1520 Cancio Meliá, M. vv.aa., Compendio de Derecho penal, Parte especial, Vol. I, op. cit., p. 415.

1521 GonZÁlez Rus, JJ., vv.aa., Derecho penal español, Parte especial, op. cit., p. 152.

1522 CORCOY BIDASOlO M / CARDENAL MONTRAVETA S / FERnÁndEZ BAUTISTA S / GALLEGO SOLER JI / GÓMEZ Martín V / Hortal IBARRa JC., Manual práctico de Derecho penal, Parte Especial, op. cit., p. 130. 
embargo, en nuestra opinión, basta con la representación del autor de que tales medios son idóneos para la causación de un resultado lesivo más grave como los contemplados en el arts. 149 y 150 CP. De esta manera, la utilización de técnicas de persuasión coercitivas puede tratarse como un delito de peligro concreto del art. $148 \mathrm{CP}$ en relación al riesgo de un resultado de una enfermedad psíquica del art. 149 CP. A este respecto, el TS explica, en su Sentencia de 17 de junio de 1998, que debe hacerse un doble análisis en la determinación normativa del art. 148 CP: verificar la naturaleza, forma y composición del instrumento, y la aplicación de la intensidad, dirección y la acción peligrosa contra la víctima, como la aplicación de sustancias toxicas ${ }^{1523}$. No es suficiente que el instrumento sea peligroso en abstracto, sino que dicha peligrosidad debe ser conocida por el autor, de lo contrario la conducta se reconduciría al delito imprudente y la tentativa sería atípica. Además es compatible el tipo agravado con la alevosía, el abuso de superioridad (STS de 25 de marzo de 2000) y la vulnerabilidad de la víctima, lo que nos plantea la posibilidad de aplicar estas agravantes en las técnicas de persuasión cuando entrañan peligro para la salud.

Utilizando estos argumentos consideramos que análogamente pueden incluirse las técnicas de persuasión coercitivas a modo de delito de peligro, no en tanto al instrumento en sí, sino en la forma de aplicación sobre la víctima ${ }^{1524}$, que puedan llevar a una grave enfermedad somática ${ }^{1525}$ o psíquica, como sería la adicción comportamental, a causa de la persuasión coercitiva que produce un déficit de socialización, pero con la particularidad de que al tratarse de un delito de peligro sería indiferente el ánimo subjetivo en el resultado (dolo o imprudencia), bastando un conocimiento aproximado de la peligrosidad sobre dicha utilización o dolo de peligro, no un conocimiento sobre la causación del resultado grave. Se puede aplicar dicho artículo, en la fenomenología sectaria, cuando la víctima fuere una persona especialmente vulnerable que conviva con el autor, como sucedería en los casos de sujetos que entran en la secta con una depresión anterior y conocida por el autor, esto es, aplicar la «agravante victimológica» ${ }^{1526}$ del aparado $5^{\circ}$ del art. $148 \mathrm{CP}$, cuestión que se da en ocasiones en la fenomenología sectariacriminal, o cuando la víctima llega con una enfermedad manifiesta previa o calificada de indefensión personal del apartado $3^{\circ}$ del art. $148 \mathrm{CP}$, que tras la reforma del Código penal por la

\footnotetext{
1523 CANCIO Meliá, M., vv.aa., Compendio de Derecho penal, Parte especial, Vol. I, op. cit., p. 416.

${ }^{1524}$ Por eso señala el TS y la doctrina que la mera exhibición de un arma, o una vara, o bate de béisbol, no fundamenta la agravación sino el sentido en que se apliquen sobre la víctima (STS 30 de septiembre de 1997).

${ }^{1525}$ Según la Circular 2/1999 de la Fiscalía General del Estado se entiende por grave enfermedad somática, la afección que crea un cierto riesgo vital como enfermedad psíquica grave que determina un riesgo psicótico profundo o de notoria incapacidad, vid. Herrera Moreno, M., vv.aa., Lecciones de Derecho penal, Parte Especial, T. I, op. cit., p. 107.

${ }^{1526}$ ID., ibidem, op. cit., p. 104.
} 
LO 1/2005, de 30 de marzo, parece ampliar el catálogo de este tipo de víctimas con la expresión «con discapacidad necesitada de especial protección», y que «al combinarse con los factores de desamparo situacionales o relacionales» ${ }^{1527}$ es aprovechada por el líder y/o el grupo, lo cual hace más reprochable el abuso. Nada impide en los casos expuestos de las sectas aplicar la agravación del apartado $5^{\circ}$ cuyo fundamento agravatorio es análogo al del $3^{\circ}$ del art. $148 \mathrm{CP}$, por cuanto que en los casos estudiados, se desprende la vulnerabilidad de la víctima en relación a su estado previo, o por sus circunstancias afectivas como la dependencia física y psíquica ${ }^{1528}$.

En nuestra opinión, dicha agravante, que mediaría por regla general en el delito de persuasión coercitiva (delito de coacciones y delito de lesiones graves) por la orientación de los medios de captación de la sectas coercitivas, y el tipo de sectadependiente que entra a formar parte de la organización y la relación que se crea durante la convivencia, recuerda el mismo fundamento agravatorio, tanto en tentativa como en consumación del delito de la violencia de género (arts. 153 y $173 \mathrm{CP})^{1529}$ y en cuya regulación la especial vulnerabilidad de la víctima, y a su vez, el especial dominio del autor, se funden en el mayor desvalor del hecho y su comunicabilidad del sentido criminal, fundamento que también subyace en la dinámica criminal de la persuasión coercitiva de las sectas. Esto significa que en unidad de acción confluyen agravantes específicas en los delitos de lesiones, lo que nos lleva a concluir también que aparecen implícitas las agravantes generales del art. $22 \mathrm{CP}$ en el delito de coacciones por persuasión coercitiva al menos en el tipo doloso (alevosía, abuso de superioridad y abuso de confianza).

De otra parte, si bien el art. $148 \mathrm{CP}$ criminaliza estados de peligro, nos interesa en nuestra problemática la causación de resultados lesivos. La doctrina ${ }^{1530}$ está de acuerdo en considerar que la perdurabilidad de la lesión es la clave y el fundamento de la agravación por el resultado en el art. 149 CP, en nuestro caso, en relación a la causación de una grave enfermedad somática o psíquica por medio de la persuasión coercitiva, cuya valoración vuelve a hacerse depender de la lex artis, del facultativo médico y de los peritos en los procedimientos judiciales, tanto en la

${ }^{1527}$ ID., ibidem, op. cit., p. 105.

${ }^{1528}$ Esto lo resalta GONZÁLEZ RUS «respecto del autor que hacen a la víctima particularmente susceptible de recibir de éste herida o lesión física o moral. Se requiere que esa situación de debilidad respecto del autor sea de cierta entidad e importancia («especialmente»). Por lo demás, es indiferente cuál sea la relación que se encuentra en el origen de la especial vulnerabilidad: relaciones familiares, afectivas, económicas, etc.», GONZÁLEZ RUS, JJ., vv.aa., Derecho penal español, Parte especial, op. cit., p. 154.

${ }^{1529}$ También se refiere a dicho fundamento HERRERA Moreno, M., vv.aa., Lecciones de Derecho penal, Parte Especial, T. I, op. cit., pp. 105 y 114.

${ }^{1530}$ CAnCiO Meliá, M., vv.aa., Compendio de Derecho penal, Parte especial, Vol. I, op. cit., p. 420. 
determinación exacta de la perdurabilidad como en el concepto normativo de la gravedad ${ }^{1531}$. Estamos al respecto de acuerdo con GoNZÁLEZ RUS ${ }^{1532}$ en que no se precisa que dicha lesión grave sea incurable, puesto que la agravación se fundamenta más en la perdurabilidad y dificultad de sanación que en la incurabilidad, que en cuyo caso, únicamente sería motivo para elevar al máximo la pena por el mayor desvalor del resultado.

De ahí que podamos concluir que la persuasión coercitiva que causa un déficit de socialización, que según los casos depende de la fortaleza de la víctima, de la prolongación del déficit, intensidad, etc., pueda tratarse como un delito de peligro del art. $148 \mathrm{CP}$, y en otros casos como delito de lesiones agravado por el resultado grave de lesión somática o psíquica. La problemática estriba en diferenciar los casos del $148 \mathrm{CP}$ y los de tentativa del $149 \mathrm{CP}$, puesto que al tratarse el art. $148 \mathrm{CP}$ de un delito de peligro, se puede confundir con la tentativa imprudente del art. 149 CP. En nuestra opinión, el dolo del art. 148 CP se trata de un dolo de peligro en la utilización del medio, mientras que el art. 149 CP trata exclusivamente del resultado, por lo que el dolo o la imprudencia se refieren al resultado, de lo que deviene que sean posibles ambos tipos según las circunstancias del caso y del autor.

Dicho esto, en relación al ámbito de nuestro estudio, parece claro que se pueda criminalizar al sujeto que sigue utilizando las técnicas de persuasión mediante el delito de peligro del art. 148 $\mathrm{CP}$, una vez se haya consumado el delito de coacciones a través de la persuasión coercitiva, y postergar la aparición de la probabilidad del resultado a la tentativa de delito contra la integridad psíquica. Esto es una cuestión de imputación, entonces, de los resultados tardíos. No obstante, entre ambos (art. 148 y $149 \mathrm{CP}$ ) se puede aplicar el concurso de leyes mediante el principio de subsidiariedad.

En nuestra opinión, la persuasión coercitiva es un proceso gradual de incapacidad de la libertad de voluntad, que si bien no resulta un claro trastorno psíquico de los catalogados en los manuales diagnósticos, sí que tardía y estadísticamente restringen la capacidad por medio de la eliminación de posibilidades y expectativas, lo que produce un «síndrome disociativo atípico» (adicción comportamental) u otra enfermedad, que permanece oculto o latente en el sujeto por la habitualidad de no poder escoger otras posibilidades y que aflora drásticamente como adicción comportamental una veces, y normalmente como trastorno postraumático, es decir, como consecuencia psíquica de la incapacidad de la libertad de voluntad y/o del freno o retroceso de esa «reforma del pensamiento». Y así estimamos que la persuasión coercitiva es un ataque a la

\footnotetext{
1531 CORCOY Bidasolo M / CARdenal Montraveta S / Fernández BaUtista S / Gallego Soler JI / GómeZ MARTín V / HoRTAl IBARRA JC., Manual práctico de Derecho penal, Parte Especial, op. cit., p. 137.

${ }^{1532}$ GonZÁlez Rus, JJ., vv.aa., Derecho penal español, Parte especial, op. cit., p. 156.
} 
libertad de actuar en general y a la libertad de conciencia, como restricción del horizonte de expectativas relativa a la causación de un déficit de socialización no permitido en derecho, que normalmente, y de forma tardía, causa una adicción.

\section{La dificultad de persecución penal}

En relación a la dificultad de perseguir los delitos de persuasión coercitiva, en nuestra opinión, la falta de incidencia corporal que tienen normalmente las técnicas de persuasión coercitiva, y la falta consentimiento de la víctima en la comprobación sobre la realidad del sometimiento a técnicas de persuasión coercitiva -salvo en los casos extremos de desnutrición, autolesiones, etc. - dificultan la persecución criminal de las organizaciones sectarias criminales y la autoría, porque las lesiones no son manifiestamente visibles, se reproducen en la psique o personalidad del sujeto y en ámbitos privados o secretos, y sólo afloran claramente cuando el sujeto abandona o se le expulsa del grupo, es decir, de forma tardía, por lo que la conexión de dicha lesión con la organización criminal y la autoría se dificulta también por el paso del tiempo. Esto trae problemas sobre imputación objetiva de los resultados tardíos, sobre lo que luego nos ocuparemos.

Dicho esto, en ocasiones se han utilizado técnicas de desprogramación ${ }^{1533}$ o contrarreforma del pensamiento para sanar y devolver al sujeto su libertad de obrar, sin embargo la aplicación de estas técnicas pueden constituir un delito, precisamente también de coacciones y/o contra la integridad psíquica, o de secuestro ${ }^{1534}$-recuérdese el caso CEIS y la condena del TEDH a España- si se imparten sin el consentimiento del sujeto, salvo en los raros casos ya mencionados de evidente incapacidad del sujeto. Por ello, aunque la finalidad de las técnicas de desprogramación o contrarreforma del pensamiento de un sujeto al que se le ha manipulado, «es contrarrestar el supuesto «lavado de cerebro» de ciertas organizaciones religiosas (...) en ocasiones, violentan la voluntad del prosélito lesionando gravemente su derecho de libertad religiosa ${ }^{1535}$. A este respecto el Tribunal Supremo de Estados Unidos ha declarado, amparándose en el derecho constitucional a la libertad religiosa (free exercise clause, y stablishment clause), que las prácticas de proselitismo mediante técnicas para la

1533 Sobre el estudio de la «desprogramación», CLARK, J., Comunicación personal, 1981.

1534 Vidal Manzanares, C., El infierno de las sectas, op. cit., pp. 168 y 169 explica que su aplicación en mayores de edad puede tratarse como secuestro, la única posibilidad es solicitar judicialmente la incapacitación legal.

1535 Motilla, A., Sectas y Derecho en España, op, cit., p. 185; en sentido similar VidAL MANZANARES, C., Diccionario de sectas y ocultismo, Verbo Divino, Estella, Navarra, 1991, p. 59; ID., El infierno de las sectas, op. cit., pp. 168 y 169. 
despersonalización vulneran la libertad religiosa, no así, claro está, los simples actos tendentes a convencer (evangelización/ proselitismo).

La prueba de un una persuasión coercitiva sería, como decimos, un «contra lavado de cerebro» o «desprogramación», que no se puede imponer en contra de la voluntad de un sujeto mayor de edad, ni a menor de edad con suficiente madurez, pues la libertad de conciencia es un derecho personal, que sólo puede ser ejercido por la misma persona, también de los menores de edad con suficiente madurez ${ }^{1536}$, a pesar de que la CE en su art. 27.3 garantice el «derecho que asiste a los padres para que sus hijos reciban la formación religiosa y moral que esté de acuerdo con sus convicciones». Por el contrario, si el menor no tiene la capacidad de comprensión necesaria, o si no tiene ni la madurez necesitada, el juez, en caso de conflicto del hijo con los padres, podrá denegar al menor entrar o profesar una religión o creencia, ya sea sectaria o no. En la actualidad está tomando relevancia en contra de la «desprogramación», los «consejeros de salida» (exit counseling), menos ofensiva porque cuenta con la libre participación del adepto.

Otra posibilidad consiste en realizar la declaración de incapacidad del artículo 200 CC, o en su caso aplicar el art. 211 del mismo cuerpo legal, un internamiento forzoso «por razón de trastorno psíquico de una persona que no esté en condiciones de decidir por sí». Si se probase un trastorno psíquico en un adepto, es aquí de donde viene, en nuestra opinión, la posible solución al problema para la persecución de tales conductas. Debe tenerse en cuenta que el art. 200 CC, parece limitarse a aquellas enfermedades mentales de carácter persistente, lo que dificulta la declaración de incapacidad de adeptos pues el «síndrome disociativo atípico» como trastorno típico resultante de la persuasión coercitiva es de carácter transitorio porque tiene reversibilidad, sin embargo en sí misma la lesión es permanente, lo que lleva a concluir de igual modo que el delito de lesiones es grave según el art. 149 CP (grave enfermedad somática o psíquica).

En nuestra opinión, la persuasión coercitiva es un proceso gradual de incapacidad de la libertad de voluntad, que si bien no resulta un claro trastorno psíquico de los catalogados en los manuales diagnósticos, sí que restringen la capacidad por medio de la eliminación de posibilidades y expectativas según lo visto, lo que produce en su caso un «síndrome disociativo atípico» (adicción), que permanece oculto o latente o resulta tardío en el sujeto por la habitualidad de no poder escoger otras posibilidades, que aflora drásticamente, normalmente

\footnotetext{
${ }^{1536}$ Lo cierto es que - tal y como recuerda LÓPEZ ALARCÓN- «siempre que concurran en el menor las condiciones de madurez que le permiten tomar decisiones por sí mismo» no se podrá imponer, ni una religión ni una técnica de desprogramación en contra de su voluntad, LÓPEZ ALARCóN, M., «El interés religioso y su tutela por el Estado», vv.aa., Derecho Eclesiástico del Estado Español, 2a ed., Pamplona, 1983, p. 539.
} 
como trastorno postraumático, es decir, como consecuencia psíquica de la incapacidad de la libertad de voluntad y/o del freno o retroceso de esa «reforma del pensamiento». Sentada la base de que las técnicas de persuasión coercitiva gradualmente incapacitan al sujeto en dos estados diferenciados, por un lado un primer momento de déficit de socialización, y por otro, normalmente posterior una lesión psíquica con algún trastorno o adicción comportamental, la causación de un déficit de socialización puede incluirse en la formula civil de incapacitación del art. $200 \mathrm{CC}$ y, a los efectos del delito de lesiones, incluir el «síndrome disociativo atípico», la «adicción»y otros trastornos sectarios y post-sectarios en el catálogo de enfermedades somáticas o psíquicas.

Así las cosas, el procedimiento legal a seguir en tales casos será una demanda civil de incapacitación por parte de los familiares y/o Ministerio Fiscal, cuando existan indicios claros del proceso de desocialización o de adicción comportamental, para que una vez conseguida la incapacitación, los tutores y/o el Ministerio Fiscal puedan querellarse criminalmente contra el grupo por incurrir en el delito de coacciones y/o en el delito contra la integridad psíquica, intentada o consumada, pero a su vez, para tratar al sujeto mediante pautas socializantes en el caso de déficits de socialización, o mediante tratamientos médicos en el caso de una enfermedad psíquica o una adicción comportamental.

La problemática vendrá también de que un tratamiento psicológico no tiene la entidad de tratamiento médico, por lo que en el caso de que únicamente se precisase éste, como podría ser en casos de procesos de desocialización leves y/o cortos en el tiempo, no se podría imputar el delito de lesiones, sino exclusivamente el delito de coacciones. No obstante, y en nuestra opinión, este tipo de lesiones psíquicas precisan de tratamiento psiquiátrico o médico en virtud de la naturaleza adictiva que causa la persuasión coercitiva. Es decir, en todo caso, la aplicación de un tratamiento psicológico por sí solo no fundamentaría la imputación objetiva de un delito de lesiones, salvo si tal tratamiento psicológico ha sido prescrito al menos por un médico, psiquiatra o psicólogo clínico, aunque posteriormente se delegue al psicólogo o al auxiliar el seguimiento y la práctica efectiva del tratamiento ${ }^{1537}$.

No obstante, debemos terminar comentando que después de lo estudiado nos sorprenda que casi la práctica totalidad de los estudios sobre sectas, tanto doctrinales como pertenecientes a otras ciencias, consideran que no existe un vacío legal en el ámbito de las sectas, en el sentido de

1537 SSTS 355/2003 de 11 de marzo, y 372/2003 de 14 de marzo. 
concluir que el ordenamiento jurídico actual es suficiente ${ }^{1538}$ para dar una respuesta punible a las sectas y que únicamente existen carencias preventivas. Por nuestra parte, según los tipos analizados, es posible la criminalización de las conductas que atentan contra la capacidad o formación de la libertad, contra la capacidad de decidir, la capacidad de ejecución de la voluntad y la libertad, sin embargo, al no existir un tipo específicamente diseñado para combatir conductas de persuasión coercitiva, se difumina su criminalización mediante los tipos tradicionales.

\section{VII.- Delitos contra la vida}

No es normal que una secta criminal induzca u ordene el suicidio de sus miembros, pues esto no reportaría beneficios. El afán de lucro es uno de los principales fines de una secta criminal, pero en ocasiones se llegan a tales extremos cuando la dinámica grupal alcanza la modificación de los conceptos esenciales de la sociedad. En este caso, los conceptos vida/muerte pierden su sentido y vigencia social.

Son cuantiosos los ejemplos de suicidios colectivos ${ }^{1539}$ (asesinatos en masa) o inducciones de suicidio aislados o asesinatos en la fenomenología criminal de las sectas enemigas. Se comenta ${ }^{1540}$ que en estos casos existe una delgada línea entre una autoría mediata de asesinato o inducción al suicidio (143.1 CP) y la ayuda al suicidio (143. 2 y 3 CP). Se suele argumentar que el auxilio al suicido merece una pena menor, porque el sujeto consiente libremente el auxilio de un tercero para causarse la muerte. Para que la aportación de un sujeto a la muerte de un tercero sea constitutiva de asesinato se suele exigir que la víctima sea un instrumento necesario para su

${ }^{1538}$ CUGAT MAURI, Miriam, Sectas y sectarios ante el derecho penal, Revista de Derecho y proceso penal, núm. 22, Aranzadi-Thomson Reuters, Navarra, 2010; FONT BOIX, I., «El concepto de manipulación mental en las llamadas sectas», op. cit., pp. 355 y ss., pero reconoce sobre la fórmula alteración o control de la personalidad «salvo que el legislador - superando en este caso el trabajo de los psiquiatras - fuera capaz de precisar las bases materiales sobre las que edificar una noción en la actualidad tan etérea»; ID., «Propuesta de despenalización radical en la legislación española de los medios de control o de alteración de la personalidad en relación con las llamadas sectas», op. cit., pp. 89 y ss; Goti OrdeñanA, J., «Síntesis conclusiva», vv.aa., Aspectos socio-jurídicos de las sectas desde una perspectiva comparada, op. cit., p. 404; MAQUEDA ABREU, Má,., «Las sectas destructivas ante el Derecho», op. cit., p. 246; MARTín SÁNCHEZ, I., El Derecho a la formación de la conciencia, op. cit., p. 282; si bien tiempo después aceptará cierta necesidad de legislar MotiLla, A., Sectas y Derecho en España, op. cit., p. 215; PÉREZ-MADRID, F., La tutela penal del factor religioso en el Derecho español, op. cit., p. 203; TAMARIT SUMALLA, JM ${ }^{\mathrm{a}}$., La libertad ideológica, op. cit., pp. 247 y ss; RoDRíGUEZ, P., Adicción a sectas, op. cit., pp. 343 y ss; ID., «Estado actual de la problemática sectaria en España», Sectas y Sociedad, 1987, Barcelona, p. 11; VÁzQUEZ, JMª, Familia y sectas, op. cit., p. 76; aunque con salvedades, VIDAL MANZANARES, C., Psicología de las sectas, op. cit., pp. 136 a 139; ID., El infierno de las sectas, op. cit., p. 160 reclama más control administrativo a favor de los adeptos y especialmente de los menores.

1539 NAVAs RENEDO, B., Tratamiento jurídico de las sectas, op. cit., p. 312, en donde cronológicamente muestra algunos ejemplos: el de la secta «El Templo del Pueblo» en Guyana en 1978, con 914 muertos, el de la secta de los «Davidianos» en Waco, en 1993, con 88 muertos, y los 800 muertos en el año 2000, de la secta «Movimiento de la Restauración de los diez mandamientos de Dios», en Uganda.

${ }^{1540}$ MuÑoz CONDE, F., «Provocación al suicidio mediante engaño: un caso límite entre autoría mediata en asesinato e inducción y ayuda al suicidio», $A D P C P, 1987$, pp. 301 a 317. 
propia muerte. Sin embargo, sobre esto último, hay que realizar algunas matizaciones porque en la dinámica comportamental de los miembros de sectas, existe cierta participación consciente que pone en tela de juicio la tradicional concepción y trascendencia jurídico-penal en el principio de responsabilidad de la víctima.

En el caso de que la víctima sufriera una persuasión coercitiva, es decir, un sujeto al que se le hubiera mermado la capacidad cognitiva y/o volitiva, o al menos se conociera por el autor que pude dominar su voluntad, el autor respondería por asesinato, porque la alevosía radicaría en la modalidad de «aprovechamiento de una especial situación de desvalimiento», o en definitiva «empleando en la ejecución medios, modos o formas que tiendan directamente o especialmente a asegurarla», como en este caso procura la persuasión coercitiva a través del concepto de violencia o engaño en la libertad de voluntad de la víctima y problemas de concurso entre la persuasión y el delito de asesinato.

El Tribunal Supremo alemán, en una importante Sentencia de fecha 5 de julio de 1976, comentaba que «(s)i se oculta al que está quitando la vida, que realmente está causando la muerte, hay que considerar que el que provoca este error y con ayuda conduce conscientemente y voluntariamente el proceso que desemboca o debe desembocar en la muerte, es autor de un delito contra la vida... en virtud de su superior conocimiento, con el que manipula al engañado y lo convierte en instrumento contra sí mismo». También es factible que un sujeto se vea obligado a procurarse la muerte, aun conociendo que después de ella no hay vida alguna, en el caso de que el deber moral de la secta le lleve al conflicto entre seguir vivo o seguir la orden, o en casos en los que los conceptos esenciales de la Sociedad, en este caso, la vida, pierden vigencia y se trasforman en una garantía de expectativa deficitaria. Aquí la problemática reside en ciertos márgenes de libertad de la víctima, lo que plantea la posibilidad de la coautoría del propio «asesinato». Sobre esta temática volveremos al tratar la autoría y la participación.

Un caso digno de mención fue la Sentencia de 29 de julio del Tribunal de segunda instancia de Lyon, que condenó a tres años de cárcel a Jean-Jacques Mazier, ex-presidente local de la Iglesia de la Cienciología, por haber inducido al suicidio a una mujer que pertenecía a este grupo religioso $^{1541}$. Sin embargo, la Sentencia declaró que la Cienciología podía considerase una religión y nada tuvo que ver con este hecho.

${ }^{1541}$ Vid., Revista ZENIT, Kerygma, Itd., Lyon, 30 julio de 1997. 
Otro caso al que ya hemos hecho referencia es el suscitado en la Sentencia de Audiencia Provincial de Alicante, sección $3^{\text {a }}$, de 12 abril de $2003^{1542}$ (rec. 26-2003), sobre un homicidio imprudente por dos sujetos afiliados al grupo Osho Commune Internacional, filial de Osho Rajneesh, y que versa sobre la práctica «terapéutica» denominada «niño interior» ya comentada. La Sentencia consideró probada la relación causal entre la acción de los sujetos intervinientes y la muerte de la víctima como fundamento de la imputación del delito de homicidio a título de imprudencia.

Más recientemente el parricidio en la secta Antarés de la Luz, en la que una madre colaboró en el sacrificio quemando vivo a su hijo recién nacido el 23 de noviembre de 2012 por considerarlo el Anticristo y con el fin de salvar el mundo ${ }^{1543}$, o el ocurrido en Tenerife en la que la líder preparó a 33 seguidores para el «suicidio» con el objetivo de «prevenir el fin del mundo» ${ }^{1544}$. De otra parte, el médico aleman Ryke Geerd HAMER, creador de la llamada Nueva Medicina Germánica, fue condenado 3 años de prisión por ejercicio ilegal de la Medicina y estafa, puesto que oficialmente estaba inhabilitado para ejercerla y asesoraba a personas que le habían consultado sobres problemas de cáncer.

De este modo la controversia es si pueden considerarse estas tendencias de acabar con la vida propia de suicidios o, al contrario, de homicidios o asesinatos, tal y como considera parte de los estudios en psicología ${ }^{1545}$.

\section{VIII.- Delitos patrimoniales}

La estafa es otro de los ilícitos estrella en los que incurren las sectas criminales. Prometen soluciones a los problemas y una supuesta salvación a un precio muy alto que desconoce el adepto y al que no se le suministra información sobre la realidad y finalidad del grupo ${ }^{1546}$. La estafa es una conducta injusta muy cercana al proselitismo ilícito. Se promete algo que no se da, ni se pretende dar. Se juega con las debilidades de las personas. Los líderes y miembros activos

1542 SAP de Alicante, Sección $3^{\text {a }}$, de 12 abril de 200, rec. 26-2003, sobre recurso de apelación contra la Sentencia núm. 406/02, de fecha 10 septiembre, dictada por el Juzgado de lo Penal núm. 1 de Benidorm, Procedimiento Abreviado núm. 76/00.

${ }^{1543}$ Vid. CueVAs BARRANQUero, JM., Evaluación de persuasión coercitiva en contextos grupales, op. cit., p. 34.

${ }^{1544}$ Vid. ID., ibidem, op. cit., p. 62.

1545 Por ejemplo CUEVAS BARRANQUERO, JM., Evaluación de persuasión coercitiva en contextos grupales, op. cit., p. 62 comenta que «(e)n definitiva, alteraciones de la conciencia y graves distorsiones cognitivas y de la capacidad crítica que provocan que la muerte no fuera, verdaderamente, una decisión elegida voluntariamente, sino la única opción de escape ante la creencia firme en una muerte dolorosa e inminente»; SINGER MT / LALICH J., Las sectas entre nosotros, op. cit., pp. 327 y ss.

${ }^{1546}$ Se comenta al respecto que muchos ex-miembros de sectas llegan a decir que «(s)i hubiera sabido por anticipado cada una de las cosas que finalmente, y en forma gradual, me llevarían a hacer, nunca habría ingresado», SINGER MT / LALICH J., Las sectas entre nosotros, op. cit., p. 101. 
son conoceros que el sujeto captado se acerca a un grupo de esta naturaleza para conseguir aliviar su dolor, o buscar la salvación, y con este conocimiento parten con ventaja para materializar el fin delictivo, en muchísimos casos la estafa.

La diferencia con la simple y sana evangelización o con la venta de servicios/productos religiosos con respecto al proselitismo ilícito y a la estafa radica en la intención de engañar bajo la promesa de realizar o conseguir algo que desde el principio se conoce que no se puede dar o al menos existe una garantía de expectativa cognitiva deficitaria.

Interesa en la estafa y en nuestro ámbito de estudio principalmente el concepto de engaño. No se trata de «cualquier engaño», ni de cualquier «mentira» (se ha superado la concepción de la «buena fe», si bien se afirma por algunos, como veremos, el derecho de veracidad o fidelidad), sino aquellos que son «bastantes» (idoneidad objetiva) para producir el error que ha de producirse por el engaño, y en definitiva darse un acto de disposición patrimonial o todos los actos tendentes a tal efecto (tentativa), en perjuicio propio o de tercero y con ánimo de lucro (elemento subjetivo de lo injusto, se excluye la imprudencia).

Aquí interesa en la dinámica criminal de las sectas la relación de idoneidad entre las características y circunstancias de autor y víctima, por un lado los especiales conocimientos del autor que le otorgar un mayor dominio, y por otro la credulidad de la víctima o su especial vulnerabilidad (por esto es un «delito de relación»), al menos si son conocidas por el autor para aprovecharse y no haya cierta falta de diligencia de la víctima, y en la actualidad la agravante sólo en las relaciones existentes entre víctima y defraudador como abuso de confianza (art. 250.1.6 $\mathrm{CPv}$ que elimina la anterior agravante de abuso de superioridad en las circunstancias personales de la víctima del art. $529.5^{\circ} \mathrm{CPd}$ ).

Así y de tal modo, es habitual en la doctrina y jurisprudencia rechazar la estafa en los casos de curanderos, exorcistas, ofertas paranormales o extrasensoriales, etc., al faltar una peligrosidad objetiva, sin embargo se suele aceptar si se crean falsas ideas o representaciones de la realidad $^{1547}$ (no cuando el sujeto se percata y el acto de disposición es pura liberalidad), aunque existen dudas según los casos sobre los «juicios de valor».

1547 Por ejemplo, Bustos Ramírez, J., Manual de Derecho penal, Parte especial, op. cit., p. 192, «salvo que se lleven a cabo maquinaciones especiales para crear en cualquier persona una falsa idea de la realidad»; CORCOY

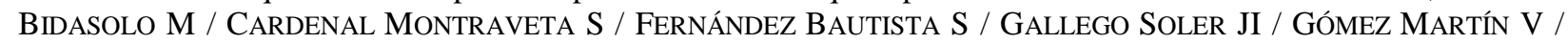
Hortal IBARRA JC., Manual práctico de Derecho penal, Parte Especial, op. cit., pp. 567 y 568 comentan la STS de 6 de mayo de 2002 en relación a la «atipicidad parcial de quien afirma que posee facultades paranormales o extrasensoriales; el delito surge cuando se abusa de la credulidad de los perjudicados una vez que ha sido captada su voluntad por el sujeto activo obteniendo desplazamiento patrimonial por trabajos distintos a la mera consulta», y exponen el caso de la SAP de Zaragoza, de 10 de marzo de 1999 que consiste en una paciente aquejada de artrosis degenerativa sometida a un tratamiento de acupuntura y Moxa para curar su enfermedad, concluyendo acertadamente, que «(s)i engaño es la discordancia entre la realidad y la manifestación de ésta que se ofrece por el 
Al respecto, PASTOR MUÑOZ entiende que «los motivos supersticiosos quedan fuera del modelo de racionalidad vigente, así que, si un sujeto decide basar sus decisiones en informaciones supersticiosas, lo hace por su cuenta y riesgo. Si el vendedor de un producto miente sobre la posición de las estrellas, no se hace competente por la decisión económica del comprador, aun cuando este último tome su decisión con base en esa información inveraz. En tal caso puede decirse que el comprador está en un error y que el vendedor lo ha causado, pero ese déficit de información no tiene (normativamente) nada que ver con la decisión de disposición. Por consiguiente, no hay engaño típico y el acto de disposición se debe interpretar como una decisión libre y responsable del disponente (...) la víctima no debe confiar normativamente en que determinados productos sean eficaces. Ello es así porque la víctima se ha de ajustar al modelo de racionalidad vigente en el mercado» ${ }^{1548}$, pero matiza que «cuando la afirmación de que el producto es eficaz se considere verosímil, se abre la puerta a la posibilidad de apreciar está, mientras que esta última debe negarse cuando el mensaje del autor solamente pueda interpretarse como expresión de una ilusión», salvo que la víctima pueda considerarse «estructuralmente débil» ${ }^{1549}$, con lo que nos mostramos conformes. Sin embargo esta penalista relaciona la debilidad con la inimputabilidad y no considera acertado concluir que exista en el autor en estos casos un mayor deber de veracidad (en cuyo caso lo lleva a la sustracción), salvo

sujeto activo, ninguna duda debe existir al respecto de que concurre (...) engaño, por cuanto es un dato no controvertido científicamente que una enfermedad ósea degenerativa no tiene curación, sino únicamente tratamientos paliativos para mitigar el dolor. Hacer creer a quien está sufriendo estos males que la acupuntura y las sesiones de lo que se ha denominado «Moxa», que no es otra cosa que quemar unas palmatorias en las palmas de las manos, que con ese tratamiento sanará es objetivamente falso», con la aplicación de la agravante del $250.1^{\circ}$ por la agravación de la salud, y el delito continuado, ID., ibidem, op. cit., pp. 576 y 577; PÉREZ MANZANO, Mercedes, vv.aa., Manual de Derecho Penal, Parte Especial, Delitos patrimoniales y socioeconómicos, $2^{\mathrm{a}}$ ed., Editorial Centro de Estudios Ramón Areces, 1993, pp. 277 y 284 porque el acto de disposición no se da por el error, sino por la «caridad, curiosidad, ignorancia absoluta previa o creencias previas adoptadas por el sujeto. Aunque reconoce que el error puede estar motivado por la falsa representación, ID., ibidem, op. cit., p. 284 nota 106. Sin embargo la STS, de 2 de febrero de 2007, absolvió a una curandera que quería acabar con el cáncer por medios supersticiosos, al entender que la inverosimilitud de los medios curativos no constituían engaño sino un acto de fe, de modo que la confianza en la magia no puede ser objeto de tutela penal, vid. HERRERA MoRENO, M., vv.aa., Lecciones de Derecho penal, Parte Especial, T. II, op. cit., p. 94.

1548 PASTOR MuÑoz, N., La determinación del engaño típico en el delito de estafa, pról. Jesús-María Silva Sánchez, Marcial Pons, Madrid-Barcelona, 2004, p. 248.

1549 ID., ibidem, op. cit., p. 249 y pp. 256 y ss. Expone el caso del BGHSt 34, 199, en el que el Tribunal Supremo Alemán «condenó por estafa a quienes ofrecían baños rejuvenecedores (en diez minutos, cinco años más joven), pastillas de adelgazamiento y de crecimiento acelerado del cabello y otros productos semejantes; para llegar a esta solución, el Tribunal se apoyó, en cierta medida, en el argumento de la «verosimilitud» de la oferta. Con todo, la decisión del BGH de condenar por estafa es, a mi entender, discutible, pues las afirmaciones realizadas por los vendedores sobre las virtudes de los productos eran difícilmente creíbles para un ciudadano medio, así que la conducta de la víctima debería haber sido calificada de excesivamente crédula (y, por tanto, de conducta por su cuenta y riesgo). Un problema distinto es el tratamiento de los casos de venta de ilusiones a víctimas débiles y, en concreto, a víctimas de capacidad intelectual disminuida o de formación cultural muy reducida», ID., ibidem, op. cit., p. 249. 
que la víctima no tenga una debilidad que fundamente la inimputabilidad» ${ }^{1550}$. Pero según nuestras conclusiones, la debilidad no lleva per se a la inimputabilidad, sino en su caso al delito de persuasión coercitiva o al de lesiones psíquicas, cuyos márgenes de libertad no fundamentan la inimputabilidad, sino inclusive cierta responsabilidad en la intervención de posteriores delitos.

Interesa especialmente la estafa en comisión por omisión, por ejemplo cuando existe competencia de evitar el error en el que incurre la víctima o un tercero, si bien la doctrina discrepa sobre su posibilidad incluso llevándolo a un asunto civil. En nuestra opinión, la comisión por omisión es representativa en los casos de nuestro estudio como una modalidad muy habitual según hemos concluido respecto a la confianza que genera garantía o garantía que genera confianza ${ }^{1551}$

El problema en la estafa también redunda en la intromisión o limitación de la libertad, de modo que se pueden apreciar problemas concursales con la persuasión coercitiva. Esto es porque pueden coincidir el tipo de engaño coercitvo en ambos delitos.

A este respecto, miembros de la Iglesia de la Cienciología fueron imputados por estafa por la acusación formulada del Ministerio Fiscal (no por los perjudicados). La Audiencia provincial de Madrid en la ya tan citada Sentencia de 28 de noviembre de 2001, absolvió a los imputados por estimar que no concurría el requisito esencial de la estafa, el engaño ${ }^{1552}$. La Audiencia provincial concluyó que no se vislumbraba, con la necesaria nitidez, engaño ninguno ${ }^{1553}$. En primer lugar se sobreseyó el procedimiento sobre este ilícito por desistimiento de la acción por parte de los particulares, y en segundo lugar, los perjudicados dieron altas cantidades de dinero a cambio de determinados cursos formativos para alcanzar la cualidad de «Claro», cursos efectivamente se realizaron. Comenta al respecto la Sentencia que «(c)laro que numerosas declaraciones vertidas en el acto del plenario permiten concluir que los servicios prestados por la organización, incluidas las curas, auditorías y recorridos de purificación, no eran gratuitos. Al revés, exigían desembolsos de sumas elevadas de dinero. Así se desprende de la declaración del testigo Antonio J. G. U., quien afirmó que para conseguir el objetivo de llegar a «claro» le pidieron la suma de 2.000.000 de ptas». Pero - como sigue afirmando la Sentencia- el cobro de tales cantidades no es

\footnotetext{
${ }^{1550}$ Entiende que «(e)n estos supuestos, los deberes de veracidad del autor frente a la víctima débil son los mismos que tendría frente a una víctima normal, salvo que se constate que el autor ha adaptado su comportamiento a la debilidad de la víctima para sacar provecho de la situación, es decir, que se ha separado del comportamiento estándar propio de su posición en la relación económica. En esos supuestos, el acto de adaptación debe interpretarse como un acto de asunción de mayores deberes de veracidad, ID., ibidem, op. cit., pp. 257 y 258.

${ }^{1551} \mathrm{Al}$ respecto basta ver también la modalidad de estafa impropia del art. $251.2^{\circ} \mathrm{CP}$ en relación a la ocultación de carga, o generalmente en la omisión del deber de declarar algún dato.

${ }_{1552}$ SAP de Madrid núm. 335-2001, de 28 de noviembre de 2001.

${ }^{1553}$ FJ $3^{\circ}$ de SAP Madrid núm. 335-2001, de 28 de noviembre de 2001.
} 
suficiente para dilucidar el elemento central del ilícito, el engaño, pues muchos de los miembros alcanzaron tal cualidad, y los que no lo alcanzaron, en la mayoría de casos no se sintieron engañados, por lo que el medio utilizado, el E- Meter ${ }^{1554}$, aunque es un aparato inocuo y que funciona -opinan algunos- falsamente a modo máquina de la verdad, no es bastante para la imputación objetiva del delito ${ }^{1555}$. No obstante, bien es cierto que a los perjudicados que se sintieron engañados la Cienciología les devolvió las cantidades pagadas por tales cursos, sobreseyéndose la causa finalmente sobre este injusto en la mayoría de acciones iniciadas.

En el proceso de Niños de Dios, el Ministerio Fiscal acusó por el delito de estafa a los miembros de este grupo, en concreto, por la adquisición de donativos bajo la apariencia de obrar como misioneros. La Sentencia de la Audiencia Provincial desechó la estafa, consideró que no se apreciaba engaño. Comenta la Sentencia que los «misioneros» se presentaban necesitados de alimentos y abrigos, lo que era cierto por los escasos recursos que poseían. El hecho de que se presentasen como misioneros tampoco desprende una artimaña de engaño, realmente pertenecían al grupo religiosos también denominado Familias Misioneras, y como dice la Sentencia «no existe prueba de que así no se considerasen, pues como destaca el Ministerio Fiscal grupos afines existían en otros países y alguno de ellos claramente tercermundistas e incluso en los últimos lugares de la hambruna, como acontece con Bangla-Desh, y de otra nunca se presentaban con «hábitos» o vestimenta que pudiere inducir a confusión respecto a los misioneros de la religión predominante en España» ${ }^{1556}$.

Prosigue la meritada Sentencia que «(l)os actos de disposición fueron donaciones de mera liberalidad (artículo 818 del Código Civil) o remuneratorios (artículo 819) como la «voluntad» frente al reparto de «casetes», folletos de divulgación, «posters»; de otra parte lo donado carecía de entidad patrimonial para el donante, no para los donatarios, al consistir en prendas con taras, alimentos que por su pronta caducidad no podían comercializarse, pero sin ser consumidos con inmediatez, o como el ortopédico que la primera vez regaló la plantilla que hizo a una persona presente pero cobró puntualmente el segundo encargo, sin resistencia por los del grupo, debiendo destacarse que prácticamente en todos los casos los donatarios, que en realidad se identifican por

1554 Aparato patentado por la Cienciología para realizar los «auditing» o también llamadas sesiones de perfeccionamiento que, a través de las preguntas del «auditor» (instructor o terapeuta) cuantifica los niveles eléctricos de la piel de la persona, a modo de máquina de la verdad, aunque hay quienes consideran que la aguja es manipulada durante las sesiones para sonsacar secretos personales del sujeto.

${ }^{1555}$ La SAP de Madrid núm. 335-2001, de 28 de noviembre de 2001 en su FJ $3^{\text {o: }}$ «Sin embargo, el cobro de cantidades por los servicios prestados, y para la financiación de la organización, es algo que no puede, ni con mucho, ser demostrativo del tantas veces mencionado delito de estafa. Frente a testigos como Ana G. R. se han sentido engañados, por no obtener el beneficio que esperaban, hay otros que sostienen lo contrario, y además se trata de personas que no colaboran con la organización».

${ }^{1556}$ FJ $7^{\circ}$, de la SAP de Barcelona, Sección $3^{\mathrm{a}}$, de 29 junio de 1993. 
aceptarlo los acusados, firmaban albaranes en los que estampaban su real identidad proporcionando, como queda dicho, su real domicilio» ${ }^{1557}$.

Sin embargo, la oferta de una religión o la oferta de evangelización, cuando no sea más que una terapia de relajación o medida terapéutica basada en el psicoanálisis como parece que ofertan algunos grupos, podría considerarse una estafa patrimonial masiva, o inclusive una estafa que afecta a los intereses generales, cuando el sujeto desconoce la realidad de la terapia o medida, lo que haría actuar al Ministerio Público de oficio. En definitiva podríamos decir que la oferta religiosa de multitud de sectas o grupos religiosos, no cumple la cualidad fundamental de religión propia, ni siquiera de religiosidad. En ocasiones la oferta no supone más que medidas de relajación o terapéuticas que como el psicoanálisis pertenecen al ámbito de la ciencia de la psicología, y que para ser practicada precisa de la titulación oficial o académica legalmente establecida. Si el sujeto desconoce este alcance, ni se le informa, según los casos, además de un delito de intrusismo profesional podría concurrir el delito de estafa si, en efecto, no existe una doctrina o credo que respalde la medida de relajación o terapéutica.

En otro orden, la falsedad documental suele aparecer en grupos de esta índole criminal como apoyo a la perpetración de las estafas. En ocasiones se ha falsificado la titularidad de títulos oficiales para el ejercicio de profesiones de un determinado ámbito, o la falsificación de la inscripción sobre filiación o sobre el estado civil.

Un caso sonado sobre esta última modalidad lo encontramos en la Sentencia de la Audiencia Provincial de Barcelona, Sección 4, de 21 de diciembre de 1989, sobre el grupo religioso Raschimura, cuyo líder Raschimura Yogui fue condenado por ordenar a miembros de su grupo casarse con cuatro mujeres del mismo grupo para inscribir en el Registro Civil, a nombre de éstos, los hijos que había tenido con ellas, con el objetivo de que los niños pasasen a ser hijos de las cuatro parejas. La sentencia condenó por un delito de falsedad en documento público por «haber faltado a la verdad en las declaraciones que efectuaron en el Registro Civil», pero se apreció la concurrencia de la eximente incompleta de enajenación mental por disminución de la capacidad volitiva en los demás intervinientes, por el control mental realizado por el líder de esta secta. Llama poderosamente la atención que la Sentencia aplique esta eximente incompleta, pero no condene, ya fuere por falta de acusación del Ministerio Fiscal o por lo que sea, por el control mental o persuasión coercitiva que aminoró la voluntad de los intervinientes. Quizá la falta de condena fuere por la ausencia de acusación en el escrito de conclusiones provisionales, pero cierto es que la Ilustrísima Audiencia pudo deducir testimonio, a la postre, para la incoación de

1557 Ibidem 
un procedimiento por delito contra la integridad moral al menos. Otro caso también de relevancia mediática fue la condena de la Sentencia de la Audiencia Provincial de Huelva, de fecha 21 de noviembre de 1992, por falsificación de recetas médicas en las que se utilizaban nombres y números de colegiados falsos, para que la líder obtuviera sustancias que posteriormente suministraba a sus fieles.

En suma, tras el análisis de los diversos tipos delictivos que se manifiestan aparentemente en la dinámica criminal de las sectas, se puede concluir que las técnicas de persuasión coercitiva encajan mejor en el concepto de violencia y en la forma comisiva del delito de coacciones como eliminación de alternativas y en relación a la incapacidad de formación de la voluntad, o como restricción de alternativas en relación a la incapacidad de decisión propia. En ambos supuestos se puede distinguir entre el delito de lesiones psicológicas o adicción comportamental y el delito de coacciones respectivamente, y en ambos casos perpetrados mediante la persuasión coercitiva dolosa o imprudente. En definitiva, este sería el delito estricto sensu de las sectas coercitivas, al que habrá que sumar en su caso, con los problemas de concurso que se forman, otros delitos habitualmente comunes: los delitos contra la vida, contra el patrimonio, contra la libertad e indemnidad sexual y el delito de intrusismo profesional (también el delito de asociacionismo ilícito y el delito de organización como veremos infra). En todos estos casos, además, no ha de olvidarse que la persuasión coercitiva se puede ejercer en autores de conciencia, por convicción y en los enemigos sin que cambie su conceptualización, o dicho de otro modo, en estas tipologías aparecen también interferencias de imputación atribuible a tercero que repercuten en la responsabilidad de estas tipologías. 


\section{CAPÍtulo Vi}

\section{IMPUTACIÓN OBJETIVA EN LA «PERSUASIÓN COERCITIVA» COMO EJEMPLO DE DÉFICIT DE SOCIALIZACIÓN ATRIBUIDO A TERCERO}

\section{I.- Introducción}

Concluimos en el capítulo segundo que en ocasiones el autor de conciencia obra bajo un déficit de comunicación o socialización atribuido a la norma, por cuanto en ciertos casos la norma no ha provisto de alternativas de comportamiento. Este déficit nos sirvió para fundamentar el estado de necesidad exculpante en casos especiales de autoría de conciencia, en contraposición al autor por convicción y al enemigo. Sin embargo, también señalamos que pueden existir interferencias imputables a un tercero en la conducta libre del autor de conciencia, por convicción y en el enemigo. En el ámbito de las sectas se ha podido comprobar como la conducta de un tercero, o inclusive la dinámica grupal, interfieren en la responsabilidad de éstos mediante la persuasión coercitiva. En este capítulo analizaremos los presupuestos objetivos de la imputación a un tercero que crea los condicionantes de la persuasión coercitiva como déficit de socialización y que afecta a la responsabilidad de dichas tipologías criminales enmarcadas en el supuesto de las sectas coercitivas.

Así las cosas, tradicionalmente la doctrina se ha ocupado de la problemática que estriba en la imputación objetiva del tipo, que en la actualidad la moderna teoría de la imputación objetiva trata de resolver, no sin problemas de toda índole, sobre qué condiciones puede atribuirse un resultado a una conducta. Debemos analizar en qué circunstancias puede atribuirse a un sujeto la acción de persuasión y el resultado de coacción o lesión psicológica. Existen diferentes teorías que plantean soluciones significativamente divergentes, entre ellas: teoría de la equivalencia de las condiciones, teoría de la conditio sine qua non y teoría del riesgo.

Sin llegar a sostener un determinismo absoluto, los defensores del libre albedrío también tendrán que reconocer que ciertas formas de psiquismo, a pesar de su extraordinaria dificultad en hallar la causalidad, llevan a condicionar la voluntad en casos tales como la inducción, los consejos, la propia coautoría, la sugestión y evidentemente la persuasión coercitiva. Precisamente, uno de los temas controvertidos en la doctrina penal es la imputación de los cursos 
causales no verificables, aquellos en los que las ciencias aún no han señalado la causa, sin embargo, la doctrina está de acuerdo en que aun sin dicha comprobación existe cierta relación. Estos casos son lo que se producen en la persuasión coercitiva, no así en la adicción comportamental, en donde la intensidad es tal que es más fácil comprobarla por la ciencia médica.

Estamos de acuerdo con gran parte de la doctrina en que no pueden establecerse leyes generales sobre la causalidad, ni tomar una como imperativo categórico y desdeñar otra, sino que según el caso todas tienen una mayor o menor relevancia. En nuestro ámbito de estudio se debe determinar qué riesgo ha causado el resultado de la coacción, es decir, si entre la creación de un riesgo y el resultado producido hay una relación que fundamenta la imputación del resultado, esto es, si existe «relación de riesgo». En este sentido la teoría de la conditio sine qua non y la fórmula hipotética no son satisfactorias. Otro sector de la doctrina se decanta por el criterio del comportamiento alternativo conforme a Derecho que hubiera evitado el resultado, pero este criterio es sumamente arbitrario cuando en el caso en cuestión apenas existen alternativas o cuando la norma no orienta sobre el comportamiento alternativo según lo expresado: escases de alternativas.

Por nuestra parte, es de utilidad para determinar si un riesgo es el causante del resultado los criterios generales que utiliza JAKOBS ${ }^{1558}$, quien afirma que los riesgos inherentes del contacto social son permitidos, pero no cuando se vulneran las normas generando un peligro para los demás (desatención de las normas de tráfico rodado), en la infracción de normas técnicas, como la lex artis, y también en aquellos ámbitos en los que sin estar regulados existe un modelo de comportamiento habitual: nivel de tolerancia. Los conocimientos especiales del autor no pueden ser imputados si no son exigidos normativa o socialmente en el concreto ámbito de organización, o en el caso de capacidades extraordinarias, lo que precisa del principio de confianza para concretar el riesgo permitido.

\section{II.- Instituciones de la imputación objetiva en la persuasión coercitiva como déficit de socialización atribuido a tercero}

El quebrantamiento del rol supone el fundamento de la imputación objetiva como hemos visto en el capítulo tercero, sin embargo este quebrantamiento se asienta en la infracción de un elemento normativo: cuando el sujeto se sale del haz de luz del foco o faro de guía que la norma funcionalmente le había orientado correctamente. En este cometido, la doctrina ha distinguido

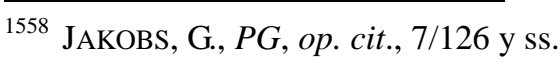


varios principios que vamos a trasladar al ámbito de las sectas criminales, y especialmente a la imputación de la persuasión coercitiva como causa de déficit de socialización o adicción comportamental atribuido a tercero: principio de riesgo permitido y no permitido; principio de imputación o autopuesta en peligro de la propia víctima o riesgo propio; principio de confianza; y principio de prohibición de regreso.

\section{A. Riesgo permitido y no permitido en el sectarismo}

1. Riesgo permitido

Es evidente que la sociedad actual configura riesgos propios de una sociedad democrática, a la que se le ha denominado sociedad del riesgo. El precio de la libertad es poder perderla por defraudaciones de terceros, por peligros inevitables como las catástrofes naturales o las desgracias, por infortunios, pero también nuestras propias elecciones o decisiones, o la falta de ellas, puedan suponer riesgos. Se dice que existe una «familiaridad con el riesgo». Es evidente también que la construcción social establece riesgos permitidos y no permitidos y que la permisividad la delimita la propia sociedad ${ }^{1559}$. Lo no permitido es la limitación de un derecho, de manera que la construcción social genera ámbitos de riesgo. Torear, boxear o escalar, son conductas que reflejan un riesgo normativamente permitido. En estos casos hay una permisividad social en riesgos permitidos, tolerables y socialmente adecuados que no conllevan responsabilidad alguna ${ }^{1560}$, por lo que se deben asumir las consecuencias de la autopuesta en peligro, salvo que un tercero quebrante un riesgo no permitido.

Los riesgos permitidos son aquéllos que son imprescindibles para el funcionamiento de la sociedad $^{1561}$, o con otras palabras, existen conductas peligrosas que los terceros han de soportar, o al menos, no son jurídicamente desaprobadas. Para determinar qué conductas se deben soportar se han utilizado diversos criterios: la ponderación de intereses, la utilidad social, la adecuación social y la función social.

Debemos detenernos en estas dos últimas propuestas. Si bien WELzEL ${ }^{1562}$ expuso que el Derecho tiene una adecuación social, que las normas tienen que soslayarse a cierta identidad con

\footnotetext{
${ }^{1559}$ Polaino NaVArrete, M., Lecciones de Derecho penal, Parte General, T. II, op. cit., p. 89; POLAINO-ORTS, M., «Imputación objetiva: esencia y significado», op. cit., pp. 43 y ss.

${ }^{1560}$ Polaino Navarrete, M., Lecciones de Derecho penal, Parte General, T. II, op. cit., p. 89; POLAINO-ORTS, M., «Imputación objetiva: esencia y significado», op. cit., pp. 43 y ss.

1561 PIÑA Rochefort, JI., Rol social y sistema de imputación, op. cit., p. 394; Así, como bien recuerda POLAINOORTS «la capacidad de gestión de un riesgo tiene como fundamento, paradójicamente, la permisividad social ante la creación del mismo. Y todo ello genera, como lógicamente puede comprenderse, una familiarización con el riesgo», POLAINO-ORTS, M., «Imputación objetiva: esencia y significado», op. cit., p. 47. 84.

${ }_{1562}$ Welzel, H., El nuevo sistema de Derecho penal, op. cit., p. 54; ID., Derecho penal alemán, op. cit., pp. 83 y
} 
la sociedad y que así ciertas conductas están permitidas porque respetan el orden social, la reformulación de JАKOBS ${ }^{1563}$, sin negar la teoría de la adecuación social centra el debate en que ciertas conductas si bien producen riesgos y están permitidas, tienen una permisividad porque fomentan el contacto social, la interacción, existe una legitimación funcional por su propia evolución. De esta manera, parece lógico establecer que el Derecho configura un espacio normativo en el que se regulan las conductas peligrosas, sobre las que se establecen las condiciones de permisividad de forma expresa ${ }^{1564}$, si bien esto sólo sucede en aquellas actividades sociales que conocemos que pueden generar altos riesgos y consecuencias, mientras que por lo general, la norma nada dice sobre nuestros quehaceres diarios, tan sólo orienta conductas o alternativas, salvo en determinados casos en los que el Derecho penal concreta la conducta obligatoria o desaprobada (tipicidad).

De esta manera, y en relación a nuestro ámbito de estudio, la permisividad religiosa y de conciencia suponen igualmente productos de la Sociedad, si bien el sujeto también en estos casos, cuando decide sobre una determinada postura religiosa o convicción trascendental de pensamiento, se expone a un riesgo: que la idea religiosa se fanatice o sea aprovechada por terceros. La Constitución, como identificación de la sociedad, permite que los ciudadanos (los ciudadanos han permitido, en pasiva) desarrollen conductas riesgosas, también en la moral. Por ejemplo, la inscripción de una entidad religiosa supone un reconocimiento de la permisividad del riesgo a que los sujetos modifiquen su conciencia. Esta permisividad normativa no desarrolla concretamente, a diferencia de las normas que reglan ámbitos riesgosos concretos, cómo el sujeto ha de comportarse dentro de esa permisividad, sino que ha de extrapolarse de otras normas de flanqueo, por ejemplo, la familia que se regula en el Código civil y el Código penal expresamente desaprueba conductas muy concretas (omisión del deber de socorro, delitos de organización y de infracción de deber), de modo tal que resulta que la permisividad del riesgo en el ámbito religioso consolida una conducta en el tiempo que a la postre el Derecho penal frena exclamando jesto no está permitido, es un riesgo no permitido! Esta comunicación es la que crea el conflicto de conciencia entre una conducta consolidada en el tiempo y la vigencia de una norma que frena la orientación de una conducta riesgosa pero socialmente consolidada, que en ocasiones especiales produce lo que hemos denominado contraorientación normativa y que puede tratarse como una causa de exculpación en el estado de necesidad.

\footnotetext{
1563 JAKOBS, G., «El delito imprudente», trad. Manuel Cancio Meliá, JAKOBS, G., Estudios de Derecho penal, op. cit., pp. 172 y ss., p. 212; ID., La imputación objetiva en Derecho penal, op. cit., pp. 118 y ss; LUHMANN, N., El Derecho de la sociedad, op. cit., pp. 181 y ss., y pp. 198 y ss.

${ }^{1564}$ Más ampliamente MARAVER GÓMEZ, M., El principio de confianza en Derecho penal, op. cit., pp. 360 lo denomina riesgo permitido en «sentido estricto».
} 
Así las cosas, el fundamento de que ante tales o cuales tratamientos médicos determinados sujetos, inclusive menores de edad, pero con capacidad de decisión, puedan rechazarlos, poniendo en peligro su vida, es el riesgo permitido. De tal manera las funciones diferenciadas de rol suponen riesgos permitidos o «excepción al neminem laedere» ${ }^{1565}$. Por otro lado, la creación de un riesgo no permitido, o la «no neutralización de un riesgo» ${ }^{1566}$ del que se es competente, supone el quebrantamiento del rol común o especial, en definitiva, el sustrato de la imputación objetiva, tanto en los delitos dolosos como imprudentes ${ }^{1567}$; sin embargo, este quebrantamiento no responderá de cuantas consecuencias lesivas se produzcan, sólo de las que competen al rol. Quien quebranta su rol normativo crea voluntariamente otro rol, un rol especial de autor o partícipe, de tal manera que ha de hacerse cargo de las consecuencias inherentes a tal toma de dominio o deber. Podría decirse que el delito, como comunicación contrafáctica a la norma, crea otra norma especial de la que es competente el sujeto. De esta manera el riesgo no permitido es una cuestión estrictamente objetiva de imputación de la conducta que tiene la misma trascendencia en los delitos dolosos e imprudentes, o dicho de otro modo, tal valoración del riesgo, también en la tentativa, es ajena a la valoración del tipo subjetivo o representación subjetiva del autor ${ }^{1568}$.

Dicho todo lo cual, el ingreso de un sujeto en una confesión religiosa o sectaria supone una actividad lícita, pero a su vez, un riesgo permitido, en tanto que la asunción o aceptación de conceptos morales y religiosos modifican per se la visión del mundo, modifican nuestra voluntad, y consecuentemente nuestras decisiones y la ejecución de las mismas, afectan a nuestra visión de la dignidad, a nuestra personalidad, bienes que son irrenunciables pero sí modificables. Si bien la legalización de un grupo o asociación supone un indicio o prueba iuris tamtum de que la actividad no irrogará riesgos no permitidos, de forma que la inscripción del grupo religioso constituye una norma, y por ende una expectativa para sus miembros de que sus creencias y su ejercicio son lícitos, sí produce, al igual que cualquier otro ámbito, un riesgo, pero en este caso permitido. Entonces en la configuración de los riesgos permitidos jurídico-penales el Sistema se nutre procesando otras normas, en este caso extra-penales (administrativas), la legalización de la doctrina y ejercicio religioso, que sólo podrán valorarse en el sistema jurídico-penal si se defrauda la permisividad del riesgo.

\footnotetext{
1565 PIÑA ROCHEFORT, JI., Rol social y sistema de imputación, op. cit., p. 398.

1566 Polaino Navarrete, M., Lecciones de Derecho penal, Parte General, T. II, op. cit., p. 90.

1567 JAKOBS, G., PG, op. cit., 7/39; PIÑA ROCHEFORT, JI., Rol social y sistema de imputación, op. cit., p. 398.

1568 JAKOBS, G., «Representación del autor e imputación objetiva», op. cit., pp. 223 y ss; MARAVER GÓMEZ, M., El principio de confianza en Derecho penal, op. cit., p. 343; REQUENA JULIANI, J., Intercambiabilidad de acción y omisión, op. cit., p. 325.
} 
La sociedad asume -y se ve todos los días- que quien entra por ejemplo en la religión cristiana, incluso de forma ortodoxa, cambia su personalidad, se dice de él: «es más bueno». Aquí se le dota de valor a ese actuar, sin embargo, cuando un mayor de edad entra en un grupo religioso menor, al que se le suele catalogar de «secta», la sociedad, y particularmente los familiares y allegados, suelen otorgar un valor negativo, se dice: «se le ha manipulado». La atribución social de un valor a una conducta permitida es una interpretación moral, otras veces moralidad, y como tal no forma parte del sistema jurídico-penal salvo escasísimas ocasiones, como en el delito de omisión deber de socorro del art. 195 CP. No se puede negar que el Derecho penal se nutre de la moral de la sociedad, pero de modo que procesa esa moral en normas jurídico-penales trasladando el código bueno/malo al código justo/injusto. Es mediante este código con el que opera el sistema jurídico-penal. Por eso, cuando el código moral se asemeja al penal se aprecia una clara influencia ${ }^{1569}$ de la moral en la norma.

Este mismo razonamiento sobre el riesgo permitido sirve también para grupos no inscritos en el correspondiente registro de entidades religiosas, que desarrollan actividades con normalidad religiosa que conoce la sociedad, por lo que no puede afirmarse que la falta de inscripción suponga un riesgo no permitido, salvo que la sociedad se contradiga a sí misma o imponga la falta de contactos sociales. En ambos casos, la práctica confesional, inscrita o no, supone un riesgo permitido.

Amén de ello, el ingreso en un grupo religioso o secta es una conducta lícita y sana en el pluralismo, y en tanto consentido e informado sobre los dogmas de fe del grupo y el fin que se pretende con estos, supone una evangelización, proselitismo o ingreso permitido en Derecho. De este modo, en iguales términos, el consentimiento para ser adoctrinado o mudar de fe supone un consentimiento válido y por lo tanto hace atípica la conducta prosélica. Sin embargo, cuando el sujeto desconoce los dogmas de fe, las consecuencias a las que lleva, y la repercusión de la dinámica grupal, cuando el sujeto desconoce que se le va a restringir el horizonte de expectativas sociales de modo que sólo se le van a presentar expectativas estrictamente del grupo, disconformes con las reglas generales y los conceptos básicos de la sociedad, esto supone un riesgo no permitido.

2. Riesgo no permitido: el quebrantamiento normativo de los roles sectarios

Hemos visto que en un sistema en el que se legitima constantemente la libertad de conciencia, la ruptura sorpresiva de dicha orientación crea una confusión/contraorientación o

${ }^{1569}$ LUHMANN, N., «La dogmática religiosa y la evolución de las sociedades», op. cit., pp. 118 y 121. 
conflicto en el autor de conciencia que fundamenta la exculpación o atenuación de la pena por déficit de comunicación/socialización atribuido a la norma, según lo expuesto supra.

Sin embargo, en otras ocasiones, la atribución del déficit viene de un tercero y/o grupo, en este caso de una secta, de modo que se produce la restricción del horizonte de expectativas, cuando tal circunstancia es desconocida por el sujeto, ya sea porque se le persuada para desatender la norma puntualmente como autor de conciencia, o para combatir la norma como autor por convicción o enemigo, supone un riesgo no permitido y el fundamento del inicio de la tentativa del delito de coacciones o persuasión coercitiva.

Dicho lo cual, la característica criminal de las sectas es la creación de riesgos no permitidos, a saber: la utilización de técnicas de persuasión coercitiva a modo de adoctrinamiento desconocido por la víctima. La restricción del horizonte de expectativas normativas y sociales ofrecidas por el Sistema, la generación de una «confianza que genera garantía» sobre una expectativa «realmente» desconocida que trasforma la conducta en un claro perjuicio del propio sujeto o de terceros supone la irrogación de un riesgo no permitido y el inicio de la tentativa, esto es, cuando se crea un «déficit de garantía cognitiva».

La doctrina funcionalista afirma que sólo es imputable a los sujetos el quebrantamiento de la expectativa que forme parte del rol común o especial, es decir, de su ámbito de competencia ${ }^{1570}$. Sin embargo, en el desempeño del rol y la permisividad de los riesgos sucede que en determinadas ocasiones se exige que el sujeto siga conformándose como tal ante el devenir, acomodándose a «situaciones normales», o -dicho de otro modo- no se puede «instrumentalizar el rol», no se puede alegar siempre que se actuaba dentro del riesgo permitido cuando las circunstancias han variado, porque las circunstancias operan como entorno del sistema del rol, y producen entradas que varían las funciones del rol, aquí el sujeto deberá emplear sus capacidades para desempeñar la variación del rol ${ }^{1571}$. Entonces, lo que puede atribuirse es la dejación de los deberes propios e inherentes de la función del rol concreto en su espacio-temporal normativo y cognitivo. La variación del entorno puede modificar las funciones del rol, incluso del rol común. De tal modo se fundamentaba que en determinadas situaciones los padres han de acomodar su comportamiento a las nuevas circunstancias, como el conocimiento especial de que el menor precisa una trasfusión de sangre, de lo que se desprende el fundamento de la imputación objetiva del delito de homicidio en comisión por omisión.

\footnotetext{
${ }^{1570}$ POLAINO-ORTS, M., «Imputación objetiva: esencia y significado», op. cit., pp. 35 y ss; ID., Funcionalismo normativo, op. cit., pp. 74 y ss. y pp. 118 y ss; POLAINO NAVARRETE, M., Lecciones de Derecho penal, Parte General, II, op. cit., p. 90; REQUENA JULIANI, J., Intercambiabilidad de acción y omisión, op. cit., pp. 147 y ss. pp. 233 y ss. y pp. 326 y 327.

${ }^{1571}$ PIÑA ROCHEFORT, JI., Rol social y sistema de imputación, op. cit., pp. 402 y ss.
} 
Resulta que por ejemplo el líder de una secta -también podría trasladarse la situación, aunque «mejor» vista a las ordenes monasteriales y al ejercito-cuando conoce que un miembro, por las largas jornadas de ayuno que se imponen (en el ejército los entrenamientos físicos y psicológicos), comienza a desfallecer, o a tener delirios, trasforma su rol y ha de advertir que las circunstancias (del entorno) se han modificado de tal manera que precisa reajustar sus funciones a la nueva situación. En estos casos, no deberá inducir a la continuación de la orden cuando se infiera de dicha situación que el sujeto tiene sus capacidades mermadas de tal forma que no existe una autopuesta en peligro conocida por el sujeto, sino una consecuencia desconocida, o una consecuencia que no se consentía. La orden de ayuno en sí misma es neutra, pero deja de serlo cuando, por ejemplo, por las especiales circunstancias del sujeto repercute en su libertad (por ejemplo, si es diabético), y aunque la propia «víctima» no lo conozca, si de quien emana la orden aprecia dicha dolencia de forma objetiva incurre en una conducta que traspasa el riesgo permitido. Aquí entrarían las controversias doctrinales sobre la imputación de los riesgos insignificantes o poco probables. En nuestra opinión, y siguiendo a $\operatorname{JESCHECK}^{1572}$, no pueden descartarse las anomalías de la propia víctima, aun siendo desconocidas por el autor, porque se protegen puestas en peligro también atípicas, es decir, el derecho a no ser dañado.

La cuestión se reconduce inevitablemente a la pregunta de si un rol común tiene deberes de protección (posición de garante). Pues bien, ya hemos tratado -en el capítulo tercero- la delimitación entre los tipos 195 y 196 con el 11 CP y hemos concluido que se aprecian deberes también en el desempeño de un rol común cuando existe deber de aseguramiento, asunción, confianza, o en la «estrecha comunidad de vida» ${ }^{1573}$, si bien en los delitos de infracción de deber estos fundamentos de responsabilidad están mejor tasados al objeto de delimitar la cláusula de correspondencia entre omisión y comisión, pero el fundamento es el mismo: la relación sinalagmática entre libertad/responsabilidad o neminem laede ${ }^{1574}$. Sin embargo, entre la responsabilidad por organización y la institucional lo único que varía es una cuestión ajena al fundamento de responsabilidad, la competencia en uno y otro caso, que procede de la libertad del

\footnotetext{
1572 JeSCHECK HH / WeIGEND T., Tratado, op. cit., 28, IV 6. Así también la STS de 6 de abril de 1993 en la que se imputa el resultado de muerte por homicidio imprudente a un marido que golpeó en el cuello de la esposa, y que por existir una miocarditis desconocida desencadeno el fatal suceso. También la STS de 29 de mayo de 1999 en la que se imputó la muerte de un enfermo de SIDA por imprudencia al sujeto que si bien desconocía dicha circunstancia le propino un golpe que a una persona sana, en principio, únicamente le hubiera causado una simple lesión. En este sentido, no interrumpe el curso causal los accidentes por las circunstancias preexistentes o concomitantes de la víctima, la embriaguez o drogodependencia, GonZÁlez Rus, JJ., vv.aa., Derecho penal español, Parte especial, op. cit., p. 79.

1573 JAKOBS, G., $P G$, op. cit., $29 / 70$.

1574 JAKOBS, G., PG, op. cit., 28/4 y 29/28; PIÑA ROCHEFORT, JI., Rol social y sistema de imputación, op. cit., p. 406; REQUENA JULIANI, J., Intercambiabilidad de acción y omisión, op. cit., pp. 189 y ss. p. 325; SÁNCHEZ-VERA, J., Delito de infracción de deber y participación delictiva, op. cit., pp. 83 y ss.
} 
sujeto, hasta el punto que una simple variación del entorno puede hacer variar del rol común al especial y viceversa, concurrir o activarse uno después del otro.

Otras veces, y ésta es la cuestión central, la convivencia genera deberes por asunción, pero sólo surgiría la confianza especial cuando se promete el auxilio y se llevan a cabo actos claros de preparación para en su caso cumplir el deber, o en la unión de ámbitos de organización como en la «comunidad del riesgo» en la que se acuerda el auxilio mutuo, también en la «estrecha comunidad de vida» (por estrecha relación familiar, amistosa o sentimental) o en la denominada «comunidad de intereses» (en la relaciones de novios, parejas de hecho), se está obligado a la evitación de riegos vitales en la que existe riesgos mayores a los normales, cuya obligación surge de la superación común (también en casos de sustitución de la confianza especial de la protección estatal como en el caso de bomberos voluntarios ${ }^{1575}$ ). En estos casos parece que en la comunidad de intereses, del riesgo, o vital, nace una expectativa social como fuente de deber, donde el acuerdo puede ser tácito, inclusive -como apunta POLAINO NAVARRETE- de una fuente de la comisión por omisión: «en función de su posición en el grupo social se determinará la exigibilidad de un determinado deber, de una determinada forma de conducta» ${ }^{1576}$. A este respecto, WELZEL ${ }^{1577}$, entre otros, se refirió además de las anteriores comunidades a la «especial relación de lealtad» entre comerciantes, que se puede asociar mejor, en nuestra opinión, que la «comunidad de vida» al tipo de organización sectaria, o cualquier otra en la que medie la «especial honradez», por cuanto su infracción representa un engaño grave que genera garantía.

Comentamos en el capítulo tercero que la «asunción de un deber» supone el inicio de una competencia del rol denominada «responsabilidad por asunción», que además puede liberar a quien previamente ha tenido dicha competencia al tratarse de una confianza «cualificada»o especial que crea una «incumbencia institucional» con el mismo fundamento que en la injerencia $^{1578}$, pero por una «expectativa cognitiva», no normativa, pues esta última se garantizaría jurídicamente. En la cognitiva existe una «conexión fáctica», un promesa de una prestación «expresa o concluyente», y el tercero deja de asumir la protección, aun cuando se conozca después de la asunción que dicha protección no habría sido eficaz, aun cuando no se conozca dicha protección por el tercero, también en casos de asunción de un riesgo aun permitido, y en casos de asunción que no eliminan la cualificación del rol por completo, todo

\footnotetext{
1575 JAKOBS, G., PG, op. cit., 29/70; PIÑA ROCHEFORT, JI., Rol social y sistema de imputación, op. cit., p. 405.

1576 Polaino Navarrete, M., Acción, omisión y sujetos en la Teoría del delito, op. cit., p. 99.

1577 Welzel, H., Derecho penal alemán, op. cit., pp. 300 y 301; KAUFMANN, A., Dogmática de los delitos de omisión, op. cit., pp. 264 y 293; MAURACH, R., Tratado, II, op. cit., pp. 288 y 289.

1578 JAKOBS, G., PG, op. cit., 29/46 a 29/52; similarmente POLAINO NAVARRETE, M., Acción, omisión y sujetos en la Teoría del delito, op. cit., p. 91.
} 
ello, salvo que esté viciada dicha asunción ${ }^{1579}$. Sin embargo, los deberes por responsabilidad institucional, en sentido estricto, se equiparan a deberes de comisión por la importancia básica de la existencia de la sociedad, como las relaciones paterno-filiales, la confianza especial y los deberes estatales ${ }^{1580}$.

Así las cosas, ¿quebranta una expectativa de confianza especial por asunción el líder de una secta y/o el grupo religioso, o una confianza especial de un deber institucional cuando se comunica la garantía de una expectativa «realmente» desconocida por la Sociedad, de modo que trasforma la conducta del receptor previamente persuadida coercitivamente?

El líder, y el grupo criminal sectario, crean un conjunto de normas paralelas, divergentes o combativas, pero coexistentes con las normas de un Estado o sistema normativo. De tal manera, el líder de un grupo religioso, y por dinámica grupal, entonces, el grupo mismo (organización sistémica), crean una confianza que genera garantía, y con la aceptación de la confianza depositada por el adepto se crea un deber especial en relación a la protección de sus miembros. La cuestión es si este deber especial viene de una confianza especial de la «asunción de un deber» que genere responsabilidad por organización o por infracción de un deber institucional. La respuesta es de evidente trascendencia en el título de responsabilidad, si bien ya hemos concluido supra que dicha relación, al basarse en una confianza que genera garantía, lleva a concluir que se crea una responsabilidad de corte institucional.

En nuestra opinión, dicha confianza se asemeja a la asunción de un deber estrictamente especial, y por tanto institucional, puesto que se crea ya no una expectativa cognitiva sino una garantía de expectativa cognitiva (confianza que genera garantía) pero en cuyo contenido existe un «déficit de garantía cognitiva». Son aquellos casos en los que el líder y/o el grupo asignan un deber especial para el adepto: comprar determinados productos, realizar tal conducta contra sus propios intereses, «suicidarse». Esto es porque se garantiza esta expectativa cognitivamente de forma reglada mediante la normatividad sistémica del grupo que genera una responsabilidad institucional: a los comunicadores de tal «garantía» les hace responder en calidad de autor.

En este sentido tenemos dos responsabilidades. Una en la que el deber viene directamente del líder por las normas que ha creado, otra del grupo por «estrecha comunidad de vida» (análoga a la estrecha relación familiar, amistosa o sentimental), o mejor, por «estrecha relación de

\footnotetext{
1579 JAKOBS, G., PG, op. cit., 29/47; PIÑA ROCHEFORT, JI., Rol social y sistema de imputación, op. cit., pp. 418 y 419; MARAVER GÓMEZ, M., El principio de confianza en Derecho penal, op. cit., pp. 126 y ss.

1580 JAKOBS, G., $P G$, op. cit., 29/58; PIÑA ROCHEFORT, JI., Rol social y sistema de imputación, op. cit., pp. 296 y ss. y pp. 419 a 421.
} 
lealtad», puesto que todas la acciones u omisiones del grupo refrendan la «garantía» de la expectativa u omiten la advertencia del peligro.

El adepto a sectas coercitivas en primer lugar ve defraudada la confianza cuando no se le informa correctamente de la trascendencia de la doctrina, cuando se defrauda una expectativa cognitiva normativamente institucionalizada a través de la garantía que se comunica por el líder y/o grupo, de tal modo que se enfrenta a la dicotomía de la elección entre las funciones del rol común y/o especial atribuido por el Sistema normativo y social y el rol especial que le comunica el líder y/o la comunidad sectaria de actuar conforme a dicha garantía de expectativas cognitivas normativizadas especialmente por la dinámica del grupo.

Llegados diversos factores, circunstancias organizativas espacio-temporales, la norma sectaria y la del Sistema se cortan en sus esferas de actuación, lo que generará el conflicto de conciencia (conocimiento de las normas opuestas), ya no por un déficit atribuido a la norma, sino atribuido a la norma sectaria, lo que significa que se atribuye al líder y al grupo por la dinámica conjunta realizada. Otras veces, no será un conflicto, sino la generación de una convicción que puede llegar a ser enemiga según hemos concluido, pero con la también peculiaridad de que dicha convicción se puede atribuir al tercero líder y/o grupo, de manera que el sujeto puede ocupar una doble posición de víctima y autor en caso de perpetrar un delito directamente vinculado a la comunicación de la garantía de la expectativa cognitiva normativizada.

En definitiva, la construcción social sectaria cuando produce los condicionantes necesarios para fortalecer en el sujeto la adecuación de su conducta a la norma sectaria a través de la persuasión coercitiva crea un caldo de cultivo, un «déficit de garantía cognitiva» o una garantía de expectativas cognitivas normativizadas que irroga un riesgo no permitido, que por otro lado constituye un fundamento de punibilidad de la organización. En estos casos pueden entrar a confluir tanto conductas propias del autor de conciencia como del autor por convicción y del enemigo. La diferencia estriba en que hay organizaciones de las que emanan normas de las que la posterior conducta deficitaria actúa como en la de un autor de conciencia, es decir, sin negar la vigencia de la norma, y otras en las que la norma sectaria lleva a la conductas del autor por convicción o del enemigo que, según el grado, combaten la vigencia de la norma y/o al sistema, respectivamente. Pero en ambos casos, la creación del déficit de garantía cognitiva supone en la dinámica grupal la constitución de una organización criminal por un riesgo no permitido en la persuasión coercitiva a través de la norma sectaria. La dinámica comportamental del grupo ratifica la garantía de la expectativa cognitiva normativizada pero que en cuyo contenido existe 
un déficit de garantía cognitiva cuando se trasforman los conceptos esenciales de la Sociedad: dinero, salud, vida, muerte, etc.

De este modo es comprensible que la organización criminal constituya un peligro objetivo autónomo y diferenciado del delito-fin relacionado con la persuasión coercitiva, y a su vez del delito de lesiones psíquicas, pero cuya especialidad viene de la retroalimentación entre organización y persuasión coercitiva y/o adicción comportamental, de manera que es difícil establecer cuál va antes que la otra, si la organización es un factor más de la persuasión, o si la persuasión habilita la organización. A nuestro modo de entender, esta pregunta es innecesaria porque se produce la paradoja del huevo y la gallina. No se puede empíricamente demostrar tampoco de dónde nació el caldo de cultivo del nazismo, si de una primera organización de diversas personas o de la concreta situación en la Europa de entreguerras que dio origen a los movimientos totalitarios. Es más práctico y funcional considerar que al tratarse la organización de un subsistema en el más puro sentido luhmanniano, tanto la organización como la persuasión pertenezcan al mismo hecho, de modo que ambas se constituyan como operaciones propias del subsistema, y que así se retroalimentan de forma autopoiética y autorreferencial.

Sin embargo, al objeto de imputar el delito de persuasión coercitiva y de lesiones psíquicas, habrá que delimitar cuándo comienza la tentativa en uno y otro caso.

\section{Fundamento de punibilidad y tentativa de las técnicas de persuasión coercitiva y de la}

\section{dinámica comportamental}

Ha existido siempre una polémica en la tentativa de coacciones realizada a través de hipnosis o narcóticos, polémica que se puede trasladar a la tentativa de persuasión coercitiva y de lesión psicológica en nuestro ámbito de estudio.

Resumidamente, consideramos que toda la polémica viene centrada en el valor o fundamento que se otorga a la punibilidad de la tentativa, en este caso, cuándo es punible, cuándo comienza, su delimitación con los actos preparatorios y su distinción con la tentativa inidónea. Estando conformes en que el delito de coacciones, y por tanto el injusto de la persuasión coercitiva, constituyen un delito de resultado (también permanente), esto permitirá su graduación en actos preparatorios, en tentativa inacabada y en tentativa acabada. Al tratarse de técnicas tan diferentes y que dependen de muchas circunstancias para conseguir el resultado de una incapacidad de libertad de voluntad, es preciso delimitar el fundamento de punibilidad, y de aquí, la delimitación con los actos preparatorios y la tentativa inacabada de la acabada. 
Quienes ${ }^{1581}$ defienden un fundamento de punibilidad de la tentativa, basado en la peligrosidad para el bien jurídico, lógicamente no aceptan la punibilidad de la tentativa inidónea que no sea peligrosa ex ante, esto es, porque la asimilan a la tentativa absolutamente inidónea. Por otro lado, quienes ${ }^{1582}$ defienden la punibilidad de la tentativa no peligrosa o inidónea ex ante -sin aceptarse la punibilidad de la irreal, supersticiosa o absolutamente inidónea- buscan un fundamento ligado a la imputación de la tipicidad en el incumplimiento de los deberes.

A nuestro juicio, el fallo proviene de asimilar la tentativa inidónea que no sea objetivamente peligrosa a la tentativa irreal, supersticiosa o absolutamente inidónea, y quizá esto provenga por la derogación del art. 52.2 CP español, que penaba la tentativa inidónea, hecho del cual algunos ${ }^{1583}$ se han servido para defender la impunidad, y del actual art. 16 CP con su vocablo «objetivamente» ${ }^{1584}$. Cabe decir -en concordancia con SILVA SÁNCHEZ ${ }^{1585}$ - que el art. $16 \mathrm{CP}$, en contra de la opinión de parte de la doctrina ${ }^{1586}$, no imposibilita la punibilidad de algunas tentativas inidóneas en el sentido objetivista de esta expresión (de ello son buen ejemplo los delitos de emprendimiento ${ }^{1587}$ ), pues desde una panorámica estrictamente objetivista, la cual toma todos los elementos conocidos ex ante, parece claro que la mayoría de tentativas no serían

1581 Entre otros AlCÁCER GUIRAO, R., La tentativa inidónea, op. cit., pp. 176 y ss., y pp. 466 y ss; BACIGALUPO, E., «Sobre la tentativa inidónea en el Derecho vigente y en el Proyecto de Código Penal», La Ley, núm. 2, 1981, p. 971; BlAnco LozAno, C., La omisión del deber de socorro en Derecho penal, Bosch, 2009, p. 292; GIMBERNAT, E., «Diatriba del Nuevo Código Penal», La Ley, 1996, III, p. 1335, también en Prólogo a la $2^{a}$ ed. del Código penal de Tecnos, Tecnos, Madrid, 1996, pp. 17 y ss; LuZÓn PEÑA, D-M., Curso de Derecho Penal, Parte General, op. cit., p. 469; Muñoz Conde F / García ArÁn M., PG, op, cit., pp. 416 y ss; Polaino Navarrete, en Cobo Del Rosal (dir.), Comentarios al Código penal, I, 1999, art. 16, pp. 841 y ss. En Alemania entre otros, RoxIN, «Acerca de la punibilidad de la tentativa inidónea», Revista Latinoamericana de Derecho, núm. 9-10, 2009, pp. 294 y ss., se acoge a la falta de merecimiento de pena al no ser peligrosa para el bien jurídico.

1582 Gracia MARTín, L., «Sobre la punibilidad de la llamada tentativa inidónea en el nuevo Código penal español de 1995 (Comentario a la Sentencia de la Audiencia Provincial de Zaragoza de 24 de Mayo de 1996)»,

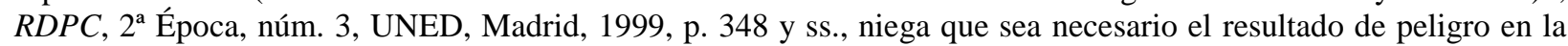
tentativa, pues con la peligrosidad de la acción basta. No obstante la acción peligrosa no es el fundamento de la tentativa, porque «basta con que el autor haya realizado actos que sean subsumibles en la acción típica» p. 344; MIR PUIG, S., «Sobre la punibilidad de la tentativa inidónea en el nuevo código penal», RECPC, núm. 3, 2001, pp. 13 y ss., si se acredita el peligro estadístico; PÉREZ DEL VALLE, C., «La individualización de la pena y su revisión», Estudios sobre el nuevo Código Penal, dirigiros por Rosal Blasco, 1997, p. 57; SolA RECHE, E., La llamada tentativa inidónea del delito. Aspectos básicos, $1^{\mathrm{a}}$ ed., Comares, 2006; ID., «Sobre el concepto de tentativa idónea», El nuevo Derecho penal español, Estudios penales en memoria del profesor José Manuel Valle Muñiz, Fermín Morales Prats y Gonzalo Quintero Olivares (coords.), 2001, pp. 778 y ss., pero sin aceptar la punibilidad de la tentativa no peligrosa por razón de la protección al bien jurídico y por razones de intervención mínima.

1583 LUZÓn CUESTA, José María, Compendio de Derecho Penal, Parte General, 1996, p. 198.

1584 GimbernAt, E., «Diatriba del Nuevo Código Penal», op. cit., p. 1335, también en Prólogo a la $2^{a}$ ed. del Código penal de Tecnos, op. cit., pp. 15 a 32, lo equipara al hombre medio con los conocimientos defectuosos del autor y los nomológicos y objetivos; GRACIA MARTín, L., «Sobre la punibilidad», op. cit., pp. 358 y 359, considera que es la adecuación de la representación del autor a los conocimientos sobre lo nomológico; SILVA SÁNCHEZ, J-Ma ., El Nuevo Código penal: cinco cuestiones fundamentales, op. cit., p. 137.

1585 SILVA SÁNCHEZ, J-M ${ }^{\mathrm{a}}$., El Nuevo Código penal: cinco cuestiones fundamentales, op. cit., pp. 133 y ss.

1586 Por ejemplo GonZÁleZ MATEOS, JC., «Esencia de la norma», op. cit., p. 202.

${ }^{1587}$ Polaino NaVArReTe, M., Injusto de Tentativa y Vigencia, op. cit., p. 742, los delitos de emprendimiento «implican sin más la equiparación de la tentativa con la consumación... que implica introducir un tratamiento valorativo que es extraño al sistema general incriminador del iter criminis» (cursiva del autor). 
punibles, pero más aun toda tentativa sería inidónea desde una perspectiva ex post. Así también el requisito «deberían producir el resultado» del art. $16 \mathrm{CP}$, desde un sentido estrictamente objetivo, excluye las tentativas poco probables, con lo que parecería exigirse una probabilidad alta del resultado para la punibilidad, pero este planteamiento dejaría impune muchas de las tentativas, sobre todo aquéllas ejecutadas con pocas probabilidades, las arriesgadas.

Para la doctrina funcionalista, lo que trata de proteger el Derecho penal, como ya dijimos, no es todo ataque al bien, sino su valor en sí mismo, su valor normativo, lo cognoscible sobre éste, para orientar la conducta de forma general. Esta doctrina ${ }^{1588}$ se adelanta a la protección de bienes jurídicos pero sin llegar a negarlos. De aquí que resulte secundario el fin de protección de bienes jurídicos, es mediato $^{1589}$ al fin de la prevención general positiva. Es decir, a través de la comunicación de la vigencia de la norma, se motiva y se ilustra sobre los deberes normativos. De esta manera el delito no siempre pone realmente en peligro al bien jurídico espiritualmente entendido, pero sí debilita siempre la idea de vigencia normativa ${ }^{1590}$. Por tanto, la función del Derecho penal como fin ${ }^{1591}$ es comunicar deberes al hombre autónomo: el delito es una lesión de

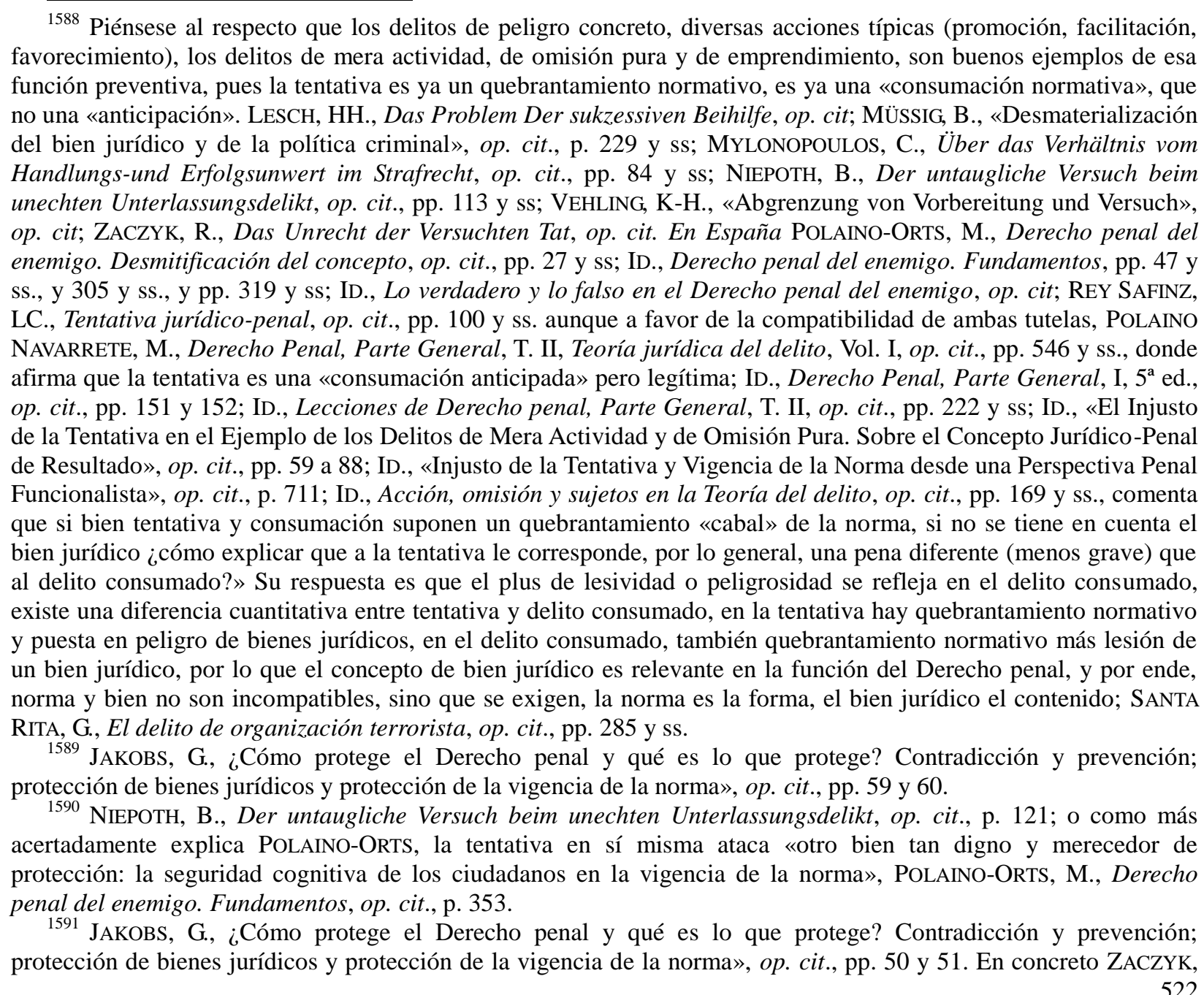


deber simbólica ${ }^{1592}$ y relevante ${ }^{1593}$. Por ende, la tentativa es ya en sí un quebranto normativo o infracción de un riesgo no permitido ${ }^{1594}$, un desvalor del resultado, causado por una expresión negativamente relevante, el desvalor de la acción. El desvalor en la tentativa y el desvalor en lo consumado es el mismo, únicamente se añade en este último un plus cuantitativo ${ }^{1595}$ : el resultado mayor de quebrantamiento normativo ${ }^{1596}$. En lógica, el desvalor del resultado en la tentativa inidónea es también el quebranto de la vigencia normativa ${ }^{1597}$. El resultado, entendido como parte objetiva de la graduación ejecutiva del delito, fundamenta la graduación de la pena, pero no la antijuricidad, pues el resultado material -en sentido ontológico- sólo se aprecia en el injusto consumado $^{1598}$.

La punibilidad de la tentativa inacabada refrenda el postulado preventivo positivo que cumple la norma penal en contra del paradigma dualista -desvalor de la acción y del resultado-, esto es, sin necesidad de esperar al inminente peligro de lesión al bien jurídico (tentativa acabada) ${ }^{1599}$.

R., Das Unrecht der Versuchten Tat, op. cit., pp. 119 y ss., sin negar la trascendencia del bien, admite la unidad de la tentativa objetiva y subjetiva como quebrantamiento de la relación interpersonal de la libertad. La tentativa no viene configurada por la lesión parcial al bien jurídico sino por el quebrantamiento de la relación o idoneidad de la acción para desvirtuar la relación de confianza. En aquellos casos en los que la inidoneidad dependa del sujeto pasivo, y no de lo naturalístico, el injusto nacerá del quebrantamiento de la confianza normativa interpersonal, ID., ibidem p. 251. De otra opinión MYLONOPOUlos, C., Über das Verhältnis vom Handlungs-und Erfolgsunwert im Strafrecht, op. cit., p. 87, entiende que la supersticiosa no es punible por insuficiencia de grado de lesión al bien, lo que incapacita la comunicación de la negación normativa.

${ }_{1592}$ Al respecto LESCH, HH., Das Problem Der sukzessiven Beihilfe, op. cit., p. 256.

1593 VeHLING, K-H., «Abgrenzung von Vorbereitung und Versuch », op. cit., p. 130.

1594 Sobre ello, VeHLING, K-H., «Abgrenzung von Vorbereitung und Versuch», op. cit., p. 87; POLAINO-ORTS, M., «Imputación objetiva: esencia y significado», op. cit., pp. 43 a 50.

1595 LESCH, HH., Das Problem Der sukzessiven Beihilfe, op. cit., 257 y ss.

1596 JAKOBS, G., $P G$, op. cit., 25/15, dice que «(e)l fundamento de punición de la tentativa es exactamente el mismo de la consumación». Particularmente MYLONOPOULOS, C., Über das Verhältnis vom Handlungs-und Erfolgsunwert im Strafrecht, op. cit., pp. 84 y ss., considera que en la tentativa se aprecia tanto un desvalor de la acción (debilitación de la vigencia normativa) como un desvalor del resultado (lesión en la consideración social del bien jurídico), pero sólo en los casos en los que la acción quebrante el fin de la norma, el deber de no lesionar, op. cit., p. 59; en contra, aunque con ciertas reservas POLAINO NAVARRETE, M., Acción, omisión y sujetos en la Teoría del delito, op. cit., pp. 169 y ss., aprecia que «esa diferencia de penalidad viene originado por el plus de peligrosidad o de lesividad que se refleja en el injusto consumado que- por lo general- es más contundente y más reprobable que en la tentativa».

${ }^{1597}$ LESCH, HH., Das Problem Der sukzessiven Beihilfe, op. cit., pp. 257 y 258.

1598 De tal modo, como argumenta POLAINO NAVARRETE, es posible la tentativa en los delitos de mera actividad simple y en los delitos de omisión pura, siempre y cuando sea posible -en virtud del grado de relevancia social- la partición de los actos: por ejemplo -comenta el autor- en el delito de falso testimonio, cabe una tentativa ya sea porque no termina de pronunciarse la última palabra, ya sea porque lo falsario se expresa con monosílabo, y éste se malinterpreta por un error acústico, POLAINO NAVARRETE, M., «Injusto de la Tentativa y Vigencia de la Norma desde una Perspectiva Penal Funcionalista», op. cit., p. 739. Según él, esto también es apreciable en los delitos de «tentativa autónoma», p. ej. art. 262 CP, inciso segundo, que tipifica la tentativa de apartar a «postores en concurso y subastas públicas», y en otros tipos como los arts. 495.1 y 595 CP, ID., ibidem pp. 740 y 741; le sigue SANTA RITA, G., El delito de organización terrorista, op. cit., pp. 639 y 640.

1599 Explica JAKOBS que «la libertad de organización interna que compete a cada persona responsable se sostiene sobre un sinalagma: la persona tiene que preocuparse de que en su esfera de organización no salgan procesos causales dañosos (...) El abandono del dominio en perjuicio potencial de otro es, una tentativa en sentido material», JAKOBS, G., $P G$, op. cit., 25/21. 
Así, lo que configura el desvalor de la acción es la vulneración de un ámbito de organización asumido por los sujetos, según su rol común o especial: los roles establecen reglas y niveles de actuación u omisión en el riesgo permitido. Por ende, el quantum de la defraudación del riesgo permitido (libertad) del que cuenta la esfera de competencia del rol producirá el mayor o menor desvalor ${ }^{1600}$. No obstante, el quebrantamiento del rol no es suficiente para imputar la tentativa, sino que faltará conocer el título de imputación (dolo o imprudencia) para atribuir relevancia penal al sentido de la acción, esto es, más allá de la mera casualidad o infortunio.

En esto, la representación del autor puede ser comunicativamente relevante cuando se expresa como racionalmente organizada, es decir, la seriedad de la perturbación cognos-normativa en la seguridad jurídica, el dolo típico, su ejecución y su punibilidad. Por el contrario, en la tentativa supersticiosa, o «burdamente insensata» se excluye la pena o se rebaja altamente en el $\S 23.3$ StGB, cuando el autor se representa el proceso causal del resultado desconectado totalmente de lo sensatamente establecido social y naturalmente, y en función de esto la pena se gradúa o elimina $^{1601}$. Esto es razón bastante para concluir que la acción comunicante-racional fundamenta la punibilidad, y la irrelevancia de la comunicación ${ }^{1602}$ la excluye.

De aquí que la ejecución de lo cognitivo que supone el dolo típico fundamenta la punibilidad $^{1603}$, pues sin éste estaríamos ante una tentativa irreal supersticiosa. De esta manera, la

\footnotetext{
${ }^{1600}$ En dicha línea VeHLing, K-H., «Abgrenzung von Vorbereitung und Versuch», op. cit., pp. 124 y ss. y pp. 147.

${ }^{1601}$ Con un ejemplo que expone JAKOBS: «La tentativa inidónea por falta burda de entendimiento es una
} tentativa comunicativamente relevante pero la cantidad de su relevancia tiende a cero; por el contrario, en los casos de las «tentativas» que aquí se consideran atípicas, el autor incurre en un error de categorías: no alcanza la cualidad de lo comunicativamente relevante. Por supuesto que el error cualitativo también puede fundamentarse en la falta burda de entendimiento (los delitos putativos...), pero el $\S 23$ apartado 3 StGB no regula un error burdo que no alcance el dolo típico, sino que regula el dolo típico burdamente erróneo. Ejemplo: si en una hoja informativa sobre plantas venenosas se incluyen por error las ortigas, una persona sin ningún tipo de conocimientos de biología se atendrá al contenido informativo de la hoja; dado que nada entiende sobre la materia — ni tan siquiera advierte los errores burdos - actúa de manera burdamente equivocada en el sentido de que no conoce lo que parece evidente. Sin embargo, es prudente atenerse a las hojas informativas en materias sobre las que se carece de conocimientos. Si hubiese prestado atención a sus sueños o hubiese deducido el carácter venenoso en función de haber encontrado alguna vez un animal muerto entre unas ortigas, su dolo hubiese errado el tipo», JAKOBS, G., «Representación del autor e imputación objetiva», op. cit., p. 239, nota 32; ID., PG, op. cit., 25/30; VEHLING, K-H., «Abgrenzung von Vorbereitung und Versuch», op. cit., p. 124.

${ }^{1602}$ Así también la STS, de 18 de mayo de 2004: «toda tentativa en la que la realización del tipo no sea dependiente de la mera imaginación del autor, sino de un plan objetivamente racional, es punible en el Derecho vigente»; JAKOBS, G., $P G$, op. cit., 25/22, que «(e)1 autor no parte de una configuración del mundo comunicativamente irrelevante sólo en la tentativa supersticiosa, sino siempre que sustenta una visión del mundo incorrecta en cuanto a sus principios, es decir, cuando deriva sus conocimientos a partir de fuentes inadecuadas por principio (sueños, sentimientos intuitivos, inspiraciones, etc.) o los «procesa» de modo inapropiado por principio... Por eso, sólo la organización racional puede constituir organización relevante».

1603 JAKOBS, G., «La idea de la normativización en la dogmática jurídico-penal», op. cit., p. 34 y 35 ; Polaino Navarrete, M., «Injusto de la Tentativa y Vigencia de la Norma desde una Perspectiva Penal Funcionalista», op. cit., p. 730, desde una posición intermedia, pero en armonía a lo anterior, considera que el injusto de la tentativa se constituye formalmente por una «desautorización de la norma», y materialmente por «una puesta en peligro de un concreto bien jurídico protegido», concepción que para nada -comenta- sea contradictoria. Por ello «(c)uando los 
tentativa se inicia penalmente (relevantemente) cuando el autor, según la representación causal del delito concebido, aúna los medios preparatorios en tal sentido que éstos contengan una unidad valorativa relevante para la producción de las consecuencias queridas con la ejecución, más allá de una valoración sumatoria de los mismos, cuando alcancen un plus de sentido criminal $^{1604}$, y más allá de los pensamientos o deseos, lo que fundamenta que el concepto de peligro inminente o potencial es únicamente descriptivo y significativo para la determinación de la pena ${ }^{1605}$. Por ello, el concepto de inmediatez de lesión normativa se entiende como criterio subjetivo del plan $^{1606}$ (representación) del autor. No es de extrañar, entonces, que JAKOBS establezca unas directrices ${ }^{1607}$ sobre el comienzo de la tentativa, pues una fórmula general no es válida por los infinitos contextos sociales y ámbitos de organización posibles.

elementos realizados para la consecución del resultado normativo son idóneos, entonces no es que sea el injusto irreal, ideal o representado, sino normativamente real y existente»; en el mismo sentido GRACIA MARTÍN niega que sea necesario el resultado de peligro en la tentativa idónea, pues con la peligrosidad de la acción basta, GRACIA MARTín, L., «Sobre la punibilidad», op. cit., pp. 335 y ss., es decir, «basta con que el autor haya realizado actos que sean subsumibles en la acción típica» mediante el dolo típico, ID., ibidem, op. cit., p. 344. Comenta que «debe resultar que si se dan todos los elementos esenciales o constitutivos del desvalor de la acción se habrá realizado ya un fundamento de punibilidad (un injusto) aunque estén ausentes todos los demás que no hayan sido reconocidos como esenciales», ID., ibidem p. 348. En tal sentido lo que concurre en la idónea e inidónea es el dolo típico del desvalor de la acción, lo que constituye en sí un fundamento. Mientras que la idónea es peligrosa, al menos en la acción, la inidónea no es peligrosa pero si punible, porque el autor ha iniciado la acción conforme a la representación del plan (dolo típico) de materialización de los elementos objetivos del tipo. El juicio sobre la inidoneidad impune debe de partir del juicio de un hombre inteligente que colocado «en la posición del autor en el momento de la acción y teniendo en cuenta las circunstancias del hecho cognoscibles para esa persona inteligente más las conocidas por el autor y la experiencia común de la época sobre los cursos causales, apreciara, de acuerdo con la fórmula de Engisch, que la producción del resultado aparece ex ante como absolutamente improbable», ID., ibidem op. cit., p. 354 (cursiva en original). Así es como existen tentativas inidóneas intercomunicativamente más peligrosas ex ante que las tentativas idóneas, Cuello ConTreras, J., PG, op. cit., p. 107; MIR PUIG, S., «Sobre la punibilidad», op. cit., pp. 13 y 14; la STS de 23 de septiembre de 1996 reconduce la punibilidad de la inidónea al grado de peligro inherente al intento, según lo preceptuado en el art. $62 \mathrm{CP}$. Ello quiere decir también que para una línea jurisprudencial podríamos encontrarnos casos penados más altamente en las inidóneas que en las idóneas, con lo que estamos de acuerdo. Al ser el plan efectivamente racional, es razón bastante para penar; también en el caso de quien incendia la casa creyendo que estaba la víctima, STS de 2 de junio de 2000, en contra ALCÁCER GUIRAO, R., «Tentativa y desistimiento», op. cit., p. 1454; también admiten la punibilidad de la tentativa inidónea BACIGALUPO, E., Principios, op. cit., pp. 340 y 341; LóPeZ BarJa De QUIROGA, Jacobo, Derecho penal, Parte General, III, Los fundamentos de extensión de la tipicidad, Leynfor Siglo XXI, 2001, pp. 79 y ss; REQUENA JULIANI, J., Intercambiabilidad de acción y omisión, op. cit., p. 225; SÁNCHEZ-OsTIZ, P., La libertad del Derecho penal, op. cit., pp. 101 y 102.

1604 Similar Cuello CONTRERAS, J., «Sobre el tipo de tentativa», Homenaje al profesor Dr. Gonzalo Rodríguez Mourullo, 2005, p. 260. Considera que la tentativa comienza «cuando conforme al plan del autor, se ha creado ya la situación óptima en la que, sin solución de continuidad, puede realizar su propósito, es decir, ejecutar al menos un acto que sin duda representa el comienzo de ejecución del tipo», CuEllo ConTRERAS, J., PG, op. cit., p. 89.

1605 JAKOBS, G., $P G$, op. cit., 25/56 y 57.

1606 Utilizamos el término «plan» por ser el más comprensible, sin embargo es sabido que puede actuarse dolosamente sin un plan «preconcebido», p. ej. «en un estado de arrebato pasional», JAKOBS, G., PG, op. cit., $25 / 24$.

${ }^{1607}$ En concreto, JAKOBS expone las siguientes directrices: a) Que la acción se aproxime a la consumación según la representación del autor. El concepto de inmediatez ha de ser entendido mediante la objetivación del criterio subjetivo del plan del autor, y esto sólo puede efectuarse analizando el ámbito de organización concreto, el rol y su competencia. b) Que la acción sea ya la propia acción de ejecución. JAKOBS considera que no es tentativa generalmente- dirigirse al lugar del delito. Habrá que analizar la configuración social de dicha acción para discernir entre un acto preparatorio o una tentativa. c) La proximidad temporal sin interrupción. Una alta diferencia temporal 
Lo relevante del hecho es que en la representación del autor exista una racional idoneidad ${ }^{1608}$ del ámbito de organización objetivamente ${ }^{1609}$ configurado, pero a su vez, subjetivamente intercomunicado (plan-representación). Esto significa que para la punibilidad es bastante con que el plan ejecutado contenga un mínimo de racionalidad (idoneidad intercomunicativa), a pesar de una inidoneidad objetiva.

Entonces, en nuestra opinión el fundamento de la punibilidad de la tentativa ya no es la peligrosidad $^{1610}$ ni la idoneidad, sino su causa: la imputación objetiva del dolo concomitante en la acción, o con otras palabras, la conducta racionalmente desviada de las acciones propias del concreto rol en su estricto ámbito de organización. Esto precisamente sirve para conocer su comienzo y su punibilidad, lo que posibilita desterrar el tradicional concepto de peligrosidad en dos sentidos: a) el quebrantamiento del rol mediante una racionalidad mínima (dolo) o por inaplicación de la racionalidad mínima exigible al sujeto (imprudencia); b) en los casos en los que el sujeto actúa conforme a su rol, es decir, sin defraudar la expectativa generada en la Sociedad, el peligro no podrá ser imputado porque forma parte de su libertad como rol (esfera de competencia del rol) ${ }^{1611}$.

No resultará extraño afirmar que la falta de compresión del fundamento de punibilidad de la tentativa viene precisamente de la impunidad general de la tentativa imprudente. Si como consideramos el fundamento de punibilidad es la ejecución mínimamente racional en los delitos dolosos, este fundamento también lo será en la imprudencia pero en un sentido negativo, es

entre acción y resultado no impide el inicio de tentativa, pues como explicaremos, quien intenta el delito puede haber planeado que la consumación se materialice días después. d) La propia consideración de la representación del autor en ámbitos de organización en los que la víctima organiza sus derechos de modo socialmente usual. Sensu contrario, si la conducta de la víctima es inusual, habrá concurrencia de culpas o auto-puesta en peligro, ID., ibidem, op. cit., 25/64 a 70.

${ }^{1608}$ ZACZYK, R., Das Unrecht der Versuchten Tat, op. cit., p. 252, comenta que «(c)uando menos se establezca la relación jurídica por medio de fuerzas trascendentes, menos puede constituir injusto conjurar tales fuerzas»; JAKOBS, G., «La autoría mediata con instrumentos que actúan por error como problema de imputación objetiva», op. cit., p. 258; ID., PG, op. cit., 25/36; ID., «Representación del autor», Estudios de Derecho penal, op. cit., pp. 223 y ss; ID., «Criminalización en el estado previo a la lesión de un bien jurídico», op. cit., pp. 293 y ss.

1609 JAKOBS, G., $P G$, op. cit., 25/1a.

1610 Por eso dice JAKOBS que «(e)l peligro, como concepto cuantificable, es inidóneo, pues entre preparación y tentativa se pueden distinguir a lo sumo grados de peligro, pero no (...) cualitativamente distintos», ID., ibidem, op. cit., 25/15; Cuello CONTRERAS, J., PG, op. cit., pp. 11 y 12; GONZÁlEZ MATEOS, JC., «Esencia de la norma», op. cit., p. 205.

${ }^{1611}$ Con otros ejemplos VeHLING expone esta idea. Considera que no hay tentativa alguna en el llamado «caso de las bolsas de pimienta» pues la acción de quien intenta robar con éstas y antes de echarlas es atrapado, no revela por sí misma la realización típica perseguida, no revela ejecución, pues, está socialmente permitido por la generalidad portar bolsas de pimienta. Mientras que quien se presenta en una gasolinera a altas horas de la madrugada portando armas, ha iniciado ya una ejecución, pues no está socialmente adecuado portar armas cuando se quiere entrar en un establecimiento de este tipo. En este caso, si bien no se ha empleado el arma aún, el sentido ejecutivo ha comenzado cuando el sujeto se ha colocado en la puerta, VeHLING, K-H., «Abgrenzung von Vorbereitung und Versuch», op. cit., p. 147. 
decir, por la inaplicación de la racionalidad mínima exigible al sujeto. Cuestión aparte es si merece o no criminalizarse la tentativa de los delitos imprudentes.

Lo paradójico es que se criminalizan hoy día conductas que suponen un peligro concreto, lo que tiene un gran paralelismo con la tentativa idónea, pero también otros casos cuando suponen únicamente un peligro abstracto, o sea, acciones con un «escaso»o «nulo» peligro. Los delitos de peligro abstracto, de posesión y de pertenencia son un buen ejemplo, no sin polémicas ${ }^{1612}$.

1612 Sin embargo, algún sector que admite la punibilidad de los delitos de peligro abstracto, niega la punibilidad en la inidónea, creemos que sin fundamento. Si abogamos por la punibilidad de los delitos de peligro abstracto, debemos hacerlo también en la tentativa inidónea por una sencilla razón: exigir una probabilidad del resultado es abogar por dejar impune a los autores sencillamente racionales, o que han aplicado una mínima racionalidad, pues tan inidóneo es, objetivamente hablando, conducir ebrio por un camino sin nadie alrededor a $100 \mathrm{Km}$. a la redonda, como intentar matar con una pistola que el vendedor, por error, ha vendido como buena. Por ende, el fundamento de punibilidad no puede ser el peligro objetivo.

En relación a los delitos de posesión, PASTOR MUÑOZ realiza una comparación entre los delitos de posesión y de estatus o delito de pertenencia a organización criminal o injusto sistémico en otras concepciones, al objeto de analizar la naturaleza y legitimación de estos delitos, y por ende, supone un estudio de los fundamentos de punibilidad.

Su principal conclusión es que los delitos de posesión y el delito de estatus contienen estructuras diferentes que los separan de la tradicional forma de comprensión como delitos de peligro abstracto, lo que plantea problemas sobre la legitimidad de estos delitos. En este punto, una primera aproximación a estos delitos plantea el debate de si se refieren a acciones u omisiones puras lejanas a la lesión de bienes jurídicos individuales, y si a pesar de dicha lejanía, existe un fundamento de legitimidad. Rechaza la trascendencia del concepto de acción y omisión en estos delitos para su legitimación, PASTOR MuÑOZ, Nuria, Los delitos de posesión y los delitos de estatus: una aproximación político-criminal y dogmática, Atelier, 2005, p. 45. También en este sentido POLAINO-ORTS se refiere a que estos tipos no sancionan una acción o una omisión sino «la mera situación de posesión o tenencia de una cosa», Polaino-OrTs, M., Derecho penal del enemigo. Fundamentos, op. cit., p. 361.

Propone varias estructuras, concretamente: a) la posesión de objetos peligrosos que es en sí peligrosa; b) la posesión de objetos peligrosos que pueden ser empleados de manera peligrosa; c) la posesión de objetos con la intención de cometer un delito; d) la posesión de objetos específicamente destinados a la comisión de delitos, siempre y cuando la posesión tenga un significado inequívoco de preparación; e) la pertenencia a una organización criminal; f) la posesión de objetos provenientes de la comisión de un delito. Los del grupo a) se caracterizarían, por ejemplo, por la posesión de un arma que se deja cerca de un niño, materiales reactivos en malas condiciones de seguridad. La estructura b) se ajusta, por ejemplo, a los casos de posesión de armas sin licencia que pueden ser empleadas para cometer delitos. La estructura c) representa casos en los que la posesión de objetos peligrosos no es en sí misma peligrosa para los bienes jurídicos, pero cuando se acompañan con un plan criminal delictivo, suponen una forma de preparación (intención). En este punto, la referida autora encuentra una diferencia entre las anteriores tres estructuras, que en la b) y c) «a diferencia de lo que ocurre en la primera, entre la posesión y la afección de un bien jurídico debe mediar necesariamente un comportamiento humano libre que sea peligroso para bienes jurídicos. Obviamente, esta diferencia es esencial en términos de imputación del resultado de lesión o peligro concreto, pues, de seguir las reglas generales, entenderíamos que es el comportamiento libre que sigue a la posesión, y no la posesión misma, el principal candidato a la imputación del resultado (...) A lo dicho debe añadirse una declaración: es posible que, en los casos reales, se den nuevas estructuras fruto de la combinación de las que se han propuesto aquí», PASTOR MuÑOZ, N., Los delitos de posesión y los delitos de estatus, op. cit., pp. 45 a 55.

De las estructuras de peligrosidad expuestas por la meritada autora se puede asociar en la b) como «peligro de un comportamiento futuro», las técnicas de persuasión coercitiva, de tal modo que ni su posesión, en este caso el conocimiento, ni el uso en sí mismo supone ningún peligro, sino el modo en que se emplean, al punto que resulta intrascendente para la legitimación/fundamentación de la punibilidad el uso imprudente o doloso, aspectos subjetivos que modularían, si quiera, una mayor responsabilidad. En este punto, alcanza comprensión la similitud estructural del delito de lesiones del art. $148 \mathrm{CP}$ cuando se emplearen medios peligrosos, por cuanto la idoneidad de dicha peligrosidad se refiere en ambos supuestos a un uso o aumento de la peligrosidad. Lo mismo cabe decir sobre forma de configurarse una dinámica comportamental grupal, cuando más allá del dolo o la imprudencia en la organización, la misma supone un peligro objetivo para según dicha configuración, lo que se asemeja también a la estructura e) en relación al delito de estatus o injusto sistémico. 


\section{De todo lo anterior se puede concluir que el comienzo de la tentativa es una cuestión de}

imputación objetiva de los elementes subjetivos (dolo e imprudencia), una vez se ha trasgredido el riesgo permitido.

Sin embargo, PASTOR MUÑOZ considera que en las estructuras c), d) y e) falta la peligrosidad objetiva, que se suple por un «equivalente funcional» de legitimación de la punibilidad «con la manifestación objetiva de la peligrosidad subjetiva del autor», que cuanto que tal manifestación tiene un contenido «comunicativo perturbador», ID., ibidem, op. cit., pp. 61 y 62, y en relación a la estructura b), se refiere a la «suposición» de peligrosidad, lo que fundamenta su ilegitimidad, ID., ibidem, op. cit., pp. 59 y 79; similarmente SANTA RITA, G., El delito de organización terrorista, op. cit., pp. 218 y ss. Críticamente POLAINO-ORTS, M., Derecho penal del enemigo. Fundamentos, op. cit., p. 369.

La comunicación perturbadora la fundamenta en la seguridad o expectativa normativa lo que le lleva a concluir que se trata de delitos autónomos, no en la cognitiva, en contra de las apreciaciones de JAKOBS, PASTOR MuÑOZ, N., Los delitos de posesión y los delitos de estatus, op. cit., pp. 69 y 72; JAKOBS, G., «Criminalización en el estadio previo a la lesión de un bien jurídico», Estudios de Derecho penal, Madrid, 1997, pp. 314 y ss. Sin embargo, el error en el que incurre la referida autora es que trata estas estructuras como actos preparatorios o adelantamiento anterior a la lesión del bien jurídico. Dicha conclusión ha de mantenerse en reserva por cuanto la autonomía, y por ende, el fundamento de punibilidad de éstos no pende de la conexión con un determinado delito-fin, sino con una peligrosidad manifestada objetivamente que precisa su revocación normativa, o como comenta POLAINO-ORTS de «una imputación de una peligrosidad iuris et de iure, donde la posesión de un objeto peligroso es considerada ya per se peligrosa con independencia de que se dé o no un uso (correcto o incorrecto) de ese objeto peligroso», POLAINOORTS, M., Derecho penal del enemigo. Fundamentos, op. cit., p. 365. Críticamente SANTA RITA, G., El delito de organización terrorista, op. cit., pp. 218 y ss., precisa la posesión de objetos peligrosos con la intención de cometer delitos. Esto significa que «la lesión del bien jurídico empieza en este caso antes (no cuando se lesiona el bien individual, sino cuando se lesiona el bien jurídico colectivo de seguridad») POLAINO-ORTS, M., Derecho penal del enemigo. Fundamentos, op. cit., p. 368. En nuestra opinión, por eso habitualmente se criminalizará separadamente o con mayor gravedad cuando se ejecuta el delito-fin. No puede hablarse de adelantamiento o anticipación de la barrera punitiva, cuando dicha autonomía es funcional para la seguridad.

De la controvertida anticipación, tanto PASTOR MUÑOZ como POLAINO-ORTS extraen que se trataría de tipos del Derecho penal del enemigo. Comenta la primera que «estos tipos de posesión y estatus podrían considerarse efectivamente manifestaciones de un Derecho penal del enemigo (...) la pena es una reacción a la manifestación de la peligrosidad subjetiva que lesiona la seguridad (entendida en términos normativos)», PASTOR MUÑOZ, N., Los delitos de posesión y los delitos de estatus, op. cit., p. 78. El segundo se refiere a que dicha anticipación subyace en la criminalización autónoma de otro bien jurídico, la seguridad como contenido mínimo para desarrollarse «comunicativamente la vida dentro de parámetros de normalidad», POLAINO-ORTS, M., Derecho penal del enemigo. Fundamentos, op. cit., p. 369. La discrepancia entre ambos está en que el sentido comunicativo, según POLAINOORTS y con lo que estamos de acuerdo, también aparece en el Derecho penal del enemigo, ID., ibidem, op. cit., pp. 373 y ss. Por eso PASTOR MUÑOZ parece tratar los fundamentos del Derecho penal del enemigo dentro del subsistema del Derecho penal del ciudadano, sin embargo, cabe aclarar que la nota relevante es que la comunicación que se manifiesta (se constata) con los delitos de posesión y estatus, es que en éstos, dicha comunicación se diferenciada del Derecho penal del ciudadano porque el primero utiliza criterios operacionales distintos pero basados también en único Sistema, la Sociedad, y con esto, se respeta que tales focos de peligro encuentren la legitimidad de su punibilidad en el quebrantamiento de la seguridad cognitiva que tienen los ciudadanos en la vigencia de las normas, que supone una operación propia de ambos subsistemas. Por eso, tampoco podemos estar de acuerdo con la interpretación que hace la meritada autora en cuanto que JAKOBS concibe y precisa en la estructura b) un sentido inequívoco de preparación «que no pueden ser utilizados para fines legales», JAKOBS, G., «Criminalización en el estadio previo a la lesión de un bien jurídico», op. cit., p. 310. Esto porque para ello hace falta conocer el determinado delito-fin, no se conoce qué delito se va a realizar con el arma, homicidio o robo por ejemplo, ni su utilización dolosa, imprudente o para fines lícitos (parece también rechazar la exigencia de un fundamento del tipo subjetivo, POLAINO-ORTS, M., Derecho penal del enemigo. Fundamentos, op. cit., p. 370), sino únicamente su configuración de sentido comunicativo criminal o «unidad social de sentido» en la terminología de POLAINO-ORTS, y que fundamenta la «idoneidad lesiva que se deriva de la posesión», ID., ibidem, op. cit., p. 370. De aquí que se quebrante la seguridad cognitiva y finalmente la normativa: «seguridad cognitiva en la vigencia de la norma», ID., ibidem, op. cit., pp. 370 y ss. Esto no resta importancia a la necesidad de criminalizar este tipo de peligrosidad al tratarse de tipos que escapan de la estructura subsistémica del Derecho penal del ciudadano, y penetran en otro subsistema diferenciado, al que se ha denominado, según lo expuesto supra, Derecho penal del enemigo, en el que prima un combate sobre la seguridad cognitiva. 
En el caso de las sectas criminales, y en relación a la persuasión coercitiva, la tentativa comienza entonces cuando se inicia la restricción del horizonte de expectativas normativas y sociales, de modo que los conocimientos previos o actos anteriores constituirían actos preparatorios, en principio impunes por este delito, sin embargo dichos conocimientos puestos en común sí que pueden constituir un fundamento de punibilidad de la organización.

Puesto que las técnicas de persuasión coercitiva y la dinámica comportamental criminal en sí mismas no tienen diferencias apreciables con técnicas terapéuticas o comportamientos grupales rigurosos, el fundamento de criminalidad que se determina en ambos casos parte de la configuración de sentido criminal, esto sin atender al plus cognitivo ni al determinado delito-fin, porque el fundamento de punibilidad, su legitimación en el Derecho penal, viene de la utilización peligrosa o configuración riesgosa para la seguridad cognitiva, de modo que también la idoneidad se refiere a dicho foco de peligro. El tipo subjetivo es ajeno al fundamento. La Sociedad y su Sistema precisan desterrar operaciones que atentan a sus cimientos asegurativos, no permite entradas, influjos, en este caso, manifestaciones que en sí mismas constituyen focos de peligro. De aquí que en el sistema de conciencia, la finalidad dolosa o la actitud imprudente no aporten más que una calificación cuantitativa y cualificativa del quebrantamiento de la seguridad cognitiva y a la postre normativa. Por eso, también, la idoneidad se refiere al foco de peligro comunicado. Cuestión distinta es que el legislador penal, por razones de estricta políticacriminal, haya circunscrito, por lo general, estas estructuras como delitos dolosos.

Concretamente y en nuestro ámbito de estudio, la doctrina española tradicionalmente se encuentra dividida sobre los momentos y grados de ejecución del delito de coacciones, entre los que exigen que el sujeto pasivo omita lo que la ley no prohíbe o efectúe lo que no quiere sea justo o injusto $^{1613}$, los que consideran que al tener el delito de coacciones un elemento subjetivo de lo injusto se consumará cuando además de doblegarse la voluntad ajena se materialicen los fines perseguidos ${ }^{1614}$, los que se muestran conformes con las formas imperfectas ${ }^{1615}$ y los que consideran que habrá que analizar la naturaleza del medio desde una posición ex ante, aunque también ex-post para conocer la idoneidad del medio coactivo ${ }^{1616}$.

Como adelantábamos, la polémica verdaderamente se centra en las coacciones por el suministro de narcóticos u otras técnicas como la hipnosis y que, por nuestra parte, hemos

1613 Higuera GUIMERÁ, JF., El delito de coacciones, op. cit., p. 237.

1614 Cuello Calón, E., Derecho penal, Parte Especial, T. II, op. cit., p. 813.

1615 RodríGUEZ DEVESA JMa / JASO ROLdÁn T / RODRÍGUEZ MUÑ̃Z JA., PE, op. cit., p. 306; RODRíGUEZ DEVESA JM / SERRANO GÓMEZ A., PE, op. cit., p. 290.

1616 MIR PUIG, S., «El delito de coacciones en el Código penal», op. cit., pp. 289 y 290; HiGUERA GUIMERÁ, JF., El delito de coacciones, op. cit., 145; desde 1976 mantiene esta línea, aunque se aferra con mayor fuerza al concepto virtual de juicio ex ante MuÑoz Conde, F., Derecho penal, Parte especial, Universidad de Sevilla, 1976, p. 104. 
asociado a la persuasión coercitiva en el concepto normativo de violencia. Sobre esta polémica, TORÍO ${ }^{1617}$ precisaba dos circunstancias para apreciar la susceptibilidad del medio como coacción, en concreto un «mal actual» para doblegar la voluntad y proposición de un mal en caso de desoír la voluntad ajena, de tal modo que consideraba que la consumación de la coacción no se materializa por la administración de narcóticos por ejemplo, sino cuando se ataca la libre ejecución de la voluntad, y por lo tanto, cuando se ataque la libre formación de la voluntad, por eso, sólo la resolución criminal dirigida a constreñir puede entenderse como forma imperfecta de ejecución.

Por nuestra parte, opinamos que las técnicas de persuasión son idóneas per se según los postulados que hemos desarrollado, salvo superstición, por lo que habrá que analizar cómo se aplican dichas técnicas, durante cuánto tiempo, su intensidad y la personalidad de la víctima para conocer si efectivamente han sido aplicadas con total idoneidad intercomunicativa para quebrantar la libertad de voluntad y la gravedad de la acción y del resultado. Este análisis sólo se puede realizar conociendo la representación del plan criminal del autor, si el autor en su mente ha configurado un plan criminal en la aplicación de las técnicas de persuasión suficientemente idóneo para alcanzar el resultado, o con otras palabras, que haya aplicado una mínima racionalidad en el plan sin saltarse las mínimas leyes causales. Por ejemplo, quien pretende persuadir coercitivamente por medio de la introducción de dedos en los odios, ya no sólo no estará llevando a cabo un plan inidóneo, sino imposible o inclusive supersticioso, sin embargo, si a los anteriores datos se suma que el autor conoce que la víctima es altamente sugestionable por su debilidad mental u otra circunstancia como para saberse él una autoridad, el plan resulta altamente idóneo. En el mismo sentido serán punibles si se aplican estás técnicas de forma imprudente, sin aplicar la racionalidad mínima exigible al sujeto cuando interactúe con estás.

Por ello, el planteamiento antaño de alguna sentencia del Tribunal Supremo, la de 27 de diciembre de 1945, que requería únicamente que la violencia «sea capaz por su gravedad o naturaleza de cohibir el ánimo de cualquier persona dotada de temple ordinario», nos parece lógicamente obsoleto. Sin embargo, el Tribunal Supremo, allá por los años sesenta, empezó a referirse, al menos parcialmente, a lo que estamos aludiendo: «es preciso valorar en primer término, la cultura, la educación y el ambiente social en que se desenvuelve los sujetos activos y pasivos», y la coacción por «el aprovechamiento de la incultura de la víctima».

La relación entre la intensidad del medio que coacciona y el resultado material causado no plantea una especial problemática, pues no se precisa de una fuerza física o psíquica mayor, sino

1617 TORío LóPEZ, A., «La estructura típica del delito de coacción», op. cit., pp. 407 y 408. 
que en nuestra opinión, se precisa la susceptibilidad concreta del medio para la producción material en relación a la racionalidad. La problemática de la susceptibilidad o idoneidad del medio que parte de la virtualidad ex ante como criterio determinador de la susceptibilidad, sólo puede ser empleado restrictivamente para los casos de fuerza en lo material, pues en la vis psíquica, la coacción no depende tanto de las leyes naturales de la materia como de la subjetividad personal de cada ser humano. Por lo tanto, para apreciar la susceptibilidad del medio coaccionar de la voluntad a través de lo psíquico deberá partirse de un baremo objetivado del ser humano, y en concreto, del ser humano inherente en nuestra sociedad actual, la persona. El criterio de temporalidad virtual ex ante sirve para apreciar la susceptibilidad del medio coaccionador en lo material, pues la ciencia material tiene medios idóneos para determinar las fuerzas, inclusive en diversos sujetos y medidas. Pero la virtualidad ex ante y la ciencia de la mente no están tan avanzadas en la determinación de la medición del grado de sugestionabilidad o persuasión, por ello es necesaria la objetivación del ser humano, de sus cualidades, de sus circunstancias, de sus miedos, de su entorno, no en cuanto a un «hombre medio», lo que haría nuevamente aumentar la punibilidad a casos de aplicación media de conocimientos, y dejar de criminalizar persuasiones a sujetos con flaqueza de espíritu, debilidad mental o sugestionabilidad, lo cual en su caso y por el contrario, sería constitutivo de agravante genérica, sino a un hombre mínimo: aquél que siempre concurre como persona en Derecho ${ }^{1618}$.

Así, la tentativa de la persuasión coercitiva comienza con el inicio de la restricción del horizonte de expectativas normativas y sociales comunicadas por el Sistema, así que cuando efectivamente se afecta a la capacidad de libertad de voluntad en sus tres vertientes (capacidad o formación, decisión y ejecución) se consuma el delito. Mientras que la tentativa del delito de lesión psicológica comienza con la eliminación del horizonte de expectativas y los actos previos corresponden al riesgo típico de la coacción por persuasión coercitiva.

\footnotetext{
1618 A favor de este planteamiento se ha mostrado con otras palabras HIGUERA GUIMERÁ entre otros. Restringe la concepción del «hombre medio», en el siguiente sentido: «a falta de datos más concretos que pueda tener el sujeto activo sobre el sujeto pasivo, pero la existencia de tales datos puede poner de manifiesto una personalidad dotada de más o menos temple que el hombre ordinario, y lo decisivo ya no será entonces el baremo del hombre medio, sino las características del sujeto pasivo conocidas por el autor», HIGUERA GUIMERÁ, JF., El delito de coacciones, op. cit., 145; similarmente MIR PUIG. S., «El delito de coacciones en el Código penal», op. cit., pp. 289 y 290.
} 
B. Sobre la relevancia del consentimiento en las coacciones y en el delito de lesiones: su ubicación jurídico penal y trascendencia en la persuasión coercitiva y en la adicción comportamental

\section{El consentimiento en la coacción}

Es opinión común que la libertad es un derecho de libre disposición, por lo que el consentimiento sería una causa de atipicidad por ser renunciable, ahora bien, el consentimiento prestado por error, violencia, intimidación o dolo es nulo (art. 1265 CC). Así, si concurre el consentimiento válido en los delitos contra la libertad, como en los delitos de detenciones ilegales, las coacciones o en el allanamiento de morada, no se produce la lesión, pues el consentimiento expresa un «acuerdo», «asentimiento»o «conformidad (Einverständnis) -así lo denomina la doctrina alemana- para defender en estos supuestos la atipicidad («teoría unitaria del consentimiento») ${ }^{1619}$. Basta que el sujeto activo conozca el consentimiento y su objeto, incluso que conozca un consentimiento presunto ${ }^{1620}$. Claro está que si el consentimiento está viciado no tendrá el efecto de eliminar la lesión ${ }^{1621}$. Sin embargo, para la «teoría de la dirección» ${ }^{1622}$ no haría falta el conocimiento del consentimiento por el sujeto activo.

Por nuestra parte, consideramos que la terminología adoptada por la doctrina alemana es más precisa, pues el «acuerdo» entre «víctima» y «autor» expresa la falta de lesión en el bien privado, la atipicidad, mientras que el «consentimiento» se refiere una causa de justificación ${ }^{1623}$, salvo excepciones como la de los contratos de adhesión o contratos masa ${ }^{1624}$, pero que responden a un planteamiento distinto del que ahora nos ocupa.

${ }^{1619}$ RoxIN, C., $P G$, I, op. cit., p. 516.

${ }^{1620}$ Higuera GuIMERÁ comenta al respecto que «(e)l consentimiento presunto en el delito de coacciones, excluye el tipo, cuando el acto coactivo se ejecuta en interés del sujeto pasivo, si según un juicio objetivo hubiese podido esperarse su consentimiento (...) no tiene significado penal el consentimiento posterior (aprobación), pues estaríamos e presencia del perdón, que solamente es aplicable a aquellos delitos perseguibles mediante denuncia o querella de la agraviado», HigUERA GUIMERÁ, JF., El delito de coacciones, op. cit., pp. 229 y 230.

${ }^{1621}$ HIGUERA GUIMERÁ que el consentimiento será válido cuando «la persona tenga conocimiento del alcance de la renuncia», por lo que un consentimiento viciado sería ineficaz, ID., ibidem, op. cit., p. 228.

${ }^{1622}$ HigUERA GUIMERÁ critica que «sus defensores al castigar al autor por lo menos por la tentativa inidónea, están abandonando su premisa inicial, pues con ello, dan a entender que el consentimiento no conocido por el autor, al menos elimina el resultado», ID., ibidem, op. cit., p. 229.

${ }^{1623}$ En el mismo sentido la doctrina dominante COBO Del Rosal M / ViVES ANTón TS., PG, op. cit., p. 375 , MIR PUIG, S., $P G$, op cit., p. 520.

1624 Explica BAJO FERNÁNDEZ que «(p)or lo que se refiere al consentimiento como causa de justificación, cobra importancia en el delito de coacciones el fenómeno moderno de los contratos de adhesión en los que la firma del contratante, normalmente consumidor o usuario, implica consentimiento de una serie de actuaciones (corte de suministro en caso de impago, por ejemplo). Pues bien, por las particulares características de los contratos de adhesión o contratos masas, el consentimiento del consumidor o usuario no debe considerarse relevante para excluir el delito de coacciones, por tratarse de servicios públicos o suministros de bienes y servicios en los que una actuación como la "consentida" entrañaría un atentado contra la buena fe y abuso de derecho», BAJO FERNÁNDEZ M / Díaz-Maroto Y Villarejo J., Manual de Derecho Penal, Parte especial, Delito contra la libertad y seguridad, libertad sexual, honor y estado civil, op. cit., 124. 
En lo que a nuestra investigación compete, el consentimiento del sujeto pasivo a una reforma del pensamiento, por la naturaleza de la libertad y disponibilidad del pensamiento, no sería un delito de coacciones, sería atípico. Esto sería tan legítimo como la propia libertad de mudar de religión, ideología o de opinión, siempre y cuando no se usen técnicas de persuasión desconocidas por el sujeto pasivo, ni se cree una adicción comportamental en la que se anule el razonamiento del sujeto o que entrañe peligro para la integridad psíquica, puesto que en estos casos lo fundamental para la licitud de una renuncia a la propia voluntad o libertad es la posibilidad de revocación. Se anularía precisamente la libertad y la dignidad del sujeto, es decir, la parte esencial, indisponible e irrenunciable del derecho cuando no existe posibilidad de revocación. El consentimiento ha de ser esencialmente revocable, lo que exige entonces que el sujeto mantenga la posibilidad de ejercitar la libertad y la capacidad para esa revocación. Una merma en cualquiera de ellas, sea en la libertad, por habérsele reducido o anulado por el completo el horizonte de expectativas, sea en la capacidad, por haber sido limitada o anulada su capacidad mental, anula el consentimiento ya prestado por haber sido eliminado un requisito esencial: la revocabilidad.

En coherencia con la posibilidad de revocación, RODRÍGUEZ-CARBALLEIRA ${ }^{1625}$ propuso alguna medida similar a la del periodo de reflexión que se introdujo en la mal llamada multipropiedad (derecho de aprovechamiento por turnos) o como en la publicidad, que no puede ser engañosa, subliminal ni fraudulenta. Esto tiene sentido en cuanto a que la oferta religiosa también es un producto destinado al consumidor, y al tratarse de cuestiones transcendentales de la conciencia y la voluntad, supone un asunto altamente riesgoso que precisa de control.

Llama la atención que algún autor ${ }^{1626}$ haya abogado por la justificación de las coacciones en el caso Riera Blume comentado, con base a que la voluntad de los "secuestrados" estaba anulada porque la organización la anuló, y por lo tanto no es antijurídica al concurrir el consentimiento de los familiares quienes la sustituyeron.

Por lo tanto, la desocialización o elección de un horizonte con escasas posibilidades el aislamiento social y cultural libremente elegidos por el sujeto, aunque pueda causar un déficit de socialización, supone una conducta neutra, o sea, permitida en derecho, o riesgo permitido en derecho, incluso si se quiere una «autopuesta» en peligro aunque el sujeto se aleje de una sociedad normativizada y se acerque al estado de naturaleza.

1625 RODRÍGUEZ-CARBALleIRA, A., «La actuación de las sectas coercitivas», op. cit., p. 267.

${ }^{1626}$ MONGE FERNÁNDEZ, Antonia, «Derecho a la libertad y a la seguridad. Comentario a la sentencia del Tribunal Europeo de Derechos Humanos de 14 de octubre de 1999. Caso Riera Blume y otros contra España», AP, 25, 2001, p. 568. 


\section{Consentimiento en las lesiones}

Con los anteriores códigos penales y reformas la doctrina penal no se ponía de acuerdo sobre el efecto del consentimiento de las lesiones ${ }^{1627}$. En nuestro actual Código penal, el consentimiento de la víctima en las lesiones producidas directamente por tercero (heterolesión) no elimina la tipicidad de los delitos contra la integridad física, ni en aquellos casos en los que el consentimiento es expresión del libre desarrollo de la personalidad (art. $10 \mathrm{CE}$ ), sino que se atenúa la pena cuando el consentimiento no está viciado. Sin embargo, la doctrina mayoritaria sí que está de acuerdo en la impunidad de la participación del tercero en las lesiones producidas directamente por la víctima (autolesión) cuando media el consentimiento libre. Así, la participación en las autolesiones se considera atípica, mientras que las lesiones causadas por tercero pero consentidas por el titular son típicas, por lo que responde aunque la responsabilidad se atenúa en virtud del art. $155 \mathrm{CP}^{1628}$.

Así, el art. 155 CP disminuye el injusto y la pena del autor de las lesiones cuando medie consentimiento en las mismas, y bajo ciertas circunstancias, rebajando la pena en uno o dos grados, lo que concede relevancia en la antijuricidad, disminuyendo el contenido injusto del hecho (casos de ablación, doping, si bien se discute en casos de SIDA). Entonces, el fundamento de atenuación de la pena es el mismo que en el homicidio consentido o en la eutanasia. El legislador en estos casos, ha actuado también de forma paternalista por entender que el bien jurídico es esencial para la sociedad, si bien se atenúa porque la acción criminal se considera que se movió por un evidente motivo de solidaridad con el prójimo ${ }^{1629}$, lo que en nuestra opinión, como ya manifestamos, es incoherente ${ }^{1630}$ y supone una contraorientación normativa que sólo se podría reparar de lege ferenda, o en algunos casos, con el estado de necesidad exculpante.

En las lesiones realizadas por tratamiento médico, la mayor parte de la doctrina está de acuerdo en que el seguimiento de la lex artis hace a las lesiones ser atípicas aunque el resultado

\footnotetext{
${ }^{1627}$ Con la reforma de 1983, el párrafo segundo del art. 428 CP concedía relevancia del consentimiento para eximir de responsabilidad en los supuestos de trasplantes, cirugía y esterilización en el mismo supuesto del actual $155 \mathrm{CP}$ actual, lo cual resultaba ya sorprendente porque o la salud es un bien jurídico disponible y debe reconocerse relevancia al consentimiento inclusive en los casos fuera de las intervenciones médicas, o es indisponible y por tanto sin ninguna relevancia, GonZÁlez Rus, JJ., vv.aa., Derecho penal español, Parte especial, op. cit., p. 143.

${ }^{1628}$ ID., ibidem, op. cit., p. 144; HERRERA MORENO, M., vv.aa., Lecciones de Derecho penal, Parte Especial, T. I, op. cit., p. 116.

${ }^{1629}$ Peñaranda Ramos, E., vv.aa., Compendio de Derecho penal, Parte especial, Vol. I, op. cit., p. 376

1630 Similarmente GARCÍA ÁlvareZ, P., La puesta en peligro, op. cit., pp. 482 y ss con base al libre desarrollo de la personalidad; MARTíNEZ RUIZ comenta que «resulta más que discutible la necesidad y la conveniencia de atenuar la pena del delito de lesiones en uno o dos grados», MARTíneZ RuIZ, J., El delito de lesiones, op. cit., pp. 27.
} 
sea negativo ${ }^{1631}$; sin embargo, si no media el consentimiento, algunos penalistas -como GONZÁLEZ RUS ${ }^{1632}$ - alegan, acertadamente, que podría concurrir con el delito de lesiones un delito de coacciones, lo que resulta análogo a nuestras conclusiones de la intermediación en el delito de coacciones el de lesiones psíquicas en el injusto de la persuasión coercitiva.

Sin embargo, al consentimiento en las lesiones de las intervenciones médicas, como los trasplantes de órganos y las operaciones de esterilidad y cirugía transexual (art. $156 \mathrm{CP}$ ), la doctrina $^{1633}$ le otorga mayoritariamente una eficacia justificante sólo en estos casos excepcionales, cuyo fundamento también incurre en criterios de solidaridad pero sobre todo en el fomento de la salud (trasplante de órganos) y desarrollo de la personalidad o de género

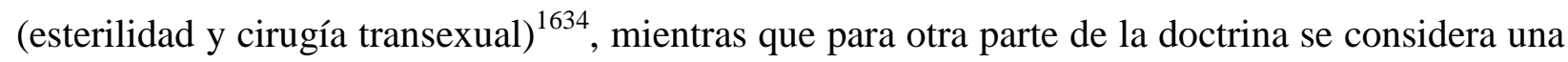
causa de atipicidad manteniendo la coherencia con la solución a las lesiones de cualquier otra lesión producida por necesidad médica ${ }^{1635}$.

En nuestra opinión, para que se pueda apreciar la atenuante en las lesiones por un tercero consentidas (heterolesión), basta con que la capacidad del sujeto sea reconocible por algún medio («teoría de la dirección intermedia») y que el consentimiento se muestre claramente, es indiferente que la declaración de voluntad sea expresa $^{1636}$ o tácita -es decir, aquella que se emite por medios que sin ser los habituales para una declaración de voluntad, expresan igualmente la voluntad del sujeto, distinta al consentimiento presunto, que es el que puede exigir una labor interpretativa o no expresa claramente cuál era la voluntad-, de forma previa o actual a la lesión, espontáneamente. Con ello parece exigirse que el consentimiento provenga de un acercamiento del propio sujeto que consiente, es decir que el sujeto activo de la lesión no busque el consentimiento del sujeto pasivo, del tal modo, la mayor parte de la doctrina excluye el consentimiento tácito posterior a la lesión o bajo precio, recompensa o promesa ${ }^{1637}$.

1631 GonZÁlez Rus, JJ., vv.aa., Derecho penal español, Parte especial, op. cit., p. 145.

1632 ID., ibidem, op. cit., p. 146.

1633 CANCIO Melí́, M., Conducta de la víctima e imputación objetiva en Derecho penal. Estudio sobre los ámbitos de responsabilidad de víctima y autor en actividades arriesgadas, $2^{\mathrm{a}}$ ed., Bosch, Barcelona, 2001, pp. 148 y ss; García Álvarez, P., La puesta en peligro, op. cit., pp. 357 a 360, siguiendo los planteamientos de LUZÓN PEÑA, D-M., Curso de Derecho penal, Parte General, op. cit., pp. 507 y ss; GonZÁlez Rus, JJ., vv.aa., Derecho penal español, Parte especial, op. cit., p. 145; Peñaranda RAmos, E., vv.aa., Compendio de Derecho penal, Parte especial, Vol. I, op. cit., p. 376; POlaino-Lorente A / POlaino NAVARrete M., «Dimensiones PsicológicoPsiquiátrica y Jurídico-Penal en el ejercicio de la sofrología», op. cit., p. 36.

${ }^{1634}$ GonZÁlez Rus, JJ., vv.aa., Derecho penal español, Parte especial, op. cit., p. 145; PEÑARANDA RAMOS, E., vv.aa., Compendio de Derecho penal, Parte especial, Vol. I, op. cit., p. 383.

${ }^{1635}$ Corcoy Bidasolo M / Cardenal Montraveta S / Fernández Bautista S / Gallego Soler JI / Gómez Martín V / Hortal IBARRa JC., Manual práctico de Derecho penal, Parte Especial, op. cit., pp. 124 y 125.

1636 Herrera Moreno, M., vv.aa., Lecciones de Derecho penal, Parte Especial, T. I, op. cit., p. 116.

1637 Peñaranda Ramos, E., vv.aa., Compendio de Derecho penal, Parte especial, Vol. I, op. cit., pp. 374 y 379 , y pp. 384386 
Para apreciar un consentimiento válido con efecto jurídico-penal justificante, se requiere por la doctrina, en primer lugar, que exista una capacidad natural de discernir que permita al sujeto pasivo advertir el significado y consecuencias esenciales de su consentimiento. Este conocimiento no parece tan claro que lo tengan determinados miembros de sectas criminales que han sido sometidos a la persuasión coercitiva y que tienen restringido o eliminado el horizonte de expectativas, cuando media una garantía de la expectativa contra-cognitiva o «deficitaria» que trasforma la conducta del sujeto, en este caso, para consentir la heterolesión, o inclusive realizar una autolesión.

En este sentido, RodRíGUEZ Mourullo estimó que el consentimiento de un adepto al que se le apliquen técnicas de persuasión es ineficaz en los supuestos en los que el sujeto activo «vulnera algún principio constitucional como el de dignidad de la persona o el pleno desarrollo de la personalidad» ${ }^{1638}$ o en casos de error ${ }^{1639}$. Por eso, si bien pudiere parecer, en un principio, que el consentimiento excluiría la tipicidad de la conducta en los delitos de libertad (coacciones), tiene excepciones, cuando verdaderamente se restringe la esencia del derecho fundamental: la libertad de actuar en general, la dignidad o la personalidad aunque el sujeto consienta y conozca las consecuencias de la aplicación de tales técnicas. En este sentido, algún sector doctrinal ${ }^{1640}$ entiende que el consentimiento de la víctima en la aplicación de tales técnicas, si bien parece que se presta con libertad, puede estar viciado a consecuencia de las citadas lesiones psíquicas y de los lavados de cerebro.

\section{Conclusiones parciales}

Hay en nuestra opinión una premisa fundamental en la problemática sectaria que no puede ser vulnerada, la irrenunciabilidad o indisponibilidad de la capacidad de libertad de voluntad asociada a la dignidad como persona. Dicha concepción tiene trascendencia en la disponibilidad de la salud personal, pero no cuando se afecta de forma esencial al derecho de la capacidad de libertad de voluntad, es decir, cuando el sujeto ya no tenga capacidad para volver hacia atrás, o modificar su voluntad de actuar en general. De esta manera, podemos concluir con HERRERA MORENO $^{1641}$ que la salud personal es indisponible cuando queda afectada la dignidad humana y

\footnotetext{
${ }^{1638}$ Vid. Alzaga, Oscar, (dir.), Comentarios a las Leyes Políticas: Constitución española de 1978, Vol. II, Ed. Revista de Derecho Público, Madrid, 1984, p. 436.

1639 Peñaranda Ramos, E., vv.aa., Compendio de Derecho penal, Parte especial, Vol. I, op. cit., p. 373.

1640 Por ejemplo, JORDÁn VILlACAMPA, Mál., «Las sectas pseudorreligiosas», op. cit., p. 68. En el mismo sentido, JAVALOY MAZÓN Federico / RODRÍGUEZ-CARBALLEIRA Álvaro, «Las sectas ante los Tribunales. El rol del psicólogo», Anuario de Sociología y Psicología Jurídicas, 13, 1987, p. 79.

${ }^{1641}$ Herrera Moreno, M., vv.aa., Lecciones de Derecho penal, Parte Especial, T. I, op. cit., p. 116.
} 
el libre desarrollo de la personalidad ${ }^{1642}$, pero más exactamente cuando se afecta a la libertad de actuar en general en alguna de sus tres dimensiones: capacidad o formación de voluntad, capacidad de decisión y ejecución de la voluntad.

Muy acertadamente ha expuesto CANCIO MELIÁ que en cuestión de consentimiento por la víctima de la acción peligrosa, o en las consecuencias del riesgo, hay que atender a la autorresponsabilidad de la víctima ${ }^{1643}$, concepto que está vinculado a la formulación de JAKOBS $^{1644}$ acerca de la obligación de soportar los costes del contacto social asumido por la víctima. De esta manera, desarrolla un nuevo criterio de imputación objetiva sobre la figura de la víctima y su responsabilidad, como eje potencial del desplazamiento de la imputación del que se presumía autor.

Así, este planteamiento nos parece más adecuado para analizar aquellas conductas en las que la víctima participa de su propia lesión, cuando se introduce en una configuración riesgosa no del todo clara, de modo que la cuestión del vicio del consentimiento se traslada también, tal y como hemos expuesto, a una cuestión de autorresponsabilidad y de posibilidades o de horizonte de expectativas: posibilidad de revocación.

Pasamos a analizar esta cuestión por entrar en el núcleo del debate de la fenomenología criminal de las sectas: las heterolesiones y autopuestas en peligro.

4. Autopuesta en peligro, imputación de la víctima sectaria de las consecuencias por su ingreso sectario y consentimiento de la persuasión coercitiva

Hemos comentado con anterioridad que la actual construcción social puede denominarse Sociedad del Riesgo. Esto, respeto a la libertad, tiene sus consecuencias: la responsabilidad de cada uno por sus actos, también del sujeto cuando se coloca en una situación de riesgo (gestión del riesgo por el propio ciudadano y las autopuestas en peligro). La contraprestación que tiene que pagar el sujeto auto-responsable es la asunción de las consecuencias por actos libres y voluntarios. Esta esfera de libertad se concede per se, por ser persona en Derecho.

1642 NAVAS Renedo, B., Tratamiento jurídico de las sectas, op. cit., pp. 314 y 315 dice que «la doctrina penal entiende que dicho consentimiento debe resultar ineficaz siempre que vulnere algún principio constitucional como el de la dignidad de la persona o el pleno desarrollo de la personalidad».

1643 Dice al respecto que «en un primer escalón sistemático no se trata de la representación de la voluntad de disponer del bien, sino de modo más general de la imputación del comportamiento del sujeto lesionado a sí mismo y de la modificación específica que de ello deriva en la configuración los ámbitos de responsabilidad de los demás intervinientes, y esta configuración previa a una eventual modificación a través de la voluntad a una disposición (consentimiento). Una solución general adecuada a la problemática (y autónoma, desvinculada del consentimiento), por tanto, sólo podrá fundamentarse si se parte de la base de la atribución, independiente en principio de la actitud interna, de ámbitos de responsabilidad», CANCIO MELIÁ, M., Conducta de la víctima e imputación objetiva, op. cit., p. 174.

${ }^{1644}$ JAKOBS, G., $P G$, op. cit., 7/126 y ss. 
La autopuesta en peligro o, a riesgo de la propia víctima, o imputación a la víctima, se fundamenta en dos principios: la libertad de la persona en la organización de su vida y la autorresponsabilidad. De aquí que el ejercicio del rol excluye la participación punible salvo que se limite o se anule la capacidad de libertad de voluntad o de decisión de la víctima, en cuyo caso estaremos en una heteropuesta en peligro (heterolesión) ${ }^{1645}$, lo que significa que la resolución del problema entre una autopuesta en peligro y su participación y una heteropuesta y su participación pasa por la validez del consentimiento, cuestión que es crucial en los tipos de inducción al suicidio, en la cooperación en el homicidio consentido (art. 143 CP) y en las lesiones consentidas, en los que al consentimiento de la víctima no se otorga pleno «valor» ${ }^{1646}$, pero también resulta trascendental la conducta de la víctima (imputación a la víctima). De aquí que la invalidez del consentimiento de la víctima no sea el único dato relevante en la imputación del autor o partícipe, sino también la propia conducta de la víctima, quien puede no consentir o ser ineficaz su consentimiento pero crear un riesgo y que resulte imputable a ésta.

En este sentido ya expuso RoxiN ${ }^{1647}$ que puesto que en Alemania no está penada la participación en el suicidio, de tal manera la participación en la conducta de autopuesta en peligro no entra en el fin de protección de la norma, sólo serían perseguibles la participación en «heteropuestas en peligro consentidas» en la medida que el partícipe tenga el mismo conocimiento sobre el riesgo y su probabilidad de resultado.

CANCIO MELIÁ fundamenta la autorresponsabilidad de la víctima en el carácter preferente de su ámbito de competencia de sus propios bienes, de modo que la participación en esta competencia no se puede imputar al partícipe, porque es imputable a la víctima, no ya subjetiva, sino objetivamente ${ }^{1648}$. Por eso, la teoría que confiere relevancia al consentimiento olvida el riesgo permitido. El conocimiento del riesgo es sólo un «indicio de que el suceso ha de imputarse a la víctima» ${ }^{1649}$. De este modo, tomando como punto de referencia el principio de

1645 RoxIN, C., «Sobre el fin de protección de la norma en los delitos imprudentes», RoxIN, C., Problemas básicos de Derecho penal, trad. y notas Diego-Manuel Luzón Peña, Reus, Madrid, 1976, pp. 181 a 199; CANCIO Meliá, M., Conducta de la víctima e imputación objetiva, op. cit., pp. 284 y ss; GARCía ÁlvareZ, P., La puesta en peligro, op. cit., pp. 365 y ss. y pp. 525 y ss; POlAINO NAVARRETE, M., Lecciones de Derecho penal, Parte General, T. II, op. cit., pp. 90 a 92; POLAINO-ORTS, M., «Imputación objetiva: esencia y significado», op. cit., pp. 50 y ss.

${ }^{1646}$ CANCIO Meliá, M., Conducta de la víctima e imputación objetiva, op. cit., pp. 142 y ss; GARCÍA ÁlvAREZ, P., La puesta en peligro, op. cit., pp. 410 y ss.

${ }^{1647}$ ROXIN, «Sobre el fin de protección de la norma en los delitos imprudentes», op. cit., pp. 181 a 199.

1648 Cancio Meliá, M., Conducta de la víctima, op. cit., pp. 284 y ss; similarmente JAKOBS, G., PG, op. cit., 7/126; FEIJOO SÁNCHEZ, BJ., Homicidio y lesiones imprudentes: requisitos y límites materiales, Edijus, Zaragoza, 1999, pp. 109 y ss; TAMARIT Sumalla, JMª ., La víctima en el Derecho penal, Aranzadi, 1998, pp. 92 y ss. y pp. 127 y ss., si bien como teoría del tipo objetivo, salvo «abuso» por parte del interviniente.

${ }^{1649}$ CANCIO MELIÁ, M., Conducta de la víctima, op. cit., pp. 176 y 177. 
autorresponsabilidad de las personas ${ }^{1650}$, concluye que debe ser imputada la conducta al ámbito de responsabilidad preferente de ésta cuando: «a) la actividad permanezca en el ámbito de lo organizado conjuntamente por el autor y víctima, b) la conducta de la víctima no haya sido instrumentalizada por el autor, por carecer ésta de responsabilidad o de la base cognitiva necesarias para poder ser considerada (auto-responsable), c) el autor no tenga un deber de protección específico frente a los bienes de la víctima. La «imputación a la víctima» impide que la contribución del autor al suceso sea jurídico-penalmente típica -salvo normas penales especiales que eliminen el ámbito (general) de responsabilidad preferente de la víctima-; constituye una institución dogmática específica en la teoría del tipo» ${ }^{1651}$. Con la regulación especial se refiere a los artículos de la intervención en suicidio ajeno del art. $143 \mathrm{CP}^{1652}$. En conclusión, la autorresponsabilidad de la víctima supone un elemento del tipo.

Esto significa - a nuestro modo de ver- que la víctima puede ser sujeto activo, y cuando tenga dominio de sí mismo, autor, si bien la tipicidad de la imputación a la propia víctima se refiere a motivos de política criminal cuando afecta a bienes de gran relevancia como la integridad física, o a causas de exculpación o de impunidad (falta merecimiento de pena) si atendemos al intento de suicido, pero de igual punto es antijurídico al faltar un reconocimiento normativo del derecho al suicidio. Sin embargo, CANCIO MELIÁ puntualiza que la organización conjunta entre autor y víctima no lleva a la calificación de coautoría, «porque el tipo no está destinado a evitar tales sucesos» ${ }^{1653}$ («especificidad normativa» ${ }^{1654}$ ), sino al carácter «no accesorio» de la imputación a la víctima ${ }^{1655}$, salvo extralimitación de la organización conjunta que pueda ser imputable como conducta típica al autor ${ }^{1656}$.

De otra parte, LUZÓN PEÑA, con base al principio romano de «alteridad» y «no identidad» ${ }^{1657}$ entre autor y víctima, concluye que «el control o dominio compartido del riesgo (sobre el hecho peligroso) entre la víctima y un tercero, da lugar a que en estos casos lo que en

${ }^{1650}$ ID., ibidem, op. cit., pp. 277 a 282.

${ }^{1651}$ ID., ibidem, op. cit., pp. 286 y 287.

${ }^{1652}$ ID., ibidem, op. cit., pp. 43 y ss.

${ }^{1653}$ ID., ibidem, op. cit., p. 306, si bien refiriéndose al «alcance del tipo» propuesto por RoXIN.

${ }^{1654}$ ID., ibidem, op. cit., p. 308, comenta aquí que nadie dudaría que en el caso de las motocicletas, entrega de heroína o en el de la botella, si «se hubiera visto afectado un tercero no interviniente en la interacción o un sujeto no responsable, nadie dudaría de que las correspondientes conductas deberían ser consideradas típicas».

${ }^{1655}$ ID., ibidem, op. cit., p. 292.

${ }^{1656}$ ID., ibidem, op. cit., pp. 294 a 295. En concreto «sólo cuando la conducta del autor deba ser interpretada, en términos objetivos, como infractora de la norma de conducta jurídico-penal, podrá afirmarse que existe un comportamiento objetivamente típico», ID., ibidem, op. cit., p. 301.

${ }^{1657}$ LuZÓN PEÑA, M-D., «Principio de alteridad o de identidad vs. principio de autorresponsabilidad. Participación en autopuesta en peligro consentida y equivalencia: el criterio del control del riesgo (versión con precisiones)», Libertades, Revista de la Fundación Internacional de Ciencias penales, núm. 0, Madrid, 2012, p. 26 y ss. 
principio sería coautoría del tercero (coautoría si se trata de control o dominio compartido de dos terceros en la puesta en peligro de un bien jurídico ajeno), valorativamente se convierta en simple participación secundaria (y atípica) en la autopuesta en peligro de la víctima» ${ }^{1658}$.

Si bien LUZÓN PEÑA acierta en comparar ambos sucesos como una cuestión de coautoría cuando el bien es ajeno a la organización, «valorativamente» se convierte en simple participación secundaría atípica. Ese adverbio es del todo significativo por cuanto revela que efectivamente hay que anteponer una valoración para no incurrir en ese binomio autor-víctima, pero en nuestra opinión, no es del todo dogmático, puesto que se reconoce la autoría de la víctima, de modo que el valor que se le otorga a la conducta de la víctima es el rebajamiento cualitativo a mero partícipe del tercero. Otra cosa será que la conducta de la víctima desplace por entero la responsabilidad del otro, pero cuando no sea así no es del todo adecuado rebajar su aportación de autor a partícipe, cuestión que evidentemente no sucede en la organización criminal o en la coautoría dolosa e imprudente. Por eso no es del todo disparatado concluir que en dicha relación en la que se comparte el riesgo ambos sujetos son autores o coautores, así que el resultado fatal, en ocasiones, es una consecuencia naturalística irremediable, ajena a la imputación objetiva. Ambos son responsables, si bien uno de ellos acaba siendo la víctima.

En sentido disidente, GARCíA Álvarez ${ }^{1659}$ considera que la clave se sustenta en la «determinación objetiva y positiva de hecho» entre la participación en una autopuesta en peligro que al ser atípica hace atípica la intervención, máxime si es imprudente. Así, sólo son punibles las conductas de participación dolosas tipificadas o la participación en delitos de peligro autónomos ${ }^{1660}$, por lo que relega la heteropuesta en peligro a la regulación especial del art. 143.1 y 2 CP sobre la inducción y la cooperación necesaria al suicidio. Por eso entiende que si existe consentimiento, entendido éste como comprensión del riesgo y bienes jurídicos arriesgados y finalmente afectados ${ }^{1661}$, y la disponibilidad sobre la vida y la integridad, la conducta del tercero será atípica a pesar de dicha heteropuesta, en el sentido de que es disponible por el principio de «libre desarrollo de la personalidad», por lo tanto es atípica tanto en el resultado contra la vida como en las lesiones (art. $155 \mathrm{CP})^{1662}$.

${ }^{1658}$ ID., ibidem, op. cit., p. 32.

${ }^{1659}$ GARCía ÁLVAREZ, P., La puesta en peligro, op. cit., pp. 357 a 360, siguiendo los planteamientos de LuZÓN PeÑa, Curso de Derecho penal, Parte General, I, op. cit., pp. 507 y ss; críticamente CANCIO Melí́, M., Conducta de la víctima e imputación objetiva, op. cit., pp. 386 y 387, por cuanto la autopuesta en peligro y heteropuesta en peligro impone criterios de consentimiento, máxime en relación a la legislación alemana que cuenta ya con una diferenciación «tajante», y menos aún en nuestro ordenamiento que no cuenta con esta peculiaridad.

${ }^{1660}$ GARCía Álvarez, P., La puesta en peligro, op. cit., p. 360.

1661 ID., ibidem, op. cit., p. 439.

1662 ID., ibidem, op. cit., pp. 457 y 464. 
De ahí que -según GARCíA ÁLVAREZ- cuando la participación en la autopuesta niega el libre desarrollo de la personalidad, como en la cooperación ejecutiva al suicidio del art. 143.3 CP, no existe plena disponibilidad porque la destrucción de la vida elimina el libre desarrollo de la personalidad $^{1663}$, o en el caso de las lesiones, el consentimiento no constituye la exteriorización el libre desarrollo de su personalidad ${ }^{1664}$. La referida penalista pone el acento en la perspectiva de la imputación de la víctima, para diferenciar entre suicidio y autopuesta en peligro. El consentimiento que determina la impunidad del tercero se refiere a su validez en relación a la expresión del libre desarrollo de la personalidad (sin coacción, amenaza o engaño), en aquellas conductas de riesgo que abarcan el resultado ${ }^{1665}$, con lo que adopta los postulados del dominio del hecho de la teoría de la autoría y participación de RoXIN ${ }^{1666}$.

Por otro lado, MARAVER GóMEZ considera que la imputación de la autopuesta en peligro a la víctima y la exclusión de la imputación del partícipe se fundamenta en la prohibición de regreso que se produce en la negación de la posición de garante en participación, y a la vez en que el principio de confianza niega el deber de cuidado del partícipe, en cuanto que existe plena responsabilidad de la víctima. Con estas conclusiones critica la tesis de CANCIO MELIÁ en que la perspectiva sobre la que hay que prestar atención en la imputación objetiva no es la de la víctima (imputación de la víctima), esto sería la consecuencia de la valoración del ámbito de responsabilidad del autor mediante los criterios de la prohibición de regreso en la posición de garante $^{1667}$, y del principio de confianza como criterio post-valorativo al anterior en la determinación del deber de cuidado, en el sentido de que no puede establecerse una prohibición de regreso (participación en una autolesión o en una autopuesta en peligro), sino una heterolesión o heteropuesta en peligro ${ }^{1668}$.

De esta manera, muy acertadamente aclara que la víctima interviene en un momento posterior de manera responsable, y a la inversa, si al primer sujeto se le puede imputar la conducta peligrosa del tercero-víctima se le podrá considerar partícipe de manera accesoria conforme a las normas de la Parte General del Código penal, salvo la regulación especial del art.

\footnotetext{
${ }^{1663}$ ID., ibidem, op. cit., p. 505, y p. 513 concluye que «no podrá negarse que se lesione o se ponga en peligro (de manera que pueda reputarse jurídicopenalmente) el bien jurídico de la vida, en los supuestos en los que su titular disponga de ella para ponerles término, ya que su destrucción impide todo desarrollo de la personalidad. Sin embargo, si la vida es, únicamente, puesta en peligro, podremos negar que se cree un riesgo jurídicopenalmente relevante para este bien jurídico y, por tanto, la tipicidad de tal conducta, si dicho acto de disposición es expresión del libre desarrollo de la personalidad de su titular y el tercero se limita a actuar dentro de lo consentido».

1664 ID., ibidem, op. cit., p. 488.

1665 ID., ibidem, op. cit., pp. 525 y ss.

1666 ID., ibidem, op. cit., pp. 162 a 249.

1667 MARAVER GÓMEZ, M., El principio de confianza en Derecho penal, op. cit., pp. 379 y ss. y nota 220.

1668 ID., ibidem, op. cit., pp. 384 y ss.
} 
143.1 y $2 \mathrm{CP}^{1669}$, o autor de la heterolesión o de la heteropuesta en peligro, pues aunque la víctima tenga el domino del hecho, o sea responsable del hecho, no afirma la producción de un suicido o autolesión o autopuesta, sino que constatada la posición de garante, el principio de confianza se aplica en la conducta incorrecta de la propia víctima, de manera tal que si se ha detectado que se va a comportar o ha empezado a comportarse arriesgadamente el garante no puede apelar a la confianza para limitar el deber de cuidado ${ }^{1670}$. Concluye gráficamente que «sólo puede confiar quien se ha comportado correctamente» ${ }^{1671}$.

En este punto ha de plantearse si los casos de autopuesta en peligro son una solución plausible en la entrada de un presectario o adepto que se introduce en una secta criminal, de modo tal que signifique su propia responsabilidad de las consecuencias de su obrar conforme al rol sectario. Pues bien, a las personas en Derecho se les presupone responsabilidad, se les presupone la libertad de sus actos, por ello, como decíamos, quien ingresa en un grupo sectario y amolda su conducta libremente a los dictados del líder, a su doctrina y a la dinámica grupal, ha de soportar sus consecuencias penales, salvo si el sujeto no tiene capacidad de libre voluntad, ya sea por aplicación de técnicas de persuasión, por una adicción comportamental concurrente o independiente de dichas técnicas, o por causas ajenas a las anteriores, como la incapacidad de decidir por manifiesta inmadurez de un menor de edad, o por otras causas de inimputabilidad.

Sin embargo no supone una auto-puesta en peligro de un sujeto ingresar en un grupo, en el que a pesar de no aplicársele técnicas de persuasión, desconozca el fin delictivo del grupo, y antes de poderse conocer los fines delictivos, las normas sectarias y/o la dinámica grupal crean los condicionantes de la persuasión coercitiva y/o una adicción comportamental. Es decir, sin conocimiento ni posibilidad de conocimiento del sujeto no puede hablarse de una auto-puesta en peligro de la víctima, o dicho de otro modo, la auto-puesta en peligro parte del principio de confianza, y ésta de la verdad o de la información suministrada por quien genera la confianza, esto es, de un horizonte de expectativas normativas y sociales, por lo que la garantía sobre expectativas cognitivas que no pueden garantizarse y que trasforman los conceptos esenciales de la Sociedad (dinero, salud, vida, muerte, etc.), constituye una garantía deficitaria cuando incapacita al sujeto en su libertad de voluntad (horizonte de expectativas normativas y sociales orientadas por el Sistema). Esto es sólo legítimo como cuestión de $f e$, sin embargo, cuando se trasforma la conducta del sujeto, previa mediación de un ámbito de confianza especial que

\footnotetext{
1669 ID., ibidem, op. cit., p. 381.

${ }^{1670}$ ID., ibidem, op. cit., p. 386.

${ }^{1671}$ ID., ibidem, op. cit., p. 398.
} 
genera una garantía deficitaria respecto al Sistema, genera responsabilidad por autoría tanto en los autores materiales como en la propia víctima, o cuando ésta irroga daños en terceros.

\section{Principio de confianza. El vicio del consentimiento informado como fundamento penal}

en la persuasión coercitiva: «comunidad especial de confianza» y «garantía de expectativa cognitiva deficitaria»

Posiblemente el fundamento sobre el que giran los demás elementos de la imputación objetiva sea el principio de confianza, principio por el que las personas orientan su conducta conforme a la interacción con los demás y con la norma ${ }^{1672}$. La confianza -como afirma LUHMANN ${ }^{1673}$ - es una expectativa social o generalizada de que los demás manejan su libertad previsiblemente, lo que hace que se reduzca la complejidad social, anticipa el futuro o lo condiciona para ser utilizado en el presente con seguridad.

Las personas depositan confianza en los comportamientos futuros de los demás (confianza intersubjetiva/personal), también en cómo se aplicará una norma (confianza en el sistema normativo). De tal forma se puede adecuar el comportamiento en el presente, por eso la confianza anticipa el futuro. Así, la confianza se posibilita en cuanto expectativa con base a la familiaridad o las experiencias previas, pero lo mismo sucede con la desconfianza ${ }^{1674}$

A la postre, la confianza produce reglas normativas, y a la inversa, las normas posibilitan la confianza de las personas en que su comportamiento es «seguro» o supone normativamente un riesgo permitido ${ }^{1675}$. Por tanto, puede concluirse que la confianza configura los ámbitos de responsabilidad ${ }^{1676}$, especialmente en el deber de cuidado/protección. Este principio fomenta la relación de las personas y la experiencia vital, y sin él difícilmente existiría una sociedad en paz sino caótica. Esta confianza, dentro también del llamado riesgo permitido, aglutina buena parte de las conductas de los sujetos libres en la construcción social: la confianza en el funcionamiento de los roles.

\footnotetext{
${ }^{1672}$ El principio de confianza normativo ha tenido gran trascendencia en la responsabilidad en ámbitos riesgosos, como en la medicina, los accidentes laborales o la fabricación de productos, si bien en la actualidad se considera por gran parte de la teoría moderna de la imputación objetiva un criterio delimitador de la imputación objetiva penal. Ampliamente ID., ibidem, op. cit., pp. 36 a 96, y pp. 98 a 120.

${ }^{1673}$ LuhmanN, N., La confianza, op. cit., pp. 39 y ss., pp. 15 y ss., y pp. 69, asimismo el tiempo también puede entenderse como una reducción de la complejidad, ID., ibidem, op. cit., p. 25.

${ }^{1674}$ ID., ibidem, op. cit., pp. 32 y 33, y pp. 123 y ss.

1675 ID., ibidem, op. cit., p. 59.

1676 ID., ibidem, op. cit., pp. 59 a 63; FEIJOO SÁNCHEZ, BJ., Imputación objetiva en Derecho penal, Lima, 2002,
} pp. 298 y ss; JAKOBS, G., «La imputación objetiva, especialmente en el ámbito de las instituciones jurídico-penales "riesgo permitido", "prohibición de regreso" y "principio de confianza"», Estudios de Derecho penal, op. cit., pp. 209 y ss; POLAINO-ORTS, M., «Imputación objetiva: esencia y significado», op. cit., pp. 56 y ss; PIÑA ROCHEFORT, JI., Rol social y sistema de imputación, op. cit., pp. 376 a 393. 
Este principio, como decimos, es co-natural a la libertad, pues la alternativa al caos y al temor es la confianza. Hay que concluir -dice LUHMANN ${ }^{1677}$ - que el hombre por naturaleza tiene que otorgar confianza, y por ende, también al ejercicio de la esfera de competencias del rol en la sociedad. Sin embargo, la confianza tiene límites o excepciones puesto que nunca es unilateral, sino que precisa al menos de dos partes: sólo se puede confiar si alguien ofrece confianza ${ }^{1678}$. Esta es la manera en la que se estructura una sociedad responsable, sana y libre en el marco del Derecho $^{1679}$. Lo contrario, la desconfianza, si fuere una Ley Universal o la autorreferencia de la operatividad del Sistema, impediría el normal desarrollo de una sociedad estable porque haría que no nadie actuase, sería el caos. Por eso la confianza proviene de la verdad, como una Ley a la que se le otorga el valor «bueno», y moralmente «bien» en el más puro sentido kantiano, no obstante, desde nuestra perspectiva funcionalista, la confianza es una operación propia, autorreferencial y autopoiética del Sistema social que se irroga en los demás subsistemas como el Derecho penal.

Lo problemático del principio de confianza estriba en las relaciones especiales. Por ejemplo, en el cuidado de los niños la confianza social es menor, por eso la expectativa normativa exige un mayor cuidado, sin embargo, también existe confianza en relaciones «normales», del día a día, por ejemplo en el tráfico rodado, o cuando se acepta la confianza depositada por otro (asunción), cuando falla la confianza de uno sobre otro debiéndose asumir la responsabilidad por dicho motivo de ausencia de confianza (deber de saber y deber de utilizar el conocimiento: posición de garantía ${ }^{1680}$, pero también en la denominada comunidad del riesgo. En caso de menores y de incapaces no se trata de la confianza, o de desconfianza mejor dicho, sino de la competencia por organización e institucional, por cuanto existe un déficit de las capacidades del otro rol. Dicha posición de garante o competencia es especial ${ }^{1681}$, no común, puesto que no se puede exigir que todos los ciudadanos estén alerta de los quehaceres de los menores aunque entren en nuestro campo de organización, o de los incapaces con los que no se tiene relación,

${ }^{1677}$ LuHMANN, N., La confianza, op. cit., p. 6 y p. 51.

1678 Polaino NaVARRete, M., Lecciones de Derecho penal, Parte General, T. II, op. cit., p. 93.

${ }^{1679}$ POLAINO-ORTS, M., «Imputación objetiva: esencia y significado», op. cit., pp. 56 a 59.

${ }^{1680}$ PIÑA RoCHEFORT, JI., Rol social y sistema de imputación, op. cit., pp. 383 y ss., expone el ejemplo de médico que se percata de que la enfermera está exhausta, debiendo asumir el control de esterilización del material quirúrgico. Lo relevante es si el sujeto está obligado a saberlo y a utilizar ese conocimiento como constitutivo de la posición de garante. Se ve claramente en las relaciones de la división del trabajo y la confianza, más allá de la relación horizontal o vertical ascendente o descendente, adquiere relevancia la función de cada rol, los ámbitos de deberes de cada uno, ID., ibidem, op. cit., pp. 387 y ss; MARAVER GÓMEZ, M., El principio de confianza en Derecho penal, op. cit., pp. 137 y ss.

${ }^{1681}$ PIÑA ROCHEFORT, JI., Rol social y sistema de imputación, op. cit., pp. 390 a 392. 
salvo que se haya asumida dicha función en un momento determinado y se les irrogue un riesgo o exista el deber de socorro.

Como ya explicamos supra, interesa la confianza que nace en las relaciones sectarias. También hemos aclarado que existe diferencia entre la confianza especial que se deriva del deber de garante en la asunción de la responsabilidad por organización y la confianza especial en la responsabilidad institucional, y concluimos que en las relaciones sectarias se crea una confianza especial que genera una responsabilidad institucional. Por eso no podemos estar de acuerdo con PIÑA ROCHEFORT, quien -en contra de JAKOBS- entiende que en la «comunidad de peligro» (en nuestro estudio hemos determinado que la comunidad de peligro o del riesgo es análoga a la comunidad de confianza/vida o estrecha comunidad de vida/intereses o de lealtad) no existe posición de garante de una confianza especial estrictamente institucional, sino que se trata de casos de responsabilidad por asunción. Si bien nada impide que pueda existir posición de garante en cuanto al resultado, PIÑA ROCHEFORT aclara - con lo que estamos también de acuerdo- que existen dos casos, uno en el que el propio rol crea la confianza especial y por la que surge la posición de garante, y otros casos en que el rol, en cuanto a que forma parte de una estructura que genera confianza -en nuestro ámbito de estudio la organización sectaria- emana la fuente la posición de garante por la confianza especial depositada en una institución, como los médicos en el hospital, dirigiéndose la confianza del sujeto a dicha institución y a su estructura, gestionando según dicha estructura la garantía (por ejemplo el plan del servicio sería la estructura de dicha institución en algún caso) ${ }^{1682}$.

Análogamente, este sería el caso de la confianza de los adeptos en la estructura organizativa de la secta y en la dinámica grupal, de tal modo que la defraudación de la confianza genera el incumplimiento de un deber institucional y la responsabilidad por autoría, y puesto que todos son parte, o son en sí mismos la organización (injusto sistémico), estos postulados llevan a que todos intervienen en coautoría en la persuasión coercitiva, lo que genera un especial binomio autor-víctima en la misma personan respecto al delito de persuasión coercitiva.

Quien ingresa en una confesión religiosa, o en un grupo al que la sociedad le denomina secta, confía cognitivamente que no se le irrogarán riesgos, pero no por eso se crea una posición de garante en el líder y/o en la comunidad de miembros. Como rol social, el rol de adepto asume un riesgo permitido en el cambio de su cosmovisión y personalidad. Confía que la modificación de sus valores no persiga fines delictivos, o que no anule o disminuya su capacidad de voluntad. Por eso, la entrada en una u otra entidad religiosa ha de basarse en el principio de confianza, pero

1682 ID., ibidem, op. cit., pp. 423. 
éste a su vez en la información adecuada para que el sujeto sustente su confianza en un riesgo permitido. Así, aquellas consecuencias derivadas del quebrantamiento de la confianza especial deberán ser soportadas por el rol de líder y/o la comunidad porque han creado dicha confianza, y siempre que se hayan trasformado los conceptos esenciales del Sistema (dinero, verdad, poder, amor, vida, muerte, salud, etc.).

En este sentido, como bien razona LUHMANN, la confianza se relaciona como posibilidad de adoptar una decisión, de otro modo se habla de esperanza. La confianza refleja la posibilidad de que las cosas pueden suceder de otra manera, pero se adopta una decisión teniendo en cuenta esas otras posibilidades (contingencia), mientras que la esperanza elimina esas posibilidades, por eso la confianza también puede ser imprudente ${ }^{1683}$. Esto sucede en muchos ingresos sectarios, donde a pesar de intuirse la criminalidad, el sujeto se arriesga, tiene esperanza en una salvación superior, sin aceptar medios criminales contra otros, lo que determina, en nuestra opinión, que la confianza siempre es arriesgada, pero en determinados ámbitos (p. ej. la entrada en un grupo ultra, fanático, combativo, y/o desocializado), supone una empresa más arriesgada que con el tiempo se legitima, se vive en esa «comunidad del riesgo».

En este contexto podemos utilizar un ejemplo de LUHMANN en relación a la confianza con un objeto, algo que es independiente de los intereses específicos individuales y de los contextos de la experiencia. Comenta que «la confianza en una persona especial -podemos incluir en este sentido al líder de una secta criminal y al grupo de miembros- se activará dondequiera que el que confía encuentre a esa persona, sin considerar los respectivos contextos de rol», de tal forma, máxime en la familia cuya función es la socialización ${ }^{1684}$. En la socialización interviene la confianza de los sujetos en otras personas, en instituciones, en el Sistema. Como decíamos, para que tal confianza se genere se precisa de una comunicación con información (familiaridad o experiencias). En cuanto surge un déficit de comunicación, por déficit de la información, se puede imputar al que envía la comunicación defectuosa, pero a su vez al que la recepciona y acepta la comunicación deficitaria, por presentar un déficit de socialización, de modo que haga lo mismo con otro, y así en cadena (comunidad de riesgo no permitido).

Así, en el caso de la sectas coercitivas la comunicación es claramente defectuosa, cuestión que es imputable al líder y/o al grupo que envía dicha comunicación al realizar un específico o

${ }_{1683}$ LuHMANN, N., La confianza, op. cit., pp. 40 y 41.

${ }^{1684}$ ID., ibidem, op. cit., pp. 46 y 47. Similarmente comenta LUHMANN pero en un contexto abstracto que «(l)a certeza interna (...) puede basarse en el hecho de que el objeto de la confianza cumple con una función indispensable para la estructura interna: el procesamiento de la experiencia. En consecuencia, un debilitamiento de la confianza producirá consecuencias de largo alcance para la confianza en sí mismo y no será juzgado como una posibilidad porque conducirá a grandes cambios en las disposiciones internar, para lo cual el sistema carece de tiempo, energía o apoyo del entorno», ID., ibidem, op. cit., p. 45. 
general ocultamiento relevante para el receptor de la comunicación; por ejemplo, el nuevo miembro desconocía que para «salvarse» precisa escalar metas mediante cursos de precio progresivamente alto, de modo que cuando se ha completado la persuasión coercitiva (desocialización de modo coercitivo), el déficit de socialización produce la aceptación de cursos cada vez más caros, pero a su vez, con esta conducta el sujeto deficitario está comunicando una específica forma de persuasión coercitiva, que generará déficit de socialización en otros sujetos que vayan sumándose al grupo o que sigan perteneciendo activamente, adecuándose la conducta a esta forma específica, y así en cadena.

De este modo, en las sectas coercitivas se traslada la confianza en un «medio de comunicación» que - de forma similar a la que expone LUHMANN ${ }^{1685}$ - puede considerarse «simbólicamente generalizado», como confianza en la verdad, en el amor, en el poder y en el dinero. En este sentido, la confianza del adepto en el grupo, en la norma sectaria y en el líder, se trasforma en la «verdad» ${ }^{1686}$, se confía en la verdad, y se comunica en tanto verdad. Unas veces, se confía sobre lo que se dice, por ejemplo: la doctrina moral sectaria, la llegada del fin del mundo, morir para trasladarse a otros planetas o salvarse. Otras veces, la comunicación del grupo se centra en el amor: el sujeto es especialmente amado y ha de amar en la misma proporción. De otra parte, el grupo representa el poder encarnado en el líder, fuente de la comunicación de la verdad, orienta cómo ejercitar el amor y de cómo obedecer al poder/autoridad. Estas circunstancias generan una garantía de una expectativa cognitiva que se va normativizando, pero a la vez constituye la restricción o la eliminación del horizonte de expectativas normativas y sociales comunicadas por el Sistema: la incapacidad de libertad de voluntad. Esto es, según lo visto, un riesgo no permitido y el fundamento de punibilidad e inicio de la tentativa de persuasión coercitiva.

Por otra parte el dinero, en conexión con otros medios de comunicación, puede transformarse como símbolo de verdad, amor, de poder o superación del adepto. Son numerosos los casos en los que los adeptos han de pagar gran des sumas de dinero para acceder a la verdad, y de tal forma conseguir el objetivo: la salvación. Por eso no nos preocupa el qué, sino el cómo se desarrollan estos medios de comunicación en una determinada sociedad, grupo o institución diferencia.

Entonces, la verdad o la garantía de expectativa cognitiva que trasforma la voluntad en el mundo religioso o de conciencia, como creencia o «tener como verdadero», es el medio de

\footnotetext{
1685 ID., ibidem, op. cit., p. 82.

${ }^{1686}$ Comenta LuHMANN que «(1)a confianza solamente es posible donde la verdad es posible», ID., ibidem, op. cit., p. 80 y 96.
} 
comunicación utilizado que genera un riesgo no permitido cuando la trasformación de los conceptos esenciales del Sistema Social (dinero, verdad, poder, amor, vida, muerte, salud, etc.), mutan de tal forma que modifican la voluntad en claro perjuicio del sujeto y/o de terceros. De otro modo no sería posible la adecuación de comportamiento conforme al grupo y al líder. Es el cómo se trata la verdad, cómo se comunica y se trasforma la garantía de la expectativa cognitiva, si contradice realidad cognitiva y la norma jurídica, lo que fundamenta en ambos casos tanto la punibilidad de la organización como el injusto de la persuasión coercitiva, y a la postre la concurrencia de tipologías criminales de conciencia como la categoría conceptual de autor de conciencia con déficit de socialización atribuido a tercero, o la autoría por convicción o del enemigo con déficit de socialización atribuido a tercero, respectivamente. A causa de esto, es el fundamento de la tentativa según lo expuesto supra.

Si bien nada puede decirse sobre que un adepto gaste todo su dinero y su tiempo en el grupo, cuando el déficit de información en la comunicación resulta relevante para el adepto, de tal modo que su decisión sobre la expectativa hubiera sido otra, o sea, que su comportamiento hubiera sido no pagar, hacer o no hacer, en este caso en perjuicio propio, o de otros, como autoría con déficit de socialización atribuido a tercero, puede concluirse que existe quebrantamiento de una confianza estrictamente especial que genera responsabilidad por infracción de un deber institucional, si bien la consumación del delito-fin estricto sensu de la persuasión coercitiva viene ya de antes.

La confianza (verdad-garantía de expectativa cognitiva) que el adepto tiene con el «suicidio», que le trasladará a otro planeta, vulnera el riesgo permitido cuando el que envía la información desconoce dicho extremo, conoce la ficción, o existe un hecho fáctico que pone en seria duda su propia confianza en que exista tal posibilidad, por ejemplo, cuando el líder no se suicida. Sin embargo estos son datos meramente indiciarios de la intención dolosa o imprudente del autor. La cuestión relevante es si se ha producido tal intensidad en los factores (aislamiento social, adoctrinamiento, persuasión, situación de inferioridad, etc.) que haya restringido o eliminado el horizonte de expectativas normativas y sociales en el sujeto, sustituyéndose conceptos como el dinero, poder, amor, salud, vida o muerte, por otros matizados: no es dinero, se ama, no se quebranta la salud, no es vida, no es muerte. Es decir, se sustituye por esa garantía de expectativa cognitiva cuyo contenido es deficitario. 
Puede concluirse que las sectas coercitivas crean una expectativa ficticia respecto a los límites de comportamiento que genera el Sistema Social ${ }^{1687}$. De tal modo que en la confianza especial se posibilita la restricción o eliminación del horizonte de expectativas, según hemos explicado, si bien sólo cuando dicha confianza esté viciada, cuando se comunica como garantía, surgirá un principio de responsabilidad. Quien convence de que con el «suicidio» se adquiere prontamente la salvación o se traslada a otro planeta está creando una expectativa que no puede garantizar, de tal modo que la relevancia de dicha expectativa si conforma la resolución del suicidio incrementa el riesgo sin garantía alguna, o de forma irresoluble, por cuanto el fin de la vida es irretroactivo. El injusto proviene de la creación de una expectativa que no se puede garantizar, sin embargo la confianza obliga o educa ${ }^{1688}$, lo que nada tiene que ver con la doctrina de la salvación de muchas religiones que no impulsan al suicidio, sino a la tranquilidad del ser durante la vida, y si bien, en nuestra opinión, el suicidio es en sí mismo una conducta más de la libertad de voluntad -en el más puro sentido expresado por SCHOPENHAUER (aquietamiento de la voluntad) -, cuestión distinta es el fomento de una expectativa cognitiva deficitaria. En estos términos, coincidimos con LUHMANN ${ }^{1689}$ en que el problema no es quién gana la confianza, sino cómo se gana. Entonces ese cómo es el injusto.

Esto también nos lleva a que en los grupos de personas, más aun en los grupos criminales y prototípicamente en los sectarios, existe una «comunidad de confianza» por estrecha comunidad de vida o interés, análoga a la «comunidad del riesgo» conectada a la «estrecha relación de lealtad», en cuanto que los sentimientos de cada miembro se alinean con la comunidad, y por ende en la voluntad del líder. De este modo, la confianza resulta ser un sistema de aprendizaje/verdad/garantía propio del grupo, en el que se despoja la expectativa normativa y social como lo incorrecto/falso. Así, mediante este sistema de confianza/verdad/garantía (otras veces la lealtad en las órdenes que emanan de los estados totalitarios, también en supuestos concretos del Ejército) los grupos criminales por motivos de conciencia, o por convicción, causan directamente la persuasión coercitiva.

En un sistema de confianza en el grupo criminal, la confianza se auto-diferencia de otros sistemas de confianza sociales. Este sistema funcional se difumina en los grupos sectarios y exponencialmente en las sectas como organización criminal: la confianza es total (apenas existe, o no existe desconfianza, no se desarrollan otros sistemas de confianza como los que se

\footnotetext{
${ }^{1687}$ Como dice LUHMANN «(a)dquirir confianza personal significa quitar las expectativas estandarizadas (...) de nuestro semejante y reemplazarlas con aquellas que solamente él, como persona individual, con su estilo único puede garantizar la satisfacción», ID., ibidem, op. cit., p. 108.

1688 ID., ibidem, op. cit., p. 111.

${ }^{1689}$ ID., ibidem, op. cit., p. 105.
} 
depositan en la Ley y en la Familia), por eso existe un gran poder de obediencia a la autoridad y/o a la dinámica criminal, entonces la confianza reside en ese sistema.

6. Prohibición de regreso en la permisión de creencias y «comunidad especial de confianza» y «garantía de expectativa cognitiva deficitaria»

La prohibición de regreso elimina la imputación objetiva de aquellos comportamientos del rol aparentemente delictivos en los que previamente el sujeto realiza una conducta neutral, exigida o normativa dentro de las competencias de su rol, y aun cuando el sujeto tuviera el conocimiento de que su aportación al hecho fuese a ser empleada por un tercero para la comisión delictiva. El sujeto realiza una conducta dentro de las competencias de su rol, por lo que dicha conducta es normativamente «neutra» o «estereotipada», si bien otro sujeto emplea esta circunstancia para cometer un delito ${ }^{1690}$, de tal manera que los conocimientos que tenga el sujeto sobre la utilización delictiva por un tercero de su aportación neutral no constituyen fundamento alguno de imputación objetiva, salvo casos muy excepcionales, como el ya planteado de la institución paterno-filial que por modificación de las reglas cognitivas (modificación de la lex artis) o por una mayor exigencia de protección se requiere la utilización de los conocimientos especiales (el padre que tiene conocimientos especiales de medicina y no los aplica para salvar a su hijo $\left.{ }^{1691}\right)$, también cuando se obra como rol común pero con deber de aseguramiento de la organización ajena por asunción o confianza, o en la omisión del deber de socorro cuya exigencia difumina la naturaleza de la posición de garante ${ }^{1692}$.

Todo lo más - como bien apunta POLAINO NAVARRETE ${ }^{1693}$ - se podría imputar un delito de omisión de denunciar la comisión de delitos, esto es, un delito de «solidaridad mínima», pero no de garante, en el caso del taxista que a sabiendas de que sus clientes lo están utilizando para cometer y huir de un robo, no lo denunciase. Por eso la imputación objetiva depende de la infracción objetiva, no de los conocimientos. Así las cosas, parte de la doctrina ${ }^{1694}$ tampoco considera relevantes los conocimientos especiales en la imputación objetiva, sólo aquellos que pertenecen, son adquiridos o son inherentes al rol: no existe exigencia normativa alguna de tenerlos o ejercitarlos.

\footnotetext{
${ }^{1690}$ Polaino NaVarrete, M., Lecciones de Derecho penal, Parte General, T. II, op. cit., p. 94.

1691 JAKOBS, G., PG, op. cit., 7/50 y 15/12; PIÑA ROCHEFORT, JI., El rol social y sistema de imputación, op. cit., p. 375; POLAINO-ORTS, M., «Imputación objetiva: esencia y significado», op. cit., p. 83.

1692 PIÑA ROCHEFORT, JI., Rol social y sistema de imputación, op. cit., pp. 371 a 373.

1693 Polaino NaVArrete, M., Lecciones de Derecho penal, Parte General, T. II, op. cit., p. 95.

1694 JakOBS, G., PG, op. cit., 7/50 y 15/12; Polaino NAVARreTe, M., Lecciones de Derecho penal, Parte General, T. II, op. cit., p. 93; POLAINO-ORTS, M., «Imputación objetiva: esencia y significado», op. cit., pp. 80 y ss.
} 
Sin embargo, excedería del riesgo permitido, o no supondría una conducta neutral, si previamente el sujeto modifica el destino, buscando no sólo la participación con el tercero, sino también la exención de responsabilidad, alegando dicha prohibición de regreso, con lo que inclusive podría aplicarse, en nuestra opinión, los fundamentos de la actio libera in causa y de tal modo excluirse la participación imprudente en la autoría dolosa ${ }^{1695}$ o imprudente ${ }^{1696}$ si la conducta del partícipe es autónoma y sin conexión de sentido criminal o realiza acciones cotidianas, o -como más exactamente explica PIÑA ROCHEFORT- cuando el partícipe tiene una posición de garante ${ }^{1697}$ por las condición de su rol en una determinada circunstancia. De aquí que la doctrina funcionalista ${ }^{1698}$ suele alegar que los conocimientos especiales son impunes, salvo las modificaciones del destino señaladas.

Otros autores -como MARAVER GÓMEZ ${ }^{1699}$ - consideran que la prohibición de regreso sirve de criterio para delimitar la posición de garante mediante la delimitación negativa del riesgo de la conducta y en los delitos de resultado ${ }^{1700}$ y a la vez criterio delimitador de la autoría y la participación en cuanto que los autores son garantes del riesgo de manera directa y los partícipes de manera indirecta y accesoria ${ }^{1701}$. Sin embargo, el principio de confianza -según MARAVER GóMEZ- sirve para delimitar el deber de cuidado - o riesgo permitido en «sentido estricto» - una vez que se ha acreditado la posición de garante ${ }^{1702}$. La prohibición de regreso podrá aplicarse si existe un ámbito de responsabilidad ajeno, una relación negativa con el bien jurídico y el tercero $^{1703}$, por eso resulta irrelevante el carácter activo u omisivo, doloso o imprudente de la conducta del tercero, y la conducta dolosa o imprudente del primer sujeto ${ }^{1704}$.

\footnotetext{
1695 JAKOBS, G., PG, op. cit., 24/14; ROXIN, C., PG, I, op. cit., pp. 1006 y ss. En contra, por ejemplo, JESCHECK HH / WEIGEND T., Tratado, op. cit, 54, IV 1.

1696 JAKOBS, G., PG, op. cit., 24/17 y 24/21; ID., «La prohibición de regreso en los delitos de resultado. Estudio sobre el fundamento de la responsabilidad jurídico-penal en la comisión», trad. Manuel Cancio Meliá, JAKOBS, G., Estudios penales de Derecho penal, op. cit., pp. 261 y ss; ID., La imputación objetiva en Derecho penal, op. cit., pp. 161 y ss.

${ }^{1697}$ PIÑA RoCHEFORT, JI., El rol social y sistema de imputación, op. cit., p. 362, expone que en el ejemplo del vendedor de cuchillos que lo vende a quien participa en una riña, conociendo que se usará para lesionar, el «saber» o «no saber» no aporta nada a la imputación objetiva, sino si tiene posición de garante. Así, puesto que el vendedor está desarrollando una función propia de su rol, no tiene obligación de abstenerse por lo que no participa ni dolosa ni imprudentemente, ID., ibidem, op. cit., p. 367. Y a la inversa, concluye taxativamente que «nadie puede instrumentalizar un rol para irrogarse ámbitos de organización ajenos», ID., ibidem, op. cit., p. 364. En este sentido expone el ejemplo de quien abre la tienda para proporcionar el cuchillo o lo regala, ID., ibidem, op. cit., p. 368.

1698 JAKBOS, G., «Representación del autor e imputación objetiva», op. cit., p. 236; PIÑA ROCHEFORT, JI., El rol social y sistema de imputación, op. cit., p. 369.

${ }^{1699}$ MARAVER GÓMEZ, M., El principio de confianza en Derecho penal, op. cit., pp. 254 y ss. y pp. 362 y ss.

${ }^{1700}$ ID., ibidem, op. cit., pp. 362 y ss.

${ }^{1701}$ ID., ibidem, op. cit., pp. 366 y ss., se sirve de un concepto restrictivo de autor.

1702 ID., ibidem, op. cit., pp. 368 y ss.

${ }^{1703}$ ID., ibidem, op. cit., pp. 260 y ss.

${ }^{1704}$ ID., ibidem, op. cit., pp. 266 y ss.
} 
De otra, el principio de confianza sirve para delimitar «negativamente» el deber de cuidado de la posición de cuidado con el riesgo en relación al principio de autorresponsabilidad ${ }^{1705}$, en tanto exista un ámbito de responsabilidad ajeno y una relación negativa con el riesgo en cuanto a la inexistencia del deber de aplicar medidas de doble aseguramiento ${ }^{1706}$, y a la inexistencia de deberes frente a terceros (relación negativa con el tercero) ${ }^{1707}$, todo ello sin que concurran circunstancias concretas que evidencien un comportamiento incorrecto del tercero ${ }^{1708}$. Así, como hemos dicho, resulta irrelevante el carácter omisivo o activo, doloso o imprudente de la conducta del tercero, o el carácter doloso o imprudente del primer sujeto ${ }^{1709}$.

De esto puede concluirse que MARAVER GóMEZ defiende un carácter estrictamente objetivo de la prohibición de regreso y del principio de confianza. Su principal conclusión es que ambos criterios sirven para determinar la creación de un riesgo típico desaprobado como imputación objetiva de la conducta, pero también en la relación del riesgo y el resultado como imputación objetiva del resultado ${ }^{1710}$.

Dicho esto, nos adherimos a los planteamientos funcionalistas explicados, porque de tal manera podemos discernir entre conductas de ingreso en grupos religiosos, que como consecuencia de la permisión de creencias no pueden después ser imputadas, y aquellas conductas, tanto relativas al ingreso como las que se desarrollan dentro de la organización, que generan tal confianza especial que trasforma los conceptos esenciales del Sistema Social.

De aquí que la permisión de creencias, del ejercicio de cultos, y la práctica más inherente a la conciencia no pueda restringirse salvo en supuestos muy tasados previamente por la norma, y cuando se facilite la alternatividad del comportamiento adecuado a la norma. Cuando la norma quebrantada no ofrece alternativas claras de comportamiento y se activa sorpresivamente en el sentido ya aclarado, la norma se autocontraorienta en relación al Sistema normativo y social que previamente ha socializado al sujeto, de manera que su vigencia se difumina, constituyéndose los casos excepcionales de autoría de conciencia por inexigibilidad, y faculta la aplicación del estado de necesidad exculpante.

En los casos en los que la permisión de creencias y su ejercicio no encuentran limitación normativa previa resulta coherente mantener la neutralidad de la conducta en virtud de la

\footnotetext{
${ }^{1705}$ ID., ibidem, op. cit., pp. 273 y ss.

${ }^{1706}$ ID., ibidem, op. cit., p. 293 comenta que «puede hablarse de doble aseguramiento porque a pesar de que el tercero tenga un propio deber de controlar o asegurar el riesgo, el primer sujeto tiene también un deber de evitar que ese riesgo llegue a producir el resultado lesivo».

1707 ID., ibidem, op. cit., pp. 294.

1708 ID., ibidem, op. cit., pp. 298 y ss.

1709 ID., ibidem, op. cit., pp. 305 y ss.

1710 ID., ibidem, op. cit., pp. 406 y 407.
} 
prohibición de regreso. Estos son los casos de manifestación doctrinal del apocalipsis, creencia en la vida y contacto con extraterrestres, productos de salvación del alma (desde objetos religiosos a cursos de meditación y relajación del alma). Sin embargo, cuando el rol, en este caso el de creyente, un rol común como cualquier otro, salvo en la especialidad de su creencia (todos creemos o no creemos en algo trascendental), gana la confianza general, unida a la dinámica grupal en la que el adepto está incurso, su rol pasa de ser común a especial, cuando en virtud de esa garantía deposita su confianza total, por lo que en el momento en el que el rol ya especial instrumentaliza su especialidad en el sentido de concretar una garantía expectativa determinada, modificando o aumentando el riesgo de trasformación de la dirección de la conducta del adepto, se restringe o se elimina el horizonte de expectativas por modificación de los conceptos esenciales del Sistema: vida, muerte, bienestar, dinero, salud, etc.

Con palabras simples, si bien la creencia y la divulgación del apocalipsis, en cursos de «sanación», etc., constituyen permisiones de creencias amparadas por la prohibición de regreso, de modo que la imputación objetiva se desconecta, la constitución de una relación especial de confianza que se desarrolla en un dinámica de comportamiento grupal, y en algunos casos, los conocimientos especiales del sujeto que ha propiciado la confianza y en el que se deposita (conoce que el adepto compra productos inocuos) constituyen la imputación objetiva en calidad de autor, semejante a la responsabilidad por incumplimiento de deberes institucionales, también en aquellos casos de instrumentalización del rol especial generado, de modo que bajo estas premisas de verdad/garantía/confianza especial, la modificación de la voluntad en perjuicio propio o tercero genera la responsabilidad en calidad de autor, similar al sujeto que tiene la garantía de proteger y no alentar irrealidades perjudiciales en menores inmaduros o víctimas con especial vulnerabilidad, porque se crea una posición de superioridad «moral».

Así, en ocasiones, la manifestación y divulgación de un apocalipsis inminente, o venta de productos «religiosos», pueden constituir un riesgo no permitido, en el que el dolo o la imprudencia es cuestión de valoración ulterior. De esto resulta que la prohibición de regreso y el principio de confianza estén estrechamente conectados, se auto-modifiquen y dependan según el contexto el uno del otro.

\section{Imputación objetiva de los resultados dañosos tardios: lesiones psíquicas}

1. Introducción a la dimensión temporalmente tardía del resultado

Hemos visto la posibilidad de encuadrar la persuasión coercitiva en el tipo delictivo de las coacciones, aunque no sin problemática. Dicha problemática se recrudece con la posibilidad de 
imputar un delito de lesiones a consecuencia de las coacciones, y si se puede hacer responsable al autor de la coacción (persuasión coercitiva) de un segundo resultado, por regla general tardío. Este segundo resultado aparece normalmente de forma clara y visible cuando el adepto abandona el grupo, y por ende, se ha de resolver y determinar si dicho segundo resultado se puede imputar al autor de la persuasión coercitiva.

En esta dinámica pueden aparecer daños sobrevenidos, permanentes y otros resultados tardíos. En los primeros se parte de una primera lesión no curada que unida a otras circunstancias causan otra segunda lesión indirectamente; los daños permanentes se caracterizan por una lesión duradera que condiciona también indirectamente otra lesión que se produce con posterioridad; y los resultados tardíos son los que proceden de una conducta peligrosa que causa la lesión de una manera directa pero sin que se manifieste hasta mucho tiempo después ${ }^{1711}$.

Dicho esto, en relación al ámbito de nuestro estudio, parece claro que se pueda criminalizar al sujeto que sigue utilizando las técnicas de persuasión mediante el delito de peligro del art. 148 CP una vez se haya consumado el delito de coacciones a través de la persuasión coercitiva, y postergar la aparición de la probabilidad del resultado a la tentativa de delito contra la integridad psíquica y en su caso aplicar el concurso de leyes entre el art. 148 y 149 CP a favor de este último en virtud del principio de subsidiariedad. Esto es, entonces, una cuestión de imputación de los resultados tardios.

\section{Imputación de los resultados tardíos}

Hemos visto que los adeptos de sectas coercitivas en muchas ocasiones entran en el grupo con problemas psicológicos previos que son aprovechados por el grupo para completar con mayor probabilidad la persuasión coercitiva, dando como resultado unos daños sobrevenidos en el sentido expuesto. Se aprecia una primera lesión no curada, que unida a otras circunstancias, en este caso, una persuasión coercitiva menos intensa, dan como resultado una segunda lesión, en este caso la coacción, y tiempo después, en su caso, la lesión psicológica.

Sin embargo, también son admisibles otros supuestos. La causación de un daño permanente como es la coacción ${ }^{1712}$ que se produce por persuasión coercitiva puede dar como consecuencia final, y tiempo después, la lesión psicológica. Y también, la creación de un riesgo puede dar

\footnotetext{
1711 Aceptan esta clasificación SILVA SÁNCHEZ, J-Mª, «Sobre la relevancia jurídico-penal de la no-inmediatez en la producción del resultado», Estudios penales en memoria del profesor Agustín Fernández-Albor, Seminario de Derecho penal e Instituto de Criminología, Universidad de Santiago de Compostela, Santiago de Compostela, 1989, pp. 678 y ss; también VÁsques ShIMAJUko, Shikara, La imputación de los resultados tardíos. Acerca de la dimensión temporal de la imputación objetiva, B de F, Montevideo-Buenos Aires, pp. 74 y ss. y p. 355.

${ }^{1712}$ JAKOBS, G., $P G, 32 / 27$.
} 
como resultado una lesión tiempo después, en este caso psicológica, normalmente cuando el sujeto sale de la dinámica grupal ${ }^{1713}$.

VÁSQUES considera que tanto en los resultados sobrevenidos como en los permanentes el resultado posterior viene a consecuencia de la intermediación de otras circunstancias, por lo que hay que determinar si una conducta ha creado un riesgo penalmente relevante para producir la segunda lesión, más allá del tiempo trascurrido entre el primer y segundo resultado. Concluye que la dimensión temporal como elemento central de la imputación objetiva sólo se aprecia en los llamados resultados tardíos, para lo que ha de tenerse muy en cuenta la configuración temporal de la sociedad ${ }^{1714}$.

Las consecuencias tardías o daños sobrevenidos posteriormente, como decíamos, suelen referirse a unas primeras afecciones en la víctima, unas lesiones físicas o psíquicas, y posteriormente la muerte, por ejemplo, la víctima pierde el juicio y se suicida. Algunos autores imputan ambos resultados, salvo si la víctima ha aumentado significativamente el riesgo del segundo resultado, por ejemplo, cuando se comporta de forma insensata e irracional, pero si tal insensatez deviene de la creación de una lesión psicológica, nadie durará que existe un claro indicio de la conexión de imputabilidad, por el que bastará certificar la relación de la lesión con la toma de la resolución suicida ${ }^{1715}$.

${ }^{1713}$ VÁSQUES SHIMAJUKO, S., La imputación de los resultados tardíos, op. cit., p. 355.

1714 ID., ibidem, op. cit., p. 355.

1715 Otra parte de la doctrina niega la imputación aunque la víctima haya actuado adecuadamente con posterioridad al hecho, como Roxin, quien alega que en la lesión se consume el riesgo de otro proceso causal porque considerar lo contrario sería obligar al autor a un deber de vigilancia permanente. Así, diferencia entre aquellos daños causados lenta pero continuadamente y otros en los que la enfermedad se detiene y años después se muere súbitamente, lo que le lleva a afirmar la imputación en los primeros y reducirla a las lesiones en los segundos. Su razonamiento se basa en la determinación del «fin de protección de la norma»: si la lesión que sobreviene no es de los que el fin de la norma no trata de evitar, menos aún en los casos de daños permanentes, RoXIN, C., «Sobre el fin de protección de la norma en los delitos imprudentes», op. cit., pp. 181 a 199; JAKOBS por su parte, lleva la imputación a la parte de la conducta del autor que ha trasgredido el riesgo permitido, casos en los se crea un riesgo penalmente relevante. De aquí que cuando la víctima obra bajo una situación desventajosa causada por el autor, se pueda seguir imputando el resultado, JAKOBS, G., PG, op. cit., 7/75 y ss; ID., La imputación objetiva en Derecho penal, op. cit., pp. 185 y ss; sin embargo, de otra parte, GóMEZ RIVERO centra la solución en la comprobación de que el riesgo evoluciona a un resultado dañoso en «misma unidad explicativa», GómEZ RIVERO, $\mathrm{M}^{\mathrm{a} C} \mathrm{C}$., La imputación de los resultados producidos a largo plazo: especial referencia a la problemática del SIDA, Valencia, 1998, pp. 52 y ss. y pp. 91 y ss. Fundamenta la «procedencia de la imputación» como nueva categoría dogmática ubicada después de la imputación y entre el tipo y la antijuricidad, por lo que en algunos casos la realización de un resultado tardío a través de una conducta imprudente no encontraría adecuación ni procedencia de la necesidad de una pena, al asemejarse a las tentativas imprudentes impunes, ID., ibidem, op. cit., p. 110. Un caso de esta naturaleza sería la trasmisión dolosa del VIH cuando la víctima muere muchos años después, más ampliamente ID., ibidem, op. cit., pp. 52 y ss; SILVA SÁNCHEZ considera que la lejanía entre acción y resultado no es impedimento para imputar dicho resultado tardío, sin embargo propone una atenuación general de lege ferenda de la pena para estos casos, puesto que una conducta peligrosa que produce un resultado a largo tiempo, demuestra que es menos peligrosa que otra que causa el resultado inmediatamente o a corto plazo, SILVA SÁNCHEZ, J-M ${ }^{\mathrm{a}}$, «Sobre la relevancia jurídicopenal de la no-inmediatez en la producción del resultado», op. cit., pp. 681 a 683; SCHÜNEMANN, por otro lado, considera que no es imputable la muerte que se produce mucho tiempo después porque sobrepasa el tipo objetivo de 
Por su parte, VÁSQUES opina que «no cabe concebir como riesgo típico la potencialidad de una acción de causar consecuencias lesivas fuera del plazo de imputación objetiva de la conducta. La condición de riesgo típicamente relevante se establece en la medida en que éste es idóneo para producir un resultado también típicamente relevante, y las consecuencias manifestadas más allá del plazo de imputación no lo son» ${ }^{1716}$. Alega, acertadamente, que los criterios como el grado de riesgo o la forma en que se desenvuelve no sirven para establecer una regla de imputación objetiva ni seguridad jurídica en el límite temporal de la imputación del resultado $^{1717}$.

El citado autor propone una solución socio-normativa a dicha problemática. Parte de la concepción de los sistemas autopoiéticos de LUHMANN ${ }^{1718}$, de la Sociología del tiempo, y del modelo de imputación objetiva de JAKOBS. En relación al primero, acierta en comprender que la sociedad y sus subsistemas se expresan como comunicaciones interrelacionadas entre los sistemas, los subsistemas y sus entornos. En esta interrelación comunicativa en el sistema jurídico se expresa el sentido binario «conforme a Derecho/contrario a Derecho» ${ }^{1719}{ }_{-0}$ sea, justo/injusto- que se recombina mediante las normas jurídicas a las situaciones concretas, con el entorno/ambiente. De tal forma «el sistema jurídico modifica sus normas a fin de poder procesar la información de su entorno y adaptarse a él (...) ha tenido en cuenta el trascurso del tiempo de distintas maneras» ${ }^{1720}$.

De este modo, VÁSQUES encuentra en la prescripción de la pena el límite que la Sociedad ha impuesto para el «proceso de superación social del pasado que ella trae consigo» ${ }^{1721}$. Dicha observación supone una interpretación externa, o sea, desde la sociedad, que ha de trasladarse a la situación concreta en el sistema jurídico mediante una observación-interpretación interna con la aplicación analógica in bonam partem de los plazos de prescripción ${ }^{1722}$ y el decaimiento de la necesidad preventivo-general de penar por el paso del tiempo, distinto que el merecimiento de la pena al centrarse exclusivamente en las circunstancias del autor y víctima, lo que en nuestra opinión, al tratarse de una operación concreta, no trasciende en la operatividad total del

matar. Su propuesta se trata de una cuestión del tipo objetivo, SchüNEMANN, B., «Problemas jurídico-penales relacionados con el SIDA», Problemas jurídico penal del Sida, Santiago Mir Puig (ed.), Barcelona, 1993, p. 29 y ss.

${ }^{1716}$ VÁSQUES SHIMAJUKO, S., La imputación de los resultados tardíos, op. cit., p. 309.

1717 ID., ibidem, op. cit., p. 355.

1718 Para un mayor conocimiento de la traslación de la fundamentación que extrae, ID., ibidem, op. cit., pp. 130 y Ss.

1719 ID., ibidem, op. cit., pp. 162 y ss. y p. 356.

1720 ID., ibidem, op. cit., p. 357.

${ }^{1721}$ ID., ibidem, op. cit., p. 357. Lo fundamenta en relación a que el sistema de la Sociedad realiza un proceso de conversión de los hechos en Historia que no es otra cosa que la «(re)construcción de la realidad que, en términos jurídicos, lleva a cabo el propio sistema», ID., ibidem, op. cit., op. cit., p. 246.

${ }^{1722}$ ID., ibidem, op. cit., pp. 279 y ss. 
subsistema de Derecho penal, pudiendo entonces decaer «la necesidad de pena y no su merecimiento» ${ }^{1723}$. De aquí que el subsistema tome operaciones, en concreto delitos como imprescriptibles de modo que destierre dichas operaciones porque atentan contra toda la operatividad, por eso debe valorarlas siempre, haciéndolas imprescriptibles.

Pero antes de esto - como bien razona VÁSQUES- ha de preguntarse si el riesgo creado está desaprobado en relación con el resultado tardío, de lo que deviene que la problemática no se centra en la imputación objetiva del resultado sino en la conducta riesgosa ${ }^{1724}$, por eso, los plazos de prescripción legales comunican qué conductas prosiguen siendo riesgosas al objeto de imputar el resultado tardío como «plazo de imputación objetiva de la conducta» o «alcance temporal del riesgo típico», que si superados, dejan de ser penalmente relevantes, de tal forma que cualquier resultado que se concrete fuera de estos plazos de la imputación de la conducta no se podrá vincular con ésta en una relación de sentido ${ }^{1725}$, Así, la relación de sentido entre conducta y resultado dentro de los plazos de imputación de la conducta vendrán a sostener «una relación de sentido de unidad delictiva» ${ }^{1726}$.

Un buen ejemplo de lo dicho es la diferenciación de la imputación objetiva de los delitos permanentes y los delitos de estado como los delitos de daños y falsificación de documentos. En ambos se suscita la prolongación de la consumación, sin embargo, la cuestión trascendental para la imputación tardía del resultado es que el autor tenga la capacidad de prolongarla. Esto sucede en los delitos permanentes, no así -según VÁSQUES- en los delitos de estado ${ }^{1727}$. En nuestra opinión, también se incluiría en los delitos permanentes los delitos de pertenencia a $\operatorname{organización}^{1728}$, por cuanto la capacidad de seguir perteneciendo pasa por la voluntad del sujeto, tanto dolosa o como imprudentemente, como veremos, cuya trascendencia es la persistente comisión del tipo, por esto son delitos permanentes y de aquí la posibilidad de resultados tardíos derivados de dicha permanencia permanente ${ }^{1729}$.

Así, estamos de acuerdo con este penalista en que sólo cuando el autor abandona el control se puede hablar de «consumación definitiva», y desde aquí el comienzo de la «superación social del

${ }^{1723}$ ID., ibidem, op. cit., p. 261.

1724 ID., ibidem, op. cit., pp. 284 y ss.

1725 ID., ibidem, op. cit., p. 358.

1726 ID., ibidem, op. cit., pp. 289 y 358.

${ }^{1727}$ ID., ibidem, op. cit., p. 203 y pp. 313 a 317.

1728 JAKOBS, G., $P G, 32 / 28$.

${ }^{1729}$ Esto al constituir «la realización de la acción típica y la situación antijurídica (...) un único hecho penalmente relevante y no la suma de múltiples acciones individuales (...) El delito permanente aparece, así, como una forma de unidad típica de acción (...) La mayor intensidad de la afección al interés protegido, producto de la persistente realización del tipo penal, fundamenta, por el contrario, un incremento cuantitativo del injusto», lo cual se asemeja al delito continuado pero se diferencia en la dilación temporal entre la sucesivas acciones, VÁSQUES SHIMAJUKO, S., La imputación de los resultados tardíos, op. cit., pp. 206 a 208 y p. 245. 
delito» ${ }^{1730}$. Esta conclusión trasladada al ámbito de nuestro estudio, nos lleva a concluir anticipadamente que en las dinámicas de persuasión coercitiva, salvo reconstrucción del horizonte de expectativas o su complementación total, el autor o autores siguen teniendo el control del riesgo, de tal manera que se puede imputar el resultado tardío, al tratarse de este delito, si bien de resultado, de consumación permanente del resultado por la especialidad de la dinámica de ataque, tal y como sucede en algunas modalidades de detención ilegal ${ }^{1731}$, lo que fundamenta a la vez una mayor previsión penológica.

De lo anterior el citado penalista también extrae una importante conclusión, que puede ser trasladada a nuestra problemática referida a la causación de una adicción comportamental tardía como lesión psíquica. Considera que «el cómputo de alcance temporal del riesgo típico no debe tomar como puntos de referencia la pena que debe aplicarse al hecho efectivamente acontecido o la que correspondería al autor si hubiese una «correspondencia temporal» entre riesgo creado y el resultado producido, es decir, como si el resultado hubiese acaecido en el período fijado por el riesgo de la acción realizada. En ambos casos, se estaría tomando como referencia el hecho total y no sólo la conducta. Por esa razón, la necesidad preventivo-general de la pena debe ponerse en relación con la pena que le correspondería a la tentativa del delito cometido, para lo cual se deberá tener en cuenta, por una parte, el grado de peligro que lleva consigo el comportamiento y, por otra, el grado de ejecución alcanzado (art. $62 \mathrm{CP}){ }^{1732}$. De esta manera concluye que «(e)1 art. 132.2 CP no conecta la imprescriptibilidad con la pena de los respectivos delitos consumados, sino que como dicho precepto lo expresa, son las «penas impuestas», por éstos las que no prescriben. Por consiguiente, en los delitos considerados imprescriptibles (...), también la pena de la tentativa es imprescriptible» ${ }^{1733}$. Desde luego la argumentación es cuando menos poética y eleva a la sociología a la categoría suprema de filosofía, en este caso, filosofía del tiempo $^{1734}$.

${ }^{1730}$ ID., ibidem, op. cit., p. 314, de aquí que no exista control en las consecuencias del SIDA.

${ }^{1731}$ POLAINO NAVARRETE, M., El delito de detención ilegal, op. cit., pp. 148 y ss.

1732 VÁSQUES SHIMAJUKO, S., La imputación de los resultados tardíos, op. cit., pp. 293 y 294.

${ }^{1733}$ Expone un ejemplo: «en un caso de homicidio, a cuya tentativa le corresponda la pena de prisión de ocho años (...), el alcance temporal del riesgo típico sería quince años (...) De esa manera, sólo podrá afirmarse la existencia de una relación de sentido de unidad delictiva entre acción y resultado -y, por tanto, un resultado típico de homicidio- si la muerte de la víctima tiene lugar dentro del plazo de quince años», ID., ibidem, op. cit., p. 295.

${ }^{1734}$ Concluye VÁSQUES finalmente que «la necesidad preventivo-general de la pena que se ve afectada por el transcurso de un considerable tiempo es la relativa al comportamiento realizado y no a la necesidad de pena que recae sobre el resultado (...) el cálculo del plazo de prescripción de la pena -que sirve de base al alcance temporal del riesgo típico- no puede tener como punto de referencia la pena del delito consumado, sino la que le corresponde a la tentativa del mismo», ID., ibidem, op. cit., p. 358. 


\section{Conclusión}

A lo que nuestra investigación respecta, tenemos que concretar si la adicción comportamental o los trastornos psicológicos como el delito de lesiones pueden ser tratadas como un daño sobrevenido, daño permanente o como resultado tardío. Y en este punto, es necesario determinar también si la persuasión coercitiva realizada directamente mediante técnicas de persuasión o indirectamente mediante la dinámica criminal, que constituyen los factores para producir el déficit de socialización, llevan a un segundo resultado, como adicción comportamental, en este caso tardío.

Aquí parece importante señalar el juicio de previsibilidad que algunos autores requieren ${ }^{1735}$, o el riesgo típico causado al que se refiere VÁSQUES. La persuasión coercitiva como delito de coacciones $-\mathrm{y}$ de resultado- se produce continuamente, su consumación es permanente, y su resultado tardío depende de la intensidad de las técnicas de persuasión, de la dinámica comportamental grupal y de la propia capacidad y antecedentes del sujeto, de modo que el riesgo de producción del resultado de adicción comportamental como lesión psíquica se retrasa, pero avanza progresivamente bajo el control de la propia dinámica comportamental aprendida, se ajusta a una inercia de comportamiento en tanto no se reconstruya el horizonte de expectativas o se complete con las ofrecidas por el Sistema normativo y social.

Puesto que hemos concluido que la persuasión coercitiva, por norma general, acaece y se apropia del sujeto antes de la lesión psíquica o adicción comportamental, estos suponen un resultado tardío del riesgo típico de la persuasión, por lo que una vez que el sujeto tiene un déficit de socialización, la misma dinámica criminal continuada va produciendo la adicción comportamental como lesión psicológica, de modo que sólo si acaece durante la vigencia de la prescripción de la tentativa de lesiones podrá imputarse dicho resultado, generándose igualmente problemas de concurso entre el resultado permanente de coacciones y la tentativa o consumación del delito de lesiones psíquicas o como adicción comportamental.

\section{III.- Déficit de socialización del autor atribuible a tercero y estado de necesidad exculpante}

\section{A. Introducción}

Expusimos supra que el fundamento material de culpabilidad viene por una motivación normativa normal y funcional, es decir, la atribuibilidad de lo injusto del hecho es la capacidad del sujeto a adecuarse a los dictados de la norma otorgándole validez. En este sentido, aceptamos

\footnotetext{
${ }^{1735}$ GÓMEZ RIVERO, MC., La imputación de los resultados producidos a largo plazo, op. cit., pp. 52 y ss.
} 
los postulados de JAKOBS sobre el concepto funcional de culpabilidad que se relaciona con el concepto de socialización.

En la tradición jurídico-penal existe un recelo en aceptar los resultados del psicoanálisis en los condicionamientos psíquico-sociales con trascendencia en la dogmática (dolo directo, dolo eventual, imprudencia consciente e inconsciente) y en la imputación del delito por la indemostrabilidad empírica y el peligro de psicologizar la dogmática ${ }^{1736}$. Sin embargo, $\operatorname{MOSER}^{1737}$ se refirió a la necesidad de ajustar la dogmática jurídico-penal a los resultados del psicoanálisis individual en los denominados déficits de socialización, diferenciados de las enfermedades propiamente dichas, o a factores biológicos, que causan inimputabilidad. También las teorías psicológicas desde una perspectiva colectiva encuentran argumentos de los condicionamientos sociales en la conducta delictiva en procesos de socialización defectuosos que genera una personalidad inestable entre el Yo, el Super-yo y el Super-yo colectivo, con diferentes consecuencias para la doctrina y estudios de campo: exonerantes o de máxima culpabilidad y posturas prevencionistas ${ }^{1738}$.

DÍEZ RIPOLLÉS resalta la opinión de OSTERMEYER que «con planteamientos frecuentemente entrelazados con los de la denominada «teoría de la definición» intenta mostrar la medida en que las necesidades psicológico-colectivas condicionan ese proceso jurídicopenal inicial» ${ }^{1739}$, y se muestra favorable a la teoría psicológico-individual en la formulación y constatación de los elementos subjetivos del delito, aunque con matices en que su legitimación se realiza a través de las «convicciones generales de la sociedad» ${ }^{1740}$. Tanto es así que afirma que «podría decirse que en la actualidad estamos presenciando una profundización en ese análisis psicológico-individual

${ }^{1736}$ Ampliamente DíEZ RIPOLLÉS, JL, Los elementos subjetivos del delito. Bases metodológicas, Tirant lo Blanch, Valencia, 1990, pp. 68 y ss. y pp. 155 y ss.

${ }^{1737}$ Vid. ID., ibidem, op. cit., p. 68 (MOSER, Tilmann, «Nachwort», Psychoanalyse und Justiz, Mitscherlich, Suhrkamp. 1971, pp. 416 y ss.).

${ }^{1738}$ Ampliamente DíEZ RIPOLLÉS, JL., Los elementos subjetivos del delito, op. cit., pp. 155 y ss.

1739 Prosigue diciendo que «(p)ara este autor la determinación de las conductas que deben ser consideradas dignas de punición por el Derecho penal así como la intensidad de la penalidad que debe serles impuesta no están en razón directa con su dañosidad social, al menos tal como este concepto habitualmente se entiende. Hay sin duda conductas de una mayor nocividad o peligrosidad sociales que no resultan penadas o lo están levemente. El baremo con cuya ayuda se establecen aquellas variables es el de la mayor o menor presión que determinadas pulsiones asociales reprimidas estén ejerciendo sobre el débil Yo de los ciudadanos de orden; a partir de un cierto nivel de presión la conducta inconscientemente deseada pasará a considerarse punible, y la intensidad de la pena variará con la de esa presión. El autor ejemplifica tal proceder con los delitos sexuales, contrarios a la vida o integridad corporal, patrimonio y seguridad del tráfico. En realidad, señala Ostermeyer, la definición de lo que sea la criminalidad, si verdaderamente la sociedad quiere descargar sus agresiones a través de ella, no puede tener como objeto al hecho criminal sino a la persona criminal. Sólo ella, en cuanto capaz de asumir las cualidades que el Super-yo colectivo atribuye al criminal, posibilita los diversos mecanismos de identificación sustitutiva ya descritos», ID., ibidem, op. cit., pp. 173 y 174 (OSTERMEYER, Helmut, Die bestrafte Gesellschaft, Hanser Verlag, München, 1975, pp. 75 a 77 y pp. 208 a 210).

${ }^{1740}$ DíEZ RIPOLLÉS, JL., Los elementos subjetivos del delito, op. cit., pp. 304 y ss. y pp. 315 y ss. 
al ahogarse desde diferentes tendencias por la necesidad de atender a aspectos habitualmente descuidados como la afectividad, las alteraciones motivacionales y, sobre todo, los procesos de socialización, sin quedarse, como venía siendo frecuente, en las perturbaciones más directamente vinculadas al intelecto y a la voluntad» ${ }^{1741}$, cuya trascendencia tiene repercusiones en toda la teoría del delito y también concretamente en la culpabilidad.

En las teorías interaccionistas o sociales, además de los conocidos conceptos de verdad de HABERMAS, el concepto de «socialización» de LUHMANN, partiendo de su renombrada teoría de la legitimación a través del procedimiento ${ }^{1742}$, en la que en realidad el consenso se halla más en el poder que en la verdad, en el poder funcional de eliminar disenso o protestas, explica que «(e)lla no tiene que ver con una trasmisión de modelos de conformidad, sino con la alternativa, constantemente reproducida por la comunicación, entre conformidad o desviación, adaptación o contradicción» ${ }^{1743}$, por eso concluye que «(e)l proceso de (auto-)socialización puede ser definido, por consiguiente, como el proceso de formación de expectativas que después, a su vez, regulan qué eventos son posibles para el sistema» ${ }^{1744}$.

De aquí que la posibilidad de motivación normativa de un sujeto que infringe una norma de determinación puede ser imposible en tres casos y con tres consecuencias penales: primero, cuando hubiera sido así para todos los hombres estaríamos ante una causa natural y no humana, por lo que no existe infracción antijurídica; segundo, esta imposibilidad también puede ser desde una posición ex ante; y tercero, en ocasiones, la imposibilidad de motivación puede provenir de una merma de la confianza en la expectativa que ha generado la norma.

En este sentido, la culpabilidad es la falta de fidelidad al Derecho cuando el sujeto tiene alternativas en su esfera de auto-organización para actuar de otra forma que no quebrante la norma. Entonces, la culpabilidad no es una construcción psicológica ni neurológica, sino social, de tal modo que la culpabilidad tiene una función preventiva, general y positiva de mantener el Sistema social, comunicando que ciertas conductas defraudan la expectativa social de los demás, pero más si cabe, al propio Sistema social. Por esto la pena cumple la función de restablecer la defraudación generada en el sistema, la pena lo reconstruye.

${ }^{1741}$ ID., ibidem, op. cit., p. 333.

1742 LUHMANN, N., Legitimation durch Verfahren, op. cit; ID., «Sistema jurídico y dogmática jurídica», op. cit.

1743 Luhmann, N., «Inclusión y exclusión», Luhmann, N., Complejidad y modernidad: De la unidad a la diferencia, Trotta, ed. y trad. Josetxo Berian y José María García Blanco, 1998, p. 248.

${ }^{1744}$ ID., ibidem, op. cit., p. 248; PARSONS, T., vv.aa., Hacia una teoría general de la acción, op. cit., pp. 36 y 41 en donde se explica que «(c)uando se ha internalizado los patrones culturales se convierten en elementos constitutivos de los sistemas y de los sistemas de las personalidades. Todos los sistemas concretos de acción tienen un sistema cultural, y, al mismo tiempo, son un conjunto de personalidades (o sectores de ellas), y un sistema social (o subsistema)». 
JAKOBS se pronuncia a favor de la aplicación de la causa de inexigibilidad en supuestos excepcionalísimos cuando no se afecte a la vigencia del ordenamiento jurídico aunque el conflicto sea tan irresoluble e imperioso ${ }^{1745}$. Por eso sólo aprecia tres posibilidades de atenuación: a) Cuando el autor infrinja una norma pero no afecte a su propia vigencia o se reconozca la misma, por ejemplo en el supuesto del médico que inyecta un líquido letal a un enfermo terminal amigo, por petición de éste hacía tiempo. b) En los casos de déficit de socialización del autor, cuando dicho déficit es atribuible a terceros, por ejemplo explica, cuando haya sido educado incorrectamente o inducido a situaciones de fragilidad comprensible. $c$ ) Y por último, aunque parcialmente, cuando el sujeto ante un deber institucional no dispone de alternativa de organización de dicha institución pero en la que el deber no informa en el cómo realizar la organización adecuada a la norma. Sobre esta conclusión expone la negativa de un médico al aborto, en la que si bien el médico tiene un deber de actuar institucionalizado tiene la oportunidad de organizar dicho deber de tal manera que elimine la posición de garante, sin afectar a la norma ni crear un daño. Sin embargo, por el contrario, en los casos de los padres testigos de Jehová que rechazan asistencia para el hijo menor de edad, acepta una posible exculpación plena o parcial al faltar dicha alternatividad de organización. Admite también la posibilidad de la exculpación en aquellos casos en los que la víctima consiente la reducción de su protección, como por ejemplo el caso de quien conoce de su pareja el rechazo de la trasfusión, y llegado el día, y ante la imposibilidad de negarse el necesitado por inconsciencia, la pareja no consiente la asistencia médica ${ }^{1746}$.

En suma, parece vincular necesariamente los defectos cognitivos con el criterio de la inexigibilidad de la conducta y con los casos de conflicto de conciencia, como en el caso de los Testigos de Jehová, mientras que en el caso del terrorista, éste comete un defecto volitivo imperdonable o defecto cognitivo basado en un defecto volitivo (indiferencia) también imperdonable. Considera que los defectos cognitivos son en principio perdonables, y los defectos

\footnotetext{
1745 JAKOBS, G., $P G, 20 / 24$. Recuérdese que dijimos que JAKOBS comentaba que «no es lo mismo que un miembro de una determinada confesión religiosa, por lo demás, un sujeto plenamente integrado, en una situación puntual no cumpla con sus deberes por su fe, que un terrorista combata globalmente al Estado», JAKOBS, G., «El lado subjetivo del hecho», op. cit., p. 98.

1746 JAKOBS, G., $P G, 20 / 24$. Críticamente JERICÓ que el primero de los postulados es demasiado amplio y sucede en casi todos los casos de conflicto de conciencia. El supuesto de déficit de socialización, en su opinión se reconduciría a los supuestos de error de prohibición sobre los límites de una cauda de justificación, aunque acepta que el sujeto crea que es justificable la aniquilación. En los supuestos de omisión del deber institucional, opina que no es necesario acudir a la inexigibilidad, sino a la atipicidad. Considera que las normas que obligan a un comportamiento positivo en protección de bienes jurídicos supraindividuales no tienen tanta relevancia como en la de bienes jurídicos individuales, con lo que no estamos de acuerdo, JERICÓ OJER, L., El conflicto de conciencia, op. cit., pp. 402 a 404.
} 
volitivos son imperdonables, pero los defectos cognitivos que se basan en la indiferencia, es decir, en un defecto volitivo, son también imperdonables ${ }^{1747}$.

\section{B. Imputación del déficit de socialización por educación totalitaria y/o criminal y estado de} necesidad exculpante

Como ya hemos señalado, desde el siglo XIX cobraron fuerza las teorías de la socialización. El cambio fundamental se produjo con el paulatino abandono de una concepción puramente idealista para poner el punto de análisis y estudio en la Sociedad. Desde WEBER se introdujo una forma de observación sociológica que se fue depurando con las teorías de la comunicación de MEAD, entre otros, y con la teoría de la conciencia colectiva de DURKHEIM. Con PARSONS se inició un método de análisis que pretendía ser puramente sistémico y funcionalista (sistema de las personalidades, sociales y culturales) pero sin dejar de observar la racionalidad de la acción dentro del sistema. Con HABERMAS el método funcionalista de la teoría de la acción alcanza su máxima representación, si bien ha sido LUHMANN quien de una vez por todas ha planteado un análisis puramente sistémico y extra-moral.

En definitiva, con el irrumpir de las teorías sociológicas se llega a una importante conclusión: el hombre no depende sólo de sí mismo ni de la fuerza que ejerce sobre este la Sociedad, sino que es una combinación del todo y ninguna más relevante, es una cuestión de posibilidades. Las personas crean socialización pero a la vez son socializadas. La acción no es una combinación de impulsos unidireccionales que propicia un factor o varios, la acción es una comunicación social en la que intervienen comunicaciones particulares entre sistemas: esto es la posibilidad.

Desde estos planteamientos que hemos ido desarrollando, no resulta extraño apreciar que el comportamiento de las personas, más que condicionadas o determinadas, planteen dudas sobre el sentido comunicativo en un determinado sistema. En esto radican los denominados déficit de socialización, normativo o atribuido a tercero, desde el prototípico caso de tribus que cuentan con una regulación penal diferenciada en algunos países, al aislamiento comunicativo que sufre un menor autista, el sujeto que ha sido encerrado desde la infancia o el paradigmático de cierta juventud durante el nacionalsocialismo.

Pues bien, en este tránsito entre comportamientos responsables y los casos de sujetos claramente desocializados en los que existe un amplio acuerdo sobre la «comprensión» social de la conducta, median otros a los que quizá por cuestiones morales no se les reconoce la misma

1747 JAKOBS, G., «El lado subjetivo del hecho», op. cit., p. 87 y pp. 99 y 100.; ID., $P G$, op. cit., pp. 20/20 y ss; ID., «Sobre el tratamiento de los defectos volitivos y de los defectos cognitivos», Estudios de Derecho penal, op. cit., pp. 127 y ss. 
relevancia. Me refiero a que si se comprende que el comportamiento está mediatizado por en el sinalagma de la comunicación de al menos dos partes, cuando falla, habrá que concluir que la orientación de alguna de las dos partes no se ha podido orientar en la dialéctica comunicativa concreta en el sistema que se trate. Esto es lo que sucede en nuestra opinión cuando media una distorsión de los canales de comunicación que ofrece el Sistema Social. Como hemos explicado, unas veces esta falta de comunicación y su fallo orientativo es atribuible al propio Sistema, otras al mismo sujeto y otras a un tercero que interviene. Estos últimos casos se agudizan en los déficits de socialización por educación totalitaria o criminal.

Al respecto JAKOBS ${ }^{1748}$ expone dentro del denominado déficit de socialización por educación totalitaria el ejemplo paradigmático de una persona de veintiún años educada en el totalitarismo durante la Segunda Guerra Mundial, y por ello se considera obligada a actuar en el exterminio judío. En estos casos, reconoce una exculpación al menos parcial.

Paralelamente, puede citarse el estudio de MiLgRAm en su interesante obra sobre la obediencia a la autoridad. Este sociólogo realizó varios experimentos ${ }^{1749}$ en la Universidad de Yale en el marco de la obediencia asumida de manera voluntaria a una autoridad, sin intimidación alguna, en los que pudo constatar que «(l)a esencia de la obediencia consiste en el hecho de que una persona viene a considerarse a sí misma como un instrumento que ejecuta los deseos de otra persona que por lo mismo no se tiene a sí misma por responsable de sus actos» ${ }^{1750}$. De tal manera negó que exista una causa sádica en la obediencia a órdenes criminales,

1748 JAKOBS, G., $P G$, op. cit., 20/24.

${ }^{1749}$ Los experimentos que realizó MilgRAm consistieron en comprender como fue posible que millones de personas fueran sacrificadas durante el Tercer Reich mediante órdenes. Se preparó a la población para que aceptara la destrucción de los judíos como algo bueno y beneficioso para Alemania, Milgram, S., Obediencia a la autoridad, op. cit., p. 22. Los experimentos consistieron en engañar a un sujeto al que la autoridad, en este caso, el experimentador dentro del marco de la Universidad de Yale -que otorgaba cierta legitimidad- ordenaba administrar (ficticiamente) descargas eléctricas a otra persona - un actor- cada vez que fallara en las respuestas que previamente debía memorizar. La moral se deja de un lado, o más bien se trasforma como bueno «vivir conforme a las expectativas que la autoridad se ha forjado respecto de uno mismo», ID., ibidem, op. cit., p. 21. Existe una estructuración jerárquica social y comunicativa que impide romper con una autoridad que parece legítima, se pierde la visión de las consecuencias de la conducta que se traslada a la autoridad, el sujeto se descarga de responsabilidad psicológicamente cuando se es un «eslabón intermedio» en la cadena de órdenes, ID., ibidem, op. cit., pp. 23 y pp. 137 y ss: «cuando es llamado al servicio militar y se le ordena que arroje bombas sobre la población civil, lo hace. Esta acción no tiene su origen en su propio sistema motivacional, y por ello no queda reprimido por las fuerzas inhibitorias de su sistema psicológico interno». Esto recuerda la teoría de Roxin sobre la autoría mediata en aparatos de poder organizados, Roxin, C., Autoría y dominio del hecho, op. cit., pp. 269 a 279 y pp. 723 a 739.

${ }^{1750}$ MILGRAM, S., Obediencia a la autoridad, op. cit., p. 10; similarmente BARON Robert A / BYRNE Donn, Psicología Social, $10^{\mathrm{a}}$ ed., Pearson Educación, Madrid, 2005. Al hilo merece destacarse otras teorías como la ya citada de la «disonancia cognoscitiva» que fundamenta la discrepancia habitual entre el pensar (también convicciones morales) y el hacer, FESTINGER, L., Teoría de la disonancia cognoscitiva, op. cit; también la teoría de la «closed mind» de ROKEACH apela a determinadas circunstancias en las que los argumentos racionales no puedes penetrar en algunas personalidades, por ejemplo esto es característico de la «auténtica confesión» de los miembros de una religión, ROKEACH, Milton, The open and the closed mind: investigations into the nature of belief systems and personality systems, Basic Books, New York, 1960; la teoría del «verdadero creyente», HofFER, Eric, The true 
el problema no es el totalitarismo en sí mismo, la causa de dicha sumisión a la autoridad no se cultiva en estados autoritarios como el del nacionalsocialismo, sino un problema con la autoridad $^{1751}$. El sometimiento voluntario a la autoridad constituye una forma de moralidad relacionados con la lealtad, el deber y la disciplina que puede igualmente trasladarse al binomio norma/sujeto, sólo que en ocasiones dicha norma es injusta, pero si posee el mismo potencial configurador y orientador de las conductas de los sujetos puede deshumanizar la acción y conducirse inevitablemente a adecuarse conforme a una norma injusta pero con rango de autoridad legitimada.

MiLgRAm explica que la lejanía del sufrimiento de las víctimas, cuanto más lejano o difícil de ver, facilita la conducta sumisa a la autoridad, resulta más sencillo ejecutar una orden en la que no se aprecian, mediante los sentidos, las repercusiones de dicha ejecución, o dicho de otra manera, la cercanía a la autoridad despojaba de responsabilidad al sujeto ejecutor. Por el contrario, la presencia de la víctima en el campo de acción sensitivo (sonido, visión, tacto, etc.) quiebra considerablemente la obediencia a la autoridad ${ }^{1752}$, de tal modo que «el hecho de cambiar la estructura de las relaciones espaciales conduce a un posible desplazamiento de alianzas a lo largo de diversas condiciones experimentales» ${ }^{1753}$, lo que recuerda los conceptos input y output de LUHMANN, o déficit de socialización expuesto por JAKOBS, por cuanto los sujetos siguen la obediencia a la autoridad aun quebrantándose sus principios morales.

Esto se debe, como decíamos, a una trasformación de los conceptos esenciales del Sistema Social (dinero, verdad, poder, amor, salud, vida, muerte), estructuralmente ahora adecuados en la correspondencia a una autoridad, a la que se le otorga el beneficio de la legitimidad. Lo mismo cabe trasladarse a la norma cuando ésta adquiere cierta legitimidad en la estructura social que hace orientar la conducta de los ciudadanos. La misma obediencia a la autoridad normativa en Estados democráticos civilizados y con una sociedad funcionalmente diferenciada se aprecia en el desastre nazi pero a la inversa, o procurándose conductas claramente criminales, en este caso, la obediencia a la autoridad de la norma nazi, a la que se le otorgó legitimidad social, procuró la ejecución ciega de los mandatos, cuyos ejecutores trasladaron la responsabilidad a la norma, o más exactamente, a la autoridad.

believer. Thoughts on the Nature of Mass Movements, Nueva York, 1951; o la teoría de la «alienación» como fenómeno social en cuanto a «enajenación»/«cosificación» de la personalidad objetivamente (estado, burocracia) y subjetivamente o de sí mismo, SCHAFF, Adam, La alienación como fenómeno social, trad. Alejandro Venegas, Grijalbo, Barcelona, 1979.

${ }^{1751}$ MILGRAM, S., Obediencia a la autoridad, op. cit., p. 167.

1752 ID., ibidem, op. cit., pp. 42, 46, 64 y 65

1753 ID., ibidem, op. cit., pp. 47 y 47. 
Existe de tal modo un paralelismo comunicativo-social entre la autoridad y la norma, se funden en la legitimidad de ambas en un solo cuerpo directriz. Existe un «contrato social implícito» que debe de cumplirse, que se refuerza en la idea de que la víctima también está obligada normativamente a someterse a la voluntad de la autoridad ${ }^{1754}$, cuestión que también fue advertida por Hannah ARENDT ${ }^{1755}$, si bien discernió claramente entre el sometimiento a la autoridad (Estados autoritarios, dictatoriales, tiránicos, ) y el sometimiento totalitario (Estados totalitarios). Tal conclusión de ARENDT se basa en que la masa se aplica únicamente a las personas no identificables en ninguna organización, su aislamiento social es de lo que se aprovecha el totalitarismo a diferencia del autoritarismo ${ }^{1756}$. Esto es la dominación total que significa el totalitarismo ${ }^{1757}$, mientras que el autoritarismo dictatorial o tiránico no puede llegar a someter por completo al individuo porque se basa en una ideología de la propia autoridad, o dicho de otro modo, el totalitarismo no tiene ideología concreta más que la dominación y la destrucción de todo y de todos, la autoridad es un factor relevante en la sumisión y en el

${ }^{1754}$ ID., ibidem, op. cit., pp. 68 y ss.

${ }^{1755}$ ARENDT describió en su libro Eichmann en Jerusalén, a un pobre burócrata que se limitaba en su despacho a cumplir con su obligación, concluyendo que el mal (böse) es algo estrictamente banal. ARENDT relata como Eichmann, jefe de emigración en el nacionalsocialismo, a pesar de conocer la «solución final» de los judíos, la lejanía ante tal barbarie unido a otras soluciones anteriormente propuestas como la expulsión, la evacuación, la deportación y a que había sido un ciudadano fiel cumplidor de las leyes y órdenes de Hitler, le colocan como un instrumento, ARENDT, Hannah, Eichmann en Jerusalén, Ed. Debolsillo, 2006, op. cit., p. 44. No se sentía culpable ni moral ni jurídicamente, obedecía ciegamente en el más sentido kantiano: «obediencia de los cadáveres» como él mismo la denominaba, ID., ibidem, op. cit., p. 199. Era un Befehlsträger, un portador de órdenes como los propios nazis preferían denominar, en vez de un Befehlsempfänger, un receptor de órdenes, ID., ibidem, op. cit., p. 48. Eichmann explicó que la lealtad a Hitler era más allá de la norma, o dicho más precisamente «las palabras del Führer tenían fuerza de ley». Esto significaba que si la orden venía directamente de Hitler no era necesario que constara por escrito, ni fuera una norma, por el contrario, toda orden o conducta que contradijera la «palabra» de Hitler era ilegal, ID., ibidem, op. cit., p. 216. Muy acertadamente ARENDT explicó que «(l)a distinción entre una orden y la palabra del Führer radicaba en que la validez de esta última no quedaba limitada en el espacio y el tiempo, lo cual es la característica más destacada de la primera. Esta es también la razón en cuya virtud la orden dada por el Führer de que se llevara a término la Solución Final fue seguida por un diluvio de reglamentos y ordenanzas (...); la orden de Hitler, a diferencia de las órdenes corrientes, recibió el tratamiento propio de una ley (...) Y, al igual que la ley de los países civilizados presupone que la voz de la conciencia dice a todos «no matarás», aun cuando los naturales deseos e inclinaciones de los hombres les induzcan a veces al crimen, del mismo modo la ley común de Hitler exigía que la voz de la conciencia dijera a todos «debes matar», pese a que los organizadores de las matanzas sabían muy bien que matar es algo que va contra los normales deseos e inclinaciones de la mayoría de los humanos. El mal, en el Tercer Reich, había perdido aquella característica por la que generalmente se le distingue, es decir, la característica de constituir una tentación», ID., ibidem, op. cit., p. 219; ID., Los orígenes del totalitarismo, pról. Salvador Giner, trad. Guillermo Solana, $7^{\mathrm{a}}$ reimpresión 2014 de la $1^{\mathrm{a}}$ ed. 2006, Alianza Editorial, pp. 502 y ss; ALLPORT explicaba que «el oficial nazi que estuvo a cargo de los asesinatos en masa de Auschwitz, el coronel Hoes, aclaró muy bien que fue precisamente este incesante adoctrinamiento verbal el que lo convenció, tanto a él como a sus compañeros de crimen, que los judíos eran realmente culpables de todo y que debían ser exterminados. Se hace evidente, en consecuencia, que en ciertas circunstancias se producirá la progresión gradual que lleva de la agresión verbal a la violencia, del rumor al tumulto, de la murmuración al genocidio», ALLPORT, GW., La naturaleza del perjuicio, op. cit., p. 76.

${ }_{1756}$ ARENDT, H., Los orígenes del totalitarismo, op. cit., pp. 438 y ss.

${ }^{1757}$ Según refiere, «(l)os movimientos totalitarios son organizaciones de masas de individuos atomizados y aislados (...) su más conspicua característica externa es su exigencia de una lealtad total, irrestringida, incondicional e inalterable del miembro individual», ID., ibidem, op. cit., p. 453. 
aislamiento, sin embargo, por sí sólo no puede eliminar el horizonte de expectativas, únicamente restringirlo $^{1758}$. La combinación de los demás factores, en nuestro caso, el comportamiento grupal también restringido en las expectativas, pueden llevar al totalitarismo, a la sumisión completa y, en concreto, la voluntad de poder de un sujeto ${ }^{1759}$. La propaganda totalitaria entonces no está dirigida a la persuasión como resulta en determinadas formas de la autoridad y concretamente en el autoritarismo, sino en la organización totalitaria para procurar la sumisión total $^{1760}$. Puede decirse que el totalitarismo supone un sistema que pretende estar estrictamente cerrado a las comunicaciones de otros sistemas o entornos, en todo lo que acaece, todo comportamiento es atribuible al líder por la identificación semejante entre éste y los demás, y nadie tiene la sensación de culpabilidad ${ }^{1761}$, como afirma MiLGRAM. De ahí que ARENDT ${ }^{1762}$, junto a otros, hayan visto que el totalitarismo tiene claras similitudes con las sectas o sociedades secretas en el ritual, si bien difieren en que el primero no quiere estar en sigilo sino «a la luz del día» como decía Hitler en Mi lucha.

Esto en nuestra opinión refrenda, nos guste o no, salvo que exijamos al común de los mortales un heroísmo o una autoconsciencia suprema del deber moral como ley universal, que no todos pueden acceder a tales imperativos - como si todos pudiéramos saber en cualquier circunstancia cuál es la ley universal de la naturaleza- y si bien esta falta de atención o acceso a aplicar correctamente un deber atemporal no exime de responsabilidad por cuanto el sujeto no es un animal, es evidente que la capacidad de voluntad y de conciencia están disminuidas, no en el modo de coerción, pues estos «instrumentos» no padecían ningún trastorno, sino que la norma, la ley, la autoridad, la orden, esto es, el conjunto del totalitarismo, subyugaban, transformaban la voluntad y la conciencia moral a otra conforme a aquellas. Se restringía o se eliminaba el horizonte de expectativas normativas y sociales conforme a un Sistema de libertades, de tal suerte que la sociedad en la que se ve inmerso el sujeto le «socializa» (le comunica continuamente) en un comportamiento determinado, lo que fundamenta, en casos excepcionales, un estado de necesidad exculpante en mayor o menor medida.

Parece estar de acuerdo ARENDT con aquellas conclusiones que tiempo después dispuso en Sobre la violencia, cuando se hizo eco del documento oficial Report on Violence in America: «La fuerza y la violencia son probablemente técnicas de control social y de persuasión cuando

${ }^{1758}$ ID., ibidem, op. cit., p. 550.

1759 ID., ibidem, op. cit., p. 455.

${ }^{1760}$ ID., ibidem, op. cit., p. 498.

${ }^{1761}$ ID., ibidem, op. cit., p. 514. En esta labor también propicia la falta de responsabilidad la duplicación de organismos, ID., ibidem, op. cit., p. 554.

${ }^{1762}$ ID., ibidem, op. cit., pp. 515 y ss. 
disfrutan de un completo apoyo social» ${ }^{1763}$. De esta manera la filósofa se atreve a concluir que «el instinto de sumisión, un ardiente deseo de obedecer y de ser dominado por un hombre fuerte, es por lo menos tan prominente en la psicología humana como el deseo de poder y, políticamente, resulta quizá más relevante (...): la de que la voluntad de poder y la voluntad de sumisión se hallan interconectadas» ${ }^{1764}$. Por eso distingue entre poder y violencia, el primero precisa del número, de la cantidad, de la superioridad de la organización, pertenece a un grupo y sigue existiendo mientras el grupo esté unido, la segunda descansa en los instrumentos de Uno contra Todos, sin embargo la autoridad se refiere a la relación personal (padres e hijos, profesor alumno) y tiene el indiscutible reconocimiento de no precisar ni de la coacción ni de la persuasión, basta con el «respeto» ${ }^{1765}$.

Volviendo a MiLgRAM, una importante conclusión a la que llega es que también en la ejecución de órdenes que claramente atentaban contra la víctima el ejecutor sentía un conflicto aun a pesar de llevarse a cabo la orden tal y como la autoridad la programaba ${ }^{1766}$. Resulta interesante dicha conclusión por cuanto podemos apreciar conductas en el autor por convicción,

1763 ARENDT, H., Sobre la violencia, trad. Guillermo Solana, $1^{\mathrm{a}}$ reimp. 2014 de la $2^{\mathrm{a}}$ ed. 2013, Alianza Editorial,
p. 32 , informe de la Comisión Nacional sobre Causas y la Prevención de la Violencia, junio de 1969 en EEUU.
${ }_{1764}$ ID., ibidem, op. cit., p. 54.
1765 ID., ibidem, op. cit., p. 57 a 61. Un siglo antes, en NIETZSCHE -siempre preocupado por la doctrina del Ser como Voluntad de Poder- la autoridad política, el Gobierno, no tienen poder físico ni moral, los que tienen el primer poder carecen del segundo, sólo quien tiene autoridad moral es una verdadera autoridad, sin embargo el poder político ha perdido este tipo de poder, ha dejado de ser una verdadera autoridad porque las normas que emanan de él son arbitrarias; al respecto PUY, Francisco, El Derecho y el Estado en Nietzsche, Editora Nacional, Madrid, 1966, p. 101. De tal manera sólo quien tiene Poder tiene Derecho. En opinión de PUY, el filósofo alemán «trata de poner de relieve en el plano jurídico-oral la exigencia de objetividad, resalando la necesidad de la fuerza coactiva como requisito ineludible de la vigencia del derecho», ID., ibidem, op., cit., p. 206. Si bien en nuestra opinión, si la coacción no lleva equiparada la superioridad moral o de estima, dicha coacción está abocada al fracaso más tarde o más temprano. Para NIETZSCHE supone una estructura siempre jerarquizada mediante el Poder, si bien, al igual que en LUHMANN, funcionalmente jerarquizada, sin embargo éste último nunca llegó a reconocerlo, de manera que quien rechaza la superioridad del Poder, destruye su superioridad moral y esto es visto por el superior o la autoridad como inmoralista ¿acaso un desertor de la SS nazi no era un inmoral o un autor por convicción para el Estado nacionalsocialista? ¿no pasaba a ser un «enemigo»? Entonces, ¿un terrorista que obedece órdenes ante una superioridad moral es un inmoral? ¿es un peligro para la convivencia? Evidentemente que sí, pero esa respuesta depende del valor Justicia, una virtud que es eminentemente social dice NIETZSCHE, NIETZSCHE, F., El caminante y su sombra, op. cit., Parte Segunda, af. 34.

NIETZSCHE expuso un genial ejemplo de la intercambiabilidad de la moral o de su paradoja: Un viajero en un barco se percata durante una tormenta de la incompetencia del capitán para gobernar la nave por poseer mayores conocimientos náuticos. ¿Acaso debe someterse a la autoridad o revelarse y ocupar su rol? ¿En el primer caso nos encontramos con la obediencia funcional a la autoridad, en el segundo ante un héroe o autor por convicción? ¿Qué postura debemos adoptar? Esta pregunta sólo se puede responder si otorgamos un valor a la norma de forma espacio-temporal. Lo que hoy es heroísmo, mañana es una actitud peligrosa, incluso enemiga, es decir, existe un valor eminentemente social, NIETZSCHE, F., Aurora, op. cit., Libro Quinto, af. 436.

${ }^{1766}$ Milgram, S., Obediencia a la autoridad, op. cit., p. 49. Recuerda también: «¿Cuál es la fuente de esta ansiedad? Su origen se halla en la larga historia de socialización del individuo. A lo largo de ese paso de la criatura biológica hasta la persona civilizada, ha internalizado las reglas básicas de la vida social. Y a la más básica de todas ellas la constituye el respeto a la autoridad», ID., ibidem, op. cit., p. 142; asimismo «todo signo de tensión haya de ser considerado como una prueba del fracaso de la autoridad en trasformar a la persona en un estado puro de agencia», ID., ibidem, op. cit., p. 146, por tanto a mayor tensión, mayor probabilidad de ruptura de la obediencia. 
en el terrorista por ejemplo, cierto conflicto en el mandato de no dañar y la conducta dañosa realizada. En el autor por convicción no podemos desechar la idea de cierto conflicto moral ${ }^{1767}$, si bien no con tanta contundencia como en el autor de conciencia, lo que supone que no pueda constituir una diferencia cualitativa entre ambos tipos de autores.

Lo que sucede en el autor por convicción es que la obediencia a la autoridad o a la norma criminal disipa el impulso conflictivo con la norma justa. También durante el nacionalsocialismo el ejecutor de la norma podía saber que, por mucho que existiera una autorización normativa para el exterminio, la conducta era reprochable en el plano supranormativo, si bien se ejecutaba sin miramientos al trasladarse la responsabilidad moral y jurídica a la autoridad o norma, o sea, cuando existía una restricción o eliminación del horizonte de expectativas normativas y sociales ofrecidas por el sistema supranormativo. Así parece que en el autor por convicción no existe un sentimiento de responsabilidad moral ni jurídica, si bien puede existir cierto conflicto aunque no determinante como sucede en el autor de conciencia, quien siente la norma justa de tal manera que propicia un conflicto irresoluble con la norma moral, aunque finalmente es ésta última la que se ejecuta.

En la relación sujeto-autoridad/norma estima MILGRAM que existe un «contexto institucional» ${ }^{1768}$ que en nuestra opinión tiene semejanza con la idea del deber en virtud de responsabilidad institucional (delitos de infracción de deber). En el fenómeno criminal sectario, la autoridad/líder y sus prerrogativas/normas suponen la institucionalización del deber «sectario» en contraposición al deber normativo del Estado de Derecho. Aparece aquí claramente la institucionalización de rol de ejecutor ${ }^{1769}$ de la norma instaurada por la autoridad/líder de la secta criminal. Cada sujeto supone un rol social en la organización sectaria con derechos y deberes funcionalmente diferenciados en el sistema normativo. El sujeto que obedece, su rol, es parte de un «sistema total» ${ }^{1770}$ que controla la autoridad al realizar la distribución jerárquica del poder, es decir, según el grado de funciones atribuidas al rol. Lo significativo es que el poder de autoridad sobrevuela a la organización y al sistema de funciones

\footnotetext{
${ }^{1767}$ MiLgRAm expone uno de los casos, uno de los participantes en el experimento aludía: «Lo que me aterra es que pudiera tener semejante capacidad de obediencia y de sumisión a una idea central, es decir al de un experimento de memoria, aun cuando se me fuera haciendo cada vez más claro que la adhesión continuada a este valor se daba a expensas de la violación de otro valor, es decir "No hagas daño a otra persona que está indefensa y no te hace daño alguno"», ID., ibidem, op. cit., p. 59.

${ }^{1768}$ ID., ibidem, op. cit., pp. 70 y ss. En su experimento es el conocimiento del sujeto de que el experimento se llevaba a cabo dentro de marco institucional de una universidad tan prestigiosa como la de Yale, sin embargo también se obedecía en contextos institucionales no especialmente famosas o distinguidas.

${ }^{1769}$ Estamos de acuerdo con MILGRAM cuando afirma que «(e)s posible que la categoría de institución, juzgada de acuerdo con la función que profesa, más bien que por su posición cualitativa dentro de esta categoría, sea la que gana nuestra docilidad», ID., ibidem, op. cit., pp. 72 y 73.

${ }^{1770}$ ID., ibidem, op. cit., p. 93
} 
sin precisar órdenes directas. El sometimiento a la autoridad se debe también implícitamente con los postulados doctrinales morales sin necesidad de repetir constantemente la orden, incluso criminal. Esta orden se comunica implícitamente en el contexto institucional, y se acepta en el mismo sentido de modo que la acción criminal supone la alienación con la autoridad, pero a la vez, supone la reafirmación social de la norma y de su legitimación, hasta el punto de que supone una medida de protección de la vigencia suprema de la autoridad y de las normas que promulga, ¡el líder no puede ser una víctima!, no es fungible, no puede ser sustituido personalmente por otros, sino por una clara sustitución expresa señalada por él mismo.

Esto se debe a que en organizaciones fuertemente estratificadas o jerarquizadas la figura personal es difícilmente sustituible o delegable, salvo la inserción cotidiana de otros sujetos en las labores de mando normativo, a modo de traslación y distribución de poderes en determinados $\operatorname{casos}^{1771}$, lo que reafirma la idea, tantas veces repetida por LUHMANN, de que el hombre forma parte del entorno del sistema, no está en el sistema, en este caso jerárquicamente organizado. No obstante, las organizaciones modernas se caracterizan, como veremos en el capítulo octavo, por la organización sistémica no claramente jerarquizada.

La obediencia a la autoridad personal o delegada en la norma como representación de la voluntad de la autoridad se distingue de la simple «conformidad» de la dinámica o presión grupal $^{1772}$ en casos de ambigüedad. Los sujetos actúan conforme al grupo (conformidad/principio de reciprocidad), y el grupo obedece a la autoridad (obediencia) dentro de una estructura jerarquizada de la organización, o sistémica. En la conformidad se aprecia la imitación conductual de los sujetos a la dinámica grupal, lo que supone una prerrogativa normativa implícita en la conformidad, mientras que en la obediencia la orden suele ser manifestada de forma explícita. Lo más significativo entre ambas dinámicas es que en la conformidad, el sujeto aceptante asume su propia responsabilidad, negando que el poder

\footnotetext{
${ }^{1771}$ Comenta MiLgRAM que «(m)uchas de las acciones que emprenden en su vida ordinaria los individuos y que creen ellos que brotan de sus cualidades morales internas, se ven sin duda alguna influidas de manera semejante por la autoridad», ID., ibidem, op. cit., pp. 103 y 104. Por ello, la contradicción entre autoridades veta el sentido comunicativo de la orden y que llegue a los receptores, pierde poder cuando dicha contradicción se envuelve en una estructura jerarquizada del más alto nivel al inferior. Así, una contradicción entre autoridades más cercanas en el escalafón propicia el déficit comunicativo de la prerrogativa normativa, y a la inversa, si dicha contradicción está alejada entre eslabones, existe la tendencia a seguir la situada en un mayor escalafón jerárquico, ID., ibidem, op. cit., p. 109. Explica que «(1)a autoridad no es una mera designación de poder, sino la tendencia de un lugar particular de acción dentro de una ocasión socialmente definida (...) Esto es suficiente para dar cierta fuerza a la autoridad (...) Los sistemas de autoridad se tienen que basar en personas que se estructuren jerárquicamente», ID., ibidem, op. cit., p. 110; ARENDT, H., Los orígenes del totalitarismo, op. cit., p. 502: «Una cadena de mando jerárquicamente organizada significa que el poder del que manda depende de todo el sistema jerárquico en el que opera».

1772 ASCH, Solomon E., «Effects of Group Pressure upon the Modification and Distortion of Judgement», en H. Guetzkow (ed.), Groups, Leaderschip, and Men, Pittsburgh: Carnegie Press, 1951; AllPORT, GW., La naturaleza del perjuicio, op. cit., pp. 435 y ss.
} 
influenciante del grupo sea la causa de la adecuación de la conducta, asume su comportamiento como voluntario y libre, mientras que en la obediencia, el sujeto acepta que su conducta proviene de la prerrogativa en la obediencia a la autoridad, por eso mismo se descarga el sujeto de responsabilidad moral y jurídica, no ha sido libre dice, su comportamiento no es claramente voluntario $^{1773}$

Puede decirse que sólo en caso de una conformidad o dinámica grupal claramente contradictoria con la autoridad es cuando el grupo deja de obedecer, y a la inversa, cuando la autoridad consigue crear la conformidad del grupo, todos los sujetos se «conforman» en dicha dinámica al son de la obediencia a la autoridad, o como hemos perfilado durante esta investigación, también de la dinámica comportamental. Por ello no es necesario en la estructura jerárquica (o sistémica) expresar constantemente órdenes por la autoridad, una sola orden y/o la dinámica comportamental del grupo crea el caldo de cultivo para que los sujetos comiencen a obedecer, y una vez se ejecuta por el grupo, la perpetuación de la orden se establece gracias a la conformidad de la dinámica grupal, sin más actuación expresa del líder, sin más necesidad. Es la naturaleza periódica de la acción de los sujetos como dinámica grupal, la que legitima la unión y la obediencia a la autoridad o norma, como vivencia sacralizada, que confirma las expectativas grupales en la seguridad de que la dinámica grupal es correcta y conforme a los postulados de la autoridad $^{1774}$. Esto es en definitiva el totalitarismo.

En este sentido, la teoría de la organización ${ }^{1775}$ concluyó que el hecho organizativo del poder proviene de la ejecución de las «tareas-deberes» que se distribuyen entre los asociados a la organización, de manera que en las sectas se conciben esas tareas y deberes según el modelo

1773 Milgram, S., Obediencia a la autoridad, op. cit., pp. 112 y 113.

1774 MILGRAM considera que la obediencia a la autoridad viene del establecimiento del rol social a la largo de la historia, del respeto a la autoridad. Con sus palabras, que recuerdan las de LUHMANN: «Consideremos un grupo de autómatas a, b, c, etc., diseñado cada uno de ellos para funcionar aislados. Cada autómata queda caracterizado como un sistema abierto que requiere una energía de entrada que le viene de su entorno, para mantener sus estados internos. La necesidad de esa energía ambiental (por ejemplo, la alimentación) requiere un aparato para buscar, ingerir, y convertir partes de ese entorno en formas nutritivas utilizables (...) Es decir, otros autómatas habrán de ser tratados simplemente como partes de entorno, y habrán de ser destruidos o manipulados conforme a su valor nutritivo. De ahí que haya de añadirse al diseño un nuevo rasgo crítico: un inhibidor que impida que los autómatas actúen unos contra otros. Añadiendo este inhibidor general, serán capaces estos autómatas de ocupar el mismo espacio geográfico sin peligro de destrucción mutua. Cuanto mayor sea el grado de mutua dependencia entre autómatas, más ampliamente ordenados y más efectivos habrán de ser estos mecanismos inhibitorios», ID., ibidem, op. cit., pp. 121 y 122; utilizando los criterios y postulados de ASHBY, William Ross, An Introduction to Cybernetics, London, Chapman and Hall Ltd. 1956. Esto en definitiva produce una manera de comportarse no autómata, voluntariamente libre, sino sistémica «cuando queda el autómata integrado en una estructura organizativa más amplia» (ID., ibidem, op. cit., p. 126, lo denomina «estado agentico», en vez de sistémico) con base a esa conformidad o consenso operativo entre los sujetos, GoFFMANN, Erving, The Presentation of Self in Everyday Life, New York, Doubleday Anchor Books, 1959.

${ }^{1775}$ Por ejemplo MARCh James G / SimON Herbert A., Teoría de la organización, trad. Juan Maluquer Wahl, Ariel, Barcelona, 1961. 
weberiano y parsoniano ${ }^{1776}$ en un sistema de organización piramidal, jerárquico y cerrado, bajo una estructura familiar sectaria entorno al líder y al grupo, como institución global o totalitaria que propicia el aislamiento social en pro de la liberación.

Pero LuHMANN, con mayor concreción, explica que en las organizaciones «-por ejemplo, la sumisión a la autoridad a cambio de una retribución- se hace posible reproducir modos artificiales de comportamiento de manera relativamente duraderas; y ello a pesar de una condición de miembro que es libremente elegida y variable (...) El ámbito de los motivos queda generalizado en torno a la condición de miembros: los soldados marchan, los secretarios redactan actas y los ministros gobiernan; y lo hacen en la situación dada, tanto si les gusta como si no. Bajo la forma de reglas relativas a la condición de miembros, pueden configurarse estructuras de cargos y límites de comunicación, derechos a la utilización de medios y responsabilidades, cadenas de mando y mecanismos de control diferenciados (...) únicamente con el mecanismo de la organización puede alcanzarse una medida tan elevada de generalización de motivos y especificación del comportamiento como la que precisa la sociedad moderna en muchos de sus más importantes ámbitos funcionales» ${ }^{1777}$. Por eso concluye que «(l)os sistemas de organización someten a todos sus miembros a un modo jerárquico de tratamiento y decisiones de conflictos, y hacen del reconocimiento del mismo una obligación de la condición de miembros» en las que se

${ }^{1776}$ Vid. VÁZQUEZ, JMª, Familia y sectas, op. cit., p. 56. En el mismo sentido AZCONA, F., «Las Sectas en España», op. cit., pp. 176 y ss. Ya manifestó FREUD al respecto que «(t)al masa primaria es una reunión de individuos que han reemplazado su ideal del «yo» por un mismo objeto, a consecuencia de lo cual se ha establecido entre ellos una general y recíproca identificación del "yo"», FREUD, S., Psicología de las masas, op. cit., p. 55. El hombre es «un animal de horda; esto es, un elemento constitutivo de una horda conducida por un jefe», y así es la masa, el colectivo, ID., ibidem, op. cit., p. 61. Esto lo explica argumentando que el hombre no se ha desprendido todavía de la necesidad del grupo de tener un jefe al igual que hace milenios en la horda primitiva. Se necesita aun hoy de un jefe que ame a los iguales por igual, sin embargo el jefe no necesita amar, es independiente. Cuando el padre en la horda primitiva murió fue reemplazado por la divinización, de lo que significativamente se extrae que esto es un factor vital en el concepto evolutivo de la civilización. Este caso también se ve en el hipnotizador que despoja al sujeto de voluntad, o en el caso del sujeto que dota de poder al hipnotizador a la sazón de un líder, ID., ibidem, op. cit., p. 64. Piénsese ahora en sujetos con capacidades sugestivas, atractivas, carismáticas y seductoras. El poder es inmenso. FREUD realizó un estudio descomunal de las psiconeurosis en aquellos sujetos que ven coartados sus deseos y tendencias en su fin, lo que explica que la neurosis haga al sujeto asocial y tendente a la disgregación social. Inversamente explica que es observable en la formación colectiva donde «se atenúan las neurosis e incluso llegan a desaparecer (...) No es tampoco difícil reconocer en todas las adhesiones a sectas o comunidades místicoreligiosas o filosófico-místicas la manifestación del deseo de hallar un remedio indirecto contra diversas neurosis», ID., ibidem, op. cit., p. 82.

${ }^{1777}$ LUHMANN, N., «Interacción, organización, sociedad. Aplicaciones de la teoría de sistemas», op. cit., pp. 202 y 203; antes PARSONS, T., vv.aa., Hacia una teoría general de la acción, op. cit., p. 224 comentaba que «(u)n sistema de valor que estima muy altamente a la autoridad es conceptualmente semejante, por ejemplo, con la necesidad de dominio de la personalidad y con un alto grado de concentración de la autoridad en el sistema social, y parece derivarse, asimismo, de combinaciones entre las variables patrones». En otro lado comenta similarmente que «(d)esde el punto de vista subjetivo, es posible, mediante la «educación» y la «propaganda», afectar los sentimientos de las masas influyendo en varias de sus manifestaciones (...) Lo importante es que las probabilidades de una influencia exitosa no dependen fundamentalmente de la «racionalidad» aparente de lo que se trasmite, sino de su relación con el equilibrio funcional del sistema en que incide», ID., Ensayos de teoría sociológica, op. cit., p. 214. 
puede realizar algún tipo de protesta moral para influir en las decisiones del grupo, si bien la obligación «típica» de los miembros es la de ocultar hacia fuera los conflictos internos (las opiniones) ${ }^{1778}$. Mientras que las instituciones constituyen expectativas generalizadas de mayor fiabilidad social como en el «compromiso». Pero en un mundo de sistemas sociales todos debemos contar con la contingencia que suponen los otros (alter) en nuestras propias expectativas.

De esta manera el poder, ya fuere político o de una organización, también de las criminales, es un medio de comunicación simbólicamente generalizado, adicional al lenguaje ${ }^{1779}$, como también lo es el Derecho, la Economía, etc., que genera el objeto de expectativas. Cuanto más poder se tiene se eliminan otras alternativas de los sujetos sometidos al poder, lo que se diferencia de la coacción específica ${ }^{1780}$, de modo que lo que suceda entre el poseedor del poder y el sometido al poder, únicamente se atribuye al primero como obra suya ${ }^{1781}$. Por eso comenta que «(l)os símbolos generalizados del código, los deberes e insignias del cargo y las ideologías y condiciones de legitimidad sirven para ayudar al proceso de articulación, pero el proceso mismo de comunicación sólo cristaliza motivos cuando se está ejerciendo el poder» ${ }^{1782}$.

Sin embargo, el poder, la obediencia a la autoridad, también pueden ser ejercidos sin dar ninguna orden, quien obedece también gana influencia en el poder, incluso poder mismo al estimularse al poseedor del poder de manera que no siempre tenga que estar dando órdenes, así en una alto rendimiento del poder, éste se hace impersonal, se puede intercambiar o se eligen portavoces del poder, que en definitiva hacen confiable la organización, y de esta manera se posibilita la cadena de acciones de poder con la que se consigue hacer más asequible la obtención de mayores grados de poder del que puede ejercer un solo poseedor de poder ${ }^{1783}$. Esta forma de administrar el poder se ve claramente en la dinámica grupal que por inercia, incluso sin

\footnotetext{
${ }^{1778}$ LUHMANN, N., «Interacción, organización, sociedad. Aplicaciones de la teoría de sistemas», op. cit., pp. 209 y ss.

${ }^{1779}$ LuhManN, N., Poder, op. cit., p. 11.

${ }^{1780}$ ID., ibidem, op. cit., p. 14.

${ }^{1781}$ ID., ibidem, op. cit., p. 23.

1782 ID., ibidem, op. cit., p. 31. Así ocurre que en las relaciones de poder «(p)or ambas partes, además de la simple pluralidad de posibilidades, debe haber un orden de preferencias que debe esquematizarse en términos de, por un lado, evaluación positiva y, por otro lado, evaluación negativa, del cual la otra parte debe estar enterada. Al usar este supuesto por ambas partes puede producirse una combinación hipotética de alternativas evitables, en su mayoría simplemente por medio de la amenaza de sanciones, que el poseedor mismo del poder preferiría evitar (...) de tal modo que la persona sujeta al poder tenga una preferencia mayor por evitar su alternativa que la que tendría el portador del poder, en nuestro ejemplo, la lucha física», ID., ibidem, op. cit., pp. 31 y 32.

${ }^{1783}$ ID., ibidem, op. cit., p. 52 a 59.
} 
órdenes expresas ${ }^{1784}$, realiza determinadas conductas criminales, o participan en la formación de dinámicas criminales, de manera que el poder ilegal también constituye poder.

El poder precisa entonces de motivación, pero a la vez de credibilidad de la motivación ${ }^{1785}$. La motivación respalda la imputación al sujeto motivador, y el obediente traslada su hecho al motivador, en este caso, al poseedor de poder. De aquí que «la persona sujeta al poder no parece tener motivos que se reconozcan como propios, sin embargo esto no libera de responsabilidad a quien sigue la orden, sin embargo, comenta LUHMANN «un código de poder debe tener presente esta tendencia para cambiar la imputación y poder legalizarla y formalizarla, al darle a la persona sujeta al poder, por ejemplo, la posibilidad de ser obligada oficialmente y, así, liberarla de la responsabilidad» ${ }^{1786}$, de manera que el poder siempre busca legitimarse y para ello es preciso un «consenso de valor» ${ }^{1787}$. De esta argumentación resulta lógico concluir que también en los estados totalitarios que perpetran crímenes contra la humanidad existe un poder legítimo ante sus ciudadanos. Lo que avala esta legitimidad son las estructuras y procesos que el poder controla, conforme a los cuales existen otras alternativas de actuación de los ciudadanos ${ }^{1788}$. En este tipo de estados no existe ninguna alternativa más que obedecer: ese es el único horizonte de expectativas.

Sin embargo Luhmann, a diferencia de Milgram y otros, considera que en la influencia en la generación de motivos de la acciones de los terceros se distingue entre «autoridad»como influencia generalizada en el tiempo (tradición), y el «liderazgo» como influencia circunstancialmente generalizada (imitación) y que supone un deseo de seguir la influencia porque otros la están siguiendo. El líder puede elegir a quien dirigir cuando sabe que influye en varias personas, con lo que la influencia directa sobre una determinada persona consigue ser un factor en la orientación de otros y la creación de roles. También en cierta medida sucede algo parecido con la reputación. En estos casos (autoridad/liderazgo/reputación) se generalizan motivos en la sociedad u organización, si bien el poder se diferencia de la influencia en que puede independizarse de las condiciones particulares de la motivación, pero puede concluirse que tanto con el poder como con la influencia (autoridad o liderazgo), las personas obedientes

\footnotetext{
${ }^{1784}$ ARENDT señala el Documento de Nuremberg PS 3063 en el «Centre de Documentation Juive» en París, que refiere que las órdenes en el nacionalsocialismo eran «intencionadamente vagas o formuladas con la esperanza de que quien las recibía reconociera la intención del que expresaba la orden y actuaría conforme a ello», ARENDT, H., Los orígenes del totalitarismo, op. cit., p. 543 y nota 31.

${ }^{1785}$ Luhmann, N., Poder, op. cit., p. 71.

${ }^{1786}$ ID., ibidem, op. cit., p. 76.

${ }^{1787}$ ID., ibidem, op. cit., p. 79.

1788 ID., ibidem, op. cit., pp. 83.
} 
aceptan la reducción de su potencial de su acción por parte de otros ${ }^{1789}$. De tal manera, y abstractamente, la moral per se no tiene cabida en la racionalidad de la autoridad/líder en cuanto poder, sino simplemente en el hecho de obtener más posibilidades y eliminar limitaciones (contingencia), de manera que resulta hasta democrático y normalizado en el concreto ámbito que se ubique el poder ${ }^{1790}$.

Puede verse fácilmente que quien ostenta el poder, ya sea como autoridad o como líder, desempeña un rol especial ${ }^{1791}$ aceptado (asunción) tanto por el poseedor del poder como por el obediente o sometido al poder, así también entre varios portadores del poder, pero que en la jerarquía o en la configuración sistémica supone una forma de organización tanto comunicada como institucional. El superior, así, siempre supone un rol especial ante el inferior, que debe obediencia por influencia de la autoridad o por liderazgo delegado. Sin embargo dichas formas de poder se ven abocadas al fracaso cuando no se cumplen las expectativas de los miembros del grupo (sectario), a veces expectativas exageradas o manifiestamente irreales y supersticiosas, y se descubre la diferencia entre la posibilidad ofertada y la realidad, momento en el cual los adeptos suelen abandonar la secta y comienzan a aflorar los trastornos sobre los que ya nos hemos pronunciado, pero en otras ocasiones preceptúa la restricción o eliminación de expectativas trasformando los conceptos esenciales de convivencia (dinero, verdad, amor, poder, salud, vida, muerte) incapacitando al sujeto y trasformando su voluntad en su propio perjuicio o de terceros ${ }^{1792}$. Esto es en definitiva un caso de «aislamiento del mundo ficticio» ${ }^{1793}$. Sin alternativas, aislado, no hay poder.

Así, la autoridad o líder crea restricciones de alternativas para los roles comunes que están en el grupo, supone una contingencia o reducción de la complejidad, un foco de orientación de conductas que disminuye las alternativas de los otros, de modo que se anticipan modelos de conductas futuras y se dinamizan (lo que puede ocurrir en un tiempo) sin expresa orden, modelos conductuales pero con la reducción de la capacidad de motivación de la acción conforme a las expectativas normativas y sociales que comunica el Sistema de libertades. De esta manera se restringen las alternativas de los otros, restricción que, asentada en el tiempo, produce la semejanza entre norma y autoridad/líder con la consecuente eliminación de la vigencia de la

\footnotetext{
${ }^{1789}$ ID., ibidem, op. cit., pp. 106 a 112.

${ }^{1790}$ ID., ibidem, op. cit., p. 114.

${ }^{1791}$ ID., ibidem, op. cit., p. 118.

1792 ARENDT comentó similarmente que «el dirigente totalitario se ve enfrentado con una doble tarea que al principio parece contradictorio hasta el punto del absurdo: ha de establecer el mundo ficticio del movimiento como una realidad tangible operante de la vida cotidiana y, por otra parte, tiene que impedir que ese nuevo mundo desarrolle una nueva estabilidad», ARENDT, H., Los orígenes del totalitarismo, op. cit., p. 535.

${ }^{1793}$ ID., ibidem, op. cit., p. 590.
} 
norma jurídica. En este contexto, la diferencia entre un poder legítimo y otro individualizado en una organización, incluso delegado, jerarquizado o sistémico, es que la legitimidad proviene de la participación en términos de similar posibilidad de los intervinientes. El dato significativo es que en los estados totalitarios sucede a la inversa: la legitimidad viene determinada por la falta de posibilidades o alternativas y de la nula o escasísima participación de los sujetos conformados con el poder, de manera que la única alternativa es la obediencia, la sumisión, o incluso creencia ideológica en los postulados de la autoridad/líder como «verdad» ${ }^{1794}$. Prácticamente se puede decir que los modelos totalitarios o fuertemente autoritarios propician sistemas cerrados, cuya apertura es condición del cerramiento de sus operaciones ficticias respecto a los demás sistemas y, en los que se condiciona la eliminación de la comunicación con otros sistemas o entornos ${ }^{1795}$.

Dicho esto, cobra sentido la diferencia entre poder organizacional y poder personal, que estriba en que el primero se relaciona con los miembros como un todo, mientras que el segundo con el deseo particular entre el que posee el poder y el que necesita desear ${ }^{1796}$. De este modo, podemos extrapolar esta concepción al ámbito criminal sectario en el que se suceden unas normas mínimas emanadas del poder personal y a la postre la dinámica comportamental generalizada de la orden (medio de comunicación simbólicamente generalizado en el poder), esto es: un poder organizacional consigue aumentar el poder ${ }^{1797}$. Se oficializa mediante reglas del poder organizacional, pero a la vez se puede personalizar y cambiar a voluntad del poder personal.

En este sentido, la teoría de la organización se asemeja a los postulados de LUHMANN en que el hecho organizativo del poder proviene en la ejecución de las «tareas-deberes» que se distribuyen entre los asociados a la organización según un sistema de organización piramidal, jerárquica y cerrada, bajo una estructura familiar sectaria en torno al líder y al grupo, como institución global o totalitaria que propicia el aislamiento social en pro de la liberación ${ }^{1798}$. Entonces podemos coincidir con estos modelos de pensamiento, que las sectas, aunque más

\footnotetext{
${ }^{1794}$ Similarmente parece también decirlo LuHMAnN, N., Poder, op. cit., pp. 135 y 136.

1795 A este respecto nos sirven las palabras de ARENDT que señalaba que «(l)a dominación total, que aspira a organizar la pluralidad y diferenciación infinitas de los seres humanos como si la humanidad fuese justamente un individuo, sólo es posible si todas y cada una de las personas pudieran ser reducidas a una identidad nunca cambiante de reacciones, de forma tal que pudieran intercambiarse al azar cada uno de estos haces de reacciones», ARENDT, H., Los orígenes del totalitarismo, op. cit., p. 589.

1796 Luhmann, N., Poder, op. cit., p. 146.

1797 ID., ibidem, op. cit., p. 148. Comenta taxativamente que «(e)l poder desarrolla, por decirlo así, a pesar de la organización», ID., ibidem, op. cit., pp. 157 y 158.

${ }^{1798}$ Vid. VÁZQUEZ, JMa ., Familia y sectas, op. cit., p. 56; AZCONA, F., «Las Sectas en España», op. cit., pp. 176 y ss.
} 
precisamente debemos reconducirlas a las criminales, son instituciones totales y sociales cuyo punto central está en la autoridad ${ }^{1799}$.

En conclusión, el concepto de autoridad se extrapola en cada agrupación de sujetos, y de manera potenciada en grupos sectarios, pero también se ha podido reconocer en estados «totalitarios», por eso la autoridad tiene la misma función que la norma, se identifica de manera tal que la obediencia a una autoridad de la que emanan directrices delictivas tiene la misma función que la norma jurídica legítima en un Estado de Derecho, la autoridad supone un faro de guía, un foco, la orientación de conductas en un determinado grupo, a veces en una nación precisamente «totalitaria», que paradójicamente crea la irresponsabilidad en el mismo sentido que quien en un Estado de Derecho orienta su conducta conforme a la norma obra lícitamente, en la obediencia a la autoridad totalitarista la asociación de irresponsabilidad es la misma. Tanto es así que en el nazismo, la conducta de ordenar la muerte de judíos era atípica, y por lo tanto irresponsable en ese espacio-tiempo normativo, sin embargo con el fin de la Segunda Guerra Mundial, la entrada del Estado de Derecho reprochó normativamente al estado totalitario/autoritario dicha orden y las normas asociadas en la función de ese sistema normativo. Por eso, en nuestra opinión, los sujetos que ejecutaban esas órdenes eran irresponsables si bien siguen siendo autores, ya no por la atipicidad de su conducta, sino porque una vez estabilizado el Sistema con el Estado de Derecho, el subsistema jurídico-penal sólo puede considerar esas conductas realizadas bajo un estado de necesidad exculpante, siempre que concurran los presupuestos citados.

En la misma medida, en grupos criminales que actúan en coautoría funcional, algunos de los miembros pueden actuar bajo un estado de necesidad exculpante en cuanto a la relación con la obediencia a la autoridad, a pesar de que sean prototípicos de la autoría por convicción. El valor de la moral buena/mala nada aporta a la responsabilidad de la conducta, puesto que sólo es un criterio determinado en un espacio-tiempo social sino su carácter como funcional o disfuncional en el sistema social concreto.

En la autoría de conciencia se encuentran motivos «comprensibles», conflictos «inevitables». A esto ha atendido la doctrina penal que ha encontrado argumentos de exención o de atenuación, ya fuere en una u otra categoría de la dogmática penal. Todas las propuestas otorgan un valor al motivo o al objeto del motivo, el derecho concreto, a veces amparado en el libre desarrollo de la persona, otras en la libertad de conciencia, sin embargo en cuanto se otorga un valor se está

\footnotetext{
${ }^{1799}$ VÁZQUEZ, JMa., Familia y sectas, op. cit., pp. 57 a 59; en el sentido de «instituciones totales», AZCONA, F., «Las Sectas en España», op. cit., pp. 176 y ss.
} 
significando la función social de ese valor, por lo que si lo tratamos sin valor, o sea, funcionalmente, únicamente el problema a resolver es si dicha conducta es funcional o disfuncional, o lo mismo es decir, si afecta la vigencia de la norma o la combate.

En este sentido, un autor por convicción puede combatir la norma y al Sistema de modo tal que crea una disfunción que incapacita la propia operatividad del Sistema. Esto es lo que se criminaliza en los delitos de terrorismo cuando se habla de que ataca un bien jurídico superior como subvertir el orden o alterar la paz, pero aun con dicha convicción combativa del Sistema, determinadas conductas pueden resultar de un estado de necesidad exculpante. Esta es la razón por la que la moral tiene un valor social. Cuando una conducta es claramente opuesta al valor moral de la sociedad es porque crea una disfunción en el Sistema basada en motivos morales, o dicho de otro hay una entrada moral en el Sistema que no se identifica con la Sociedad, por eso el autor de conciencia no crea dicha disfunción, tiene suficientes argumentos a su favor que no son vistos por la Sociedad como peligro de la operaciones del Sistema, sino que ya han sido tenidos en cuenta, por ejemplo con la inscripción de la entidad religiosa, o con la «permisividad» o «falta de persecución». Por ejemplo, al insumiso no se le castigaba por pensar anteriormente en la falta de autoridad militar, sino sólo cuando la norma le ordenaba el servicio militar. Por eso los argumentos a favor de la irresponsabilidad o exención de la pena siempre se han basado en motivos que provienen de la propia funcionalidad de la conducta en cuanto operación en el Sistema, o dicho de otro modo, es valorada como una operación del Sistema, aunque fuera una conducta típica y reprochable.

Así las cosas, el riesgo no permitido es el ocultamiento del totalitarismo, no en sí, puesto que puede ser aceptado o no. Si lo es, surgirá la responsabilidad estricta que fuere, derivada de conductas inherentes a tal totalitarismo, por ejemplo así lo fue el holocausto judío. Pero antes de dichos extremismos surge una responsabilidad en la conducta, no en el resultado, me refiero a la responsabilidad por la creación de un riesgo no permitido: el totalitarismo que restringe o elimina el horizonte de expectativas normativas y sociales que comunica el Sistema, es ya una tentativa contra el ordenamiento jurídico, contra el Sistema, al suponer ya una operación disfuncional para el Sistema, por eso este riesgo puede considerarse una forma objetiva de peligrosidad, y criminalizarse como delito de organización, o sea, como injusto sistémico. 


\section{Imputación del déficit de socialización por educación cultural y tradicional y estado de} necesidad exculpante

Suele utilizarse el déficit de socialización por educación cultural tradicional en los casos de mutilación genital que fueron especialmente criminalizados por la Ley Orgánica 11/2003, de 29 de septiembre al introducir en el apartado en el art. 149 CP penas de seis a doce años por la causación de impotencia, esterilidad, grave deformidad y lesiones psicológicas ${ }^{1800}$.

Si bien se han esgrimido múltiples causas de motivación por las que se practica la mutilación genital, tales como la educación cultura tradicional, el control del hombre sobre la mujer, la limitación de la reproducción de la mujer, motivos de higiene e incluso estéticos, la doctrina está de acuerdo en que no existen una clara relación con la motivación religiosa, sino en opinión de la mayor parte de la doctrina ${ }^{1801}$, a la que nos adherimos, por motivos culturales y tradicionales, si bien reprochables como la dominación del hombre hacia la mujer desde tiempos inmemorables. Así, toda la doctrina que se ha pronunciado sobre el tema niega cualquier tipo de exención o privilegio penal.

Se ha indicado que no se trata de conflictos de conciencia, sino de autoría por convicción, en el que el sujeto se siente «movido por una tradición, carente de carácter religioso», y al no tratarse de un conflicto de conciencia, por ello no puede privilegiarse ${ }^{1802}$. Desde nuestros planteamientos, la falta de conflicto de conciencia no es el elemento central en la autoría por convicción, y esto porque precisamente las causas culturales y tradicionales convergentes pueden fundamentar por sí solas la exoneración o disculpa. De aquí que no resulte del todo ilógico aplicar en casos excepcionales de déficit de socialización por causas culturales y tradicionales, sin tratar la cuestión como casos de error de prohibición, la causa del estado de necesidad exculpante completo o incompleto, aunque no exista un conflicto de conciencia del todo puro.

En contra de la atenuación de esta criminalidad se ha pronunciado expresamente JERICÓ ${ }^{1803}$, que afirma que es inadmisible que estas prácticas queden sin sanción penal, puesto que existe suficiente gravedad en la salud física y psíquica. Es mucho más difícil aplicar el principio de tolerancia en aquellos supuestos que afectan a bienes individuales que en aquellos casos que

\footnotetext{
${ }^{1800}$ HerRera MORENO, M., «Multiculturalidad y tutela penal: a propósito de la problemática sobre la mutilación genital femenina», RDP, 5, 2002, pp. 67 y ss; JERICÓ OJER, L., El conflicto de conciencia, op. cit., p. 571.

${ }^{1801}$ HerRerA MORENO, M., «Multiculturalidad y tutela penal», op. cit., p. 56 se refiere al control patriarcal de la sexualidad; JERICÓ OJER, L., El conflicto de conciencia, op. cit., p. 572 porque el imperativo de conciencia sería algo excepcional; MONGE FERNÁNDEZ, A., El extranjero frente al Derecho penal. El error cultural y su incidencia en la culpabilidad, $1^{\mathrm{a}}$ ed., Bosch, 2008, pp. 52 y 53.

1802 Monge FernándeZ, A., El extranjero frente al Derecho penal. El error cultural y su incidencia en la culpabilidad, op. cit., p. 53.

1803 JERICÓ OJER, L., El conflicto de conciencia, op. cit., p. 573.
} 
afectan a deberes de abstención o a bienes supraindividuales, máxime cuando en la mayoría de casos se afecta a menores de edad que no prestan su consentimiento. Tampoco puede concurrir una causa de justificación porque además de faltar el consentimiento válido no se aprecia la concurrencia de un mal jurídico y, en su caso, no sería comparable con la pérdida de la salud. A causa de esto, niega cualquier tipo de privilegio incluso en la institución de la culpabilidad o de la inimputabilidad, si bien se muestra partidaria de la tesis de TAMARIT SUMALLA ${ }^{1804}$ sobre la posibilidad de apreciar una alteración de la percepción en casos de aislamiento cultural, lo que sería ajeno al motivo o el conflicto de conciencia ${ }^{1805}$. La referida autora también señala que difícilmente se apreciará la eximente de miedo insuperable, aunque no descarta la atenuación en algún caso de motivación por mero convencimiento que proceda de la tradición y de la costumbre $^{1806}$. Si bien JERICÓ no admite generalmente alguna causa de exención o de atenuación, no niega la posibilidad de que en casos excepcionales pueda existir un déficit de socialización, que al menos asociado a un trastorno o un miedo insuperable, posibilite la atenuación.

De otra parte, sobre la posibilidad del error de prohibición en el alcance de la norma de validez, muy acertadamente HERRERA MORENO ${ }^{1807}$ se ha referido a que tales prácticas realizadas en nuestro país no entrarían en casos de error de prohibición, por cuanto la realización, normalmente en la clandestinidad, acredita que el autor conoce la norma de prohibición. Sin embargo puede haber supuestos excepcionales, como el ocultamiento, o mejor, el aislamiento cultural, en los que se parte de la tradición y configuración societaria de un grupo o familia, que fundamente la posibilidad de déficit de socialización estrictamente relacionado con causas tradicionales y culturales como forma de vida, que a pesar de la cercanía geografía no se produzca la comunicación orientativa de la norma, y se realicen determinadas conductas que pueden estar asociadas a la inexigibilidad y al estado de necesidad exculpante, en el modo que lo hemos tratado supra.

Así, toda la doctrina que se ha pronunciado al respecto, como decíamos, considera que efectivamente existe una causa cultural y tradicional. No es lo mismo haber nacido y vivido con estas prácticas y luego desplazarse a algún país en donde se prohíban, que nacer en nuestro país o en alguno de nuestro entorno, y practicarlas o someterse a ellas.

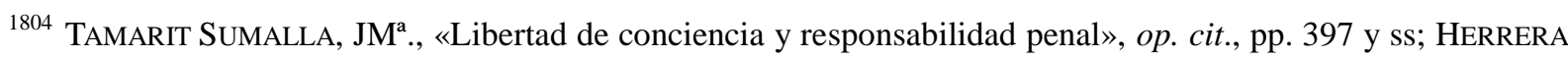
MoReno, M., «Multiculturalidad y tutela penal», op. cit., p. 75 considera excepcionalmente en supuestos de exaltación fanática pero en relación a la anomalía o alteración psíquica del art. 20.1 CP.

1805 JERICÓ OJER, L., El conflicto de conciencia, op. cit., p. 575.

1806 ID., ibidem, op. cit., p. 576.

1807 HerRera MORENO, M., «Multiculturalidad y tutela penal», op. cit., p. 75.
} 
En el primer caso hay claramente un déficit de socialización que si bien no impide la valoración de la norma, salvo casos extrañísimos como por ejemplo en los que el autor practicara la mutilación en el mismo día de su llegada al país, sí que puede apreciarse un claro condicionamiento social que si bien no le impide conocer la norma, sí le impide orientarse conforme a ésta, restándole ya no valor, sino legitimidad ocasional, lo que nos llevaría nuevamente a una causa de inexigibilidad por déficit de socialización cuando exista suficiente intensidad. Esto mismo puede producirse con la educación, por ejemplo en una atmósfera familiar autoritaria en relación a los menores (aprendizaje subordinado), a pesar de un contexto social de libertades ${ }^{1808}$.

En aquellas conductas en las que el motivo sea aprovecharse de dicho déficit, o en casos de instrumentalización del rol especial en un grupo o familia, máxime con menores de edad sin madurez al respecto, la conducta será especialmente recalcitrante por la fuerza de dominación que se ejerce, o sea, con convicción criminal, que seguramente en la mayoría de casos llevaría a aplicar la agravante por motivos sexuales del art. $22 \cdot 4^{\mathrm{a}} \mathrm{CP}$.

Trasladadas dichas conclusiones al ámbito sectario, igualmente la entrada voluntaria de un sujeto en una organización, aun sin conocer la finalidad dolosa criminal sobre la que se funda, puede verse incurso en la dinámica grupal de conformidad (compromiso y obligación). El puente $^{1809}$ de unión entre el sujeto y la organización es una expectativa ideológica o moral, mientras que la desobediencia se produce cuando entra en tensión (duda sobre la expectativa) la orden y/o conformidad con el sujeto autónomo que provoca en caso de desobediencia un «sentimiento que nos roe, de que no hemos sido fieles» ${ }^{1810}$. Esta es la causa de que se produzcan, a la postre, una vez el sujeto sale de la organización, los trastornos postraumáticos ya estudiados supra. No obstante, cabe señalar que la educación es sólo una parte de la socialización, de cuya

${ }^{1808}$ Por ejemplo ALLPORT explicaba que «el niño que recibe una disciplina severa, a quien nunca se le permite afirmar su voluntad contra la de sus padres, difícilmente podrá evitar percibir la existencia como algo amenazador. La vida, se ve forzado a suponer, no se basa en la aceptación tolerante, sino en una relación de poder», esto es su filosofía de vida, AllPORT, GW., La naturaleza del perjuicio, op. cit., pp. 345 y ss.

${ }^{1809}$ MILGRAM también encontró en la obediencia a la autoridad causas ambientales, o mejor, sociológicas como la familia, que no deja de ser, en verdad, una institución que promulga reglamentos de obediencia organizativa, sistémica, a la par de otro marco institucional de autoridad como la escuela, el servicio militar, MILGRAM, S., Obediencia a la autoridad, op. cit., pp. 129 y ss., o en esencia y en nuestra opinión, el ordenamiento jurídico en cuanto sistema de obediencia impersonal o comunicación normativa de orientación de conductas. Resulta llamativo que el rol social dentro de la familia u otra institución se adecúe a ésta de modo que pierda dicha condición social en otra institución, o si se prefiere, la obediencia a la autoridad en un determinado contexto social/institucional termina en ese contexto: «la autoridad de un piloto sobre sus pasajeros no se extiende más allá del avión. La autoridad se halla sostenida por la norma; el ente participa de la esperanza de que determinadas situaciones tienen de ordinario una figura que las controla socialmente. La autoridad no tiene por qué poseer un estado superior en el sentido de «prestigio», ID., ibidem, op. cit., pp. 132.

${ }^{1810}$ ID., ibidem, op. cit., p. 153. 
falta no estriba siempre un déficit de socialización ${ }^{1811}$. El caso paradigmático de nuestras conclusiones es el de dos niñas hindús encontradas en 1922 que vivían con una familia de lobos. Estaban perfectamente sanas, sin ningún tipo de retraso mental, salvo que el comportamiento estaba asociado al animal (caminaban a «cuatro patas», no hablaban). Una de ellas murió al poco de ser encontrada, la otra nunca llegó a hablar bien y habitualmente se desplazaba sobre las cuatro extremidades. Efectivamente, esta niña nunca llegó a integrarse en el Sistema Social, no podía observar lo que no se puede observar. Su déficit de socialización, claramente pleno, representa un caso que explica nuestro modelo.

En conclusión, la restricción del horizonte de expectativas causado por una limitación significativa de la socialización del sujeto a través de condicionantes educacionales y tradicionales, sobre todo desde la infancia, fundamenta el déficit de socialización que posibilitaría aplicar el estado de necesidad exculpante. Este déficit sostiene también el déficit de socialización por educación autoritaria y criminal al que nos referíamos supra, de manera que se presenta como una causa «esencial» del déficit de socialización, en cuyo máximo grado causa la eliminación del horizonte de expectativas como lesión psíquica de trastorno o adicción comportamental completas, lo que traslada la problemática a la falta de acción humana en casos extremos, o de inimputabilidad.

\section{Imputación del déficit de socialización del autor atribuible al mismo: imputación a la} víctima

No es difícil imaginar situaciones en las que un sujeto se adentre en un grupo, del tipo que sea, en este caso religioso, conociendo el alto riesgo de convertir la fe, modificar la conducta, o dicho de otro modo, no resultará extraño apreciar casos en los que el adepto a un grupo religioso tenga un déficit de socialización atribuido a una conducta previamente deseada y querida por éste o, al menos, asumida, y por ello estrictamente imputable a éste.

Estos casos se pueden dividir entre los meramente dolosos y aquellos en los que el sujeto entra en un grupo y conoce y acepta la alta probabilidad de que la conducta que exigida habitualmente le trasforma su conciencia, y que de esto se derivará en la obligación de atender

\footnotetext{
1811 Similarmente LUHMANN al decir que «(l)a educación no puede simplemente asumir la tarea de la socialización. Ella no es, por ejemplo, la forma racional de la socialización. En relación con ésta no representa ningún progreso, no es ninguna fórmula segura para llevarla mejor a efecto. Ella se desarrolla como correlato de la creciente complejidad de la sociedad, y tiene por función, sobre todo, proveer a los cambios personales de transferibilidad a otros sistemas distintos de aquel en el que se originaron», LUHMANN, N., «Socialización y educación», Luhmann, N., Complejidad y modernidad: De la unidad a la diferencia, Trotta, ed. y trad. Josetxo Berian y José María García Blanco, 1998, pp. 255 y 256, originariamente LUHMANN, N., «Die "Form Person”», Soziologische Ausklärung, 1985.
} 
las órdenes o la dinámica criminal. Aquí la imputación del déficit de socialización viene de la conducta de la propia víctima (imputación objetiva de la víctima) en el sentido expuesto por CANCIO MELIÁ, si bien los títulos de imputación en caso de intervención criminal se trasladan a la coautoría -como estudiaremos infra- en aquellos casos en los que el adepto se adentra en un grupo fundamentalista conociendo dichos extremismos y voluntariamente, tras reforzamientos de esa previa aceptación fundamentalista, acuerda perpetrar un delito.

La problemática aquí se centra en aquellos casos en los que el sujeto, aceptando la peligrosidad que supone su anexión al grupo (recuérdese la personalidad presectaria) peligrosidad que se refiere a la autopuesta en peligro de sufrir un cambio radical de conciencia y a la probabilidad de perpetrar delitos ineludiblemente, bajo los efectos intensos de la nueva conciencia que producen un déficit de socialización exculpante, si puede imputarse al sujeto el delito cometido dolosa o imprudentemente con toda responsabilidad por esa autopuesta en peligro previa. Sobre esto volveremos más ampliamente cuando se trate la autoría y participación en el capítulo séptimo.

E. Trascendencia jurídico-penal del estado de necesidad exculpante por déficit de socialización atribuido a tercero: completación de la reformulación del estado de necesidad exculpante

Hemos señalado en el capítulo segundo que el déficit de socialización/comunicación atribuido a la norma (en este caso en el autor de conciencia) o a tercero, reformula los requisitos del estado de necesidad exculpante. Tras el estudio de las causas de déficit de socialización como restricción del horizonte de alternativas asociadas a la persuasión coercitiva, se pueden completar definitivamente la reformulación del estado de necesidad exculpante. Gravedad, mal, subjetividad y punibilidad se trasforman en virtud de una causa previa que limita la capacidad de voluntad atribuida a tercero. Este caso es aplicable también al autor de conciencia, por convicción y al enemigo sin que cambie su conceptualización, o más exactamente, el déficit de socialización atribuido a tercero puede modular, crear o modificar estas tipologías criminales como en el caso de una propia decisión. Por eso en este sentido no es del todo exacto que el concepto de enemigo que defiende parte de la doctrina funcionalista sea voluntario o potestativo, sino que en ocasiones puede atribuirse a una fuerza exterior, a un tercero, esto es si entendemos por voluntario la plena capacidad de la voluntad.

Sobre el conocimiento de la gravedad, el autor, a causa de ese déficit atribuido a un tercero, no conoce la probabilidad de la gravedad ni la gravedad en sí misma, obra conforme a 
conciencia, incurriendo en el delito imprudentemente, o en delitos de peligro según hemos explicado supra, o dolosamente no sólo para conservar la posición o el bien jurídico, en contra de la opinión de gran parte de la doctrina: el autor está obligado a mejorar su posición por orden, mandato o adecuación a la dinámica criminal de la organización.

Todos los males que exige la causa de exculpación, y que paradójicamente se refieren al derecho de la libertad de conciencia, ideológica, política o, en definitiva, a la moral, pueden ser típicos o naturales, pero en todo caso reales, en caso contrario, si falta la realidad del mal, estaríamos ante un miedo insuperable $u$ otra circunstancia.

La situación de necesidad ha podido ser provocada culpablemente por el autor de conciencia, por convicción o por el enemigo, pero en estos casos, y esta es la diferencia, es atribuible al tercero en los casos especiales expuestos. De igual modo, tampoco se exige la obligación de sacrificarse. En este sentido, el déficit produce también conductas dolosas o imprudentemente provocadas. Esto es porque existe una «provocación», orientación o atribución previa a un tercero. Entonces, tampoco se exige la proporcionalidad de los males, o aquel axioma de que no se puede ocasionar un daño relevantemente mayor como exige la doctrina en supuestos generales.

Sobre el elemento subjetivo "para evitar un mal» no existe equiparación entre el elemento subjetivo en el estado de necesidad justificante y el exculpante, máxime en las situaciones especiales de la autoría de conciencia, por convicción y en las del enemigo. Por un lado, por la conexión entrelazada de conciencia y voluntad, por otro, por el déficit de socialización que produce la persuasión coercitiva (a diferencia del déficit de comunicación/socialización atribuido a la norma en algunas conductas del autor de conciencia).

De todo lo anterior se argumenta la falta de necesidad de una pena cuando exista un grado tan intenso de socialización atribuido a tercero. En situaciones de déficit pleno de socialización atribuido a un tercero, la pena será incapaz de resocializar al sujeto porque el sujeto es incapaz de comprender el significado de la pena. En estos casos, parece lógico aplicar una medida de seguridad resocializante adecuada a la intensidad y tipo de desocialización. En todos los casos en los que el déficit no sea tan intenso y claro que justifique el estado de necesidad exculpante completo, sino el incompleto, de igual manera, parece lógico concluir que una pena no tendría sentido resocializador en el sujeto, y sí una medida de seguridad proporcional a dicha intensidad semi-plena. 


\section{IV.- La persuasión coercitiva y pluralidad de víctimas}

\section{A. Concurso de delitos}

En la problemática de los concursos se plantea en primer lugar la cuestión de la unidad típica (o jurídica) o natural de la acción a diferencia de la pluralidad de acciones. La cuestión es trascendental porque modula la comprensión del concurso aparente de normas y el concurso de delitos (real o ideal), si bien por cuestiones de espacio no podemos abordar plenamente.

$\mathrm{Al}$ respecto acogemos la tesis ${ }^{1812}$ que aboga por el concurso real de delitos cuando un autor realiza coacción sobre varios sujetos, o en nuestro caso una persuasión coercitiva. Esto es porque si bien puede existir una sola y misma acción (unidad de acción y no pluralidad de acciones), ésta se bifurca en varias direcciones, por eso los resultados son varios, de modo que también son varios los hechos, o dicho con otras palabras, también el asesino que coloca una bomba realiza una sola acción que merece la respuesta penal por cada resultado de muerte o tentativa al tratarse de bienes personales, de manera que efectivamente existe más de un hecho, a pesar de que algunos actos singulares se realicen dolosamente y otros imprudentemente ${ }^{1813}$. Especialmente puede verse esto cuando surge una competencia institucional por la creación de confianza que genera garantía o garantía que genera confianza en los delitos de comisión por omisión ${ }^{1814}$ («unidad de la omisión») y trasladarse para resolver la problemática en nuestro ámbito de estudio.

También, según lo visto, el ataque es permanente en cuanto a cada víctima, por lo que mayoritariamente la doctrina sostiene la unidad de acción, inclusive si hay varias acciones coactivas, por ejemplo fisiológicas y psicológicas (cognitivas, medioambientales, etc.), pero continuado, va consumando resultados en diferentes víctimas, lo que plantearía la posibilidad del delito continuado o el delito masa, sin embargo el art. 74.3 CP no lo permite al tratarse de bienes personales (salvo contra el honor y contra la libertad e indemnidad sexuales no sin discusión, además de los patrimoniales). Habrá que concluir también que los delitos imprudentes con resultado siempre se realizan en unidad de acción ${ }^{1815}$, lo que es trasladable a la persuasión coercitiva en su modalidad, al menos de lege ferenda, salvo que se creen nuevas inobservancias.

\footnotetext{
1812 MIR PUIG, S., «El delito de coacciones en el Código penal», op. cit., pp 302 a 304; por el contrario a favor del concurso ideal WelzEL, H., Derecho penal alemán, op. cit., p. 318.

1813 JAKOBS, G., PG, op. cit., 32/8; en relación al resultado cualificado JESCHECK HH / WEIGEND T., Tratado, op. cit., 66, III 3, sin embargo acepta el concurso ideal cuando «el resultado cualificado no sólo puede ser realizado imprudentemente sino también de forma dolosa sin que por ello decaiga el tipo básico del delito agravado, entonces debe aceptarse un concurso ideal con el tipo doloso o imprudente que corresponda, puesto que sólo de este modo queda claro si en el caso concreto la consecuencia más grave fue provocada dolosa o imprudentemente».

1814 JAKOBS, G., PG, op. cit., 32/31 y ss; JESCHECK HH / WEIGEND T., Tratado, op. cit., 66, IV 2.

1815 JESCHECK HH / WEIGEND T., Tratado, op. cit., 66, IV 1.
} 
De otra parte, decíamos que el delito de coacciones es un tipo de recogida que viene incluido en otros tipos penales, lo que plantea problemas de concurso. Bien es cierto que en la mayoría de ocasiones el concurso se deberá reconducir al de leyes, en casos como por ejemplo entre el delito de coacciones y el delito de detención ilegal, pero sólo cuando exista una privación de la libertad de movimientos para abandonar un lugar ${ }^{1816}$. Téngase en cuenta que en el delito de coacciones se protege la libertad de la voluntad, por lo que en caso de atacarse además otro bien jurídico, no perteneciente estrictamente a la libertad, se podría aplicar el concurso de delitos ${ }^{1817}$ como solución a las «conminaciones penales (solución primaria, orientada a la medición de la pena)» ${ }^{1818}$. Pero en sentido contrario, cuando además de atacarse la libertad de la voluntad se quebrante necesariamente otro bien jurídico podrá plantearse el concurso de leyes ${ }^{1819}$, por ejemplo y sin que haya mucha discusión, cuando se pretenda constreñir la voluntad mediante lesiones, en nuestro ámbito de estudio normalmente lesiones psíquicas.

Como expresa NAVAS RENEDO, algún sector doctrinal ${ }^{1820}$ «con relación al tema de las sectas se plantea la posibilidad de que el consentimiento, a simple vista prestado libremente, se pudiera encontrar viciado como consecuencia de las citadas lesiones psíquicas y de los lavados de cerebro». Hemos podido comprobar que esta posibilidad no tiene la dirección correcta, pues las lesiones psíquicas son normalmente ajenas al previo consentimiento. De tal manera, también hemos desterrado esa corriente de pensamiento que considera que los miembros de sectas se adentran con trastornos o debilidades previas (personalidad presectaria) como si el consentimiento ya estuviera viciado, sino que las lesiones psíquicas como la adicción o los trastornos son consecuencias no siempre resultantes de un déficit de socialización (persuasión coercitiva), normalmente prolongado y/o intenso.

\footnotetext{
${ }^{1816}$ RODRÍGUEZ DEVESA JMa / JASO ROLdÁN T / RODRÍGUEZ MUÑOZ JA., PE, op. cit., p. 311; RODRÍGUEZ DEVESA JMa / SERRANO GÓMEZ A., PE, op. cit., p. 309.

1817 Cervelló Donderis, V., El delito de coacciones, op cit., p. 99 como concurso medial; HiGUERA GUIMERÁ, JF., El delito de coacciones, op. cit., p. 305; MIR PUIG, S., «El delito de coacciones en el Código penal», op. cit., pp. 304 y ss. como concurso ideal; RODRÍGUEZ DEVESA JM / SERRANO GÓMEZ A., PE, op. cit., p. 309.

1818 JAKOBS G., $P G$, op. cit., 31/9 en relación al concurso ideal.

1819 ID., ibidem, op. cit., 31/2: esto es que «varias formulaciones de delitos («leyes») concurren en la determinación del injusto; una de esas formulaciones agota la determinación del delito».

${ }^{1820}$ Por ejemplo JORDÁN VILLACAMPA, Mª L, «Las sectas pseudorreligiosas», op. cit., p. 68, en donde dice: «hay una clase distinta de coerción que es la que extingue el consentimiento de la persona y que es la conocida comúnmente como lavado de cerebro, brainwashing. En este caso la capacidad para afirmar las creencias religiosas desaparecen». De la misma opinión, JAVALOY MAZÓN F / RODRÍGUEZ-CARBALLEIRA A., Las sectas ante los Tribunales, op. cit., p. 79, en donde dicen: «además, la alegación de que existe consentimiento en el sectario pierde fuerza si consideramos que éste no dispone de autonomía y voluntad suficiente para poder tomar conciencia de la causa externa que forzó su transformación y cree ser él mismo el único causante de su evolución psíquica».
} 
Así pues, parte de la doctrina ${ }^{1821}$ reconoce que cierta persuasión coercitiva supone también un ataque a la integridad psíquica y a la dignidad humana que puede producir trastornos psíquicos. Por regla general, la lesión psíquica viene a consecuencia de una agresión física y se considera dicha secuela, o segundo resultado, inherente a la lesión física, de modo que el sufrimiento psicológico sólo merece una reparación civil, pero cuando el resultado causado psicológicamente supere el normal padecimiento mental puede concursar idealmente con el delito de lesiones físicas ${ }^{1822}$, como sucede en algunos casos de agresión sexual y violencia de género. La lesión a la libertad de actuar en general puede causar, según lo visto, un segundo resultado claro, inherente al quebranto de la libertad de actuar especialmente psicológico, pero que suele aflorar tiempo después de la salida del adepto de la secta, lo que crea problemas de imputación objetiva por el distanciamiento temporal entre la acción persuasiva que da como resultado el constreñimiento de la libertad de actuar y el segundo resultado como lesión psicológica. De especial interés en nuestro caso es la reiterada doctrina del TS en el concurso ideal entre agresiones sexuales y el delito de lesiones (STS de 2 de marzo de 2001), lo que análogamente puede apreciarse en el delito de coacciones (persuasión coercitiva) y el delito de lesiones psíquicas, puesto que la violencia empleada en la coacción da como resultado otro tipo. Aquí el problema es que también en el concurso ideal media una misma unidad de acción con pluralidad de tipos ${ }^{1823}$.

Los trastornos que produce la persuasión coercitiva constituyen per se un delito de lesiones que concurren con el delito de coacciones agravado. Esta criminalización separada que críticamente puede llevar a una valoración repetida o doble valoración ${ }^{1824}$, refleja nuevamente la laguna penal de un delito autónomo de persuasión coercitiva, pues tales técnicas en muchas ocasiones conllevan una lesión psíquica o al menos un peligro concreto del art. 148 CP o una tentativa en dolo eventual (el autor se representa la probabilidad de causar la lesión psíquica) del art. 149 CP. Por ello los delitos estudiados, y en concreto el delito de coacciones, que tiene señalada una pena máxima de tres años de prisión cuando afecta a derechos fundamentales como la libertad de conciencia, no contemplan una pena proporcional a la gravedad del ataque que suponen la aplicación de estas técnicas.

1821 ALFONSO PÉREZ MI / DíAZ BAÑos M / GARCÍA MuÑoz G., «Los Nuevos Movimientos religiosos ante la ley y la jurisprudencia (comentario a la Sentencia del Tribunal Constitucional 46/2001, de 15 de febrero)», Anales de Derecho, Universidad de Murcia. número 20, 2002, p. 242.

1822 Herrera Moreno, M., vv.aa., Lecciones de Derecho penal, Parte Especial, T. I, op. cit., pp. 101, 105 y 114.

${ }^{1823}$ Así se refería en su tiempo MAURACH, R., Tratado, II, op. cit., 55, I A.

1824 JAKOBS, G., $P G$, op. cit., 31/12. Como afirma JAKOBS, «(l)a diferencia entre concurso de leyes y concurso ideal reside, pues, únicamente en que en el concurso de leyes el contenido delictivo de la ley desplazada cabe tenerlo en cuenta genuinamente en la ley a aplicar, mientras que en el concurso ideal el contenido delictivo de la ley concurrente sólo se puede valorar a través de la suma de ambas», ID., ibidem, op. cit., 31/38. 
Al respecto, efectivamente, se ha considerado la aplicación del concurso ideal de delitos y no de leyes o normas. La diferencia estriba en que en el concurso ideal un solo hecho constituye dos o más infracciones que según el art. 77 del CP se castigarán aplicando la mitad superior de la infracción más altamente penada de los delitos en concurso, mientras que en el concurso de leyes, sólo se aplicará la pena de uno de los dos delitos. A primera vista se podría concluir que el concurso entre el delito de coacciones y el de lesiones psíquicas se habría de resolver de igual forma que lo hace la jurisprudencia del Tribunal Supremo y parte de la doctrina, en relación al delito de malos tratos y lesiones psicológicas ${ }^{1825}$.

Sin embargo, si seguimos esta línea de pensamiento, puede darse el caso de que al atacarse la libertad de obrar no se produzca aún una lesión psíquica, sino que por la fortaleza u otras circunstancias del sujeto, y pese a la aplicación idónea de las técnicas, su integridad psíquica resista, pero fuere previsible su afección, con lo que tendríamos un delito consumado de coacciones (la víctima tiene mermada su voluntad) pero al no padecerse aún una lesión psíquica consumada, estaremos ante un concurso con otro de peligro de lesiones del art. $148 \mathrm{CP}$ o en grado de tentativa inacabada o acabada del art. $149 \mathrm{CP}$, que según las reglas del concurso ideal de delitos habrá que aplicar, al igual que en el concurso de coacciones consumadas y lesiones psíquicas consumadas, el más grave en la mitad superior de la extensión de la pena, es decir, el delito de lesiones de peligro o de lesiones psíquicas porque estas técnicas, por su peligrosidad, son susceptibles, per se, de causar siempre las lesiones agravadas del art. 149 CP (grave enfermedad somática o psíquica). La cuestión es si aplicar el art. 148 CP o 149 CP en grado de tentativa que se resolvería, en nuestra opinión, por el concurso de leyes a favor de este último, en función del principio de subsidiariedad ${ }^{1826}$ tácita.

Es de reparar que en caso de que ambos delitos estén consumados (coacciones y lesiones), lo cierto es que al aplicarse un concurso ideal de delitos la aplicación de la pena en su mitad superior para el delito más altamente penado, el de lesiones graves, tendrá una pena de 9 años y un día a 12 años de prisión. Esta pena y su extensión pueden no reflejar todo lo injusto de la acción y del resultado. Piénsese en un adepto que durante toda su vida ha sido sometido a las

${ }^{1825}$ La STS, de 26 de enero del 2011, al resolver el recurso núm. 10793/2010 reiteró que «(s)i además se hubiera considerado la concurrencia de un daño psíquico nos encontraríamos ante un delito de lesiones, cuya autonomía exigiría la sanción separada». En este sentido BAJO FERNÁNDEZ y DÍAZ-MAROTO se refieren a que «(c)uando la violencia utilizada se convierte en lesiones habrá de apreciarse concurso de delitos entre el delito de coacciones y el delito de lesiones, siempre que la violencia haya rebasado la necesaria para doblegar la voluntad del sujeto pasivo», Bajo Fernández M / Díaz-Maroto Villarejo J., Manual de Derecho Penal, Parte Especial, Delitos contra la libertad y seguridad, libertad sexual, honor y estado civil, op. cit., p. 126; MIR PUIG, S., «El delito de coacciones en el Código penal», op. cit., pp. 305 y 306.

${ }^{1826}$ Por ejemplo JaKOBS, G., PG, op. cit., 31/26 y ss; MAURACH, R., Tratado, II, op. cit., 55, I B 3 a); STRATENWERTH, G., PG, I, op. cit., p. 457. 
directrices del líder, que haya realizado delitos para la organización, y tenga una grave enfermedad psíquica incurable o prácticamente incurable.

\section{B. Concurso de leyes}

El fundamento de la agravación del delito de coacciones cuando el objeto sea impedir el ejercicio de derechos fundamentales es la preeminencia de tales derechos dentro del ordenamiento jurídico ${ }^{1827}$. Resultado de esto es que el ataque contra un derecho fundamental como es la libertad de actuar en general, de modo que el resultado causado produzca tal intensidad en un déficit de socialización, o adicción comportamental o enfermedad, es que se criminaliza en el ámbito del delito de coacciones en el primer caso de forma agravada (principio de subsidiariedad $)^{1828}$, y en los segundos como tentativa cuando exista una alta probabilidad, aplicando el concurso ideal. Sin embargo, consideramos que en nuestro ámbito de estudio este camino no es del todo correcto y nos decantamos finalmente por el concurso de leyes por las siguientes razones.

JAKOBS concluye que «las lesiones graves frente a las coacciones necesariamente conectadas al hecho (...), sin que la especialidad frente a un quantum tan alto de coacciones ni siquiera se pudiera entrar a discutir en otras cualificaciones» ${ }^{1829}$. Esto es del todo cierto, pero en la fenomenología criminal vista, el resultado de lesión está conectado al de coacciones sólo como estadística, por eso necesariamente se han de separar el resultado de coacciones y el de lesiones, y siempre que surja una clara ejecución o peligro de atentado contra la integridad psíquica aplicar la tentativa o, en su caso, el delito consumado de lesiones psíquicas en concurso de leyes. La cuestión fundamental es cuándo surge dicha ejecución del delito de lesiones psíquicas. Como en el ejemplo que expone JАKOBS sobre el delito de violación y la detención ilegal, sólo cuando se comience a ejecutar la primera podrá apreciarse el concurso de leyes a favor de la violación ${ }^{1830}$. Al así sucede entre las coacciones realizadas mediante persuasión coercitiva y el delito de lesiones psíquicas. Así las cosas se ha de preguntar si aplicar la especialidad, la subsidiariedad, la consunción o la alternatividad, todos del art. $8 \mathrm{CP}$.

En la especialidad pueden suceder varios tipos de casos: en la especialidad estricta, en los delitos independientes, en los delitos compuestos y en los que la idea básica de un tipo es la especial en otros. Por otro lado, el principio de subsidiariedad expresa o tácita cuando rige el

\footnotetext{
${ }^{1827}$ Vid. DíAZ-Maroto Y Villarejo, J., vv.aa., Compendio de Derecho Penal, Parte especial, Vol. II, op. cit., p. 83.

1828 CERVElló DONDERIs, V., El delito de coacciones, op. cit., p. 105.

1829 JAKOBS, G., $P G$, op. cit., 31/13.

1830 ID., ibidem, op. cit., 31/14.
} 
precepto auxiliar (la consumación entraña tentativa y preparación en sus casos, así también la autoría agota las formas de intervención previas). El de la consunción se aplica cuando un delito es la forma de comisión de otro o en el caso del hecho posterior impune (o copenado), en definitiva cuando lo agota por ser modalmente una consecuencia más grave. Y finalmente el de alternatividad, que rige cuando fallan los anteriores. Apunta acertadamente JAKOBS que en verdad los tres primeros se refieren al de especialidad, los restantes se difieren en los motivos. La falta de comprensión de esto genera problemas de aplicación ${ }^{1831}$.

Nuestro parecer al respecto es el siguiente: la consumación del delito de coacciones en cuanto persuasión coercitiva se produce con la restricción del horizonte de expectativas cuando se afecta en la capacidad de decisión o en la ejecución de la decisión, de manera que cuando se ha alcanzado este resultado (consumación material) permanente, puede empezar la ejecución del delito de lesiones psíquicas agravadas por el resultado del art. 149 CP. De forma que aunque tratándose de dos delitos con bienes jurídicos diferenciados se puedan criminalizar mediante el concurso de leyes. Esto es porque el delito de lesiones también es un delito contra la libertad ${ }^{1832}$, y que la coacción mediante la persuasión es un tipo de recogida, de forma que parecería conveniente aplicar el delito principal y eliminar el delito subsidiario (el de coacciones) al tratarse de un tipo de recogida aplicando entonces el criterio de la subsidiariedad ${ }^{1833}$.

Sin embargo, nos parece más correcto aplicar en nuestro caso el principio de consunción puesto que con las coacciones se cumple una forma de ataque contra la salud ${ }^{1834}$, la persuasión aquí es un «hecho concomitante», no es un acto preparatorio sino un delito autónomo según lo referido, en las lesiones se engloba un mayor desvalor del injusto normativo o lesión jurídica ${ }^{1835}$, es decir, no es un estadio anterior de la evolución de un mismo ataque del delito contra la

${ }^{1831}$ ID., ibidem, op. cit., op. cit., 31/ 17 y ss.

1832 Comentaba MAURACH que la identidad de bienes jurídicos hace presumir que una de las concurrentes figuras criminales prima desplazando a los restantes tipos, MAURACH, R., Tratado, II, op. cit., 55, I B 2.

${ }^{1833}$ MAURACH, R., Tratado, II, op. cit., 55, I B 3 a), aunque también acepta la consunción ID., ibidem, op. cit., 55, I C 2 a). Coherentemente POLAINO NAVARRETE entiende que «(e)n el supuesto en que la finalidad aspirada por el autor alcanza la efectiva concreción de los delitos de lesiones graves o de homicidio (asesinato), puede estimarse como procedente un concurso de leyes, (...) en virtud del principio de subsunción», POLAINO NAVARRETE, M., El bien jurídico en el Derecho penal, op. cit., p. 362. Lo que se explica fundamentalmente en que la negación de diversos bienes jurídicos lleva a la aplicación del concurso de leyes, ID., ibidem, op. cit., p. 361.

${ }^{1834}$ Similarmente JAKOBS comenta que «la libertad de formar la voluntad o de ponerla en práctica (...) son menos graves, en una valoración usual, que la intrusión física que las fundamenta», JAKOBS, G., PG, op. cit., 31/30.

1835 POLAINO NAVARRETE sobre el principio de consunción recuerda que «el desvalor principal absorbe o engloba al menos trascendente que queda extinguido por su integración en aquél». La expresión legal más «amplio o complejo» es equívoca y ha de ser entendida correctamente en el sentido de una mayor «trascendencia o entidad» valorativa de precepto pero no en la acepción del alcance complejidad de la estructura típica (...) radica en la mayor gravedad del desvalor normativo del injusto que trae fundamento de la mayor entidad de la lesión jurídica, apreciada en una relación de contraste referida al nivel de ponderación de las dos normas afectadas», POLAINO NAVARRETE, M., Lecciones de Derecho penal, Parte General, T. II, op. cit., p. 254. 
integridad, aun cuando estemos en fase de tentativa porque en las lesiones graves se amplifica el daño contra la libertad (principio de alternatividad en este último caso). Al igual que el allanamiento de morada se consume en el robo en vivienda, así también las coacciones cometidas con persuasión coercitiva suponen una modalidad, que no un simple tipo básico o más amplio (a pesar de ser de recogida) ni acto preparatorio del delito contra la integridad. Así, tampoco es el principio de especialidad el aplicable porque en definitiva tampoco puede concluirse que el delito de lesiones sea un tipo especial, sino que en el ataque contra la salud aparece comúnmente el ataque contra la libertad, y esto también cuando el consentimiento está viciado.

Ha de dejarse claro que, efectivamente, el concurso de leyes no excluye por completo el injusto desplazado, sino que puede servir en la medición de la pena ${ }^{1836}$, lo que en este caso llevaría, sin ser incoherentes, a la mitad superior hasta la máxima extensión, si tomamos por dato cualificante, por ejemplo, la amplia temporalidad de la violencia (coacción), o la intensidad de alguna técnica aplicada o consecuencia no estrictamente lesiva en la salud, incluso aumentar la pena mínima al de la norma desplazada, o también aplicarse la norma desplazada al interviniente en la norma desplazada, en nuestro caso el interviniente en la coacciones por persuasión coercitiva, significativamente cuando actúa dolosamente y desconoce elementos cualificantes, también personalísimo ${ }^{1837}$.

También cabe concluir con JAKOBS que «la exculpación plena en los delitos más específicos y más graves es siempre también exculpación en el delito general, y en caso de especialidad cualificante $-\mathrm{O}$, dados iguales marcos penales, de especialidad que sólo se refiere a un tipo de hecho- se puede castigar por tentativa del delito base, pues si la tentativa de la cualificación es impune, ello sólo quiere decir que los elementos cualificantes no dan lugar a punibilidad alguna; pero no afecta a lo que haya que decidir en relación con la tentativa del delito base» ${ }^{1838}$, en nuestro caso el de coacciones por persuasión coercitiva.

De este modo con la solución en el concurso de leyes, y en concreto mediante el principio de consunción, se resuelve de mejor manera la problemática, respetándose la identidad normativa

${ }^{1836}$ Ya en su tiempo Stratenwerth, G., PG, I, op. cit., p. 458; Welzel, H., Derecho penal alemán, op. cit., p. 320; JAKOBS, G., PG, op. cit., 31/39. En todo caso también en el concurso ideal, como bien apunta BACIGALUPO parece lógico que se aplique la pena mínima más alta de las que confluyen porque la pluralidad de delitos no puede beneficiar al autor, BACIGALUPO, E., Principios, op. cit., p. 435.

1837 JAKOBS, G., $P G$, op. cit., 31/42.

1838 ID., ibidem, op. cit., 31/44 y ss. El concurso ideal configura un injusto agravado por «la circunstancia -decía WELZEL- de concurrir simultáneamente diversos tipos en la valoración penal de un hecho, que sólo en su conjunto agotan el contenido de injusto de éste en todo su sentido», por eso rige el principio de absorción en esta modalidad, Welzel, H., Derecho penal alemán, op. cit., p. 317. 
de cada injusto pero siendo coherentes con su co-funcionalidad, y así no incurrir en el habitual error de apreciar el concurso ideal, que primeramente parece resolverlo, pues en éste la ley aplicable se determina por la suma de ambos injustos ${ }^{1839}$, sin embargo no se respeta la cuestión trascendental: que las coacciones por persuasión coercitiva es una modalidad relevante del delito contra la integridad, si bien no siempre da como resultado dicha lesión, lo que obliga a desconectarlo de una misma unidad de acción con dos resultados que ambos unidos hicieran aplicable el concurso ideal.

Finalmente, en el caso de las agravantes señaladas en la dinámica habitual de las sectas coercitivas (alevosía, abuso de superioridad y de confianza), nada impide que la concurrencia de éstas en la ejecución de la persuasión coercitiva se traslade a la agravación del delito de lesiones psicológicas cuando aparezca y se aplique el concurso de leyes en su versión de la consunción, precisamente por lo que decíamos supra, que la persuasión supone una modalidad de lesiones en el caso de que se comience a afectar a la salud, de modo que en este caso surgirán problemas de ne bis in ídem con agravantes específicas en el concurso con otros delitos, como en los delitos contra la libertad e indemnidad sexual. En la persuasión coercitiva confluyen las agravantes alevosía, abuso de superioridad y de confianza en unidad de acción, lo que posibilita la aplicación de las agravantes específicas del delito de persuasión directamente en el delito de violación con el concurso de leyes.

En cuanto al delito de abusos sexuales al asimilarse estructuralmente el tipo de engaño y violencia de la persuasión coercitiva en la falta o vicio de consentimiento del art. 181.2 CP no podrá aplicarse la agravante del apartado 5 «si concurriere la circunstancia $3 .^{a}$ o la $4 .^{a}$, de las previstas en el apartado 1 del artículo 180 de este Código», puesto que ya se incluye en el tipo básico del art. $181 \mathrm{CP}$ el vicio de la obtención del consentimiento o su falta, y la misma conclusión en relación a la modalidad de engaño de la coacción por persuasión coercitiva que se consume en el concepto de engaño o abuso «de posición de reconocida confianza, autoridad sobre la víctima (...) con persona mayor de dieciséis años y menor de dieciocho» del art. 182.1 $\mathrm{CP}$, con la prohibición de aplicación en la relación a la agravante de acceso carnal si concurriera la circunstancia $3^{\mathrm{a}}$, o la 4 $4^{\mathrm{a}}$, de las previstas en el artículo 180.1 de este Código.

De otra parte, respecto al concurso con otros delitos que suelen existir en las sectas criminales (contra la vida, delitos patrimoniales, contra la libertad e indemnidad sexual y de intrusismo profesional), comentábamos que las sectas criminales suelen utilizar técnicas terapéuticas a modo de persuasión coercitiva, sin posesión del título o habilitación legal requerida, de lo que

1839 JAKOBS, $P G$, op. cit., 31/38. 
deviene ya no sólo un intrusismo profesional cuando constituyan actos propios de la profesión y delito contra la libertad de obrar en general, sino en ocasiones un atentado contra la integridad psíquica, y que a la vez facilita delitos patrimoniales y contra la libertad e indemnidad sexual.

El debate sobre el concurso de la persuasión coercitiva con estos delitos-fin contiene la misma polémica que con el delito de lesiones psicológicas. En nuestra opinión se resuelve también mediante el concurso de leyes a favor del homicidio, estafa, violación o abusos al consumirse en éstos y en su seno objetivo la restricción del horizonte de expectativas con la violencia, el engaño o el abuso. Esto es así porque el eje central de la configuración normativa del delito de persuasión coercitiva es la asimilación objetiva con el concepto de «violencia», o en su caso «engaño»o «abuso», lo que plantea el debate normativo con formas de violencia en el delito de homicidio y asesinato, o con el delito de estafa respectivamente. En este caso, la cuestión para resolver los concursos a través del concurso de leyes. y no el estrictamente el ideal, es que en la persuasión coercitiva, y en definitiva la violencia, el engaño o abuso (obtención del consentimiento), poseen una gravedad significativamente mayor en los delitos de homicidio, asesinato, estafa, violación o abusos, que consume a la violencia, al engaño o al abuso de la persuasión como modalidad de los anteriores. Aquí el autor incurre en la infracción de una ley de varias formas (concurso de leyes heterogéneo). Así es como entre la coacción realizada mediante persuasión coercitiva con violencia o engaño o abuso y el delito de violación o abusos sexuales (delitos de varios actos) se ha de aplicar el concurso de leyes ${ }^{1840}$ cuando el concepto de violencia, engaño o abuso consumen la modalidad de la persuasión si pertenece a una modalidad consumativa.

Sin embargo, cuando la persuasión coercitiva o el delito contra la integridad psíquica resultante contengan una autónoma gravedad respecto al homicidio, la estafa, la violación o abusos, en el sentido de que no supongan una modalidad de ejecución se deberá aplicar aquéllos en concurso ideal con los otros. Por ejemplo, cuando resultare una lesión psicológica junto a los anteriores (y específicamente en el homicidio intentado) parece más adecuado el concurso ideal, y esto porque se suman dos gravedades diferenciadas normativamente, lógicamente si están conectadas, y esto a pesar del criterio de parte de la doctrina en relación al homicidio intentado, pues en verdad aquí sucede que la modalidad de las lesiones psicológicas al ser graves fundamentalmente por su permanencia se separan del supuesto habitual de una lesión para

\footnotetext{
${ }^{1840}$ Así en los delitos de varios actos al prevalecer un bien jurídico sobre los demás que justifica la conminación penal unitaria, o por el reconocimiento del legislador de un único bien jurídico que inspiran el principio de especialidad o consunción, Polaino NAVARrete, M., El bien jurídico en el Derecho penal, op. cit., p. 364.
} 
producir la muerte que daría como resultado el concurso de leyes ${ }^{1841}$. Con otro ejemplo: no es lo mismo persuadir coercitivamente durante años y después perpetrar una violación utilizando esta circunstancia. Aquí las gravedades se desconectan propiciando el concurso ideal (o real en casos claramente diferenciados).

En el caso del intrusismo profesional cuando sirviere para producir el engaño en la estafa y el vicio del consentimiento en las lesiones, es recomendable, según lo expuesto supra, aplicar el concurso medial por la concreta protección de la potestad del Estado y la seguridad de las personas que habilita la concurrencia autónoma. Sin embargo en casos especiales de «medicina alternativa» en los que se produzca una confianza que genere garantía o garantía que genere confianza (en ambos casos una garantía deficitaria), al no constituir un acto propio de la profesión puede apreciarse una modalidad del delito de estafa o contra la integridad porque dicha garantía deficitaria propicia a una modalidad de engaño bastante o del vicio del consentimiento que hace desatender el cuidado del patrimonio o la salud.

Finalmente la problemática también está en el concurso de todos ellos (homicidio, asesinato, estafa, violación o abusos e intrusismo). Parece conveniente que entre los delitos de estafa, violación o abuso sexual y contra la vida se deba apreciar el concurso ideal sólo en el caso de que exista una «acción común», de lo contrario habrá que convenir el concurso real de delitos, aunque antes bien habrá que hacer un concurso entre cada tipología de delitos en función del número de víctimas (pena global por cada tipología y en consecuencia una pena operativa) y muchas de las veces en nuestro ámbito de estudio mediante el delito continuado (excepto en delitos con bienes eminentemente personales), y posteriormente aplicar el concurso ideal.

\section{Especial referencia al intrusismo profesional}

Según la tipología de la secta criminal encontraremos a veces que también existen unos delitos comunes que se engarzan precisamente con la tipología de la secta. Resulta común que aquellas sectas criminales que ofertan la salvación mediante la curación del alma, ofrezcan, como condición indispensable para esto, que el sujeto se someta a tratamientos que en muchas de las ocasiones, requieren de la habilitación médica.

El tipo de intrusismo profesional $(403 \mathrm{CP})$ se articula en dos conductas alternativas, a saber: la ausencia de título académico expedido o reconocido en España, o la carencia de título oficial que acredite la capacitación necesaria que habilite legalmente el ejercicio de la profesión que se

\footnotetext{
1841 JAKOBS, G., PG, op. cit., 31/32 en relación a las lesiones como hemos concomitantes de homicidio, salvo en las lesiones graves que aplica el concurso ideal.
} 
desempeñe, estableciendo en ambos casos penas de multa. El segundo párrafo del artículo 403 se dedica a la agravación de la pena cuando el culpable de alguna de las conductas del tipo básico, se atribuya públicamente la cualidad profesional por el título al que se refiere, o ejerciere los actos en un local o establecimiento abierto al público en el que se anunciare la prestación de servicios propios de aquella profesión y estableciendo en estos casos penas de prisión de seis meses a dos años. Recuérdese al respecto que ya se dijo en precedentes capítulos que, en muchas ocasiones el líder de una secta y/o miembros activos se atribuyen falsamente este tipo de conocimientos para adquirir respeto de los adeptos, como elemento para conseguir, en consecuencia, la persuasión coercitiva. La consumación se produce por la actividad profesional, por los actos propios.

La problemática es si algunas prácticas de sanadores, curanderos y en las creencias supersticiosas (oraciones, rituales, etc...) pueden constituir un acto propio de una profesión con exigencias de titulación. Aquí la doctrina mayoritaria considera que no ${ }^{1842}$, sin embargo, si seguimos la opinión de que se trata de un delito pluriofensivo ${ }^{1843}$, que además de atacar la seguridad en relación a la potestad del Estado en la dispensación y contra los profesionales, afecta también de manera muy directa a las personas, a su seguridad y confianza en una garantía que en este caso es deficitaria objetivamente, podremos concluir que en ocasiones, el ofrecimiento del servicio cuando media una expectativa deficitaria, cuando produce la desatención de la víctima en su patrimonio (sin que tenga que exigirse remuneraciones excesivamente superiores a lo normal como se ha fundamento en alguna ocasión) o en salud (como «medicina alternativa», en concreto consideran que integran el tipo las SSTS 8 de junio de 1992; de 19 de junio de 1989; de 2 de julio de 1966; SSAP Islas Baleares de 13 de octubre de1999 y Cantabria 16 de abril de $1998^{1844}$ ), si bien la conducta no será típica de intrusismo, sí que puede apreciarse una modalidad del delito de estafa o contra la integridad porque la creación de una confianza que genera garantía o garantía que genera confianza (en ambos deficitaria) es una modalidad de engaño bastante, y en concurrencia de estafa y delito contra la integridad aplicar concurso ideal. Pero en el caso de que efectivamente se ejerciten actos propios

1842 Por ejemplo Echano Basaldua, Juan Ignacio, vv.aa., Compendio de Derecho Penal, Parte especial, Vol. II, Dir. Miguel Bajo Fernández, Centro de Estudios Ramón Areces, 1998, p. 821; HernándeZ TrIVIÑo Aurelio / ZUGALDÍA ESPINAR José Miguel, «La medicina popular y la medicina alternativa ante el Derecho penal: especial consideración del delito de intrusismo», CPC, 54, 1994, pp. 927 y ss; LLORIA GARCÍA, Paz, El delito de intrusismo profesional: (bien jurídico y configuración de injusto), Tirant lo Blanch, Valencia, 2001, p. 376 y ss.

${ }^{1843}$ LUZÓN PEÑA, D-M., «Problemas del intrusismo en el Derecho penal», ADPCP, 1985, p. 688; indirectamente y de modo reflejo sin que pueda constituir bien jurídico en las personas porque se comete aunque no se les afecte Echano Basaldua, JI, vv.aa., Compendio de Derecho Penal, Parte especial, Vol. II, op. cit., p. 820.

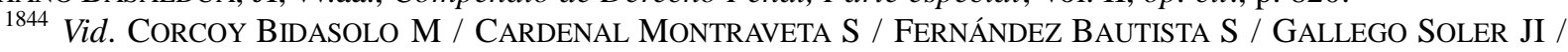
Gómez Martín V / Hortal IBarra JC., Manual práctico de Derecho penal, Parte Especial, op. cit., p. 468. 
el intrusismo puede concurrir con el de estafa o con el delito contra la integridad mediante el concurso medial ${ }^{1845}$.

Entonces la cuestión en relación a la denominada «medicina alternativa» es si a pesar de no constituir un acto propio de la profesión la producción de una garantía que crea la confianza o confianza que genera garantía, respecto a que se están realizando actos propios de la medicina que haga incurrir a la «víctima» en la creencia de que está siendo sanada, pueda considerarse intrusismo. Esta conclusión no sería acertada porque el tipo objetivo elimina esta posibilidad, pero no impide que sea una modalidad de otros injustos como el de estafa o contra la integridad. En este punto la doctrina mayoritaria y la jurisprudencia ${ }^{1846}$ respecto a la «medicina alternativa» consideran que el cobro de cantidades no es un acto propio de la profesión, por lo que no se incurriría en el tipo de estafa, sin embargo parecerá lógico concluir por nuestra parte que no es necesario el cobro para realizar actos propios de la profesión ${ }^{1847}$, además si entendemos los donativos como forma de remuneración, tan habituales en nuestro ámbito de estudio. Y llama la atención porque ya el art. 324 CPd, antes de la entrada en vigor del CP 1995, ya preveía la sanción en caso de uso de uniforme, traje, insignia o condecoraciones que se agravaba por el uso indebido de hábito eclesiástico o religioso, lo que ayudaba a comprender que el intrusismo podía resultar una forma delictiva de estafa, pero en nuestro ámbito de estudio, al derogarse estas modalidades y al atacarse con el intrusismo la potestad del Estado, la confianza y seguridad de las personas de forma específica (bienes jurídicos diversos), puede aplicarse directamente el tipo de la estafa o en su caso el delito contra la integridad, si se ha creado una garantía que genera confianza o viceversa, o también en su caso un concurso medial si se realizan acto propios de la profesión en contra de la opinión de parte de la doctrina ${ }^{1848}$.

Conviene sobre todo en lo anterior ver algunos casos concretos. En el famoso proceso contra la Iglesia de la Cienciología, el Ministerio Fiscal también la acusó en su escrito de conclusiones provisionales del delito de intrusismo profesional del actual artículo $403 \mathrm{del} \mathrm{CP}$ (anterior 321 del CP de 1973), es decir, ejercer actos propios de una profesión sin poseer el correspondiente título

\footnotetext{
${ }^{1845}$ Aplica el concurso ideal en caso del delito doloso de intrusismo y lesiones imprudente ECHANO BASALDUA, JI, vv.aa., Compendio de Derecho Penal, Parte especial, Vol. II, op. cit., p. 821.

1846 SSTS de 7 de junio de 1986; de 3 de marzo de 1997.

${ }^{1847}$ Lo advirtió Bustos Ramírez, J., Manual de Derecho penal, Parte especial, op. cit., p. 352. A favor del concurso ideal CORCOY BidASOlo M / CARDENAL MONTRAVETA S / FERnÁNDEZ BAUTISTA S / GALLEGo SOLER JI / Gómez Martín V / HorTal IBARRA JC., Manual práctico de Derecho penal, Parte Especial, op. cit., p. 572.

1848 Parte de la doctrina entiende que este delito es de unidad típica en sentido estricto, por lo que no puede apreciarse el delito continuado ni el concurso de delitos porque los actos profesionales constituyen un todo, LLORIA GARCÍA, El delito de intrusismo profesional: (bien jurídico y configuración de injusto), op. cit., , p. 414; MORILLAS Cueva entiende que es de mera actividad que se perfecciona con el acto propio aunque puede darse la tentativa, Morillas Cueva, L., vv.aa., Derecho penal español, Parte especial, op. cit., p. 855.
} 
académico expedido o reconocido en España. La Audiencia provincial de Madrid consideró que los elementos probados sobre esta conducta no eran típicos. Entendió que la realización del test de denominado E-Meter y la rehabilitación de toxicómanos y otros sujetos (pre-claros) a través de la denominada técnica de «auditación» ${ }^{1849}$ no son constitutivos de intrusismo profesional ${ }^{1850}$, y esto a pesar de que la imputación de este delito sirvió de base al Ministerio Fiscal para fundamentar el delito de asociación ilícita.

Otro de los casos famosos por los que fueron imputados miembros de una secta por intrusismo profesional fue el caso CEIS. En este caso ya comentado, la Audiencia Provincial de Barcelona de 16 de julio de 1990 condenó a determinados miembros por el delito de intrusismo profesional con la agravante de reincidencia y por delitos de promoción y explotación de la prostitución. Los acusados, crearon y dirigieron el Centro Esotérico de Investigaciones (CEIS), se presentaban ante los clientes como psicólogos, condición profesional que no ostentaban por medio de ningún título ni conocimiento acreditativo. Inclusive se reconoce en la Sentencia que utilizaron técnicas de captación y control psicológico para introducirlos en la misma y para «inducirlos» a la prostitución. Los condenados ofrecían sus servicios a través de pasquines y anuncios de prensa ${ }^{1851}$. Este es de los pocos ejemplos en España que se ha acreditado que una secta ha funcionado como organización criminal y por ende como enemiga. La condena fue ratificada por el Tribunal Constitucional en la Sentencia núm. 240-2005 de 10 de octubre de $2005\left(\mathrm{FJ}^{\circ}\right)$.

Es de vital importancia dejar claro que entre las diversas actividades de la profesión médica se encuentra la prescripción facultativa de medicamentos ${ }^{1852}$. Precisamente ello fue condición suficiente para que la Sentencia del Tribunal Supremo de 10 octubre de 2005 ratificara la culpabilidad de los miembros de esta secta en el delito de intrusito profesional.

\footnotetext{
1849 Técnica terapéutica que consiste en hacer retroceder al sujeto, quasi-hipnóticamente, hasta un trance pasado en el que se le insertó involuntariamente durante una inconsciencia, un «engrama» o conducta moralmente rechazable para la doctrina de la Cienciología. Dice su fundador que «(l)a «inconsciencia» es la única fuente de la aberración», HubBARD, Ronald L., Dianética. El poder de la mente sobre el cuerpo, NEW ERA Publications Internacional ApS, p. 39.

${ }^{1850}$ En concreto: "no puede dar lugar a un delito de intrusismo. No es un acto propio de la medicina psiquiátrica, como viene a sostener el Ministerio Fiscal. Es una técnica desarrollada por HUBBARD a través de un aparato, desde luego, inocuo para la salud física, y que no exige conocimientos de psiquiatría ni psicología. Basta el entrenamiento o formación que facilita la entidad que lleve a cabo dicha prueba. Tal y como puso de manifiesto el doctor G. A. en el acto del plenario, la comunicación no es un riesgo, ni es específica del tratamiento psiquiátrico, «se utiliza en charlas, con los amigos, la pareja, compañeros de oficina» (todo lo cual es perfectamente predicable de la auditación). Mucho más si las personas que lo utilizan lo consideran una práctica religiosa», FJ $6^{\circ} \mathrm{SAP}$ Madrid, de 28 noviembre de 2001. Sin embargo INTROVIGNE, testigo en calidad de experto en el proceso de la Cienciología en Lyon, declaró que en el libro Dianética, La ciencia moderna de la salud mental, se aplica un conocimiento no profesional del psicoanálisis, vid., Revista ZENIT, Kerygma, ltd., Lyon, 30 julio de 1997.

${ }^{1851}$ FJ $1^{\circ}$ de la SAP de Barcelona, de 16 de julio de 1990.

${ }^{1852} \mathrm{FJ}^{\circ}$ de la STS, de 10 octubre de 2005 (rec. 1252-2004).
} 
Sin embargo queremos matizar que respecto a la práctica de la ciencia médica existe una problemática que afecta intensamente en la tipicidad de conductas de miembros pertenecientes a grupos sectarios. Comenta la STS, de 13 de junio de 1990, que «un médico no especialista no puede dedicarse de manera continua al diagnóstico y tratamiento de enfermedades incluidas en el cuadro de especialidades médicas». Sin embargo, la Sentencia del Tribunal Supremo de 1 de abril de 2003 entendió acertadamente que «no existe en nuestro sistema jurídico una profesión de especialista médico legalmente establecida y regulada, con definición de actos propios y específicos, diferenciada de la actividad del médico. Existe, eso sí, una regulación de las especialidades médicas, a los efectos del Servicio Nacional de Salud fundamentalmente, pero carente de rango legal y sin constitución de una profesión específica que atribuya a los especialistas la exclusividad de determinados actos médicos, y la prohibición de realización de los mismo a los médicos no especialistas o titulados en otra especialidad, más o menos próxima. En definitiva, legalmente la única profesión colegiada es la de médico y no la de especialista, salvando el caso de la odontología que constituye un supuesto específico con regulación legal propia».

En este sentido, podemos concluir que el uso de la hipnosis, el uso de drogas que coadyudan al sueño, así como la utilización de técnicas de persuasión psicológicas y fisiológicas en tanto entrañen un peligro para la salud, reconducen a la exigencia legal de posesión de título académico u oficial para la práctica de tales especialidades profesionales, que se ubican en el ámbito de la psicología y psiquiatría. Por ello, el uso de la hipnosis y uso de drogas susceptibles de producir sueño para la práctica hipnótica, sin el debido conocimiento del sujeto pasivo acarrea un atentado contra la libertad, en concreto se incurre, al menos, en un delito de coacciones ${ }^{1853}$. Y en concreto, la Sentencia de la Audiencia Provincial de Barcelona de 16 de Julio de 1990 señalaba respecto a la secta CEIS que era «una estructura organizativa (que se caracteriza por) la utilización de terapias con pretensiones de tratamiento psicológico». En conclusión, las sectas coercitivas suelen utilizar técnicas terapéuticas a modo de persuasión coercitiva, sin posesión del título o habilitación legal requerida, de lo que deviene ya no sólo un intrusismo profesional y delito contra la libertad de obrar en general, sino en ocasiones un atentado contra la integridad psíquica, y que a la vez facilita delitos patrimoniales y contra la libertad e indemnidad sexual.

${ }^{1853} \mathrm{Al}$ respecto el citado $\mathrm{FJ} 3^{\circ}$ de la STS, de 10 octubre de 2005, rec. 1252-2004. 


\section{V.- Posibilidad de apreciación de actio libera in causa: desvirtuación de la libertad personal válida}

\section{A. Introducción y planteamientos}

En el ámbito de la persuasión coercitiva, según lo expuesto, el consentimiento para una persuasión de cambio de doctrinas o sentimientos, etc. es lícita e incluso sana en una sociedad de libertades. Tanto es así que la aceptación libre de postulados criminales, sea de órdenes o dinámicas criminales que inducen al delito, constituye otra conducta libre de déficit de sociabilización «atribuido al propio autor», ya sea por motivos de conciencia, por convicción o enemistad, que no plantea casos de alic.

La problemática, en nuestra opinión, estriba cuando existe algún tipo de imprudencia previa o autopuesta en peligro atribuible al autor. En el capítulo segundo concluimos que existe la posibilidad de apreciar conductas criminales del autor de conciencia y del autor por convicción imprudentes, si bien ahí no vimos más problemática que dicha posibilidad como formas de autoría directa.

Cuando existe una conducta imprudente previa del autor o autopuesta en peligro, que procura el déficit de socialización atribuido también a tercero, y que lleva a la concurrencia de un estado de necesidad exculpante, estamos en verdad hablando de concurrencia de culpas, o más exactamente de una «comunidad riesgosa imprudente», o en casos en los que la persuasión coercitiva se realiza por un autor doloso y la víctima participa «imprudentemente» o como «autopuesta en peligro», se produce cierta dosis de imputación a la víctima que puede tener consecuencias en el título de imputación de ésta.

Entonces, la pregunta versa sobre si el delito que se comete bajo esa causa de exculpación por déficit de socialización se puede imputar nuevamente al propio autor a través de la alic. $\mathrm{O}$ en el mismo caso, cuando la conducta se declara inimputable por una causa de inculpabilidad, esto es, la adicción comportamental referida, si se puede imputar nuevamente a la víctima a través de la alic. Si bien es cierto que el precepto que recoge la alic, el art. $20.1^{\circ} \mathrm{CP}$, habla de trastornos transitorios, y que hemos concluido que la incapacidad de voluntad en el déficit de socialización que causa la exculpación o el trastorno de la adicción comportamental son ambos permanentes, aunque reversibles, en nuestra opinión posibilita normativamente la pregunta sobre la alic.

Pues bien, la alic representa casos en los que el autor realiza una acción reprochable antes de la comisión irresponsable de un delito (actio praecedens). Las divergencias doctrinales se refieren a los conceptos de irresponsabilidad. Quienes mantienen un modelo en el que el sujeto provoca la irresponsabilidad desde cualquier punto de la dogmática (Ausgangssituation), afirman 
la alic en los supuestos de falta de acción, mientras que quienes defienden un modelo basado en que el autor provoca un estado defectuoso relativo a la culpabilidad no suelen aceptar la posibilidad de que la falta de acción provocada sea un caso de alic. Estas diferencias parten precisamente del concepto de alic que se conciba.

Resumidamente existe un debate doctrinal entre el «modelo de excepción» (Ausnahmemodell) y el «modelo de la acción típica» (Tatbestandsmodell) ${ }^{1854}$.

HRUSCHKA ${ }^{1855}$ defiende un modelo de imputación excepcional de las acciones que a pesar de no ser libres en sí, lo eran anteriormente. Precisamente este es el fundamento histórico de la alic que reproduce el modelo aceptado mayoritariamente por la doctrina alemana. La alic para esta parte de la doctrina es una excepción a la eximente actual del primer párrafo del art. $20.1^{\circ} \mathrm{CP}$. Se defiende que, si bien estos preceptos requieren que el momento de la realización de la acción típica coincida con el momento de la capacidad de culpabilidad, se renuncia a esta simultaneidad bajo la construcción de una «responsabilidad diagonal». Con este modelo se castiga como hecho doloso y culpable cuando la acción dolosa sólo ocurre en el momento de la inimputabilidad, a pesar de que antes de ésta se hubiese obrado imprudentemente, de tal manera que se amplía la punibilidad.

En concreto, HRUSCHKA basa su argumentación en una reducción teleológica de la diferenciación de imputación. Considera que las normas imponen deberes u obligaciones. Mientras que en la infracción de los deberes se realiza una imputación ordinaria acorde a los principios de coincidencia, en la infracción de una obligación (causa consecuente de la posterior infracción de la norma como deber), como, por ejemplo, provocar el estado de necesidad exculpante, se imputa la conducta final en estado defectuoso con criterios de imputación extraordinaria, y ello «porque la persona involucrada en la situación es responsable de las razones que excluyen la imputación» ${ }^{1856}$.

\footnotetext{
${ }^{1854}$ Ausnahmemodell, tradicionalmente denominado «método de la reducción» (Methode der Reduktion). Tatbestandsmodell, denominado también «método del rodeo» (Methode der Umgehung) o «teoría de la anticipación» (Vorverlegungstheorie).

${ }^{1855}$ Este modelo fue en primer lugar defendido por HRUSCHKA, J., «Über Tun und Unterlassen und über Fahrlässigkeit», Festschrift für Bockelmann, 1979, p. 421, ID., Strafrecht nach logisch-analytischer methode, $2^{\mathrm{a}}$ ed., 1988, pp. 343 y ss; ID., «Actio libera in causa y autoría mediata», HRUSCHKA, J., Imputación y Derecho penal, op. cit., pp. 157 a 168, trad. de «“Actio libera in causa” und mittelbare Täterschaft», Festschrift für Karl Heinz Gössel, zum 79. Geburtstag am 16 Oktober 2002, Heilderberg, 2002, pp. 145 a 155. Posteriormente se adhirieron otros como AlONSO ÁlAMO, Mercedes, «La acción "libera in causa”», ADPCP, XLII, 1989, op. cit., p. 59; SÁNCHEZ-OSTIZ, P., La libertad del Derecho penal, op. cit., p. 75. El modelo de excepción de HRUSCHKA critica el modelo de la extensión típica (Ausdehnungsmodell) al considerar que la acción precedente, provocación del estado defectuoso, es un acto preparatorio, HRUSCHKA, J., «Der Begriff der actio libera in causa und die Begründung ihre Strafbarkeit BGHSt», JuS, 21, 1968, p. 556; JESCHECK HH / WEIGEND T., Tratado, op. cit., 40, VI.

${ }^{1856}$ HRUSCHKA, J., «Actio libera in causa y autoría mediata», op. cit., p. 161. Esta forma de conceptualizar y resolver la problemática se basa en unas consideraciones dogmáticas de la imputación de distintas clases: la
} 
Lo problemático será -como indica DEMETRIO CRESPO- que incluso en la imprudencia genérica «al autor no se le castiga por haber infringido un mandato jurídico relativo a recabar determinadas informaciones, sino por realizar una acción de forma contraria a la prohibición pese a no disponer de un estado de información suficiente» ${ }^{1857}$. Podemos estar parcialmente de acuerdo con este autor, sin embargo consideramos que el delito imprudente también provoca el quebrantamiento de la vigencia de la norma. Por ello mismo, y en nuestra opinión, la doctrina no acaba de hacer un estudio profundo sobre la categoría dogmática de la imprudencia estructurada formalmente como en el dolo. De tal suerte, cabría preguntarse si es necesario y en algunos casos criminalizar las tentativas de imprudencia grave.

La segunda explicación, llamada modelo de la acción típica que procede del Derecho anglosajón, parte de considerar a la «causa libre» como acción típica, es decir, como comportamiento doloso eventual (actio libera in causa dolosa) o imprudente (actio libera in causa imprudente). Se ha comentado ${ }^{1858}$ que el origen histórico y actual de la actio libera in causa se basa en la categoría de la imputación, por lo que sólo podrá hacerse responsable la acción en estado de imputabilidad. Nuestro TS parece defender este segundo modelo bajo el argumento de que sus postulados son más acordes a las exigencias del principio de legalidad del art. 25.1 CE. Se critica en este sentido que el primer modelo, el de «excepción», quebranta este principio al establecer, precisamente, una excepción.

En otro orden se ha defendido por parte de la doctrina ${ }^{1859}$ que la estructura de la alic sirve para todas las categorías de la teoría del delito, si bien, la mayoría de la doctrina la reconduce a

ordinaria de primer nivel como imputación del hecho, la de segundo nivel como imputación del hecho antijurídico a la culpabilidad, y un tercer nivel en la imputación extraordinaria. De aquí que HRUSCHKA defienda la superación del angosto catálogo sistemático de la teoría jurídica del delito basado en la tipicidad, antijuricidad, culpabilidad y punibilidad, a favor de la imputación ordinaria y extraordinaria. Más ampliamente HRUSCHKA, J., «Reglas de comportamiento y reglas de imputación», op. cit., pp. 27 a 40; SÁNCHEZ-OsTIZ, P., La libertad del Derecho penal, op. cit., especialmente pp. 41 a 48 y pp. 119 a 160.

${ }^{1857}$ DEMETRIO CRESPO, E., «La actio libera in causa: ¿Una excepción a las exigencias de la culpabilidad por el hecho?», Luis Alberto Arroyo Zapatero y Ignacio Berdugo Gómez de la Torre (coords.), Homenaje al Dr. Marino Barbero Santos, «in memorian», Vol. 1, Universidad de Castilla-La Mancha, Universidad de Salamanca, 2001, p. 997.

${ }^{1858}$ RoXIN, C., «Observaciones sobre la "actio libera in causa"», trad. Francisco Muñoz Conde, $A D P C P$, eneroabril, 1988, pp. 25 y ss; SILVA SÁNCHEZ, J-M", «La estructura de la "actio libera in causa" en los delitos cometidos bajo un síndrome de abstinencia de drogas», La Ley, 1988, 22, enero, p. 2.

${ }^{1859}$ De este modo se ha planteado la alic como solución en casos de ausencia de acción (omissio libera in causa). En concreto, para JESCHECK, la alic se aplicaría exclusivamente a la acción e imputación, JESCHECK HH / WeIGEND T., Tratado, 40, VI. Se plantea la asimilación de estructuras en la imputación objetiva, con lo que estamos totalmente de acuerdo. Quien dolosamente evita su imputación objetiva de causación de un resultado lesivo o su tentativa crea precisamente un ámbito de falta de imputación de la que es responsable. Para HRUSCHKA, la ausencia de acción sería un caso de autoría directa, HRUSCHKA, J., «Das Strafrecht neu durchdenken!», GA, 1981. Se ha sostenido la alic en ausencia de conciencia de antijuricidad (actio illicita in causa), HRUSCHKA, J., Strafrecht nach logisch-analytischer methode, op. cit., p. 381. En de error de tipo y de error de prohibición JOSHI JUBERT, Ujala, La doctrina de la «actio libera in causa» (ausencia de acción o inimputabilidad provocada por el sujeto), Bosch, 
una o pocas categorías asociadas de la estructura de la alic. La mayor parte de la doctrina alemana y española, salvo excepciones contadas, aceptan la necesidad y merecimiento de la pena en los casos de actio libera in causa, y por tanto la punibilidad ${ }^{1860}$.

Sin embargo, JAKOBS únicamente admite el modelo de acción típica basado en la inimputabilidad, si bien cabe hacer algunas matizaciones. Recuerda que habrá que dilucidar en estos casos si se «dificulta la obediencia a la norma desde una consideración psicológica». De aquí que habrá que analizar el comportamiento «previo» del sujeto como fuente de responsabilidad $^{1861}$ (por ser una especie de autor inmediato ${ }^{1862}$ ), ya sea porque tal comportamiento ocasiona (suceso causal) o tiene ya en sí culpa. Comenta que si bien la pérdida por el sujeto de la capacidad de orientación conforme a la norma puede ser causada objetivamente por un tercero, incluso por la víctima, habrá que dilucidar también la capacidad del autor para orientarse conforme a la norma, es decir, no sólo la causación ajena de la inexigibilidad crea la irresponsabilidad, sino también la capacidad del propio sujeto-autor, lo que análogamente puede trasladarse al déficit de socialización o a la adicción comportamental ${ }^{1863}$. Cabe concluir que el déficit de socialización o la adicción comportamental pueden imputarse a la propia víctima cuando es ésta la que aumenta el riesgo, a pesar de la intervención dolosa o imprudente de un tercero.

JAKOBS considera que la alic representa en sí misma una causa libre en todo el proceso de la alic. No debe valorarse en sí misma la culpabilidad, sino la propia acción, así no se vulnera el

Barcelona, 1992, pp. 87. En la provocación de una causa de exculpación (el estado de necesidad exculpante, HruschKa y MIR PUIG) HRUSCHKA, J., Strafrecht nach logisch-analytischer methode, op. cit., p. 349; MIR PUIG, $P G$, op. cit., p. 657. Sin embargo la doctrina crítica lo considera inaplicable porque para ello ya existe la categoría del error vencible o invencible en los casos en los que la provocación se deba a la imprudencia. También en la legítima defensa, en el estado de necesidad justificante. Otros autores únicamente aceptan que la teoría de la alic puede aplicarse en estados de inimputabilidad provocados, ya sea dolosa o imprudentemente, como por ejemplo defiende JAKOBS, pues considera que la ausencia de acción en el prototípico caso de la madre con sueño agitado, se resolvería con la teoría de la acción, JAKOBS, G., $P G$, op. cit., 17/64.

${ }^{1860}$ En concreto, JOSHI JUBERT fundamenta la punibilidad en la conducta de provocación, pero sólo en el caso de que dicho comportamiento sea relevante, que contenga un peligro directo, que tal peligro se conecte con la acción provocante, que exista conexión de causación entre el resultado injusto y el estado defectuoso, y que subjetivamente tales elementos prevean (probabilidad) la causación del resultado injusto. En tal medida, para este autor, el fundamento de la punibilidad es la provocación relevante, JOSHI JUBERT, U., La doctrina, op. cit., p. 281 y 282.

1861 JAKOBS, G., PG, op. cit., 17/71; ID., «La denominada actio libera in causa», trad. Pilar González Rivero, JAKoBS, G., Dogmática de Derecho penal y la configuración normativa de la sociedad, op. cit., pp. 209 a 230 , también con el mismo título en Revista Peruana de Doctrina y Jurisprudencia Penales, 2, 2001, pp. 201 y ss.

${ }^{1862}$ Críticamente HRUSCHKA porque considera que en la autoría mediata el autor mediato debe esperar a que el otro cometa el hecho, mientras que en la alic esto no sucede, HRUSCHKA, J., "“Actio libera in causa" y autoría mediata», op. cit., pp. 164 a 168.

${ }^{1863}$ Lo que importa, dice JAKOBS, es de «qué ámbito de organización procede el riesgo de que se vea dificultad la obediencia a la norma. Si la dificultad es consecuencia de un comportamiento previo antijurídico de la víctima, el autor no es responsable de ello, y no es posible configurar con mayor rigor el baremo que se le ha de aplicar (...) La dificultad de la motivación debe ser consecuencia específica de la antijuricidad o del riesgo especial (...) Quien, practicando juegos ilícitos, sufre un estado pasional, merece el mismo tratamiento que si lo hubiera sufrido estando permitido el juego», JAKOBS, G., $P G$, op. cit., 17/74. 
principio de coincidencia, pues el estado defectuoso es de naturaleza y no de acción típica ${ }^{1864}$. Efectivamente, la valoración de la conducta previa no se refiere a la valoración de la acción u omisión típica, sino al estado defectuoso, de tal modo que trasladada esta conclusión al ámbito de estudio se puede anticipar que la conducta de autopuesta en peligro consciente, aquella de un sujeto que podía apreciar que las dinámicas grupales le producirían un déficit de socialización o estados adictivos, no es en sí misma una conducta típica, o al menos, no se ha de valorar como una conducta típica, sino siempre como una conducta de riesgo, de autopuesta en peligro, en definitiva, una conducta que sigue formando parte de la liberalidad del sujeto en conformar su conciencia y su voluntad.

Lo anterior no se contradice con que defendamos el «modelo de la acción típica». Este modelo es más acorde a la legalidad y se ajusta a la experiencia delictiva de algunos autores de conciencia y por convicción. De este modo es de aceptar la consideración de JOSHI JUBERT ${ }^{1865}$, de gran parte de la doctrina ${ }^{1866}$ y del TS, que la alic puede estar presente en toda la teoría del delito, y a la vez, cabe añadir, en todo tipo de delitos, no sólo de resultado -como dice RoxiN-, si bien excepciona aquellos delitos de propia mano «impropios» que no permitan tampoco la estructura de la autoría mediata ${ }^{1867}$. De aquí que aceptemos similitudes de la estructura de la imprudencia con la actio libera in causa ${ }^{1868}$, sin embargo algún sector doctrinal se muestra contrario a aceptar la estructura de la alic para los casos de imprudencia, alegando que la propia imprudencia resuelve los $\operatorname{casos}^{1869}$.

En nuestra opinión es sostenible la actio libera in causa por imprudencia en el modelo de acción típica, como previsibilidad de que la acción precedente puede dar como consecuencia una

\footnotetext{
${ }^{1864}$ En concreto dice que «no se puede mantener, ni siquiera en el ámbito del Derecho; pues el sujeto embriagado ni puede manifestarse de modo responsable como inculpado ni tiene en otro sentido capacidad para realizar actos procesales», JAKOBS, G., «La idea de la normativización en la dogmática jurídico-penal», op. cit., p. 26.

1865 JOSHI JUBERT, U., La doctrina, op. cit., p. 92.

1866 Por ejemplo DEMETRIO CRESPO, E., La tentativa en la autoría mediata y en la actio libera in causa. Una contribución al estudio del fundamento de punición y al comienzo de la tentativa, Comares, 2003, pp. 127 y ss.

1867 RoxIN, C., «Observaciones sobre la "actio libera in causa"», op. cit., pp. 31 y 32.

1868 En concreto JOSHI JUBERT considera que «no se le castiga porque ex-post se comprueba que podía haber advertido el peligro, sino porque ex-ante el hombre medio hubiera advertido el peligro», JOSHI JUBERT, U., La doctrina, op. cit., p. 104; de igual manera que en el caso de actio libera in causa dolosa, dice COBO DEL ROSAL, «parece lo más correcto sostener que quien se coloca voluntariamente en situación de inimputabilidad para llevar a cabo el delito, está ya iniciando su ejecución», en la alic imprudente, la autocolocación culposa de un sujeto en dicha situación, puede imputársele, COBo Del RosAL M / VIVES ANTÓN TS., PG, op. cit., p. 609.

1869 Dentro de los defensores del modelo de la acción típica RoXIN, C., «Observaciones sobre la "actio libera in causa"», op. cit., pp. 26 y ss. porque la única diferencia es que en la alic imprudente «existen entre la acción imprudente y el resultado todavía otras acciones realizadas por el autor en estado de inculpabilidad, en las que falta la imprudencia «habitual». Pero esto no constituye una desviación de la estructura jurídica, sino solo una imagen fenomenológica». En el sector del modelo de excepción, HRUSCHKA, J., «Der Begriff der actio libera in causa und die Begründung ihre Strafbarkeit -BGHSt», JuS, 21, 1968; ALONSO ÁlAMO, M., «La acción "libera in causa"», op. cit., p. 98.
} 
lesión jurídica a tercero, si bien si el perjuicio recae sobre el mismo sujeto, en principio, ello implica una autopuesta en peligro. La cuestión es entonces, cuándo se inicia la conducta imputable, si con el inicio de la afección defectuosa o con su consumación.

En los casos de consentimiento libre al adoctrinamiento, tanto en el autor de conciencia, por convicción y en el enemigo, no habría un déficit o adicción comportamental jurídicamente relevante a los efectos de irresponsabilidad penal, porque suponen casos de libertad de mudar o cambiar de pensamientos, convicciones, atribuible al propio autor y a su libertad (conversión). Los casos que se resolverían a través de la alic son aquéllos en los que existe una imprudencia por parte del sujeto, una intervención en la imputación objetiva de la propia víctima que causa el déficit de socialización en concurrencia de un tercero doloso o imprudente, que a la postre lleva a cometer un delito contra un tercero o en perjuicio propio, lo que nos lleva a plantearnos la alic en la autoría mediata o en la autoría mediata dual respectivamente, pero también se puede plantear la posibilidad de la coautoría.

Esta cuestión está relacionada con nuestro estudio por el denominado en Alemania «verschuldete Affekt»: la provocación de un estado pasional que podía ser evitado por el autor. Por ejemplo, en el caso prototípico de omisión del deber de socorro de los padres Testigos de Jehová a su hijo menor de edad mediante la falta de consentimiento para la transfusión, alguna sentencia y una escasa parte de la doctrina han aceptado el arrebato como causa atenuante en tales casos, o según nuestra postura, un déficit de comunicación/socialización de la norma, o un déficit de socialización atribuido a un tercero. En nuestra opinión, ya dijimos que la autoría de conciencia o por convicción no son casos de trastorno mental transitorio, si bien puede concurrir alguna vez un arrebato espontáneo, en cuyo caso, tampoco creemos que se pueda aceptar la doctrina de la actio libera in omitiendo bajo el fundamento del verschuldete Affekt, pues si bien en España no se aprecian problemas para esta aplicación, porque el propio art. $20.1^{\circ} \mathrm{CP}$ acepta la actio libera in causa en casos de semi-imputabilidad (por ello que algunos autores como JosHI JUBERT $^{1870}$ entienden que los casos de actio libera in omitiendo se pueden explicar por la injerencia, es decir, por la mala gestión de los peligros), la propia naturaleza del arrebato, en estas situaciones de conciencia, por su espontaneidad, impide retrotraer o justificar la culpabilidad en el estado previo, o en la mala gestión de los peligros, salvo que admitiésemos que de dicha mala gestión se causa directamente el momento del estado defectuoso y criminal, en cuyo caso, análogamente también en la adicción comportamental, atribuiríamos culpablemente el delito por esa mala gestión como injerencia propia.

${ }^{1870}$ JOSHI JUBERT, U., La doctrina, op. cit., p. 209. 
En este caso, pensamos que habría una diferencia cualitativa importante entre el arrebato y la adicción comportamental, pues en el estado pasional la mala gestión supondría un riesgo permitido, o sea, no haber prevenido el acopio de sangre del menor para realizar la transfusión, lo que resultaría ya no una injerencia, sino con este razonamiento, el incumplimiento de un deber, que no es el caso porque nadie está obligado normativamente a tal medida, salvo que entendamos la injerencia como auto-responsabilidad en la falta de cuidado mental ante una futura circunstancia de este tipo, lo que sería tanto como decir que los Testigos de Jehová deberían tratarse psiquiátricamente desde el momento que tengan un hijo para en caso de que llegue la situación estar preparados para no incurrir en un arrebato que cause la omisión de socorro, o la comisión por omisión.

En concreto, algunos autores como RoxIN ${ }^{1871}$, sin aceptar el modelo de excepción para estos casos, fundamentan el modelo de acción típica con base a una infracción del deber de mandato de la norma. Señala que si bien el sujeto en un primer momento obra y después omite, se le debe castigar por omisión pues la conducta final así se materializa. También SILVA SÁNCHEZ ${ }^{1872}$ considera que no se infringe el deber, sino el mandato sobre las libertades ajenas de no causar el resultado, pues el sujeto tiene la obligación de observancia, de vigilancia, y que a pesar de no ser imputada en el hecho lesivo por la falta de acción o culpabilidad, sí la acción provocante -la falta de vigilancia- que precisamente causa objetivamente el resultado en comisión por omisión.

Efectivamente tanto en el déficit de socialización atribuido a tercero como en la adicción comportamental puede haber una mala gestión previa del sujeto, una injerencia imprudente (heteropuesta en peligro) como aquel que se adentra en un adoctrinamiento en la Guerra Santa, o aquel que empieza a fumar genera el riesgo análogo de una adicción comportamental en similitud a la adicción comportamental sectaria, que sin pretender colaborar o ser parte de una organización criminal, ni realizar conductas criminales, o en el segundo caso, sin pretender ser adicto al tabaco o a la norma o dinámica sectaria, conoce que su incursión en el riesgo puede llevar, en menor o mayor medida a tales resultados (culpa consciente).

Son de resaltar las apreciaciones de JOSHI JUBERT sobre la «provocación relevante» ${ }^{1873}$. La citada penalista entiende que la acción con plenitud de capacidad de culpabilidad y la acción con falta de culpabilidad o de propia acción deben ser equiparadas. Señala varios elementos que deben concurrir. Por un lado, y en relación a los elementos objetivos, señala la producción de un

\footnotetext{
${ }^{1871}$ RoxIN, C., «El límite entre comisión y omisión», RoxIn, C., Problemas básicos del Derecho penal, op. cit., pp. 228 y ss; ID., «Observaciones sobre la "actio libera in causa"», op. cit., p. 26.

1872 Silva SÁNCHEZ, J-Mª, El delito de omisión. Concepto y sistema, op. cit., pp. 265 y ss.

1873 Joshi JUBERT, U., La doctrina, op. cit., p. 282; ID., «Actio libera in causa y delitos cometidos bajo la influencia de las drogas: una nueva orientación en la jurisprudencia del tribunal Supremo», La Ley, 1/1994, p. 1104.
} 
peligro para el bien jurídico, la relación directa entre provocación y acción que crea el peligro, y la auto-colocación en un estado de no control. De otra parte, indica que los elementos subjetivos se refieren a la posibilidad de previsión o previsibilidad de pérdida de las facultades humanas, creación de un peligro concreto para el bien jurídico y la probabilidad de resultado lesivo para el bien jurídico. Así, afirma que la acción u omisión tendente a auto-eliminar la capacidad natural del ser humano exigida por el normativismo jurídico-penal es ya en sí misma comienzo de ejecución inmediata de lesión a la norma penal. Explica que entre la acción precedente en estado de culpabilidad y la acción en estado defectuoso, con la que se lesiona la norma, existe una relación psicológica causal. La acción precedente es ya en sí misma el principio de ejecución típica, antijurídica y culpable, que si bien está desconectada espacial y temporalmente (normalmente es así) de la acción lesiva en estado «defectuoso», es causada e imputada objetivamente por el autor de la acción precedente. En tal sentido, la acción precedente contiene una desvalorización de la vigencia de la norma, en tanto deber en sí mismo, de actuar o de omitir, para no irrogar daños. En sí misma la acción precedente abandona el sentido de los actos preparatorios para dotar a esta acción de un contenido global de ejecución, de modo que fundamenta la punibilidad y su inicio.

Este razonamiento evidencia una similitud estructural entre la alic y la autoría mediata en la solución individual o del autor mediato ${ }^{1874}$, pues la tentativa comienza cuando el dominio del hecho sobre un instrumento incide sobre éste, así también comienza la tentativa en la alic, cuando uno mismo, dolosa, imprudentemente o como autopuesta en peligro, se trata como instrumento delictivo.

Así, una gran mayoría de la doctrina científica jurídico-penal acepta el paralelismo estructural de las dos categorías jurídico-penales, actio libera in causa y autoría mediata. JAKOBS ${ }^{1875}$ considera que tal paralelismo estructural es apreciable en la alic-inimputabilidad, pero sin exigirse en la alic la eliminación total de exigibilidad de la conducta, porque en la alic, al ser el hombre de atrás el mismo instrumento futuro (autoría mediata dual), hace falta un dominio que se abandone en el estado defectuoso, por lo que en la alic existe una continuidad material.

En la autoría mediata la acción del instrumento es humana y voluntaria, pero no culpable, y, a diferencia de la actio libera in causa -en la que, en nuestra opinión, la acción en estado defectuoso puede suceder por estados instintivos, por ejemplo, el caso de la madre con sueño agitado que duerme con el bebé- lleva a considerar que el modelo de acción típica acepta los

1874 JAKOBS, G., $P G$, op. cit., 21/105; ID., «La autoría mediata con instrumentos que actúan por error como problema de imputación objetiva», op. cit.

1875 JAKOBS, G., PG, op. cit., $17 / 64$. 
postulados de la autoría mediata en la solución individual o del autor mediato, lo que reafirma que la tentativa comience con la acción precedente, por ejemplo, en la acción de comenzar a beber en la autoría mediata dual, o cuando el hombre de atrás afecta o comienza a dominar al instrumento.

En nuestro ámbito de estudio, la problemática se centra en la siguiente cuestión: ¿comienza la tentativa cuando se comienza a incidir con dominio del hecho o cuando se ha incidido con plena seguridad o cuando se ha llegado a dominar, o sea, cuando ya se ha dejado de dominar? Responder a esta pregunta es crucial para comprender el concurso y la ejecución en los delitos de organización criminal, persuasión coercitiva y adicción comportamental, pues nuestros postulados previos nos llevan a que los tres injustos comienzan a ejecutarse en distintos tiempos y el momento consumativo de cada uno es distinto: primero se consuma la organización, después se inicia la persuasión coercitiva o intervención imprudente imputable a la víctima y, por último, en su caso, la lesión psicológica como adicción comportamental.

La teoría de la solución global o del instrumento defiende que el ser humano instrumentalizado no es un instrumento con nulidad de las facultades humanas en similitud a un animal, y así, la imputación al hombre de atrás viene justificada por la acción típica realizada por el sujeto instrumentalizado, como si fuera aquél el que la hubiere realizado ${ }^{1876}$. Estamos de acuerdo con RoxiN $^{1877}$ en estimar que afirmar la teoría global llevaría a consecuencias insatisfactorias, pues habría que entender que la tentativa comienza en algunos casos cuando el autor mediato esté inconsciente, por ejemplo cuando se echa a dormir, sin dolo ni culpabilidad. Esto sería contrario a la exigencia de que en la tentativa tiene que haber dolo actual, además de que contradiría que la ejecución debe ser realizada por el inmediato. En definitiva, la solución global de la autoría mediata implica una analogía con la coautoría para los casos de delimitación entre actos preparatorios y tentativa que se aleja de los postulados propios de la autoría mediata como son la falta de decisión delictiva en común y la ejecución conjunta.

\footnotetext{
${ }^{1876}$ En este sentido se pronunció en la doctrina alemana STRATENWERTH, G., PG, I, op. cit., pp. 342 y 343.

1877 RoXIN manifiesta que «hay que seguir manteniendo con énfasis que existe tentativa acabada cuando un responsable pone en marcha un curso causal y pierde su dirección, al traspasarlo a otra persona que actúa sin culpabilidad o sin dolo y que es la que en definitiva tiene que llegar al resultado. En tales casos, el autor ha pasado «la prueba de fuego de la situación crítica» (BOCKELMANN) y realiza todo lo que por su parte era necesario para producir el resultado. La ley no atiende a la inmediata puesta en peligro de la víctima, ni tampoco al actuar del intermediario, sino sólo al «comenzar a» que realiza el autor; pero éste no puede comenzar más que cuando el suceso ha salido claramente de su esfera de influencia. También el dolo y la culpabilidad, que tienen que estar presentes en el momento de la tentativa, sólo pueden referirse al momento en que el autor todavía actúa. Si, por ejemplo, tras «traspasar» el asunto al intermediario que actúa sin capacidad de culpabilidad o sin dolo, se echa a dormir, nada impide que, si todo transcurre conforme a lo previsto, pueda ser castigado por delito doloso. Si se mantiene otra opinión ¿cómo puede explicarse que alguien que está durmiendo comience dolosamente $(i)$ a ejecutar un hecho?», RoxIN, C., «Observaciones sobre la "actio libera in causa"», op. cit., p. 30.
} 
Así, la particular visión de RoxIN sobre la tentativa en la autoría mediata dentro de la teoría individual se centra en que el comienzo de la tentativa viene causada por el peligro inmediato para el bien jurídico, e inclusive sin este peligro, cuando existe una tentativa inacabada o por inacción dominativa del hecho por el sujeto mediato, según la representación de su plan, lo que significa que si no acaba el dominio del hecho, no cabe hablar aún de tentativa, ya que si el sujeto todavía no ha abandonado tal dominio es precisamente porque según su plan cabe realizar más aportaciones asegurativas para la ejecución por el instrumento. De esta manera, si seguimos la teoría de $\operatorname{RoxIN}^{1878}$-que refrenda, parcialmente, la teoría de la solución global o del instrumento-, sólo podría apreciarse la tentativa cuando desaparezca ese dominio del hecho, por ejemplo, se apreciaría la tentativa acabada en el último trago, pero la inacabada en los últimos tragos antes de alcanzar la inimputabilidad, por lo que trasladado a la alic se entendería el comienzo de la tentativa en el momento en el que se pierdan las facultades naturales de dominio sobre uno mismo. Esto no nos parece acertado pues desvirtúa precisamente el concepto de acción precedente relevante y el fundamento de punibilidad de la conducta en el inicio de la defraudación de la norma, pues de lo contrario habría que esperar a esa pérdida de facultad, o fin de la acción-omisión para criminalizar un comportamiento en grado de tentativa. Trasladado esto a la autoría mediata, tampoco se entiende por qué ha de esperarse a que el sujeto pierda el dominio del hecho sobre el sujeto instrumentalizado, pues lo que interesa es conocer la representación del autor sobre el plan delictivo para con ello conocer la posibilidad de revocación delictiva, el desistimiento ${ }^{1879}$. Así, para este penalista, la incidencia sobre el instrumento es ya tentativa cuando desaparece el dominio sobre el instrumento, y termina la tentativa (tentativa acabada) cuando el instrumento sale del poder de dominio del autor mediato. Este fundamento lo traslada para la tentativa en la actio libera in causa, al considerar que la tentativa comienza cuando el sujeto se coloca en la incapacidad de culpabilidad ${ }^{1880}$.

En contra de esta particular teoría cabe hacer la crítica contraria, precisamente por su escasa función preventiva general que considera impune las conductas del autor mediato que no son realizas por el instrumento. Las críticas a RoXIN se centran en la escasa fuerza normativa del concepto de dominio del hecho, cuando en muchos casos parece desaparecer o tener una intensidad mínima: el elemento del dominio del hecho es flexible.

\footnotetext{
1878 ID., ibidem, op. cit., pp. 29 a 32; ID., PG, I, op. cit., p. 885.

1879 DEMETRIO CRESPO considera que «mientras que la autoría mediata, dada su estructura de tentativa acabada, precisa necesariamente un desistimiento activo, en la alic es igualmente posible un desistimiento pasivo», DEMETRIO CRESPO, E., La tentativa en la autoría mediata y en la actio libera in causa, op. cit., p. 142.

${ }^{1880}$ ROXIN, C., «Observaciones sobre la "actio libera in causa"», op. cit., pp. 29 y 30.
} 
Por nuestra parte, nos adherimos a los postulados generales de la tentativa de la teoría de la solución individual (Einzellösung) o del autor mediato. La tentativa comienza en el momento en el que el autor mediato incide sobre el autor inmediato o instrumento (Einwirkungslehre), lo que trasladado a la autoría mediata dual o a la imputación objetiva a la propia víctima sucede cuando el propio sujeto se autocoloca en una situación previsible de pérdida de la capacidad de libertad de voluntad, aunque como ya hemos explicado anteriormente esta solución tiene problemas cuando no existe una incidencia sobre el autor inmediato, una incidencia material o conexa. En nuestra opinión, la incidencia debe ser suficiente, significativa, real e idónea. Con ello queremos dejar patente que no basta ni es presupuesto necesario la materialidad de la incidencia sobre el sujeto de delante o por el mismo sujeto, pues en los casos de persuasión coercitiva a los que aludíamos supra ya explicábamos que no existe una incidencia verdaderamente material, pues hay una desconexión objetiva y subjetiva entre el inicio de la afección y el resultado en virtud de los márgenes de libertad de la víctima y/o autor.

La inserción de valores contradictorios con el ordenamiento jurídico, y más concretamente el inicio de la restricción del horizonte de expectativas normativas y sociales conforme al Sistema o su eliminación, es el presupuesto para acreditar ya una incidencia en el instrumento. Lo que habrá que matizar si esta incidencia es un acto preparatorio o una tentativa. En nuestra opinión, habrá que examinar la representación del autor en el caso de autores mediatos o la consciencia o inconsciencia de la propia víctima en su conducta imprudente o de autopuesta en peligro.

FARRÉ TREPAT y DEMETRIO CRESPO ${ }^{1881}$ consideran que habrá que atender al grado de peligrosidad existente entre la acción que incide sobre el sujeto-instrumento y la propia ejecución llevada a cabo por éste, por lo que en aquellos casos de lejanía del factor nos encontraremos ante actos que deben ser imputados como actos preparatorios, precisamente por la falta de peligro inminente para el bien jurídico. La inminencia de la peligrosidad debe ser entendida como

\footnotetext{
${ }^{1881}$ FARRÉ TREPAT, Elena, «Sobre el comienzo de la tentativa en la omisión, en la autoría mediata y en la actio libera in causa», Estudios Penales y Criminológicos, XIII, 1990, pp. 73 y ss. pp. 77 y 80. Llega a considerar que la tentativa comienza con la antijuricidad del acto del autor mediato, siendo el grado de peligrosidad o proximidad de éste con el bien jurídico, elementos para graduar la pena aplicable en su extensión abstracta. También a favor de estas consideraciones, excepto en el elemento de la condición objetiva de punibilidad, al entenderla insatisfactoria; DEMETRIO CRESPO, E., La tentativa en la autoría mediata y en la actio libera in causa, op. cit., pp. 112, 113, y 115; ID., «Sobre el comienzo de la tentativa en la autoría mediata», www.cienciaspenales.net, pp. 18 y ss., también en Nuevas formulaciones en las Ciencias Penales. Homenaje a Claus Roxin, Córdoba, Argentina, Lerner, 2001, pp. 273 a 294. En contra de este planteamiento se ha manifestado ALCÁCER GUIRAO arguyendo que «considerar el dar principio a la ejecución como una condición objetiva de punibilidad, adelantando el comienzo de lo prohibido a un momento anterior, supone considerar a Derecho la totalidad de los actos preparatorios», y así, el sujeto mediato sigue teniendo domino del hecho, pues es él quien puede cortar la ejecución, es decir, desistir voluntariamente, cuestión que aparece en toda tentativa, como graduación no consumada. De tal suerte, la norma puede seguir motivando al sujeto hasta el extremo de convencerle para que desista, ALCÁCER GUIRAO, R., Tentativa y formas de autoría. Sobre el comienzo de la realización típica, $1^{\mathrm{a}}$ ed., Edisofer, 2001, pp. 147 y 148.
} 
condición objetiva de punibilidad que se añade al injusto de la tentativa, y así, en tal medida, rebasado tal límite, se establece como graduación de la pena aplicable ${ }^{1882}$.

En nuestra opinión, esta teoría en relación a la exigencia de la peligrosidad inminente como la condición objetiva de punibilidad- se aleja de los parámetros de representación del autor, sin éste no podemos conocer el grado de peligrosidad imputable subjetivamente. En el caso del miembro sectario que es persuadido coercitivamente, la persuasión puede haber sido producida años antes a la ejecución del delito-fin, por lo que la desconexión temporal no es ápice para no atribuir objetivamente el grado de tentativa, pues si el autor mediato, según su representación del plan, únicamente tenía que esperar a que el hijo del persuadido precisase de asistencia vital bajo consentimiento, o a que materialice su «suicidio», la desconexión temporal no acredita la ausencia de peligro. El peligro existe desde que se inicia la persuasión coercitiva idónea como adicción comportamental o como déficit de socialización. Así, cuando es el propio sujeto al que le es atribuible objetivamente la imprudencia o heteropuesta en peligro, la tentativa comienza con el inicio de riesgo de causación del déficit de socialización o la adicción comportamental.

En atención a lo dicho, habrá tentativa acabada cuando se termine de dominar, de influenciar. Pero cuando se influye, no sobre el instrumento, sino sobre la situación, la tentativa empezará cuando se empiece a influir sobre ésta, es decir, cuando se crea tal situación que habilita la dominación del hecho, en nuestro caso, con aquellas circunstancias descritas que propician el déficit de socialización: restricción del horizonte de expectativas normativas y sociales sobre las que orienta el Sistema.

Lo más reseñable en la teoría de JAKOBS es precisamente la coherencia con el concepto de dominio. El autor mediato debe conocer todas las circunstancias que le hacen autor mediato. Si falta algún elemento esencial, falta el dominio, al menos subjetivo, lo que en nuestra opinión no eliminaría la posibilidad de autoría mediata imprudente en el autor mediato: «en la autoría mediata debe saber que realiza las circunstancias que excluyen el comportamiento responsable (o, si se realiza autolesión: cuasi-responsable) del instrumento» ${ }^{1883}$, lo que en caso contrario, si desconoce que es un autor imputable, llevaría a una tentativa de autoría mediata, es decir, tentativa en coautoría o participación. Asimismo, en la imputación a la propia víctima como autor de su propio defecto, éste al menos precisa de cierta cognoscibilidad del riesgo de su conducta, o dicho de otra manera, que su imprudencia o autopuesta en peligro sea consciente sobre la posibilidad del resultado defectuoso. Así JAKOBS estima que en los casos antes

\footnotetext{
1882 FARRÉ TREPAT, E., «Sobre el comienzo de la tentativa», op. cit., pp. 114.

1883 JAKOBS, G., PG, op. cit., 21/107.
} 
expuestos de autolesiones dolosas de sujetos responsables el deber de impedirlas «no surge de esta especial confianza, en particular no para médicos», es decir, no surge para éstos la posición de garante. De tal suerte, la Sentencia del $\mathrm{BGH}^{1884}$ concluye que no se puede apreciar la posición de garante en el padre o en los médicos cuando la víctima de la autolesión tiene dominio de hecho, pero sí en la omisión cuando no la tiene, lo que puede trasladarse a los casos de adeptos que se auto-irrogan el riesgo de incapacidad de libertad de voluntad.

La doctrina crítica afirma que la alic se desvirtúa en la comisión imprudente, pues existe una desconexión entre la acción precedente relevante y la acción que causa la lesión al bien jurídico, pues si la imprudencia es ilícita es precisamente por la inobservancia del cuidado objetivamente debido, de lo que resulta que no sea necesario acudir a la doctrina de la alic $^{1885}$. Estamos de acuerdo con esto siempre y cuando no se admita la tentativa en la imprudencia. Sin embargo, nuestra posición va más allá. Al existir un fundamento de punibilidad en la tentativa de la imprudencia grave, obliga a considerar que también las conductas imprudentes que llevan a estados defectuosos de responsabilidad se pueden resolver con la alic.

Sin embargo, JOSHI JUBERT ${ }^{1886}$ resalta la impunidad de casos de alic en los que no se da comienzo a la ejecución del resultado, sino únicamente la acción precedente, por ejemplo, podríamos asimilar estos casos a los de incursión en grupos fundamentalistas en los que se conoce la posibilidad de adoctrinamientos contra el Sistema, lo que llevaría a la impunidad de estos casos si el sujeto sufre una déficit y/o perpetra un delito contra tercero o en perjuicio propio. Acertadamente DEMETRIO CRESPO critica que «si adoptamos esa actio praecedens como punto de referencia objetivo/subjetivo de la imputación es porque ex ante podemos afirmar que allí radica ya el comienzo de la tentativa» ${ }^{1887}$.

Así las cosas, la gran dificultad para los partidarios del modelo de la acción típica, entre los que nos encontramos, es responder a la relación causal entre la acción precedente y el resultado realizado en estado defectuoso. La respuesta a esta pregunta resulta más fácil para los partidarios del modelo de la excepción, pues para estos la tentativa comienza en la acción en estado defectuoso, y por tanto la relación causal es más fácilmente apreciable, sin embargo, se ven obligados a considerar que la acción provocante del estado defectuoso, es decir, por ejemplo la

\footnotetext{
${ }^{1884}$ BGH, 32, pp. 367 y ss., y 373 y ss., vid. JAKOBS, G., PG, op. cit., 29/70, nota 141.

1885 Joshi JUBERT, U., La doctrina, op. cit., p. 395, DEMETRIO CRESPO, E., La tentativa en la autoría mediata y en la actio libera in causa, op. cit., p. 136.

${ }^{1886}$ JOSHI JUBERT, U., La doctrina, op. cit., p. 416. Similarmente FARRÉ TREPAT opina que el injusto de la tentativa viene configurado por la acción de puesta en peligro inminente para el bien jurídico, FARRÉ TREPAT, E., «Sobre el comienzo de la tentativa», op. cit., p. 46 y pp. 80 y 81.

${ }^{1887}$ DEMETRIO CRESPO, E., Tentativa en la autoría mediata, op. cit., p. 140.
} 
acción de embriagarse, es únicamente un acto preparatorio ${ }^{1888}$; pues aunque exista dolo en ese momento, no es todavía un injusto.

Pero esta tesis olvida la referencia al plan del autor. Para JAKOBS, quien defiende el modelo de acción típica al concebir un concepto de culpabilidad de modo funcional ${ }^{1889}$, no es necesaria la culpabilidad en el propio hecho material de lesión. Así, conforme a la representación del autor, según el caso, podemos discernir entre los actos preparatorios y el principio de ejecución, y por tanto entre tentativa acabada e inacabada, pero sobre todo, la referencia a la representación ayuda a delimitar el delito objetivamente imputable al autor, conclusión que ya fue expuesta supra, pero que también sirven de fundamento de punibilidad y de comienzo de la actio libera in causa. La dificultad en la que incurre el modelo de la acción típica sobre la delimitación de la tentativa acabada e inacabada puede salvarse si consideramos que habrá tentativa en la alic con el inicio de la acción que provoca después el estado defectuoso y por tanto la tentativa acabada comenzará «con la ejecución del último acto necesario para ocasionar la inimputabilidad» ${ }^{1890}$, precisamente porque el domino del hecho comienza con la acción de pérdida del estado defectuoso y termina (tentativa acabada) con la pérdida de tal dominio, por lo que el desistimiento sólo podrá apreciarse mientras exista domino del hecho (libertad, voluntariedad, espontaneidad), pues una vez acabada la tentativa ya no existirá un desistimiento voluntario.

Podemos asumir que no existe objeción alguna para postular la actio libera in causa en la imprudencia consciente de sujetos que «permiten» un adoctrinamiento que cause un déficit de socialización atribuido a tercero pero en concurrencia imputable al propio sujeto, o una adicción comportamental, que en ambos casos lleve a una lesión jurídica de los derechos del propio

${ }^{1888}$ HRUSCHKA, J., Strafrecht nach logisch-analytischer methode, op. cit., pp. 335 y ss; JESCHECK HH / Weigend T., Tratado, op. cit., 40, VI; Stratenwerth, G., PG, I, op. cit., p. 245 y ss; Alonso Álamo, M., «La acción "libera in causa"», op. cit., pp. 57 y ss.

${ }^{1889}$ El concepto de culpabilidad funcional de JAKOBS es atacado por JOSHI JUBERT apelando a la inseguridad jurídica, pero a su vez admite igualmente que la acción precedente es el fundamento de punibilidad de la alic, JosHI JUBERT, U., La doctrina, op. cit., pp. 345 a 347.

1890 JAKOBS, G., PG, op. cit., 17/68. En concreto JOSHI JUBERT fundamenta su teoría de la alic sobre el presupuesto de la acción provocante y relevante. Entiende que tal acción tiene ya suficiente capacidad de relación causal con el resultado. Esta acción de provocación sólo será relevante cuando ponga en peligro inmediata y/o directamente al bien jurídico, pero según la configuración subjetiva del plan del autor sobre el devenir causal de la acción, con lo que se podrá averiguar cuál de los bienes jurídicos puestos en peligro es el que quiere lesionar (dolo) o puede lesionarse (imprudencia) y así, la acción que provoca el estado defectuoso es, comienzo de la tentativa, del injusto, y por tanto, comienzo de lo relevante penalmente. JOSHI JUBERT, U., La doctrina, op. cit., pp. 362 y ss. JOSHI JUBERT considera la alic, como un sub-caso de autoría mediata, por lo que habrá que reconducir la estructura de la autoría mediata a la alic. Así la tentativa comienza cuando se incide sobre el instrumento, es decir, cuando el autor incide sobre sí mismo, con la acción de procurarse un estado de irresponsabilidad, lo que es en definitiva, cuando se pierde el dominio del curso causal, el dominio del hecho, en estos casos, el dominio funcional, lo que supone una congruencia estructural con la categoría de la inducción. Así también lo entiende JAKOBS, G., PG, op. cit., $17 / 64$. 
sujeto, o contra un tercero, lo que nos planteará la problemática de la autoría mediata, o de la coautoría y participación en las lesiones de los propios bienes jurídicos o de terceros.

\section{B. Conclusión y trascendencia de la actio libera in causa en la tentativa de persuasión} coercitiva y en la imputación objetiva a la propia víctima

Pues bien, según lo expuesto supra, cuando existe el influjo imprudente de un sujeto en la restricción del horizonte de expectativas y una conducta imprudente sobre la posibilidad de causación del defecto (imprudencia consciente o heteropuesta en peligro) que procura el déficit de socialización atribuido también a tercero, y que lleva a la concurrencia de un estado de necesidad exculpante, estamos en verdad hablando de concurrencia de culpas, o más exactamente de una «comunidad riesgosa imprudente», cuando la víctima se causa su propia lesión con intervención también de un tercero, o un grupo exactamente, como en los casos de dinámicas grupales que restringen el horizonte de expectativas.

Entonces, la pregunta es si esa causa de exculpación se puede imputar nuevamente al propio autor a través de la actio libera in causa. O en el mismo caso, cuando la conducta se declara inimputable por una causa de inculpabilidad por adicción comportamental o trastorno mental, si se puede imputar nuevamente al propio autor a través de la actio libera in causa.

En verdad, el tradicional modelo de autores dolosos (líder y/o miembros activos) de la persuasión coercitiva si bien es cierto no puede explicar muchas de las situaciones dramáticas que se viven en este tipo de grupos. De aquí la necesidad de regular la tipicidad de la persuasión coercitiva imprudente como delito de coacciones. La casuística que hemos analizado desde varias perspectivas (filosófica, histórica, sociológica, psicológica, médica y neurocientífica) nos hace concluir que es una dinámica comportamental común, la que como comunidad de confianza especial, vida en común, estrecha relación de intereses y de lealtad, propicia un caldo de cultivo en la dinámica criminal y en común organización, en la que sin saberse a veces muy bien quién la inicia (habitualmente se dice que es el líder dolosamente), suele concurrir una «comunidad riesgosa imprudente».

Lo que sucede $-\mathrm{y}$ aquí nos servimos de la actio libera in causa en su modelo de acción típica y de la tentativa en los postulados de solución individual- es que si bien la conducta previa del sujeto es imprudente, en el sentido de que se puede representar cierto riesgo del totalitarismo y del autoritarismo, tanto la conducta que el propio sujeto realiza en contra de sus intereses, como la comisión de delitos ordenados, o conforme a la doctrina de dinámica grupal, se puede imputar imprudentemente al propio sujeto y a todo el grupo. De aquí se fundamenta la responsabilidad 
imprudente en el delito cometido bajo dicho defecto, pero también la responsabilidad de cada sujeto del grupo en la causación del defecto como delito de persuasión coercitiva imprudente, o en su caso doloso, y por lo tanto también del delito perpetrado por el ejecutor.

Esto significa que los títulos de imputación divergen entre la imprudencia consciente y la inconsciente, de manera que la primera faculta la aplicación de la alic aunque concurra un posterior déficit de socialización, puesto que la segunda lleva a una total victimización. Sin embargo, en esta convergencia de la previsibilidad existen diferentes casos:

$1^{\circ}$ Un sujeto quiere convertir su conciencia en una causa ineludible de la voluntad, esto es fanatizando postulados contra el Sistema o particularmente contra una norma. Aquí subyacen casos de autoría por convicción, del enemigo o del autor de conciencia en los que el déficit de socialización es atribuible dolosamente al sujeto, por lo que aunque el delito sea imprudente, se puede responsabilizar a título doloso. Estos casos serían los de autoría de conciencia imprudente, si bien también es posible en la autoría por convicción o en la del enemigo.

$2^{\circ}$ Un sujeto se autocoloca en una autopuesta en peligro de adoctrinamiento o de persuasión sin intervención de terceros. Aquí aunque la culpa consciente sin mediación de tercero cause un déficit de socialización, lleva a imputar responsablemente el delito doloso a título culposo. Algunos de estos supuestos podrían encontrarse en casos especiales del terrorismo individual. Sin embargo, en los casos de culpa inconsciente o autopuesta en peligro inconsciente sobre la causación de un déficit de socialización que a la postre causa un resultado injusto, salvo deber especial en su evitación, llevan a la causa de exculpación del estado de necesidad. En caso de deber especial habrá que determinar si la causación de la inconsciencia se puede atribuir al sujeto, en cuyo caso, nada impide responsabilizar a título imprudente.

$3^{\circ}$ Un sujeto se adentra en un grupo del que se puede conocer su adoctrinamiento totalitario y autoritario, postulados que rayan lo ilícito, y/o que de la dinámica grupal se puede conocer que los extremismos de los conceptos esenciales del Sistema (dinero, verdad, poder, salud, vida, muerte) exigen su intervención en el reforzamiento de su restricción o eliminación en la dinámica grupal. Aquí el sujeto entra en una heteropuesta en peligro de sus propios bienes de forma semi-consciente, en cuanto que si bien conoce dicho peligro no desea ex initio un resultado perjudicial para él ni para tercero. La posterior consciencia del peligro o la posterior aceptación del adoctrinamiento y su participación en dicha mediación ante terceros o en perjuicio propio, aun cuando medie un déficit de socialización exculpante o adicción comportamental inimputable, pueden ser responsabilizados en el delito-fin contra tercero a título de imprudencia. Cuando únicamente se produce un perjuicio propio, evidentemente no se puede criminalizar su 
propia «desgracia», pero nada impide que su dosis de culpabilidad se le atribuya en la intervención contra tercero a título imprudente, o la autoría de los terceros en la causación de dicho déficit como delito de persuasión coercitiva, o en la adicción comportamental como delito de lesiones, doloso o imprudente en su caso. Con esto se puede concluir un caso paradigmático de la problemática de las sectas coercitivas: la «comunidad riesgosa imprudente», en la que cada sujeto es responsable de su propio injusto dentro de una misma comunidad que produce el resultado.

$4^{\circ}$ También se fundamenta de aquí otra importante conclusión sobre la que abundaremos: la organización criminal de las sectas, la mayoría de veces, responde más a una imputación personal de imprudencia consciente, en cadena o simultánea por la persuasión coercitiva de todos los miembros, que puede imputarse dolosamente en los casos en los que cada sujeto -a pesar de constituir su propia conducta una imprudencia sobre la posibilidad de causar el defecto en el tercero- conoce que la conducta de los demás miembros del grupo aumenta la probabilidad, de tal manera que su propia acción junto a la de los demás constituye un «dolo grupal» del que el sujeto en particular conoce la probabilidad del resultado. De aquí la imputación personal a titulo doloso por dicho delito y la configuración de un dolo grupal como organización criminal cuando existe una «comunidad especial de confianza» que propicia un deber positivo de cada sujeto en los demás.

De esta manera evitamos -o, mejor dicho, solucionamos- tener que proponer la criminalización de la organización criminal imprudente, si bien, no existe obstáculo como veremos en el siguiente capítulo en relación al art. $515.2^{\circ} \mathrm{CP}$ y al delito de coacciones.

Puesto que hemos concluido supra que tanto en el delito de coacciones como en la persuasión coercitiva concurre un singular elemento subjetivo del injusto, en el sentido expuesto por PolAino NAVARRETE, esto es, la finalidad de restringir la voluntad, un plus en el dolo, y que por otra parte, era recomendable la tipificación, de lege ferenda, de las coacciones imprudentes graves, como la persuasión coercitiva realizada imprudentemente en culpa consciente, para evitar problemáticas de la modalidad imprudente, si bien hemos concluido que la fórmula legal no la impide según los postulados que hemos venido manteniendo, y tal y como fundamentaremos en el siguiente capítulo, aunque cada conducta de persuasión coercitiva tratada individualmente y personalmente sea imprudente, existe un deber especial de protección en relación a determinados resultados cuando se configura una «comunidad especial de confianza». 


\section{Proposiciones conclusivas y de lege ferenda}

Lo expuesto en este capítulo y anteriores prueba la necesidad de recoger esta forma de criminalidad de las sectas coercitivas en un nuevo delito, llámese tradicionalmente «lavado de cerebro», o como se ha concluido aquí: delito de «persuasión coercitiva». Éste precisa para evitar problemáticas y recurrir a fórmulas complejas la tipificación de la comisión imprudente.

Resumo mis consideraciones en las siguientes propuestas conclusivas:

1) El delito de coacciones recoge, con mayor precisión que otras figuras delictivas, la dinámica criminal y resultado de la persuasión coercitiva en cuanto ataque a la capacidad de libertad de voluntad de actuar en general y a formación de la libertad de conciencia, en su forma agravada de delito contra los derechos fundamentales, si bien la penalidad, aun en esta forma agravada es claramente insuficiente en determinados casos graves, máxime por la concurrencia de agravantes genéricas (alevosía, abuso de superioridad y confianza) que precisa una reformulación de la extensión de la pena en sentido amplio, al objeto de cubrir todas la posibilidades. La pena a la que puede llegar la consumación de tales prácticas no es proporcional a la ofensa y bienes jurídicos afectados (libertad de actuar, libertad de conciencia y la integridad psíquica) cuando la intensidad del ataque, el incremento de la probabilidad del resultado y diminución de la posibilidad de defensa, el abuso de superioridad y confianza, la perdurabilidad del quebrantamiento de dichos bienes (consumación permanente), el periodo en que se han vulnerado y las consecuencias inherentes producidas exigen, además de la tipificación de esta dinámica criminal, una pena (funcionalmente) equiparable a la gravedad de la acción y del resultado producido en la víctima, similar al delito de detención ilegal agravado, por cuanto éste es una especificidad agravada del delito contra la libertad en su modalidad ambulatoria, especificidad que se cumple en con la persuasión coercitiva, y similar al delito de lesiones graves, lo que aconseja una pena abstracta (límite mínimo y máximo de pena) suficientemente amplio para que el Juez pueda determinar la pena a cada caso en concreto.

2) El concepto de violencia y engaño de la persuasión coercitiva se asimila a los conceptos de violencia y engaño de otros delitos normalmente concurrentes (coacciones, contra la vida, patrimoniales, libertad e indemnidad sexual e intrusismo), lo que genera problemas de concurso que generalmente se resuelven por el de leyes, en los que median agravantes genéricas (alevosía, abuso de superioridad y confianza) y, de otra parte, problemas de ne bis in idem con agravantes específicas o accidentales cuando coinciden agravantes genéricas en el tipo básico. La persuasión coercitiva consumada produce per se un ataque a la salud psíquica y un segundo resultado tardío en un delito de lesiones psíquicas graves, lo que produce un concurso de leyes con el delito de 
coacciones, que por las reglas del art. 8 del Código penal aconsejan la aplicación del principio de consunción al tratarse la persuasión coercitiva de una modalidad del delito de lesiones cuando éste resultare.

3) La dinámica criminal utilizada para perpetrar los delitos, las técnicas de persuasión coercitiva, son en sí mismas acciones peligrosas para los bienes jurídicos mencionados. Representan un desvalor de la acción al modo de la alevosía, abuso de superioridad y de confianza, o de un arma o instrumento peligroso para tales bienes y su resultado ataca a bienes fundamentales de estricta necesidad de la persona. La inclusión de la modalidad del engaño parece también adecuada en virtud de la semejanza en la gravedad de lo injusto, a pesar de no corresponder al concepto de violencia, y porque en definitiva el engaño también supone una restricción palpable del horizonte de expectativas, similar a la estafa, o como modalidades del delito de detención ilegal o inducción al suicidio.

4) Los déficits de socialización por educación totalitaria y/o criminal y por educación cultural y tradicional son presupuestos de la causa de exculpación de estado de necesidad exculpante, basado en la incapacidad de libertad de voluntad por la restricción o eliminación del horizonte de expectativas normativas y sociales sobre las que el Sistema orienta.

5) La imprudencia consciente o autopuesta en peligro que causa un déficit de socialización exculpante de estado de necesidad completa el tradicional modelo de autores dolosos, y puede imputarse mediante la alic a la conducta precedente de la propia víctima (imputación de la propia víctima) sin perjuicio de la imputación por la intervención o aportación de un tercero doloso o imprudente.

6) La dinámica comportamental grupal que genera un riesgo manifiesto en persuasiones coercitivas recíprocas, fundamenta la punibilidad de la organización criminal imprudente que, según los casos, puede imputarse dolosamente.

7) La persuasión coercitiva que condiciona la creación de un déficit de socialización atribuible a tercero puede modular, crear o modificar las tipologías criminales de la autoría de conciencia, por convicción y de enemigo, como si de una decisión propia se tratara.

Llegados a este punto, planteamos la siguiente propuesta de tipificación de lege ferenda, que en nuestra opinión se podría ubicar en un art. 172 CP quater:

«Será castigado con la pena de prisión de tres a seis años:

El que mediante violencia, intimidación, engaño bastante o mediante técnicas o procedimientos de persuasión coercitiva físicas y/o psíquicas, incapacitara la libre formación de la voluntad, la libertad de decisión y/o de ejecución. 
La pena también se agravará en uno o dos grados si el hecho se perpetrare sobre incapaz, menor de edad, sobre persona con estado de ignorancia o con especial vulnerabilidad social, y en dos grados siempre que se perpetre sobre un grupo de personas.

Será castigado con la pena de uno a tres años las conductas anteriores que se realizaren con imprudencia consciente grave.

En caso de que estas conductas se realizan en el seno de una organización, a los directivos, jefes, líderes y miembros activos, de hecho o de derecho se les impondrá la pena veinte a veinticinco años de prisión y multa de 200.000 euros en supuestos dolosos, y de seis a doce años de prisión y multa de 100.000 en supuestos de imprudencia grave».

Con esta formulación del injusto podemos conseguir aclarar varios puntos:

$1^{\text {o }}$ Separar el injusto del art. $522 \mathrm{CP}$ dedicado expresamente a la protección de la manifestación externa del derecho a la libertad religiosa o de conciencia, de manera que con el nuevo tipo se criminaliza el ataque a la modalidad interna, en concreto, a la capacidad de libertad de voluntad sin perjuicio del concurso con éste y otros delitos.

$2^{\circ}$ Se incluye una fórmula amplia de medios de comisión incapacitantes de la libertad, resolviendo las controversias mediante la fórmula «técnicas o procedimientos de persuasión coercitiva físicas y/o psíquicas» análogamente al concepto de violencia, e introduciendo el «engaño bastante» como una forma más de incapacitación de la libertad de voluntad (restricción de las expectativas), similarmente al elemento central del delito de estafa. La incapacitación de la «libre formación de la voluntad, la libertad de decisión y/o de ejecución» ha de ser entendida conforme al concepto de merma o restricción, al objeto de dejar la eliminación de la capacidad completa o plena al delito de lesiones mediante adicción comportamental o trastornos psíquicos.

$3^{\circ}$ La penalidad se aumenta por el mayor desvalor de la acción y del resultado, se asimila al delito de detención ilegal y por debajo del delito de lesiones especialmente agravadas por el resultado, pero con suficiente amplitud en la pena abstracta al objeto de poder determinar distintas gravedades de la acción y del resultado. El concepto de violencia o engaño incluyen el mayor desvalor con el que se perpetran estas conductas mediante la alevosía, el abuso de superioridad y de confianza, si bien esto genera problemas en el tipo imprudente.

$4^{\circ}$ La penalidad se agrava en caso de víctimas incapaces, menores de edad, sobre personas con estados de ignorancia o con especial vulnerabilidad social, refiriéndonos con esta expresión a una fórmula de numerus apertus con la que pueden específicamente entrar otras formas relevantes no estrictamente endógenas y diversos tipos de déficits de socialización (por ejemplo el aislamiento social). De esta manera se asimila el tipo a las agravaciones de los delitos de detención ilegal y secuestro y contra la libertad e indemnidad sexual, pero a la vez, se distinguen 
los supuestos de aprovechamiento de tales circunstancias de los que no, de modo que generalmente el sujeto pasivo puede ser cualquier persona física, independientemente de su credo, religión o ideología (también ateísmo o incredulidad), agravándose cuando se perpetre sobre un grupo de personas. Así también se resuelven los problemas de baja penalidad del delito de coacciones agravado cuando afecta a derechos fundamentales.

$5^{\circ}$ Con la criminalización de este injusto se consiguen disipar las lagunas punitivas del delito autónomo de «manipulación mental» al que hace referencia el art. 515.2 ${ }^{\circ} \mathrm{CP}$.

$6^{\circ}$ Se criminaliza expresamente la organización dolosa o que con imprudencia grave cause este tipo de resultado.

$7^{\circ}$ Se criminaliza de forma agravada, similarmente al delito de organización terrorista, la pertenencia a organización criminal dolosa o por imprudencia grave.

$8^{\circ}$ La imprudencia consciente en la incursión de un déficit de socialización y cuyo resultado es un delito doloso o imprudente puede resolverse mediante la alic en un delito imprudente del todo responsable, lo que no niega la responsabilidad en calidad de autor o autores de quienes han intervenido en la causación de dicho déficit como delito de persuasión coercitiva doloso o imprudente.

$9^{\circ} \mathrm{Y}$, por último, se compatibiliza gradualmente la criminalización de la organización criminal dolosa o imprudente, con el delito de persuasión coercitiva y el delito de lesiones, de manera que se diferencian los momentos ejecutivos y consumativos de cada uno, excepto en el de pertenencia que se trata de un delito de estatus. 


\section{CAPítulo VII}

\section{DINÁMICA COMPORTAMENTAL DE LOS DELITOS-FIN EN LAS SECTAS COERCITIVAS COMO INJUSTO SISTÉMICO}

\section{I.- Inducción y persuasión coercitiva en los delitos-fin sectarios}

A. La persuasión como forma de inducción y diferenciación normativa con la persuasión coercitiva

No es difícil advertir que la persuasión y la inducción para que un tercero cometa un injusto son formas de participación, cuyo fundamento puede hallarse en distintas soluciones, si bien la persuasión también puede ser un delito autónomo según las conclusiones a las que hemos llegado y que pueden afectar tanto al autor de conciencia, por convicción como al enemigo.

Existe acuerdo unánime en que la inducción es una forma de participación que se rige por las reglas de accesoriedad por el hecho ajeno, si bien, en la actual discusión doctrinal, son cada vez más las voces que otorgan mayor protagonismo a la inducción como una forma de autoría que despoja de sentido a la autoría mediata y a la prohibición de regreso en casos de autopuestas en peligro que tienen como finalidad la comisión de delitos. Sin embargo, esta tendencia doctrinal no elimina el campo propio de la inducción cuando no pueda ser tratada como autoría, sino como «simple» ${ }^{1891}$ y pura inducción participativa al hecho ajeno, que refuerza la idea de que la aportación del inductor, en su propio campo, merece una menor pena que el autor a pesar de la previsión legal del $\mathrm{CP}$ que equipara su penalidad abstracta.

Se ha dicho que el fundamento primario de punibilidad de la inducción está en que es el primer elemento causal del hecho que posteriormente finaliza el autor material. Se trata a la inducción como el primer desencadenante del hecho delictivo. Sin embargo, achacar la causalidad del hecho al primer acto -el de inducción- sería negar toda libertad al autor, tratarlo como inimputable cuando menos, lo cual sí parecería factible en el persuadido coercitivamente si el grado de afección es tal que incida totalmente en el grado de decisión de éste, que lo cree y domine por completo, como aquellos casos a los que nos hemos referido de adicción comportamental.

${ }^{1891}$ SÁNCHEZ-VERA, J., «En los límites de la inducción», InDret, 2/2012, p. 15. 
Sin embargo, según las conclusiones a las que hemos llegado en la persuasión coercitiva, si bien constituye un delito coacciones grave, el injusto no se fundamenta en el dominio de la voluntad, sino, generalmente, en la creación de un déficit de socialización que restringe el horizonte de posibilidades y por tanto la elección de expectativas. De este modo concluimos que la persuasión coercitiva es un modo de restringir la capacidad de voluntad y decisión como delito de coacciones. La pregunta dogmática que nos debemos hacer de esta conclusión es, en verdad, si ha de tratarse esta forma de restricción de la capacidad de voluntad como una forma de participación representada en la inducción o coautoría, o una forma de autoría de dominio de la voluntad en autoría mediata. En este apartado nos centraremos en analizar qué diferencias existen entre una conducta propiamente dicha de persuasión coercitiva y la inducción, y en su caso, qué trascendencia tiene en la dogmática-penal. A este respecto, GóMEZ RIVERo considera que el único fundamento para equiparar la pena del inductor y la del autor es el aspecto volitivo doloso $^{1892}$. En esta medida, la semejanza con la persuasión coercitiva parece nula por cuanto la persuasión se puede realizar con imprudencia consciente.

Según la Real Academia de la Lengua Española, el verbo inducir significa «instigar, persuadir, mover a alguien», pero también como segunda acepción «ocasionar». Sin embargo, el Diccionario establece en relación a la acción de manipular que consiste en «intervenir con medios hábiles y, a veces, arteros, en la política, en el mercado, en la información, etc., con distorsión de la verdad o la justicia, y al servicio de intereses particulares». Mientras que sobre la acción de persuadir dice que supone «inducir, mover, obligar a alguien con razones a creer o hacer algo». De estas definiciones, y en relación a las consideraciones de estudios especializados que hemos tratado en el capítulo cuarto sobre el concepto de persuasión, no escapará que nada impide que ésta pueda realizarse imprudentemente, de modo que se abandona el tradicional postulado de que la persuasión ha de ser intencional.

Así las cosas, si tratamos la inducción como la influencia de sugestión del inductor que llega a controlar la decisión o voluntad del inducido, la peligrosidad se hallaría, precisamente, en el escaso margen para el desistimiento tanto del inducido como del propio inductor sobre él, dada la anulación de la personalidad, lo que llevaría a un escaso margen de control por el inductor. Sin embargo, la tradicional idea de que el Derecho penal sólo puede imputar peligros no responde precisamente a la pregunta de qué es un peligro. La nueva teoría de la imputación objetiva trata de responder a la pregunta de qué riesgos son precisamente desaprobados (creación desaprobada

\footnotetext{
1892 GÓMEZ Rivero, Mª C., La inducción, op. cit., p. 68: «que el nacimiento de la voluntad delictiva sea obra del inductor condiciona la propia existencia de la inducción».
} 
de un peligro). Cierto es que el Derecho penal debe combatir creaciones desaprobadas de riesgos imputables a sujetos libres. Esto se ve claramente en la asociación de los fundamentos de punibilidad de los delitos imprudentes y en la imputación objetiva de los delitos dolosos ${ }^{1893}$, es decir, un peligro abarcado por el autor mediante dolo o imprudencia ${ }^{1894}$.

Al hilo de esto, señala GómEZ RIVERo que el desvalor de la inducción punible será el que «alcance un determinado grado de peligrosidad para incidir en la motivación del autor, venciendo las inhibiciones que para él pudiera suponer la comisión del delito» ${ }^{1895}$. Considera que los siguientes conceptos sirven para objetivar la peligrosidad de la acción de inducción: la peligrosidad en la introducción de elementos objetivos de viabilidad del plan que sugestionan un plan concreto con particularidades. En estos casos, sólo si las particularidades son de tal entidad que convencen al autor o ayudan a su decisión final, puede hablarse de inducción, mientras que si la particularidad se sustenta en la simple idea vaga de cometer un delito, la particularidad brilla por su ausencia. Sin embargo, si el inductor da el plan a seguir, ¿qué diferencia habrá ahora con la coautoría? Se podría considerar que en los casos de coautoría al existir, por lo general y previamente, una resolución condicionada, no podrá hablarse de inducción ${ }^{1896}$.

Todo esto, en nuestra opinión, es ajeno a la persuasión coercitiva, puesto que en ésta se crea (dolosa o imprudentemente) un déficit en las posibilidades de elección, equiparable a la incapacidad de la libertad de voluntad y de la decisión, pero con la peculiaridad de que no se disminuyen las capacidades volitivas ni cognitivas inherentes al sujeto, por lo que es posible una persuasión y a la postre una inducción o una coautoría en un posterior delito-fin.

$\mathrm{Si}$ el inductor da elementos inhibitorios, o ventajas para la consecución delictiva, o mediante la aportación de una promesa o una recompensa hace definitivamente decidirse al autor, estas aportaciones se pueden reconducir a figuras menos problemáticas como la coautoría o la participación. Sólo si se aporta una organización extraña a los datos conocidos por el autor, es decir, sólo cuando se aporta un dato no neutral que pretende modificar el destino estaríamos ante una aportación objetivamente peligrosa que constituye una inducción. Así, los especiales

1893 MARTínEZ ESCAMILlA, Margarita, La imputación objetiva del resultado, Edersa, 1992, pp. 84 y ss. pp. 247 y 248; Corcoy Bidasolo, M., El delito imprudente, op. cit., pp. 335 y ss; MIR PUIG, S., PG, op. cit., p. 245; GóMEZ RIVERO, $\mathrm{M}^{\mathrm{a} C}$., La inducción, op. cit., p. 73 y ss., apoya la teoría del peligro objetivo desde una perspectiva ex ante sobre la peligrosidad de la situación, su probabilidad y mediante la adecuación del juicio de un hombre prudentemedio; GómEZ BENíTEZ, JM., Teoría jurídica del delito, op. cit., p. 187; GIMBERNAT, E., Delitos cualificados por el resultado y causalidad, Centro de Estudios Ramón Areces, 1990, p. 155.

${ }^{1894}$ CORCOY BIDASOLO, M., El delito imprudente, op. cit., p. 339.

1895 GÓMEZ RIVERO, Mª C., La inducción, op. cit., p. 71.

1896 Otros como CUELlo CONTRERAS, consideran que la previa conspiración es una forma de inducción recíproca, CuEllo CONTRERAS, J., La conspiración para cometer delito: interpretación del art. 4, 1, C.P: Los actos preparatorios de la participación, Bosch, 1978, p. 189. Añade que la autoría es una forma más grave que la inducción, ID., ibidem, op. cit., p. 191. 
elementos subjetivos ${ }^{1897}$ conocidos por el inductor son relevantes en la imputación penal, lo cual responde, según el contexto, a la pregunta sobre la existencia de la peligrosidad mínimamente racional en la representación del autor, provocada por el inductor. Pero este mismo fundamento sirve en la persuasión coercitiva, por cuanto la restricción del horizonte de posibilidades supone una aportación objetivamente peligrosa, no neutral, cuando dicho horizonte desocializa al sujeto y procura la incapacidad de la voluntad.

Se dice que la inducción es una influencia psicológica que parece inherente a la propia acción de la inducción ${ }^{1898}$. En la inducción parece necesario que el desvalor de la acción se materialice en un resultado que se puede concretar en que en el autor nazca la resolución delictiva o dependencia de la resolución, y por otro lado, que comience un principio de ejecución, es decir, se exige por la mayoría de la doctrina ${ }^{1899}$ un doble resultado. Por eso, la falta del segundo resultado se reconduce, al menos en Alemania, a la figura punible de la inducción intentada. El primer resultado al que se refiere, el nacimiento de la resolución y su dependencia, debe desvincularse de otras conductas como la complicidad, la cooperación y la autoría mediata. De aquí que le asista razón a SÁNCHEZ-VERA en que «reforzar el dolo no es determinarlo, sino ayudar a su mantenimiento o consolidación de modo que no decaiga, y la ayuda es complicidad» ${ }^{1900}$, por eso concluye que «cuando exista simultaneidad entre el supuesto

1897 GÓMEZ Rivero, Mª., La inducción, op. cit., p. 88, concluye que «si bien los especiales conocimientos del hombre de atrás pueden incidir en la superación de los límites de riesgo tolerado, por convertir en peligrosa una incitación que de otro modo no lo sería, no pueden transformar en incitadora, ni por tanto en inducción, una actuación que se limita a crear las condiciones para que el autor, autónomamente, se decide en cualquier sentido, por mucho que su personalidad haga previsible cuál sea éste».

1898 En concreto, para GÓMEZ RIVERO, la acción típica de inducir «consiste en el ejercicio por el inductor de una incitación o actividad persuasiva a la que es inherente la noción de influjo psíquico, que, desde una perspectiva abstracta y ex ante, representa un riesgo penalmente relevante de que el destinatario adopte y ejecute la resolución delictiva, peligrosidad que se traduce así en la capacidad potencial de la incitación para vencer sus inhibiciones para la comisión del delito, y en definitiva, para inclinar su voluntad en el sentido del comportamiento que se le propone», ID., ibidem, op. cit., pp. 169 y 170. Al respecto no podemos estar de acuerdo en dos sentidos. Por un lado, la referida autora asemeja la inducción a la actividad de persuasión cuando ésta tiene otros efectos normativos según lo dicho, y por otro, comete una incoherencia entre su planteamiento garantista de los bienes jurídicos, ligados ahora con una peligrosidad potencial de la conducta que se desligada precisamente del bien jurídico, puesto que en la persuasión coercitiva, a la que ella parece llamar manipulación, se quebranta la libertad, mientras que la inducción supone la atribución de otro injusto, el que sea (también podría ser la persuasión coercitiva) por la elevación del riesgo de realización, de tal manera que es compatible el injusto de la persuasión coercitiva con una posterior inducción a otro a cometer un delito, inclusive para que cometa una persuasión coercitiva sobre otro (inducción en cadena). También en contra en Alemania, JESCHECK HH / WEIGEND T., Tratado, op. cit., 64, II 2; JAKOBS, G., PG, op. cit., 22/23.

${ }^{1899}$ En España BALDÓ LAVILlA, Francisco, «Algunos aspectos conceptuales de la inducción», ADPCP, 1989, p. 1093; Gómez Benítez, JM., Teoría jurídica del delito, op. cit., p. 519; MIR PUIG, S., PG, op. cit., p. 430; MUÑOZ CONDE F / GARCÍA ARÁn M., PG, op. cit., pp. 445 y ss; RuIZ AnTón, Luis Felipe, El agente provocador en el Derecho penal, Editoriales de Derecho Reunidas, 1982, p. 214; SÁNCHEZ-VERA, J., «En los límites de la inducción», op. cit., p. 16. En Alemania, JAKOBS, G., PG, op. cit., 22/22; RoXIN, C., «Sobre autoría y participación en el Derecho penal», Problemas actuales de las Ciencias Penales y la Filosofía del Derecho, Homenaje al Profesor Luis Jiménez de Asúa, trad. Enrique Bacigalupo Zapater, Buenos Aires, 1970, 26.16.

${ }^{1900}$ SÁNCHEZ-VERA, J., «En los límites de la inducción», op. cit., p. 23. 
comportamiento instigador y la supuesta acción inducida, no puede ser afirmada una renovación del dolo -ni menos su creación- ni, por ende, una inducción» ${ }^{1901}$.

Estamos de acuerdo con la afirmación de GÓMEZ RiVERo que concluye que «el límite mínimo de la intensidad del influjo psíquico y, por tanto, la capacidad mínima de la eficacia de la técnica incitadora a emplear, vendrá determinada por la circunstancia de que más allá de un mero reforzamiento de la resolución (complicidad psíquica ${ }^{1902}$ ), la incitación se haya convertido en desencadenante de la misma, su límite máximo habrá que marcarlo ahora allí donde la forma de instigar actúe eliminando o debilitando sustancialmente la formación libre de la voluntad del inducido». Sin embargo, comenta la referida penalista que esto llevará a la autoría mediata, conclusión con la que no podemos estar de acuerdo porque en la restricción de la voluntad, según lo explicado, no siempre media un dominio de la voluntad por coacción, sino la restricción del horizonte de alternativas, posibilidades que tienen analogía con la coacción, pero la trascendencia jurídico-penal es otra.

Sin embargo, en el déficit de socialización creado por persuasión coercitiva el sujeto es libre en su capacidad de voluntad, simplemente las posibilidades de acción o de omisión son menores o dirigidas a una acción en contra de sus propios intereses o de otros, esto es, se restringe el horizonte de expectativas conforme al Sistema Social, mientras que en la inducción sucede precisamente lo contrario, se amplía el horizonte de expectativas en un sentido criminal. Así se compatibilizan el injusto de la persuasión coercitiva y posteriores formas de participación en otros delitos cuando entre ambas media el déficit de socialización, pero a la vez, también se compatibilizan la adicción comportamental tras un déficit de socialización prolongado con la autoría mediata y la «autoría mediata dual», en la que el persuadido actúa contra sí mismo, y en adicciones plenas, la autoría directa. De tal manera, la invitación para cometer un delito, la recomendación específica o genérica, el consejo sobre las posibilidades de éxito, no pueden tratarse ni como inducción o persuasión coercitiva, pues nada añade a la voluntad del autor, o su incidencia en ella no genera un peligro significativamente importante para crear la

\footnotetext{
${ }^{1901}$ ID., ibidem, op. cit., p. 26.

1902 En este sentido y sobre la teoría de la preponderancia en los motivos que empuja a cometer el delito, RoxIN, C., Autoría y dominio del hecho, op. cit., pp. 550 y ss; FERnÁNDEZ IBÁÑEZ, E., La autoría mediata en aparatos, op. cit., pp. 225 y ss. Comenta que la diferencia entre complicidad psíquica e inducción se basa en la provocación de una resolución, por la que cuando se provoca será una inducción, mientras que si sólo se completa, reforzando o estabilizando, será una complicidad psíquica, mientras que en los aparatos organizados de poder, no estaríamos ante un omnímodo facturus, los ejecutores inmediatos no están dispuestos incondicionalmente ID., ibidem, op. cit., pp. 229 a 236.
} 
intercomunicación, pues si bien no puede tratarse de una acción neutra, sí es una complicidad psicológica que no cambia ni la voluntad ni la conciencia del autor ${ }^{1903}$.

Sobre las incitaciones implícitas, como actos estimulantes, algunos autores niegan su cualidad para formar parte de la inducción por falta del influjo psicológico ${ }^{1904}$, mientras que a otros les basta con que se cree una situación estimulante como criterio que fundamenta la punibilidad. Por nuestra parte, nos adherimos a la primera postura porque suponen conductas neutras o formas de complicidad psicológica, de tal manera que tras una persuasión coercitiva también es posible una complicidad psicológica o coautoría.

De otra parte, no podemos estar de acuerdo con la idea que mantiene que la inducción precisa de una comunicación verbal ${ }^{1905}$, y esto porque la inducción o la persuasión coercitiva no tienen por qué realizarse verbalmente según lo expuesto supra, si bien es la forma más usual ${ }^{1906}$, inclusive la forma omisiva sería una forma de inducción o de persuasión coercitiva. Piénsese por ejemplo en un líder de una secta que no socorre a un miembro en peligro de muerte, los demás miembros de la secta obrarán igual porque efectivamente dicha omisión, según las circunstancias, puede llegar a ser una persuasión in situ. Sensu contrario, sería despreciar la punibilidad de las formas más sofisticadas de inducción ${ }^{1907}$ o de persuasión. En nuestro caso, la persuasión in situ supone una orden tácita, no estrictamente una forma conclusiva de persuasión o técnica de persuasión, puesto que para que se omita la acción de los demás, es preciso que se haya finalizado la persuasión coercitiva como déficit de socialización, de modo que en este caso, la orden tácita ejecutada en omisión por los demás miembros supone una responsabilidad por coautoría en virtud de la comunidad especial de confianza ${ }^{1908}$.

${ }^{1903}$ En esta dirección también GóMEZ RIVERO, MåC., La inducción, op. cit., pp. 177 y 178, y pp. 421 y 422. En concreto comenta que «la simple invitación, sugerencia o consejo no adopta por sí sola de peligrosidad a la incitación, entendiendo por tal la capacidad de tal propuesta para vencer las inhibiciones del autor y conseguir que adopte la resolución de delinquir. Por ello si concurren otros elementos que le confieran dicho carácter peligroso, la incitación formulada de este modo se situaría dentro de los límites de la inducción», ID., ibidem, op. cit., p. 178.

${ }^{1904}$ RoXIN, C., «Sobre autoría y participación en el Derecho penal», op. cit., 26.58; ID., Autoría y dominio del hecho, op. cit., pp. 565 a 567; JESCHECK HH / WEIGEND T., Tratado, op. cit., 64, II 2; JAKOBS, PG, op. cit., 22/22 afirma que la voluntad del inducido debe depender o estar en función de la del inductor; STRATENWERTH, G., $P G, \mathrm{I}$, op. cit., 354 y ss; Welzel, H., Derecho penal alemán, op. cit., pp. 166 y ss. En España, BALDó LAVILLA, F., «Algunos aspectos conceptuales de la inducción», op. cit., p. 1098; RODRÍGUEZ DEVESA JMa / SERRANO GÓMEZ A., PG, op. cit., pp. 810 y ss; RUIZ AnTón, LF., El agente provocador, op. cit., pp. 224 y ss; MIR PUIG, S., PG, op. cit., pp. 429 y ss.

1905 GÓMEZ RiVERO, Mª., La inducción, op. cit., p. 188.

1906 Polaino NavarRete Miguel / POLAINO-ORTS Miguel, Cometer delitos con palabras. Teoría de los actos de habla y funcionalismo jurídico-penal, Dykinson, Madrid, 2004, p. 70.

1907 GÓMEZ Rivero, Mª., La inducción, op. cit., p. 189.

1908 A este respecto, y a colación recuerda GÓMEZ RIVERO que «no toda creación de una situación incitadora fundamenta el desvalor de la acción de la inducción, sino sólo aquéllas que, teniendo en cuenta los especiales conocimientos del inductor, se consideren relevantes en términos de probabilidad del incremento del riesgo de la producción del delito, como presupuesto necesario de imputación objetiva», ID., ibidem, op. cit., p. 195. Finalmente 
La cuestión es si efectivamente hay una inducción, un influjo psicológico, o persuasión coercitiva, da igual el cómo, lo relevante es que se cambie o se genere una voluntad, o en su caso que se persuada, y para ello, más allá del título de imputación (dolo o imprudencia), lo relevante es la idoneidad de la acción u omisión que hace nacer la resolución del hombre de delante. El cómo se realice distinguirá una complicidad psicológica, una coautoría o una inducción, compatibles todas con una previa persuasión coercitiva. Ese aumento del riesgo puede reconducirse a la posición de garante (injerencia), o -como dice GómEz RIVERO- «debe apreciarse cuando la noticia que se comunica o la situación que se hace creer es sólo fruto de la invención» 1909 .

Visto todo lo anterior, ya se puede vislumbrar la diferencia más importante entre inducción y persuasión coercitiva. En la persuasión coercitiva, el persuadido no es consciente de la acción de persuasión coercitiva, si bien se siente obligado a actuar de una determinada manera por la restricción del horizonte de elección de expectativas (dolosa o imprudente), mientras que en la inducción, el inducido conoce el objeto de la inducción y el sujeto inductor, se amplía el horizonte en un sentido criminal comunicativo. $\mathrm{O}$ con otras palabras, en ambas acepciones se introduce el verbo de uno y otro, pero la persuasión coercitiva se postula como una subespecie de la inducción claramente más grave en cuanto que incapacita al sujeto en su libertad, y por eso constituye un injusto propio, que si bien tiene reminiscencias con la inducción, su gravedad se eleva a injusto autónomo, sin perjuicio de posteriores formas de autoría y participación, que como en la inducción amplían el horizonte, la libertad de actuar en este caso criminalmente.

Sin embargo, en la manipulación, se introduce una distorsión de la realidad que puede cambiar, o no, al sujeto sobre el que se ejerce la manipulación, en esto la información es sesgada o trasformada, lo que si bien se asimila o recuerda a la restricción del horizonte de posibilidades que fundamenta la persuasión coercitiva como déficit de socialización, en la manipulación permanece la libertad de la voluntad inalterada, en verdad con menos fuerza que en la inducción

afirma que «esta forma implícita de incitar, cuya capacidad para inducir la doctrina niega mayoritariamente, se revela como una forma apta o no para inducir dependiendo, al igual que sucede con las formas explícitas de incitar, de las circunstancias del caso concreto. Por ello, con el sólo dato del carácter implícito de la incitación no se puede concluir, ni afirmar en general que se trate de una conducta impune, o constitutiva todo lo más de un supuesto de complicidad, ni que tenga siempre capacidad apta para inducir, sino que necesario será tener en cuenta la concurrencia o no de otros factores de peligrosidad». Podemos estar de acuerdo en ello, sin embargo podemos añadir que la inducción implícita es simplemente una forma, un modus, que como bien dice la autora, nada añade ni quita, pues habrá que ver lo circundante. En otro sentido, es conveniente recordar la argumentación de SÁNCHEZ-VERA, quien considera que la dejación de un padre que conoce que su hijo está induciendo a un tercero para cometer un injusto, no es una autoría por posición de garante sino una inducción omisiva, pero, en coherencia con nuestros postulados, se trataría más bien de una coautoría, SÁNCHEZ-VERA, J., Delito de infracción de deber y participación delictiva, op. cit., p. 213; ID., «En los límites de la inducción», op. cit., pp. 31 y 32.

1909 GÓMEZ RIVERO, MåC., La inducción, op. cit., p. 87. 
por el simple hecho de la irrealidad de la información, que el sujeto puede aceptar o no. Esta reflexión sitúa a la manipulación en una categoría intermedia entre la inducción y la persuasión coercitiva e igualmente puede realizarse sin intencionalidad.

No obstante, y esta es la principal conclusión, la cercanía estructural de la inducción y la persuasión hace que esta última pueda comprenderse también como una forma de inducción, generalmente no verbal u omisiva, que operaría como forma de participación tras el delito autónomo de persuasión coercitiva, desconectado de éste como forma de participación en posteriores delitos-fin.

\section{B. La coinducción, la inducción mediata y en cadena}

La incitación a enfermos mentales o menores es similar a la de adeptos previamente persuadidos coercitivamente sobre los que se ha conseguido el plus de la adicción comportamental, de forma que la inducción mediata sí puede ser un caso especialmente típico de las conductas de las sectas coercitivas, es decir, utilizar a un tercero como inductor-instrumento para que otro delinca como inducción en cadena. Pero la inducción también puede realizarse sobre sujetos que sin representar una merma de la capacidad volitiva y/o cognitiva tienen un déficit de socialización que restringe el horizonte de posibilidades, y por ende la capacidad exógena de elección.

En el primer caso se cometería un delito para cometer otro, es decir, el delito de coacciones, y en su caso el delito contra la integridad psíquica, servirían para que a la postre, con la debida desconexión de los injustos con la intervención, el adepto cometa otro delito. Mientras que en la inducción, al poseer el inducido el dominio (sujeto libre), el injusto y la gravedad atribuible al hombre de atrás-inductor será menor. La equiparación de la pena se debe más a razones de política criminal que a dogmáticas. Es decir, la persuasión coercitiva como injusto autónomo facilita formas de participación como la coautoría o la inducción en posteriores delitos-fin.

Los partidarios del principio de responsabilidad ${ }^{1910}$ concluyen que si el autor es irresponsable el hombre de atrás debe ser un autor mediato y no un inductor. En este caso, Roxin diferencia entre si la alteración se produce en la capacidad de comprensión del sentido de la acción, lo que llevaría en este caso a la autoría mediata, o una alteración en la capacidad de motivación, que llevaría a una participación ${ }^{1911}$. Mientras que los que apelan a que la ausencia de culpabilidad no

\footnotetext{
${ }^{1910}$ Roxin, C., Autoría y dominio del hecho, op. cit., pp. 232 y 233 y pp. 287 a 297., ID., ibidem, op. cit., p. 236.

1911 ID., ibidem, op. cit., p. 236. Acerca de los menores de edad, ROXIN entiende que serán también casos de autoría mediata, si tienen menos de catorce años, similares a los mayores de edad que carecen de voluntad debido a un estado de necesidad por falta de antijuricidad material, ID., ibidem, op. cit., pp. 266 y 267; DE OLIVEIRA 
reconduce directamente a tal solución comentan que habrá que vislumbrar la capacidad de cada autor $^{1912}$, es decir, el grado de determinación en cada caso y su determinación en el injusto o en la culpabilidad. Así, la incitación a enfermos mentales o menores es similar al de la persuasión coercitiva con déficit de socialización de miembros de la secta. Tanto a un deficiente como a un enfermo se le puede dominar para que yerren en su capacidad de comprensión de la acción como a un hombre sano o imputable, lo cual quiere decir que el enfermo o deficiente no dejarán de ser imputables si su merma no actúa en la causa del error, es decir, habrá que valorar la relevancia de dicho error. Así, si el error o motivo relevante se ejerce sobre un hecho que es atribuible exclusivamente al autor de atrás, más allá de la condición de imputable o semi-imputable responderá el causante de dicho error, en igual medida que si es el causante de un error volitivo que genera en el hombre de delante un error cognitivo.

El problema de la inducción en cadena es la determinación de la responsabilidad del primer inductor y de los restantes inductores antes del ejecutor. En Alemania parece no haber problema en ese reconocimiento para la aplicación de la misma pena ${ }^{1913}$, fundamentalmente por el parágrafo 30.I sobre la tentativa de inducción, sin embargo, un sector extrae otra solución, mucho más polémica si cabe, la autoría mediata, en concreto, respecto a los aparatos de poder organizado. La inducción en cadena y que parte de la doctrina defiende ${ }^{1914}$ se refiere, en nuestro

MonTEIRO, Luciana, La autoría mediata en los delitos imprudentes, Tirant lo Blanch, 2013, pp. 522 y ss., si bien reconoce que no en todos los casos y per se, ID., ibidem, op. cit., p. 527.

1912 JESCHECK HH / WeIGEND T., Tratado, op. cit., 64, II 2; JAKOBS, G., PG, op. cit., 22/22 y 22/30; WELZEL, H., Derecho penal alemán, op. cit., p. 103. En España GÓMEZ BENÍTEZ, JM., Teoría jurídica del delito, op. cit., p. 142: «sólo cuando la deficiencia o anomalía mental del autor afecte a su capacidad de comprensión del alcance de la acción que ejecuta, entiendo deberá apreciarse la autoría mediata, puesto que será sólo entonces cuando el hombre de atrás ostente el dominio de la voluntad del autor, quien debido a su situación de desconocimiento del alcance de su acción obraría de un modo análogo al que lo hace en error de tipo». GóMEZ RIVERo considera que si la afección es sobre la capacidad de motivación -sobre la culpabilidad- ello únicamente dotará de mayor peligrosidad la acción del inductor porque en principio una persona sana no sería influenciada pero no llevará esto por sí mismo a la autoría mediata ya que sería desconocer el dominio del hecho del menor que si bien tiene una escala de valores aun no normalmente constituida, si entiende el carácter injusto de la conducta, GóMEZ RIVERO, M ${ }^{\mathrm{a} C}$., La inducción, op. cit., p. 104, textualmente dice que «sólo cuando la carencia o atenuación de la capacidad de culpabilidad determine que el autor no pueda comprender el alcance de su acción, bien porque su propia deficiencia le impida cualquier tipo de comprensión, bien porque, aun teniéndola en principio, se le engañe, de un modo más o menos burdo -según su grado de anomalía- sobre el verdadero sentido de la acción que se le propone, habrá que decir que se han traspasado los límites de la inducción y que pisamos el terreno propio de la autoría mediata. Cuando por el contrario el inimputable o semimputable tenga capacidad de comprensión del carácter ilícito de la acción que realiza, estaremos ante un caso de inducción, por mucho que los motivos que le impulsan a la adopción de la resolución sólo pudieran impulsar a actuar a quien carece de madurez mental»; similarmente BOLEA BARDÓN, C, Autoría mediata en Derecho penal, Tirant lo Blanch, Valencia, 2000, p. 327.

1913 GÓMEZ BENíteZ, JM., Teoría jurídica del delito, op. cit., p. 532.

1914 En este sentido se pronuncian JESCHECK HH / WEIGEND T., Tratado, op. cit., 64, II 2; JAKOBS, G., PG, op. cit., 22/28 y 27/3; MEZGER, E., Tratado, II, op. cit., pp. 326; MIR PUIG, S., PG, op. cit., p. 432; POLAINO NaVArRete, M., Lecciones de Derecho penal, Parte General, T. II, op. cit., p. 247; RODRÍGUEZ DEVESA JM ${ }^{\mathrm{a}} /$ SERRANO GómeZ A., PG, op. cit., p. 810; RoXIN, C., «Sobre autoría y participación en el Derecho penal», op. cit., 26.107. 
ámbito de estudio, a la orden del líder a uno miembro o de la orden que proviene de la dinámica grupal, relativa a la ejecución de un delito, en el que a su vez se ordena a otros, hasta que finalmente llega al autor material del delito.

También se ha tratado por otros sectores la inducción en cadena como una forma de participación de la participación ${ }^{1915}$, con otras palabras, tratar la participación como tipos penales autónomos. Pero quienes ${ }^{1916}$ aducen que la responsabilidad de la participación deviene del hecho principal negarán la participación de los sujetos intermedios, y sólo será relevante la del primer incitador. Otra posibilidad plantea GóMEZ BENÍTEZ ${ }^{1917}$, quien entiende la inducción en cadena como una participación mediata.

Esta conclusión ha sido criticada por GóMEZ RIVERO ${ }^{1918}$ por la injustificada equiparación de la pena entre el inductor y el autor, puesto que es dudoso que se pueda establecer la misma peligrosidad debido al número de intermediarios que puede haber en la cadena. Entiende que la figura jurídica aplicable sería la provocación en casos de inducción a un sujeto sin desvalor del resultado por falta de ejecución, o en su caso, la cooperación necesaria en el inducido, salvo los casos en los que el inductor dirige su influencia en un inducido para que efectivamente sea un inductor de un tercero, casos que reconduce a la tentativa de inducción porque en el inducidoinductor no nacería la resolución de delinquir. Sin embargo, en nuestra opinión, este último caso al menos es un claro caso de coautoría ${ }^{1919}$.

Si bien la doctrina mayoritaria no reconoce la inducción en cadena, por el adverbio «directamente» del art. $28.2^{\circ} \mathrm{CP}$, como bien recuerda POLAINO NAVARRETE «según el DRAE, «de un modo directo» y «directo» es aquello que se hace «derecho o en línea recta», y «que se encamina a una mira u objetivo (por ejemplo: inducir a alguien a que se suicide) puede realizarse perfectamente con intermediario, sin dejar de ser directa, y también sin dejar de representar un peligro latente, evidente e inminente para el bien jurídico» ${ }^{1920}$. Con esta argumentación estamos

1915 STRATENWERTH, G., $P G$, I, op. cit., pp. 356 y 357.

${ }^{1916}$ RoxIN, C., «Sobre autoría y participación en el Derecho penal», op. cit., 26.108.

${ }^{1917}$ GÓMEZ BENíteZ, JM., Teoría jurídica del delito, op. cit., p. 532; también MuÑoz CONDE F / GARCía ARÁN M., $P G$, op. cit., p. 446 incluso de «autoría individual» o «coautoría». En contra, la mayoría de la doctrina, GIMBERnat, E., Autor y cómplice en Derecho penal, Universidad de Madrid, Facultad de Derecho, Madrid, 1966, pp. 329 y ss.

${ }^{1918}$ GÓMEZ Rivero, MáC., La inducción, op. cit., p. 126, y nota núm. 266.

${ }^{1919}$ ID., ibidem, op. cit., p. 124 y 125. En conclusión la citada autora comenta: «que el legislador prevea expresamente un régimen distinto en la Parte Especial, se traduciría, bien en un supuesto de provocación, que, en su caso, entraría en concurso de leyes con la cooperación necesaria cuando el destinatario al que se dirigió el primer inductor con la intención de que ejecutase el hecho se limita a incitar -con independencia del éxito que en concreto tenga- a otra persona para que emprenda su ejecución, bien directamente en un supuesto de cooperación necesaria cuando el requerimiento del primer incitador se refería desde a que el destinatario incitase a un tercero», ID., ibidem, op. cit., p. 126.

${ }^{1920}$ POlaino NaVARRete, M., Lecciones de Derecho penal, Parte General, T. II, op. cit., p. 247. 
de acuerdo, porque reluce el concepto de idoneidad objetiva, de modo que es perfectamente ya no sólo posible, sino habitual, que varios sujetos se induzcan a la comisión de un delito como forma de «pasarse el marrón», o como forma en la que el resultado se asegure en virtud de los sujetos de la cadena.

Así, tampoco hay problema en aceptar la coinducción por dos o más sujetos sobre el inducido, o la inducción imprudente, o «inducción a un delito imprudente», como acertadamente expone POLAINO NAVARRETE ${ }^{1921}$ en el ejemplo de un copiloto que alienta al conductor a que conduzca más deprisa, lo que causa el accidente de un tercero. De otra, la inducción mediata, que se ha reconocido por parte de la doctrina -como JOSHI JUBERT, MIR PUIG, y más recientemente por $\mathrm{ABOSO}^{1922}$ - en casos en los que el instrumento induce a un tercero, lo que se diferencia de la inducción en cadena en que en ésta los sujetos conocen la inducción y la orden.

De esta manera, y en conclusión, puesto que la persuasión coercitiva supone una subespecie más grave de inducción, por sus particularidades y similitudes estructurales, no hay problema en admitir también la copersuasión, persuasión en cadena y mediata en el ámbito de las sectas criminales como formas de participación en el delito autónomo de persuasión coercitiva en el injusto de las coacciones, pero también como formas de inducción en posteriores delitos-fin.

\section{La inducción y la persuasión coercitiva omisivas y en comisión por omisión}

Ha de plantearse si la inducción puede realizarse en omisión, y si es posible apreciarla en la dinámica de las sectas coercitivas como forma ajena a la estricta persuasión coercitiva sobre la que hemos concluido que constituye un delito autónomo.

Según SÁNCHEZ-VERA, «importa sólo si ha existido una defraudación de la expectativa, resultando intrascendente la forma externa de la misma - por acción o por omisión» ${ }^{1923}{ }^{-}$. Siguiendo la anterior argumentación, la punibilidad del hecho viene causada de la defraudación

${ }^{1921}$ ID., ibidem, op. cit., p. 247.

1922 JOSHI JUBERT, U., «Sobre el concepto de organización en el delito de tráfico de drogas», op. cit., p. 676 y ss; MIR PUIG, S., Adiciones de Derecho penal español a JESCHECK, Tratado de Derecho Penal, Parte General, II, Bosch, Barcelona, 1981, pp. 973 y ss; ABOSO, GE, Los límites de la autoría mediata, op. cit., pp. 442 porque «la escala individual entre inductor y autor desaparece, ya que la propia organización se vale de un grupo importante de personas para funcionar delictivamente, por ende, la organización ilícita emitida para los integrantes de la cúpula criminal debe necesariamente recorrer ciertos canales de comunicación previamente adoptados para el mejor funcionamiento de la organización. El ejecutor sabe que la orden delictiva se origina de los mandos superiores, no del último dador de la orden, que actúa, a lo sumo, como cooperador necesario o cómplice en la trasmisión de dicha orden. El automatismo propio del funcionamiento del aparato de poder hace posible que las órdenes emitidas por los mandos superiores sean trasmitidas de manera directa hasta los ejecutores. En consecuencia, la llamada «inducción mediata» se atribuye como obra propia del hombre de detrás, es decir, es la inducción directa que se realiza al instrumento. No es necesario que el instigador conozca al instigado o viceversa. Por lo demás, los que ofician de intermediarios entre el centro decisorio del aparato de poder y los ejecutores deberán responder como cooperadores necesarios o cómplices, según el caso y la importancia de su aporte».

${ }^{1923}$ SÁNCHEZ-VERA, J., Delito de infracción de deber y participación delictiva, op. cit., p. 277. 
por omisión (no agarrar el perro, no frenar la máquina) de la expectativa negativa que pende sobre toda persona -habitualmente denominados casos de injerencia o asunción-, que no precisa, naturalmente, de un fundamento jurídico especial, puesto que nace de la «obligación originaria» de no dañar esferas jurídicas ajenas (lo mismo que la defraudación mediante una acción). Estos casos constituyen delitos de dominio del hecho y no de infracción de deber ${ }^{1924}$. Lo anterior se fundamenta en la institución negativa neminem laede, es decir, la obligación originaria de no dañar, y de tal modo SÁNCHEZ-VERA ${ }^{1925}$ considera que la dejación de un padre que conoce que su hijo está induciendo a un tercero para cometer un injusto no es una autoría por posición de garante sino una inducción omisiva, y por lo mismo cuando los intervinientes son instrumentos semi-imputables se genera una cadena de autorías mediatas.

Sin embargo, hay quienes aducen que en la comisión por omisión además de la posición de garante hacen falta requisitos adicionales ${ }^{1926}$. Inclusive se ha llegado a decir ${ }^{1927}$ que la injerencia es más grave por si sola que la posición de garante (institucional).

Como hemos indicado, la trascendencia jurídico-penal de las diversas formas de concebir la responsabilidad por organización e institucional es la autoría y participación. Quienes ${ }^{1928}$ consideran que la comisión por omisión se fundamenta en una infracción de deber y por tanto toda intervención es en autoría, no aceptan la participación como sí lo hace otro sector bajo el argumento del dominio del hecho para el autor y el potencial del partícipe. Un último sector intermedio entre las dos anteriores corrientes lo representan quienes ${ }^{1929}$ entienden que sólo será partícipe si no puede realizar el hecho por autoría, mientras que otros usan el criterio del ánimo de autoría o de participación, y finalmente hay quienes entienden que la diferencia estribará en si la acción ataca al bien jurídico (autoría) o únicamente supone un peligro (participación). Como dijimos, hay penalistas que admiten la omisión como forma de inducción ${ }^{1930}$, mientras que la

1924 ID., ibidem, op. cit., p. 278.

1925 ID., ibidem, op. cit., p. 213 y pp. 222 y ss.

1926 GIMBERNAT, E., «Recensión al libro de Bacigalupo "Delitos impropios de omisión”», op. cit., p. 726; GÓMEZ Rivero, Ma C., La inducción, op. cit., p. 201; MuÑOZ CONDE F / GARCÍA ARÁN M., PG, op. cit., pp. 241 y ss; SilvA

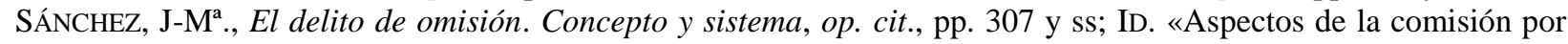
omisión: Fundamento y formas de intervención. El ejemplo del funcionario penitenciario», op. cit; MIR PUIG, S., $P G$, pp. 263 y ss.

${ }_{1927}$ Vid. GÓMEZ Rivero, MåC., La inducción, op. cit., p. 202.

1928 Kaufmann, A., Dogmática de los delitos de omisión, op. cit., pp. 281 y ss; Stratenwerth, G., PG, op. cit., p. 289. En España Bustos RAmíRez J / HormazÁBAl MAlarÉE H., Lecciones de derecho penal, op. cit., p. 340; BaCIGAlupo, E., Principios, op. cit., pp. 393 y ss.

${ }^{1929}$ Roxin, C., Autoría y dominio del hecho, op. cit., pp. 456 y ss; STRATENWERTH, G., PG, I, op. cit., pp. 309 y SS.

${ }^{1930}$ MezGer, E., Tratado, II, op. cit., p. 223. 
doctrina mayoritaria deniega esta posibilidad por faltar la equivalencia estructural de la omisión respecto a la acción ${ }^{1931}$.

Sin embargo, como bien aclara SÁNCHEZ-VERA, no todos los delitos de comisión por omisión son de infracción de deber, pues el código jurídico se basa en expectativas del determinado rol $^{1932}$. Así, estamos de acuerdo en que no toda omisión puede trasladarse a una comisión por omisión, hace falta un deber de aseguramiento, puesto que, como resalta el citado «(d)e otro modo, habría una conversión, ex art. $11 \mathrm{CP}$, de prácticamente todos los cómplices o inductores, en autores por omisión, siempre que, como es muy habitual, tuviesen la más mínima oportunidad de, tras su aporte, impedir el resultado, por ejemplo, simplemente, denunciando. La solución se puede resumir diciendo que, en este tipo de casos, debe imperar una «prohibición de sobrevaloración del aporte» ${ }^{1933}$.

De lo anterior podemos concluir, junto a nuestras otras propuestas analizadas en capítulos anteriores, que la omisión también puede ser una forma de inducción o de persuasión que puede equivaler a una acción cuando medida una confianza (normalmente comunitaria y grupal) que genera garantía, y de aquí la responsabilidad «específicamente» institucional. A la vez existen formas de inducción y/o persuasión coercitiva en las sectas criminales, de modo que la persuasión coercitiva como delito autónomo se desconecta de una posterior inducción, y a la vez, en otros casos, se pueda realizar la autoría mediata en sujetos con adicción comportamental completa, o autoría directa en casos de adicción plena, sin perjuicio de la inducción a sujetos con adicción comportamental semi-completa o semi-imputables.

\section{La inducción o persuasión coercitiva mediante doctrinas no neutrales}

Tras lo anterior, cabe preguntarse ya si los dogmas de fe de algunos grupos religiosos que contradicen el ordenamiento jurídico pueden tratarse como una forma de inducción del líder y/o del grupo para cometer delitos, esto igualmente tanto en el autor de conciencia, por convicción y

1931 KaUfMann, A., Dogmática de los delitos de omisión, op. cit., pp. 203 y ss; JesCHECK HH / WEIGEND T., Tratado, op. cit., 64, II 2; RoXIN, C., Autoría y dominio del hecho, op. cit., p. 550 y ss. En España GóMEZ RIVERO, M ${ }^{\mathrm{a} C}$., La inducción, op. cit., p. 212; MIR PUIG, S., Adiciones de Derecho penal español a JESCHECK, op. cit., p. 975; RUIZ ANTÓN, LF., El agente provocador, op. cit., p. 217.

${ }^{1932} \mathrm{Al}$ respecto señala que «(e)l sistema jurídico, pues, trabaja -en lo tocante a los delitos de dominio de hecho, en donde no hay roles especiales- con expectativas referidas a personas, y no con acciones u omisiones que, como tales, per se, como datos del mundo exterior que no han sido trasformados por el código jurídico, no son tenidos en cuenta». Y añade finalmente que «(d)e esta forma, importa sólo si ha existido una defraudación de la expectativa, resultando intrascendente la forma externa de la misma -por acción o por omisión-», SÁNCHEZ-VERA, J., Delito de infracción de deber y participación delictiva, op. cit., p. 277.

1933 SÁNCHEZ-VERA, J., «En los límites de la inducción», op. cit., p. 33. 
en el enemigo. Para esto han de distinguirse los conceptos de inducción y persuasión coercitiva que antes hemos realizado.

Las doctrinas sectarias que choquen con la Ley penal, o que por su aplicabilidad material quebranten una norma penal, constituyen formas de inducción y por tanto reprochables penalmente, cuando más allá de la libertad de conciencia aporten datos subjetivos, datos no aceptados por la sociedad en general, por las ciencias recocidas normativamente. Con un ejemplo, si una doctrina religiosa, como se ha dado el caso, afirma que el apocalipsis es inminente y que es mejor suicidarse, dichas manifestaciones, si bien pueden circunscribirse en el legítimo ámbito de la libertad de pensamiento interno, su exteriorización en una comunidad (religiosa) totalitaria, es decir, en una comunidad en la que la pertenencia de los adeptos implica en sí el seguimiento de las doctrina y órdenes del líder (sirva también el ejemplo del nacionalsocialismo), constituye la aportación de un dato subjetivo que contiene un déficit de garantía cognitiva, contrario a la verdad conocida por las ciencias físicas, un dato no neutro, o mejor, la creación de una confianza que genera garantía que, en cuanto deficitaria, que crea un riesgo (existe un déficit), cuyas consecuencias competen a quien las manifiesta, cuando existe una especial confianza cognitiva que genera una especial confianza normativa en el contenido de la garantía.

Entonces, puede ya concluirse que el establecimiento de una doctrina sectaria, ya sea en un libro «sagrado», o en cualquier forma de expresión, puede constituir una forma de persuasión coercitiva que genere déficit de socialización como injusto autónomo, pero a su vez, posteriormente una forma de inducción como orden tácita de cometer delitos, siempre y cuando la doctrina o dogma de fe en cuestión suponga la irrogación de un riesgo no permitido, no neutral, que como consecuencia de su ejercicio quebrante per se una norma penal. En estos casos, la orden tácita puede constituir una provocación (acto preparatorio), que adoptará la forma de la inducción cuando se comienza a ejecutar por el miembro de la secta.

\section{E. Conclusiones parciales: inducción como injusto autónomo de persuasión coercitiva e}

inducción como forma de participación

En la inducción, como en cualquier forma de intervención penal, se amplía el horizonte de expectativas criminales, mientras que en la persuasión coercitiva se restringe, lo cual no es incompatible con una persuasión como forma de inducción si dicha restricción tiene el efecto de ampliar las posibilidades criminales del inductor sin mermar la capacidad de voluntad del inducido. De aquí que sean posibles las combinaciones de una primera persuasión coercitiva 
como injusto autónomo y una posterior forma de intervención como inducción en el mismo sujeto. Así también hemos dejado patente que la persuasión coercitiva puede perpetrarse de forma imprudente, esto es, sin intencionalidad, sin verbalización, omisivamente, en comisión por omisión, en cadena y/o mediatamente.

\section{II.- Intervención delictiva en la creación y/o utilización del déficit de socialización exculpante y en la adicción comportamental}

Las teorías sobre la autoría y participación son variadas y nada pacíficas. Acertadamente CORCINO BARRUETA ${ }^{1934}$ alude a que la problemática de la intervención delictiva estriba en entenderla tradicionalmente como una forma de autoría individual, al utilizarse figuras tradicionales como la causalidad, el dolo y la decisión común. Fundamentalmente, las diferencias están en la concepción del tipo de autoría: unitaria, subjetiva, extensiva, restrictiva, objetivomaterial, objetivo formal o funcional.

La diferencia de aplicación de la teoría de la autoría y participación en Alemania y en España proviene de que en Alemania la figura de la tentativa de inducción se criminaliza como coautor al que ya antes de la ejecución de propia mano comienza a realizar el tipo, mientras que en España al faltar tal regulación devendrá impune. La incorrección de una y otra regulación nace de la incoherencia con el propio fundamento de la coautoría, al ser posible la coautoría de inducción en tentativa, y por ende ser necesaria la accesoriedad para la imputación, cuestión que niegan de forma errónea, en este aspecto, los defensores de la teoría del dominio del hecho, puesto que desde sus planteamientos no se podrá entender que hay coautoría si el último interviniente no hace aportación alguna con su propia mano, relegando la cuestión a la complicidad, por ejemplo. Mientras que en España significa renunciar a un fundamento de punibilidad, del cual en verdad, no puede negarse que exista un quebrantamiento normativo.

1934 CORCINO BARRUETA, F., «Coautoría, imputación objetiva y semántica social», en KINDHÄUSER U / POLAINO-ORTS M / CORCINO BARRUETA F., Imputación objetiva e imputación subjetiva en Derecho penal, op. cit., p. 87; CARO JOHN, JA., «Algunas consideraciones sobre los delitos de infracción de deber», Aspectos Fundamentales de la Parte general del Código Penal Peruano, Anuario de Derecho Penal, 2003, Fondo Editorial de la Pontificia Universidad Católica del Perú, Lima, 2003; ID., «La autoría mediata por dominio de organización: Una perspectiva Fáctico Normativa», elaborado por la Clínica Jurídica de Acciones de Interés Público de la facultad de Derecho de la Pontificia Universidad Católica del Perú, Lima, 2008, www.clinica-jurídica.com, consultado en fecha 15 enero de 2015; previamente JAKOBS, G., «El ocaso del dominio del hecho. Una contribución a la normativización de los conceptos jurídicos», JAKOBS Günther / CANCIO Melí́ Manuel, El Sistema funcional del Derecho penal, Lima, 2000, p. 90. 


\section{A. La superioridad del dominio sistémico de la decisión}

\section{El dominio de la voluntad en virtud de creación o aprovechamiento de coacción}

Con la obra de Roxin Autoría y dominio del hecho, se inició un debate sobre las teorías de la autoría y participación por dominio de la voluntad por coacción, miedo, error, dominio funcional (coautoría) y dominio en aparatos organizados de poder. De este modo se precisa distinguir en nuestro estudio el delito de persuasión coercitiva, como delito de coacciones, autónomo, de una forma de participación por dominio de la voluntad como autoría mediata, o como forma de inducción o coautoría.

\section{Además del dominio de la decisión suele citarse el dominio sobre la configuración material} ejecutiva del hecho en aquellos casos en los que el sujeto mediato prepara el hecho, y el inmediato sólo activa el tipo delictivo. El domino no sólo viene configurado por la superioridad de la decisión, sino también por el quantum y cualidad de la ejecución, en otras ocasiones por la creencia de que el instrumento es tal ${ }^{1935}$.

\footnotetext{
1935 En tal sentido JAKOBS afirma que «(e)l deber de tener presente el defecto acaba cuando la aportación del hombre de atrás, de acuerdo con las reglas de la prohibición de regreso (...) no puede constituir ni siquiera participación accesoria; pues en tales casos el hombre de atrás no organiza delito alguno, sino que, por otra parte, su comportamiento se ve continuado hacia lo delictivo. Ejemplo: Cuando un enfermo mental amenaza con matarse, o con matar a otro, si el «hombre de atrás» llega a casarse, o a emigrar o a profesar en determinada religión, la ejecución del comportamiento no querido por la persona que amenaza fundamenta a lo sumo responsabilidad por el artículo 323 c StGB (si es que el «hombre de atrás» no es garante por otros motivos, como p. ej., al ser padre del enfermo mental)», JAKOBS, G., PG, op. cit., 21/71a. Otro problema es si el autor mediato es tal aun desconociendo la cualidad de instrumento del inmediato, o en casos en los que tal aprovechamiento no es fundamental objetiva ni subjetivamente en la ejecución delictiva, el hecho principal sigue perteneciendo al mediato, éste será autor mediato del delito, pero en los casos en los que el supuesto inmediato realice un exceso cualitativo, el autor mediato sólo responderá como inductor o tentativa de autoría mediata. Estos son casos de «autoría mediata parcial» -en la terminología de JAKOBS, ID., ibidem, op. cit., 21/94. (dominio parcial cualitativo)- el sujeto mediato pide la realización de un determinado delito pero conociendo que el inmediato causará también otro. Puede pensarse que existe un concurso ideal o medial en el que la responsabilidad del autor mediato es dolosa en los dos delitos, y también dolosa para el inmediato por el primer delito, pero al desconocer las consecuencias del segundo podrá imputársele por imprudencia cuando fuere previsible o irresponsable en caso de imposibilidad de prever. En principio, la dominabilidad es única del autor mediato, mientras que los demás son instrumentos de instrumentos. En tales conexiones puede existir algún sujeto con semi-imputabilidad, o total imputabilidad, lo que cabría resolverse como coautoría con atenuante para éste ( «autoría mediata parcial»). También puede aplicarse esta solución en casos de provocación de un error de prohibición o como simple coautoría en caso de imputabilidad de uno de los intervinientes en la conexión, cuando a pesar de la falta de resolución conjunta se conoce el fin de tales conexiones, es decir, ese ámbito de organización injusto (dolo). Comenta JAKOBS al respecto que el autor mediato «debe saber que realiza las circunstancias que excluyen el comportamiento responsable (o, si se realiza autolesión: cuasiresponsable) del instrumento», ID., ibidem, op. cit., 21/107; lo que en caso contrario, si desconoce que es un autor imputable, llevaría a una tentativa de autoría mediata, es decir, tentativa en coautoría o participación.

Otro grupo de casos que nos podemos encontrar es la autoría mediata en la que el sujeto inmediato actúa sin dolo, casos de error que podrá o no ser evitable, se puede responsabilizar al inmediato por imprudencia, mientras que el autor mediato por dolo. El dominio parcial, por ejemplo, sobre la consecuencia de una determinada intensidad de golpes, que si bien el autor mediato conoce que producen consecuencias lesivas fuera de la normalidad en virtud de las circunstancias físicas o psíquicas de la víctima, sólo se le podrá castigar por imprudencia cuando de alguna manera le sea exigible conocer el trasfondo de la acción-resultado. En el mismo sentido, el error causado por el autor mediato sobre el inmediato en los presupuestos de una causa de justificación, o sobre ella misma o sobre su existencia, también plantea la misma problemática.
} 
La problemática a la que se enfrenta nuestro estudio son los casos de varios autores inmediatos a los que se les ha persuadido coercitivamente y que atentan contra otros o contra sí mismos. En este grupo de casos podemos señalar varios supuestos.

En el ámbito sectario los suicidios/asesinatos en masa suelen resolverse como autoría mediata de autolesión. En tales casos, y siguiendo a JAKOBS, habrá que dilucidar si la víctima y propio autor material de su lesión ha incurrido en un error provocado por el autor mediato, y si éste ha creado un riesgo especial del que era competente (imprudencia), o lo ha creado dolosamente, aunándose tal error y el resultado por la dominabilidad del autor mediato ${ }^{1936}$. Consecuentemente, también es plausible la punibilidad de la hetero-autolesión en la persuasión coercitiva, cuando la víctima desconozca los efectos lesivos futuros. En estos casos, parece necesario apreciar la posición de garante del autor mediato, pues de lo contrario, podría estimarse impune, o al menos únicamente como inducción al suicidio cuando el sujeto inducido adopte la idea criminal pero sin ejecutar acción alguna tendente al resultado delictivo. Sin embargo con la autoría mediata, y siguiendo la posición doctrinal denominada «solución del autor mediato», bastaría con el inicio de la acción de persuasión sobre el sujeto para entenderse iniciada la tentativa, esto es porque tal acción es suficientemente relevante y peligrosa para la afección al bien jurídico como hemos visto, sin que sea necesario esperar a que el autor inmediato, inicie la ejecución delictiva o su autolesión.

En este sentido, tradicionalmente desde la concepción del dominio del hecho ${ }^{1937}$ de RoxIN, se concibe la utilización de un instrumento sin culpabilidad como una autoría mediata en el dominio de la voluntad en virtud de coacción, como «presión motivadora sobre el ejecutor», o error como «superioridad intelectual in concreto» ${ }^{1938}$. Estos casos también se pueden reconducir a los de error sobre el sentido concreto de la acción, que RoXIN ${ }^{1939}$ considera casos de autoría mediata, mientras que $\mathrm{JAKOBS}^{1940}$ lo reconduce al de error sobre el motivo, generalmente irrelevante. Lo que se debate es si la acción nace de un motivo por el cual si fuere conocido por el inmediato le haría no actuar.

\footnotetext{
${ }^{1936}$ En este supuesto JAKOBS cita el ejemplo del caso Sirius sobre el que infra volveremos, JAKOBS, G., PG, op. cit., 21/78, nota 142 .

${ }^{1937}$ Recientemente sobre el dominio «finalista» del hecho, ABOSO, GE., Los límites de la autoría mediata, op. cit., pp. 433 y ss. Críticamente porque en los delitos imprudentes no hay finalidad, Roso CAÑADILLAS, Raquel, Autoría y participación imprudente, Comares, 2002, pp. 518 y ss.

1938 RoXIN, C., Autoría y dominio del hecho, op. cit., p 166; entre otros, DíAz Y GARCía CONLLEDO comenta que lo relevante es saber si el autor inmediato actúa como autor, si determina objetivamente y positivamente el hecho, DíAZ Y GARCía Conlledo, M., La autoría en Derecho penal, pról. Diego-Manuel Luzón Peña, PPU, Barcelona, 1991, pp. 646 y ss; GIMBERNAT, E., Autor y cómplice, op. cit.

1939 RoXin, C., Autoría y dominio del hecho, op. cit., pp. 237.

1940 JAKOBS, G., $P G$, op. cit., 21/101.
} 
Estos casos de error sobre el motivo se suelen tratar también como casos de inducción por fuerza moral o coacción moral, o en nuestro caso también se pueden describir como una forma de participación después de la persuasión coercitiva. En ambos casos existe un aprovechamiento de la superioridad ${ }^{1941}$ o de las circunstancias del hombre de delante que puede considerarse también un caso de autoría, por ejemplo, cuando el líder se aprovecha de su superioridad y fuerza moral para doblegar la voluntad del adepto (semi-imputable). En realidad, la autoría mediata fundamentada por esta fuerza moral sólo existiría en los casos de la adicción comportamental ya explicada, es decir, en casos sin márgenes (horizontes) de libertad y no en los restantes. A este respecto, también gran parte en la doctrina ${ }^{1942}$ reconduce estos supuestos al miedo insuperable o al estado de necesidad justificante o exculpante del autor inmediato. Cabe destacar aquí brevemente las amenazas o coacciones implícitas por una dependencia psicológica en un medio familiar, social, laboral o, concretamente en nuestro estudio, en un medio religioso. Parte de la doctrina opina ${ }^{1943}$ que carecerán de relevancia especial pues sólo parecen modos más intensos que otros para hacer surgir la resolución delictiva. Sin embargo, según los supuestos que hemos planteado de inducción por fuerza moral, no se puede rechazar su especialidad como delito autónomo de persuasión coercitiva.

Por tal motivo, en los casos de imputabilidad disminuida la mayor parte de la doctrina ${ }^{1944}$ no acepta la estructura de la autoría mediata, sino la coautoría. El autor mediato no tiene pleno dominio del hecho y el inmediato tiene parcialmente el dominio del hecho, por lo que la coautoría resuelve en mejor medida tales presupuestos, y por ende, parece igualmente ajustarse mejor a la problemática de los delitos perpetrados por adeptos de sectas que con déficit de socialización o adicción comportamental semi-completa comenten delitos contra sus propios bienes o contra los de terceros, ya sean autores de conciencia, por convicción o enemigos. Amén de ello, en los casos de adicción comportamental, la diferencia cualitativa es que la alteración o anomalía mental incida en los pros y los contras para actuar ${ }^{1945}$. Lo mismo cabe concluir en

\footnotetext{
1941 JAKOBS, G., «La autoría mediata con instrumentos que actúan por error como problema de imputación objetiva», op. cit., pp. 265 y ss.

1942 FERNÁNDEZ IBÁÑEZ, E., La autoría mediata en aparatos, op. cit., pp. 330 y 331 en casos incompletos puede ser inducción o autoría mediata; HeRnÁndez Plasencia, José Ulises, La autoría mediata en Derecho Penal, Comares, Granada, 1996, pp. 159 y ss., acepta que la autoría mediata en sujetos responsables; GóMEZ RIVERO, $\mathrm{M}^{\mathrm{a} C}$., La inducción, op. cit., pp. 246 y ss. Comenta al respecto GóMEZ RIVERo que si bien la evitabilidad se basa en la responsabilidad del sujeto, el concepto de instrumento o inducido se basa por el contrario en «si esa falta de conocimiento determinó una situación de predominio del hombre de atrás sobre el acontecer típico, o si a pesar de tal desconocimiento, el autor siguió conservando el dominio del hecho», ID., ibidem, op. cit., p. 232.

1943 GÓMEZ RiVERO, Mª C., La inducción, op. cit., p. 252.

1944 Véase a este respecto JAKOBS, G., PG, op. cit., 21/94.

1945 En concreto, arguye GóMEZ RIVERO, con razón, que «ese factor de alteración mental, que impide al autor motivarse conforme a los mandatos normativos, y le impulsa a decidirse a favor del delito, el que convierte en
} 
casos de persuasión coercitiva que genera el déficit de socialización y a la postre se realiza una inducción, o inducción en cadena.

El aprovechamiento por el hombre de atrás de un error en el sentido de la acción del hombre de delante contempla soluciones diferentes, precisamente porque el aprovechar una falsa motivación no altera el concepto de inducción, como dice RoxiN ${ }^{1946}$, de aquí también que tras una persuasión coercitiva que produzca un déficit de socialización o adicción comportamental semi-completa, el mismo sujeto que los ha creado dolosa o imprudentemente se pueda aprovechar posteriormente de forma dolosa, $\mathrm{u}$ otros también se pueden aprovechar de dicha causa dolosa jo imprudentemente! para que, en ambos casos, cometa un delito contra sí mismo o contra tercero ${ }^{1947}$.

No vamos a entrar en si existe una causa de justificación en el ejecutor de una orden en cumplimiento de un deber ${ }^{1948}$, porque ya ha sido ampliamente debatida en el capítulo segundo. Nos interesa qué solución es más correcta en la autoría y participación en la relación del déficit de socialización como causa de exclusión de la culpabilidad, pues no consideramos que exista problema en apreciar en casos de adicción comportamental la autoría mediata en el delito-fin, si bien, cuando dicha adicción sea semi-completa tampoco hay problema en aceptar la coautoría o la inducción en casos especiales como vamos a ver.

Como decíamos, Roxin concibe el dominio de la voluntad en virtud de coacción como autoría mediata $^{1949}$ cuando de tal intensidad se exime de responsabilidad al que actúa por delante ${ }^{1950}$. Si

especialmente peligrosas incitaciones que, en sí, no motivarían a nadie «en su sano juicio», y nos presenta al autor como un cuasi instrumento de la voluntad del hombre de atrás, que, sin embargo, sigue siendo un inductor, y no un autor mediato. Por lo demás (...) esta especial peligrosidad de cara a la adopción de la resolución supone la alteración motivacional del destinatario, puede lograrse tanto ofreciendo ventajas o argumentando razones ciertas (...), como acudiendo a engaños más burdos, de acuerdo con el grado de alteración o anomalía mental que sufra el destinatario», GÓMEZ RIVERO, M ${ }^{\mathrm{a} C}$., La inducción, op. cit., pp. 254 y 255. Y finalmente concluye que «en los casos en que la ausencia o disminución de la culpabilidad del autor, por no incidir en su capacidad de comprensión del sentido de la acción que realiza, no impida considerarle inducido, dicha alteración va a actuar fundamentando ya de por sí la peligrosidad que requiere el desvalor de acción de la inducción, lo que en todo caso requerirá comprobar que realmente esa deficiencia o anomalía ha influido en las posibilidad de éxito de la incitación, convirtiéndola en un riesgo no tolerado», ID., ibidem, op. cit., p. 256.

1946 RoXIN, C., «Sobre autoría y participación en el Derecho penal», op. cit., 25.80.

1947 Si bien como dice GóMEZ RIVERO, «que a efectos de penalidad quede un cierto descontento por tratar igual al que consigue que otro adopte la resolución de delinquir mediante artimañas engañosas, que al que provoca tal decisión utilizando en su incitación argumentos verdaderos», GómEZ RIVERO, Mª C., La inducción, op. cit., p. 237. Concluye GómEZ RIVERO en el sentido expuesto por JAKOBS que «la determinación de cuándo el hombre de atrás domina la voluntad del autor, y, en definitiva, la apreciación de la autoría mediata, no descansa en la actuación del ejecutor en una situación de error, relevante si se quiere desde un punto de vista fenomenológico, ni siquiera en la posibilidad de formular criterios objetivos fronterizos entre autoría mediata e inducción, sino en si dicho error afecta o no a la valoración jurídica del hecho, sea determinando en el autor un error sobre la propia tipicidad de su acción, sobre su subsunción o sobre su antijuricidad», ID., ibidem, op. cit., pp. 244 y 245.

1948 Ampliamente sobre esta causa de justificación desde la teoría de aparatos organizados de poder, FERNÁNDEZ IBÁÑEZ, E., La autoría mediata en aparatos, op. cit., pp. 173 a 180.

1949 RoXIN, C., Autoría y dominio del hecho, op. cit., p 166. 
bien comenta que no toda «influencia volitiva» supone dominio del hecho, por cuanto si al ejecutor directo le queda libertad de decidir, la influencia del hombre de atrás no puede suponer dominio porque se desterrarían los conceptos de inducción y complicidad, de manera que el dominio se refiere a la responsabilidad, no al efecto psicologizante. Por ejemplo, en el estado de necesidad coactivo del hombre de delante creado por el hombre de atrás, éste es el señor del hecho, y por lo tanto autor mediato, salvo que la presión motivacional no surja de él «sino de otras circunstancias» ${ }^{1951}$. La dificultad en la que entra es explicar cómo el autor inmediato que tiene dominio de la acción, y por tanto aún es autor, deja de serlo de modo que su autoría se trasfiere al hombre de atrás ${ }^{1952}$.

Sin embargo, en el estado de necesidad exculpante supralegal, sobre los procesos de eutanasia de médicos oficiales que cooperaron en la muerte antijurídica de enfermos mentales para salvar a otros, RoxIN refiere que la necesidad de obrar antijurídicamente viene de la presión. Así, la creación dolosa de un estado de necesidad exculpante supralegal, sería un caso de autoría mediata por la presión del conflicto moral que se resuelve a favor del instinto de conservación porque inhibe la conducta conforme a la moral ${ }^{1953}$.

La formulación de Roxin puede aplicarse, en nuestra opinión, a la inversa. Cuando el estado de necesidad exculpante proviene de motivos morales y concretamente de un déficit de socialización atribuido a un tercero, el dominio de la voluntad se disipa de tal grado que desaparece cuando están desconectados objetiva y/o subjetivamente la producción del estado exculpante y el hecho o por la utilización imprudente o dolosa de otro. Esto es porque existen márgenes de libertad del autor inmediato que reconducen la imputación a la de autoría. Así, no hay impedimento en aceptar un injusto previo de persuasión coercitiva y una posterior coautoría $o$ inducción, cuando el autor, previamente víctima de la persuasión coercitiva, se adentra imprudente y conscientemente en una «comunidad de riesgo», si bien después se produce de tal

${ }^{1950}$ ID., ibidem, op. cit., p. 171.

1951 ID., ibidem, op. cit., pp. 168 a 175; ABOSO, GE, Los límites de la autoría mediata, op. cit., p. 440.

1952 Comenta ROXIN al respecto que «(d)e ahí se obtiene el resultado de que aquel que simplemente ejerce sobre el agente directo influencia más o menos intensa, no tiene el dominio en sentido jurídico, porque se mantiene la responsabilidad en el ejecutor. Pero a quien influye en otro de manera que éste et iure se ve exonerado de responsabilidad, ha de considerársele titular del dominio de la voluntad», Roxin, C., Autoría y dominio del hecho, op. cit., p. 172; DE OlIVEIRA, L., La autoría mediata en los delitos imprudentes, op. cit., p. 345 y pp. 431 y ss.

${ }_{1953}$ RoXIN concluye que si «el autor actúa, tiene que imponer una decisión de conciencia (que surge del núcleo moral de su responsabilidad y en esa medida es absolutamente suya y «libre») superando la resistencia indolente de los niveles más bajos de su personalidad. Así pues, no es «no libre» en el sentido en que cabe admitirlo (...) con el concepto de la responsabilidad jurídica. El legislador exime al autor directo (pues autor lo es ya en virtud de su dominio de la acción) no por razones psicológicas, sino porque respeta su decisión libre por motivos éticossociales», RoXIN, C., Autoría y dominio del hecho, op. cit., p. 178. Otras voces como la de BOLEA BARDÓN discrepan en que no se puede aplicar la autoría mediata si el ejecutor se ha colocado de manera voluntaria o involuntaria en una situación de inimputabilidad, esto porque no existe dominio o posibilidad de manipulación, razón que la lleva a calificar la conducta de inducción, BOLEA BARDón, C., Autoría mediata, op. cit., p. 332. 
comunidad un déficit de socialización, ya sea tanto en un autor de conciencia, por convicción y/o en un enemigo.

Tan es así que el propio Roxin acepta que «cuando en estado de necesidad exculpante supralegal varias personas cooperan para alcanzar un resultado, la distinción entre las diversas formas de participación ha de llevarse a cabo del mismo modo que en la realización de delito común no coactiva», es decir, como dominio del hecho funcional, o dicho más exactamente como una coautoría, cuando se incita al autor en estado de necesidad a cometer el delito o se le auxilia es la misma situación coactiva ${ }^{1954}$. Por eso, cuando habla de situaciones análogas al estado de necesidad como en el constreñimiento psíquico análogo al estado de necesidad no exculpante (estado de necesidad coactivo para autolesionarse), explica que por ejemplo cuando un sujeto que determina a una mujer influenciable y sometida a él sexual y psicológicamente para que mate a su esposo, bajo la amenaza de dejarla, existe dominio del hombre de atrás «allí donde la decisión última y determinante le corresponde a él (...) En todas las demás situaciones sólo se da un mayor o menor influjo del sujeto de detrás» ${ }^{1955}$. Así, en el estado de necesidad coactivo para la autolesión o suicidio, quien engaña a alguien para que se suicide, o a un enfermo mental o menor, sin una posición especial de deber, crea o capta «el sentido jurídico del hecho mejor que el ejecutor (...) se da una supradeterminación configuradora de sentido que atribuye al sujeto de detrás el dominio del hecho» ${ }^{1956}$. Esto es, cuando dichos errores sobre el riesgo son relevantes para la decisión se crea una autoría mediata de homicidio, salvo que el delito que se produzca -concluye- sea mucho más grave que la referida coacción como reconoce parte de la doctrina ${ }^{1957}$. Esta conclusión se debe a una desconexión objetiva de los injustos que no permite la autoría mediata.

${ }^{1954}$ RoXIN, C., Autoría y dominio del hecho, op. cit., p. 179. Similarmente DE OLIVEIRA se refiere a que «si el déficit motivacional del sujeto no se debe a meras creencias u opiniones subjetivas individuales acerca de la necesidad de actuar conforme a Derecho, sino que aparece como consecuencia de una situación motivacional anormal en un contexto de conflicto de intereses reconocido normativamente (...) no hay razones suficientes para impedir la caracterización de la autoría mediata cuando el instrumento se ve en estas circunstancias como consecuencia de la influencia del hombre de atrás sobre su ámbito de autonomía privada y actúa justamente a causa de la coacción ejercida por aquél», DE OlIVEIRA, L., La autoría mediata en los delitos imprudentes, op. cit., p. 457.

1955 RoxIN, C., Autoría y dominio del hecho, op. cit., p. 181.

1956 ID., ibidem, op. cit., pp. 185 y ss., pp. 251 y 511 y ss; también DE OLIVEIRA, L., La autoría mediata en los delitos imprudentes, op. cit., pp. 433 y ss.

${ }^{1957}$ RoXIN, C., PG, I, op. cit., 20/26. A este respecto DE OLIVEIRA asimila el estado de necesidad justificante o el miedo insuperable a la situación coactiva creada, lo que le lleva a admitir que también mediaría el delito de coacciones y la autoría mediata en el delito consecuente de la creación del déficit, DE OLIVEIRA, L., La autoría mediata en los delitos imprudentes, op. cit., pp. 434 y 435. Sin embargo, DE OLIVEIRA en el mismo sentido expuesto por Bolea BARdón (Bolea BARDón, C., Autoría mediata, op. cit., p. 255), aclara que si bien no hay problema en aceptar la vis absoluta en el concepto de violencia tanto en el delito de coacciones como en la creación de un estado de necesidad coactivo en la autoría mediata, «la vis compulsiva que caracteriza la instrumentalización a través de una situación de necesidad coactiva corresponde a la fuerza que afecta a la capacidad de decisión y valoración del sujeto, capaz de restringir la autonomía privada, pero sin llegar a anularla por completo. Siendo así que el término 
La problemática surge cuando el autor no crea la situación de necesidad, sino que simplemente se aprovecha, digamos que de forma indirecta mediante el incremento del riesgo, llevando así al ejecutor a realizar el delito. Parte de la doctrina ${ }^{1958}$ admite esta forma como autoría mediata, sin embargo, no podemos estar de acuerdo con esta posición, porque si bien cuando se engaña de forma relevante, o se crea una influencia tal, el dominio, si se quiere decir así, sigue estando en el ejecutor o víctima, esto también se aprecia en cualquier coautoría. Siempre hay alguien con mejores razones, motivos, incluso a veces se engaña al ejecutor sobre el precio, sin embargo, todos siguen siendo libres.

Creo que aquí Roxin y la doctrina que le apoya valoran estos casos psicológicamente, como si un engaño relevante en la toma de la decisión fuera algo malo jurídicamente per se, a pesar de que el sujeto acabe por ser víctima (autoría mediata dual). También en toda coautoría los autores pueden ver defraudada su expectativa criminal, sin que por esto se les considere «instrumentos». Simplemente, la responsabilidad individual de algunos coautores se atenúa, o se excluye, lo que en caso de ser víctima de uno mismo no lleva a la consideración de la autoría mediata sino a un supuesto normalmente denominado de «autor detrás del autor». Esto se debe a que se introduce en la valoración consideraciones genuinamente morales (positivas o negativas): si no hay impedimento alguno en tratar como coautoría los casos de aparatos organizados de poder y los de déficit de socialización aunque sea atribuido a un tercero (por ejemplo, el joven nazi que ejecuta la orden de matar) cuando la víctima es el mismo sujeto que de propia mano ejecuta la acción, no podemos concluir dogmáticamente otra cosa, sino igualmente la concurrencia de dos autorías en un suicidio, esto es una coautoría y en casos especiales una inducción.

Por eso se ve obligado a diferenciar el estado de necesidad coactivo de autoconservación como un caso de disculpa. La coacción para el suicidio supone la superación por el hombre de atrás de ese mismo instinto que lleva al suicidio del hombre de delante por el dominio de la voluntad que «consiste en que coloca a la víctima en una situación ineludible (...) Tal es indudablemente el caso cuando el amenazado, por ejemplo, para salvar a su allegado mata a otro. ¿Por qué iba a ser distinto -dice Roxin- cuando uno se da muerte a sí mismo con igual finalidad?» ${ }^{1959}$.

coacción aquí empleado asume un significado más amplio que el del tipo de coacciones, es decir, significa «la acción de constreñir la voluntad de alguien a hacer alguna cosa», incluyendo en ella tanto la violencia como la intimidación, De OliveIRA, L., La autoría mediata en los delitos imprudentes, op. cit., p. 436.

1958 Bolea BARdón, C., Autoría mediata, op. cit., pp. 301 y ss; De OliveIRA, L., La autoría mediata en los delitos imprudentes, op. cit., pp. 470 y ss; HERNÁNDEZ PLASENCIA, JU, La autoría mediata, op. cit., p. 166.

${ }^{1959}$ RoXIN, C., Autoría y dominio del hecho, op. cit., pp. 185 y ss., p. 187. 
Esta consideración es la seguida por la doctrina mayoritaria, pero según lo visto, al inductor de un suicidio, también en los casos a los que se alude de autoría mediata dual, no se le criminaliza por cometer el homicidio, sino por convencer o por utilizar al sujeto como autor de sí mismo. Si en el primer caso es punible por convencer cuando se crea una situación relevante en la decisión del otro, pues cuando se aprovecha de una superioridad psicológica estamos ante lo mismo, por muy influenciable que sea la víctima, salvo, claro está, en casos de enfermos mentales o menores sin madurez alguna. Por eso, cuando existe simplemente una influencia relevante se criminaliza al hacedor por dicha acción, no por el resultado, lo que sucede es que el desvalor del hecho se valora en relación al desvalor de la acción/omisión del sujeto con el resultado o peligro, se valora en relación a un tipo penal, pero no fundamenta la imputación del injusto del sujeto, sólo sirve para comprender la imputación del tipo y la penalidad ${ }^{1960}$.

En verdad, toda la teoría de la autoría mediata por dominio de la voluntad en virtud de coacción o error se ha creado para resolver la imputación de la vulneración de los derechos de uno mismo de propia mano. El suicidio, a pesar de la gran influencia relevante del tercero, no deja de ser un acto libre. Al igual que en cualquier otra coautoría, diversos sujetos ven defraudadas sus expectativas criminales: obtener por culpa de otro interviniente menos dinero. Entender lo contrario sería aceptar la autoría mediata en aquel que ordena un asesinato poniendo un motivo relevante en un tercero. Lo que sucede es que se valora el mismo hecho unas veces positivamente y otras negativamente. Se valora positivamente que alguien induzca con motivos relevantes a un tercero a suicidarse o para que sirva como «instrumento» de un delito contra otro, y otras veces negativamente, cuando un sujeto introduce la idea de robar un banco y el otro lo acepta, aquí no hay inducción, sino proposición de una coautoría de robo, y según avanza el plan pasa a ser una coautoría. Sin embargo en ambos supuestos lo único que cambia es la valoración psicológica: repulsión (positivamente) o aceptación (negativamente). Repulsión porque en el primer supuesto el mismo sujeto es víctima o sirve para el plan de matar a otro. Aceptación porque en el segundo parece existir un acuerdo contra los bienes de otro. El poder o dominio de la voluntad es ajena a la cuestión en sujetos libres, o mínimamente libres. Siempre en toda

\footnotetext{
1960 BACIGALUPO, al igual que ROXIN y STRATENWERTH, comentaba al respecto que «el que obra coaccionado lo hace, sin duda, con dolo: coactus voluit. Tiene, por lo tanto, dominio de la acción para cuya ejecución se lo coacciona y consecuentemente también la posibilidad de obrar de otra manera. Por ello se piensa que el que coacciona será en todo caso un inductor, pues ha creado en el autor el dolo, no importando para nada que lo haya hecho mediante coacción o persuasión (...) podrá admitirse autoría mediata en los casos en que el coaccionado haya perdido, por la intensidad del efecto de la coacción, «la última y relevante decisión sobre lo que ocurrirá», de tal forma que ésta se traslada a las manos del que ejerce aquélla», BACIGALUPO, E., Principios, op. cit., p. 370; RoXIN, C., Autoría y dominio del hecho, op. cit., pp. 157 y 158; STRATENWERTH, G., PG, op. cit., pp. 314 y ss.
} 
coautoría hay un sujeto dominante de la voluntad de los demás y esto no es ápice para tratarlo como inductor o como autor mediato.

El problema viene de la introducción en los Códigos penales de una degradación de los conceptos de intervención que ha sido interpretado tradicionalmente como títulos de responsabilidad jurídica. De aquí vienen los problemas sobre el concepto de autor pero, en verdad, todos los intervinientes en el hecho típico son coautores, sin perjuicio de que cada uno realiza un injusto propio: el llamado inductor, por introducir una idea criminal relevante, el cooperador necesario por aportaciones útiles, pero en definitiva son todos coautores con responsabilidad criminal distinta según su injusto propio, si bien depende la punibilidad del inicio de la ejecución por uno de ellos (accesoriedad).

En conclusión, la doctrina se ha visto obligada a responder a cada concepto como si fueran distintos, lo que ha llevado a incoherencias tales como tratar el dominio de la voluntad unas veces como autoría mediata cuando el sujeto es víctima de sí mismo o, cuando sirve para la idea criminal de otro en los aparatos organizados de poder, pero esto no es aceptable dogmáticamente cuando varios preparan o cometen un delito contra otro o contra uno mismo y existen márgenes/horizontes de libertad.

\section{Dominio de la voluntad en virtud de error}

Como hemos señalado, el dominio de la voluntad en virtud de error también es tratado habitualmente como autoría mediata ${ }^{1961}$, sin embargo, aquí la doctrina discrepa más que en los casos de dominio de la voluntad. Sobre esto, Roxin explica que el que yerra sin dolo ni culpabilidad no domina la situación, ni el hombre de atrás domina al ejecutor, sino que existe una «supradeterminación final del curso causal como criterio del dominio de la voluntad» ${ }^{1962}$. Así, a diferencia del dominio de la voluntad, cuando existe error el hombre de delante actúa sin conocer el significado de la acción, atípica o imprudentemente, o bajo defectos sobre la apreciación

\footnotetext{
${ }^{1961}$ Roxin, C., Autoría y dominio del hecho, op. cit., p. 196; ABoso, GE, Los límites de la autoría mediata, op. cit., p. 437; DE OLIVEIRA, L., La autoría mediata en los delitos imprudentes, op. cit., pp. 474 y ss., cuando el engaño afecta a la esfera de autonomía privada repercutiendo en la decisión racional y reflexiva del hombre de delante sobre los factores y circunstancias que afectan a su comportamiento, sin embargo, aclara que el error no depende del desnivel cognoscitivo, simplemente ha de haber instrumentalización consciente del hombre de atrás como «preponderancia», ID., ibidem, op. cit., p. 477. Al desnivel cognitivo se refiere en la posibilidad tanto del dolo del hombre de atrás e imprudencia del de delante, o la imprudencia consciente del hombre de atrás e imprudencia inconsciente del instrumento, ID., ibidem, op. cit., p. 486. Así es ya sea con error de tipo mediante la manipulación de datos que llegan distorsionados al hombre de delante aunque el instrumento resulte punible, ID., ibidem, op. cit., p. 483 y s, o error en los motivos, ID., ibidem, op. cit., p. 497 y ss; GARCÍA ÁlvareZ, P., La puesta en peligro, op. cit., pp. 185 y ss. y 202 y ss.

${ }_{1962}$ Roxin, C., Autoría y dominio del hecho, op. cit., p. 196.
} 
normativa, lo que le despoja del dominio y de la autoría ${ }^{1963}$ aunque resulte inculpado (error vencible $)^{1964}$.

Según explica Roxin, cuando el ejecutor obra con imprudencia inconsciente «la imputación se basa en circunstancias que son irrelevantes para el dominio de la voluntad por parte del sujeto de atrás. Lo que acarrea el juicio de desvalor jurídico al que obra con imprudencia inconsciente es precisamente el hecho de que se ha dejado ajustar al plan del sujeto de detrás como mero factor condicionante debido a una falta de cuidado (...) La calificación de imprudencia no excluye, entonces, el dominio del hecho del sujeto de atrás; antes al contrario, lo requiere precisamente», y por lo tanto se trata de casos de autoría mediata y no de participación ${ }^{1965}$. Sin embargo, en la imprudencia consciente el sujeto de delante advierte la posibilidad del resultado, por eso puede decidir libremente. Existe dominio del hecho, ya no por dominio de la voluntad en virtud de coacción, sino por dominio de la voluntad en virtud de finalidad rectora del curso del hecho en «todo aquel resultado que el autor se haya representado en concreto como consecuencia posible en su actuar dirigido» ${ }^{1966}$. De aquí extrae una diferencia en la autoría mediata y en la inducción: «El que para uno el resultado sea sumamente indeseado y para otro bienvenido no influye en absoluto en el dominio del hecho» ${ }^{1967}$, pero «(c)uando uno advierte las posibles consecuencias de su actuar, su decisión irreflexiva sigue siendo decisión suya, y merced a ello no se da dominio del tercero», lo que lleva en realidad a supuestos de participación ${ }^{1968}$.

No obstante, comenta que el autor inmediato cuando no abarca el sentido social de su conducta es distinto de ser culpable de asesinato o de homicidio que matar por necesidad a otro para conservar la vida, pues sólo quien además conoce los elementos de la reprochabilidad, el injusto material, comprende el verdadero significado de su obrar ${ }^{1969}$. Según esto, sólo puede hablarse de dirección del acontecer por el sujeto de atrás cuando tiene un mayor conocimiento causal que influye en la materialización del hecho ${ }^{1970}$. Por eso concluye ROXIN que existe

1963 ID., ibidem, op. cit., pp. 196 a 218; DE OLIVEIRA, L., La autoría mediata en los delitos imprudentes, op. cit., pp. 346 y 347.

1964 RoXIN, C., Autoría y dominio del hecho, op. cit., pp. 222 a 231.

1965 ID., ibidem, op. cit., p. 203.

${ }^{1966}$ ID., ibidem, op. cit., p. 214; ABOSO, GE, Los límites de la autoría mediata, op. cit., p. 437; acogiendo sus postulados generales pero críticamente al respecto, DE OlIVEIRA, L., La autoría mediata en los delitos imprudentes, op. cit., p. 349: «cuanto más se extiende la idea de finalidad más se pierde».

${ }^{1967}$ Roxin, C., Autoría y dominio del hecho, op. cit., p. 214.

${ }^{1968}$ ID., ibidem, op. cit., p. 216. Entonces la problemática se centra en situaciones en las que el sujeto de atrás sabe más que el autor directo que actúa con imprudencia consciente, de tal modo que «en estos supuestos obra dolosamente y finalmente también el ejecutor engañado, de manera que no puede hablarse de supradeterminación de un mero curso causal», y por ende no se resuelven con la autoría mediata, ID., ibidem, op. cit., p. 218.

${ }^{1969}$ ID., ibidem, op. cit., p. 236.

${ }^{1970}$ ID., ibidem, op. cit., p. 248. Por ejemplo cuando A no habría actuado si hubiera sabido que la bomba iba a estallar con mayor probabilidad, de manera que el sujeto de detrás provoca o aprovecha un error sobre el riesgo que 
autoría mediata en los casos en los que el ejecutor, si bien obra atípicamente, yerra sobre el motivo. Según esto, cuando el defecto recae sobre la capacidad de motivación, el sujeto obra con conocimiento de la ilicitud pero no tiene la capacidad de obrar conforme a una correcta comprensión. Por ejemplo en el suicidio provocado, en relación a un desconocimiento en el engaño relativo a la vida, se daría autoría medita si el error estriba en la supradeterminación dirigida de la configuración de sentido concreto de la acción ${ }^{1971}$.

Sin embargo, en nuestra opinión, salvo enfermedad mental o minoría de edad e inmadurez (en nuestro estudio, también en casos de adicción comportamental completa), difícilmente se darán los casos de autoría mediata de homicidio o asesinato, puesto que si bien el sujeto introduce una idea relevante en el resultado, la supuesta víctima tiene márgenes (horizontes) de libertad para configurar sus creencias, salvo estupidez o debilidad mental, etc., lo cual lleva a resolver estos casos como una coautoría, o como considera parte de la doctrina con la inducción ${ }^{1972}$, no sobre la muerte, sino por el injusto propio de convencer o introducir una idea relevante engañosa, esto es: un delito contra la libertad que especialmente se castiga como delito autónomo con estructura de participación. Sin embargo, en el caso de la inducción se imputa respecto al resultado para su ubicación en el tipo, pero el injusto es del todo ajeno al resultado, es decir, su fundamento es el quebrantamiento de un riesgo no permitido o como conducta no neutral: no dañar y deber de cuidado en no dañar.

Esto lo reconoce el propio Roxin como un punto débil de su teoría cuando dice que «(q)uien se quita la vida ha sabido todo lo que es jurídicamente relevante en el hecho, sin importar bajo qué presupuestos lo haya realizado» ${ }^{1973}$. Por eso se ve obligado a reajustar su teoría del dominio del hecho ante situaciones que parecerían contradictorias y tiene que utilizar como criterio de imputación «el sentido jurídicamente relevante de un hecho criminal» ${ }^{1974}$, pero en los casos de error en el motivo se ve obligado a concluir que no se permite estimar una supraformación configuradora de sentido, y por eso se conceptualiza como inducción al vulnerarse la ética

capta el sentido jurídico del hecho mejor que el ejecutor, es decir, conoce circunstancias relevantes para la culpabilidad y fundamenta la autoría mediata, ID., ibidem, op. cit., p. 251.

${ }^{1971}$ ID., ibidem, op. cit., pp. 254 y 262. Aquí Roxin, en relación al defecto que reside en el ámbito volitivo, el sujeto obra dolosamente y con plena comprensión del sentido, pero le falta la capacidad de inhibición (el significado moral y social del hecho), por eso afirma la autoría mediata, pues si bien tiene el dominio de la acción en el sentido de la ejecución del tipo dolosa y de propia mano (por eso es autor disculpado), le falta el dominio de la voluntad, ID., ibidem, op. cit., pp. 262 a 265; también GARCÍA ÁlvarEZ, P., La puesta en peligro, op. cit., pp. 165 y ss., y pp. 186 y ss; ABOso, GE, Los límites de la autoría mediata, op. cit., pp. 437438.

1972 García Álvarez, P., La puesta en peligro, op. cit., pp. 207 y ss; ABOSO, GE, Los límites de la autoría mediata, op. cit., p. 438.

${ }_{1973}$ RoXIN, C., Autoría y dominio del hecho, op. cit., p. 236.

1974 ID., ibidem, op. cit., p. 254. 
social, no así cuando la víctima es un enfermo incurable ${ }^{1975}$. De aquí que tenga que admitir que a pesar de la supradeterminación, si un sujeto pone un revolver a una chica, aun conociendo que su amante no se va a suicidar con ella, sólo puede hablarse, quizá, de complicidad. A estas conclusiones se ve obligado a llegar, porque en los casos expuestos de heterolesión o heteropuesta en peligro resulta psicológicamente más difícil llegar a la autoría mediata. Esta solución llevaría a reajustar nuevamente el principio de responsabilidad. Pero según la concepción aquí mantenida, al tratarse de un injusto propio del sujeto, depende de la ejecución de la «víctima» pero se pena en relación al resultado o bien jurídico para ubicarlo sistemáticamente en el tipo. Sin embargo, el fundamento criminal es otro: el quebrantamiento de la norma que impide irrogar riesgos ${ }^{1976}$ o dañar.

De otra parte, HERNÁNDEZ PLASENCIA ${ }^{1977}$ considera que la instrumentalización en la ausencia o déficit de libertad resolutiva o ejecutiva es el dato relevante para distinguir entre autoría mediata e inducción, sin que el aspecto responsable del hombre de delante varíe la solución (por ejemplo en casos de miedo insuperable con culpabilidad disminuida ${ }^{1978}$ ), puesto que aun con responsabilidad el sujeto puede sufrir instrumentalización, tanto creándose la situación de coacción o error (directamente), como aprovechando dicha situación (indirectamente). De este modo, admite la autoría mediata en delitos imprudentes al poner la cuestión relevante en la cognoscibilidad $^{1979}$ de manera directa o indirecta, tanto si se crea el déficit como si se aprovecha de él, divergiendo las posturas en relación a la actuación por imprudencia inconsciente.

1975 ID., ibidem, op. cit., p. 255.

1976 ABOSO, GE, Los límites de la autoría mediata, op. cit., pp. 441 y 442 admite que «tampoco el dominio de riesgo logra soportar este escollo (refiriéndose al su rechazo a la aplicación de la autoría mediata por dominio de organización, y el criterio de fungibilidad, o el criterio de disposición incondicional) porque dicha propuesta se basa de manera exclusiva en el desvalor del resultado y su aplicación resulta contradictoria con el punto de partida constituido (se refiere al dominio finalista del hecho) sostenido por sus partidarios, basado en el principio de autonomía».

${ }^{1977}$ HeRnÁNDEZ Plasencia, JU., La autoría mediata, op. cit., pp. 126 y ss; similarmente De OliVEIRA, L., La autoría mediata en los delitos imprudentes, op. cit., pp. 358 y pp. 399 a 405.

1978 HERNÁNDEZ PlASENCIA, JU., La autoría mediata, op. cit., pp. 194 y 195.

1979 Admite la imprudencia inconsciente en la autoría mediata en delitos imprudentes HERNÁNDEZ PLASENCIA, JU., La autoría mediata, op. cit., pp. 333 a 335 y 338 y ss; no acepta esta posibilidad DE OLIVEIRA, L., La autoría mediata en los delitos imprudentes, op. cit., pp. 358, 396 y ss., 429 y ss. y pp. 613 y ss. Concretamente dice que «la autoría del hombre de atrás depende de la consciente y voluntaria utilización del sujeto de delante como instrumento para que éste realice una conducta arriesgada, con independencia de si se da cuenta, en el momento de la determinación al instrumento, de que esta conducta resulta valorada desde criterios jurídico-penales como imprudente», ID., ibidem, op. cit., p. 422, pero acaba reconociendo que «(e)l empleo de la coacción como herramienta para llevar a cabo una instrumentalización eficaz no puede ser, por tanto, en sí misma accidental o fortuita, ni siquiera imprudente. De esta forma, la instrumentalización ciertamente denota una elevada carga de intencionalidad por parte del hombre de atrás, lo que puede conducir a la duda de si realmente es posible seguir hablando de autoría mediata mediante coacción en el ámbito de los delitos imprudentes. Especialmente porque en la fase inicial de la instrumentalización (...) el sujeto de delante que se siente coaccionado puede justamente intentar disuadir al hombre de atrás de sus intenciones haciéndole ver las consecuencias a que conduciría la realización de la conducta peligrosa. Sin embargo (...), incluso cuando la actuación del hombre de atrás se dirija a la realización 
Así las cosas, la cuestión clave en las diversas posturas es la configuración de la responsabilidad. Mientras Roxin y parte de la doctrina acogen un relajamiento del principio de responsabilidad que incluye la instrumentalización de sujetos responsables de algún modo en la autoría mediata, JAKOBS ${ }^{1980}$ y otro sector que comparte sus fundamentos hacen de este principio el eje relevante de la determinación de la autoría mediata: al respecto comenta que el legislador alemán, en el parágrafo 26 y 27 StGB no ha querido criminalizar cuando sólo el hombre de atrás tiene dolo, renunciando a la accesoriedad cuando el instrumento actúa imprudentemente ${ }^{1981}$.

Particularmente BOLEA BARDÓN halla el fundamento de la responsabilidad en el dominio normativo sobre el riesgo, de manera que sólo cuando exista vis absoluta y error de tipo habrá autoría mediata, pero cuando exista cierto margen de libertad, de elección del riesgo, concluye que serán casos de «autor detrás del autor» ${ }^{1982}$. Y DE OLIVEIRA da con la clave en la discusión entre autoría y participación: «basta con que se cambie el criterio de autoría para que caiga por tierra la necesidad de tener presente el componente de la finalidad del dominio, o la idea de la autonomía en base a la conciencia del riesgo de cara a identificar los casos en que se

dolosa de un delito -normalmente de peligro- puede que se produzca un resultado imprudente diferente de lo que había sido inicialmente planeado y que deba responder de éste a título de autor mediato», ID., ibidem, op. cit., pp. 444 y 445, lo que le hace incurrir en la falta de apreciación entre dolo eventual e imprudencia consciente, sin aclarar esta cuestión, salvo para admitir una conducta inicial dolosa y resultado imprudente, lo que recuerda también la coautoría con exceso del ejecutor. Otros autores que admiten la autoría mediata en los delitos imprudentes, DEL CASTILlo CodES, Enrique, La imprudencia: autoría y participación, Dykinson, Madrid, 2007, pp. 35 y ss; DÍAZ Y García Conlledo, M., La autoría en Derecho penal, op. cit., pp. 633 y ss; FeIJoo SÁncheZ, BJ., Homicidio y lesiones imprudente, op. cit., 117 y ss; LUZÓn PEÑA, M-D., Curso de Derecho penal, Parte General, I, op. cit., p. 509; Roso CAÑADILlaS, R., Autoría y participación imprudente, op. cit., pp. 550 a 561.

1980 JAKOBS, G., PG, op. cit., 21/113; ID., «La autoría mediata con instrumentos que actúan por error como problema de imputación objetiva», op. cit; CANCIO MELIÁ, M., Conducta de la víctima, op. cit., pp. 277 y ss. y 349 y ss; ID., «La exclusión de la tipicidad por la responsabilidad de la víctima (imputación objetiva)», Universidad Externado de Colombia, 1998, pp. 264 y ss; FEIJOO SÁNCHEZ considera que al instrumento, en ocasiones, se le puede imputar el tipo objetivo, pero a veces no cuando concurre una causa de justificación, error invencible y en casos de inexigibilidad, de manera que cuando exista error vencible no se trate de autoría mediata sino de participación del hombre de atrás, FEIJOO SÁNCHEZ, BJ., Homicidio y lesiones imprudentes, op. cit., pp. 114 y ss; MARAVER GómEZ, M., El principio de confianza, op. cit., pp. 184 y ss. y 261; SÁNCHEZ-VERA alude a que el instrumento es aquél que se interpone como factor natural, SÁNCHEZ-VERA, J., «Sobre la figura de la autoría mediata y su tan sólo fenomenológica "trascendencia"», ADPCP, 51, 1998, pp. 347 y ss; ROBLES PLANAS, Ricardo, «Participación en el delito e imprudencia», $R D P C, 6,2000$, pp. 246 y ss.

1981 JAKOBS, G., $P G$, op. cit., 21/74 y ss. En esta línea también OLMEDO CARDENETE aboga por la inducción cuando el sujeto sea plenamente responsable o semi-plenamente, y coherentemente cuando no existan los presupuestos de la inducción, como coautoría o autoría accesoria, OlmEdo CARDENETE, Miguel Domingo, La inducción como forma de participación accesoria, Edersa, Madrid, 1999, pp. 574 y ss.

1982 Bolea BARDón, Autoría mediata, op. cit., pp. 115 y ss. y pp. 140 y ss; lo llega a reconocer RoXIN, C., Autoría y dominio del hecho, op. cit., p. 167; críticamente pero dubitativa también DE OLIVEIRA, L., La autoría mediata en los delitos imprudentes, op. cit., p. 548 comenta que «(n)o existe aquí, sin embargo, una relación horizontal de reciprocidad y solidaridad en la decisión y en el reparto de tareas, como normalmente sucede en la coautoría. Sino que más bien se establece una relación de verticalidad que encuentra muchos puntos en común con la autoría mediata, aunque resulte difícil aclarar, en base a las discusiones doctrinales, en qué consisten exactamente estas diferencias y cómo quedan finalmente delimitadas ambas figuras». 
caracterizaría la figura del autor detrás del autor» ${ }^{1983}$. Entonces la pregunta es qué razón o fundamento es el mejor, tanto de lege data como en su caso de lege ferenda.

En nuestra opinión, según las conclusiones que hemos alcanzado, el Derecho es un subsistema del sistema mayor, la Sociedad, de modo que sólo puede abarcar operaciones clausuradas en el código justo/injusto, pero a la vez evolucionar y abrirse conforme a los movimientos del entorno. Así, en una sociedad que dice propugnar las libertades, también incluso la autorresponsabilidad de la víctima como contraprestación de la imputación objetiva al autor, sucede que en ese trinomio autor/víctima/sociedad todos son responsables salvo prueba objetiva, de lo que deviene que la relajación del principio de responsabilidad (tanto en autor como en víctima) se contradice con este presupuesto a modo de input moralizante del entorno en el subsistema Derecho, o dicho de otro modo, se referiría a una sobreprotección de la víctima o negación de su libertad.

La problemática que aparece es que en ocasiones es la propia víctima la que se «autoinstrumentaliza», tanto en delitos dolosos como imprudentes ${ }^{1984}$. De esta manera es posible aceptar una cadena o dinámica criminal con sujetos con déficit de socialización exculpante o semi-imputables por adicción comportamental, ya sean autores de conciencia o por convicción y/o enemigos, dirigida unas veces por autores responsables y otras por autores con déficit de socialización exculpante o imprudentes que pueden ser igualmente autores de conciencia o por

\footnotetext{
${ }^{1983}$ De OliveIRA, L., La autoría mediata en los delitos imprudentes, op. cit., p. 549. De OliVEIRA pone la relevancia en que efectivamente exista instrumentalización por el hombre de atrás, ya sea provocando la situación de manera consciente, lo que la lleva a negar la autoría mediata cuando la instrumentalización se realiza en imprudencia inconsciente, o mediante el aprovechamiento de tal situación, ID., ibidem, op. cit., pp. 375 y ss. A este punto llega, tras explicar que la autonomía privada del individuo es reconocida como garantía individual, y de aquí la prohibición de interferencia ajena en la instrumentalización como supuesto de autoría mediata, ID., ibidem, op. cit., p. 378. Si bien reconoce que el déficit cognitivo o de la capacidad racional y/o reflexiva, no siempre puede tratarse de autoría mediata, sino sólo cuando se ejerce la instrumentalización, ID., ibidem, op. cit., p. 380. De manera que cuando la víctima es el mismo sujeto instrumentalizado, acude a la autoría mediata, pero creemos que incoherentemente concluye que en el delito de estafa y en los delitos contra los derechos del trabajador (art. 311 y ss. CP) se trata de una autoría directa, ID., ibidem, op. cit., p. 386. Sin embargo, la única diferencia que encuentra entre autoría mediata e inducción es la «incidencia de mayor gravedad y cualitativamente distinta de la que fuera ejercida por el inductor», con lo que dice adherirse a la propuesta de GómEZ RIVERO antes vista, ID., ibidem, op. cit., pp. 409 a 413; GÓMEZ RiVERO, MC., La inducción, op. cit., pp. 169 y ss.

${ }^{1984}$ De forma que «el propio autor - dice JAKOBS- puede convertirse a sí mismo, como autor mediato, en instrumento, colocándose en una situación que excluya la antijuricidad, y en la que cometerá un hecho previamente conocido o cognoscible como antijurídico. De modo distinto a como ocurre en el supuesto básico de la autoría mediata, en el que basta que el autor mediato sea responsable de cualquier circunstancia que excluya la culpabilidad del instrumento, en la ALIC hace falta precisamente eliminar la imputabilidad; no basta la creación de una situación en que está excluida en si la exigibilidad (...) únicamente los supuestos en los que el autor se priva a sí mismo de la imputabilidad mediante estupefacientes», JAKOBS, G., PG, op. cit., 17/64 y ss. Así también HERNÁNDEZ PLASENCIA trata la auto-instrumentalización como autoría directa, sin tener que entrar así en la alic, HERNÁNDEZ PLASENCIA, JU., La autoría mediata, op. cit., pp. 375 y ss; también en cuanto que la alic se trata de la acción del mismo autor, AlCÁCER GUIRAO, R., Actio libera in causa dolosa e imprudente: La estructura temporal de la responsabilidad, Atelier, 2005, pp. 105 y ss; DEMETRIO CRESPO, E., La tentativa en la autoría mediata y en la actio libera in causa, op. cit., pp. 133 y ss; DE OlIVEIRA, L., La autoría mediata en los delitos imprudentes, op. cit., pp. 390 y 391.
} 
convicción y/o enemigos, de tal manera que en la cadena o dinámica criminal, cada uno responde según su «injusto propio» ${ }^{1985}$.

De otra parte, si bien HIRSCH también concluye que existe autoría mediata en los casos de dominio de la voluntad, comenta dos excepciones que vienen a refrendar lo dicho, acercándose a la postura funcionalista. Por un lado, en aquellos casos en los que el autor inmediato no es culpable por una previsión legal abstracta que nada tiene que ver con una incapacidad cognitiva, y por otro lado, cuando el hombre de atrás no conoce el déficit de la capacidad cognitiva del autor inmediato ${ }^{1986}$. El primer supuesto es claramente reconducible a los casos de déficit de socialización atribuido a un tercero que hemos expuesto, y los segundos, a casos aun más especiales de adicción comportamental. Ambos supuestos se asemejan a la problemática de la dinámica criminal de las sectas.

Así las cosas, el engaño relevante o la causación de error en adeptos que actúan por imprudencia consciente defrauda una expectativa normativa atribuida a un tercero, si bien en ese margen de libertad relacionado con la «consciencia» del hecho la defraudación no conduce a una orientación cognitiva o defraudación cognitiva de la «víctima», sino exclusivamente una defraudación normativa, se crea una «comunidad del riesgo defectuosa», en la que el autor incurre en un injusto doloso o imprudente, y la víctima imprudentemente, pero no se comunica el injusto como tal al que engaña o al sujeto que hace al otro incurrir en un error como autoría mediata por dominación de la voluntad por coacción o error, sino sólo en cuanto imputación e injusto propio. Lo que sucede es que al inductor de suicidio se le atribuye la defraudación de una expectativa normativa que se vincula al tipo, en este caso, de suicidio, y al tradicionalmente llamado autor mediato se le asimila como dominador de la voluntad, pero el sujeto actúa con imprudencia consciente en la dinámica criminal o aceptando consejos ficticios que modifican los conceptos esenciales del Sistema Social como el de la vida, o de otra forma acepta la influencia, la subordinación, es decir sólo la consciencia del peligro que supone la influencia moral o religiosa. Ese margen de libertad despoja al «hombre de atrás» de dominio alguno, en cuyo resultado, la víctima deja de serlo como «instrumento»: o sea: al primero se le reprocha un injusto propio.

\footnotetext{
1985 JAKOBS, G., «Una teoría de la intervención delictiva», JAKOBS, G., El lado comunicativo y el lado silencioso del Derecho penal. Expectativas normativas, intervención delictiva, Derecho penal del enemigo, edición Miguel Polaino-Orts, Universidad de Sevilla, 2014, pp. 57 y ss.

${ }^{1986}$ HIRSCH, HJ., «Acerca de los límites de la autoría mediata», HIRSCH, HJ., Derecho penal, Obras completas, Libro Homenaje, T. I, a cargo de José Cerezo Mir y Edgardo Alberto Donna, Rubinzal-Culzoni, Santafe, 1999, p. 204.
} 
Aquí debemos traer a colación las consideraciones de JAKOBS sobre los instrumentos que actúan por error. Partimos de la base por él expuesta de que la representación del autor, su rol, y la asunción del instrumento de su rol en lo determinado objetiva y subjetivamente por el mediato determinarán la imputación objetiva. Así, aplicado esto al ámbito de la persuasión coercitiva, la competencia del individuo en el ámbito social se matiza por el rol asumido por el sujeto. Esto es: quien causa un error con riesgo conocido o conocible de que el instrumento produzca un resultado jurídico-penal relevante es objetivamente autor mediato, pero no cuando la conducta del hombre de atrás es socialmente adecuada ${ }^{1987}$. La competencia que asume el hombre de atrás sobre el hecho debe matizarse con los parámetros de riesgo permitido, confianza social, rol social y previsibilidad, pero también las consecuencias observadas o el tipo de error creado. Según estos parámetros, el sujeto de atrás será imputable objetivamente del hecho si rebasa los grados permitidos por la adecuación social establecida por el rol asumido en el hecho ${ }^{1988}$. Así, estamos de acuerdo con JAKOBS en que «un error que per se es asunto de quien yerra se convierte también en asunto del hombre de atrás cuando éste entra en el contexto específico del comportamiento del otro, condicionado por el error ${ }^{1989}$. Esto quiere decir que el hombre de atrás como autor imputable de error debe al menos prever que su conducta condiciona un error, un error de tal entidad que da como consecuencia un injusto, y así el comportamiento del hombre de atrás crea un error cuya probable consecuencia es un injusto no imputable al hombre de delante, precisamente porque tal error es inevitable o quasi inevitable (en otros casos). La competencia de los errores de los otros viene determinada por la función de rol asumida por el sujeto de atrás y

${ }^{1987}$ Pues como dice JAKOBS con otra clase de ejemplo, quien deja un martillo a otro, conociendo que el hombre de delante lo utilizará para colocar un cuadro, y aunque conozca la posibilidad de que éste se haga daño y agujere el cuadro, no es autor mediato de daños y de auto-lesiones si esto sucede, pues la conducta en sí es adecuada socialmente, el riesgo es permitido por la sociedad. En este caso, el rol asumido por el autor de detrás y el rol asumido por el autor de delante es normativamente normal, pues las conductas referenciadas demuestran una normalidad jurídica y social, precisamente porque la sociedad crea esa normalidad, y esa normalidad es fuente de adecuación estricta de la norma en el caso expuesto, JAKOBS, G., «La autoría mediata con instrumentos que actúan por error como problema de imputación objetiva», op. cit., p. 254.

${ }^{1988}$ El error en Derecho penal puede deberse a lo cognitivo, a lo volitivo o a ambos. Según el tipo de error podrá excluir la imputación objetiva del instrumento errado, por ejemplo en casos de error cognitivo, error de conocimiento excusable. Si bien el mero desconocimiento no crea la irresponsabilidad penal, sí lo hará en casos de error debido al desconocimiento inevitable. Esto no trae problemas, pero sí cuando el error cognitivo, o el error sobre el conocimiento de la norma es evitable, lo que traerá consecuencias en la imputación objetiva en la autoría mediata con instrumentos que actúan bajo este error. Y en el mismo sentido, cuando el error es volitivo -indiferencia en el deber de conocer la norma- el error tendrá graves consecuencias en la imputación objetiva de la participación. Esta última forma de error es definida por JAKOBS como casos de «ficción de error», aunque como dice, al tratarse de casos de participación conllevará consecuencias en la medición de la pena, JAKOBS, G., «La autoría mediata con instrumentos que actúan por error como problema de imputación objetiva», op. cit., p. 253. El criterio del riesgo permitido relaja la imputación objetiva, pues si el autor mediato actúa dentro de los parámetros socialmente admitidos de riesgo permitido, y por tanto sin vulnerar la confianza cognitiva-normativa, no podrá hablarse de dominio sobre instrumento imputable penalmente. El error provocado por el hombre de atrás tiene que ser no sólo suficiente sino objetivamente peligroso desde su propio conocimiento, bien dolosamente, bien imprudentemente.

${ }^{1989}$ ID., ibidem, op. cit., p. 256. 
del que se despreocupa el hombre de delante precisamente por asumir el rol contrario: despreocupación del rol del hombre de delante por asunción por el rol del hombre de atrás. Cuando esa despreocupación se desvincula del rol competente por el hombre de delante podrá imputarse objetivamente, y en su medida, el resultado ${ }^{1990}$.

Así, puede haber competencia objetivo-penal tanto en el comportamiento que inicia el hombre de delante como del error que se causa. Tanto en uno como en otro, el hombre de atrás tiene competencia, pero en virtud del grado de riesgo permitido socialmente podrá o no atribuirse objetivamente el resultado. Esto mismo sirve para la imputación objetiva del hombre de delante o víctima. De tal modo, la competencia puede traer defectos cognitivos o volitivos ${ }^{1991}$, pero cuando los defectos cognitivos del hombre de delante vienen causados por defectos volitivos del mismo no cabe hablar de autoría mediata, sino de autoría principal del hombre de delante. El hombre de atrás no habrá tenido nada que ver a pesar de haber causado el error cognitivo, pues antes de esto viene el error volitivo de quien era finalmente competente, o dicho de otro modo, y reformulado en nuestro ámbito de estudio, si lo desconocido es asunto de la incumbencia del suicida, no habrá autoría mediata.

Sin embargo, desde nuestros planteamientos existen casos especiales, los déficit de socialización atribuido a tercero, en los que la modificación de los conceptos esenciales del Sistema Social (dinero, salud, vida, muerte, etc.) por la generación de la aludida garantía de expectativa cognitiva, a pesar de la aparente y exclusiva incumbencia del suicida se puede trasladar la responsabilidad al hombre de atrás y al seguir teniendo la «víctima» cierto margen de libertad tratarse paradójicamente como coautoría. Recuérdese que en la problemática de las sectas coercitivas se incluyen casos en los que determinados sujetos, tanto el líder como miembros activos pero también simples adeptos, se presentan como consejeros $^{1992}$ sobre cuestiones tales como la veracidad de utilidad de programas terapéuticos, así que la confianza

\footnotetext{
${ }^{1990}$ Así, por ejemplo, quien presta un arma a quien conoce perfectamente el funcionamiento de éstas, y dispara en un campo en el que es previsible que tras los arbustos hay personas, el hombre de atrás no ha creado un riesgo de su competencia, sino la competencia es del hombre de delante. En el mismo ejemplo, si quien dispara debía conocer que alguna función del arma estaba descompensada y su tiro se desvía sustancialmente dando en una persona, la competencia sobre el error es mayor del que tiene en propiedad del arma, pero también del que dispara, cuando puedo conocer tales taras.

1991 JAKOBS, G., PG, op. cit., 21/77 y ss; ID., «Sobre el tratamiento de los defectos volitivos y de los defectos cognitivos», JАKOBS, G., Estudios de Derecho penal, op. cit., pp. 127; ID., «La organización de autolesión y heterolesión, especialmente en caso de muerte», op. cit., pp. 404 a 406.

1992 JAKOBS nos da un ejemplo que nos puede servir para determinados casos de sectas criminales, si bien, según lo dicho, diferimos en la conclusión. Dice el referido penalista que «puede ocurrir que el autor mediato se haga pasar por especialista sin serlo: quien afirma conocer la situación y ser competente para dar consejos, debe quedar vinculado a esa representación de su propia persona. Aquí han de ubicarse los casos más comunes, es decir, todos aquellos en los que el autor mediato desempeña el papel de un consejero y produce el error del otro a través de sus consejos», JAKOBS, G., «La autoría mediata con instrumentos que actúan por error como problema de imputación objetiva», op. cit., p. 258.
} 
generada, del todo especial, crea una competencia sobre el error causado por el autor, ya sea dolosa o imprudentemente, sobre la conducta de la víctima cuando se perjudique en sus propios bienes -comprando el producto, estafa- o trasmitiendo la inveracidad de las cualidades del producto a otros adeptos, del que conscientemente se puede conocer su inocuidad. Los consejos en esta especial dinámica criminal son fuente de riego que rebasa lo permitido y la competencia del que los da, y en tal medida, es una fuente generadora de errores que pueden y llevan a la comisión de delitos cuando se elimina o se restringe el horizonte de expectativas.

Por nuestra parte, desechada la autoría mediata con instrumentos culpables, no habrá impedimento en hablar de «autor tras el autor», o de supuesto de coautoría en la que cada «autor» responde de su propio injusto, inclusive bajo exculpación, o por otras razones de política criminal como la impunidad del suicidio intentado. La falta de entendimiento viene en estos casos límite, y en definitiva, de la punibilidad de la tentativa de inducción generalizada en Alemania, y sólo especialmente criminalizada en España en el art. 143 CP, pero dogmáticamente, es decir, normativamente, no hay impedimento en sostener la configuración del «autor tras el autor» o la coautoría de injustos propios.

Todo lo anterior nos lleva a concluir en la necesidad dogmática de un concepto sistémico de autoría. Esto se puede apreciar en que las diversas categorías de la intervención se han planteado en las legislaciones penales como sucesos fenomenológicos de autoría, salvo quizá la de complicidad, que responde su punibilidad más a criterios de política criminal que a dogmática penal. En contra de esta conclusión parte de la doctrina opina ${ }^{1993}$ que el concepto funcional de autor responde al concepto extensivo de autor que responde a su vez a criterios del clásico concepto unitario de autor. Sin embargo, la interpretación que aquí se hace no depende de la función, sino del sistema de los elementos que entran en consideración en el hecho: los intervinientes y su entorno (otros intervinientes).

B. La intervención delictiva en aparatos organizados de poder: criterios de imputación y su trascendencia en las sectas coercitivas

Las cuestiones anteriores han de ser completadas bajo el presupuesto de la organización responsable de los miembros, sean autores de conciencia, por convicción o enemigos, en las sectas coercitivas. Para ello nos hemos servido del problemático caso de los aparatos organizados de poder, porque a priori se asimilan a aquéllas, y en cuya solución convergen las más diferentes opiniones sobre la autoría y participación.

1993 Díaz Y García Conlledo, M., La autoría en Derecho penal, op. cit., p. 347. 


\section{Solución en la autoría mediata}

El dominio funcional del hecho parte de entender a los coautores como dominadores funcionales o co-dominadores del hecho delictivo, si bien previamente debe existir un acuerdo previo o determinación conjunta y la aportación de cada sujeto para que efectivamente la representación de la organización delictiva tenga potencialidad para la consecución del fin. Críticamente se ha apelado a la irrealidad de que los coautores dominen conjuntamente el hecho, puesto que únicamente dominan su propia aportación. Ello lleva a considerar que esta teoría corresponde a una imputación accesoria una vez comenzada la ejecución de propia mano por un sujeto, se eleva al título de imputación de la coautoría si ha demostrado dominio del hecho en su aportación ejecutiva.

Sin embargo, es comúnmente aceptado por casi toda la doctrina ${ }^{1994}$ que el dominio de la voluntad (por error, miedo o coacción) de un sujeto para cometer un delito, supone un supuesto de autoría mediata. De aquí que los casos expuestos por la teoría de la autoría mediata en aparatos organizados de poder, sobre que los ejecutores en Alemania (tanto en la extinta RDA como durante el Tercer Reich) no actuaban por error ni coacción. Este es el punto de partida de las divergencias de la estructuración dogmática de la forma y responsabilidad de los intervinientes. Tanto es así que suele decirse que el incumplimiento de las órdenes por los intervinientes únicamente conllevaba medidas disciplinarias.

La cuestión es la autoría intelectual que supone el paradigma del líder, o jefe de una banda, o grupo criminal, que sin intervenir materialmente organiza la aportación de los intervinientes en el hecho. En esta figura, no regulada, se incluye tanto al coautor como al instigador o inductor, pero también al autor mediato en un intento de fundamentar la denominada autoría mediata en aparatos organizados de poder.

${ }^{1994}$ RoXIN, C., Autoría y dominio del hecho, op. cit., pp. 165 a 303; FERNÁNDEZ IBÁÑEZ, E., La autoría mediata en aparatos, op. cit., pp. 81 y ss., advierte la vinculación entre casos de error sobre causas de inculpabilidad, ya fuere de estado de necesidad o de miedo insuperable, con la coacción. Y añade que «(e)l argumento de reconducir todos los supuestos de coacción no excluyente de culpabilidad a la inducción con el propósito de no vaciar de contenido esta figura accesoria no me parece defendible. La responsabilidad del hombre de atrás como autor mediato, como vengo sosteniendo hasta ahora, no va a poder condicionarse a la responsabilidad del hombre de delante, pues ello desconocería la realidad del comportamiento realmente efectuado por el hombre de atrás (...) Excepcionar expresamente el principio de responsabilidad también para los casos de dominio de la voluntad en virtud de coacción, sin embargo, apenas si ha recibido aceptación», ID., ibidem, op. cit., p. 84; BOLEA BARDÓN, C., Autoría mediata, op. cit., pp. 306 y ss; HeRnÁNDEZ PlASENCIA, JU., La autoría mediata, op. cit., p. 163. 
RoXIN $^{1995}$ traslada la problemática del autor intelectual a la autoría mediata de aparatos organizados de poder sobre la medida de los siguientes fundamentos: un aparato de poder jerarquizado verticalmente ${ }^{1996}$, con una gran cantidad de miembros que actúan automáticamente cuando se les ordena ejecutar un hecho delictivo; control de la organización delictiva del hecho por el hombre de atrás, pero responsabilidad tanto de éste como del hombre de delante; fungibilidad de un amplio número de los ejecutores (anónimos y sustituibles ${ }^{1997}$ ) basada en la jerarquía y en el totalitarismo de la organización. Su propuesta se aplica a aparatos de poder estatal, a los aparatos no gubernamentales y a la criminalidad organizada (organizaciones secretas, terroristas, mafias) siempre que el fin de la organización sea contrariar el ordenamiento jurídico, y especialmente las normas penales positivas ${ }^{1998}$. De esto último se puede deducir que también se aplicaría en las sectas coercitivas, sin que por nuestra parte sea especialmente relevante que exista una gran cantidad de miembros, sino el grado de compromiso, obediencia o dependencia que exista, entones, dependería la conceptualización de aparato de poder según el tipo de organización y dinámica criminal, o sea, no se aplicaría en todo los casos ${ }^{1999}$. Por eso, acierta, parcialmente, cuando rechaza su aplicación al ámbito empresarial, porque entiende que los presupuestos estructurales del dominio de organización por dominio de la voluntad, en virtud

1995 Roxin, C., Autoría y dominio del hecho, op. cit., pp. 269 y ss., y pp. 723 y ss. Le siguen FARALDO CABANA, Patricia, Responsabilidad penal del dirigente en estructuras jerárquicas, $1^{\mathrm{a}}$ ed., Tirant lo Blanch, 2003, pp. 301 y ss; FERNÁNDEZ IBÁÑEZ, E., La autoría mediata en aparatos, op. cit., pp. 122 y ss; BOLEA BARDÓN, C., Autoría mediata, op. cit., pp. 287 y 369; GóMEZ BENÍTEZ, JM., «El dominio del hecho en la autoría mediata (validez y límites)», ADPCP, 1984, pp. 112 y ss; ID., Teoría jurídica del Delito, op. cit., pp. 141 y ss; MUÑOZ CONDE, F., «Dominio de la voluntad en virtud de aparatos organizados en organizaciones "no desvinculadas del Derecho"?», $R P, 2000$, núm. 6, p. 110 y ss; ID., ¿Cómo imputar a título de autores a las personas que, sin realizar acciones ejecutivas deciden la realización de un delito en el ámbito de la delincuencia organizada y empresarial?», Modernas Tendencias en la Ciencia del Derecho Penal y en la Criminología, UNED, Facultad de Derecho, Madrid, 2001, pp. 501 a 531; con discrepancias DíAZ Y GARCÍA CONLLEDO, M., La autoría en Derecho penal, op. cit., pp. 647 y ss., y esto es porque aunque aboga por un concepto restrictivo de autor, considera que autor sólo puede ser quien realiza la «acción típica nuclear», ID., ibidem, op. cit., p. 515, de tal modo explica que la «conducta de autoría sólo es la que más directamente ataque la norma directa de prohibición (o mandato) de conductas contenida en cada tipo de delito: sólo esa conducta merece y necesita (...) el más alto grado de responsabilidad», de aquí que no acepte del todo la autoría mediata en los aparatos organizados, ni la coautoría, sino la inducción, salvo que una norma especial lo tipifique como autor, ID., ibidem, op. cit., p. 683.

${ }^{1996}$ RoXIN, C., Autoría y dominio del hecho, op. cit., pp. 723 y ss; FERNÁNDEZ IBÁÑEZ, E., La autoría mediata en aparatos, op. cit., pp. 155 y ss.

${ }^{1997}$ Roxin, C., Autoría y dominio del hecho, op. cit., p. 273. Otros penalistas en vez de «fungibilidad» han hablado de «disposición incondicional», o «inclinación al hecho».

${ }^{1998}$ RoXIN, C., Autoría y dominio del hecho, op. cit., p. 278; BGHSt 40, 219, en relación a los soldados del muro.

1999 RoxIN, C., «Problemas de autoría y participación en la criminalidad organizada», Delincuencia organizada: aspectos penales, procesales y criminológicos, Universidad de Huelva, 1999, p. 198; MUÑOZ CONDE, F., «¿Dominio de la voluntad en virtud de aparatos organizados en organizaciones "no desvinculadas del Derecho"?», op. cit., p. 110 y ss; ID., ¿Cómo imputar a título de autores a las personas que, sin realizar acciones ejecutivas deciden la realización de un delito en el ámbito de la delincuencia organizada y empresarial?», op. cit., pp. 501 y ss; FERNÁNDEZ IBÁÑEZ, E., La autoría mediata en aparatos, op. cit., p. 111. 
de error y de coacción, en este caso, son insatisfactorios ${ }^{2000}$. Esto es porque el empleado aunque sea fungible en la organización, no se puede vincular a las órdenes antijurídicas ${ }^{2001}$ que vayan contra los principios supralegales, si bien en nuestra opinión no habría impedimento en aplicar esta teoría cuando se cumplan sus postulados, máxime en grandes empresas. Sin embargo, no consideramos que la cantidad de miembros fundamente la fungibilidad, sino como veremos es la organización y funcionamiento sistémico lo que genera un peligro objetivo y la respuesta penal en la atribución de responsabilidades aun cuando sean pocos los miembros y se trate de otro tipo de organización no supragubernamental o aparato de poder.

En este caso, no sería muy desacertado llegar a las mismas conclusiones al respecto de las denominadas estafas por hipotecas subprime, acciones preferentes y subordinadas y en la delincuencia económica o terrorismo ${ }^{2002}$, en los que la cantidad de miembros es algo meramente estadístico, si bien, a juicio propio, como más adelante explicaremos, se trataría de casos de coautoría con responsabilidad atenuada según el injusto propio de cada intervinientes y según los casos.

Si RoXIN ${ }^{2003}$ afirma que en los aparatos organizados de poder desvinculados del Derecho el ejecutor inmediato puede reconocer los principios supralegales - de modo que constituyen una ley accesible de la naturaleza- no comprendemos qué razón tiene la autoría mediata y por qué rechaza la coautoría en los aparatos organizados de poder ${ }^{2004}$. El debate doctrinal se centra entonces en el tipo de responsabilidad del líder o dirigentes de la organización criminal. Habrá que diferenciar la responsabilidad individual de los líderes o dirigentes y el injusto sistémico y el delito-fin en coautoría, pues una organización criminal no tiene por qué tener un fin principal delictivo o exclusivo, sino que puede ser secundario o medial $\left(515.2^{\circ} \mathrm{CP}\right)$.

${ }^{2000}$ FERNÁNDEZ IBÁÑEZ, E., La autoría mediata en aparatos, op. cit., p. 2.

2001 RoXIN, C., Autoría y dominio del hecho, op. cit., pp. 269 y ss., y pp. 723 y ss; le siguen, FERNÁNDEZ IBÁÑEZ, E., La autoría mediata en aparatos, op. cit., pp. 122 y ss; BOLEA BARDÓN, C., Autoría mediata, op. cit., pp. 287 y 369. Sobre la doctrina alemana que compatibiliza la instrumentalización y la actuación responsable del ejecutor, JAKOBS, G., «La normativización del Derecho penal en el ejemplo de la participación», op. cit., p. 634.

${ }^{2002}$ MUÑOZ CONDE defiende la extrapolación de la teoría de la autoría mediata en aparatos de poder a la delincuencia económica y terrorismo, MUÑOZ CONDE, F., «Problemas de autoría y participación en el Derecho penal Económico. ¿Cómo imputar a título de autores a las personas que sin realizar acciones ejecutivas, deciden la realización de un delito en el ámbito de la delincuencia económica?», La Ley, enero 2002, núm. 9, p. 59.

${ }^{2003}$ RoXIN, C., Autoría y dominio del hecho, op. cit., pp. 276 y ss; MuÑOZ ConDE, F., «¿Dominio de la voluntad en virtud de aparatos organizados en organizaciones "no desvinculadas del Derecho"?», op. cit., p. 107.

${ }^{2004}$ FERNÁNDEZ IBÁÑEZ comenta críticamente la postura de ROXIN: «(1)os ejecutores cumplen libre y responsablemente las instrucciones de sus superiores independientemente de que el aparato se encuentre o no al margen del Derecho. La fungibilidad, la jerarquía y el consecuente automatismo no desaparecen por el conocimiento de que las actuaciones se lleven a cabo en un aparente marco de legalidad (...) Ceguera, tolerancia, indiferencia o cobardía, en cualquier caso, la imbricación de la conducta delictiva en el entorno legislativo, judicial, político y social de su tiempo no va a repercutir entonces en un mayor o menor dominio del hecho de quien bajo el amparo de una organización lleva a cabo los más horribles crímenes», FERNÁNDEZ IBÁÑEZ, E., La autoría mediata en aparatos, op. cit., pp. 201 y 202. 
Lo que suele ocurrir en las sectas coercitivas es que se utiliza un medio ilegítimo como la «manipulación mental»o «persuasión coercitiva» para fines lícitos, o dicho de otro modo, basta la idoneidad de los sujetos ${ }^{2005}$ y la dinámica criminal, no tanto una gran cantidad de sujetos fungibles o intercambiables para conseguir el resultado, lo que demuestra que no es necesario partir de la estructura de la autoría mediata, sino distinguir el injusto sistémico y la intervención en el delito-fin, salvo pena de incurrir en incoherencia en la tentativa de autoría mediata en aparatos organizados de poder con el delito de organización criminal.

Según Roxin, no cabe hablar aún de tentativa si el sujeto no ha abandonado el dominio, cuando según su plan se pueden realizar más aportaciones asegurativas para la ejecución del instrumento $^{2006}$. Así para este autor, la incidencia sobre el instrumento es ya en sí tentativa pero referida al momento en que se abandona dicha incidencia sobre el instrumento, y termina la tentativa cuando el instrumento sale del poder de dominio del autor mediato. Si esto fuera así, ¿dónde estaría la diferencia entre delito de organización criminal «estatal» o «mafiosa» y el delito-fin intentado? Con palabras simples: si acogemos la teoría de RoxIN, la aplicación de la autoría mediata no dejaría espacio a la punibilidad del delito de organización o injusto sistémico, porque el dominio del hecho en la autoría mediata criminalizaría ya el dominio de la organización, salvo incurrir en ne bis in idem, no podría criminalizarse, paradójicamente, la organización de poder de tipo, al menos, estatal. Él basa su teoría de los aparatos organizados de poder como autoría mediata en el dominio de la organización como supuesto de dominio de la voluntad. La organización funciona «automáticamente», independientemente de sus sujetos porque estos son variables, de tal modo que el hombre de atrás confía que la orden se va a cumplir 2007 .

FERNÁNDEZ IBÁÑEZ ${ }^{2008}$ amplía la propuesta de RoXIN realizando matizaciones y aportaciones nuevas. Comenta que el funcionamiento automático del aparato no está vacío normativamente hablando, porque se basa en la disposición jerárquica que ampara la orden y la fungibilidad de los miembros ${ }^{2009}$ que actúan como instrumentos de carácter fundamentalmente «extensivo» ${ }^{2010}$.

\footnotetext{
2005 MEINI, Iván, Responsabilidad penal del empresario por los hechos cometidos por sus subordinaos, Tirant lo Blanch, Valencia, 2003, pp. 166 y ss; FERNÁNDEZ IBÁÑEZ, E., La autoría mediata en aparatos, op. cit., p. 138.

${ }^{2006}$ RoXIN, C., «Observaciones sobre la "actio libera in causa"», op. cit., pp. 29 a 32; ID., PG, I, op. cit., p. 885.

${ }^{2007}$ RoXIN, C., Autoría y participación, op. cit., p. 272. Similarmente ARENDT, H., Los orígenes del totalitarismo, op. cit., p. 514, comenta que el líder totalitario «reivindica la responsabilidad personal por cada acción, acto o fechoría, obra de cualquier miembro o funcionario (...) Esta responsabilidad personal es el más importante aspecto organizativo del llamado principio del jefe (...) Esta perfecta identificación del jefe con cada subjefe designado y este monopolio de la responsabilidad por todo lo que se hace son también los más conspicuos signos de la diferencia decisiva entre un jefe totalitario y un dictador o un déspota ordinario».

${ }^{2008}$ FERNÁNDEZ IBÁÑ̃Z, E., La autoría mediata en aparatos, op. cit., pp. 122 y ss.

2009 ID., ibidem, op. cit., p. 19 y pp. 122 y ss.
} 
El art. 28 CP y el parágrafo 25 StGB sólo hablan de realizar el hecho «por medio de otro», no de la responsabilidad de este otro, por lo que según la citada puede aceptarse el dominio de organización del hombre de atrás «amparado por la organización» ${ }^{2011}$. Otro fundamento sobre el que se basa la citada autora es que la dogmática tradicional sobre la participación no ha podido satisfacer la hipótesis de «comisión colectiva en la criminal organizada» ${ }^{2012}$. Sin embargo, en nuestra opinión, con los planteamientos del injusto sistémico se consigue resolver, y de tal manera no tener que aplicar la autoría mediata para dotar de coherencia al dominio de la organización. Éste puede realizarse sin una clara determinación del delito-fin, e incluso con aportaciones imprudentes como veremos.

\section{Solución en la coautoría}

Resulta a este respecto interesante la opinión de $S_{C H U L Z}{ }^{2013}$. Los ejecutores -refiriéndose al Tercer Reich- tenían responsabilidad pero actuaban bajo una coacción que no venía de los hombres de atrás, sino que era inherente a todo sistema de injusto de los regímenes totalitarios, tal y como hemos descrito nosotros supra, sin embargo, este penalista no acepta la justificación ni la exculpación porque los ejecutores con su actuar, simplemente pretendían no degradarse socialmente. No obstante, acepta en los ejecutores la causa incompleta de estado de necesidad exculpante en virtud del parágrafo 35 StGB en relación con el meritado 46, fundamentada en la presión psíquica, y de tal manera concluye que existe mayor responsabilidad en el hombre de atrás que en el ejecutor.

Los razonamientos de SCHULZ se asimilan a los expuestos en esta investigación, porque el fundamento de criminalidad y de imputación en el delito-fin viene en ocasiones completado previamente por la organización o injusto sistémico, de modo que la coautoría en la organización dolosa o imprudente se traslada también después al delito-fin en el momento que se concreta. Lo que sucede es que aquellos casos de co-inducción e inducción en cadena y mediata que se suelen plantear en los aparatos organizados de poder, se acomodan mejor a la estructura de la coautoría, sin más, en la que cada interviniente coautor, perpetra y se le criminaliza según su injusto propio.

Visto lo anterior acogemos los presupuestos del funcionalismo normativista, que junto a otros sectores trata a los autores intelectuales como coautores. Esto es porque el ejecutor no es un «instrumento» propio de la autoría mediata, sino -como denomina JAKOBS- un autor directo

${ }^{2010}$ ID., ibidem, op. cit., p. 97.

2011 ID., ibidem, op. cit., p. 95.

2012 ID., ibidem, op. cit., p. 96.

2013 Vid. ID., ibidem, op. cit., pp. 106 y 107 (SCHULZ, U., «Die mittelbare Täterschaft kraft Organistationsherrschaft - eine notwendige Rechtsfortbildung?», JuS, 1997, pp. 112 y 113). 
disfrazado, lo que en verdad encierra una coautoría ${ }^{2014}$. El dominio sólo aporta la graduación de la autoría a la participación, no el injusto de la intervención en sí mismo, ni aporta el dato de si el sujeto es irresponsable aun parcialmente. Además, es natural que casi siempre haya un autor que tenga la mejor idea, plan o representación de la organización delictiva dentro de la comunidad normativo-delictiva, o también, si el ejecutor se deja corromper es porque es responsable y no podemos hablar de un acto automático. De este modo la fungibilidad no aporta nada al delito-fin, sólo existiría un dominio superior en casos de superioridad jurídica, y esto puede venir de una persona y/o del todo el grupo.

La solución de la coautoría en los aparatos organizados de poder, según JAKOBS ${ }^{2015}$, pasa por comprender que existe una «decisión ajustada» entre todos, sin que en nuestra opinión con esta formulación se esté reajustando o reinterpretando el requisito de la «decisión conjunta»o «acuerdo de voluntades» de la coautoría. Conforme ha explicado convincentemente $\mathrm{LESCH}^{2016}$, el

2014 JAKOBS, G., «El ocaso del dominio del hecho», op. cit., p. 192; ID., PG, op. cit., 21/52 y 21/103; ID., «La normativización del Derecho penal en el ejemplo de la participación», op. cit., p. 638; en el mismo sentido CoRCINO BARrueta, F., «Coautoría, imputación objetiva y semántica social», op. cit., p. 131; refiriéndose a que no es necesaria una «comunidad subjetiva» en la coautoría, GARCÍA DEL BLANCO, M ${ }^{\mathrm{a}}$ Victoria, La coautoría en Derecho penal, Tirant lo Blanch, Valencia, 2006, p. 687 y ss; JOSHI JUBERT, U, «Sobre el concepto de organización en el delito de tráfico de drogas en la jurisprudencia del TS», ADPCP, 1995, pp. 662 y ss; HERNÁNDEZ PLASENCIA, JU., La autoría mediata, op. cit., 264 y ss; Polaino NAVARrete, M., Lecciones de Derecho penal, Parte General, T. II, op. cit., p. 246, considera que «para resolver este tipo de supuestos de criminalidad organizada no es necesaria la doctrina de la autoría mediata en aparatos organizados de poder: el mando superior es garante, como evidentemente lo es, entonces le compete un deber positivo y responde, pues, como autor (no mediato) de un delito de competencia institucional (...) la doctrina de la autoría mediata en aparatos de poder se muestra como perturbadora, incorrecta e infructuosa»; Robles PlanAs, R., La participación en el delito: fundamento y límites, Marcial Pons, Madrid, 2003, p. 271, lleva estos casos a la autoría vertical porque sólo existe un hecho, por eso responden como coautores; SÁNCHEZ-VERA, J., «Sobre la figura de la autoría mediata y su tan sólo fenomenológica "trascendencia"», op. cit., pp. 347 y 348; ID., El denominado «delito de propia mano». Respuesta a una situación jurisprudencial, Dykinson, Madrid, 2004, p. 192; ID., «En los límites de la inducción», op. cit., p. 12 recuerda que «(e)l Estatuto de Roma de la Corte Penal Internacional, en sus arts. 25 y 28, dedicado a la «responsabilidad penal individual» y a la «responsabilidad de los jefes y otros superiores», no parece querer dejar margen a muchas distinciones: lo relevante es la imputación, por encima de la autoría o participación, pues en gran medida son equiparadas en dichos preceptos todas las figuras, constituyendo lo que podríamos denominar la «auténtica» participación una verdadera excepción». En Alemania, JESCHECK HH / WEIGEND T., Tratado, op. cit., 62, II 8, hablan de la conciencia en común entre líder y ejecutor sobre el hecho a realizar por la pertenencia a la organización; LESCH., HH., «Intervención delictiva e imputación objetiva», op. cit., p. 940; STRATENWERTH, G., PG, I, op. cit., pp. 330 y 331, explica que «autor de la mesa de escritorio» es el señor real del suceso, y eso porque en las estructuras organizadas hay instrumentos intercambiables a voluntad, así, si bien utiliza la fundamentación de RoXIN, no concluye que sea una autoría mediata. Parcialmente críticos con la solución clásica de la autoría mediata y abogando por la teoría del dominio por organización con base a la «voluntad del resultado típico como producto de su propio comportamiento», AMBOS Kai / GRAMMER Christoph, «Dominio del hecho por organización. La responsabilidad de la conducta militar argentina por la muerte de Elisabeth Käsermann», Revista Penal, núm. 12, 2002, pp. 30 y ss; AMBOS, K., «Dominio del hecho por dominio de voluntad en virtud de aparaos organizados de poder. Una valoración crítica y ulteriores aportaciones», $R D P C, 2^{\text {a }}$ época, 3,1999 , pp. 143 y ss.

2015 JAKOBS, $P G$, op. cit., 21/44.

${ }^{2016}$ LESCH, HH., «Intervención delictiva e imputación objetiva», op. cit., pp. 955 y ss; CARO JOHN, JA., «Participación delictiva y el deber de solidaridad mínima», Eduardo Montealegre Lynett (coord.), Derecho pena y Sociedad. Estudios sobre las obras de Günther Jakobs y Claus Roxin, y sobre las estructuras modernas de la imputación objetiva, T. II, Centro de Investigaciones en Filosofía y Derecho, Universidad Externado de Colombia, Bogotá, Colombia, 2007, p. 39; desde una concepción restrictiva de autor mantiene que no es necesaria una 
acuerdo no es la base de la imputación, sino la consecución de un objetivo criminal, lo que magistralmente critica la doctrina de la autoría mediata, que se ve abocada a reinterpretar el principio de responsabilidad. No hay diferencia objetiva entre el aporte del autor y el partícipe, al menos en la ejecución del tipo, ni uno tiene más domino del hecho que el otro. La clave se halla en las competencias de cada rol, en su ya mencionada esfera de libertad y deberes, y en la tipología criminal de delitos de organización o de dominio y los de infracción de deber. El primero atiende a la organización del hecho por un rol común, el segundo por la defraudación de un rol especial por la atribución de una esfera de libertad personal como en el ámbito de las relaciones paterno-filiales, aunque en nuestra opinión, en este último caso no siempre es así, es posible un delito de responsabilidad por organización de los padres contra los intereses del menor, tal y como expusimos en el capítulo tercero. Las conductas de los autores y partícipes y la graduación de responsabilidad no dependen de la aportación objetiva de cada uno, sino de la división del trabajo, del quebrantamiento del rol y de que la defraudación mediante la aportación contenga un sentido criminal significativo y comunicante. Los partícipes no actúan de forma desinteresada al hecho, puesto que se comunican, interceden y confabulan con el autor o coautores acordando el hecho.

Por todo ello, se ha definido la coautoría como una «comunidad normativa», también en la aportación en el estadio previo. Dicho de otro modo, el interviniente en un estadio previo que coloca la pistola para que la encuentre quien sabe que quiere matar a otro, interviene ya un hecho. Cuando el autor comienza a ejecutar, el interviniente comete el hecho ya no por propia mano sino ajena, con independencia de que el autor conozca quién colocó el arma con la que finalmente ejecuta o mata. Así, acertadamente se afirma que «la imputación del injusto no depende de lo que el autor fácticamente desea, sino de si lo que desea se corresponde con lo que normativamente debe desear. De ahí que actualmente la voluntad psíquica-real del autor se deja de lado como fundamento del injusto (...) el criterio subjetivo juega un papel importante en función del que desempeña el aspecto objetivo» ${ }^{2017}$, y por ende, no se precisa un acuerdo previo, ni tácito ni implícito, sino una construcción contranormativa. Lo relevante procede del contexto delictivo, de cómo se ha articulado la activicidad criminal en un determinado contexto criminal, y en definitiva serán intervinientes quienes contradicen su rol con una conducta típica. Así el

comunidad subjetiva en la expresión «conjuntamente», GARCíA DEL BLANCO, Mª V, La coautoría en Derecho penal, op. cit., pp. 687 y ss; en este sentido, POLAINO NAVARRETE se refiere a que en la coautoría no es el dominio funcional el fundamento criminal («irrelevante»), sino la atribución de sentido delictivo a una conducta imputable a varios sujetos como obra conjunta», por eso es posible la coautoría omisiva, POLAINO NAVARRETE, M., Lecciones de Derecho penal, Parte General, T. II, op. cit., p. 242.

2017 CORCINO BARRUETA, F., «Coautoría, imputación objetiva y semántica social», op. cit., pp. 121 y ss. 
concepto de autoría y consecuentemente de coautoría se basa en la llamada «semántica social»o competencias del rol social $^{2018}$.

La coautoría en los estadios previos tiene la misma dinámica, es una división delictiva del trabajo, no del injusto futuro, sino una infracción de la obligación del deber de cuidado, es el quebrantamiento de un deber primario, general, pero a su vez también normativo. JAKOBS se preguntaba, en relación a los deberes negativos (no dañar): «ipor qué razón responde también el interviniente en el estado previo, cuando no realiza injusto alguno, pero la ejecución alcanza al menos el estado de la tentativa? (...) ¿Quién afirma entonces que el interviniente en el estado previo no realiza a través de la ejecución por su parte un injusto propio, aunque sea a través de mano ajena?» ${ }^{2019}$. Responde que el injusto jurídico-penal comienza con la tentativa por quien lleva a cabo de propia mano la ejecución, pero también están los injustos propios de los intervinientes en el estado previo que hayan aportado «de una manera concretizada, prestaciones necesarias con vistas a la realización típica (...) «promoción» del complejo de prestaciones concluido con la realización del tipo» ${ }^{2020}$, de tal manera que «la accesoriedad como regla para la imputación como propio de un injusto realizado por mano ajena no conoce una vinculación del injusto de la intervención en un injusto de otro (...) Por el contrario (...) todo interviniente encuentra su propio injusto en la ejecución y sólo ahí» ${ }^{2021}$. Estamos de acuerdo con JAKOBS, pues no de otra manera se puede entender que las aportaciones relevantes entre unos y otros intervinientes puedan considerarse como coautoría ${ }^{2022}$.

La consecuencia jurídico-penal de esta tesis es que la aportación relevante en el estado previo no es aún injusto pero «conforma un fundamento de imputar la posterior lesión de la garantía a través del ejecutor a quien actúa en el estado previo como su propia lesión de garantía (por mano ajena). Por ello, puede formularse que a los riesgos no permitidos en la ejecución se corresponde

\footnotetext{
${ }^{2018}$ LESCH, HH., «Intervención delictiva e imputación objetiva», op. cit., pp. 942 y ss; CARO JOHN, JA., «Participación delictiva y el deber de solidaridad mínima», op. cit., p. 39; ID., «Sobre la no punibilidad de las conductas neutrales», RPDJP, núm. 5, Lima, 2004, p. 85 y ss; CORCINO BARRUETA, F., «Coautoría, imputación objetiva y semántica social», op. cit., pp. 115 y ss; JAKOBS, G., «Accesoriedad sobre los presupuestos de la

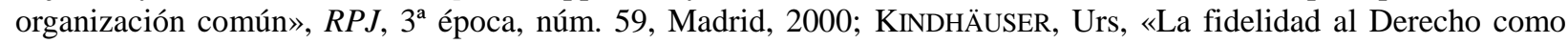
categoría de la culpabilidad», Cuestiones actuales de derecho penal y patrimonial, Aras Editores, Lima, 2005.

2019 JAKOBS, G., «Una teoría de la intervención delictiva», op. cit., p. 57.

2020 ID., ibidem, op. cit., p. 58.

2021 ID., ibidem, op. cit., p. 59.

2022 Con un ejemplo que expone: si un interviniente aporta a un ladrón -que desconoce su aportación- reteniendo a una persona dispuesta a evitar el hecho, «(p)ara la doctrina usual este caso resultará embarazoso. El aporte substancial después del comienzo de la tentativa habla a favor de la coautoría pero falta la decisión común hacia el hecho. Ello sucede cuando se intentan conseguir disposiciones sobre psicologismo en lugar de proceder de manera normativa», ID., ibidem, op. cit., p. 59.
} 
con la lesión de obligaciones en la intervención delictiva (...) debiendo acarrear por ello con el inconveniente de no poder desvincularse de la ejecución» ${ }^{2023}$.

De aquí que JAKOBS ${ }^{2024}$ concluya cinco reglas generales sobre la teoría de la intervención delictiva que «(e)n todos los grupos de casos mencionados no depende de si y de cómo quieran vincularse los actores, y especialmente no depende de si concurre acuerdo común, sino que depende únicamente de lo que signifique la conducta desde un punto de vista social» ${ }^{2025}$, de la comprensión social. Menciona las muertes organizadas de personas judías durante el nacionalsocialismo «porque el significado constatado una y otra vez de cada hecho individual como parte de la ejecución de un programa pone de manifiesto que se trata de un hecho global. Cada ejecución se convierte, con ello, en intervención delictiva en millones de ejecuciones posteriores» ${ }^{2026}$. Concluye que las figuras de autor, inductor, cooperador necesario son «excesivamente poco elásticas»: a cada interviniente se le imputa la ejecución como injusto propio $^{2027}$. No resultará ilógico deducir que en los deberes positivos «no existe, respecto de los obligados, intervención delictiva, sino antes bien sólo ejecución» ${ }^{2028}$, y si bien no todos pueden «corromper con sus propias manos las instituciones, pero por supuesto sí por mano ajena» ${ }^{2029}$.

De esta formulación se hace comprensible, como dijimos supra, que los llamados delitos de organización, en los que se hace necesaria la participación de varios sujetos, habitualmente especializados, cada uno aporta algo adecuado al fin, lo que se ha denominado «injusto

2023 ID., ibidem, op. cit., p. 63.

${ }^{2024}$ Primera, que quien a través de su conducta no modifica nada en el ámbito de organización de otra, o sólo modifica algunas sobre las que tenía derecho, no interviene. Segunda, las aportaciones usuales del mundo cotidiano «no dependen de cómo pretenda el receptor concebir el aporte en cuestión». Tercera, la habitualidad de una prestación cotidiana tiene un contexto usual que configura el entorno, de tal manera que la «prestación pierde su neutralidad y devendrá delictiva cuando el delito determina precisamente el contorno». Cuarta, «(c)uando su conducta se orienta especialmente de manera delictiva según el plan de otro (esto es: por su parte fracasa si el otro desiste de su propósito delictivo), entonces no puede desvincularse de la realización del delito (...) quien aporta a un plan significativamente delictivo una prestación idónea no puede desvincularse de la realización de ese plan». Quinta, «quien aporta a otro, de manera recurrente, prestaciones cotidianas interviene en un delito en la medida en que el «mosaico» resultante muestra la continuidad delictiva. Esto es, quien se hace pasar por «conseguidor» no será juzgado por lo que en el caso concreto «consigue», sino por lo que muestra el cuadro completo», ID., ibidem, op. cit., p. 63 a 66.

${ }^{2025}$ ID., ibidem, op. cit., p. 66.

2026 ID., ibidem, op. cit., p. 67.

${ }^{2027}$ ID., ibidem, op. cit., p. 67. Al respecto POLAINO-ORTS comenta que «los diversos títulos de intervención delictiva no presentan una diferencia cualitativa sino cuantitativa. Dicho de otro modo: entre autor y cómplice, entre cooperador necesario y un inductor no existen diferencias cualitativas sino cuantitativas, de manera que no son cosas diversas ni responsables de delitos diferentes sino todos ello responsables de un mismo delito. Hablando en términos jocosos, pero gráficos: cada uno de ellos come más o menos, pero la tarta es de todos», POLAINO-ORTS, G., «Gunther Jakobs y el funcionalismo jurídico-penal», JАKOBS, G., El lado comunicativo y el lado silencioso del Derecho penal. Expectativas normativas, intervención delictiva, Derecho penal del enemigo, op. cit., p. 39.

2028 JAKOBS, G., «Una teoría de la intervención delictiva», op. cit., p. 70.

${ }^{2029}$ ID., ibidem, op. cit., p. 72. 
sistémico» o «imputación colectiva» ${ }^{2030}$, precisamente cada sujeto aporta algo que por sí sólo sería ya no sólo inidóneo sino imposible para el delito, pero que sumados todos alcanzan significación y relevancia jurídica, o al menos peligro, es un injusto directo a la agrupación, asociación o entidad distinta de la imputación de cada miembro por el delito en concreto que persigan o que hayan comenzado a ejecutar o consumado, que versará en la aportación cuantitativa o cualitativa. De esta manera se reduce la complejidad: esto significa que la organización es una forma de facilitación del injusto, o en sí mismo un peligro autónomo. Entonces, aparece por un lado un fundamento de ilegalización de la organización, de otra, la pertenencia como atribución-aportación personal de cada individuo a la organización, y finalmente otra en la imputación del delito-fin a los que participen concretamente en este.

De tal modo, la incoherencia en la que incurren los postulados de la autoría mediata es responsabilizar a los «mandos intermedios» con base a distintos niveles de un sistema, como propone parte de la doctrina ${ }^{2031}$, lo que desintegra la posibilidad de una coautoría con un gran número de sujetos, o -como indicábamos- la distinción entre delito sistémico y delito-fin. La doctrina roxiniana parece desterrar al autor intelectual («jefe de la banda») del concepto de autoría, o dicho de otro modo -según Roxin y sus seguidores más ortodoxos- en la autoría mediata en aparatos organizados, si seguimos el razonamiento, el autor intelectual no sería autor («mediato»).

La crítica que expone gran parte de la doctrina ${ }^{2032}$ a la solución de la coautoría en los aparatos organizados es que no se cumplen los requisitos tradicionales de la coautoría, tales como el

${ }^{2030}$ LAMPE, Ernst-Joachim, «Injusto del sistema y sistemas de injusto», trad. Carlos Gómez-Jara Díez, ErnstJoachim LAMPE, La Dogmática jurídico-penal entre la ontología social y el funcionalismo, ed. y trad. española de Gómez-Jara Díez C / Orce G / Polaino-Orts M., Grijley, Lima, 2003, pp. 97 y ss. En este caso LuHMANN conceptualizó las organizaciones como sistemas sociales a camino entre la interacción y la Sociedad, que se caracterizan por la afiliación y por la toma de decisiones que se enlazan unas con otras, que genera la reducción de la posibilidad de comportamientos espontáneos a pesar de que la afiliación es libre, LuHMANN, N., Organización y decisión, op. cit., pp. 24 y 25; ID., Organización y decisión. Autopoiesis, acción y entendimiento comunicativo, op. cit., pp. 14 y ss; ID., «Interacción, organización, sociedad. Aplicaciones de la teoría de sistemas», op. cit., pp. 202 y 203. Por eso las organizaciones no están constituidas por personas, sino por roles que son expectativas de comportamiento, por eso el sistema de conciencia de cada sujeto, las implicaciones psíquicas y motivos no son relevantes en la organización como dinámica comportamental sistémica, ID., ibidem, op. cit., pp. 202 y 203. Le sigue en este sentido VÁSQUES SHIMAJUKO, S., La imputación de los resultados tardíos, op. cit., pp. 149 y 150.

${ }^{2031}$ ROXIN critica que se cree una coautoría por quien sólo ha creado unas condiciones previas, pues entiende que no es su peligrosidad criminal como principal responsable el fundamento, sino su posición central en el hecho típico, puesto que en ocasiones, sólo interviene en la fase de preparación, Roxin, C., Autoría y dominio del hecho, op. cit., pp. 308 y ss. y pp. 330 y ss; FERNÁNDEZ IBÁÑEZ, E., La autoría mediata en aparatos, op. cit., pp. 277 y 278.

${ }^{2032}$ FERNÁNDEZ IBÁÑEZ, E., La autoría mediata en aparatos, op. cit., pp. 160 y ss., se basa en el caso Eichmann como mando intermedio responsable. Explica que si bien el Tribunal de Distrito de Jerusalén aplicó la coautoría, la argumentación que esgrimió sustentaba la autoría mediata porque en «la medida de responsabilidad más bien aumenta cuanto más alejado se esté de aquél que con sus manos hace funcionar el arma asesina y más se acerque uno a los puestos superiores de la cadena de mando», ID., ibidem, op. cit., p. 164; otros llevan los mandos 
acuerdo en común ${ }^{2033}$, la realización conjunta del hecho, el conocimiento personal de los demás coautores $^{2034}$ ni la igualdad de rango o la forma horizontal ${ }^{2035}$.

No hay problema alguno en admitir la coautoría en un sujeto que tan solo interviene en la fase preparatoria en virtud del dominio funcional ${ }^{2036}$, sin que suponga, como dice la crítica ${ }^{2037}$, un peligro en el adelantamiento de la barrera punitiva, puesto que también es autor el que realiza un acto preparatorio individualmente ${ }^{2038}$. HERNÁNDEZ PLASENCIA acierta al entender que no toda instrumentalización hace al ejecutor irresponsable ${ }^{2039}$. Sirva de ejemplo el ejecutor que actúa por error de tipo vencible, o sea, imprudentemente, cuestión que reconoce gran parte de la doctrina como casos de autoría mediata ${ }^{2040}$.

\section{Solución en la inducción}

También existe la posibilidad de tratar los aparatos de poder como forma de participación mediante inducción ${ }^{2041}$. Así lo entiende el propio JAKOBS ${ }^{2042}$ cuando no se dan los presupuestos

intermedios a la complicidad, GIMBERnAT, E., Autor y cómplice, op. cit., p. 191 y ss; HeRnáNDEZ PlasenCIA, JU, La autoría mediata, op. cit., pp. 276 y ss.

${ }^{2033}$ Por ejemplo DíAZ Y GARCía CONLLEDO explica la coautoría como conjunto de personas, pero en la que ninguna, por sí sola, resulta autora del hecho, pero en la que sí existe «determinación positiva conjunta», y si bien restringe bastante el campo de la coautoría, consigue diferenciar la coautoría de la pluriautoría, DíAz Y GARCÍA CONLEDO, M., La autoría en Derecho penal, op. cit., p. 690. En la pluriautoría cada interviniente realiza una acción completa de autoría consumada o intentada, de modo que cuando no hay acuerdo únicamente se deriva que no se es coautor, ID., ibidem, op. cit., p. 397. Su planteamiento además de diferenciar la coautoría y la pluriautoría en si la conducta completa el tipo, con lo que podemos estar de acuerdo, incluye igualmente el acuerdo para diferenciarlos, lo que en nuestra opinión no resulta necesario.

${ }^{2034}$ FERNÁNDEZ IBÁÑEZ, E., La autoría mediata en aparatos, op. cit., pp. 253 a 264. Critica que la orden pueda ser previa al acuerdo «tácito», ID., ibidem, op. cit., p. 263.

${ }^{2035}$ ID., ibidem, op. cit., pp. 288 a 295.

${ }^{2036}$ Advierte de forma acertada CORCINO BARRUETA que asumir la teoría de la autoría mediata en aparatos organizados de poder propiciaría distinguir «si el jefe de una banda imparte unas instrucciones por su teléfono móvil justo en el momento de la ejecución, o si esas instrucciones fueron adoctrinadas a los ejecutores de tal manera que éstos no necesitaron repetición alguna. Asimismo, la culpabilidad del ejecutor u hombre de delante es incorrecta, y contradice conceptualmente la institución de la autoría mediata y la coautoría, puesto que quien da una orden delictiva ya ejecuta un acto típico, puesto que entre los intervinientes existe una división social del trabajo en la organización delictiva», CORCINO BARRUETA, F., «Coautoría, imputación objetiva y semántica social», op. cit., pp. 131 y ss; JAKOBS, G., «El ocaso del dominio del hecho», op. cit., p. 114; ID., PG, op. cit., 21/48 y ss; LeSCH, HH., «Intervención delictiva e imputación objetiva», op. cit., pp. 947 y ss.

${ }^{2037}$ FeRnÁNDEZ IBÁÑEZ, E., La autoría mediata en aparatos, op. cit., pp. 286 y ss; MUÑOZ CONDE, F., «Problemas de autoría y participación en la criminalidad organizada», Delincuencia organizada: aspectos penales, procesales y criminológicos, Universidad de Huelva, 1999, p. 157.

${ }_{2038}$ JAKOBS, G., «Una teoría de la intervención delictiva», op. cit., pp. 55 a 76.

2039 HERNÁNDEZ PlASENCIA, JU., La autoría mediata, op. cit., p. 160.

2040 JaKOBS, G., PG, op. cit., 21/74 y ss; Bolea BARDÓn, C., Autoría mediata, op. cit., p. 182; Olmedo CARDENETE, MD., La inducción como forma de participación accesoria, op. cit., p. 595; FERNÁNDEZ IBÁÑEZ, E., La autoría mediata en aparatos, op. cit., p. 61.

${ }^{2041}$ DONNA, Edgardo Alberto., «El concepto de autoría y la teoría de los aparatos de poder de Roxin», Modernas Tendencias en la Ciencia del Derecho penal y en la Criminología, UNED, Facultad de Derecho Madrid, pp. 556 y ss; GIMBERnAT, E., Autor y cómplice, op. cit., 189 y ss., refiriéndose al líder o dirigente, si bien reconoce que no queda más remedio por la redacción del $\mathrm{CP}$, de tal manera que sólo es autor quien crea la ideología; OLMEDO CARDENETE, MD., La inducción como forma de participación accesoria, op. cit., pp. 427 y ss., acepta la cadena de 
vistos de la coautoría según su concepción normativa. Estamos de acuerdo con esta postura, si bien, generalmente será la coautoría la que mejor resuelve la estructura penal de los aparatos organizados de poder, sobre todo en una la dinámica criminal imprudente, sin perjuicio de que en casos especiales aparezcan aportaciones que podamos calificar como co-inducción e inducción en cadena o mediata, en el sentido expuesto supra.

Interesa resaltar las consideraciones dogmáticas de HRUSCHKA sobre la inducción. Para este penalista la inducción se deriva de los presupuestos de la prohibición de regreso, fundamentalmente en la versión ofrecida inicialmente por FRANK. A esta conclusión llega tras examinar los fundamentos históricos de la autoría y la participación y el concepto de libertad clásico reformulado más ampliamente ${ }^{2043}$. En relación a esta conclusión explica que «(l)a acción libre de un autor no es el efecto de una «causa» en el sentido fuerte de causa. Tampoco la acción del inductor determina el hecho del inducido, y en este sentido el inductor no «causa» el hecho del autor y el resultado del hecho (...) Esta falta de equivalencia se expresa comúnmente con la expresión de «naturaleza accesoria» de la inducción» ${ }^{2044}$. La cuestión clave, para HRUSCHKA, es que se puede considerar libre la acción tras la cual ya no es posible retroceder, de manera que sólo éste puede ser autor causante del hecho ${ }^{2045}$. Por este motivo sólo se puede ser autor o inductor, pero no las dos cosas a la vez, y esto vale tanto para el autor mediato como para el inmediato, salvo «autocontradicción» del Derecho penal ${ }^{2046}$.

Sin embargo -como muy bien precisa-, la doctrina del «autor tras el autor» está alcanzando suficiente relevancia para tenerse en cuenta si se consideran como autoría mediata los supuestos en los que también se incluye un autor inmediato con voluntad y culpabilidad (con «volición» y «voluntariamente» ${ }^{2047}$ ), lo que supone el reconocimiento de la «limitación»-también en los

inducción-complicidad y complicidad-inducción; RODRÍGUEZ DEVESA JM / SERRANO GÓMEZ, A., PG, op. cit., pp. 810 y 811; responsabiliza de inductor al que da la última orden, HeRNÁNDEZ PlASENCIA, JU., La autoría mediata, op. cit., pp. 272 y ss.

2042 JAKOBS, G., $P G$, op. cit., 21/103

2043 Dice HRUSCHKA que «(s)ólo puedo ser autor $o$ bien inductor, pero no ambas cosas a la vez, porque con una y la misma acción sólo puedo causar o no causar el resultado descrito en el tipo; en efecto, no puedo a la vez causar y no causar. Como la prohibición de regreso misma, la exclusión en relación a la categoría de «hecho» es también constitutiva del concepto de inducción», HRUSCHKA, J., «Prohibición de regreso y concepto de inducción. Consecuencias», HRUSCHKA, J., Imputación y Derecho penal, op. cit., p. 175.

${ }^{2044}$ HRUSCHKA, J., «Prohibición de regreso y concepto de inducción», op. cit., pp. 178 y 179. Tanto es así que remontándose a construcciones dogmáticas del siglo XIX llega a la conclusión que el cambio de concepto a finales de dicho siglo de Urheber entre el Urheber físico como persona que inmediatamente realiza por sí mismo la infracción, y el intelectual como la persona que determina la voluntad de otro, se comenzó a utilizar la palabra Thäter como sinónimo del primer concepto, y Anstifter como Uhheber intelectual, que condujo a la confusión de los términos y a las conceptualizaciones actuales de autoría e inducción, ID., ibidem, op. cit., pp. 181 y 182

2045 ID., ibidem, op. cit., p. 188.

2046 ID., ibidem, op. cit., pp. 189 y 190.

2047 En la terminología de HrUSCHKA, ID., ibidem, op. cit., p. 191. 
aparatos de poder- de la accesoriedad de la inducción, invadiendo la autoría mediata el ámbito «genuino» de la inducción. De manera que aboga por considerar al «autor detrás del autor» como inductor a pesar de que se le denomine ahora autor ${ }^{2048}$. De aquí concluye que existe el peligro de un progresivo crecimiento de «ficticia autoría mediata» ${ }^{2049}$.

Especialmente en este respecto merece destacar la concepción de GÓMEZ RIVERO ${ }^{2050}$, que resuelve la estructura de los aparatos organizados de poder en la unión de varios tipos de intervinientes: un cooperador necesario-cooperador necesario e inductor-autor, lo que parece corresponder, más bien, a una inducción en cadena.

De otra parte, la doctrina mayoritaria ${ }^{2051}$, casi unánimemente, no acepta la inducción de un omnimodo facturus, porque éste constituye un objeto inidóneo al estar convencido previa y definitivamente a realizar el delito en todos sus elementos. En los aparatos organizados de poder no estaríamos ante un omnimodo facturus puesto que los ejecutores inmediatos no están dispuestos incondicionalmente, de modo que para no incurrir en contradicción con la teoría de la autoría mediata en aparatos organizados, parte de la doctrina, se ve obligada a distinguir entre una persona «decidida»y una persona «dispuesta» ${ }^{2052}$. En nuestra opinión, este criterio diferenciador no elimina la posibilidad de la coautoría, por cuanto si bien casi toda la doctrina no aprecia inducción en una persona decidida, esto se puede deber al acuerdo de voluntades, al igual que sucede en una persona dispuesta que después decide actuar conforme con otro. Esto depende de la organización del delito, no de la estructura del delito que previamente se interese.

Por nuestra parte, y resumiendo, lo fundamental en la autoría mediata es la responsabilidad del autor mediato, en nuestro caso del líder y miembros activos, por el dominio de la decisión, un domino funcional en cuanto elimina el horizonte de expectativas como incapacidad «completa» de formación de la libertad de voluntad, incapacidad de decisión o la ejecución de la decisión del

${ }^{2048}$ ID., ibidem, op. cit., p. 192. Al respecto comenta que «(l)a aceptación de un «autor tras el autor» no habría sido necesaria, puesto que el inductor ya es "sancionado como un autor" (...) Quizá eso no habría sucedido si al inductor no se le llamara hoy día "inductor", sino "Urheber" intelectual», ID., ibidem, op. cit., p. 193.

2049 ID., ibidem, op. cit., p. 194. De tal manera HRUSCHKA rechaza la posibilidad de la inducción imprudente como autor de una imprudencia en virtud de la prohibición de regreso al valer todo aquello que beneficia a inductor doloso. Sin embargo JESCHECK acepta esta posibilidad como autoría imprudente. Su razonamiento, con el que estamos de acuerdo, es que lo determinante es la infracción de cuidado: «(d)e ahí que autor del delito imprudente es todo aquel que, con infracción del cuidado necesario en el tráfico jurídico, coopera a la realización del tipo (...) En conclusión, tampoco existe diferencia entre la autoría y la participación en la imprudencia consciente», JESCHECK HH / WEIGEND T., Tratado, op. cit., 61, VI.

${ }^{2050}$ GÓMEZ Rivero, Mª C., La inducción, op. cit., pp. 125 y ss. Críticamente FERNÁNDEZ IBÁÑEZ, E., La autoría mediata en aparatos, op. cit., pp. 413 y ss., ni el cooperador necesario, ni el inductor, pero tampoco el cómplice tienen el dominio del hecho.

${ }^{2051}$ Vid. y de esta opinión FERNÁNDEZ IBÁÑEZ, E., La autoría mediata en aparatos, op. cit., pp. 213 y 214 ; JAKOBS, G., $P G$, op. cit., 22/24 y 25/24 pero se puede intentar en virtud de 30.1 StGB; también JESCHECK HH / WEIGEND T., Tratado, op. cit., 64, II 2; SÁNCHEZ-VERA, J., «En los límites de la inducción», op. cit., pp. 26 y ss.

2052 FERNÁNDEZ IBÁÑEZ, E., La autoría mediata en aparatos, op. cit., pp. pp. 229 a 236 
autor inmediato, en este caso del adepto que tiene mermado completamente el horizonte de expectativas normativas y sociales que comunica el Sistema, por lo que cuando dicha incapacidad se anula plenamente, surge la responsabilidad y autoría directa, a diferencia de la persuasión coercitiva que genera déficit de socialización, en la que la restricción del horizonte de expectativas supone un margen de libertad que, sin dejar de constituir la conducta del hombre de atrás un injusto autónomo de coacciones, genera también responsabilidad en el autor inmediato, si bien concurre una causa de exculpación de estado de necesidad exculpante, es decir, es víctima y autor, esto es, coautor de su propio perjuicio y en su caso del delito-fin.

Sólo cuando se crea una adicción comportamental que es aprovechada por el hombre de atrás, de forma que la superioridad cuantitativa del «grupo mediato» puede configurar una superioridad del dominio de la decisión sobre los demás, y en final ejecutor, la voluntad grupal supone una coautoría mediata. Sin embargo, cuando el sujeto sólo sufre un déficit de socialización, la libertad que aún posee impide que la voluntad grupal se constituya como coautoría mediata, sino como coautoría en su propio perjuicio y en el delito-fin.

\section{Coautoría imprudente}

La coautoría en la imprudencia, al igual que la coautoría de sujetos que desconocen la aportación de otros, se fundamenta en la organización delictiva, precisamente en la organización imprudente. Por ello decae el fundamento del injusto de la teoría del dominio del hecho en la coautoría de delitos imprudentes, porque es incapaz de desvincularse del lado subjetivo del hecho. Dicho de otra manera, es posible que dos personas, sin acuerdo o determinación previa, ni aportación planeada o representada, cometan el injusto del homicidio colocando cada uno una dosis de veneno, que por sí sola es inocua pero unidas causan la muerte.

BONET EsTEVA acierta de pleno en que la problemática en las sectas o en estos «grupos organizados» viene de una distorsión de la imputación ${ }^{2053}$ de la autoría y la participación cuando media la persuasión coercitiva: «(l)as formas de autoría del líder del grupo dependerán, en gran

\footnotetext{
${ }^{2053}$ Comenta al respecto que «(e)ste tipo de estructuras que, en terminología psicológica, se denomina «entrada consciente», introduce elementos de distorsión en la imputación de la autoría criminal ya que entre órdenes o mandatos iniciales de comisión de un delito y el verdadero resultado lesivo acostumbran a interponer una serie de individuos diferentes con un grado distinto de relación objetiva y subjetiva con el atentado concreto contra el bien jurídico que se pretenda lesionar en ese momento (...) entre aquellas personas -el líder- que idea un plan con finalizadores lucrativas mediante la venta de productos curativos, que en realidad no son tales, y el miembro concreto del grupo de terapia que invierte una gran cantidad de dinero en estos productos pueden interponerse una diversidad de agentes que van desde aquél que realiza un proselitismo inocente y que cree sinceramente en la bondad de la terapia y de los productos hasta aquel otro que se implica con el pleno conocimiento de la ineficacia del producto y de la farsa de la escenificación terapéutica, pasando por los adoctrinamientos que pueden tener como resultado la susodicha persuasión coercitiva mental», BONET ESTEVA, M., «Grupos de manipulación mental», op. cit., p. 158.
} 
medida, del tipo de relación que establezca con sus adeptos-colaboradores y del grado de conciencia de la realización de los hechos que éstos tengas» ${ }^{2054}$. Lo comentado por la citada autora es totalmente cierto y apoya en parte nuestras conclusiones, sin embargo, la explicación no deja de ser una descripción de todas la posibilidades jurídicas de la autoría y participación, pero en definitiva aporta una conclusión previa, aquella que en las sectas coercitivas las dinámicas criminales se comenten en diversas formas de participación, y aquella en la que una conducta dolosa, con intermediación de sujetos conscientes y otros inconscientes, se utilicen para perpetrar en cadena o simultáneamente un delito-fin ${ }^{2055}$. Esto nos lleva a la posibilidad de que la conducta de quien o quienes imprudentemente ordenan cometer delitos junto con la intervención de tantos terceros con culpa consciente, o como instrumentos, constituyen una cadena que trasmite finalmente la orden al ejecutor, como coautores o coinductores con inducción en cadena y/o mediata en su caso.

No estamos de acuerdo con esta autora en que «(c)uando (...) el adepto intermedio no actúe dolosamente y fuere un mero instrumento en manos del líder, este último sería el autor mediato y quien tendría el dominio de los hechos, aun cuando se interpusiesen más adeptos no dolosos en la cadena de instrumentalización». Y no estamos de acuerdo porque aplica la autoría mediata en cadena en organizaciones delictivas, suponiendo que en estos casos el adepto intermedio no actúa dolosamente, como si la actuación imprudente del adepto intermedio prejuzgara definitivamente una solución en la autoría mediata, lo que también prejuzga la situación como si en estas organizaciones sus integrantes fueren robots, inconscientes o engañados completos.

La utilización de miembros para cometer delitos sobre sí mismos, o para que estos cometan delitos sobre terceros, se realiza igualmente por sujetos que son a la vez víctimas de la persuasión -como bien apunta BONET ESTEVA- lo que recuerda la autoría mediata en cadena ${ }^{2056}$, sin embargo, en nuestra opinión, existe una organización criminal en coautoría, coautoría en el delito de persuasión coercitiva y coautoría o co-inducción en cadena sobre los delitos-fin.

En este sentido tenemos tres grupos de casos: $1^{o}$ la utilización por parte de la organización de sujetos bajo persuasión coercitiva con déficit de socialización, o adicción comportamental para

2054 ID., ibidem, op. cit., p. 158.

2055 Concretamente dice que «(c)uando los miembros intermedios actúen dolosamente cabe plantearse, $(\ldots)$ dos posibilidades; primera, que el líder genere en el miembro intermedio la idea, o dé la orden de generar la idea de cometer un delito, en cuyo caso se estaría ante estructuras típicas de la inducción directa si se tratara, por ejemplo, de colaborar en la ejecución en un suicidio, o en cadena, si lo generado fuera la idea de inducir al sectario víctima final a cometer un delito como, por ejemplo, la apropiación de patrimonio ajeno. La segunda posibilidad, es aquella que contempla que entre el líder y los jefes o miembros interpuestos haya una distribución funcional de la actuación criminal respondiendo a un plan ideado de antemano y respecto al cual tienen dominio funcional de los hechos, en cuyo caso adeptos y líderes responderían a título de coautores», ID., ibidem, op. cit., p. 158.

${ }^{2056}$ ID., ibidem, op. cit., p 162. 
que comentan delitos contra terceros o contra sí mismos (autores de conciencia, por convicción o enemigos); $2^{o}$ de otra parte, sujetos enteramente libres que desde el inicio conocen y están de acuerdo con la organización criminal (autores por convicción y/o enemigos); y $3^{o}$ otros que «inocentemente» participan sin conocimiento como instrumentos no dolosos, pero a los que nos hemos referido que pueden actuar de forma tan imprudente que mediante la aplicación de la alic pueden considerarse coautores o inductores dolosos o imprudentes.

A este respecto, RoxiN ${ }^{2057}$ considera que estos casos han de matizarse entre los de imprudencia inconsciente y consciente. Mediante un ejemplo expone que puede haber casos en los que el hombre de atrás persuade al ejecutor de que el riesgo de su conducta es bajo, aun a sabiendas de que es seguro que se produzca el resultado, así que si el ejecutor actúa conscientemente sobre la posibilidad del resultado pero no sobre su probabilidad, el hombre de atrás es autor mediato. Sin embargo, consideramos más acertada la conclusión de HERNÁNDEZ PLASENCIA $^{2058}$ que rechaza que en esos casos exista dominio sobre la voluntad, porque si el ejecutor advierte la peligrosidad, aun en imprudencia consciente, el hombre de atrás entonces es inductor, si bien, según los postulados a los que hemos llegado, tampoco habría impedimento en afirmar la coautoría en un «instrumento» irresponsable por causa de exculpación que mediante la alic pasa a ser un autor con imprudencia consciente.

Las propuestas de la autoría accesoria (Nebentäterschaft) en los aparatos organizados son escasas $^{2059}$, pues suele considerarse que la autoría accesoria son varias autorías individuales que vienen a converger en un hecho típico. Lo paradigmático es que si bien casi la totalidad de la doctrina no reconoce la coautoría imprudente, sí que algunos autores admiten en términos generales la autoría accesoria imprudente cuando falta el elemento subjetivo de la coautoría, el acuerdo $^{2060}$, de forma que se pueda participar en el desvalor del resultado. Sólo una conducta

2057 Roxin, C., PG, I, op. cit., I, pp. 423 y ss., y pp. 1018 y ss; STRATENwerth, G., PG, I, op. cit., p. 320; Bacigalupo, E., Principios, op. cit., p. 370.

2058 HERNÁNDEZ PlASENCIA, JU., La autoría mediata, op. cit., p. 42, p. 275 , p. 342.

2059 Parcialmente Bolea BARdón, C., Autoría mediata, op. cit., p. 362.

${ }^{2060}$ RoXIN, C., «Las formas de intervención en el delito: estado de la cuestión», trad. María Teresa Castiñeira Palou, vv.aa., Sobre el estado de la teoría del delito, op. cit., pp. 175 y ss; CORCOY BIDASOLO, M., El delito imprudente, op. cit., pp. 349 y ss; DíAz Y GARCíA CONLledo, M., La autoría en Derecho penal, op. cit., p. 365; DONNA, Edgardo Alberto, La autoría y participación criminal, Comares, Granada, 2006, pp. 100 y ss; GUTIÉRREZ RoDRÍGUEZ, María, La responsabilidad penal del coautor: Fundamento y límites, Tirant lo Blanch, 2001, p. 206; JesCHECK HH / WeIGEND T., Tratado, op. cit., 63, II 3; LUZÓN PEÑA, M-D., «La determinación objetiva del hecho. Observaciones sobre autoría en los delitos dolosos e imprudentes de resultado», $A D C P C, 1989$, p. 899; ID., Curso de Derecho Penal, Parte General, I, op. cit., p. 510; Roso CAÑAdLlas, R., Autoría y participación imprudente, op. cit., pp. 589 y ss., cuando no exista el elemento subjetivo de la coautoría, el acuerdo, pero concurren los presupuestos objetivos de ésta, sin embargo razona que no es posible aplicar el principio de imputación recíproca, «pues a nadie se le puede hacer responsable por algo de lo que no ha tenido conocimiento», y por lo tanto impune por ser una tentativa imprudente, pero comenta que en la mayoría de ocasiones el resultado era previsible, por lo que existe imprudencia consumada, ID., ibidem, op. cit., p. 593. Convincentemente concluye que «nos podemos 
determina el resultado, las demás serán participaciones impunes o no, según si se participa en un delito doloso (caso Vinader) o imprudente, si bien, como decimos, la doctrina llega a soluciones diferentes, pero con dichos fundamentos se puede defender la coautoría imprudente en la organización delictiva, y a la postre en casos análogos a los de los aparatos organizados de poder, tales como las sectas coercitivas.

La concepción funcionalista y sistémica de la coautoría «no se fundamenta en el marco de lo subjetivo, sino únicamente en el marco de la imputación objetiva. La coautoría es en principio posible también en los delitos imprudentes y ello es debido a que los delitos dolosos e imprudentes no se diferencian respecto a la imputación subjetiva, entonces no es necesaria ni siquiera una coordinación consciente y querida de la ejecución de un comportamiento para la consecución del resultado que ha resultado fallido» ${ }^{2061}$. De este modo, cada vez más se admite por la doctrina la coautoría imprudente generalmente ${ }^{2062}$, y también en supuestos de acuerdos de

encontrar con una participación imprudente objetiva o subjetiva, bien sea porque exista un acuerdo entre el partícipe imprudente y el autor doloso, bien sea porque el autor doloso se aprovecha de la imprudencia del partícipe imprudente, pero sin que exista un acuerdo, aunque el favorecedor imprudente podía o debía haber previsto semejante posibilidad, ID., ibidem, op. cit., p. 604.

${ }^{2061}$ CORCINO BARRUETA, F., «Coautoría, imputación objetiva y semántica social», op. cit., pp. 123 y 124; antes también LESCH, HH., «Intervención delictiva e imputación objetiva», op. cit; con similares argumentos pero concluyendo también en la participación imprudente ROBLES PLANAS, R., «Participación en el delito e imprudencia», op. cit, p. 244 y p. 249; GARCÍA DEL BLANCO, MªV., La coautoría en Derecho penal, op. cit., pp. 687 y ss; amplias referencias de la doctrina alemana a favor en Roxin, C., Autoría y dominio del hecho, op. cit., p. 740 nota 532 y p. 741 nota 533 entre los que nombra a MEZGER, OTTO y SCHMIDHÄUSER.

2062 Corcino Barrueta, F., «Coautoría, imputación objetiva y semántica social», op. cit., pp. 123 y 124; recientemente DEL CASTILlo CoDES explica de forma convincente que «si (...) hemos mantenido que toda imprudencia consciente, subjetivamente, en el conocimiento de un sector relevante de las circunstancias fundamentadoras del peligro para el bien jurídico, y que el sujeto, al actuar con conocimiento de dichas circunstancias, se decide por el foco de riesgo que resulta de su actuación, es perfectamente admisible que varios sujetos se concierten para generar, en común, un determinado foco de peligro. Ciertamente, que tal decisión común no se proyectará sobre el resultado lesivo, dado que el mismo no forma parte del tipo imprudente ni, por tanto, es abarcado por la voluntad de los intervinientes, pero sí sobre las circunstancias riesgosas de las que se derivará el resultado. Toda vez que el autor imprudente siempre actúa en dirección consciente hacia una determinada meta, que no es otra que la formación del foco de peligro, puede constatarse una decisión de varios sujetos hacia un mismo fin penalmente relevante», Del CASTILlo CoDES, E., La imprudencia: autoría y participación, op. cit., p. 194. De esta manera, continúa el citado autor explicando que «el riesgo resultante de la actuación de varios reviste mayor intensidad y, con ello, incrementa la probabilidad de lesión para el bien jurídico (considero admisible esta forma de intervención en todos aquello supuestos en los que también un solo interviniente habría podido causar la lesión del bien jurídico), siempre que la actuación conjunta de varios haya supuesto un aumento de las probabilidades de lesión, pues de este modo se puede efectuar una imputación recíproca con independencia de la concreta eficacia de la conducta de cada uno respecto del resultado final», ID., ibidem, op. cit., p. 195; GUTIÉRREZ RODRÍGUEZ, M., La responsabilidad penal del coautor, op. cit., pp. 603 y ss., basta una capacidad lesiva directa parcial; LESCH, HH., «Intervención delictiva e imputación objetiva», op. cit; exige el común acuerdo LUZÓN PEÑA, M-D., «La determinación objetiva del hecho. Observaciones sobre autoría en los delitos dolosos e imprudentes de resultado», op. cit., p. 907; ID., Curso de Derecho Penal, Parte General, I, op. cit., p. 510; Roso CAÑADILlaS, R., Autoría y participación imprudente, op. cit., pp. 561 y ss., la admite como aportaciones incompletas y sólo de su unión se llega al resultado. 
órganos colegiados en la responsabilidad por el producto y en los delitos ambientales ${ }^{2063}$, lo que se asemeja, sin lugar a dudas, a la dinámica criminal de la persuasión coercitiva expuesta. Por eso RoXIN se vio obligado a reformular el «dominio del hecho» en los delitos imprudentes ${ }^{2064}$.

Sobre la coautoría imprudente creemos conveniente resaltar el ejemplo que expone DEL CASTILlO CODES ${ }^{2065}$ de dos guardias que simultáneamente disparan a un delincuente, al objeto de tratar nuestra problemática en las organizaciones criminales sectarias. El resultado de lesión o muerte por uno de ellos considera que es un caso de coautoría imprudente, porque el citado penalista se fija en el título de imputación del cuidado inobservado; sin embargo -como bien señala Roso CAÑADILLAS-, la coautoría imprudente no abarca el resultado lesivo pero sí las circunstancias riesgosas $^{2066}$, de ahí que concluya que en este ejemplo existe una pluriautoría ${ }^{2067}$. En nuestra opinión, aquí sólo habría una autoría, salvo que se explique que los disparos del otro agente contribuyeron a que la víctima estuviera más indefensa, a que no huyera, o a aumentar la probabilidad del resultado, por ejemplo trasladándola a un lugar más visible y/o indefenso, máxime cuando en el caso que se cita el resultado se produjo cuando ambos dispararon a las ruedas, lo que acredita que el disparo del otro nada tiene que ver con el aumento del riesgo y del resultado.

Tampoco estoy de acuerdo con el citado autor en que las actuaciones de los sujetos deban de ser simultáneas ${ }^{2068}$, basta con que una y otra aumenten el riesgo, tengan el mismo título de

\footnotetext{
${ }^{2063}$ ROXIN afirma que «(l)o mismo es aplicable al supuesto en que un grupo, mediante obrar conjunto descuidado, causa un resultado sin que pueda verificarse quién del grupo ha realizado con su propia conducta, la aportación causal», RoxIN, C., Autoría y dominio del hecho, op. cit., p. 741.

${ }^{2064} \mathrm{Al}$ respecto comenta sobre los delitos imprudentes «que la autoría única se basa exclusivamente en la imputación objetiva. Por consiguiente, habría que formar un concepto de «comisión conjunta» que se apartara de la coautoría de los delitos de dominio», ID., ibidem, op. cit., p. 741. ROXIN se apoya en el estudio de RENZIKOWSKI, para corregir las incoherencias del dominio del hecho en los delitos imprudentes. RENZIKOWSKI requiere «en principio, un proyecto conjunto de acción. Este «hecho global» debe presentarse como creación de un peligro jurídicamente desaprobado. Asimismo, los coautores han de haber realizado las aportaciones previstas en el plan conjunto, no siendo necesaria la realización causal entre el resultado y cada una de las aportaciones. Por último, la imputación presupone que cada interviniente pudiera y debiera darse cuenta de la peligrosidad del proyecto conjunto», vid. RoXIN, C., Autoría y dominio del hecho, op. cit., pp. 741 y 742 (RENZIKOWSKI, Joachim, Restriktive Täterbegriff und fahrlässige Beiteiligung, 1997, pp. 288 y ss); más ampliamente, Roso CAÑADILLAS, R., Autoría y participación imprudente, op. cit., pp. 575 a 577. ROXIN también nombra a WEISSER, del que dice que requiere para la autoría imprudente «que los intervinientes estén sometidos objetivamente al mismo deber de cuidado, que cooperen voluntariamente en realizar la acción u omisión descuidada y que cada coautor sea consciente de que a los demás se le dirigen las mismas exigencias de cuidado que a él», y comenta que «(t)al puede ser el punto de partida», vid. RoxIn, C., Autoría y dominio del hecho, op. cit., p. 742 (WEISSER, Bettina, «Gibt es eine fahrlässige Mittäterschaft?», JZ, 53, 1998, p. 239). Más ampliamente Roso CAÑADILlAS, R., Autoría y participación imprudente, op. cit., pp. 572 a 575.

2065 Del CASTILlO CODES, E., La imprudencia: autoría y participación, op. cit, pp. 195 y 196.

2066 Roso CAÑAdILLAS, R., Autoría y participación imprudente, op. cit., pp. 581 a 587.

2067 ID., ibidem, op. cit., pp. 434 a 436.

2068 Del CASTILlo CODES, E., La imprudencia: autoría y participación, op. cit, p. 198, sin embargo se aparta de su criterio referido que una sola conducta o todas por sí solas pueden causar el resultado y admite que en los casos de «concurrencia de culpas» las conductas por sí solas no hubieran causado ninguna el resultado, lo cual me parece
} 
imputación objetiva, con independencia si una comenzó y terminó antes, o que la otra fuera la que finalmente produjo el resultado, pues la conexión de la coautoría estriba en la unión de imputaciones parcialmente riesgosas, sin significado alguno por sí solas ${ }^{2069}$, pero en la que ambas producen el resultado, de tal modo que la imputación no estriba en que cada interviniente comete una imprudencia en su propio actuar, sino en que no observa la actuación del otro cuando debió atender también a su actuación, al ser cada uno garante de la evitación del resultado.

Así las cosas, estamos de acuerdo en que la organización delictiva o codelincuencia imprudente, que -según refiere Roso CAÑADILLAS ${ }^{2070}$ - no ha recibido atención por parte de la jurisprudencia porque se aferra a que si no existe concurso de voluntades o pactum sceleris sólo existiría concurso o concurrencia de conductas imprudentes, es decir, intervención por separado $^{2071}$. La conclusión es que el cambio de situación de delito imprudente a doloso, o

contradictorio con sus postulados, si bien admite que «(1)o anterior nos plantea una cuestión problemática, a saber: en los supuestos que nos ocupan, ningún interviniente es subjetivamente responsable por la totalidad del riesgo creado, ya que, como hemos visto, el conocimiento de cada uno de ellos se proyecta sobre los factores de riesgo que genera su propia conducta, pero desconoce, en cambio, los que pertenecen a la del otro (...) Desde el punto de vista objetivo, el riesgo creado por la confluencia de ambas conductas es superior al resultado de cada una de ellas, aisladamente considerada, pero como hemos indicado, ninguno de los intervinientes tiene consciencia de todas las circunstancias que integran dicho peligro final. La consecuencia que de ello se deriva, es que no resulta admisible la autoría sobre la totalidad del riesgo creado ni, consiguientemente, sobre el resultado lesivo. Cada uno de los intervinientes es autor de la parte de riesgo respectivamente generado a través de su conducta, pero no de aquél exceso resultante de la confluencia de ambas, puesto que su conocimiento no abarca el citado plus, y una de las consecuencias más importantes a las que hemos llegado en este trabajo, es que solo se puede responder por lo que se conoce», ID., ibidem, op. cit., pp. 201 y 202.

2069 Roso CAÑADILLAS, R., Autoría y participación imprudente, op. cit., p. 224.

${ }^{2070}$ ID., ibidem, op. cit., pp. 422 y ss.

${ }^{2071} \mathrm{Si}$ bien cabe precisar que existe jurisprudencia sobre acuerdo imprudente, y por lo tanto, sobre codelincuencia y coautoría imprudente, la casuística jurisprudencial se ha ocupado de casos como el de la «cesión del volante», «cesión del vehículo», el caso del director general de una inmobiliaria que ordena al jefe de obra prescindir del arquitecto y aparejador, o el anterior citado sobre falta de medidas de seguridad por parte del jefe de obra y el arquitecto, en los que precisa un «acuerdo o coincidencia de voluntades en la realización de un mismo acto peligroso», lo que nos lleva a considerar que no existen, hasta ahora, aportaciones claras sobre la coautoría imprudente, y menos aún como fundamento de punibilidad de una organización. Y es que la dificultad estriba, como bien apunta Roso CAÑADILLAS, en los casos en los que no se puede probar quien es el autor, sin embargo, «con la aplicación de la coautoría (...) se puede salvar los problemas de prueba (...) y llegar así a la condena como autores de todos los intervinientes que de común acuerdo han llevado a cabo la actuación peligrosa, o bien han perseguido y querido el resultado lesivo (en el caso del delito doloso)», ID., ibidem, op. cit., p. 429. Si bien admite que por aplicación del indubio pro reo llevaran a la absolución, y que en todo caso se resuelven mejor con la pluriautoría («coautoría aditiva») porque «cada uno de ellos utiliza el arma de modo imprudente infringiendo la norma de cuidado. Por tanto, si se supiese cuál de ellos ha producido el homicidio, lesiones imprudentes, sólo se le condenaría a él y no al resto de los intervinientes. Ello no es más que la prueba de que no existe coautoría, por lo que acudir a esta figura para castigar constituye la conculcación del principio procesal del indubio pro reo y negar, finalmente, la absolución a personas inocentes», ID., ibidem, op. cit., p. 433 y p. 435; DíAZ Y GARCÍA CONLLEDO, M., La autoría en Derecho penal, op. cit., p. 585 resuelve los casos claros de autoría aditiva mediante la cooperación ejecutiva de art. $14.1^{\circ} \mathrm{CPd}$. Por nuestra parte, el error de este planteamiento, más allá de la prueba de la intervención en el resultado o en la tentativa (tentativa imprudente, si bien no punible salvo en delitos de peligro como delito consumado), cuestión evidente en todos los procesos, es la exigencia de un acuerdo, pues sin éste también puede existir coautoría en una concepción extensa de pluriautoría utilizada por otros, o como en la coautoría funcional sistémica. 
viceversa, se trata como autoría todo comportamiento imprudente, mientras que en los delitos dolosos se permite la graduación en la participación porque «el tipo objetivo doloso queda mejor limitado, dibujado, configurado, señalado y marcado que el delito imprudente» ${ }^{2072}$. Así, no habría problema en admitir la participación en los delitos imprudentes ${ }^{2073}$, bajo pena de incurrir en el absurdo señalado por la citada autora, y del mismo modo, excluir conductas de la imputación objetiva cuando no supongan un riesgo, o sean conductas neutrales, o en definitiva, cuando no exista competencia o deber de aseguramiento o protección. Si bien, como decíamos, la graduación de los títulos de intervención, también en el delito imprudente, es puramente fenomenológica y no responde más que a explicaciones de lege data, no a criterios dogmáticos basados en el injusto propio. Entonces, la imputación objetiva y la imputación del título de participación no coinciden ${ }^{2074}$.

Así Roso CAÑADILLAS se ve obligada a concluir que en los casos de muerte o lesión por la conducción de un vehículo, al tratarse de un delito de propia mano «la acción de pilotaje en la conducción (delito de peligro anticipado al correlativo delito de lesión imprudente)», difícilmente podrá apreciarse la coautoría «ya por la propia estructura del tipo y de la conducta no cabría la coautoría en el caso de que sólo fuese uno el que condujese», salvo en los casos en que se comparten los mandos, Roso CAÑADILlAS, R., Autoría y participación imprudente, op. cit., pp. 443 y 445. Por eso, de estos planteamiento se ve obligada a afirmar que en la concurrencia de culpas, la falta de acuerdo previo afecta a varias instituciones dogmáticas como en la participación en el desvalor subjetivo del injusto, o en la imputación objetiva, por eso no aclara qué conclusión subyace, y si bien admite, acertadamente, que la valoración deberá ser normativa, no ontológica o causalísta, sin embargo, yerra en que «-la víctima no puede ser considerada autora desde un concepto normativo de autor, ya que no lleva a cabo acciones típicas-, con lo que los efectos de la concurrencia de imprudencias sólo se constriñen a degradar la imprudencia del autor-agente, pero no llegarían a excluir su responsabilidad penal por el hecho de ser finalmente un simple partícipe imprudente, al considerar el TS la concurrencia de imprudencias como un problema sólo de causalidad (...) conduce en el ámbito de la circulación a un concepto unitario de autor», ID., ibidem, op. cit., pp. 449 y 450. Así, los casos de coautoría imprudente se fundamentan no tanto en la imputación objetiva sino en los propios criterios de coautoría e imputación recíproca, ID., ibidem, op. cit., op. cit., p. 516.

${ }^{2072}$ ID., ibidem, op. cit., pp. 507 y 508: «Por tanto, si la descripción típica es la misma en el delito doloso que en el delito imprudente (...) no se logra entender la razón de por qué prescindir de un filtro limitador de la tipicidad objetiva en la imprudencia (...) declarando la responsabilidad por autoría ante aportaciones que objetivamente no determinan el resultado», lo cual es claramente injusto.

${ }^{2073}$ ROBLES PlanAS, R., «Participación en el delito e imprudencia», op. cit, p. 244 explica que «el hecho de que el partícipe obre dolosa o imprudentemente carece de relevancia para la determinación de la existencia objetiva de la participación. La subjetividad del partícipe no aporta ningún dato relevante para la imputación del hecho. En efecto, por un lado, con la mera aportación de participación es imposible identificar qué tipo de delito realiza objetivamente el partícipe (de manera que su conducta no está prohibida por atípica). Sólo con la exteriorización del hecho (inicio de la tentativa) es posible afirmar su tipicidad objetiva. Por otro lado, algo parecido sucede con el aspecto subjetivo. Dado que con la mera aportación de participación no puede aún identificarse la tipicidad objetiva de su conducta, tampoco podrá afirmarse cómo está subjetivamente abarcada (en términos dolo/imprudencia). De nuevo, sólo con la exteriorización del hecho que llega a ser objetivamente típico puede afirmarse la existencia de dolo o imprudencia referida a esa exteriorización (riesgo típico). De lo anterior también puede deducirse la irrelevancia de la distinción dolo/imprudencia referida a la aportación del partícipe en sí misma (aisladamente) considerada. Únicamente cuando tal aportación llega a formar una unidad de sentido con el hecho principal (co-configuración), existiendo entonces un título de imputación objetiva suficiente, puede pasar a analizarse la manera en que cada interviniente abarca subjetivamente el riesgo fundado en común».

${ }^{2074}$ ROSO CAÑADILLAS, R., Autoría y participación imprudente, op. cit., pp. 511 y ss., también en los casos de autoría medita imprudente, ID., ibidem, op. cit., p. 516; DíAZ Y GARCÍA CONLlEDO, M., La autoría en Derecho penal, op. cit., pp. 496 y 497 comenta que «la imputación objetiva del resultado ha de darse tanto en el autor como en los partícipes y el hecho de que los principios de tal imputación objetiva hayan de ser distintos para uno y para 
Roso CAÑADILLAS, con razonamientos semejantes, llega a conclusiones distintas a la que en esta investigación se mantienen. Considera que en la autoría mediata el hombre de atrás también puede actuar en imprudencia inconsciente, y más si cabe con imprudencia consciente, cuya trascendencia reside en pasar de ser un partícipe imprudente e impune, a un autor mediato imprudente y punible ${ }^{2075}$. Si bien, por nuestra parte, ambos casos se pueden resolver con la coautoría, tanto en la aportación con imprudencia consciente como inconsciente. De esta manera, estamos de acuerdo con aquellas posturas que concluyen que la finalidad o la conciencia en el hecho nada aporta en las formas de intervención criminal $^{2076}$.

Por tales motivos, el acuerdo común en la coautoría imprudente «puede ser expreso o tácito y simultáneo o anterior, al igual que en el dolo» ${ }^{2077}$. Basta que los sujetos tengan una voluntad conjunta de acción descuidada que infringe la norma de cuidado, consciente o no de la acción de descuidado $^{2078}$, cuestión que según lo visto no es del todo inexistente en la dinámica de las sectas coercitivas, sino que representa un caso prototípico de cómo se pueden llegar a determinados resultados a pesar de la falta de intencionalidad, inclusive en el supuesto de que todos podían conocer que la unión de sus imprudencias lleva al resultado, lo que puede trasladarse en ocasiones a configurarse un «dolo eventual grupal».

\section{El problema de la reciprocidad de los criterios de imputación}

En nuestra opinión, el error de todos los planteamientos que niegan la coautoría proviene de exigirse generalmente la «imputación recíproca», esto es, que sea necesario que todos los intervinientes incumplan las mismas exigencias de cuidado, de modo que si uno incumple deberes de organización y otro institucional, no se cumpliría la coautoría. Parte de la doctrina exige que cada interviniente sea consciente de que los demás tienen la misma exigencia de tipo jurídico $^{2079}$. Si se exige un mismo deber de cuidado: ¿qué sentido tiene fundamentar la coautoría

otros no significa absolutamente nada, pues posiblemente también han de jugar de manera distinta en los delitos dolosos y en los imprudentes, sin que por ello nadie identifique imputación objetiva y dolo o imprudencia».

2075 Roso CAÑAdillas, R., Autoría y participación imprudente, op. cit., p. 531 y pp. 543 y ss.

2076 DíAZ Y GARCÍA CONlledo, M., La autoría en Derecho penal, op. cit., p. 575 concluye que «se exija finalidad o se exija consciencia, lo que está claro es que ello nada tiene que ver con la posición interna del sujeto respecto a su forma de intervención en el hecho, nada tiene que ver con querer el hecho como propio o ajeno, con tener voluntad preponderante o no, con actuar en interés propio o ajeno, etc.»; HERNÁNDEZ PLASENCIA, JU., La autoría mediata, op. cit., pp. 69 y ss; Roso CAÑADILlAS, R., Autoría y participación imprudente, op. cit., p. 521.

2077 Roso CAÑADILlAS, R., Autoría y participación imprudente, op. cit., p. 581; GUTIÉRREZ RODRÍGUEZ, M., La responsabilidad penal del coautor, op. cit., p. 179 y ss.

2078 DÍAZ Y GARCía CONLLEDO, M., La autoría en Derecho penal, op. cit., pp. 655 y ss; GUTIÉRREZ RODRÍGUEZ, M., La responsabilidad penal del coautor, op. cit., pp. 149 y ss., y p. 252; Roso CAÑADILLAS, R., Autoría y participación imprudente, op. cit., pp. 581 y 582.

${ }^{2079}$ WeISSER, B., «Gibt es eine fahrlässige Mittäterschaft?», op. cit., p. 237, vid. DEL CASTILlo CODES, E., La imprudencia: autoría y participación, op. cit., p. 195. Al respecto, expone el ejemplo del propietario de una obra que 
en el aumento de las probabilidades de lesión, con independencia de la concreta eficacia de la conducta de cada uno respecto del resultado final? Si éste es el fundamento de la coautoría, habrá que concluir que también en distintos incumplimientos de deber se generará la situación riesgosa (tentativa imprudente) o el resultado (consumación imprudente). Si bien es cierto que estos casos se pueden fundamentar en la autoría accesoria o, mejor, en autorías independientes, cada uno responsable de un delito distinto.

Un ejemplo: un sujeto introduce veneno en el desayuno de un menor, y el padre que conoce este hecho o desatiende el cuidado no hace nada. En este ejemplo no se puede negar que existe coautoría a pesar de que los deberes sean distintos, si bien la mayor parte de la doctrina sigue refiriéndose a este tipo de casos como autoría accesoria por la «concurrencia casual» de $\operatorname{ambos}^{2080}$. Sin embargo, desde nuestra posición, ambos son competentes del resultado, el primero por el axioma «no dañar», el segundo por un deber institucional, puesto que si la infracción por organización como la de deber se fundamentan en imputaciones (fundamentos normativos distintos), no es del todo cierto que la coautoría se sustente en criterios de imputación semejantes y únicos, pues tal y como hemos visto la coautoría imprudente ayuda a comprender que no es necesario una unicidad de imputaciones. Exclusivamente las situaciones de uno y otro autor no se conectarán si tienen deberes distintos en cuanto al resultado, o sea, si el primero sólo tiene un deber de actuar (solidario) en la omisión del deber de socorro, y el segundo de organización o institucional en cuanto al resultado.

Otro ejemplo: si un sujeto debió conocer que un menor está en peligro de muerte y su padre tampoco observa el peligro cuando debió hacerlo, ambos no son coautores del mismo delito, sino cada uno es responsable de su propia competencia, uno por omisión del deber de socorro, otro por homicidio imprudente. Sensu contrario, sobre un mismo hecho, dos sujetos pueden concertar o no un resultado, y la producción del mismo sigue siendo obra conjunta a pesar de los distintos fundamentos de imputación de la autoría, porque la situación no varía cuando ambos son competentes del resultado y éste se produce por la conducta de ambos. En el ejemplo del veneno

no observa las medidas de seguridad y el arquitecto que no las subsana. Sin embargo en este ejemplo, su conclusión hace desaparecer casi por completo la posibilidad de la coautoría imprudente. Lo cierto es que el propietario, en el ejemplo expuesto también es responsable de la conducta del arquitecto desde el momento en que «ayuda» con su inobservancia al descuido del arquitecto, o dicho de otro modo, el arquitecto no habría incurrido en error si previamente el propietario no hubiera dejado de observar las medidas de seguridad, de modo que en ambos aparece una realización conjunta de un mismo hecho lesivo, si bien cada uno con distinto criterio de responsabilidad en el delito imputado. Por ejemplo, en la muerte por derrumbamiento de la fachada ambos son responsables del delito de homicidio imprudente en coautoría, lo que sucede es que la mayor responsabilidad de uno se traslada al otro porque ambos son competentes «positivamente» de vigilar los resultados del trabajo del otro, si bien dentro de las limitaciones normativas de cada profesión.

${ }^{2080}$ SÁNCHEZ-VERA, J., Delito de infracción de deber y participación delictiva, op. cit., p. 201. 
que hemos expuesto, el resultado no se hubiese producido si el padre hubiera actuado conforme a su deber, lo que demuestra que a pesar que la colocación del veneno sea por un tercero, el resultado se produce por obra conjunta, o dicho de otro modo, el resultado no se hubiese producido con la conducta conforme a deber del padre.

Esto mismo vale en la coautoría imprudente con títulos de imputación distintos: al resultado le es ajeno el fundamento de imputación si se produce por la infracción alternativa de uno y otro sujeto. Esto se debe a que la cronología de las infracciones o los distintos criterios de imputación son cuestiones fenomenológicas en el resultado. La cuestión central es si ambos son autores de un mismo hecho, en cuyo caso, todos responden del todo al igual que sucede en la coautoría de dos sujetos responsables por organización o por infracción de deber.

Parte de la doctrina ha estimado que cada uno está obligado independientemente de la infracción de otros especialmente obligados (deber personalísimo) para fundamentar que no existe coautoría sino autorías ${ }^{2081}$. La base de este argumento viene de la consideración de que el incumplimiento de un deber institucional supone un «injusto doble» al incumplirse también el deber general de no dañar (nemimen laede): responsabilidad por organización. Sin embargo, cuando SÁNCHEZ-VERA ${ }^{2082}$-entre otros- fundamenta este «injusto doble», al objeto de separar los criterios de imputación y responsabilidad para negar la coautoría en casos de disparidad, creemos que se olvida que ni ScHOPENHAUER ni otros filósofos que dedujeron las dos responsabilidades se pronunciaron realmente en el sentido de dos injustos materiales, sino de «injusticia repetida» o «injusticia redoblada» como ampliación del deber negativo «no dañar» en un deber en sentido estricto: deber positivo que amplía la punibilidad al tratarse de una forma de injusticia ${ }^{2083}$.

Puesto que tanto acción como omisión son formas fenomenológicas de injusto tanto en el deber negativo «no dañar» como en el positivo, éste último es una ampliación de ese deber general de las personas, en un deber más estrictamente normativizado, de este modo, en el deber positivo se anticipa la punibilidad de lo injusto en los deberes institucionales (estatales,

\footnotetext{
${ }^{2081}$ JAKOBS, G., PG, op. cit., 21/22; SÁNCHEZ-VERA, J., Delito de infracción de deber y participación delictiva, op. cit., p. 202.

${ }^{2082}$ SÁNCHEZ-VERA, J., Delito de infracción de deber y participación delictiva, op. cit., pp. 99 y ss., refiriéndose a SCHOPENHAUER, A., El mundo como voluntad y representación, T. I, op. cit., Libro IV, 62 y ss; ID., El fundamento de la moral, op. cit., 17, pp. 103 y ss.

${ }^{2083}$ SCHOPENHAUER exponía que cuando por ejemplo «un hombre ha aceptado expresamente la obligación de proteger a otro en cierta cosa determinada, pues el descuidar esta obligación sería ya hacer mal al protegido, cometer una injusticia; también la hay cuando, no contento con esto, el mismo protector ataca y perjudica al que él debía proteger en la cosa en la que le debía protección», SCHOPENHAUER, A. El fundamento de la moral, op. cit., p. 111. Y así también, comenta que«(1)o que hace despreciable al engaño es que hipócritamente desarma a su víctima, antes de atacarla», ID., ibidem, op. cit., p. 113.
} 
familiares, etc.), sigue siendo inherente al deber general, lo que sucede es que se amplía estrictamente a un contenido positivo, por eso no es verdaderamente un «injusto doble», sino «estricto», al que se le suele asociar un mayor injusto precisamente por el valor que se le ha otorgado/relacionado a ese deber positivo a un sujeto concreto, pero que emana igualmente del deber general de «no dañar» (la justicia es negativa).

Por eso los términos de un injusto «repetido», «redoblado»o «doble» son incorrectos. La infracción se asocia normativa y habitualmente a un mayor injusto moral, esto es lo que entendemos que decía SCHOPENHAUER, pero el mayor injusto normativo se refiere a la ampliación del deber en un punto estricto, anticipando y ampliando las formas de asegurar el derecho. El resultado y el injusto es el mismo, tanto si un sujeto mata a un menor por acción o por comisión por omisión (injerencia o institucional), como si lo hace un padre de una u otra forma: no hay dos muertes en este último caso, sino una ampliación de la punibilidad como reverso del mayor margen de libertad positiva que otorga un deber positivo.

Se pasa por alto, entonces, que en caso de dos obligados el resultado sigue siendo la obra conjunta de los dos sujetos al igual que en la llamada coautoría por «omisión múltiple cumulativa ${ }^{2084}$. En el ejemplo de abandono por varios funcionarios de la vigilancia de presos, efectivamente aquí no parece existir mucho problema en admitir la coautoría o una «omisión cumulativa», porque se ve claramente que el resultado es obra conjunta de todos, pero en este caso se añade un dato que le es ajeno al deber de aseguramiento o salvación del bien, el dolo. Es decir, también en caso de falta de conocimiento o acuerdo, si se produce el resultado, existe responsabilidad por dolo o imprudencia de todos ellos, y el resultado se sigue causando de forma conjunta, o dicho de otra forma, la infracción de cada uno aporta relevantemente un factor de causación del resultado.

Dicho esto, también en la infracción de un deber, la infracción de cada uno aporta relevantemente el resultado, aun si falta el acuerdo, incluso sin conocimiento exacto. En el ejemplo discutido de deberes personalísimos, la infracción de uno y la infracción de otro, si bien es del todo personal, sigue causando el resultado conjuntamente porque si al menos uno de ellos hubiera actuado el resultado no se hubiese producido, o dicho de otra forma, la infracción de uno ayuda relevantemente a la infracción del otro. Con un ejemplo: si dos padres no alimentan a su hijo ya sea por imprudencia grave o dolosamente, aun sin acuerdo, la obra de uno ayuda a la del otro de tal forma que son intercambiables, pero cada deber positivo también contiene el negativo de no dañar, por esto, en el deber positivo se contiene el deber de vigilar el cumplimiento del

${ }^{2084}$ SÁNCHEZ-VERA, J., Delito de infracción de deber y participación delictiva, op. cit., p. 203. 
deber positivo de otros, cuando se conoce o se debe conocer que existe infracción del otro. Que el deber sea personalísimo únicamente fundamenta el título de imputación en autoría, no si el resultado se debe a una obra conjunta. Que el deber no sea conjunto o repartido normativamente tampoco fundamenta que el resultado no sea obra de todos. Ese deber conjunto, aun normativo, es puramente fenomenológico para el resultado, a éste sólo le importa que se haya causado con infracción normativa con dolo o imprudencia.

El ejemplo que expone parte de la doctrina, aun con distinta conclusión, fundamenta nuestra posición. El funcionario que facilita la fuga (u omite cerrar la puerta) actúa en tentativa, siendo ajeno el obrar de los demás funcionarios que omiten el deber. Esto es bien cierto, pero el resultado es el mismo, el preso se ha fugado por la aportación relevante de cada uno, si bien unos lo consuman y otro, el primero, lo intenta de forma acabada, de modo que ha de responder también por la consumación porque la aportación de los demás, aun sin conocimiento, o imprudentemente se comunica al primero porque el resultado se produce por una cuestión fenomenológica. También quien roba en un supermercado sin conocer que en ese momento otro ladrón distrae al vigilante sin acuerdo en común, se aprovecha de algo que desde su perspectiva es un fenómeno que le aporta consumar el resultado, como sería el caso de que en ese momento llueva y esto impidiese la vigilancia al guarda de seguridad: el resultado se ha producido. Lo que sucede es que unas veces éste se produce con la aportación de otro sin acuerdo, pero ambas conductas en conjunto son relevantes para el resultado. Y en el ejemplo de dos padres que omiten la alimentación del hijo, aun con imprudencia, la obra de cada uno supone su responsabilidad por autoría, pero el resultado no se hubiese causado sin la omisión de uno de ellos. Esta intercambiabilidad «positiva» de los sujetos es lo que fundamenta la obra común precisamente.

La solución contraria, la que niega la coautoría y fundamenta la autoría individual, se ve abocada a solucionar el caso de dos padres que se conciertan en matar a su hijo con el siguiente argumento: «no estamos ante un delito de infracción de deber en coautoría, sino ante dos delitos de infracción de deber independientes y ante una responsabilidad en coautoría pero por un delito de dominio» ${ }^{2085}$, lo cual se soluciona a través del concurso de leyes por el criterio de especialidad del art. $8.1^{\circ} \mathrm{CP}$, a favor de la infracción del deber institucional, puesto que además de dañar la institución negativa (no dañar) se daña positivamente tanto si lo comete por acción u omisión ${ }^{2086}$. La coherencia es innegable, pero paradójicamente se habla de dos delitos por cada sujeto ¿acaso hay dos muertes, o una muerte y una omisión del deber de socorro? Este razonamiento no acaba

\footnotetext{
2085 ID., ibidem, op. cit., p. 205.

${ }^{2086}$ ID., ibidem, op. cit., pp. 261 y ss. y p. 292.
} 
por refutar el hecho de que ambas aportaciones son relevantes en la causación del resultado. Tanto deber tenía uno como otro, y el resultado se produce por obra conjunta. Si al menos uno hubiera actuado conforme a deber el resultado no se hubiese producido, salvo por ejemplo una intervención directa en el impedimento de la denuncia. En este último caso sí que habría para el caso dos delitos de distinto título en el mismo sujeto, uno en la muerte por responsabilidad institucional, y otro por organización al impedir la denuncia.

En conclusión, la infracción de cada uno fundamenta su título de responsabilidad en autoría, pero esta responsabilidad, la institucional, también fundamenta el deber de impedir daños por terceros, de manera que la omisión del otro también supone un deber positivo del otro, aun cuando haya sido diligente debe actuar evitando la conducta irresponsable del otro. De lo contrario no puede refugiarse en que él completó todo el deber positivo, porque éste también incluye asegurar la reparación de la omisión del otro con deber institucional. De aquí que la omisión de uno en la falta de reparación del otro, también sea competencia suya, de forma tal que constituye una obra conjunta para el resultado, una coautoría.

Las conclusiones alcanzadas se aprecian sin lugar a dudas en la dinámica comportamental de las sectas coercitivas. El buen hacer de un miembro no inhabilita su competencia en el deber de actuar cuando otro desatiende su deber institucional o produce activa o omisivamente una organización que causa el delito. Ejemplo de esto es cuando un adepto que no interviene en la persuasión coercitiva omite, ya no el socorro, sino actos tendentes a proteger cuando otro adepto o el grupo dolosa o imprudentemente ejecutan la persuasión coercitiva. En nuestra opinión aquí existe una coautoría con títulos de responsabilidad propios pero cuyo resultado es producto de la suma de ambas partes, uno por responsabilidad institucional, otros por organización. Si bien lo habitual en estos casos es la responsabilidad de ambas partes por responsabilidad institucional en virtud de la comunidad del riesgo a la que hemos hecho referencia.

\section{III.- Autoría y participación en los delitos-fin prototípicos de las sectas coercitivas}

\section{A. Desconexión de injusto autónomo de persuasión coercitiva y formas de participación} en el delito-fin

El modelo tradicional del estado de necesidad coactivo o exculpante, o el dominio de la voluntad en virtud de coacción o error, que se soluciona mediante la autoría mediata, no puede ser aplicado en los supuestos de la persuasión coercitiva al tratarse de un injusto autónomo suficientemente grave (desconexión objetiva con el delito-fin o a la inversa, el delito-fin es más grave lo que plantea la solución por el concurso de leyes habitualmente) y del que depende una 
dinámica sistémica de su ejecución (desconexión subjetiva, varios tipos subjetivos e intervinientes), lo que permite la criminalización autónoma del delito de persuasión coercitiva y el delito-fin del que se trate sin perjuicio de los concursos. Esto se debe fundamentalmente a un concepto de responsabilidad funcional en la autoría y participación y a la casuística propia de la persuasión coercitiva que contiene márgenes de libertad.

De este modo, el modelo de la autoría mediata en aparatos organizados de poder, paradigmático en la fenomenología de las sectas coercitivas, es insuficiente e incoherente con sus propios postulados de dominio de la voluntad, sobre todo en el denominado dominio de la voluntad psicológica o en virtud de error, según los casos de intervención con imprudencia consciente o semi-imputabilidad. Además, sus postulados rivalizan con el modelo de injusto sistémico que infra desarrollaremos más detalladamente, y en el que se armoniza mejor la coautoría en la organización y la coautoría en el delito-fin con responsabilidad individual por medio del injusto propio cometido por cada sujeto, sin que se quebrante la imputación objetiva del delito de organización y el injusto individual, de manera que ambos convergen, si bien son autónomos e independientes.

De aquí que podamos por nuestra parte concluir que no existe autoría mediata en la dinámica criminal de las sectas coercitivas, sino coautoría con títulos de responsabilidad diferenciados tanto en la imputación del delito sistémico como en el delito de persuasión coercitiva y otros delitos-fin (sin perjuicio de los concursos entre estos dos últimos) cuando la persuasión coercitiva sirve de delito medio para otros delitos-fin, como por ejemplo delitos contra la vida, contra el patrimonio y contra la libertad e indemnidad sexual.

En contra, la doctrina mayoritaria ${ }^{2087}$ considera que la víctima que actúa imprudentemente contra sus propios bienes no puede ser autora, sin embargo este postulado puede ser criticado en los casos mencionados.

\section{Desconexión objetiva: el concurso entre el delito de coacciones mediante persuasión}

coercitiva y el delito-fin

RODRÍGUEZ DEVESA ${ }^{2088}$ comentaba que «(s)i el acto al cual el coaccionado ha sido compelido fuera delito, éste podrá siempre alegar en su favor la fuerza irresistible y, cuando se den los requisitos exigidos, el miedo insuperable. En tales supuestos, el autor será castigado en concurso

\footnotetext{
2087 JAKOBS, G., PG, op. cit., 21/77; GÓMEZ RIVERO, MªC., La inducción, op. cit., pp. 335 y ss; CORCOY Bidasolo, M., El delito imprudente, op. cit., pp. 349 y ss; Del Castillo Codes, E., La imprudencia: autoría y participación, op. cit, p. 202; Roso CAÑADILlAS, R., Autoría y participación imprudente, op. cit., p. 516.

${ }^{2088}$ RodríGUeZ DeVESA JMa / JASO ROLdÁN T / RODRÍGUEZ MUÑOZ JA., PE, op. cit., p 306; RODRÍGUEZ DEVESA JM / SERRANO GÓMEZ A., PE, op. cit., p. 291.
} 
real por la coacción cometida y por el delito que el coaccionado llevó a cabo por la compulsión». De esta manera se preveía la posibilidad de ser coaccionado y culpable por el delito, pero eximido por una causa de exculpación. Quizá este pensamiento resume toda esta investigación.

A este respecto la propuesta de ADOMEIT $^{2089}$ plantea diferenciar la coacción como forma de participación de la coacción como injusto propio, puesto que una cosa es coaccionar y otra el delito que se consigue con esa coacción. Si bien esta propuesta se asemeja a nuestros postulados, sin embargo no acaba por explicarla completamente. No desconecta objetiva y subjetivamente ambas cuestiones ni delimita ambas figuras, que si bien pueden ser concurrentes, tienen problemáticas distintas según lo expuesto.

Por otro lado, estiman BAJO FERNÁNDEZ y DíAZ-MAROTO que «(s)i la coacción es el medio para obligar al sujeto pasivo a cometer un delito, habrá un concurso de delitos entre el delito de coacciones como autor directo y el realizado por el coaccionado como autor mediato» ${ }^{2090}$. En el delito-fin cometido por un «instrumento» se refieren al autor como mediato, pero nada impide hablar de que la víctima de la coacción ya no sea un instrumento cuando se realiza el delito-fin, si ha mantenido resquicios de libertad como en el supuesto tratado de déficit de socialización.

En efecto, nuestros postulados llevan a apreciar la persuasión coercitiva como delito medio para otro u otros delitos-fin en los que la víctima participa en el delito medio y a su vez es víctima-autora en el delito-fin, lo que plantea el problema de los concursos que hemos resulto supra, pero todo esto sobre la base de un concepto de responsabilidad coherente con el concepto de libertad de una sociedad funcional, coherente con esos resquicios (márgenes/horizontes) de libertad que aún procura el déficit de socialización causado por persuasión coercitiva y que representa el postulado de la víctima-autor en casos especiales.

\section{Desconexión subjetiva: del título de imputación por dolo o imprudencia y de la}

\section{responsabilidad de los intervinientes}

En nuestro marco de estudio no hay inconveniente en estimar la «unidad de acción entre hechos dolosos e imprudentes (...) la ejecución de unos daños dolosos es al mismo tiempo ejecución de unas lesiones u homicidio imprudente» ${ }^{2091}$, lo que también puede ser a la inversa, la ejecución imprudente y posteriormente utilizado el hecho resultante (la persuasión coercitiva)

\footnotetext{
${ }^{2089}$ ADOMEIT, Klaus, «Die Mauerschützenprozesse - rechtsphilosophisch», NJW, 1993, p. 2915 y ss; críticamente y comentando que la coacción no representa una forma de intervención ni accesoria ni principal, sino una autoría mediata FERNÁNDEZ IBÁÑEZ, E., La autoría mediata en aparatos, op. cit., p. 19 y pp. 122 y ss.

${ }^{2090}$ Bajo Fernández M / DíAz-Maroto Y Villarejo J., Manual de Derecho Penal, Parte Especial, Delitos contra la libertad y seguridad, libertad sexual, honor y estado civil, op. cit., p. 126.

2091 JAKOBS, G., PG, op. cit., 33/6.
} 
dolosamente para otro delito-fin. Pero aquí ya no habrá una unidad o continuidad del dominio, sino una desconexión subjetiva del título de imputación que fundamenta también la atribución de dos injustos (el delito medio y el delito fin). Y lo mismo cabe apreciar cuando la persuasión y el delito-fin se realizan ambos dolosa o imprudentemente.

Esto se debe a la consumación del primero y nueva resolución delictiva del segundo por la desconexión subjetiva de la responsabilidad que también procuran los márgenes de libertad del denominado «instrumento», o con nuestra terminología, por el postulado del sujeto víctima-autor con déficit de socialización, coautor en el delito medio y en el delito-fin aunque sea contra sus propios bienes. Efectivamente, el presupuesto de responsabilidad de la víctima-autor en el delito medio y fin produce que tanto la conducta dolosa o imprudente del autor de la persuasión coercitiva impidan hablar de una continuidad en la resolución delictiva, aunque sea dolosa, para cometer el delito-fin. Esos márgenes/horizontes de libertad de la víctima(-autor) impide un dominio al modo descrito por la teoría tradicional de la autoría mediata.

En un sentido muy similar se ha manifestado GARCÍA DEL BLANCO, en relación al injusto simple o coautoría. Estima que «cuando en un mismo «hecho» intervengan diferentes sujetos realizándolo, ahora sí, conjuntamente, nada impide que la responsabilidad penal de cada uno de ellos sea totalmente diferente dependiendo del tipo aplicable conforme a los requisitos objetivos y subjetivos que se cumplan en cada una de las conductas» ${ }^{2092}$. Su afirmación hay que entenderla en cuanto que la expresión «conjuntamente» del art. 28 CP no supone la necesidad de la comunidad subjetiva ${ }^{2093}$. Sostiene coherentemente que «puesto que la peligrosidad objetiva de la conducta de cada uno de los sujetos que interviene en una realización objetivamente conjunta depende del contexto en el que realiza su intervención, la determinación de tal peligrosidad estará en función de que el sujeto en concreto conozca o hubiera debido de conocer el peligro inherente al conjunto, lo cual no depende en todo caso de la existencia de mutuo acuerdo (...), en su caso, en la responsabilidad por imprudencia» ${ }^{2094}$. Así, le asiste razón en que la diferencia entre autoría accesoria y coautoría resulta ficticia, porque el mutuo acuerdo no permite superar los límites de la responsabilidad individual, pero tampoco «aporta un mayor desvalor a la conducta de cada uno de los coautores que hubieran adquirido los mismos conocimientos por otra vía distinta» ${ }^{2095}$.

\footnotetext{
2092 García Del Blanco, Mª V., La coautoría en Derecho penal, op. cit., p. 682, si bien defiende un concepto restrictivo de autor.

${ }^{2093}$ ID., ibidem, op. cit., pp. 687 y ss.

2094 ID., ibidem, op. cit., p. 693.

2095 ID., ibidem, op. cit., p. 695.
} 
El caso paradigmático en nuestro estudio es la comisión conjunta de la persuasión coercitiva imprudentemente y la comisión imprudente del delito fin por medio de un sujeto con déficit de socialización doloso, pero sin culpabilidad (estado de necesidad exculpante) o reconvertido mediante la alic a imputación imprudente, de manera que se fundamenta, en ambos casos la coautoría cuando el delito-fin se comete sobre tercero o cuando se comete contra los bienes del propio sujeto. Y es así porque el dolo, el acuerdo común y la imprudencia son elementos fenomenológicos del resultado, éste también se puede producir por infortunios, por eso estos tres elementos únicamente informan sobre el quantum de responsabilidad una vez se trasgrede el riesgo permitido. Efectivamente, entre estos elementos media una razón cuantitativa en el riesgo de producción del resultado, de manera que el acuerdo en común aumenta la probabilidad del resultado pero no elimina que otras formas - sin que haya acuerdo en común, o una conducta riesgosa o imprudente- produzcan conjuntamente éste.

Así las cosas, no habrá inconveniente en imputar al primer autor, aquel que inicia la persuasión coercitiva como delito medio, otro u otros delitos fin, como concurso de leyes (persuasión coercitiva y delitos contra la vida o contra la integridad psíquica, etc...), o como concurso real cuando temporalmente estén claramente diferenciados, si bien aquí surgirá la problemática de los límites de penalidad máxima previsto en el art. $76 \mathrm{CP}$ cuando existan, como parece suceder, cuantiosos daños o numerosas víctimas, lo que vulneraría el principio de proporcionalidad $^{2096}$, o como delito medial cuando suponga una misma unidad de acción (o pluralidad de acciones) y el delito-fin no pueda englobarse conforme al principio de consunción referido supra.

\section{B. Delitos contra la vida: trascendencia en el binomio «víctima-autor»}

La trascendencia de las conclusiones a las que hemos llegado es más apreciable en los delitos especiales de inducción. En concreto, el Código penal castiga la inducción al suicidio en el art. 143.1 CP, la cooperación necesaria en el art. 143.2 CP y la cooperación necesaria hasta la ejecución en el art. 143.3 (homicidio a petición). Las tres primeras formas giran en torno a la aceptación de la muerte de la víctima, y en las dos primeras es ésta quien ejecuta por sí misma la acción de matar, lo que indica - como bien señala POLAINO-ORTS- una «cierta predisposición

\footnotetext{
${ }^{2096}$ POLAINO NAVARRETE apunta a dicha crítica y entiende que puede resolver de mejor manera una «fórmula matemático-jurídica fundamentada en criterios normativos de valoración y de proporcionalidad», en función del número de infracciones penales cometidas, la gravedad respectiva de las mismas, la superación de los tradicionales criterios de cálculo, a un nuevo límite jurídico relativo que renuncie al redondeo, y otro absoluto que elimine el actual «tope fijo», POlaino NAVARreTe, M., Lecciones de Derecho penal, Parte General, T. II, op. cit., pp. 267 y ss.
} 
voluntaria a procurar la propia muerte» que también se aprecia en la eutanasia ${ }^{2097}$. En tal sentido, POLAINO-ORTS entiende que en la ayuda al suicidio, al no estar prohibida, la participación debe ser también impune ${ }^{2098}$, porque «(s)ólo cuando se violenta la libre toma de decisión por parte del suicida se convierte el hecho del suicidio en algo con relevancia social, perdiendo -ahora sí, con razón- su carácter personalísimo y fundando un injusto penal» ${ }^{2099}$.

Con dicha opinión estamos totalmente de acuerdo, máxime cuando se toma dicha decisión por rechazo de un tratamiento médico al que el sujeto no quiere someterse por los peligros de graves secuelas (no por peligro de muerte) o cuando se rechaza por motivos de conciencia, o sea, en ambos casos, por la primacía de un derecho, la libertad personal en cuanto disponibilidad fáctica pero en lo que nos interesa también jurídica o normativa de un sujeto imputable, o sea, responsable, lo que significa que conozca la trascendencia, el fin final de dicha decisión, de tal modo que el suicidio se corresponde con un concepto normativo y de imputación objetiva de la autopuesta en peligro del sujeto, o dicho de otro modo de riesgo permitido ${ }^{2100}$.

Por ello, la gran diferencia entre los tipos del art. 143.2 y 3 respecto al art. 143.1 es que la decisión de suicidio en éste último delito exige que haya sido influenciada, cuasi-manipulada, pues lo que sucede realmente para entender que hay inducción es que se «ha de incidir sobre alguien que previamente no está decidido a cometer la infracción (...) la incitación ha de ser intensa y adecuada, de forma que motive suficientemente al inducido a la perpetración del hecho deseado» ${ }^{2101}$, es decir, amplía el horizonte de expectativas en un sentido prohibido, mientras que en los dos siguientes apartados la decisión es tomada «libremente» por el sujeto que va a suicidarse. Aquí se evidencian unos elementos objetivos del tipo que se gradúan en función de la intensidad y el grado de realización por parte del tercero sobre el suicida, por eso se dice que la cooperación necesaria al suicidio y finalmente ejecutada hasta la muerte merece una mayor condena, mientras que en las formas del apartado $1 .^{\circ}$ y $2 .^{\circ}$ sólo se exige la inducción o cooperación necesaria respectivamente.

De esto resulta que el fundamento de punibilidad de las diferentes modalidades de auxilio al suicidio, tal y como advierte POLAINO-ORTS, es la «invasión ilegítima» de un tercero en la organización/decisión ajena mediante una «persuasiva voluntad superior», a través de una «especie de engaño» o «propulsión fraudulenta» en una decisión personalísima e

\footnotetext{
2097 Polaino-Orts, M., vv.aa., Lecciones de Derecho Penal, Parte Especial, T. I, op. cit., p. 63.

2098 ID., ibidem, op. cit., p. 64.

2099 ID., ibidem, op. cit., p. 64.

${ }^{2100}$ ID., ibidem, op. cit., pp. 65 y 66.

${ }^{2101}$ Véase sobre estos últimos entrecomillados la STS, de 5 de mayo de 1988.
} 
intransferible ${ }^{2102}$, sin embargo, apunta el citado autor que esta invasión en la decisión ajena no se tiene por qué dar en la simple cooperación al suicidio, y de tal modo, esta cooperación debe ser impune $^{2103}$, pues aquí no se respeta el fundamento de punibilidad acorde al sentido del bien jurídico de la vida y la disponibilidad que hemos determinado. Dicho de otra manera, el legislador presume iure et de iure que la cooperación al suicidio es una invasión ilegítima, sin embargo dicha presunción precisamente sí constituye, además de una intromisión ilegítima del Derecho en la organización de la propia vida, también de la muerte. Ha de probarse, en verdad, que ha existido tal invasión ${ }^{2104}$, de tal suerte que ese influjo que se criminaliza en el delito del art. 143.1 CP más que un delito contra la vida parece un delito contra la libertad o contra el derecho a decidir sobre la propia vida ${ }^{2105}$.

Tampoco queda claro que la inducción del art. 143.1 CP contenga los mismos presupuestos que la inducción de la Parte general en relación a si ha de ser directa y efectiva. Parte de la doctrina considera que sólo sería punible si efectivamente se llega a morir. Esta corriente de opinión trata al resultado como una condición objetiva de punibilidad que aplica la doctrina de la inducción de la Parte General del Código penal (inducción directa y eficaz) a la Parte Especial, y en concreto a este delito, lo que hace rechazar a este sector doctrinal la tentativa y la inducción en cadena ${ }^{2106}$. Sin embargo esto no es tan claro.

En nuestro ámbito de estudio, la problemática estriba entre la libertad de autopuesta en peligro, o derecho al suicidio como comportamiento libre, espontáneo y voluntario, y la introducción de ideas como ampliación del horizonte de lo prohibido o la restricción del horizonte de expectativas, y por ende, de la capacidad de elección en sujetos con déficit de socialización. La delgada línea entre intervenciones en suicidios libremente decididos y una intervención criminal es tan fina que no permite un tratamiento detallado, sino criterios generales. De otra parte, se entiende que no habrá problema en concluir que la persuasión al suicidio o la orden directa sobre sujetos con adicción comportamental, creada o simplemente aprovechada por el hombre de atrás, se pueden reconducir a la autoría mediata, sin embargo en cuanto hay márgenes (horizontes) de libertad habrá que reconocer al menos una heteropuesta en peligro de la víctima, de tal manera que la víctima es participa responsablemente de su propia tentativa de muerte y el hombre de atrás es autor o inductor, según los casos.

\footnotetext{
${ }^{2102}$ Polaino-OrTs, M., vv.aa., Lecciones de Derecho Penal, Parte Especial, T. I, op. cit., p. 67.

2103 ID., ibidem, op. cit., p. 67.

2104 ID., ibidem, op. cit., p. 66.

2105 ID., ibidem, op. cit., p. 70.

${ }^{2106} \mathrm{Vid}$. y en contra de dicha opinión POLAINO-ORTS, ID., ibidem, op. cit., pp. 69 y 70.
} 
Comentamos en capítulos precedentes que la autopuesta en peligro o a riesgo de la propia víctima o imputación de la víctima, se fundamenta en dos principios: la libertad de la persona en la organización de su vida y la autorresponsabilidad. Tanto es así, que el ejercicio del rol excluye la participación punible salvo que se limite o se anule la libertad de decisión de la víctima, en cuyo caso estaremos en una heteropuesta en peligro (heterolesión) ${ }^{2107}$, lo que significa que la resolución del problema entre una autopuesta en peligro y su participación y una heteropuesta y su participación pasan por determinar la validez del consentimiento, pero en relación a su «valor» ${ }^{2108}$, lo que se conecta con la conducta realizada por la propia víctima.

En este sentido, ya expuso RoxiN ${ }^{2109}$ que, puesto que en Alemania no está penado la participación en el suicidio, de tal manera que la participación en la conducta de autopuesta en peligro no entra en el fin de protección de la norma, sólo serían perseguibles la participación en «heteropuestas en peligro consentidas» en la medida que el partícipe tenga el mismo conocimiento sobre el riesgo y su probabilidad de resultado. Resuelve del mismo modo los casos de favorecimiento de auto-puesta en peligro, siempre y cuando sean equiparables, es decir, que la víctima sea responsable, consciente del peligro, pero además, que el actuar de ese otro sea concorde al consentimiento de la víctima, o sea, en nuestra opinión, que estén de acuerdo en la «comunidad del riesgo», ya que en caso contrario el exceso de riesgo si fuera causa del resultado podría ser imputado al tercero al que se le consintió, al igual que en la autoría mediata en la que el déficit de responsabilidad del hombre de delante es causado, o aprovechada la causa del déficit o inferioridad psíquica, o tenga incumbencia de tenerlo en cuenta por el hombre de atrás. Sin embargo, puesto que en casos de déficit de socialización existen esos márgenes de libertad (restricción del horizonte de expectativas), más que autoría mediata, hay una coautoría en la que la «víctima» al ser una causa libre de su propio perjuicio, encuentra el fundamento de política criminal de impunidad, pero nada impide hablar del tercero como autor y de coautoría con la víctima.

En este sentido, CANCIO MELIÁ entiende que la autorresponsabilidad de la víctima se fundamenta en el carácter preferente de su ámbito de competencia de sus propios bienes, de modo que la participación en esta competencia no se puede imputar al partícipe porque es

${ }^{2107}$ RoXIN, C., «Sobre el fin de protección de la norma en los delitos imprudentes», op. cit., pp. 181 a 199 ; CANCIO Meliá, M., Conducta de la víctima e imputación objetiva, op. cit., pp. 284 y ss; POLAINO NAVARRETE, M., Lecciones de Derecho penal, Parte General, T. II, op. cit., pp. 90 a 92; POLAINO-ORTS, M., «Imputación objetiva: esencia y significado», op. cit., pp. 50 y ss.

${ }^{2108}$ CANCIO MELIÁ, M., Conducta de la víctima e imputación objetiva, op. cit., pp. 142 y ss; GARCÍA ÁlVAREZ, P., La puesta en peligro, op. cit., pp. 410 y ss.

${ }^{2109}$ RoXIN, «Sobre el fin de protección de la norma en los delitos imprudentes», op. cit., pp. 181 a 199. 
imputable a la víctima, no ya subjetivamente, sino objetivamente ${ }^{2110}$, si bien estimamos por nuestra parte que en cuanto exista una restricción de la capacidad de libre voluntad, aquellos casos de déficit de socialización atribuible a un tercero, aun con la participación por imprudencia consciente de la víctima pueden reconducirse a casos de coautoría, de forma que se compatibilizan los injustos propios de cada interviniente y la responsabilidad individual en cada caso. CANCIO MELIÁ relaciona la confluencia de riesgos con la autoría accesoria, en el modo expuesto por CORCOY BIDASOLO como «responsabilidad múltiple» ${ }^{2111}$, si bien con atenuación de la responsabilidad del autor en casos en que no hay una exclusión de la imputación objetiva de la víctima $^{2112}$, como hace el TS, pues cuando son dos autores imprudentes «que contribuyen ambos a la lesión de los bienes de un tercero - un caso en el que debe afirmarse la autoría de ambos-, en el presente contexto, si bien no se produce una atribución de todo el suceso al ámbito de responsabilidad, sí parece adecuado valorar la aportación de la víctima mediante una reducción de la responsabilidad del autor» ${ }^{2113}$. Sin embargo, el error viene de la falta de comprensión, ya comentada, de la coautoría imprudente, o dicho de otro modo, existe la posibilidad de atribuir a cada sujeto la obra global, tanto si afecta a un tercero como si afecta a uno de los intervinientes, aunque sea víctima, de manera que sólo uno de ellos responde culpablemente.

También CANCIO MELIÁ se refiere a la instrumentalización de la víctima como situaciones de organización conjunta de superioridad del autor, por concurrir en la víctima defectos de responsabilidad o cognitivos, cuya responsabilidad ha de ser normativa, y esto porque el mero deseo o los simples conocimientos superiores del autor sobre el riesgo son insuficientes para determinar la autoría mediata tanto en delitos dolosos como imprudentes. Como bien comenta, la trascendencia de la explicación en Alemania es o la impunidad o la autoría mediata de homicidio o asesinato a falta de regulación del auxilio, o inducción al suicidio, problemática que no existe en España. En los casos de defectos de responsabilidad de la víctima, distingue entre «constitucionales» que parte de la doctrina alemana, según las reglas del parágrafo 216 StGB del homicidio por petición, se basa en la validez del consentimiento, y otra parte en la imputabilidad, que acoge en relación a la delimitación de los ámbitos de responsabilidad de cada interviniente $^{2114}$, y los «situacionales» por estado de necesidad exculpante o justificante. Sin embargo niega virtualidad a que en los defectos cognitivos de la víctima exista «dominio por

\footnotetext{
${ }^{2110}$ CANCIO Meliá, M., Conducta de la víctima e imputación objetiva, op. cit., pp. 284 y ss.

${ }^{2111}$ ID., ibidem, op. cit., pp. 345 y ss; CORCOY BIDASOLO, M., El delito imprudente, op. cit., p. 358.

2112 CANCIO Meliá, M., Conducta de la víctima, op. cit., p. 347.

2113 ID., ibidem, op. cit., p. 348.

${ }^{2114}$ ID., ibidem, op. cit., p. 360.
} 
conocimiento», cuando la víctima yerra sobre la «cualidad mortal de la acción» ${ }^{2115}$, cuestión con la que está de acuerdo pero sobre la que pone la problemática de los casos en los que el «autor» dice a la víctima que tiene una enfermedad incurable y ésta reacciona suicidándose, de forma que no parece que pueda haber autoría mediata, a pesar de que en el caso Sirius -que trataremos infra- el objetivo del autor era cobrar el seguro de vida que previamente había convencido a la víctima para contratar ${ }^{2116}$. Concluye que la clave está en si el resultado viene de una organización conjunta, o si la víctima «se ve incluida en una configuración ajena de la actividad que debe atribuirse al autor», y esto sólo se puede hacer mediante una consideración conjunta de ambos, de modo que no habrá organización conjunta «cuando el contexto imputable a la víctima sea distinto e inferior en potencial lesivo al contexto imputable al autor» ${ }^{2117}$.

Pero como bien indica JAKOBS ${ }^{2118}$, el problema viene de que en supuestos de heterolesión, el hombre de atrás puede invocar la responsabilidad del sujeto víctima e instrumento. De manera similar, REQUENA ${ }^{2119}$ considera que si la víctima desvía la dirección del peligro creado por el autor, sería un caso de autopuesta en peligro, y por lo tanto imputado a la víctima al actuar dominando el curso causal peligroso, salvo que el titular de la organización del peligro que desvía la víctima tiene un mejor conocimiento que ésta, lo que convierte al primero en garante «cuando tenía (...) el deber de despejar el error» (competencia). De esta manera el autor es garante frente a la víctima cuando el peligro creado constituye un «riesgo especial» aunque sea permitido.

En contra de CANCIO MEliÁ, considera GARCía Álvarez ${ }^{2120}$ que la clave estriba en la «determinación objetiva y positiva de hecho», de modo que cuando la participación en la autopuesta niega el libre desarrollo de la personalidad existe un fundamento de punibilidad,

${ }^{2115}$ ID., ibidem, op. cit., pp. 366 y ss.

${ }^{2116} \mathrm{Sin}$ embargo, apela que en otros casos, como en los de entrega de estupefacientes o contagio de enfermedades, si bien puede ser decisivo el nivel de conocimientos de víctima y autor, como en la consideración común que estableció el BGH (BGHSt 32) en el caso de la jeringuilla, que concluyó la punibilidad del autor cuando «aprehende el riesgo mejor que quien se pone a sí mismo en peligro», reitera que los conocimientos superiores son insuficientes, puesto que se adhiere al pensamiento de JAKOBS que sobre la sentencia dice que confunde el hecho psíquico con la regulación normativa, o sea, quien es el competente, ID., ibidem, op. cit., p. 371, vid. en relación a JAKOBS, G., $P G$, op. cit., 21/78, nota núm. 142b.

${ }^{2117}$ Cancio Melí́, M., Conducta de la víctima, op. cit., pp. 371 y 372.

2118 JAKOBS, G., $P G$, op. cit., 7/79; ID., «La organización de autolesión y heterolesión, especialmente en caso de muerte», op. cit., p. 396, y pp. 403 y ss.

${ }^{2119}$ REQUENA JULIANI, J., Intercambiabilidad de acción y omisión, op. cit., pp. 298 a 320, especialmente pp. 306 y 307, y pp. 330 y ss.

${ }_{2120}$ GARCÍA ÁlLVAREZ, P., La puesta en peligro, op. cit., pp. 357 a 360, siguiendo los planteamientos de LUZÓN PeÑa, D-M., Curso de Derecho penal, Parte General, I, op. cit., pp. 507 y ss. Similarmente De OliveIRA, L., La autoría mediata en los delitos imprudentes, op. cit., pp. 552 y ss., deja también fuera de estos casos la autopuesta en peligro y heteropuesta en peligro consentida, por atípicas en el primer caso, y por participación impune en el segundo. 
como en la cooperación ejecutiva al suicidio del art. 143.3 CP, no existe plena disponibilidad porque la destrucción de la vida elimina el libre desarrollo de la personalidad ${ }^{2121}$, o en el caso de las lesiones, donde el consentimiento no constituye la exteriorización del libre desarrollo de su personalidad $^{2122}$ porque la conducta riesgosa no abarca el resultado ${ }^{2123}$. Entiende que la no evitación de un suicidio (con dominio del hecho del suicida-autor, o éste utilizando a un instrumento o con el común acuerdo con tercero, lo que constituye una «autolesión» ${ }^{2124}$ ) constituiría un delito de omisión del deber de socorro por incumplimiento del mandato de solidaridad mínima, o en determinados casos, un delito de homicidio si existe la posición de garante $^{2125}$. Sólo podrá existir homicidio consentido ( «heterolesión consentida») cuando el titular del bien quiere ponerle fin pero en la que interviene un tercero con dominio del hecho ${ }^{2126}$. Por eso la intervención en la autolesión no siempre es impune, puede incurrir en el art. $143 \mathrm{CP}^{2127}$ cuando el tercero interviniente tiene el dominio del hecho aunque sí existe autoderminación positiva del titular del bien se reconducirá al art. $143.3 \mathrm{CP}^{2128}$. Es indiferente la calificación de una contribución a una autolesión o heterolesión consentida ${ }^{2129}$. Sin embargo, no puede hablarse de suicidio cuando un enfermo rechaza un tratamiento porque quiere vivir pero no a toda costa, es el propio titular del bien el que determina la conducta de riesgo, son autopuestas en peligro $^{2130}$.

En sentido similar, DE OLIVEIRA concluye que «sólo tiene sentido punir al tercero que interviene en una puesta en peligro de la integridad física de la víctima que resulte en una lesión imprudente, si este tercero puede ser reputado autor según el art. 152 CP 1995, siendo del todo

${ }^{2121}$ García Álvarez, P., La puesta en peligro, op. cit., p. 505, y p. 513 concluye que «no podrá negarse que se lesione o se ponga en peligro (de manera que pueda reputarse jurídicopenalmente) el bien jurídico de la vida, en los supuestos en los que su titular disponga de ella para ponerles término, ya que su destrucción impide todo desarrollo de la personalidad. Sin embargo, si la vida es, únicamente, puesta en peligro, podremos negar que se cree un riesgo jurídicopenalmente relevante para este bien jurídico y, por tanto, la tipicidad de tal conducta, si dicho acto de disposición es expresión del libre desarrollo de la personalidad de su titular y el tercero se limita a actuar dentro de lo consentido».

${ }^{2122}$ ID., ibidem, op. cit., p. 488.

${ }^{2123}$ ID., ibidem, op. cit., pp. 525 y ss.

2124 ID., ibidem, op. cit., p. 203.

2125 Explica que «(h)abrá autoría mediata de homicidio o asesinato, en vez de una conducta de participación en un suicidio ajeno, cuando, aunque sea el propio titular del bien jurídico afectado el que realice la conducta mortal, el tercero haya hecho que ponga términos a su vida un incapaz de comprensión o juicio, ya sea por razones de edad o de enfermedad mental; o una persona a la que haya sumido en un estado de necesidad o privado de la libertad de voluntad o de la capacidad necesaria para comprender el alcance de su conducta, ya sea mediante engaños, coacciones o amenazas, o cuyo error o estado de necesidad haya utilizado a tales efectos», ID., ibidem, op. cit., p. 204.

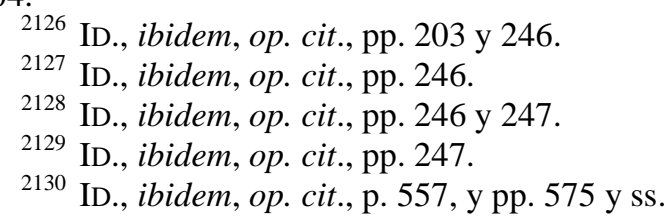


posible la realización mediata del delito de lesiones imprudentes con víctima-instrumento en la medida en que se cumplan determinados requisitos ${ }^{2131}$, y en relación al homicidio imprudente «en la puesta en peligro de la vida la víctima que resulte en la muerte no planificada de ésta (imprudente) sólo responde el tercero que interviene en dicha puesta en peligro si lo hace en calidad de autor. No siendo punible la participación en un acto imprudente de la víctima (autopuesta en peligro) que resulte en su propia muerte, una vez que el art. 143 CP 1995 sólo se prevén, en los apartados 1, 2, y 3, conductas de participación dolosa en un suicidio (autolesión dolosa)» ${ }^{2132}$. Centra el fundamento de punibilidad en la afección a la libertad de decisión o a la libertad de ejecución de lo decidido, cuyo resultado coincida con lo determinado por el hombre de atrás ${ }^{2133}$.

Por otro lado, MARAVER GóMEZ considera que la imputación de la autopuesta en peligro a la víctima y la exclusión de la partición en ésta se fundamenta en la prohibición de regreso que se produce en la negación de la posición de garante en participación y a la vez en que en el principio de confianza se niega el deber de cuidado del partícipe, en cuanto que existe plena responsabilidad de la víctima ${ }^{2134}$. De esta manera, muy acertadamente aclara que la víctima interviene en un momento posterior de manera responsable, y a la inversa, si al primer sujeto se le puede imputar la conducta peligrosa del tercero-víctima se le podrá considerar partícipe de manera accesoria conforme a las normas de la Parte general del Código penal, salvo la regulación especial del art. 143.1 y $2 \mathrm{CP}^{2135}$, o autor de la heterolesión o de la heteropuesta en peligro, pues aunque la víctima tenga el domino del hecho, o sea responsable del hecho, no afirma la producción de un suicido o autolesión o autopuesta, sino que constatada la posición de garante, el principio de confianza se aplica en la conducta incorrecta de la propia víctima de manera tal que si se ha detectado que se va a comportar o ha empezado a comportarse arriesgadamente el garante no puede apelar a la confianza para limitar el deber de cuidado ${ }^{2136}$ : «sólo puede confiar quien se ha comportado correctamente» ${ }^{2137}$.

Pues bien, a las personas en Derecho se les presupone responsabilidad, es decir, la libertad de sus actos, por ello, como decíamos, quien ingresa en un grupo sectario y amolda su conducta libremente, a los dictados del líder y de su doctrina y a la dinámica grupal, ha de soportar sus

\footnotetext{
${ }^{2131}$ DE OlIVEIRA, L., La autoría mediata en los delitos imprudentes, op. cit., pp. 557 y 609.

2132 ID., ibidem, op. cit., p. 558.

2133 ID., ibidem, op. cit., p. 564.

${ }^{2134}$ MARAVER GómEZ, M., El principio de confianza en Derecho penal, op. cit., pp. 379 y ss. nota 220 y pp. 384

${ }^{2135}$ ID., ibidem, op. cit., p. 381.

${ }^{2136}$ ID., ibidem, op. cit., p. 386.

${ }^{2137}$ ID., ibidem, op. cit., p. 398.
} y ss. 
consecuencias penales en el delito-fin, aunque se le cree un déficit de socialización y exista un fundamento autónomo de responsabilidad por tal creación.

MARTÍNEZ ESCAMILLA ${ }^{2138}$ entiende que la provocación imprudente del tercero en el suicidio no es una cuestión estrictamente de imputación objetiva, sino de autoría y participación. A este respecto, recuerda ${ }^{2139}$ el caso del policía alemán que con conocimiento de la depresión e ingesta del alcohol de su amiga, deja en la guantera una pistola cargada que finalmente ésta utiliza para suicidarse. Si bien el Tribunal Supremo alemán en la Sentencia reconoce que el policía infringió una norma de cuidado, puesto que en el Código penal alemán sólo es punible el auxilio ejecutivo al suicido, deja impune la conducta. El argumento que utiliza la doctrina es que si es impune la participación dolosa en un suicidio, más si cabe la imprudente, sin embargo, en nuestro Derecho sí que es punible la inducción, lo que plantea el problema de la inducción imprudente o autoría imprudente de un homicidio imprudente, al menos sí imputable a ese interviniente aunque la actuación de la víctima sea con conciencia y voluntad de morir.

Sin embargo, a esta conclusión se opone que el homicidio y el suicidio son realidades $\operatorname{distintas}^{2140}$, y es verdad, pero tal y como hemos ido concluyendo, cada interviniente en un hecho antijurídico responde por su propio injusto, de manera que si a uno no se le pena por razones de política criminal (tentativa de suicidio), o cuando esto ya no es posible por el fallecimiento, dichas circunstancias fenomenológicas no deben eliminar la imputación del tercero interviniente en su propio hecho. La contraorientación normativa se produce cuando observamos el hecho desde la perspectiva del suicida y las trasladamos al interviniente. Desde aquí, evidentemente todo pasa por un suicidio, por eso dicha postura doctrinal se ve abocada a tratar el hecho como un suicidio, pero desde una perspectiva de segundo orden (observador del observador), o sea, desde el sistema jurídico, ya ni tan siquiera desde la exclusiva perspectiva del interviniente, el hecho no deja de contener un injusto de intervención en un homicidio, y lo mismo cabe decir de la intervención imprudente de las autolesiones.

Al respecto, SILVA SÁNCHEZ ${ }^{2141}$ comenta que la conducta de la víctima es libre, por lo que la intervención (caso del policía) sólo podría entenderse como participación imprudente de un

${ }^{2138}$ MARTíNEZ ESCAMILLA, M., La imputación objetiva del resultado, op. cit., p. 245.

${ }^{2139}$ BGH, 24, 342; MARTíNEZ EsCAMILlA, M., La imputación objetiva del resultado, op. cit., p. 352; RoXIN, C., «Sobre el fin de protección de la norma en los delitos imprudentes», op. cit., pp. 183 y 184; CORCOY BIDASOLO, M., El delito imprudente, op. cit., pp. 557 y ss.

${ }^{2140}$ Vid. y así también MARTíNEZ ESCAMILLA, M., La imputación objetiva del resultado, op. cit., p. 354.

${ }^{2141}$ SILVA SÁNCHEZ, J-Mª., «Causación de la propia muerte y responsabilidad penal de terceros», op. cit., pp. 471 a 477 . 
suicidio, lo cual es impune. Sin embargo, RoxIN ${ }^{2142}$ opina que se dan todos los requisitos de la imputación, pero no se fundamentan en el ámbito de protección de la norma, que lo que prohíbe es no matar, no se refiere a conductas suicidas. CORCOY BIDASOLO expone que el riesgo no proviene de lo objetivo (la pistola en la guantera), sino que el policía «sabía de sus pensamientos suicidas», lo que revela que al menos existe la tipicidad del riesgo ${ }^{2143}$. De aquí extrae la existencia de un «injusto típico», que unido al caso de que el suicida tenga dominio del riesgo hará que éste sea «autor y el interviniente partícipe y como tal, impune», salvo que el suicidio no sea libre «el sujeto que ha creado el riesgo se convierte en autor mediato, al poseer el dominio del hecho, y le será imputable la muerte como homicidio imprudente, siempre que se pruebe (...) la relación del riesgo» ${ }^{2144}$. En el caso del policía, concluye que ese conocimiento eleva el riesgo de tal modo que existe relación del riesgo y el resultado, de manera que el suicidio no es libre y se puede imputar el homicidio imprudente, inclusive desde el planteamiento roxiniano del fin de la norma, ésta prohíbe poner al alcance de una persona con tendencias suicidas acentuadas una pistola cargada ${ }^{2145}$. Evidentemente no podemos estar de acuerdo con esta argumentación ni conclusión.

La trascendencia y la contraorientación normativa de este caso es que si la «víctima» hubiese pedido que el policía la disparase, éste hubiera respondido por el tipo de auxilio ejecutivo en Alemania, lo cual es absurdo porque en este supuesto la petición es un elemento naturalístico que no modifica el contexto ni el destino, de lo que deviene que en la argumentación se haya introducido un elemento de la moralidad contra la norma para revertir la primera conclusión normativa de que, en efecto, existía infracción del cuidado. En este caso, salvo expresa garantía asumida por el policía sobre la integridad de la mujer, no existe competencia alguna, máxime cuando la colocación de la pistola en la guantera por un policía supone un acto manifiestamente neutro.

La problemática en verdad está en la intervención imprudente de una autopuesta en peligro de la víctima que no desea la muerte o la lesión, pero son previsibles. Aquí la doctrina acertadamente opina que cualquier intervención de tercero en la autopuesta en peligro de la víctima es impune ${ }^{2146}$, cuestión que es del todo distinta que las conductas suicidas o de lesión, porque la autopuesta en peligro es del todo atípica, por eso cuando dicha participación modifica 
el hecho de modo que puede tratarse de heteropuesta en peligro, la situación variará en función de injusto propio del interviniente. Esto se ve en la inducción al suicidio, típico en España pero no en Alemania salvo contribución ejecutiva en el suicidio, pero no en la aportación del interviniente en las autolesiones, también claramente atípicas.

También FRISCH ${ }^{2147}$ considera la participación en las lesiones, suicidio y autopuestas en peligro impunes, sin embargo limita esta conclusión a casos de mayor conocimiento del interviniente sobre el riesgo pero entendido como «distinta posición de los intereses» ${ }^{2148}$.

Por nuestra parte, compartimos el criterio expuesto por POLAINO-ORTs ${ }^{2149}$, en el sentido de entender que la gestión de la vida es un acto libre pero también personalísimo, hasta el punto que la cooperación en el suicidio no debería ser punible por cuanto si aceptamos que la vida es un derecho personalísimo, y estrictamente disponible para el propio sujeto, la cooperación al suicidio no puede ser punible porque absurdamente supondría un «suicidio en autoría mediata», como refiere JAKOBS ${ }^{2150}$ : «Siempre que la víctima manifieste de modo responsable que quiere morir, el riesgo de error va en perjuicio suyo» ${ }^{2151} 2152$. Sin embargo esto no contradice nuestra conclusión de una coautoría entre ambos cuando media la persuasión coercitiva y la víctima participa de su propia muerte como expondremos infra.

Así, compartimos la opinión -muy acertadamente fundada- de POLAINO-ORTS, quien se ha pronunciado rechazando cualquier tipo de responsabilidad en la no evitación de la muerte suicida por cuanto supondría imponer a los ciudadanos «deberes excedentes de su rol y convertirlos en controladores de ámbitos de organización ajenos» ${ }^{2153}$, por lo que debe excluirse cualquier tipo de «heteroadministración» por un tercero en la esfera de libertad de los ciudadanos.

Dicho esto, JАKOBS entiende que la diferencia entre autolesión y heterolesión consentida viene marcada por el parágrafo $216 \mathrm{StGB}$, porque en este precepto algunas participaciones de

${ }^{2147}$ FRISCH, Wolfgand, Tipo penal e imputación objetiva, Colex, 1995, pp. 47 y ss. y p. 129

${ }^{2148}$ ID., ibidem, op. cit., p. 138.

${ }^{2149}$ Polaino-OrTS, M., vv.aa., Lecciones de Derecho Penal, Parte Especial, T. I, op. cit., pp. 66, 74 y 75; en sentido similar BAUCELLS I LLADÓs, J., La delincuencia por convicción, op. cit., p. 215.

${ }^{2150}$ JAKOBS, G., «La autoría mediata con instrumentos que actúan por error como problema de imputación objetiva», op. cit., pp. 249 a 268; ID., «La organización de autolesión y heterolesión, especialmente en caso de muerte», op. cit., pp. 404 y ss; en el mismo sentido POLAINO-ORTS, M., vv.aa., Lecciones de Derecho Penal, Parte Especial, T. I, op. cit., p. 68.

${ }^{2151}$ JAKOBS, G., $P G$, op. cit., 29/70, nota 141.

${ }^{2152} \mathrm{Y}$ concluye que «por lo que concierne a los conatos de suicidio mediante los que la víctima pretende reclamar que se le atienda, no es posible fundamentar cómo es que la víctima, con tal comportamiento, va a poder imponer, a otras personas deberes sancionables jurídico-penalmente (...) a la tentativa de quitarse la vida que no acarreará la muerte sigue la voluntad presunta del paciente en el sentido de que le curen; aquí se convierte (...) el médico en garante», JAKOBS, G., $P G$, op. cit., 29/70, nota núm. 141; similarmente POlAINO-ORTS, M., vv.aa., Lecciones de Derecho Penal, Parte Especial, T. I, p. 74; Jericó OJER, L., El conflicto de conciencia, op. cit., pp. $534 \mathrm{y} \mathrm{ss}$.

${ }^{2153}$ Polaino-OrTs, M., vv.aa., Lecciones de Derecho Penal, Parte Especial, T. I, p. 74. 
autolesión (o autopuesta en peligro) son tratadas como heterolesión (heteropuesta en peligro), como en el homicidio a petición, y no como mera participación en el suicidio (impune), lo que fundamenta que quien actúa en último lugar no siempre tiene el dominio del hecho a pesar de tomar la decisión ${ }^{2154}$, por eso, dicho criterio es algo naturalístico, no diferencia entre suicidio y homicidio, sino lo que ocurra a continuación es su propio hecho, el que actúa en último lugar no es el garante, sino sólo es garante el que tiene el deber de evitación y actúa de propia mano ${ }^{2155}$, por eso, el garante lo es tanto en los delitos de comisión por omisión como en los comisivos. La cuestión no es quién realiza el último acto o si existe posibilidad de evitación, sino el deber de evitar una posibilidad de evitación ${ }^{2156}$. Por eso es preciso saber cuándo nace la competencia del obligado y sobre qué se es competente ${ }^{2157}$. Concluye que sólo habrá heterolesión si la competencia del tercero viene después de la de la víctima ${ }^{2158}$, entonces la autopuesta en peligro o autolesión surge cuando el sujeto pone él mismo en riesgo sus bienes, o simultáneamente con un tercero, bastando que el primero pueda sustraerse de los efectos cuando lo desee, o cuando el riesgo proceda del tercero, omite salvarse, teniendo capacidad para ello, puesto que en tales casos existe dominio de la decisión por el sujeto. De esta regla excepciona los supuestos de autoría mediata, en los que el sujeto desconoce el riesgo (autoría mediata con instrumento cuasi no doloso), en los que se obliga por el tercero a sacrificar otros bienes para salvar otros (autoría mediata con instrumento cuasi justificante) y en los que la víctima es un enfermo mental o menor de edad (autoría mediata con instrumento cuasi inculpable) ${ }^{2159}$.

${ }^{2154}$ JAKOBS, G., «La organización de autolesión y heterolesión, especialmente en caso de muerte», op. cit., pp. 396 y ss.

${ }^{2155}$ ID., ibidem, op. cit., p. 399; críticamente al respecto pero resaltando el beneficio de equiparar autolesión y autopuesta en peligro para comprender el suicidio como autoría, y la heterolesión y heteropuesta en peligro consentida, GARCÍA ÁlVAREZ, P., La puesta en peligro, op. cit., pp. 80 y ss. y pp. 91 y ss. respectivamente.

${ }^{2156}$ JAKOBS, G., «La organización de autolesión y heterolesión, especialmente en caso de muerte», op. cit., p. 400.

${ }^{2157}$ ID., ibidem, op. cit., pp. 400 y 401; ID., «La competencia por organización en el delito de omisión. Consideraciones sobre la superficialidad de la distinción entre comisión y omisión», op. cit., p. 359 y ss.

2158 JAKOBS, G., «La organización de autolesión y heterolesión, especialmente en caso de muerte», op. cit., p. 403. Críticamente GARCÍA ÁlVAREZ considera que «siempre que sea el tercero el que actúe creando un riesgo, es él el garante de que tal riesgo no se realice y, por tanto, actuará en último lugar, con lo que volvemos a encontrarnos en el punto de partida», y conocedor JAKOBS de esto, por eso introduce que no existe responsabilidad cuando el tercero interviene en último lugar con posición de garante y el titular del bien omite la salvación o su protección, por eso concluye que no consigue una distinción nítida entre autolesiones y heterolesiones consentidas, GARCÍA ÁLVAREZ, P., La puesta en peligro, op. cit., pp. 83 y 84; además le critica en que utilizando los criterios generales de autoría y participación no lo haga el parágrafo 216 StGB, ID., ibidem, op. cit., p. 89.

${ }^{2159}$ JAKOBS, G., «La organización de autolesión y heterolesión, especialmente en caso de muerte», op. cit., pp. 404 y ss. 
Sobre la ayuda a morir activa con petición del interesado, prevista en el parágrafo 216 del StGB alemán, JАKOBS ${ }^{2160}$ considera que este precepto sólo debería contemplar las muertes irracionales, porque en los demás casos activos, debería de respetarse la autodeterminación del sujeto, como igualmente sucede en los demás casos de eutanasia pasiva o indirecta.

Lo que parece claro es que sí que hay un derecho a la autopuesta ${ }^{2161}$ en peligro de la vida, lo que fundamenta la falta de desamparo en la omisión del deber de socorro, por lo que hasta que no se afectara objetivamente a la vida, la acción de puesta en peligro estaría permitida. Amén de ello, la participación en la puesta en peligro es impune, e inclusive, conforme considera parte de la doctrina, podríamos señalar que no corresponde en verdad a una acción de suicidio $^{2162}$, sino a la decisión de no vivir de cualquier modo. En este sentido ${ }^{2163}$, resulta importante tener en cuenta si el sujeto quiere realmente suicidarse o simplemente realiza una conducta de autopuesta en peligro. Parte de la doctrina ${ }^{2164}$ considera que se precisa dolo directo para poder hablar de acción suicida, porque se requiere una verdadera intención de morir, querer este resultado, mientras que otro sector ${ }^{2165}$ considera que bastaría con el dolo eventual, lo cual, en nuestra opinión, dificulta la distinción con la culpa consciente. A nuestro modo de ver, como dijimos en el capítulo tercero, el suicidio se caracteriza por la clara voluntad del resultado de muerte. Que coexistan otros deseos antes que la muerte aunque aceptada como probable, lleva a que se considere una autopuesta en peligro o autolesión, también en los casos de «culpa consciente», si bien aquí será más bien un «riesgo permitido».

Dicho lo cual, la problemática en la fenomenología criminal de las sectas está en la diferenciación de suicidios colectivos, o inducciones de suicidio o asesinatos. A este respecto, ya expusimos que el Tribunal Supremo alemán, en Sentencia de 5 de julio de 1976, diferenciaba:

${ }^{2160}$ JAKOBS, G., «Sobre el injusto del suicidio y del homicidio a petición. Estudio sobre la relación entre juricidad y eticidad», op. cit., pp. 345 y ss; ID., Suicidio, eutanasia y Derecho penal, op. cit., pp. 25 y ss.

${ }^{2161}$ En el mismo sentido GómeZ Rivero, M ${ }^{\mathrm{a} C}$., La responsabilidad penal del médico, op. cit., pp. 202 y ss; JERICÓ OJER, L., El conflicto de conciencia, op. cit., pp. 490 y 491; FlORES MENDOZA, F., Objeción de conciencia, op. cit., p. 380; TAMARIT SUMALLA, JM ${ }^{\mathrm{a}}$, «Responsabilidad penal de terceros ante la negativa a la trasfusión de sangre de Testigo de Jehová menor de edad con resultado de muerte», op. cit., p. 2.

${ }^{2162}$ En el mismo sentido GARCía ÁlvareZ, P., La puesta en peligro, op. cit., pp. 544 y ss; Gómez RIVERO, MC., La responsabilidad penal del médico, op. cit., pp. 202 y ss; TAMARIT SUMALLA, JM ${ }^{\mathrm{a}}$, La libertad ideológica, op. cit., p. 425. Contrariamente ROMEO CASABONA, CM${ }^{\mathrm{a}}$., El médico y el Derecho penal, op. cit., p. 375; FLORES MENDOZA, F., La objeción de conciencia, op. cit., pp. 376 y ss.

2163 JAKOBS, G., «La organización de autolesión y heterolesión, especialmente en caso de muerte», op. cit., pp. 395 a 412.

${ }^{2164}$ BAjo Fernández, M., Manual de Derecho penal, Parte Especial, I, delitos contra las personas, op. cit., p. 90; GARCía Álvarez, P., La puesta en peligro, op. cit., p. 101 y 104; LUZÓN PEÑA, D-M., «Problemas de las trasmisión y prevención del SIDA en el Derecho penal español», op. cit., p. 15; SILVA SÁNCHEZ, J-Mª., «Causación de la propia muerte y responsabilidad penal de terceros», op. cit., p. 457.

${ }^{2165}$ DÍAZ Y GARCÍA CONLLEDO, M., «Homicidio consentido y participación en el suicidio», op. cit., p. 3332; DÍEZ RIPOLLÉS JL / GRACIA MARTín L., Delitos contra bienes jurídicos fundamentales. Vida humana independiente y libertad, op. cit., p. 215. 
«(s)i se oculta al que está quitando la vida, que realmente está causando la muerte, hay que considerar que el que provoca este error y con ayuda conduce conscientemente y voluntariamente el proceso que desemboca o debe desembocar en la muerte, es autor de un delito contra la vida... en virtud de su superior conocimiento, con el que manipula al engañado y lo convierte en instrumento contra sí mismo» ${ }^{2166}$.

De aquí que se haya comentado ${ }^{2167}$ que existe una delgada línea entre una autoría mediata (el autor que utiliza a una persona como instrumento para cometer el delito) de asesinato o inducción al suicidio (143.1 CP) y la ayuda al suicidio (143. 2 y 3 CP), requiriéndose para que la aportación de un sujeto a la muerte de un tercero sea constitutiva de asesinato que la víctima sea un instrumento necesario para su propia muerte: «sólo la provocación de un error sobre la cualidad letal de la acción, o sobre el hecho mismo de la muerte, puede fundamentar una autoría mediata del que provoca este tipo de error y con ello un asesinato. La provocación de error sobre el sentido mismo de la acción suicida, por el contrario, todo lo más puede ser castigado como inducción o ayuda al suicidio» ${ }^{2168}$.

Singularmente se plantean en la inducción al suicidio problemáticas de participación delictiva y de delimitación con el homicidio en autoría mediata cuando el instrumento es el mismo que la

${ }^{2166}$ El caso versa sobre una persona que «convenció a su novia para que, tras hacer un seguro de vida del que él era beneficiario, se matara, asegurándole que inmediatamente se reencarnaría en otro cuerpo, por supuesto más hermoso y joven, que estaba preparado para ella en el lago Ginebra y luego seguiría viviendo en otro planeta, el Sirio, de donde él procedía». Véase más ampliamente MuÑOZ CONDE, F., «Provocación al suicidio mediante engaño: un caso límite entre autoría mediata en asesinato e inducción y ayuda al suicidio», ADPCP, 1987, pp. 301 a 317, también con el mismo título en Revista de la Facultad de Derecho de la Universidad de Granada, núm. 13, 1987, pp. 19 a 38; MAQUEDA ABREU, MáL., Las sectas destructivas ante el derecho, op. cit., p. 235.

${ }^{2167}$ MUÑOZ CONDE, F., «Provocación al suicidio mediante engaño: un caso límite entre autoría mediata en asesinato e inducción y ayuda al suicidio», op. cit., pp. 301 a 317; en el mismo sentido, DE OLIVEIRA, L., La autoría mediata en los delitos imprudentes, op. cit., p. 499 porque resulta inadecuado acudir a la inducción, mejor la autoría mediata.

${ }^{2168}$ Considera que «(s)i el suicidio provocado por engaños de tercero puede seguir considerándose como el suicidio libre y consciente que sirve de base y referencia a los comportamientos tipificados en el artículo 409, la calificación de autoría mediata en homicidio o asesinato debe ser rechazada, porque, aunque falsificada en su razón última, la decisión final corresponde al suicida, que se configura así como el único dominador del hecho, verdadero dueño de sus decisiones existenciales», MuÑOZ CONDE, F., «Provocación al suicidio mediante engaño: un caso límite entre autoría mediata en asesinato e inducción y ayuda al suicidio», op. cit., pp. 301 y ss; ID., Derecho Penal, Parte Especial, Tirant lo Blanch, Valencia, 1992, p. 68 y ss; ID., Derecho Penal, Parte Especial, 15ª ed. revisada y puesta al día, Tirant lo Blanch, Valencia, 2004, pp. 69 y ss; así también GARCíA ÁLVAREZ entiende que «habrá autoría mediata de homicidio o asesinato, en vez de una conducta de participación en un suicidio ajeno, cuando, aunque sea el propio titular del bien jurídico el que realice la conducta mortal, el tercero haya hecho que ponga término a su vida un incapaz de comprensión o juicio, ya sea por razones de edad o de enfermedad mental; o una persona a la que haya sumido previamente en un estado de necesidad o privado de la libertad de voluntad o de la capacidad necesaria para comprender el alcance de su conducta, ya sea mediante engaños, coacciones o amenazas, o cuyo error o estado de necesidad haya utilizado a tales efectos», GARCíA ÁlVAREZ, P., La puesta en peligro, op. cit., p. 195; en opinión de BONET ESTEVA en el caso de que se haya hecho surgir la idea de morir que anteriormente no tenía, estaremos ante casos de inducción al suicidio, BONET ESTEVA, M., «Grupos de manipulación mental», op. cit., p. 157. 
víctima, lo que POLAINO-ORTS ${ }^{2169}$ denomina «autoría mediata dual», de tal modo que la «diferencia entre inducción al suicidio y homicidio (o asesinato) en autoría mediata dual reside en el grado de aceptación o tolerancia frente a la propia muerte: en el primer caso quien mata acepta también el hecho de la muerte como propio y, por ello, busca de algún modo su propia muerte, aunque esa decisión no la haya tomado solo, sino en comandita o alentado por el inductor: en todo caso, mantiene capacidad para decidir quitarse su vida; en cambio, en el homicidio en autoría mediata dual quien se mata no actúa en ejercicio libre dentro de su capacidad de decidir sobre su propia vida, sino que esa capacidad se ha visto plenamente anulada por una voluntad superior (...) mediante la provocación o aprovechamiento del déficit de autorresponsabilidad del sujeto pasivo (KINDHÄUSER)», a diferencia de la opinión de parte de la doctrina que aplica a la inducción los postulados de la inducción de la Parte general, lo que les aboca a requerir que sea «efectiva» $\mathrm{y}$ «directa», por lo que según este autor es perfectamente posible la inducción en cadena o con intermediario, la inducción de la inducción y la tentativa, mientras que el engaño entraría en el homicidio como en los llamados «pactos suicidas por amor» en los que sólo se suicida el engañado, casos que en los que se propicia fraudulentamente la muerte (incitar a beber una bebida venenosa haciendo creer que es inocua) y el famoso caso del planeta Sirius de la jurisprudencia alemana ${ }^{2170}$.

Los hechos de este caso fueron los siguientes: un sujeto durante varios años persuadió y se ganó la confianza absoluta de una joven. Le hizo creer que procedía del planeta Sirius, que había sido enviado a la Tierra para salvar a determinadas personas importantes que habitarían en ese planeta superior en otros cuerpos y que ella era una de las elegidas. El sujeto convenció a la joven para que contratase un seguro de vida a su nombre. La persuadió para que causase su propia muerte, momento en el cual se hallaría en un nuevo cuerpo y le devolvería el dinero obtenido del seguro al entrar en Sirius. Sin embargo la joven consiguió sobrevivir.

La cuestión problemática en Alemania era concretar si existió inducción o cooperación necesaria al suicido intentado ya que en su legislación son impunes estas últimas, o si se trataba de una tentativa de asesinato en autoría mediata. Esta última fue la solución que declaró el BGH alemán porque concluyó que existía un instrumento no doloso, si bien señaló que el caso también se resolvería mediante la autoría mediata si la víctima hubiese creído que para despertar en una nueva vida debía morir, de modo que no sólo en el error en los motivos sino también en el hecho

\footnotetext{
${ }^{2169}$ Polaino-OrTs, M., vv.aa., Lecciones de Derecho Penal, Parte Especial, T. I, op. cit., p. 70; POLAINO Navarrete, M., vv.aa., Lecciones de Derecho penal, Parte General, T. II, op. cit., p. 243.

${ }^{2170}$ Polaino-OrTs, M, vv.aa., Lecciones de Derecho Penal, Parte Especial, T. I, op. cit., pp. 71 y 72.
} 
de que tras la muerte no moriría realmente motivó a la víctima. JAKOBS ${ }^{2171}$ opina que este suceso si bien puede ser un caso extremo de autoría mediata, en la Sentencia influyó la necesidad de proteger a la víctima porque estaba perturbada psíquicamente, pero era irrelevante el engaño sobre la resurrección.

Otro caso significativo en nuestra opinión y por tratarse de asesinato en masa, fue en 1997 el de la secta WW Higher Source («Puerta del Cielo») de San Diego. 39 miembros de la secta se suicidaron por la inminente llegada del cometa Hale-Boop, tras los mensajes que la misma secta difundía por Internet sobre la llegada inminente y apocalíptica del cometa. En concreto, su líder dijo haber encontrado su alma gemela en una enfermera dedicada a la astrología y al ocultismo y que poco a poco, a lo largo de 20 años, cultivaron la idea en los miembros del grupo de la necesidad de realizar un viaje astral mediante el cometa Hale-Hoop dirección a Sirio ${ }^{2172}$.

Nos parecen relevantes en este punto para llegar a una conclusión las reflexiones de LUHMANN acerca de la organización. Una organización es una construcción -autopoiética- de una dinámica comportamental del grupo más allá de los individuos, en la que la racionalidad individual deja paso a una racionalidad propia de la organización, de forma que a través del autorrefuerzo reflexivo «pueden transformarse incluso probabilidades escasas en premisas de decisión altamente probables» ${ }^{2173}$.

De aquí que sean altamente peligrosos aquellos grupos que suspiran por el Fin del Mundo, el fin apocalíptico o el Armagedón ${ }^{2174}$, que en algunas ocasiones ha llevado a que miembros del grupo se suiciden. La pregunta que ha de hacerse es si la introducción de doctrina de fe sobre la

2171 JAKOBS, G., $P G$, op. cit., 21/77, nota 142.

2172 Difundieron esta «alucinación» por internet, se decía en estos mensajes que «su llegada es, afortunadamente, muy significativa para nosotros aquí, en la «Puerta del Cielo». La fortuna se deriva de que Nuestro Miembro más Antiguo en el Nivel más Evolucionado Superior al Humano, (el «Reino del Cielo») nos ha dejado claro que la aproximación del Hale Bopp es la «señal» que esperábamos -el momento de la llegada de una nave espacial desde el Nivel Superior al Humano que nos conducirá a nuestra casa en «Su Mundo» -en los cielos siderales», vid. Periódico El Mundo, 28 de marzo de 1997. Así también Robert Nichols se suicidó, en cuya nota de despedida decía: «Estoy viajando hacia el cometa Hale-Boop para reunirme con aquéllos que me han precedido», vid., AzCONA, F., «Origen, evolución y situación actual del fenómeno sectario en España», GUERRA M / AZCONA F / LORDA JL., Sectas ¿De qué hablamos? Historia de las religiones, Sociología y Evangelización, $1^{a}$ ed., Navarra Gráfica Ediciones, Cuadernos del Instituto Martín de Azpilcueta, 1999, p. 87.

${ }^{2173}$ Así «(e)s característico de un decidir sobre decisiones -comenta LUHMANN- que, debido a que dirige otras decisiones, es menos formalmente regulado y puede ser manipulado en forma reflexible. Con esto se ganan libertades, incluso libertades para mantenerse o estafar a la organización. Correspondientemente a esto, es aumentada la responsabilidad. Mediante el perfeccionamiento reflexivo del proceso de decisión se trasforman también las no-decisiones en decisiones», LuHMANN, N., Organización y decisión. Autopoiesis, acción y entendimiento comunicativo, op. cit., p. 49.

${ }^{2174}$ GuerRA, M., «Lo que es y lo que no es una secta», op. cit., p. 77, comenta que los Testigos de Jehová han anunciado el fin del mundo en los años 1914, 1925 y 1975. Muchos miembros de este grupo vendieron todas sus propiedades para hacer proselitismo fuera de su ciudad sobre la llegada del fin del mundo; los adventistas del séptimo día para el año 1843 y después en 1884; la Familia en 1993; Misión Rama entre 1975 y el año 2000 ; Edelweiss en 1992; y la Iglesia Universal de Dios en 1936, 1947, 1972 y 1975. 
inminente llegada del fin del mundo es punible y en concepto de qué, inducción, cooperación, o autoría en comisión por omisión, o coautoría.

A este respecto, en el caso El Rey de los Gatos, el Tribunal Supremo alemán ${ }^{2175}$ condenó a dos personas como autores mediatos de una tentativa de asesinato por haber creado en otra un error de prohibición vencible, cuando le hicieron creer en la existencia de un Rey de los Gatos que representaba el mal y la convencieron para que asesinara a la ex pareja de uno de los autores mediatos, asegurando que de tal modo evitaría que el Rey de los Gatos exterminará la humanidad y que la prohibición de matar no tiene vigencia cuando existe tal peligro para la raza humana. $\mathrm{O}$ el caso comentado del Tribunal de segunda instancia de Lyon, que en sentencia de 29 de julio, condenó a tres años de cárcel al ex-presidente local de la Iglesia de la Cienciología por haber inducido al suicidio a una mujer que pertenecía a este grupo religioso ${ }^{2176}$.

En opinión de RoxIN ${ }^{2177}$, estos casos de error de prohibición, al igual que los de tipo, se resuelven en función de si el ejecutor advierte la antijuricidad material o dañosidad, en cuyo caso el hombre de atrás sólo será partícipe, y al contrario, si no la advierte será un autor mediato, diferenciando así, entre conciencia de los datos objetivos formales y la conciencia de la antijuricidad material. Críticamente FERNÁNDEZ IBÁÑEZ ${ }^{2178}$ estima que «la clave de la atribución de la culpabilidad (plena o atenuada) será precisamente la conciencia de que la conducta se opone al Derecho, por mucho que su percepción personal acierte o no al enjuiciar la reprobabilidad social. Este supuesto no podría en ningún caso ser calificado de autor mediato. En realidad, estos casos entroncan directamente con aquellos que la doctrina viene calificando de autor por convicción, en los que «no hay culpabilidad moral, pero sí culpabilidad jurídica», y si ello -como parece querer decir RoxIN- tuviera que desembocar en privar de la condición de autor de quien así actúa para atribuírsela a quien se aprovecha de ello, se llegaría a hacer depender «la vigencia del ordenamiento jurídico de la aceptación en conciencia de sus nomas por los ciudadanos». Por otro lado, en opinión de BOLEA BARDÓN ${ }^{2179}$, se puede reconducir a la autoría mediata si existe provocación antes de la instrumentalización que suponga un riesgo para el bien jurídico, mientras que si sólo se aprovecha del error de prohibición, el hombre de atrás será un inductor o cooperador necesario.

\footnotetext{
${ }^{2175}$ BGHSt 35, 347, ampliamente vid. FERNÁNDEZ IBÁÑEZ, E., La autoría mediata en aparatos, op. cit., pp. 68 y Ss.

${ }^{2176}$ Vid., ZENIT, Kerygma, ltd., Lyon, 30 julio de 1997.

2177 RoXIN, C., Autoría y participación, op. cit., pp. 211 a 224; HeRnÁNDEZ PlASENCIA, JU., La autoría mediata, op. cit., pp. 211 y ss.

${ }^{2178}$ FERNÁNDEZ IBÁÑEZ, E., La autoría mediata en aparatos, op. cit., pp. 73 y 74, haciendo referencia en el entrecomillado a CEREZo MIR, J., Curso de Derecho Penal español, Parte General, III/2, op. cit., p. 35.

2179 Bolea BARDón, C., Autoría mediata, op. cit., pp. 222 a 225.
} 
En nuestra opinión, la imputación objetiva por participación de la víctima o de un tercero, cuando el agente provoca, favorece o induce a la víctima para que por ejemplo se suicide o incurra en un riesgo consciente, son equiparables a los casos en los que tanto la doctrina mayoritaria como la jurisprudencia niegan la imputación del homicidio por falta de una «causalidad adecuada o eficiente, próxima, directa y eficaz» (STS de 15 de diciembre de 1977), o concretamente en el favorecimiento de la autopuesta en peligro de la víctima por entregar estupefacientes, por cuanto a la larga, si bien el suministro continuado acarrea la muerte, o reduce la expectativa de vida, algo que es evidente y conocido por todos, en las primeras etapas de la jurisprudencia se condenaba al suministrador por un delito de homicidio en dolo eventual, pero en la actualidad, sensatamente, la doctrina ${ }^{2180}$ y la jurisprudencia desvinculan la imputación por la consciente puesta en peligro de la víctima, salvo si ésta no fuera consciente de la dosis que se le suministra, o si su pureza estuviera fuera de lo habitual (riesgo extraordinario) como recuerda la STS de 20 de febrero de 1993.

En este sentido, la diferencia entre una autopuesta en peligro o suicidio y una inducción y el homicidio o asesinato en autoría mediata reside en el grado de aceptación de la propia muerte en todo su sentido y trascendencia. En el modo expuesto por JAKOBS ${ }^{2181}$, el dato relevante es si el sujeto quiere realmente suicidarse o simplemente realiza una conducta de autopuesta en peligro. En nuestra opinión, el suicidio se caracteriza por una clara voluntad de que concurra el resultado de muerte. Otros resultados por encima de la muerte aceptada como probable (dolo eventual) o en culpa consciente, o mejor como riesgo permitido, llevará a que la acción sea una autopuesta en peligro o autolesión. Así, sólo en los casos en los que el sujeto no conozca el resultado material de su conducta, de modo que no conozca la consecuencia de su autopuesta en peligro motivada por un tercero, se podrá imputar como inducción, si bien, con nuestros postulados, nada impide tratar estos casos como coautoría con responsabilidades diferenciadas a cada interviniente.

En este caso el fundamento de punibilidad de la intervención se razona en una restricción de las expectativas, mediante la confianza especial que genera garantía (garantía de expectativa cognitiva que se normativiza) que incapacita a la propia víctima en su libertad de voluntad, que sin eliminarla, trasforma los conceptos esenciales del Sistema normativo y social (vida, salud, etc.) de modo que se auto-causa su muerte como autor (autoría dual) ya que aún tiene márgenes (horizontes) de libertad, y lo que fundamenta la responsabilidad en la coautoría en la que cada

\footnotetext{
2180 JAKOBS, G., $P G$, op. cit., 21/78.

2181 ID., ibidem, op. cit., $21 / 79$ y $21 / 80$.
} 
interviniente aporta algo relevante: el autor aporta la restricción del horizonte de expectativas o lo utiliza y la víctima-autor su propia autocausación, si bien la responsabilidad se individualiza. Por esto, la realización material del delito, en verdad, no aporta mucho a la concreción del título de imputación, es simplemente algo fenomenológico muchas de las veces.

$\mathrm{Si}$ el sujeto tiene restringidas por completo esas expectativas e ineludiblemente llega a obrar en contra de su propia vida o sus derechos estaremos en casos de homicidio o asesinato en autoría mediata. De tal manera, se mantiene el título de imputación en la autoría, sin transformarse únicamente por una fenomenología naturalística de quién sea víctima o perjudicado $^{2182}$. De aquí que un sujeto con déficit de socialización no culpable pueda ser autor de un delito contra sí mismo, en coautoría, si bien la forma aceptada generalmente en casos de suicidio es la inducción, porque se introduce una valoración moralizante acerca de que la víctima no puede ser tratada de autor, pero en puridad, esto rompe con la dogmática jurídico-penal de la autoría: que alguien sea víctima de un perjuicio es un dato naturalístico, no normativo.

Esta conclusión viene a ratificar pero a la vez a complementar la alcanzada por JAKOBS en cuanto que la competencia puede traer defectos cognitivos o volitivos ${ }^{2183}$, pero cuando los defectos cognitivos del hombre de delante vienen causados por defectos volitivos del mismo no cabe hablar de autoría mediata, sino de autoría principal del hombre de delante, pues el hombre de atrás no habrá tenido nada que ver, a pesar de haber causado el error cognitivo, pues antes de ello viene el error volitivo de quien era finalmente competente, o dicho de otro modo, si lo desconocido es asunto de la incumbencia del suicida, no habrá autoría mediata. Así, si lo desconocido es atribuible al hombre de atrás (restricción del horizonte como déficit de garantía cognitiva) estaremos en casos de inducción al suicidio, por ejemplo, cuando el sujeto desconoce que «realmente» va a morir cuando piensa que la causación de la muerte del cuerpo no es más que un tránsito a otra forma de vida. La inducción aquí va referida a restringir la propia consideración sobre el hecho, pero como una forma de realizar la autoría que convence o autor intelectual, mientras que si el error o el motivo, o la fuerza persuasiva se refieren a conseguir la aceptación de una conducta inevitable, sin márgenes (horizontes) de libertad como en el caso de

${ }^{2182}$ Por eso añade JAKOBS que «(e)n los supuestos de autolesión, consciente en parte, del instrumento, subsiste la responsabilidad por la «añadidura en concepto de autor», ejemplo: El autor mediato proporciona una pipa de opio, conociendo las circunstancias a quien está dispuesto a fumarse una pipa de hachís; autoría mediata por la medida de autolesión no advertida por el ejecutor (...) la estafa no es sino una tipificación de autoría mediata, con actuación no dolosa del instrumento en relación con la disposición patrimonial», JAKOBS, G., «La organización de autolesión y heterolesión, especialmente en caso de muerte», op. cit., pp. 395 a 412.

${ }^{2183}$ JAKOBS, G., PG, op. cit., 21/77 y ss; ID., «Sobre el tratamiento de los defectos volitivos y de los defectos cognitivos», JAKOBS, G., Estudios de Derecho penal, op. cit., pp. 127; ID., «La organización de autolesión y heterolesión, especialmente en caso de muerte», op. cit., pp. 404 a 406. 
adicción comportamental mediante la restricción del horizonte de expectativas, la única expectativa es la aportación de la muerte, sin más sentido, lo que fundamenta la autoría mediata y en casos especialmente graves de adicción plena, la autoría directa.

Amén de todo lo anterior, vamos a realizar la siguiente propuesta dogmática. La problemática de la solución a la que hemos llegado, aquella que la intervención en la resolución del suicidio no puede tratarse en los casos de los suicidios ordenados o persuadidos en sectas, salvo excepciones de autoría mediata o directa, sino como una coautoría, puede ser satisfactoria en España y solucionar los casos de tentativa de inducción.

En España, la falta de criminalización de la tentativa de inducción como participación se debe a la rigidez de los conceptos de autoría e inducción, en verdad de todas las formas de intervención. Como ya dijimos, en toda coautoría siempre hay alguien que expone la mejor idea, o de alguna forma domina la resolución, sin que nos veamos abocados a reconocer una coinducción. Es más, el reconocimiento aquí de formas de inducción tales como la co-inducción o la inducción en cadena no es más que el reconocimiento de formas de coautoría. Sin embargo, el problema en Alemania viene de la impunidad de la participación dolosa en el suicidio (parágrafo 216 StGB en relación al 26 y ss.).

La problemática de la que trata la cuestión sucede cuando uno de los sujetos es víctima de su propio hecho con la mediación relevante de otro. Lo paradigmático es que cuando dos sujetos se juntan para cometer un delito se trata como coautoría, y cuando uno es su propia víctima, sólo hay un autor o inductor. A nuestro modo de ver, la victimología y víctimodogmática ${ }^{2184}$ (también aquellas propuestas que hemos visto sobre la imputación objetiva a la víctima), ocultan la necesidad dogmática de tratar a la víctima como «sujeto activo» ${ }^{2185}$ de su propia lesión, o sea,

${ }^{2184}$ Ampliamente CANCIO Meliá, M., Conducta de la víctima e imputación objetiva, op. cit., pp. 221 a 256, si bien la considera dentro de la teoría del delito; la consideran «superflua» TAMARIT SUMALLA, JMa ${ }^{\mathrm{a}}$, La víctima en el Derecho penal, op. cit., pp. 92 y ss., pp. 127 y ss; y GARCíA ÁLVAREZ, P., La víctima en el Derecho penal español, Tirant lo Blanch, Valencia, 2014, p. 188; BUSTOS RAMíREZ comenta que «podría llegar al absurdo de constituir a la víctima en único autor», Bustos RAMÍREZ Juan / LARRAURI PIJOAN Elena, Víctimología: presente y futuro (Hacia un sistema penal de alternativas), $1^{\mathrm{a}}$ ed., PPU, Barcelona, 1993, p. 71; SCHÜNEMANN considera que no se aprecia en la parte general, si bien modula en los tipos especiales, ScHÜNEMANN, B., «Sistema del Derecho penal y victimodogmática», José Luis Díez Ripollés, Carlos María Romeo Casabona, Luis Gracia Martín, Juan Felipe Higuera Guimerá (Edit.), La ciencia del Derecho penal ante el nuevo siglo, Libro Homenaje al Profesor Doctor José Cerezo Mir, reimp. 2003 de la $1^{\text {a }}$ ed., 2002, Tecnos, pp. 165 y ss.

2185 Afirma POLAINO NAVARRETE que «el concepto de autor es más restringido, más angosto, que el de sujeto activo. O lo que es lo mismo: el sujeto activo es una categoría más amplia que la de autor, de manera que el sujeto activo no es únicamente el autor del delito, sino algo más: abarca al autor material o inmediato, al autor mediato, a los coautores, al inductor directo, al cooperador necesario y al cómplice (...) no sólo lo es del delito consumado, sino del delito en grado de tentativa o preparación», POLAINO NAVARRETE, M., Acción, omisión y sujetos en la teoría del delito, op. cit., pp. 104 y 105; similarmente y ampliamente GÓRRIZ ROYO, Elena M ${ }^{\mathrm{a}}$, El concepto de autor en Derecho penal, pról. Tomás Salvador Vives Antón, Tirant lo Blanch, Valencia, 2008, pp. 73 y ss. y 417 y ss., defiende un concepto restrictivo de autor desde una «concepción significativa de la acción», y así la imposibilidad de construir un concepto general de autor para todos los tipos de acción. 
dentro de los sujetos que realizan el tipo objetivo en determinados delitos (estafas, consentimiento de la propia muerte), sin embargo, se les excluye, especialmente en el suicidio, por motivos de política-criminal, pero esta exclusión viene de una necesidad de prevención general positiva, no es dogmática. De otra, entonces, la pregunta también lleva a si la víctima puede ser autor de su propio delito, con o sin colaboración de otro, puesto que -como resaltara WELzel- el «quien» de la descripción típica es el autor, o inclusive desde las teorías del concepto restrictivo de autor, lleva a que en el suicidio o en la heterolesión, la víctima sin lugar a dudas es también ese «quien» ${ }^{2186}$, de modo que la doctrina mayoritaria asocia la autoría con la completa o parte relevante normativa de la descripción típica, y de aquí que también anticipadamente se pueda concluir que la víctima puede ser autor de su propio delito, tanto en la formulación típica como en su realización, siendo cuestión aparte la responsabilidad final. Evidentemente el tipo no se dirige contra la víctima, ni a la protección en sí de la misma víctima, sino de sus derechos, por eso mismo también la imputación a la conducta de la víctima en un hecho que le perjudica, cuando ésta no acciona determinados derechos, los ejercita voluntariamente contra sí misma (víctima voluntaria ${ }^{2187}$, con consentimiento en bienes semidisponibles como la vida y la integridad) o los ejercita de forma descuidada, modela o excluye la intervención de un tercero en concepto de autor y su imputación. Esto demuestra que el concepto de víctima entra tanto en la categoría general de sujeto activo en determinados delitos (p. ej. estafas, consentimiento de la propia muerte), pero especialmente en ciertas ocasiones en la de autor, lo que propicia la irresponsabilidad del tercero como autor o interviniente (concurrencia de engaño por la «víctima» en el timo de la estampita, participación en el suicidio, legítima defensa o estados de necesidad justificante y exculpante con provocación suficiente, la alevosía, el abuso de superioridad, la confianza, las lesiones consentidas en las relaciones sadomasoquistas o consentimiento en las lesiones que median con precio, recompensa o promesa ${ }^{2188}$ ).

En la imputación objetiva al autor, las teorías de la imputación a la conducta de la víctima ${ }^{2189}$ tienen en cuenta este elemento para la atribución de la responsabilidad a título de autor del

${ }^{2186}$ Welzel, H., Derecho penal alemán, op. cit., pp. 94 y 286. También se pregunta si la víctima puede ser autor de su hecho, o la «única autoría», o concurrente como autoría accesoria, LuZÓn PEÑA, D-M., Curso de Derecho penal, Parte General, I, op. cit., pp. 526 y ss.

${ }^{2187}$ García Álvarez, P., La víctima en el Derecho penal español, op. cit., pp. 42 y ss.

${ }^{2188}$ Críticamente contra la responsabilidad en casos de sadomasoquismo y lesiones consentidas bajo precio, recompensa o promesa, siempre que exista libertad sin abuso de superioridad (libre desarrollo de la personalidad) ID., ibidem, op. cit., pp. 67 y ss.

${ }^{2189}$ CANCIO Melí, M., Conducta de la víctima e imputación objetiva, op. cit., pp. 284 y ss; similarmente JAKOBS, G., PG, op. cit., 7/126; FEIJOO SÁNCHEZ, BJ., Homicidio y lesiones imprudentes, op. cit., pp. 109 y ss;

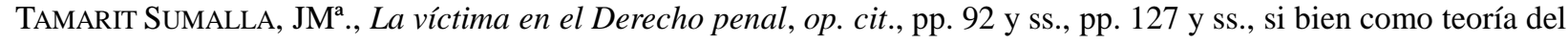
tipo objetivo, salvo «abuso» por parte del interviniente. 
interviniente, lo que suscita un debate puramente dogmático (victimodogmática), y cuestiones aparte serían la necesidad de tutela penal (prevención general, teoría de la pena y política criminal) o como se expone en esta investigación, también suscita debate en la autoría y participación y su imputación objetiva ${ }^{2190}$. De aquí que en coherencia también con la teorías del dominio del hecho la víctima pueda ser «sujeto activo»y, especialmente, «autora», máxime en casos tan evidentes como en la concurrencia de culpas, ámbito que tradicionalmente pertenece al Derecho civil salvo algunas Sentencias del TS y tribunales menores en materia penal ${ }^{2191}$. Así se ha expresado parte de la doctrina que aboga por sanciones a las víctimas como medida políticocriminal $^{2192}$.

En esta encrucijada adquiere trascendencia que dentro del riesgo permitido (autopuesta en peligro y ciertos casos de heteropuestas en peligro consentidas), la víctima sea autorresponsable de sucesos e inclusive se le exija un plus de seguridad cognitiva mediante su propia conducta, como cerrar las puertas, en el sentido expuesto por CARO JOHN. Con dicha imputación a la víctima se soluciona que el Derecho penal tenga que intervenir en cualquier lesión, se orienta al sujeto a auto-protegerse más allá de la orientación normativa expresa. Sin embargo, cuando un sujeto supera el umbral del riesgo permitido de forma autorresponsable o quasi-responsable surge esa cuestión que estamos debatiendo: si la víctima es también autor con su propio comportamiento, coautor, y a la vez contra tercero.

Sobre esta base hemos resuelto que en los casos en los que la «víctima» conozca parcialmente el sentido del hecho, en nuestro ámbito de estudio, la muerte, no estaríamos ante casos de autoría mediata, sino en casos de formas de autoría a la que actualmente se denomina inducción, pero este planteamiento ha de ponerse definitivamente en reserva, porque nadie negará que si el inducido comete un delito contra tercero, la diferencia con la coautoría es prácticamente inexistente, máxime cuando hemos reconocido la coautoría imprudente, porque no hace falta un

2190 Similarmente LuZÓn PEÑA, D-M., Curso de Derecho penal, Parte General, I, op. cit., pp. 526 y ss; CANCIO Meliá, M., Conducta de la víctima e imputación objetiva, op. cit., pp. 284 y ss; GARCÍA ÁlVAREZ, P., La puesta en peligro, op. cit., p. 424 y ss; ID., La víctima en el Derecho penal español, p. 180 y pp. 198 y 199 comenta que «(l)a víctima se ha convertido en una co-responsable del delito, lo que en principio no sería criticable si de verdad se constatara en los diferentes casos que nos encontramos ante auténtico co-responsables del delito que, precisamente por haber asumido voluntariamente los riesgos de afección de sus bienes jurídicos o solicitado la lesión de los mismos, perderían incluso su carácter de auténticas víctimas, al convertirse en una especie de "víctimas voluntarias"»).

${ }^{2191}$ Vid. y críticamente GARCíA ÁlVAREZ, P., La víctima en el Derecho penal español, op. cit., p. 180 y pp. 189 y SS.

${ }^{2192}$ Vid. CANCIO Meliá, M., Conducta de la víctima e imputación objetiva, op. cit., pp. 234 y ss., si bien no se muestra de acuerdo con la sanción, reconoce: «hasta qué punto en el ámbito general de los conceptos «víctima» y «autor»se produce una enorme confusión». Así, en ocasiones la víctima no merece protección, no desde una visión «victimo-dogmática», sino desde la primera fase de la imputación objetiva, en la imputación de la conducta», ID., ibidem, op. cit., p. 255 y pp. 305 y ss. 
acuerdo de voluntades expreso, tácito ni doloso, sino la intervención de cada uno, que sumadas todas las aportaciones aumenten el riesgo o causen el resultado, de tal manera que cuando uno de los sujetos inducidos a cometer un injusto es la propia víctima (de igual modo la tentativa sobre este respecto), y en coherencia con los postulados de la tentativa de autoría mediata en la solución individual, llevarán a que la acción de resolución criminal tratada como inducción al suicidio no se criminalice en España, sólo si se consuma. Pero este planteamiento es incongruente, desde el momento en que el suicidio, al no existir un reconocimiento positivo del derecho a la muerte, es una conducta antijurídica, del punto que obliga a la intervención, al menos de las fuerzas de seguridad del Estado, si bien, y aquí está la clave, por razones de política criminal no se pena al suicida, sin embargo, es autor de su propio hecho, o dicho de otro modo tiene dominio del hecho. Pero también existe dominio del hecho cuando un tercero le induce de tal manera que el inducido conoce la realidad del riesgo (tomar drogas, la muerte en el caso Sirius), por eso con la relajación, o ampliación del concepto de coautoría (pues admitimos la coautoría imprudente, y las formas de inducción referidas) el sujeto es autor de su propia muerte, de modo que fuera de los casos de la autoría mediata y autoría directa relacionados con la eliminación del horizonte de expectativas (adicción comportamental o trastornos completos o plenos), la intervención del inductor se puede tratar como una «coautoría dual», en la que ambos son autores, y la víctima autora de su propio hecho, pudiéndose criminalizar perfectamente así la tentativa de inducción, si la tratamos como una coautoría, o sea dos autores, uno plenamente responsable, y la víctima que también es responsable de su hecho antijurídico (salvo casos de derecho a tratamientos médicos vitales, etc.) pero que no es criminalizado unas veces por política criminal, otras por déficit de socialización cuando actúa contra tercero, y en ausencia de cualquier tipo de exoneración como coautoría de un delito contra terceros.

Sólo así podemos comprender la incoherencia de criminalizar la inducción al suicidio o la eutanasia, en la que en ambas la víctima tiene dominio de su propio hecho. Se criminaliza exclusivamente al inductor no por el resultado, que si fuera así llevaría a la figura del homicidio, sino como delito contra la libertad, o de restricción parcial de la libertad, pero en verdad, dogmáticamente encierra una «coautoría dual», no una autoría mediata ni estrictamente una inducción.

Por eso nos adherimos a la conclusión de LUHMANN acerca de que «(c)on la normatividad sólo se establece que determinadas expectativas, aunque no se cumplan, siguen siendo válidas como expectativas. En ello radica ya una directiva de distinción según el esquema 
expectativa/desengaño» ${ }^{2193}$. Así, puesto que la norma no puede garantizar una vida en el más allá, sino sólo que aquellos que así lo consideren, actúen conforme a sus convicciones, quien interviene en dicho desengaño, aun con la muerte, vulnera una expectativa que el Derecho no le puede otorgar, de aquí la antijuricidad de la conducta suicida, si bien no punible. Pero cuando un sujeto introduce esa idea, vulnera ya la expectativa, por mucho que el tercero libremente (inducido o coautor) tenga dicha convicción hasta ese resultado. Esto es porque la norma garantiza la defraudación actualizada, se desconoce el paraíso, Sirio, u otra garantía no confirmada por el Sistema normativo y social, de modo que cuando se genera tal garantía de forma tan especial que trasforma la conducta por esa previa restricción, es cuando surge el déficit de garantía de expectativa cognitiva, que constituye ya un injusto del todo relevante como autoría, y sin que esta atribución del título de imputación modifique la propia contribución de la víctima cuando tiene márgenes de libertad como autor de sí mismo, o sea: coautoría con responsabilidades de injusto individualizadas y desconectadas objetiva y subjetivamente.

\section{El intrusismo profesional}

Resulta común que aquellas sectas criminales que ofertan la salvación mediante la curación del alma ofrezcan, como condición indispensable para la pertenencia, que el sujeto se someta a tratamientos que en muchas de las ocasiones requieren de la habilitación médica. Recuérdese al respecto que ya se dijo que en muchas ocasiones el líder de una secta se atribuye falsamente este tipo de conocimientos para adquirir respeto (confianza especial) de los adeptos, como elemento para conseguir, en consecuencia, la persuasión coercitiva.

Recuérdese que se dijo que entre las diversas actividades de la profesión médica se encuentra la prescripción facultativa de medicamentos y que la Sentencia del Tribunal Supremo de 1 de abril de 2003 consideró que no existe una profesión legalmente establecida de especialista diferenciada de la actividad del médico, por lo que el ejercicio especialista no puede criminalizarse ni como intrusismo ni como delito contra la integridad. Lo ocurrido en el caso de la Sentencia del Tribunal Supremo de 10 octubre de 2005 que ratificó la condena por delito de intrusito profesional a miembros de una secta, fue que prescribían medicamentos sin titulación ni habilitación legal.

${ }^{2193}$ LuHMANN, N., El derecho de la sociedad, op. cit., p. 116 y 118. 
En concreto, la práctica de la hipnosis y la sofrología que algunos grupos ejercen sólo coinciden en la exigencia de titulación profesional, se requiere una titulación médica ${ }^{2194}$ por cuanto que en su aplicación existen riesgos de lesiones psicológicas, o de que afloren o se agraven. Con dicha titulación su práctica es atípica ${ }^{2195}$, pero la experiencia demuestra que se ejercitan sin titulación, aunque no parecen existir denuncias al respecto, por lo que pueden considerarse delitos de intrusismo profesional. Asimismo el uso de la hipnosis y de drogas susceptibles de producir sueño para la práctica hipnótica sin el debido conocimiento del sujeto pasivo puede acarrear un atentado contra la libertad, en concreto se incurriría, al menos, en un delito de coacciones $^{2196}$ y en su caso en el delito de lesiones psíquicas. De aquí que hayamos asemejado la violencia producida por estos medios con las técnicas de persuasión coercitiva, si bien, con los matices señalados.

Aprecia también la doctrina del Tribunal Supremo ${ }^{2197}$, y esto es lo que nos interesa ahora, que el uso de la técnica hipnótica y/o uso de narcóticos sin la posesión del título médico, haciéndose pasar por tal, supone la perpetración típica de un delito de intrusismo profesional. Esto significa que también pueda tratarse el uso de las técnicas de persuasión coercitiva, en diversos casos, como un delito de intrusismo profesional, cuando se enmascaran como medida terapéutica, sin embargo, dada la naturaleza contra la que se dirige, se verá consumido por el delito de coacciones generalmente, excepto en aquellos casos que la víctima haya consentido por mor de la apariencia profesional, con lo cual, podría plantearse el concurso medial del delito de coacciones y el de intrusismo.

Recuérdese que en el famoso proceso contra la Iglesia de la Cienciología ${ }^{2198}$, el Ministerio Fiscal también acusó por el delito de intrusismo profesional, lo que reforzó la acusación para fundamentar el delito de asociación ilícita. La Audiencia provincial de Madrid consideró que los elementos probados sobre esta conducta no eran típicos porque «(n)o es un acto propio de la medicina psiquiátrica», en concreto, se refería a la realización del test denominado E-Meter como aparato medidor de las alteraciones internas corporales y la rehabilitación de toxicómanos y otros sujetos a través de la técnica de la «auditación».

${ }^{2194}$ Recuérdese en el mismo sentido POLAINO-Lorente A / POLAINO NAVARrete M., «Dimensiones Psicológico-Psiquiátrica y Jurídico-Penal en el ejercicio de la sofrología», op. cit., p. 26.

2195 ID., ibidem, op. cit., p. 39.

${ }^{2196}$ En este sentido la citado FJ $3^{\circ}$ de la STS, de 10 de octubre de 2005, rec. 1252-2004.

${ }^{2197}$ En concreto "aprovecharon los acusados la confianza que la misma había depositado en ellos, como consecuencia de su amistad precedente, a lo que se añade su creencia de encontrarse en manos de un profesional de la medicina que, a través de tales fármacos, estaba tratándola de su enfermedad precedente», FJ $3^{\circ}$ STS, de 10 octubre de 2005, rec. 1252-2004.

2198 SAP Madrid, de 28 noviembre de 2001. 
Otro de los casos en que fueron imputados miembros de una secta por intrusismo profesional, fue el de CEIS ya comentado. Los acusados se presentaban ante los clientes como psicólogos, condición profesional que no ostentaban por medio de ningún título ni conocimiento acreditativo. Inclusive se reconoce en la Sentencia que utilizaron técnicas de captación y control psicológico para introducirlos en la misma y para «inducirlos» a la prostitución ${ }^{2199}$. Y más recientemente el caso del médico alemán Ryke Geerd Hamer condenado en Francia por el ejercicio ilegal de la medicina.

Así, antes hemos concluido que en la problemática de las sectas criminales se incluyen casos en los que determinados sujetos, tanto el líder como miembros activos, pero también simples adeptos, se presentan como consejeros sobre cuestiones tales como la veracidad de utilidad de programas terapéuticos, de manera que la confianza generada, del todo especial, que produce una competencia sobre el error causado por el autor, ya sea dolosa o imprudente, en la conducta de la víctima cuando se perjudique en sus propios bienes -sometiéndose a dicho «tratamiento», o comprando el producto como estafa, o trasmitiendo la inveracidad de las cualidades del producto a otros adeptos, del que conscientemente se puede conocer su inocuidad, o pagando tratamientos sobre los que nada se consigue-, crea un vínculo del que si se produce el motivo relevante del obrar de la víctima, pueda ser imputado ya no sólo como delito de intrusismo profesional, sino en concurso con la estafa cuando median cantidades.

En este sentido, la víctima del intrusismo también participa en muchas ocasiones de su propio infortunio, omitiendo fáciles actuaciones de comprobación de las atribuciones especiales que se asigna el líder y/o grupo, o mediante credulidad sobre la transcendencia «terapéutica» de la oferta especial. Aquí comienza igualmente cierta participación de la víctima de modo que comunica con su comportamiento la legitimidad y vigencia de dichas facultades esotéricas, y en definitiva, una mayor probabilidad de la perpetración de la persuasión coercitiva y/o la estafa en calidad de coautora, si bien en unos casos no criminalizada por ser el propio perjudicado, y en otras sí cuando se comete otro delito-fin contra terceros aunque exonerada completa o parcialmente por el déficit de socialización que causa la persuasión coercitiva.

\section{Estafas y falsedades documentales: trascendencia en el binomio «víctima-autor»}

Las sectas coercitivas «garantizan» soluciones a un precio muy alto ocultando información sobre la realidad y finalidad del grupo. La oferta de una religión o la oferta de evangelización, cuando no sea más que una terapia de relajación o medida terapéutica basada en el psicoanálisis,

\footnotetext{
${ }^{2199}$ FJ $1^{\circ}$ de la SAP de Barcelona, de 16 de julio de 1990, ratificada por STC 240-2005, de 10 de octubre.
} 
como parece que ofertan algunos grupos, podría considerarse una estafa masiva, o inclusive una estafa que afecta a los intereses generales cuando se oferta una garantía de expectativa cognitiva, del todo deficitaria, si se ha restringido el horizonte de expectativas o se ha aprovechado tal circunstancia.

Recuérdese que miembros de la Iglesia de la Cienciología fueron imputados por estafa por la acusación formulada del Ministerio Fiscal (no por los perjudicados). La Audiencia provincial de Madrid en la citada Sentencia de 28 de noviembre de 2001, absolvió a los imputados por estimar que no concurría el requisito esencial de la estafa, el engaño ${ }^{2200}$. Aunque los perjudicados dieron altas cantidades de dinero a cambio de determinados cursos formativos para alcanzar la categoría de «Claro», dichos cursos se realizaron y muchos de los miembros alcanzaron tal cualidad, y los que no lo alcanzaron en la mayoría de casos no se sintieron engañados. También recuérdese que en el proceso de Niños de Dios se acusó de estafa por la adquisición de donativos bajo la apariencia de obrar como misioneros. La Sentencia desechó la estafa porque el hecho de que se presentasen como misioneros tampoco desprendía una artimaña de engaño, realmente pertenecían al grupo religioso ${ }^{2201}$. Sin embargo y como dijimos, está el caso con mayor divulgación, el del médico alemán Ryke Geerd Hamer condenado en Francia, además de por ejercicio ilegal de la medicina, por delito de estafa, esto al entender el Tribunal que ofertaba una medicina curativa no comprobada con cobro de donativos u honorarios.

Pues bien, dicho esto, la estafa es una conducta injusta muy cercana a la persuasión coercitiva. En ambos supuestos existe cierta participación relevante de la víctima como autoraresponsable contra sí misma, de hecho, tradicionalmente han existido tanto posturas que asocian la responsabilidad de la estafa a la causalidad, a la conducta de la víctima, ya sea introduciendo el principio de responsabilidad en el tipo o incluyendo criterios materiales en dicho principio mientras que otras posturas lo relacionan con el principio de deber de veracidad $^{2202}$. A este

2200 SAP de Madrid núm. 335-2001, de 28 de noviembre de 2001.

${ }^{2201}$ FJ $^{\circ}$ SAP de Barcelona, Sección $3^{\text {a }}$, de 29 junio de 1993.

2202 Más ampliamente sobre la doctrina y las diversas concepciones PASTOR MUÑOZ, N., «El redescubrimiento de la responsabilidad de la víctima en la dogmática de las estafas», ¿Libertad económica o fraudes punibles? Riesgos penalmente relevantes e irrelevantes en la actividad económico-empresarial, Jesús-María Silva Sánchez (dir.), Marcial Pons, Madrid-Barcelona, 2003, pp. 75 y ss; ID., La determinación del engaño típico en el delito de estafa, op. cit., 2004. Tiempo antes en la doctrina alemana se pronunció MERKEL en el sentido de la propia responsabilidad de víctima sin la cual no existiría el delito de estafa al no haber ni violencia ni engaño, MERKEL, Adolf, Derecho penal, Parte especial, T. II, trad. P. Dorado, La España Moderna, Madrid, p. 65; lo relaciona con la estructura de la autoría mediata KINDHÄUSER, U., «La estafa como autoría mediata», trad. Jorge Fernando Perdomo Torres, KINDHÄUSER, U., Estudios de Derecho penal patrimonial, José Antonio Caro John y Percy García Cavero (Edit.), $1^{\text {a }}$ ed., Grijley, 2002, pp. 83 a 124, originalmente en alemán «Betrug als vertypte mittelbare Täterschaft», publicado en el Libro Homenaje a Günter Bemmann, 1997, pp. 339 a 361; también en el sentido de que el delito de estafa encierra la estructura de la autoría mediata con instrumentos no dolosos en relación a la disposición patrimonial, JAKOBS, G., PG, op. cit., 21/80 en relación con 29/29 y ss; ID., «Coacciones por medio de violencia», 
respecto, PASTOR MUÑOZ ${ }^{2203}$ comenta que desde la victimodogmática habría que cerrar la cuestión, no tanto en relación a las dudas de la víctima sobre la veracidad del negocio, sino si debe o no debe dudar/confiar. Eso es porque el deber de veracidad no es el objeto de protección, sino sólo en cuanto expectativa de la víctima en un contexto concreto de protección de su patrimonio y en relación a ese deber de veracidad del autor en este contexto ${ }^{2204}$. Aquí introduce la referida penalista que ha de protegerse «una garantía normativa del mínimo de veracidad» para que pueda funcionar el mercado pero, en este ámbito penal concreto, en relación a los comportamientos patrimoniales de sus titulares y en su funcionalidad en el mercado ${ }^{2205}$.

El tipo de estafa -según ha puesto de manifiesto KINDHÄUSER, entre otros- esconde la estructura de la autoría mediata ${ }^{2206}$. Sin embargo, en el delito de estafa se pueden aplicar reglas generales de la parte general, estrictamente se puede hablar de un delito de autoría mediata tipificada $^{2207}$ cuando el hombre de delante sufre un déficit atribuible al hombre de atrás, ya fuere por haberlo generado o por no haberlo evitado cuando existía ese deber. No obstante, en ambos casos se manifiesta un deber de veracidad de origen legal o institucional infringido, que genera la estructura de la autoría mediata, lo que fundamenta también la responsabilidad del engaño por omisión $^{2208}$. KINDHÄUSER invoca en este punto la argumentación de JAKOBS de que en casos de error de prohibición evitable el hombre de delante es responsable también, la responsabilidad se puede trasladar al comportamiento imprudente de la víctima en la estafa como autoría mediata, o en casos de duda cuando alcance la «densidad en el dolo» ${ }^{2209}$.

op. cit., pp. 439 a 459; similarmente PAWLIK, M., Das unerlaubte Verhalten beim Betrug, Köln, Berlin, Bonn, München, 1999; también STS 14 de septiembre de 2001 que trata la estafa como delito contra la libertad y por ende con la estructura de criterios de la parte general de autoría y participación como inducción o autoría mediata, vid., y en este sentido LÓPEZ BARJA DE QUIROGA, Jacobo, «Problemas actuales de los delitos de estafa, fraude de subvenciones, apropiación indebida y administración desleal», vv.aa., Derecho penal económico, Consejo General del Poder Judicial, Manuales de Formación Continuada, Madrid, 2001, pp. 434 y ss.

${ }^{2203}$ A este respecto criticando la postura de AMELUNG, PASTOR MUÑOZ, N., «El redescubrimiento de la responsabilidad de la víctima en la dogmática de las estafas», op. cit., p. 73.

${ }^{2204}$ PASTOR MUÑOZ, N., «El redescubrimiento de la responsabilidad de la víctima en la dogmática de las estafas», op. cit., p. 84.

${ }^{2205}$ ID., ibidem, op. cit., pp. 84 a 87; ID., La determinación del engaño típico en el delito de estafa, op. cit., pp. 209 y ss.

${ }^{2206}$ En concreto dice que «en un delito de la parte especial pueden estar incorporados estructuras de la parte general y que, por tanto, la interpretación de tal delito se puede entender como aplicación de las correspondientes reglas de la parte general. Los delitos del Derecho penal alemán son en su gran mayoría de «autoría neutra», es decir, no son formas de autoría mediata ni inmediata», KINDHÄUSER, U., «La estafa como autoría mediata», op. cit., pp. $83 \mathrm{y}$ ss.

2207 ID., ibidem, op. cit., p. 104.

2208 ID., ibidem, op. cit., pp. 108 y ss.

2209 ID., ibidem, op. cit., pp. 92 y 93 y pp. 115 a 117, en relación a la concepción de autor único en la imprudencia JAKOBS, G., $P G$, op. cit., 21/111 y ss. Concretamente KINDHÄUSER comenta que «(l)a prohibición de estafa no salvaguarda solamente al sensato, ponderador racional, sino -independientemente de su situación psíquicaa todo aquél que pueda reivindicar, con respecto a determinados hechos, no ser engañado o ser liberado de una representación falsa», ID., ibidem, op. cit., p. 116. 
Con argumentos funcionalistas, PAWLIK ${ }^{2210}$ diferencia la responsabilidad por asunción, por deber del tráfico y por injerencia del autor en el delito de estafa, utilizando los fundamentos esgrimidos por JAKOBS, de modo que la responsabilidad por asunción viene de la disminución de la protección de la víctima bajo la promesa de compensación del autor. Aquí la víctima goza de mayor libertad de organización, por eso la responsabilidad del autor comienza cuando se inicia la disposición patrimonial, y esto se debe a que la organización perjudicial de la propia víctima es generada por la asunción del autor, mientras que en la responsabilidad por el tráfico y por injerencia, el autor genera un déficit directo en la víctima, de modo que la responsabilidad viene antes de que se genere la disposición.

Sin embargo, estos planteamientos siguen anquilosados en la concepción tradicionalista de la autoría mediata. Por nuestra parte, cuando la víctima participa bajo imprudencia consciente, conoce el traslado patrimonial y la peligrosidad de su actuar voluntario, se puede tratar como una inducción, o más exactamente como una «coautoría dual» en la que la víctima no es responsable por razones de política criminal y de la función de la norma. Esta forma de comprender el delito de estafa se ve claramente en la dinámica criminal de las sectas que venden productos conociendo su inocuidad, pero también cuando varios, imprudentemente, lo venden a terceros, y estos últimos con imprudencia consiente lo venden a otros. De tal manera, todos son coautores de todos los hechos, no son casos estrictos de autoría mediata sino que la víctima puede ser a la vez por su propio comportamiento que le sume como víctima, autora de otros delitos contra terceros, o con palabras simples, el comportamiento de la víctima, si bien excluye su responsabilidad en el injusto que le perjudica, su intervención voluntaria en éste lo es en autoría ante perjuicios de terceros. Esto es porque su comportamiento puede generar garantía en los terceros de manera que su propia conducta como víctima haga incurrir en un deber de aseguramiento, en un deber asegurador, o en un deber institucionalizado como en el caso de desarrollarse el comportamiento dentro de la una organización, esto es: cada uno responde de su propio injusto.

En el mismo sentido como explicábamos, el delito de coacciones como persuasión coercitiva no encierra la estructura de la autoría mediata dual, sino que puesto que en ocasiones existe una desconexión de este injusto con el delito-fin, objetiva y subjetivamente, hace posibles ambas incriminaciones, y todos como coautores. De aquí que la solución en este caso también se vea en la estructura de imputación de la estafa. Todo esto supone un nuevo campo de estudio que podemos denominar «víctima-autor».

\footnotetext{
${ }^{2210}$ PAWLIK, M., Das unerlaubte Verhalten beim Betrug, op. cit., pp. 134 y ss.
} 
Como hemos indicado, la tradicional concepción de que la víctima no es autora de su propio delito ha impedido por norma general que en la participación imprudente o autopuesta en peligro de la víctima no se le atribuya el hecho posterior contra terceros, cuando en realidad, encierra una coautoría en la que es perfectamente posible el inicio doloso de uno o varios autores, con la intermediación en cadena o simultáneamente de sujetos dolosos o imprudentes sobre su propio perjuicio y/o en perjuicio de terceros.

\section{E. Delitos de abuso sexual mediante o sin reclamo sexual}

Los abusos sexuales, distintos a las agresiones sexuales por no mediar violencia ni intimidación, pueden realizarse con consentimiento de la persona abusada. De aquí que también en estos delitos, al igual que en la persuasión coercitiva y en la estafa, también exista cierta participación de la víctima contra sus propios bienes y derechos, lo que fundamenta de igual modo la dualidad dogmática de víctima-autor y la coautoría con títulos de responsabilidad individualizados objetiva y subjetivamente.

El líder o sujeto con similares poderes y el grupo pueden realizar el abuso con prevalecimiento de superioridad sobre personas a las que se ha mermado su capacidad volitiva o se aprovecha de tal ocasión. El consentimiento, en todo caso, es una aportación que puede eliminar la tipicidad, sin embargo cuando está limitado a unas expectativas restringidas, en un mundo desocializado respecto el Sistema normativo y social, el sentido de deseo o permisión sexual, es decir, el concepto de libertad sexual se ve restringido conforme a la expectativa sectaria, de manera que la víctima es autora de su propia vulneración. Aquí subyace el binomio víctima-autor en el perjuicio propio y delito-fin, y la constitución de un caso paradigmático de coautoría con títulos de responsabilidad individualizados objetiva y subjetivamente ${ }^{2211}$.

Esto tiene sentido en el supuesto frecuente en el que el líder impone para la salvación que las mujeres accedan a su deseo libidinoso. Surge una garantía de expectativa deficitaria que vicia el consentimiento en razón de tal persuasión coercitiva y comunidad de especial de confianza. A la postre quien es abusado mediante la obtención viciada del consentimiento o faltando éste sin violencia ni intimidación, permite en esa comunidad especial de confianza la perpetración de semejantes injustos (comisión por omisión) o participa en su consumación, todo ello sin perjuicio del déficit exculpante pero del que resulta el binomio víctima-autor.

\footnotetext{
${ }^{2211}$ Recuérdese la condena a los dirigentes de Edelweiss por 28 delitos de corrupción de menores, STS de 22 de octubre de 1991 y la STS de 28 de Junio de 2006, rec. 2451-2005. Tambén en el caso de una agresión sexual de un miembro y monitor juvenil de «Adventistas del Séptimo día» a uno de sus miembros, la STS de 28 junio de 2006

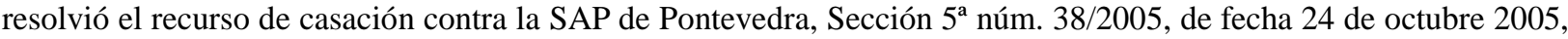
en la causa 4/2004 dimanante del Sumario núm. 2/2004 del Juzgado de Instrucción núm. 7 de Vigo.
} 


\section{Capítulo ViII}

\section{LA ASOCIACIÓN ILÍCITA, LA ORGANIZACIÓN CRIMINAL Y LOS GRUPOS CRIMINALES COMO INJUSTO SISTÉMICO}

\section{I.- Introducción}

En los últimos años, ha tenido lugar una construcción doctrinal, posteriormente recogida por el Código penal, para la criminalización de la persona jurídica. Se ha sostenido la responsabilidad con base a la teoría de los sistemas sociales autopoiéticos, superando el esquema de la heterorresponsabilidad al de autorresponsabilidad ${ }^{2212}$. Esta nueva forma de concebir la responsabilidad penal de la empresa y de la persona jurídica puede aplicarse igualmente a las asociaciones criminales tradicionales y a las que se constituyen bajo formas novedosas: todas se constituyen de forma autopoiética y de tal forma se puede establecer un nuevo modelo de culpabilidad.

$\mathrm{El}$ art. 22 de la CE declara ilegales a las asociaciones que persigan fines delictivos o utilicen medios tipificados como delitos. Esta declaración constitucional se reflejaba en el derogado art. 174 del CP de $1973^{2213}$. Si bien durante esta investigación nos hemos referido indistintamente tanto a asociaciones, organizaciones y a grupos criminales, normativamente existen diferencias tipológicas. El art. 570.1 bis CP, párrafo segundo establece que «la organización criminal es la agrupación formada por más de dos personas de carácter estable o por tiempo indefinido, que de manera concertada y coordinada se repartan diversas tareas o funciones con el fin de cometer delitos, así como de llevar a cabo la perpetración reiterada de faltas». En dicha noción legal se fundamenta que el elemento esencial de la ilegalidad es la finalidad delictiva, o más exactamente, un contexto potencialmente peligroso para la seguridad normativa. Al respecto SANTA RITA ha resaltado que una diferencia notable entre asociación ilícita, concretamente la

\footnotetext{
${ }^{2212}$ Ampliamente y con bibliografía alemana y española GóMEZ-JARA DíEZ, Carlos, «Autoorganización empresarial y autorresponsabilidad empresarial. Hacia una verdadera responsabilidad penal de las personas jurídicas», RECPC, núm. 08-05, 2006, pp. 2 y ss; ID., Teoría de sistemas y Derecho penal. Fundamentos y posibilidades de aplicación, Comares, 2005.

${ }^{2213}$ El citado precepto establecía como ilícitas: " $1^{\circ}$ Las que tuvieran por objeto cometer algún delito o, después de constituidas, promuevan su comisión. $2^{\circ}$ las que, aun teniendo por objeto un fin lícito emplearen medios violentos para su consecución. $3^{\circ}$ Las organizaciones clandestinas o de carácter paramilitar. $4^{\circ}$ Las que promuevan la discriminación racial o inciten a ella».
} 
terrorista, y la organización criminal es que esta última busca el secretismo en cuanto al mensaje comunicativo $^{2214}$.

Sin embargo, el art. 570.1 ter CP, párrafo segundo, establece: «(a) efectos de este Código se entienden por grupo criminal, la unión de dos o más personas que sin reunir alguna o algunas de las características de la organización criminal definida en el artículo anterior, tenga por finalidad o por objeto la preparación concertada de delitos o la comisión concertada y reiterada de faltas». De aquí se desprende la notable diferencia de que el grupo criminal no requiere de estabilidad o de indefinidad temporal, ni el concierto y coordinación en el reparto de tareas, por lo que aquellas organizaciones de carácter esporádico de escasa configuración organizativa pueden trasladarse al concepto de grupo criminal $^{2215}$.

Y de otra parte, el Código penal criminaliza generalmente el asociacionismo ilícito. El art. $515 \mathrm{CP}$ declara ilícitas las asociaciones que tengan por objeto cometer delitos, o una vez constituidas los promuevan o se organicen para cometer faltas $\left(515.1^{\circ} \mathrm{CP}\right)$; aquellas que, aun teniendo un fin lícito, «empleen medios violentos o de alteración o control de la personalidad para su consecución» $\left(515.2^{\circ} \mathrm{CP}\right)$; las de carácter paramilitar $\left(515.3^{\circ} \mathrm{CP}\right)$; o las que «fomenten, promuevan o inciten directa o indirectamente al odio, hostilidad, discriminación o violencia contra personas, grupos o asociaciones» $\left(515.4^{\circ} \mathrm{CP}\right)$. En el examen entre este tipo y el 570.1 bis $\mathrm{CP}$, párrafo segundo, se pone de manifiesto la similitud normativa ${ }^{2216}$, lo que crea la exigencia de precisar normativamente la clase de fenomenología criminal de cada tipo de pluralidad de sujetos delictivos.

El art. 517 CP criminaliza la cualidad que represente el sujeto en la organización criminal. Para parte de la doctrina miembros activos son todos aquellos que, sin ser fundadores, directores o presidentes, desarrollan actividades dentro de la asociación o en el marco de la misma. En cambio, serán meros asistentes los que acuden a la sesión sin ser miembros de la asociación ${ }^{2217}$. En nuestra opinión, debe considerarse como elemento esencial, no la cualidad social atribuida a tales sujetos en sus propios estatutos o reglas de hecho internas, sino el «dominio social»o «funcional» que tenga cada sujeto. El resto de casos en los que no se les pueda imputar esa cualidad activa en el dominio social -según MANZANARES SAMANIEGO- quedarán excluidos de

2214 SANTA RITA, G., El delito de organización terrorista, op. cit., pp. 186 y 187.

2215 También en este sentido SANTA RITA, ID., ibidem, op. cit., p. 194.

2216 También así SANTA RITA, ID., ibidem, op. cit., pp. 198 y ss.

2217 Manzanares Samaniego José Luis / Albacar LóPez José Luis, Código Penal, Comentarios y Jurisprudencia, Granada, 1990, pp. 754 y ss; también ALFonso Pérez MI / DíAz BAÑos M / GARCía MuÑoz G., «Los Nuevos Movimientos religiosos ante la ley y la jurisprudencia», op. cit., p. 238; de la misma opinión ALONSO Herreros R / MuÑz CALAz B / RAmos SuÁReZ A / RodríGueZ, JA., «Actitud del ordenamiento español ante las sectas», op. cit., p. 49. 
tal calificativo de participación penal, es decir, de la autoría, de la cooperación o de la complicidad $^{2218}$. Pero esta afirmación es incoherente, pues no parece lógico que quien no tiene cualidad activa o dominio social no pueda ser cómplice de la asociación ilícita, pues, el concepto de complicidad del art. $29 \mathrm{CP}$ se refiere a los que, no hallándose comprendidos en el art. $28 \mathrm{CP}$, cooperan a la ejecución del hecho con actos anteriores o simultáneos, o inclusive, no vemos impedimento para una coautoría funcional, sobre todo en nuestro ámbito de estudio por la especialidad de la dinámica grupal.

Así es acertada la inclusión de la responsabilidad de los «miembros activos», pues no son sólo responsables los que dirigen de alguna manera la asociación ilícita, sino también aquellos miembros cercanos a los líderes que tienen un papel activo y fundamental. La dificultad de la declaración de ilegalidad de una secta criminal estriba en la compleja prueba de que aquellos que realizan los ilícitos penales actúan en nombre de la secta, pues sin tal estrecha conexión sólo se puede imputar y condenar por el delito-fin realizado por el sujeto individualmente.

$\mathrm{El}$ art. $515.3^{\circ} \mathrm{CP}$, aunque declara como asociación ilícita sólo a las de carácter paramilitar, se refiere también, según la doctrina jurisprudencial ${ }^{2219}$ a las «secretas» que refiere el art. $22.5 \mathrm{CE}$. De este modo, algunas sectas podrían declararse ilegales si guardan el secretismo de sus actividades y si tienen finalidad delictiva, o emplean medios delictivos para conseguir fines lícitos.

En el marco de estudio y vistos los postulados, estructuras y dinámicas comportamentales de las sectas coercitivas, no resultará extraño que se asemejen a organizaciones paramilitares. Si bien no portan «armas» estrictamente hablando, el uso de las referidas técnicas de persuasión tiene la potencialidad de causar daños análogos a los de un arma peligrosa, según las conclusiones a las que hemos llegado en el capítulo quinto. En el concepto jurídico «paramilitar» se aglutinan los conceptos de secretismo y ocultación, si bien es cierto que esto por sí sólo no plantea tipicidad penal, pues debe existir un ánimo tendencial al delito o existir una peligrosidad objetiva de cometerse delitos-fin.

\footnotetext{
2218 Manzanares Samaniego Jl / Albacar López JL., Código Penal, Comentarios y Jurisprudencia, op. cit., p. 754.

${ }^{2219}$ La SAP Barcelona, sección 3 $3^{\mathrm{a}}$, de 29 de junio de 1989, en su FJ 14 ${ }^{\circ}$ dice: «Podría pensarse ante un enunciado tan escasamente perfilado, que se penaliza toda asociación encubierta u oculta, ya que iniciado el camino de los sinónimos por el legislador, parece la vía adecuada, pero la prohibición de analogía en el Derecho Penal y lo restringido que se exige a las limitaciones por lo Convenios y Pactos Internacionales hacen recapitular y volver sobre el texto constitucional como auténtico a fines hermenéuticos». Además la STS, de 30 de octubre de 1994 recuerda que los fines y medios de una sociedad secreta pueden ser delictivos, sin necesidad de recurrir al secretismo para ilegalizarla.
} 
Las sectas criminales, en tanto organizaciones que utilicen «medios (...) de alteración o control de la personalidad para su consecución», constituyen por la simple unión de voluntades o desatención conjunta, aun sin concretarse el delito-fin perseguido, un delito de estatus que merece ya una respuesta penal por la manifiesta peligrosidad objetiva. Este acuerdo o desatención conjunta de voluntades, sin embargo, puede manifestarse de forma expresa mediante una orden que se acata por los demás miembros, o de forma tácita, mediante una doctrina implícita en el ideario religioso o filosófico del grupo, y cuyos miembros siguen irremediablemente por motivos de conciencia o por convicción (déficit de socialización atribuido al propio autor) o por una merma de su capacidad volitiva, por causa de la persuasión coercitiva que produzca el déficit de socialización, o en su caso, la adicción comportamental. De este modo, el acuerdo de voluntades sobre el que se basa la criminalización de una organización (también la coautoría) puede sostenerse sin que exista un acuerdo explícito, o en casos en los que como los de coautoría imprudente (u obrar conjunto descuidado), cada sujeto aporta algo que si bien por sí sólo no representa peligrosidad alguna, sí lo hará conjuntamente con la conducta de los demás, y sobre lo que los miembros tienen un deber especial de garante en virtud de la confianza especial generada.

Por eso llama poderosamente la atención que el delito del art. $515.2^{\circ} \mathrm{CP}$ criminalice a aquéllas asociaciones que sin tener fines delictivos «empleen medios violentos o de alteración o control de la personalidad» para conseguir fines lícitos, y sin embargo no exista en nuestro Código penal un delito autónomo de persuasión coercitiva. Y llama la atención porque se criminaliza a la organización que ejecute medios de persuasión coercitiva mental pero no se castiga, o por lo menos no existe tipificación alguna concreta, que condene dicha expresión criminal. En este sentido, parece que el Código penal adopta una figura singular si no aceptamos el delito autónomo de persuasión coercitiva, a saber: que establece la punibilidad de una organización por la utilización de instrumentos. Si esto fuere así, se debería concluir que el Código penal en este apartado utiliza la teoría de los aparatos organizados de poder con la forma de responsabilidad de la autoría mediata. Pero en todo caso, volveríamos a la misma problemática, que la creación de la «alteración mental o control de la personalidad» quedase impune, cuando según las conclusiones a las que hemos llegado dicha lesión tiene un fundamento propio y autónomo de punibilidad, y esto se aprecia, sobre todo, en la desconexión espacio-temporal entre el uso de estas técnicas y el delito-fin ejecutado por el autor inmediato. De tal modo, que el elemento objetivo «empleen» pueda realizarse tanto dolosa como imprudentemente, pero a la vez, desconectarse del delito-fin 
en ambas formas de imputación subjetiva ${ }^{2220}$.

Podría decirse también, entonces, que si no existe tipificación alguna del delito de persuasión coercitiva autónomo, la modalidad de «alteración mental o control de la personalidad» del delito de organización del art. $515.2^{\circ} \mathrm{CP}$ carecería de justificación penal, sería inconstitucional, porque no se puede criminalizar una organización que utiliza medios que no están tipificados como delito para fines lícitos. Lo que nuevamente nos lleva a la conclusión de que esta modalidad está criminalizando autorías mediatas en aparatos organizados, empresariales o de poder, sin embargo, esta conclusión no resuelve la problemática, porque trata a los miembros intermedios como «instrumentos», cuando en verdad existen márgenes (horizontes) de libertad que fundamentan la coautoría y no criminaliza lo injusto de incapacitar la libertad de voluntad.

Parece ser, en contraposición al punto primero del citado artículo, que este delito requiere la «acreditación» del empleo de la violencia o de la persuasión coercitiva. Esta interpretación, más acorde al sentido literal que al teleológico, restringiría profundamente su aplicación en el ámbito de las sectas criminales que utilicen técnicas de persuasión, a pesar de que sea uno de los propósitos de su regulación, pues la acreditación de tales técnicas no viene de la prueba o análisis de un único comportamiento, sea el del autor mediato o inmediato, sino del conjunto de sujetos de la organización. Difícilmente, por no decir imposible, se podría realizar la persuasión coercitiva por un único sujeto sobre otro. Para ello, harían falta otros muchos factores que excepcionaría la organización criminal, y dependería de conductas engañosas y una actitud psíquica frágil de la víctima o autor inmediato, pero no se puede rechazar esta posibilidad.

Una interpretación más acorde al sentido teleológico de su tipificación es entender que al igual que en el punto primero del art. 515 CP basta con la utilización, uso o empleo de estos medios violentos o de persuasión coercitiva para conseguir los fines lícitos, lo que facilita la comisión imprudente (uso conjunto descuidado), y por ende, avala la idea de una comisión imprudente grupal y la responsabilidad organizativa por imprudencia, sin desterrar los casos, aunque escasos de una persuasión coercitiva, adoctrinamiento o formación dolosa, como sucede en el terrorismo yihadista, si bien con la incursión imprudente de algunos sujetos. En este punto, como dijimos, son interesantes algunas sentencias y comentarios de expertos que vinculan las

\footnotetext{
${ }^{2220}$ Sobre esto el FJ $13^{\circ}$ SAP de Barcelona, de 29 junio de 1993 sobre el proceso penal de Niños de Dios comentaba que «(e)n este punto como la limitación penal al derecho de asociación no puede ir más lejos que el texto de la Constitución y los Pactos o Convenios Supranacionales, será obligado asumir ese "perseguir fines», ya que la utilización de medios recogida como supuesto $2^{\circ}$ del artículo 173 no es aquí contemplado como imputación, a que literalmente hace referencia el citado $n^{o} 2$ del artículo 22 de la Constitución, y de ello doctrinalmente se extrae que quedan fuera del tipo los objetivos periféricos, mediales secundarios o circunstanciales, de tal modo que «los delitos» han de constituir la finalidad o meta, o una de ellas relevante, de la organización asociativa, y esto como algo bien diferenciado de puntuales objetivos de sus miembros o asociados».
} 
formas sectarias con las del terrorismo, en concreto con la formas de captación y al impulso motivacional para cometer delitos ${ }^{2221}$.

Nuestra jurisprudencia denuncia a lo largo de las múltiples sentencias la falta de prueba de comisión de delitos por sectas, o la falta de prueba en la finalidad delictiva, pero esto supone un error de bulto, puesto que conforme ya hemos fundamentado no es necesaria la concreción del delito-fin, basta con la peligrosidad de la unión de voluntades, dolosa o por imprudencia consciente al igual que en la coautoría imprudente. En este sentido, el punto $4^{\circ}$ del art. $515 \mathrm{CP}$ que criminaliza las organizaciones que promuevan la discriminación, el odio o la violencia contra personas, grupos o asociaciones por razón de su ideología, religión o creencias es buena muestra de que, efectivamente, no se precisa la concreción del delito-fin, al menos en la referencia al odio, de tal manera que el tipo en cuestión está dedicado a penalizar a aquellas organizaciones que incurren en apología del delito del art. 18 del CP.

La agravante contenida en el art. 570.2 bis CP aumenta las penas en su mitad superior cuando la organización -que en estos casos SANTA RITA denomina «macro organizaciones» ${ }^{2222}$ - esté formada por un elevado grupo de personas, disponga de armas o instrumentos peligrosos o disponga de medios tecnológicos avanzados de comunicación y trasporte. Puede trasladarse al ámbito fenomenológico de las sectas criminales, ya no por el elevado número de sujetos, elemento circunstancial y que no define estrictamente su naturaleza, si bien aumentaría en su caso la peligrosidad, sino el uso de «instrumentos peligrosos», a los que hemos asociado con la utilización de técnicas de persuasión coercitiva, y que en el ámbito terrorista ha permitido $\operatorname{abogar}^{2223}$ por un concepto extensivo en virtud del uso que se haga, y no del instrumento en sí mismo, lo que en semejanza al concepto de violencia tratado en el delito de coacciones y al de instrumentos del art. $148 \mathrm{CP}$, cuando se utilizan sobre un elevado número de víctimas, posibilita que el precepto puede utilizarse para los casos de persuasiones masivas, puesto que si bien este elemento se refiere al componente elevado de miembros de la organización, al tratarse la persuasión coercitiva de un ataque principalmente generalizado sobre los propios miembros y de

${ }^{2221}$ En concreto, el FJ $3^{\text {o }}$ de la Sentencia del TS núm. 739-1995, de 28 junio, dice al respecto de las formas de captación y entrenamiento que usa el terrorismo de ETA que «a la dureza del trato, esta Sala ha percibido una cierta ironía en el sagaz escrito del Excmo. Señor Fiscal, sobre el durísimo trato infligido por los etarras durante su reclutamiento, pero a los que no cabe objeción por la voluntaria aceptación, por el declarante que los relata (...) y que recuerdan, sin querer, algunos viejos ritos de iniciación de algunas tribus primitivas o de nuevas sectas urbanas». También los asimilan RODRÍGUEZ-CARBALLEIRA Álvaro / MARTíN-PEÑA Javier / ALMENDROS Carmen / ESCARTÍN SOLANELLES Jordi / PORRÚA GARCÍA Clara, «Un análisis psicosocial del grupo terrorista como secta», op. cit., pp. 183 a 195.

${ }_{2222}$ SANTA RITA, G., El delito de organización terrorista, op. cit., pp. 201 y ss.

2223 ID., ibidem, op. cit., p. 209. 
una cuestión de peligrosidad e inseguridad cognitiva, es adaptable a la fenomenología de grupos u organizaciones criminales sectarias como casos especialmente paradigmáticos.

Las principales conclusiones a la que podemos llegar son dos. De una parte, después de haber analizado los conceptos de grupo, organización, macro organización y asociación ilícita, la fenomenología de las sectas criminales responde a supuestos de macro organización, al menos por el uso de la persuasión coercitiva, o de organización, en detrimento del de grupo criminal que normativamente escasea en el reparto de tareas y en la estabilidad o indefinidad temporal. De otra, que no existe una clara intención de sancionar exclusivamente los comportamientos estrictamente dolosos, sino que el fundamento de punibilidad basado en la peligrosidad objetiva e inseguridad cognitiva también sostiene una hipotética organización criminal de tipo imprudente o riesgoso, donde la falta de acuerdo, en semejanza a la coautoría imprudente, no es un elemento esencial de atipicidad en la intervención y configuración del injusto.

\section{II.- $\quad$ El injusto sistémico}

La criminalización de las organizaciones se debe al auge masivo en los últimos tiempos de la criminalidad económica y de empresa (delitos societarios entre otros), que se caracterizan por la intervención de varios sujetos, habitualmente especializados, cada uno con una aportación criminal adecuada al fin. Esto es porque precisamente cada sujeto aporta algo para el buen fin criminal, pero que por sí sólo sería inidóneo para tal fin, sin embargo sumadas todas las aportaciones de cada interviniente se alcanza significación y relevancia jurídica, o al menos suponen un peligro. Repárese que esta misma forma de estructurar el fundamento de punibilidad se aprecia en la coautoría dolosa pero también en la imprudente.

LAMPE señaló que los sistemas de injusto son sistemas sociales, construcciones sociales con un fin asocial, cuya suma de individuos y operatividad posibilita la organización mediante la comunicación interna y constante al igual que sucede en otros tipos de sistemas sociales. Se ha caracterizado a esta fenomenología comportamental como «injusto sistémico» o «imputación colectiva» ${ }^{2224}$, precisamente porque cada sujeto aporta algo que por sí sólo sería, ya no sólo inidóneo, sino imposible para el delito, pero que sumados todos alcanzan significación y relevancia jurídica, o al menos un peligro objetivo. Sin embargo esta forma de concebir la organización criminal punible supone un injusto directo de la agrupación, asociación o de la

\footnotetext{
${ }^{2224}$ LAMPE, EJ, «Injusto del sistema y sistemas de injusto», op. cit., pp. 97 y ss; con bibliografía al respeto SÁNCHEZ GARCÍA DE PAZ, I., La criminalidad organizada. Aspectos penales, procesales, administrativos y policiales, Dykinson, 2005, pp. 63 y ss.
} 
entidad, distinta de la imputación de cada miembro por el delito en concreto que persigan, o que hayan comenzado a ejecutar, o consumado, que versará en estos últimos casos de la aportación cuantitativa o cualitativa.

Al respecto, LUHMANN explicaba que la organización supone un modo particular de formar sistemas $^{2225}$. Las organizaciones son sistemas autopoiéticos ${ }^{2226}$ en los que se producen y se reproducen por operaciones propias, de forma que son sistemas históricos no calculables pero a la vez reductores de la complejidad. Estas operaciones están formadas principalmente por decisiones, que ofrecen la peculiaridad de autodiferenciarse de otros sistemas autopoiéticos, de modo que cada decisión produce una operación en la organización que trata de «absorber incertidumbre» que viene del «entorno» (otros sistemas) para transformarla en certidumbre, de aquí que antes de cada decisión existan premisas de decisión ${ }^{2227}$ (en las sectas coercitivas, los dogmas por ejemplo, en relación a la inminente apocalipsis, constituye una premisa de decisión sobre la decisión de suicidios colectivos). En cuanto conceptos autopoiéticos, las organizaciones están clausuradas en sus propias operaciones, y de aquí que sean sistemas autónomos ${ }^{2228}$, lo que trasladado al ámbito penal significaría en toda coherencia que las organizaciones criminales del tipo que fueren constituyen per se sistemas de injusto autónomos, pero como cualquier injusto, depende de comunicaciones con otros subsistemas o sistemas (el Derecho civil, la Política), por eso el injusto autónomo se abre a otras posibilidades tales como su propia evolución, por ejemplo cambio de fines, o aumento de la peligrosidad al incorporar instrumentos peligrosos.

${ }^{2225}$ Dice al respecto que «al aumentar o reducir las contingencias. Este principio se lleva hacia los sistemas organizativos y se formula por medio de cargos de identificación. Cada cargo indica un punto que une programas conductuales contingentes (= condiciones para la corrección de la conducta), y relaciones de comunicación contingentes, en cada caso, con una persona contingente (...) esta identidad, como punto de referencia para hacer conexiones, reduce la arbitrariedad de estas contingencias», LUHMANN, N., Poder, op. cit., p. 140.

${ }^{2226}$ Debemos ahora aclarar más si cabe este concepto que toma LUHMANN de MATURANA y de VARELA. Para estos últimos el concepto de autopoiesis significa la auto-creación circular y espontánea de la operativa de los sistemas vivos que niega la intencionalidad en la constitución o en su operar, y afirma su clausura operacional, cuestión que LUHMANN traslada a los sistemas, MATURANA Humberto / VARELA Francisco, De máquinas y seres vivos. Autopoiesis: la organización de lo vivo, $5^{\mathrm{a}}$ ed., Editorial Universitaria, Chile, 1998, pp. 28 y ss. En concreto comentan de forma gráfica que «(1)a organización del individuo es autopoiética, y en esto estriba toda su importancia (...) La fenomenología individual de los hombres en cuanto componentes estaría subordinada a la autopoiesis de la sociedad», ID., ibidem, op. cit., p. 113. También LUHMANN toma otros conceptos para su construcción de los sistemas de la cibernética de WIENER con el concepto de «retroalimentación» de los sistemas sociales, y el concepto de circularidad y el «principio del orden a partir del ruido» de FOERSTER, WIENER, Norbert, Cibernética y sociedad, trad. José Novo Cerro, $3^{\mathrm{a}}$ ed., Ed. Sudamericana, Buenos Aires, 1988; FOERSTER, Heinz von, Las semillas de la cibernética. Obras escogidas, $1^{\text {a }}$ ed., Marcelo Pakman (Edit.), presentación Carlos Sluzki, Gedisa, Barcelona, 1991; y antes en la «teoría general de los sistemas», BERTALANFFY, Ludwig von, Teoría general de los sistemas. Fundamentos, desarrollo, aplicaciones, trad. Juan Almela, $7^{\mathrm{a}}$ reimp. de la $1^{\text {a }}$ ed. 1976, Fondo de Cultura Económica, México, 1989.

${ }^{2227}$ LuHMANN, N., Organización y decisión, op. cit., pp. 25 y 26; ID., Organización y decisión. Autopoiesis, acción y entendimiento comunicativo, op. cit., pp. 14 y ss.

${ }^{2228}$ LuHMANN, N., Organización y decisión, op. cit., p 74. 
Una propiedad de las organizaciones es que sus decisiones (operaciones) consisten en una sucesión de eventos que guardan una clara relación en la operatividad de la organización que no permite dividirlos sin incurrir en una paradoja ${ }^{222}$, por cuanto lo que antes sucede como operación absorbe la incertidumbre del futuro y lo establece como certidumbre, de manera que «instantes temporales desaparecen por sí mismos, aunque no se haga nada» ${ }^{230}$. En este punto es interesante la analogía de los sistemas, y en concreto del delito sistémico, con el «segundo principio de la termodinámica», por el que los acontecimientos físicos tienden (entropía) hacia la probabilidad del equilibrio a pesar de su estado inicialmente desordenado, o la teoría del «principio del orden a partir del ruido», por la que el desorden de un sistema autodesorganizado se autoorganiza por su aleatoriedad y su selectividad funcional ${ }^{2231}$. Esto significa que la desorganización tiende hacia la probabilidad de la organización. Entonces no será extraño que la desorganización criminal, sea dolosa o imprudente, pueda producir organización o aumento de alternativas criminales, de modo que el concepto de idoneidad delictiva puede ser interpretado bajo este postulado de la tendencia a la probabilidad del equilibrio de la organización, o como en el caso de la organización imprudente, se aumentan las alternativas criminales si bien más imprevisibles que en la dolosa, lo que constituye un claro fundamento de peligrosidad, que en ciertos casos puede ser mayor que en la organización dolosa.

De aquí también que se pueda concluir que el injusto sistémico de la organización criminal constituye un delito permanente mientras exista la organización, al menos peligrosa. El delito (sistémico) se consuma espontáneamente (esto es, por su autopoiesis) y traslada el instante de la consumación hasta el fin de la organización, por eso puede ser imputado el delito mientras exista la organización al tratarse este injusto de la decisión de organización, aun cuando fuere imprudente dicha decisión (la constitución del sistema u organización no siempre es intencional). Con la decisión de pertenencia y con la organización en sí misma se está trayendo al presente un futuro criminal, una peligrosidad que se actualiza en el presente ${ }^{2232}$. Esto mismo sirve también para comprender que una decisión criminal (exteriorizada) constituye ya «algo» injusto.

Tras esta forma de observar las organizaciones, para el subsistema del Derecho penal es indiferente si dichas decisiones son tomadas con toda conciencia y voluntad (dolo), como un

${ }^{2229}$ ID., ibidem, op. cit., pp. 25 y 26.

2230 ID., ibidem, op. cit., p. 186.

${ }^{2231}$ FOERSTER, Hv, «Sobre sistemas autoorganizados y sus ambientes», Las semillas de la cibernética. Obras escogidas, op. cit., pp. 39 y ss.

${ }^{2232}$ A este respecto LUHMANN señaló que «(u)na decisión divide «su» tiempo en pasado y futuro. El pasado está dado en el modus de lo no modificable y el futuro en el modus del no-estar-aún-determinado. Desde ambos horizontes temporales, al momento inactuales, la decisión extiende puntos de apoyo para su propia realización actual», LuHMANN, N., Organización y decisión, op. cit., p. 206. 
riesgo (dolo eventual e imprudencia consciente, autopuesta en peligro) o como creación de un riesgo (peligro, imprudencia). Para el Derecho penal interesa si una operación (comportamiento) puede valorarse e incluirse en el Sistema Social o debe descartarse reparándose el daño producido, o directamente no tenerla en cuenta, esto significa: si ha producido comunicación. De este modo cualquier operación realizada por una organización que pone en peligro la operatividad del Sistema Social, se combate de tal modo que se expulsa del mismo, siendo de este modo ajeno el dolo o la imprudencia: es tratado como un peligro. Dicho esto, parece más comprensible la idea de que el subsistema del Derecho penal no siempre opera con atribuciones de los sistemas psíquicos (pensamientos) de las personas, sino como un sistema amoral que defiende su operatividad.

Así las cosas, las organizaciones no están constituidas por personas, sino por roles (expectativas de comportamiento), por eso el sistema de conciencia de cada sujeto, las implicaciones psíquicas y motivos, no son relevantes en la organización como dinámica comportamental sistémica ${ }^{2233}$. De esta manera se reduce la complejidad, lo que significa que la organización es una forma de facilitación del injusto, o en sí mismo un peligro autónomo. Entonces, se razona un fundamento de ilegalización de la organización dolosa o imprudente, y de otra, la pertenencia como atribución-aportación personal a cada individuo.

Según LUHMANN, la membrecía a una organización -que en nuestra opinión también puede trasladarse sin problema alguno a la criminal- se refiere al cálculo económico de utilidades, la vinculación contractual conforme a la organización o no y a un interés de carrera (en nuestro caso a la carrera criminal en el ámbito penal) ${ }^{2234}$. Con esto, el concepto de membrecía tiene el efecto de comunicar en dos sentidos: hacia el exterior comunica que existe pertenencia o no, y hacia el interior, los requisitos mínimos de la membrecía ${ }^{2235}$, de modo que la organización realiza una tarea de «inclusión» altamente «selectiva» pero a la vez de «exclusión» generalizada, a diferencia de los sistemas que realizan una operación de inclusión generalizada y excepcionalmente de exclusión ${ }^{2236}$ (Derecho penal del enemigo) y de esta forma en las organizaciones, la Sociedad deja fracasar los principios fundamentales de libertad igualdad ${ }^{2237}$.

${ }^{2233}$ LUhMANN, N., Organización y decisión. Autopoiesis, acción y entendimiento comunicativo, op. cit., pp. 49 y 50, y pp. 82 y ss; ID., «Interacción, organización, Sociedad. Aplicaciones de la teoría de sistemas» op. cit., pp. 203 y 203. Le sigue en este sentido, VÁSQUES ShIMAJUKO, S., La imputación de los resultados tardíos, op. cit., pp. 149 y 150.

${ }^{2234}$ Por eso «(e)l rol de miembro, en este sentido, es una formula global de acoplamientos estructurales, cuyas irritaciones son elaboradas - de manera muy distinta, no integrable y continuamente sorprendente- en los sistemas psíquicos y en las organizaciones», LuHMANN, N., Organización y decisión, op. cit., pp. 139 y 140.

${ }_{2235}$ ID., ibidem, op. cit., p. 141.

2236 ID., ibidem, op. cit., p. 450.

${ }^{2237}$ ID., ibidem, op. cit., p. 452. 
Al Derecho penal (del ciudadano), cuando menos, únicamente le interesa la comunicación exterior, al menos en una primera valoración puesto que puede haber membrecías fortuitas, erróneas, imprudentes, si bien, pasado un cierto tiempo, al Derecho penal le es indiferente el motivo de la pertenencia bastando el hecho de que se pertenece a un sistema peligroso, por eso se responsabiliza como autor de pertenencia a organización criminal.

Otro concepto luhmanniano que se puede trasladar específicamente a las organizaciones criminales, y más exactamente a las sectas criminales y/o coercitivas, es el de «cultura organizacional». Hay decisiones decidibles a través de premisas de decisión, y otras indecidibles, de manera que se introduce en la organización una forma cultural en la organización que hace referencia explícita o implícitamente a la historia propia de esa organización ${ }^{2238}$, pero ésta no forma parte del sistema sino que el sistema la toma de fuera para hacer comparaciones con otros sistemas, así sólo mediante la programación la organización alcanza cierta causalidad y diferenciación con otros sistemas. GÓMEZ-JARA estima que puede fundamentarse la responsabilidad de la organización en que «la cultura empresarial tiene una determinada vigencia que puede cuestionar la vigencia del ordenamiento jurídico. Por ello se puede identificar en la cultura empresarial el cuestionamiento de la vigencia de la norma por parte del sistema organizativo empresarial» ${ }^{2239}$. La culpabilidad individual y empresarial es funcionalmente equivalente en tres puntos: la cultura organizativa de la empresa contribuye a la vigencia de la norma y en su reverso la defrauda ${ }^{2240}$; la libertad de autoorganización y la responsabilidad por las consecuencias, análogo al neminem laede ${ }^{2241}$; y la participación de la empresa en el discurso público $^{2242}$. La responsabilidad de las organizaciones (empresariales) no se deriva de la actuación estricto sensu de las personas físicas ni de los órganos que la dirigen, sino de la institucionalización de la autorresponsabilidad organizativa ${ }^{2243}$.

Una organización es una institución ${ }^{2244}$ y de aquí surgen deberes inherentes a la adhesión a tal institución «(p)uesto que comoquiera se desee definir el concepto de poder, para cualquier

\footnotetext{
${ }^{2238}$ ID., ibidem, op. cit., pp. 280 y 285; GÓMEZ-JARA DíEZ, C., «Autoorganización empresarial y autorresponsabilidad empresarial. Hacia una verdadera responsabilidad penal de las personas jurídicas», op. cit., pp. 8 y ss. y pp. 14 y ss.

2239 GÓMEZ-JARA DíEZ, C., «Autoorganización empresarial y autorresponsabilidad empresarial. Hacia una verdadera responsabilidad penal de las personas jurídicas», op. cit., p. 15; ID., La culpabilidad penal de la empresa, Marcial Pons, Madrid-Barcelona, 2005, p. 75.

${ }^{2240}$ GÓMEZ-JARA DíEZ, C., «Autoorganización empresarial y autorresponsabilidad empresarial. Hacia una verdadera responsabilidad penal de las personas jurídicas», op. cit., pp. 17 y 18.

${ }^{2241}$ ID., ibidem, op. cit., pp. 18 y 19.

${ }^{2242}$ ID., ibidem, op. cit., pp. 19 y 20.

${ }^{2243}$ ID., ibidem, op. cit., pp. 24 a 26; ID., La culpabilidad penal de la empresa, op. cit., pp. 91 y ss; SANTA RITA, G., El delito de organización terrorista, op. cit., pp. 386 y ss.

${ }^{2244}$ LuhmanN, N., Organización y decisión, op. cit., p. 255.
} 
conocedor del ambiente interno de una organización (...), es claro que el perfil de poder de una organización no coincide con la súper- y subordinación formal de los puestos» ${ }^{2245}$; «(e)n las organizaciones, el poder es más bien una forma simplificada de observación del futuro, de fijación de inseguridad» ${ }^{2246}$. Esto simplifica el problema de que una organización criminal es una coautoría de mayor calado cuantitativo y cualitativo. Cuantitativo respecto a las aportaciones al menos peligrosas, cualitativo respecto a la probabilidad del riesgo para el Sistema, o en sí ya una operación que atenta contra el Sistema social.

De esta forma de observar la organización como una institución, podemos distinguir tres tipos de injustos:

Primero, el que criminaliza la misma organización con el art. $515 \mathrm{CP}$, de manera que el fin que se persigue es neutralizar la organización mediante la declaración de ilicitud por su peligrosidad para el Sistema Social, este sería el sistema de injusto propiamente o constitutivo, a diferencia de la coautoría que sería un sistema de injusto simple.

Segundo, puesto que la organización está compuesta de personas (también instrumentos peligrosos como las armas: decomiso), se atribuye responsabilidad personalmente a la aportación individual pero tomando como base el injusto sistémico propiamente dicho, de forma que la aportación individual de cada sujeto criminalmente atribuible puede inclusive ser imprudente pero en relación al tipo de organización altamente peligrosa, lo que significa que dicha aportación es el sistema en sí mismo pero observado en la dirección a la persona concreta, y de aquí que el pensamiento (sistema psíquico: dolo, imprudencia) sea en ocasiones indiferente cuando, como organización, comunica peligrosidad para el sistema social.

Por ello me parecen correctas las palabras de LUHMANN sobre la comunicación de decisiones en una organización y su relevancia en el sistema social ${ }^{2247}$. La organización tiene un saber propio y ajeno al saber de cada individuo ${ }^{2248}$ cuando de dicho saber se determina la absorción de incertidumbre como certidumbre, o sea, peligrosidad objetiva, lo cual es bastante para atribuir

${ }^{2245}$ ID., ibidem, op. cit., p. 239.

2246 ID., ibidem, op. cit., p. 141.

${ }^{2247}$ En concreto: «Si se entienden las decisiones en un sentido psíquico, esto es si se centra en que alguien, en la elección de su comportamiento, se hace consciente de que habría sido posible también otro comportamiento, entonces se trata de un fenómeno cotidiano que reside en el espacio de atención psíquicamente disponible y que varía con éste. Es también del todo normal que a nivel social sea visible, que alguien se ha decidido por un determinado comportamiento, aunque el aludido inicialmente no haya tomado consciencia que le ha acontecido una decisión y se venga a dar cuenta del hecho solamente por su resonancia social», ID., ibidem, op. cit., p. 91 y añade que «(l)os planteamiento teóricos relativos a la cultura y a la institución rechazan aún más decididamente el recurso a lo psíquico. No es posible descubrir lo que constituye la unidad de una acción, ni el modo en el cual la identidad de un actor puede ser determinada con la ayuda de procesos de atribución de acciones, escarbando en la vida psíquica interior de aquél. Identificaciones de este tipo -se sostiene- serían factibles de consenso sólo sobre la base de datos culturales y únicamente gracias a su institucionalización», ID., ibidem, op. cit., p. 114.

${ }^{2248}$ ID., ibidem, op. cit., p. 222. 
responsabilidad a la organización ${ }^{2249}$, si bien habrá que interrogar a cada individuo para atribuirle responsabilidad en los delitos-fin. De aquí viene que una organización criminal pueda considerarse como tal aquella que pone en peligro el Sistema aunque las aportaciones de los sujetos sean imprudentes o fortuitas.

Tercero, la responsabilidad por la preparación, ejecución o consumación del delito-fin.

Las organizaciones modernas, más si cabe las criminales, si bien poseen relaciones de dominio, jerarquías, no pueden tratarse como una operación especial ${ }^{2250}$ de la organización, sino como una estructura que no condiciona la mayor o menor peligrosidad para el Sistema. Esto se ve claramente en aquellas organizaciones sectarias criminales que han perdido al líder y/o cuando han aumentado de tal manera sus miembros que se hace necesario una puesta en común de los ámbitos centrales de la organización ${ }^{2251}$, si bien es cierto que la jerarquía, en cuanto dependencia de ámbitos de decisión -criminal-, interesa al Derecho penal como foco de mayor responsabilidad, pero no fundamenta per se la responsabilidad de la organización ni la pertenencia.

Precisamente la consumación del injusto sistémico es la conjunción de sujetos para un fin delictivo, a pesar de que aún no se haya determinado qué norma penal se pretende defraudar, y como decimos, sin que sea necesario que se haya ejecutado o consumado el resultado delictivo propio de los delitos-fin. Este fundamento, a juicio propio, no descarta, sino fundamenta más si cabe, un injusto de organización criminal de tipo imprudente o estrictamente peligroso, lo cual, desde hace unos años, se empieza a barajar por la doctrina y algún tipo penal parece ya tipificarlo en la ejecución del delito-fin (blanqueo de capitales, contrabando).

Dentro de esta forma de configurar el injusto, podemos señalar, de una parte, la organización delictiva en sí misma (coautoría) como un injusto simple ${ }^{2252}$, que genera en muchos casos un mayor injusto precisamente por la seguridad y garantía de consumación delictiva, gracias a la aportación ad hoc de varios sujetos, y que suele agravarse en ocasiones cuando dicha conjunción de sujetos asegura el resultado o imposibilitan la defensa de la víctima (alevosía); y de otra, la

${ }^{2249}$ ID., ibidem, op. cit., p. 235.

${ }^{2250} \mathrm{Al}$ respecto resulta interesante que «la jerarquización de los conductos comunicacionales es una contribución entre otras: una aportación al desplazamiento de problemas, un aporte a la trasformación de problemas en otros problemas», ID., ibidem, op. cit., p. 373.

${ }^{2251}$ LUHMANN comenta que «(1)a teoría de las operaciones autopoiéticas separadas lleva finalmente a la conclusión, de que pueden continuar existiendo organizaciones sin que un individuo, según su autocomprensión, se beneficie con ello», ID., ibidem, op. cit., p. 114.

${ }^{2252}$ POLAINO-ORTS, M, Derecho penal del enemigo. Fundamentos, op. cit., p. 394; SANTA RitA, G., El delito de organización terrorista, op. cit., p. 380. 
organización criminal como injusto constitutivo ${ }^{2253}$ (banda, asociación o entidad con o sin personalidad jurídica) cuyo fin es el delito, y que ha venido a denominarse delito de «estatus» por cuanto la criminalidad se refiere a la simple pertenencia, al estado, aunque seguiremos la denominación de «injusto sistémico», porque sus características se asemejan a un sistema en el sentido utilizado por LUHMANN con la teoría de los sistemas sociales ${ }^{2254}$. Si bien el delito de «estatus», «pertenencia»o «sistémico» ha sido denunciado por vulnerar el principio ne bis in idem, existen sólidos fundamentos de punibilidad que ha desarrollado la doctrina que se ha ocupado del fenómeno socio-jurídico -ya comentado en anteriores capítulos- del Derecho penal del enemigo.

Sin embargo, nada de esto aporta al fundamento de punibilidad de este tipo de organizaciones, puesto que la suma de miembros no aportada nada distinto a una coautoría con múltiples intervinientes en la que sólo, en algunos casos, se criminalizan los actos preparatorios del delito, la conspiración, provocación o proposición al delito. En el delito de organización -como bien precisa SILVA SÁNCHEZ ${ }^{2255}$ - existe una institución antisocial que se constituye con independencia de los miembros como sistema de injusto o injusto sistémico autónomo, que inclusive -en opinión de LAMPE ${ }^{2256}$ - hace posible el intercambio de sus partes, de sus sujetos, lo que recuerda el argumento de RoXIN ${ }^{2257}$ sobre la «fungibilidad» $\mathrm{O}$ «intercambiabilidad» de los miembros en la autoría mediata de los aparatos organizados de poder.

Así, reunirse de forma idónea para algún día cometer un delito constituye un injusto en sí mismo, un delito de sistema, que tiene su fundamento de punibilidad en la idoneidad para defraudar las expectativas, supone un claro peligro objetivo para la Sociedad y la norma, con capacidad intrínseca de conmover y comunicar una inseguridad cognitiva a la sociedad en la norma. De esta manera, el injusto sistémico se configura en una parte objetiva, la reunión de varias personas, y una subjetiva, el fin aún indeterminado de delinquir: ¿acaso el Derecho penal debe renunciar a intervenir simplemente porque los sujetos aún no han decidido el destino

\footnotetext{
${ }^{2253}$ Polaino-OrTs, M., Derecho penal del enemigo. Fundamentos, op. cit., p. 394; SANTA RitA, G., El delito de organización terrorista, op. cit., p. 381.

${ }^{2254}$ LuhManN, N., Organización y decisión, op. cit; ID., Poder, op. cit., p. 140.

2255 SILVA SÁNCHEZ, J-M" «“"Pertenencia” o “intervención”? Del delito de "pertenencia a una organización criminal" a la figura de la "participación a través de la organización", en el delito», Octavio de Toledo y Ubieto / Gurdiel Sierra / Cortés Bechiarelli (coords.), Estudios en recuerdo del Profesor Ruiz Antón, Tirant lo Blanch, Valencia, 2004, p. 1075; ID., «La "intervención a través de la organización”, ¿una forma moderna de participación en el delito?», CANCIO Meliá Manuel / Silva SÁncheZ Jesús-María, Delitos de organización, B de F, MontevideoBuenos Aires, 2008, pp. 87 y ss.

${ }^{2256}$ LAMPE, EJ, «Injusto del sistema y sistemas de injusto», op. cit., pp. 111; POLAINO-ORTS, M., Derecho penal del enemigo. Fundamentos, op. cit., p. 395; SANTA RITA, G., El delito de organización terrorista, op. cit., pp. 358 y 371.

${ }^{2257}$ RoXIN, C., Autoría y dominio del hecho, op. cit., pp. 269 y ss., y pp. 723 y ss; FERNÁNDEZ IBÁÑEZ, E., La autoría mediata en aparatos, op. cit., pp. 122 y ss.
} 
delictivo de su empresa criminal? Lo que se plantea es si acaso el Derecho penal debe renunciar a intervenir simplemente porque los sujetos no hayan decidido todavía el destino delictivo de su empresa criminal.

Al respecto, POLAINO-ORTS expresa -muy acertadamente- que «sólo la organización criminal constituye el sistema de injusto, y cada miembro de la organización es técnicamente la organización en sí» $^{2258}$. En tal sentido se fundamenta el art. $22 \mathrm{CE}$, que declara ilegales a las asociaciones que persigan fines o utilicen medios tipificados como delitos. Ello, en contra de la opinión de parte de la doctrina, no es una vulneración de la máxima ulpiana cogitationis poenam nemo patitur (el pensamiento no delinque), sino que por el contrario, más allá de la manifestación de querer realizar el delito, ese pensamiento ya se ha manifestado de forma especialmente grave en la reunión de varias personas, conociendo cada una de ellas que es para delinquir, o habiendo debido no irrogar peligros (imprudencia), o cuando existen deberes de salvación o protección.

Con el acuerdo de voluntades se concreta una expresión de sentido criminal. Este acuerdo se refiere al dolo, pero tal y como hemos configurado la fundamentación del injusto sistémico, no existe impedimento en que la agrupación de personas que irroga riesgos contra terceros (obrar conjunto descuidado), contenga un fundamento de punibilidad inclusive más grave en ocasiones que el injusto simple de la coautoría, en este caso de la coautoría imprudente.

POLAINO-ORTS argumenta que en el injusto sistémico se cumple un elemento objetivo, la agrupación de personas, que en sí misma es neutral, la asociación o la reunión es un acto constitucionalmente protegido, por lo que se precisa de un elemento subjetivo, que más allá del simple pensamiento y sin constituir -dicho elemento subjetivo- una determinación del delito-fin, aclare el sentido comunicativo de la organización como foco real de peligro ${ }^{2259}$. En sentido similar, pero agudizando la solución, SANTA RITA explica que tanto el elemento objetivo (la agrupación/acuerdo) como el subjetivo (fin de cometer delitos) son en sí mismos neutrales, pero que ambos unidos conforman una empresa criminal desestabilizadora del Estado ${ }^{2260}$. A este respecto, acertadamente también alude a la teoría de la identificación social de los miembros con la organización, de modo que la temporalidad supone un factor de refuerzo de la identificación y «(e)n este sentido se asemejan mucho a las sectas donde es relativamente sencillo entrar y muy

\footnotetext{
${ }^{2258}$ POLAINO-ORTS, M., «La imputación objetiva: esencia y significado», op. cit., p. 71. Cursiva en el original.

2259 Polaino-OrTs, M., Derecho penal del enemigo. Fundamentos, op. cit., pp. 400 y 415; SANTA RITA, G., El delito de organización terrorista, op. cit., p. 351 y pp. 581 y ss.

2260 SANTA RITA, G., El delito de organización terrorista, op. cit., pp. 352 y ss. POLAINO-ORTS, M., «Prólogo» a SANTA RITA, G., El delito de organización terrorista, op. cit., p. 25.
} 
difícil salir» ${ }^{2261}$. Bajo estos postulados concluye que no existe impedimento en admitir la tentativa de delito de organización dogmática e hipotéticamente, pero al ser un delito ya anticipativo, la tentativa pierde sentido porque, en su opinión, no se genera inseguridad cognitiva o mínimo de peligrosidad típica ${ }^{2262}$, por eso apela a la «máxima precaución para no vulnerar el principio de legalidad» en casos tales como la conspiración, proposición y provocación para crear una organización criminal porque lleva a un retroceso excesivo de los actos preparatorios por falta de peligrosidad real ${ }^{2263}$.

A juicio propio, y en contra del general criterio de que la autoría en la organización criminal precisa de un dolo en la «conformación» ${ }^{2264}$, el fundamento de punibilidad reside en la especial potencialidad de lesión de la norma, lo que nos hace concluir que la conjunción de personas que actúan u omiten imprudentemente, si crea la misma potencialidad objetiva de lesión (inseguridad cognitiva), también fundamentaría la punibilidad, aunque en imprudencia o comunidad del riesgo contra terceros, sin que se desvirtúe el fundamento, sino que adquiere todo el sentido de punibilidad de la organización.

$\mathrm{Al}$ respecto, SILVA SÁNCHEZ ha expuesto que esta fórmula del injusto sistémico imputado a las personas representa un «modelo de transferencia» de la responsabilidad, por la adhesión o pertenencia simple al grupo, pero sin que se considere relevante, en este estado, las aportaciones que cada sujeto realice en el delito-fin, puesto que su aportación se sumará en su propio injusto. Mientras que POLAINO-ORTS considera -más acertadamente-que no debe conjugarse el delito sistémico y el delito-fin, puesto que el segundo aún no ha podido producirse: «en una dinámica en la que cada sujeto se halla totalmente sometido al poder constitutivo de la organización, o en otros términos: lo que aporta cada sujeto es per se algo naturalístico, es el entorno; sólo la organización criminal constituye el sistema de injusto, y -en este sentido- cada miembro de la organización es técnicamente la organización en sí» ${ }^{2265}$, y esto porque el injusto sistémico no depende de la peligrosidad del aporte individual de cada sujeto en el delito-fin. Piénsese que la reunión para cometer un delito, antes de decidir cuál se realizará, supone ya una defraudación de la vigencia de la norma, inadmisible en cualquier Estado de Derecho.

${ }^{2261}$ SANTA RITA, G., El delito de organización terrorista, op. cit., pp. 371 y 372, alude a MARCH JG / SIMON HA., Teoría de la organización, op. cit., p. 80.

2262 SANTA RITA, G., El delito de organización terrorista, op. cit., p. 666.

2263 ID., ibidem, op. cit., pp. 650 y ss.

2264 ID., ibidem, op. cit., p. 581.

2265 POLAINO-ORTS, M., «La imputación objetiva: esencia y significado», op. cit., p. 71. Cursiva en el original. SANTA RITA, G., El delito de organización terrorista, op. cit., pp. 590 y ss. 
De este modo, mediante la organización criminal se inhiben los factores de sentimiento de responsabilidad criminal ${ }^{2266}$, y se consigue una nueva forma de autoritarismo y/o peligrosidad objetiva para el Sistema social y normativo. En esta conjunción de sujetos para un fin delictivo no se precisa que se pongan de acuerdo sobre qué delito van a cometer, puesto que la mera conjunción de voluntades sobre la perpetración de fines delictivos supone la peligrosidad objetiva de un inconcreto delito (delito-fin), o con otras palabras, un acto con suficiente relevancia y peligrosidad que ha de ser reprimido penalmente ya en ese momento. Así, reunirse de forma idónea para algún día cometer un delito es un delito en sí mismo, es decir, un injusto sistémico que tiene -en nuestra opinión- su fundamento de punibilidad en la idoneidad para defraudar las expectativas, la norma.

El injusto sistémico es independiente, o sea, autónomo del delito-fin que pretenda ejecutar la organización. La misma organización viene criminalizada sin necesidad de esperar a la ejecución del delito-fin, o lo que es lo mismo, la organización supone un sistema de injusto que atenta contra la seguridad general y la paz social, y por ende, un sistema antijurídico que precisa de respuesta penal contra ese sistema y las operaciones (sujetos) que intervienen. De aquí que al Sistema le sea indiferente, en ocasiones, el sistema psíquico, el dolo o la imprudencia, sólo la peligrosidad objetiva de su operatividad le interesa, de manera que puede atribuir responsabilidad ya no sólo en caso de operaciones (conductas) dolosas, sino también cuando resultan de una imprudencia grave (desatención del deber de cuidado del que se es competente), o en casos de comisión por omisión por infracción de los deberes en la organización, o en la institucional como es el caso de la confianza que genera garantía de los miembros de las sectas coercitivas.

La crítica a este tipo de configuración del injusto llama la atención en que quien se organiza para cometer delitos sea doblemente penado, de una parte por organizarse, de otra por ejecutar o consumar el delito. Esta crítica puede parecer correcta, máxime cuando en la autoría mediata no se criminaliza, en principio, la causación del comportamiento instrumental, pero según nuestras conclusiones, no habrá impedimento en criminalizar ambas conductas. Por un lado, por el delito de organización por su especial peligrosidad y el delito-fin al menos iniciado y, de otro lado, la creación de la instrumentalización, y también el delito-fin, cuando puedan desconectarse ambas conductas (la creación de la instrumentalización y el delito-fin), o sea, cuando sea aprovechado

\footnotetext{
${ }^{2266}$ Polaino-OrTs, M., Derecho penal del enemigo. Fundamentos, op. cit., p. 394.
} 
por un tercero, o cuando quien la crea cambia su título de imputación, o aun cuando no se desconecten, la instrumentalización adquiera tal gravedad de forma autónoma ${ }^{2267}$.

No son pocos los casos en los que a los Tribunales exclusivamente llevan estas dobles imputaciones de delito de organización y delito fin, cuestión que es inviable en nuestro Código penal en casos de coautoría. No se criminaliza la coautoría por un lado, y por otro el delito cometido en coautoría, aunque si bien este acuerdo de voluntades puede servir para alzar al máximo la individualización y determinación de la pena a cada interviniente. SILVA SÁNCHEZ aboga por un fundamento de injusto anticipado que trata a la organización como un inicio de ejecución del delito-fin que persigue, o con otras palabras, el Derecho penal sólo puede intervenir cuando se comienza a ejecutar el delito-fin ${ }^{2268}$ y se comienza a realizar un hecho injusto (principio del hecho), con lo que el fundamento de imputación a cada interviniente deviene de su propia actuación a dicha organización, no por la simple pertenencia, con lo que, según este autor, se consigue una fundamentación sistemática-dogmática de estos delitos adecuada a la imputación de la participación ${ }^{2269}$. De esta manera -en nuestra opinión- apela a una análoga fundamentación de la anticipación de la barrera punitiva como actos de proposición, conspiración y provocación en los actos preparatorios de la coautoría.

En contra de este criterio se ha manifestado POLAINO-ORTs ${ }^{2270}$. Arguye -con lo que estamos de acuerdo- que el delito de organización supone un delito de injusto sistémico autónomo y diferenciada del delito-fin, diferente a la suma de los sujetos que la integran, según hemos explicado supra, sin negar por ello la evidente anticipación punitiva de estos $\operatorname{actos}^{2271}$ pero en relación a un injusto más abstracto: «la lesión del bien jurídico empieza en este caso antes (no cuando se lesiona el bien individual, sino cuando se lesiona el bien jurídico colectivo de seguridad») ${ }^{2272}$. Para fundamentar este argumento, POLAINO-ORTS se basa en el Derecho comparado, en Códigos penales como el colombiano que criminalizan el concierto para delinquir cuando los delitos que se pretenden perpetrar son de gran entidad. En este sentido, reconoce que

\footnotetext{
${ }^{2267}$ Comenta la STS, de 7 de mayo de 1997 que «(s)e insinúa una supuesta infracción del principio «ne bis in idem», por haber sido condenado ya el recurrente como autor del delito de colaboración (...) Dicha infracción no cabe estimarla concurrente en el caso actual pues, como señala la Sentencia de esta Sala de 24 de enero 1983, entre otras, es plenamente compatible la sanción como colaboración con banda armada de una conducta continuada de facilitación de informaciones genéricas, desvinculada de hechos delictivos concretos, con la participación como cómplice (...) en un acto delictivo determinado».

${ }_{2268}$ SILVA SÁNCHEZ, J-M" « « “Pertenencia” o “intervención”?», op. cit., pp. 1076 y 1077.

2269 SILVA SÁNCHEZ, J-M" « «"Pertenencia” o “intervención”?», op. cit., p. 1078.

2270 Polaino-OrTs, M., Derecho penal del enemigo. Fundamentos, op. cit., pp. 405 y ss; SANTA RITA, G., El delito de organización terrorista, op. cit., pp. 590 y ss.

${ }^{2271}$ Polaino-OrTs, M., Derecho penal del enemigo. Fundamentos, op. cit., p. 410; SANTA RiTA, G., El delito de organización terrorista, op. cit., pp. 640 y 641.

${ }_{2272}$ Polaino-OrTs, M., Derecho penal del enemigo. Fundamentos, op. cit., p. 368; SANTA RiTA, G., El delito de organización terrorista, op. cit., pp. 640 y 641.
} 
en estos casos no se podría hablar de injusto sistémico porque este delito dependería del delitofin que se pretendía ejecutar, a modo de acto preparatorio del delito-fin, sin embargo, afirma que este razonamiento es engañoso, porque de igual manera la simple organización supone un ataque a la seguridad cognitiva en la vigencia de la norma, y de manera indirecta la lesión futura del bien jurídico (peligrosidad hipotética), lo que constituye un paradigma del Derecho penal del enemigo, precisamente porque de forma clara se quebranta la seguridad cognitiva en la vigencia de la norma con la simple organización.

No se vulnera, entonces, el principio del hecho, sino que éste se reinterpreta con las necesidades de la Sociedad, «siendo la organización criminal una asociación disfuncional, esto es, un sistema de injusto que desestabiliza la estructura social, todo sujeto que se asocie con los miembros de esa agrupación, convirtiéndose de ese modo en miembro de la misma, se está arrogando una esfera de organización delictiva que excede, con mucho, del mero pensamiento: (...) la conducta objetiva de afiliación a una organización criminal (...) deja de ser neutral, para tener un significado objetivo de organización delictiva (...), los fines delictivos con que se reúnen los sujetos dejan de ser meros pensamientos de cometer delitos futuros, esto es, dejan de ser peligrosidad no ya hipotética sino inclusive prescindible (no exigible), para convertirse en proyecciones actuales de una gestión incorrecta y peligrosa del rol que les incumbe como ciudadanos respetuosos de las normas en su conjunto» ${ }^{2273}$, por lo que el delito sistémico se ve ya consumado en la organización con base a la «desestabilización social, un estado de zozobra que impide a los ciudadanos desarrollar con un mínimo de seguridad su personalidad en Derecho» ${ }^{2274}$, aun sin que exista peligro alguno en la comisión del delito-fin, y es que el ser miembros de la organización, opina este autor, es ya un hecho propio del sujeto ${ }^{2275}$. Así, en contra de la opinión de SILVA SÁnCHEZ, el concepto de asociación ha de ser asimilado al de asociación de hecho. Al respecto, la Sentencia Audiencia Provincial de Barcelona de 29 junio de 1993 sobre el caso de la secta «Niños de Dios» comentaba que «sólo interesará constatar que asociación es equivalente a organización de hecho y concretar lo que por «objeto» haya de entenderse $^{2276}$.

De este modo, POLAINO-ORTs llega a la conclusión de que el delito de organización supone un delito por la institución de una dinámica criminal, que tiene una expresión de sentido

\footnotetext{
2273 Polaino-OrTs, M., Derecho penal del enemigo. Fundamentos, op. cit., p. 408; SANTA RitA, G., El delito de organización terrorista, op. cit., pp. 345 y ss.

${ }^{2274}$ Polaino-OrTs, M., Derecho penal del enemigo. Fundamentos, op. cit., p. 409; SANTA RITA, G., El delito de organización terrorista, op. cit., pp. 345 y ss.

${ }_{2275}$ POlaino-OrTs, M., Derecho penal del enemigo. Fundamentos, op. cit., p. 409; SANTA Rita, G., El delito de organización terrorista, op. cit., pp. 590 y ss.

${ }^{2276}$ FJ $13^{\circ}$ SAP de Barcelona, de 29 junio de 1993, sobre el proceso de la secta Niños de Dios.
} 
comunicativamente relevante, idóneo y entonces real para y con el sistema Sociedad (sistema democrático y de Derecho), como habitualmente se comprende de las organizaciones terroristas, al aumentarse las posibilidades reales de perpetrarse el delito-fin pero sin depender de éste ${ }^{2277}$. Así, este autor, al que nos adherimos, se basa en un fundamento de derecho penal funcionalista, en el que la organización supone un sentido comunicativo de un código simbólico del miedo contra los principios del sistema social democrático. Sólo así puede comprenderse que el riesgo que causa la organización suponga un riesgo real, cierto e inminente, que hace necesaria, pero a la vez, fundamenta, la aplicación del Derecho penal del enemigo ${ }^{2278}$.

Mientras SILVA SÁNCHEZ afirma un modelo de imputación por el propio hecho realizado por cada interviniente, en virtud del dominio de organización que cada uno aporta, al estilo de aparatos organizados de poder en el que los sujetos pasivos estarían exentos a pesar de la aceptación de la membrecía por falta de un aporte a la organización ${ }^{2279}$, POLAINO-ORTS defiende un modelo de injusto propiamente sistémico, en el que la imputación individual se sustenta en el fenómeno colectivo de la organización, en el que las aportaciones de cada sujeto, no es que se trasfirieren al delito de organización, sino que son en sí mismas conductas de la organización, cada uno de los miembros no supone un peligro en sí mismo, porque cada uno está sometido al «poder constitutivo de la organización», la aportación es «algo naturalístico, es el entorno; sólo la organización criminal constituye el sistema de injusto» ${ }^{2280}$.

POLAINO-ORTS afirma que el sujeto, sea activo o pasivo, actúe o no actúe, sólo tendrá trascendencia en los delitos-fin. Sin embargo, para la imputación del delito-fin, en caso de aportaciones por terceros externos a la organización, se precisa un aporte relevante fehacientemente probado (información, financiación, reclutamiento, infractora lógica) más allá del moral o ideológico, rigiendo la prohibición de regreso para tales terceros externos en caso de que el aporte fuera conforme a derecho (exigible). En nuestra opinión, esta argumentación no desnaturaliza el propio concepto de injusto sistémico, puesto que si bien la aportación de terceros externos supone una contribución al delito-fin, en el injusto sistémico basta con la aceptación de la membrecía más allá -entiendo- del apoyo meramente moral o ideológico, o sea, con aportaciones que revelen la aceptación de la membrecía en la organización en el más puro sentido de conspiración, aun sin determinar el delito-fin. De aquí que SANTA RITA también haya

\footnotetext{
${ }^{2277}$ Polaino-OrTs, M., Derecho penal del enemigo. Fundamentos, op. cit., pp. 410 a 415; SANTA RITA, G., El delito de organización terrorista, op. cit., p. 583.

2278 Polaino-OrTs, M., Derecho penal del enemigo. Fundamentos, op. cit., p. 415; SANTA RiTA, G., El delito de organización terrorista, op. cit., p. 608.

2279 SILVA SÁNCHEZ, J-Ma, «¿“Pertenencia” o “intervención”?», op. cit., pp. 1082

${ }^{2280}$ Polaino-OrTs, M., Derecho penal del enemigo. Fundamentos, op. cit., pp. 420 y 421; SANTA RITA, G., El delito de organización terrorista, op. cit., pp. 345 y ss. y p. 601.
} 
llegado a afirmar que «el hecho de participar aunque fuera accesoriamente con la banda terrorista, forzosamente, genera una vinculación (...) no son «clubes sociales» a los que se pueda entrar y salir con absoluta libertad» ${ }^{2281}$.

De otra parte, CANCIO MEliá propone que el delito de organización criminalice sólo a aquellas que posean una fortaleza estructural, o al menos la necesidad de rebajar la pena a aquellas que no representen dicha tónica, es decir, parece exigir la idoneidad de organización, no el mero acuerdo de organizarse, puesto que con el modelo criminal actual se están sancionando cualquier agrupación criminal. La criminalización ha de ser excepcional pero a la vez que provenga de un foco de peligro real $^{2282}$. No podríamos estar más de acuerdo con esta argumentación, pues el fundamento de punibilidad, tanto de la tentativa como de cualquier injusto, es la idoneidad del plan criminal comprendido de forma intersubjetiva o intercomunicativa, de tal manera que la conjunción de voluntades, aun con toda la intención criminal, si no representa la potencialidad criminal, y para esto no se precisa aún conocer la representación del plan del delito-fin, no es punible, sin embargo, de aquí viene un problema evidente: sin la representación de un plan del delito-fin ¿cómo puede explicarse la punibilidad de un injusto sistémico? La respuesta parece difícil, tan difícil que incurriría en contradicción, pero creemos que existe una fácil respuesta si atendemos a las dinámicas en otro tipo de imputación subjetiva, en la imprudencia. Aquí, la imputación se debe a la inobservancia del cuidado exigido, en este sentido, sin un fin, por lo que no habrá problema en reconocer que en tanto que el fundamento de criminalidad de los delitos imprudentes está en el incumplimiento de un deber, de igual modo, en la criminalidad organizada, el fundamento estriba en ese incumplimiento, por lo que el fundamento de punibilidad aparece tanto en la comisión dolosa como culposa, y amén de ello, sin necesidad de esperar a la representación del plan en los delitos de organización dolosos, el simple acuerdo de voluntades para delinquir sin la determinación del delito-fin, supone el incumplimiento de un deber genérico, no dañar, que traspasa el simple pensamiento impune con la materialización del acuerdo de voluntades, y en su consecuencia, también se fundamenta en la criminalidad organizada imprudente, con la conjunción, si bien no de voluntades porque no estamos en la comisión dolosa, sí con la conjunción de «conductas» que generan el incumplimiento, todas ellas juntas, y no cada una por sí sola, el deber genérico de no dañar.

${ }^{2281}$ SANTA RiTA, G., El delito de organización terrorista, op. cit., p. 601 y más ampliamente pp. 606 a 619.

2282 CANCIO MEliá, M., «El injusto de los delitos de organización: peligro y significado», CANCIO MELIÁ Manuel / Silva SÁNCHEZ Jesús-María, Delitos de organización, B de F, Montevideo-Buenos Aires, 2008, p. 83; de la misma opinión, Polaino-OrTs, M., Derecho penal del enemigo. Fundamentos, op. cit., p. 425; SANTA RITA, G., El delito de organización terrorista, op. cit., pp. 345 y ss. 
No resultará extraño concluir que entre una organización criminal, como delito sistémico, y los denominados aparatos organizados de poder, no exista ninguna diferencia cualitativa, sino simplemente cuantitativa ${ }^{2283}$. Poder de fungibilidad en los miembros y en las dinámicas estructurales y organizativas existe, tanto en los primeros como en los segundos, o dicho de otro modo, si seguimos los postulaos de RoXIN sobre la irresponsabilidad penal de los mandos intermedios, nos veríamos abocados a concluir en el absurdo de la irresponsabilidad de las organizaciones criminales, incluso tratar el injusto sistémico como forma de preparación del delito-fin en una única autoría o simple coautoría.

ARENDT tenía razón: «(t)odo depende del poder que haya tras la violencia ${ }^{2284}$. Y es que la responsabilidad en la participación del delito sistémico proviene de actos expresos de poder y sumisión $^{2285}$. Por eso podemos también concluir, tal y como dijimos, que se puede producir la concurrencia de los delitos de organización criminal, persuasión coercitiva y adicción comportamental o lesión psíquica, pues nuestros postulados previos nos llevan a que los tres se consuman progresivamente: el momento consumativo de cada uno es distinto. Primero se consuma la organización, después la persuasión coercitiva y por último, y en su caso, la lesión psicológica. Esta conclusión no es incompatible con aquella a la que expresamente nos hemos adherido (LAMPE, POLAINO-ORTS y SANTA RITA), en relación a que el injusto sistémico, y por ende la responsabilidad de cada sujeto no depende del inicio de la ejecución del delito-fin, o en su caso, visto como un acto preparatorio, sino que la conducta de cada sujeto es en sí misma una conducta de la organización, cada uno de los miembros no supone un peligro en sí mismo, pero con las demás conductas se genera el injusto potencialmente peligroso que fundamenta la punibilidad tanto dolosa como por imprudencia grave al igual que el injusto simple de la coautoría imprudente. Lo que sucede en la organización criminal imprudente es que esta misma dinámica criminal supone el inicio de ejecución del delito de persuasión coercitiva (tentativa), y

\footnotetext{
${ }^{2283}$ ARENDT, H., Sobre la violencia, op. cit., p. 62 y 63 concluye acertadamente que la violencia se distingue por su carácter instrumental de modo que está fenomenológicamente próxima a la «potencia» puesto que los instrumentos de la violencia, como cualquier otra herramienta (¡póngase aquí un miembro de la organización $i$ ), se conciben y se emplean para «multiplicar» la potencia natural, hasta que en su última fase de desarrollo pueda sustituirse.

${ }^{2284}$ ID., ibidem, op. cit., p. 66.

2285 ARENDT comentaba siguiendo a FANON que «(e)n realidad, en todas las empresas ilegales, delictivas o políticas, el grupo, por su propia seguridad, exigirá "que cada individuo realice una acción irrevocable" con la que rompa su unión con la sociedad respetable, antes de ser admitido en la comunidad de violencia. Pero una vez que un hombre sea admitido, caerá bajo el intoxicante hechizo de "la práctica de la violencia (que) une a los hombres en un todo, dado que cada individuo constituye un eslabón de violencia en la gran cadena, una parte del gran organismo de la violencia que ha brotado"», ID., ibidem, op. cit., p. 88 (FANON, Frantz, The Wretched of the Earth, Grove Press edition, 1968, pp. 85 y 93 respectivamente).
} 
en su caso, de la adicción comportamental, pero esto es por la especialidad de la dinámica grupal.

Sin embargo, en casos de organización criminal «estrictamente dolosa», de igual manera, el acuerdo de voluntades aun sin la determinación del delito-fin constituirá el fundamento de punibilidad de la organización criminal, en la que podrá haber igualmente miembros que actúen con su membrecía imprudentemente, si bien, en este caso, habrá que esperar a la determinación de la representación del plan delictivo para hallar el fundamento de punibilidad y la imputación objetiva, aquí referido al delito de persuasión coercitiva o adicción comportamental.

Así, el delito de colaboración o pertenencia a organización criminal, es un tipo de peligro abstracto como dice la Sentencia del Tribunal Supremo de 24 de enero de 1992, no se penaliza la producción de un peligro concreto, sino la conducta que pudiere acarrear un peligro para el bien jurídico que se tutela, lo que fundamenta nuestra conclusión sobre la punibilidad de la organización criminal de tipo imprudente. La criminalización de estas conductas demuestra la preocupación del legislador, y también de la Sociedad, en sancionar las conductas periféricas del terrorismo, como es la colaboración o la apología ${ }^{2286}$, en las que no es necesaria la identidad ideológica o política del sujeto colaborador con el grupo, como dice la STS de 19 de mayo de $2003^{2287}$

Así las cosas, la diferencia entre pertenencia y colaboración, según la jurisprudencia, la podemos encontrar en la STS de 17 de marzo de 1997, en donde se afirma que la pertenencia a una banda armada se circunscribe en una conducta que durante largo tiempo facilita información. Mientras que por colaboración debemos entender, una colaboración no ejecutiva, y que sólo penaliza al sujeto como autor (art. $28 \mathrm{CP}$ ) o cómplice si llegará a ejecutarse el «riesgo» prevenido. De este modo, ese «riesgo» es el eje central que fundamenta la punibilidad de la pertenencia como delito sistémico.

\footnotetext{
${ }^{2286}$ LAMARCA PÉREZ, Carmen, Tratamiento jurídico del terrorismo, Centro de Publicaciones del Ministerio de Justicia, Secretaria General Técnica, Madrid, 1985, p. 197.

${ }^{2287}$ La referida STS comenta que «prescindiendo en todo caso de la coincidencia de fines, pues lo que aquí se sanciona no es la adhesión ideológica ni la prosecución de determinados objetivos políticos o ideológicos, sino poner a disposición de la banda armada determinadas aportaciones, conociendo que los medios y métodos empleados por la organización consisten en hacer uso de la violencia». No consideran punible el apoyo moral, GANZENMÜLlER C / FERnÁNDEZ GARCÍA EM / ESCUDERO JF / FRIGOLA J / VENTOLA F., Delitos contra el orden público, terrorismo, contra el Estado o la comunidad internacional, Bosch, Barcelona, 1998, p. 352.
} 


\section{III.- Fundamentos de imputación objetiva del injusto sistémico: doctrinas sectarias coercitivas, totalitarismo y dinámica comportamental grupal}

Hemos comentado que la mayoría de expertos en sectas y en persuasión coercitiva coinciden en afirmar que este fenómeno se realiza dentro de grupos organizados, jerarquizados, que diseñan una dinámica de conducta grupal propia ${ }^{2288}$. Cabe preguntarse entonces si las doctrinas de las sectas son constitutivas de los impulsos delictivos de sus miembros, y por lo tanto, si pueden sancionarse anticipadamente. Como la mayoría de la doctrina, concretamente BARBA LÓPEZ considera que «los poderes públicos (...) no podrán prejuzgar las creencias o ideologías de tales grupos, sino las acciones llevadas por las mismas, los métodos utilizados en la aplicación de sus creencias, sancionando las que violen cualquier sector de la legalidad vigente» ${ }^{2289}$.

En nuestra opinión, la persecución de la organizaciones criminales asociadas a sectas parece difícil por la falta de pruebas, ya sea por la interferencia de las propias sectas al pagar prontamente indemnizaciones derivadas de la comisión de delitos ${ }^{2290}$ o por la tradicional exigencia de la conjunción de voluntades en relación a la doctrina, estructura y dinámica grupal con finalidad delictiva. En este sentido, la pregunta fundamental es si la conjunción de la doctrina, la estructura y la dinámica grupal genera un peligro objetivo tal que sea merecedora de la sanción penal.

Una de las soluciones planteadas para la persecución de las sectas criminales sería atribuir la carga de la prueba a estas entidades, pero con ello se desvirtuaría el derecho a la presunción de inocencia a modo de prueba diabólica, que nuestra Constitución prohíbe en los procesos penales, aunque algunos consideran que sería una medida de lege ferenda ${ }^{2291}$.

En el proceso penal contra miembros de la secta Niños de Dios, el Tribunal Supremo comentaba la acusación de una dinámica grupal y doctrina religiosa como elementos que favorecían el control mental ${ }^{2292}$. En este caso el Tribunal Supremo no entra a valorar la ilicitud

${ }^{2288}$ BONET ESTEVA, M., «Grupos de manipulación mental», op. cit., p. 157.

2289 BARBA LóPEZ D / GARcía Oliva FJ / GARcíA-PARdo GóMEZ D / MORALES MONTEOLIVA Y / VALENCIA BENÍTEZ F., «La protección jurídica del individuo ante las sectas destructivas», op. cit., pp. 78 y 79.

${ }^{2290}$ FJ 16º SAP de Barcelona, de 29 junio de 1993: «por cuanto apoyándose tal acusación en los delitos descartados de «estafa», «lesiones» y «fundación de establecimiento de enseñanza», como objetivo o finalidad del grupo, al no existir prueba de su comisión o intención plasmada de cometerlos es obvio no cabe apertura a otros ilícitos penales».

2291 BARBa LÓPEZ D / GARcía Oliva FJ / GARcía-PARdo Gómez D / MORALES MONTEOLIVA Y / VALENCIA BENÍTEZ F., «La protección jurídica del individuo ante las sectas destructivas», op. cit., p. 81.

${ }^{2292}$ Concretamente refería que «en un intento loable de construir una realidad fáctica cercana a sus posiciones, selecciona una serie de pasajes de los libros incorporados a la causa, tratando de poner de relieve que en ellos se contienen una serie de directrices dadas por la jerarquía del grupo para la organización y funcionamiento del mismo, resaltando, al mismo tiempo, que dicho material es de exclusivo manejo por sus componentes y sustraído al conocimiento del resto de la sociedad. Los documentos hacen referencia a las reglas de seguridad, a la organización de un sistema cerrado de educación de los menores en el ámbito reducido del grupo y trata de 
de la doctrina sectaria por una cuestión meramente formal, sin embargo pudo haber entrado en la cuestión, al menos para fundamentar una eventual condena por los delitos-fin.

A las mismas conclusiones llegaba la Audiencia Provincial de Madrid en el caso del proceso penal de la Cienciología. La Sentencia comenta que no se extraen de los documentos doctrinales o políticos del grupo religioso ningún indicio o promoción de delitos ${ }^{2293}$. Las normas que integran el denominado «Código del Auditor» (una especie de Código ético) de la Iglesia de la Cienciología, no parecen incitar o promover dentro de la entidad religiosa al delito de coacciones, a pesar que en él se declare «supresivo» a quien se desvincule de la doctrina del fundador, o de las pautas marcadas por la directiva o de la propia auditación que se propone en el Código $^{2294}$.

Estamos de acuerdo con la referida Sentencia en que no es suficiente una simple «hipótesis de futuro», sin embargo, y sin extraer del siguiente argumento una imputación al referido grupo religioso, la Sentencia también comenta que no basta con la «simple tendencia», lo cual nos parece incorrecto en virtud de los postulados del delito sistémico al que hemos llegado anteriormente. En este sentido, la concreción de un ánimo tendencial al delito, a pesar de la falta de determinación estricta, es suficiente para que se cree un peligro objetivo merecedor de la respuesta penal, por cuanto el fundamento de punibilidad del delito de organización no se fundamenta en la aportación concreta de cada miembro, ni de la determinación de un delito-fin, sino de la conjunción de un sentido criminal en el contexto. De aquí que las doctrinas que «animan» al odio, a la lucha contra el ordenamiento, sumado en otras ocasiones a la dinámica

informar a los niños de los peligros y perversiones del sistema establecido. Utilizando otros pasajes de los numerosos documentos invocados, intenta demostrar que uno de los acusados es el líder de la secta y que ejerce un férreo control sobre las finanzas y el comportamiento de los componentes imponiendo reglas de disciplina. No tomaremos en consideración los documentos que hacen referencia a los comportamientos sexuales de los miembros del grupo en cuanto que el Ministerio Fiscal no ha formulado acusación sobre delitos relativos a la prostitución o corrupción de menores (...) tergiversaríamos el sentido y finalidad del recurso de casación si hiciésemos, en este momento, una lectura correctora y reinterpretativa del contenido de los documentos trasmutando su mensaje original por otro distinto sin haber escuchado de manera directa e inmediata las versiones y explicaciones vertidas por los acusados y por todos los demás que intervienen en las sesiones del juicio oral», FJ $1^{\circ}$ STS, de 30 de octubre de 1994 sobre el proceso penal de la secta Niños de Dios.

${ }^{2293}$ En concreto dice que «debe seguir rechazándose que tal carta política pueda servir de sustento al delito de asociación ilícita. En el peor de los casos, constituiría una invitación genérica a llevar la defensa de la organización hasta unos hipotéticos ilícitos contra la libertad. Pero ello es insuficiente, por cuanto el ilícito a cometer no puede ser indeterminado. Es exigible su individualización, dado que el art. 10 CP (...) se refiere a una acción u omisión, por tanto no basta con una simple tendencia o hipótesis de futuro», FJ $3^{\circ}$ STS 739-1995, de 28 junio.

${ }^{2294}$ Dice la Sentencia que «de su contenido sólo puede concluirse que se trata de un riguroso código de conducta, que pretende fundamentalmente proteger a la organización, y en el que, por supuesto, las conductas más perseguidas son las que atentan contra ella, constituyendo la sanción más grave la expulsión del individuo, de lo cual se da publicidad entre los cienciólogos, con la finalidad de que el expulsado no los dañe o contamine, actuación que se identifica con la “declaración de supresivo”», FJ 3º de la STS 739-1995, de 28 junio. 
grupal, fundamentan aquella conclusión de que el delito de organización supone un delito sistémico per se, sin que se precise la concreción del delito-fin.

En tanto así, deben analizarse en mayor profundidad las doctrinas religiosas, el ideario o doctrina del grupo y consecuentemente su estructura y dinámica grupal para determinar si el ente asociativo, mediante su doctrina, induce, promueve o favorece la comisión de delitos, aun a pesar de que en la misma doctrina no se especifiquen, pero se pueda concretar el sentido criminal. También habrá que analizar si sumadas todas las disposiciones de la doctrina se genera un riesgo no permitido en Derecho, y en su caso, una tentativa o acto preparatorio del delito-fin. Por ejemplo, nadie negara que la interpretación más radical de la yihad en el Islam o la Guerra Santa en el Cristianismo nada tienen de delictivo, ni mucho menos como delito-fin del Islam o del Cristianismo estricto sensu, sin embargo, si algunos sujetos interpretan estas disposiciones como expresión de lucha contra otros pueblos, en cuanto se elevan a deber moral adquieren un sentido especialmente recalcitrante, se crea un riesgo no permitido en el caso de que varios sujetos se aúnen para elevar esta idea a la categoría de credo, que junto a la desocialización genere un odio que per se, y en una organización, lleva a una actitud de lucha contra el ordenamiento jurídico.

Que varios sujetos se aúnen para fomentar entre ellos el odio, por ejemplo a los judíos, manifestando la necesidad de una genérica eliminación racial, constituye un delito sistémico que supera el delito de provocación al odio del art. 510 CP cuando se expresa como organización criminal del art. $515.4^{\circ} \mathrm{CP}$ (las organizaciones que promueven el odio, hostilidad, discriminación o violencia), sin que sea necesario que se concrete cómo deben desaparecer los judíos, si con un exterminio o con un encarcelamiento masivo, y sin que comiencen a preparar o iniciar un delitofin. Por ello, nadie negará que el odio, ya no individualizado, cuestión que está dentro de los límites del pensamiento no punible salvo manifestaciones concretas, sino la conjunción de cada uno de los odios, cuando adquiera cierta intensidad precisamente por dicha conjunción, se comunique con expresión de sentido criminal. Entonces, no cabe confundir el delito sistémico de la organización criminal, en la que no es necesaria la concreción del delito-fin, con la conspiración, la proposición, o provocación al delito, que constituyen actos preparatorios de un delito-fin.

La Ley Orgánica 5/2010 de reforma del Código penal amplió el concepto de colaboración con banda armada al objeto de cubrir supuestos «captación», adoctrinamiento»o «adiestramiento» del denominado terrorismo, principalmente referido al islámico, modificado por la reciente LO 2/2015, de 30 de marzo, por la que se modifica la LO 10/1995, de 23 de noviembre, del Código 
Penal, en materia de delitos de terrorismo («B.O.E.» 31 marzo), cuyo art. 577.2 dispone: «Las penas previstas en el apartado anterior se impondrán a quienes lleven a cabo cualquier actividad de captación, adoctrinamiento o adiestramiento, que esté dirigida o que, por su contenido, resulte idónea para incitar a incorporarse a una organización o grupo terrorista, o para cometer cualquiera de los delitos comprendidos en este Capítulo». La pena se refiere al art. 577.1 CP, de cinco a diez años y multa de dieciocho a veinticuatro meses.

Dicho párrafo se inspira en la Decisión Marco de la Unión Europea 2002/745 2295; sin embargo, nada dice sobre el concepto de adoctrinamiento y formación, lo que nos obliga a revisar el DRAE, en el que se conceptualiza como «instruir a alguien en el conocimiento o enseñanza de una doctrina, inculcarle determinadas ideas o creencias». Como bien pone de manifiesto JUANES PECES ${ }^{2296}$, habrá que determinar si el adoctrinamiento, en cada caso, sobre la superioridad moral del Islam y a la Guerra Santa lleva a la existencia de un adoctrinamiento punible en la forma de colaboración con el terrorismo, lo que supone delimitar las conductas punibles, del derecho a la libertad de conciencia y de expresión.

Lo cierto es que de la tipificación del adoctrinamiento terrorista se infiere, por un lado, la comprensión de peligro objetivo de estas conductas para la convivencia en paz de la sociedad, y por otro, la semejanza del tipo objetivo con la asociación ilícita que emplea medios de alteración o control mental aun para realizar conductas lícitas, y si bien el adoctrinamiento se considera como una conducta autónoma de colaboración o una forma de participación de delitos-fin de terrorismo, el empleo de estas técnicas a la vez criminaliza la asociación de forma genérica o como delito de injusto sistémico, de lo que deviene en verdad una «desestructuración» del fundamento punitivo, por cuanto en el primero se criminaliza la participación y en el segundo la asociación en la utilización de un delito medial en principio impune, salvo que concluyamos que la alteración o control mental se perseguiría con el delito de coacciones, con la diferencia de que en el delito de asociacionismo ilícito, el empleo de estas técnicas se responsabilizarían a título de autor de coacciones, mientras que el adoctrinamiento como forma de participación en del delitofin de terrorismo. De aquí que podamos concluir que el adoctrinamiento referido a la lucha

${ }^{2295}$ La Decisión Marco de la Unión Europea 2002/745 considera captación la petición a otra persona de que cometa algunos de los delitos de integración o colaboración con grupo terrorista, asesinatos, homicidios, secuestros o toma de rehenes, lesiones, destrucciones masivas que pongan en peligro la vida o la integridad, apoderamiento de aeronaves, buques, liberación de sustancias peligrosas, provocación de incendios, etc. Por adiestramiento entiende la referida Decisión Marco la impartición de instrucciones sobre fabricación o uso de explosivos, sustancias nocivas o peligrosas, armas, a sabiendas de que dicho adiestramiento se utilizara para fines terroristas, lo que suscita la problemática debatida entre imprudencia consciente y dolo eventual.

2296 JUANES PECES, Ángel, «Efectos de la reforma del Código penal en materia de organizaciones criminales y terrorismo», XXXIII Jornadas de la Abogacía General del Estado, El Nuevo Código penal, 18 de noviembre de 2010, Editada por el Ministerio de Justicia, Secretaria General Técnica, pp. 572 a 577. 
contra el ordenamiento jurídico sea un fundamento de punibilidad de una organización, aun sin la concreción de qué parte se pretende quebrantar, y a la vez, que el simple empleo de estas técnicas, aun sin dolo, pueda criminalizarse por imprudencia.

De este modo, la doctrina o la ideología que adquiere cierta intensidad en la dinámica grupal, y expresión ineludible de combate al Sistema, o aumento del riesgo, pueden criminalizarse sin que exista una determinación del delito-fin. De aquí que no haya que esperar que un hipotético grupo o Estado manifieste la clara intención de aniquilar otro grupo o luchar contra el Sistema normativo democrático y de libertades, como sucedió en el nacionalsocialismo, sino que los postulados del injusto sistémico permite la intervención penal cuando se crea tal caldo de cultivo que procura una deficitaria expectativa cognitiva normativizada mediante el aislamiento social en el que incide la conducta que restringe o elimina el horizonte de expectativas orientadas por el Sistema normativo y social, esto es, un peligro objetivo.

\section{IV.- Injusto sistémico imprudente}

Los resultados de la investigación a la que se ha llegado nos ha llevado a la posibilidad de un delito de organización criminal o injusto sistémico imprudente. Esta idea no es descabellada por cuanto nuestro actual Código penal criminaliza diversas formas de organización imprudente, y como dijimos supondría una realidad derivada de la coautoría imprudente en la que en ambas existe un obrar conjunto descuidado. Un fenómeno tipificado en este sentido se observa en la criminalidad de los delitos de blanqueo y en el contrabando imprudente, y de la posible comisión imprudente del delito de fraude a la hacienda pública.

Sobre este último, si bien la doctrina casi unánimemente sólo contempla la actuación dolosa, COLINA RAMÍREZ ${ }^{2297}$ parece no descartar la comisión imprudente de lege ferenda, a pesar de abogar por la incriminación dolosa de lege data. Su conclusión sobre un especial elemento subjetivo de defraudar, o ánimo de lucro, parece dejar la puerta abierta a la incriminación de lege data de la conducta en imprudencia consciente: «se puede establecer que el simple incumplimiento formal aunado al conocimiento de la existencia de la obligación de pagar el tributo correspondiente en relación con el hecho generador, es más que suficiente para imputar el delito de defraudación tributaria», al no exigirse un animus lucrandi ni ningún otro singular elemento subjetivo, «pues si bien se puede argumentar su existencia en base a que tal

${ }^{2297}$ COLINA RAMíRez, Edgar Iván, La defraudación tributaria en el Código penal español. Análisis jurídicodogmático del art. 305 CP, pról. Miguel Polaino-Orts, Bosch, 2010, pp. 213 a 221. Señala que «sin comportar pues restricción alguna para la aplicación de la figura del delito sin la incorporación del ánimo de defraudar o el ánimo de causación de un perjuicio», ID., ibidem, op. cit., p. 218. 
comportamiento siempre conlleva a la obtención de una ventaja al peculio del sujeto, se pueden dar casos en los que el delito de defraudación tributaria, es el medio para encubrir otros delitos o el sujeto sea un delincuente por convicción» ${ }^{2298}$.

Asimismo, Polaino NAVARRETE ${ }^{2299}$ se pronunció hace tiempo en la posibilidad de la comisión culposa en materia de incumplimiento de las condiciones de subvenciones o la utilización de la subvención para otros fines de forma imprudente.

Respecto al blanqueo de capitales, el art. 1.2.d) de la Ley 10/2010 de 28 de abril, de Prevención del Blanqueo de Capitales y de la financiación del terrorismo, supone una norma penal en blanco del delito contra la Hacienda pública de blanqueo de capitales del art. $301 \mathrm{CP}$, en relación con la punibilidad de la organización criminal dedica al blanqueo del art. $302 \mathrm{CP}$, que refiere que «a los efectos de esta Ley se entenderá por bienes procedentes de una actividad delictiva todo tipo de activos cuya adquisición o posesión tenga su origen en un delito, tanto materiales como inmateriales, muebles o inmuebles, tangibles o intangibles, así como los documentos o instrumentos jurídicos con independencia de su forma, incluidas la electrónica o la digital, que acrediten la propiedad de dichos activos o un derecho sobre los mismos, con inclusión de la cuota defraudada en el caso de los delitos contra la Hacienda Pública». De tal suerte, existe la palpable posibilidad de la incriminación culposa, por eso ha sido criticada por la doctrina $^{2300}$.

${ }^{2298}$ ID., ibidem, op. cit., p. 219.

${ }^{2299}$ Polaino NAVARRETE, M., «El delito fiscal. Secuencias fallidas de una reforma penal», Estudios Penitenciarios y Criminológicos, Vol. IX, 1986, Cursos y Congresos núm. 40, Servicios de Publicaciones de la Universidad de Santiago de Compostela, p. 193.

${ }^{2300}$ Sin embargo en palabras de MUÑOZ VILLAREAL la crítica «hace referencia a la inseguridad jurídica que supone la regulación como infracción administrativa de las contravenciones a la Ley 10/2010, puesto que el incumplimiento de las obligaciones por parte de empleados y directivos podría ocasionar que se incurra en un delito de blanqueo, ya que la jurisprudencia admite la forma culposa del delito de blanqueo, al considerar delictivas aquellas conductas consistentes en la omisión del cumplimiento adecuado (correspondiendo la interpretación de lo que se considera adecuado a las autoridades administrativas y judiciales) de las obligaciones legales de prevención del Blanqueo de Capitales que tengan el resultado de favorecer la comisión del delito de blanqueo a terceras personas», de tal forma que en su redacción actual, «puede incurrirse en un delito de Blanqueo de Capitales tanto de forma culposa (consistente en la adquisición, posesión, utilización, conversión, o transmisión de bienes, sabiendo que éstos tienen su origen en una actividad delictiva, cometida por su autor o por cualquiera tercera persona, o la realización de cualquier otro acto para ocultar o encubrir su origen ilícito, o para ayudar a la persona que haya participado en la infracción o infracciones a eludir las consecuencias legales de sus actos) como imprudente (si bien hay dudas dogmáticas y jurisprudenciales al respecto), y en ese caso la pena máxima se reduce de los seis años a dos años, manteniéndose tanto la pena mínima de prisión de seis meses como la multa del tanto al triple del valor de los bienes blanqueados. En su forma imprudente, como indica la doctrina, sólo podrá ser cometido el citado delito por los sujetos obligados por la normativa de prevención del blanqueo y de la financiación del terrorismo a los que se refiere el art. 2 de la Ley 10/2010. Ya que el legislador consideró (ex lege) que el incumplimiento de la Ley 10/2010 supondría una negligencia merecedora de reproche penal cuando, como consecuencia de ella, se permite la entrada en el sistema económico de los fondos ilegales», MUÑoz VILLAREAL, Alberto, «El delito de blanqueo de capitales y los delitos contra la hacienda pública», Revista Jurídica de Castilla y León, núm. 34, septiembre 2014, pp. 5 y 6. 
En el mismo sentido, la LO 6/2011, de 30 de junio, por la que se modifica la LO 12/1995, de 12 de diciembre, de represión del contrabando, ya en su Preámbulo razona la necesidad de criminalizar las conductas imprudentes, y en su art. 2.5 en relación con el apartado 6 y 7 se recoge la comisión por imprudencia grave, que tal y como recoge el Preámbulo se refiere al «modo de realización del delito de contrabando y previendo (...) la responsabilidad penal de las personas jurídicas y de las empresas, organizaciones, grupos, entidades o agrupaciones carentes de personalidad jurídica, en línea con las últimas modificaciones del Código penal».

De otra parte, la reforma del Código penal por la Ley 2/2015, de 30 de marzo, ha incluido el delito de colaboración imprudente con organización terrorista en el art. $577.3 \mathrm{CP}$, lo que amplía la punibilidad de las conductas periféricas. Llama entonces la atención que dicha ampliación no se haya resuelto en las conductas propiamente terroristas, sino en cuanto a la simple colaboración, pues parece lógico que también una organización puede imprudentemente atemorizar a la población y/subvertir el orden, en definitiva, atacar gravemente por imprudencia también grave el Sistema.

Así las cosas, y en conclusión, no parece que exista impedimento legal alguno para conforme al art. $515.2^{\circ} \mathrm{CP}$ se declare ilícita una organización o grupo cuyas conductas, si bien pudieran pretender fines lícitos, realizan la manipulación mental o persuasión coercitiva de forma imprudente y grave, si bien, a pesar de la delimitación entre culpa consciente y dolo eventual, que exigiría la comisión por imprudencia grave del conjunto de sujetos, cuando del adoctrinamiento se presuma que puede llevar a tal restricción del horizonte de expectativas que limite la capacidad de libertad de voluntad.

\section{V.- Breve referencia a procesos penales a grupos religiosos por asociación ilícita}

\section{A. El proceso penal a la Iglesia de la Cienciología}

En el informe de fecha 4 de agosto de 1999 del Ministerio de Justicia del Estado Federado de Baviera, titulado La fabricación del hombre-máquina en el laboratorio de aprendizaje cibernético, su autor, Jünger KELTSCH, resalta la problemática peligrosidad que sustenta este grupo en la región bávara.

En España, sin embargo, la Sentencia de la Audiencia Provincial de Madrid de 18 de noviembre de 2001, sobre el proceso penal de la Cienciología, si bien resume en los hechos probados parte del entramado histórico moral y empresarial del que se vale este grupo, no lo condenó por ninguno de los delitos por los que fue acusado, ni tampoco a sus miembros. La Iglesia de la Cienciología quedó absuelta de los delitos de coacciones, estafa, contra la Hacienda 
Pública, contra la libertad y seguridad en el trabajo, intrusismo, lesiones, amenazas, usurpación de funciones, denuncia falsa, detención ilegal y omisión de impedir determinados delitos, todo ello por falta de concreción de los hechos acusatorios. La conclusión a la que llega la Sentencia es que no existe un mínimo de concreción de los hechos que prueben un mínimo tendencia criminal de los sujetos que integran al determinado grupo, y por tanto un mínimo tendencial del ente empresario-criminal ${ }^{2301}$. En concreto afirma la Sentencia que «no permite identificar con claridad qué hechos sirven de apoyo al ánimo tendencial de algunos de los delitos que el Ministerio Fiscal describe posteriormente en el aludido apartado II de su escrito de acusación, y que, además, hace extensivo a todas las asociaciones de las que formaban parte integrante los acusados en determinados momentos del desarrollo de su vida social» ${ }^{2302}$. El Ministerio Fiscal no llegó a probar, según la Sentencia, los delitos referenciados que serían consecuencia necesaria del principal requisito del tipo de asociación ilícita ${ }^{2303}$. Parece ser que la Audiencia Provincial

${ }^{2301}$ Recuerda la Sentencia que «(d)e acuerdo con la STS 28-10-1997 (RJ 1997, 7843), el concepto de asociación, a los efectos de tal ilícito, supone una pluralidad de personas, a su vez independientes y autónomas respecto de cada uno de los individuos que la constituyen, todos ellos concertados a un fin determinado que inicialmente no tiene porqué ser ilícito. Igualmente la STS 3-5-2001 (RJ 2001, 2943) establece que tal ilícito precisa de la unión de varias personas organizadas para determinados fines, con las siguientes exigencias: a) pluralidad de personas asociadas para llevar a cabo una determinada actividad; b) existencia de organización más o menos compleja en función del tipo de actividad prevista; c) consistencia o permanencia en el sentido de que el acuerdo asociativo ha de ser duradero y no puramente transitorio; d) el fin de la asociación, en el caso del art. 515.1 inciso primero (o art. 173.1, inciso $1^{\circ}$ ), CP/1973, ha de ser la comisión de delitos, lo que supone una cierta determinación de la ilícita actividad, sin llegar a la precisión total de cada acción individual en tiempo y lugar», FJ $3^{\circ}$ SAP Madrid de 28 noviembre de 2001.

${ }^{2302}$ FJ $3^{\circ}$ SAP Madrid de 28 noviembre de 2001.

${ }^{2303}$ En concreto la Sentencia dice al respecto que «la participación de los distintos acusados, quienes, eso sí, aparecen unidos por el lazo común de dar a conocer la doctrina del fundador, L. R. H., y aplicar su tecnología, o sólo esto último -en el caso de los centros destinados a la rehabilitación de toxicómanos (...) es lo que permite concluir que, en principio y respecto de todos los acusados (...), puede apreciarse la concurrencia de los tres primeros requisitos del delito de asociación ilícita, es decir, pluralidad de personas para llevar a cabo una determinada actividad; existencia de una organización; y consistencia o permanencia, en el sentido de que el acuerdo asociativo ha de ser duradero, y no puramente transitorio. Cuestión mucho más compleja es demostrar que el fin de las diferentes asociaciones era la comisión de los delitos que describe el Ministerio Fiscal, cuando menos alguno de ellos, o alternativamente promovieran su comisión una vez constituidas», FJ $3^{\circ}$ SAP Madrid de 28 noviembre de 2001. La Sentencia sigue su razonamiento afirmando que «el delito de asociación ilícita para delinquir no debe confundirse con el delito o delitos cometidos en el desenvolvimiento de un fin social. Todo ello incide de una forma negativa en la sistemática de esta resolución, al vernos obligados a extraer del conjunto bastante inconexo de los hechos del escrito de acusación reflejados en el apartado A), aquellos que pudieran tener reflejo en conductas ilícitas, lo que conlleva una labor de deducción o de inferencia importante, con el peligro de excederse de lo que en puridad es objeto de acusación. Por otra parte, debe ponerse de manifiesto que esa falta de concreción sólo puede complementarse excepcionalmente a través de los hechos que sirven de fundamento a los delitos correspondientes a los apartados B) al G), por cuanto la mayor parte de ellos reflejan hechos punibles, con intervención concreta de algunos de los imputados, pero sin poder hacerlo extensivo a los restantes, lo que difumina la idea de asociación. Buena prueba de ello es que tanto en la calificación provisional como en la definitiva, a la acusada Antonia N. C. se le imputaba exclusivamente el delito de asociación ilícita», FJ $3^{\circ}$ SAP Madrid de 28 noviembre de 2001. El principal imputado en el proceso de la Cienciología, el que fuera Presidente de la misma, se le declarado absuelto por los delitos delito de asociación ilícita de los arts. $173.1^{\circ}$, y alternativamente el $2^{\circ}$, y 174 del C.P. de 1973, de un delito de detención ilegal previsto en el art. $163.1^{\circ}$ del nuevo C.P, de un delito de lesiones del art. 421 en relación con el art. $420.1^{\circ}$ del C.P. de 1973, de un delito de lesiones del art. 421 en relación con el art. 
parte de la premisa, que en nuestra opinión hay que poner en duda, de que la prueba de los demás delitos imputados es consecuencia necesaria de la tipicidad del delito de asociación ilícita del art. $515.1^{\circ} \mathrm{CPv}$.

Según las conclusiones a las que hemos llegado sobre el fundamento de punibilidad del injusto sistémico no haría falta esta concreción del delito-fin, es más, podría imputarse aún con la actuación culposa similar a la coautoría imprudente cuando exista peligrosidad objetiva de que dinámica grupal genera un déficit de garantía cognitiva normativizada al modo de restricción o eliminación del horizonte de expectativas del Sistema normativo y social.

Por otro lado, la Sentencia de la Audiencia Provincial de Madrid de 5 abril de $2002^{2304}$, absolvió al acusado de los delitos de asociación ilícita, detención ilegal, lesiones, salud pública e intrusismo, pero en este caso por haber retirado el Ministerio Fiscal la acusación que inicialmente formuló a la par del anterior proceso de la Cienciología mencionado, haciéndose de tal forma efectivo el controvertido principio de oportunidad de acusación que tiene el Ministerio Fiscal de perseguir o no una causa.

Actualmente, la Cienciología está inscrita en el registro de entidades religiosas, no sin todos los impedimentos legales que la Administración utilizó para denegarla, como vimos, con los mismos derechos que cualquier otra religión declarada en nuestro país. Sin embargo, en opinión de algunos, no es más que una empresa que oferta un tratamiento similar al psicoanálisis sin poseer habilitación legal para ello, y que el tratamiento que oferta causa lesiones psicológicas, cuando no una persuasión coercitiva. Es decir, hay quienes consideran que existe una publicidad engañosa, que no lleva per se a los parámetros del delito de estafa, al faltar en la «víctima» el sentimiento de engaño. Sin embargo, el art. 287 CP, permite la persecución del delito de estafa de oficio, sin necesidad de denuncia previa, cuando afecte a una pluralidad de personas o afecte a intereses generales del Estado.

Se ha afirmado ${ }^{2305}$ que España es el país que marca la diferencia, pues la Cienciología ha sido condenada por estafa en otros países. Cabe recordar que Francia condenó con más de 600.000 euros de multa a la Cienciología por un delito de estafa por la venta del denominado «electrómetro» (E-Meter), del que la Iglesia decía que servía para medir la carga mental ${ }^{2306}$. Sin embargo, no pueden establecerse prejuicios contra este grupo o cualquier otro. La dificultad estriba en la prueba de esa restricción o eliminación del horizonte de expectativas, cuestión que art. $403.2^{\circ}$ del C.P. de 1995, y de un delito de lesiones del art. 420.4 del C.P de 1995.

${ }^{2304}$ SAP de Madrid núm. 123-2002, Sección 4 ${ }^{\text {a }}$, de 5 abril de 2002.

2305 RodríGUEZ, P., «La Justicia ante el fenómeno de las sectas», op. cit., pp. 325 a 383

${ }^{2306}$ Periódico digital El Mundo.es, martes 27 de octubre de 2009. 
escapa de nuestro estudio, si bien, nadie negará que en la constitución del nacionalsocialismo o en algunos grupos fundamentalistas religiosos subyace en toda su organización sistémica, un peligro objetivo para el Sistema que fundamentaba su persecución en tal estadio.

\section{B. El proceso penal a Niños de Dios (Familias Misioneras)}

Otro de los pocos casos en los que se ha acusado a un grupo religioso del delito de asociación ilícita es el proceso a Niños de Dios o Familias Misioneras. La Sentencia de la Audiencia Provincial de Barcelona de 29 junio de 1993 absolvió a los miembros activos de todos los delitos de los que estaban acusados, en concreto, de los delitos de lesiones psicológicas, fundación de centro de enseñanza sin autorización y, principalmente del delito de asociación ilícita, todos estos delitos respecto al Código penal de 1973. La Sentencia razona ${ }^{2307}$ la peligrosidad que supone declarar de ilegal a un grupo religioso por sus creencias calificadas pseudo-religiosas, máxime cuando no se disponen de datos suficientes, de indicios de criminalidad organizada, o por lo menos que los delitos que pudieran cometer sus miembros se vinculan a una voluntad común del grupo. Finalmente el Tribunal Supremo en Sentencia 1669/1994, de 30 de octubre, declaró no haber lugar al mismo, y desestimó finalmente la condena por el delito de asociación ilícita y

\footnotetext{
${ }^{2307}$ Dice la referenciada Sentencia sobre el delito principal de asociación ilícita: $" 1^{\circ}$ ) Es novedoso, en un contexto histórico de crecientes interrelaciones culturales recurrentes, se interese de una Sección Penal de una Audiencia Provincial una declaración de ilicitud de una secta fundada en los Estados Unidos, donde presumiblemente se radicarían sus órganos rectores, con base a que sus objetivos sean cometer estafas, lesionar psicológicamente a los hijos de sus miembros y fundar en el extranjero o en su propio país establecimientos de enseñanza contrarios a las Leyes, así como una condena a su disolución, la disolución de «algo» con estructura supranacional, sin haber intervenido la INTERPOL para fijar aún aproximadamente datos referentes a unos ilícitos asimismo tipificados, quizás salvo el último, en su país de origen y demás por los que se ramifica. $2^{\circ}$ ) Aun limitados a España constando que las Familias Misioneras o Niños de Dios, pues se entiende irrelevante, tienen Centros u Hogares en localidades pertenecientes a diversas Comunidades Autónomas, distintos Tribunales Superiores de Justicia, y atribuyéndose a todos idéntica ideología, objetivos y medios operativos, parece, «ab initio» más idóneo al principio de igualdad una actuación coordinada de la Fiscalía General del Estado, inicial o ulterior al inicio de la fase instructora, sin que esto pueda tomarse como injerencia de tal órgano del Estado pues se hace exclusivamente a los efectos de reafirmar el criterio del Tribunal respecto a la atipicidad de las conductas enjuiciadas en este proceso. $3^{\circ}$ ) La problemática de las «sectas», en sentido amplio pero propio, en el área del Derecho Penal se nos aparece como de «lege ferenda» si lo que se trata es de penar a los grupos en sus peculiares usos y modos de vida, en sus creencias calificadas de pseudo-religiosas, y sobre ello algo ha dicho hace menos de una semana la ONU, más allá de puntuales conductas de sus jefes o simples miembros, sin posible ubicación técnico-jurídica en el actual tipo de asociación ilícita, y parece haber sido el criterio de la misma Fiscalía en el caso de la llamada «Secta Ceis», aun cuando allí no se trataba más que de un grupo ceñido a Cataluña y cuyos objetivos lejanos a cualquier implicación mística, esotérica o bíblica se radicaban en un bajo epicureísmo económico-sexual, pues en este supuesto a pesar de ser evidentes los delitos relativos a la prostitución, como recoge la Sección Décima de esta misma Audiencia y sanciona el Tribunal Supremo, para nada se alude, se invoca el tipo de asociación ilícita», FJ 20 SAP de Barcelona, sección 3ª de 29 junio de 1993. La actividad delictiva, de tipo asociativo, y que fue el objeto de acusación por el Ministerio Fiscal, puede resumirse en la clandestinidad de la organización y su ocultación a la sociedad, una simple asociación secreta que no tiene más que una simple sanción de ilegalidad pero no punitiva. Entonces, el propio Ministerio Fiscal descartó que este grupo se tratase de una asociación de corte paramilitar, fundamentalmente porque fue el propio Ministerio Fiscal quien abandonó este concepto jurídico-penal incriminatorio, zanjándose de tal manera cualquier posibilidad de fundamentarla.
} 
$\operatorname{otros}^{2308}$ porque la simple configuración quasi-paramilitar y el secretismo no son bastante para un reproche penal ${ }^{2309}$, sin embargo, yerra al exigir, para tal reproche penal, una finalidad delictiva concreta, lo cual, según lo expuesto supra no es necesario.

\section{El controvertido caso de la secta CEIS}

Los directivos de la secta CEIS fueron declarados culpables de los delitos de intrusismo profesional y de promoción y explotación de la prostitución. El primero de ellos se acreditó por las diversas declaraciones testificales, y especialmente por la declaración de un funcionario de policía infiltrado en ella. Se acreditó también la utilización de pasquines y anuncios publicitarios de servicios psicológicos que esta entidad esotérica ofrecía, sin posesión de la condición profesional exigida, ni título oficial o académico legalmente reconocido. En relación con los delitos de prostitución, la prueba consistió además de la declaración del policía infiltrado, en el testimonio de una de las personas que fue obligada a ejercerla, declaraciones del ex marido de una de las adeptas y la declaración de un ex adepto. Además se acreditó la existencia de anuncios y reclamos que ofertaban servicios sexuales por miembros de tal organización.

Puede parecer ilógico que no se imputara desde un principio ni se declarara la ilegalidad de este grupo, cuando al menos puede concluirse, indiciariamente, que la unión de tales acusados tenía por objetivo cometer a través del ente asociativo delitos de proxenetismo e intrusismo profesional. En este sentido comentó, coherentemente, sobre este caso la Sentencia del Tribunal Constitucional núm. 240/2005, de 10 de octubre de $2005^{2310}$ (caso Riera Blume, CEIS), en armonía a la SAP de Barcelona de 19 de julio de 1990 (FJ 3º que «(l)a generación por parte de los acusados de una organización con los fines ilícitos indicados se sustenta sobre el propio testimonio de los mismos, sobre las declaraciones ya indicadas de un antiguo miembro de la misma y de un funcionario

${ }^{2308}$ La STS refería que «(l)os datos fácticos que proporciona la sentencia sólo permiten sostener que los acusados formaban un grupo o comunidad y que los métodos pedagógicos eran semejantes a las clásicas escuelas premilitares de corte prusiano. Es evidente y así se deduce de la lectura del texto de la sentencia que dicho grupo no estaba inscrito en ningún registro oficial ni de confesiones religiosas ni de centros de enseñanza», FJ $5^{\circ}$ STS, de 30 octubre de 1994, rec. 3032-1993.

${ }^{2309}$ Afirma la Sentencia que «(l)a redacción del precepto obliga a realizar una interpretación teleológica porque la mera exégesis gramatical del texto nos llevaría a establecer una presunción de que todas las asociaciones clandestinas tienen fines delictivos, lo que no resulta factible en la esfera del Derecho penal. Es lógico que el sistema democrático exija claridad, transparencia y publicidad a las asociaciones y que el secretismo u oscurantismo abra vía franca a la prohibición y desautorización administrativa, pero como señala un sector de la doctrina, "confundir contravención al ordenamiento con el injusto típico, al socaire del desarrollo de un precepto constitucional, significa tanto como desconocer, no sólo el objeto oculto de determinadas asociaciones, sino el fundamento y los límites del ius puniendi en un Estado de Derecho». El reproche penal puede activarse en el caso de que los fines y medios de una sociedad secreta sean en sí mismos delictivos ya que el ocultismo no es inexorablemente indiciario de ilegalidad penal», FJ 5 STS, de 30 octubre de 1994, rec. 3032-1993.

${ }^{2310}$ FJ $8^{\circ}$ de la STC 240/2005, de 10 de octubre de 2005, caso Riera Blume. 
infiltrado, y sobre las declaraciones de múltiples allegados de personas que se integraron en el centro».

\section{VI.- Toma de postura}

Podría decirse que la instrucción de los casos sobre sectas criminales y/o coercitivas yerran desde el inicio cuando pretenden concretar el delito-fin, olvidando que basta una simple comunión de voluntades que pretenda dolosa (también imprudentemente) realizar fines delictivos aun sin haberse concretado. Llama atención que el Tribunal Supremo declarare que los menores que se integraban en este tipo de grupos, apartados de la sociedad, podrían sufrir en el futuro consecuencias disociativas, pero que no podría entenderse como lesión psicológica ${ }^{2311}$. Sin embargo, no resultará irracional pensar que el aislamiento social como forma de vida de algunos grupos pueda resultar perjudicial en el desarrollo psicosocial de los menores, un riesgo no permitido cuando se infiera un perjuicio que no tiene por qué ser estrictamente psicológico, sino que tal y como hemos concluido, bastaría la idoneidad de la creación de déficits de socialización y la restricción del horizonte de expectativas para imputar una tentativa de persuasión coercitiva como delito de coacción según los casos, con lo que resulta esencial analizar la conducta sistémica de cada grupo para poder discernir entre el derecho a acomodar el desarrollo vital al sentimiento religioso y las pautas conductuales que restringen la capacidad de libertad. Esto ha de ser supervisado ya en la inscripción registral al menos.

Precisamente, la falta de estudio sobre la estructura, el comportamiento grupal y las doctrinas morales o filosóficas de algunos grupos hace imposible discernir entre una simple asociación religiosa, una clandestina y una organización criminal. La meritada Sentencia Audiencia Provincial de Barcelona, de 29 junio de 1993, sobre el proceso de judicial al grupo Niños de Dios, resumía ejemplarmente el fundamento de una organización criminal sistémica: «sólo interesará constatar que asociación es equivalente a organización de hecho y concretar lo que por «objeto» haya de entenderse» ${ }^{2312}$.

Los fundamentos del injusto sistémico llevan aquí a que podamos concluir que confluyen varios tipos de organización delictiva son:

a) De una parte, la organización sectaria estrictamente dolosa, en la que varios sujetos se

${ }^{2311}$ Dice la STS, de 30 octubre de 1994, en su FJ $4^{\circ}$ que «eludían enviar a sus hijos en edad escolar a centros de enseñanza oficiales, públicos o privados, optando por enseñarles ellos mismos aplicando las técnicas de lo que en los países anglosajones se conoce como home school, con una organización semejante a la que rige «en colegios religiosos en régimen de internado y a las clásicas escuelas premilitares de corte prusiano. Las clases se complementaban con lecturas bíblicas o textos escogidos de sus publicaciones».

${ }^{2312}$ FJ $13^{\circ}$ SAP de Barcelona, de 29 junio de 1993, sobre el proceso de la secta Niños de Dios. 
agrupan (lo mismo cabe en la coautoría) para cometer delitos-fin contra sujetos-víctimas aun sin concretarse el delito, o mediante la persuasión coercitiva se consigue la creación de déficits de socialización y/o adicciones comportamentales. Después estos déficits, tanto de socialización como comportamental, según los casos, se pueden utilizar por los autores dolosos para otros delitos-fin como «instrumentos» contra otros, o contra los propios miembros, lo que suponen casos de coautoría cuando media una instrumentalización del déficit de socialización con imputación a la propia víctima, o autoría mediata dolosa o autoría mediata dual en casos de adicción comportamental. A este tipo de organización la podemos denominar injusto sistémico propio u organización delictiva propiamente dolosa. Aquí la conducta y el dolo son propiamente sistémicos.

b) De otra parte, pueda criminalizarse como injusto sistémico impropio u organización delictiva impropia. Las conductas de cada miembro de la organización son por sí solas neutras, pero cada sujeto conoce que con la suma de las demás conductas neutras se crea un alto riesgo, cada sujeto conoce la alta probabilidad, aunque no se desee el resultado, pero se acepta como probable. Aquí el dolo es eventual, se refiere al conocimiento y aceptación por cada sujeto de que todas las conductas neutras más la suya propia llevan a un resultado injusto, entonces el dolo es propiamente sistémico, pero no la conducta. Cada sujeto es garante de los demás por «comunidad de riesgo» $\mathrm{o}$ «estrecha relación de lealtad» basadas en la «confianza estrictamente especial», si bien la conducta es neutra en sí misma (apoyar un credo, realizar actos de culto) comunica a los demás la obligatoriedad de una norma conductual que trasgrede el riesgo permitido cuando trasforma los conceptos esenciales del Sistema.

c) En tercer lugar, también se pueden apreciar casos en los que los miembros realizan conductas neutras, y cada sujeto abarca en imprudencia consciente el resultado atendiendo a las conductas neutras de los demás miembros. La suma de todas propicia un aumento del riesgo que si bien no es aceptado por cada sujeto, ni se aprecia altamente probable, precisa la reacción penal por la especial peligrosidad en el resultado. Aquí también cada sujeto es garante de los demás por «comunidad» basada en la «confianza estrictamente especial», y juega un papel importante la consciencia de cada sujeto de que la suma de las demás conductas neutras puede producir el resultado aunque no se acepta su causación, puesto que la inconsciencia sin déficit volitivo grave, o deber, no dejaría de ser un infortunio o una conducta tan escasamente reprochable que ilegitima la intervención penal. Este tipo de injusto sistémico se puede denominar «comunidad riesgosa propiamente».

d) Y, por último, un caso paradigmático, y que en nuestra opinión es el más frecuente en todo 
tipo de organización criminal sectaria, basado en la contingencia de todas las anteriores. En él convergen autores dolosos, autores doloso-eventuales, autores con imprudencia consciente en el resultado y el binomio autores-víctimas. Aquí la fórmula de imputación se asemeja a la tradicional autoría accesoria o, en este caso, coautoría accesoria elevada a organización. Evidentemente aquí la problemática se centra en si una aportación escasa merece el reproche en calidad de autor, que en la doctrina alemana lleva a defender en los delitos imprudentes un concepto unitario de autor.

Por nuestra parte, consideramos que la elevación de participación a autoría se debe a un fundamento funcional o sistémico (deber), en tanto quebrantamiento de la norma y en cuanto se configura una comunidad riesgosa o se interviene en una garantía que crea confianza o confianza que genera garantía. Todo ello sin perjuicio de la responsabilidad final de cada autor por la especialidad de sus circunstancias (déficit de socialización/comunicación atribuido a la norma o a tercero).

La determinación de tal peligrosidad para el resultado depende de la competencia de cada sujeto concreto, con o sin acuerdo común, cuando de la competencia de cada uno está en el hecho de que no se produzca el resultado, y de esto que sea indiferente uno u otro, el dolo, el acuerdo o la imprudencia, salvo infortunio. El deber se refiere a un resultado, de manera que en un mismo hecho pueden intervenir distintos títulos y criterios de imputación. 


\section{CONCLUSIONES}

En el Capítulo I hemos analizado en el primer capítulo las consideraciones filosóficas y científicas de la conciencia, la voluntad y la moral y su incidencia en el sistema social para hallar una primera aproximación de los conceptos con el fin de precisar los presupuestos de la autoría de conciencia, por convicción y del enemigo.

1. El origen de los auténticos conflictos de conciencia entre deber moral y el deber jurídico se encuentra en el momento en que la ley jurídica se desvinculó de la ley divina.

2. En la conciencia se crean alternativas de comportamiento que son elegidas por voluntad con más o menos convicción. Estas alternativas conforman un horizonte de expectativas que supone un principio para la voluntad inmaterial y constituye el primer presupuesto de la libertad de voluntad. Esta libertad se desarrolla posteriormente con la elección de las expectativas que se representa el sujeto en todo el horizonte de posibilidades. Sin embargo, antes de la conciencia y la representación de los horizontes, se precisa una predisposición a la que se puede denominar Voluntad, en virtud de la cual y de su intensidad, restringe, amplía o selecciona el horizonte de expectativas. En la unión de la conciencia y en la voluntad subyace el producto de la libertad.

3. La libertad de conciencia se puede concebir como el propio e ineludible sistema psíquico de pensamientos que conforma la conciencia. La multiplicidad de pensamientos y sentimientos constituyen un sistema autopoiético y autorreferencial cerrado que se abre o se interpenetra por la fuerza del Derecho, la autoridad, la educación, es decir, por otros sistemas. Esta interpenetración es la función del Derecho: orienta normativamente a los sujetos. Los límites a la libertad de conciencia constituyen entonces entradas o influencias de la moral general en el sistema del Derecho, a modo de mínimos éticos, que en ocasiones producen la contraorientación normativa con la libertad de conciencia en grupos minoritarios o conciencias individuales. Sin embargo, cuando se valora se corre el peligro, con el tiempo, de incurrir en contradicciones/paradojas. Esto sucede muchas de las veces cuando se trata el Derecho con influjos de la moral. Para evitar estas paradojas es conveniente partir de la premisa de que los sistemas no trabajan con operaciones propias de la moral, sino con las suyas propias, trasformando las influencias de la moral en sus operaciones. Esto significa que también la moral del individuo o de minorías integra las influencias circunstanciales de la moral general, con lo que respuesta a ciertas conductas con base a la moral general crea la paradoja o contradicción consigo misma. Sin embargo, si tratamos la cuestión como una operación propia de los sistemas, 
en el influjo de la moral general se contiene también el de los grupos minoritarios e individuales, de modo que los sistemas lo trasforman en una operación propia, esto es en su propia comunicación.

4. La objeción de conciencia realizada por minorías, o individualmente, es un derecho general a la formación y elección de conciencia, principalmente expresado en el art. 16 CE, que encuentra limitaciones particulares y funcionales en el comportamiento exteriorizado según la operatividad básica de la Sociedad. La objeción de conciencia admite varios niveles de ejercicio: la formación del horizonte de alternativas y expectativas, el derecho a formar y tener conciencia propia o colectiva, libertad para expresarla, y libertad de práctica o de adecuar la conducta a la conciencia.

5. La libertad de conciencia y su tratamiento penal suponen la reafirmación de la operación psíquica de la conciencia y del sentimiento religioso como expresión material de la voluntad en la conducta. Así hemos concluido que diversas conductas que normalmente se han tratado de autoría de conciencia pueden valorarse como autoría por convicción y viceversa, y esto es porque tradicionalmente se ha tratado esta problemática como un asunto de moralidad del Sistema, no de forma puramente normativa y funcional. Desde esta otra forma de observar se tienen en cuenta la trasformación de la comunicación de cada tipo de autor en la operatividad del sistema. Sólo así se evita incurrir en paradojas.

6. La moral y la conciencia constituyen asuntos riesgosos.

En el Capítulo II nos hemos sumergido en los conceptos y tratamiento penal que la doctrina especializada ha realizado en el pasado y en la actualidad en el autor de conciencia, por convicción y enemigo, y sobre la base de un modelo de pensamiento asociado a la teoría de los sistemas sociales hemos fundamentado diferencias funcionales a nivel conceptual y de tratamiento penal en dichas tipologías criminales.

1. Una visión global del tratamiento científico nos ha permitido averiguar que existe la tendencia a atenuar o eximir de responsabilidad a los autores de conciencia y culpar al máximo al autor por convicción y al enemigo.

2. En el autor de conciencia existe una conexión inevitable entre conciencia y moral del que surge el conflicto entre conciencia y norma, que en casos especialísimos cuando la norma es incapaz de orientar al sujeto debido a una contraorientación normativo fundamenta el déficit de socialización normativo y la aplicación del estado de necesidad exculpante. A dicha conclusión hemos llegado por las siguientes delimitaciones conceptuales y normativas: 
a) El autor de conciencia no ataca el contenido material-objetivo de la norma, ni pretende negar la vigencia de la norma ni la vigencia general del sistema normativo ni social, no disiente del contenido objetivo-material de la norma, sino puntualmente, circunstancial $e$ individualmente, para sí mismo, de la obligación hacia él dirigida en exclusiva por considerar que otro «valor» tiene mayor validez que le obliga a obrar de forma ineludible por la estrecha relación entre conciencia y voluntad, por eso estadísticamente desatiende la norma de forma omisiva. Suele realizar delitos de omisión simple (omisión del deber de socorro, objeción de conciencia), y en otras ocasiones actúa adecuando su comportamiento a la esfera de libertad de un tercero (eutanasia), por eso únicamente quebranta el bien jurídico espiritualizado pero sin que exista impedimento alguno en apreciar comportamientos activos o en comisión por omisión según las circunstancias. Su quebrantamiento es una «expresión espiritualizada» que comunica sólo subjetivamente que la norma no está vigente en ese determinado espacio-tiempo exclusivo en sí mismo.

b) Sobre la base de esta conceptualización la diferencia que existe entre el delincuente habitual y el autor de conciencia es que el primero no pretende instaurar un orden, sino desatender la norma como forma de vida. Conoce que su actuar es injusto y acepta sus consecuencias. Comete el delito dolosa o imprudentemente. El autor de conciencia, a diferencia del delincuente habitual, si bien no niega la virtualidad de la vigencia de la norma, sí antepone una norma configurada en su interior, mientras que el delincuente habitual opta por la desatención de la alternatividad que le otorga la norma, con o sin convicción.

c) En determinadas circunstancias el contenido material de la norma que ordena realizar u omitir alguna conducta se activa dirigiéndose hacia el sujeto debido a especiales circunstancias sorpresivas. Es la norma la que sufre un déficit de comunicación que se produce en la contraorientación con la norma que habilita y orienta al sujeto en el ejercicio del Derecho a la libertad de conciencia. Si bien la norma incumplida está vigente, su contenido material se activa cuando la norma previa -el derecho a la libertad de conciencia- ya ha socializado al sujeto a crearse un horizonte de expectativas en relación a su conciencia determinada para manifestarla y ejercitarla. Esta socialización de la norma produce en casos especiales la inevitabilidad de la conducta. La norma quebrantada es incapaz de socializar y orientar al sujeto. Por eso normalmente el autor de conciencia, no sólo no se siente culpable moralmente, sino tampoco jurídicamente.

d) Esta contraorientación normativa produce una falta de alternativas de comportamiento y en consecuencia una escasa exigibilidad normativa que fundamenta un déficit de comunicación 
que elimina o disminuye la culpabilidad del sujeto. La razón fundamental es que el Sistema, en ocasiones, crea paradojas en su propia operatividad con las que ha de convivir reconociendo sus incorrecciones, de forma tal que las da por propias y renuncia a sancionarlas evitándose así incurrir en otra paradoja.

3. Tanto el autor de conciencia como el autor por convicción y el enemigo realizan comportamientos criminales de forma ineludible por la estrecha conexión entre conciencia y voluntad, por lo que la diferenciación conceptual y de tratamiento penal no puede ser estrictamente moral, ni cuantitativa sino funcionalmente sistémica.

a) El autor por convicción se ha conceptualizado tradicionalmente como aquel sujeto que otorga licitud general al delito. Comunica que ni es vinculante la norma, que no está vigente, ni otorga vigencia a la configuración normativa de la sociedad.

b) El autor por convicción también realiza injustos menores, y pueden aparecer motivos de atenuación y conducta omisivas. La modalidad comisiva es una cuestión meramente estadística. Tampoco existe una diferencia relevante entre ambos tipos de autoría en el tipo de ataque a bienes supraindividuales o personales. Los ataques a bienes personales pueden elevarse interpretarse funcionalmente- a un ataque al Sistema (terrorismo contra los bienes personales) y viceversa.

4. Todo enemigo es un autor por convicción, sin embargo, no todo autor por convicción es un enemigo del Sistema. Esto se explica de la siguiente manera y tiene importantes consecuencias en el tratamiento penal.

a) El enemigo es siempre un autor por convicción (doloso, culposo o peligroso). Su principal característica es que combate el orden sociopolítico y normativo. Quiere ordenar para todos una configuración normativa de la Sociedad adecuada a sus propias ideas, por eso normalmente actúa de forma activa, pero esto es sólo también un dato meramente estadístico que depende de la configuración y circunstancias que se presentan, de la organización del delito y de la competencia del autor al igual que en el autor de conciencia. El enemigo no sufre en puridad ningún «conflicto» de conciencia, sin embargo, su delito se presenta normalmente tan ineludible como en el autor de conciencia.

b) El Derecho penal de enemigo combate focos de peligro. También conductas imprudentes o despreocupadas, los delitos de posesión, contra el tráfico vial, la reincidencia y la habitualidad entrando en el denominado Derecho penal del enemigo. La razón entonces es la peligrosidado amenaza objetiva a la subsistencia y seguridad de las operaciones del Sistema. Las 
organizaciones criminales constituyen casos paradigmáticos del Derecho penal del enemigo y de la autoría por convicción.

c) El autor por convicción no es siempre un enemigo del Sistema. A este tipo le podemos denominar siguiendo a JAKOBS como autor por convicción «blando». A diferencia del enemigo no hace de dicha desautorización un modo de vida criminal, o un ataque continuo y/o organizado contra la norma. Su comportamiento no siempre pone en peligro la operatividad funcional del Sistema como en el enemigo.

d) La fundamental diferencia entre un delincuente habitual y un enemigo es la pura convicción que éste último tiene en que su actuar criminal es lícito y necesario para un fin subjetivamente lícito aplicable a su espacio y tiempo y a toda la Sociedad, mientras que el delincuente habitual no tiene que actuar por motivos morales, políticos o ideológicos, no es su intención derogar ni cuestionar objetivamente la validez de la norma, ni combatirla. Un delincuente habitual puede ser un autor por convicción y a la vez no suponer una peligrosidad objetiva que lo eleve a la categoría de enemigo.

e) La convicción injusta del autor por convicción y del enemigo es la desatención de la alternatividad de otra conducta que la norma propone, a diferencia del autor de conciencia que en casos especiales su conducta se debe a la falta de alternativas de comportamiento conforme a Derecho.

5. La fuerza de la convicción, cuantitativamente hablando, no aporta nada a la distinción entre enemigo, autor por convicción y de conciencia. La distinción es otra: una diferencia cualitativa en el «valor» que el Sistema diferencialmente otorga al motivo del delito y al sentido de la comunicación. Esto supone un criterio funcional sistémico. El Sistema cuenta con la actuación de terceros en la responsabilidad y con los entornos. En la mayoría de ocasiones, la condición de autor por convicción y de enemigo es voluntaria y el déficit de socialización puede ser atribuido exclusivamente a éstos. Pero que una conducta altamente penada es propia del autor por convicción y/o del enemigo y pueda eximirse en función de déficits de socialización, y que otra más levemente penada que es propia del autor de conciencia pueda merecer la máxima culpabilidad, depende de la valoración que se haga en la propia subsistencia y operatividad del Sistema en su diferenciación. Si catalogamos cada tipología con base a la estadística delictiva (gravedad, forma de comisión, motivos, etc.) estaríamos analizando el hecho moralmente.

6. Cabe la posibilidad de que la autoría de conciencia, por convicción y el enemigo también se extienda a determinados casos de delitos imprudentes si entendemos que un conocimiento exigible normativamente o el obrar descuidado de forma consciente o inconsciente puede partir 
de una previa convicción que causa el déficit cognitivo y después el déficit volitivo del delito imprudente. Esta posibilidad se ve más claramente en los delitos de peligro y concretamente en los delitos de tráfico rodado.

7. En la autoría de conciencia se han planteado por la doctrinal-penal y la criminología soluciones de atipicidad, error de prohibición, de inimputabilidad o semi-imputabilidad, de causas de exculpación y de impunidad o falta de merecimiento de una pena.

a) Los casos de conflicto entre bienes personales y disponibles, por ejemplo en el caso de rechazo de un tratamiento médico vital, el motivo de conciencia y la atipicidad son ajemos a dicha situación. La conciencia no determina el tratamiento penal.

b) Hemos concluido que el art. 20.5 $\mathrm{CP}$ recoge dos tipos de eximentes: justificadora $y$ disculpante. El estado de necesidad justificante se refiere a que el valor del «mal» causado no sea mayor que el que se evita, esto es una ponderación objetiva, mientras que en el estado de necesidad disculpante la ponderación es subjetiva. El conflicto entre males iguales pertenece al estado de necesidad disculpante porque la situación es valorada por el sujeto como «ausencia de derecho», al tratarse de males jurídicos. Objetivamente el derecho no da razón alguna para que ante una necesidad extrema la vida del autor valga más que la de otro. En el estado de necesidad exculpante el sujeto está en un estado de naturaleza, trata de proteger su vida aun en perjuicio de otro. El sistema-jurídico penal no puede entrar a valorar dicha conducta por eso ha tenido que amparar un ámbito propio en casos especiales en las causas de exculpación.

c) La razón de exoneración en casos especiales del autor de conciencia es estrictamente normativa y funcional. No hay una razón normativa de ponderación de bienes o estrictamente de males, sino una contraorientación normativa entre la norma que habilita al sujeto a ejercitar su conciencia en una determinada dirección y la norma que es incumplida cuando se activa su vigencia material: contraorientación de la norma con la Sociedad o falta de identidad entre norma y Sociedad.

d) La cuestión relevante es la intensidad de las circunstancias que han producido la socialización amparada por el derecho a la libertad de conciencia y las circunstancias en la que aparece la activación de la norma incumplida en razón de la contraorientación. Habrá que analizar las circunstancias concretas y concomitantes entre las que se desenvuelve esa conexión permitida por la primera norma y la sorpresividad de las circunstancias de la activación normativa material de la segunda norma: la cotidianidad del ejercicio de la libertad de conciencia puesta en relación con la intensidad de comunicación del deber de actuar. 
8. La falta de comunicación sobre la alternatividad de la conducta produce un déficit de comunicación/socialización atribuido a la norma que modifica los requisitos del estado de necesidad exculpante. Esto se debe a que el déficit normativo particular que se produce en el sujeto, relaja o modifica las exigencias normativas del estado de necesidad exculpante.

a) El postulado de la probabilidad de la gravedad se ve relajado o modificado en la autoría de conciencia o por convicción imprudente. El autor, a causa de ese déficit atribuido a la norma $o$ a un tercero, puede llegar a desconocer dicha probabilidad. La situación de necesidad exculpante se puede dar en casos en las que dolosamente se pretende mejorar la posición o el bien jurídico. Estos últimos casos se pueden comprobar, especialmente, en la autoría de conciencia, por convicción y en el enemigo, cuando por un déficit de socialización atribuido a un tercero el autor está obligado a mejorar su posición por orden, mandato o adecuación a la dinámica criminal de la organización, sin embargo en el autor de conciencia que obra con el fin de mejorar su situación, no se le puede comprender un déficit de comunicación/socialización atribuido a la norma porque el límite está en que el sujeto no aproveche dicho déficit para mejorar su situación.

b) El mal puede producirse en un amplio catálogo de bienes. La procedencia del mal puede ser típica o natural pero siempre real, en caso contrario estaríamos ante una causa de exculpación de miedo insuperable u otra circunstancia.

c) La situación de necesidad ha podido ser provocada culpablemente por el autor de conciencia que tiene un déficit de comunicación atribuible a la norma. Tampoco se exige la obligación de sacrificarse. Este déficit produce también conductas dolosa o imprudentemente provocadas.

d) En este déficit normativo la necesidad no se refiere a la «irreparabilidad» del bien o del derecho ni a su «importancia o insustituabilidad, sino exclusivamente a la conexión ineludible entre conciencia y voluntad que la norma ha permitido mediante la socialización.

e) En el elemento subjetivo «para evitar un mal» no existe equiparación entre el estado de necesidad justificante y el exculpante por la conexión irresistible entre conciencia y voluntad y por el déficit normativo o de socialización.

f) Se fundamenta la falta de necesidad de una pena cuando exista un grado suficientemente intenso de déficit normativo y de socialización. La pena no respondería a criterios de socialización porque el autor de conciencia obra a causa de una previa socialización normativa, ya está socializado. En situaciones de déficits plenos de socialización atribuido a un tercero, la pena será incapaz de resocializar al sujeto porque el sujeto es incapaz de comprender el 
significado de la pena, por lo que es más coherente aplicar una medida de seguridad resocializante adecuada a la intensidad y tipo de socialización anterior. Cuando el déficit no sea tan intenso puede aplicarse el estado de necesidad exculpante incompleto en el que una pena no tendría sentido resocializador y coherentemente sí una medida de seguridad proporcional a dicha intensidad.

En el Capítulo III hemos analizado los conflictos particulares de la autoría de conciencia y por convicción asociados normalmente a la autonomía de la voluntad, al deber de solidaridad, a los delitos electorales y contra el Tribunal del Jurado entre otros, al objeto de comprobar si los fundamentos generales a los que hemos llegado anteriormente pueden aplicarse a los casos particulares.

1. Con el reconocimiento de la autonomía de la voluntad se fundamenta la legalidad del rechazo de tratamientos médicos vitales, el derecho a la autopuesta en peligro e incluso el derecho al suicidio, y hemos trasladado las soluciones generales del conflicto de conciencia y los postulados del autor por convicción y del enemigo a los casos particulares de omisión del deber de socorro, al homicidio en comisión por omisión, al delito electoral y al delitro contra el Tribunal del Jurado.

2. Nuestro ordenamiento jurídico incurre en varias paradojas, como criminalizar el «auxilio al suicidio»y atenuar la pena por motivos humanitarios y morales, cuando en otros casos, la descriminalización o atipicidad de otras conductas se fundamentan paradójicamente en las mismas razones (el aborto).

3. Cuando existe una conducta alternativa para cumplir el deber, ya sea porque la norma la recoge, o porque sustancialmente equivale al cumplimiento, el motivo de conciencia es ajeno a la atipicidad de la conducta. La alternatividad de la conducta puede realizarse tanto en los deberes que generan la responsabilidad por organización como en la institucional, si bien cuando la norma no informa sobre cómo realizar una conducta alternativa y existen motivos de conciencia ineludibles subyace el déficit de comunicación/socialización atribuido a la norma que fundamenta el estado de necesidad exculpante completa o incompletamente, según los casos.

4. Se puede intercambiar la acción y la omisión en dichas tipologías, o concurrir a la vez, según las circunstancias del caso, del contexto y de la competencia del rol, hasta el punto que no existe mayor energía en las acciones $u$ omisiones precisamente por dicha intercambiabilidad y dependencia del contexto organizativo y competencial, y, por lo tanto, se puede aplicar el estado de necesidad exculpante en la omisión del deber de socorro del tipo básico, agravado y en la 
comisión por omisión del art. 11 CP que se genera por organización o por infracción de un deber institucional. Consideramos que no existe un deber mayor en los delitos de omisión que en los de comisión puesto que los mandatos de hacer o de prohibición de hacer dependen de la organización de un ámbito. El deber de organización como el institucional pueden concurrir en una misma situación, aparecer uno después de otro cronológicamente o intercambiarse.

5. De aquí que hayamos podido llegar a la conclusión de que no pueden establecerse diferencias normativas en el tratamiento del autor de conciencia por el simple hecho de haber omitido ejecutar un deber. No puede ser fundamento de la autoría de conciencia la mayor exigibilidad del mandato de hacer, ni por ende puede fundamentarse la autoría por convicción y el enemigo en los mandatos de omitir, sino que en todos existe, según las circunstancias, un deber de protección derivado de la organización propia, o un deber institucionalizado en otras ocasiones.

7. La diferencia entonces no es la acción ni la omisión, ni el mayor deber cualitativo de los deberes institucionalizados, sino cómo el Sistema valora las circunstancias del autor y las que hacen que se active uno u otro tipo de deber en la total operatividad del Sistema, y en definitiva si todas ellas pueden integrarse como una operación similar a la propia funcionalidad del Sistema (no sin sanción o exculpación) o ha de excluirlas.

8. En ocasiones especiales la falta de alternativas de comportamiento es atribuida al déficit de comunicación normativa que propicia la intensa socialización particular del Derecho a la libertad de conciencia, lo que fundamenta en esos casos especiales la conceptualización del autor de conciencia y la eximente o atenuante del estado de necesidad exculpante por una escasa exigibilidad en razón de que en la operatividad del Sistema, la valoración del hecho no puede crear la paradoja de contradecirse consigomo misma. Sin embargo en el autor por convicción («blando») y en el enemigo (autor por convicción «duro»), salvo interferencia imputable a tercero, el Sistema ha provisto de alternativas de comportamiento para ejercitar la conciencia del tipo que fuere, por lo que su defraudación se valora negativamente, unas veces sancionando y otras, las más graves, excluyéndola a un subsistema especial de operatividad al que se ha denominado Derecho penal del enemigo.

En el Capítulo IV hemos analizado el caso paradigmático de las sectas criminales -premisa de estudio de esta investigación, si bien para ello ha sido necesario analizar primero lo anterior-, en donde confluyen las tipologías citadas pero en las que en ocasiones aparece la interferencia de terceros en las conductas de éstos. Aquí hemos analizado la problemática teniendo en cuenta la 
posibilidad de la intervención de conductas libres pero también desde el presupuesto de conductas coaccionadas, arrojándose un mundo de posibilidades y tratamientos penales tan amplios que hemos tratado de solucionar con postulados generales.

1. En las sectas criminales se comprenden las tres tipologías criminales (autor de conciencia, por convicción y el enemigo).

2. Hemos clasificado dos conceptos de sectas: sectas criminales y sectas coercitivas. La primera designa grupos criminales que se amparan en cierta forma de religiosidad o cosmovisión para perpetrar algún delito. La segunda se dirige exclusivamente a las sectas que utilizan de algún modo técnicas de persuasión coercitiva. Las técnicas de persuasión coercitiva suponen un tipo fenomenológico de las sectas criminales, pero aparecen en otros tipos de grupos $u$ organizaciones ajenas al ámbito religioso.

3. Hemos desarrollado un modelo de pensamiento sobre las técnicas de persuasión coercitiva sobre la base expuesta en los capítulos precedentes, esto es de forma funcionalmente sistémica cuyo punto central es la restricción o eliminación del horizonte de expectativas. En la restricción al sujeto se le merma la capacidad de voluntad en relación a la formación de un horizonte de expectativas lo que conlleva la merma en la capacidad de decisión/elección. En la eliminación existe la exclusividad de una expectativa, generalmente la del comportamiento del líder y la grupal, que lleva a que se anule la capacidad de la voluntad como en una adicción comportamental o trastorno psíquico. De esta forma se puede explicar que en la restricción del horizonte de expectativas el sujeto sigue teniendo capacidad de voluntad, que a diferencia de eliminación, fundamenta cierta responsabilidad del sujeto lo que plantea problemáticas en los títulos de responsabilidad.

4. Estas conclusiones sirven tanto para la tipología del autor de conciencia, por convicción y el enemigo. En cualquiera de ellos aparecen presupuestos de interferencia imputable a terceros que condicionan o afectan a la libertad de la conducta por mediación de la persuasión coercitiva sin que cambie su conceptualización.

5. Hemos sentado la base de que las técnicas de persuasión pueden realizarse sin intención, lo que abre la posibilidad de la incriminación culposa.

En el Capítulo $V$ examinamos si en nuestro Código penal existen suficientes herramientas contra la fenomenología criminal de las sectas y especialmente contra las técnicas de persuasión analizadas en el capítulo anterior. El resultado arroja que la singularidad de estas técnicas precisa 
de nuevos tipos y una sistematización de los conceptos normativos que especialmente sancionen su utilización.

1. La persuasión coercitiva ataca la libertad de la voluntad en sí misma, e inherentemente la libertad de conciencia. Las técnicas de persuasión coercitiva constituyen una forma de vis compulsiva cuando causan un déficit de socialización, o en los casos más graves de vis absoluta cuando producen una adicción comportamental o trastorno psíquico completo. En otras ocasiones se utiliza un engaño persuasivo que puede asimilarse al coercitivo. Las técnicas de persuasión coercitiva entonces constituyen una violencia o engaño coercitivo semejante al concepto de violencia del delito de coacciones. De este modo la eliminación de alternativas se relaciona con la incapacidad de formación de la voluntad, y la restricción de alternativas se relaciona con la merma de capacidad de voluntad en la formación de un horizonte de expectativas y con la decisión propia. De ambos presupuestos de la conciencia y la voluntad se puede distinguir entre delito de lesiones psicológicas o adicción comportamental realizadas bajo la modalidad de la persuasión coercitiva como eliminación del horizonte de expectativas y en definitiva una forma de vis absoluta y el delito de coacciones bajo esta misma dinámica especial como restricción del horizonte de expectativas que encaja en la forma de vis compulsiva.

2. La especialidad del delito de coacciones agravado recoge con mayor exactitud el tipo de ataque especial que supone la persuasión coercitiva al vulnerar inherentemente la libertad de conciencia, en detrimento de otros delitos como el de proselitismo ilícito, el delito detención ilegal, el delito contra la integridad moral o de torturas a los que absorbe.

3. La similitud del delito de coacciones en la modalidad de persuasión coercitiva con el delito de detención ilegal, tanto en su estructura típica como por las modalidades del ataque, permite la comisión imprudente global del tipo de injusto en razón de culpa consciente en el primer (acción) y segundo momento (resultado) de la conducta típica en cuanto a la acción de impedir, y más dudosa en la acción de compeler, sin embargo, la intercambiabilidad de la acción y omisión desarrollada en el capítulo tercero hace superflua esta distinción. La imprudencia inconsciente y la acción y resultado leve se asemejaría a casos fortuitos, o sin necesidad de prevención criminal, salvo deber de aseguramiento, salvación o ilicitud previa.

4. En el delito de coacciones realizado en la modalidad de persuasión coercitiva, en su dinámica criminal y en unidad de acción, confluyen paradigmáticamente agravantes generales del art. $22 \mathrm{CP}$, al menos en el tipo doloso (alevosía, abuso de superioridad y abuso de confianza) lo que ayuda a fundamentar la necesidad de un tipo específico de persuasión coercitiva. 
5. El delito de persuasión coercitiva es el delito sectario por excelencia de las sectas a las que hemos denominado coercitivas precisamente por dicha propiedad. Sin embargo, el delito sectario unas veces sirve de delito-medio para otros delitos-fin, como los delitos contra la vida, contra el patrimonio, contra la libertad e indemnidad sexual y el delito de intrusismo profesional (también el delito de asociacionismo ilícito y el delito de organización) y en otras únicamente concurren alguno o algunos de los anteriores generando en su caso concursos de delitos o de leyes.

6. La persuasión coercitiva se puede ejercer en autores de conciencia, por convicción y en los enemigos sin que cambie su conceptualización diferenciada. En estas tipologías aparecen también interferencias de imputación atribuible a tercero que repercute en la responsabilidad de estas tipologías.

En el Capítulo VI se han analizados los criterios generales de la imputación objetiva aplicados a la persuasión coercitiva y, particularmente, los casos especiales de déficit de socialización atribuido a tercero y/o a la víctima en la concurrencia de intervención de injustos asociados a las sectas criminales.

1. En cuestión de consentimiento por la víctima de la acción peligrosa o en las consecuencias del riesgo hay que atender a la autorresponsabilidad de la víctima como criterio de imputación objetiva. El vicio del consentimiento se traslada también a una cuestión de autorresponsabilidad y de posibilidades o de horizonte de expectativas: posibilidad de revocación.

2. Un criterio funcional de autorresponsabilidad en las heterolesiones y autopuestas en peligro confirma que la víctima puede ser sujeto activo, y cuando tenga dominio de sí mismo, autor. La tipicidad de la imputación a la propia víctima cuando afecta a bienes de gran relevancia como la integridad física, o a causas de exculpación o de impunidad (falta merecimiento de pena) se refieren a motivos de política criminal si atendemos por ejemplo a que el intento de suicido es antijurídico, al faltar un reconocimiento normativo del derecho al suicidio.

3. El tratamiento de un concepto de autorresponsabilidad de la víctima permite concluir que quien ingresa en un grupo y amolda su conducta libremente a los dictados del líder, a su doctrina y a la dinámica grupal ha de soportar sus consecuencias penales. Sin embargo, la garantía sobre expectativas cognitivas mediante el abuso de una confianza especial que trasforman los conceptos esenciales de la Sociedad (dinero, salud, vida, muerte, etc.), constituye una garantía deficitaria cuando incapacita la libertad de voluntad en el modo de restricción o eliminación del horizonte de expectativas normativas y sociales del Sistema, generando la responsabilidad por 
autoría en los perjuicios que la propia víctima se irrogue o irrogue sobre terceros pero a la vez la aplicación del estado de necesidad exculpante cuando las persuasión coercitiva procura el déficit de socialización esto es, tanto en la categoría conceptual de autor de conciencia como en la autoría por convicción y en el enemigo. Esto se debe a que en las sectas coercitivas la comunicación es defectuosa, cuestión imputable al líder y/o al grupo que envía dicha comunicación al realizar un específico o general ocultamiento relevante para el receptor de la comunicación.

a) En las sectas coercitivas se traslada la confianza en un «medio de comunicación» que puede considerarse «simbólicamente generalizado». La confianza del adepto en el grupo, en la norma sectaria y en el líder se trasforma en la «verdad», constituyendo un mundo diferente: el de la restricción o la eliminación del horizonte de expectativas normativas y sociales comunicadas por el Sistema que fundamenta la incapacidad de libertad de voluntad. Esto es un riesgo no permitido y constituye el fundamento de punibilidad e inicio de la tentativa de persuasión coercitiva.

b) En cualquier tipo de grupo, en los grupos criminales y prototípicamente en los sectarios se puede generar una «comunidad de confianza» análoga a la «comunidad del riesgo». La confianza resulta ser un sistema de aprendizaje/verdad/garantía del grupo. La confianza reside en el sistema.

4. La adicción comportamental y los trastornos mentales como delitos de lesiones pueden ser tratados como resultado tardío del riesgo típico de la persuasión. En el delito de coacciones en su modalidad de persuasión coercitiva su consumación es permanente. El resultado tardío de la adicción comportamental o del trastorno psíquicos dependen de la intensidad de las técnicas de persuasión, de la dinámica comportamental grupal y de la propia capacidad y antecedentes del sujeto. Su imputación depende del límite de vigencia de la prescripción de la tentativa de lesiones.

5. Los déficits de socialización por educación totalitaria y/o criminal y por educación cultural y tradicional atribuidos a tercero son presupuestos de la causa de exculpación de estado de necesidad exculpante, basado en la incapacidad de libertad de voluntad por la restricción o eliminación del horizonte de expectativas normativas y sociales sobre las que el Sistema orienta, y reformula también los requisitos del estado de necesidad exculpante con las mismas consecuencias normativas que el producido en el déficit de comunicación normativo: gravedad, mal, subjetividad y punibilidad se trasforman en virtud de una causa previa que limita la capacidad de voluntad atribuida a tercero, tanto en el autor de conciencia, por convicción o al 
enemigo sin que por ello cambie su conceptualización. Esto significa que puede modular, crear o modificar estas tipologías criminales como en el caso de una propia decisión

6. Hemos resulto que a pesar de una causa de exculpación o de inculpabilidad por adicción comportamental o trastorno psíquico se puede volver a imputar nuevamente al propio autor a través de la actio libera in causa. En la dinámica criminal de las sectas coercitivas se aprecian tres tipos de conductas individualizadas de los adeptos:

a) El caso de un sujeto que quiere convertir su conciencia en una causa ineludible de la voluntad fanatizando postulados contra el Sistema o particularmente contra una norma. Aquí subyacen casos de autoría por convicción, del enemigo o del autor de conciencia en los que el déficit de socialización es atribuible dolosamente al sujeto, por lo que aunque el delito se cometa imprudentemente se puede responsabilizar a título doloso.

b) El caso de un sujeto que se coloca en una autopuesta en peligro de adoctrinamiento o de persuasión sin intervención de terceros. Aquí, aunque la culpa consciente sin mediación de tercero cause un déficit de socialización lleva a imputar responsablemente el delito doloso $a$ título culposo. Los casos de culpa inconsciente o autopuesta en peligro inconsciente sobre la causación de un déficit de socialización que a la postre causa un resultado injusto, salvo deber especial en su evitación, llevan a la causa de exculpación del estado de necesidad.

c) $\mathrm{Y}$ el caso de un sujeto que se adentra en un grupo del que se puede conocer su adoctrinamiento totalitario. Aquí el sujeto entra en una heteropuesta en peligro de sus propios bienes de forma semi-consciente, en cuanto que si bien conoce dicho peligro no desea un resultado perjudicial para él ni para tercero. La posterior consciencia del peligro o la posterior aceptación del adoctrinamiento y su participación ante terceros o en perjuicio propio, aun cuando medie un déficit de socialización exculpante o adicción comportamental inimputable, pueden ser responsabilizados en el delito-fin contra tercero a título de imprudencia. La imprudencia inconsciente lleva a una total victimización, pero nada impide que las dosis de culpabilidad se atribuyan en la intervención contra tercero a título imprudente. Este ejemplo supone un caso paradigmático de la problemática de las sectas coercitivas: la «comunidad riesgosa imprudente», en la que cada sujeto es responsable de su propio injusto dentro de una misma comunidad que produce el resultado en cadena o simultáneamente por la persuasión coercitiva de todos los miembros, y que puede imputarse dolosamente en los casos en los que cada sujeto -a pesar de constituir su propia conducta una imprudencia sobre la posibilidad de causar el defecto en el tercero- conoce que la conducta de los demás miembros del grupo aumenta la probabilidad, de 
manera que su propia acción junto a la de los demás constituye un «dolo grupal» del que el sujeto en particular conoce la probabilidad del resultado.

7. Se precisa de una nueva regulación que criminalice la utilización de las técnicas de persuasión coercitivas. El delito de coacciones agravado recoge con mayor precisión que otras figuras delictivas la dinámica criminal y resultado de la persuasión coercitiva, pero su penalidad es insuficiente en casos graves en función de un mayor desvalor de la acción y del resultado (bienes jurídicos afectados, intensidad, temporalidad, probabilidad de resultado, concurrencia general de agravantes genéricas como la alevosía, el abuso de superioridad y confianza) que precisa una reformulación de la extensión de la pena en sentido amplio.

8. La concurrencia de intervinientes, víctimas y delitos en la dinámica criminal de las sectas coercitivas genera problemas de concurso que hemos resuelto de la siguiente manera:

a) La concurrencia de la persuasión coercitiva y el delito lesiones psicológicas se resuelve por el concurso de leyes en virtud del principio de consunción porque la persuasión coercitiva, una vez se ha consumado, supone una modalidad de riesgo contra la integridad psíquica.

b) La concurrencia del delito de coacciones como persuasión coercitiva con otros delitos como el de homicidio, estafa, violación o abusos sexuales se resuelve también mediante el concurso de leyes al consumirse en éstos y en su seno objetivo la restricción del horizonte de expectativas. La configuración normativa del delito de persuasión coercitiva se asimila objetivamente al concepto de «violencia», o en su caso al de «engaño» o «abuso» como modalidad de los anteriores (concurso de leyes heterogéneo). Pero en el caso de que la persuasión coercitiva o el delito contra la integridad psíquica contengan una gravedad autónoma respecto al homicidio, la estafa, la violación o abusos, en el sentido de que no suponga una habitual forma de producirlos, los actos y gravedades se desconectan propiciando el concurso ideal (o real en casos claramente diferenciados).

c) Cuando el intrusismo profesional sirve para producir el engaño o la desatención de la salud es recomendable aplicar el concurso medial con los delitos de estafa o de lesiones, esto debido a la concreta protección de la potestad del Estado y seguridad de las personas que habilita la concurrencia. Cuando no se realicen actos propios como en el caso de la «medicina alternativa», puede apreciarse una modalidad del delito de estafa o contra la integridad porque la creación de una confianza que genera garantía o garantía que genera confianza (deficitarias), constituyen una modalidad de engaño bastante o del vicio del consentimiento, que hace desatender el cuidado del patrimonio o la salud. 
d) En el concurso de todos ellos es conveniente que el caso de los delitos de estafa, violación o abuso sexual y contra la vida aplicar el concurso ideal si existe una «acción común», de lo contrario habrá que aplicar el concurso real de delitos, realizando previamente un concurso entre cada tipología de delitos en función del número de víctimas (pena global por cada tipología y en consecuencia una pena operativa) y muchas veces mediante el delito continuado (excepto en delitos con bienes eminentemente personales) para posteriormente aplicar el concurso ideal.

e) Las agravantes señaladas en la dinámica habitual de las sectas coercitivas (alevosía, abuso de superioridad y de confianza), al corresponder a una misma unidad de acción, se trasladan al delito de lesiones psicológicas, contra la integridad e indemnidad sexual, contra la vida y en sus casos a la estafa, lo que posibilita la aplicación de las agravantes específicas de cada tipo. Especialmente en el delito de abusos sexuales al asimilarse estructuralmente el tipo de engaño y violencia de la persuasión coercitiva en la falta o vicio de consentimiento del art. $181.2 \mathrm{CP}$ no podrá aplicarse la agravante del apartado 5 en el supuesto si concurriere la circunstancia $3{ }^{a}$ (cuando la víctima sea especialmente vulnerable, en nuestro caso por enfermedad, discapacidad o situación) o la $4 .^{a}$ (cuando, para la ejecución del delito, el responsable se haya prevalido de una relación de superioridad) de las previstas en el apartado 1 del artículo 180 de este Código, puesto que ya se incluyen en el tipo básico del art. $181 \mathrm{CP}$ el vicio de la obtención del consentimiento o su falta. A la misma conclusión se llegó en relación a la modalidad de engaño de la coacción por persuasión coercitiva que se consume en el concepto de engaño o abuso «de posición de reconocida confianza, autoridad sobre la víctima (...) con persona mayor de dieciséis años y menor de dieciocho» del art. $182.1 \mathrm{CP}$.

9. Hemos planteado una propuesta de tipificación de lege ferenda que podría ubicarse en el art. 172 quater del CP.

En el Capítulo VII, tras el análisis de la imputación objetiva de los déficits de socialización, nos hemos adentrado en la institución de la autoría y participación en el delito de persuasión coercitiva y en la concurrencia con otros delitos, al objeto de distinguir el delito autónomo de coacciones mediante persuasión coercitiva de las formas de autoría y participación.

1. En la inducción como en cualquier forma de intervención penal se amplía el horizonte de expectativas criminales, mientras que en la persuasión coercitiva se restringe. De este planteamiento se puede concluir que es compatible una dinámica en la que se produzca una persuasión coercitiva y posteriormente una inducción propiamente dicha o una persuasión como 
forma de inducción si dicha restricción tiene el efecto de ampliar las posibilidades criminales sin mermar la capacidad de voluntad del inducido.

2. La persuasión coercitiva puede realizarse de forma imprudente, sin verbalización, omisivamente, en comisión por omisión, en cadena y/o mediatamente.

3. El delito de coacciones mediante persuasión coercitiva es un delito autónomo que no permite aplicar el modelo tradicional del estado de necesidad coactivo o exculpante, o el dominio de la voluntad en virtud de coacción o error que se solucionan mediante la autoría mediata. Esto se debe fundamentalmente a un concepto de responsabilidad funcional en la autoría y participación.

4. Hemos utilizado el controvertido ejemplo de los aparatos organizados de poder porque se asemejan a la dinámica de las sectas persuasivas. El modelo de la autoría mediata en aparatos organizados de poder es insuficiente e incoherente con sus propios postulados de dominio de la voluntad psicológica o en virtud de error según los casos de intervención con imprudencia consciente o semi-imputabilidad porque en virtud de un concepto de responsabilidad funcional, la coautoría con títulos de responsabilidad diferenciados tanto en la imputación del delito sistémico como en el delito de persuasión coercitiva y otros delitos-fin (sin perjuicio de los concursos) explica mejor los casos en los que la persuasión coercitiva sirve de delito medio para otros delitos-fin.

5. Lo anterior se explica por dos tipos de desconexiones normativas: desconexión objetiva de injustos y desconexión subjetiva de la responsabilidad y de los títulos de responsabilidad:

a) Nuestros postulados llevan a apreciar la persuasión coercitiva como delito medio para otro $\mathrm{u}$ otros delitos-fin en los que la víctima participa en el delito medio y a su vez es víctima-autora en el delito-fin, lo que permite tratar estos casos con la fórmula dogmática de la víctima-autor. Esto se debe a la autonomía del tipo de injusto del delito de coacciones en su modalidad de persuasión coercitiva. Dicha autonomía procura una desconexión objetiva de injustos lo que alcanza soluciones en los concursos de leyes y de delitos descritos.

b) En estas dinámicas hay también una desconexión subjetiva del título de imputación por dolo o imprudencia y de la responsabilidad de los intervinientes. No hay un dominio al modo descrito por la teoría tradicional de la autoría mediata, porque el concepto de responsabilidad funcional que hemos postulado y los márgenes de libertad que procura la persuasión coercitiva en su versión de restricción del horizonte de expectativas permite sostener que no exista continuidad en la resolución delictiva incluso en la comisión dolosa en el delito medio y fin. El único caso que permitiría la autoría mediata sería aquel dominio que procura la adicción 
comportamental o los trastornos psíquicos completos, y en casos especiales la autoría directa cuando sean plenos.

6. El dolo, el acuerdo común y la imprudencia son elementos fenomenológicos del resultado, solo informan sobre el quantum de responsabilidad una vez se trasgrede el riesgo permitido. El deber se refiere a la competencia sobre un resultado, de manera que en un mismo hecho pueden intervenir distintos títulos y criterios de imputación.

En el Capítulo VIII, el examen de los fundamentos del injusto sistémico lleva a concluir que confluyen varios tipos de organización delictiva en las sectas coercitivas:

1. Una organización sectaria estrictamente dolosa a la que hemos denominado injusto sistémico propio u organización delictiva propiamente dolosa. La conducta y el dolo son propiamente sistémicos.

2. Otra a la que hemos denominado injusto sistémico impropio u organización delictiva impropia en la que las conductas de cada miembro de la organización son por sí solas neutras, pero cada sujeto conoce que con la suma de las demás conductas neutras se crea un alto riesgo que aunque no se desee el resultado se acepta como probable, es decir, aquí el dolo es eventual, se refiere al conocimiento y aceptación por cada sujeto de que todas las conductas neutras más la suya propia llevan a un resultado injusto: el dolo es propiamente sistémico, pero no la conducta porque cada sujeto es garante de los demás por «comunidad de riesgo» basada en la «confianza estrictamente especial» que trasforma los conceptos esenciales del Sistema.

3. Una tercera hipótesis de injusto sistémico, que hemos denominado «comunidad riesgosa propiamente», en la que cada sujeto abarca en imprudencia consciente el resultado atendiendo a las conductas neutras de los demás miembros pero la suma de todas propicia un aumento del riesgo que si bien no es aceptado por cada sujeto, ni se aprecia altamente probable, fundamenta la reacción penal por la especial peligrosidad en el resultado. Esto se debe igualmente a que cada sujeto es garante de los demás por «comunidad» basada en la «confianza estrictamente especial».

4. Y un caso especialísimo pero muy frecuente en todo tipo de dinámicas grupales basado en la contingencia de todas las anteriores: autores dolosos, autores doloso-eventuales, autores con imprudencia consciente en el resultado y el binomio autores-víctimas. El fundamento de imputación es la coautoría accesoria elevada a organización. Habrá que determinar en cada caso si una aportación escasa merece el reproche en calidad de autor. 


\section{BIBLIOGRAFÍA}

ABoso, Gustavo Eduardo, Los límites de la autoría mediata, B de F, 2012.

ACINAS, Juan Claudio, «Sobre los límites de la desobediencia civil», Sistema 97, Madrid, julio, 1990.

ADOMEIT, Klaus, «Die Mauerschützenprozesse - rechtsphilosophisch», NJW, 1993, pp. 2914 a 2916.

AguAdo CoRreA, Teresa, El principio de proporcionalidad de Derecho penal, Ed. Edersa, Madrid, 1999.

-, ID., Inexigibilidad de otra conducta en derecho penal, Comares, Granada, 2004.

AGUILAR Ros, Paloma, «Religión y capacidad de obrar (los no católicos en el derecho romano-visigodo)», vv.aa.,

Aspectos socio-jurídicos de las sectas desde una perspectiva comparada / The Oñati Internacional Institute for the

Sociology of Law, 1991, edited by Juan Goti Ordeñana.

AlCÁCER GuIRAO, Rafael, La tentativa inidónea: fundamento de punición y configuración del injusto, Comares, Granada, 2000.

-, ID., Tentativa y formas de autoría. Sobre el comienzo de la realización típica, $1^{\mathrm{a}}$ ed., Edisofer, 2001.

-, ID., «Comienzo de la tentativa en la comisión por omisión», $C P C, 2001,73$, pp. 7 a 33.

-, ID., «Tentativa y desistimiento en la comisión por omisión», La Ley, 2002, 5, pp. 1453 a 1465.

-, ID., Actio libera in causa dolosa e imprudente: La estructura temporal de la responsabilidad, Atelier, 2005.

ALDONEY RAMÍREZ, Rodrigo, «Tratamiento jurídico penal de la eutanasia», RP, núm. 16, pp. 171 a 214.

Alfonso PÉREz MI / DíAz BAÑos M / GARCía MuÑoz G., «Los Nuevos Movimientos religiosos ante la ley y la jurisprudencia (comentario a la Sentencia del Tribunal Constitucional 46/2001, de 15 de febrero)», Anales de Derecho, núm. 20, 2002.

ALLPORT, Gordon W., La naturaleza del perjuicio, $4^{\mathrm{a}}$ ed., Ed. Universitaria de Buenos Aires, 1971.

Allmendros Carmen / GÁMEZ-GuAdIX Manuel / CARrobles José Antonio / RodríGuEZ-CARBALLEIRA Álvaro, «Abuso psicológico en grupos manipuladores», Behavioral Psychology/Psicología Conductal, 19, pp. 157 a 182.

ALONSO ÁlAMO, Mercedes, «La acción "libera in causa”», ADPCP, XLII, 1989, pp. 55 a 108.

Alonso Herreros Rubén / MuÑIz CAlAZ Bernardino / RAmos SuÁrez Ana / RoDríGuez Juan Antonio, «Actitud del ordenamiento español ante las sectas», Sectas y Derechos Humanos / III Congreso Interuniversitario de Derecho Eclesiástico para Estudiantes, 21-24 Abril 1994, coordina la edición, Mª Elena Buqueras Segura.

AlzagA, Oscar (Dir.), Comentarios a las Leyes Políticas: Constitución española de 1978, Vol. II, Ed. Revista de Derecho Público, Madrid, 1984.

AмBos, Kai, «Dominio del hecho por dominio de voluntad en virtud de aparaos organizados de poder. Una valoración crítica y ulteriores aportaciones», RDPC, $2^{\mathrm{a}}$ época, 3, 1999.

AMBOS Kai / GRAMMER Christoph, «Dominio del hecho por organización. La responsabilidad de la conducta militar argentina por la muerte de Elisabeth Käsermann», RP, núm. 12, 2002.

Amorós Buqueras A / COllado CAÑo ML / MARTíneZ Villaseñor L., «Concepto jurídico de sectas», Sectas y Derechos Humanos / III Congreso Interuniversitario de Derecho Eclesiástico para Estudiantes, 21-24 Abril 1994, coordina la edición, $\mathrm{M}^{\mathrm{a}}$ Elena Buqueras Segura.

ARENDT, Hannah., Eichmann en Jerusalén, Ed. Debolsillo, 2006.

-, ID., Los orígenes del totalitarismo, pról. Salvador Giner, trad. Guillermo Solana, $7^{\text {a }}$ reimpresión 2014 de la $1^{\text {a }}$ ed. 2006, Alianza Editorial.

-, ID., Sobre la violencia, trad. Guillermo Solana, $1^{\mathrm{a}}$ reimp. 2014 de la $2^{\mathrm{a}}$ ed. 2013, Alianza Editorial.

ARISTÓTEles, Política, intro. Carlos García Gual, trad. Patricio de Azcárate, Austral, 2011.

-, ID., Ética eudemia, intro. trad. y notas Carlos Megino Rodríguez, $1^{a}$ reimp. 2009 de la $1^{a}$ ed. Alianza Editorial.

-, ID., Ética a Nicómaco, pról. Teresa Martínez Manzano, trad. Julio Pallí Bonet, Ed. Gredos, 2014.

ASCH, Solomon E., «Effects of Group Pressure upon the Modification and Distortion of Judgement», H. Guetzkow (ed.), Groups, Leaderschip, and Men, Pittsburgh: Carnegie Press, 1951.

ASHBY, William Ross, An Introduction to Cybernetics, London, Chapman and Hall Ltd. 1956.

ATIEnZA, Manuel, «La filosofía del Derecho de Felipe González Vicén», El lenguaje del Derecho, Buenos Aires, 1983.

AZCONA, Francisco, «Las Sectas en España», Cuadernos de realidad social, núm. 35-36, 1990.

-, ID., «Origen, evolución y situación actual del fenómeno sectario en España», GUERRA M / AZCONA F / LORDA JL., Sectas ¿De qué hablamos? Historia de las religiones, Sociología y Evangelización, $1^{\mathrm{a}}$ ed., Navarra Gráfica Ediciones, Cuadernos del Instituto Martín de Azpilcueta, 1999.

-, ID., «Lo que es y lo que no es una secta», GuERRA M / AzCONA F / LORDA JL., Sectas ¿De qué hablamos? Historia de las religiones, Sociología y Evangelización, $1^{\mathrm{a}}$ ed., Navarra Gráfica Ediciones, Cuadernos del Instituto Martín de Azpilcueta, 1999.

BAAMONDE, José María, La Manipulación Psicológica de las Sectas, Ediciones San Pablo, Madrid, 2003. 
BACIGALUPO ZAPATER, Enrique, «Conducta precedente y posición de garantía en el Derecho penal», ADPCP, 1970, pp. 35 a 48.

-, ID., «Sobre la tentativa inidónea en el Derecho vigente y en el Proyecto de Código Penal», La Ley, núm. 2, 1981, pp. 969 a 973.

-, ID., «La rigurosa aplicación de la ley según el artículo $2^{\circ} \mathrm{CP}$, Vinculación del juez a la ley penal, CDJ, XVIII, Consejo General del Poder Judicial, 1995.

-, ID., Principios de Derecho penal, Parte General, Akal, 4ª ed., Madrid, 1997.

BAJo Fernández Miguel / DíAZ-MARoto Y Villarejo Julio, Manual de Derecho Penal, Parte especial, Delito contra la libertad y seguridad, libertad sexual, honor y estado civil, $3^{\text {a }}$ ed., Editorial Centro de Estudios Ramón Areces, 1995.

BAJO FERNÁNDEZ, Miguel, «La intervención médica contra la voluntad del paciente», ADPCP, 1979.

-, ID., «Agresión médica y consentimiento del paciente», CPC, núm. 25, 1985, pp. 127 a 138.

-, ID., Manual de Derecho penal, Parte Especial, I, delitos contra las personas, $2^{\text {a }}$ ed., CEURA, Madrid, 1987.

-, ID., «El delito de coacciones», Estudios penales. Libro homenaje al Prof. Agustín Fernández Albor, Santiago de Compostela, 1989, pp. 57 a 72.

-, ID., «La nueva Ley de Autonomía del paciente», Dogmática y Ley Penal, Libro Homenaje a Enrique Bacigalupo, T. II, 2004, pp. 931 a 942.

BALBUENA PÉREZ, David Eleuterio, Derecho penal, neurociencia y libertad. Una aproximación teórica al replanteamiento de la responsabilidad penal a propósito de las aportaciones neurocientíficas sobre el proceso mental para formación de la voluntad, Ed. Marben, Asunción, 2014.

BALDÓ LAVILLA, Francisco, «Algunos aspectos conceptuales de la inducción», ADPCP, 1989, pp. 1091 y ss.

BALLESTA, Félix, «Mecanismos psicológicos de vinculación a las sectas», vv.aa., Aspectos socio-jurídicos de las sectas desde una perspectiva comparada / The Oñati Internacional Institute for the Sociology of Law, 1991, edited by Juan Goti Ordeñana.

BARba LÓPEz Daniel / García Oliva Francisco Javier / García-PARdo Gómez David / MoRAles MonteOliva Yolanda / VALENCIA BENÍTEZ Fernando, «La protección jurídica del individuo ante las sectas destructivas», Sectas y Derechos Humanos / III Congreso Interuniversitario de Derecho Eclesiástico para Estudiantes, 21-24 Abril 1994, coordina la edición, $M^{\text {a }}$ Elena Buqueras Segura.

BARON Robert A / BYRne Donn, Psicología Social, 10a ed., Pearson Educación, Madrid, 2005.

BARKER, Eileen, The Making of Mooni: Choice or Brainwashing, Oxford, Black-well, 1984.

BAUCELlS I LLADÓS, Joan, La delincuencia por convicción, Tirant lo Blanch, Valencia, 2000.

BECK, Huber F., How to respond to the Cults. A Sociological Study of Jehova's Witnesses, Oxford, Basil Blackwell, 1979.

BECKER, Howard S., Outsiders: Studies in the sociology of deviance, Free Press, New York, 1963.

BenterraK Ayensa Miriam / COllado MÁrquez Ana Isabel / Fuentes CASTILlejos Miguel / Martínez Rubio Agustina / REDONDO GARCÍA Manuela, «Aspectos históricos y sociológicos de las sectas en España», Sectas y Derechos Humanos / III Congreso Interuniversitario de Derecho Eclesiástico para Estudiantes, 21-24 Abril 1994, coordina la edición, $M^{\text {a }}$ Elena Buqueras Segura.

BERGUA, Juan B., «Zarathustra y su doctrina», El Avesta, textos relativos al Mazdeísmo o Zoroastrismo, primera de las grandes religiones, trad. Juan B. Bergua, $2^{\mathrm{a}}$ ed., 1992.

BERnSmann, Klaus, Entschuldigung durch Notstand: Studien zu § 35 StGB, Carl Heymanns, 1989.

BERTALANFFY, Ludwig von, Teoría general de los sistemas. Fundamentos, desarrollo, aplicaciones, trad. Juan Almela, $7^{\text {a }}$ reimp. de la $1^{\text {a }}$ ed. 1976, Fondo de Cultura Económica, México, 1989.

BERZ, Ulrich, Formelle Tatbestandsverwirklichung und materieller Rechtsgüterschutz, Eine Untersuchung zu den Gefährdung- und Unternehmensdelikten, 1986.

Blanco Lozano, Carlos, La omisión del deber de socorro en Derecho penal, Bosch, 2009.

-, ID., vvaa., Lecciones de Derecho Penal, Parte Especial, T. I, Dir. Miguel Polaino Navarrete, Martos Nuñez Juan Antonio / Herrera Moreno Myriam / Blanco LozAno Carlos / Monge Fernández Antonia / ReQueJo Conde Carmen / POLAINO-ORTS Miguel Tecnos, 2010.

BLEI, Hermann, Strafrecht, T. I, Allgemeiner Teil, $18^{\mathrm{a}}$ ed., 1983.

BLUM, Ernest, «Freud y la conciencia moral», ACHÄR / ZBINDEN / JUNG, vv.aa., La conciencia moral, trad. del original Das Gewissen, Rascher, Zürich, 1958 de Lucio García Ortega, Tribuna de la Revista de Occidente, 1961.

BocKelmanN, Paul, «Zur problematik der Sonderbehandlung von überzeugungsverbrecher», Festschrift für Welzel, Berlin, 1974, pp. 543 a 556.

Bolea BARdón, C., Autoría mediata en Derecho penal, Tirant lo Blanch, Valencia, 2000.

BONET EsTEVA, Margarita, «Grupos de manipulación mental ¿Un cambio de paradigma en el tratamiento jurídico penal?», Estudios penales en homenaje al profesor Cobo del Rosal, enero 2005.

BoPP, Ulrich, Der Gewissenstäter und das Grundrecht der Gewissensfreheit, Freiburger Rechts und Staatswissenschaftliche Abhandlungen, Band 38, C.F. Müller Juristischer Verlag, Karlsruhe, 1974. 
Bosch, Juan, «Bibliografía española sobre sectas y nuevos movimientos religiosos», Cuadernos de Realidades Sociales, núm. 35-36, ejemplar dedicado a Las Sectas en España, 1990, pp. 7 a 16.

-, ID., «Un capítulo especial del "revival religioso". Los "Nuevos Movimientos Religiosos” en España», Razón y Fe, $1.110,1991$, pp. 390 a 403.

-, ID., Para conocer las sectas, Estella, 1993.

BRomLEY David G / SHUPE Anson D., «Just a few years seem like a lifetime: a role theory approach to participation in religious movements», Kriesberg, L. (ed.), Research in Social Movements, Conflicts and Chance, 2, Greenwich, Connecticut, JAI Press., pp. 149 a 185.

BUDZINSKI, Wilhelm, Der Überzeugungsverbrecher, Borna-Leipzip, 1931.

BUENO ARÚS, Francisco, «Principios generales de la legislación antiterrorista», Revista de la Facultad de Derecho de la Universidad Complutense, núm. 11, Madrid, 1986, pp. 135 y ss.

-, ID., «El rechazo del tratamiento en el ámbito hospitalario», AP, T. I, núm. 31, 1991, pp. 395 a 406.

BuEno SAlinAS, Santiago, «El ámbito de amparo del derecho de libertad religiosa y las asociaciones», Anuario de Derecho Eclesiástico del Estado, 1985.

BuJÁn, Javier Alejandro, Elementos de Criminología en la Realidad Social, Depalma, Buenos Aires, 1998.

BUQUERAS, María Elena, «Las religiones alternativas y el derecho a la libertad religiosa», vv.aa., Derecho y Opinión, núm. 0, 1992, pp. 93 a 102.

BURKHARDT, Björn, «La comprensión de la acción desde la perspectiva del agente en el derecho penal», ALCÁCER GUIRAO, R., El problema de la libertad de la acción en el Derecho Penal, Buenos Aires, 2007.

BURSKI, Ulrich von, Die Zeugen Jehovas, die Gewissensfreiheit und das Strafrecht, Inagural-Disertation zum Erlangung der Doktorwürde der Rechts und Staatswissenschaftlichen Fakultät der Albert Ludwigs, Universität zu Freiburg im Breisgau, 1970.

Bustos Ramírez Juan / HormazÁBAl MalaréE Hernán, Lecciones de derecho penal, Teoría del delito, teoría del sujeto responsable y circunstancias del delito, Vol. II, Trotta, 1999.

Bustos RAMíReZ Juan / LARRAURI PIJOAN Elena, Víctimología: presente y futuro (Hacia un sistema penal de alternativas), $1^{\text {a }}$ ed., PPU, Barcelona, 1993.

Bustos RAmíreZ, Juan, Control Social y sistema penal, PPU, 1987.

ID., Manual de Derecho penal, Parte especial, $2^{a}$ ed., aumentada, corregida y puesta al día, Ariel, Barcelona, 1991.

CÁMARA VILlAR, Gregorio, «La objeción de conciencia en España como derecho fundamental y el principio de igualdad», Anuario de Derecho Público. Estudios Políticos, 2, 1989-1990.

-, ID., La objeción de conciencia al servicio militar: (las dimensiones constitucionales del problema, Civitas, Madrid, 1991.

CAncio Meliá, Manuel, «De los delitos cometidos con ocasión del ejercicio de los derechos fundamentales y de las libertades públicas garantizadas en la Constitución», Comentarios al Código penal de 1995, Gonzalo Rodríguez Mourullo (dir.), Madrid, 1997.

-, ID., «De los delitos contra la libertad de conciencia, los sentimientos religiosos y el respeto a los difuntos», Comentarios al Código penal de 1995, Gonzalo Rodríguez Mourullo (dir.), Madrid, 1997.

-, ID., «La exclusión de la tipicidad por la responsabilidad de la víctima (imputación objetiva)», Universidad Externado de Colombia, 1998.

-, ID., «El injusto de los delitos de organización: peligro y significado», CANCIO MELIÁ Manuel / SILVA SÁNCHEZ JesúsMaría, Delitos de organización, B de F, Montevideo-Buenos Aires, 2008, pp. 15 y ss.

-, ID., Conducta de la víctima e imputación objetiva en Derecho penal. Estudio sobre los ámbitos de responsabilidad de víctima y autor en actividades arriesgadas, $2^{\mathrm{a}}$ ed., Bosch, Barcelona, 2001.

-, ID., Vid: JAKOBS Günther / CANCiO Meliá Manuel, Derecho penal del enemigo, $1^{\text {a }}$ ed., Thomson Civitas, 2003.

-, ID., «Psicopatía y Derecho penal: algunas consideraciones introductorias», Fernández Teruelo JG / González Tascón MM / Villa Sieiro SV (Coords.), Estudios penales en homenaje al profesor Rodrigo Fabio Suárez Montes, Constitutio Criminalis Carolina, Oviedo, 2013.

-, ID., vv.aa., Compendio de Derecho penal, Parte especial, Vol. I, CANCIO MELiá Manuel / FEIJOO SÁnCHEZ Bernardo / Peñaranda Ramos Enrique / PÉrez Manzano Mercedes, Dir. Miguel Bajo Fernández, Editorial Centro de Estudios Ramón Areces, 2003.

CANTERAS MurILlO, Andrés, «Asociacionismo y libertad individual: Los movimientos religiosos-sectarios», vv.aa., Aspectos socio-jurídicos de las sectas desde una perspectiva comparada / The Oñati Internacional Institute for the Sociology of Law, 1991, edited by Juan Goti Ordeñana.

CANTO, Jesús M., Psicología social e influencia. Estrategias del poder y procedimientos de cambio, Ed. Aljibe, Málaga, 1994.

-, ID., Psicología de los grupos: estructura y procesos, Ed. Aljibe, Málaga, 1998.

CARbonell Mateu, Juan Carlos, La justificación penal. Fundamento, naturaleza y fuentes, Edersa, Madrid, 1982.

-, ID., «Libre desarrollo de la personalidad y delitos contra la vida. Dos cuestiones: suicidio y aborto», CPC, 45, 1991.

Carbonell Mateu Juan Carlos / González Cussac José Luis, Derecho Penal, Parte Especial, $2^{a}$ ed., Valencia, 1996. 
Carbonell Mateu Juan Carlos / GonzÁlez Cussac José Luis, Comentarios al Código penal de 1995, Vives Antón (coord.), Vol. I, Valencia, 1996.

Carmona Salgado Concepción / González Rus Juan José / Morillas Cueva Lorenzo / Polaino Navarrete Miguel / Portilla Contreras Guillermo, Curso de Derecho penal Español, Parte Especial, I, Marcial Pons, Madrid, 1996.

CARO JOHN, José Antonio, «Algunas consideraciones sobre los delitos de infracción de deber», Aspectos Fundamentales de la Parte general del Código Penal Peruano, Anuario de Derecho Penal, 2003, Fondo Editorial de la Pontificia Universidad Católica del Perú, Lima, 2003.

-, ID., «Sobre la no punibilidad de las conductas neutrales», RPDJP, núm. 5, Lima, 2004.

-, ID., «Derecho penal del enemigo: garantía estatal de una Libertad real del ciudadano. Una glosa a Miguel PolainoOrts», RPDJP, núm. 7, Instituto Peruano de Ciencias Penales, Grijley, Lima, 2006.

-, ID., «Participación delictiva y el deber de solidaridad mínima», Eduardo Montealegre Lynett (coord.), Derecho pena y Sociedad. Estudios sobre las obras de Günther Jakobs y Claus Roxin, y sobre las estructuras modernas de la imputación objetiva, T. II, Centro de Investigaciones en Filosofía y Derecho, Universidad Externado de Colombia, Bogotá, Colombia, 2007.

-, ID., «La autoría mediata por dominio de organización: Una perspectiva Fáctico Normativa», elaborado por la Clínica Jurídica de Acciones de Interés Público de la facultad de Derecho de la Pontificia Universidad Católica del Perú, Lima, 2008, www.clinica-jurídica.com, consultado en fecha 15 enero de 2015.

-, ID., La imputación objetiva en la participación delictiva, Grijley, Lima, 2003, reedición 2009.

CARRERA, Antonio, 127 preguntas sobre la secta de Jehová, Chihuahua, 1994.

CASTRO JOVER, Adoración, «La libertad de conciencia y la objeción de conciencia individual en la jurisprudencia constitucional española», La libertad religiosa y de conciencia ante la justicia constitucional, ed. Javier MartínezTorrón, Actas del VIII Congreso Internacional de Derecho eclesiástico del Estado, Comares, Granada, 1998, pp. 133 a 186.

CEREzo MIR, J., «La eximente de obrar en cumplimiento de un deber o en el ejercicio legítimo de un derecho, oficio o cargo», ADPCP, 1987, pp. 273 a 299.

-, ID., «El delito como acción culpable», Carlos María Romeo Casabona (ed.), Dogmática penal, Política Criminal y Criminología en evolución, La Laguna, 1997, pp. 19 a 50.

-, ID., Derecho penal, Parte general, II, Teoría jurídica del delito, $2^{a}$ reimp. 2000, de la $6^{\text {a }}$ ed. 1998, Tecnos.

-, ID., Derecho Penal, Parte General, Lecciones, (26-40), $2^{\mathrm{a}}$ ed., 2000, UNED.

-, ID., Curso de Derecho Penal Español. Parte General, III, Teoría Jurídica del delito/2, 5 reimp. 2005 , de la $1^{\text {a }}$ ed. 2001, Tecnos.

Cervelló Donderis, Vicenta, El delito de coacciones en el Código penal de 1995, Tirant lo Blanch, Valencia, 1999.

CHERY, Henri Charles, ¿Qué es una secta? en 2000 años de Cristianismo, T.V, Madrid, 1979.

CIALDINI, Robert B., Influence: The New Psychology of Modern Persuasión, New York, Quill, 1984.

-, ID., Influencia. Ciencia y práctica. Cuáles son los factores determinantes para que una persona diga sí a otra persona, Prodilu, Barcelona, 1990.

ClARK, J., Comunicación personal, 1981.

Cobo Del Rosal Manuel / Vives AnTón Tomás Salvador, Derecho Penal, Parte General, (PG), 5ª ed., Tirant lo Blanch, Valencia, 1999.

COlina RAMÍREZ, Edgar Iván, La defraudación tributaria en el Código penal español. Análisis jurídico-dogmático del art. 305 CP, pról. Miguel Polaino-Orts, Bosch, 2010.

CONGRESO DE JuRISTAS ALEMANES de 1926 en Colonia, «Verhandlungen des Deutschen juristentag zu Köln», BD.II, Berlín und Leipzig, 1927.

CONTRERAS MAZARIO, José María, «La libertad de conciencia, objeción de conciencia, insumisión y Derecho (comentario a la sentencia núm. 75/92 del Juzgado de lo penal nº 4 de Madrid)», Ley y conciencia. Moral legalizada y moral critica en la aplicación del derecho, Edición a cargo de Gregorio Peces-Barba, Instituto de Derechos Humanos Bartolomé de las Casas. Universidad Carlos III de Madrid. Boletín oficial de Estado, Madrid 1993, pp. 37 a 62.

COPPI, F., «Plagio», Enciclopedia del Diritto, Vol. XXXIII, Giuffré Editore, 1983, pp. 932 y ss.

CORCINO BARRUETA, Fernando, «Coautoría, imputación objetiva y semántica social», KINDHÄUSER Urs / POLAINOORTS Miguel / CORCINO BARRUETA Fernando, Imputación objetiva e imputación subjetiva en Derecho penal, pról. Miguel Polaino Navarrete, Grijley, Perú, 2009, pp. 85 a 136.

Corcoy Bidasolo Mirentxu / CARdenal Montraveta Sergi / Fernández Bautista Silvia / Gallego Soler José Ignacio / Gómez MARTín Víctor / HorTAL IBARRA Juan Carlos, Manual práctico de Derecho penal, Parte Especial. Doctrina y jurisprudencia, con casos solucionados, coord. Mirentxu Corcoy Bidasolo, $2^{\mathrm{a}}$ ed., ampliada y puesta al día, Tirant lo Blanch, Valencia, 2004.

Corcoy Bidasolo, Mirentxu, El delito imprudente. Criterios de imputación del resultado, $1^{\mathrm{a}}$ ed., PPU, Barcelona, 1989. 
-, ID., «Problemas jurídico-penales de la objeción de conciencia en el ámbito de las actividades sanitarias», Estudios de Bioética y Derecho, 2000, pp. 65 a 100.

Córdoba RoDA, Juan, «El delito de detenciones ilegales en el Código penal español», ADPCP, 1964.

-, ID., Culpabilidad y pena, Bosch, 1997.

CUADRADO RuIZ, María Ángeles, «La comisión por omisión como problema dogmático», ADPCP, 1997 , pp. 387 a 456.

-, ID., La responsabilidad por omisión de los deberes del empresario (análisis crítico del art. 363 del Código penal), Bosch, Barcelona, 1998.

-, ID., «La posición de garante», $R D P C, 6,2000$, pp. 11 a 68.

Cuello Calón, Eugenio, Derecho penal, Parte Especial, T. II. 14ª ed., revisada y puesta al día por Cesar Camargo Hernández, Barcelona, 1975.

CuEllo Contreras, Joaquín, La conspiración para cometer delito: interpretación del art. 4, 1, C.P: Los actos preparatorios de la participación, Bosch, 1978.

-, ID., Derecho penal español, Parte General. Nociones introductorias, Teoría del delito, (PG), $3^{\mathrm{a}}$ ed., Madrid, 2002.

-, ID., «Sobre el tipo de tentativa», Homenaje al profesor Dr. Gonzalo Rodríguez Mourullo, 2005, pp. 253 a 266.

Cuerda Arnau, María Luisa, «Comentario al art. $20.5^{\circ} \mathrm{CP}$, coord. Vives Antón, Comentarios al Código penal de 1995, T. I, Valencia, 1996, pp. 140 a 162.

-, ID., El miedo insuperable. Su delimitación frente al estado de necesidad, Tirant lo Blanch, Universitat de Valencia, Valencia, 1997.

CUERDA RIEZU, Antonio, El delito de aborto ante la Propuesta de Anteproyecto del nuevo Código penal, Documentación Jurídica, I, Monográfico dedicado a la Propuesta de Anteproyecto del nuevo Código penal, 1983, pp. 339 a 383.

-, ID., La colisión de deberes en Derecho Penal, Tecnos, Madrid, 1984.

-, ID., «Sobre el concurso entre causas de justificación», Causas de Justificación y de atipicidad en Derecho Penal, DM Luzón Peña y S. Mir Puig (Coord.), Aranzadi, Pamplona, 1995.

Cuevas BARRAnquero, José Miguel, «Aspectos psicológicos de las sectas destructivas. Situación de las sectas en España y formas de combatirlas. Características de los líderes y los miembros del grupo», Tratado de Medicina Legal y Ciencias Forenses, S. Salgado (dir.), Vol. IV, Barcelona, 2012, pp. 1471 a 1501.

-, ID., Evaluación de persuasión coercitiva en contextos grupales, Publicaciones y Divulgaciones, Facultad de Psicología, Universidad de Málaga, 2016.

Cuevas Barranquero José Miguel / CAnTo OrTiz Jesús M., Sectas, Cómo funcionan, cómo son sus líderes, efectos destructivos y cómo combatirlas, Ediciones Aljibe, 2006.

Cugat Mauri, Miriam, Sectas y sectarios ante el Derecho penal, Revista de Derecho y proceso penal, núm. 22, Aranzadi-Thomson Reuters, Navarra, 2010.

DARIES, Joachim Georg, Observationes Iuris Naturalis, Socialis et Gentium, 1789, Vol. II, XX-XXII.

DE Asís RoIG, Rafael, «Las tres conciencias», Ley y conciencia. Moral legalizada y moral critica en la aplicación del derecho, Edición a cargo de Gregorio Peces-Barba, Instituto de Derechos Humanos Bartolomé de las Casas. Universidad Carlos III de Madrid. Boletín oficial de Estado, Madrid 1993.

DE CRESCENZO, Luciano, Historia de la filosofía griega, II, 6ª ed., Ed. Seix Barral, 1997.

DE GoITA, Javier, El sectarismo roto. Entre la libertad y el sectarismo II, Cuadernos de Teología Deusto, núm. 13, Universidad de Deusto, Bilbao, 1997.

DE LuCAS Javier / VIDAL Ernesto / ANTÓN María Jesús, «Desobediencia o respeto a la conciencia», Ley y conciencia. Moral legalizada y moral critica en la aplicación del derecho, Edición a cargo de Gregorio Peces-Barba, Instituto de Derechos Humanos Bartolomé de las Casas. Universidad Carlos III de Madrid. Boletín oficial de Estado, Madrid 1993, pp. 91 a 125.

De OliVeIRA MonteIRO, Luciana, La Autoría mediata en los delitos imprudentes, Tirant lo Blanch, 2013.

Del CASTILlo CODES, Enrique, La imprudencia: autoría y participación, Dykinson, Madrid, 2007.

DEL RE, Michele C., «Modellamento psichico e diritto penale: tutela penale dell'integrità psichica», Giustizia Penale, 11, 1983, pp. 173 a 190.

Del Rosal Blasco, Bernardo, vv.aa., Derecho penal español, Parte especial, $2^{\mathrm{a}}$ ed., revisada, coord. Manuel Cobo del Rosal, Dykinson, 2005.

DEMETRIO CRESPO, Eduardo, «La actio libera in causa: ¿Una excepción a las exigencias de la culpabilidad por el hecho?», Luis Alberto Arroyo Zapatero y Ignacio Berdugo Gómez de la Torre (coords.), Homenaje al Dr. Marino Barbero Santos, «in memorian», Vol. 1, Universidad de Castilla-La Mancha, Univeridad de Salamanca, 2001, pp. 993 a 1012.

-, ID., «La libertad de voluntad, investigación sobre el cerebro y responsabilidad penal. Aproximación a los fundamentos del moderno debate sobre Neurociencias y Derecho penal», InDret., 2011.

-, ID., «Sobre el comienzo de la tentativa en la autoría mediata», www.cienciaspenales.net, también en Nuevas formulaciones en las Ciencias Penales. Homenaje a Claus Roxin, Córdoba, Argentina, Lerner, 2001, pp. 273 a 294. 
-, ID., La tentativa en la autoría mediata y en la actio libera in causa. Una contribución al estudio del fundamento de punición y al comienzo de la tentativa, Comares, 2003.

DíAZ GARCíA, Elías, De la maldad estatal y la soberanía popular, Debate, Madrid, 1984.

DíAz PALOS, Fernando, Voz «Coacción», Nueva Enciclopedia Jurídica Seix, T. VI, Barcelona, 1954.

-, ID., Voz «Miedo insuperable», Nueva Enciclopedia Jurídica Seix, T. XVI, Barcelona, 1978.

DíAZ Y GARcía ConLlEDo, Miguel, La autoría en Derecho penal, pról. D-M Luzón Peña, PPU, Barcelona, 1991.

-, ID., «Homicidio consentido y participación en el suicidio», Enciclopedia Jurídica Básica, Vol. II, Civitas, Madrid, 1995 , p. 3331 a 3335.

Díaz-Maroto Y Villarejo, Julio, vv.aa., Compendio de Derecho Penal, Parte especial, Vol. II, DíaZ-Maroto Y VILLAREJO Julio / ECHANO BASALDUA Juan Ignacio / LASCURAín SÁNCHEZ Juan Antonio / LOZANO MiRALLES José / Mendoza Buergo Blanca / Molina Fernández Fernando / PÉrez Manzano Mercedes / SuÁRez GonzÁlez Carlos / Dir. Miguel BAJo FernándeZ, Centro de Estudios Ramón Areces, 1998.

DíEZ RIPOLlÉS José Luis / GRACIA MARTín Luis, Delitos contra bienes jurídicos fundamentales. Vida humana independiente y libertad, Tirant lo Blanch, Valencia, 1993.

DíEZ RIPOLLÉS, José Luis, «La atenuante de obrar por motivos morales, altruistas o patrióticos de notoria importancia», $A D P C P, 1979$.

-, ID., «La huelga de hambre en el ámbito penitenciario», $C P C, 30,1986$.

-, ID., Los elementos subjetivos del delito. Bases metodológicas, Tirant lo Blanch, Valencia, 1990.

DOISE, W., «Las relaciones entre grupos», MOSCOVICI, S., (ed.), Psicología Social (I), Paidós, Barcelona, 1985.

DonNA, Edgardo Alberto, «El concepto de autoría y la teoría de los aparatos de poder de Roxin», vv.aa., Modernas Tendencias en la Ciencia del Derecho penal y en la Criminología, UNED, Facultad de Derecho Madrid, 2000, pp. 533 a 557.

-, ID., La autoría y participación criminal, Comares, Granada, 2006.

DSM-V, Diagnostic and Statistical Manual of Mental Disorders, Ed. American Psychiatric Association.

DURKHEIM, Émile, La división del trabajo social, Akal, 1987.

-, ID., Sociología y filosofía, Comares, 2006.

-, ID., El suicidio. Un estudio de Sociología, revisión traducción Sandra Chaparro, 2a ed., Akal, 2012.

-, ID., Las formas elementales de la vida religiosa, Alianza Editorial, 2014.

EBERT, Udo, Der Überzeugungstäter in der neueren Rechtsentwicklung, Duncker \& Humblot, Berlín, 1975.

ECHEBARRÍA ECHABE, Agustín, «Procesos grupales y construcción de la identidad: el caso de las sectas», vv.aa., Aspectos socio-jurídicos de las sectas desde una perspectiva comparada / The Oñati Internacional Institute for the Sociology of Law, 1991, edited by Juan Goti Ordeñana.

Engisch, Karl, La teoría de la libertad de la voluntad en la actual doctrina filosófica del Derecho Penal, $1^{\mathrm{a}}$ ed., Ed. B de F 2006.

ENRoth, Ronald S., The Lure of the Cults and new Religions. Why They Attract and What We Can Do, Downers Grove, Illinois, Intervarsity Press., 1977.

-, ID., Las sectas y la Juventud, Crie, Tarrasa, 1980.

EPICTETO, Manual, Disertaciones por Arriano, trad. intr. y notas Paloma Ortiz García, Gredos, 2001.

ERICKSON, Milton H., The Nature of Hypnosis and Suggestion, Vol. 1, Irvington Publishers, 1980.

ESCOBAR ROCA, Guillermo, La objeción de conciencia en la Constitución española, Centro de Estudios Constitucionales, Madrid, 1993.

ESCRIVÁ IVARS, Javier, «La objeción de conciencia al uso de determinados medios terapéuticos», La objeción de conciencia. Actas del VI Congreso Internacional de Derecho Eclesiástico del Estado, Valencia 28-30 mayo de 1992, V. Guitarte Izquierdo y J. Escrivá Ivars (Eds.), Generalitat Valenciana y Consejo General del Poder Judicial, Valencia, 1993.

FANON, Frantz, The Wretched of the Earth, Grove Press edition, 1968.

FARALDO CABANA, Patricia, Responsabilidad penal del dirigente en estructuras jerárquicas, $1^{\mathrm{a}}$ ed., Tirant lo Blanch, 2003.

FARBER IE / HARLOW Harry F / WeSt Jolyon Louis, «Brainwashing. Conditioning and D.D.D.», Sociometry, 20, pp. 271 a 285.

FARÍAS DÍAZ, Álvaro, Sectas y manipulación mental. Un enfoque desde la psicología, $1^{\mathrm{a}}$ ed., Vita Brevis, Colección RIES núm. 3, Red Iberoamericana de Estudios de las Sectas, 2015.

FARRÉ TREPAT, Elena, «Sobre el comienzo de la tentativa en la omisión, en la autoría mediata y en la actio libera in causa», Estudios Penales y Criminológicos, XIII, 1990.

FEIJOO SÁNCHEZ, Bernardo José, Homicidio y lesiones imprudentes: requisitos y límites materiales, Edijus, Zaragoza, 1999.

-, ID., «Prevención general positiva: estabilización normativa mediante imposición de males. Una réplica a la teoría de la pena de Günther Jakobs», Teoría funcional de la pena y de la culpabilidad, Civitas, 2007.

-, ID., «Derecho penal y Neurociencias. ¿Una relación tormentosa?», InDret, 2/2011. 
-, ID., «Culpabilidad jurídico-penal y Neurociencias», Eduardo Demetrio Crespo (dir.) / Manuel Maroto Calatayud (coord.), Neurociencias y Derecho penal. Nuevas perspectivas en el ámbito de la culpabilidad y tratamiento jurídicopenal de la peligrosidad, Edisofer, Madrid, 2013, pp. 269 a 298.

FERNÁNDEZ-CORONADO, Ana, «La tutela penal de la libertad de conciencia», ADEE, 1986, pp. 17 a 56.

-, ID., «Reflexiones en torno a la función del Registro de entidades religiosas (A propósito de la Sentencia de la Audiencia Nacional de 11 de octubre de 2007 sobre inscripción de la Iglesia de la Scientology)», Laicidad y Libertades. Escritos Jurídicos, núm. 7, 2007, páginas 389 a 402.

FERNÁNDEZ GARCÍA, Eusebio, La obediencia al Derecho, Madrid, 1987.

-, ID., «Conciencia y respeto al Derecho», Ley y conciencia. Moral legalizada y moral critica en la aplicación del derecho, Edición a cargo de Gregorio Peces-Barba, Instituto de Derechos Humanos Bartolomé de las Casas, Universidad Carlos III de Madrid, Boletín oficial de Estado, Madrid 1993.

FERrari, Silvio, Diritto dell' uomo e libertà dei gruppi religiosi. Problemi giuridici dei nuovi movimenti religiosi, Editado por Silvio Ferrari, Università degli Studi di Parma, Publicazioni della Facoltà di Giurisprudenza, nuova serie, 7, Padova (Cedam) 1989.

-, ID., «Il proselitismo tra diritti delle religioni e diritti degli Stati», Religión, matrimonio y Derecho ante el siglo XXI. Estudios en homenaje al Profesor Rafael Navarro-Valls, J. Martínez-Torrón / S. Meseguer Velasco / R. Palomino Lozano, (Coords.), Vol. I, Iustel, Madrid, 2013.

FERrer SAMA, Antonio, Comentarios al Código penal, T. IV, Murcia, 1956.

FERrI, Enrico, Sociologia Criminale, $4^{\mathrm{a}}$ ed., Fratelli Boca, Torino, 1900.

-, ID., Principii di Diritto Criminale. Delinquente e delitto, Torino, 1928.

FESTINGER, Leon, «A theory of comparison processes», Human Relations, 7, 1954, pp. 117 a 140.

-, ID., Teoría de la disonancia cognoscitiva, CEC, Madrid, 1975.

FICHTE, JG, Fundamentos del Derecho natural según los principios de la doctrina de la ciencia, trad. José Luis Villacañas Berlanga, Manuel Ramos Valera y Faustino Oncina Coves, Centro de Estudios Constitucionales, Madrid, 1994.

-, ID., El destino del hombre, trad. Juan Ramón Gallo Reyzábal, Ed. Sígueme, Salamanca, 2011, sobre el original Die Bestimmung des Menschen, 1800.

FIoraVAnti, Maurizio, Los derechos fundamentales. Apuntes de Historia de las constituciones, presentación Clara Álvarez Alonso, trad. Manuel Martínez Neira, $3^{\text {a }}$ ed., Trotta, 2000.

Flores MendozA, Fátima, Objeción de conciencia en Derecho penal, Comares, Granada, 2001.

FONT BoIX, Ignacio, «El concepto de manipulación mental en las llamadas sectas», Ius Canonicum, XLII, 83, 2002, pp. 331 a 358.

-, ID., «Propuesta de despenalización radical en la legislación española de los medios de control o de alteración de la personalidad en relación con las llamadas sectas», Cuadernos doctorales: derecho canónico, derecho eclesiástico del Estado, 20, 2003-2004, pp. 79 a 116.

FOERSTER, Heinz von, «Sobre sistemas autoorganizados y sus ambientes», Las semillas de la cibernética. Obras escogidas, $1^{\text {a }}$ ed., Marcelo Pakman (Edit.), presentación Carlos Sluzki, Gedisa, Barcelona, 1991, pp. 39 a 53.

FOREL, Auguste, «Der Hipnotismus und seine Strafrechliche Bedeutung», Zeitschrift für die gesamte Strafrechtswissenschaft, 9.

FRANK, Reinhard, «Über den Aufbau des Schuldbegriffs», Festgabe für die Juristische Facultät der Universitat Giessen, Giessen, 1907.

FRELLESEN, Peter, Die Zumutbarkeit der Hilfeleistung, Frankfurt a. Main, 1980.

FREUD, Sigmund, Psicología de las masas, 8a reimpresión, Alianza Editorial, 2008.

FREUDENTHAL, Berthol, Schuld und Vorwurf im geltenden Strafrecht, Tübingen, 1922.

FRIAS LINARES, Mercedes, «El fenómeno del sectarismo en occidente: condicionantes históricos, sociológicos y jurídicos», vv.aa., Aspectos socio-jurídicos de las sectas desde una perspectiva comparada / The Oñati Internacional Institute for the Sociology of Law, 1991, edited by Juan Goti Ordeñana, pp. 103 a 116.

FRISCH, Wolfgand, Tipo penal e imputación objetiva, Colex, 1995.

GANZENMÜLler C / FERnÁNDEZ GARcía EM / Escudero JF / FrigOla J / Ventola F., Delitos contra el orden público, terrorismo, contra el Estado o la comunidad internacional, Bosch, Barcelona, 1998.

GARCÍA ÁlVAREZ, P., La puesta en peligro de la vida y/o integridad física asumida voluntariamente por su titular, Tirant lo Blanch, Valencia, 1999.

-, ID., La víctima en el Derecho penal español, Tirant lo Blanch, Valencia, 2014.

GARCÍA ARÁN, Mercedes, «La objeción de conciencia del médico en relación a la interrupción del embarazo», El aborto. Un tema para debate, Madrid, 1982.

-, ID., «Culpabilidad, legitimación y proceso», ADPCP, 1988.

García Del Blanco, Mª Victoria, La coautoría en Derecho penal, Tirant lo Blanch, Valencia, 2006.

GARCía GonZÁleZ, Teodoro, Los testigos de Jehová. Una guía para católicos, $1^{\mathrm{a}}$ ed., Vita Brevis, Colección RIES núm. 1, Red Iberoamericana de Estudio de las Sectas, 2003. 
GARCÍA HERNANDO, Julián, «La tipología como problema al estudio de las sectas», vv.aa., Las sectas en una sociedad en trasformación, dir. Oleza Le-Senne, Fundación para el Análisis y los Estudios Sociales, Madrid, 1997, pp. 78 a 125.

García Herrera, Miguel Ángel, La objeción de conciencia en materia de aborto, Departamento de Sanidad, Servicio Central de Publicaciones del Gobierno Vasco, Vitoria, 1991.

GARCÍA RIVAS, Nicolás, «Los delitos de insumisión en la legislación española», ADPCP, 1992.

García-Pablos De Molina, Antonio, Asociaciones ilícitas en el Código Penal, Bosch, Barcelona, 1997.

-, ID., Tratado de Criminología, $4^{\mathrm{a}}$ ed., Tirant lo Blanch, Valencia, 2009.

GAROFALO, Raffaele, Estudios criminalistas, Librería Suárez, Madrid, 1986.

GASCÓN ABEllán, Marina, Obediencia al Derecho y objeción de conciencia, $1^{\mathrm{a}}$ ed., Centro de Estudios Constitucionales, Madrid, 1990.

-, ID., «A vueltas con la insumisión», Jueces para la Democracia, 27, 1996.

GAUPP, R., «Der überzeugungsverbrecher», Monatsschrift für kriminalpsychologie und Strafrechtsreform, Carl Winters Universitätsbuchhandlung, Heidelberg, 1926, pp. 394 a 401.

GIMBERNAT ORDEIG, Enrique, «Recensión al libro de Bacigalupo "Delitos impropios de omisión”», ADPCP, 1970.

-, ID., Introducción a la Parte General del Derecho penal español, Universidad Complutense, Madrid, 1979.

-, ID., Delitos cualificados por el resultado y causalidad, Centro de Estudios Ramón Areces, 1990.

-, ID., «El estado de necesidad: un problema de antijuricidad», Estudios de Derecho penal, $3^{\mathrm{a}}$ ed., Tecnos, 1990, pp. 218 a 230 .

-, ID., «El sistema del Derecho penal en actualidad», Estudios de Derecho penal, $3^{\text {a }}$ ed., Tecnos, 1990, pp. 162 a 181.

-, ID., «Eutanasia y Derecho Penal», Estudios de Derecho penal, $3^{\text {a }}$ ed., Tecnos, 1990, pp. 51 a 54.

-, ID., «Inducción y auxilio al suicidio», Estudios de Derecho penal, $3^{\mathrm{a}}$ ed., Tecnos, 1990, pp. 275 a 286.

-, ID., «Diatriba del Nuevo Código Penal», La Ley, 1996, III, 1334 a 1338, también en Prólogo a la $2^{a}$ ed. del Código penal de Tecnos, Tecnos, Madrid, 1996, pp. 15 a 32.

-, ID., «La distinción entre delitos propios (puros) y delitos impropios de omisión (o de comisión por omisión)», vv.aa., La ciencia del Derecho Penal ante el nuevo siglo, Libro Homenaje al profesor Doctor Don José Cerezo Mir, Tecnos, Madrid, 2002, pp. 685 a 709.

GöDAN, Jürgen Christoph, Die Rechtsfigur des überzeugungstäters, Duncker \& Humlot, Berlin, 1975.

GofFMAn, Erving, The Presentation of Self in Everyday Life, New York, Doubleday Anchor Books, 1959.

GolDSCHMIDT, J., La concepción normativa de la culpabilidad, trad. M. de Goldschmidt y Ricardo Núñez, Buenos Aires, 1943, pp. 38 y ss; ID., «Der Notstand, ein Schuldproblem», ÖstZStr, 1913; ID., «Normativer Schuldbegriff», Festgabe für Reinhar von Frank, Band I, Tübingen.

Gómez Benítez, José Manuel, Teoría jurídica del delito. Derecho Penal, Parte General, Madrid, 1984.

-, ID., «El dominio del hecho en la autoría mediata (validez y límites)», ADPCP, 1984.

-, ID., «Consideraciones sobre lo antijurídico, lo culpable y lo punible, con ocasión de conductas típicas realizadas por motivos de conciencia», Ley y conciencia. Moral legalizada y moral critica en la aplicación del derecho. Edición a cargo de Gregorio Peces-Barba. Instituto de derechos humanos Bartolomé de las Casas. Universidad Carlos III de Madrid. Boletín oficial de Estado, Madrid 1993.

GÓMEZ-JARA DíEZ, Carlos, La culpabilidad penal de la empresa, Marcial Pons, Madrid-Barcelona, 2005.

-, ID., Teoría de sistemas y Derecho penal. Fundamentos y posibilidades de aplicación, Comares, 2005.

-, ID., «Autoorganización empresarial y autorresponsabilidad empresarial. Hacia una verdadera responsabilidad penal de las personas jurídicas», RECPC, núm. 08-05, 2006.

GómEZ RIVERO, Mª Carmen, La inducción a cometer delito, Tirant lo Blanch, Valencia, 1995.

-, ID., «La producción del resultado muerte o lesiones en relación al supuesto agravatorio del art. 489 ter.», La Ley, 1995.

-, ID., La imputación de los resultados producidos a largo plazo: especial referencia a la problemática del SIDA, Valencia, 1998.

-, ID., La responsabilidad penal del médico, Tirant lo Blanch, Valencia, 2003.

GonZÁlez CuSSAC, José Luis, «Los nuevos delitos contenidos en la Ley Orgánica del Tribunal del Jurado», El nuevo Código penal: presupuestos y fundamentos, Libro Homenaje a Ángel Torío, Estudios de Derecho penal, 1999, pp. 741 a 754.

GonZÁLEZ MATEOS, José Carlos, «Esencia de la norma penal y antijuricidad de la tentativa», Anuario de la Facultad de Derecho, Band, 18, Universidad Extremadura, Cáceres, 2000.

GonzÁlez Rus, Juan José, vv.aa., Curso de Derecho penal Español, Parte Especial, I, Marcial Pons, Madrid, 1996.

-, ID., Derecho penal español, Parte especial, $2^{\mathrm{a}}$ ed. revisada, coord. Manuel Cobo del Rosal, Dykinson, 2005.

GonZÁLEZ VICÉN, Felipe, «La obediencia al Derecho», vv.aa., Estudios de Filosofía del Derecho, Universidad de La Laguna, 1979.

Goodman, Felicitas D., The Exorcism of Anneliese Michel, Wipf \& Stock Publishers, 2005.

GöPPINGER, Hans, Criminología, trad. Mª Schwarck e Ignacio Luzarraga Castro, 2a ed., Reus, 1973. 
GóRriz Royo, Elena M ${ }^{\mathrm{a}}$, El concepto de autor en Derecho penal, pról. Tomás Salvador Vives Antón, Tirant lo Blanch, Valencia, 2008.

Goti ORDEÑANA, Juan, «Concepto histórico y concepto actual de secta», vv.aa., Aspectos socio-jurídicos de las sectas desde una perspectiva comparada / The Oñati Internacional Institute for the Sociology of Law, 1991, edited by Juan Goti Ordeñana, pp. 77 a 102.

-, ID., «Síntesis conclusiva», vv.aa., Aspectos socio-jurídicos de las sectas desde una perspectiva comparada / The Oñati Internacional Institute for the Sociology of Law, 1991, edited by Juan Goti Ordeñana.

-, ID., Sistema de Derecho Eclesiástico, Parte Especial, San Sebastián, 1992.

-, ID., «Tratamiento jurídico de las sectas en España», Estudios de Juventud, 53/01, pp. 141 a 152.

Gracia Martín, Luis, El actuar en lugar de otro en Derecho penal, Vol. I, Prensas universitarias de Zaragoza, Zaragoza, 1985.

-, ID., «La comisión por omisión en el Derecho penal español», AP, 1995, 2, pp. 683 a 715.

-, ID., «El “iter criminis”, El Código Penal Español de 1995, El sistema de responsabilidad en el nuevo Código penal», CDJ, XXVII, Escuela Judicial y Consejo General del Poder Judicial, Madrid, 1996.

-, ID., vv.aa., Comentario al Código penal, Parte Especial I (títulos I a VI y faltas correspondientes), coords. José Luis Díez Ripollés y Luis Gracia Martín, Tirant lo Blanch, Valencia, 1997.

-, ID., «Sobre la punibilidad de la llamada tentativa inidónea en el nuevo Código penal español de 1995 (Comentario a la Sentencia de la Audiencia Provincial de Zaragoza de 24 de Mayo de 1996)», RDPC, $2^{a}$ Época, núm. 3, UNED, Madrid, 1999.

-, ID., «Los delitos de comisión por omisión (una exposición crítica de la doctrina dominante)», Modernas tendencias en la Ciencia del Derecho Penal y en la Criminología, UNED, Madrid, 2001, pp. 411 a 482.

-, ID., Fundamentos de dogmática penal. Una introducción a la concepción finalista de la responsabilidad penal, Atelier, 2006.

GREENFIELD, Robert, El supermercado espiritual, Anagrama, Barcelona, 1979.

GREFFENIUS, Gunter, Der Täter aus Überzeugung und der Täter aus Gewissensnot, Kriminologische Schriftenreihe aus der Deutschen Kriminologischen Gessellschaft, Hamburg, 1969.

GUCKEMHEIMER, E., Der begriff der ehrosen Gesinnung im Strafrecht, Editorial Gente, Hamburg, 1921.

Guerra, Manuel, «Lo que es y lo que no es una secta», Guerra M / AzConA F / Lorda JL., Sectas ¿De qué hablamos? Historia de las religiones, Sociología y Evangelización, $1^{\mathrm{a}}$ ed., Navarra gráfica Ediciones, Cuadernos del Instituto Martín de Azpilcueta, 1999.

GUISASOLA LERMA, Cristina, Reincidencia y delincuencia habitual (regulación legal, balance crítico y propuesta de lege ferenda), Tirant lo Blanch, 2008.

GUTIÉRREZ RoDríGUEZ, María, La responsabilidad penal del coautor: Fundamento y límites, Tirant lo Blanch, 2001.

Habermas, Jünger, Teoría de la acción comunicativa, II, Crítica de razón funcionalista, reimp. de 1992 de la $1^{\text {a }}$ ed., 1987, Taurus Humanidades.

-, ID., Facticidad y validez. Sobre el derecho y el Estado democrático de derecho en términos de teoría del discurso, intr. y trad. Manuel Jiménez Redondo, $4^{\mathrm{a}}$ ed. revisada, Ed. Trotta, 2005.

HARTMANN, Nicolai, Ética, presentación y trad. Javier Palacios, Ed. Encuentro, 2011.

HASSAN, Steven, Cómo combatir las técnicas de control mental de las sectas, pról. Margaret Thaler Singer, Urano, 1995.

HASSEMER Winfried / Muñoz CONDE Francisco, Política criminal y sistema del Derecho penal, trad. Muñoz Conde, Barcelona, 1972.

-, ID., Introducción a la criminología y al derecho penal, Tirant lo Blanch, Valencia, 1989.

-, ID., Introducción a la Criminología, Tirant lo Blanch, Valencia, 2002.

HASSEMER, Winfried, «Religionsdelikte in der säkularisierten Rechtsordung», LOMBARDIVALLAURI / DILCHER, Cristianesimo, Secolarizzazine, diritto moderno, II, Milano, 1981, pp. 1320 a 1330.

-, ID., «Neurociencias y culpabilidad en Derecho penal», InDret., 2/11.

HEGEL, Georg Wilhelm Friedrich, Fundamentos de la filosofía del Derecho, Ed. K.H. Ilting, trad. Carlos Díaz, Libertarias/Prodhufi, $1^{\text {a }}$ ed. 1993.

-, ID., Fenomenología del espíritu, trad. Wenceslao Roges, $20^{\mathrm{a}}$ reimpresión de la $1^{\mathrm{a}}$ ed. en español, Fondo de Cultura Económica, 2010.

HeIDEGGER, M., Tiempo y ser, intr. Manuel Garrido, trad. Manuel Garrido, José Luis Molinuevo y Félix Duque, Tecnos, reimpresión $5^{\mathrm{a}}$ ed., 2013.

-, ID., El ser y el tiempo, Fondo de Cultura Económica, trad. del original Sein und Zeit de 1927 José Gaos, $3^{\mathrm{a}}$ reimp. de la $2^{\mathrm{a}}$ ed, México, Buenos Aires, 2014

-, ID., Nietzsche, trad. Juan Luis Vermal, Ariel, $4^{\mathrm{a}}$ impresión de la $1^{\mathrm{a}}$ ed. 2014.

HEINITZ, Ernst, «Der überzeugung-stäter im Strafrecht», ZStW, 1966, núm. 78, pp. 615 a 637.

HENKEL, Heinrich, «Zumutbarkeit und Unzumutbarkeit als regulatives Prinzip», Festschrift für Mezger zum 70. Geburtstag, München, Berlin, 1954, pp. 249 a 309. 
HernándeZ Plasencia, José Ulises, La autoría mediata en Derecho Penal, Comares, Granada, 1996.

HeRnÁNDEZ TRIVIÑo Aurelio / ZugALdíA EsPINAR José Miguel, «La medicina popular y la medicina alternativa ante el Derecho penal: especial consideración del delito de intrusismo», CPC, 54, 1994, pp. 927 a 941.

HERrera Moreno, Myriam, «Multiculturalidad y tutela penal: a propósito de la problemática sobre la mutilación genital femenina», RDP, 5, 2002, pp. 49 a 84.

-, ID., vv.aa., Lecciones de Derecho penal, Parte especial, T. I, Dir. Miguel Polaino NaVArRETE / MARTOS NúÑEZ Juan Antonio / Herrera Moreno Myriam / Blanco LozAno Carlos / Monge FeRnández Antonia / ReQUEJo CONDE Carmen / Polaino-ORTs Miguel, Tecnos, Madrid, 2010.

-, ID., vv.aa., Lecciones de Derecho penal, Parte especial, T. II, Dir. Miguel Polaino NAVARreTE / MARTOS NúÑEZ Juan Antonio / Herrera Moreno Myriam / Blanco Lozano Carlos / Monge Fernández Antonia / Aguado Correa Teresa / ReQuejo Conde Carmen / RANDo CASEMEIRo Pablo / PolAino-OrTs Miguel, Tecnos, Madrid, 2011.

Herrero Herrero, César, Criminología (Parte general y especial), 2a ed., Dykinson, Madrid, 2001.

Higuera GuimerÁ, Juan Felipe, El delito de coacciones, pról. José Cerezo Mir, 2a ed., revisada y ampliada, Bosch, 1983.

-, ID., La eximente de miedo insuperable en el Derecho penal común y militar español, Bosch, Barcelona, 1991.

HIRSCH, Hans Joaquim, «Strafrecht und rechtsfreier Raum», Bockelmann-Festschrift, München 1979, pp. 89 y ss.

-, ID., Strafrecht und Überzeugungstäter, Walter de Gruyter, Berlin/Nueva York, 1996.

-, ID., «Acerca de los límites de la autoría mediata», Derecho penal, Obras completas, Libro Homenaje, T. I. a cargo de José Cerezo Mir y Edgardo Alberto Donna, Rubinzal-Culzoni, Santafe, 1999.

-, ID., «Derecho penal y autor por convicción», trad. Patricia Laurenzo Copello, Hirsch, HJ., Derecho Penal Obras Completas, Libro Homenaje, T. II, Rubinzal Culzoni, Buenos Aires, 2000, pp. 171 a 207.

-, ID., «Acerca de la actual discusión alemana sobre libertad de voluntad y Derecho Penal», Eduardo Demetrio Crespo (dir.) / Manuel Maroto Calatayud (coord), Neurociencias y Derecho penal. Nuevas perspectivas en el ámbito de la culpabilidad y tratamiento jurídico-penal de la peligrosidad, Edisofer, Madrid, 2013.

HobBes, Thomas, Del ciudadano y Leviatán, $4^{\text {a }}$ ed., Tecnos, 1996.

HOFFER, Eric, The true believer. Thoughts on the Nature of Mass Movements, Nueva York, 1951.

HorSTER, Detlef, «Posfacio», LuHMAnN, Niklas, La moral de la sociedad, op. cit., p. 348.

Hovland Carl I / JANIS IL / Kelly HH., «Comunication and persuasion», Psychological studies of opinión change, Yale University Press, New Haven, 1953.

HRUSCHKA, Joachim, «Der Begriff der actio libera in causa und die Begründung ihre Strafbarkeit -BGHSt», JuS, 21, 1968.

-, ID., «Über Tun und Unterlassen und über Fahrlässigkeit», Festschrift für Bockelmann, 1979.

-, ID., «Das Strafrecht neu durchdenken!», GA, 1981.

-, ID., Strafrecht nach logisch-analytischer methode, $2^{\mathrm{a}}$ ed., 1988.

-, ID., "“Actio libera in causa” y autoría mediata», HRUSCHKA, J., Imputación y Derecho penal. Estudios sobre la teoría de la imputación, ed. Pablo Sánchez-Ostiz, pról. J-Ma Silva Sánchez, 1ª ed. 2005, pp. 157 a 168, trad. de «“Actio libera in causa" und mittelbare Täterschaft», Festschrift für Karl Heinz Gössel, zum 79. Geburtstag am 16 Oktober 2002, Heilderberg, 2002, pp. 145 a 155.

-, ID., «Causas de justificación y causas de exculpación: La tabla de Carnéades en la doctrina de Gentz y Kant», HruschKA, J., Imputación y Derecho penal. Estudios sobre la teoría de la imputación, ed. Pablo Sánchez-Ostiz, pról. J-Ma Silva Sánchez, $1^{\text {a }}$ ed. 2005, pp. 89 a 99.

-, ID., «La coacción en el sistema de Derecho penal», HRUSCHKA, J., Imputación y Derecho penal. Estudios sobre la teoría de la imputación, ed. Pablo Sánchez-Ostiz, pról. J-Mª Silva Sánchez, 1a ed. 2005, pp. 197 a 218.

-, ID., «Prohibición de regreso y concepto de inducción. Consecuencias», HRUSCHKA, J., Imputación y Derecho penal. Estudios sobre la teoría de la imputación, ed. Pablo Sánchez-Ostiz, pról. J-Ma Silva Sánchez, $1^{\text {a }}$ ed. 2005 , pp. 169 a 195.

-, ID., «Reglas de comportamiento y reglas de imputación», Hruschka, J., Imputación y Derecho penal. Estudios sobre la teoría de la imputación, ed. Pablo Sánchez-Ostiz, pról. J-Mª Silva Sánchez, 1ª ed. 2005, pp. 27 a 40.

HUBBARD, Ronald L., Dianética. El poder de la mente sobre el cuerpo, NEW ERA Publications Internacional ApS.

HUERTA TOCILDO, Susana, «Injerencia y artículo 489 bis, 3 CP», ADPCP, 1985.

-, ID., Principales novedades de los delitos de omisión en el Código Penal de 1995, Tirant lo Blanch, Valencia, 1997.

HunTER, Edward, Brainwashing. The Story of Men Who Defied It, Forgotter Books, 1956.

IGLESIAS Río, Miguel Ángel, Fundamento y requisitos estructurales de la legítima defensa. Consideración especial a las restricciones ético-sociales, Comares, Granada, 1999.

JAKOBS Günther / CANCIO MELIÁ Manuel, Derecho penal del enemigo, Civitas, 2003.

-, ID., El Sistema funcional del Derecho penal, Lima, 2000.

JAKOBS Günther / STRUENSEE Eberhard, «Problemas capitales del Derecho penal moderno», Libro Homenaje a Hans Welzel, trad. Marcelo A. Sancinetti, Buenos Aires, 1998. 
JAKOBS, Günther, Sociedad, norma y persona en una teoría de un Derecho penal funcional, trad. Manuel Cancio Meliá y Bernardo Feijoo Sánchez, Civitas, Madrid, 1996.

-, ID., La imputación objetiva en Derecho penal, estudio preliminar Carlos J. Suárez González y Manuel Cancio Meliá, trad. Manuel Cancio Meliá, Civitas, 1996.

-, ID., Suicidio, eutanasia y Derecho penal, pról. Francisco Muñoz Conde, trad. Francisco Muñoz Conde y Patricia García Álvarez, Tirant lo Blanch, Valencia, 1999.

-, ID., «Coacciones por medio de violencia», trad. Carlos J. Suárez González, Jakobs, G., Estudios de Derecho penal, $1^{\mathrm{a}}$ ed., Civitas, Madrid, 1997, pp. 439 a 459.

-, ID., «Criminalización en el estado previo a la lesión de un bien jurídico», trad. Enrique Peñaranda Ramos, JAKOBS, G., Estudios de Derecho penal, $1^{\text {a }}$ ed., Civitas, Madrid, 1997, pp. 293 a 324.

-, ID., «La competencia por organización en el delito de omisión. Consideraciones sobre la superficialidad de la distinción entre comisión y omisión», trad. Enrique Peñaranda Ramos, JAKOBS, G., Estudios de Derecho penal, $1^{\mathrm{a}}$ ed., Civitas, Madrid, 1997, pp. 347 a 363.

-, ID., «La organización de autolesión y heterolesión, especialmente en caso de muerte», trad. Manuel Cancio Meliá, JAKOBS, G., Estudios de Derecho penal, 1ª ed., Civitas, Madrid, 1997, pp. 395 a 412.

-, ID., «Las coacciones por medio de amenazas como delito contra la libertad», trad. Carlos J. Suárez González, JAKOBS, G., Estudios de Derecho penal, $1^{\text {a }}$ ed., Civitas, Madrid, 1997, pp. 461 a 480.

-, ID., Derecho penal, Parte General, Fundamentos y teoría de la imputación, $(P G)$, trad. Joaquín Cuello Contreras y José Luis Serrano González de Murillo, Marcial Pons, 1997.

-, ID., «El concepto jurídico-penal de acción», trad. Manuel Cancio Meliá, JAKOBS, G., Estudios de Derecho penal, $1^{\mathrm{a}}$ ed., Civitas, Madrid, 1997, pp. 101 a 126.

-, ID., «El delito imprudente», trad. Manuel Cancio Meliá, JAKOBS, G., Estudios de Derecho penal, $1^{\mathrm{a}}$ ed., Civitas, Madrid, 1997, pp. 167 a 196.

-, ID., Estudios de Derecho penal, trad. y estudio preliminar de Enrique Peñaranda Ramos, Carlos J. Suárez González y Manuel Cancio Meliá, $1^{a}$ ed., Civitas, Madrid, 1997.

-, ID., «La imputación objetiva, especialmente en el ámbito de las instituciones jurídico-penales "riesgo permitido", "prohibición de regreso" y "principio de confianza"», trad. Enrique Peñaranda Ramos, JAKOBS, G., Estudios de Derecho penal, 1ª ed., Civitas, Madrid, 1997, pp. 209 a 222.

-, ID., «La interrupción del tratamiento a solicitud del paciente y el parágrafo 216 StGB (homicidio a petición de la víctima)», trad. Manuel Cancio Meliá, JAKOBS, G., Estudios de Derecho penal, $1^{\text {a }}$ ed., Civitas, Madrid, 1997, pp. 413 a 422 .

-, ID., «La prohibición de regreso en los delitos de resultado. Estudio sobre el fundamento de la responsabilidad jurídico-penal en la comisión», trad. Manuel Cancio Meliá, JAKOBS, G., Estudios penales de Derecho penal, $1^{\text {a }}$ ed., Civitas, Madrid, 1997.

-, ID., «Representación del autor e imputación objetiva», trad. Carlos J. Suárez González, JAKOBS, G., Estudios de Derecho penal, $1^{\text {a }}$ ed., Civitas, Madrid, 1997, pp. 223 a 240.

-, ID., «Sobre el tratamiento de los defectos volitivos y de los defectos cognitivos», trad. Carlos J. Suárez González, JAKOBS, G., Estudios de Derecho penal, $1^{\text {a }}$ ed., Civitas, Madrid, 1997, pp. 127 a 146.

-, ID., «Conocimiento y desconocimiento de la norma», trad. Marcelo A. Sancinetti, JAKOBS Günther / STRUENSEE Eberhard / SAncinetTi Marcelo A., Problemas capitales del Derecho penal moderno. Libro Homenaje a Hans Welzel, Hamurabi, Buenos Aires, 1998, pp. 57 a 80.

-, ID., «Accesoriedad sobre los presupuestos de la organización común», RPJ, $3^{\text {a }}$ época, núm. 59, Madrid, 2000.

-, ID., «El ocaso del dominio del hecho. Una contribución a la normativización de los conceptos jurídicos», JAKOBS Günther / CANCIO Melí́ Manuel, El Sistema funcional del Derecho penal, Lima, 2000.

-, ID., Bases para una teoría funcional del Derecho penal, trad. Cancio Meliá / Feijoo Sánchez / Peñaranda Ramos / Sancinetti / Suárez González, presentación Dino Carlos Caro Coria, Palestra Editores, Lima, 2000.

-, ID., «La autoría mediata con instrumentos que actúan por error como problema de imputación objetiva», trad. Manuel Cancio Meliá, JakoBs, G., Bases para una teoría funcional del Derecho penal, $1^{\text {a }}$ ed., Palestra Editores, Lima, 2000, pp. 249 a 268, también en con el mismo título en Cuadernos de Conferencias y Artículos, núm. 15, Universidad Externado de Colombia, $1^{a}$ ed., Bogotá, 1996.

-, ID., «La omisión, estado de la cuestión», trad. Javier Sánchez-Vera Gómez-Trelles, Roxin Claus / JAKOBS Günther / SCHÜNEMANn Benrd / Frisch Wolfgand / KÖHLER Michael, Sobre el estado de la teoría del delito, (Seminario en la Universitat Pompeu Fabra), 1ª ed., Civitas, Madrid, 2000, pp. 131 a 153.

-, ID., «La relevancia del dominio del acto para la determinación de la participación», trad. Miguel Polaino Navarrete, $R C P$, núm. 6, Corrientes/Argentina, 2000, pp. 87 a 106.

-, ID., «Sobre el injusto del suicidio y del homicidio a petición. Estudio sobre la relación entre juricidad y eticidad», trad. Manuel Cancio Meliá, JAKOBS, G., Bases para una teoría funcional, $1^{\text {a }}$ ed., Palestra Editores, Lima, 2000. pp. 309 a 348. 
-, ID., «Sobre la teoría de la pena», trad. Manuel Cancio Meliá, JAKOBS, G., Bases para una teoría funcional del Derecho penal, presentación Dino Carlos Caro Coria, $1^{a}$ ed., Palestra Editores, Lima, 2000, pp. 59 a 108, también con el mismo título en Cuadernos de conferencias y artículos, trad. Manuel Cancio Meliá, núm. 16, Centro de Investigaciones de Derecho Penal y Filosofía del Derecho, Universidad Externado de Colombia, Bogotá, 1999.

-, ID., Injerencia y dominio del hecho. Dos estudios sobre la parte general del derecho penal, trad. Manuel Cancio Meliá, Bogotá, 2001.

-, ID., «La normativización del Derecho penal en el ejemplo de la participación», trad. Manuel Cancio Meliá, Modernas tendencias en la ciencia del Derecho pena y la criminología, UNED, Madrid, 2001, pp. 619 a 642.

-, ID., «Consumación material en los delitos contra la persona. Al mismo tiempo, una contribución a la generalización de la parte especial», trad. Sergi Cardenal Montraveta, revisada por Manuel Cancio Meliá, RECPC, núm. 04-13, 2002, el original apareció en Schünemann, Achenbach, Bottke, Haffke, Rudolphi (eds.), Festschrift für Claus Roxin zum 70. Geburstag, am 15. Mai 2001, 2001, pp. 793 a 810.

-, ID., ¿Cómo protege el Derecho penal y qué es lo que protege? Contradicción y prevención; protección de bienes jurídicos y protección de la vigencia de la norma», trad. Manuel Cancio Meliá, JAKOBS, G., Sobre la normativización de dogmática jurídico-penal, trad. Manuel Cancio Meliá y Bernardo José Feijoo Sánchez, $1^{a}$ ed., Thomson Civitas, 2003, pp. 47 a 74.

-, ID., «Derecho penal del ciudadano y Derecho penal del enemigo», trad. Manuel Cancio Meliá del manuscrito en alemán «Bürgerstrafrecht und Feindstrafrecht», JAKOBS Günther / CANCIO MELIÁ Manuel, Derecho penal del enemigo, $1^{\mathrm{a}}$ ed., Thomson Civitas, 2003, pp. 19 a 56.

-, ID., «El lado subjetivo del hecho», trad. Manuel Cancio Meliá del manuscrito «Die subjektive Tatseite», JAKOBS, G., Sobre la normativización de dogmática jurídico-penal, trad. Manuel Cancio Meliá y Bernardo José Feijoo Sánchez, $1^{\mathrm{a}}$ ed., Thomson Civitas, 2003, pp. 75 a 100.

-, ID., «La idea de la normativización en la dogmática jurídico-penal», trad. Manuel Cancio Meliá del manuscrito Die Idee der Normativierung in der Strafrechtsdogmatik, JAKOBS, G., Sobre la normativización de dogmática jurídicopenal, trad. Manuel Cancio Meliá y Bernardo José Feijoo Sánchez, 1a ed., Thomson Civitas, 2003.

-, ID., Sobre la normativización de la dogmática jurídico-penal, trad. Manuel Cancio Meliá y Bernardo José Feijoo Sánchez, Thomson Civitas 2003.

-, ID., «Acción y omisión en Derecho penal», trad. Carlos Rey Sanfiz y Javier Sánchez-Vera Gómez-Trelles, JAKOBS, G., Dogmática de Derecho penal y la configuración normativa de la sociedad, $1^{\mathrm{a}}$ ed., Thomson Civitas, 2004, pp. 149 a 170, también con el mismo título en $C P C$, trad. Carlos Rey Sanfiz y Javier Sánchez-Vera Gómez-Trelles, 2001.

-, ID., Dogmática de Derecho penal y la configuración normativa de la sociedad, $1^{\text {a }}$ ed., Thomson Civitas, 2004.

-, ID., «La ciencia del Derecho penal ante las exigencias del presente», trad. Teresa Manso Porto, JAKOBS, G., Dogmática de Derecho penal y la configuración normativa de la sociedad, $1^{\mathrm{a}}$ ed., Thomson Civitas, $2004, \mathrm{pp} .27$ a 50.

-, ID., «La denominada actio libera in causa», trad. Pilar González Rivero, JAKOBS, G., Dogmática de Derecho penal y la configuración normativa de la sociedad, $1^{\text {a }}$ ed., Thomson Civitas, 2004, pp. 209 a 230, también con el mismo título en Revista Peruana de Doctrina y Jurisprudencia Penales, 2, 2001, pp. 201 y ss.

-, ID., «La imputación penal de la acción y de la omisión», trad. Javier Sánchez-Vera Gómez-Trelles, JAKOBS, G. Dogmática de Derecho penal y la configuración normativa de la Sociedad, $1^{a}$ ed., Thomson Civitas, 2004, pp. 99 a 148, con el mismo título en Cuadernos de Conferencias y artículos, trad. Javier Sánchez-Vera, núm. 12, Universidad Externado de Colombia, Centro de Investigaciones de Derecho Penal y Filosofía del Derecho, 1996.

-, ID., «Personalidad y exclusión en Derecho penal», trad. Teresa Manso Porto, JAKOBS, G., Dogmática de Derecho penal y la configuración normativa de la sociedad, $1^{\mathrm{a}}$ ed., Thomson Civitas, Madrid, 2004, pp. 51 a 74, también en Courakis ed., Die Strafrechtwissenschaft im 21. Jahrhundert, Festschrift für Dionysios Spinellis, T. 1, 2001.

-, ID., «Una teoría de la intervención delictiva», JAKOBS, G., El lado comunicativo y el lado silencioso del Derecho penal. Expectativas normativas, intervención delictiva, Derecho penal del enemigo, edición a cargo de Miguel Polaino-Orts, Universidad de Sevilla, 2014, pp. 55 a 76.

JANSÁ, Josep Ma., La Coartación de la Libertad a través de las sectas Destructivas, Una Sutil Forma de Violencia, Barcelona, 2003.

JAVALOY MAZÓN Federico / RoDRÍGUEZ-CARBALLEIRA Álvaro, «Las sectas ante los Tribunales. El rol del psicólogo», Anuario de Sociología y Psicología Jurídicas, 13, 1987, pp. 73 a 82.

JERICÓ OJER, Leticia, «La desobediencia civil: Concepto y tratamiento jurídico (A propósito del corte de carreteras para solicitar la gratuidad de la autopista A-15 y otros supuestos análogos», Revista Jurídica de Navarra, 39, 2005 , pp. 139 a 174.

-, ID., El conflicto de conciencia ante el derecho penal, Wolters Kluwer, La Ley, 2007.

JESCHECK Hans-Heinrich / WeIGEND Thomas, Tratado de Derecho penal, Parte General, $5^{\mathrm{a}}$ ed., ampliada y renovada, trad. Miguel Olmedo Cardenete, Granada, 2002.

JiMÉNEZ DE AsúA, Luis, Tratado de Derecho penal, T. III, Losada, Buenos Aires, 1951. 
JIMÉNEZ DíAZ, María José, «Delitos relativos a la prestación social sustitutoria. Su problemática aplicación», II Parte, CPC, 55, 1995, pp. 43 a 122.

JiMÉNEZ VILLAREJO, José, «Objeción de conciencia e insumisión. Una aproximación desde el derecho penal», Vinculación del Juez a la ley penal, CDJ, XVII, Consejo General del Poder Judicial, Madrid, 1995.

JORDÁN VILLACAMPA, María Luisa, «Aproximación al tema de las sectas pseudorreligiosas», Dimensiones Jurídicas del Factor Religioso. Estudio al profesor López Alarcón, Murcia, 1987.

-, ID., Las sectas pseudorreligiosas, Ministerio de Justicia, Centro de publicaciones, Madrid, 1991.

JORGE BARREIRO, Agustín, «La relevancia jurídico-penal del consentimiento del paciente en tratamientos médicoquirúrgicos», $C P C, 1982$.

JOSHI JUBERT, Ujala, La doctrina de la «actio libera in causa» (ausencia de acción o inimputabilidad provocada por el sujeto), Bosch, Barcelona, 1992.

-, ID., «Actio libera in causa y delitos cometidos bajo la influencia de las drogas: una nueva orientación en la jurisprudencia del tribunal Supremo», La Ley, 1/1994.

-, ID., «Sobre el concepto de organización en el delito de tráfico de drogas en la jurisprudencia del TS», ADPCP, 1995, pp. 657 a 683.

JUANES PECES, Ángel, «Efectos de la reforma del Código penal en materia de organizaciones criminales y terrorismo», XXXIII Jornadas de la Abogacía General del Estado, El Nuevo Código penal, 18 de noviembre de 2010, Editada por el Ministerio de Justicia, Secretaria General Técnica, pp. 561 a 578.

KANT, Immanuel, «Über den Gemeinspruch: Das mag in der Theorie richtig sein, taugt aber nicht für die Praxis», Berlinische Monatsschrift, Vol. 22, 1793.

-, ID., Sobre la paz perpetua, trad. Joaquín Abellán y presentación Antonio Truyol y Serra, $6^{a}$ ed., Madrid, Tecnos, 1998.

-, ID., Crítica de la razón práctica, versión castellana y estudio preliminar de Roberto R. Aramayo, $5^{\mathrm{a}}$ reimpresión, Alianza Editorial, 2007.

-, ID., Fundamentación para una metafísica de las costumbres, trad., estudio preliminar y apéndices Roberto Rodríguez Aramayo, $3^{\text {a }}$ reimp. 2008 de la $1^{a}$ ed. 2002, Alianza Editorial.

-, ID., Crítica del juicio, ed. y trad. Manuel García Morente, $2^{\text {a }}$ ed, Austral, Ciencias y Humanidades, 2009.

KaUfmann, Armin, Die Dogmatik der Unterlassungsdelikte, Göttingen, 1959.

-, ID., «Die Dogmatik im Alternativ-Entwurf», ZstW, 80, 1968, pp. 34 a 53.

-, ID., «Die Dogmatik im Alternativ-Entwurf», Strafrechtsdogmatik zwischen Sein und Wert, Carl Heymanns Verlag, Köln, 1982 (colección de artículos).

-, ID., Dogmática de los delitos de omisión, trad. Joaquín Cuello Contreras, José Luis Serrano González de Murillo (Edt.), Marcial Pons, 2006.

KAUFMANN, Arthur, Das Schuldprinzip. Eine strafrechtlich-rechtsphilosophische, Carl Winter, Heidelberg, 1961.

-, ID., «Rechtsfreier Raum und eigenverantwortliche Entscheidung», Maurach-Festschrift, Karlsruhe, 1972, pp. 327 y ss.

-, ID., «¿Relativización de la protección jurídica de la vida?», trad. Silva Sánchez, CPC, núm. 31, 1987, pp. 39 a 54.

KINDHÄUSER, Urs, Gefährdung als Straftat, Frankfurt, 1989.

-, ID., «La estafa como autoría mediata», trad. Jorge Fernando Perdomo Torres, KINDHÄUSER, U., Estudios de Derecho penal patrimonial, José Antonio Caro John y Percy García Cavero (Edit.), $1^{\text {a }}$ ed., Grijley, 2002, pp. 83 a 124, originalmente en alemán «Betrug als vertypte mittelbare Täterschaft», publicado en el Libro Homenaje a Günter Bemmann, 1997, pp. 339 a 361.

-, ID., «La fidelidad al Derecho como categoría de la culpabilidad», Cuestiones actuales de derecho penal y patrimonial, Aras Editores, Lima, 2005.

KNODEL, Klaus Dieter, Der Begriff der Gewalt im Strafrecht, München, Berlin, 1962.

LABRAda RuBio, Valle, Introducción a la teoría de los Derechos Humanos: Fundamento. Historia. Declaración Universal de 10 de diciembre de 1948, Civitas, $1^{\text {a }}$ ed., 1998.

LAMARCA PÉREZ, Carmen, Tratamiento jurídico del terrorismo, Centro de Publicaciones del Ministerio de Justicia, Secretaria General Técnica, Madrid, 1985.

LAMPE, Ernst-Joachim, «Injusto del sistema y sistemas de injusto», trad. Carlos Gómez-Jara Díez, Ernst-Joachim LAMPE, La Dogmática jurídico-penal entre la ontología social y el funcionalismo, ed. y trad. española de GómezJara Díez C / Orce G / Polaino-Orts M., Grijley, Lima, 2003, pp. 97 y ss.

LANDA, Shirley, «Niños en sectas. Sus relaciones familiares y su educación», Sectas y Sociedad, Ponencia del I Congreso Internacional celebrado en San Cugat del Vallés, Asociación Pro-Juventud, Barcelona, 1987.

LANGONE, Michael D., La conversión a las sectas peligrosas: teoría, investigación y tratamiento, Boston, 1981.

-, ID., «Psychological abuse», Cultic Studies Journal, 9, 1992, pp. 206 a 218.

Lascuraín SÁnchez, Juan Antonio, vv.aa., Compendio de Derecho Penal, Parte especial, Vol. II, DíAZ-Maroto Y VILLAREJO Julio / ECHANO BASALDUA Juan Ignacio / LASCURAÍn SÁNCHEZ Juan Antonio / LOZANO MIRALLES José / 
Mendoza Buergo Blanca / Molina Fernández Fernando / PÉRez Manzano Mercedes / SuÁrez GonzÁlez Carlos / Dir. Miguel Bajo Fernández, Centro de Estudios Ramón Areces, 1998.

LAURenzo Copello, Patricia, Dolo y conocimiento, Tirant lo Blanch, Valencia, 1999.

LE Bon, Gustave, Psicología de las multitudes, $28^{a}$ ed. Feliz Alcan, París, 1921.

LEMERT, Edwin M., Human deviance, social problems and social control, Prentice-Hall, Englewood Cliffs, 1967.

LESCH, Heiko Hartmunt, Das Problem Der sukzessiven Beihilfe, Frankfurt am Main, New York, P. Lang, 1992.

-, ID., «Intervención delictiva e imputación objetiva», trad. Javier Sánchez-Vera, ADPCP, 1995, pp. 911 a 972.

-, ID., «La función de la pena», trad. Javier Sánchez, Cuadernos Luis Jiménez de Asúa, núm. 4, Dykinson, Madrid, 1999.

LIFTON, Robert, Thought Reform and Psychology of Totalism: A Study of Brainwashing in Red China, Nueva York, Norton, 1961.

LISZT, Franz von, Tratado de Derecho penal, T. II, trad. Jiménez de Asúa y Quintiliano Saldaña, $3^{\text {a }}$ ed. de $20^{\text {a }}$ ed. alemana, Ed. Reus.

LlAMAZARES FERNÁNDEZ, Dionisio, «Sectas y Derecho fundamental de Libertad de conciencia», vv.aa., Aspectos socio-jurídicos de las sectas desde una perspectiva comparada / The Oñati Internacional Institute for the Sociology of Law, 1991, edited by Juan Goti Ordeñana.

-, ID., Derecho de la libertad de conciencia, I, Libertad de conciencia y laicidad, $1^{\text {a }}$ ed., Civitas, 1997.

Lofland, John, Doomsday Cult: A Study of Conversion, Proselytization, and Maintenance of Faith, Nueva York, Irving.

LOFLAND John / STARK Rodney, «Become a World-Saber: a theory of conversion to a deviant perspective», American Sociological Review, 30, 1965, pp. 862 a 875.

Lombroso, Cesare, L'Uomo delinquente, $2^{\mathrm{a}}$ ed., Boca, Turín, 1870.

LÓPEZ ALARCÓN, Mariano, «Dimensión orgánica de las confesiones religiosas en el Derecho español», Ius Canonicum, Vol. XX, 1980.

-, ID., «El interés religioso y su tutela por el Estado», vv.aa., Derecho Eclesiástico del Estado Español, $2^{\mathrm{a}}$ ed., Pamplona, 1983.

-, ID., «Tutela de la libertad religiosa», Derecho eclesiástico del Estado Español, coord. Javier Ferrer Ortiz, Ediciones Universidad de Navarra, 1996, pp. 153 a 188.

-, ID., «Las Sectas y los NMR's. Problemas de su tratamiento jurídico. ¿Reconocimiento o prohibición?», Ius Canonicum, Vol. 37, núm. 74, julio-diciembre, 1997, pp. 451 a 487.

LÓPEZ BARJA DE QUIROGA, Jacobo, «Problemas actuales de los delitos de estafa, fraude de subvenciones, apropiación indebida y administración desleal», vv.aa., Derecho penal económico, Consejo General del Poder Judicial, Manuales de Formación Continuada, Madrid, 2001.

-, ID., Derecho penal, Parte General, III, Los fundamentos de extensión de la tipicidad, Leynfor Siglo XXI, 2001.

LuhMANN, Niklas, «Die Gewissensfreiheit und das Gewissen», AÖR, 90, 1965, pp. 257 a 286; también en ID., «Die Gewissensfreiheit und das Gewissen», Die Ausdifferenzierung des Rechts, Frankfurt a. M., 1981, pp. 326 a 359.

-, ID., Legitimation durch Verfahren, Luchterhand Verlag, 1969.

-, ID., «Die Funktion der Gewissensfreheit im oeffentlichen Recht», Funktion des Gewissens im Recht, Frankfurt a. M., 1970 , pp. 9 a 22.

-, ID., «Das Phänomen des Gewissens und die normative Selbstbestimmung der Persönlichkeit», Franz Böckle / ErnsWolfgang Böckenförde Hg., Naturrecht in der Kritik, Mainz, Grünewald, 1973, pp. 223 a 243.

-, ID., «Sistema jurídico y dogmática jurídica», trad. Ignacio de Otto Pardo, Centro de Estudios Constitucionales, Madrid, 1983.

-, ID., «La forma “persona”», LuHMAnN, N., Complejidad y modernidad: De la unidad a la diferencia, Trotta, ed. y trad. Josetxo Berian y José María García Blanco, 1998, pp. 231 a 244, originariamente "Die "Form Person"», Soziologische Ausklärung, 1985.

-, ID., «Inclusión y exclusión», LuHmann, N., Complejidad y modernidad: De la unidad a la diferencia, Trotta, ed. y trad. Josetxo Berian y José María García Blanco, 1998, pp. 167 a 196.

-, ID., Sistemas sociales. Lineamientos para una teoría general, 2ª ed., Anthropos, 1998.

-, ID., «Socialización y educación», LuHMANN, N., Complejidad y modernidad: De la unidad a la diferencia, Trotta, ed. y trad. Josetxo Berian y José María García Blanco, 1998, pp. 245 a 256.

-, ID., El derecho de la sociedad, $2^{\mathrm{a}}$ ed., Herder, 2005.

-, ID., La confianza, $1^{\text {a }}$ reimp. 2005, de la $1^{\text {a }}$ ed., 1996, Anthropos, México.

-, ID., Organización y decisión. Autopoiesis, acción y entendimiento comunicativo, intr. Darío Rodríguez Mansilla, Anthropos, $1^{\text {a }}$ reimp. 2005, de la $1^{\text {a }}$ ed. 1997, del original «Organisation und Entscheidung. Autopoiesis, Handlung und kommunikative Vertändigung», Zeitschrift für Soziologie, 11, núm. 4, octubre de 1982.

-, ID., Poder, $1^{\text {a }}$ reimp. 2005 de la $1^{\text {a }}$ ed. 1995, Anthropos.

-, ID., La sociedad de la sociedad, Herder, 2007. 
-, ID., «El proceso de diferenciación de la religión», trad. Pedro Morandé, LuHMANN, N., Sociología de la religión, Herder, 2009, pp. 195 a 288. Corresponde al capítulo IV en LuHMAnN, N., Gesellchaftsstruktur und Semantik. Studien zur Wissenssoziologie der modernen Gessellschaft, T. III, Suhrkamp, Frankfurt, 1989.

-, ID., «La dogmática religiosa y la evolución de las sociedades», trad. Marco Ornelas, LuHMANN, N., Sociología de la religión, Herder, 2009, pp. 75 a 194. El artículo corresponde a la traducción al inglés del capítulo «Religiöse Dogmatik und Gessellschaftliche Evolution» en LuHMAnN, N., Funktion der Religion, Suhrkamp, Frankfurt, 1977, pp. 77 a 181, trad. Peter Beyer, apareció en el libro Religious dogmatics and the evolution of societies de Niklas Luhmann, New York, Ed. E. Mellen Press., 1984.

-, ID., Los derechos fundamentales como institución (Aportación a la sociología política), Universidad Iberoamericana, 2010.

-, ID., Organización y decisión, Herder, 2010.

-, ID., Paradigm Lost: sobre la reflexión ética de la moral», LuHMANN, N., La moral de la sociedad, Trotta, recopilación de artículos, 2013, pp. 237 a 252.

-, ID., «Acuerdo sobre riesgos y peligros», LuHMANN, N., La moral de la sociedad, Trotta, recopilación de artículos, 2013, pp. 321 a 332.

-, ID., «¿Hay aún en nuestra sociedad normas irrenunciables?», LuHMANN, N., La moral de la sociedad, Trotta, recopilación de artículos, 2013, pp. 215 a 236.

-, ID., «Interacción, organización, sociedad. Aplicaciones de la teoría de sistemas», LuHMANN, N., La moral de la sociedad, Trotta, recopilación de artículos, 2013, pp. 197 a 214.

-, ID., «La ética como teoría reflexiva de la moral», LuHMANN, N., La moral de la sociedad, Trotta, recopilación de artículos, 2013, pp. 253 a 320.

-, ID., «La ética económica ¿es una ética?», LuHMANN, N., La moral de la sociedad, Trotta, recopilación de artículos, 2013, pp. 185 a 196.

-, ID., «La honradez de los políticos y la superior amoralidad de la política», LuHMANN, N., La moral de la sociedad, Trotta, recopilación de artículos, 2013, pp. 153 a 164.

-, ID., La moral de la sociedad, Ed. Trotta, recopilación de artículos, 2013.

-, ID., «La moral del riesgo y el riesgo de la moral», LuHMANN, N., La moral de la sociedad, Trotta, recopilación de artículos, 2013, pp. 333 a 344.

-, ID., «Las normas desde una perspectiva sociológica», LUHMANN, N., La moral de la sociedad, Trotta, recopilación de artículos, 2013, pp. 29 a 56.

-, ID., «Política, democracia, moral», LuHMANN, N., La moral de la sociedad, Trotta, recopilación de artículos, 2013, pp. 165 A 184.

-, ID., «Sociología de la moral», LuHMANN, N., La moral de la sociedad, Trotta, recopilación de artículos, 2013, pp. 57 a 152.

LuZÓn Cuesta, José María, Compendio de Derecho Penal, Parte General, 1996.

LuZÓn Domingo, Manuel, Tratado de la culpabilidad y de la culpa penal, Ed. Hispano-Europa, Barcelona 1960.

LUZÓN PEÑA, Diego-Manuel, «Injerencia, comisión por omisión y omisión de socorro (comentario a la Sentencia TS 24-3-1974)», Derecho Penal de la Circulación, Bosch, 1ª ed., Barcelona, 1985, pp. 119 a 130.

-, ID., «Problemas del intrusismo en el Derecho penal», ADPCP, 1985, pp. 669 a 702.

-, ID., «Estado de necesidad e intervención médica (o funcionarial, o de terceros) en caso de huelga de hambre intentos de suicidio y de autolesiones: algunas tesis», La Ley, T. I, 1988, pp. 992 a 1003.

-, ID., «La determinación objetiva del hecho. Observaciones sobre autoría en los delitos dolosos e imprudentes de resultado», $A D C P C, 1989$, pp. 889 a 913.

-, ID., «Problemas de las trasmisión y prevención del SIDA en el Derecho penal español», Santiago Mir Puig (ed.), Problemas jurídico penales del SIDA, Bosch, Barcelona, 1993, pp. 11 a 23.

-, ID., Curso de Derecho penal, Parte General, I, Universitas, Madrid, 1996.

-, ID., «Principio de alteridad o de identidad vs. principio de autorresponsabilidad. Participación en autopuesta en peligro consentida y equivalencia: el criterio del control del riesgo (versión con precisiones)», Libertades, Revista de la Fundación Internacional de Ciencias penales, núm. 0, Madrid, 2012.

-, ID., «Actuación en conciencia y objeción de conciencia como causa de justificación y como causa de exculpación frente a la punición del delincuente por convicción», InDret., 1/2013.

LÜCKE, Jörg, «Die Grundsätze der Verhältnismässigkeit und der Zumutbarkeit», DÖV, 1974, pp. 769 y ss.

Manzanares Samaniego José Luis / AlbaCar LóPez José Luis, Código Penal, Comentarios y Jurisprudencia, Granada, 1990.

MAQUEDA ABREU, María Luisa, Los delitos contra la libertad y seguridad de las personas, Granada, 1988.

-, ID., «Exigibilidad y derecho a no declararse culpable», ADPCP, 1991.

-, ID., «Las sectas destructivas ante el derecho», Eguzkilore, San Sebastián, diciembre, 2004, pp. 229 a 246.

MARAVER GÓMEZ, Mario, El principio de confianza en Derecho penal. Un estudio sobre la aplicación del principio de autorresponsabilidad en la teoría de la imputación objetiva, pról. Jorge Barreiro, $1^{\text {a }}$ ed., Civitas, 2009. 
MARCh James G / Simon Herbert A., Teoría de la organización, trad. Juan Maluquer Wahl, Ariel, Barcelona, 1961.

MARÍAS, Julián, Introducción a la Política de Aristóteles, Centro de Estudios Constitucionales, Madrid, 1970.

MARTín LORENZO, María, La exculpación penal. Bases para una atribución legítima de la responsabilidad penal, Tirant lo Blanch, Valencia, 2009.

MARTín SÁNCHEZ, I., El Derecho a la formación de la conciencia y su tutela penal, Tirant lo Blanch, Valencia, 2000.

MARTíNEZ ESCAMILLA, Margarita, La imputación objetiva del resultado, Edersa, 1992.

MArTíneZ Muñoz Daniel / CARretero SÁEZ Patricia / Alonso RAMos Laura Ma / Perales PizArro Antonio / RODRÍGUEZ RUIZ Óscar, «Sectas y Derecho Internacional», Sectas y Derechos Humanos / III Congreso Interuniversitario de Derecho Eclesiástico para Estudiantes, 21-24 Abril 1994, coordina la edición, M ${ }^{\mathrm{a}}$ Elena Buqueras Segura.

MARTínEZ Ruiz, Jesús, Los delitos de lesiones, Bosch, 2002.

MARTíNEZ-TORRÓN, Javier, «La objeción de conciencia en la jurisprudencia del Tribunal Supremo norteamericano», ADEE, I, 1985, pp. 395 a 458.

-, ID., «El derecho a la libertad religiosa en la jurisprudencia en torno al Convenio Europeo de Derecho Humanos», ADEE, II, 1986, pp. 403 a 496.

-, ID., «Ley del jurado y objeción de conciencia», REDC, 48, 1996, pp. 119 a 143.

-, ID., Normas de Derecho eclesiástico, Granada, 1998.

MARTíneZ-PEREDA, José Manuel, Magia y delito en España, pról. Julio Caro Baroja, Editorial Laida, 1991.

MARVELLI Elga / SCIARRINO Maria, L'evuluzione giuridica del plagio nella normativa italiana e sammarinese, Giornale scientifico a cura dell osservatorio Nazionale Abusi Psicologici, anno 4, N. 4, dicembre 2013, Sul filo del diritto.

Maturana Humberto / VAREla Francisco, De máquinas y seres vivos. Autopoiesis: la organización de lo vivo, $5^{\mathrm{a}}$ ed., Editorial Universitaria, Chile, 1998.

MAURACH, Reinhart, Tratado de Derecho penal, II, trad. Juan Córdoba Roda, pról. Octavio Pérez Vitoria Moreno, Ariel, Barcelona, 1962.

MAYER, Jean Francois, «El mundo de los nuevos movimientos religiosos», Cristianismo y sociedad, XXV/3 núm. 93, Tierra Nueva, México, D.F., 1987, pp. 21 a 36.

MEAD, George Herbert, Espíritu, persona y sociedad. Desde el punto de vista del conductismo social, intr. Charles W. Morris, presentación a la ed. castellana Gino Germani, Paidós, Barcelona-Buenos Aires-México, 2009.

MEINI, Iván, Responsabilidad penal del empresario por los hechos cometidos por sus subordinaos, Tirant lo Blanch, Valencia, 2003.

MERKEL, Adolf, Derecho penal, Parte especial, T. II, trad. P. Dorado, La España Moderna, Madrid.

Martínez Bernal, Juan Carlos, Lavado de Cerebro y su Desprogramación Psicológica, Universidad Gestalt de América, recuperado el 31 de Julio de 2007 de http://www.mundogestalt.com.

MEYER, TF., «Nouveaux mouvements religieux: une perspectiva historique et culturelle», Diritto dell' uomo e libertà dei gruppi religiosi. Problemi giuridici dei nuovi movimenti religiosi, Editado por Silvio Ferrari, Università degli Studi di Parma, Publicazioni della Facoltà di Giurisprudenza, nuova serie, 7, Padova (Cedam) 1989.

MEZGER, Edmund, Moderne Wege der Strafrechtsdogmatik, Berlín-Munich, 1950.

-, ID., Tratado de Derecho penal, T. II, trad. de la $2^{\mathrm{a}}$ ed. alemana de 1933 y notas al Derecho penal español por José Arturo Rodríguez Muñoz y Antonio Quintano Ripollés, 3ª ed. adicionada, y puesta al día, Madrid, 1957.

-, ID., Derecho Penal, Parte Especial. Libro de estudio, trad. de la $4^{\text {a }}$ ed. alemana de 1954 por Conrado A. Finzi, Editorial Bibliográfica Argentina, Buenos Aires, 1959.

Milgram, Stanley, Obediencia a la autoridad. Un punto de vista experimental, $4^{\mathrm{a}}$ ed., Editorial Declee de Brouwer, Bilbao, 1980.

MiLleR J., «The Utilization of Hypnotic techniques in Religious Conversion», Cultics Studies Journal, 1986, Vol. 3, núm. 2, pp. 243 a 250.

MIR PUIG, Santiago, «El delito de coacciones en el Código penal», ADPCP, T. XXX, núm. 2, Madrid, 1977, pp. 269 a 306.

-, ID., Adiciones de Derecho penal español a Jescheck, Tratado de Derecho penal, Parte general, II, Bosch, Barcelona, 1981.

-, ID., Derecho penal, Parte general, $(P G), 5^{\text {a }}$ ed., Reppetor, Barcelona, 1998.

-, ID., «Sobre la punibilidad de la tentativa inidónea en el nuevo código penal», RECPC, núm. 3, 2001;

-, ID., Introducción a las bases del Derecho penal: concepto y método, Montevideo, Bosch, 2003, $2^{\mathrm{a}}$ ed. reimp. $1^{\mathrm{a}}$ ed. 1976.

MIRA BENAVENT, Javier, «El concepto de violencia en el delito de coacciones», CPC, 22, 1984, pp. 95 a 181.

Molina FernándeZ, F., vv.aa., Compendio de Derecho Penal (Parte Especial), Vol. II, Ceura, Madrid, 1998.

MONGE FERNÁNDEZ, Antonia, «Derecho a la libertad y a la seguridad. Comentario a la sentencia del Tribunal Europeo de Derechos Humanos de 14 de octubre de 1999. Caso Riera Blume y otros contra España», AP, 25, 2001, pp. 557 y ss.

-, ID., El extranjero frente al Derecho penal. El error cultural y su incidencia en la culpabilidad, $1^{\mathrm{a}}$ ed., Bosch, 2008. 
MONTIEL, Juan Pablo, «Regulaciones de excepción y prohibición de analogía», InDret, 3/2013.

Marín Monroy, Antonio, Metasofía de la cultura. Normalismo. Lógica y Antifísica de la cultura y estudio de la cultura primitiva, ed. Hermanas Marín Padilla, Cometa, Zaragoza, 1990.

MONYER H / RÖSLER F / Roth G / SCHEICH H / Singer W / ELGER CE / Friederici AD / Koch C / LUHMANN H / Von Der MALsburg C / MEnZEl R., «Das Manifest. Elf führende Neurowissenschaftler über Gegenwart und Zukunf der Hirnforschung», Gehirn \& Geist, núm. 6, 2004, pp. 30 y ss.

MoraledA, José, Las sectas hoy. Nuevos movimientos religiosos, Ed. Sal Terrae, Cuadernos Fe y Securalidad, 20, $2^{\mathrm{a}}$ ed., Bilbao, 1992.

Morillas Cueva, Lorenzo, Los delitos contra la libertad religiosa (Especial consideración del artículo 205 del Código penal español), pról. Sainz Cantero, Universidad de Granada, 1977.

-, ID., «Los delitos contra la libertad de conciencia y de culto», Documentación Jurídica, Monográfico dedicado a la Propuesta de Anteproyecto del nuevo Código penal, Vol. 2, diciembre/enero, 1983, Madrid, pp. 1339 y ss.

-, ID., vv.aa., Derecho penal español, Parte especial, $2^{\mathrm{a}}$ ed. revisada, coord. Manuel Cobo del Rosal, Dykinson, 2005.

Moscovici, S., (ed.), Psicología Social (I), Paidós, Barcelona, 1985.

Moscovici S / FAUCHEUX C., «Social influence, conformity bias, and the study of active minorities», Advances in Experimental Social Psychology, 6, 1972, pp. 149 a 202.

Moser, Tilmann, «Nachwort», Psychoanalyse und Justiz, Mitscherlich, Suhrkamp. 1971.

Motilla De La Calle, Agustín, Los Acuerdos entre el Estado español y las confesiones religiosas en el Derecho español, Bosch, Barcelona, 1985.

-, ID., Sectas y derecho en España, Editoriales de Derecho Reunidas, Madrid, 1990.

-, ID., «La protección de la religión en el Código Penal español de 1995», Quaderni di Diritto e Politica Ecclesiastica, Vol. II, Milán, 1996, pp. 453 a 463.

Moyano, Antonio Luis, Sectas, la amenaza en la sombra. Cómo actúan, quiénes son y cómo defendernos, Nowtilus Frontera, Colección La puerta del misterio, $2^{\mathrm{a}}$ ed., 2002.

Muñoz Conde Francisco / García ArÁn Mercedes, Derecho Penal, Parte General, $(P G), 6^{\mathrm{a}}$ ed. revisada y puesta al día, Tirant lo Blanch, Valencia, 2004.

MuÑoz Conde, Francisco, Derecho penal, Parte especial, Universidad de Sevilla, 1976.

-, ID., «El principio de culpabilidad», Jornadas de profesores de Derecho penal, Universidad de Santiago de Compostela, 1976.

-, ID., Introducción al Derecho penal, Bosch, Barcelona, 1975.

-, ID., «Introducción», RoXIN, C., Culpabilidad y prevención en Derecho penal, trad. intr. y notas Francisco Muñoz Conde, Reus, Madrid, 1981, pp. 13 a 40.

-, ID., «Provocación al suicidio mediante engaño: un caso límite entre autoría mediata en asesinato e inducción y ayuda al suicidio», ADPCP, 1987, pp. 301 a 317, también con el mismo título en Revista de la Facultad de Derecho de la Universidad de Granada, núm. 13, 1987, pp. 19 a 38.

-, ID., El error en Derecho penal, Tirant lo Blanch, Valencia, 1989.

-, ID., Derecho penal, Parte especial, Tirant lo Blanch, Valencia, 1992.

-, ID., «La objeción de conciencia en Derecho Penal», Política criminal y nuevo Derecho penal, Libro Homenaje a Claus Roxin, Bosch, Barcelona, 1997, pp. 279 a 294, también con el mismo título en Separata de Nueva Doctrina Penal, 1996, pp. 87 a 102.

-, ID., «Problemas de autoría y participación en la criminalidad organizada», Delincuencia organizada: aspectos penales, procesales y criminológicos, Universidad de Huelva, 1999, pp. 151 a 159.

-, ID., «¿Dominio de la voluntad en virtud de aparatos organizados en organizaciones "no desvinculadas del Derecho"?», RP, 2000, núm. 6, pp. 104 a 114.

-, ID., ¿Cómo imputar a título de autores a las personas que, sin realizar acciones ejecutivas deciden la realización de un delito en el ámbito de la delincuencia organizada y empresarial?», Modernas Tendencias en la Ciencia del Derecho penal y en la Criminología, UNED, Facultad de Derecho, Madrid, 2001, pp. 501 a 531.

-, ID., «Problemas de autoría y participación en el Derecho penal Económico. ¿Cómo imputar a título de autores a las personas que sin realizar acciones ejecutivas, deciden la realización de un delito en el ámbito de la delincuencia económica?», La Ley, enero 2002, núm. 9.

-, ID., Derecho penal, Parte especial, $(P G), 15^{\text {a }}$ ed. revisada y puesta al día, Tirant lo Blanch, Valencia, 2004.

-, ID., Teoría general del delito, $3^{\text {a }}$ ed., Tirant lo Blanch, Valencia, 2004.

-, ID., «De nuevo sobre el "Derecho penal del enemigo"», RP, núm. 16, La Ley, 2005, pp. 123 a 137.

Musti, Lucia, «Aspectos legales y jurídicos del satanismo», Sectas satánicas y fe cristina, pról. Julián García Hernando, Editorial Palabra, 1998,

Müssig, Bernd, «Desmaterialización del bien jurídico y de la política criminal. Sobre las perspectivas y los fundamentos de una teoría crítica del bien jurídico hacia el sistema», CDJP, 2001, II, pp. 229 y ss.

-, ID., «Comentario al $35 \mathrm{StGB}$ », Bernd von Heintschel-Heinergg (redactor), Münchener Kommentar zum Strafgesetzbuch, Vol. 1, 1-51 StGB, München, 2003, 35. 
Mylonopoulos, Christos, Über das Verhältnis vom Handlungs-und Erfolgsunwert im Strafrecht. Eine Studie zur Entwicklung der personale Unrechtslehren, Köln, Berlin, Bonn, München, 1981.

NAGLER, Johannes, «Der Überzeugungsverbrecher», Der Gerichtsaal Bd. 94, 1927, pp. 48 y ss.

NAVARrete Urieta, José María, «La omisión de socorro», Revista de la Facultad de Derecho de la Universidad Complutense de Madrid, RFDUCM, Vol. III, núm. 6, 1959, págs. 419 a 431.

NAVARRo VALls Rafael / MARTínEZ-TORRÓN Javier, Las objeciones de conciencia en el Derecho Español y Comparado, McGraw-Hill, Madrid, 1997.

NAVAS RENEDO, Begoña, Tratamiento jurídico de las sectas. Análisis comparativo de la situación en España y Francia, Comares, 2002.

NIEPOTH, Bukhard, Der untaugliche Versuch beim unechten Unterlassungsdelikt, Frankfurt a. M., 1994.

NIETZSCHE, Friedrich, Así habló Zaratustra, Alianza Editorial, 1997.

-, ID., Aurora, Edimat, 1998.

-, ID., El anticristo, Edimat, 1998.

-, ID., Gaya ciencia, Edimat, 1998.

-, ID., Genealogía de la moral, Edimat, 1998.

-, ID., El caminante y su sombra, estudio preliminar Enrique López Castellón y trad. Luis Díaz Marín, Edimat, 1999.

-, ID., La Voluntad de Poder, pról. Dolores Castrillo Mirat, 17 ed., Edaf, 2009.

NoLL, P., «Der überzeugungstäter im Strafrecht. Zugleich einen Auseinandersetzung mit Gustav Radbruchs rechtsphilosophischem relativismus», $Z S t W, 78,1966$, Walter de Gruyter \& co. Berlin, 1966, pp. 638 y ss.

Octavio De Toledo Y Ubieto Emilio / Huerta Tocildo Susana, Derecho penal, Parte general, Teoría jurídica del delito, $2^{a}$ ed., corregida y aumentada, Rafael Castellanos (Edit.), Madrid, 1986.

OlIVER ARAujo, Joan, La objeción de conciencia al servicio militar, Civitas, Madrid, 1993.

OlMEDO CARDENETE, Miguel Domingo, La inducción como forma de participación accesoria, Edersa, Madrid, 1999.

ORNELAS, Marco, «La sociología de la religión de Niklas Luhmann», LuHMANN, N., Sociología de la religión, Herder, 2010.

OSTERMEYER, Helmut, Die bestrafte Gesellschaft, Hanser Verlag, München, 1975.

PARDO Michael S / PATTERSON Dennis, «Fundamentos filosóficos del Derecho y la Neurociencia», InDret., $2 / 2011$.

PARSONS, Talcott, Ensayos de teoría sociológica, Paidós, Buenos Aires, 1954.

-, ID., Hacia una teoría general de la acción, vv.aa., dir. Talcott Parsons y Edward A. Shils, Ed. Kapelusz, Buenos Aires, 1968.

-, ID., La estructura de la acción social. Estudios de teoría social, con referencia a un grupo de recientes escritores europeos, I y II, Ediciones Guadarrama, Madrid, 1968.

-, ID., El sistema Social, Alianza Editorial, 1998.

PASCUAL Jordi / VidAuRRÁZAGa MEZA Enrique, Grupos de manipulación psicológica en Cataluña, situación y conceptos, Carles Riera i Albert y Jordi Pascual i Saüc (dir.), AIS, Servicio de Estudios, 2005.

PASTOR MuÑOZ, Nuria, «El redescubrimiento de la responsabilidad de la víctima en la dogmática de las estafas», ¿Libertad económica o fraudes punibles? Riesgos penalmente relevantes e irrelevantes en la actividad económicoempresarial, Jesús-María Silva Sánchez (dir.), Marcial Pons, Madrid-Barcelona, 2003, pp. 67 a 90.

-, ID., La determinación del engaño típico en el delito de estafa, pról. Jesús-María Silva Sánchez, Marcial Pons, Madrid-Barcelona, 2004.

-, ID., Los delitos de posesión y los delitos de estatus: una aproximación político-criminal y dogmática, Atelier, 2005.

PAWLIK, Michael, «Una teoría del estado de necesidad exculpante. Bases filosófico-jurídicas y configuración dogmática», InDret, 10/2015, versión originalmente en alemán en «Eine Theorie des entschuldigenden Notstandes: Recchtsphilosophische Grundlagen und dogmatische Ausgestaltung», JRE, 11, 2003, pp. 287 a 315.

PECES-BARBA, Gregorio, Derechos fundamentales, Madrid, 1983.

-, ID., «Desobediencia civil y objeción de conciencia», Anuario de Derechos Humanos, 1988-1989.

Peñaranda Ramos, Enrique, vv.aa., Compendio de Derecho Penal, Parte Especial, Vol. I, CANCIO Meliá Manuel / Feijoo SÁnchez Bernardo / Peñaranda Ramos Enrique / PÉrez Manzano Mercedes, Director Miguel Bajo Fernández, Editorial Centro de Estudios Ramón Areces, 2003.

PÉREZ Del VAlle, Carlos, Conciencia y Derecho penal. Límites a la eficacia del Derecho penal en comportamientos de conciencia, Comares, Granada, 1994.

-, ID., «La individualización de la pena y su revisión», Estudios sobre el nuevo Código Penal, dirigidos por Rosal Blasco, 1997.

-, ID., «Sobre los orígenes del "Derecho penal del enemigo”. Algunas reflexiones en torno a Hobbes y Rousseau», $C P C$, 75, 2001, pp. 597 a 613.

-, ID., «La persona del Derecho penal en la filosófica de Hegel», Dogmática y Ley penal. Libro Homenaje a Enrique Bacigalupo, T. I, Jacobo López Barja de Quiroga y José Miguel Zugaldía Espinar (coords.), Instituto Universitario de Investigaciones Ortega y Gasset, Marcial Pons, Madrid-Barcelona, 2004.

PÉREZ JA / MugnY G., «Categorización e influencia minoritaria», Anuario de Psicología, 32, 1985, pp. 99 a 116. 
PÉREZ-MadrID, Francisca, La tutela penal del factor religioso en el Derecho español, EUNSA, Ediciones Universidad de Navarra, 1995.

PÉREZ MANZANo, Mercedes, vv.aa., Manual de Derecho Penal, Parte Especial, Delitos patrimoniales y socioeconómicos, BAJO FERnÁNDEZ Miguel / PÉrez MANZANo Mercedes / SuÁrez GonZÁlez Carlos, $2^{\mathrm{a}}$ ed., Editorial Centro de Estudios Ramón Areces, 1993.

Perlado, Miguel, «La atadura sectaria», Intercambios, Papeles de Psicoanálisis, 15, 2005, pp. 27 a 35.

-, ID., «La violencia del sectarismo», Ponencia presentada en el XVII Congreso Internacional de la Asociación de Estudios Médico Psicológicos y Religiosos (AIEMPR), Estrasburgo, del 10 al 14 de julio de 2006.

-, ID., «La intervención clínica con pacientes vinculados a sectas», CUEVAS BARRANQUERo JM / PERLADO M., Abuso psicológico grupal y sectas destructivas, AIIAP, Barcelona, 2011, pp. 43 a 70.

PERRÓN, Walter, «Justificación y exclusión de la culpabilidad a la luz del Derecho comparado (con especial consideración al Derecho penal español)», trad. Silva Sánchez, ADPCP, 1988.

PETERS, Karl, «Überzeugungstäter im Strafrecht», Zeitschrift für die Gesamte Strafrechtswissenschaft, 78-1966.

-, ID., «Überzeugungstäter und Gewissenstäter», Zeitschrift für Hellmuth Mayer zum 70. Geburstag, Duncker \& Humblot, Berlin, 78, 1966, pp. 257 a 280.

-, ID., «Anmerkung zum BverfG, Beschluss v. 11.4.1972», JZ, 1972, pp. 515 a 521.

-, ID., Das Gewissen aus rechtlicher psycologischer und teologischer Sicht, I, Peters (Hrsg), Evangelischer Akademie, Mülheim a. d. Ruhr, 1974.

PIÑA ROCHEFORT, Juan Ignacio, Rol Social y sistema de imputación. Una aproximación sociológica a la función del derecho penal, pról. J-M Silva Sánchez, Bosch, Barcelona, 2005.

Planchat TeRUEl, José María, «Un conflicto entre conciencia y ley: a propósito de la incomparecencia a mesa electoral por motivos religiosos», CDJ, 1995, XVII, Vinculación del Juez a la ley, 1995, pp. 259 a 273.

PlATón, «Apología de Sócrates», Diálogos I, intr. general Emilio Lledó Íñigo, trad. y notas de Calonge Ruiz, E. Lledó Iñigo y García Gual, $2^{\mathrm{a}}$ reimp. de la $1^{\mathrm{a}}$ ed., Gredos, Madrid, 1985.

-, ID., «Critón», Diálogos I, intr. general Emilio Lledó Íñigo, trad. y notas de Calonge Ruiz, E. Lledó Iñigo y García Gual, $2^{a}$ reimp. de la $1^{a}$ ed., Gredos, Madrid, 1985.

-, ID., «Protágoras», Diálogos I, intr. Emilio Lledó Iñigo, trad. y notas de Calonge Ruiz, E. Lledó Iñigo y García Gual, Gredos, Madrid, 1985.

POlAino-LORENTE, Aquilino, «Las sectas y los problemas personales», Altarejos Francisco / POLAINO-LORENTE Aquilino / LÓPEZ-ESCOBAR Esteban, Tres reflexiones sobre sectas: (educación, psiquiatría, opinión pública), Cuadernos del Instituto Martín de Azpilcueta, Influencia sectaria e información personal, Pamplona, 1999.

Polaino-Lorente Aquilino / Polaino NAVARrete Miguel, «Dimensiones Psicológico-Psiquiátrica y Jurídico-Penal en el ejercicio de la sofrología», Revista de Estudios Penitenciales, núm. 204 a 207, 1974.

Polaino Navarrete, Miguel, Los elementos subjetivos del injusto en el Código penal español, Anales de la Universidad hispalense, Publicaciones de la Universidad de Sevilla, Serie Derecho, núm. 13, Sevilla, 1972.

-, ID., El bien jurídico en el Derecho penal, Anales de la Universidad de Sevilla, núm. 19, Servicio de Publicaciones, Sevilla, 1974.

-, ID., La voluntariedad de las acciones punibles, Sevilla, 1979.

-, ID., El delito de detención ilegal, Aranzadi, Pamplona, 1982.

-, ID., «El delito fiscal. Secuencias fallidas de una reforma penal», Estudios Penitenciarios y Criminológicos, Vol. IX, 1986, Cursos y Congresos núm. 40, Servicios de Publicaciones de la Universidad de Santiago de Compostela.

-, ID., CoBo Del Rosal (dir.), Comentarios al Código penal, I, 1999, art. 16.

-, ID., Derecho Penal, Parte General, T. II, Teoría jurídica del delito, Vol. I, Bosch, Barcelona, 2000.

-, ID., Derecho penal, Parte general, I, 5ª ed., colaboración de Miguel Polaino-Orts, Bosch, 2004.

-, ID., «El injusto de la tentativa en el ejemplo de los delitos de mera actividad y de omisión pura. Sobre el concepto jurídico-penal de resultado», $R P J$, núm. 72, 2003, pp. 59 a 88, con el mismo título también en Bogotá, Universidad Externado de Colombia. 2004.

-, ID., «Injusto de la tentativa y vigencia de la norma desde una perspectiva penal funcionalista», El pensamiento filosófico y jurídico-penal de Günther Jakobs, México D.F., Flores Editor y Distribuidor, S.A. de C.V., 2007, pp. 707 a 743 .

-, ID., Acción, omisión y sujetos en la Teoría del delito. (De la posición de garante a la responsabilidad penal de las personas jurídicas), Grijley, Perú, 2009.

-, ID., vv.aa., Lecciones de Derecho penal, Parte especial, T. I, Dir. Miguel Polaino NaVArRETE / MARTOS NúÑEZ Juan Antonio / Herrera Moreno Myriam / Blanco Lozano Carlos / Monge Fernández Antonia / ReQueJo CONDE Carmen / POLAINO-ORTS Miguel, Tecnos, Madrid, 2010.

-, ID., vv.aa., Lecciones de Derecho penal, Parte especial, T. II, Dir. Miguel Polaino NavarRETE / MARTOS NúÑEZ Juan Antonio / Herrera Moreno Myriam / Blanco Lozano Carlos / Monge Fernández Antonia / Aguado Correa Teresa / ReQuejo Conde Carmen / RANDo CASEMeIro Pablo / Polaino-Orts Miguel, Tecnos, Madrid, 2011. 
-, ID., Lecciones de Derecho penal, Parte General, T. II, Tecnos, 2013.

Polaino NAVARrete Miguel / POLAINO-ORTS Miguel, Cometer delitos con palabras. Teoría de los actos de habla y funcionalismo jurídico-penal, Dykinson, Madrid, 2004.

Polaino-OrTs, Miguel, Derecho penal del enemigo. Desmitificación del concepto, pról. Günther Jakobs, revisado por Miguel Polaino Navarrete, Grijley, Lima, 2006.

-, ID., Derecho penal del enemigo. Fundamentos, potencial de sentido y límites de vigencia, pról. Günther Jakobs, Bosch, Barcelona, 2009.

-, ID., «Imputación objetiva: esencia y significado», KINDHÄUSER Urs / POLAINO-ORTS Miguel / CORCINO BARRUETA Fernando, Imputación objetiva e imputación subjetiva en Derecho penal, Grijley, Perú, 2009, pp. 19 a 84.

-, ID., Lo verdadero y lo falso en el Derecho penal del enemigo, pról. Günther Jakobs, Grijley, Lima, 2009.

-, ID., Funcionalismo normativo. Bases dogmáticas para el nuevo Sistema de Justicia penal, Fundamentos y Función del Derecho penal, T. I, Centro de Estudios Superiores en Ciencias Jurídicas y Criminológicas (CESCIJUC), $1^{\text {a }}$ ed. 2014, México.

-, ID., vv.aa., Lecciones de Derecho penal, Parte especial, T. I, Dir. Miguel Polaino NaVARRETE / MARTOS NúÑEZ Juan Antonio / Herrera Moreno Myriam / Blanco Lozano Carlos / Monge Fernández Antonia / ReQuejo CONDE Carmen / POLAINO-ORTS Miguel, Tecnos, Madrid, 2010.

-, ID., vv.aa., Lecciones de Derecho penal, Parte especial, T. II, Dir. Miguel Polaino NavarRETE / MARTOS NúÑEZ Juan Antonio / Herrera Moreno Myriam / Blanco Lozano Carlos / Monge Fernández Antonia / AGUAdo Correa Teresa / ReQuejo Conde Carmen / RAndo CASEMEIRo Pablo / Polaino-Orts Miguel, Tecnos, Madrid, 2011.

-, ID., «Gunther Jakobs y el funcionalismo jurídico-penal», JAKOBS, G., El lado comunicativo y el lado silencioso del Derecho penal. Expectativas normativas, intervención delictiva, Derecho penal del enemigo, edición Miguel Polaino-Orts, Universidad de Sevilla, 2014, pp. 23 a 54.

-, ID., «Prólogo» a SANTA RITA TAMÉS, Gilberto, El delito de organización terrorista: un modelo de Derecho penal del enemigo. Análisis desde la perspectiva de la imputación objetiva, pról. Miguel Polaino-Orts, Bosch, 2015, pp. 21 a 27.

Portilla Contreras, Guillermo, vv.aa., Curso de Derecho penal español, Parte especial, I, Marcial Pons, Madrid, 1996.

PRAT, Joan, El estigma del extraño. Un ensayo antropológico sobre sectas religiosas, $3^{\mathrm{a}}$ ed. Ariel, 2007.

PRIETO SANCHÍs, Luis, «El derecho fundamental de libertad religiosa», IBÁN / PRIETO SANCHÍs / MotiLlA, Curso de Derecho eclesiástico, Madrid, 1991.

-, ID., «La objeción de conciencia», IBÁn / PRIETO SANCHÍs / MotILlA, Curso de Derecho eclesiástico, Madrid, 1991.

-, ID., «Insumisión y libertad de conciencia (A propósito de la sentencia 75/92 del Juzgado de lo Penal número 4 de Madrid de 3 de febrero de 1992», Ley y conciencia. Moral legalizada y moral crítica en la aplicación del Derecho, G. Peces Barba Martínez (Ed.) Instituto de Derechos Humanos Bartolomé de las Casas, Universidad Carlos III de Madrid y Boletín Oficial del Estado Madrid, 1993.

PuY, Francisco, El Derecho y el Estado en Nietzsche, Editora Nacional, Madrid, 1966.

QUINTANO RIPOLLÉS, Antonio, «La motivación moral en el Derecho penal», RGLJ, núm. 4, 1949.

-, ID., «Ideas jurídicas de Nietzsche», Anuario de Filosofía del Derecho, Madrid, 1957, pp. 175 a 194.

-, ID., «La objeción de conciencia ante el Derecho penal», Estudios penales, Homenaje a R. P. Julián Pereda, Universidad de Deusto, Bilbao, 1965.

-, ID., Tratado de la Parte especial del Derecho penal, T. I, II, Infracciones contra la personalidad, $2^{\mathrm{a}}$ ed., puesta al día por Enrique Gimbernat Ordeig, Ed. Revista de Derecho Privado, Madrid, 1972.

Quintero Olivares, Gonzalo, Parte General del Derecho penal, colaboración de Fermín Morales Prats, $1^{\text {a }}$ ed., Aranzadi, 2005.

RADBRUCH, Gustav, «El delincuente por convicción», trad. y notas José Luis Guzmán Dalbora, Universidad de Antofagasta (Chile), RECPC, núm. 7, 2005, publicado originalmente en la Zeitschrift für die gesamte Strafrechtswissenchaft, T. 44, 1924.

-, ID., «DerÜberzeugungsverbrecher», Juristische Rundschau, T. 2, 1926.

RAGER, GR. Hipnosis, Sofrología y Medicina, Ed. Scientia, Barcelona, 1973.

RAmos VÁzQUEZ, José Antonio, Ciencia, libertad y Derecho penal, (Aportaciones del determinismo y defensa de la libertad de acción como base del sistema pena), Tirant lo Blanch, Valencia, 2013.

-, ID., «La pregunta por la libertad de acción (y una respuesta desde la filosofía del lenguaje)», Eduardo Demetrio Crespo (dir.) / Manuel Maroto Calatayud (coord), Neurociencias y Derecho penal. Nuevas perspectivas en el ámbito de la culpabilidad y tratamiento jurídico-penal de la peligrosidad, Edisofer, Madrid, 2013, pp. 137 a 160.

REDONDo HermidA, Álvaro, «Las sectas dañosas ante el Derecho penal», Diario La Ley, núm. 6463, XXVII, 2006, pp. 15.

-, ID., «El delito sectario en la reciente jurisprudencia», La Ley, Vol. 8, núm. 84, 2011, pp. 73 a 84.

-, ID., «Sectas destructivas y ordenamiento jurídico», Estudios Jurídicos, 2010. 
RENZIKOWSKI, Joachim, Restriktive Täterbegriff und fahrlässige Beiteiligung, 1997.

REQUENA JULIANI, Jaime, Intercambiabilidad de acción y omisión en los delitos de dominio: posición de garante e imputación objetiva, Dykinson, Cuadernos Luis Jiménez de Asúa, 2010.

REY SAFINZ, Luis Carlos, Tentativa jurídico-penal: acercamiento al tratamiento doctrinal del fundamento de los criterios de imputación entre naturalismo y normativismo, Dykinson, Madrid, 2001.

RoBles PlANAS, Ricardo, «Participación en el delito e imprudencia», RDPC, 6, 2000, pp. 223 a 251.

-, ID., La participación en el delito: fundamento y límites, Marcial Pons, Madrid, 2003.

RocA, María José, «La interpretación del concepto "fines religiosos" y la discrecionalidad administrativa», $A D E E$, Vol. XTV, 1998.

RODRÍGUEZ-CARBALlEIRA Álvaro / ALMENDROS Carmen, «Análisis de las sectas coercitivas y de su principal problemática jurídica», Psicología jurídica, 2006, pp. 335 a 362.

RODRÍGUEZ-CARBALLEIRA Álvaro / ALMENDROS Carmen / ESCARTÍN SOLANELlES Jordi / PORRÚA GARCÍA Clara / MARTÍN-PEÑA Javier / JAVALOY Federico / CARROBLES José Antonio, «Un estudio comparativo de las estrategias de abuso psicológico: en pareja, en el lugar de trabajo y en grupos manipulativos», Anuario de Psicología, Vol. 36, núm. 3, 2005, pp. 299 a 314.

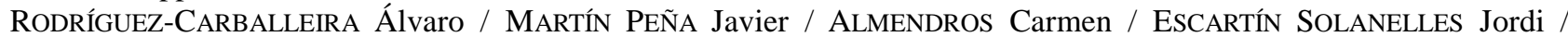
PORRÚA GARCÍA Clara, «Un análisis psicosocial del grupo terrorista como secta», Revista de Psicología Social, ejemplar dedicado a Explicaciones y análisis sobre la violencia terrorista, Vol. 24, núm. 2, 2009, pp. 183 a 195.

RoDRÍGUEZ-CARBALlEIRA, Álvaro, El lavado de cerebro, Boixareu Editores, Barcelona, 1992.

-, ID., «La persuasión coercitiva en sectas: ¿Una nueva teología?», Papers d'Estudis y Formació, núm. 9, junio de 1992.

-, ID., Psicología de la persuasión coercitiva, Universitat de Barcelona, 1992.

-, ID., «El fenómeno de las sectas coercitivas», CDJ, ejemplar dedicado a Sociología de Grupos pequeños: sectas y tribus urbanas, dir. Andrés Canteras Murillo, núm. 11, 2000, pp. 225 a 266.

-, ID., «Sectas coercitivas y juventud», Revista de Estudios de Juventud, ejemplar dedicado a Juventud, Creencias y Sectas, núm. 53, 2001, pp. 117 a 129.

-, ID., «La actuación de las sectas coercitivas», Eguzkilore, 18, San Sebastián, Diciembre 2004, pp. 247 a 268.

Rodríguez Devesa José María / JASO Roldán Tomás / RodRíGuEZ MuÑoz José Arturo, Derecho penal, Parte especial, T. II, Madrid, 1949.

Rodríguez Devesa José María / Serrano Gómez Alfonso, Derecho penal, Parte general, (PG) 17ª ed., Dykinson, Madrid, 1994.

-, ID., Derecho penal español, Parte especial, $18^{\mathrm{a}}$ ed. revisada y puesta al día por Alfonso Serrano Gómez, Dykinson, Madrid, 1995.

RodríGUEZ Mourullo, Gonzalo, La omisión de socorro en el Código penal, Madrid, 1966.

-, ID., vv.aa., Comentarios al Código penal, Madrid, 1997.

RodRíGuEZ, Pepe, Esclavos de un Mesías. Sectas y lavado de cerebro, Ed. Elfos, Barcelona, 1984.

-, ID., «Estado actual de la problemática sectaria en España», Sectas y Sociedad, Ponencia del I Congreso Internacional celebrado en San Cugat del Vallés, Asociación Pro-Juventud, Barcelona, 1987.

-, ID., El poder de las sectas, Ed. B, Barcelona, 1989.

-, ID., Las sectas hoy y aquí, Ed. Tibidabo, $3^{\mathrm{a}}$ ed., 1991.

-, ID., Adicción a sectas, Ed. B, Barcelona, 2000.

-, ID., «La Justicia ante el fenómeno de las sectas», Sociología de grupos pequeños: sectas y tribus urbanas, Consejo General del Poder Judicial, Madrid, 2001, pp. 325 a 383.

-, ID., «La sectadependencia, otra forma de adicción», Estudios de Juventud, núm. 53/2001.

RODRÍGUEZ-ARMAS, Lorenzo, Análisis del contenido esencial de los derechos fundamentales, Granada, 1996.

ROKEACH, Milton, The open and the closed mind: investigations into the nature of belief systems and personality systems, Basic Books, New York, 1960.

Romeo Casabona, Carlos María, El médico y el Derecho penal. La actividad curativa (Licitud y responsabilidad penal), Bosch, Barcelona, 1981.

-, ID., El médico ante el Derecho, $1^{\text {a }}$ ed., Servicio de Publicaciones Ministerio de Sanidad y Consumo, 1985.

-, ID., El Derecho y la Bioética ante los límites de la vida humana, Centro de estudios Ramón Areces, 1994.

-, ID., «El derecho a la objeción de conciencia», Héctor Gross Espiell Amicorum Liber. Persona humana y Derecho internacional., Vol. II, Bruylant, Bruxelles, 1997.

-, ID., «¿Límites de la posición de garante de los padres respecto al hijo menor? (La negativa de los padres, por motivos religiosos, a una transfusión de sangre vital para el hijo menor)», RDPC, 2, 1998, pp. 327 a 357.

Ropero Carrasco, Julia, La provocación del estado de necesidad en Derecho penal. Provocación de situaciones de riesgo en el tráfico automovilístico y otros estados de conflicto, Comares, Granada, 2002.

Roso CAÑADILlas, Raquel, Autoría y participación imprudente, Comares, Granada, 2002. 
Rousseau, Jean-Jacques, El contrato social o Principios de derecho político, estudio preliminar y traducción María José Villaverde, $2^{\mathrm{a}}$ ed., Tecnos, 1992

RoXIN, Claus, «Sobre autoría y participación en el Derecho penal», Problemas actuales de las Ciencias penales y la Filosofía del Derecho, Homenaje al Profesor Luis Jiménez de Asúa, trad. Bacigalupo Zapater, Buenos Aires, 1970, pp. 55 a 70 .

-, ID., «Sobre el fin de protección de la norma en los delitos imprudentes», RoxIN, C., Problemas básicos de Derecho penal, trad. y notas Luzón Peña, Reus, Madrid, 1976, pp. 181 a 199.

-, ID., «El límite entre comisión y omisión», Roxin, C., Problemas básicos de Derecho penal, trad. y notas Luzón Peña, REUS, Madrid, 1976, pp. 226 a 247.

-, ID., «Culpabilidad, prevención y responsabilidad en Derecho penal», RoxIN, C., Culpabilidad y prevención en Derecho penal, trad. intr. y notas Francisco Muñoz Conde, Reus, Madrid, 1981, pp. 147 a 186.

-, ID., «"Culpabilidad” y "Responsabilidad” como categorías sistemáticas jurídico-penales», Roxin, C., Culpabilidad y prevención en Derecho penal, trad. intr. y notas Francisco Muñoz Conde, Reus, Madrid, 1981, pp. 57 a 92.

-, ID., «Qué queda de la culpabilidad en Derecho penal», trad. Jesús-María Silva Sánchez, CPC, 30, 1986, pp. 671 y ss.

-, ID., «Die Gewissenstat als Strafbefreiungsgrund», Rechtstaat und Menschenwürde-Festschrift für Werner Maihofer, Vittorio Klostermann, Frankfurt am Main, 1988, pp. 404 y ss.

-, ID., «Observaciones sobre la "actio libera in causa"», trad. Francisco Muñoz Conde, ADPCP, enero-abril, 1988, pp. 21 a 38 .

-, ID., «Otras causas de justificación y exculpación», Justificación y exculpación en Derecho penal, coloquio hispanoalemán, Edit. Albin Eser / Enrique Gimbernat / Walter Perron, Madrid, 1995, pp. 219 a 235.

-, ID., Derecho penal, Parte general, T. I, Fundamentos. La estructura de la teoría del delito, (PG), trad. y notas Luzón Peña / Díaz y García Conlledo / De Vicente Remesal, de la 2a ed. alemana, Civitas, 1997.

-, ID., «Problemas de autoría y participación en la criminalidad organizada», Delincuencia organizada: aspectos penales, procesales y criminológicos, Universidad de Huelva, 1999, pp. 191 a 198.

-, ID., «Tratamiento jurídico-penal de la eutanasia», RECPC, 1-10, 1999.

-, ID., «Las formas de intervención en el delito: estado de la cuestión», trad. María Teresa Castiñeira Palou, RoxIN Claus / JAKOBS Günther / SCHÜNEMANN Benrd / FRISCH Wolfgand / KÖHLER Michael, Sobre el estado de la teoría del delito, (Seminario en la Universitat Pompeu Fabra), $1^{\text {a }}$ ed., Civitas, Madrid, 2000, pp. 155 a 178.

-, ID., «Acerca de la punibilidad de la tentativa inidónea», Revista Latinoamericana de Derecho, núm. 9-10, 2009.

RUBIA, Francisco José, «Neurociencia y libertad», Eduardo Demetrio Crespo (dir.) / Manuel Maroto Calatayud (coord.), Neurociencias y Derecho penal. Nuevas perspectivas en el ámbito de la culpabilidad y tratamiento jurídico-penal de la peligrosidad, Edisofer, Madrid, 2013, pp. 185 a 90.

-, ID., La ficción de la libertad, Conferencia en el Congreso Internacional de Bioética, Valencia, 14 de noviembre de 2012, www.tendencias21.net, consultado el 15 de enero de 2015.

RUDOLPHI, Hans-Joachim, Unrechtsbewusstsein, Verbotsirrtum und Vermeidbarkeit des Verbotsirrtums, 1969.

-, ID., «Die Bedeutung eines Gewissenentsscheides für das Strafrecht», Festschrift für Hans Welzel, 1974, pp. 605 a 633.

RUIZ ANTÓN, Luis Felipe, El agente provocador en el Derecho penal, Editoriales de Derecho Reunidas, 1982.

RuIZ Miguel, Alfonso, «Autonomía individual y derecho a la propia vida (Un análisis filosófico-jurídico)», Revista del Centro de Estudios Constitucionales, 14, 1993.

-, ID., «La objeción de conciencia, en general y en deberes cívicos», Revista Española de Derecho Constitucional, mayo-agosto, 1996, pp. 101 a 124.

SADE, Justine o los infortunios de la virtud, $5^{\mathrm{a}}$ ed., Ed. Espiral, 2000.

SAINZ CANTERO, José Antonio, «El delito de omisión del deber de socorro», RGLJ, 1960.

-, ID., «El desenvolvimiento histórico-dogmático del principio de "no exigibilidad"», ADPCP, 1960.

-, ID., «Las causas de inculpabilidad en el Código penal español (El principio de no exigibilidad)», RGLJ, 1963.

-, ID., La exigibilidad de conducta adecuada a la norma en Derecho Penal, Universidad de Granada, Granada, 1965.

-, ID., Lecciones de Derecho Penal, Parte General, Culpabilidad, punibilidad, formas de aparición, III, $2^{\mathrm{a}}$ ed., Bosch, Barcelona.

SAlARrullana, Pilar, Las sectas, $4^{\text {a }}$ ed., Ed. Temas de hoy, Madrid, 1990.

SÁNCHEZ GARCÍA DE PAZ, Isabel, La criminalidad organizada. Aspectos penales, procesales, administrativos y policiales, Dykinson, 2005.

SÁnchez TomÁs, José Miguel, vv.aa., Rodríguez Ramos / Cobos GómEz De LinAREs / SÁnCHEZ TOMÁs, Derecho penal. Parte especial, I, Ed. Facultad de Derecho, UCM, Madrid, 1996.

-, ID., Comisión por omisión y omisión de socorro agravada, Bosch, 2005.

SÁNCHEZ-OstiZ, Pablo, La libertad del Derecho penal. Estudios sobre la doctrina de la imputación, Atelier, 2014.

SÁNCHEZ-VERA GÓMEZ-TRELLES, Javier, «Intervención omisiva, posición de garante y prohibición de sobrevaloración del aporte», ADPCP, 1995, pp. 187 a 263. 
-, ID., «Sobre la figura de la autoría mediata y su tan sólo fenomenológica "trascendencia”», ADPCP, 51, 1998, pp. 319 a 364 .

-, ID., «En los límites de la inducción», InDret, $2 / 2012$.

-, ID., Delito de infracción de deber y participación delictiva, presentación Enrique Bacigalupo, pról. Günther Jakobs, Marcial Pons, Barcelona, 2002.

-, ID., El denominado «delito de propia mano». Respuesta a una situación jurisprudencial, Dykinson, Madrid, 2004.

SANTAMARÍA DEL Río, Luís, Entre las sectas y el fin del mundo. Una noche que murmura esperanza, $1^{\mathrm{a}}$ ed., Vita Brevis, colección RIES núm. 2, Red Iberoamericana de estudios de las sectas, 2013.

SANTA RITA TAMÉS, Gilberto, El delito de organización terrorista: un modelo de Derecho penal del enemigo. Análisis desde la perspectiva de la imputación objetiva, pról. Miguel Polaino-Orts, Bosch, 2015.

SAnto Tomás, Suma de Teología, II, Parte I-II, $2^{a}$ ed., Biblioteca de Autores Cristianos, Madrid, 1989.

-, ID., Suma de Teología, I, Parte I, 4ª ed., reimp., Biblioteca de Autores Cristianos, Madrid, 2001.

SAX, Walter, «Tatbestand und Rechtsgutsverletzung», JuS, III, 1976.

SCHAFF, Adam, La alienación como fenómeno social, trad. Alejandro Venegas, Grijalbo, Barcelona, 1979.

SCHEIN Edgar H / SCHNEIER Inge / BARKER Curtis H., Coercitive Persuasion: A socio-psychological Analusis of the Brainwashing of American Civilian Prisoners by the Chinese Communists, Nueva York, W. W. Norton, 1961.

SCHMIDHÄUSER, Eberhard, Strafrecht Teil, Lehrbuch, 2, neubearbeitete Auflage, J.C.B. Mohr, Paul Siebeck, Tubinga, 1975.

SCHOPEnHAUER, A., El fundamento de la moral, trad. D. Díaz Crespo, Ed. Atlante.

-, ID., De la voluntad en la naturaleza, Alianza Editorial, trad. Miguel de Unamuno, pról. y notas Santiago González Noriega, $1^{a}$ reimp. 2006 de la $1^{a}$ ed. 2003 en Área de conocimiento: Humanidades, 2006.

-, ID., El mundo como voluntad y representación, T. I, trad. y pról. Eduardo Ovejero y Maury, $1^{\text {a }}$ ed., Losada, Buenos Aires, 2008.

-, ID., Parerga y Paralipómena (Escritos filosóficos sobre diversos temas), pról. trad. y notas José Rafael Hernández Arias, Luis Fernando Moreno Claros y Agustín Izquierdo, 1a ed., Valdemar, 2009.

-, ID., Sobre la libertad en la voluntad, $4^{\mathrm{a}}$ reimp. 2010 de la $1^{\mathrm{a}}$ ed., 2000. Alianza Editorial.

SCHUlZ, U., «Die mittelbare Täterschaft kraft Organistationsherrschaft - eine notwendige Rechtsfortbildung?», JuS, 1997, pp. 109 a 113.

SCHÜNEMANN, Bernd, «Politisch motivierte Kriminalität», Politisch motivierte Kriminalität- echte Kriminalität? Schriftenreihe des Instituts für Konflikforschung, 4, W. De Boor (Hrsg.), S. Karger, Basel/München, 1978.

-, ID., «Die deutschsprachige Strafrechtswissenschaft nach der Strafrechtsreform im Spiegel des Leipziger Kommentars und des Wiener Kommentars», GA, 1986.

-, ID., «Problemas jurídico-penales relacionados con el SIDA», Problemas jurídico-penales del sida, Mir Puig (ed.), Barcelona, 1993, pp. 25 a 99.

-, ID., «Sistema del Derecho penal y victimodogmática», José Luis Díez Ripollés, Carlos María Romeo Casabona, Luis Gracia Martín, Juan Felipe Higuera Guimerá (Edit.), La ciencia del Derecho penal ante el nuevo siglo, Libro Homenaje al Profesor Doctor José Cerezo Mir, reimp. 2003 de la $1^{\text {a }}$ ed., 2002, Tecnos, pp. 159 a 172.

Scola A / FERrari G / PORCARElli A / FIZZOTI E / Musti L / MORONTA M., Sectas satánicas y fe cristiana, pról. Julián García Hernando, Editorial Palabra, 1998.

SeElig, Ernst, Tratado de Criminología, trad. José María Rodríguez Devesa, Madrid 1958.

SEGLERS, Álex, «La inscripción registral de las confesiones religiosas: análisis de los requisitos legales», Revista de Administración Pública, núm. 163, enero-abril, 2004, pp. 311 a 347.

SERRANO MAÍllo, Alfonso, «Exorcismo. Crimen ritual», RDPC núm. 3, UNED, 1993, pp. 997 a 1007.

SHULTE Reiner / TRÄGER Ernst, «Gewissen im Strafprozess. Eine Rehtsprechungübersicht», 25 Jahre Bundesgerichtstshof, coord. Gerda Krüger-Nieland, C.H. Beck, München, 1975, pp. 251 y ss.

SIERRA MucIENTES, Sara, La objeción de conciencia sanitaria, Dykinson, Madrid, 2000.

Sílva DíAS, Augusta, A relevância jurídico-penal das decisoes de consciência, Livraria Almedina, Coimbra, 1986.

SILVA SÁNCHEZ, Jesús-María, «Sobre el estado de necesidad en Derecho penal español», ADPCP, 1982.

-, ID., El delito de omisión. Concepto y sistemas, Bosch, Barcelona, 1986.

-, ID., «Causación de la propia muerte y responsabilidad penal de terceros (A propósito de la STS 8 de julio de 1985), ADPCP, 1987, pp. 451 a 477.

-, ID., «La responsabilidad penal del médico por omisión», La Ley, 1987, T. I, pp. 955 y ss.

-, ID., «La estructura de la "actio libera in causa" en los delitos cometidos bajo un síndrome de abstinencia de drogas», La Ley, 1988, 22, enero.

-, ID., «Problemas del tipo de omisión del deber de socorro (comentario a la STS de 27 de abril de 1987, ponente Sr. Díaz Palos)», ADPCP, 1988.

-, ID., «Aspectos de la comisión por omisión: Fundamento y formas de intervención. El ejemplo del funcionario penitenciario», $C P C$, núm. 38, 1989. 
-, ID., «Sobre la relevancia jurídico-penal de la no-inmediatez en la producción del resultado», Estudios penales en memoria del profesor Agustín Fernández-Albor, Seminario de Derecho penal e Instituto de Criminología, Universidad de Santiago de Compostela, Santiago de Compostela, 1989, pp. 677 a 687.

-, ID., Aproximación al Derecho penal contemporáneo, $1^{\mathrm{a}}$ ed., Bosch, 1992.

-, ID., El Nuevo Código penal: cinco cuestiones fundamentales, Bosch, Barcelona, 1997.

-, ID., «Sobre las situaciones de necesidad que no implican deberes de tolerancia», Consideraciones sobre la teoría del delito, Buenos Aires, 1998, pp. 221 a 257.

-, ID., vv.aa., Comentarios al Código penal, T. I, (arts. 1 a 18), dir. Cobo del Rosal, Edersa, Madrid, 1999 , pp. 440 a 488.

-, ID., «Entre la omisión de socorro y la comisión por omisión. Las estructuras de los arts. 195.3 y 196 del Código penal», vv.aa., Problemas específicos de la aplicación del Código penal, Manuales de formación continuada, núm. 4, Consejo General del Poder Judicial, Madrid, 1999, pp. 153 a 172.

-, ID., “¿“Pertenencia” o "intervención”? Del delito de "pertenencia a una organización criminal” a la figura de la "participación a través de la organización", en el delito», Octavio de Toledo y Ubieto / Gurdiel Sierra / Cortés Bechiarelli (coords.), Estudios en recuerdo del Profesor Ruiz Antón, Tirant lo Blanch, Valencia, 2004, pp. 1069 y ss.

-, ID., «La "intervención a través de la organización”, ¿una forma moderna de participación en el delito?», CANCIO Meliá Manuel / SiLva SÁnchez Jesús-María, Delitos de organización, B de F, Montevideo-Buenos Aires, 2008, pp. 87 y ss.

SIMÓN, Pablo, El consentimiento informado. Historia, teoría y práctica, Ed. Triacastela, Madrid, 2000.

SINGER, Margaret Thaler, «The Systematic Manipulation of Psychological and Social Influence», Ponencia en el encuentro anual de la Cult Awareness Network / Citizens Freedom Foundation, Washington D.C, 1982.

-, ID., «Los programas de modificación del pensamiento y la producción de casos psiquiátricos», Sectas y Sociedad, Ponencia del I Congreso Internacional celebrado en San Cugat del Vallés, Asociación Pro-Juventud, Barcelona, 1987, pp. 53 a 58.

-, ID., «Repercusión en el núcleo familiar», Sectas y Sociedad, Ponencia del I Congreso Internacional celebrado en San Cugat del Vallés, Asociación Pro-Juventud, Barcelona, 1987.

SINGER Margaret Thaler / LALICH Janja, Las sectas entre nosotros, Ed. Gedisa, Barcelona, 1997.

Sófocles, Antígona, Edipo rey, Electra, Círculo de Lectores, Barcelona, 1995 Círculo de Lectores, Barcelona, 1995.

SOLA RECHE, Esteban, «Sobre el concepto de tentativa idónea», El nuevo Derecho penal español, Estudios penales en memoria del profesor José Manuel Valle Muñiz, Fermín Morales Prats y Gonzalo Quintero Olivares (coords.), 2001, pp. 773 a 786.

-, ID., «Delitos de omisión pura y sistema de Derecho penal», vv.aa., La Ciencia del Derecho penal ante el nuevo siglo. Libro Homenaje al profesor doctor Don José Cerezo Mir, Madrid, 2002.

ID., La llamada tentativa inidónea del delito. Aspectos básicos, $1^{\mathrm{a}}$ ed., Comares, 2006.

SOLER GIL, Francisco José, «Relevancia de los experimentos de Benjamin Libet y de John-Dylan Haynes para el debate en torno a la libertad humana en los procesos de decisión», Thémata, Revista de Filosofía, núm. 41, 2009.

Souto PAZ, José Antonio, «La libertad ideológica y religiosa en la jurisprudencia constitucional», Las relaciones entre la Iglesia y el Estado. Estudios en memoria del profesor Pedro Lombardía, Madrid, 1989.

-, ID., Derecho Eclesiástico del Estado. El Derecho de la libertad de ideas y creencias, $3^{\mathrm{a}}$ ed., revisada y ampliada, Marcial Pons, Madrid, 1995.

-, ID., «Comentarios a la Carta de los Derechos Fundamentales de la Unión Europea», Revista del poder Judicial, Tercera época, núm. 61, 2001.

-, ID., Comunidad política y libertad de creencias. Introducción a las Libertades Públicas en el Derecho Comparado, $2^{\mathrm{a}}$ ed., Marcial Pons, 2003.

STRATENWERTH, G., «Dolus eventuales und bewusste Farhlässigkeit», ZStW, núm. 71, 1959, pp. 51 a 71.

-, ID., Derecho Penal, Parte General, I, El hecho punible, $(P G)$, trad. Manuel Cancio Meliá y Marcelo A. Sancinetti, Thomson, 2005.

TAJFEL, Henri, Grupos humanos y categorías sociales, Herder, Biblioteca de Psicología 15, Barcelona, 1984.

TAJFEL Henri / TURNER JC., «The social identity theory of intergroup behavior», S. Worchel / W Austin (Edit.) Psychology of Intergroup Relations, IL Nelson Hall, Chigago, 1986, pp. 7 a 24.

TAMARIT SUMALlA, José María, La libertad ideológica en el Derecho penal, PPU, Barcelona, 1989.

-, ID., «Las sectas y el Derecho penal», vv.aa., Aspectos socio-jurídicos de las sectas desde una perspectiva comparadal The Oñati Internacional Institute for the Sociology of Law, 1991, edited by Juan Goti Ordeñana.

-, ID., «La objeción de conciencia», CJ, 22, 1994, pp. 34 a 45.

-, ID., La víctima en el Derecho penal, Aranzadi, 1998.

-, ID., «Responsabilidad penal de terceros ante la negativa a la trasfusión de sangre de Testigo de Jehová menor de edad con resultado de muerte», Revista Actualidad Jurídica Aranzadi, núm. 325, 1998, pp. 1 a 6.

-, ID., «Libertad de conciencia y responsabilidad penal: relevancia de los motivos de conciencia en la valoración de la antijuricidad y culpabilidad», Laicidad y Libertades. Escritos Jurídicos, 1, 2001, pp. 383 a 402. 
-, ID., «De los delitos contra la libertad de conciencia», Quintero Olivares Gonzalo (dir.) / Valle Muñiz José Manuel (coord.), Comentarios al nuevo Código penal, Aranzadi, Pamplona, 1996.

TANnenbaum, Frank, Crime and Community, C.U. Pres, New York, 1938.

TAYLOR Ian / WALTON Paul / YOUNG Jock, La nueva criminología, contribución a una teoría de la conducta desviada, II, Editorial Amorrottu, Buenos Aires, 1990.

TeDESCHI, M., «Nuove religioni e confesión religiose», Studi in Memoria de Mario Condorelli, Vol. I, T. 2, Milano, 1988.

TIEDEMANN, Klaus, «Zur legislatorischen Behandlung des Verbotirrtums im Ordnungswidriegkeiten- und Steuerstrafrecht», Zeitschrift für die gesamte Strafrechtswissenschaft, 81, 1969, pp. 869 y ss.

TIEDEMAnN, Paul, «Der Gewissensbegriff in der höchstrichterlichen Rechtsssprechung», DöV. Heft 2 W Kohlhammer GmbH. Stuttgart, 1984, pp. 61 y ss.

TIMPE, Gerhard, Strafmilderungen des Allgemeinen Teils des StGB und das Doppelverwertungsverbot. Untersuchungen zu des 23 Abs. 2, 13 Abs.2, 17 Satz 2, 35 Abs. 1 Satz 2 und 46 Abs. 3 StGB, Berlin, 1983.

Tomás-VAliente LanuZA, Carmen, La disponibilidad de la propia vida en el Derecho penal, Centro de Estudios Políticos y Constitucionales, Madrid, 1999.

TORÍO LÓPEZ, Ángel, «Aspectos de la omisión especial de socorro», ADPCP, 1967.

-, ID., «La estructura típica del delito de coacción», Homenaje a don Emilio Gómez Orbaneja, Ed. Moneda y Crédito, Madrid, 1977, pp. 393 a 416.

-, ID., «El concepto individual de culpabilidad», $A D C P C, 1985$, pp. 285 y ss.

-, ID., «Indicaciones metódicas sobre el concepto material de culpabilidad», CPC, núm. 36, 1988.

Troeltch, Ernst, The social teaching of the Christian churches, McMillam, New York, 1931.

TURnER, JC., Social influence, Buckingham, Open University Press., 1991.

VALLE MuÑIZ, José Manuel, «Relevancia jurídico-penal de la eutanasia», CPC, 37, 1989, pp. 155 a 189.

VARONA GÓMEZ, Daniel, El miedo insuperable: una reconstrucción de la exigibilidad desde una teoría de la justicia, Comares, Granada, 2000.

VÁsques Shimajuko, Shikara, La imputación de los resultados tardios. Acerca de la dimensión temporal de la imputación objetiva, B de F, Montevideo-Buenos Aires.

VÁzQuez Honrubia, José María, «El Código Penal de 1995 y las organizaciones sectarias», Infosect, Boletín de la Asociación A.I.S.

VÁzQuez, Jesús María, «Sectas y Medios de Comunicación Social», vv.aa., Pluralismo religioso II, Sectas y nuevos movimientos religiosos, Atenas, Madrid, 1993, pp. 145 a 192.

-, ID., Familia y sectas, Instituto de Sociología Aplicada de Madrid, Madrid, 1994.

VeHLING, Karl-Heinz, «Abgrenzung von Vorbereitung und Versuch», Schriften zum Strafrecht und Strafprozeßrecht, 4, Peter Lang, Frankfurt am Main, Bern, New York, Paris, 1991.

VIADA Y VILASECA, Salvador, Código penal reformado de 1870, concordado y comentado, 4ª ed., Madrid, 1890.

VidAl MANZANARES, Cesar, El infierno de las sectas, Ediciones Mensajero, Bilbao, 1989.

-, ID., Psicología de las sectas. Una aproximación al fenómeno sectario, 2a ed., Ediciones Paulinas, 1990.

-, ID., Diccionario de sectas y ocultismo, Verbo Divino, Estella, Navarra, 1991.

VIVES ANTÓN, Tomás Salvador, «Neurociencia y determinismo reduccionista: una aproximación crítica», Eduardo Demetrio Crespo (dir.) / Manuel Maroto Calatayud (coord), Neurociencias y Derecho penal. Nuevas perspectivas en el ámbito de la culpabilidad y tratamiento jurídico-penal de la peligrosidad, Edisofer, Madrid, 2013, pp. 219 a 233.

VIVIEN, Alain, Les sectes en France, Paris, 1985.

vv.aa., «Sectas y grupos destructores de la personalidad, Cuidado: respuestas definitivas a las dudas existenciales», Revista Consumer Eroski, Sección de Psicología, núm. 33, Fundación Eroski, B ${ }^{\circ}$ San Agustín s/n. 48230 Elorrio, Vizcaya, España. Recuperado el 31 de Julio de 2007, http://revista.consumer.es.

vv.aa., «Totalisme i voracitar. Una aproximació interdisciplinária al «fenomen sectari» a Catalunya», AIS/CROAS, Barcelona, 1994.

WEBER, Max, «Kirchen» und «Sekten» in Nordamerika. Eine Kirchen und Sozialpolitische Skizze Soziologie, Weltgeschichtliche Analyse, Stuttgard, 1956.

-, ID., Sociología de la religion, La Pléyade, Buenos Aires, 1978.

-, ID., Ensayos sobre sociología de la religión, Madrid, 1992, Vol. I y Vol. II.

-, ID., La ética protestante y el espíritu del capitalismo, ed. Jorge Navarro Pérez, y pról. José Luis Villacañas, Editorial Istmo, Madrid, 1998.

WEINTZENHOFFER, Hynose et suggestion, Payot, 1905.

WEISSER, Bettina, «Gibt es eine fahrlässige Mittäterschaft?», JZ, 53, 1998, pp. 230 a 239.

Welzel, Hans, El nuevo sistema del Derecho Penal, Una introducción a la doctrina de la acción finalista, trad. José Cerezo Mir, Ariel, Barcelona, 1964.

-, ID., Derecho penal alemán, Parte General, trad. Juan Bustos Ramírez y Yáñez Pérez a la $11^{\text {a }}$ ed. alemana de $1959,2^{\text {a }}$ ed., Santiago de Chile, 1976. 
Wessels, Johannes, Derecho Penal, Parte General, trad. Conrado A. Finzi, de la $6^{\text {a }}$ ed. alemana de 1976, Depalma, Buenos Aires, 1980.

WeSt, Jolion Louis, «Propuestas de Salud Pública sobre las sectas», Sectas y Sociedad, Ponencia del I Congreso Internacional celebrado en San Cugat del Vallés, Asociación Pro-Juventud, Barcelona, 1987, pp. 29 a 40.

WILSON, Bryan, Sociología de las sectas religiosas, Guadarrama, 1970.

WIENER, Norbert, Cibernética y sociedad, trad. José Novo Cerro, $3^{\mathrm{a}}$ ed., Ed. Sudamericana, Buenos Aires, 1988.

WITTIG, Peter, «Der übergesetzliche Schuldausschliessungsgrund der Zumutbarkeit in verfassungsrechtlicher Sicht», JZ, 1969 , pp. 546 y ss.

Wood, James E., «New religions and the first Amendmen», Journal Church and State, 24, 1982, pp. 455 a 462.

ZACZYK, Rainer, Das Unrecht der Versuchten Tat, Duncker \& Humblot GmbH, Berlin, 1989.

ZAFFARONI Eugenio Raúl / Alagia Alejandro / SLOKAr Alejandro, Derecho penal, Parte general, $2^{\mathrm{a}}$ ed., Ediar, Buenos Aires, 2002.

ZIPF, Heinz, Introducción a la política criminal, Edersa, 1979.

ZUGALDÍA ESPINAR, José Miguel, «Eutanasia y homicidio a petición: situación legislativa y perspectivas políticocriminales», RFDUG, núm. 13, 1987, pp. 281 a 299.

-, ID., «El principio de culpabilidad en la reciente jurisprudencia del Tribunal Supremo», Estudios de Jurisprudencia, Revista Colex, Madrid, 1992. 